\title{
Refined families of Dothideomycetes: Dothideomycetidae and Pleosporomycetidae
}

Hongsanan $S^{1,2,6}$, Hyde $\mathrm{KD}^{2,3,7}$, Phookamsak $\mathbf{R}^{2,3,4,5,8,35}$, Wanasinghe $\mathrm{DN}^{3,4,5,35}$, McKenzie EHC ${ }^{9}$, Sarma $V^{10}$, Boonmee $S^{2,11}$, Lücking $R^{12}$, Bhat DJ $^{13}$, Liu $\mathrm{NG}^{2,14,15}$, Tennakoon DS ${ }^{2,11}$, Pem $D^{2,11}$, Karunarathna $\mathrm{A}^{2,3,4,6,51}$, Jiang $\mathrm{SH}^{17}$, Jones EBG ${ }^{18,19}$, Phillips AJL ${ }^{20}$, Manawasinghe $I^{2,7,21}$, Tibpromma $S^{3,4,5,35}$, Jayasiri $\mathrm{SC}^{2}$, Sandamali $\mathrm{DS}^{2,11,51}$, Jayawardena $\mathrm{RS}^{2,11}$, Wijayawardene $\mathrm{NN}^{22}$, Ekanayaka $\mathrm{AH}^{2}$, Jeewon $\mathrm{R}^{23}$, Lu $\mathrm{YZ}^{24}$, Dissanayake $\mathrm{AJ}^{16}$, Zeng $\mathrm{XY}^{2,25,26,33}$, Luo $\mathrm{ZL}^{27}$, Tian $\mathbf{Q}^{2}$, Phukhamsakda $\mathrm{C}^{2}$, Thambugala $\mathrm{KM}^{28}$, Dai $\mathrm{DQ}^{22}$, Chethana $\mathrm{KWT}^{2,11}$, Samarakoon $\mathrm{MC}^{2,48}$, Ertz $\mathrm{D}^{29,30}$, Bao $\mathrm{DF}^{2,6,27}$, Doilom $\mathrm{M}^{3,4,5,35}$, Liu JK ${ }^{16}$, PérezOrtega $S^{31}$, Suija $A^{32}$, Senwanna $C^{2,6}$, Wijesinghe $S^{2,11,33}$, Konta $S^{2,11}$, Niranjan $\mathbf{M}^{10,36}$, Zhang $\mathrm{SN}^{2,6}$, Ariyawansa $\mathbf{H A}^{34}$, Jiang $\mathbf{H B}^{2,3,4,11}$, Zhang $\mathrm{JF}^{2,37}$, Norphanphoun $\mathrm{C}^{2}$, de Silva $\mathrm{NI}^{3,6}$, Thiyagaraja $\mathrm{V}^{2,3,4,6}$, Zhang $\mathrm{H}^{38}$, Bezerra JDP ${ }^{39}$, Miranda-González $\mathbf{R}^{40}$, Aptroot $\mathrm{A}^{41}$, Kashiwadani $\mathbf{H}^{42}$, Harishchandra $\mathrm{D}^{2,11,21}$, Sérusiaux $\mathrm{E}^{43}$, Aluthmuhandiram JVS ${ }^{2,11,21}$, Abeywickrama PD $^{2,11,21}$, Devadatha $\mathrm{B}^{2,10}$, Wu HX ${ }^{44}$, Moon $\mathrm{KH}^{45}$, Gueidan $\mathrm{C}^{46}$, Schumm $\mathrm{F}^{47}$, Bundhun $\mathrm{D}^{2,6}$, Mapook $\mathrm{A}^{2}$, Monkai J $\mathrm{J}^{2}$, Chomnunti $\mathrm{P}^{11}$, Suetrong $\mathrm{S}^{49,50}$, Chaiwan $\mathrm{N}^{2,3}$, Dayarathne $\mathrm{MC}^{33}$, Yang $\mathrm{J}^{2,15}$, Rathnayaka $\mathrm{AR}^{2,11,51}$, Bhunjun $\mathrm{CS}^{2,11}$, Xu JC $\mathrm{JC}^{3,4,5,35}$, Zheng JS', Liu G', Feng $\mathbf{Y}^{52}$, Xie $\mathbf{N}^{1^{*}}$

${ }^{1}$ Guangdong Provincial Key Laboratory for Plant Epigenetics, Shenzhen Key Laboratory of Microbial Genetic Engineering, College of Life Science and Oceanography, Shenzhen University, Shenzhen 518060, People's Republic of China

${ }^{2}$ Center of Excellence in Fungal Research, Mae Fah Luang University, Chiang Rai 57100, Thailand

${ }^{3}$ CAS Key Laboratory for Plant Diversity and Biogeography of East Asia (KLPB), Kunming Institute of Botany, Chinese Academy of Science, Kunming 650201, Yunnan, People's Republic of China

${ }^{4}$ East and Central Asia Regional Office, World Agroforestry Centre (ICRAF), Kunming 650201, Yunnan, People's Republic of China

${ }^{5}$ Centre for Mountain Futures (CMF), Kunming Institute of Botany, Kunming 650201, Yunnan, People's Republic of China

${ }^{6}$ Department of Entomology and Plant Pathology, Faculty of Agriculture, Chiang Mai University, Chiang Mai 50002, Thailand

${ }^{7}$ Institute of Plant Health, Zhongkai University of Agriculture and Engineering, Haizhu District, Guangzhou 510225, People's Republic of China

${ }^{8}$ Research Center of Microbial Diversity and Sustainable Utilization, Faculty of Sciences, Chiang Mai University, Chiang Mai 50200, Thailand

${ }^{9}$ Manaaki Whenua-Landcare Research, Private Mail Bag 92170, Auckland, New Zealand

${ }^{10}$ Fungal Biotechnology Lab, Department of Biotechnology, School of Life Sciences, Pondicherry University, Kalapet, Pondicherry-605014, India

${ }^{11}$ School of Science, Mae Fah Luang University, Chiang Rai 57100, Thailand

${ }^{12}$ Botanischer Garten und Botanisches Museum, Freie Universität Berlin, Königin-Luise-Straße 6-8, 14195 Berlin, Germany

${ }^{13}$ 128/1-J, Azad Co-Op Housing Society, Curca, P.O. Goa Velha-403108, India.

${ }^{14}$ Faculty of Agriculture, Natural Resources and Environment, Naresuan University, Phitsanulok 65000, Thailand 
${ }^{15}$ Guizhou Key Laboratory of Agricultural Biotechnology, Guizhou Academy of Agricultural Sciences, Guiyang 550006, People's Republic of China

${ }^{16}$ School of Life Science and Technology, University of Electronic Science and Technology of China, Chengdu 611731, People's Republic of China

${ }^{17}$ State Key Laboratory of Mycology, Institute of Microbiology, Chinese Academy of Sciences, Beijing, People's Republic of China

${ }^{18}$ Department of Botany and Microbiology, College of Science, King Saud University, P.O Box 2455 Riyadh 11451 Kingdom of Saudi Arabia.

${ }^{19}$ Nantgaredig, 33B St Edwards Road, Southsea, Hants., PO5 3DH

${ }^{20}$ Faculdade de Ciências, Biosystems and Integrative Sciences Institute (BioISI), Universidade de Lisboa, Lisbon, Portugal

${ }^{21}$ Beijing Key Laboratory of Environment Friendly Management on Fruit Diseases and Pests in North China, Institute of Plant and Environment Protection, Beijing Academy of Agriculture and Forestry Sciences, Beijing, People's Republic of China

${ }^{22}$ Center for Yunnan Plateau Biological Resources Protection and Utilization, College of Biological Resource and Food Engineering, Qujing Normal University, Qujing, Yunnan 655011, People's Republic of China

${ }^{23}$ Department of Health Sciences, Faculty of Science, University of Mauritius, Reduit, Mauritius

${ }^{24}$ School of Food and Pharmaceutical Engineering, Guizhou Institute of Technology, Guiyang 550003, People's Republic of China

${ }^{25}$ State Key Laboratory Breeding Base of Green Pesticide and Agricultural Bioengineering, Key Laboratory of Green Pesticide and Agricultural Bioengineering, Ministry of Education, Guizhou University, Guiyang 550025, People's Republic of China

${ }^{26}$ The Engineering Research Center of Southwest Bio-Pharmaceutical Resource, Ministry of Education, Guizhou University, Guiyang 550025, People's Republic of China

${ }^{27}$ College of Agriculture and Biological Sciences, Dali University, Dali 671003, Yunnan, People's Republic of China

${ }^{28}$ Genetics and Molecular Biology Unit, Faculty of Applied Sciences, University of Sri Jayewardenepura, Gangodawila, Nugegoda, Sri Lanka

${ }^{29}$ Meise Botanic Garden, Department Research, Nieuwelaan 38, B-1860 Meise, Belgium

${ }^{30}$ Fédération Wallonie-Bruxelles, Service Général de l'Enseignement Supérieur et de la Recherche Scientifique, Rue A. Lavallée 1, BE-1080 Bruxelles, Belgium

${ }^{31}$ Real Jardín Botánico (CSIC), Dept. Micología, Plaza Murillo 2, E-28014 Madrid, Spain

${ }^{32}$ Institute of Ecology and Earth Sciences, University of Tartu, Lai 40, Tartu, 51005, Estonia

${ }^{33}$ Department of Plant Pathology, Agriculture College, Guizhou University, Guiyang, Guizhou Province, 550025, People's Republic of China

${ }^{34}$ Department of Plant Pathology and Microbiology, College of Bio-Resources and Agriculture, National Taiwan University, No.1, Sec. 4, Roosevelt Road, Taipei 106, Taiwan

${ }^{35}$ Honghe Center for Mountain Futures, Kunming Institute of Botany, Chinese Academy of Sciences, Honghe County 654400, Yunnan, People's Republic of China

${ }^{36}$ Department of Botany, Rajiv Gandhi University, University Road, Papum Pare, Arunachal Pradesh 791112-India

${ }^{37}$ Guizhou Tea Research Institute, Guizhou Academy of Agricultural Sciences, Guiyang 550006, People's Republic of China

${ }^{38}$ Faculty of Agriculture and Food, Kunming University of Science \& Technology, Kunming 650500, People's Republic of China

${ }^{39}$ Setor de Micologia, Departamento de Biociências e Tecnologia, Instituto de Patologia Tropical e Saúde Pública, Universidade Federal de Goiás, Rua 235 - s/n-Setor Universitário - CEP: 74605-050, Goiânia, GO, Brazil

${ }^{40}$ Department of Botany and Plant Pathology, Oregon State University, 2082 Cordley Hall, Corvallis, OR. 97331 2902, U.S.A.

${ }^{41}$ Instituto de Biociências, Universidade Federal de Mato Grosso do Sul, Avenida Costa e Silva, s/n Bairro Universitário, CEP 79070-900, Campo Grande, Mato Grosso do Sul, Brazil

${ }^{42}$ Department of Botany, National Museum of Nature and Science, 4-1-1 Amakubo, Tsukuba, Ibaraki 305-0005, Japan

${ }^{43}$ Evolution and Conservation Biology, InBios Research Center, University of Liège, Sart Tilman B22, Quartier Vallée 1, Chemin de la Vallée 4, B-4000 Liège, Belgium

${ }^{44}$ International Fungal Research and Development Centre, The Research Institute of Resource Insects, Chinese Academy of Forestry, Kunming 650224, People's Republic of China

${ }^{45}$ Biological Resources Research Department, National Institute of Biological Resources, Gyoungser-dong, Seo-gu, Incheon, 404-170 Korea

${ }^{46}$ Australian National Herbarium, National Research Collections Australia, CSIRO-NCMI, Canberra, ACT, 2601, Australia

${ }^{47}$ Mozartstraße 9, D-73117 Wangen, Germany

${ }^{48}$ Department of Biology, Faculty of Science, Chiang Mai University, Chiang Mai 50200, Thailand

${ }^{49}$ National Biobank of Thailand (NBT), National Science and Technology Development Agency (NSTDA), Thailand Science Park, Thanon Phahonyothin, Tambon Khlong Nueng, Amphoe Khlong Luang, Pathum Thani 12120, Thailand 
${ }^{50}$ BIOTEC, National Science and Technology Development Agency (NSTDA), 113 Thailand Science Park, Thanon Phahonyothin, Tambon Khlong Nueng, Amphoe Khlong Luang, Pathum Thani 12120, Thailand

${ }^{51}$ Department of Plant Medicine, National Chiayi University, 300 Syuefu Road, Chiayi City 60004, Taiwan

${ }^{52}$ College of Agriculture, Guizhou University, Guiyang, Guizhou 550025, People's Republic of China

Hongsanan S, Hyde KD, Phookamsak R, Wanasinghe DN, McKenzie EHC, Sarma VV, Boonmee S, Lücking R, Bhat DJ, Liu NG, Tennakoon DS, Pem D, Karunarathna A, Jiang SH, Jones EBG, Phillips AJL, Manawasinghe IS, Tibpromma S, Jayasiri SC, Sandamali DS, Jayawardena RS, Wijayawardene NN, Ekanayaka AH, Jeewon R, Lu YZ, Dissanayake AJ, Zeng XY, Luo ZL, Tian Q, Phukhamsakda C, Thambugala KM, Dai DQ, Chethana KWT, Samarakoon MC, Ertz D, Bao DF, Doilom M, Liu JK, Pérez-Ortega S, Suija A, Senwanna C, Wijesinghe SN, Konta S, Niranjan M, Zhang SN, Ariyawansa HA, Jiang HB, Zhang JF, Norphanphoun C, de Silva NI, Thiyagaraja V, Zhang H, Bezerra JDP, Miranda-González R, Aptroot A, Kashiwadani H, Harishchandra D, Sérusiaux E' Aluthmuhandiram JVS, Abeywickrama PD, Devadatha B, Wu HX, Moon KH, Gueidan C, Schumm F, Bundhun D, Mapook A, Monkai J, Chomnunti P, Suetrong S, Chaiwan N, Dayarathne MC, Yang J, Rathnayaka AR, Bhunjun CS, Xu JC' Zheng JS, Liu G, Feng Y, Xie N 2020 - Refined families of Dothideomycetes: Dothideomycetidae and Pleosporomycetidae. Mycosphere 11(1), 1553-2107, Doi 10.5943/mycosphere/11/1/13

\section{Abstract}

The class Dothideomycetes is the largest and most ecologically diverse class of fungi, comprising endophytes, epiphytes, saprobes, human and plant pathogens, lichens, and lichenicolous, nematode trapping and rock-inhabiting taxa. Members of this class are mainly characterized by bitunicate asci with fissitunicate dehiscence, and occur on broad range of hosts in aquatic and terrestrial habitats. Since the last monograph of families of Dothideomycetes in 2013, numerous novel species, genera, families and orders have been discovered. This has expanded information which has led to the modern classification in Dothideomycetes. In this paper, we provide a refined updated document on families of Dothideomycetes with emphasis on Dothideomycetidae and Pleosporomycetidae. We accept three orders with 25 families and four orders with 94 families in Dothideomycetidae and Pleosporomycetidae, respectively. The new family Paralophiostomataceae is introduced in Pleosporales. Each family is provided with an updated description, notes, including figures to represent the morphology, list of accepted genera, and economic and ecological significances. We also provide an overall phylogenetic tree of families in Dothideomycetes based on combined analysis of LSU, SSU, rpb-2 and tef1 sequence data, and phylogenetic trees for each order in Dothideomycetidae and Pleosporomycetidae. Familylevel trees are provided for the families which include several genera such as Mycosphaerellaceae and Teratosphaeriaceae. Two new genera (Ligninsphaeriopsis and Paralophiostoma) are introduced. Five new species (Biatrisopora borsei, Comoclathris galatellae, Ligninsphaeriopsis thailandica, Paralophiostoma hysterioides and Torula thailandica) are introduced based on morphology and phylogeny, together with nine new reports and seven new collections from different families.

Key words - 6 new taxa - Capnodiales - Dothideales -Gloniales - Hysteriales - Myriangiales Mytilinidiales - new family - new genera - new species - Pleosporales - Phylogeny - Taxonomy

\section{Introduction}

The class Dothideomycetes was estimated to consist of 19,000 species (Kirk et al. 2008). This is the largest and most ecologically diverse class of ascomycetes previously known as Loculoascomycetes (Nannfeldt 1932, Luttrell 1955, Janex-Favre 1971, Barr 1979a, b, Eriksson 1981, Reynolds 1971, Tehler 1990, 1995, Letrouit-Galinou et al. 1994, Barr \& Huhndorf 2001, Liu \& Hall 2004). Members of Dothideomycetes are mostly characterized by ascolocular ascoma development and bitunicate, fissitunicate asci (Nannfeldt 1932, Luttrell 1955, Eriksson 1981, Barr \& Huhndorf 2001, Hyde et al. 2013). Arthoniomycetes and Eurotiomycetes also share these 
characters, thus, it was unclear whether Dothideomycetes had distinct phenotypic apomorphies on which the class could be characterized (Hyde et al. 2013). Phylogenetic studies of Dothideomycetes have been provided by several authors, such as Schoch et al. (2009a), Nelsen et al. (2009, 2011a), Hyde et al. (2013), and Liu et al. (2017a), and provide good support for the Dothideomycetes lineage. Lumbsch \& Huhndorf (2010) provided an Outline of the Ascomycota and accepted 41 families comprising 249 genera in Dothideomycetes (13 families and 74 genera in subclass Dothideomycetidae, 28 and 175 genera in Pleosporomycetidae), and 116 genera as genera incertae sedis in Dothideomycetes. In Pleosporales, 28 families and 175 genera were accepted, with 12 genera listed as genera incertae sedis. Hyde et al. (2013) illustrated 138 dothideomycete genera, and provided descriptions, notes and discussed their taxonomic placement. They accepted 105 families in Dothideomycetes and suggested which genera should be placed in these families based on an updated outline of the Ascomycota provided by Lumbsch \& Huhndorf (2010). In Pleosporales, Hyde et al. (2013) accepted 88 families. These arrangements were mostly based on morphology and phylogeny. Liu et al. (2017a) provided guidelines of using divergence estimates in the classification of Dothideomycetes. They recommended that subclasses of Dothideomycetes should have evolved between 235 and 250 MYA (crown age) and 260-322 MYA (stem age), orders should have evolved between 100 and 220 MYA (crown age) and 130 and 310 MYA (stem age), and families should have evolved between 20 and 100 MYA (crown age). They also suggested that some genera should be raised to family level based on divergence estimates (Liu et al. 2017a). This additional evidence can help further resolve the classification of Dothideomycetes.

The aim of this paper is to bring together data on the orders, families and genera of Dothideomycetidae and Pleosporomycetidae to promote discussion and research on this fascinating class. Our classification is not definitive, but is a working document that can be changed and improved as data comes to light. By providing notes on each order, family and genus, we hope to initiate research in areas that are unresolved or controversial. The notes on 119 families and 988 genera in Dothideomycetidae and Pleosporomycetidae are written by 80 authors and therefore it was not possible to standardize the text. For example, some authors prefer to use "Hamathecium of cellular pseudoparaphyses, while other prefer to use "Pseudoparaphyses cellular". Similarly, some authors use I+, I-, J+, J- or amyloid or inamyloid, all of which are acceptable. Some entries are longer than others as it was not possible to get authors to completely standardize their entries. Pseudoparaphyses are one of the characters that define Dothideomycetidae and Pleosporomycetidae and have been given less attention. In earlier classifications, cellular and trabeculate pseudoparaphyses were considered important characters of Dothideomycetes orders and Melanommatales was defined as having trabeculae. Liew et al. (2000) looked at the significance of pseudoparaphyses in Loculoascomycete (Dothideomycete) taxonomy using molecular data and found that having trabeculae was not significant at the ordinal level and thus Melanommatales was reduced to family level under Pleosporales. The nature of pseudoparaphyses are often difficult to discern, especially for the novice mycologist (Taylor et al, 2004). Cellular pseudoparaphyses are usually wider than $2 \mu \mathrm{m}$, and generally do not anastomose (join together), although this may often occur above the asci and may or may not be in a gelatinous matrix (Figs 108, 157). Trabeculate pseudoparaphyses (Fig. 88), on the other hand, are usually $1 \mu \mathrm{m}$ wide or less, clearly anastomose between the asci and are embedded in a gelatinous matrix. However, the distinction is not always clear and cellular pseudoparaphyses in small ascomata or those will small spores may be thinner and appear to be trabeculae. However, in most cases they would not anastomose between the asci as in trabeculate pseudoparaphyses. In this paper, we use trabeculae or trabeculate pseudoparaphyses as those with a diameter of around $1 \mu \mathrm{m}$, which clearly anastomose between the asci and are clearly embedded in a gelatinous matrix (Fig. 88), while cellular pseudoparaphyses include all other types.

This paper is based on the previous publication 'Families of Dothideomycetes' (Hyde et al. 2013) which was the latest update and the most complete monograph of families in Dothideomycetes, included in Wijayawardene et al. (2017a) who provided 'Notes for genera: Ascomycota'. Divergence time estimates from Liu et al. (2017a) are used as addition evidence to rearrange the internal classification of this class. We included all published data that we could 
locate in 2019 and have also included some data that we were aware of up to the date of publication. This work will be an update of Dothideomycetes and useful for the research regarding Dothideomycetidae and Pleosporomycetidae over the next years, and will be further refined when numerous new data are provided as additional evidence. This monograph, however, can be improved and streamlined in future editions or updated in the webpage dothideomycetes.org. (Pem et al. 2019a).

\section{Materials \& Methods}

\section{Layout of the paper}

Each family currently accepted in Dothideomycetidae and Pleosporomycetidae is introduced with descriptions and important notes on history and current taxonomic placement. Accepted genera including the type species, and notes are provided. Basionyms are listed for each genus and type species, while all other synonyms can be found in Index Fungorum (2020). Estimates of accepted species for each genus is provided mainly based on data in Species Fungorum (2020), with species transferred to other genera or species not being included. The number of species with sequence data available in public databases (GenBank) is provided for each genus. Morphological features of each family are illustrated by representative photographic plates from type herbarium specimens, or new species/new collections with sequence data. Drawings are provided for families for which we were unable to obtain herbarium specimens or fresh collections. Notes on the ecological and economic significance are also provided for each family.

\section{Molecular phylogeny}

Phylogenetic trees of each order are provided, except for orders where too little sequence data is available. Trees for each order include representatives from all genera that have sequence data. Phylogenetic trees of families with high numbers of genera are provided separately from orderlevel trees, such as Phaeosphaeriaceae, Pleosporaceae, and Teratosphaeriaceae. In the phylogenetic trees of families in Dothideomycetes (Fig. 1), representative sequence data of each family from Dothideomycetes were obtained from GenBank following previous publications, e.g. Schoch et al. (2009a), Hyde et al. (2013), Liu et al. (2017a), Crous et al. (2019a, b). Datasets for each partition were aligned by using MAFFT (Katoh et al. 2019), and optimized manually using Bioedit (Hall 2004). Orbilia auricolor (AFTOL-ID 906) and O. vinosa (AFTOL-ID 905) were selected as the outgroup sequence based on phylogenetic placement in Beimforde et al. (2014). Four genes which are large subunits ribosomal RNA (LSU), the second largest subunit of RNA polymerase II (rpb-2), small subunits ribosomal RNA (SSU), and the translation elongation factor-1 alpha (tef1) were applied in this analysis. All absent genes were coded as missing data. Phylogenetic trees based on individual gene partitions (data not shown) were congruent with the combined LSU, rpb-2, SSU, and tef1 data sets. Although, the positions of some families were not constant, they are considered as distinct families. The phylogenetic analyses of the combined LSU, rpb-2, SSU and tef1 sequence data were performed using maximum likelihood algorithms in RAxML and Bayesian analyses.

Maximum likelihood analysis (ML) was performed in raxmlGUIv.0.9b2 (Silvestro \& Michalak 2012). The search strategy was set to bootstrapping and the analysis performed using the GTRGAMMAI model. The number of replicates was inferred using the stopping criterion (Pattengale et al. 2009). The bootstrap values expressed from 1,000 repetitions by RAxML analysis which are equal or greater than $70 \%$ are given to the left of each node (Fig. 1). The best fit model of evolution was performed in MrModeltest 2.2 (Nylander 2008). In Bayesian phylogenetic analyses, posterior probabilities (PP) were set by MCMC sampling in MrBayes v3.1.2 (Huelsenbeck \& Ronquist 2001, Zhaxybayeva \& Gogarten 2002), following the details in Cai et al. (2006a, 2008). The first $20 \%$ were discarded, and the remaining trees were used for calculating posterior probabilities. Posterior probabilities values (PP) from Bayesian analysis which are equal or greater than 0.90 are given on each node (Fig. 1). Phylogenetic tree was viewed in FigTree v.1.4.0 (Rambaut 2014). 
The methods above were applied for most of the phylogenetic trees shown in this paper. Other additional methods are mentioned in the legend of each analysis.

\section{Molecular clock analysis}

The calibration point for Capnodiales crown based on the fossil of Metacapnodiaceae was used, normal distribution with mean $=100, \mathrm{SD}=150$, and $97.5 \%$ of CI $=346$ MYA (Pérez-Ortega et al. 2016, Hyde et al. 2017, Hongsanan et al. 2016a, 2018, Samarakoon et al. 2019a). The crown age of the Dothideomycetes was calibrated using the secondary calibration, normal distribution with mean $=290, \mathrm{SD}=30$, and $97.5 \%$ of $\mathrm{CI}=349$ MYA following Phukhamsakda et al. (2016), Liu et al. (2017a, 2018c) and Zhang et al. (2019b). In the MCC tree, node bars indicate $95 \%$ confidence intervals for the divergence time estimates (Beimforde et al. 2014, Pérez-Ortega et al. 2016, Hongsanan et al. 2016a, 2018, Samarakoon et al. 2016, Hyde et al. 2017). Molecular dating analysis was carried out in BEAST package v.1.10.2 (Drummond et al. 2012). The same aligned data set from phylogenetic analyses for each gene partition were loaded to BEAUti v.1.10.2 to adjust parameters and generate the XML file. All of these gene partition comprises the same number of taxa, and names. Unlinked substitution and clock models were applied in the analysis to independently estimate each gene partition. Taxa sets were generated to add calibration information, associated with the most recent common ancestor (TMRCA). The best fit of substitution models were selected based on jModeltest2.1.1 for each gene partition; GTR $+\mathrm{I}+\mathrm{G}$ was selected for all gene regions. Lognormal distribution with uncorrelated relaxed clock model was applied. The speciation of nodes in the topology was performed using Yule process tree prior with a randomly generated starting tree. The analyses were run for 200 million generations, with sampling parameters every 5000 generations. The effective sample sizes (ESS) were checked in Tracer v.1.6. using the *.log file created by BEAST program. The acceptable ESS values are higher than 150 . The first $20 \%$ representing the burn-in phase were discarded. The remaining trees were used to combine in LogCombiner v.1.10.2. A maximum clade creditability (MCC) tree was generated by summarized and estimated data in TreeAnnotator v.1.10.2. The MCC tree was viewed in FigTree (Rambaut 2014).

\section{Table of contents and contributors \\ Dothideomycetes \\ Dothideomycetidae \\ Capnodiales}

Aeminiaceae (Hongsanan S, Hyde KD, Bhat DJ, Zheng JS)

Antennulariellaceae (Hongsanan S, Hyde KD, Bhat DJ, McKenzie EHC)

Capnodiaceae (Hongsanan S, Hyde KD, Bhat DJ)

Cladosporiaceae (Liu NG, Bhat DJ, Hyde KD)

Cystocoleaceae (Liu NG, Bhat DJ, Hyde KD)

Dissoconiaceae (Liu NG, Bhat DJ, Hyde KD)

Euantennariaceae (Hongsanan S, Hyde KD, McKenzie EHC)

Extremaceae (Liu NG, Bhat DJ, Hongsanan S, Hyde KD)

Johansoniaceae (Hongsanan S, Doilom M, Hyde KD)

Metacapnodiaceae (Hongsanan S, Bhat DJ, Chomnunti P)

Mycosphaerellaceae (Phookamsak R, McKenzie EHC, Hyde KD, Hongsanan S)

Neodevriesiaceae (Karunarathna A, Hyde KD, McKenzie EHC)

Phaeothecaceae (Hongsanan S, Bundhun D, Bhat DJ, Hyde KD)

Phaeothecoidiellaceae (Hongsanan S, Hyde KD, Bhat DJ)

Piedraiaceae (Karunarathna A, Bhat DJ, Hyde KD)

Racodiaceae (Wijesinghe SN, Hyde KD, McKenzie EHC)

Schizothyriaceae (Phookamsak R, Hyde KD, McKenzie EHC)

Teratosphaeriaceae (Wijayawardene NN, McKenzie EHC, Hyde KD, Hongsanan S)

Xenodevriesiaceae (Hongsanan S, Bhat DJ, McKenzie EHC) 


\section{Dothideales}

Dothideaceae (Wijesinghe SN, Thambugala KM, McKenzie EHC, Hyde KD)

Neocelosporiaceae (Hongsanan S, Hyde KD, McKenzie EHC)

Saccotheciaceae (Thambugala KM, Hyde KD, McKenzie EHC)

Zalariaceae (Thambugala KM, Hongsanan S, Hyde KD, McKenzie EHC)

\section{Myriangiales}

Elsinoaceae (Jayawardena RS, KD Hyde, EHC McKenzie)

Myriangiaceae (Jayawardena RS, Hyde KD, McKenzie EHC)

\section{Pleosporomycetidae}

Gloniales

Gloniaceae (Jayasiri SC, Hongsanan S, Jeewon R, Hyde KD)

\section{Hysteriales}

Hysteriaceae (Jayasiri SC, Hongsanan S, Jeewon R, Hyde KD)

\section{Mytilinidiales}

Mytilinidiaceae (Jayasiri SC, Hyde KD, Jeewon R, Hongsanan S)

\section{Pleosporales}

Acrocalymmaceae (Wijayawardene NN, Hongsanan S, Wanasinghe DN)

Aigialaceae (Doilom M, Sarma VV, Jones EBG, S Hongsanan)

Amniculicolaceae (Wanasinghe DN, Hyde KD, McKenzie EHC)

Amorosiaceae (Thambugala KM, Hyde KD, Jeewon R, McKenzie EHC)

Anteagloniaceae (Sarma VV, Devadatha B, Niranjan M, Wanasinghe DN, Hongsanan S)

Aquasubmersaceae (Hongsanan S, Zhang H, Wanasinghe DN)

Arthopyreniaceae (Thiyagaraja V, Hyde KD, Jeewon R, McKenzie EHC)

Ascocylindricaceae (Ariyawansa HA, Samarakoon MC, Jones EBG)

Astrosphaeriellaceae (Jiang HB, Phookamsak R, Jones EBG, Liu JK)

Bambusicolaceae (Pem D, Doilom M, Wanasinghe DN, Liu JK)

Biatriosporaceae (Sarma VV, Suetrong S, Liu JK)

Camarosporiaceae (Wijesinghe SN, Wanasinghe DN, Hyde KD, Jeewon R)

Camarosporidiellaceae (Wanasinghe DN, Hyde KD)

Caryosporaceae (Zhang H, Wanasinghe DN, Hyde KD, Jeewon R, McKenzie EHC)

Coniothyriaceae (Karunarathna A, Wanasinghe DN, McKenzie EHC, Liu JK)

Corynesporascaceae (Liu NG, Hyde KD, Jeewon R, McKenzie EHC)

Cryptocoryneaceae (Hongsanan S, Wijesinghe SN, Wanasinghe DN)

Cucurbitariaceae (Wanasinghe DN, McKenzie EHC, Hyde KD)

Cyclothyriellaceae (Hongsanan S, Bao DF, Hyde KD)

Dacampiaceae (Ertz D, Hyde KD, Liu JK)

Delitschiaceae (Tibpromma S, Wanasinghe DN, Liu JK)

Diademaceae (Tibpromma S, Ariyawansa HA, Liu JK)

Dictyosporiaceae (Luo ZL, Bao DF, Hongsanan S, McKenzie EHC, Hyde KD)

Didymellaceae (Manawasinghe IS, Wanasinghe DN, Hongsanan S, Jeewon R)

Didymosphaeriaceae (Tennakoon DS, Wanasinghe DN, McKenzie EHC, Liu JK)

Dothidotthiaceae (Senwanna C, Hyde KD, Jeewon R, McKenzie EHC)

Fuscostagonosporaceae (Sandamali D, Jayasiri SC, Wanasinghe DN)

Fusculinaceae (Chaiwan N, Pem D, McKenzie EHC, Liu JK)

Halojulellaceae (Sarma VV, Hongsanan S, Jones EBG, Hyde KD)

Halotthiaceae (Harishchandra D, Hongsanan S, Liu JK)

Hermatomycetaceae (Tennakoon DS, Wanasinghe DN, Hyde KD, Jeewon R)

Hypsostromataceae (Tennakoon DS, Chomnunti P, Wanasinghe DN, Liu JK) 
Latoruaceae (de Silva NI, Hongsanan S, Hyde KD, McKenzie EHC, Wijayawardene NN)

Lentimurisporaceae (Liu NG, Hyde KD)

Lentitheciaceae (Wanasinghe DN, Hongsanan S, Hyde KD)

Leptosphaeriaceae (Phukhamsakda C, Hongsanan S, Wanasinghe DN, McKenzie EHC)

Libertasomycetaceae (de Silva NI, Hongsanan S, Hyde KD)

Ligninsphaeriaceae (Zhang JF, Phukhamsakda C, Hyde KD, McKenzie EHC)

Lindgomycetaceae (Zhang H, Hongsanan S, Wanasinghe DN, Hyde KD)

Lizoniaceae (Hongsanan S, Boonmee S, Hyde KD, McKenzie EHC)

Longiostiolaceae (Phukhamsakda C, Jeewon R)

Longipedicellataceae (de Silva NI, Phukhamsakda C, Hyde KD)

Lophiostomataceae (Tibpromma S, Hongsanan S, Wanasinghe DN, Hyde KD)

Lophiotremataceae (Aluthmuhandiram JVS, Wanasinghe DN, McKenzie EHC)

Macrodiplodiopsidaceae (Wijayawardene NN, Rathnayaka AR, Wanasinghe DN)

Massariaceae (Chethana KWT, McKenzie EHC, Hyde KD)

Massarinaceae (Phukhamsakda C, Wanasinghe DN, Hyde KD)

Melanommataceae (Tian Q, Wanasinghe DN, Hongsanan S, Jeewon R, McKenzie EHC)

Morosphaeriaceae (Sarma VV, Luo ZL, Jones EBG, Bao DF)

Mycoporaceae (Hongsanan S, Rathnayaka AR, McKenzie EHC)

Neocamarosporiaceae (Sandamali D, Wanasinghe DN, Hyde KD)

Neohendersoniaceae (Sarma VV, Aluthmuhandiram JVS, Liu JK, Hyde KD)

Neomassariaceae (Ariyawansa HA, Mapook A, Hongsanan S)

Neomassarinaceae (Yang J, Phukhamsakda C, Jeewon R)

Neophaeosphaeriaceae (Hongsanan S, Karunarathna A, Wanasinghe DN, Hyde KD)

Neopyrenochaetaceae (Abeywickrama P, Jayasiri SC)

Nigrogranaceae (Wanasinghe DN, Liu JK, McKenzie EHC, Hyde KD)

Occultibambusaceae (Zhang JF, Zhang H, Hyde KD, McKenzie EHC)

Ohleriaceae (Hongsanan S, Hyde KD, McKenzie EHC)

Parabambusicolaceae (Wanasinghe DN, Hyde KD, McKenzie EHC)

Paradictyoarthriniaceae (Doilom M, Wanasinghe DN, McKenzie EHC)

Paralophiostomataceae (Niranjan M, Sarma VV, Wanasinghe DN, Jeewon R)

Parapyrenochaetaceae (Aluthmuhandiram JVS, Hongsanan S, Hyde KD)

Periconiaceae (Liu NG, Wanasinghe DN, Liu JK)

Phaeoseptaceae (Abeywickrama P, Boonmee S, Wanasinghe DN, Hyde KD)

Phaeosphaeriaceae (Phookamsak R, Tennakoon DS, Jeewon R, McKenzie EHC)

Pleomassariaceae (Chethana KWT, Wanasinghe DN, Hyde KD, McKenzie EHC)

Pleomonodictydaceae (Hongsanan S, Li JF, Wanasinghe DN, Hyde KD)

Pleosporaceae (Pem D, Hongsanan S, Wanasinghe DN, Jeewon R)

Pseudoastrosphaeriellaceae (Jiang HB, Phookamsak R, Jones EBG)

Pseudoberkleasmiaceae (Hongsanan S, Tibpromma S, Wanasinghe DN, Hyde KD)

Pseudocoleodictyosporaceae (Harishchandra D, Doilom M, Wanasinghe DN)

Pseudolophiotremataceae (Phukhamsakda C, Hongsanan S, Harishchndra D)

Pseudomassarinaceae (Phukhamsakda C, Jeewon R)

Pseudopyrenochaetaceae (Hongsanan S, Bao DF, Hyde KD, McKenzie EHC)

Pyrenochaetopsidaceae (Tibpromma S, Hongsanan S, Hyde KD, McKenzie EHC)

Roussoellaceae (Phookamsak R, Wanasinghe DN, Hyde KD, McKenzie EHC)

Salsugineaceae (Tibpromma S, Hyde KD, McKenzie EHC)

Shiraiaceae (Jiang HB, Bhunjun CS, Hyde KD, McKenzie EHC)

Sporomiaceae (Phukhamsakda C, Tibpromma S, Hongsanan S, McKenzie EHC, Hyde KD)

Striatiguttulaceae (Zhang SN, Liu JK, Hyde KD)

Sulcatisporaceae (Bundhun D, Wanasinghe DN, McKenzie EHC)

Teichosporaceae (Tennakoon DS, Hongsanan S, Wanasinghe DN, McKenzie EHC)

Testudinaceae (Sarma VV, Devadatha B, Jones EBG, Wanasinghe DN)

Tetraplosphaeriaceae (Liu NG, Hongsanan S, Jeewon R, Hyde KD) 
Thyridariaceae (Tian Q, Jones EBG, McKenzie EHC, Liu JK)

Torulaceae (Liu NG, Wanasinghe DN, Hyde KD, Liu JK)

Trematosphaeriaceae (Dayarathne MC, Jones EBG, McKenzie EHC)

Tzeananiaceae (Ariyawansa HA, Hongsanan S, Hyde KD)

Wicklowiaceae (Ariyawansa HA, Hongsanan S, Raja H, Wanasinghe DN, Hyde KD)

Zopfiaceae (Doilom M, Hongsanan S, Jones EBG, Liu JK)

\section{Outline of Dothideomycetes}

For orders and families incertae sedis in Dothideomycetes see Hongsanan et al. (2020) and Dothideomycetes genera incertae sedis see Wijayawardene et al. (2020).

\section{Dothideomycetidae}

Capnodiales Woron.

Aeminiaceae J. Trovão, I. Tiago \& A. Portugal

Aeminium J. Trovão et al.

\section{Antennulariellaceae Woron.}

Achaetobotrys Bat. \& Cif.

Antennulariella Woron.

Eumela Syd.

Capnodiaceae (Sacc.) Höhn. ex Theiss.

Capnodium Mont.

Chaetocapnodium Hongsanan \& K.D. Hyde

Conidiocarpus Woron.

Fumiglobus D.R. Reynolds \& G.S. Gilbert

Leptoxyphium Speg.

Limaciniaseta D.R. Reynolds

Readerielliopsis Crous \& Decock

Scoriadopsis Mend.

Scorias Fr.

\section{Cladosporiaceae Nann.}

Acroconidiella J.C. Lindq. \& Alippi

Cladosporium Link

Davidiellomyces Crous

Graphiopsis Trail

Neocladosporium J.D.P. Bezerra et al.

Rachicladosporium Crous et al.

Toxicocladosporium Crous \& U. Braun

Verrucocladosporium K. Schub. et al.

Cystocoleaceae Locq. ex Lücking et al.

Cystocoleus A. Massal.

Dissoconiaceae Crous \& de Hoog

Dissoconium de Hoog et al.

Globoramichloridium Y. Marín \& Crous

Pseudoveronaea Crous \& Batzer

Ramichloridium Stahel ex de Hoog

Uwebraunia Crous \& M.J. Wingf.

Euantennariaceae Hughes \& Corlett 
Capnokyma S. Hughes

Euantennaria Speg.

Hormisciomyces Bat. \& Nascim.

Plokamidomyces Bat. et al.

Rasutoria M.E. Barr

Strigopodia Bat.

Trichothallus F. Stevens

Extremaceae Quaedvl. \& Crous

Castanedospora G. Delgado \& A.N. Mill.

Extremus Quaedvl. \& Crous

Paradevriesia Crous

Petrophila de Hoog \& Quaedvl.

Pseudoramichloridium Cheew. \& Crous

Saxophila Selbmann \& de Hoog

Staninwardia B. Sutton

Vermiconia Egidi \& Onofri

Johansoniaceae Doilom et al.

Johansonia Sacc.

Orthobellus Silva \& Cavalc.

Metacapnodiaceae Hughes \& Corlett

Capnobotrys S. Hughes

Hyphosoma Syd.

Metacapnodium Speg.

Mycosphaerellaceae Lindau (Accepted genera based on molecular data)

Acervuloseptoria Crous \& Jol. Roux

Amycosphaerella Quaedvl. \& Crous

Annellosympodiella Crous \& Assefa

Apseudocercosporella Videira \& Crous

Asperisporium Maubl.

Australosphaerella Videira \& Crous

Brunneosphaerella Crous

Brunswickiella Videira \& Crous

Camptomeriphila Crous \& M.J. Wingf.

Caryophylloseptoria Verkley et al.

Catenulocercospora C. Nakash. et al.

Cercoramularia Videira et al.

Cercospora Fresen.

Cercosporella Sacc.

Cercosporidium Earle

Chuppomyces Videira \& Crous

Clarohilum Videira \& Crous

Clypeosphaerella Guatimosim et al.

Collapsimycopappus A. Hashim. et al.

Collarispora Videira \& Crous

Coremiopassalora U. Braun et al.

Cytostagonospora Bubák

Deightonomyces Videira \& Crous

Devonomyces Videira \& Crous

Dictyosporina L.M. Abreu et al. 
Distocercospora N. Pons \& B. Sutton

Distocercosporaster Videira et al.

Distomycovellosiella U. Braun et al.

Dothistroma Hulbary

Epicoleosporium Videira \& Crous

Exopassalora Videira \& Crous

Exosporium Link

Exutisphaerella Videira \& Crous

Filiella Videira \& Crous

Fulvia Cif.

Fusoidiella Videira \& Crous

Graminopassalora U. Braun et al.

Hyalocercosporidium Videira \& Crous

Hyalozasmidium U. Braun et al.

Janetia M.B. Ellis

Lecanosticta Syd.

Madagascaromyces U. Braun et al.

Microcyclosporella J. Frank et al.

Micronematomyces U. Braun et al.

Miuraea Hara

Mycodiella Crous

Mycosphaerelloides Videira \& Crous

Mycovellosiella Rangel

Neoceratosperma Crous \& Cheew.

Neocercospora M. Bakhshi et al.

Neocercosporidium Videira \& Crous

Neodeightoniella Crous \& W.J. Swart

Neomycosphaerella Crous

Neopenidiella Quaedvl. \& Crous

Neophloeospora U. Braun et al.

Neopseudocercospora Crous

Neopseudocercosporella Videira \& Crous

Neoramichloridium Phookamsak et al.

Neoseptoria Quaedvl. et al.

Nothopassalora U. Braun et al.

Nothopericoniella Videira \& Crous

Nothophaeocryptopus Videira et al.

Nothotrimmatostroma Crous

Pachyramichloridium Videira \& Crous

Pallidocercospora Crous

Pantospora Cif.

Paracercospora Deighton

Paracercosporidium Videira \& Crous

Paramycosphaerella Crous \& Jol. Roux

Paramycovellosiella Videira et al.

Parapallidocercospora Videira et al.

Passalora Fr.

Phaeocercospora Crous

Phaeophleospora Rangel

Phaeoramularia Munt.-Cvetk

Phloeospora Wallr.

Piricauda Bubák

Pleopassalora Videira \& Crous 
Pleuropassalora U. Braun et al.

Pluripassalora Videira \& Crous

Plurivorosphaerella O. Hassan \& T.H. Chang

Polyphialoseptoria Quaedvl. et al.

Polythrincium Kunze

Protostegia Cooke

Pseudocercospora Speg. (= Prathigada Subram.)

Pseudocercosporella Deighton

Pseudopericoniella Videira \& Crous

Pseudophaeophleospora C. Nakash. et al.

Pseudozasmidium Videira \& Crous

Ragnhildiana Solheim

Ramularia Unger (= Mycosphaerella)

Ramulariopsis Speg.

Ramulispora Miura

Rhachisphaerella U. Braun et al.

Rosisphaerella Videira \& Crous

Ruptoseptoria Quaedvl. et al.

Scolecostigmina U. Braun

Septoria Sacc.

Sonderhenia H.J. Swart \& J. Walker

Sphaerulina Sacc.

Stromatoseptoria Quaedvl. et al.

Sultanimyces Videira \& Crous

Trochophora R.T. Moore

Uwemyces Hern.-Restr. et al.

Virosphaerella Videira \& Crous

Xenomycosphaerella Quaedvl. \& Crous

Xenopassalora Crous

Xenoramularia Videira et al.

Xenosonderhenia Crous

Xenosonderhenioides Videira \& Crous

Zasmidium Fr. (= Periconiella Sacc. fide-Quaedvlieg et al. 2013)

Zymoseptoria Quaedvl. \& Crous

\section{Doubtful genera in Mycosphaerellaceae}

Achorodothis Syd.

Acrodesmis Syd.

Acrotheca Fuckel

Allantophomoides S.L. Wei \& T.Y. Zhang

Anematidium Gronchi

Anguillosporella U. Braun

Annellophora S. Hughes

Annellophragmia Subram.

Annellosympodia McTaggart et al.

Asteromidium Speg.

Berteromyces Cif.

Biharia Thirum. \& Mishra

Bryopelta Döbbeler \& Poelt

Camptomeris Syd.

Ceratosperma Speg.

Cercodeuterospora Curzi

Cercoseptoria Petr. 
Cercosperma G. Arnaud ex B. Sutton \& Hodges

Cercosphaerella Kleb.

Cercosporina Speg.

Cercosporiopsis Miura

Cercostigmina U. Braun

Ciferriella Petr.

Cladosporiella Deighton

Clypeispora A.W. Ramaley

Colletogloeum Petr.

Cyclodothis Syd. \& P. Syd.

Dearnessia Bubák

Denticularia Deighton

Dictyodesmium S. Hughes

Didymaria Corda

Didymellina Höhn.

Didymochora Höhn.

Elletevera Deighton

Episphaerella Petr.

Eriocercospora Deighton

Eriocercosporella Rak. Kumar

Euryachora Fuckel

Fusicladiella Höhn.

Gillotia Sacc. \& Trotter

Gloeocercospora D.C. Bain \& Edgerton ex Deighton

Gomphinaria Preuss

Haplodothis Höhn.

Hawksworthiana U. Braun

Helicomina L.S. Olive

Hoornsmania Crous

Hyalodictys Subram.

Hyalodothis Pat. \& Har.

Isariella Henn.

Isariopsella Höhn.

Isariopsis Fresen.

Jaczewskiella Murashk.

Jahniella Petr.

Laocoon J.C. David

Lecanostictopsis B. Sutton \& Crous

Lembosiopsis Theiss.

Lophiosphaerella Hara

Marcosia Syd. \& P. Syd.

Megaloseptoria Naumov

Melanodothis R.H. Arnold

Microcyclus Sacc., Syd. \& P. Syd.

Micronectriella Höhn.

Mycoporis Clem.

Neoovularia U. Braun

Neoramularia U. Braun

Oedothea Syd.

Ophiocarpella Theiss. \& Syd.

Oreophylla Cif.

Ormathodium Syd.

Ovosphaerella Laib. 
Parastenella J.C. David

Phacellium Bonord.

Phaeophloeosporella Crous \& B. Sutton

Phlyctaeniella Petr.

Pleurovularia R. Kirschner \& U. Braun

Polysporella Woron.

Pseudocercosporidium Deighton

Pseudodidymaria U. Braun

Pseudophaeoramularia U. Braun

Pseudopuccinia Höhn.

Pseudostigmidium Etayo

Pseudovularia Speg.

Quasiphloeospora B. Sutton et al.

Ramularisphaerella Kleb.

Rhabdospora (Durieu \& Mont.) Sacc.

Rhopaloconidium Petr.

Rosenscheldiella Theiss. \& Syd.

Scirrhia Nitschke ex Fuckel

Semipseudocercospora J.M. Yen

Septocylindrium Bonord. ex Sacc.

Septocyta Petr.

Septopatella Petr.

Septoriopsis Gonz. Frag. \& M.J. Paúl

Septorisphaerella Kleb.

Sirosporium Bubák \& Serebrian.

Sphaerellothecium Zopf

Spilosphaeria Rabenh.

Stenellopsis B. Huguenin

Stenospora Deighton

Stictosepta Petr.

Stigmidium Trevis.

Tandonella S.S. Prasad \& R.A.B. Verma

Tapeinosporium Bonord.

Utrechtiana Crous \& Quaedvl.

Verrucisporota D.E. Shaw \& Alcorn

Virgasporium Cooke

Walkeromyces Thaung

Neodevriesiaceae Quaedvl. \& Crous

Neodevriesia Quaedvl. \& Crous

Trichomerium Speg.

Phaeothecaceae Darveaux, in Crous et al.

Phaeotheca Sigler et al.

Phaeothecoidiellaceae K.D. Hyde \& Hongsanan (= Nowamycetaceae Crous)

Chaetothyrina Theiss.

Exopassalora Videira \& Crous

Houjia G.Y. Sun \& Crous

Nowamyces Crous

Phaeothecoidiella Batzer \& Crous

Rivilata Kohlm. et al.

Sporidesmajora Batzer \& Crous 
Translucidithyrium X.Y. Zeng \& K.D. Hyde

Piedraiaceae Viégas ex Cif. et al.

Piedraia Fons. \& Leao

Racodiaceae Link

Racodium Fr.

Schizothyriaceae Höhn. ex Trotter et al.

Amazonotheca Bat. \& H. Maia

Hexagonella F. Stevens \& Guba ex F. Stevens

Kerniomyces Toro

Lecideopsella Höhn.

Metathyriella Syd.

Mycerema Bat. et al.

Myriangiella Zimm.

Plochmopeltis Theiss.

Schizothyrium Desm.

Vonarxella Bat. et al.

Teratosphaeriaceae Crous \& U. Braun

Acidiella Hujslová \& M. Kolařík

Acidomyces B.J. Baker et al.

Acrodontium de Hoog et al.

Apenidiella Quaedvl. \& Crous

Araucasphaeria Crous \& M.J. Wingf.

Aulographina Arx \& E. Müll.

Austroafricana Quaedvl. \& Crous

Austrostigmidium Pérez-Ort. \& Garrido-Benavent

Batcheloromyces Marasas et al.

Baudoinia J.A. Scott \& Unter.

Bryochiton Döbbeler \& Poelt

Caatingomyces T.G.L. Oliveira et al.

Camarosporula Petr.

Capnobotryella Sugiy.

Catenulostroma Crous \& U. Braun

Constantinomyces Egidi \& Onofri

Davisoniella H.J. Swart

Devriesia Seifert \& N.L. Nick.

Elasticomyces Zucconi \& Selbmann

Eupenidiella Quaedvl. \& Crous

Euteratosphaeria Quaedvl. \& Crous

Friedmanniomyces Onofri

Hispidoconidioma Tsuneda \& Davey

Hortaea Nishim. \& Miyaji

Hyweljonesia R.G. Shivas et al.

Incertomyces Egidi \& Zucconi

Lapidomyces de Hoog \& Stielow

Leptomelanconium Petr.

Meristemomyces Isola \& Onofri

Microcyclospora J. Frank et al.

Monticola Selbmann \& Egidi

Myrtapenidiella Quaedvl. \& Crous 
Neocatenulostroma Quaedvl. \& Crous

Neophaeothecoidea Quaedvl. \& Crous

Neotrimmatostroma Quaedvl. \& Crous

Oleoguttula Selbmann \& de Hoog

Pachysacca Syd.

Parapenidiella Crous \& Summerell

Parateratosphaeria Quaedvl. \& Crous

Penidiella Crous \& U. Braun

Penidiellomyces Crous et al.

Penidiellopsis Sandoval-Denis et al.

Phaeothecoidea Crous

Placocrea Syd.

Pseudotaeniolina J.L. Crane \& Schokn.

Pseudoteratosphaeria Quaedvl. \& Crous

Queenslandipenidiella Quaedvl. \& Crous

Readeriella Syd. \& P. Syd.

Recurvomyces Selbmann \& de Hoog

Simplicidiella Crous et al.

Stenella Syd.

Suberoteratosphaeria Quaedvl. \& Crous

Teratoramularia Videira et al.

Teratosphaeria Syd. \& P. Syd.

Teratosphaericola Quaedvl. \& Crous

Teratosphaeriopsis Quaedvl. \& Crous

Xanthoriicola D. Hawksw.

Xenoconiothyrium Crous \& Marinc.

Xenopenidiella Quaedvl. \& Crous

Xenophacidiella Crous

Xenoteratosphaeria Quaedvl. \& Crous

\section{Xenodevriesiaceae Crous}

Xenodevriesia Crous

Capnodiales genera incertae sedis

Anariste Syd.

Arthrocatena Egidi \& Selbmann

Catenulomyces Egidi \& de Hoog

Eriosporella Höhn.

Hyphoconis Egidi \& Quaedvl.

Mucomycosphaerella Quaedvl. \& Crous

Mycophycias Kohlm. \& Volkm.-Kohlm

Neohortaea Quaedvl. \& Crous

Perusta Egidi \& Stielow

Plurispermiopsis Pereira-Carv. et al.

Pseudoepicoccum M.B. Ellis

Racoleus R. Sant. \& D. Hawksw.

Ramimonilia Stielow \& Quaedvl.

Ramopenidiella Crous \& R.G. Shivas

Rosaria N. Carter

Stigmatodothis Syd. \& P. Syd.

Stomiopeltis Theiss.

Dothideales Lindau 
Dothideaceae Chevall.

Delphinella (Sacc.) Kuntze

Dictyodothis Theiss. \& Syd.

Dothidea Fr.

Dothiora Fr.

Endoconidioma Tsuneda

Endodothiora Petr.

Kabatina R. Schneid. \& Arx

Neocylindroseptoria Thambug. \& K.D. Hyde

Phaeocryptopus Naumov

Plowrightia Sacc.

Stylodothis Arx \& E. Müll.

Sydowia Bres.

Uleodothis Theiss. \& Syd.

Neocelosporiaceae Crous

Celosporium Tsuneda \& M.L. Davey

Muellerites L. Holm

Neocelosporium Crous

Saccotheciaceae Bonord.

Aureobasidium Viala \& G. Boyer

Columnosphaeria Munk

Kabatiella Bubák

Pseudoseptoria Speg.

Pseudosydowia Thambug. \& K.D. Hyde

Saccothecium Fr.

Selenophoma Maire

Zalariaceae Visagie et al.

Zalaria Visagie et al.

Dothideales genera incertae sedis

Asteromellopsis H.E. Hess \& E. Müll.

Botryochora Torrend

Coniozyma Crous

Hormonema Lagerb. \& Melin

Pringsheimia Schulzer

Rhizosphaera L. Mangin \& Har.

Myriangiales Starbäck

Elsinoaceae Höhn. ex Sacc. \& Trotter

Elsinoë Racib.

Molleriella G. Winter

Myriangiaceae Nyl.

Anhellia Racib.

Ascostratum Syd. \& P. Syd.

Butleria Sacc.

Dictyocyclus Sivan. et al.

Eurytheca De Seynes

Hemimyriangium J. Reid \& Piroz

Mendogia Racib. 
Micularia Boedijn

Myriangium Mont. \& Berk.

Uleomyces P. Henn.

Zukaliopsis Henn.

Myriangiales genus incertae sedis

Dictyonella Höhn.

\section{Pleosporomycetidae}

Gloniales Jayasiri \& K.D. Hyde

Gloniaceae (Corda) Boehm et al.

Cenococcum Moug. \& Fr.

Glonium Mühl.

Purpurepithecium Jayasiri \& K.D. Hyde

\section{Hysteriales}

Hysteriaceae Chevall.

Actidiographium Lar. N. Vassiljeva

Gloniella Sacc.

Gloniopsis De Not.

Hysterium Pers.

Hysterobrevium E. Boehm \& C.L. Schoch

Hysterocarina Zogg

Hysterodifractum D.A.C. Almeida et al.

Hysteroglonium Rehm ex Lindau

Oedohysterium E. Boehm \& C.L. Schoch

Ostreichnion Duby

Pseudoscypha J. Reid \& Piroz.

Psiloglonium Höhn.

Rhytidhysteron Speg.

Hysteriales genera incertae sedis

Graphyllium Clem.

\section{Mytilinidiales}

Mytilinidiaceae Kirschst.

Actidium Fr.

Lophium Fr.

Mytilinidion Duby

Ostreola Darker

Peyronelia Cif. \& Gonz. Frag.

Pseudocamaropycnis Crous

Quasiconcha M.E. Barr \& M. Blackw.

Septonema Corda

Zoggium Lar.N. Vassiljeva

\section{Pleosporales}

Acrocalymmaceae Crous \& Trakun.

Acrocalymma Alcorn \& J.A.G. Irwin

Aigialaceae Suetrong et al.

Aigialus S. Schatz \& Kohlm.

Ascocratera Kohlm. 
Fissuroma Jian K. Liu et al.

Neoastrosphaeriella Jian K. Liu et al.

Posidoniomyces Vohník \& Réblová,

Rimora Kohlm. et al.

Amniculicolaceae Yin. Zhang et al.

Amniculicola Y. Zhang ter \& K.D. Hyde

Fusiformispora Phukhams. \& K.D. Hyde

Murispora Y. Zhang ter et al.

Neomassariosphaeria Yin. Zhang et al.

Pseudomassariosphaeria Phukhams. et al.

Vargamyces Tóth

Amorosiaceae Thambug. \& K.D. Hyde

Alfoldia D.G. Knapp et al.

Amorosia Mantle \& D. Hawksw.

Amorocoelophoma Jayasiri et al.

Angustimassarina Thambug. et al.

Anteagloniaceae K.D. Hyde et al.

Anteaglonium Mugambi \& Huhndorf

Flammeascoma Phookamsak \& K.D. Hyde

Purpureofaciens W. Dong et al.

Aquasubmersaceae A. Hashim. \& Kaz. Tanaka

Aquasubmersa K.D. Hyde \& Huang Zhang

Arthopyreniaceae W. Watson

Arthopyrenia A. Massal. (= Arthopyreniomyces Cif. \& Tomas.)

Mycomicrothelia Keissl.

Ascocylindricaceae Abdel-Wahab et al.

Ascocylindrica Abdel-Wahab et al.

Astrosphaeriellaceae Phookamsak et al.

Astrosphaeriella Syd. \& P. Syd.

Astrosphaeriellopsis Phookamsak et al.

Javaria Boise

Mycopepon Boise

Pithomyces Berk. \& Broome

Pteridiospora Penz. \& Sacc.

Quercicola Jayasiri et al.

Xenoastrosphaeriella Jayasiri et al.

Bambusicolaceae D.Q. Dai \& K.D. Hyde

Bambusicola D.Q. Dai \& K.D. Hyde

Leucaenicola Jayasiri et al.

Palmiascoma Phookamsak \& K.D. Hyde

Biatriosporaceae K.D. Hyde

Biatriospora K.D. Hyde \& Borse

Camarosporiaceae Wanas. et al. 
Camarosporium Schulzer

Camarosporomyces Crous

Camarosporidiellaceae Wanas. et al.

Camarosporidiella Wanas. et al.

Caryosporaceae Huang Zhang et al.

Caryospora De Not.

Coniothyriaceae W.B. Cooke

Coniothyrium Corda

Foliophoma Crous

Neoconiothyrium Crous

Ochrocladosporium Crous \& U. Braun

Staurosphaeria Rabenh. (= Hazslinszkyomyces Crous \& R.K. Schumach.)

Corynesporascaceae Sivan.

Corynespora Güssow

Corynesporasca Sivan.

Cryptocoryneaceae A. Hashim. \& Kaz. Tanaka

Cryptocoryneum Fuckel

Cucurbitariaceae G. Winter (= Fenestellaceae M.E. Barr)

Allocucurbitaria Valenz.-Lopez et al.

Astragalicola Jaklitsch \& Voglmayr

Cucitella Jaklitsch \& Voglmayr

Cucurbitaria Gray

Fenestella Tul. \& C. Tul.

Neocucurbitaria Wanas. et al.

Paracucurbitaria Valenz.-Lopez et al.

Parafenestella Jaklitsch \& Voglmayr

Protofenestella Jaklitsch \& Voglmayr

Rhytidiella Zalasky

Seltsamia Jaklitsch \& Voglmayr

Syncarpella Theiss. \& Syd.

Synfenestella Jaklitsch \& Voglmayr

Cyclothyriellaceae Jaklitsch \& Voglmayr

Cyclothyriella Jaklitsch \& Voglmayr

Massariosphaeria (E. Müll.) Crivelli

Dacampiaceae Körb.

Aaosphaeria Aptroot

Dacampia A. Massal.

Eopyrenula R.C. Harris

Leptocucurthis Aptroot

Pseudonitschkia Coppins \& S.Y Kondr

Weddellomyces D. Hawksw.

Delitschiaceae M.E. Barr

Delitschia Auersw.

Ohleriella Earle 
Semidelitschia Cain \& Luck-Allen

Diademaceae Shoemaker \& C.E. Babc.

Diadema Shoemaker \& C.E. Babc.

Dictyosporiaceae Boonmee \& K.D. Hyde

Aquadictyospora Z.L. Luo et al.

Aquaticheirospora Kodsueb \& W.H. Ho

Cheirosporium L. Cai \& K.D. Hyde

Dendryphiella Bubák \& Ranoj.

Dictyocheirospora M.J. D'souza et al.

Dictyopalmispora Pinruan et al.

Dictyosporium Corda

Digitodesmium P.M. Kirk

Gregarithecium Kaz. Tanaka \& K. Hiray.

Jalapriya M.J. D'souza et al.

Neodendryphiella Iturrieta-González et al.

Pseudocoleophoma Kaz. Tanaka \& K. Hiray.

Pseudoconiothyrium Crous \& R.K. Schumach

Pseudodictyosporium Matsush.

Vikalpa M.J. D'souza et al.

Didymellaceae Gruyter et al.

Allophoma Q. Chen \& L. Cai

Anthodidymella Phukhams. et al.

Ascochyta Lib. (= Heracleicola Tibpromma et al.)

Boeremia Aveskamp et al.

Briansuttonomyces Crous

Calophoma Q. Chen \& L. Cai

Chaetasbolisia Speg.

Cumuliphoma Valenz.-Lopez et al.

Didymella Sacc. ex D. Sacc.

Didysimulans Tibpromma et al.

Ectophoma Valenz.-Lopez et al.

Epicoccum Link

Heterophoma Q. Chen \& L. Cai

Juxtiphoma Valenz.-Lopez et al.

Leptosphaerulina McAlpine

Macroventuria Aa

Microsphaeropsis Syd. \& P. Syd.

Mixtura O.E. Erikss. \& J.Z. Yue

Monascostroma Höhn.

Neoascochyta Q. Chen \& L. Cai

Neodidymella Phookamsak et al.

Neodidymelliopsis Q. Chen \& L. Cai

Neomicrosphaeropsis Thambug. et al.

Nothophoma Q. Chen \& L. Cai

Paraboeremia Q. Chen \& L. Cai

Phoma Sacc.

Phomatodes Q. Chen \& L. Cai

Platychora Petr.

Pseudoascochyta Valenz.-Lopez et al.

Remotididymella Valenz.-Lopez et al. 
Similiphoma Valenz.-Lopez et al.

Stagonosporopsis Died.

Vacuiphoma Valenz.-Lopez et al.

Vandijckomycella Hern.-Restr. et al.

Xenodidymella Q. Chen \& L. Cai

\section{Didymosphaeriaceae Munk}

Alloconiothyrium Verkley \& Stielow

Austropleospora R.G. Shivas \& L. Morin

Barria Z.Q. Yuan

Bimuria D. Hawksw. et al.

Chromolaenicola Mapook \& K.D. Hyde

Curreya Sacc.

Cylindroaseptospora Jayasiri et al.

Deniquelata Ariyaw. \& K.D. Hyde

Didymocrea Kowalski

Didymosphaeria Fuckel

Julella Fabre

Kalmusia Niess1

Kalmusibambusa Phookamsak et al.

Karstenula Speg.

Laburnicola Wanas. et al.

Letendraea Sacc.

Lineostroma H.J. Swart

Montagnula Berl.

Neokalmusia Ariyaw. \& K.D. Hyde

Neptunomyces M. Gonçalves et al.

Paracamarosporium Wijayaw. \& K.D. Hyde

Paraconiothyrium Verkley

Paramassariosphaeria Wanas. et al.

Paraphaeosphaeria O.E. Erikss.

Phaeodothis Syd. \& P. Syd.

Pseudocamarosporium Wijayaw. \& K.D. Hyde

Pseudopithomyces Ariyaw. \& K.D. Hyde

Spegazzinia Sacc.

Tremateia Kohlm. et al.

Verrucoconiothyrium Crous

Vicosamyces Firmino et al.

Xenocamarosporium Crous \& M.J. Wingf.

Dothidotthiaceae Crous \& A.J.L. Phillips

Belizeana Kohlm. \& Volkm.

Dothidotthia Höhn.

Mycocentrospora Deighton

Phaeomycocentrospora Crous et al.

Pleiochaeta (Sacc.) S. Hughes

Thyrostroma Höhn.

Wilsonomyces Adask. et al.

Fuscostagonosporaceae Jayasiri et al.

Fuscostagonospora Kaz. Tanaka \& K. Hiray. 
Fusculina Crous \& Summerell

Gordonomyces Crous \& Marinc.

Halojulellaceae Suetrong et al.

Halojulella Suetrong et al.

Halotthiaceae Ying Zhang et al.

Brunneoclavispora Phookamsak \& K.D. Hyde

Halotthia Kohlm.

Mauritiana Poonyth et al.

Neolophiostoma S. Boonmee \& K.D. Hyde

Pontoporeia Kohlm.

Sulcosporium Phookamsak \& K.D. Hyde

Hermatomycetaceae Locq.

Hermatomyces Speg.

Hypsostromataceae Huhndorf

Hypsostroma Huhndorf

Latoruaceae Crous

Latorua Crous

Matsushimamyces Rahul Sharma \& Rohit Sharma

Polyschema H.P. Upadhyay

Pseudoasteromassaria M. Matsum. \& Kaz. Tanaka

Triseptata Boonmee \& Phookamsak

Lentimurisporaceae N.G. Liu et al.

Bahusandhika Subram.

Lentimurispora N.G. Liu et al.

Lentitheciaceae Y. Zhang ter et al.

Darksidea D.G. Knapp et al.

Halobyssothecium Dayar. et al.

Katumotoa Kaz. Tanaka \& Y. Harada

Keissleriella Höhn.

Lentithecium K.D. Hyde et al.

Murilentithecium Wanas. et al.

Neoophiosphaerella Kaz. Tanaka \& K. Hiray.

Phragmocamarosporium Wijayaw. et al.

Pleurophoma Höhn.

Poaceascoma Phookamsak \& K.D. Hyde

Pseudomurilentithecium Mapook \& K.D. Hyde

Setoseptoria Quaedvl. et al.

Tingoldiago K. Hiray. \& Kaz. Tanaka

Towyspora Wanas. et al.

Leptosphaeriaceae M.E. Barr

Alloleptosphaeria Ariyaw. et al.

Alternariaster E.G. Simmons

Chaetoplea (Sacc.) Clem.

Heterosporicola Crous

Leptosphaeria Ces. \& De Not. 
Neoleptosphaeria Ariyaw. \& K.D. Hyde

Ochraceocephala Voglmayr \& Aiello

Paraleptosphaeria Gruyter et al.

Plenodomus Preuss

Pseudoleptosphaeria Ariyaw. \& K.D. Hyde

Querciphoma Crous

Sclerenchymomyces Phukhams. \& K.D. Hyde

Sphaerellopsis Cooke

Subplenodomus Gruyter et al.

\section{Libertasomycetaceae Crous}

Libertasomyces Crous \& Roets

Neoplatysporoides Crous \& M.J. Wingf.

Ligninsphaeriaceae K.D. Hyde \& Ariyaw.

Ligninsphaeria Jin F. Zhang et al.

Ligninsphaeriopsis Phukhamsakda et al.

Lindgomycetaceae K. Hiray. et al.

Aquimassariosphaeria W. Dong \& Doilom

Arundellina Wanas. et al.

Clohesyomyces K.D. Hyde

Hongkongmyces C.C.C. Tsang et al.

Lindgomyces K. Hiray. et al.

Lolia Abdel-Aziz \& Abdel-Wahab

Neolindgomyces Jayasiri et al.

Lizoniaceae Boonmee \& K.D. Hyde

Lizonia (Ces. \& De Not.) De Not.

Longiostiolaceae Phukhams. et al.

Crassiperidium Matsum. \& Kaz. Tanaka

Longiostiolum Doilom et al.

Shearia Petr.

Longipedicellataceae Phukhams. et al.

Longipedicellata $\mathrm{H}$. Zhang et al.

Pseudoxylomyces Kaz. Tanaka \& K. Hiray.

Submerspora W. Dong et al.

Lophiostomataceae Sacc.

Alpestrisphaeria Thambug. \& K.D. Hyde

Biappendiculispora Thambug. et al.

Capulatispora Thambug. et al.

Coelodictyosporium Thambug. \& K.D. Hyde

Crassiclypeus A. Hashim. et al.

Decaisnella Fabre

Dimorphiopsis Crous

Flabellascoma A. Hashim. et al.

Guttulispora Thambug. et al.

Kiskunsagia D.G. Knapp et al.

Lentistoma A. Hashim. et al.

Leptoparies A. Hashim. et al. 
Lophiohelichrysum Dayar. et al.

Lophiopoacea Ariyaw. et al.

Lophiostoma Ces. \& De Not.

Neopaucispora Wanas. et al.

Neotrematosphaeria Thambug. et al.

Neovaginatispora A. Hashim. et al.

Parapaucispora A. Hashim. et al.

Paucispora Thambug. et al.

Platystomum Trevis.

Pseudocapulatispora Mapook \& K.D. Hyde

Pseudolophiostoma Thambug. et al.

Pseudopaucispora A. Hashim. et al.

Pseudoplatystomum Thambug. \& K.D. Hyde

Quintaria Kohlm. \& Volkm.-Kohlm

Sigarispora Thambug. \& K.D. Hyde

Vaginatispora K.D. Hyde

Lophiotremataceae K. Hiray. \& Kaz.

Atrocalyx A. Hashim. \& Kaz. Tanaka

Crassimassarina A. Hashim. \& Kaz. Tanaka

Cryptoclypeus A. Hashim. \& Kaz. Tanaka

Galeaticarpa A. Hashim. \& Kaz. Tanaka

Koordersiella Höhn.

Lophiotrema Sacc.

Pseudocryptoclypeus A. Hashim. \& Kaz. Tanaka

Macrodiplodiopsidaceae Voglmayr et al.

Macrodiplodiopsis Petr.

Pseudochaetosphaeronema Punith.

Massariaceae Nitschke

Massaria De Not.

Massarioramusculicola Huanral. et al.

Paramassaria Samarak., \& K.D. Hyde

Massarinaceae Munk

Byssothecium Fuckel

Helminthosporium Link

Massarina Sacc.

Pseudodidymosphaeria Thambug. \& K.D. Hyde

Pseudosplanchnonema Chethana \& K.D. Hyde

Semifissispora H.J. Swart

Stagonospora (Sacc.) Sacc.

Suttonomyces Wijayaw. et al.

Melanommataceae G. Winter (= Pseudodidymellaceae A. Hashim. \& Kaz. Tanaka)

Alpinaria Jaklitsch \& Voglmayr

Aposphaeria Sacc.

Asymmetricospora J. Fröhl. \& K.D. Hyde

Bertiella (Sacc.) Sacc. \& P. Syd.

Bicrouania Kohlm. \& Volkm.-Kohlm.

Byssosphaeria Cooke

Calyptronectria Speg. 
Camposporium Harkn.

Exosporiella P. Karst.

Fusiconidium Jun F. Li et al.

Herpotrichia Fuckel

Mamillisphaeria K.D. Hyde et al.

Marjia Wanas. et al.

Melanocamarosporioides D. Pem et al.

Melanocamarosporium Wijayaw. et al.

Melanocucurbitaria Wanas. et al.

Melanodiplodia Wanas. et al.

Melanomma Nitschke ex Fuckel

Monoseptella Wanas. et al.

Muriformistrickeria $\mathrm{Q}$. Tian et al.

Navicella Fabre

Neobyssosphaeria Wanas., E.B.G. Jones \& K.D. Hyde

Petrakia Syd. \& P. Syd.

Phragmocephala E.W. Mason \& S. Hughes

Phragmotrichum Kunze

Pleotrichocladium Hern.-Restr. et al.

Praetumpfia Jaklitsch \& Voglmayr

Pseudobyssosphaeria H.B. Jiang \& K.D. Hyde

Pseudodidymella C.Z. Wei et al.

Pseudostrickeria Q. Tian et al.

Sarimanas M. Matsum. et al.

Seifertia Partr. \& Morgan-Jones

Tumularia Descals \& Marvanová

Uzbekistanica Wanas. et al.

Xenostigmina Crous

Morosphaeriaceae Suetrong et al.

Aquihelicascus W. Dong et al.

Aquilomyces D.G. Knapp et al.

Clypeoloculus Kaz. Tanaka \& K. Hiray.

Helicascus Kohlm.

Morosphaeria Suetrong et al.

Neohelicascus W. Dong et al.

Mycoporaceae Zahlbr

Mycoporum Flot. ex Nyl.

Neocamarosporiaceae Wanas. et al.

Dimorphosporicola Crous

Neocamarosporium Crous \& M.J. Wingf.

Neohendersoniaceae Giraldo \& Crous

Brevicollum Kaz. Tanaka et al.

Crassiparies M. Matsum.et al.

Medicopsis Gruyter et al.

Neohendersonia Petr.

Neomedicopsis Crous \& Akulov

Neomassariaceae H.A. Ariyaw.

Neomassaria Mapook et al. 
Neomassarinaceae Mapook \& K.D. Hyde

Neomassarina Phookamsak et al.

Pseudohelminthosporium Phukhams. \& K.D. Hyde

Neophaeosphaeriaceae Ariyaw. et al.

Neophaeosphaeria M.P.S. Câmara et al.

Neopyrenochaetaceae Valenz.-Lopez et al.

Neopyrenochaeta Valenz.-Lopez et al.

Nigrogranaceae Jaklitsch \& Voglmayr

Nigrograna Gruyter et al.

Occultibambusaceae D.Q. Dai \& K.D. Hyde

Brunneofusispora S.K. Huang \& K.D. Hyde

Neooccultibambusa Doilom \& K.D. Hyde

Occultibambusa D.Q. Dai \& K.D. Hyde

Seriascoma Phookamsak et al.

Versicolorisporium Sat. Hatak. et al.

Ohleriaceae Jaklitsch \& Voglmayr

Ohleria Fuckel.

Parabambusicolaceae Kaz. Tanaka \& K. Hiray.

Aquastroma Kaz. Tanaka \& K. Hiray.

Lonicericola Phookamsak et al.

Multilocularia Phookamsak et al.

Multiseptospora Phookamsak \& K.D. Hyde

Neoaquastroma Wanas. et al.

Parabambusicola Kaz. Tanaka \& K. Hiray.

Paramonodictys N.G. Liu et al.

Paratrimmatostroma Jayasiri et al.

Pseudomonodictys Doilom et al.

Paradictyoarthriniaceae Doilom et al.

Paradictyoarthrinium Matsush.

Xenomassariosphaeria Jayasiri et al.

Paralophiostomataceae V.V. Sarma \& M. Niranjan.

Paralophiostoma V.V. Sarma \& M. Niranjan

Parapyrenochaetaceae Valenz.-Lopez et al.

Parapyrenochaeta Valenz.-Lopez

Quixadomyces Cantillo \& Gusmão.

Periconiaceae Nann.

Bambusistroma D.Q. Dai \& K.D. Hyde

Flavomyces D.G. Knapp et al.

Noosia Crous et al.

Periconia Tode

Phaeoseptaceae Boonmee et al.

Phaeoseptum Ying Zhang et al. 
Pleopunctum N.G. Liu et al.

Phaeosphaeriaceae M.E. Barr

Acericola Wanas. et al.

Alloneottiosporina Nag Raj

Allophaeosphaeria Ariyaw. et al.

Amarenographium O.E. Erikss.

Amarenomyces O.E. Erikss.

Ampelomyces Ces. ex Schltdl.

Aphanostigme Syd.

Arezzomyces Y. Marín \& Crous

Banksiophoma Crous

Bhagirathimyces S.M. Singh \& S.K. Singh

Bhatiellae Wanas. et al.

Bricookea M.E. Barr

Brunneomurispora Phookamsak et al.

Camarosporioides W.J. Li \& K.D. Hyde

Chaetosphaeronema Moesz

Dactylidina Wanas. et al.

Dematiopleospora Wanas. et al.

Didymocyrtis Vain.

Dlhawksworthia Wanas. et al.

Edenia M.C. González et al.

Embarria Wanas. et al.

Equiseticola Abdelsalam et al.

Eudarluca Speg.

Galiicola Tibpromma et al.

Hydeomyces Maharachch. et al.

Hydeopsis J.F. Zhang et al.

Italica Wanas. et al.

Jeremyomyces Crous \& R.K. Schumach.

Juncaceicola Tennakoon et al.

Kwanghwana A. Karunarathna et al.

Leptospora Rabenh.

Longispora Phukhams. \& K.D. Hyde

Loratospora Kohlm. \& Volkm.-Kohlm.

Mauginiella Cavara

Melnikia Wijayaw. et al.

Murichromolaenicola Mapook \& K.D. Hyde

Muriphaeosphaeria Phukhams. et al.

Neoophiobolus Mapook \& K.D. Hyde

Neosetophoma Gruyter et al.

Neosphaerellopsis Crous \& Trakun.

Neostagonospora Quaedvl. et al.

Neostagonosporella C.L. Yang et al.

Neosulcatispora Crous \& M.J. Wingf.

Nodulosphaeria Rabenh.

Ophiobolopsis Phookamsak et al.

Ophiobolus Riess

Ophiosimulans Tibpromma et al.

Ophiosphaerella Speg.

Paraleptospora Mapook \& K.D. Hyde

Paraloratospora Bundhun et al. 
Paraophiobolus Phookamsak et al.

Paraphoma Morgan-Jones \& J.F. White

Parastagonospora Quaedvl. et al.

Parastagonosporella M. Bakhshi et al.

Phaeopoacea Thambug. et al.

Phaeoseptoriella Crous

Phaeosphaeria I. Miyake

Phaeosphaeriopsis M.P.S. Câmara et al.

Phaeostagonospora A.W. Ramaley

Piniphoma Crous \& R.K. Schumach.

Poaceicola W.J. Li et al.

Populocrescentia Wanas. et al.

Pseudoophiobolus Phookamsak et al.

Pseudoophiosphaerella J.F. Zhang et al.

Pseudophaeosphaeria Jayasiri et al.

Pseudostaurosphaeria Mapook \& K.D. Hyde

Sclerostagonospora Höhn.

Scolicosporium Lib. ex Roum.

Septoriella Oudem. (= Wojnowicia Sacc.)

Setomelanomma M. Morelet

Setophoma Gruyter et al.

Sulcispora Shoemaker \& C.E. Babc.

Tiarospora Sacc. \& Marchal

Tintelnotia S.A. Ahmed et al.

Vagicola K.W.T. Chethana \& K.D. Hyde

Vittaliana Devadatha et al.

Vrystaatia Quaedvl. et al.

Wingfieldomyces Y. Marín \& Crous

Wojnowiciella Crous et al.

Xenophaeosphaeria Crous \& M.J. Wingf.

Xenophoma Crous \& Trakunyingcharoen Trakunyingcharoen

Xenoseptoria Quaedvl. et al.

Yunnanensis Karun. et al.

Pleomassariaceae M.E. Barr

Beverwykella Tubaki

Lichenopyrenis Calat. et al.

Myxocyclus Riess

Peridiothelia D. Hawksw.

Prosthemium Kunze

Pseudotrichia Kirschst.

Splanchnonema Corda

Pleomonodictydaceae Hern.-Restr. et al.

Pleomonodictys Hern.-Restr. et al.

Pleohelicoon Jayasiri et al.

Pleosporaceae Nitschke

Allonecte Syd.

Alternaria Nees

Bipolaris Shoemaker

Clathrospora Rabenh.

Comoclathris Clem. 
Curvularia Boedijn

Decorospora Inderb. et al.

Diademosa Shoemaker \& C.E. Babc.

Dichotomophthora Mehrl. \& Fitzp. ex P.N. Rao

Exserohilum K.J. Leonard \& Suggs

Extrawettsteinina M.E. Barr

Gibbago E.G. Simmons

Johnalcornia Y.P. Tan \& R.G. Shivas

Paradendryphiella Woudenberg \& Crous

Platysporoides (Wehm.) Shoemaker \& C.E. Babc.

Pleoseptum A.W. Ramaley \& M.E. Barr

Porocercospora Amaradasa et al.

Prathoda Subram.

Pseudoyuconia Lar.N. Vassiljeva

Pyrenophora Fr.

Stemphylium Wallr.

Tamaricicola Thambug. et al.

Typhicola Crous

Pseudoastrosphaeriellaceae Phookamsak \& K.D. Hyde

Carinispora K.D. Hyde

Pseudoastrosphaeriella Phookamsak et al.

Pseudoastrosphaeriellopsis Devadatha et al.

Pseudoberkleasmiaceae Phukhams \& K.D. Hyde

Pseudoberkleasmium Tibpromma \& K.D. Hyde

Pseudocoleodictyosporaceae Doilom \& K.D. Hyde Pseudocoleodictyospora Doilom \& K.D. Hyde

Subglobosporium Doilom \& K.D. Hyde

Pseudolophiotremataceae K.D. Hyde \& Hongsanan Clematidis Tibpromma et al.

Pseudolophiotrema A. Hashim. \& Kaz. Tanaka

Pseudomassarinaceae Phukhams \& K.D. Hyde Pseudomassarina Phukhams. \& K.D. Hyde

Pseudopyrenochaetaceae Valenz.-Lopez

Pseudopyrenochaeta Valenz.-Lopez

Pyrenochaetopsidaceae Valenz.-Lopez et al.

Pyrenochaetopsis Gruyter et al.

Neopyrenochaetopsis Valenz-Lopez et al.

Xenopyrenochaetopsis Valenz.-Lopez et al.

Roussoellaceae J.K. Liu et al.

Appendispora K.D. Hyde

Cytoplea Bizz. \& Sacc.

Elongatopedicellata J.F. Zhang et al.

Immotthia M.E. Barr

Neoroussoella Jian K. Liu et al.

Pararoussoella Wanas. et al. 
Pseudoneoconiothyrium Wanas. et al.

Pseudoroussoella Mapook \& K.D. Hyde

Roussoella Sacc.

Roussoellopsis I. Hino \& Katum.

Setoarthopyrenia Mapook \& K.D. Hyde

Xenoroussoella Mapook \& K.D. Hyde

Salsugineaceae K.D. Hyde \& Tibpromma

Acrocordiopsis Borse \& K.D. Hyde

Salsuginea K.D. Hyde

Shiraiaceae Y.X. Liu et al.

Grandigallia M.E. Barr et al.

Rubroshiraia D.Q. Dai \& K.D. Hyde

Shiraia Henn.

\section{Sporormiaceae Munk}

Chaetopreussia Locq.-Lin.

Forliomyces Phukhams. et al.

Pleophragmia Fuckel

Preussia Fuckel

Sparticola Phukhams. et al.

Sporormia De Not.

Sporormiella Ellis \& Everh.

Sporormurispora Wanas. et al.

Westerdykella Stolk

Striatiguttulaceae S.N. Zhang et al.

Longicorpus S.N. Zhang et al.

Striatiguttula S.N. Zhang et al.

Sulcatisporaceae Kaz. Tanaka \& K. Hiray.

Anthosulcatispora Phukhams. \& K.D. Hyde

Magnicamarosporium Kaz. Tanaka \& K. Hiray.

Neobambusicola Crous \& M.J. Wingf.

Parasulcatispora Phukhams. \& K.D. Hyde

Pseudobambusicola Hern.-Restr. \& Crous

Sulcatispora Kaz. Tanaka \& K. Hiray.

Teichosporaceae M.E. Barr

Asymmetrispora Thambugala \& K.D. Hyde

Aurantiascoma Thambug. \& K.D. Hyde

Chaetomastia (Sacc.) Berl.

Floricola Kohlm. \& Volkm.-Kohlm.

Loculohypoxylon M.E. Barr

Magnibotryascoma Thambug. \& K.D. Hyde

Misturatosphaeria Mugambi \& Huhndorf

Paulkirkia Wijayaw. et al.

Pseudoaurantiascoma Thambug. \& K.D. Hyde

Pseudomisturatosphaeria Thambugala \& K.D. Hyde

Ramusculicola Thambug. \& K.D. Hyde

Sinodidymella J.Z. Yue \& O.E. Erikss.

Teichospora Fuckel 


\section{Testudinaceae Arx}

Angustospora Abdel-Aziz

Halotestudina Dayarathne \& K.D. Hyde

Lepidosphaeria Parg.-Leduc

Lojkania Rehm

Muritestudina Wanas. et al.

Neotestudina Segretain \& Destombes

Testudina Bizz.

Ulospora D. Hawksw. et al.

Verruculina Kohlm. \& Volkm-Kohlm.

Tetraplosphaeriaceae Kaz. Tanaka \& K. Hiray

Byssolophis Clem.

Ernakulamia Subram.

Polyplosphaeria Kaz. Tanaka \& K. Hiray

Pseudotetraploa Kaz. Tanaka \& K. Hirayama

Quadricrura Kaz. Tanaka et al.

Shrungabeeja V.G. Rao \& K.A. Reddy

Tetraploa Berk. \& Broome

Triplosphaeria Kaz. Tanaka \& K. Hiray

Thyridariaceae Q. Tian \& K.D. Hyde

Chromolaenomyces Mapook \& K.D. Hyde

Cycasicola Wanas. et al.

Liua Phookamsak \& K.D. Hyde

Parathyridaria Jaklitsch \& Voglmayr

Pseudothyridariella Mapook \& K.D. Hyde

Thyridaria Sacc.

Thyridariella Devadatha et al.

Torulaceae Corda

Dendryphion Wallr.

Neotorula Ariyaw. et al.

Rostriconidium Z.L. Luo et al.

Rutola J.L. Crane \& Schokn.

Sporidesmioides Jun F. Li et al.

Torula Pers.

Trematosphaeriaceae K.D. Hyde et al.

Bryosphaeria Döbbeler

Falciformispora K.D. Hyde

Hadrospora Boise

Halomassarina Suetrong et al.

Raghukumaria Devadatha et al.

Trematosphaeria Fuckel

Tzeananiaceae H.A. Ariyaw. et al.

Tzeanania H.A. Ariyaw. et al.

Wicklowiaceae Ariyaw. \& K.D. Hyde

Wicklowia Raja et al.

Zopfiaceae G. Arnaud ex D. Hawksw. 
Celtidia J.M. Janse

Coronopapilla Kohlm. \& Volkm.-Kohlm.

Rechingeriella Petr.

Richonia Boud.

Zopfia Rabenh.

Zopfiofoveola D. Hawksw.

Pleosporales genera incertae sedis

Acuminatispora S.N. Zhang et al.

Aegeanispora E.B.G. Jones \& Abdel-Wahab

Antealophiotrema A. Hashim. \& Kaz. Tanaka

Ascorhombispora L. Cai \& K.D. Hyde

Atradidymella Davey \& Currah

Briansuttonia R.F. Castañeda et al.

Camarographium Bubák

Chaetodiplodia P. Karst.

Chaetophoma Cooke

Cheiromoniliophora Tzean \& J.L. Chen

Cyclothyrium Petr.

Dangeardiella Sacc. \& P. Syd.

Daruvedia Dennis

Dokmaia I. Promputtha

Farasanispora Abdel-Wahab et al.

Glaxoa P.F. Cannon

Hobus Jaklitsch \& Voglmayr

Homostegia Fuckel

Inflatispora Y. Zhang ter et al.

Isthmosporella Shearer \& J.L. Crane

Megacapitula J.L. Chen \& Tzean

Megatomentella D.A.C. Almeida et al.

Neocurreya Thambug. \& K.D. Hyde

Ostropella (Sacc.) Höhn.

Paraepicoccum Matsush.

Paraliomyces Kohlm.

Parameliola Hongsanan et al.

Perthomyces Crous

Phialophorophoma Linder

Pleosphaerellula Naumov \& Czerepan.

Pseudohendersonia Crous \& M.E. Palm

Pseudopassalora Crous

Pyrenochaeta De Not.

Rebentischia P. Karst.

Repetophragma Subram.

Scleroramularia Batzer \& Crous

Scolecobasidium E.V. Abbott

Setophaeosphaeria Crous \& Y. Zhang ter

Sirodesmium De Not.

Spiroplana Voglmayr et al.

Stuartella Fabre

Xenolophium Syd. 


\section{Results \& discussion}

The combined LSU, rpb-2, SSU and tef1 gene data set consists of 340 taxa, with 3825 characters after alignment. The best scoring RAxML tree is presented in Fig. 1 for familial levels and Fig. 2 for ordinal levels. Maximum likelihood bootstrap values (MLBS) equal or greater than $70 \%$ are given at each node. Posterior probabilities (PP) generated from Bayesian analyses equal or greater than 0.90 are shown after MLBS values. The clade of Dothideomycetes can be divided into two clades (subclasses). In our study, the subclass Dothideomycetidae includes Capnodiales, Dothideales, and Myriangiales. The second subclass, Pleosporomycetidae, includes Gloniales, Hysteriales, Mytilinidiales and Pleosporales.

\section{Dothideomycetes}

\section{Dothideomycetidae}

Lumbsch \& Huhndorf (2010) included 13 families with 74 genera in Dothideomycetidae. Hyde et al. (2013) noted that this subclass always comprises Capnodiales, Dothideales and Myriangiales. This is supported by our phylogenetic analyses (Fig. 1). Although, Trypetheliales clusters with Mytilinidiales in our analysis (Fig. 1), we do not place it in Pleosporomycetidae due to its unstable placement. The MCC tree (Fig. 2) indicates that Dothideomycetidae has stem age at 303 MYA which falls within subclass status as suggested by Liu et al. (2017a).

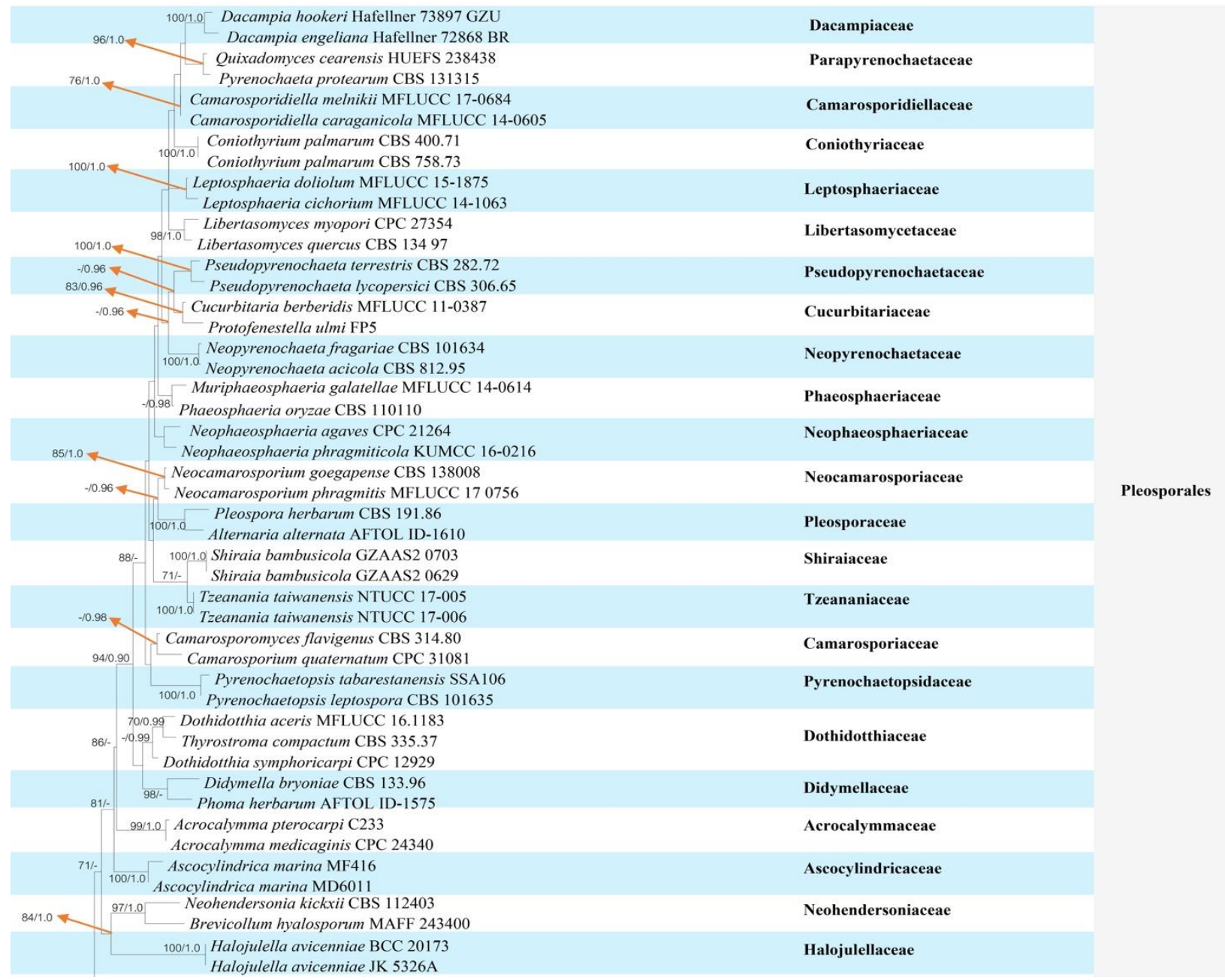

Figure 1 - Phylogram generated from maximum likelihood analysis (RAxML) of families of Dothideomycetes based on combined LSU, rpb-2, SSU and tef1 sequence data. Maximum likelihood bootstrap values equal or above $70 \%$, Bayesian posterior probabilities equal or above 0.90 (MLBS/PP) are given at the nodes. An original isolate number is noted after the species name. The tree is rooted to Orbilia auricolor (AFTOL-ID 906) and O. vinosa (AFTOL-ID 905). Hyphen (-) represents support values below $70 \%$ MLBS and 0.90 PP. 


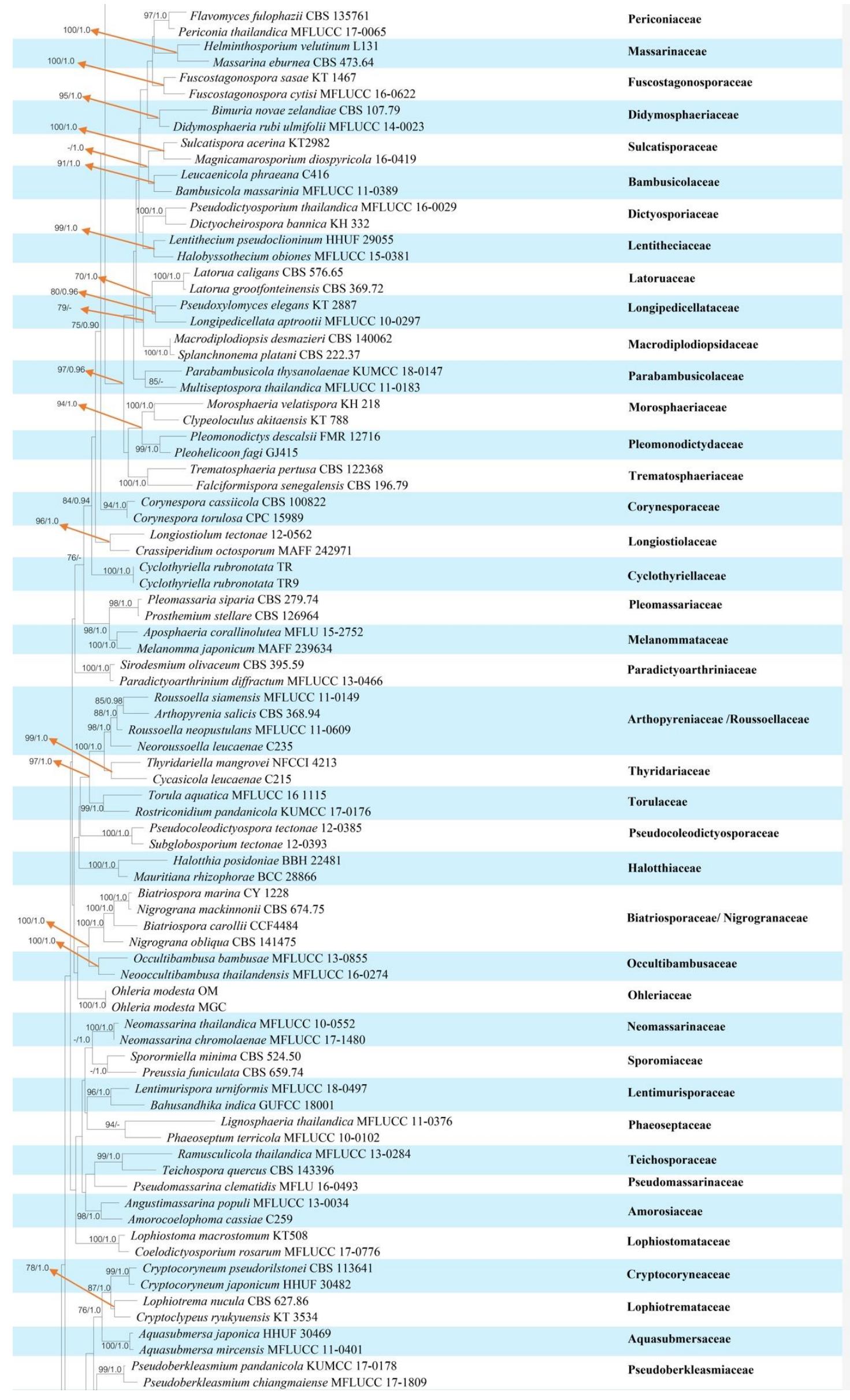

Figure 1 - Continued. 


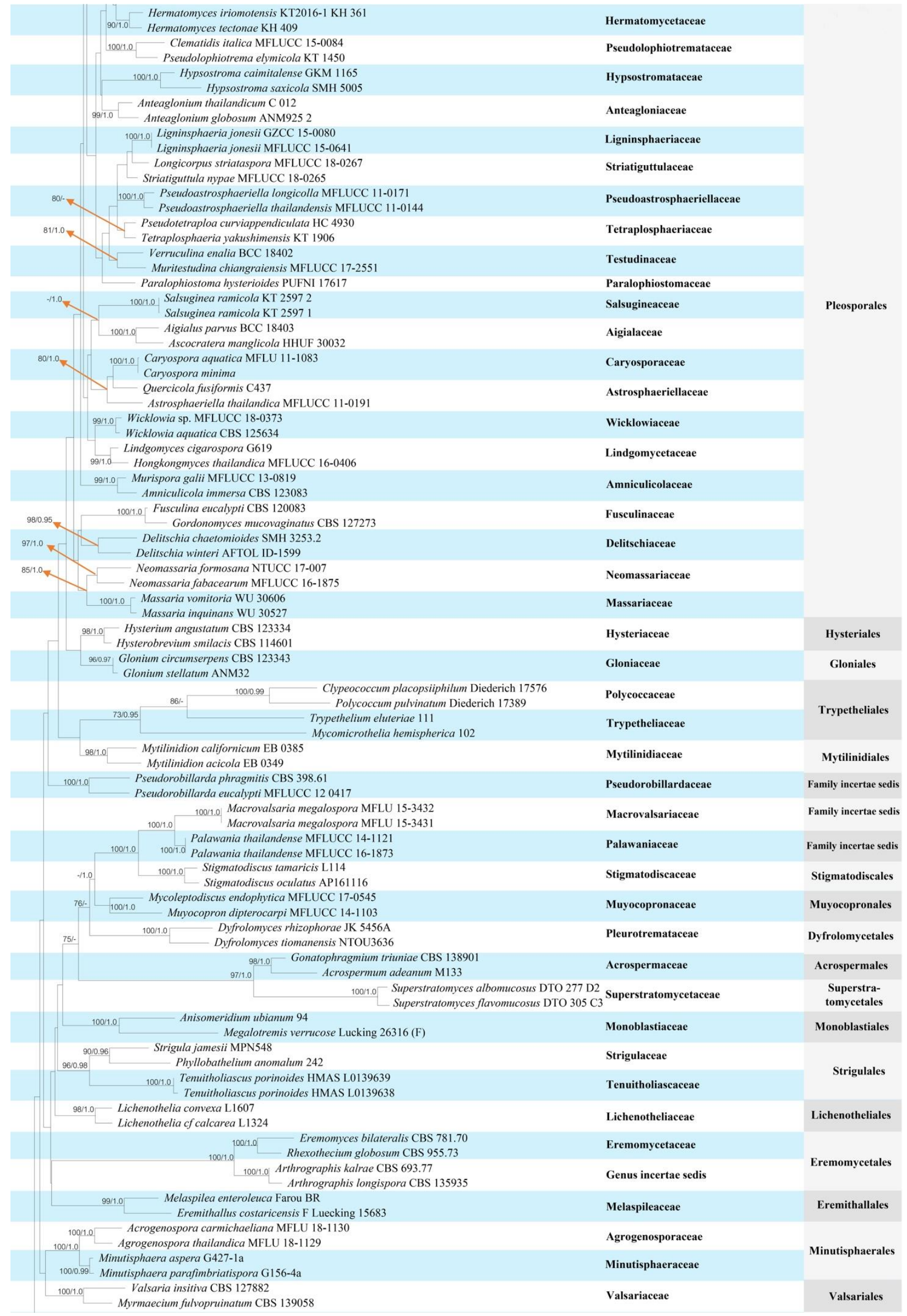

Figure 1 - Continued. 


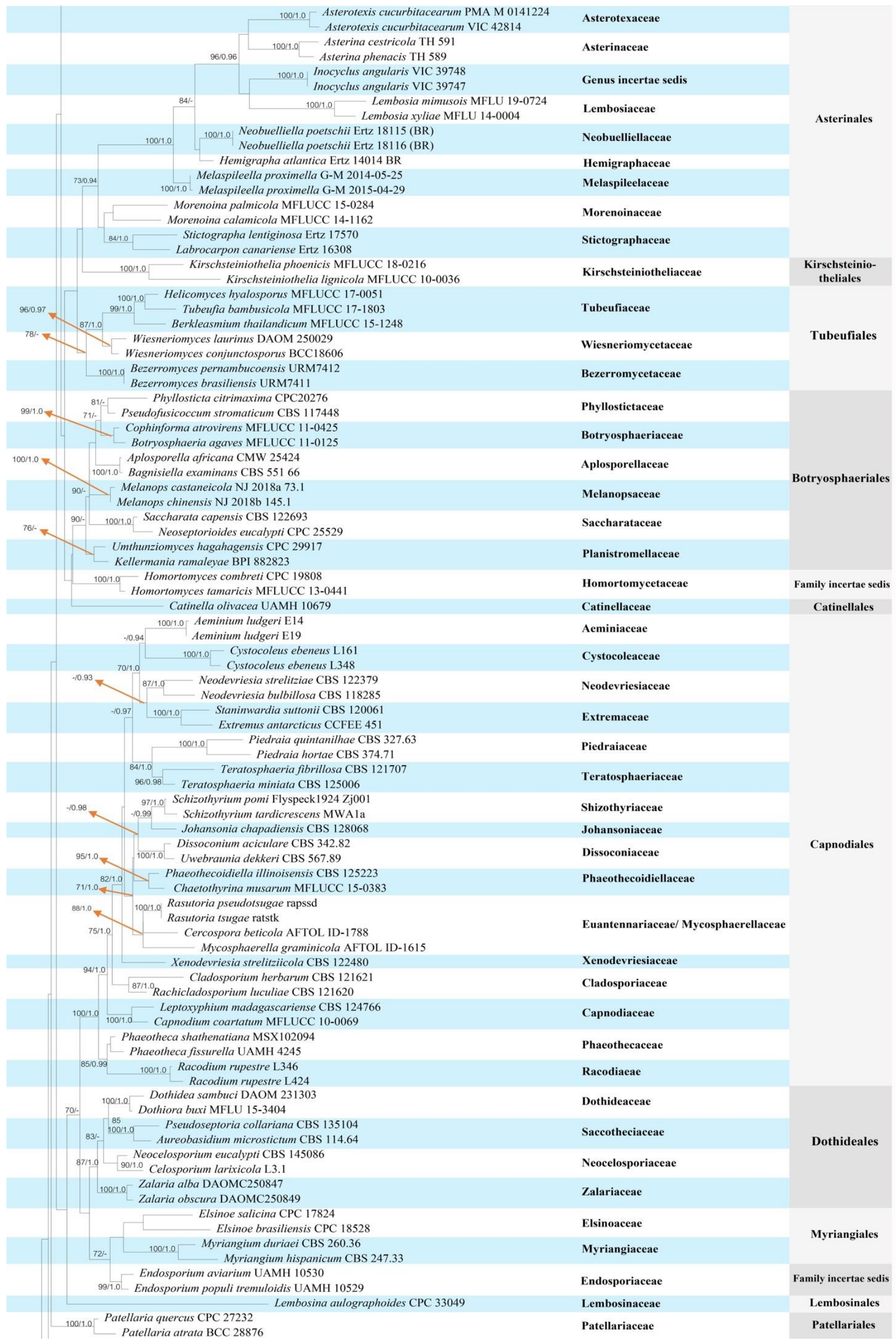

Figure 1 - Continued. 


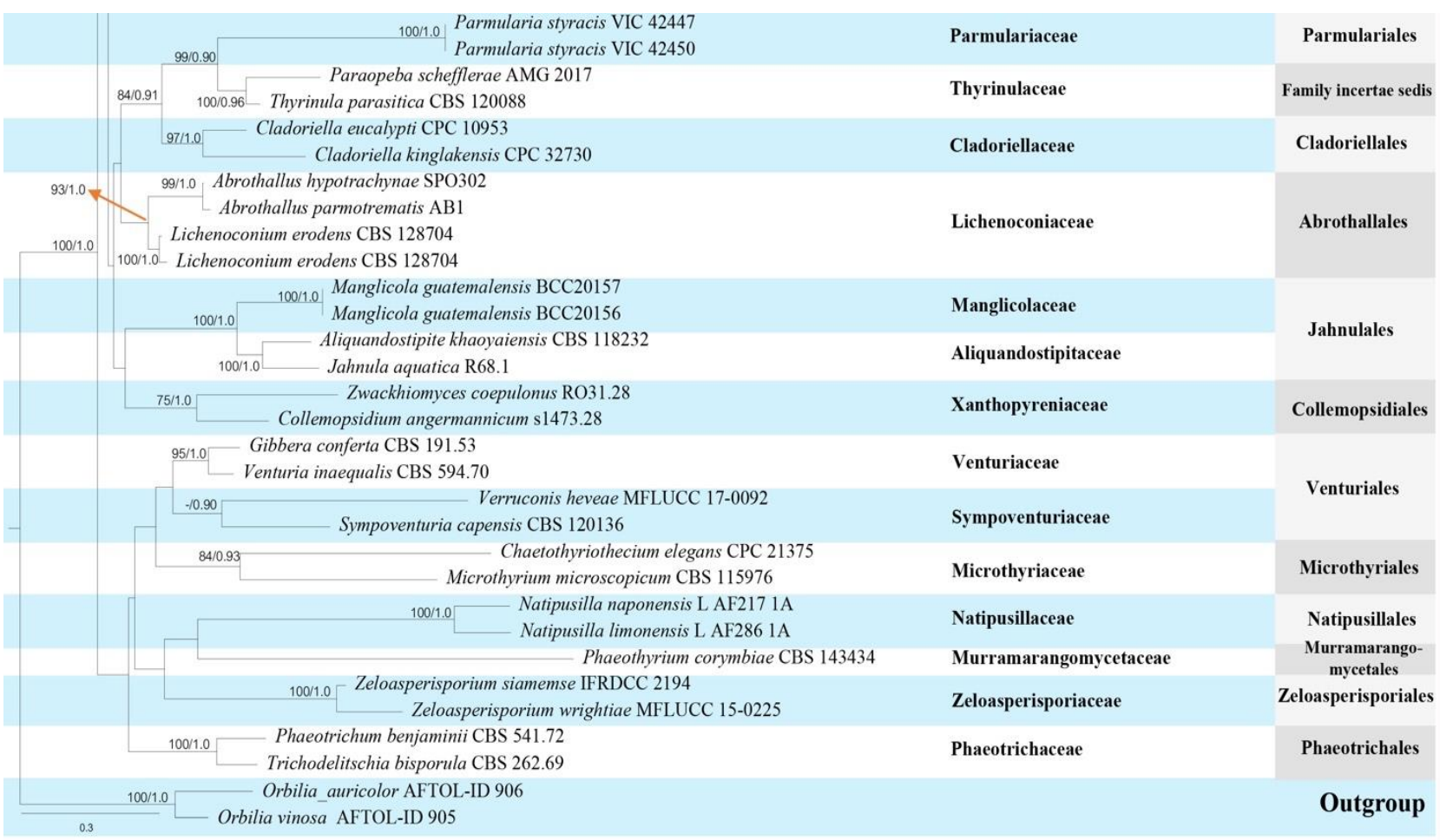

Figure 1 - Continued.

Capnodiales Woron.

Index Fungorum number: IF 90464; Facesoffungi number: FoF 07632

Capnodiales was introduced by Woronichin (1925) and accommodated the families Antennulariellaceae, Capnodiaceae, Cladosporiaceae, Coccoideaceae, Dissoconiaceae, Metacapnodiaceae, Mycosphaerellaceae, Piedraiaceae and Teratosphaeriaceae (Lumbsch \& Huhndorf 2010, Hyde et al. 2013, Chomnunti et al. 2011, 2014). Subsequently, Aeminiaceae (halotolerant on deteriorated limestones), Cystocoleaceae (lichenized), Euantennariaceae (plant parasitic), Extremaceae (extremophilic fungi), Johansoniaceae (epiphytic), Neodevriesiaceae (extremophilic fungi), Paradevriesiaceae (plant and rock-habitating fungi) surfaces, Phaeothecaceae (variety of life styles), Phaeothecoidiellaceae (sooty-blotch/flyspeck fungi), Racodiaceae (rock-habitating fungi), Schizothyriaceae (sooty-blotch/flyspeck fungi), and Xenodevriesiaceae (pathogenic or saprobic) were also accepted in this order based on phylogenetic analyses (Phookamsak et al. 2016, Hongsanan et al. 2017, Wijayawardene et al. 2017a, Doilom et al. 2018, Crous et al. 2019b), although type material of Schizothyriaceae needs to be recollected to stabilize this family. Paradevriesiaceae is synonymized under Extremaceae in this study base on its phylogenetic placement (Fig. 3). We provide a phylogenetic tree for Capnodiales (Fig. 3) including all families in this order. Phylogenetic trees of Mycosphaerellaceae and Teratosphaeriaceae are provided separately in Figs. 15 and 24.

Members of Capnodiales are mostly leaf epiphytes associated with honey dew (produced by insects), or saprobes, parasites and endophytes of plants worldwide. There have been several publications concerning rock-inhabiting fungi in the Capnodiales clade with phylogenetic analyses, but the connections between rock-inhabiting fungi and other lifestyles (i.e. plant pathogens and saprobes) found in this order are unexplained. Hongsanan et al. (2016a) provided the MCC tree for a better understanding of evolution of capnodialean families. The MCC tree answers ecological and evolutionary questions, concerning the adaptation of these groups to extreme environments. The common ancestor of species occurring in extreme habitats, such as species in Extremaceae and Neodevriesiaceae diverged after other families in Capnodiales, while earlier diverged families mostly comprise pathogens and saprobes (Ismail et al. 2016, Hongsanan et al. 2016a). In our analyses, the divergence time for Capnodiales is estimated as 221 MYA (stem age) (Fig. 2). 


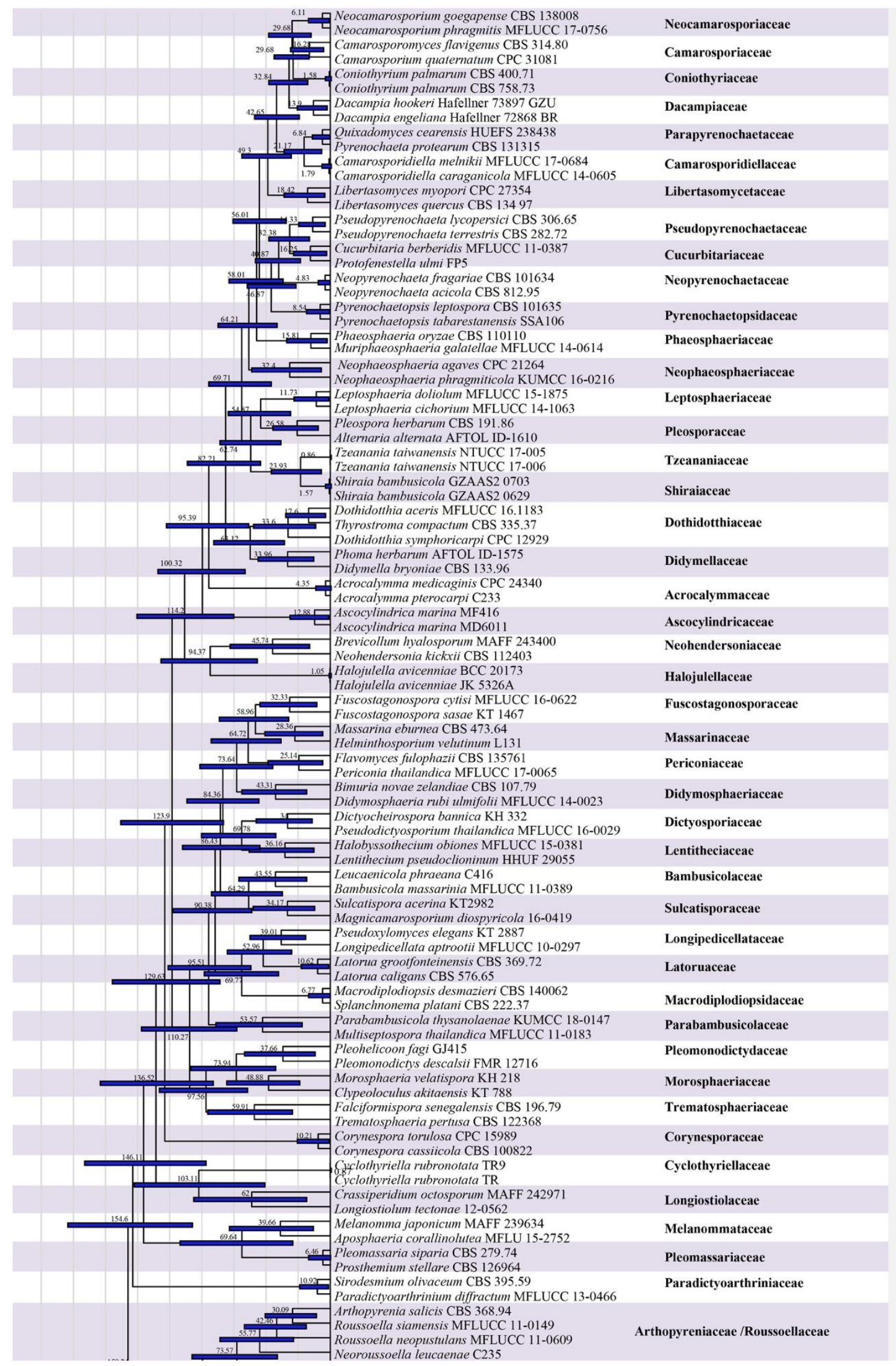

Figure 2 - The maximum clade credibility (MCC) tree of families in Dothideomycetes obtained from a Bayesian approach (BEAST). The fossil minimum age constraints and second calibrations used in this study are marked with green dots. Bars correspond to the $95 \%$ highest posterior density (HPD) intervals. The scale axis shows divergence times as millions of years ago (MYA). Geological periods are indicated at the base of the tree. 


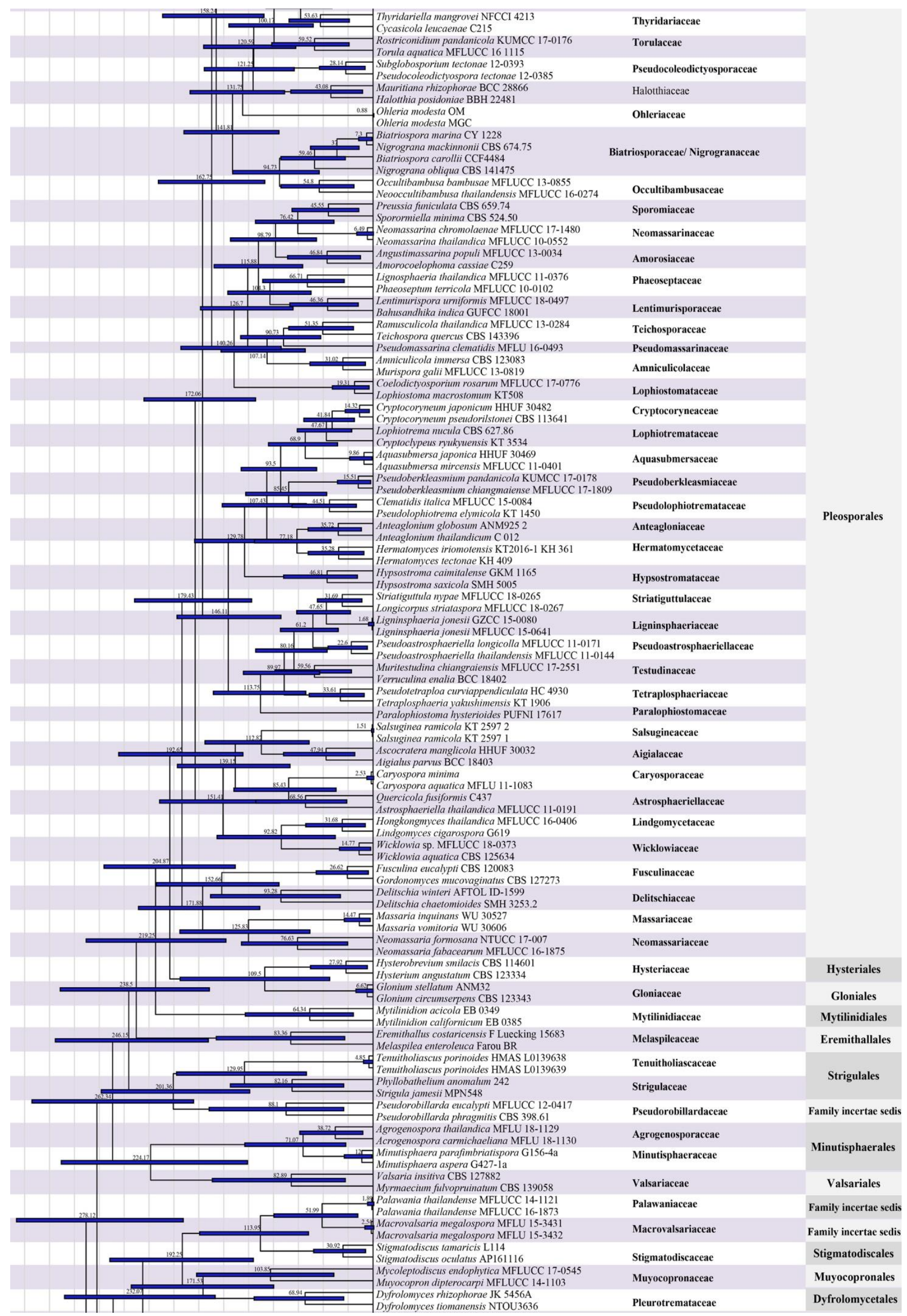

Figure 2 - Continued. 


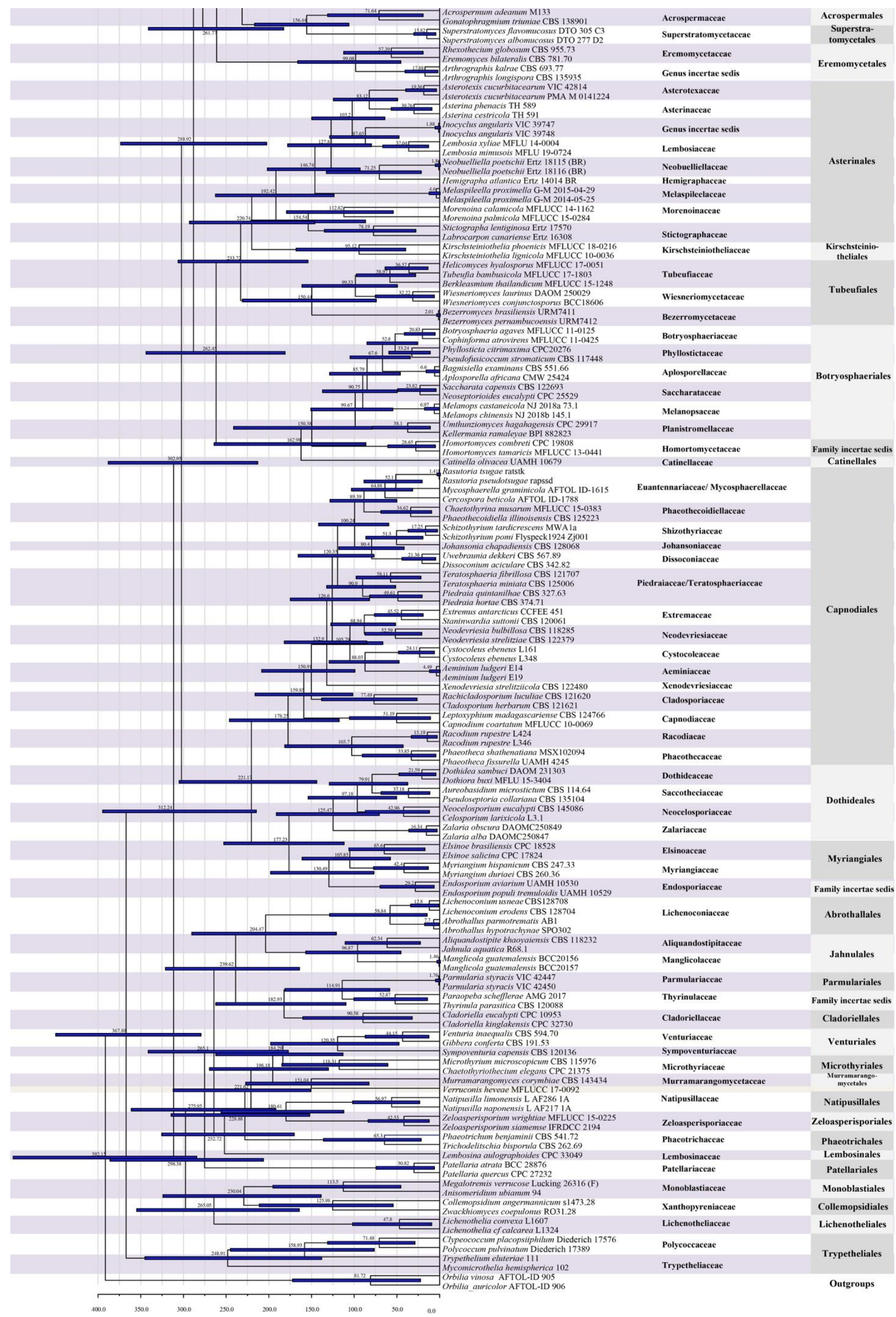

Figure 2 - Continued. 


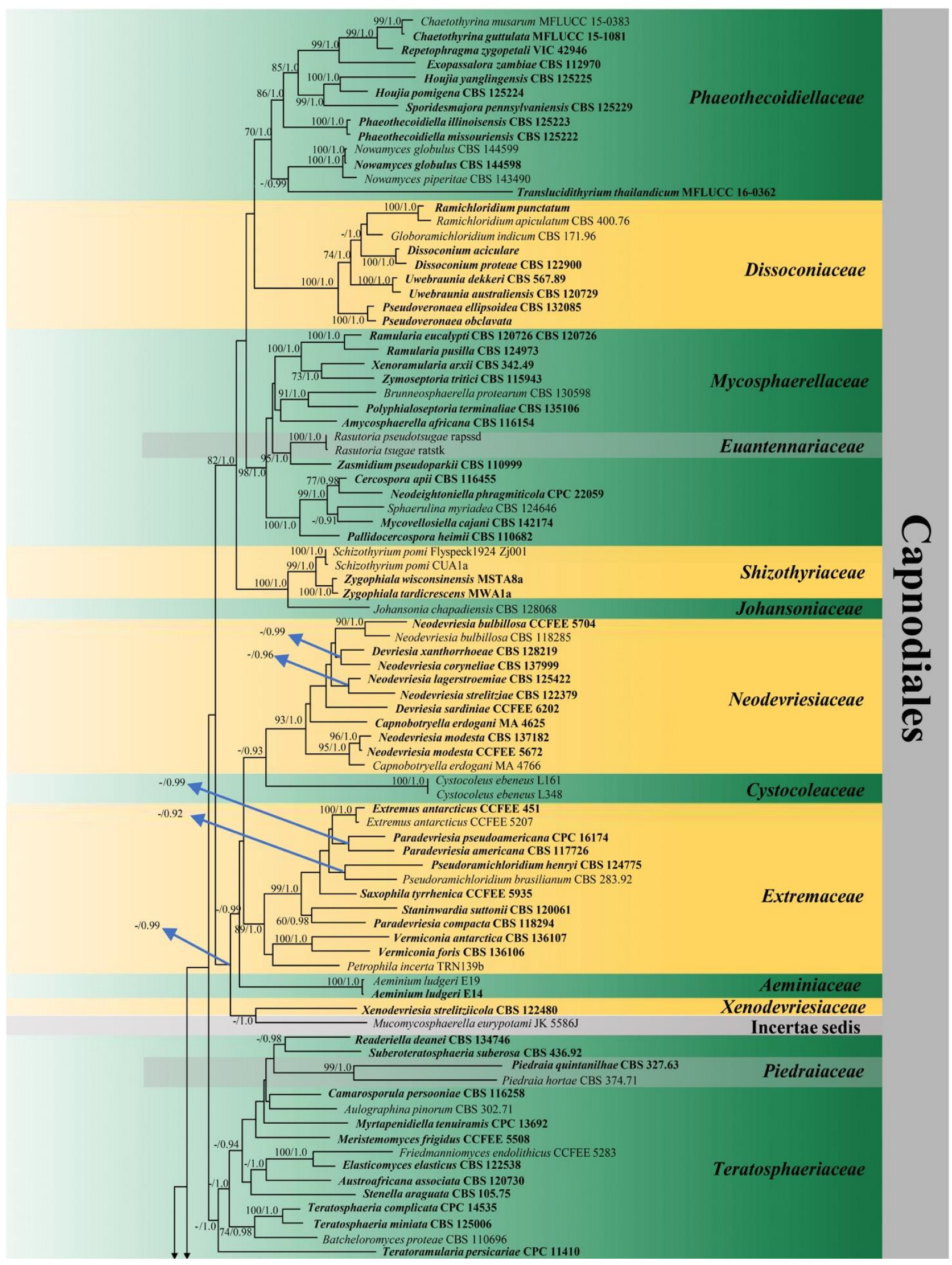

Figure 3 - Phylogram generated from maximum likelihood analysis (RAxML) of Capnodiales based on ITS, LSU and rpb-2 sequence data. Maximum likelihood bootstrap values equal or above $70 \%$, Bayesian posterior probabilities equal or above 0.90 (MLBS/PP) are given at the nodes. An original isolate number is noted after the species name. The tree is rooted to Elsinoe phaseoli (CBS 165.31). The ex-type strains are indicated in bold. Hyphen (-) represents support values below $70 \%$ MLBS and 0.90 PP. 


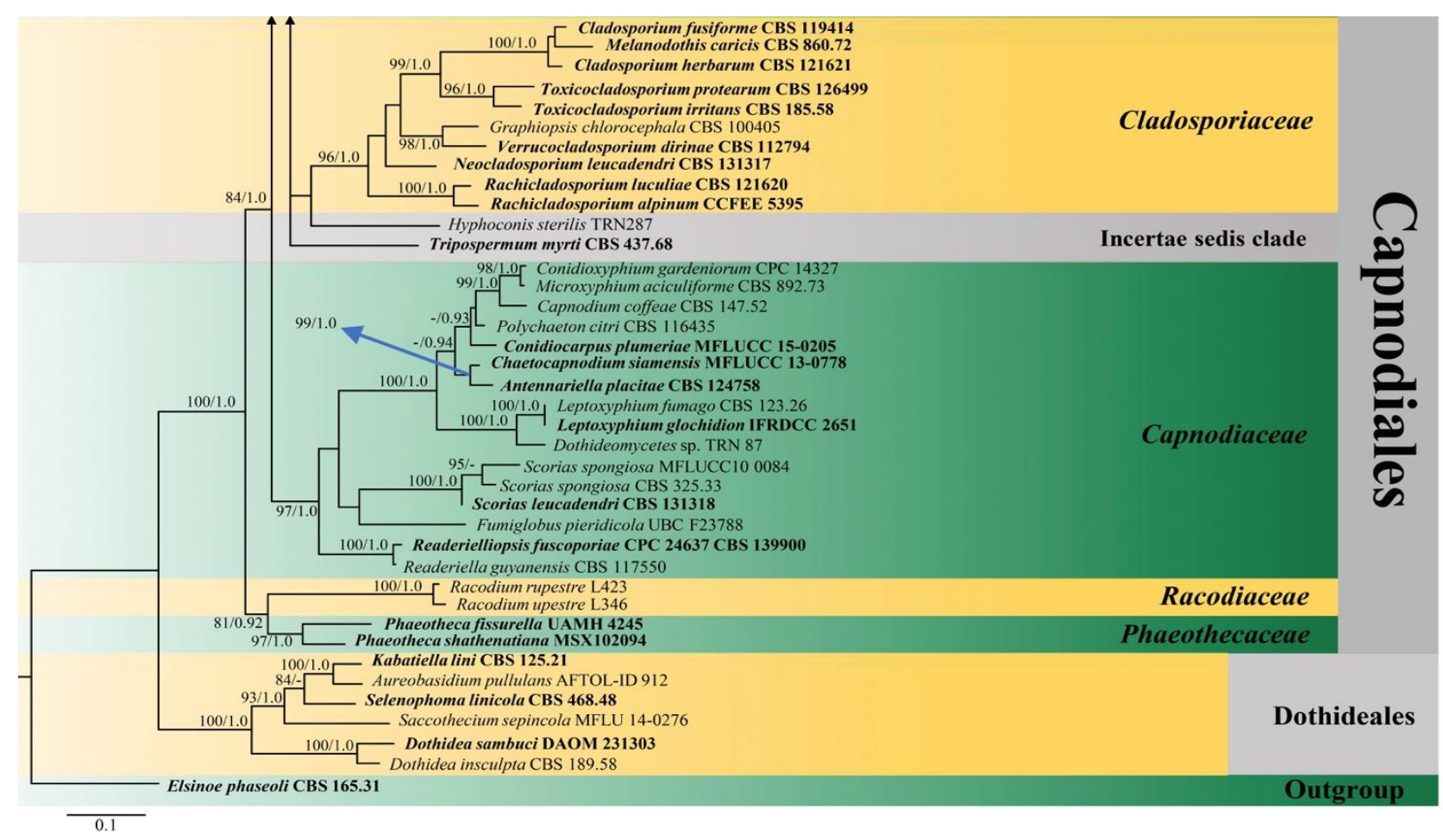

Figure 3 - Continued.

Accepted families: Aeminiaceae, Antennulariellaceae, Capnodiaceae, Cladosporiaceae, Cystocoleaceae, Dissoconiaceae, Euantennariaceae, Extremaceae, Johansoniaceae, Metacapnodiaceae, Mycosphaerellaceae, Neodevriesiaceae, Phaeothecaceae, Phaeothecoidiellaceae, Piedraiaceae, Racodiaceae, Schizothyriaceae, Teratosphaeriaceae and Xenodevriesiaceae.

Aeminiaceae J. Trovão, I. Tiago \& A. Portugal, in Trovão et al., MycoKeys 45: 62 (2019).

Index Fungorum number: IF 824975; Facesoffungi number: FoF 06985; 1 species

Halotolerant, xerophilic, and facultative alkaliphiles on deteriorated limestones. Sexual morph: Undetermined. Asexual morph: Mycelium septate, becoming wider, thick-walled, darker and developing into meristematic chains of conidia, hyphae smooth. Conidia globose, thick dark brown, with single central septa resulting from the differentiation of toruloid-like hyphal cells, smooth-walled, rugose (adapted from Trovão et al. 2019).

Type - Aeminium ludgeri J. Trovão, I. Tiago \& A. Portugal.

Notes - The family was introduced by Trovão et al. (2019) to accommodate a single genus Aeminium. Aeminiaceae contains a microcolonial black fungus occurring in deteriorated limestones. Phylogenetic analyses placed this family within Capnodiales (Trovão et al. 2019, this study).

Aeminium J. Trovão, I. Tiago \& A. Portugal, in Trovão et al., MycoKeys 45: 64 (2019).

Index Fungorum number: IF 824976; Facesoffungi number: FoF 06986; 1 morphological species (Species Fungorum 2020), 1 species with molecular data.

Type species - Aeminium ludgeri J. Trovão, I. Tiago \& A. Portugal.

Notes - The monotypic genus was established by Trovão et al. (2019), who also provided its description and illustration.

Aeminium ludgeri J. Trovão, I. Tiago \& A. Portugal, in Trovão et al., MycoKeys 45: 64 (2019).

Index Fungorum number: IF 824977; Facesoffungi number: FoF 08050.

Fig. 4

Description - see Trovão et al. (2019). 


\section{Ecological and economic significance}

Species in this family are halotolerant, xerophilic, and facultative alkaliphiles on deteriorated lime-stones. Microcolonial black fungi are one of the main factors of stone biodeterioration and correspond to aesthetic, biochemical, and biophysical alterations (Sterflinger 2000, 2010, Sterflinger \& Piñar 2013, Trovão et al. 2019).
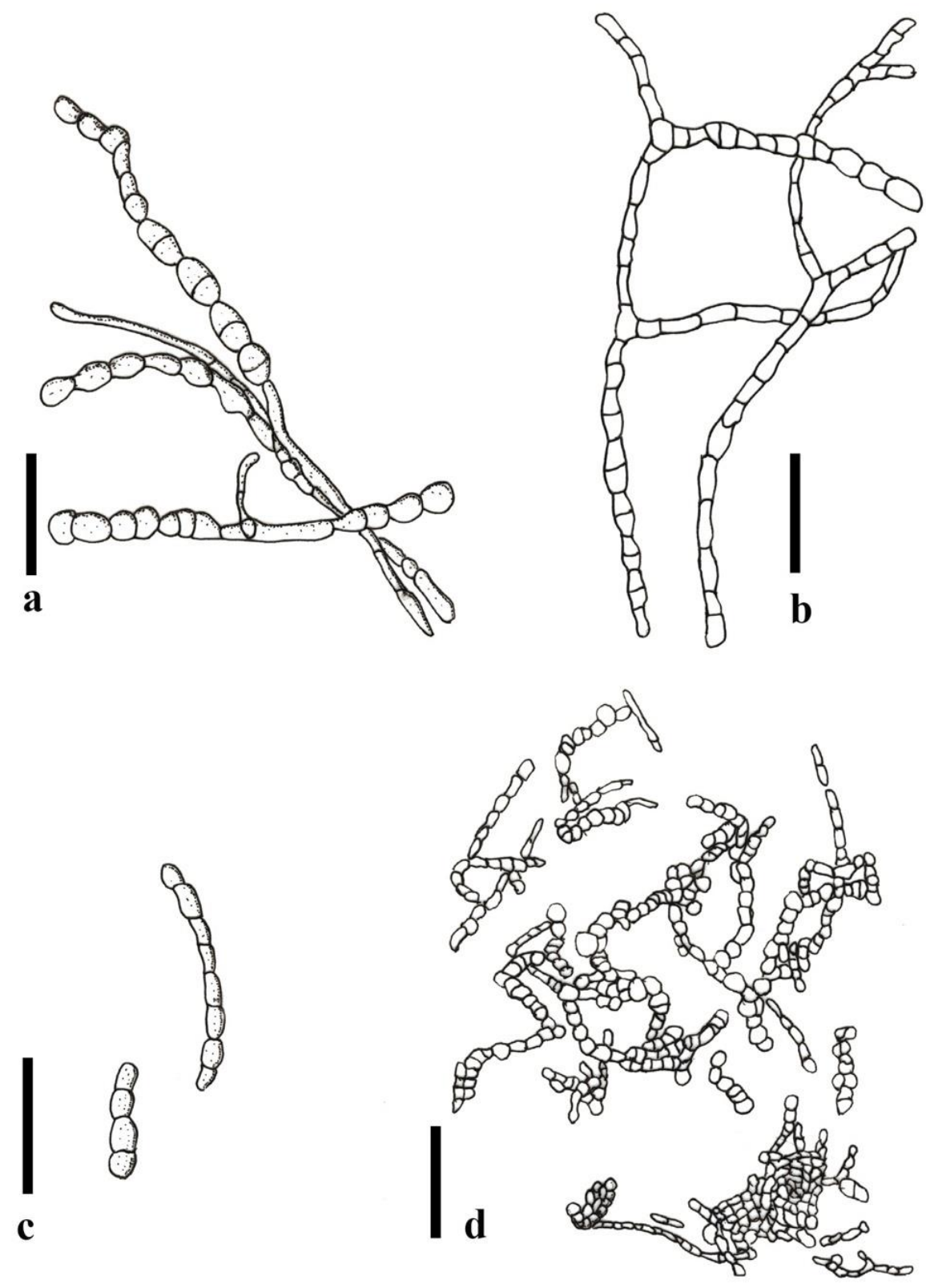

Figure 4 - Aeminium ludgeri (redrawn from Trovão et al. 2019). a Intercalary and terminal conidial chains. b Initial hyphae becoming toruloid-like. c Arthroconidia. d Toruloid-like hyphae and mature chains of arthroconidia. Scale bars: $a-c=20 \mu \mathrm{m}, d=50 \mu \mathrm{m}$.

Antennulariellaceae Woron., Annls mycol. 23(1/2): 178 (1925).

Index Fungorum number: IF 80461; Facesoffungi number: FoF 06951, 12 species.

Foliar epiphytes forming on the surface of leaves and twigs, sooty moulds on insect exudates. Subiculum dark brown to black, effuse, densely velutinous, somewhat dense or velvety. Hyphae cylindrical to moniliform, or regular, septate, deeply pigmented at the length margin, smooth or rough-walled. Erect hyphae dense or scant covering, broad and irregularly anastomosing in a network, brown to black. Sexual morph: Ascomata developing from repeated divisions of hyphae, 
subglobose, obovoid to broadly ellipsoidal, or ovoid, sessile, or with a robust stalk, brown to dark brown, with or without appendages, a central ostiole at maturity, arising from terminal or intercalary cells on aerial hyphae. Peridium thin-walled, pseudoparenchymatous. Asci 8-spored, bitunicate, fissitunicate, pyriform to ellipsoidal, or clavate. Ascospores 3-4-seriate, minute, ovoid, more or less oblong, hyaline, 1-3-septate, slightly constricted at the septum, upper cell slightly shorter and broader than the lower cell, rounded at both ends. Asexual morph: Coelomycetous or hyphomycetous. Coelomycetous (Antennariella): Pycnidia small, subglobose to obovoid, dark brown, on a short stalk or intercalary, somewhat lateral on conidiophores, with a short neck and ostioles at maturity. Pycnidial wall pseudoparenchymatous, smooth- or rough-walled. Conidiogenous cells minute, rare seen (Hughes 2000). Conidia minute, globose, more or less ellipsoidal, hyaline, aseptate (Hughes 1976). Hyphomycetous (Capnodendron): Hyphae cylindrical or irregular, septate, dark brown, smooth- or rough-walled. Conidiophores scattered or gregarious, velutinous, straight or irregularly bent, more or less cylindrical, barely different from aerial hyphae, arising as upright branches or upturned ends of hyphae, with variable in length, brown to dark brown, smooth- to rough-walled. Conidiogenous cell holoblastic, more or less ovoid, with a flat terminal, with a scar left by the fallen conidium, sessile. Conidia narrowly clavate to ellipsoidal or fusiform, straight or curved or irregularly curved, pale brown to dark brown, slightly constricted at the septa, rounded at the apex or scarred at both ends, smooth- or rough-walled, sometimes with longitudinal striations, gently or abruptly tapered at the base to a flattened or denticulate scar (Hughes 2000, Hyde et al. 2013, drawing of asexual characters can be seen in Hughes 1976).

Type - Antennulariella Woron.

Notes - Antennulariellaceae is a poorly known sooty mould family in Capnodiales. It was established by Woronichin (1925), with the generic type Antennulariella. Six genera were included in this family by Kirk et al. (2008). However, many studies included only three genera in this family, viz. Antennulariella, Achaetobotrys and Capnofrasera (Hyde et al. 2013, Chomnunti et al. 2014, Wijayawardene et al. 2017a). Wijayawardene et al. (2017b) excluded Capnofrasera from Antennulariellaceae based on its asexual morph characters without sequence data. Little sequence data are available in GenBank for Antennulariaceae (Cheewangkoon et al. 2009, Chomnunti et al. 2014). Phylogenetic placement of Antennulariaceae in Capnodiaceae, represented by the strain of Antennariella placitae, is doubtful (Cheewangkoon et al. 2009, Chomnunti et al. 2014). Due to the morphological differences, Antennulariellaceae was not considered to be a synonym of Capnodiaceae. Molecular data is therefore required to resolve its phylogenetic placement, and explain relationships between the sexual and asexual morphs of its various possible asexual genera.

Antennulariella Woron., Trudy Byuro Prikl. Bot. 8(6): 771 (1915).

Index Fungorum number: IF 221; Facesoffungi number: FoF 06951; 5 morphological species (Species Fungorum 2020), 1 species with molecular data (doubtful placement).

Type species - Antennulariella fuliginosa Woron.

Notes - Antennulariella was introduced by Woronichin (1915), with its asexual morph Antennariella. However, Antennariella was synonymized under Antennulariella due to the concept of one name for one fungus (Hyde et al. 2013). Discussions on some species of Antennulariella were provided by Hyde et al. (2013). Only one species, Antennulariella placitae (= Antennariella placitae) has sequence data available in GenBank, however the phylogenetic placement of this family cannot be resolved by this sequence data.

Antennulariella concinna (L.R. Fraser) S. Hughes, Mycologia 68(4): 719 (1976).

Fig. 5

$\equiv$ Limacinia concinna L.R. Fraser, Proc. Linn. Soc. N.S.W. 60(3-4): 171 (1935).

Index Fungorum number: IF 308726; Facesoffungi number: FoF 06952.

Mycelium superficial, cylindrical or "tube"-like, brown to dark brown, septate, smoothwalled, with constricted at and dark each septum, narrow at end cell. Sexual morph: Ascomata subglobose, developing on mycelium, with ostioles at maturity, smooth or roughened walls, dark brown to black. Hamathecium not observed in this study. Asci 8-spored, bitunicate, ellipsoid to cylindrical, with short pedicel. Ascospores overlapping, 1-3-seriate, clavate, 1-septate, 2-layered, 
slightly constricted at septum, upper cell shorter and wider lower cell, hyaline, smooth-walled to verrucose. Asexual morph: Undetermined.

Material examined - New Zealand, Auckland, Jack's Bay, Russell, on Leptospermum scoparium, 16 September 1967, J.M. Dingley (PDD 26126, non-type).

Notes - The holotype specimen of Antennulariella fuliginosa was illustrated in Hyde et al. (2013), however figures of asci and ascospores were presented as drawings. Here, we illustrate asci and ascospores of Antennulariella species using a specimen of $A$. concinna from PDD, however measurements are unavailable (Fig. 5).

\section{Other genera included}

Achaetobotrys Bat. \& Cif., Saccardoa 2: 49 (1963).

Index Fungorum number: IF 36; Facesoffungi number: FoF 06953; 3 morphological species (Species Fungorum 2020), molecular data unavailable.

Type species - Achaetobotrys affinis (L.R. Fraser) Bat. \& Cif., Saccardoa 2: 49 (1963).

$\equiv$ Henningsomyces affinis L.R. Fraser, Proc. Linn. Soc. N.S.W. 60(3-4): 172 (1935).

Notes - The genus has obovoid to broadly ellipsoidal ascostromata, lacking hyphal appendages (Hyde et al. 2013), multi-septate ascospores (based on isotype specimen of Achaetobotrys affinis in Chomnunti et al. 2014).

Eumela Syd., Annls mycol. 23(3/6): 335 (1925).

Index Fungorum number: IF 1925; Facesoffungi number: FoF 06241; 4 morphological species (Species Fungorum 2020), molecular data unavailable.

Type species - Eumela chiococcae Syd., Annls mycol. 23(3/6): 335 (1925).

Notes - The genus was placed in Pseudoperisporiaceae (Hyde et al. 2013, Kirk et al. 2013), and was treated as genus incertae sedis in Dothideomycetes by Boonmee et al. (2017). Pem et al. (2019c) included this genus in Antennulariellaceae based on its superficial subglobose to globose ascomata, with hyphal appendages, aparaphysate, and clavate to ellipsoidal, 8-spored asci (Pem et al. 2019c).

\section{Ecological and economic significance}

Species in Antennulariellaceae are poorly studied. There are no reports on their ecological and economic significance whether harmful to plants/animals or some interesting activity which might be beneficial to society. According to its appearance as a sooty mould, we assume that it has negative effects on photosynthesis affecting physiological metabolism of the plant, lower growth rates and reduced yields (Nelson 2008, Laemmlen 2011, Hyde el al. 2013, Santos et al. 2013). Interactions between Antennulariellaceae, insects and plants are still doubtful due to lack of information.

Capnodiaceae Höhn. ex Theiss., Verh. zool.-bot. Ges. Wien 66: 363 (1916).

Index Fungorum number: IF 91154; Facesoffungi number: FoF 06943, 91 species

Saprobic on honey dew produced by insects, forming blackened thalli on leaves, stems, bark, and even rocks. Thallus comprises a black, superficial, mycelial network, covering the host surface. Mycelium composed of septate, cylindrical, brown, filamentous hyphae. Sexual morph: Ascomata superficial on mycelial mass, subglobose to globose, coriaceous, with or without setae, dark brown to black, with a central ostiole. Peridium relatively thin, comprising brown, cells of textura angularis. Hamathecium lacking pseudoparaphyses. Asci 8-spored, bitunicate, with a short pedicel, lacking an ocular chamber. Ascospores 2-seriate, hyaline to brown, multi-septate or muriform. Asexual morph: Coelomycetous. Conidiomata pycnidial, elongate, with short or long narrow necks, with or without a swollen part. Ostiole hyaline to pale brown, located at the neck apex. Conidia produced within the pycnidia in the swollen part, ellipsoidal, small, 1-celled, hyaline, with or without guttules. 


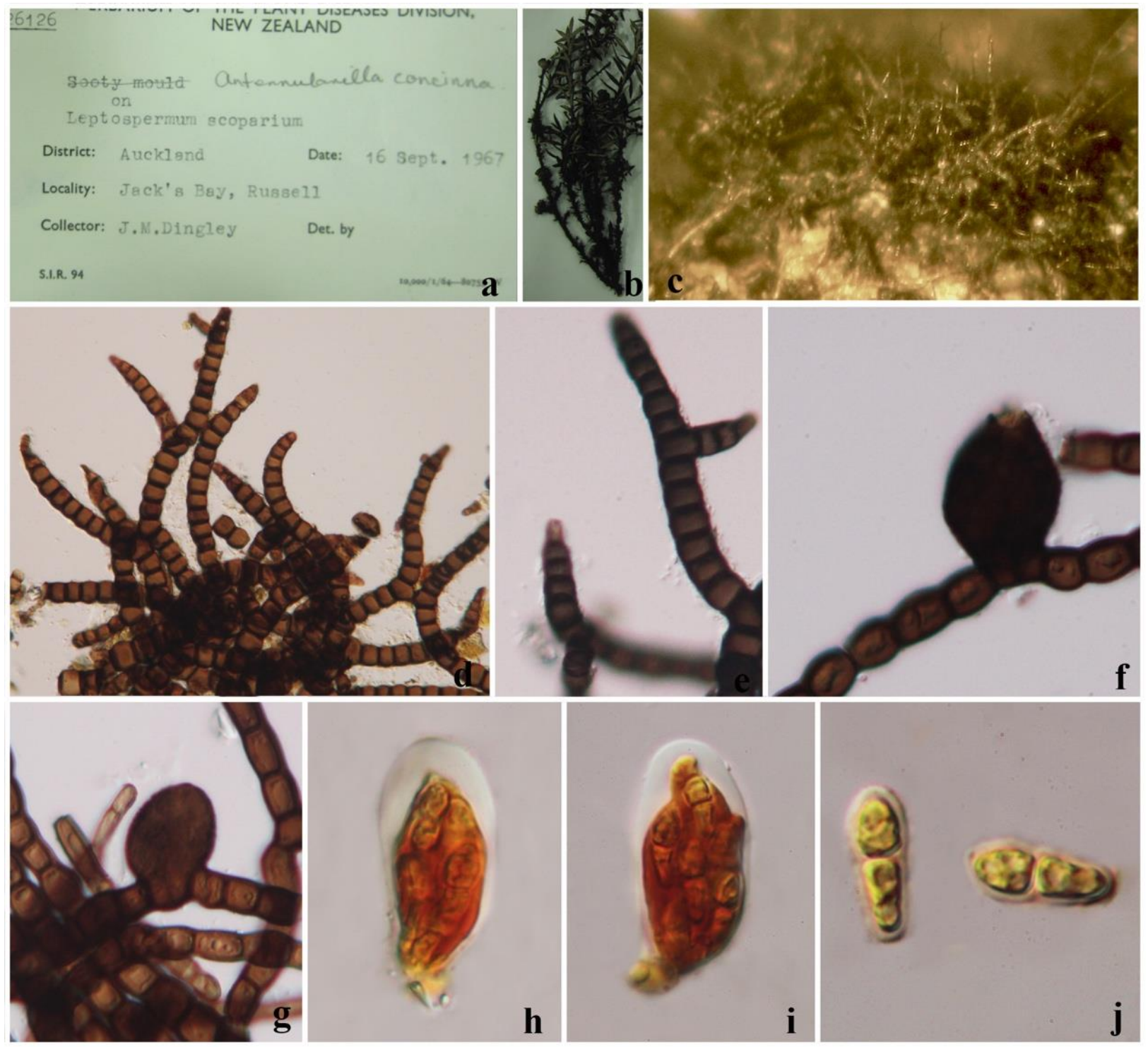

Figure 5 - Antennulariella concinna (PDD 26126). a-b Specimen and descriptions. c Ascomata on substrate. d-e Septate mycelium. f-g Ascomata. $h-i$ Ascus stained in Melzer's reagent. j Ascospores stained in Melzer's reagent.

Type - Capnodium Mont.

Notes - Capnodiaceae was introduced by Höhnel (1909c) and validated by Theissen (1916) (von Arx \& Müller 1975, Hughes 1976). Kirk et al. (2008) concluded that the family comprises 26 genera, while 13 genera were accepted by Lumbsch \& Huhndorf (2010). Chomnunti et al. (2011, 2014) accepted only six genera based on the morphology of type specimens. Ariyawansa et al. (2015a) introduced Chaetocapnodium to this family based on morphology and phylogeny. Bose et al. (2014) synonymized Phragmocapnias under Conidiocarpus. There are some rock-inhabiting taxa included within Capnodiaceae such as rock-isolate TRN87.

Aithaloderma was included in Capnodiaceae (Sydow \& Sydow 1913a, Reynolds \& Gilbert 2005, Wijayawardene et al. 2017a). We do not accept Aithaloderma in this family following Chomnunti et al. (2011) who studied the isotype specimen of Aithaloderma clavatisporum and concluded that Aithaloderma are similar to those found in Chaetothyriaceae. Plurispermiopsis was referred to Capnodiaceae by Wijayawardene et al. (2017a). However, we treat Plurispermiopsis as genus incertae sedis in Capnodiales based on its glabrous ascomata containing asci with up to 64 hyaline, short appendiculate, 1-2-(rarely 3)-septate ascospores (Pereira-Carvalho et al. 2010). Therefore, Capnodiaceae comprises Chaetocapnodium, Capnodium, Conidiocarpus, Fumiglobus, Leptoxyphium, Limaciniaseta, Readerielliopsis, Scoriadopsis and Scorias. 
Most of the species in Capnodiaceae are sooty moulds, forming hyphal networks that cover the surface of hosts. Based on the MCC tree in this study, we found that Capnodiaceae diverged as a first group from a common ancestor of Capnodiales and most of its members are saprobic. However, more collections of both rock-inhabiting fungi and saprobes of Capnodiaceae are needed to confirm the evolutionary history of a few extremotolerant taxa in the early divergence. It is possible that sooty moulds evolved in association with insects first, and later evolved into rock inhabiting taxa. The plant feeding insects would have dropped their honey dews onto the rocks Capnodium is the type genus of Capnodiaceae, and it was established by Montagne (1849) based on Fumago citri (Friend 1965). Capnodium is the sexual morph of Polychaeton, thus Capnodium was selected for conservation under the "1F1N" by Chomnunti et al. (2011). There are little sequence data for Capnodium species available in GenBank. More collections and sequence data are needed.

Capnodium Mont. Annls Sci. Nat., Bot., sér. 311: 233 (1849).

Index Fungorum number: IF 809; Facesoffungi number: FoF 06944; 40 morphological species (Species Fungorum 2020), 5 species with molecular data.

Type species - Capnodium salicinum Mont., Annls Sci. Nat., Bot., sér. 3 11: 234 (1849).

Notes - Capnodium is the type genus of Capnodiaceae, and it was established by Montagne (1849) based on Fumago citri (Friend 1965). Capnodium is the sexual morph of Polychaeton, thus Capnodium was selected for conservation under the "1F1N" by Chomnunti et al. (2011). There are little sequence data for Capnodium species available in GenBank. More collections and sequence data are needed.

\section{Other genera included}

Chaetocapnodium Hongsanan \& K.D. Hyde, in Liu et al., Fungal Diversity 72: 68 (2015).

Index Fungorum number: IF 550888; Facesoffungi number: FoF 00399; 1 morphological species (Species Fungorum 2020), 1 species with molecular data.

Type species - Chaetocapnodium siamensis Hongsanan \& K.D. Hyde, in Liu et al., Fungal Diversity: 72:69 (2015).

Notes - Chaetocapnodium is accepted in Capnodiaceae based on its saprobic habitat as sooty moulds, dark, superficial thalli on plant surfaces, and subglobose to globose ascomata with a central ostiole. Chaetocapnodium differs from other genera in having ascomatal setae (Liu et al. 2015). Phylogenetic analyses also supported its status in Capnodiaceae (Liu et al. 2015).

Conidiocarpus Woron., Key to fungi (fungi imperfecti) 2: 743 (1917).

= Phragmocapnias Theiss. \& Syd., Annls mycol. 15(6): 480 (1918) [1917]

Index Fungorum number: IF 7751; Facesoffungi number: FoF 06946; 13 morphological species (Bose et al. 2014, Index Fungorum 2020), 7 species with molecular data. (1927).

Type species - Conidiocarpus penzigii Woron. [as 'penzigi'], Annls mycol. 25(3/4): 250

$\equiv$ Phragmocapnias penzigii (Woron.) Chomnunti \& K.D. Hyde, in Chomnunti et al., Fungal Diversity 51(1): 112 (2011).

Notes - Conidiocarpus is the asexual morph of Phragmocapnias. Phragmocapnias was synonymized under Conidiocarpus based on the rules of nomenclatural priority (Bose et al. 2014, Hongsanan et al. 2015b). Conidiocarpus forms a dark, thin thallus, which comprises radiating, septate hyphae, easily removed from the host surfaces. Its sexual morph has superficial ascomata, with ascomatal setae, asci with short pedicel or sometimes apedicellate, and cylindrical to clavate, multi-septate, hyaline ascospores (Hongsanan et al. 2015b). The asexual morph of Conidiocarpus has black stalked pycnidia, with an upper brown swollen region producing conidia, ostiole surrounded by hyaline hyphae, ellipsoid, 1-celled, hyaline conidia (Chomnunti et al. 2011).

Fumiglobus D.R. Reynolds \& G.S. Gilbert, Cryptog. Mycol. 27(3): 252 (2006). 
Index Fungorum number: IF 7751; Facesoffungi number: FoF 06947; 6 morphological species (Species Fungorum 2020), 1 species with molecular data.
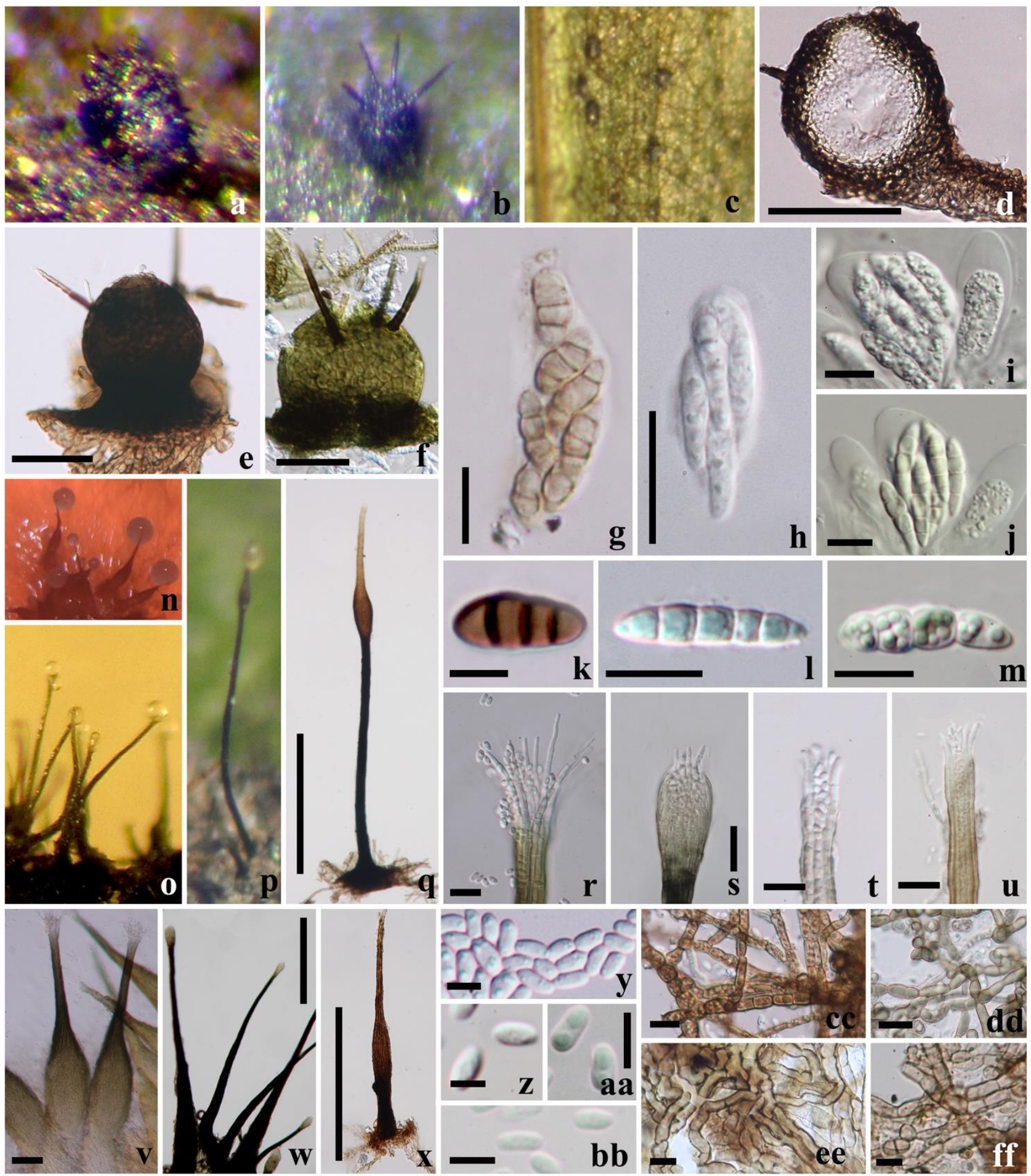

Figure 6 - Morphology of selected genera in Capnodiaceae. a-c Ascomata on the surface of leaves. $d$ Section through ascoma. e, f Ascomata when viewed in squash mounts. $g-i$ Asci. $j$ Asci in Melzer's reagent. k-m Ascospores. $n-p$ Pycnidia on surface of plants. $q, v-x$ Pycnidia when viewed in squash mount. $\mathrm{r}-\mathrm{u}$ Ostiole surrounded by hyaline hyphae. $\mathrm{y}-\mathrm{bb}$ Conidia. cc-ff Hyphal networks. Notes - a, d, g, $\mathrm{k}=$ Chaetocapnodium siamense $: \mathrm{b}, \mathrm{e}, \mathrm{h}, \mathrm{l}=$ Conidiocarpus plumeriae $: \mathrm{f}, \mathrm{i}, \mathrm{j}, \mathrm{m}=$ Conidiocarpus philippinensis: $\mathrm{t}, \mathrm{x}, \mathrm{z}, \mathrm{ff}=$ Capnodium coffeae $: \mathrm{p}, \mathrm{q}, \mathrm{u}, \mathrm{bb}$, ee $=$ Conidiocarpus $\mathrm{sp}$ : $\mathrm{o}, \mathrm{s}, \mathrm{w}, \mathrm{aa}, \mathrm{dd}=$ Leptoxyphium glochidion: $\mathrm{n}, \mathrm{r}, \mathrm{v}, \mathrm{y}, \mathrm{cc}=$ Scorias mangiferae. Scale bars: $\mathrm{w}=200$ $\mu \mathrm{m}, \mathrm{d}, \mathrm{q}, \mathrm{x}=100 \mu \mathrm{m}, \mathrm{e}, \mathrm{f}, \mathrm{v}=50 \mu \mathrm{m}, \mathrm{h}, \mathrm{s}=20 \mu \mathrm{m}, \mathrm{g}, \mathrm{i}, \mathrm{j}, \mathrm{l}, \mathrm{m}, \mathrm{aa}, \mathrm{dd}=10 \mu \mathrm{m}, \mathrm{k}, \mathrm{r}, \mathrm{u}, \mathrm{y}, \mathrm{bb}, \mathrm{cc}, \mathrm{ee}$, $\mathrm{ff}=5 \mu \mathrm{m}$. 
Type species - Fumiglobus ficinus (Bat., Nascim. \& Cif.) D.R. Reynolds \& G.S. Gilbert [as 'ficina'], Cryptog. Mycol. 27(3): 253 (2006).

三Asbolisia ficina Bat., Nascim. \& Cif., in Batista \& Ciferri, Quad. Lab. crittogam., Pavia 31: $41(1963)$.

Notes - Fumiglobus was introduced by Reynolds \& Gilbert (2006). It is characterised by pyriform bulbous pycnidia, with multi-seriate stalks, and round to slightly oval, hyaline conidia that often adhere in short chains. The first sequence data was provided by Bose et al. (2014). Their phylogenetic tree showed the placement of this genus based on Fumiglobus pieridicola within Capnodiaceae.

Leptoxyphium Speg., Physis, B. Aires 4: 294 (1918).

Index Fungorum number: IF 8762; Facesoffungi number: FoF 06949; 17 morphological species (Species Fungorum 2020), 5 species with molecular data.

Type species - Leptoxyphium graminum (Pat) Speg., Physis. B. Aires 4: 294 (1918).

三 Capnodium graminum Pat., J. Bot., Paris 11: 348 (1897).

Notes - Leptoxyphium was established by Spegazzini (1918). Members of this genus are sooty moulds and commonly found as asexual morphs. Its pynidia differ from other genera by a narrow bulbous base, with cup-like apex, which produces conidia.

Limaciniaseta D.R. Reynolds, Madroño 45(3): 250 (1998).

Index Fungorum number: IF 27922; Facesoffungi number: FoF 06948; 1 morphological species (Species Fungorum 2020), 1 species with unpublish molecular data.

Type species - Limaciniaseta californica D.R. Reynolds, Madroño 45(3): 250 (1998).

Notes - The characters of this genus are quite similar to Chaetocapnodium by ascomatial setae surrounding an ostiole. However, they differ in the clustered or solitary ascomata, and characters of basal ascomata. Molecular data is needed to confirm the relationship between Chaetocapnodium and Limaciniaseta. A short SSU sequence data of Limaciniaseta californica that is available in GenBank (2020) is insufficient to include in phylogenetic analyses.

Readerielliopsis Crous \& Decock, Persoonia 34: 195 (2015).

Index Fungorum number: IF 812436; Facesoffungi number: FoF 01736; 2 morphological species (Species Fungorum 2020), 2 species with molecular data.

Type species - Readerielliopsis fuscoporiae Crous \& Decock, Persoonia 34: 195 (2015).

Notes - The genus was established by Crous et al. (2015c). Readeriellopsis differs from Readeriella in having phialidic conidiogenesis, aggregated, with somewhat papillate conidiomata, while Readeriella has phialides with percurrent proliferation, and separate, apapillate conidiomata (Crous et al. 2015c). Phylogenetic placement of this genus within Capnodiaceae was supported in analyses of Crous et al. (2015c). The genus was treated as incertae sedis in Capnodiales by Wijayawardene et al. (2016a, 2017a). However, Readerielliopsis forms a lineage within Capnodiaceae in Wijayawardene et al. (2016a) and our analyses (Fig. 3). Therefore, we accept this genus in Capnodiaceae.

Scoriadopsis J.M. Mend., in Stevens, Annls mycol. 28 (5/6): 365 (1930).

Index Fungorum number: IF 4966; Facesoffungi number: FoF 06950; 1 morphological species (Species Fungorum 2020), molecular data unavailable.

Type species - Scoriadopsis miconiae J.M. Mend., in Stevens, Annls mycol. 28 (5/6): 365.

Notes - Scoriadopsis is poorly studied and contains a single species without molecular data. Scoriadopsis was recognized based on its sexual morph characters. It is closely associated with Meliola, and has globose or ovoid ascoma, with ostiolate, pedicellate, gelatinous, ovate asci, fusiform, 1-septate ascospores (Chomnunti et al. 2011).

Scorias Fr. Syst. mycol. 3(2): 269, 290 (1832). 
Index Fungorum number: IF 4966; Facesoffungi number: FoF 01060; 10 morphological species (Species Fungorum 2020), 5 species with molecular data.

Type species - Scorias spongiosa (Schwein.) Fr., Syst. mycol. 3(2): 291 (1832).

三Botrytis spongiosa Schwein., Schr. naturf. Ges. Leipzig 1: 127 [101 of repr.] (1822)

Notes - Scorias is also a sooty mould. Its asexual morph characters are similar to Leptoxyphium, but pycnidia are short and wide at the base in Scorias, while long pycnidia with narrow base in Leptoxyphium. The sexual morph of Scorias is characterised by subglobose to broadly ellipsoidal, dark brown to blackish, shiny ascomata, with short stalk, oblong to saccate asci, and fusiform, with 3-4 trans-septa, hyaline ascospores (Chomnunti et al. 2011). Phylogenetic analyses indicated that Scorias is a distinct genus in Capnodiaceae.

\section{Ecological and economic significance}

Capnodiaceae includes many species which are of economic importance. They play a negative role by forming black, hyphal networks on the surface of plants, especially on fruits (i.e. Conidiocarpus spp., Leptoxyphium spp.). Thus, they are important as they reduce the marketability of fruits and reduce photosynthesis of host plants (Chomnunti et al. 2014, Hongsanan et al. 2016a).

Cladosporiaceae Nann., Repert. mic. uomo: 404 (1934).

Index Fungorum number: IF 80600; Facesoffungi number: FoF 06966, 356 species.

Diverse habitats. Sexual morph: Ascomata immersed to superficial, scattered or gregarious, brown to black, globose to subglobose, uniloculate, with or without ostiolar necks. Ostiole necks, with numerous periphysoids. Peridium composed of several layers of brown, thickened cells of usually textura angularis. Hamathecium comprising hyaline, septate, subcylindrical pseudoparaphyses. Asci 8-spored, bitunicate, hyaline, smooth, sessile to subsessile, obovoid to ellipsoid or subcylindrical, with or without apical ring. Ascospores fasciculate, obovoid, guttulate, ellipsoid to fusiform, hyaline to pale brown, septate, smooth to slightly roughened, mucous sheath sometimes present. Asexual morph: Hyphomycetous. Colonies on natural substrate effuse, greyish brown to brown, velvety. Mycelium mostly immersed, composed of branched, septate, pale brown, smooth to minutely verruculose hypha. Conidiophores macronematous, mononematous, solitary, arising terminally and laterally from hyphae, erect, straight to slightly flexuous, cylindrical, oblong to filiform, sometimes geniculate, unbranched or branched. Conidiogenous cells mostly polyblastic, integrated, terminal and intercalary, often distinctly sympodially proliferating, filiform, cylindrical to oblong, conspicuous, subdenticulate to denticulate. Conidia catenate, in densely branched, acropetal chains, straight to slightly curved, subhyaline to brown, smooth or verruculose; terminal conidia globose, subglobose to obovoid, broadly rounded at the apex, intercalary conidia subglobose, broadly ellipsoid-ovoid, aseptate, with distal hila, often distinctly denticulate (photoplates of asexual can be seen in Schubert et al. 2007b, Bensch et al. 2010, 2012).

Type - Cladosporium Link.

Notes - Nannizzi (1934) introduced Cladosporiaceae to accommodate Cladosporium which is one of the largest genera of dematiaceous hyphomycetous. Braun et al. (2003) proposed a new genus Davidiella and confirmed it as the sexual morph of Cladosporium based on molecular data. The new genus was placed in Mycosphaerellaceae (Braun et al. 2003). However, Aptroot (2006) reported that the characters of ascospores in Davidiella are distinct from those of Mycosphaerella. Schoch et al. (2006) performed phylogenetic analysis using four nuclear loci (LSU, SSU, rpb-2 and tef1) and separated Davidiella into a different family from Mycosphaerella (Mycosphaerellaceae). Thus, a new family Davidiellaceae was introduced to accommodate Davidiella with its Cladosporium asexual morphs. However, Cladosporiaceae (1934) predates Davidiellaceae (2006) in Capnodiales. Cladosporiaceae comprises nine genera. Wijayawardene et al. (2014b) proposed to adopt Cladosporium over Davidiella.

Cladosporium Link, Mag. Gesell. naturf. Freunde, Berlin 7: 37 (1816) [1815].

Index Fungorum number: IF 7681; Facesoffungi number: FoF 06967; 316 morphological species (Species Fungorum 2020), 134 species with molecular data. 
Type species - Cladosporium herbarum (Pers.) Link.

$\equiv$ Dematium vulgare Pers., Mycol. eur. (Erlanga) 1: 13 (1822).

Notes - Cladosporium is one of the largest genera of hyphomycetous and is wellcircumscribed by coronate conidiogenous loci, intercalary ramoconidia and conidia in acropetal chains with hila (Bensch et al. 2010, 2012). Bensch et al. (2012) accepted 169 species in Cladosporium sensu stricto in their monographic work of the genus. Subsequently, Bensch et al. (2015) described 19 new species and provided an emended species description. Bensch et al. (2018) isolated Cladosporium from indoor environments, and more than 230 species were accepted. Three major species complexes, i.e. C. cladosporioides, $C$. herbarum and $C$. sphaerospermum are recognized in Cladosporium (Schubert et al. 2007b, 2009, Dugan et al. 2008, Bensch et al. 2010, 2015)

Cladosporium pseudocladosporioides Bensch, Crous \& U. Braun, Studies in Mycology 67: 71 (2010).

Index Fungorum number: IF 517087; Facesoffungi number: FoF 06968.

Saprobic on Nelumbo sp. Colonies on natural substrate effuse, black, velvety. Sexual morph: Undetermined. Asexual morph: Hyphomycetous. Mycelium partly immersed, partly superficial, composed of branched, septate hyphae. Conidiophores up to $250 \mu \mathrm{m}$ long, 4.0-7.5 $\mu \mathrm{m}$ wide, macronematous, mononematous, erect, straight to slightly flexuous, cylindrical, brown, paler towards apex, hyaline at apex, unbranched, septate, not constricted in the septum, smooth-walled, thick-walled. Conidiogenous cells 16-38 $\times 4-6 \mu \mathrm{m}$, polyblastic, integrated, terminal, subhyaline to pale brown, cylindrical, subdenticulate. Conidia 7-20 $\times 4-6.5 \mu \mathrm{m}(\bar{x}=12 \times 5 \mu \mathrm{m}, \mathrm{n}=30)$, catenate, small terminal conidia globose, subglobose to obovoid, subhyaline to pale brown, aseptate, broadly rounded at the apex; intercalary ramoconidia conidia subglobose, broadly ellipsoid-ovoid, pale brown to median brown, 0-3 septate, with distal hila.

Material examined - China, Guizhou, Xingyi, Anlong, on leaves of Nelumbo sp. (Nelumbonaceae), 27 October 2017, Yao Feng, AL-7 (GZAAS 20-0006), living culture GZCC 200010 .

Culture characteristics - Conidia germinating on water agar media within $24 \mathrm{~h}$. Germ tubes produced from one or both ends. Colonies on PDA circular, edge entire, mycelia dense, greyish brown from above, dark brown from below.

Notes - Bensch et al. (2010) introduced C. pseudocladosporioides. This species has been reported worldwide on diverse hosts, as well as isolated from air and soil (Bensch et al. 2010, 2012, 2018). Cladosporium pseudocladosporioides belongs to C. cladosporioides complex (Bensch et al. 2015). In the phylogenetic analyses (Fig. 8), our strain formed a strongly supported clade with eight C. pseudocladosporioides strains.

\section{Other genera included}

Acroconidiella J.C. Lindq. \& Alippi, Darwiniana 13 (2-4): 612 (1964).

Index Fungorum number: IF 7030; Facesoffungi number: FoF 06629; 5 morphological species (Species Fungorum 2020), molecular data unavailable.

Type species - Acroconidiella tropaeoli (T.E.T. Bond) J.C. Lindq. \& Alippi, Darwiniana 13 (2-4): 613 (1964).

三Heterosporium tropaeoli T.E.T. Bond, Ceylon J. Sci., Sect. A 12: 185 (1947).

Notes - Acroconidiella is characterized by macronematous, mononematous, mostly unbranched conidiophores, polytretic, terminal conidiogenous cells, and ellipsoidal, septate conidia (Ellis 1971,1976, Prasher \& Verma 2015). Prasher \& Verma (2015) provided morphological comparison of Acroconidiella species. Fresh collections are required to resolve its phylogenetic placement, since no molecular data are available for this genus.

Davidiellomyces Crous, Persoonia 38: 251 (2017).

Index Fungorum number: IF 820929; Facesoffungi number: FoF 06630; 2 morphological species (Species Fungorum 2020), 2 species with molecular data. 

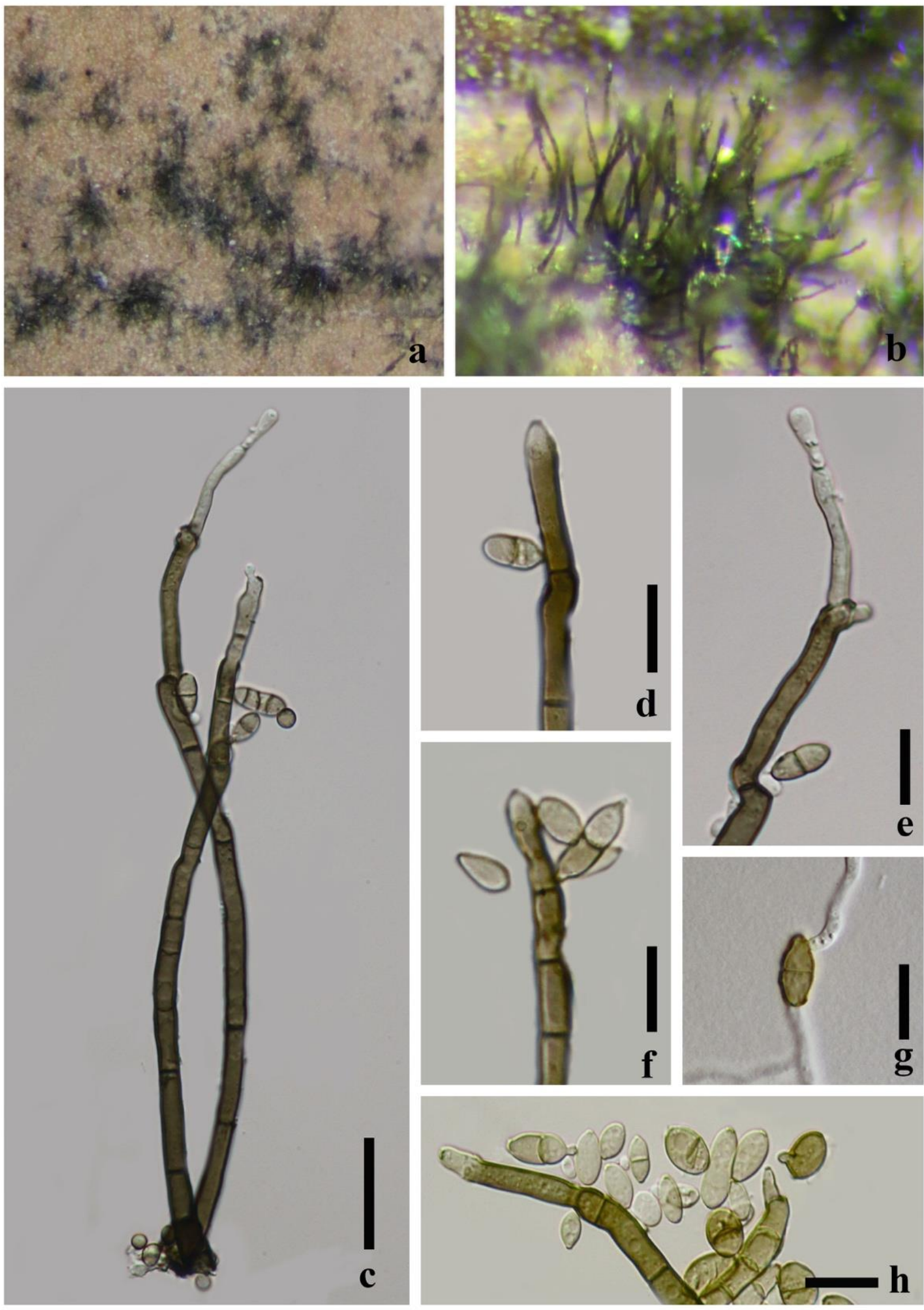

Figure 7 - Cladosporium pseudocladosporioides (GZAAS 20-0006). a, b Colonies on natural substrate $\mathrm{c}, \mathrm{h}$ Conidiophores and conidia d-f Conidiogenous cells g Germinated conidium Scale bars: $\mathrm{c}=30 \mu \mathrm{m}, \mathrm{d}-\mathrm{h}=15 \mu \mathrm{m}$. 


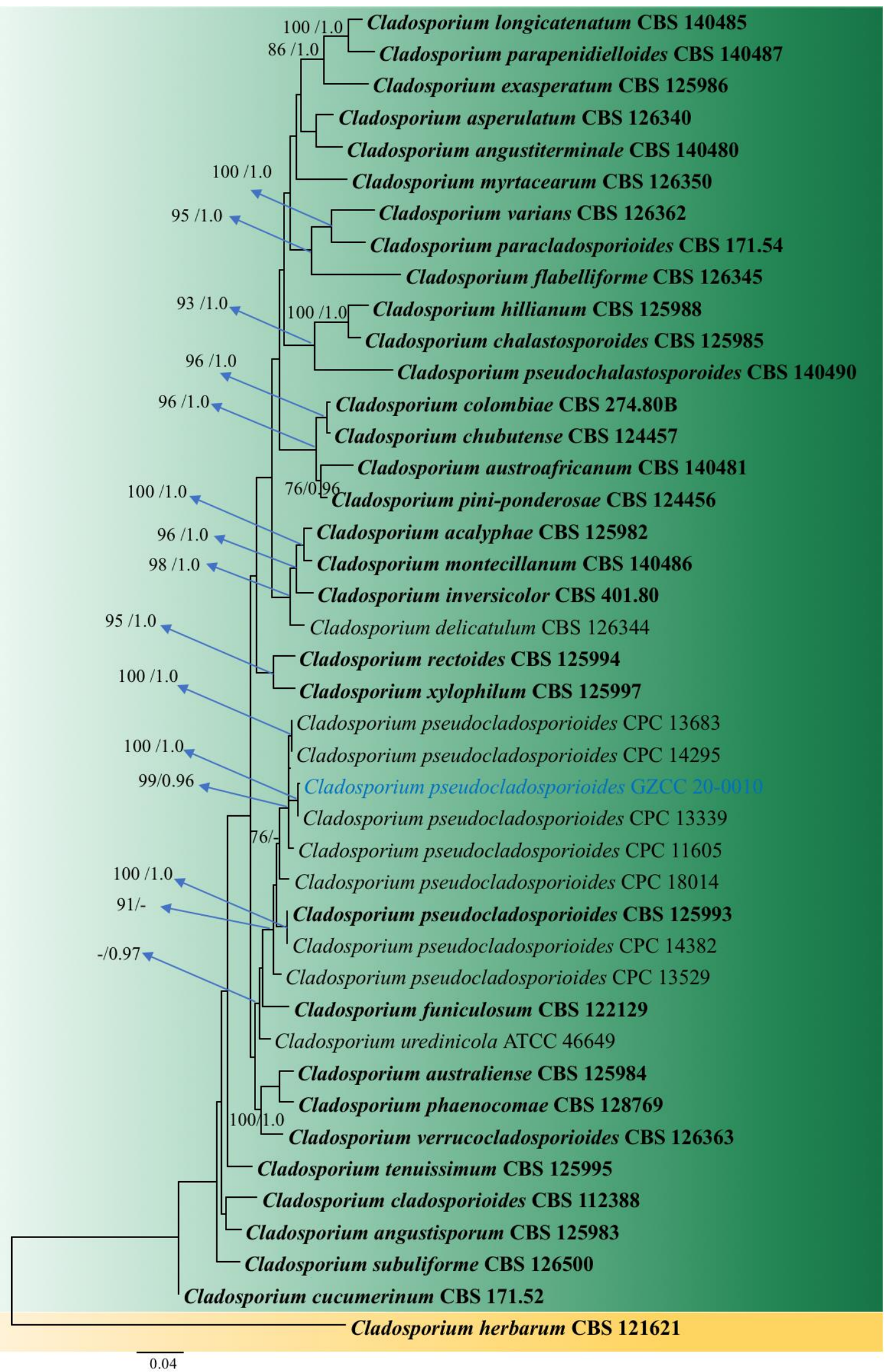

Figure 8 - Phylogram generated from maximum likelihood analysis (RAxML) of Cladosporium species based on ACT, ITS and tef1 genes. sequence data. Maximum likelihood bootstrap values equal or above $70 \%$, Bayesian posterior probabilities equal or above 0.90 (MLBS/PP) are given at the nodes. An original isolate number is noted after the species name. The tree is rooted to Cladosporium herbarum (CBS 121621). The ex-type strains are indicated in bold. Newly sequence data is in blue. Hyphen (-) represents support values below $70 \%$ MLBS and 0.90 PP. 
Type species - Davidiellomyces australiensis Crous, Persoonia 38: 251 (2017).

Notes - Davidiellomyces is a monotypic genus with the type species, D. australiensis, which was collected on leaves of Cyperaceae in Australia. The sexual morph of Davidiellomyces is characterized by globose, black, ostiolate ascomata, 8-spored, bitunicate, obovoid to broadly ellipsoid asci, and multi-seriate, hyaline, guttulate, 1-septate, fusoid-ellipsoidal ascospores with obtuse ends and mucoid sheath (Crous et al. 2017b). The asexual morph is undetermined.

Graphiopsis Trail, Scottish Naturalist 10: 75 (1889).

$\equiv$ Dichocladosporium K. Schub., U. Braun \& Crous, Stud. Mycol. 58: 96 (2007).

Index Fungorum number: IF 820929; Facesoffungi number: FoF 06631; 1 morphological species (Species Fungorum 2020), 1 species with molecular data

Type species - Graphiopsis chlorocephala (Fresen.) Trail, Scottish Naturalist 10: 75 (1889).

三Periconia chlorocephala Fresen., Beitr. Mykol. 1: 21 (1850).

Notes - Schubert et al. (2007a) assigned Cladosporium chlorocephalum to a new genus Dichocladosporium. However, Dichocladosporium was regarded as a synonym under Graphiopsis by Braun et al. (2008). Since all the Graphiopsis species were introduced before 1936, none of them has molecular data except $G$. chlorocephala. The type species is characterized by dimorphic fruiting bodies (Schubert et al. 2007a, Braun et al. 2008).

Neocladosporium J.D.P. Bezerra, Sand.-Den., Souza-Motta \& Crous, IMA Fungus 8 (1): 87 (2017).

Index Fungorum number: IF 820266; Facesoffungi number: FoF 06633; 1 morphological species (Bezerra et al. 2017), 1 species with molecular data.

Type species - Neocladosporium leucadendri (Crous) J.D.P. Bezerra, Sand.-Den., SouzaMotta \& Crous, IMA Fungus 8 (1): 87 (2017).

$\equiv$ Toxicocladosporium leucadendri Crous, in Crous et al., Persoonia 27: 157 (2011).

Notes - Bezerra et al. (2017) transferred six strains of Toxicocladosporium leucadendri to a new genus, Neocladosporium. Despite their distinct phylogenetic positions, Neocladosporium is distinguishable from Toxicocladosporium by its verruculose to warty ramoconidia (Bezerra et al. 2017).

Rachicladosporium Crous, U. Braun \& C.F. Hill, Studies in Mycology 58: 38 (2007).

Index Fungorum number: IF 504430; Facesoffungi number: FoF 06634; 13 morphological species (Species Fungorum 2020), 13 species with molecular data.

Type species - Rachicladosporium luculiae Crous, U. Braun \& C.F. Hill, Studies in Mycology 58: 39 (2007).

Notes - Rachicladosporium has cladosporium-like morphology, however, it differs from Cladosporium sensu stricto in having conidiophores with an apical rachis. Some taxa are associated with leaf spots (Crous et al. 2007b, 2014b, 2018a), while some are rock-inhabiting fungi (Egidi et al. 2014).

Toxicocladosporium Crous \& U. Braun, Studies in Mycology 58: 39 (2007).

Index Fungorum number: IF 504426; Facesoffungi number: FoF 06970; 15 morphological species (Fotedar et al. 2019), 15 species with molecular data.

Type species - Toxicocladosporium irritans Crous \& U. Braun, Studies in Mycology 58: 39 (2007).

Notes - Toxicocladosporium is characterized by dark, thick-walled conidial and conidiophore septa (Crous et al. 2007b, Bezerra et al. 2017, Fotedar et al. 2019). The genus differs from Cladosporium sensu stricto in lacking the typical coronate Cladosporium scar type (Crous et al. 2007b). All species of Toxicocladosporium have available sequence data.

Verrucocladosporium K. Schub., Aptroot \& Crous, Studies in Mycology 58: 41 (2007). 
Index Fungorum number: IF 504432; Facesoffungi number: FoF 06971; 3 morphological species (Species Fungorum 2020), 2 species with molecular data.

Type species - Verrucocladosporium dirinae K. Schub., Aptroot \& Crous, Studies in Mycology 58: 41 (2007).

Notes - Crous et al. (2007b) introduced Verrucocladosporium based on V. dirinae and assigned it as Capnodiales incertae sedis. The type species was wrongly deposited as Cladosporium arthoniae. However, Verrucocladosporium differs from Cladosporium sensu stricto in having cylindrical-filiform, non-geniculate, non-nodulose conidiophores, and non-coronate conidiogenous loci (Crous et al. 2007b). Braun et al. (2009) described the second species from thalli of Roccella boergesenii, but without molecular data. The third species was established by Crous et al. (2019e).

\section{Ecological and economic significance}

Members of Cladosporiaceae are cosmopolitan in distribution and include many species which are of economic importance. Some species (i.e. C. ossifragi, C. pseudiridis and C. vincicola) can cause leaf spots and other lesions (Schubert et al. 2007a, Braun et al. 2008). Cladosporium have also been reported as a common fungal component isolated from air and indoor environments (Bensch et al. 2012, Bensch et al. 2018), which may cause allergic lung mycoses (de Hoog et al. 2000). Cladosporiaceae species can be also saprobes, hyperparasites and endophytes, as well as soil fungi. Because of their diverse lifestyles, they may have high environmental impact.

Cystocoleaceae Locq. ex Lücking, B.P. Hodk. \& S.D. Leav., in Lücking et al., Bryologist 119(4): 401 (2017).

Index Fungorum number: IF 819262; Facesoffungi number: FoF 06637, 1 species.

Lichenized; Thallus superficial, dense, fluffy, filamentose; photobiont Trentepohlia. Hyphal sheath around the algal filaments composed of somewhat contorted, jigsaw puzzle-shaped cells forming a closed layer. Ascomata and conidiomata undetermined.

Type-Cystocoleus Thwaites.

Notes - Cystocoleaceae was first mentioned by Locquin (1984). Based on nuLSU, nuSSU and mtSSU sequence data, Muggia et al. (2008) found that Cystocoleus belonged to Capnodiales, rather than phylogenetically close to lichenized members within Dothideomycetidae. This result was subsequently confirmed by Nelsen et al. (2009) and Ertz et al. (2014). Crous et al. (2009c) revealed Cystocoleus as a member of Teratosphaeriaceae in their comprehensive study of Capnodiales. However, Cystocoleus was treated as Capnodiales genera incertae sedis in the phylogenetic study of Quaedvlieg et al. (2014). Lücking et al. (2017) validly established Cystocoleaceae and assigned it in Capnodiales. Cystocoleaceae is a monotypic family comprising a single genus Cystocoleus (Lücking et al. 2017, Wijayawardene et al. 2017a, 2018).

Cystocoleus Thwaites, Ann. Mag. nat. Hist., Ser. 2 3: 241 (1849).

Index Fungorum number: IF 7892; Facesoffungi number: FoF 06638; 1 morphological species (Species Fungorum 2020), 1 species with molecular data.

Type species - Cystocoleus ebeneus (Dillwyn) Thwaites.

Notes - Cystocoleus was introduced by Thwaites (1849) based on C. ebeneus. Subsequently, $C$. niger and $C$. rupestris were described by Rabenhorst (1870) and Hariot (1890). However, Hawksworth et al. (2011) synonymized $C$. nigra under $C$. ebeneus and transferred $C$. rupestris to Racodium. Currently, Cystocoleus is a monotypic genus containing C. ebeneus.

Cystocoleus ebeneus (Dillwyn) Thwaites, Ann. Mag. nat. Hist.: 241 (1849).

Fig. 9

$\equiv$ Conferva ebenea Dillwyn, Brit. Conferv.: tab. 101 (1809).

Index Fungorum number: IF 384110; Facesoffungi number: FoF 06942.

Description - see Tian et al. (2014).

Notes - Cystocoleus ebeneus has orange pigmented Trentepohlia photobionts. Although Cystocoleus and Racodium are different genera, C. ebeneus is scarcely distinguishable from $R$. 
rupestre. The hyphae of $C$. ebeneus are shorter and less contorted than those of $R$. rupestre (Muggia et al. 2008, Tian et al. 2014). Here, we provide a drawing of Cystocoleus ebeneus (Fig. 9).

a

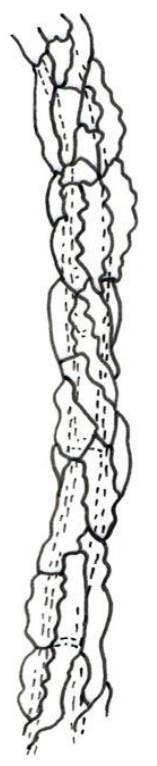

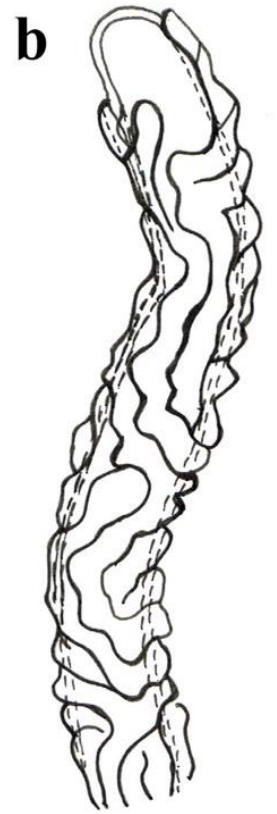

c

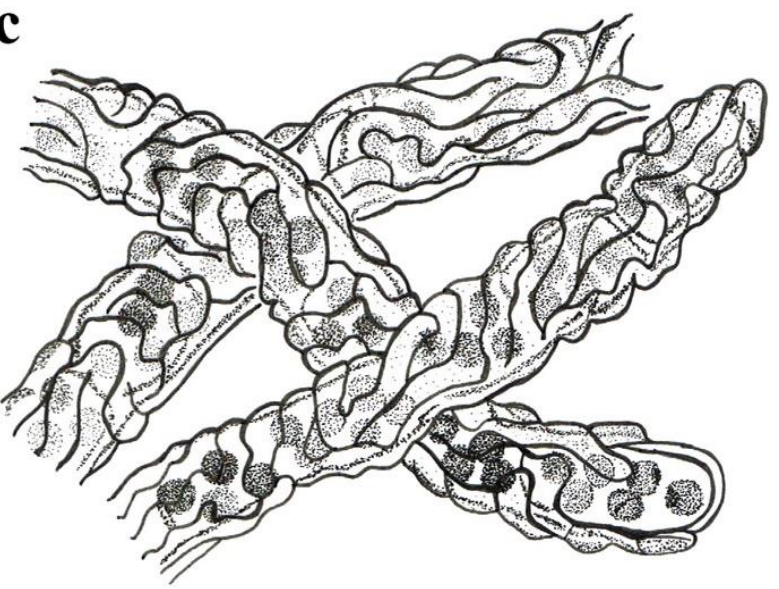

Figure 9 - Cystocoleus ebeneus (redrawn from Smith 1911 and Hawksworth et al. 2011). a A single filament. b Detail of dentate hyphal walls. c Filaments.

\section{Ecological and economic significance}

Lichens have a worldwide distribution and may be the dominant autotrophs in polar, subpolar, alpine and subalpine habitats. They can be used to date glacial moraines and as environmental bioindicators. As the photobiont of Cystocoleus, Trentepohlia are widespread in lichens and mainly distributed in tropical and subtropical areas (van den Hoek et al. 1995). Thus, Cystocoleus may play an important ecosystem stabilizing role in these regions.

Dissoconiaceae Crous \& de Hoog, Studies in Mycology 64: 36 (2009).

Index Fungorum nubmer: IF 514699; Facesoffungi number: FoF 06640, 36 species.

Saprobic, hyperparasitic on powdery mildew, pathogenic on Eucalyptus species. Mycelium internal and external, consisting of branched, septate, smooth, hyaline to pale brown hyphae. Sexual morph: Ascomata pseudothecial, immersed, globose, unilocular, papillate, ostiolate, canal periphysate. Peridium consisting of 3-4 layers, brown cells of textura angularis; inner layer of flattened, hyaline cells. Hamathecium pseudoparaphyses absent. Asci 8-spored, bitunicate. Ascospores fasciculate, ellipsoid-fusoid, hyaline, 1-septate, with or without mucoid sheath. Asexual morph: Conidiophores separate, arising from hyphae, unbranched or occasionally branched at apex, subcylindrical, subulate or lageniform to cylindrical, tapering to a bluntly rounded or truncate apex, sometimes with inflated basal cells, straight to flexuose, smooth, medium brown, 0-multi-septate. Conidiogenous cells terminal or lateral, integrated, smooth-walled, sympodially proliferating, rachis straight or flexuose, geniculate or nodose, subhyaline to brown; scars thickened or unthickened and somewhat darkened. Conidia solitary, ellipsoid to obclavate or globose, subhyaline to pale brown, 0-2-septate, smooth or verrucose, apex with or without mucoid appendage; hila somewhat darkened. Secondary conidia present or absent; developing adjacent to primary conidia, pale olivaceous to subhyaline, aseptate, pyriform; conidium discharge active or passive (photoplates of asexual can be seen in Crous \& Wingfield 1996, Crous et al. 2004). 
Type - Dissoconium de Hoog, Oorschot \& Hijwegen.

Notes - Crous et al. (2009c) studied the phylogenetic lineages within Capnodiales and established Dissoconiaceae, which included the genera Dissoconium and Ramichloridium. Li et al. (2012) introduced Pseudoveronaea in Dissoconiaceae. Uwebraunia was also accommodated in Dissoconiaceae (Li et al. 2012, Hyde et al. 2013, Quaedvlieg et al. 2014, Liu et al. 2017a). Some species in Dissoconiaceae are plant pathogens, for example, Uwebraunia dekkeri is a foliar pathogen causing leaf spots (Jackson et al. 2004), while some are commensalists associated with pathogenic species of Capnodiales.

Dissoconium de Hoog, Oorschot \& Hijwegen, Proceedings van de Koninklijke Nederlandse Akademie van Wetenschappen Section C 86 (2): 198 (1983).

Index Fungorum number: IF 11074; Facesoffungi number: FoF 06641; 5 morphological species (Species Fungorum 2020), 4 species with molecular data.

Type species - Dissoconium aciculare de Hoog, Oorschot \& Hijwegen.

Notes - Dissoconium was introduced by de Hoog et al. (1983) based on D. aciculare. Crous et al. (2004) indicated that the type of Dissoconium, D. aciculare, clustered together with Mycosphaerella communis (now as Uwebraunia communis) and M. lateralis isolates. However, the type species $D$. aciculare formed a distinct clade in Capnodiales and was not close to Mycosphaerellaceae (Crous et al. 2009c, Hyde et al. 2013). We provide a drawing of Dissoconium aciculare in Fig. 10 as we were unable to find a fresh collection.

Dissoconium aciculare de Hoog, Oorschot \& Hijwegen, Proceedings van de Koninklijke Nederlandse Akademie van Wetenschappen Section C 86 (2): 198 (1983).

Fig. 10 Index Fungorum number: IF 107937; Facesoffungi number: FoF 06940. Description - see Hoog et al. (1983).

\section{Other genera included}

Globoramichloridium Y. Marín \& Crous, Studies in Mycology 94: 81 (2019).

Index Fungorum number: IF 829622; Facesoffungi number: FoF 06643; 1 morphological species (Species Fungorum 2020), 1 species with molecular data.

Type species - Globoramichloridium indicum (Subram) Y. Marín \& Crous, Studies in Mycology 94: 82 (2019).

$\equiv$ Chloridium indicum Subram., Proc. Indian Acad. Sci., Sect. B 42: 286 (1955).

Notes - Marin-Felix et al. (2019) transferred Ramichloridium indicum and erected Globoramichloridium based on molecular data. It is characterized by geniculate or nodose conidiogenous cells with scars, and subhyaline to pale brown, broadly ellipsoidal to globose conidia with truncate bases and conspicuous hila (Marin-Felix et al. 2019). ITS and LSU sequence data are available for $G$. indicum.

Pseudoveronaea Crous \& Batzer, Persoonia 28: 118 (2012).

Index Fungorum number: IF 564667; Facesoffungi number: FoF 06644; 2 morphological species (Species Fungorum 2020), 2 species with molecular data.

Type species - Pseudoveronaea obclavata Batzer \& Crous, Persoonia 28: 119 (2012).

Notes - Pseudoveronaea was introduced by Li et al. (2012) to accommodate P. ellipsoidea and $P$. obclavata, which were isolated from fruit surfaces of Malus domestica. Pseudoveronaea is characterized by unbranched, septate conidiophores, terminal, subcylindrical conidiogenous cells forming a rachis with scars, and obclavate, 0 -2-septate conidia with appendage at subobtuse apex and darkened at truncate base (Li et al. 2012). Sequence data are available for both species.

Ramichloridium Stahel ex de Hoog, Studies in Mycology 15: 59 (1977).

= Ramichloridium Stahel, Trop. Agric., Trin. 14: 44 (1937).

Index Fungorum number: IF 509273; Facesoffungi number: FoF 06941; 23 morphological species (Species Fungorum 2020; Zheng et al. 2020), 7 species with molecular data. 
Type species - Ramichloridium apiculatum (J.H. Mill., Giddens \& A.A. Foster) de Hoog, Studies in Mycology 15: 69 (1977).

$\equiv$ Chloridium apiculatum J.H. Mill., Giddens \& A.A. Foster, Mycologia 49(6): 789 (1957).

Notes - The genus is characterized by aseptate, pale brown, smooth-walled to finely verrucose, clavate or oblong to ellipsoid, or obovate to obconical conidia. Ramichloridium species have diverse lifestyles and can be saprobes, endophytes, human and plant pathogens (Arzanlou et al. 2007, Zheng et al. 2020). Marin-Felix et al. (2019) accepted only five species in Ramichloridium, i.e. $R$. apiculatum, $R$. cucurbitae, $R$. luteum, $R$. mali and $R$. punctatum. Zheng et al. (2020) introduced a new endophytic species, $R$. endophyticum, and provided a morphological comparison with similar species.

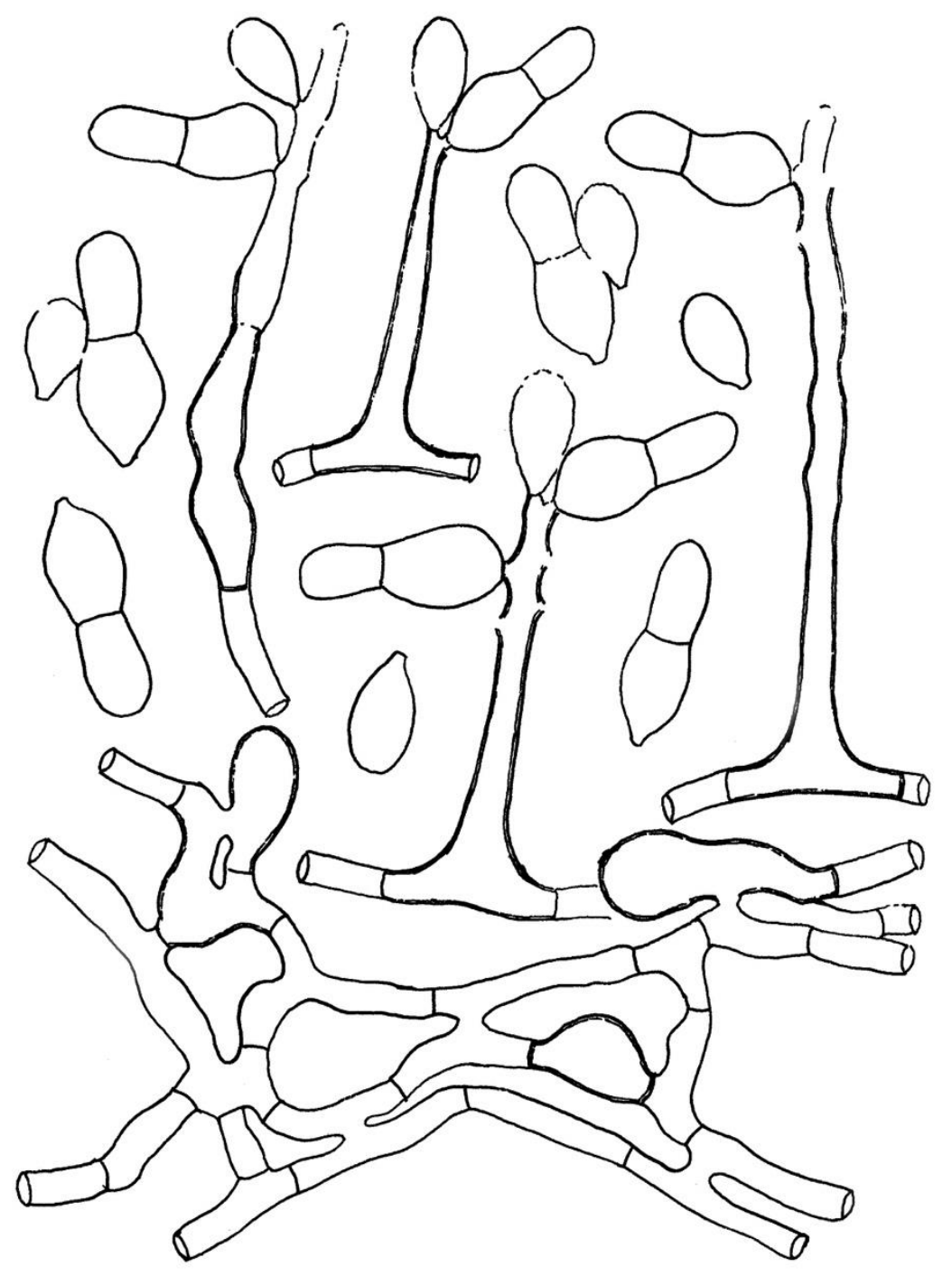

Figure 10 - Dissoconium aciculare (redrawn from Seifert et al. 2011). This drawing shows mycelium, conidiophores, conidiogenous cells and conidia of $D$. aciculare.

Uwebraunia Crous \& M.J. Wingf., Mycologia 88 (3): 446 (1996).

Index Fungorum number: IF 27643; Facesoffungi number: FoF 06646; 6 morphological species (Species Fungorum 2020), 4 species with molecular data.

Type species - Uwebraunia juvenis Crous \& M.J. Wingf., Mycologia 88 (3): 446 (1996).

Notes - Uwebraunia was introduced by Crous \& Wingfield (1996) with mycosphaerella-like sexual morphs which are characterized by immersed, globose, unilocular, papillate, ostiolate 
ascomata, 8-spored, bitunicate asci, and fasciculate, ellipsoid-fusoid, 1-septate, hyaline ascospores with or without mucoid sheath. The asexual morph of Uwebraunia has ellipsoid to obclavate, 1septate primary conidia and pyriform, aseptate secondary conidia (Li et al. 2012). Uwebraunia was treated as a synonym of Dissoconium by Seifert et al. (2011). Li et al. (2012) resurrected the generic name based on both morphology and phylogeny.

\section{Ecological and economic significance}

Dissoconiaceae species, such as D. eucalypti, can be pathogenic on Eucalyptus (Crous et al. 2007d), which are grown globally and are commercial. Members of Dissoconiaceae are also saprobic on different hosts. Thus, species of this family not only play a role in decomposing dead plant material and nutrient cycling in the ecosystem, but also have commercial importance.

Euantennariaceae S. Hughes \& Corlett ex S. Hughes, N.Z. Jl Bot. 10: 238 (1972).

Index Fungorum number: IF 81674; Facesoffungi number: FoF 06932, 23 species.

Parasitic on pine needles or leaves of others plants. Mycelium superficial, dark, frequently with erect branches. Hyphae straight to irregularly curved, occasionally anastomosing, septate, finely or coarsely rough-walled, pale brown to brown, some species formed on one cell-thick plate. Hyphal appendages on ascomata cylindrical, brown, obtuse, sometimes septate, verrucose. Sexual morph: Ascomata perithecia, scattered, or in groups, superficial or immersed on/in hyphae, subglobose, membranous, brown to dark brown, or black, ostiolate without periphysoids. Peridium thick, comprises one layer of dark brown cells of textura angularis. Hamathecium pseudoparaphyses present or absent. Asci 4-8-spored, bitunicate, fasciculate, ellipsoid to broadly ellipsoid, thin-walled, sessile, with an ocular chamber. Ascospores 2-3-seriate to irregularly arranged in asci, ellipsoid to fusiform, sometimes wider at above the middle, think-walled, pale brown to dark brown, 3-multi-septate, or dictyoseptate, constricted at the septa, smooth-walled. Asexual morph: Undetermined.

Type - Euantennaria Speg.

Notes - Euantennariaceae is a sooty mould family that was established by Hughes (1972). Species in this family share some characters with Metacapnodiaceae in its ellipsoidal asci and ellipsoidal ascospores. Euantennariaceae however, differs from Metacapnodiaceae in lacking periphysoids (Eriksson 1981). Wijayawardene et al. (2012) listed Antennatula, Capnokyma, Hormisciomyces, Plokamidomyces, Racodium and Trichothallus as asexual genera in Euantennariaceae. The family contained ten genera in Hyde et al. (2013). Currently, seven genera are accepted in Euantennariaceae because Plokamidomyces was synonymized under Trichothallus (Rossman et al. 2016) and Trichopeltheca and Racodium were transferred to Trichopeltinaceae and Racodiaceae, respectively (Hongsanan et al. 2014a, Lücking et al. 2017, Wijayawardene et al. 2017a). Sugiyama \& Hosoya (2019) introduced a new species of Antennatula based on asexual characters and mentioned Antennatula as a genus in Euantennariaceae. However, we do not accept this genus in Euantennariaceae due to lack of sequence data and sexual characters undetermined (Wijayawardene et al. 2017b).

Winton et al. (2007) provided sequence data from two species of Rasutoria to represent the phylogenetic placement of Euantennariaceae. By using three-loci analysis (ITS, LSU and SSU), two species of Rasutoria were confirmed in Capnodiales, but clustered within Mycosphaerellaceae (Winton et al. 2007, Hyde et al. 2013, Chomnunti et al. 2014). Wijayawardene et al. (2017a) treated Euantennariaceae as family incertae sedis in Dothideomycetes. Euantennariaceae and Mycosphaerellaceae could not be well-separated by phylogeny and Rasutoria shares some characters with some species in Mycosphaerellaceae (i.e. species in Phaeocryptopus and Mycosphaerella). Due to lack of sequence data of the type species of Euantennaria, the familial status of Euantennariaceae in Capnodiales is retained based on its sooty mould life style and other unique characters.

Euantennaria Speg., Physis, Rev. Soc. Arg. Cienc. Nat. 4(no. 17): 284 (1918). 
Index Fungorum number: IF 221; Facesoffungi number: FoF 06933; 9 morphological species (Species Fungorum 2020), molecular data unavailable.

Type species - Euantennaria tropicicola Speg., Boln Acad. nac. Cienc. Córdoba 23(3-4): 549 [no. 448, repr. 187] (1919).

Notes - The morphology of Euantennaria is similar to Strigopodia, thus molecular data are needed to test the possible conspecificity. Hughes (1974) reported that Euantennaria has two asexual morphs, Antennatula (phragmoconidial states) and Hormisciomyces (phialidic state).

Euantennaria mucronata (Mont.) S. Hughes, N.Z. J1 Bot. 10(2): 227 (1972).

Fig. 11

三Capnodium mucronatum Mont., Annls Sci. Nat., Bot., sér. 3 14: 175 (1849).

Index Fungorum number: IF 313958; Facesoffungi number: FoF 07633.

Material examined - New Zealand, Canterbury, on Nothofagus solandri var. cliffortioides, 14 May 1963, S. J. Hughes (PDD 21316, paratype).

Description - see description of Euantennaria mucronata (PDD 21317, paratype) in Chomnumti et al. (2014).

\section{Other genera included}

Capnokyma S. Hughes, N.Z. J1 Bot. 13(4): 638 (1975).

Index Fungorum number: IF 7495; Facesoffungi number: FoF 06934; 2 morphological species (Species Fungorum 2020), molecular data unavailable.

Type species - Capnokyma corticola S. Hughes, N.Z. J1 Bot. 13(4): 638 (1975).

Notes - Capnokyma was established by Hughes (1975), with the type species C. corticola. The genus is recognized by its erect setae-like conidiophores, blastic conidiogenesis, sessile, ellipsoidal to subcylindrical, straight or curved, 3- to multi-septate, subhyaline to dark brown phragmoconidia, with tapered ends (Eriksson 1981, Hughes 1976, Hughes \& Seifert 2012). Capnodyma corticola was found in association with Euantennaria mucronata and Spiropes dictyosporus in sooty mould colonies (Seifert \& Hughes 2000). No culture and sequence data available to explain these relationships.

Hormisciomyces Bat. \& Nascim., Anais Soc. Biol. Pernambuco 15(2): 349 (1957).

Index Fungorum number: IF 8550; Facesoffungi number: FoF 06935; 3 morphological species (Species Fungorum 2020), molecular data unavailable.

Type species - Hormisciomyces prepusus Bat. \& Nascim. [as 'prepusum'], Anais Soc. Biol. Pernambuco 15(2): 350 (1957).

Notes - This genus is one of the asexual morphs of Euantennaria (Hughes 1972, 1974, Sivanesan 1984, Hyde et al. 2013, Wijayawardene et al. 2017b). The genus produces small, hyaline, thin-walled, phialo-conidia, arising from a ring of phialidic cells (Hughes 1972, 1974). Hormisciomyces phialidic state has also been found in Antennatula fisherae and A. dingleyae. The genus was linked with Trichopeltheca by Hughes (1976). However, these links between sexual and asexual morphs and relationships with other genera are not confirmed due to lack of cultures and sequence data.

Plokamidomyces Bat., C.A.A. Costa \& Cif., Atti Ist. bot. Univ. Lab. crittog. Pavia, sér. 5 15: 47 (1957).

Index Fungorum number: IF 9478; Facesoffungi number: FoF 06936; 1 morphological species (Species Fungorum 2020), molecular data unavailable.

Type species - Plokamidomyces colensoi Bat., C.A.A. Costa \& Cif., Atti Ist. bot. Univ. Lab. crittog. Pavia, sér. 5 15: 47 (1957).

Notes - The genus was introduced with the type species $P$. colensoi based on a possible conidial state of Trichopeltina asiatica described by Batista el al. (1957). Hughes (1965) noted that phialophores of Plokamidomyces differ from setae in Trichopeltina mainly in an apical whorl of phialides, which produce minute hyaline phialospores. Wijayawardene et al. (2017b) retained this genus in Euantennariaceae. 


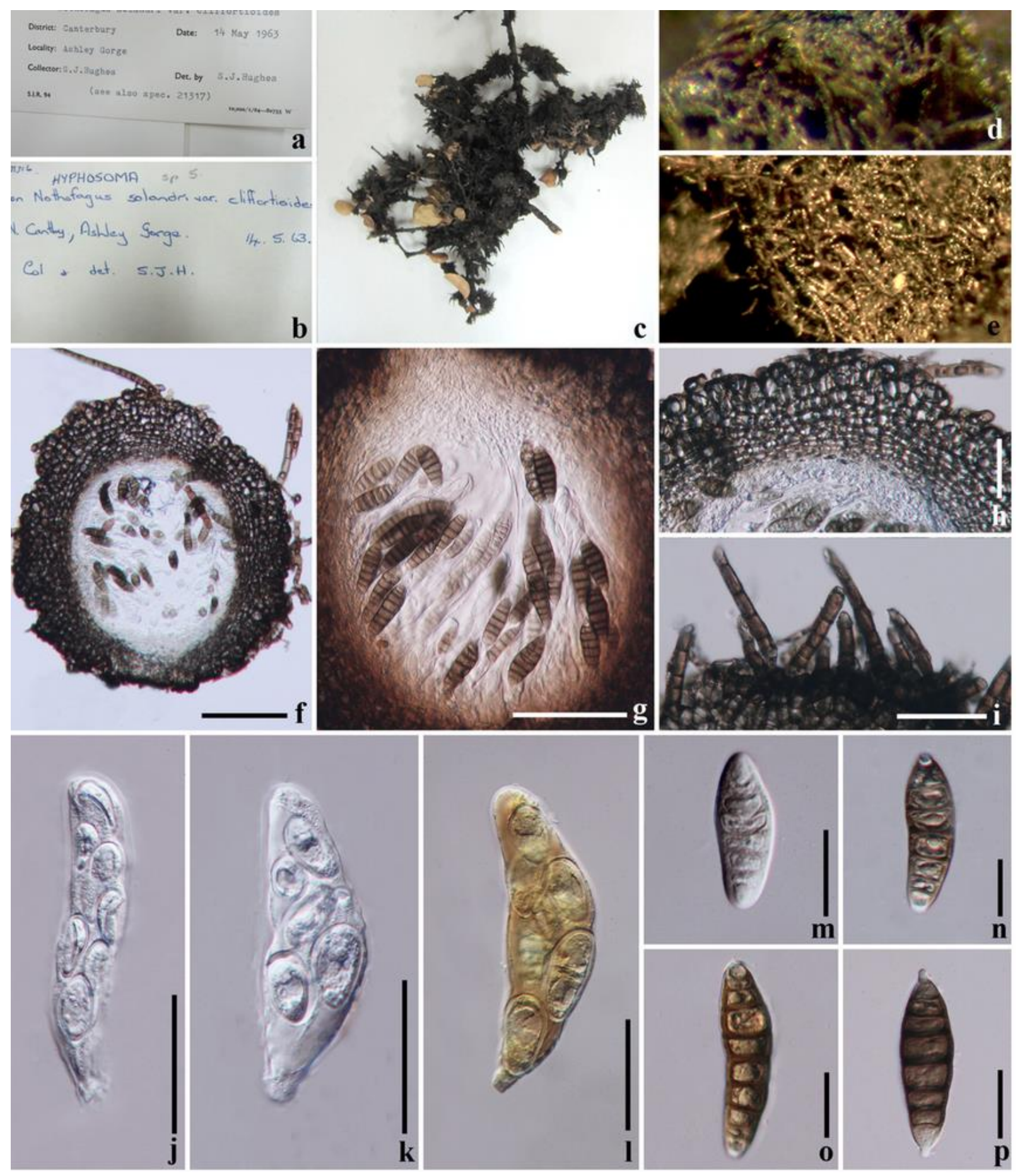

Figure 11 - Euantennaria mucronata (PDD 21316, paratype). a-c Specimen and descriptions. d, e Ascostromata on substrate. f Section through ascostroma. g Asci arrangement in ascostroma. $h$ Peridium. i Hyphae on ascostroma. j, k Ascus. 1 Ascus stained in Melzer's reagent. $m$ Ascospore when immature. $n-p$ Ascospores at maturity. Scale bars: $f, g=100 \mu \mathrm{m}, \mathrm{h}-1=50 \mu \mathrm{m}, \mathrm{m}-\mathrm{p}=20 \mu \mathrm{m}$.

Rasutoria M.E. Barr, Mycotaxon 29: 501 (1987).

Index Fungorum number: IF 25132; Facesoffungi number: FoF 06937; 2 morphological species (Species Fungorum 2020), molecular data unavailable.

Type species - Rasutoria abietis (Dearn.) M.E. Barr, Mycotaxon 29: 502 (1987).

三Dimerosporium abietis Dearn., Mycologia 18(5): 243 (1926).

Notes - Rasutoria was introduced by Barr (1987a) for Dimerosporium abietis, and is characterized by its occurrence on conifer needles, setose ascomata, superficial on a radiating mycelium that penetrates the plant stomata (Winton et al. 2007). Sequence data of two Rasutoria 
species were provided by Winton et al. (2007). However, their phylogenetic placement as a distinct family (Euantennariaceae) in Capnodiales is not well-resolved (Winton et al. 2007, Hyde et al. 2013, Chomnunti et al. 2014). Two sequences of Rasutoria have a close relationship with species of Mycosphaerella and Phaeocryptopus, Mycosphaerellaceae (Winton et al. 2007, Hyde et al. 2013, Chomnunti et al. 2014). Videira et al. (2017) synonymized these two species with sequence data under Zasmidium based on phylogenetic analyses. Morphologically, Rasutoria shares some characters with Mycosphaerella and Phaeocryptopus in its globose, thin-walled pseudothecia, without pseudoparaphyses, bitunicate, ovoid to cylindrical, 8-spored asci, and fusoid to obovate, equatorially euseptate, hyaline to pale brown ascospores (Winton et al. 2007). However, Chomnunti et al. (2014) and Wijayawardene et al. (2017a, 2018) retained this genus within Euantennariaceae based on its sooty mould lifestyle.

Strigopodia Bat., in Batista et al., Anais Soc. Biol. Pernambuco 15(2): 440 (1957).

= Chaetosaccardinula Bat., in Batista \& Peres, Brotéria, N.S. 31(2): 84 (1962).

Index Fungorum number: IF 5284; Facesoffungi number: FoF 06938; 4 morphological species (Species Fungorum 2020), molecular data unavailable.

Type species - Strigopodia piceae Bat., in Batista et al., Anais Soc. Biol. Pernambuco 15(2): 440 (1957).

Notes - The sexual genus Strigopodia was established and included in Coccodiniaceae by Barr (1987a). Lumbsch \& Huhndorf (2010) transferred the genus to Euantennariaceae based on its morphology. Sivanesan (1984) concluded that Antennatula is the asexual morph of Strigopodia. Chomnunti et al. (2014) restudied a herbarium specimen from the USA and reported that the morphology of Strigopodia is similar to Euantennaria. However, the general status of Stridopodia is retained in Euantennariaceae as no culture and sequence is available to confirm these relationships.

Trichothallus F. Stevens, Bulletin of the Bernice P. Bishop Museum, Honolulu, Hawaii 19: 85 (1925).

Index Fungorum number: IF 10300; Facesoffungi number: FoF 06939; 2 morphological species (Species Fungorum 2020), molecular data unavailable.

Type species - Trichothallus hawaiiensis F. Stevens, Bulletin of the Bernice P. Bishop Museum, Honolulu, Hawaii 19: 85 (1925).

Notes - The genus was established in Trichopeltinaceae (= Trichopeltinaceae) by Stevens (1925) to accommodate the single species T. hawaiiensis. Petrak (1951) excluded the genus from Trichopeltaceae based on the characters of its recognized setae ("tragerartige Hyphen") and phragmoconidia. Hughes (1965) stated that the component hyphae of Trichothallus have a parallel arrangement and do not diverge at right angles on the margins as they do in Trichopeltis reptans (Trichopeltaceae). Rossman et al. (2016) concluded that Plokamidomyces and Trichopeltheca are synonyms of Trichothallus.

\section{Ecological and economic significance}

Euantennariaceae are poorly studied, and lack reports on their ecological and economic significance. Interactions between species in this family, insects and plants are doubtful. However, members of this family formed black mycelium on host plants as other sooty moulds. Thus, the family is believed to play some negative role to the host, such as reducing photosynthesis in plants.

Extremaceae Quaedvl. \& Crous, Fungal Systematics and Evolution 3:127 (2019).

$=$ Paradevriesiaceae Crous, in Crous et al., FUSE 3: 98 (2019).

Index Fungorum number: IF 829394; Facesoffungi number: FoF 06847, 17 species.

Mostly rock-inhabiting. Asexual morph: Coelomycetous or hyphomycetous. When Coelomycetous (Staninwardia), Mycelium immersed, sparse, composed of pale brown septate hyphae. Conidiomata acervular, formed in the epidermis and hypodermis, erumpent with the basal wall formed of pale brown, smooth-walled pseudoparenchymatic cells. Conidia catenate, basipetal, 
pale brown, 1-septate, verruculose, both ends truncate except for the terminal conidium which is obtuse at the apex, formed in a mucilaginous sheath. When hyphomycetous, variable, filamentous, lichenicolous or yeast-like. Conidiophores micronematous to macronematous, subcylindrical to cylindrical, brown, septate, straight or flexuose. Conidiogenous cells monoblastic or polyblastic, integrated, terminal or lateral, brown, subcylindrical to ellipsoid or doliiform, scars somewhat darkened and thickened, slightly reflective or not. Conidia various in shapes, solitary or in chains, subhyaline to dark brown, aseptate or septate, smooth to slightly verruculose, sometimes with hila. Sexual morph: Undetermined.

Type - Extremus Quaedvl. \& Crous.

Notes - Extremaceae was introduced by Quaedvlieg et al. (2014) and validated by Crous et al. (2019b). Quaedvlieg et al. (2014) originally included five genera. Isola et al. (2016) introduced Saxophila to this family based on morphology and phylogeny. Most of the species in Extremaceae are rock-inhabiting taxa. However, there are also saprobic species, such as Pseudoramichloridium henryi. In addition, some taxa were isolated from soil, for example $P$. brasilianum and $P$. xinjiangens (Arzanlou et al. 2007, Jiang et al. 2017).

Paradevriesiaceae was introduced by Crous et al. (2019b) and contained Paradevriesia compacta (CBS 118294), P. americana (CBS 117726), and P. pseudoamericana (CPC 16174). They form lineages within Extremaceae in our phylogenetic tree (Fig. 3). This is because Crous et al. (2019b) did not include sequence data of Extremaceae in their phylogenetic tree. Thus, Paradevriesiaceae is synonymized under Extremaceae here.

Extremus Quaedvl. \& Crous, Fungal Systematics and Evolution 3: 127 (2019).

Index Fungorum number: IF 829395; Facesoffungi number: FoF 06848; 2 morphological species (Species Fungorum 2020), 1 species with molecular data.

Type species - Extremus adstrictus Quaedvl. \& Crous.

Notes - Extremus is the type genus of Extremaceae. Quaedvlieg et al. (2014) informally established this genus which was validated by Crous et al. (2019b). It is characterized by brown, subcylindrical to ellipsoid conidiogenous cells, catenate, subcylindrical to ellipsoid conidia with hyaline to slightly darkened hila. Quaedvlieg et al. (2014) transferred Devriesia adstricta and D. antarctica to Extremus based on phylogenetic analysis. The genus now contains two species and their morphology is only known from culture (Egidi et al. 2014).

Extremus adstrictus Quaedvl. \& Crous, Fungal Systematics and Evolution 3: 127 (2019). Fig. 12 DDevriesia adstricta Egidi \& Onofri, Fung. Diversity 65: 150 (2014).

Index Fungorum number: IF 829396; Facesoffungi number: FoF 06849.

Description - see Egidi et al. (2014).

Notes - Devriesia adstricta was introduced by Egidi et al. (2014). However, the rationale classification of $D$. adstricta and D. antarctica was not provided. These two species were distant from other Devriesia species in their phylogenetic analyses (Egidi et al. 2014). Quaedvlieg et al. (2014) introduced Extremus and included these two taxa into this genus based on a multi-gene phylogenetic analysis. We were unable to obtain fresh collection of species in Extremaceae, thus, a drawing of Extremus adstrictus is provided.

\section{Other genera included}

Castanedospora G. Delgado \& A.N. Mill., Cryptogamie Mycologie 39 (1): 118 (2018).

Index Fungorum number: IF 82458; Facesoffungi number: FoF 07191 - 1 morphological species (Delgado et al. 2018), 1 species with molecular data.

Type species - Castanedospora pachyanthicola (R.F. Castañeda \& W.B. Kendr.) G. Delgado \& A.N. Mill., Cryptogamie Mycologie 39 (1): 118 (2018).

三Sporidesmium pachyanthicola R.F. Castañeda \& W.B. Kendr., University of Waterloo Biology Series 33: 45 (1990). 

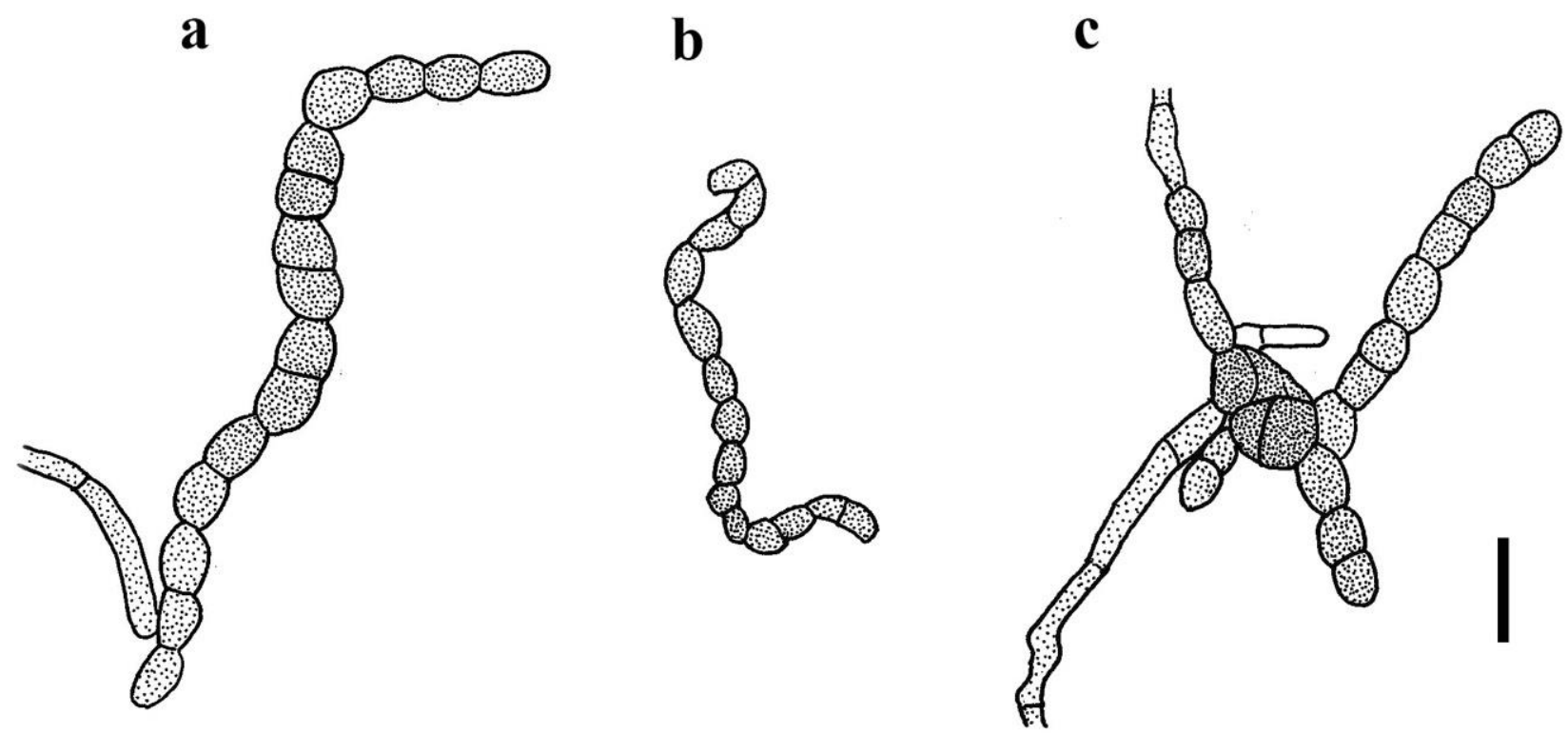

Figure 12 - Extremus adstrictus (redrawn from holotype CBS 118292 = TRN96, Egidi et al. 2014). a, b Dark brown, thick-walled, catenate conidia with a dark median septum. c Meristematic growth.

Notes - The monotypic genus Castanedospora was introduced by Delgado et al. (2018) to accommodate Sporidesmium pachyanthicola. It is characterized by cylindrical and brown conidiophores without percurrent extensions and long narrowly obclavate or subcylindrical, mutiseptate conidia with rounded apex and truncate base (Delgado et al. 2018). Sporidesmium pachyanthicola was historically assigned in Teratosphaeriaceae (Arzanlou et al. 2007). However, combined ITS and LSU sequence data indicated that this species belongs to Extremaceae (Delgado et al. 2018).

Paradevriesia Crous, Fungal Systematics and Evolution 3: 98 (2019).

Index Fungorum number: IF 829325; Facesoffungi number: FoF 07634; 3 morphological species (Species Fungorum 2020), 3 species with molecular data.

Type species - Paradevriesia americana (Crous \& Dugan) Crous, Fungal Systematics and Evolution 3: 98 (2019).

三Devriesia americana Crous \& Dugan, Stud. Mycol. 58: 42 (2007).

Notes - Paradevriesia was established by Crous et al. (2019b) based on phylogenetic analyses and a different ecology to members of Devriesia. This genus is similar to Devriesia sensu stricto which usually occurs in soil, and is thermotolerant. However, Paradevriesia species are found on plants and rock surfaces and are not thermotolerant. Three strains of Paradevriesia clustered within Extremaceae in our phylogenetic analyses (Fig. 3). This genus is characterized by macro- and micronematous conidiophores, blastic, medium brown, guttulate, subcylindrical conidiogenous cells with scars, and catenate, subcylindrical to narrowly ellipsoidal, septate conidia with a hilum (Crous et al. 2019b).

Petrophila de Hoog \& Quaedvl., Fungal Systematics and Evolution 3: 130 (2019).

Index Fungorum number: IF 829422; Facesoffungi number: FoF 06850; 1 morphological species (Species Fungorum 2020), 1 species with molecular data.

Type species - Petrophila incerta de Hoog \& Quaedvl., Fungal Systematics and Evolution 3: 130 (2019).

Notes - Petrophila was introduced by Egidi et al. (2014) and validated by Crous et al. (2019b). Petrophila is a monotypic genus with P. incerta isolated from Spain. This genus is 
characterized by erect, semi-macronematous conidiophores, intercalary conidiogenous cells, and septate conidia in culture (Egidi et al. 2014).

Pseudoramichloridium Cheewangkoon \& Crous, Persoonia 23: 75 (2009).

Index Fungorum number: IF 513854; Facesoffungi number: FoF 06851; 3 morphological species (Species Fungorum 2020), 2 species with molecular data. (2009).

Type species - Pseudoramichloridium henryi Cheewangkoon \& Crous, Persoonia 23: 75

Notes - Cheewangkoon et al. (2009) introduced Pseudoramichloridium to accommodate the type species $P$. henryi and $P$. brasilianum (previously identified as Ramichloridium brasilianum). Jiang et al. (2017) described a third species, $P$. xinjiangense, isolated from soil. Pseudoramichloridium is characterized by unbranched conidiophores, terminal or intercalary conidiogenous cells forming a rachis with polyblastic, protruding scars, and obovoid to fusiform, aseptate, subhyaline to pale brown conidia with truncate base and thickened hilum (Cheewangkoon et al. 2009, Jiang et al. 2017).

Saxophila Selbmann \& de Hoog, Fungal Systematics and Evolution 3: 131 (2019).

Index Fungorum number: IF 829431; Facesoffungi number: FoF 06852; 1 morphological species (Species Fungorum 2020), 1 species with molecular data.

Type species - Saxophila tyrrhenica Selbmann \& de Hoog, Fungal Systematics and Evolution 3: 131 (2019).

= Saxophila tyrrhenica Selbmann \& de Hoog, Fungal Diversity 76: 90 (2016). Nom. inval., Art. 40.7 (Shenzhen).

Notes - Isola et al. (2016) informally introduced the monotypic genus Saxophila, which was validated by Crous et al. (2019b). Its asexual morph, described from culture, is characterized by micronematous conidiophores and thallic-arthric conidia, while its sexual morph remains undetermined.

Staninwardia B. Sutton, Transactions of the British Mycological Society 57: 540 (1971).

Index Fungorum number: IF 10064; Facesoffungi number: FoF 06853; 2 morphological species (Species Fungorum 2020), 1 species with molecular data.

Type species - Staninwardia breviuscula B. Sutton, Transactions of the British Mycological Society 57: 541 (1971).

Notes - Staninwardia was introduced by Sutton (1971). The type species S. breviuscula was reported on Eucalyptus. Summerell et al. (2006) introduced a second species, S. suttonii also from Eucalyptus. Unlike other genera in Extremaceae, Staninwardia has a coelomycetous asexual morph. It is characterized by acervular conidiomata and basipetally catenate, 1-septate, pale brown conidia with a mucilaginous sheath (Sutton 1971, Summerell et al. 2006).

Vermiconidia Egidi \& Onofri, Fungal Systematics and Evolution 3: 131 (2019).

Index Fungorum number: IF 829433; Facesoffungi number: FoF 06854; 4 morphological species (Species Fungorum 2020), 4 species with molecular data (Egidi et al. 2014, Isola et al. 2016).

Type species - Vermiconidia foris Egidi \& Onofri, Fungal Systematics and Evolution 3: 132 (2019).

= Vermiconia foris Egidi \& Onofri, Fungal Diversity 65: 150 (2014). Nom. inval., Art. 40.7 (Shenzhen).

Notes - Egidi et al. (2014) introduced Vermiconia to accommodate $V$. antarctica, $V$. flagrans and $V$. foris. All three species were isolated from rock. Crous et al. (2019b) validated the genus name as Vermiconidia. This genus is characterized by straight conidiophores and dark brown, septate conidia resulting from acropetal, holoblastic conidiogenesis in culture (Egidi et al. 2014). 
Species in Extremaceae are mainly rock inhabiting. They play an important role in deterioration of stone. As a consequence, they cause irreversible damages to some historic cultural heritages (Onofri et al. 2014). Therefore, there is economic value to study Extremaceae species.

Johansoniaceae Doilom, Phookamsak \& K.D. Hyde, in Doilom et al., Mycosphere 9(4): 659 (2018).

Index Fungorum number: IF 554793; Facesoffungi number: FoF 04619, 16 species.

Epiphytic, saprobic, and associated with brown spots on leaves. Sexual morph: Mycelium superficial, septate, brown. Ascomata superficial, scattered, solitary, flattened, brown to black, pulvinate, uni-loculate, membranous, lacking ostioles, with or without hyphae at the base, sometimes with dots in hyphae at the central apex, with or without setae. Setae septate, pale brown to brown, surrounding ascomata, erect, straight to curved. Peridium with meandering arrangement, thin-walled at the base, with cells of textura angularis to textura globulosa. Hamathecium comprising hypha-like, branched, septate, anastomosing, cellular pseudoparaphyses, intermingled among asci. Asci 8-spored, bitunicate, ellipsoid to subcylindrical or clavate, sessile to subsessile or with short furcate pedicel, with ocular chamber, thick-walled. Ascospores 2-3-seriate, ovoid to ellipsoidal, apical cell wider than basal, hyaline, 1-septate cell, with mucilaginous sheath (adapted from Doilom et al. 2018). Asexual morph: Undetermined.

Type - Johansonia Sacc.

Notes - Crous et al. (2010) indicated that Johansonia based on sequence data of $J$. chapadiensis was a member of Capnodiales. Doilom et al. (2018) introduced Johansoniaceae to accommodate Johansonia and Orthobellus based on morphology and phylogeny by Crous et al. (2010). Our phylogenetic analyses (Fig. 3) support these results, with Johansonia forming a distint lineage within Capnodiales. Doilom et al. (2018) inferred that genera in Johansoniaceae are similar to some members in Schizothyriaceae. However, Johansoniaceae has uni-loculate ascomata, a welldeveloped peridium at the base, with narrowly anastomosing pseudoparaphyses, and mostly ellipsoid to subcylindrical or clavate asci, while members of Schizothyriaceae mostly have multiloculate ascostromata, poorly-developed peridium at the base, each ascus forming in a network-like structure, with subglobose to ovoid asci (Doilom et al. 2018).

Johansonia Sacc., Syll. fung. (Abellini) 8: 785 (1889).

Index Fungorum number: IF 2533; Facesoffungi number: FoF 07635; 13 morphological species (Species Fungorum 2020), 1 species with molecular data.

Type species - Johansonia setosa (G. Winter) Sacc.

Notes - The genus is associated with brown spots on leaves, and is characterised by superficial, solitary, pulvinate, dark brown to black ascomata, lacking ostiole, brown, straight to curved ascomatal setae, with basal T-cell devoid of rhizoids, acutely to obtusely rounded, apical septum, hypha-like, septate, branched pseudoparaphyses, subcylindrical to clavate asci, with short furcate pedicel and an ocular chamber, ovoid to ellipsoidal, septate ascospores (Doilom et al. 2018). The asexual morph is undetermined. Johansonia was placed in Schizothyriaceae, Saccardiaceae and Phillipsiellaceae (Müller \& von Arx 1962, von Arx \& Müller 1975, Barr 1993b). Wijayawardene et al. (2018) accepted this genus in Saccardiaceae. However, molecular data show that this genus is a member of Capnodiales and should be placed in its own family (Doilom et al. 2018).

Johansonia setosa (G. Winter) Sacc., Syll. fung. (Abellini) 8: 785 (1889).

Fig. 13

$\equiv$ Ravenelula setosa G. Winter, Revue mycol., Toulouse 7(no. 27): 208 (1885).

Index Fungorum number: IF 150887; Facesoffungi number: FoF 04620.

Desctiption: see Doilom et al. (2018).

Material examined - Paraguay, Guarapi, on leaves of Sapindaceae, A. Balansa (S-F5991, isotype). 

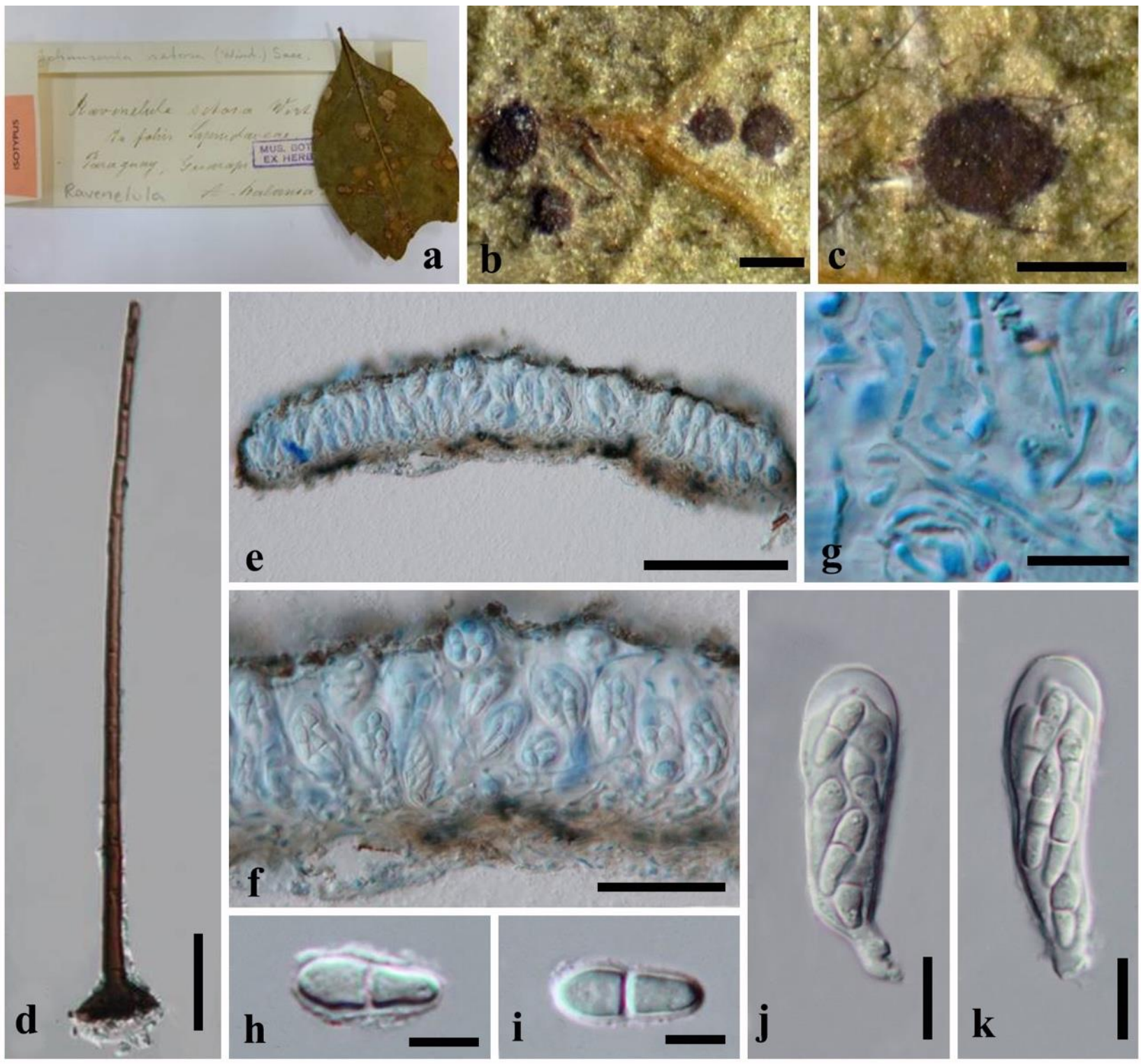

Figure 13 - Johansonia setosa (S-F5991, isotype). a Herbarium label and specimen. b, c Ascomata on leaf surface. d Setae. e, f Vertical section through an ascoma stained in lactophenol cotton blue. g Pseudoparaphyses. h, i Ascospores. j, k Asci. Scale bars: b, c = $300 \mu \mathrm{m}, \mathrm{e}=100 \mu \mathrm{m}, \mathrm{f}=30 \mu \mathrm{m}$, $\mathrm{d}=20 \mu \mathrm{m}, \mathrm{g}, \mathrm{j}, \mathrm{k}=10 \mu \mathrm{m}, \mathrm{h}, \mathrm{i}=5 \mu \mathrm{m}$.

\section{Other genus included}

Orthobellus A.A. Silva \& Cavalc., in Silva et al., Publicações Inst. Micol. Recife 691: 4 (1973).

Index Fungorum number: IF 3639; Facesoffungi number: FoF 01955; 3 morphological species (Species Fungorum 2020), molecular data unavailable.

Type species - Orthobellus leguminosarum A.A. Silva \& Cavalc., in Silva et al., Publicações. Instituto de Micologia da Universidade de Pernambuco 678: 5 (1973).

Notes - Orthobellus was included in the Schizothyriaceae (Silva et al. 1973, Wijayawardene et al. 2014b). However, it was treated as Dothideomycetes genera incertae sedis by Phookamsak et al. (2016). Doilom et al. (2018) transferred this genus to their new family Johansoniaceae based on morphology. Orthobellus is similar to Johansonia in having membranous ascomata which lack ostioles, narrowly anastomosing pseudoparaphyses thin-walled at the base and ascospores that are hyaline, ovoid to ellipsoidal, 1-septate, with an apical cell wider than basal cell (Doilom et al. 2018). It differs from Johansonia in forming short, brown, aseptate hyphae at the base of ascomata, and clavate asci. More collections with sequence data are needed to confirm the placement of Orthobellus within Johansoniaceae. 


\section{Ecological and economic significance}

Members of Johansoniaceae are epiphytic or saprobic playing a role in recycling organic matter.

Metacapnodiaceae S. Hughes \& Corlett, in Hughes, N.Z. J1 Bot. 10: 239 (1972).

Index Fungorum number: IF 81649; Facesoffungi number: FoF 06842, 28 species.

Foliar epiphytes on leaves and stems. Mycelium superficial, subiculum spongy, friable, thickwalled, moniliform, anastomosing, branched, sometimes lobed or in the form of hemisphaerical lumps, hyphae, brown to dark brown, septate, with deeply constricted at the septa, smooth or coarsely roughened. Sexual morph: Ascomata basally immersed in the subiculum, globose or broadly ellipsoidal, with numerous hypha-like, septate, appendages. Peridium comprises brown to dark brown of cells of textura angularis. Hamathecium comprising pseudoparaphyses, with numerous asci. Asci 8-spored, bitunicate, ellipsoidal with pedicel, lacking ocular chamber. Ascospores 2-3-seriate, ellipsoidal, or with conical end cells, brown to dark brown, 3-septate, occasionally slightly constricted at the septa, thick-walled, dark at the septa. Asexual morph: Hyphomycetous. Capnocybe: slimy heads phragmoconidia. Capnophialophora phialides state: plump, ampulliform phialides on the moniliform conidiophores, small ameroconidia. Capnosporium: solitary, dry phragmoconidia, produce phialides and microconidia. Hormiokrypsis: solitary, dry stauroconidia (Batista \& Nascimento 1957, Hughes 1966, Hughes \& Seifert 2012, Hyde et al. 2013, photoplates of asexual can be seen in Hughes 1981).

Type - Metacapnodium Speg.

Notes - Metacapnodiaceae is a sooty mould family which produces a hyphomycetous conidial state (Hughes 1972). This family has distinctive hyphae recognized by superficial, glossy, moniliform, widely branched, dark brown walls, strong constrictions at the septa, except for the cells of synnematous asexual morphs, which are progressively narrower and longer, usually tapered towards the apex at the ends (Hughes et al. 2012, Hyde et al. 2013). Some species in this family were discovered in fossil ambers, and were used as a representative from Dothideomycetes in divergence time estimates (Beimforde et al. 2014, Hongsanan et al. 2016a, Liu et al. 2017a). Capnocybe, Capnophialophora, Capnosporium, Hormiokrypsis and Hyphosoma were reported as asexual morph genera in Metacapnodiaceae (Hughes 1966, 1981b, Seifert et al. 2011, Wijayawardene et al. 2012). Hyde et al. (2013) reviewed this family and synonymized Capnocybe under Metacapnodium, thus the family contained six genera, Capnobotrys, Capnophialophora, Capnosporium, Hormiokrypsis, Hyphosoma and Metacapnodium. Capnophialophora, Capnosporium and Hormiokrypsis were synonymized under Metacapnodium (Rossman et al. 2016). We accept only three genera in Metacapnodiaceae (Capnobotrys, Hyphosoma and Metacapnodium). No cultures or sequence data are available for this family.

Metacapnodium Speg., Physis, Rev. Soc. Arg. Cienc. Nat. 4(no. 17): 288 (1918).

Index Fungorum number: IF 3137; Facesoffungi number: FoF 06843; 14 morphological species (Species Fungorum 2020), molecular data unavailable.

Type species - Metacapnodium juniperi (W. Phillips \& Plowr.) Speg.

Notes - All species in this genus produces phialidic Capnophialophora states (Hughes \& Seifert 2012), and some species produce Capnocybe and Capnosporium states (Hughes 1966, 1976). These three asexual genera were synonymized under the name Metacapnodium (Hyde et al. 2013, Rossman et al. 2016). Sequence data are needed to clarify the classification of Metacapnodium.

Metacapnodium juniperi (W. Phillips \& Plowr.) Speg., Physis, Rev. Soc. Arg. Cienc. Nat. 4(no. 17): 288 (1918).

Fig. 14

三Capnodium juniperi W. Phillips \& Plowr., Grevillea 13(no. 67): 75 (1885).

Index Fungorum number: IF 212907; Facesoffungi number: FoF 06844.

Description - see Hyde et al. (2013). 
Material examined - UK, Scotland, Moray coast, Forres, on bark of Juniper twigs, 2 June 1882, Rev. Dr. Keith ex herb. C.B. Plowright (K(M)164026, holotype of Capnodium juniperi).

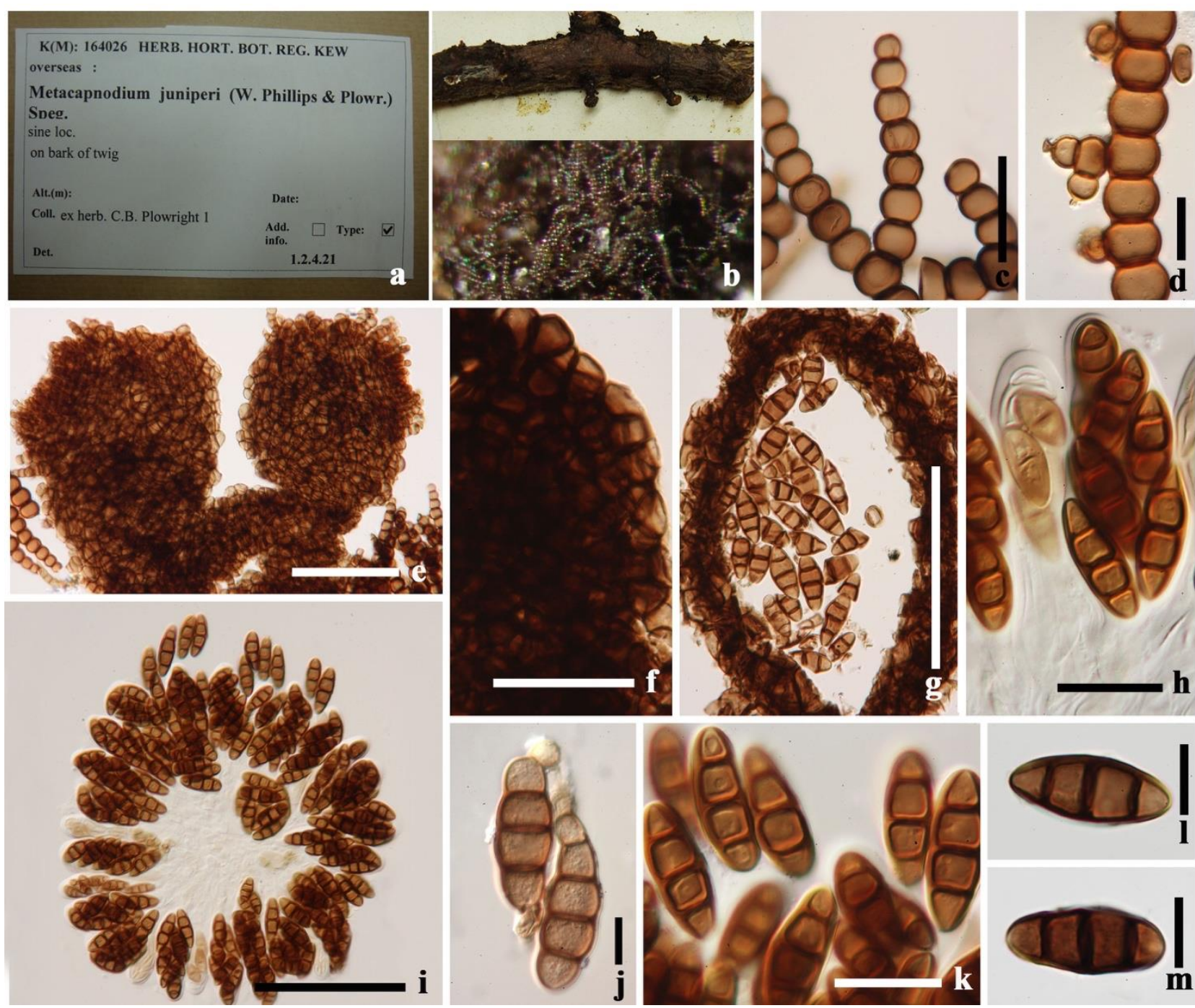

Figure 14 - Metacapnodium juniperi (K(M)164026, holotype). a Appearance on bark of Juniperus communis. b Ascomata. c Moniliform hyphae. e Ascoma wall. e Section through ascoma. $\mathrm{f}-\mathrm{h}$ Group of asci. i-k Ascospores. Scale Bars: e, $\mathrm{g}, \mathrm{i}=100 \mu \mathrm{m}, \mathrm{c}, \mathrm{f}=50 \mu \mathrm{m}, \mathrm{d}, \mathrm{k}=20 \mu \mathrm{m}, \mathrm{h}=15$ $\mu \mathrm{m}, \mathrm{j}, 1, \mathrm{~m}=10 \mu \mathrm{m}$.

\section{Other genera included}

Capnobotrys S. Hughes, N.Z. Jl Bot. 8(2): 205 (1970).

Index Fungorum number: IF 7490; Facesoffungi number: FoF 06845; 9 morphological species (Species Fungorum 2020), molecular data unavailable.

Type species - Capnobotrys neesii S. Hughes, N.Z. Jl Bot. 8(2): 205 (1970).

Notes - Capnobotrys is one of the synasexual morphs of Metacapnodiaceae, which was erected by Hughes (1970). Morphological characters of Capnobotrys species were provided in Hughes (1981). The genus differs from Metacapnodium in having 1-septate or somewhat 2- to multi-septate, conidia developing successively on clustered sympodulae on mononematous hyphae, while Metacapnodium has conidia develop successively on densely crowned sympodulae on synnematous hyphae, and 3-8-septate, ellipsoidal, 3-septate, brown ascospores (Hyde et al. 2013, key to genera of Metacapnodiaceae).

Hyphosoma Syd., Annls mycol. 22(3/6): 315 (1924). 
Index Fungorum number: IF 8608; Facesoffungi number: FoF 06846; 5 morphological species (Species Fungorum 2020), molecular data unavailable.

Type species - Hyphosoma hypoxyloides Syd., Annls mycol. 22(3/6): 315 (1924).

Notes - Hughes (1970) concluded that the type species H. hypoxyloides is best considered a nomen confusum (Art. 69) based on a collection from New Zealand. Hyphosoma is retained as a distinct genus in Metacapnodiaceae (Wijayawardene et al. 2012, 2017a, Hyde et al. 2013, Chomnunti et al. 2014). Hyphae of this genus has two kinds which are (1) toruloid or moniliform, with secede as 2-celled conidia which vary greatly in size, (2) long, branched, slightly constricted at the septa, do not secede, but bear oblong-fusoid to clavate-fusoid with 8- to 13-septate conidia (Hughes 1970).

\section{Ecological and economic significance}

Metacapnodiaceae is an important but poorly studied family in Dothideomycetes. It occurs on leaves and stems of plants as sooty moulds, however, there is no report on its harmful effect on economic crops. Nutrient uptake mechanisms of species in Metacapnodiaceae should be studied to understand its nutritional mode and distribution. Sequence data of this family is very important in terms of the evolution study using fossil records, since some Metacapnodiaceae species were discovered in fossil ambers.

Mycosphaerellaceae Lindau, in Engler \& Prantl, Nat. Pflanzenfam., Teil. I (Leipzig) 1(1): 421 (1897).

Index Fungorum number: IF 81043; Facesoffungi number: FoF 00119, >5900 species.

ESphaerellaceae Nitschke, Verh. Naturhist. Vereins Preuss. Rheinl. 26: 74. 1869, nom. illeg. (Art. 18.3 and 57.1), non Sphaerellaceae (algae).

Pathogens, endophytes, saprobes, epiphytes on flowering plants or lichens as well as fungicolous on other fungi. Sexual morph: Ascostromata solitary to gregarious, semi-immersed to superficial, dark brown to black, circular to elongate, stromatic, uni- to multi-loculate, sometimes forming pseudostroma or clypeus, or forming hypostroma within ovary of host, glabrous to setose, ostiolate. Ascomata dark brown to black, immersed to semi-immersed in raised, superficial pseudostroma or hypostroma, scattered to clustered, globose to subglobose, ostiole central, with protruding papilla. Peridium thin to thick-walled, composed of cell layers, of dark brown to black, thickened, pseudoparenchymatous cells, arranged in a textura angularis. Hamathecium lacking pseudoparaphyses, occasionally with interthecial filaments (Brunneosphaerella). Asci 8-spored, bitunicate, fissitunicate, cylindrical to cylindric-clavate, or ampulliform, sessile to subsessile, apical rounded, thickened, sometimes with distinct ocular chamber. Ascospores 2-3-seriate, or overlapping, ellipsoidal to obclavate, oblong to cylindrical, hyaline to subhyaline or pale yellowish, aseptate or septate, often constrict at the septum, smooth or rough-walled, with small guttules. Asexual morph: Hyphomycetous, cercosporoid and ramularioid fungi, cercospora-, passalora-, pseudocercospora-, pseudocercosporella-, ramularia- and zasmidium-like. Conidiophores single or in group (fascicles), synnematous, or sporodochia. Conidiogenous cells integrated, terminal or intercalary, with holoblastic conidiogenesis.

Type - Ramularia Unger.

Notes - Mycosphaerellaceae is the largest family in Capnodiales, Dothideomycetes containing 127 genera and more than 5,900 species (Videira et al. 2017, Wijayawardene et al. 2018). The family was introduced by Engler \& Prantl (1897) with Mycosphaerella as the generic type, initially including 14 genera based on morphological characteristics viz. Achorodothis, Brunneosphaerella, Cymadothea, Euryachora, Gillotia, Melanodothis, Mycosphaerella, Placocrea, Polysporella, Pseudostigmidium, Sphaerellothecium, Sphaerulina, Stigmidium, and Wernerella (Lumbsch \& Huhndorf 2010). The family has long been historically discussed based on morphology as well as phylogeny (Crous 2009, Crous et al. 2007a, Hyde et al. 2013, Quaedvlieg et al. 2013, Videira et al. 2017). Phylogenetic studies by Schoch et al. (2006) and Crous et al. (2007a, $2009 \mathrm{c}$ ) confirmed the phylogenetic affinity of Mycosphaerellaceae in Capnodiales and demonstrated that the mycosphaerella-like sexual morph is polyphyletic forming clades in 
Mycosphaerellaceae and other closely related families such as Dissoconiaceae, Davidiellaceae and Teratosphaeriaceae (Hyde et al. 2013). Many Mycosphaerella sensu lato have been segregated at the generic level based on differences of their asexual morphs (Crous et al. 2013a, b, Quaedvlieg et al. 2014, Videira et al. 2017). Hyde et al. (2013) re-circumscribed the genera in Mycosphaerellaceae based on morphological studies of the generic types as well as the representative species, coupled with phylogenetic analysis and accepted 46 genera in this family. Subsequent authors have included many genera in Mycosphaerellaceae based on molecular data coupled with morphological characteristics of their asexual morphs (Crous et al. 2016a, b, 2017a, 2019d, Quaedvlieg et al. 2014, Bakhshi et al. 2015, Guatimosim et al. 2016, Videira et al. 2016, 2017, Hyde et al. 2017, Thambugala et al. 2017b, Hassan \& Chang 2019). However, the phylogenetic position of many genera in Mycosphaerellaceae are unresolved due to lack of molecular data from the generic types viz. Achorodothis, Anguillosporella, Annellophora, Annellophragmia, Annellosympodia, Camptomeris, Ceratosperma, Cercosperma, Cercosphaerella, Cladosporiella, Clypeispora, Episphaerella, Euryachora, Gillotia, Lembosiopsis, Lophiosphaerella, Melanodothis, Mycoporis, Mycovellosiella, Polysporella, Pseudostigmidium, Sirosporium, Sphaerellothecium and Stigmidium (Videira et al. 2017). Videira et al. (2017) attempted to resolve the phylogenetic relationships of the genera in Mycosphaerellaceae based on phylogenetic analyses of a combined LSU, ITS and rpb-2 sequence dataset. Based on these analyses Videira et al. (2017) introduced 32 additional genera and listed 225 genera in Mycosphaerellaceae. Based on morphological characteristics, Boonmee et al. (2017) placed Episphaerella in Mycosphaerellaceae. Boonmee et al. (2017) excluded Placocrea from Mycosphaerellaceae and treated the genus in Teratosphaeriaceae based on the presence of anastomosing pseudoparaphyses. Wijayawardene et al. (2018) listed 129 genera in Mycosphaerellaceae including Placocrea. We follow the latest treatment and updated accounts of Mycosphaerellaceae in Hyde et al. (2013), Boonmee et al. (2017) and Videira et al. (2017). Videira et al. (2017) placed Acrocladium in Mycosphaerellaceae based only on morphology. However, the generic nomenclature is illegitimate. Hence, we exclude this genus from Mycosphaerellaceae. More than 100 genera were previously treated in Mycosphaerellaceae based only on morphological characteristics and some other genera have also been treated as synonyms of the genera in Mycosphaerellaceae (Hyde et al. 2013, Boonmee et al. 2017, Videira et al. 2017). The generic status of these genera is questionable due to the lack of molecular data of the generic type to confirm their phylogenetic affinities in Mycosphaerellaceae. Hence, we accept 112 genera in Mycosphaerellaceae based on molecular data and the other 107 genera are treated as doubtful genera in Mycosphaerellaceae pending further studies. Detailed notes of the genera mainly can be found in Hyde et al. (2013) and Videira et al. (2017).

Ramularia Unger, Exanth. Pflanzen (Wien): 119 (1833).

= Mycosphaerella Johanson, Öfvers. K. Svensk. Vetensk.-Akad. Förhandl. 41(no. 9): 163 (1884) [1884-1885].

Index Fungorum number: IF 9691; Facesoffungi number: FoF 09222; 1,662 morphological species (1,252 species as Mycosphaerella and 410 species as Ramularia) (Species Fungorum 2020), 154 species with molecular data (71 species as Mycosphaerella and 83 species as Ramularia).

Type species - Ramularia endophylla Verkley \& U. Braun, in Verkley, Crous, Groenewald, Braun \& Aptroot, Mycol. Res. 108(11): 1276 (2004).

ESphaeria punctiformis Pers., Ann. Bot. (Usteri) 11: 26 (1794).

= Mycosphaerella punctiformis (Pers.) Starbäck, Bih. K. svenska VetenskAkad. Handl., Afd. 3 15(no. 2): 9 (1889).

Notes - Mycosphaerella was introduced by Johanson (1884) and is typified by $M$. punctiformis. The genus was introduced to accommodate many important pathogenic fungi characterizing by having tiny, black ascomata, immersed to semi-immersed, globose to subglobose, ostiolate, with papillate, thin-walled peridium of 1-3 layers, 8-spored, bitunicate, cylindrical to cylindric-obclavate, subsessile asci, lacking pseudoparaphyses, and hyaline, fusoid-ellipsoidal, 1septate ascospores (Crous et al. 2009e, Hyde et al. 2013). 


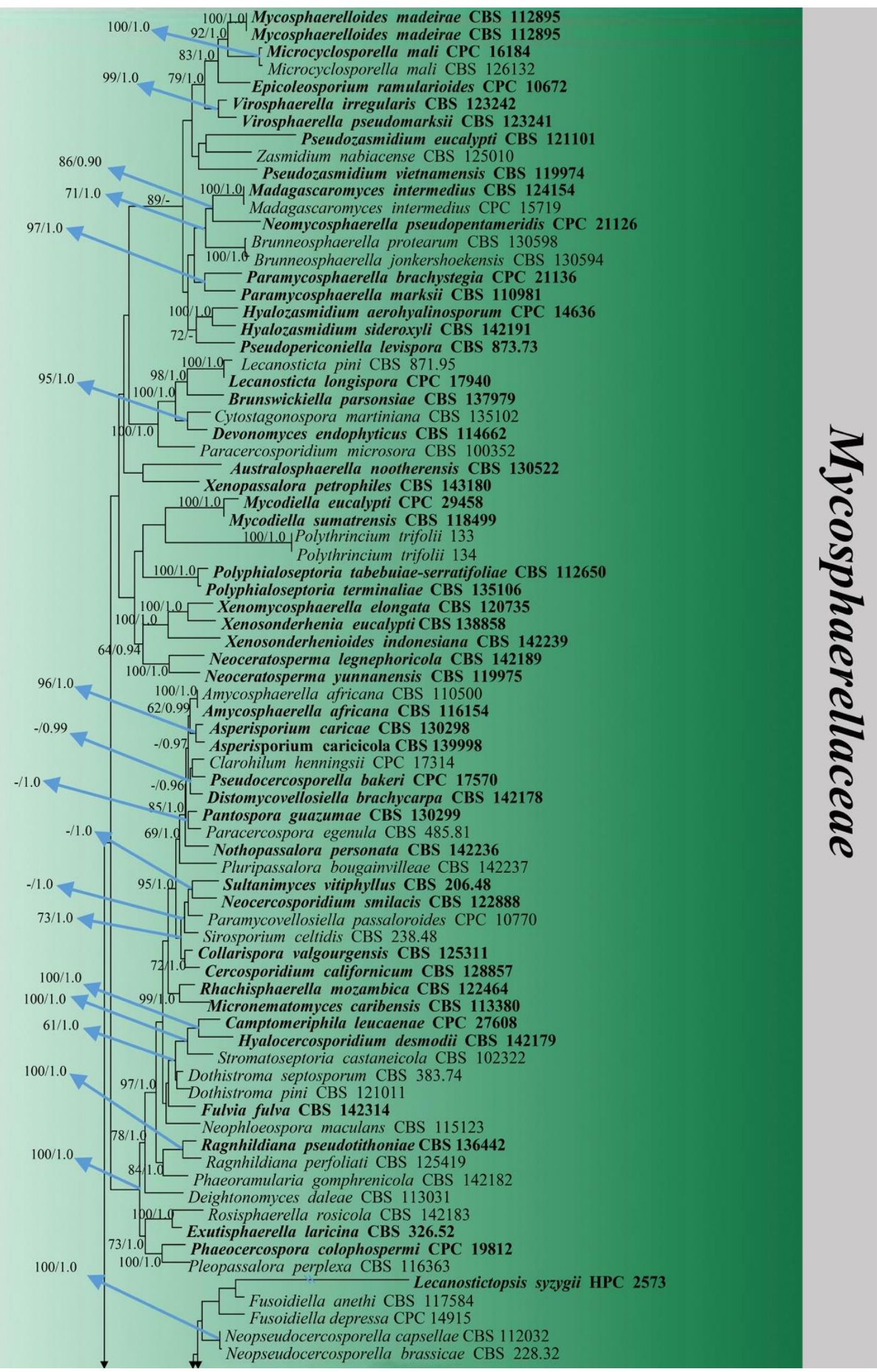

Figure 15 - Phylogram generated from maximum likelihood analysis (RAxML) of Mycosphaerellaceae based on ITS, LSU and rpb-2 sequence data. Maximum likelihood bootstrap values equal or above $70 \%$, Bayesian posterior probabilities equal or above 0.90 (MLBS/PP) are given at the nodes. An original isolate number is noted after the species name. The tree is rooted to Phaeotheca fissurella (UAMH 4245). The ex-type strains are indicated in bold. Hyphen (-) represents support values below $70 \%$ MLBS and 0.90 PP. 


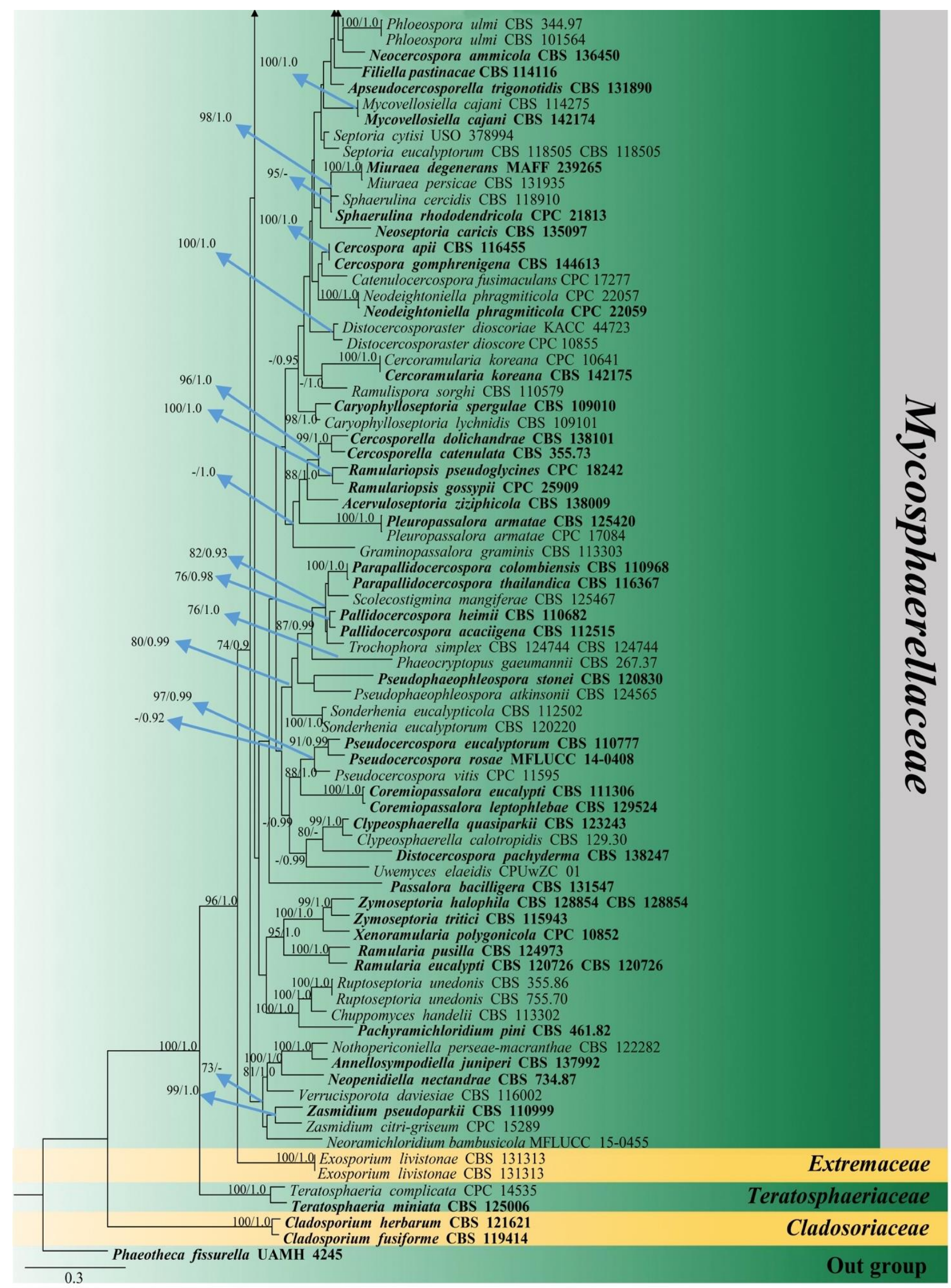

Figure 15 - Continued. 


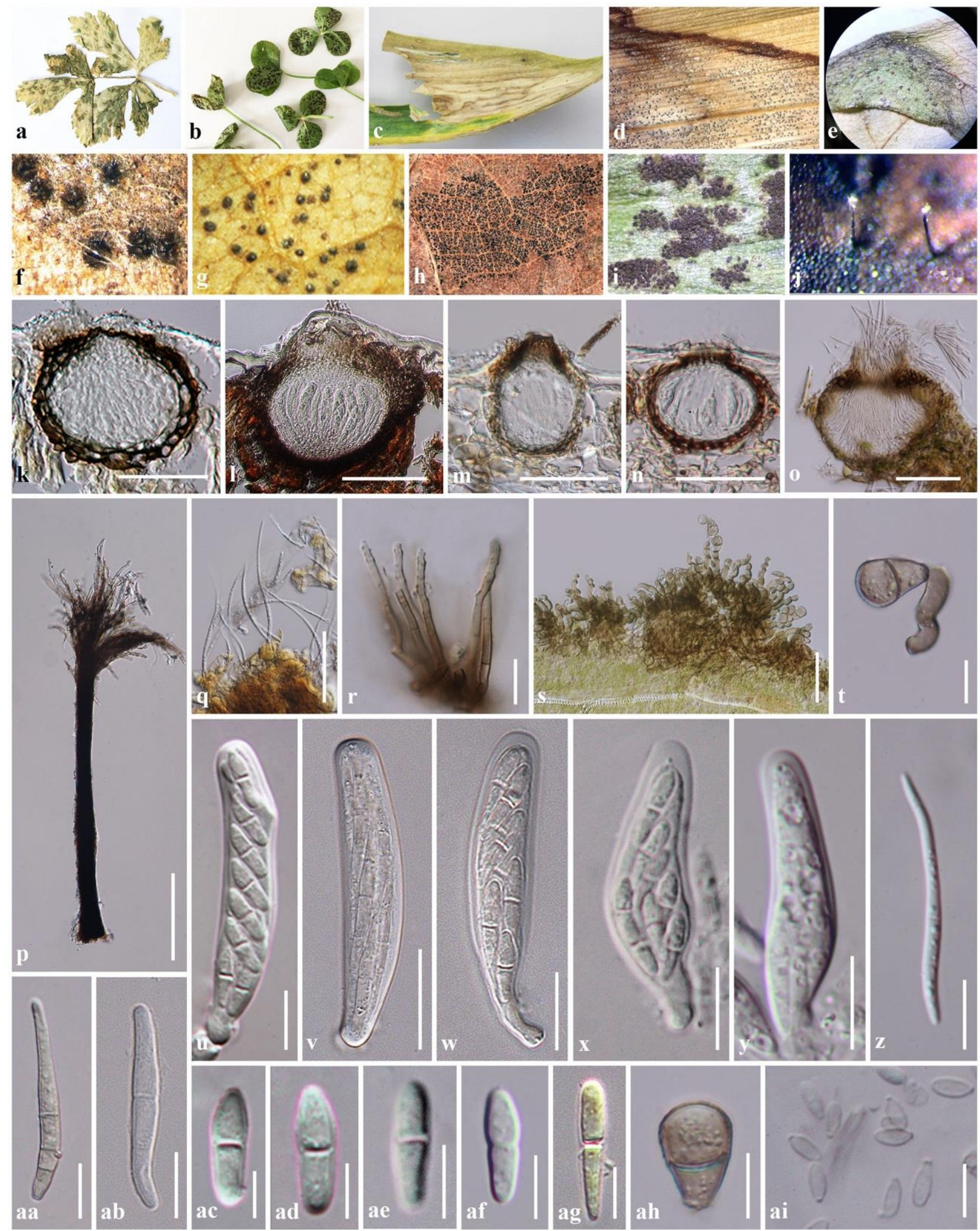

Figure 16 - Representative genera in Mycosphaerellaceae: Brunneosphaerella protearum (f, 1, w, ag); Cercospora sp. (q); Mycosphaerella punctiformis (g, k, u, ac, ad); Neoramichloridium bambusicola (c, r, ai); Pallidocercospora acaciigena (m, y, af); Polythrincium trifolii (b, i, s, t, ah); Pseudocercospora maetaengensis (j, p, aa); Septoria apiicola (a, e, o, z); Sphaerulina myriadea (h, $\mathrm{v}, \mathrm{ab}$ ); Zasmidium musae (d, n, x, ae). a-j Appearances of ascomata/ sporodochia synnemata/ conidiomata on hosts. $\mathrm{k}-\mathrm{o}$ Sections through ascomata/conidiomata. $\mathrm{p}$ Synnemata of Pseudocercospora maetaengensis. $\mathrm{q}$, $\mathrm{t}$ Conidiophores with attached conidia. $\mathrm{r}$ Conidiophores. $\mathrm{s}$ Section through sporodochia. u-y Asci. z, aa, ah, ai Conidia. ac-ag Ascospores (note ag = stained 
in Melzer's reagent). Scale bars: $1=100 \mu \mathrm{m}, \mathrm{k}, \mathrm{m}-\mathrm{o}, \mathrm{q}, \mathrm{s}=50 \mu \mathrm{m}, \mathrm{p}, \mathrm{r}, \mathrm{v}, \mathrm{w}=20 \mu \mathrm{m}, \mathrm{t}, \mathrm{u}, \mathrm{x}-\mathrm{z}, \mathrm{ab}$, ag, ah $=10 \mu \mathrm{m}$, aa, ac-af, ai $=5 \mu \mathrm{m}$.
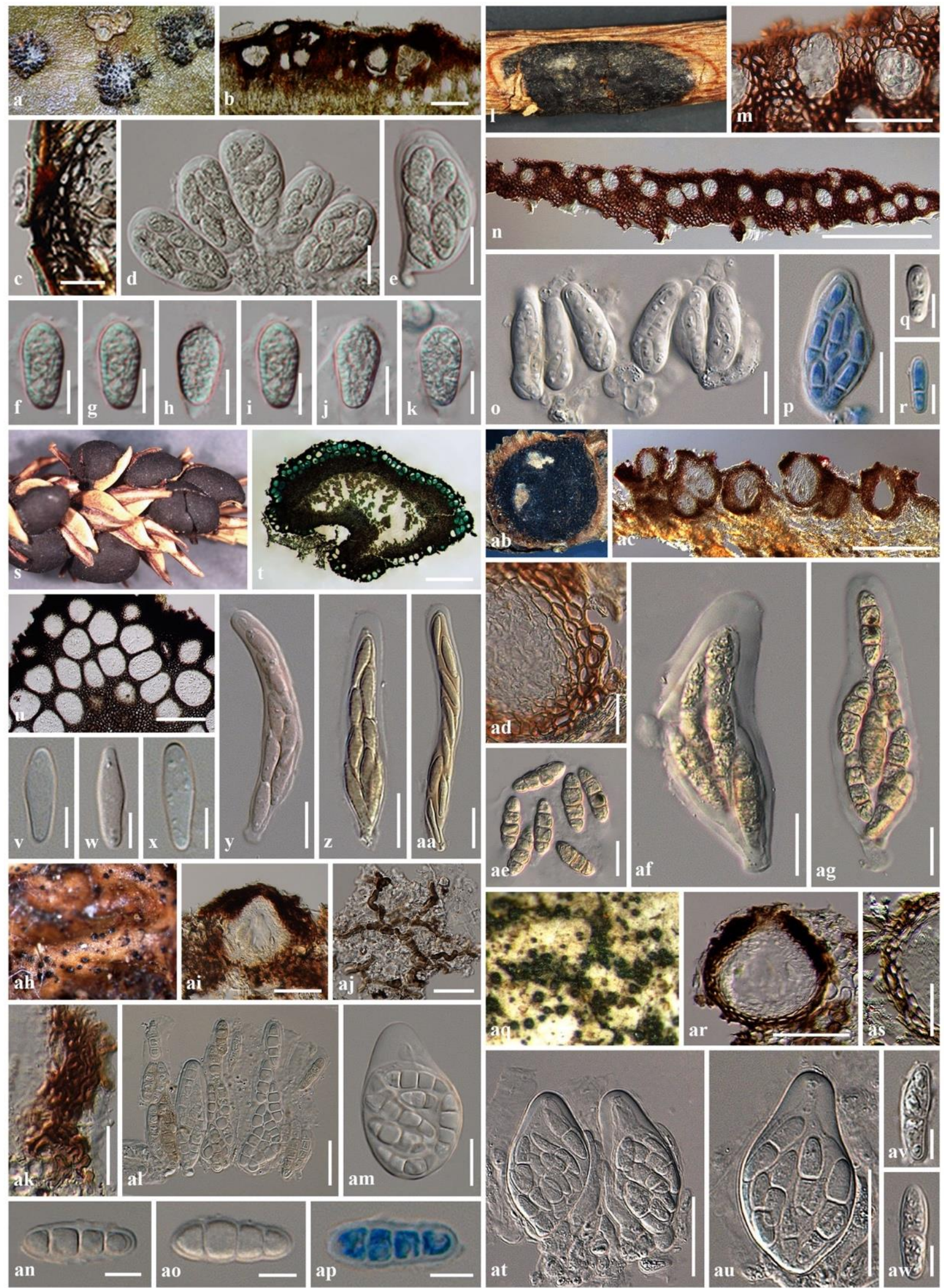

Figure 17 - Representative doubtful genera in Mycosphaerellaceae. a-k Achorodothis poasensis (S-F12569, type). 1-r Euryachora sedi (S-F40747). s-aa Melanodothis caricis (DAOM 116433, type). ab-ag Gillotia orbicularis (S-F9063, type). ah-ap Pseudostigmidium nephromiarium 
(E00223833, type). aq-aw Stigmidium schaereri (BPI 748632). Scale bars: $\mathrm{t}=500 \mu \mathrm{m}, \mathrm{n}, \mathrm{ac}=200$ $\mu \mathrm{m}, \mathrm{b}, \mathrm{u}=100 \mu \mathrm{m}, \mathrm{m}, \mathrm{ai}, \mathrm{ar}=50 \mu \mathrm{m}, \mathrm{c}, \mathrm{ad}-\mathrm{ag}, \mathrm{aj}-\mathrm{al}, \mathrm{as}-\mathrm{au}=20 \mu \mathrm{m}, \mathrm{f}-\mathrm{k}, \mathrm{o}, \mathrm{p}, \mathrm{y}, \mathrm{z}, \mathrm{aa}, \mathrm{am}=10$ $\mu \mathrm{m}, \mathrm{q}, \mathrm{r}, \mathrm{v}-\mathrm{x}$, an-ap, av, aw $=5 \mu \mathrm{m}$.

The asexual morph of Mycosphaerella has been linked to the hyphomycetous genus Ramularia which is characterized by solitary to fasciculate, hyaline conidiophores, distinct, thickened, darkened and refractive conidiogenous loci, and aseptate to transversely septate hyaline conidia with thickened, darkened, refractive scars, lacking appressoria (Verkley et al. 2004, Crous et al. 2009e, Videira et al. 2015b, 2016). Mycosphaerella and Ramularia are polyphyletic (Crous et al. 2007a, 2009e, Videira et al. 2015b, 2016). These two genera have a long historical discussion by many authors (Braun 1995, Crous et al. 2009c, e, Kirschner 2009, Videira et al. 2015b, 2016). Recently, many new genera were introduced to accommodate Mycosphaerella sensu lato and Ramularia sensu lata (Videira et al. 2016, 2017). Based on the agreement for naming of pleomorphic fungi in the International Code of Nomenclature for algae, fungi and plants, Mycosphaerella was treated as a synonym of Ramularia, the oldest name (Wingfield et al. 2012, Rossman et al. 2015, Videira et al. 2015b, 2016).

\section{Other genera included in Mycosphaerellaceae based on molecular data}

Acervuloseptoria Crous \& Jol. Roux, in Crous et al., Persoonia 32: 275 (2014).

Index Fungorum number: IF 808951; Facesoffungi number: FoF 08471; 2 morphological species (Species Fungorum 2020), 2 species with molecular data.

Type species - Acervuloseptoria ziziphicola Crous \& Jol. Roux, in Crous et al., Persoonia 32: 275 (2014).

Notes - see Crous et al. (2014a, 2015b).

Amycosphaerella Quaedvl. \& Crous, in Quaedvlieg et al., Persoonia 33: 22 (2014).

Index Fungorum number: IF 807780; Facesoffungi number: FoF 08472; 2 morphological species (Species Fungorum 2020), 2 species with molecular data.

Type species - Amycosphaerella africana (Crous \& M.J. Wingf.) Quaedvl. \& Crous, in Quaedvlieg et al., Persoonia 33: 22 (2014).

三 Mycosphaerella africana Crous \& M.J. Wingf., Mycologia 88(3): 450 (1996).

Notes - see Quaedvlieg et al. (2014) and Videira et al. (2017).

Annellosympodiella Crous \& Assefa, in Crous et al., Persoonia 32: 245 (2014)

Index Fungorum number: IF 808928; Facesoffungi number: FoF 08473; 1 morphological species (Species Fungorum 2020), 1 species with molecular data.

Type species - Annellosympodiella juniperi Crous \& Assefa, in Crous et al., Persoonia 32: 245 (2014).

Notes - see Crous et al. (2014a) and Videira et al. (2017).

Apseudocercosporella Videira \& Crous, in Videira et al., Stud. Mycol. 83: 89 (2016).

Index Fungorum number: IF 816816; Facesoffungi number: FoF 08474; 1 morphological species (Species Fungorum 2020), 1 species with molecular data.

Type species - Apseudocercosporella trigonotidis Videira, H.D. Shin \& Crous, in Videira et al., Stud. Mycol. 83: 89 (2016).

Notes - see Videira et al. $(2016,2017)$.

Asperisporium Maubl., Bull. Soc. mycol. Fr. 29(3): 357 (1913).

Index Fungorum number: IF 7249; Facesoffungi number: FoF 08475; 17 morphological species (Species Fungorum 2020), 2 species with molecular data.

Type species - Asperisporium caricae (Speg.) Maubl., Lavoura 16: 207 (1913).

三 Cercospora caricae Speg., Anal. Soc. cient. argent. 22(4): 215 (1886). 
Notes - see Schubert \& Braun (2005), Minnis et al. (2011), Crous et al. (2015b) and Videira et al. (2017).

Australosphaerella Videira \& Crous, in Videira et al., Stud. Mycol. 87: 370 (2017).

Index Fungorum number: IF 822579; Facesoffungi number: FoF 08476; 1 morphological species (Species Fungorum 2020), 1 species with molecular data.

Type species - Australosphaerella nootherensis (Carnegie) Videira \& Crous, in Videira et al., Stud. Mycol. 87: 370 (2017). (2011).

三 Mycosphaerella nootherensis Carnegie, in Carnegie et al., Australas. Pl. Path. 40(4): 377

Notes - see Videira et al. (2017).

Brunneosphaerella Crous, in Crous et al., Stud. Mycol. 64: 31 (2009).

Index Fungorum number: IF 514694; Facesoffungi number: FoF 08477; 4 morphological species (Species Fungorum 2020), 4 species with molecular data.

Type species - Brunneosphaerella protearum (Syd. \& P. Syd.) Crous, in Crous et al., Stud. Mycol. 64: 31 (2009).

三Leptosphaeria protearum Syd. \& P. Syd., Annls mycol. 10(5): 441 (1912).

Notes - see Crous et al. (2009c, 2011c), Videira et al. (2017) and Marin-Felix et al. (2019).

Brunswickiella Videira \& Crous, in Videira et al., Stud. Mycol. 87: 352 (2017).

Index Fungorum number: IF 822694; Facesoffungi number: FoF 08478; 1 morphological species (Species Fungorum 2020), 1 species with molecular data.

Type species - Brunswickiella parsonsiae (Crous \& Summerell) Videira \& Crous, in Videira et al., Stud. Mycol. 87: 352 (2017).

$\equiv$ Phaeophleospora parsonsiae Crous \& Summerell [as 'parsoniae'], in Crous et al., Persoonia 32: 217 (2014).

Notes - see Crous et al. (2009c) and Videira et al. (2017).

Camptomeriphila Crous \& M.J. Wingf., in Crous et al., Persoonia 37: 335 (2016).

Index Fungorum number: IF 819083; Facesoffungi number: FoF 08479; 1 morphological species (Species Fungorum 2020), 1 species with molecular data.

Type species - Camptomeriphila leucaenae Crous \& M.J. Wingf., in Crous et al., Persoonia 37: 335 (2016).

Notes - see Crous et al. (2016a).

Caryophylloseptoria Verkley, Quaedvl. \& Crous, Stud. Mycol. 75: 233 (2013).

Index Fungorum number: IF 804469; Facesoffungi number: FoF 08480; 4 morphological species (Species Fungorum 2020), 4 species with molecular data.

Type species - Caryophylloseptoria lychnidis (Desm.) Verkley, Quaedvl. \& Crous, Stud. Mycol. 75: 234 (2013).

三Septoria lychnidis Desm., Annls Sci. Nat., Bot., sér. 3 11(2): 347 (1849).

Notes - see Verkley et al. (2013) and Videira et al. (2017).

Catenulocercospora C. Nakash., Videira \& Crous, in Videira et al., Stud. Mycol. 87: 303 (2017).

Index Fungorum number: IF 822580; Facesoffungi number: FoF 08481; 1 morphological species (Species Fungorum 2020), 1 species with molecular data.

Type species - Catenulocercospora fusimaculans (G.F. Atk.) C. Nakash., Videira \& Crous, in Videira et al., Stud. Mycol. 87: 303 (2017).

三Cercospora fusimaculans G.F. Atk., J. Elisha Mitchell scient. Soc. 8(2): 50 (1892).

Notes - see Videira et al. (2017). 
Cercoramularia Videira, H.D. Shin, C. Nakash. \& Crous, in Videira et al., Stud. Mycol. 87: 299 (2017).

Index Fungorum number: IF 822581; Facesoffungi number: FoF 08482; 1 morphological species (Species Fungorum 2020), 1 species with molecular data.

Type species - Cercoramularia koreana Videira, H.D. Shin, C. Nakash. \& Crous, in Videira et al., Stud. Mycol. 87: 299 (2017).

Notes - see Videira et al. (2017).

Cercospora Fresen. ex Fuckel, Hedwigia 2(15): 133 (1863).

Index Fungorum number: IF 7545; Facesoffungi number: FoF 08483; 754 morphological species (Species Fungorum 2020), 106 species with molecular data.

Type species - Cercospora apii Fresen., Beitr. Mykol. 3: 91 (1863).

Notes - see Groenewald et al. (2005, 2013), Braun et al. (2013, 2015), Braun \& Crous (2016) and Videira et al. (2017).

Cercosporella Sacc., Michelia 2(no. 6): 20 (1880).

Index Fungorum number: IF 7546; Facesoffungi number: FoF 08484; 71 morphological species (Species Fungorum 2020), 5 species with molecular data.

Type species - Cercosporella cana (Sacc.) Sacc., Michelia 2(no. 6): 20 (1880).

Notes - see Kirschner (2009) and Videira et al. (2016, 2017).

Cercosporidium Earle, Muhlenbergia 1(2): 16 (1901).

Index Fungorum number: IF 7547; Facesoffungi number: FoF 08485; 10 morphological species (Species Fungorum 2020), 2 species with molecular data.

Type species - Scolicotrichum euphorbiae Tracy \& Earle, Bull. Torrey bot. Club 23(5): 209 (1896).

Notes - see Koike et al. (2011) and Videira et al. (2017).

Chuppomyces Videira \& Crous, in Videira et al., Stud. Mycol. 87: 370 (2017).

Index Fungorum number: IF 822582; Facesoffungi number: FoF 08486; 1 morphological species (Species Fungorum 2020), 1 species with molecular data.

Type species - Chuppomyces handelii (Bubák) U. Braun, C. Nakash., Videira \& Crous, in Videira et al., Stud. Mycol. 87: 370 (2017).

三 Cercospora handelii Bubák, in Handel-Mazzetti, Annln K. K. naturh. Hofmus. Wien 23: 106 (1909).

Notes - see Videira et al. (2017).

Clarohilum Videira \& Crous, in Videira et al., Stud. Mycol. 87: 334 (2017).

Index Fungorum number: IF 822583; Facesoffungi number: FoF 08487; 1 morphological species (Species Fungorum 2020), 1 species with molecular data.

Type species - Clarohilum henningsii (Allesch.) Videira \& Crous, in Videira et al., Stud. Mycol. 87: 334 (2017).

三 Cercospora henningsii Allesch., in Hennings, Pflanzenw. Ost-Afrikas Nachbarg., Teil C: 35 (1895).

Notes - see Videira et al. (2017).

Clypeosphaerella Guatim., R.W. Barreto \& Crous, in Guatimosim et al., Persoonia 37: 121 (2016). Index Fungorum number: IF 812820; Facesoffungi number: FoF 08488; 3 morphological species (Species Fungorum 2020), 3 species with molecular data.

Type species - Clypeosphaerella quasiparkii (Cheew., K.D. Hyde \& Crous) Guatim., R.W. Barreto \& Crous, in Guatimosim, et al., Persoonia 37: 121 (2016).

三Mycosphaerella quasiparkii Cheew., K.D. Hyde \& Crous, Persoonia 21: 85 (2008).

Notes - see Guatimosim et al. (2016) and Videira et al. (2017). 
Collapsimycopappus A. Hashim., Y. Harada \& Kaz. Tanaka, in Hashimoto et al. Forest Pathology: e12452.

MycoBank MB824336; Facesoffungi number: FoF 08489; 1 morphological species (Hashimoto et al. 2018b), 1 species with molecular data.

Type species - Collapsimycopappus styracis A. Hashim., Y. Harada \& Kaz. Tanaka, in Hashimoto et al. Forest Pathology: e12452.

Notes - see Hashimoto et al. (2018b).

Collarispora Videira \& Crous, in Videira et al., Stud. Mycol. 87: 325 (2017).

Index Fungorum number: IF 822584; Facesoffungi number: FoF 08490; 1 morphological species (Species Fungorum 2020), 1 species with molecular data.

Type species - Collarispora valgourgensis (Crous) Videira \& Crous, in Videira et al., Stud. Mycol. 87: 325 (2017).

三 Mycosphaerella valgourgensis Crous, in Crous et al., Persoonia 26: 151 (2011).

Notes - see Videira et al. (2017).

Coremiopassalora U. Braun, C. Nakash., Videira \& Crous, in Videira et al., Stud. Mycol. 87: 316 (2017).

Index Fungorum number: IF 822585; Facesoffungi number: FoF 08491; 2 morphological species (Species Fungorum 2020), 2 species with molecular data.

Type species - Coremiopassalora eucalypti (Crous \& Alfenas) U. Braun, C. Nakash., Videira \& Crous, in Videira et al., Stud. Mycol. 87: 316 (2017).

=Mycovellosiella eucalypti Crous \& Alfenas, in Crous, Mycol. Mem. 21: 105 (1998).

Notes - see Videira et al. (2017).

Cytostagonospora Bubák, Annls mycol. 14(3/4): 150 (1916).

Index Fungorum number: IF 7910; Facesoffungi number: FoF 07226; 3 morphological species (Species Fungorum 2020), 1 species with molecular data.

Type species - Cytostagonospora photiniicola Bubák [as 'photinicola'], Annls mycol. 14(3/4): 150 (1916).

Notes - see Quaedvlieg et al. (2013) and Videira et al. (2017).

Deightonomyces Videira \& Crous, in Videira et al., Stud. Mycol. 87: 347 (2017).

Index Fungorum number: IF 822586; Facesoffungi number: FoF 08492; 1 morphological species (Species Fungorum 2020), 1 species with molecular data.

Type species - Deightonomyces daleae (Ellis \& Kellerm.) Videira \& Crous, in Videira et al., Stud. Mycol. 87: 347 (2017).

ECercospora daleae Ellis \& Kellerm., J. Mycol. 4(1): 6 (1888).

Notes - see Videira et al. (2017).

Devonomyces Videira \& Crous, in Videira et al., Stud. Mycol. 87: 353 (2017).

Index Fungorum number: IF 822695; Facesoffungi number: FoF 08493;1 morphological species (Species Fungorum 2020), 1 species with molecular data.

Type species - Devonomyces endophyticus (Crous \& H. Sm. ter) Videira \& Crous, in Videira et al., Stud. Mycol. 87: 353 (2017).

$\equiv$ Mycosphaerella endophytica Crous \& H. Sm. ter, in Crous, Mycol. Mem. 21: 54 (1998).

Notes - see Videira et al. (2017).

Dictyosporina L.M. Abreu, R.F. Castañeda \& O.L. Pereira, in Hyde et al., Fungal Diversity 87: 63 (2017).

Index Fungorum number: IF 821781; Facesoffungi number: FoF 03438; 1 morphological species (Species Fungorum 2020), 1 species with molecular data. 
Type species - Dictyosporina ferruginea L.M. Abreu, R.F. Castañeda \& O.L. Pereira, in Hyde et al., Fungal Diversity 87: 63 (2017).

Notes - see Hyde et al. (2017).

Distocercospora N. Pons \& B. Sutton, Mycol. Pap. 160: 60 (1988).

Index Fungorum number: IF 11075; Facesoffungi number: FoF 08494; 4 morphological species (Species Fungorum 2020), 1 species with molecular data.

Type species - Distocercospora pachyderma (Syd. \& P. Syd.) N. Pons \& B. Sutton, Mycol. Pap. 160: 60 (1988).

三 Cercospora pachyderma Syd. \& P. Syd., Annls mycol. 12(2): 203 (1914).

Notes - see Braun et al. (2013, 2014) and Videira et al. (2017).

Distocercosporaster Videira, H.D. Shin, C. Nakash. \& Crous, in Videira et al., Stud. Mycol. 87: 304 (2017).

Index Fungorum number: IF 822587; Facesoffungi number: FoF 08495; 1 morphological species (Species Fungorum 2020), 1 species with molecular data.

Type species - Distocercosporaster dioscoreae (Ellis \& G. Martin) Videira et al., Stud. Mycol. 87: 304 (2017).

三 Cercospora dioscoreae Ellis \& G. Martin, Am. Nat. 16(12): 1003 (1882).

Notes - see Videira et al. (2017).

Distomycovellosiella U. Braun, C. Nakash., Videira \& Crous, in Videira et al., Stud. Mycol. 87: 330 (2017).

Index Fungorum number: IF 822588; Facesoffungi number: FoF 08496; 1 morphological species (Species Fungorum 2020), 1 species with molecular data.

Type species - Distomycovellosiella brachycarpa (Syd.) U. Braun, C. Nakash., Videira \& Crous, in Videira et al., Stud. Mycol. 87: 330 (2017).

三 Cercospora brachycarpa Syd., Annls mycol. 28(1/2): 207 (1930).

Notes - see Videira et al. (2017).

Dothistroma Hulbary, Bull. Ill. nat. Hist. Surv. 21: 235 (1941).

Index Fungorum number: IF 8102; Facesoffungi number: FoF 08497; 3 morphological species (Species Fungorum 2020), 2 species with molecular data.

Type species - Dothistroma pini Hulbary, Bull. Ill. St. nat. Hist. Surv. 21(7): 235 (1941).

Notes - see Videira et al. (2017).

Epicoleosporium Videira \& Crous, in Videira et al., Stud. Mycol. 83: 100 (2016).

Index Fungorum number: IF 816817; Facesoffungi number: FoF 08498; 1 morphological species (Species Fungorum 2020), 1 species with molecular data.

Type species - Epicoleosporium ramularioides Videira, H.D. Shin \& Crous, in Videira et al., Stud. Mycol. 83: 100 (2016).

Notes - see Videira et al. (2016, 2017).

Exopassalora Videira \& Crous, in Videira et al., Stud. Mycol. 87: 380 (2017).

Index Fungorum number: IF 822589; Facesoffungi number: FoF 07641; 1 morphological species (Species Fungorum 2020), 1 species with molecular data.

Type species - Exopassalora zambiae (Crous \& T.A. Cout.) Videira \& Crous, in Videira et al., Stud. Mycol. 87: 380 (2017).

$\equiv$ Passalora zambiae Crous \& T.A. Cout., in Crous et al., Stud. Mycol. 50(1): 209 (2004).

Notes - see Videira et al. (2017).

Exosporium Link, Mag. Gesell. naturf. Freunde, Berlin 3(1-2): 9 (1809). 
Index Fungorum number: IF 8240; Facesoffungi number: FoF 08499; 42 morphological species (Species Fungorum 2020), 3 species with molecular data.

Type species - Exosporium tiliae Link, Mag. Gesell. naturf. Freunde, Berlin 3(1-2): 10 (1809).

Notes - see Videira et al. (2017).

Exutisphaerella Videira \& Crous, in Videira et al., Stud. Mycol. 87: 351 (2017).

Index Fungorum number: IF 822590; Facesoffungi number: FoF 08500; 1 morphological species (Species Fungorum 2020), 1 species with molecular data.

Type species - Exutisphaerella laricina (R. Hartig) Videira \& Crous, in Videira et al., Stud. Mycol. 87: 352 (2017).

Notes - see Videira et al. (2017).

Filiella Videira \& Crous, in Videira et al., Stud. Mycol. 83: 88 (2016).

Index Fungorum number: IF 816823; Facesoffungi number: FoF 08501; 1 morphological species (Species Fungorum 2020), 1 species with molecular data.

Type species - Filiella pastinacae (P. Karst.) Videira \& Crous, in Videira et al., Stud. Mycol. 83: 88 (2016).

ECercosporella pastinacae P. Karst., Hedwigia 23(4): 63 (1884).

Notes - see Videira et al. (2016, 2017).

Fulvia Cif., Atti Ist. bot. Univ. Lab. crittog. Pavia, sér. 5 10(2): 246 (1954).

Index Fungorum number: IF 8276; Facesoffungi number: FoF 08502; 1 morphological species (Species Fungorum 2020), 1 species with molecular data.

Type species - Fulvia fulva (Cooke) Cif., Atti Ist. bot. Univ. Lab. crittog. Pavia, sér. 5 10(1): 246 (1954).

三Cladosporium fulvum Cooke, Grevillea 12(no. 61): 32 (1883).

Notes - see Videira et al. (2017).

Fusoidiella Videira \& Crous, in Videira et al., Stud. Mycol. 83: 87 (2016).

Index Fungorum number: IF 816818; Facesoffungi number: FoF 08503; 2 morphological species (Species Fungorum 2020), 2 species with molecular data.

Type species - Fusoidiella depressa (Berk. \& Broome) Videira \& Crous, in Videira et al., Stud. Mycol. 83: 88 (2016).

$\equiv$ Cladosporium depressum Berk. \& Broome, Ann. Mag. nat. Hist., Ser. 2 7: 99 (1851).

Notes - see Videira et al. $(2016,2017)$.

Graminopassalora U. Braun, C. Nakash., Videira \& Crous, in Videira et al., Stud. Mycol. 87: 307 (2017).

Index Fungorum number: IF 822591; Facesoffungi number: FoF 08504; 1 morphological species (Species Fungorum 2020), 1 species with molecular data.

Type species - Graminopassalora graminis (Fuckel) U. Braun, C. Nakash., Videira \& Crous, in Videira et al., Stud. Mycol. 87: 308 (2017).

三Scolicotrichum graminis Fuckel, Jb. nassau. Ver. Naturk. 23-24: 107 (1870) [1869-70]

Notes - see Videira et al. (2017).

Hyalocercosporidium Videira \& Crous, in Videira et al., Stud. Mycol. 87: 339 (2017)

Index Fungorum number: IF 822592; Facesoffungi number: FoF 08505; 1 morphological species (Species Fungorum 2020), 1 species with molecular data.

Type species - Hyalocercosporidium desmodii Videira \& Crous, in Videira et al., Stud. Mycol. 87: 340 (2017).

Notes - see Videira et al. (2017). 
Hyalozasmidium U. Braun, C. Nakash., Videira \& Crous, in Videira et al., Stud. Mycol. 87: 375 (2017).

Index Fungorum number: IF 822593; Facesoffungi number: FoF 08506; 2 morphological species (Species Fungorum 2020), 2 species with molecular data.

Type species - Hyalozasmidium aerohyalinosporum (Crous \& Summerell) Videira \& Crous, in Videira et al., Stud. Mycol. 87: 375 (2017).

三Zasmidium aerohyalinosporum Crous \& Summerell, Persoonia 23: 144 (2009).

Notes - see Videira et al. (2017).

Janetia M.B. Ellis, More Dematiaceous Hyphomycetes (Kew): 33 (1976).

Index Fungorum number: IF 8650; Facesoffungi number: FoF 08507; 14 morphological species (Species Fungorum 2020), 2 species with molecular data.

Type species - Janetia euphorbiae M.B. Ellis, More Dematiaceous Hyphomycetes (Kew): 33 (1976).

Notes - see Da Silva et al. (2016) and Videira et al. (2017).

Lecanosticta Syd., in Sydow \& Petrak, Annls mycol. 20(3/4): 211 (1922).

Index Fungorum number: IF 8720; Facesoffungi number: FoF 08508; 10 morphological species (Species Fungorum 2020), 9 species with molecular data.

Type species - Lecanosticta pini Syd., in Sydow \& Petrak, Annls mycol. 20(3/4): 211 (1922)

Notes - see Quaedvlieg et al. (2012) and Videira et al. (2017).

Madagascaromyces U. Braun, C. Nakash., Videira \& Crous, in Videira et al., Stud. Mycol. 87: 376 (2017).

Index Fungorum number: IF 822594; Facesoffungi number: FoF 08509; 1 morphological species (Species Fungorum 2020), 1 species with molecular data.

Type species - Madagascaromyces intermedius (Crous \& M.J. Wingf.) Videira \& Crous, in Videira et al., Stud. Mycol. 87: 376 (2017).

三 Passalora intermedia Crous \& M.J. Wingf., Persoonia 22: 88 (2009).

Notes - see Videira et al. (2017).

Microcyclosporella J. Frank, Schroers \& Crous, in Frank et al., Persoonia 24: 101 (2010).

Index Fungorum number: IF 516840; Facesoffungi number: FoF 08510;1 morphological species (Species Fungorum 2020), 1 species with molecular data.

Type species - Microcyclosporella mali J. Frank, Schroers \& Crous, in Frank et al., Persoonia 24: 101 (2010).

Notes - see Frank et al. (2010) and Videira et al. (2016, 2017).

Micronematomyces U. Braun, C. Nakash., Videira \& Crous, in Videira et al., Stud. Mycol. 87: 337 (2017).

Index Fungorum number: IF 822595; Facesoffungi number: FoF 08511; 2 morphological species (Species Fungorum 2020), 2 species with molecular data.

Type species - Micronematomyces caribensis (Crous \& Den Breeÿen) U. Braun, C. Nakash., Videira \& Crous, in Videira et al., Stud. Mycol. 87: 337 (2017).

$\equiv$ Passalora caribensis Crous \& Den Breeÿen, in Breeÿen, Groenewald, Verkley \& Crous, Fungal Diversity 23: 98 (2006).

Notes - see Videira et al. (2017).

Miuraea Hara, Byogaichu-Hoten (Manual of Pests and Diseases): 779 (1948).

Index Fungorum number: IF 8957; Facesoffungi number: FoF 08512; 1 morphological species (Species Fungorum 2020), 1 species with molecular data.

Type species - Miuraea degenerans (Syd. \& P. Syd.) Hara, Byogaichu-Hoten (Manual of Pests and Diseases): 260 (1948). 
EClasterosporium degenerans Syd. \& P. Syd., Annls mycol. 12(2): 164 (1914).

Notes - see Videira et al. (2017).

Mycodiella Crous, in Crous et al., Persoonia 37: 337 (2016).

Index Fungorum number: IF 819085; Facesoffungi number: FoF 08513; 3 morphological species (Species Fungorum 2020), 2 species with molecular data.

Type species - Mycodiella eucalypti Crous, in Crous et al., Persoonia 37: 337 (2016).

Notes - see Crous et al. (2016a) and Videira et al. (2017).

Mycosphaerelloides Videira \& Crous, in Videira et al., Stud. Mycol. 83: 99 (2016).

Index Fungorum number: IF 816819; Facesoffungi number: FoF 08514; 1 morphological species (Species Fungorum 2020), 1 species with molecular data.

Type species - Mycosphaerelloides madeirae (Crous \& Denman) Videira \& Crous, in Videira, Groenewald, Braun, Shin \& Crous, Stud. Mycol. 83: 100 (2016). (2004).

$\equiv$ Mycosphaerella madeirae Crous \& Denman, in Crous et al., Stud. Mycol. 50(1): 204

Notes - see Videira et al. $(2016,2017)$.

Mycovellosiella Rangel, Archos Jard. bot., Rio de J. 2: 71 (1917).

Index Fungorum number: IF 9038; Facesoffungi number: FoF 08515; 34 morphological species (Species Fungorum 2020), 4 species with molecular data.

Type species - Mycovellosiella cajani (Henn.) Rangel ex Trotter, Syll. fung. (Abellini) 25: 942 (1931).

ECercospora cajani Henn., Hedwigia 41: 309 (1902).

Notes - see Videira et al. (2017).

Neoceratosperma Crous \& Cheew., in Crous et al., Persoonia 32: 257 (2014).

Index Fungorum number: IF 808935; Facesoffungi number: FoF 08516; 6 morphological species (Species Fungorum 2020), 6 species with molecular data.

Type species - Neoceratosperma eucalypti Crous \& Cheew., in Crous et al., Persoonia 32: 257 (2014).

Notes - see Crous et al. (2014a) and Videira et al. (2017).

Neocercospora Bakhshi, Arzanlou, Babai-ahari \& Crous, in Bakhshi et al., Phytotaxa 213: 28 (2015).

Index Fungorum number: IF 812284; Facesoffungi number: FoF 08517; 1 morphological species (Species Fungorum 2020), 1 species with molecular data.

Type species - Neocercospora ammicola Bakhshi, Arzanlou, Babai-ahari \& Crous, in Bakhshi et al., Phytotaxa 213: 28 (2015).

Notes - see Bakhshi et al. (2015) and Videira et al. (2017).

Neocercosporidium Videira \& Crous, in Videira et al., Stud. Mycol. 87: 325 (2017).

Index Fungorum number: IF 822596; Facesoffungi number: FoF 08518; 1 morphological species (Species Fungorum 2020), 1 species with molecular data.

Type species - Neocercosporidium smilacis (Thüm.) U. Braun, C. Nakash., Videira \& Crous, in Videira et al., Stud. Mycol. 87: 326 (2017).

三Cercospora smilacis Thüm., Inst. Rev. Cient. Litt., Coimbra 27: 14 (1879).

Notes - see Videira et al. (2017).

Neodeightoniella Crous \& W.J. Swart, in Crous et al., Persoonia 31: 211 (2013).

Index Fungorum number: IF 805827; Facesoffungi number: FoF 08519; 1 morphological species (Species Fungorum 2020), 1 species with molecular data. 
Type species - Neodeightoniella phragmiticola Crous \& W.J. Swart, in Crous et al., Persoonia 31: 211 (2013).

Notes - see Crous et al. (2013b) and Videira et al. (2017).

Neomycosphaerella Crous, in Crous et al., Persoonia 31: 195 (2013).

Index Fungorum number: IF 805814; Facesoffungi number: FoF 08520; 1 morphological species (Species Fungorum 2020), 1 species with molecular data.

Type species - Neomycosphaerella pseudopentameridis Crous, in Crous et al., Persoonia 31: 195 (2013).

Notes - see Crous et al. (2013b) and Videira et al. (2017).

Neopenidiella Quaedvl. \& Crous, in Quaedvlieg et al., Persoonia 33: 22 (2014).

Index Fungorum number: IF 807778; Facesoffungi number: FoF 08521; 1 morphological species (Species Fungorum 2020), 1 species with molecular data.

Type species - Neopenidiella nectandrae (Crous, U. Braun \& R.F. Castañeda) Quaedvl. \& Crous, in Quaedvlieg et al., Persoonia 33: 22 (2014).

$\equiv$ Penidiella nectandrae Crous, U. Braun \& R.F. Castañeda, in Crous, Braun \& Groenewald, Stud. Mycol. 58: 20 (2007).

Notes - see Quaedvlieg et al. (2014) and Videira et al. (2017).

Neophloeospora U. Braun, C. Nakash., Videira \& Crous, in Videira et al., Stud. Mycol. 87: 338 (2017).

Index Fungorum number: IF 822598; Facesoffungi number: FoF 08522; 1 morphological species (Species Fungorum 2020), 1 species with molecular data.

Type species - Neophloeospora maculans (Berenger) Videira \& Crous, in Videira et al., Stud. Mycol. 87: 338 (2017).

三Fusarium maculans Bérenger, Atti Riunione Sci. Ital. (Milano) 6: 474 (1845).

Notes - see Videira et al. (2017).

Neopseudocercospora Crous, in Crous et al., Persoonia 31: 219 (2013).

Index Fungorum number: IF 805834; Facesoffungi number: FoF 08523; 2 morphological species (Species Fungorum 2020), 1 species with molecular data. (2013).

Type species - Neopseudocercospora terminaliae Crous, in Crous et al., Persoonia 31: 219

Notes - see Crous et al. (2013b), Braun et al. (2014) and Videira et al. (2017).

Neopseudocercosporella Videira \& Crous, in Videira et al., Stud. Mycol. 83: 80 (2016).

Index Fungorum number: IF 816820; Facesoffungi number: FoF 08524; 2 morphological species (Species Fungorum 2020), 2 species with molecular data.

Type species - Neopseudocercosporella capsellae (Ellis \& Everh.) Videira \& Crous, in Videira et al., Stud. Mycol. 83: 86 (2016).

三 Cylindrosporium capsellae Ellis \& Everh., J. Mycol. 3(11): 130 (1887).

Notes - see Videira et al. (2016, 2017).

Neoramichloridium Phookamsak, Thambug. \& K.D. Hyde, in Thambugala et al., Mycosphere 8(4): 732 (2017).

Index Fungorum number: IF 553183; Facesoffungi number: FoF 08525; 1 morphological species (Species Fungorum 2020), 1 species with molecular data.

Type species - Neoramichloridium bambusicola Thambug., Phookamsak \& K.D. Hyde, in Thambugala et al., Mycosphere 8(4): 732 (2017).

Notes - see Thambugala et al. (2017b).

Neoseptoria Quaedvl., Verkley \& Crous, Stud. Mycol. 75: 352 (2013). 
Index Fungorum number: IF 804421; Facesoffungi number: FoF 08526; 1 morphological species (Species Fungorum 2020), 1 species with molecular data.

Type species - Neoseptoria caricis Quaedvl., Verkley \& Crous, Stud. Mycol. 75: 352 (2013).

Notes - see Quaedvlieg et al. (2013) and Videira et al. (2017).

Nothopassalora U. Braun, C. Nakash., Videira \& Crous, in Videira et al., Stud. Mycol. 87: 333 (2017).

Index Fungorum number: IF 822696; Facesoffungi number: FoF 08527; 1 morphological species (Species Fungorum 2020), 1 species with molecular data.

Type species - Nothopassalora personata (Berk. \& M.A. Curtis) U. Braun, C. Nakash., Videira \& Crous, in Videira et al., Stud. Mycol. 87: 333 (2017).

三 Cladosporium personatum Berk. \& M.A. Curtis, in Berkeley, Grevillea 3(no. 27): 106 (1875).

Notes - see Videira et al. (2017).

Nothopericoniella Videira \& Crous, in Videira et al., Stud. Mycol. 87: 364 (2017).

Index Fungorum number: IF 822697; Facesoffungi number: FoF 08528; 1 morphological species (Species Fungorum 2020), 1 species with molecular data.

Type species - Nothopericoniella perseae-macranthae (Hosag. \& U. Braun) Videira \& Crous, in Videira et al., Stud. Mycol. 87: 364 (2017). [1995].

$\equiv$ Periconiella perseae-macranthae Hosag. \& U. Braun, Indian Phytopath. 48(3): 260 (1996)

Notes - see Videira et al. (2017).

Nothophaeocryptopus Videira, C. Nakash. \& Crous, in Videira et al., Stud. Mycol. 87: 309 (2017). Index Fungorum number: IF 822698; Facesoffungi number: FoF 08529; 1 morphological species (Species Fungorum 2020), 1 species with molecular data.

Type species - Nothophaeocryptopus gaeumannii (T. Rohde) Videira, C. Nakash., U. Braun \& Crous, in Videira et al., Stud. Mycol. 87: 309 (2017).

三Adelopus gaeumannii T. Rohde [as 'gaeumanni'], Silva 24: 51 (1936).

Notes - see Videira et al. (2017).

Nothotrimmatostroma Crous, in Crous et al., Stud. Mycol. 94: 206 (2019).

Index Fungorum number: IF 832033; Facesoffungi number: FoF 08530; 2 morphological species (Species Fungorum 2020), 2 species with molecular data.

Type species - Nothotrimmatostroma bifarium (Gadgil \& M.A. Dick) Crous, in Crous et al., Stud. Mycol. 94: 207 (2019).

三Trimmatostroma bifarium Gadgil \& M.A. Dick, N.Z. J1 Bot. 21(1): 49 (1983).

Notes - see Crous et al. (2019d).

Pachyramichloridium Videira \& Crous, in Videira et al., Stud. Mycol. 87: 371 (2017).

Index Fungorum number: IF 822600; Facesoffungi number: FoF 08531; 1 morphological species (Species Fungorum 2020), 1 species with molecular data.

Type species - Pachyramichloridium pini (de Hoog \& Rahman) C. Nakash., Videira \& Crous, in Videira et al., Stud. Mycol. 87: 371 (2017).

$\equiv$ Ramichloridium pini de Hoog \& Rahman, in de Hoog, Rahman \& Boekhout, Trans. Br. mycol. Soc. 81(3): 485 (1983).

Notes - see Videira et al. (2017).

Pallidocercospora Crous, in Crous et al., Stud. Mycol. 75: 73 (2012) [2013].

Index Fungorum number: IF 564820; Facesoffungi number: FoF 08532; 8 morphological species (Species Fungorum 2020), 8 species with molecular data. 
Type species - Pallidocercospora heimii (Crous) Crous, in Crous et al., Stud. Mycol. 75: 74 (2012) [2013].

EPseudocercospora heimii Crous, in Crous \& Swart, S. African Forestry J1 172: 4 (1995).

Notes - see Crous et al. (2013a), Hyde et al. (2016) and Videira et al. (2017).

Pantospora Cif., Annls mycol. 36(2/3): 242 (1938).

Index Fungorum number: IF 9201; Facesoffungi number: FoF 08533; 2 morphological species (Species Fungorum 2020), 2 species with molecular data.

Type species - Pantospora guazumae Cif., Annls mycol. 36(2/3): 240 (1938).

Notes - see Minnis et al. (2011), Braun et al. (2013) and Videira et al. (2017).

Paracercospora Deighton, Mycol. Pap. 144: 47 (1979).

Index Fungorum number: IF 9206; Facesoffungi number: FoF 08534; 3 morphological species (Species Fungorum 2020), 1 species with molecular data.

Type species - Paracercospora egenula (Syd.) Deighton, Mycol. Pap. 144: 48 (1979).

$\equiv$ Cercoseptoria egenula Syd., Annls mycol. 33(3/4): 235 (1935).

Notes - see Braun et al. (2013), Crous et al. (2013a), Ou et al. (2015), Vaghefi et al. (2016) and Videira et al. (2017).

Paracercosporidium Videira \& Crous, in Videira et al., Stud. Mycol. 87: 319 (2017).

Index Fungorum number: IF 822601; Facesoffungi number: FoF 08535; 2 morphological species (Species Fungorum 2020), 2 species with molecular data.

Type species - Paracercosporidium microsorum (Sacc.) U. Braun, C. Nakash., Videira \& Crous, in Videira et al., Stud. Mycol. 87: 319 (2017).

三 Cercospora microsora Sacc., Michelia 2(no. 6): 128 (1880).

Notes - see Videira et al. (2017).

Paramycosphaerella Crous \& Jol. Roux, in Crous et al., Persoonia 31: 245 (2013).

Index Fungorum number: IF 805850; Facesoffungi number: FoF 08536; 11 morphological species (Species Fungorum 2020), 11 species with molecular data.

Type species - Paramycosphaerella brachystegiae Crous \& Jol. Roux [as 'brachystegia'], in Crous et al., Persoonia 31: 245 (2013).

Notes - see Crous et al. (2013b) and Videira et al. (2017).

Paramycovellosiella Videira, H.D. Shin \& Crous, in Videira et al., Stud. Mycol. 87: 327 (2017).

Index Fungorum number: IF 822603; Facesoffungi number: FoF 08537; 1 morphological species (Species Fungorum 2020), 1 species with molecular data.

Type species - Paramycovellosiella passaloroides (G. Winter) Videira, H.D. Shin \& Crous, in Videira et al., Stud. Mycol. 87: 327 (2017).

Notes - see Videira et al. (2017).

Parapallidocercospora Videira, Crous, U. Braun \& C. Nakash., in Videira et al., Stud. Mycol. 87: 310 (2017).

Index Fungorum number: IF 822604; Facesoffungi number: FoF 08538; 2 morphological species (Species Fungorum 2020), 2 species with molecular data.

Type species - Parapallidocercospora colombiensis (Crous \& M.J. Wingf.) Videira \& Crous, in Videira et al., Stud. Mycol. 87: 310 (2017).

$\equiv$ Pseudocercospora colombiensis Crous \& M.J. Wingf., in Crous, Mycol. Mem. 21: 42 (1998).

Notes - see Videira et al. (2017).

Passalora Fr., Summa veg. Scand., Sectio Post. (Stockholm): 500 (1849). 
Index Fungorum number: IF 9233; Facesoffungi number: FoF 08539; 557 morphological species (Species Fungorum 2020), 17 species with molecular data.

Type species - Passalora bacilligera (Mont. \& Fr.) Mont. \& Fr., Syll. gen. sp. crypt. (Paris): 305 (1856).

三Cladosporium bacilligerum Mont. \& Fr., in Montagne, Annls Sci. Nat., Bot., sér. 2 6: 31 (1836).

Notes - see Braun et al. (2013), Crous et al. (2013a) and Videira et al. (2017).

Phaeocercospora Crous, in Crous et al., Persoonia 28: 171 (2012).

Index Fungorum number: IF 800386; Facesoffungi number: FoF 08540; 2 morphological species (Species Fungorum 2020), 2 species with molecular data. (2012).

Type species - Phaeocercospora colophospermi Crous, in Crous et al., Persoonia 28: 171

Notes - see Crous et al. (2012) and Videira et al. (2017).

Phaeophleospora Rangel, Arq. Mus. Nac. Rio de Janeiro 18(7-9): 162 (1917).

Index Fungorum number: IF 9311; Facesoffungi number: FoF 08541; 19 morphological species (Species Fungorum 2020), 11 species with molecular data.

Type species - Phaeophleospora eugeniae Rangel, Arq. Mus. Nac. Rio de Janeiro 18(7-9): 162 (1917).

Notes - see Quaedvlieg et al. (2014), Crous et al. (2015c), Guatimosim et al. (2016) and Videira et al. (2017).

Phaeoramularia Munt.-Cvetk., Lilloa 30: 182 (1960).

Index Fungorum number: IF 9314; Facesoffungi number: FoF 08542; 27 morphological species (Species Fungorum 2020), 9 species with molecular data.

Type species - Phaeoramularia gomphrenicola (Speg.) Munt.-Cvetk., Lilloa 30: 209 (1960).

三Cercospora gomphrenicola Speg., Anal. Soc. cient. argent. 13(1): 29 (1882).

Notes - see Videira et al. (2017).

Phloeospora Wallr., Fl. crypt. Germ. (Norimbergae) 2: 176 (1833).

Index Fungorum number: IF 9351; Facesoffungi number: FoF 08543; 30 morphological species (Species Fungorum 2020), 1 species with molecular data.

Type species - Phloeospora ulmi (Fr.) Wallr., Fl. crypt. Germ. (Norimbergae) 2: 177 (1833).

$\equiv$ Septoria ulmi Fr. [as 'Septaria'], Novit. fl. svec. 5(cont.): 78 (1819).

Notes - see Quaedvlieg et al. (2013) and Videira et al. (2017).

Piricauda Bubák, Annls mycol. 12(2): 218 (1914).

Index Fungorum number: IF 9404; Facesoffungi number: FoF 08544; 30 morphological species (Species Fungorum 2020), 2 species with molecular data.

Type species - Piricauda uleana (Sacc. \& P. Syd.) Bubák, Annls mycol. 12(2): 218 (1914).

三Stigmella uleana Sacc. \& P. Syd., Atti del Congr. bot. di Palermo: 57 (1902).

Notes - Wijayawardene et al. (2020) tentatively placed this genus in Mycosphaerellaceae based on phylogenetic placement of Piricauda paraguayensis in Da Silva et al. (2016).

Pleopassalora Videira \& Crous, in Videira et al., Stud. Mycol. 87: 348 (2017).

Index Fungorum number: IF 822608; Facesoffungi number: FoF 08545; 2 morphological species (Species Fungorum 2020), 2 species with molecular data.

Type species - Pleopassalora perplexa (Beilharz, Pascoe, M.J. Wingf. \& Crous) Videira \& Crous, in Videira et al., Stud. Mycol. 87: 348 (2017).

Notes - see Videira et al. (2017). 
Pleuropassalora U. Braun, C. Nakash., Videira \& Crous, in Videira et al., Stud. Mycol. 87: 307 (2017).

Index Fungorum number: IF 822610; Facesoffungi number: FoF 08546; 1 morphological species (Species Fungorum 2020), 1 species with molecular data.

Type species - Pleuropassalora armatae (Crous \& A.R. Wood) U. Braun, C. Nakash., Videira \& Crous, in Videira et al., Stud. Mycol. 87: 307 (2017).

$\equiv$ Passalora armatae Crous \& A.R. Wood, in Crous, Schoch, Hyde, Wood, Gueidan, Hoog \& Groenewald, Stud. Mycol. 64: 35 (2009).

Notes - see Videira et al. (2017).

Pluripassalora Videira \& Crous, in Videira et al., Stud. Mycol. 87: 336 (2017).

Index Fungorum number: IF 822611; Facesoffungi number: FoF 08547; 1 morphological species (Species Fungorum 2020), 1 species with molecular data.

Type species - Pluripassalora bougainvilleae (Munt.-Cvetk.) U. Braun, C. Nakash., Videira \& Crous, in Videira et al., Stud. Mycol. 87: 336 (2017).

$\equiv$ Cercospora bougainvilleae Munt.-Cvetk., Revista Argent. Agron. 24: 84 (1957).

Notes - see Videira et al. (2017).

Plurivorosphaerella O. Hassan \& T.H. Chang, Pl. Dis. 103(2): 210 (2018).

Index Fungorum number: IF 825548; Facesoffungi number: FoF 08548; 1 morphological species (Species Fungorum 2020), 1 species with molecular data.

Type species - Plurivorosphaerella nawae (Hiura \& Ikata) O. Hassan \& T. Chang, Pl. Dis. 103(2): 210 (2018).

इ Mycosphaerella nawae Hiura \& Ikata, Research Bulletin of the Faculty of Agriculture, Gifu University 5: 1 (1929).

Notes - see Hassan \& Chang (2019).

Polyphialoseptoria Quaedvl., R.W. Barreto, Verkley \& Crous, Stud. Mycol. 75: 355 (2013).

Index Fungorum number: IF 804425; Facesoffungi number: FoF 07511; 3 morphological species (Species Fungorum 2020), 3 species with molecular data.

Type species - Polyphialoseptoria terminaliae Quaedvl., R.W. Barreto, Verkley \& Crous, Stud. Mycol. 75: 356 (2013).

Notes - see Quaedvlieg et al. (2013) and Videira et al. et al. (2017).

Polythrincium Kunze, Mykologische Hefte (Leipzig) 1: 13 (1817).

Index Fungorum number: IF 9515; Facesoffungi number: FoF 08549; 1 morphological species (Species Fungorum 2020), 1 species with molecular data.

Type species - Polythrincium trifolii Kunze, Mykologische Hefte (Leipzig) 1: 14 (1817).

Notes - see Tibpromma et al. (2017) and Videira et al. (2017).

Protostegia Cooke, Grevillea 9(no. 49): 19 (1880).

Index Fungorum number: IF 9540; Facesoffungi number: FoF 08550; 2 morphological species (Species Fungorum 2020), 2 species with molecular data.

Type species - Protostegia eucleae Kalchbr. \& Cooke, Grevillea 9(no. 49): 19 (1880).

Notes - see Crous et al. (2015a) and Videira et al. (2017).

Pseudocercospora Speg., Anal. Mus. nac. B. Aires, Ser. 3 13: 437 (1910).

Index Fungorum number: IF 9559; Facesoffungi number: FoF 08551; 1498 morphological species (Species Fungorum 2020), > 100 species with molecular data.

Type species - Pseudocercospora vitis (Lév.) Speg., Anal. Mus. nac. B. Aires, Ser. 3 13: 438 (1910) [1911].

三Septonema vitis Lév., Annls Sci. Nat., Bot., sér. 3 9: 261 (1848).

Notes - see Crous et al. (2013a) and Videira et al. (2017). 
Pseudocercosporella Deighton, Mycol. Pap. 133: 38 (1973).

Index Fungorum number: IF 9560; Facesoffungi number: FoF 08552; 96 morphological species (Species Fungorum 2020), 13 species with molecular data.

Type species - Pseudocercosporella ipomoeae Sawada ex Deighton, Mycol. Pap. 133: 38 (1973).

Notes - see Frank et al. (2010) and Videira et al. (2017).

Pseudopericoniella Videira \& Crous, in Videira et al., Stud. Mycol. 87: 374 (2017).

Index Fungorum number: IF 822699; Facesoffungi number: FoF 08553; 1 morphological species (Species Fungorum 2020), 1 species with molecular data.

Type species - Pseudopericoniella levispora (Arzanlou, W. Gams \& Crous) Videira \& Crous, in Videira et al., Stud. Mycol. 87: 374 (2017).

三 Periconiella levispora Arzanlou, W. Gams \& Crous, in Arzanlou, Groenewald, Gams, Braun, Shin \& Crous, Stud. Mycol. 58: 68 (2007).

Notes - see Videira et al. (2017).

Pseudophaeophleospora C. Nakash., Videira \& Crous, in Videira et al., Stud. Mycol. 87: 311 (2017).

Index Fungorum number: IF 822700; Facesoffungi number: FoF 08554; 3 morphological species (Species Fungorum 2020), 3 species with molecular data.

Type species - Pseudophaeophleospora stonei (Crous) C. Nakash., Videira \& Crous, in Videira et al., Stud. Mycol. 87: 311 (2017).

三 Phaeophleospora stonei Crous, in Crous, Summerell, Carnegie, Mohammed, Himaman \& Groenewald, Fungal Diversity 26(1): 169 (2007).

Notes - see Videira et al. (2017) and Crous et al. (2019b).

Pseudozasmidium Videira \& Crous, in Videira et al., Stud. Mycol. 87: 378 (2017).

Index Fungorum number: IF 822701; Facesoffungi number: FoF 08555; 4 morphological species (Species Fungorum 2020), 3 species with molecular data.

Type species - Pseudozasmidium parkii (Crous \& Alfenas) Videira \& Crous, in Videira et al., Stud. Mycol. 87: 379 (2017).

三Stenella parkii Crous \& Alfenas, Mycologia 87(1): 121 (1995).

Notes - see Videira et al. (2017).

Ragnhildiana Solheim, Mycologia 23(5): 402 (1931).

Index Fungorum number: IF 9686; Facesoffungi number: FoF 08556; 8 morphological species (Species Fungorum 2020), 6 species with molecular data.

Type species - Ragnhildiana agerati (F. Stevens) F. Stevens \& Solheim, Mycologia 23(5): $402(1931)$.

$\equiv$ Cercospora agerati F. Stevens, Bulletin of the Bernice P. Bishop Museum, Honolulu, Hawaii 19: 154 (1925).

Notes - see Videira et al. (2017).

Ramulariopsis Speg., Anal. Mus. nac. B. Aires, Ser. 3 13: 421 (1910).

Index Fungorum number: IF 9692; Facesoffungi number: FoF 08557; 5 morphological species (Species Fungorum 2020), 2 species with molecular data.

Type species - Ramulariopsis cnidoscoli Speg., Anal. Mus. nac. B. Aires, Ser. 3 13: 422 (1910).

Notes - see Videira et al. $(2016,2017)$.

Ramulispora Miura, Koshurei Agric. Exp. Sta. S. Manchur. Railway Co. Report 11: 43 (1920).

Index Fungorum number: IF 9695; Facesoffungi number: FoF 08558; 12 morphological species (Species Fungorum 2020), 3 species with molecular data. 
Type species - Ramulispora andropogonis Miura, Koshurei Agric. Exp. Sta. S. Manchur. Railway Co. Report 11: 43 (1920).

Notes - see Crous et al. (2003a, 2009e) and Videira et al. (2017).

Rhachisphaerella U. Braun, C. Nakash., Videira \& Crous, in Videira et al., Stud. Mycol. 87: 337 (2017).

Index Fungorum number: IF 822702; Facesoffungi number: FoF 08559; 1 morphological species (Species Fungorum 2020), 1 species with molecular data.

Type species - Rhachisphaerella mozambica (Arzanlou \& Crous) Videira \& Crous, in Videira et al., Stud. Mycol. 87: 338 (2017).

三 Mycosphaerella mozambica Arzanlou \& Crous, Persoonia 20: 26 (2008).

Notes - see Videira et al. (2017).

Rosisphaerella Videira \& Crous, in Videira et al., Stud. Mycol. 87: 350 (2017).

Index Fungorum number: IF 822703; Facesoffungi number: FoF 08560; 1 morphological species (Species Fungorum 2020), 1 species with molecular data.

Type species - Rosisphaerella rosicola (Pass.) U. Braun, C. Nakash., Videira \& Crous, in Videira et al., Stud. Mycol. 87: 350 (2017).

ECercospora rosicola Pass., in Thümen, Just's Bot. Jahresber. 3: 276 (1877).

Notes - see Videira et al. (2017).

Ruptoseptoria Quaedvl., Verkley \& Crous, Stud. Mycol. 75: 356 (2013).

Index Fungorum number: IF 804428; Facesoffungi number: FoF 08561; 1 morphological species (Species Fungorum 2020), 1 species with molecular data.

Type species - Ruptoseptoria unedonis (Roberge ex Desm.) Quaedvl., Verkley \& Crous, Stud. Mycol. 75: 357 (2013).

三Septoria unedonis Roberge ex Desm., Annls Sci. Nat., Bot., sér. 3 8: 20 (1847).

Notes - see Quaedvlieg et al. (2013) and Videira et al. (2017).

Scolecostigmina U. Braun, in Braun et al., N.Z. J1 Bot. 37(2): 323 (1999).

Index Fungorum number: IF 28294; Facesoffungi number: FoF 08562; 22 morphological species (Species Fungorum 2020), 2 species with molecular data.

Type species - Scolecostigmina mangiferae (Koord.) U. Braun \& Mouch., in Braun et al., N.Z. Jl Bot. 37(2): 323 (1999).

$\equiv$ Cercospora mangiferae Koord., Verh. K. Akad. Wet., tweede sect. 13(4): 236 (1907).

Notes - see Crous et al. (2013a) and Videira et al. (2017).

Septoria Sacc., in Saccardo, Syll. Fung. 3: 474 (1884).

Index Fungorum number: IF 9894; Facesoffungi number: FoF 07588; 579 morphological species (Species Fungorum 2020), > 100 species with molecular data.

Type species - Septoria cytisi Desm., in Saccardo, Ann. Sci. Nat., Bot., Sér. 8: 24 (1847).

Notes - see Quaedvlieg et al. (2013) and Videira et al. (2017).

Sonderhenia H.J. Swart \& J. Walker, in Swart \& Walker, Trans. Brit. Mycol. Soc. 90: 640 (1988). Index Fungorum number: IF 11192; Facesoffungi number: FoF 01702; 3 morphological species (Species Fungorum 2020), 3 species with molecular data.

Type species - Sonderhenia eucalyptorum (Hansf.) H.J. Swart \& J. Walker, in Swart \& Walker, Trans. Brit. Mycol. Soc. 90: 640 (1988).

$\equiv$ Hendersonia eucalyptorum Hansf., Proc. Linn. Soc. N.S.W. 79(3-4): 135 (1954).

Notes - see Crous et al. (2013a) Videira et al. (2017).

Sphaerulina Sacc., in Saccardo, Michelia 1: 399 (1878). 
Index Fungorum number: IF 5128; Facesoffungi number: FoF 08563; 71 morphological species (Species Fungorum 2020), 31 species with molecular data.

Type species - Sphaerulina myriadea (DC.) Sacc., in Saccardo, Michelia 1: 399 (1878).

三Sphaeria myriadea DC., Fl. franç., Edn 3 (Paris) 5/6: 145 (1815).

Notes - see Crous et al. (2011d), Quaedvlieg et al. (2013) and Videira et al. (2017).

Stromatoseptoria Quaedvl., Verkley \& Crous, Stud. Mycol. 75: 353 (2013).

Index Fungorum number: IF 804423; Facesoffungi number: FoF 08564; 1 morphological species (Species Fungorum 2020), 1 species with molecular data.

Type species - Stromatoseptoria castaneicola (Desm.) Quaedvl., Verkley \& Crous, Stud. Mycol. 75: 353 (2013).

三Septoria castaneicola Desm. [as 'castanicola'], Annls Sci. Nat., Bot., sér. 3 8: 26 (1847).

Notes - see Quaedvlieg et al. (2013) and Videira et al. (2017).

Sultanimyces Videira \& Crous, in Videira et al., Stud. Mycol. 87: 326 (2017).

Index Fungorum number: IF 822704; Facesoffungi number: FoF 08565; 1 morphological species (Species Fungorum 2020), 1 species with molecular data.

Type species - Sultanimyces vitiphyllus (Speschnew) Videira \& Crous, in Videira et al., Stud. Mycol. 87: 327 (2017).

三 Coryneum vitiphyllum Speschnew, Trudy Tiflissk. Bot. Sada 5: 177 (1901).

Notes - see Videira et al. (2017).

Trochophora R.T. Moore, Mycologia 47(1): 90 (1955).

Index Fungorum number: IF 10323; Facesoffungi number: FoF 08566; 1 morphological species (Species Fungorum 2020), 1 species with molecular data.

Type species - Trochophora simplex (Petch) R.T. Moore, Mycologia 47(1): 90 (1955).

三 Helicostilbe simplex Petch, Ann. R. bot. Gdns Peradeniya 7(4): 321 (1922).

Notes - see Zhao et al. (2007), Crous et al. (2013a) and Videira et al. (2017).

Uwemyces Hern.-Restr., Sarria \& Crous, in Crous et al., Persoonia 36: 455 (2016).

Index Fungorum number: IF 816986; Facesoffungi number: FoF 08567; 1 morphological species (Species Fungorum 2020), 1 species with molecular data.

Type species - Uwemyces elaeidis (Steyaert) Hern.-Restr., Sarria \& Crous, in Crous et al., Persoonia 36: 455 (2016).

$\equiv$ Cercospora elaeidis Steyaert, Bull. Soc. R. Bot. Belg., sér. 2 30(1-2): 35 (1948).

Notes - see Crous et al. (2016b) and Videira et al. (2017).

Virosphaerella Videira \& Crous, in Videira et al., Stud. Mycol. 87: 377 (2017).

Index Fungorum number: IF 822705; Facesoffungi number: FoF 08568; 2 morphological species (Species Fungorum 2020), 2 species with molecular data.

Type species - Virosphaerella pseudomarksii (Cheew., K.D. Hyde \& Crous) Videira \& Crous, in Videira et al., Stud. Mycol. 87: 378 (2017).

三 Mycosphaerella pseudomarksii Cheew., K.D. Hyde \& Crous, Persoonia 21: 83 (2008).

Notes - see Videira et al. (2017).

Xenomycosphaerella Quaedvl. \& Crous, in Quaedvlieg et al., Persoonia 33: 24 (2014).

Index Fungorum number: IF 807787; Facesoffungi number: FoF 08569; 2 morphological species (Species Fungorum 2020), 2 species with molecular data.

Type species - Xenomycosphaerella elongata (Crous \& M.J. Wingf.) Quaedvl. \& Crous, in Quaedvlieg et al., Persoonia 33: 24 (2014). (2007).

三 Mycosphaerella elongata Crous \& M.J. Wingf., in Crous et al., Fungal Diversity 26(1): 163

Notes - see Quaedvlieg et al. (2014), Guatimosim et al. (2016) and Videira et al. (2017). 
Xenoramularia Videira, H.D. Shin \& Crous, in Videira et al., Stud. Mycol. 83: 96 (2016). Index Fungorum number: IF 816822; Facesoffungi number: FoF 08570; 3 morphological species (Species Fungorum 2020), 3 species with molecular data.

Type species - Xenoramularia polygonicola Videira, H.D. Shin \& Crous, in Videira et al., Stud. Mycol. 83: 97 (2016).

Notes - see Videira et al. $(2016,2017)$.

Xenopassalora Crous, in Crous et al., Persoonia 39: 367 (2017).

Index Fungorum number: IF 823376; Facesoffungi number: FoF 08571; 1 morphological species (Species Fungorum 2020), 1 species with molecular data.

Type species - Xenopassalora petrophiles Crous, in Crous et al., Persoonia 39: 367 (2017).

Notes - see Crous et al. (2017a).

Xenosonderhenia Crous, in Crous et al., Persoonia 28: 175 (2012).

Index Fungorum number: IF 800389; Facesoffungi number: FoF 08572; 3 morphological species (Species Fungorum 2020), 3 species with molecular data.

Type species - Xenosonderhenia syzygii Crous, in Crous et al., Persoonia 28: 175 (2012).

Notes - see Crous et al. (2012, 2014b, 2018a) and Videira et al. (2017).

Xenosonderhenioides Videira \& Crous, in Videira et al., Stud. Mycol. 87: 368 (2017)

Index Fungorum number: IF 822706; Facesoffungi number: FoF 08573; 1 morphological species (Species Fungorum 2020), 1 species with molecular data.

Type species - Xenosonderhenioides indonesiana C. Nakash., Videira \& Crous, in Videira et al., Stud. Mycol. 87: 368 (2017).

Notes - see Videira et al. (2017).

Zasmidium Fr., Summa veg. Scand., Sectio Post. (Stockholm): 407 (1849).

$=$ Periconiella Sacc., in Saccardo \& Berlese, Atti Inst. Veneto Sci. lett., ed Arti, Sér. 6 3: 727 (1885).

Index Fungorum number: IF 22396; Facesoffungi number: FoF 08574; 223 morphological species (Species Fungorum 2020), 53 species with molecular data.

Type species - Zasmidium cellare (Pers.) Fr., Summa veg. Scand., Sectio Post. (Stockholm): 407 (1849).

ERacodium cellare Pers., Neues Mag. Bot. 1: 123 (1794).

Notes - see Braun et al. (2013) and Videira et al. (2017).

Zymoseptoria Quaedvl. \& Crous, in Quaedvlieg et al., Persoonia 26: 64 (2011).

Index Fungorum number: IF 517922; Facesoffungi number: FoF 08575; 8 morphological species (Species Fungorum 2020), 8 species with molecular data.

Type species - Zymoseptoria tritici (Roberge ex Desm.) Quaedvl. \& Crous, in Quaedvlieg et al., Persoonia 26: 67 (2011).

ESeptoria tritici Roberge ex Desm., Annls Sci. Nat., Bot., sér. 2 17: 107 (1842).

Notes - see Quaedvlieg et al. (2011), Stukenbrock et al. (2012), Videira et al. (2017) and Crous et al. (2018c).

\section{Doubtful genera in Mycosphaerellaceae}

Acrodesmis Syd., Annls mycol. 24(5/6): 424 (1926).

Index Fungorum number: IF 7033; Facesoffungi number: FoF 08576; 1 morphological species (Species Fungorum 2020), molecular data unavailable.

Type species - Acrodesmis cestri Syd., Annls mycol. 24(5/6): 424 (1926).

Notes - Detailed morphological description was provided by Videira et al. (2017).

Achorodothis Syd., Annls mycol. 24(5/6):380 (1926). 
Index Fungorum number: IF 40; Facesoffungi number: FoF 08577; 2 morphological species (Species Fungorum 2020), molecular data unavailable.

Type species - Achorodothis poasensis Syd., Annls mycol. 24(5/6): 380 (1926).

Notes - see Sydow (1926) and Videira et al. (2017).

Acrotheca Fuckel, Jb. nassau. Ver. Naturk. 15: 42 (1860).

Index Fungorum number: IF 7047; Facesoffungi number: FoF 08578; 5 morphological species (Species Fungorum 2020), molecular data unavailable.

Type species - Acrotheca gei Fuckel, Jb. nassau. Ver. Naturk. 15: 43 (1860).

Notes - Braun (1996) discussed the identity of Acrotheca gei and also listed the species as a synonym of Ramularia gei; however, the name is illegitimate (Art. 53.1; Index Fungorum 2020). Videira et al. (2017) reinstated the genus in Mycosphaerellaceae.

Allantophomoides S.L. Wei \& T.Y. Zhang, Mycosystema 22(1): 9 (2003).

Index Fungorum number: IF 28720; Facesoffungi number: FoF 08579; 1 morphological species (Species Fungorum 2020), molecular data unavailable.

Type species - Allantophomoides carotae S.L. Wei \& T.Y. Zhang, Mycosystema 22(1): 9 (2003).

Notes - see Wei \& Zhang (2003) and Videira et al. 2017).

Anematidium Gronchi, Boll. Ist. Sieroterap. Milan. 10(5): 242 (1931).

Index Fungorum number: IF 7153; Facesoffungi number: FoF 08580; 1 morphological species (Species Fungorum 2020), molecular data unavailable.

Type species - Anematidium oxiphilum Gronchi, Boll. Ist. Sieroterap. Milan. 10(5) (1931).

Notes - see Gronchi (1931) and Videira et al. (2017).

Anguillosporella U. Braun, Monogr. Cercosporella, Ramularia Allied Genera (Phytopath. Hyphom.) 1: 233 (1995).

Index Fungorum number: IF 27557; Facesoffungi number: FoF 06210; 2 morphological species (Species Fungorum 2020), molecular data unavailable.

Type species - Anguillosporella vermiformis (Davis) U. Braun, Monogr. Cercosporella, Ramularia Allied Genera (Phytopath. Hyphom.) 1: 234 (1995).

三 Cylindrosporium vermiforme Davis, Trans. Wis. Acad. Sci. Arts Lett. 18(1): 104 (1915).

Notes - see Braun (1995) and Videira et al. (2017).

Annellophora S. Hughes, Trans. Br. mycol. Soc. 34(4): 544 (1952) [1951].

Index Fungorum number: IF 7162; Facesoffungi number: FoF 08581; 11 morphological species (Species Fungorum 2020), molecular data unavailable. (1952).

Type species - Annellophora solani (Syd.) S. Hughes, Trans. Br. mycol. Soc. 34(4): 544

EChaetotrichum solani Syd., Annls mycol. 25(1/2): 150 (1927)

Notes - see Hughes (1951a), Ellis (1971, 1957), and Videira et al. (2017).

Annellophragmia Subram., Proc. Indian Acad. Sci., Sect. B 58: 349 (1963).

Index Fungorum number: IF 7164; Facesoffungi number: FoF 08582; 1 morphological species (Species Fungorum 2020), molecular data unavailable.

Type species - Annellophragmia coonoorensis (Subram.) Subram., Proc. Indian natn Sci. Acad., Part B. Biol. Sci. 58: 349 (1963).

$\equiv$ Arthrobotryum coonoorense Subram., Proc. Indian natn Sci. Acad., Part B. Biol. Sci. 42: 285 (1955).

Notes - see Subramanian (1963) and Videira et al. (2017).

Annellosympodia McTaggart, R.G. Shivas \& U. Braun, Australas. Pl. Path. 36(6): 574 (2007). 
Index Fungorum number: IF 510980; Facesoffungi number: FoF 08583; 1 morphological species (Species Fungorum 2020), molecular data unavailable.

Type species - Annellosympodia orbiculata McTaggart, R.G. Shivas \& U. Braun, Australas. Pl. Path. 36(6): 574 (2007).

Notes - see McTaggart et al. (2007) and Videira et al. (2017).

Asteromidium Speg., Anal. Soc. cient. argent. 26(1): 66 (1888).

Index Fungorum number: IF 7263; Facesoffungi number: FoF 07126; 3 morphological species (Species Fungorum 2020), molecular data unavailable.

Type species - Asteromidium imperspicuum Speg., Anal. Soc. cient. argent. 26(1): 66 (1888).

Notes - see Spegazzini (1888), Quaedvlieg et al. (2013), and Videira et al. (2017).

Berteromyces Cif., Sydowia 8(1-6): 267 (1954).

Index Fungorum number: IF 7363; Facesoffungi number: FoF 08583; 1 morphological species (Species Fungorum 2020), molecular data unavailable.

Type species - Berteromyces aeneus Cif., Sydowia 8(1-6): 267 (1954).

Notes - see Crous \& Braun (2003) and Videira et al. (2017).

Biharia Thirum. \& Mishra, Sydowia 7(1-4): 79 (1953).

Index Fungorum number: IF 7369; Facesoffungi number: FoF 08584; 2 morphological species (Species Fungorum 2020), molecular data unavailable.

Type species - Biharia vangueriae Thirum. \& Mishra, Sydowia 7(1-4): 79 (1953).

Notes - see Thirumalachar \& Mishra (1953), Kamal (2010), and Videira et al. (2017).

Bryopelta Döbbeler \& Poelt, in Döbbeler, Mitt. bot. StSamml., Münch. 14: 126 (1978).

Index Fungorum number: IF 665; Facesoffungi number: FoF 08585; 1 morphological species (Species Fungorum 2020), molecular data unavailable.

Type species - Bryopelta variabilis Döbbeler \& Poelt, Mitt. bot. StSamml., Münch. 14: 126 (1978).

Notes - see Döbbeler (1978), Li et al. (2014), and Videira et al. (2017

Camptomeris Syd., Annls mycol. 25(1/2): 14 (1927).

Index Fungorum number: IF 7480; Facesoffungi number: FoF 08586; 10 morphological species (Species Fungorum 2020), molecular data unavailable.

Type species - Camptomeris calliandrae Syd., Annls mycol. 25(1/2): 143 (1927).

Notes - see Sydow (1927) and Videira et al. (2017).

Ceratosperma Speg., Physis, Rev. Soc. Arg. Cienc. Nat. 4(no. 17): 284 (1918).

Index Fungorum number: IF 895; Facesoffungi number: FoF 08587; 1 morphological species (Species Fungorum 2020), molecular data unavailable.

Type species - Ceratosperma theobromae (Faber) Speg., Physis, Rev. Soc. Arg. Cienc. Nat. 4(no. 17): 284 (1918).

E Ceratocarpia theobromae Faber, Arbeiten Kaiserl. Biol. Anst. Ld.- u. Forstw. 7: 220 (1909)

Notes - see Videira et al. (2017) and Wijayawardene et al. (2018).

Cercodeuterospora Curzi, Boll. R. Staz. Patalog. Veget. Roma 12: 3 (1932).

Index Fungorum number: IF 895; Facesoffungi number: FoF 08588; 1 morphological species (Species Fungorum 2020), molecular data unavailable.

Type species - Cercodeuterospora trichophila Curzi, Boll. R. Staz. Patalog. Veget. Roma 12: 151 (1932).

Notes - see Curzi 1932 and Videira et al. (2017). 
Cercoseptoria Petr., Annls mycol. 23(1/2): 69 (1925).

Index Fungorum number: IF 7543; Facesoffungi number: FoF 09185; 15 morphological species (Species Fungorum 2020), molecular data unavailable.

Type species - Cercoseptoria chamaesyces (F. Stevens \& Dalbey) Petr., Annls mycol. 23(1/2): 69 (1925).

ESeptoriopsis chamaesyces F. Stevens \& Dalbey, Mycologia 11(1): 4 (1918) [1919]

Notes - see Petrak (1925), Deighton (1976,1987), and Videira et al. (2017).

Cercosperma G. Arnaud ex B. Sutton \& Hodges, Nova Hedwigia 35(4): 798 (1983) [1981].

Index Fungorum number: IF 7544; Facesoffungi number: FoF 08589; 2 morphological species (Species Fungorum 2020), molecular data unavailable.

Type species - Cercosperma arnaudii B. Sutton \& Hodges, Nova Hedwigia 35(4): 800 (1983) [1981].

Notes - see Videira et al. (2017).

Cercosphaerella Kleb., Haupt- und Nebenfruchtformen der Ascomyzeten (Leipzig) 1: 132 (1918).

Index Fungorum number: IF 907; Facesoffungi number: FoF 08590; 1 morphological species (Species Fungorum 2020), molecular data unavailable.

Type species - Cercosphaerella millegrana (Cooke) Kleb., Haupt- und Nebenfruchtformen der Ascomyzeten (Leipzig) 1: 132 (1918).

ESphaerella millegrana Cooke, Handb. Brit. Fungi 2: 915 (1871).

Notes - see Cooke (1871) and Videira et al. (2017).

Cercosporina Speg., Anal. Mus. nac. B. Aires, Ser. 3 13: 424 (1910) [1911].

Index Fungorum number: IF 7548; Facesoffungi number: FoF 08591; 5 morphological species (Species Fungorum 2020), molecular data unavailable.

Type species - Cercosporina asparagicola Speg., Anal. Mus. nac. B. Aires, Ser. 3 13: 424 (1910) [1911].

Notes - Cercosporina is currently treated as a synonym of Cercospora (Videira et al. 2017, Index Fungorum 2020). However, the generic type Cercosporina asparagicola lacks molecular data to clarify its phylogenetic affinity. Videira et al. (2017) listed the genus in Mycosphaerellaceae.

Cercosporiopsis Miura, Flora of Manchuria and East Mongolia, III Cryptogams, Fungi (Industr. Contr. S. Manch. Rly 27): 527 (1928).

Index Fungorum number: IF 7549; Facesoffungi number: FoF 08592; 3 morphological species (Species Fungorum 2020), molecular data unavailable.

Type species - Cercosporiopsis menispermi (Ellis \& Holw.) Miura, Flora of Manchuria and East Mongolia, III Cryptogams, Fungi (Industr. Contr. S. Manch. Rly 27): 527 (1928).

三 Cercospora menispermi Ellis \& Holw., J. Mycol. 4(1): 6 (1888).

Notes - see Crous \& Braun 2003 and Videira et al. (2017).

Cercostigmina U. Braun, Cryptog. bot. 4(1): 107 (1993).

Index Fungorum number: IF 25183; Facesoffungi number: FoF 08593; 4 morphological species (Species Fungorum 2020), molecular data unavailable.

Type species - Cercostigmina concentrica (Cooke \& Ellis) U. Braun, Cryptog. bot. 4(1): 108 (1993).

ECercospora concentrica Cooke \& Ellis, Grevillea 5(no. 35): 90 (1877).

Notes - see Videira et al. (2017).

Ciferriella Petr., Annls mycol. 28(5/6): 409 (1930).

Index Fungorum number: IF 263446; Facesoffungi number: FoF 09186; 1 morphological species (this study), molecular data unavailable. 
Type species - Ciferriella domingensis Petr. \& Cif., Annls mycol. 28(5/6): 409 (1930).

Notes - Quaedvlieg et al. (2013) treated Ciferriella as a synonym of Pseudocercospora based on morphological characteristics and the type species of Ciferriella also occurred on Vitex, typically Pseudocercospora (Quaedvlieg et al. 2013). However, the generic type of Ciferriella lacks molecular data to confirm their congeneric with Pseudocercospora. Therefore, we tentative listed the genus in doubtful genere in Mycosphaerellaceae until the molecular data of the generic type is obtained to confirm its phylogenetic placement.

Cladosporiella Deighton, in Deighton \& Pirozynski, Mycol. Pap. 101: 34 (1965).

Index Fungorum number: IF 7680; Facesoffungi number: FoF 08594; 5 morphological species (Species Fungorum 2020), molecular data unavailable.

Type species - Cladosporiella cercosporicola Deighton, in Deighton \& Pirozynski, Mycol. Pap. 101: 35 (1965).

Notes - The genus is different from Passalora by only its hyperparasitic habit but Passalora is a complex genus. Therefore, Videira et al. (2017) maintained the genus in Mycosphaerellaceae as a separated genus.

Clypeispora A.W. Ramaley, Mycotaxon 40: 13 (1991).

Index Fungorum number: IF 11280; Facesoffungi number: FoF 08595; 1 morphological species (Species Fungorum 2020), molecular data unavailable.

Type species - Clypeispora angustifoliorum A.W. Ramaley, Mycotaxon 40: 13 (1991).

Notes - see Ramaley (1991) and Videira et al. (2017).

Colletogloeum Petr., Sydowia 7(5-6): 368 (1953).

Index Fungorum number: IF 7733; Facesoffungi number: FoF 08596; 15 morphological species (Species Fungorum 2020), molecular data unavailable.

Type species - Colletogloeum dalbergiae (S. Ahmad) Petr., Sydowia 7(5-6): 369 (1953).

$\equiv$ Septogloeum dalbergiae S. Ahmad, Sydowia 7(1-4): 269 (1953).

Notes - see Petrak (1953) and Videira et al. (2017).

Cyclodothis Syd. \& P. Syd., in Sydow \& Sydow, Annls mycol. 11(3): 266 (1913).

Index Fungorum number: IF 1371; Facesoffungi number: FoF 08597; 2 morphological species (Species Fungorum 2020), molecular data unavailable.

Type species - Cyclodothis pulchella Syd. \& P. Syd., Annls mycol. 11(3): 266 (1913).

Notes - see Videira et al. (2017).

Dearnessia Bubák, Hedwigia 58: 25 (1916).

Index Fungorum number: IF 7932; Facesoffungi number: FoF 07271; 1 morphological species (Species Fungorum 2020), molecular data unavailable.

Type species - Dearnessia apocyni Bubák, Hedwigia 58: 25 (1916).

Notes - see Quaedvlieg et al. (2013) and Videira et al. (2017).

Denticularia Deighton, Trans. Br. mycol. Soc. 59(3): 421 (1972).

Index Fungorum number: IF 7956; Facesoffungi number: FoF 08598; 7 morphological species (Species Fungorum 2020), molecular data unavailable.

Type species - Denticularia modesta (Syd.) Deighton, Trans. Br. mycol. Soc. 59(3): 422 (1972).

三 Cladosporium modestum Syd., Annls mycol. 37(3): 252 (1939).

Notes - see Videira et al. (2017).

Dictyodesmium S. Hughes, Mycol. Pap. 36: 29 (1951).

Index Fungorum number: IF 7997; Facesoffungi number: FoF 08599; 3 morphological species (Species Fungorum 2020), molecular data unavailable. 

(1951).

Type species - Dictyodesmium ulmicola (Ellis \& Kellerm.) S. Hughes, Mycol. Pap. 36: 29

ECeratophorum ulmicola Ellis \& Kellerm., J. Mycol. 3(11): 127 (1887).

Notes - see Videira et al. (2017).

Didymaria Corda, Icon. fung. (Prague) 5: 9 (1842).

Index Fungorum number: IF 8004; Facesoffungi number: FoF 08600; 8 morphological species (Species Fungorum 2020), molecular data unavailable.

Type species - Didymaria ungeri Corda, Icon. fung. (Prague) 1: 32, 199 (1837).

Notes -Didymaria was regarded as a synonym of Ramularia by Braun (1998). However, the molecular data of the generic type of Didymaria is unavailable. Thus, the congeneric status of Didymaria and Ramularia is still unclear and unproven.

Didymellina Höhn., Annls mycol. 16(1/2): 66 (1918).

Index Fungorum number: IF 1549; Facesoffungi number: FoF 08601; 3 morphological species (Species Fungorum 2020), molecular data unavailable.

Type species - Didymellina iridis (Desm.) Höhn., Annls mycol. 16(1/2): 66 (1918).

Notes - see Braun et al. (2003) and Videira et al. (2017).

Didymochora Höhn., Hedwigia 60: 172 (1918).

Index Fungorum number: IF 8012; Facesoffungi number: FoF 08602; 1 morphological species (Species Fungorum 2020), molecular data unavailable.

Type species - Didymochora betulina Höhn., Hedwigia 60: 172 (1918).

Notes - see Videira et al. (2017).

Elletevera Deighton, Mycol. Pap. 118: 17 (1969).

Index Fungorum number: IF 8140; Facesoffungi number: FoF 08603; 2 morphological species (Species Fungorum 2020), molecular data unavailable.

Type species - Elletevera parasitica (Ellis \& Everh.) Deighton, Mycol. Pap. 118: 19 (1969).

三 Pyricularia parasitica Ellis \& Everh., Proc. Acad. nat. Sci. Philad. 45: 462 (1894) [1893].

Notes - see Videira et al. (2017).

Episphaerella Petr., Annls mycol. 22(1/2): 126 (1924).

Index Fungorum number: IF 1875; Facesoffungi number: FoF 08604; 11 morphological species (Species Fungorum 2020), 1 species with molecular data.

Type species - Episphaerella manihotis (Henn.) Petr., Annls mycol. 22(1/2): 126 (1924).

$\equiv$ Dimerosporium manihotis Henn., Hedwigia 43(6): 354 (1904).

Notes - see Boonmee et al. (2017).

Eriocercospora Deighton, Mycol. Pap. 118: 5 (1969).

Index Fungorum number: IF 8200; Facesoffungi number: FoF 08605; 3 morphological species (Species Fungorum 2020), molecular data unavailable.

Type species - Eriocercospora balladynae (Hansf.) Deighton, Mycol. Pap. 118: 6 (1969).

$\equiv$ Helminthosporium balladynae Hansf., Proc. Linn. Soc. London 157: 39 (1945) [1944-45].

Notes - see Videira et al. (2017).

Eriocercosporella Rak. Kumar, A.N. Rai \& Kamal ex U. Braun, Monogr. Cercosporella, Ramularia Allied Genera (Phytopath. Hyphom.) 2: 398 (1998).

Index Fungorum number: IF 13082; Facesoffungi number: FoF 08606; 2 morphological species (Species Fungorum 2020), molecular data unavailable.

Type species - Eriocercosporella indica R. Kumar, A.N. Rai \& Kamal ex U. Braun, Monogr. Cercosporella, Ramularia Allied Genera (Phytopath. Hyphom.) 2: 398 (1998).

Notes - see Braun et al. (2013) and Videira et al. (2017). 
Euryachora Fuckel, Jb. nassau. Ver. Naturk. 23-24: 220 (1870) [1869-70].

Index Fungorum number: IF 1943; Facesoffungi number: FoF 08607; 12 morphological species (Species Fungorum 2020), molecular data unavailable.

Type species - Euryachora sedi (Link) Fuckel [as 'sebi'], Jb. nassau. Ver. Naturk. 23-24: 220 (1870) [1869-70].

三Leptostroma sedi Link, Handb. Erk. Gew. 3: 345 (1833).

Notes - see Videira et al. (2017).

Fusicladiella Höhn., Ber. dt. bot. Ges. 37: 155 (1919).

Index Fungorum number: IF 8288; Facesoffungi number: FoF 08608; 6 morphological species (Species Fungorum 2020), molecular data unavailable.

Type species - Fusicladiella aronici (Sacc.) Höhn., Ber. dt. bot. Ges. 37: 155 (1919).

$\equiv$ Fusicladium aronici Sacc., Michelia 2(no. 6): 171 (1880).

Notes - see Videira et al. (2017).

Gillotia Sacc. \& Trotter, Syll. fung. (Abellini) 22(1): 253 (1913).

Index Fungorum number: IF 2067; Facesoffungi number: FoF 08609; 4 morphological species (Species Fungorum 2020), molecular data unavailable.

Type species - Gillotia orbicularis (Syd. \& P. Syd.) Sacc. \& Trotter, Syll. fung. (Abellini) 22(1): 253 (1913).

$\equiv$ Diplotheca orbicularis Syd. \& P. Syd., Annls mycol. 5(4): 357 (1907).

Notes - see Videira et al. (2017).

Gloeocercospora D.C. Bain \& Edgerton ex Deighton, Trans. Br. mycol. Soc. 57(2): 358 (1971).

Index Fungorum number: IF 8349; Facesoffungi number: FoF 08610; 2 morphological species (Species Fungorum 2020), 1 species with molecular data.

Type species - Gloeocercospora sorghi D.C. Bain \& Edgerton ex Deighton, Trans. Br. mycol. Soc. 57(2): 359 (1971).

Notes - see Videira et al. (2017).

Gomphinaria Preuss, Linnaea 24: 130 (1851).

Index Fungorum number: IF 8373; Facesoffungi number: FoF 08611; 1 morphological species (Species Fungorum 2020), molecular data unavailable.

Type species - Gomphinaria amoena Preuss, Linnaea 24: 130 (1851).

Notes - see Arzanlou et al. (2007) and Videira et al. (2017).

Haplodothis Höhn., Sber. Akad. Wiss. Wien, Math.-naturw. Kl., Abt. 1 120: 423 (1911).

Index Fungorum number: IF 2229; Facesoffungi number: FoF 08612; 2 morphological species (Species Fungorum 2020), molecular data unavailable.

Type species - Haplodothis singularis (Henn.) Höhn., Sber. Akad. Wiss. Wien, Math.naturw. Kl., Abt. 1 120: 424 (1911).

三Lizonia singularis Henn., Hedwigia 42(Beibl.): (80) (1903).

Notes - see Videira et al. (2015a, b, 2016, 2017).

Hawksworthiana U. Braun, Int. J. Mycol. Lichenol. 3(2-3): 276 (1988).

Index Fungorum number: IF 11094; Facesoffungi number: FoF 08613; 1 morphological species (Species Fungorum 2020), molecular data unavailable.

Type species - Hawksworthiana peltigericola (D. Hawksw.) U. Braun, Int. J. Mycol. Lichenol. 3(2-3): 276 (1988).

$\equiv$ Ramularia peltigericola D. Hawksw., Notes R. bot. Gdn Edinb. 38(1): 172 (1980).

Notes - see Videira et al. (2016, 2017).

Helicomina L.S. Olive, Mycologia 40(1): 16 (1948). 
Index Fungorum number: IF 8474; Facesoffungi number: FoF 08614; 8 morphological species (Species Fungorum 2020), molecular data unavailable.

Type species - Helicomina caperoniae L.S. Olive, Mycologia 40(1): 17 (1948).

Notes - see Crous et al. (2013a) and Videira et al. (2016, 2017).

Hoornsmania Crous, in Crous et al., Fungal Planet, A Global Initiative to Promote the Study of Fungal Biodiversity 11-21: 11: [2] (2007).

Index Fungorum number: IF 501110; Facesoffungi number: FoF 06632; 1 morphological species (Species Fungorum 2020), molecular data unavailable.

Type species - Hoornsmania pyrina Crous, Fungal Planet 11-21: 11: [2] (2007).

Notes - see Crous (2007) and Videira et al. (2017).

Hyalodictys Subram., Proc. Indian Acad. Sci., P1. Sci.: 8. 1962.

Index Fungorum number: IF 8575; Facesoffungi number: FoF 08615; 1 morphological species (this study), molecular data unavailable.

Type species - Hyalodictys degenerans (Syd. \& P. Syd.) Subram., Proc. Indian natn Sci. Acad., Part B. Biol. Sci. 55: 8 (1962).

三Clasterosporium degenerans Syd. \& P. Syd., Annls mycol. 12(2): 164 (1914).

Notes - This genus was treated as a synonym of Miuraea in Videira et al. (2017). We tentatively place Hyalodictys as doubtful genera in Mycosphaerellaceae until molecular data is available.

Hyalodothis Pat. \& Har., Bull. Soc. mycol. Fr. 9(4): 210 (1893).

Index Fungorum number: IF 2387; Facesoffungi number: FoF 08616; 1 morphological species (Species Fungorum 2020), molecular data unavailable.

Type species - Hyalodothis clavus Pat. \& Har., Bull. Soc. mycol. Fr. 9(4): 210 (1893).

Notes - see Videira et al. (2017).

Isariella Henn., Hedwigia 48: 19 (1908).

Index Fungorum number: IF 8637; Facesoffungi number: FoF 08617; 2 morphological species (Species Fungorum 2020), molecular data unavailable.

Type species - Isariella auerswaldiae Henn., Hedwigia 48: 19 (1908).

Notes - see Seifert et al. (2011) and Videira et al. (2017).

Isariopsella Höhn., in Weese, Mitt. bot. Inst. tech. Hochsch. Wien 6(2): 68 (1929).

Index Fungorum number: IF 8638; Facesoffungi number: FoF 08618; 3 morphological species (Species Fungorum 2020), molecular data unavailable.

Type species - Isariopsella vossiana (Thüm.) Höhn., in Weese, Mitt. bot. Inst. tech. Hochsch. Wien 6(2): 68 (1929).

$\equiv$ Ramularia vossiana Thüm., Oesterr. bot. Z. 29: 359 (1879).

Notes - see Videira et al. (2017).

Isariopsis Fresen., Beitr. Mykol. 3: 87 (1863).

Index Fungorum number: IF 8639; Facesoffungi number: FoF 08619; 6 morphological species (Species Fungorum 2020), molecular data unavailable.

Type species - Isariopsis pusilla Fresen., Beitr. Mykol. 3: 87 (1863).

Notes - see Videira et al. (2017).

Jaczewskiella Murashk., Mater. Mikol. Fitopat. Ross. 5(2): 5 (1926).

Index Fungorum number: IF 8647; Facesoffungi number: FoF 08620; 1 morphological species (Species Fungorum 2020), molecular data unavailable.

Type species - Jaczewskiella altajensis Murashk., Mater. Mikol. Fitopat. Ross. 5(2): 4 (1926). 
Notes - see Videira et al. (2017).

Jahniella Petr., Annls mycol. 18(4/6): 123 (1921) [1920].

Index Fungorum number: IF 8648; Facesoffungi number: FoF 07395; 1 morphological species (Species Fungorum 2020), molecular data unavailable.

Type species - Jahniella bohemica Petr., Annls mycol. 18(4/6): 123 (1921) [1920].

Notes - see Quaedvlieg et al. (2013) and Videira et al. (2017).

Laocoon J.C. David [as 'Laocoön'], Mycol. Pap. 172: 116 (1997).

Index Fungorum number: IF 622358; Facesoffungi number: FoF 08621; 1 morphological species (Species Fungorum 2020), molecular data unavailable.

Type species - Laocoon paradoxus (Syd. \& P. Syd.) J.C. David, Mycol. Pap. 172: 116 (1997).

$\equiv$ Heterosporium paradoxum Syd. \& P. Syd., in Fuhrmann \& Mayor, Mém. Soc. Sci. Nat. Neuchâtel 5: 441 (1914).

Notes - see Seifert et al. (2011) and Videira et al. (2017).

Lecanostictopsis B. Sutton \& Crous, Mycol. Res. 101(2): 215 (1997).

Index Fungorum number: IF 27754; Facesoffungi number: FoF 08622; 4 morphological species (Species Fungorum 2020), 1 species with molecular data. (1997).

Type species - Lecanostictopsis kamatii (Ullasa) B. Sutton \& Crous, Mycol. Res. 101(2): 216

三Stigmina kamatii Ullasa, Archos Inst. biol., S. Paulo 40(2): 153 (1973).

Notes - see Seifert et al. (2011) and Videira et al. (2017).

Lembosiopsis Theiss., in Theissen \& Sydow, Annls mycol. 15(6): 422 (1918) [1917].

Index Fungorum number: IF 2731; Facesoffungi number: FoF 08623; 3 morphological species (Species Fungorum 2020), molecular data unavailable.

Type species - Lembosiopsis andromedae (Tracy \& Earle) Theiss., Annls mycol. 15(6): 422 (1918) [1917].

Notes - see Hongsanan et al. (2014b) and Videira et al. (2017).

Lophiosphaerella Hara, Byogaichu-Hoten (Manual of Pests and Diseases): 778 (1948).

Index Fungorum number: IF 2932; Facesoffungi number: FoF 08624; 2 morphological species (Species Fungorum 2020), molecular data unavailable.

Type species - Lophiosphaerella euryae (Syd. \& P. Syd.) Hara, Byogaichu-Hoten (Manual of Pests and Diseases): 345 (1948).

$\equiv$ Aulographum euryae Syd. \& P. Syd., Mém. Herb. Boissier 4: 5 (1900).

Notes - see Li et al. (2014) and Videira et al. (2017).

Marcosia Syd. \& P. Syd., Ann. Mycol.14: 96. 1916.

Index Fungorum number: IF 8843; Facesoffungi number: FoF 09306; 1 morphological species (Videira et al. 2017, this study), molecular data unavailable.

Type species - Marcosia ulei Syd. \& P. Syd., Annls mycol. 14(1/2): 96 (1916)

Notes - see Crous et al. (2013a) and Videira et al. (2017).

Megaloseptoria Naumov, Bolêz. Rast. 14: 144 (1925).

Index Fungorum number: IF 8876; Facesoffungi number: FoF 08625;1 morphological species (Species Fungorum 2020), molecular data unavailable.

Type species - Megaloseptoria mirabilis Naumov, Morbi Plant. Script. Sect. Phytopath. Hort.

Bot. Prince. USSR 14: 144 (1925).

Notes - see Quaedvlieg et al. (2013) and Videira et al. (2017). 
Melanodothis R.H. Arnold, Can. J. Bot. 49: 2188 (1972).

Index Fungorum number: IF 3067; Facesoffungi number: FoF 08626;1 morphological species (Species Fungorum 2020), molecular data unavailable.

Type species - Melanodothis caricis R.H. Arnold, Can. J. Bot. 49: 2188 (1972) [1971].

Notes - see Arnold (1972) and Videira et al. (2017).

Microcyclus Sacc., Syd. \& P. Syd., in Sydow \& Sydow, Annls mycol. 2(2): 165 (1904).

Index Fungorum number: IF 3160; Facesoffungi number: FoF 08627; 23 morphological species (Species Fungorum 2020), 1 species with molecular data.

Type species - Microcyclus angolensis Sacc., Syd. \& P. Syd., Annls mycol. 2(2): 165 (1904).

Notes - see Da Hora Júnior et al. (2014) and Videira et al. (2017).

Micronectriella Höhn., Sber. Akad. Wiss. Wien, Math.-naturw. Kl., Abt. 1 115: 1194 (1906).

Index Fungorum number: IF 3176; Facesoffungi number: FoF 08628; 2 morphological species (Species Fungorum 2020), molecular data unavailable.

Type species - Micronectriella pterocarpi (Racib.) Höhn., Sber. Akad. Wiss. Wien, Math.naturw. Kl., Abt. 1 115: 1194 (1906).

三 Micronectria pterocarpi Racib., Parasit. Alg. Pilze Java's (Jakarta) 3: 21 (1900).

Notes - see Da Hora Júnior et al. (2014) and Videira et al. (2017).

Mycoporis Clem., Gen. fung. (Minneapolis): 50 (1909).

Index Fungorum number: IF 5909; Facesoffungi number: FoF 00120; 1 morphological species (Species Fungorum 2020), molecular data unavailable.

Type species - Mycoporis perexigua (Müll. Arg.) Clem., Gen. fung. (Minneapolis): [173] (1909).

三 Mycoporellum perexiguum Müll. Arg., Nuovo G. bot. ital. 23(3): 399 (1891).

Notes - see Thambugala et al. (2014a) and Videira et al. (2017).

Neoovularia U. Braun, Nova Hedwigia 54(3-4): 473 (1992).

Index Fungorum number: IF 26306; Facesoffungi number: FoF 08629; 3 morphological species (Species Fungorum 2020), molecular data unavailable. (1992).

Type species - Neoovularia nomuriana (Sacc.) U. Braun, Nova Hedwigia 54(3-4): 474

三 Tuberculina nomuriana Sacc., in Nomura, Atti Ist. bot. R. Univ. Pavia, 2 Sér. 9: 38 (1904).

Notes - see Videira et al. (2016, 2017).

Neoramularia U. Braun, Nova Hedwigia 53: 291 (1991).

Index Fungorum number: IF 11285; Facesoffungi number: FoF 08630; 10 morphological species (Species Fungorum 2020), molecular data unavailable. (1991).

Type species - Neoramularia eurotiae (Gamalizk.) U. Braun, Nova Hedwigia 53(3-4): 292

E Ramularia eurotiae Gamalizk., in Domaschova \& Gamalitzkaja, Trudy Inst. Bot. Acad. Sci. Kazakh SSR 13: 278 (1962).

Notes - see Videira et al. $(2016,2017)$.

Oedothea Syd., Annls mycol. 28(1/2): 202 (1930).

Index Fungorum number: IF 9139; Facesoffungi number: FoF 08631; 1 morphological species (Species Fungorum 2020), molecular data unavailable.

Type species - Oedothea vismiae Syd., Annls mycol. 28(1/2): 203 (1930).

Notes - see Videira et al. (2017).

Ophiocarpella Theiss. \& Syd., Annls mycol. 13(5/6): 644 (1915). 
Index Fungorum number: IF 3594; Facesoffungi number: FoF 08632; 1 morphological species (Species Fungorum 2020), molecular data unavailable. (1915).

Type species - Ophiocarpella tarda (Harkn.) Theiss. \& Syd., Annls mycol. 13(5/6): 645

$\equiv$ Ophiodothis tarda Harkn., Bull. Calif. Acad. Sci. 1(no. 1): 46 (1884).

Notes - see Videira et al. (2017).

Oreophylla Cif., Sydowia 8(1-6): 253 (1954).

Index Fungorum number: IF 9171; Facesoffungi number: FoF 08633; 1 morphological species (Species Fungorum 2020), molecular data unavailable. (1954).

Type species - Oreophylla angelae-mariae Cif. [as 'angelaemariae'], Sydowia 8(1-6): 254

Notes - see Videira et al. (2017).

Ormathodium Syd., Annls mycol. 26(1/2): 138 (1928).

Index Fungorum number: IF 22284; Facesoffungi number: FoF 08634; 3 morphological species (Index Fungorum 2020), molecular data unavailable.

Type species - Ormathodium styracis Syd., Annls mycol. 26(1/2): 138 (1928).

Notes - see Videira et al. (2017).

Ovosphaerella Laib., Centbl. Bakt. ParasitKde, Abt. II 55: 293 (1922).

Index Fungorum number: IF 3659; Facesoffungi number: FoF 08635; 1 morphological species (Index Fungorum 2020), molecular data unavailable.

Type species - Ovosphaerella lapathi Laib., Centbl. Bakt. ParasitKde, Abt. II 55: 293 (1922)

Notes - see Videira et al. (2017).

Parastenella J.C. David, Mycol. Res. 95(1): 124 (1991).

Index Fungorum number: IF 25569; Facesoffungi number: FoF 08636; 3 morphological species (Species Fungorum 2020), 2 species with molecular data.

Type species - Parastenella magnoliae (Weedon) J.C. David, Mycol. Res. 95(1): 124 (1991).

三 Heterosporium magnoliae Weedon, Mycologia 18(5): 222 (1926).

Notes - see Braun et al. (2013) and Videira et al. (2017).

Phacellium Bonord., in Rabenhorst, Fungi europ. exsicc., Edn 2, ser. 2: no. 288 (1860).

Index Fungorum number: IF 9286; Facesoffungi number: FoF 08637; 64 morphological species (Species Fungorum 2020), 8 species with molecular data.

Type species - Phacellium inhonestum Bonord., in Rabenhorst, Fungi europ. exsicc., Edn 2, ser. 2: no. 288 (1860).

Notes - see Videira et al. (2017).

Phaeophloeosporella Crous \& B. Sutton, S. Afr. J. Bot. 63(5): 281 (1997).

Index Fungorum number: IF 27761; Facesoffungi number: FoF 08639; 1 morphological species (Species Fungorum 2020), molecular data unavailable.

Type species - Phaeophloeosporella ekebergiae (Syd. \& P. Syd.) Crous \& B. Sutton, S. Afr. J. Bot. 63(5): 281 (1997).

$\equiv$ Cercosporella ekebergiae Syd. \& P. Syd., Annls mycol. 12(3): 267 (1914).

Notes - see Videira et al. (2017).

Phlyctaeniella Petr., Annls mycol. 20(5/6): 323 (1922).

Index Fungorum number: IF 9351; Facesoffungi number: FoF 07492; 30 morphological species (Species Fungorum 2020), 1 species with molecular data.

Type species - Phlyctaeniella polonica Petr., Annls mycol. 20(5/6): 323 (1922).

Notes - see Quaedvlieg et al. (2013) and Videira et al. (2017). 
Pleurovularia R. Kirschner \& U. Braun, Mycoscience 43(1): 16 (2002).

Index Fungorum number: IF 28597; Facesoffungi number: FoF 08640; 1 morphological species (Species Fungorum 2020), molecular data unavailable.

Type species - Pleurovularia polliniae (Henn.) R. Kirschner \& U. Braun, Mycoscience 43(1): 18 (2002).

$\equiv$ Ovularia polliniae Henn., Bot. Jb. 38: 165 (1905).

Notes - see Videira et al. (2017).

Polysporella Woron., Izv. Kavkaz. Muz. 10(1): 7 (1916).

Index Fungorum number: IF 28793; Facesoffungi number: FoF 08641; 1 morphological species (Species Fungorum 2020), molecular data unavailable.

Type species - Polysporella woronowii Woron., Izv. Kavkaz. Muz. 10(1): 7 (1916).

Notes - see Videira et al. (2017).

Pseudocercosporidium Deighton, Mycol. Pap. 133: 55 (1973).

Index Fungorum number: IF 9561; Facesoffungi number: FoF 08643; 1 morphological species (Species Fungorum 2020), molecular data unavailable. (1973).

Type species - Pseudocercosporidium venezuelanum (Syd.) Deighton, Mycol. Pap. 133: 56

ECercosporidium venezuelanum Syd., Annls mycol. 28(1/2): 218 (1930).

Notes - see Braun et al. (2013) and Videira et al. (2017).

Pseudodidymaria U. Braun, Cryptog. bot. 4(1): 110 (1993).

Index Fungorum number: IF 11485; Facesoffungi number: FoF 08644; 3 morphological species (Species Fungorum 2020), molecular data unavailable.

Type species - Pseudodidymaria wyethiae (Ellis \& Everh.) U. Braun, Cryptog. bot. 4(1): 110 (1993).

三 Marssonia wyethiae Ellis \& Everh., Proc. Acad. nat. Sci. Philad. 46(3): 373 (1894).

Notes - see Videira et al. (2016, 2017).

Pseudophaeoramularia U. Braun, Trudy Botanicheskogo Instituta im. V.L. Komarova 20: 18 (1997).

Index Fungorum number: IF 27801; Facesoffungi number: FoF 08645; 1 morphological species (Species Fungorum 2020), molecular data unavailable.

Type species - Pseudophaeoramularia geranii (W.B. Cooke \& C.G. Shaw) U. Braun, in Braun \& Mel'nik, Trudy Botanicheskogo Instituta im. V.L. Komarova 20: 19 (1997).

$\equiv$ Cercosporella geranii W.B. Cooke \& C.G. Shaw, Lloydia 15: 126 (1952).

Notes - see Videira et al. (2017).

Pseudopuccinia Höhn., in Weese, Mitt. bot. Inst. tech. Hochsch. Wien 2(2): 41 (1925).

Index Fungorum number: IF 9606; Facesoffungi number: FoF 08646; 1 morphological species (Species Fungorum 2020), molecular data unavailable.

Type species - Pseudopuccinia thermopsidis (Harkn.) Höhn. [as 'thermopsis'], in Weese, Mitt. bot. Inst. tech. Hochsch. Wien 2(2): 42 (1926).

三Stigmina thermopsidis Harkn., Bull. Calif. Acad. Sci. 1(no. 1): 37 (1884).

Notes - see Videira et al. (2017).

Pseudostigmidium Etayo, in Etayo \& Rosato, Biblthca Lichenol. 98: 193 (2008) .

Index Fungorum number: IF 532868; Facesoffungi number: FoF 08647; 5 morphological species (Species Fungorum 2020), molecular data unavailable.

Type species - Pseudostigmidium nephromiarium (Linds.) Etayo, in Etayo \& Sancho, Biblthca Lichenol. 98: 204 (2008).

三 Microthelia nephromiaria Linds., Trans. R. Soc. Edinb. 25: 539 (1869). 
Notes - see Videira et al. (2017).

Pseudovularia Speg., Anal. Mus. nac. B. Aires, Ser. 3 13: 418 (1910) [1911].

Index Fungorum number: IF 9622; Facesoffungi number: FoF 08648; 1 morphological species (this study), molecular data unavailable. [1911]

Type species - Pseudovularia trifolii Speg., Anal. Mus. nac. B. Aires, Ser. 3 13: 418 (1910)

Notes - The genus was considered as a synonym of Ramularia based on morphology (Videira et al. 2017). Due to lack of sequence data of the type species, we tentatively treat Pseudovularia as a doubtful genus in Mycosphaerellaceae.

Quasiphloeospora B. Sutton, Crous \& Shamoun, Mycol. Res. 100(8): 979 (1996).

Index Fungorum number: IF 27631; Facesoffungi number: FoF 08649; 1 morphological species (Species Fungorum 2020), molecular data unavailable.

Type species - Quasiphloeospora saximontanensis (Deighton) B. Sutton, Crous \& Shamoun, in Sutton, Shamoun \& Crous, Mycol. Res. 100(8): 981 (1996).

三Cercospora saximontanensis Deighton, Mycol. Pap. 151: 7 (1983).

Notes - see Videira et al. (2017).

Ramularisphaerella Kleb., Haupt- und Nebenfruchtformen der Ascomyzeten (Leipzig) 1: 131 (1918).

Index Fungorum number: IF 4654; Facesoffungi number: FoF 08650; 1 morphological species (Species Fungorum 2020), molecular data unavailable.

Type species - Ramularisphaerella hieracii (Sacc. \& Briard) Kleb., Haupt- und Nebenfruchtformen der Ascomyzeten (Leipzig) 1: 131 (1918).

$\equiv$ Sphaerella nebulosa var. hieracii Sacc. \& Briard, Revue mycol., Toulouse 7(no. 27): 208 (1885).

Notes - see Videira et al. (2017).

Rhabdospora (Durieu \& Mont.) Sacc., Syll. fung. (Abellini) 3: 578 (1884).

Index Fungorum number: IF 9707; Facesoffungi number: FoF 08651; 60 morphological species (Species Fungorum 2020), 3 species with molecular data.

Type species - Rhabdospora oleandri (Durieu \& Mont.) Sacc., Syll. fung. (Abellini) 3: 583 (1884). (1849).

$\equiv$ Septoria oleandri Durieu \& Mont., in Durieu, Expl. Sci. Alg., Fl. Algér. 1(livr. 15): 593

Notes - see Videira et al. (2017).

Rhopaloconidium Petr., Sydowia 6(1-4): 300 (1952).

Index Fungorum number: IF 9744; Facesoffungi number: FoF 08652; 1 morphological species (Species Fungorum 2020), molecular data unavailable. (1952).

Type species - Rhopaloconidium asiminae (Ellis \& Morgan) Petr., Sydowia 6(1-4): 301

$\equiv$ Phloeospora asiminae Ellis \& Morgan, in Martin, J. Mycol. 3(8): 88 (1887).

Notes - see Videira et al. (2017).

Rosenscheldiella Theiss. \& Syd., Annls mycol. 13(5/6): 645 (1915).

Index Fungorum number: IF 4788; Facesoffungi number: FoF 08653; 19 morphological species (Species Fungorum 2020), 2 species with molecular data. (1915).

Type species - Rosenscheldiella styracis (Henn.) Theiss. \& Syd., Annls mycol. 13(5/6): 645

$\equiv$ Naemacyclus styracis Henn., Hedwigia 48: 8 (1908).

Notes - see Videira et al. (2017). 
Scirrhia Nitschke ex Fuckel, Jb. nassau. Ver. Naturk. 23-24: 220 (1870) [1869-70].

Index Fungorum number: IF 4922; Facesoffungi number: FoF 08654; 24 morphological species (Species Fungorum 2020), molecular data unavailable.

Type species - Scirrhia rimosa (Alb. \& Schwein.) Fuckel, Jb. nassau. Ver. Naturk. 23-24: 221 (1870).

$\equiv$ Sphaeria rimosa Alb. \& Schwein., Consp. fung. (Leipzig): 13 (1805).

Notes - see Videira et al. (2017).

Semipseudocercospora J.M. Yen, Mycotaxon 17: 361 (1983).

Index Fungorum number: IF 25847; Facesoffungi number: FoF 08655; 2 morphological species (Species Fungorum 2020), molecular data unavailable.

Type species - Semipseudocercospora peristrophes-acuminatae (J.M. Yen) J.M. Yen, Mycotaxon 17: 363 (1983).

三Cercospora peristrophes-acuminatae J.M. Yen, Revue Mycol., Paris 29: 234 (1964).

Notes - see Videira et al. (2017).

Septocylindrium Bonord. ex Sacc., in Saccardo, Michelia 2: 15 (1880).

Index Fungorum number: IF 9878; Facesoffungi number: FoF 08656; 7 morphological species (Species Fungorum 2020), 1 species with molecular data.

Type species - Septocylindrium bonordenii Sacc., in Saccardo, Michelia 1: 89 (1877).

Notes - see Videira et al. (2017).

Septocyta Petr., in Petrak, Ann. Mycol. 25: 330 (1927).

Index Fungorum number: IF 9879; Facesoffungi number: FoF 08657; 5 morphological species (Species Fungorum 2020), 1 species with molecular data.

Type species - Septocyta ramealis (Roberge ex Desm.) Petr., in Petrak, Ann. Mycol. 25: 330 (1927).

ESeptoria ramealis Roberge ex Desm., Pl. Crypt. Nord France, Edn 1: no. 2189 (1851).

Notes - see Quaedvlieg et al. (2013) and Videira et al. (2017).

Septopatella Petr., in Petrak, Ann. Mycol. 23: 128 (1925).

Index Fungorum number: IF 9889; Facesoffungi number: FoF 07587; 1 morphological species (Species Fungorum 2020), molecular data unavailable.

Type species - Septopatella septata (Jaap) Petr., in Petrak, Ann. Mycol. 23: 129 (1925).

三Pseudocenangium septatum Jaap, Annls mycol. 6(3): 219 (1908).

Notes - see Quaedvlieg et al. (2013) and Videira et al. (2017).

Septoriopsis Gonz. Frag. \& M.J. Paúl, in González Fragoso, Bol. Real Soc. Esp. Hist. Nat. 15: 127 (1915).

Index Fungorum number: IF 9897; Facesoffungi number: FoF 08658; 3 morphological species (Species Fungorum 2020), molecular data unavailable.

Type species - Septoriopsis citri Gonz. Frag. \& M.J. Paúl, in González Fragoso, Bol. Real Soc. Esp. Hist. Nat. 15: 127 (1915).

Notes - see Videira et al. (2017).

Septorisphaerella Kleb., in Klebahn, Haupt- und Nebenfruchtformen der Ascomyzeten (Leipzig) 1: 131 (1918).

Index Fungorum number: IF 5005; Facesoffungi number: FoF 08659; 1 morphological species (Species Fungorum 2020), molecular data unavailable.

Type species - Septorisphaerella hippocastani (Jaap) Kleb., in Klebahn, Haupt- und Nebenfruchtformen der Ascomyzeten (Leipzig) 1: 131 (1918).

三 Mycosphaerella hippocastani Jaap, Fungi Selecti Exsicc. Suppl. 46: 33 (1917).

Notes - see Videira et al. (2017). 
Sirosporium Bubák \& Serebrian., in Bubák, Hedwigia 52: 273 (1912).

Index Fungorum number: IF 9944; Facesoffungi number: FoF 08660; 28 morphological species (Species Fungorum 2020), 2 species with molecular data.

Type species - Sirosporium antenniforme (Berk. \& M.A. Curtis) Bubák \& Serebrian., in Bubák, Hedwigia 52: 273 (1912) .

$\equiv$ Macrosporium antenniforme Berk. \& M.A. Curtis [as 'antennaeforme'], N. Amer. Fung.: no. $642(1875)$.

Notes - see Braun et al. (2013) and Videira et al. (2017).

Sphaerellothecium Zopf, Nova Acta Acad. Caes. Leop.-Carol. German. Nat. Cur. 70(2): 184 (1897).

Index Fungorum number: IF 5085; Facesoffungi number: FoF 08661; 37 morphological species (Species Fungorum 2020), molecular data unavailable.

Type species - Sphaerellothecium araneosum (Rehm) Zopf, in Zopf, Nova Acta Acad. Caes. Leop.-Carol. German. Nat. Cur. 70: 178 (1897).

三Sphaerella araneosa Rehm ex Arnold, Verh. zool.-bot. Ges. Wien 23: 115 (1873).

Notes - see Chomnunti et al. (2011) and Videira et al. (2017).

Spilosphaeria Rabenh., in Rabenhorst, Klotzschii Herb. Viv. Mycol., Ed. Nov., Ser. Prima, Cent. 5: no. 442 (1857).

Index Fungorum number: IF 10005; Facesoffungi number: FoF 08662; 8 morphological species (Index Fungorum 2020), molecular data unavailable.

Type species - Spilosphaeria polygonorum (Desm.) Rabenh., Klotzschii Herb. Viv. Mycol., Edn Nov, Ser. Sec., Cent. 5: no. 442a (1857).

三Septoria polygonorum Desm., Annls Sci. Nat., Bot., sér. 2 17: 108 (1842).

Notes - see Videira et al. (2017).

Stenospora Deighton, in Deighton, Mycol. Pap. 118: 22 (1969).

Index Fungorum number: IF 10086; Facesoffungi number: FoF 08663; 1 morphological species (Species Fungorum 2020), molecular data unavailable.

Type species - Stenospora uredinicola Deighton, in Deighton, Mycol. Pap. 118: 23 (1969).

Notes - see Videira et al. (2017).

Stenellopsis B. Huguenin, in Huguenin, Bull. Trimestriel Soc. Mycol. France 81: 695 (1966).

Index Fungorum number: IF 10083; Facesoffungi number: FoF 08664; 4 morphological species (Species Fungorum 2020), molecular data unavailable.

Type species - Stenellopsis fagraeae B. Huguenin, in Huguenin, Bull. Trimestriel Soc. Mycol. France 81: 695 (1966).

Notes - see Videira et al. (2017).

Stictosepta Petr., in Petrak, Sydowia 17: 230 (1964).

Index Fungorum number: IF 10100; Facesoffungi number: FoF 07603; 1 morphological species (Species Fungorum 2020), molecular data unavailable.

Type species - Stictosepta cupularis Petr., in Petrak, Sydowia 17: 231 (1964).

Notes - see Quaedvlieg et al. (2013) and Videira et al. (2017).

Stigmidium Trevis., Conspect. Verruc.: 17 (1860).

Index Fungorum number: IF 5261; Facesoffungi number: FoF 08665; 96 morphological species (Species Fungorum 2020), molecular data unavailable.

Type species - Stigmidium schaereri (A. Massal.) Trevis., Conspect. Verruc.: 17 (1860).

ESphaeria schaereri A. Massal., Lecidea Hookeri: 8 (1853).

Notes - see Videira et al. (2017). 
Tandonella S.S. Prasad \& R.A.B. Verma, Indian Phytopath. 23(1): 112 (1970).

Index Fungorum number: IF 10175; Facesoffungi number: FoF 08667; 6 morphological species (Species Fungorum 2020), molecular data unavailable.

Type species - Tandonella ziziphi S.S. Prasad \& R.A.B. Verma, Indian Phytopath. 23(1): 112 (1970).

Notes - see Videira et al. (2017).

Tapeinosporium Bonord., Bot. Ztg. 11: 285 (1853).

Index Fungorum number: IF 10176; Facesoffungi number: FoF 08668; 1 morphological species (Index Fungorum 2020), molecular data unavailable.

Type species - Tapeinosporium viride Bonord., Bot. Ztg. 11: 285 (1853).

Notes - see Videira et al. (2017).

Utrechtiana Crous \& Quaedvl., in Crous et al., Persoonia 26: 153 (2011).

Index Fungorum number: IF 560179; Facesoffungi number: FoF 08669; 3 morphological species (Species Fungorum 2020), 3 species with molecular data. (2011).

Type species - Utrechtiana cibiessia Crous \& Quaedvl., in Crous et al., Persoonia 26: 153

Notes - see Videira et al. (2017).

Verrucisporota D.E. Shaw \& Alcorn, Aust. Syst. Bot. 6(3): 273 (1993).

Index Fungorum number: IF 26057; Facesoffungi number: FoF 08670; 5 morphological species (Species Fungorum 2020), 2 species (as Zasmidium) with sequence data.

Type species - Verrucispora proteacearum D.E. Shaw \& Alcorn, Proc. Linn. Soc. N.S.W. 92: 171 (1967).

Notes - Braun et al. (2013) and Videira et al. (2017) considered Verrucisporota as a synonym of Zasmidium based on phylogenetic placement of non-type materials. We decide to keep Verrucisporota as doubtful genus in Mycosphaerellaceae until sequence data of the type species is available.

Virgasporium Cooke, Grevillea 3(no. 28): 182 (1875).

Index Fungorum number: IF 10410; Facesoffungi number: FoF 08671; 6 morphological species (This study), 3 species with molecular data.

Type species - Virgasporium maculatum Cooke, Grevillea 3(no. 28): 182 (1875).

Notes - Virgasporium was considered as unconfirmed synonym of Cercospora in Videira et al. (2017). The type species need to be recollected to clarify its taxonomic placement.

Walkeromyces Thaung, Trans. Br. mycol. Soc. 66(2): 213 (1976).

Index Fungorum number: IF 10427; Facesoffungi number: FoF 08672; 1 morphological species (Species Fungorum 2020), molecular data unavailable.

Type species - Walkeromyces grewiae Thaung, Trans. Br. mycol. Soc. 66(2): 213 (1976).

Notes - see Videira et al. (2017).

\section{Ecological and economic significance}

Mycosphaerellaceae is crucial from agricultural and economic perspectives (Braun et al. 2013, Crous et al. 2013a, Quaedvlieg et al. 2013, Videira et al. 2016, 2017). Species of Mycosphaerellaceae are widely distributed and can be found as pathogens, endophytes, saprobes, epiphytes and fungicolous taxa occurring on various hosts worldwide (Quaedvlieg et al. 2013, Hongsanan et al. 2014b, Videira et al. 2016, 2017, Farr \& Rossman 2020). Many genera of Mycosphaerellaceae have been reported as quarantine regulated, such as Dothistroma, Lecanosticta Pseudocercospora, Septoria, Sphaerulina, causing important disease on economic crops (Barnes et al. 2004, 2016, Quaedvlieg et al. 2012, 2013, Crous et al. 2013a, Videira et al. 2017). Some genera produce fungal toxins or proteinaceous effectors suppressing host defense responses and biotrophic 
growth (Bradshaw 2004, Bradshaw \& Zhang 2006, de Wit 2016, Videira et al. 2017). Some mycosphaerellaceous endophytes have also the potential ability as sources of natural products important in medicine and agriculture (Aly et al. 2012, Gond et al. 2014, Videira et al. 2017). However, there has no species of Mycosphaerellaceae reported as a human pathogen (Videira et al. 2017).

Neodevriesiaceae Quaedvl. \& Crous, in Quaedvlieg et al., Persoonia 33: 24 (2014).

Index Fungorum number: IF 807766; Facesoffungi number: FoF 07636, 55 species.

Foliicolous, saprobic or pathogenic on plants. Sexual morph: Ascomata pseudothecial, black, immersed, substomatal on leaves. Peridium of 2-3 layers, composed of medium brown cells of textura angularis. Asci 8-spored, aparaphysate, bitunicate, subsessile, obovoid to broadly ellipsoid, straight to slightly curved. Ascospores overlapping 3- to multi-seriate, fusoid-ellipsoidal with obtuse ends, hyaline, medianly 1-septate, aguttulate, thick-walled, straight. Germinating ascospores on MEA become brown and verruculose. Asexual morph: Hyphomycetous. Hyphae variable, filamentous. Conidiophores pigmented, proliferating sympodially. Conidia solitary or in short mostly unbranched chains, subcylindrical to narrowly fusoid-ellipsoidal or obclavate, rarely septate, solitary conidia composed of a central stalk and two lateral arms with 1-2 transverse septa, brown.

Type - Neodevriesia Quaedvl. \& Crous.

Notes - Neodevriesiaceae was introduced by Quaedvlieg et al. (2014). The phylogenetic placement of Devriesia was initially ambiguous (Wang et al. 2016). Based on ITS phylogeny, Seifert et al. (2004) revealed the marginal placement of Devriesia in Mycosphaerellaceae. LSU based phylogeny by Crous et al. (2007a) supported the separation of Teratosphaeriaceae from Mycosphaerellaceae and Devriesia was included under Teratosphaeriaceae. Multi-locus phylogenetic analysis revealed the polyphyly of Devriesia and divided the genus into four distinct clades Devriesia sensu stricto, and Devriesia sensu lato 1, 2, and 3 (Crous et al. 2009c, Frank et al. 2010). Quaedvlieg et al. (2014) described Devriesia sensu lato 3 as Neodevriesia (Neodevriesiaceae).

Neodevriesia Quaedvl. \& Crous, in Quaedvlieg et al., Persoonia 33: 24 (2014).

Index Fungorum number: IF 807768; Facesoffungi number: FoF 07637; 28 morphological species (Species Fungorum 2020), 25 species with molecular data.

Type species - Neodevriesia hilliana (Crous \& U. Braun) Quaedvl. \& Crous.

Notes - Neodevriesia was established by Quaedvlieg et al. (2014). It has medium brown and unbranched conidiophores, thick-walled, medium brown, rarely septate conidia, short and mostly unbranched conidial chains and lacked chlamydospores. Crous et al. (2015b) described a new species and made 12 new combinations in Neodevriesia.

Neodevriesia hilliana (Crous \& U. Braun) Quaedvl. \& Crous, in Quaedvlieg et al., Persoonia 33: 24 (2014). Fig. 18

三Devriesia hilliana Crous \& U. Braun, in Crous et al., Stud. Mycol. 64: 37 (2009).

Index Fungorum number: IF 807771; Facesoffungi number: FoF 07638.

Description - see Crous et al. (2009c).

Material examined - New Zealand, Auckland, Auckland University Campus, Princes Street, on Macrozamia communis, 20 April 2008, C.F. Hill (CBS H-20340, holotype), culture ex-type CPC 15382 = CBS 123187.

Notes - Neodevriesia hilliana has medium brown, unbranched conidiophores, thick-walled, medium brown, rarely septate conidia, short and mostly unbrached conidial chains and lacks chlamydospores (Crous et al. 2009c). We were unable to obtain fresh collection; thus, a re-drawing is provided in Fig. 18. 

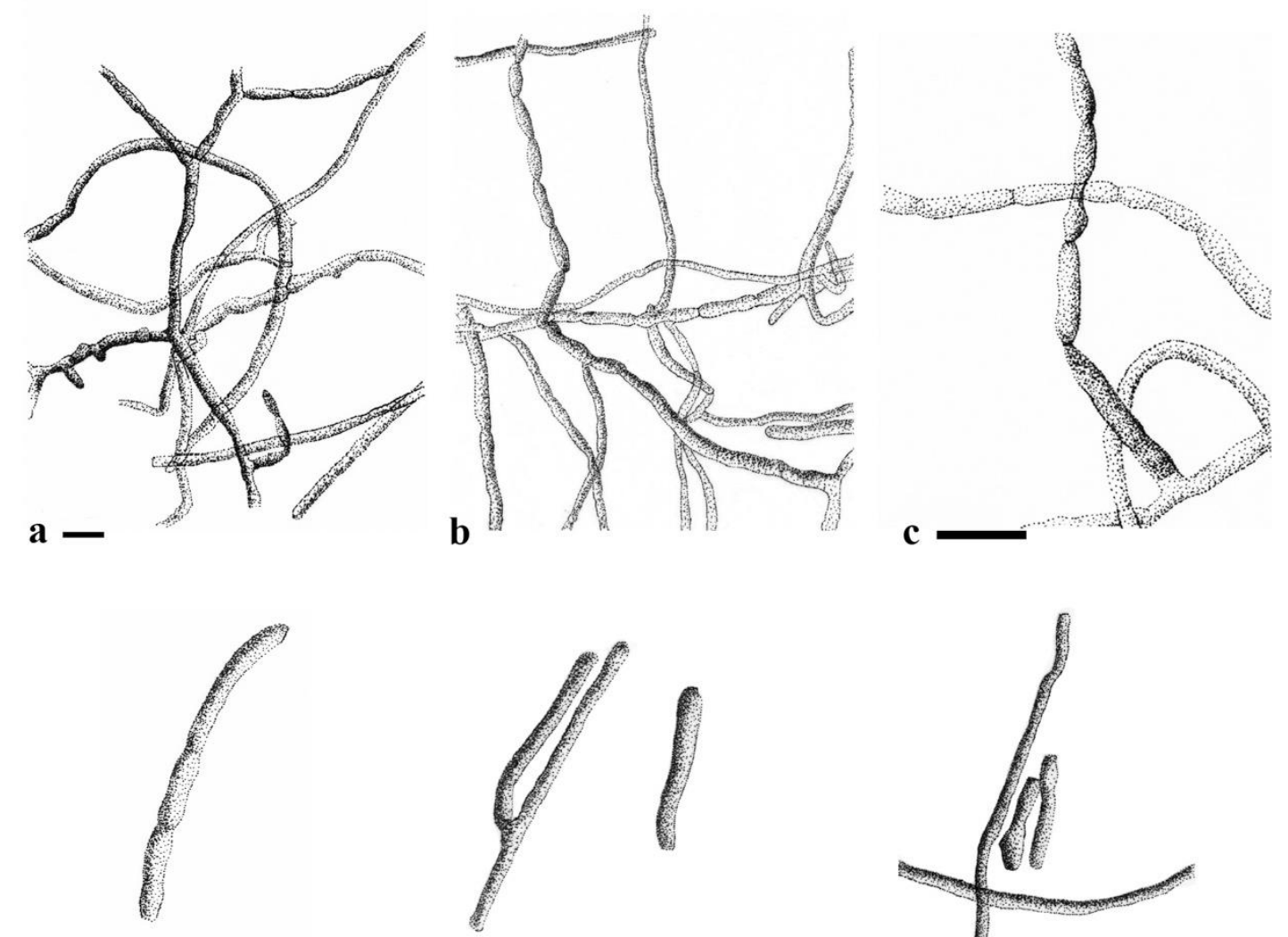

d
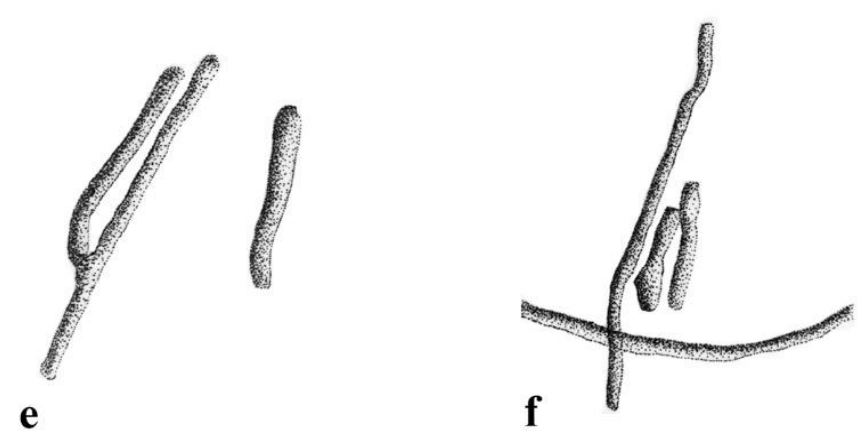

Figure 18 - Neodevriesia hilliana (redrawn from Crous et al. 2009c). a-c Conidiophores giving rise to catenulate conidia. $\mathrm{d}-\mathrm{f}$ Fragmenting conidial segments from aerial hyphae. Scale bars: $\mathrm{a}-\mathrm{f}=$ $10 \mu \mathrm{m}$.

\section{Other genus included}

Tripospermum Speg., Physis, Rev. Soc. Arg. Cienc. Nat. 4(no. 17): 295 (1918).

Index Fungorum number: IF 10316; Facesoffungi number: FoF 08051; 27 morphological species (Species Fungorum 2020), 3 species with molecular data.

Type species - Tripospermum acerinum (P. Syd.) P. Syd., Physis, Rev. Soc. Arg. Cienc. Nat. 4(no. 17): 295 (1918).

$\equiv$ Triposporium acerinum P. Syd., Hedwigia 38(Beibl.): (144) (1899).

Notes - Tripospermum myrti (CBC 437.68) formed a lineage within Neodevriesiaceae (Quaedvlieg et al. (2014). However, it forms a lineage outside Neodevriesiaceae in our phylogenetic tree (Fig. 3). Chomnunti et al. (2012) noted that Trichomerium, a sooty mould genus from Eurotiomycetes, possibly has Tripospermum as its asexual morphs. Crous et al. (2014a) found a Tripospermum-like taxon and sequence data indicated that it belongs to Trichomerium, thus they named it as Trichomerium dioscoreae. A tripospermum-like conidial taxon was found in association with sooty mould species Trichomerium gloeosporum (Hongsanan et al. 2016b), and its sequence data (ITS) showed it as the asexual morph of Trichomerium gloeosporum (Hongsanan et al. 2016b). Trichomerium chiangmaiensis was introduced by Maharachchikumbura et al. (2018), and its phylogenetic placement is in Eurotiomycetes. Since Tripospermum species formed in two different classes, we suggest to treat Tripospermum in Neodevriesiaceae as Trichomerium sensu lato until sequence data of the type species is available.

\section{Ecological and economic significance}

Members of Neodevriesiaceae have a wide range of ecological preferences as extremophiles (e.g. N. bulbillosa and N. imbrexigena), foliicolous taxa (e.g. N. queenslandica), mycoparasites (e.g. N. coryneliae), and plant pathogens (e.g. N. capensis) (Crous et al. 2014a, 2015c, Quaedvlieg et al. 
2014). Neodevriesia grateloupiae was found from marine algae. Further studies are needed regarding fungal communities on marine algae as algae play an important role in marine ecosystems (Wang et al. 2017).

Phaeothecaceae Darveaux, in Crous et al., Persoonia 41: 393 (2018).

Index Fungorum number: IF 828184; Facesoffungi number: FoF 07639, 5 species.

Sexual morph: Undetermined. Asexual morph: Hyphomycetous. Mycelium hyaline to brown, smooth-walled, septate, branched hyphae that swell up in terminal or intercalary cells, and develop numerous endoconidia. Conidiophores reduced to conidiogenous cells. Conidiogenous cells integrated, brown, expanding as endoconidia, finally rupturing and releasing mature endoconidia. Endoconidia globose to obovoid, brown when seen en mass, pale brown when viewed individually, aseptate to muriformly septate, thin- to thick-walled, smooth. Secondary conidia none (adapted from Crous et al. 2018a).

Notes - The family was established by Crous et al. (2018a) to accommodate a single genus Phaeotheca based on phylogenetic placement of $P$. fissurella and P. shathenatiana.

Phaeotheca Sigler, Tsuneda \& J.W. Carmich., Mycotaxon 12(2): 450 (1981).

Index Fungorum number: IF 9323; Facesoffungi number: FoF 07640; 5 morphological species (Species Fungorum 2020), 2 species with molecular data.

Type species - Phaeotheca fissurella Sigler, Tsuneda \& J.W. Carmich., Mycotaxon 12(2): 450 (1981).

Notes - The phylogenetic placement of this genus was determined by Crous et al. (2018a). Five epithets are listed in Index Fungorum (2020), but sequence data are available for only two species ( $P$. fissurella and $P$. shathenatiana, Crous et al. 2018a). We were unable to obtain fresh collections to illustrate this genus. Thus, a drawing of $P$. shathenatiana and $P$. salicorniae is provided (Fig. 19). Morphological characters can be seen in Crous et al. (2018a).

\section{Ecological and economic significance}

Phaeothecaceae is poorly known. However, the five species of Phaeotheca indicate the variety of life styles. The type species, Phaeotheca fissurella was found on Cronartium coleosporioides canker on Pinus contorta. Some species were found on leaves and twigs $(P$. salicorniae) and even a humidifier of air-conditioning system ( $P$. triangularis). It will be interesting to discover more species in this family to understand their roles in ecosystems.

Phaeothecoidiellaceae K.D. Hyde \& Hongsanan, in Hongsanan et al., Mycosphere 8(1): 137-146 (2017).

= Nowamycetaceae Crous, in Crous, Wingfield, Cheewangkoon, Carnegie, Burgess, Summerell, Edwards, Taylor, Groenewald, Stud. Mycol. 94: 209 (2019).

Index Fungorum number: IF 552766; Facesoffungi number: FoF 02883, 25 species.

Epiphytes or pathogens on fruits, leaves, and stems. Thallus very thin, covering surface of host with dark brown hyphae, sometimes absent. Superficial hyphae septate, not constricted at the septum, branched, brown to dark brown. Sexual morph: Thyriothecia superficial on host surface, circular, flattened, poorly developed at the base, thin-walled, brown to dark brown, with or without central ostiole. Thyriothecial setae arising from the surface of thyriothecia, brown to dark brown, smooth-walled, thyriothecial setae absent in some species. Upper wall comprises interwoven, dark brown cells. Peridium comprises two layers with flattened cells of textura angularis, inner layer hyaline, outer layer dark brown or reddish brown. Hamathecium comprising cellular pseudoparaphyses. Asci 8-spored, bitunicate, subcylindrical to obovoid, or globose to subglobose, pedicellate or apedicellate, with or without ocular chamber. Ascospores 2-3-seriate or irregularly overlapping, ellipsoid, hyaline, 1-septate, with or without appendages. Asexual morph: Hyphomycetous. Colonies effuse to punctiform. Mycelium septate, branched, brown to dark brown, sometimes covered in a mucilaginous sheath. Endoconidia phragmospores inside hyphae, pale brown to brown, aseptate, subcylindrical to broadly ellipsoid, thin-walled, roughened upon release, 
sometimes with a thin inconspicuous septum. Conidiophores intercalary, dark-brown, subcylindrical to cuneiform, reduced to conidiogenous cells, with conidiogenesis holoblastic to phialidic. Conidia broadly ellipsoid to subcylindrical or obclavate, truncate at base, rounded at apex, brown, transversely septate, tapering to a cuneiform with a truncate hilum at base (adapted from Yang et al. 2010, Hongsanan et al. 2017).

Type - Phaeothecoidiella Batzer \& Crous.

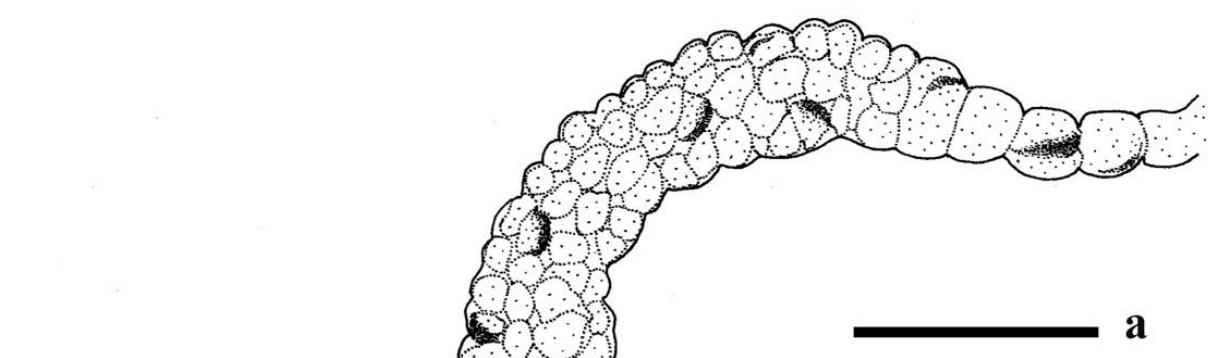

b
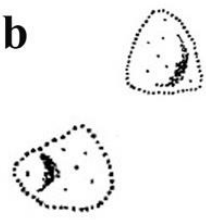

c
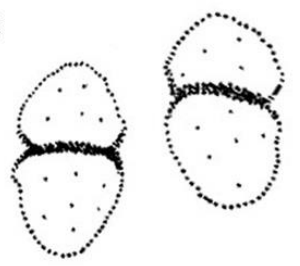
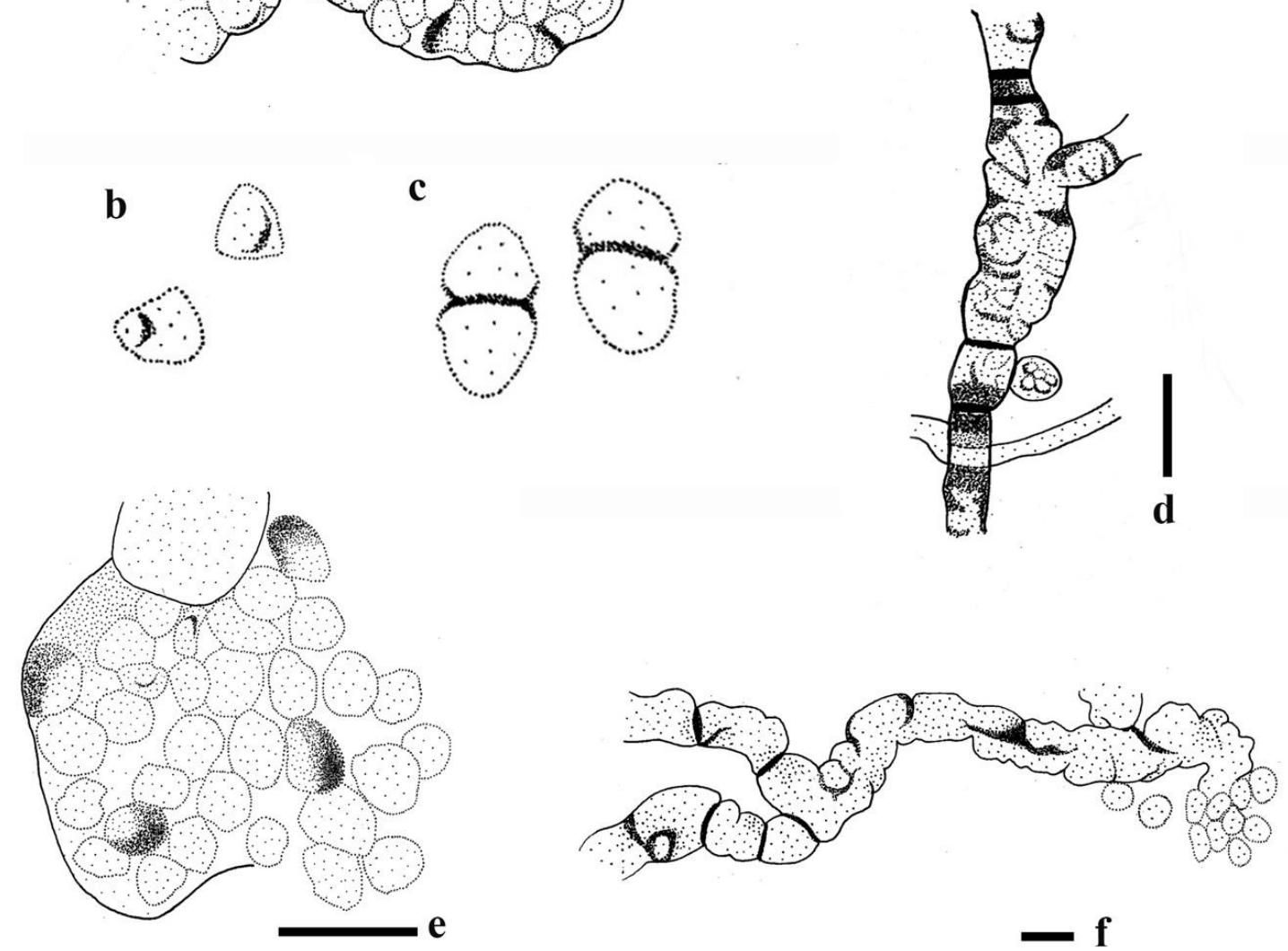

- f

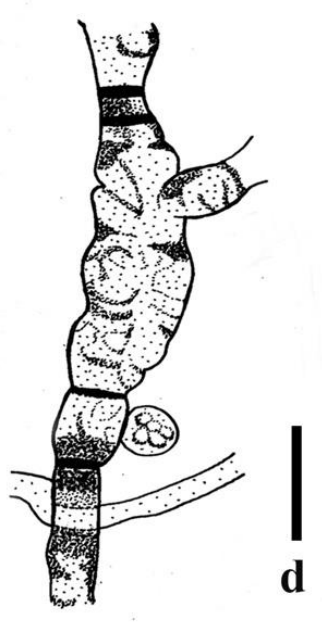

Figure 19 - Phaeotheca salicorniae (redrawn from Crous et al. 2016, CPC 27406). a Hyphae with endoconidia growing on water agar with sterilised pine needles (PNA). b, c Immature and mature conidia. d Integrated conidiogenous cells swelling and compartmentalising. e Sausage-like appearance of conidiogenous cell development and rupture. f Conidiogenous cell rupturing to release endospores. Notes $-\mathrm{a}-\mathrm{c}=$ Phaeotheca salicorniae (redrawn from Crous et al. 2016b, CPC 27406), $\mathrm{d}-\mathrm{f}=$ Phaeotheca shathenatiana (redrawn from Crous et al. 2018a, MSX102094). Scale bars: $\mathrm{a}, \mathrm{d}-\mathrm{f}=10 \mu \mathrm{m}$.

Notes - Phaeothecoidiellaceae is a family causing sooty blotch and flyspeck diseases. It was established within Capnodiales to accommodate Chaetothyrina, Houjia and Phaeothecoidiella by Hongsanan et al. (2017). Phylogenetically, these genera formed a distinct clade sister to the Dissoconiaceae, Mycosphaerellaceae and Schizothyriaceae clades in Capnodiales (Yang et al. 
2010, this study). Zeng et al. (2018b) introduced a new genus Translucidithyrium to this family based on morphology and phylogeny. Nowamycetaceae was introduced by Crous et al. (2019d) to accommodate two species of Nowamyces ( $N$. globulus and $N$. piperitae). Phylogenetic analyses supported this family in Capnodiales. By including all genera of Phaeothecoidiellaceae that have sequence data in our phylogenetic analysis, we found that Nowamycetaceae species clustered within Phaeothecoidiellaceae. Thus, we synonymise Nowamycetaceae in Phaeothecoidiellaceae.

Phaeothecoidiella Batzer \& Crous, in Yang et al., Persoonia 24: 30 (2010).

Index Fungorum number: IF 5514394; Facesoffungi number: FoF 06973; 2 morphological species (Species Fungorum 2020), 2 species with molecular data.

Type species - Phaeothecoidiella missouriensis Batzer \& Crous, in Yang et al., Persoonia 24: 32 (2010).

Notes - Phaeothecoidiella is an asexual hyphomycetous genus found on surface of apples (Yang et al. 2010). Phaeothecoidiella is similar to Phaeotheca, Hyphospora and Phaeothecoidea (Yang et al. 2010). Hyphae of this genus, however, are covered in a prominent mucilaginous sheath, thus Hughes (1976) suggested that the taxa could occur elsewhere in nature as true sooty moulds. Yang et al. (2010) stated that Phaeothecoidiella species are probably opportunistic on the surface of apple fruits. Phaeothecoidiella contains two species with sequence data in GenBank (Yang et al. 2010). Phylogenetic analyses based on ITS, LSU and SSU data indicate that Phaeothecoidiella is closely related to Chaetothyrina species within Phaeothecoidiellaceae (Hongsanan et al. 2017).

\section{Other genera included}

Chaetothyrina Theiss., Annls mycol. 11(6): 495 (1913).

Index Fungorum number: IF 976; Facesoffungi number: FoF 06974; 15 morphological species (Species Fungorum 2020), 4 species with molecular data.

Type species - Chaetothyrina musarum (Speg.) Theiss., Annls mycol. 11(6): 495 (1913).

$\equiv$ Chaetothyrium musarum Speg., Anal. Mus. nac. Hist. nat. B. Aires 6: 297 (1898).

Notes - This genus causes flyspeck disease on various plants and fruits. Chaetothyrina was placed in Micropeltidaceae based on its flattened thyriothecium, with interwoven cells (Wu et al. 2011, Hongsanan et al. 2017). Chaetothyrina however, differs from other genera in Micropeltidaceae in having inconspicuous superficial hyphae (sometimes this may be absent), dark brown thyriothecia with setae, and 1-septate ascospores (Reynolds \& Gilbert 2005, Singtripop et al. 2016, Hongsanan et al. 2017); Micropeltidaceae species have bluish or greenish to black thyriothecia, with multi-septate ascospores (Wu et al. 2011, Hongsanan et al. 2015a). Phylogenetically, Chaetothyrina clusters within the new family Phaeothecoidiellaceae, Capnodiales (Hongsanan et al. 2017).

Chaetothyrina musarum (Speg.) Theiss., Annls mycol. 11(6): 495 (1913).

Fig. 20

$\equiv$ Chaetothyrium musarum Speg., Anal. Mus. nac. Hist. nat. B. Aires 6: 297 (1898).

Index Fungorum number: IF 239828; Facesoffungi number: FoF 02009.

Epiphytic on the surface of fruit of Musa sp. Sexual morph: Thyriothecia 114-160 × 106-154 $\mu \mathrm{m}(\bar{x}=132 \times 125 \mu \mathrm{m}, \mathrm{n}=5)$, superficial, solitary, circular, brown to dark brown, rounded at the margin, easily removed from host surface, poorly developed at the base, with setae, ostiole central, lacking superficial mycelium. Setae 93-118 $\mu \mathrm{m}$ long, arising from the surface of thyriothecia, straight, rounded at the apex, unbranched, septate, darkened at the septa, brown to dark brown. Upper wall 2-3 layers of cells of textura epidermoidea, brown to dark brown. Hamathecium comprising septate, pseudoparaphyses. Asci 25-40 × 12-16 $\mu \mathrm{m}(\bar{x}=35 \times 14 \mu \mathrm{m}, \mathrm{n}=8)$, 8-spored, bitunicate, broadly obovoid to pyriform, rounded at apex, with an ocular chamber. Ascospores 10$14 \times 3-5 \mu \mathrm{m}(\bar{x}=13 \times 4 \mu \mathrm{m}, \mathrm{n}=20), 2-3$-seriate, broadly ellipsoidal to fusoid, hyaline, 1-septate, slightly constricted at the septum, upper cell mostly larger than lower cell, rounded ends, smoothwalled.

Material examined - Mexico, Intercepted Laredo Texas, on fruit of Musa sp., 6 December 1959, Lopez A. (BPI 646468). 


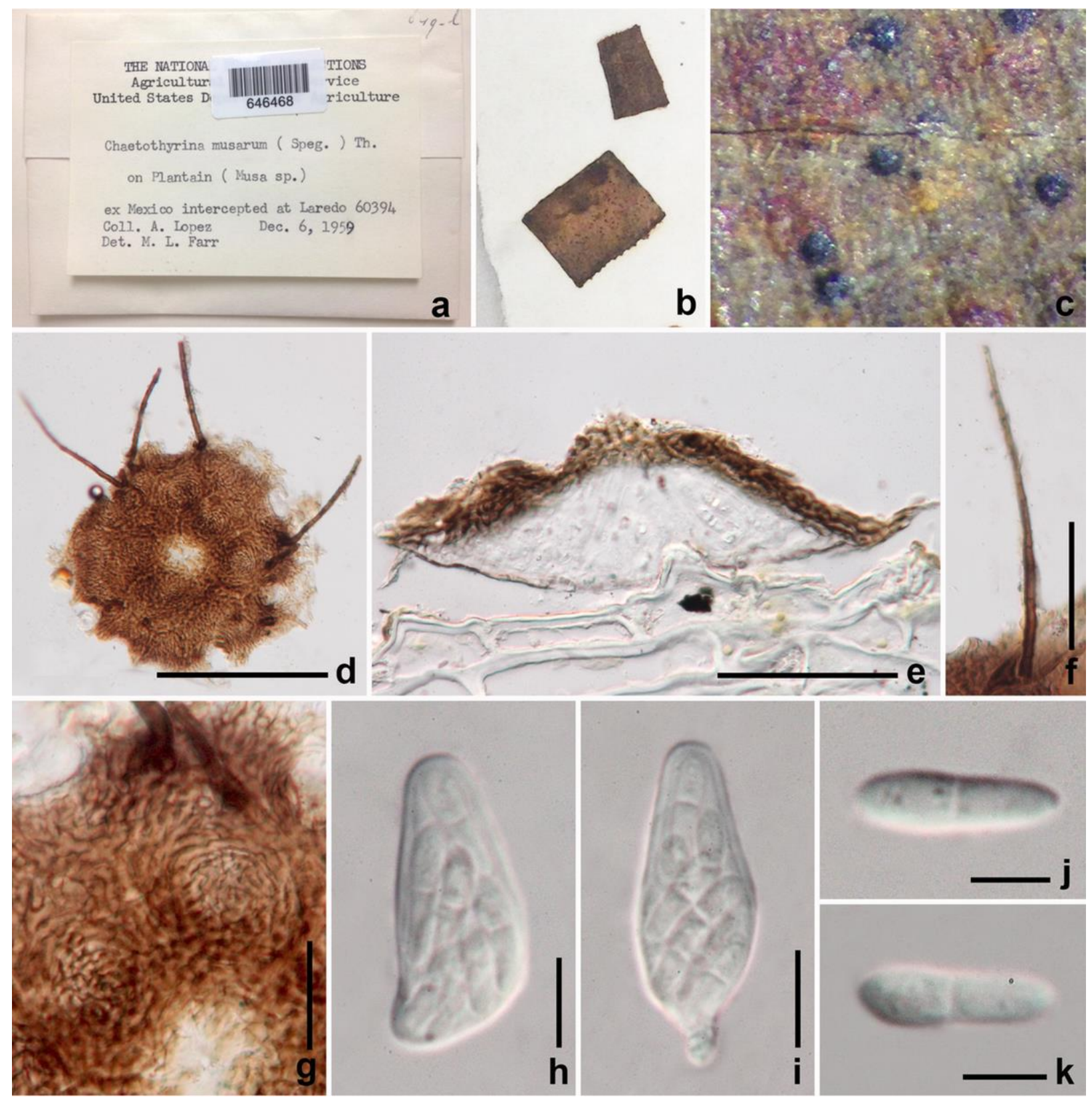

Figure 20 - Chaetothyrina musarum (BPI 646468). a, b Herbarium specimens. c Thyriothecium on host surface. $d$ Thyriothecia when viewed in squash mount. e Section through thyriothecium. f Seta arising from the surface of thyriothecium. $g$ Upper wall of thyriothecium when viewed in squash mount. h, i Asci. j, k Ascospores. Scale bars: $d=100 \mu \mathrm{m}, \mathrm{e}, \mathrm{f}=50 \mu \mathrm{m}, \mathrm{g}-\mathrm{i}=10 \mu \mathrm{m}, \mathrm{j}, \mathrm{k}=5 \mu \mathrm{m}$.

Exopassalora Videira \& Crous, in Videira et al., Stud. Mycol. 87: 380 (2017).

Index Fungorum number: IF 822589; Facesoffungi number: FoF 07641; 1 morphological species (Species Fungorum 2020), 1 species with molecular data.

Type species - Exopassalora zambiae (Crous \& T.A. Cout.) Videira \& Crous, in Videira et al., Stud. Mycol. 87: 380 (2017).

$\equiv$ Passalora zambiae Crous \& T.A. Cout., in Crous et al., Stud. Mycol. 50(1): 209 (2004).

Notes - This genus is phytopathogenic and is characterised by brown hyphae, with dark brown chlamydospore-like hyphal swellings, brown conodiophores arising from the mycelium, proliferating sympodially, cells terminal and intercalary conidiogenous cells, with conspicuous, darkened, refractive conidiogenous loci. Conidia are ellipsoidal, tapering to subtruncate, straight or slightly curved, branched chains and brown. Phylogenetic analyses placed this genus in Phaeothecoidiellaceae (Videira et al. 2017, this study). 
Houjia G.Y. Sun \& Crous, in Yang et al., Persoonia 24: 33 (2010).

Index Fungorum number: IF 514397; Facesoffungi number: FoF 06975; 2 morphological species (Species Fungorum 2020), 2 species confirmed, molecular data available for an unnamed species in the genus.

Type species - Houjia yanglingensis G.Y. Sun \& Crous, in Yang et al., Persoonia 24: 34 (2010).

Notes - Houjia was found on surface of apples by Yang et al. (2010). It is an asexual hyphomycetous genus of Phaeothecoidiellaceae based on phylogenetic analyses (Hongsanan et al. 2017, this study). Houjia is characterised by branched, septate hyphae, conidiophores reduced to conidiogenous cells, monoblastic, solitary conidiogenous cells that are not aggregated in clusters, and broadly ellipsoid to subcylindrical or obclavate, medium brown, euseptate conidia, tapering to a cuneiform base with a truncate hilum (Yang et al. 2010).

Nowamyces Crous, in Crous et al., Stud. Mycol. 94: 209 (2020).

Index Fungorum number: IF 832037; Facesoffungi number: FoF 07642; 2 morphological species (Species Fungorum 2020), 2 species with molecular data.

Type species - Nowamyces globulus Crous, in Crous et al., Stud. Mycol. 94: 210 (2019).

Notes - Two species are accepted in this genus, $N$. globulus and $N$. piperitae (Crous et al. 2019a). They are teratosphaeria-like and can be distinguished by molecular data. Crous et al. (2019a) included this genus in Nowamycetaceae. However, Nowamycetaceae is synonymized under Phaeothecoidiellaceae in our study based on phylogenetic analyses (Fig. 3), thus Nowamyces is transferred to Phaeothecoidiellaceae. Crous et al. (2019a) suggested that $N$. piperitae is plant pathogenic as it was associated with prominent leaf spots. Nowamyces globulus was assumed to be of minor relevance as it was associated with Teratosphaeria nubilosa leaf spots on Eucalyptus globulus.

Rivilata Kohlm., Volkm.-Kohlm. \& O.E. Erikss., Can. J. Bot. 76(3): 470 (1998).

Index Fungorum number: IF 27932; Facesoffungi number: FoF 07643; 1 morphological species (Species Fungorum 2020), molecular data unavailable. (1998).

Type species - Rivilata ius Kohlm., Volkm.-Kohlm. \& O.E. Erikss., Can. J. Bot. 76(3): 472

Notes - The genus was considered to be similar to Schizothyrium, but it differs in having subcuticular ascomata, while Schizothyrium has epicuticular ascomata (Kohlmeyer et al. 1998). Doilom et al. (2018) re-examinded the holotype specimen of Rivilata ius and included Rivilata in Phaeothecoidiellaceae and noted that it is similar to Translucidithyrium. Rivilata is characterized by brown, flattened thyriothecia, developing under the cuticle and becoming superficial, a hymenium covered by an epithecium, and ellipsoidal, uniseptate, upper cell, wider than the lower one, and hyaline ascospores, with oil droplets (Doilom et al. 2018).

Sporidesmajora Batzer \& Crous, in Yang et al., Persoonia 24: 35 (2010).

Index Fungorum number: IF 514400; Facesoffungi number: FoF 07644; 1 morphological species (Species Fungorum 2020), 1 species with molecular data available.

Type species - Sporidesmajora pennsylvaniensis Batzer \& Crous, in Yang et al., Persoonia 24: 35 (2010).

Notes - The genus is monotypic. Sporidesmajora has long, multi-septate conidiophores that frequently have a subconical, dark pigmented apical cell, with a single holoblastic conidium, obclavate conidia that are frequently very long, with a multi-euseptate, obconical basal cell (Yang et al. 2010).

Translucidithyrium X.Y. Zeng \& K.D. Hyde, in Zeng et al., Mycol. Progr. 17(9): 1090 (2018).

Index Fungorum number: IF 824636; Facesoffungi number: FoF 04090; 1 morphological species (Species Fungorum 2020), 1 species with molecular data. 
Type species - Translucidithyrium thailandicum X.Y. Zeng \& K.D. Hyde, in Zeng et al., Mycol. Progr. 17(9): 1090 (2018).

Notes - The genus was established with a single species T. thailandicum. Translucidithyrium is similar to Myriangiaceae and Schizothyriaceae, but differs in lacking a network-like structure surrounding locules (Zeng et al. 2018b). In the phylogenetic analysis Translucidithyrium clustered with other genera in Phaeothecoidiellaceae, but as a distinct genus.

\section{Ecological and economic significance}

Species in this family are frequently found on the surface of fruits and cause sooty blotch and flyspeck (SBFS) diseases. They occur in humid temperate regions especially on pomaceous fruits, resulting in economic losses for growers (Yang et al. 2010).

Piedraiaceae Viégas ex Cif., Bat. \& S. Camposa, Publicações Inst. Micol. Recife 45(1-6): 7 (1956). Index Fungorum number: IF 82066; Facesoffungi number: FoF 06972, 2 species.

Pathogenic on human hair. Sexual morph: Ascostroma with pseodoparenchymatic tissue, vary in size and shape. but usually flat, elongated and with a rough surface, dark in colour, multi-loculate in section, containing numerous cavities, irregularly distributed throughout. Each locule becomes erumpent as the asci mature, and can be visible as a small dimple, and contains a single ascus. Pseudostiolate locules, without pseudoparaphyses, with paraphysoids. Asci 8-spored, bitunicate, subglobose to broadly ellipsoidal. Ascospores overlapping, fusiform, curved, more or less straight to falcate, tapering towards both ends, hyaline, rarely light yellowish or greenish, aseptate, thinwalled, with tapering gelatinous appendages or without appendages. Germination by several germ tubes (Ciferri et al. 1956, von Arx \& Müller 1975, Eriksson 1981, Liu 2011). Asexual morph: Undetermined.

Type - Piedraia Fonseca \& Leão.

Notes - Piedraiaceae was described by Ciferri et al. (1956) under Myriangiales. Piedraiaceae consists of only one genus Piedraia recorded in tropical regions with two species, $P$. hortae the type species and $P$. quintanilhae. Piedraia hortae (sexual morph) is a superficial keratinolytic parasite on human hair, known as "black piedra". The asexual morph of $P$. hortae is undetermined. Phylogenetic analyses indicated that Piedraia hortae is closely related to Mycosphaerella (Lindemuth et al. 2001, Selbmann et al. 2005). Multi-gene analysis of Dothideomycetes (Schoch et al. 2006) included Paedraiaceae under Capnodiales. Crous et al. (2009c) provided sequence data of four strains of Piedraia hortae (CBS 276.32, CBS 374.71, CBS 375.71, and CBS 480.64) and $P$. quintanilhae (CBS 327.63). They found that Piedraiaceae clustered within Teratosphaeriaceae with high bootstrap support (>95\% MLBS). Thus, Crous et al. (2009c) treated Piedraia under Teratosphaeriaceae. This result is the same as in Chomnunti et al. (2014) and this study (Fig. 3). However, Teratosphaeriaceae mostly contains plant pathogens. Thus, Piedraiaceae is retained until more evidence is available to resolve its taxonomic placement.

Piedraia Fonseca \& Leão, Memórias do Instituto Oswaldo Cruz 21 (suppl. 4): 125 (1928).

Index Fungorum number: IF 4098; Facesoffungi number: FoF 06139; 2 morphological species (Species Fungorum 2020), 2 species with molecular data.

Type species - Piedraia hortae Fonseca \& Leão.

Notes - The genus causes disease of human hair. Two species are accepted $P$. hortae and $P$. quintailhae. Piedraia quintanilhae differs from $P$. hortae in having ascospores without appendages. Piedraia is also commonly found in soil, stagnant water and crops as dematiaceous filamentous fungi.

Piedraia hortae Fonseca \& Leão, Supplemento 4(Suppl.): 124 (1928).

Fig. 21

Index Fungorum number: IF 267365; Facesoffungi number: FoF 06140.

Notes - Piedraia hortae causes black piedra which is an important disease in South America, Asia and Pacific islands. We provide the drawing of Piedraia hortae in Fig. 21. 


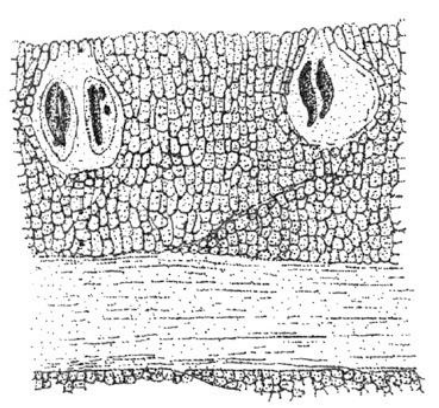

a

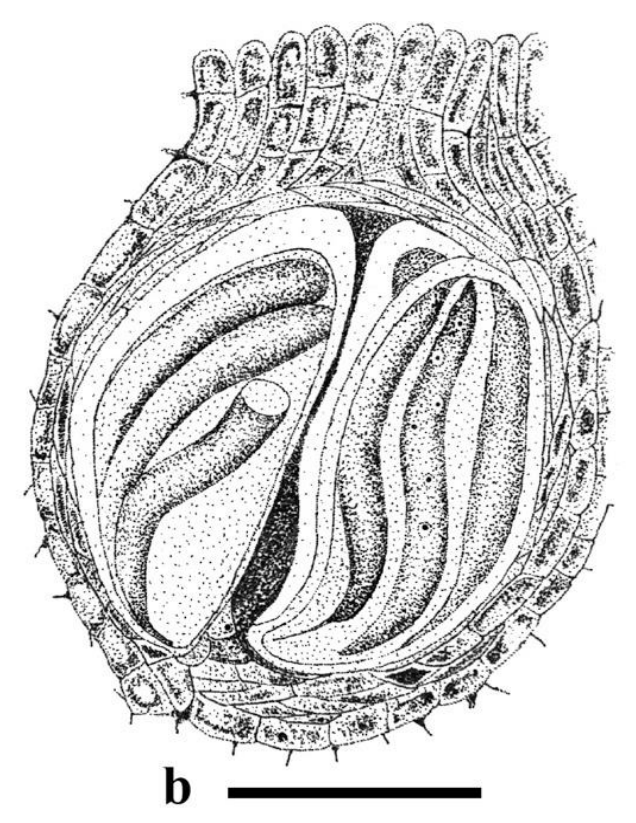

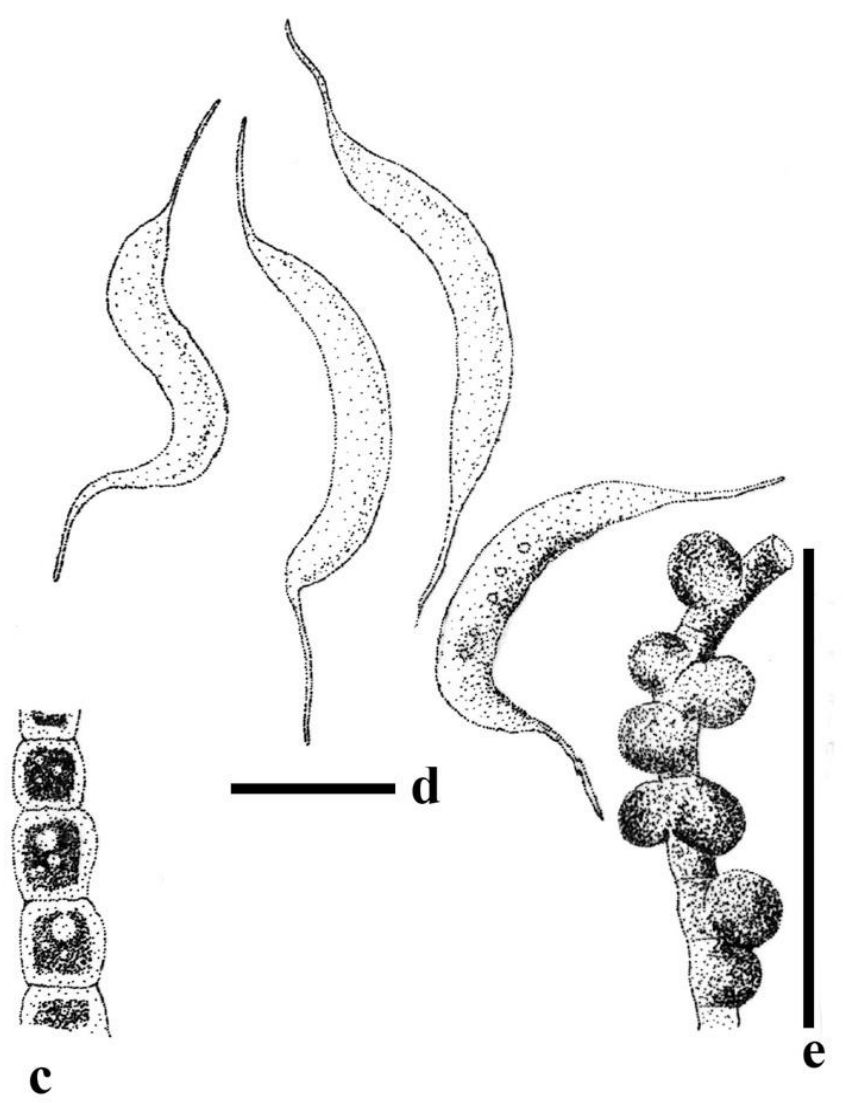

Figure 21 - Piedraia hortae (redrawn from Viegas 1943). a Stroma on human hair. b Vertical section through ascoma. c Hypha on the culture. d Ascospores. e Peripilar nodules grown on hypha on culture. Scale bars: $\mathrm{a}-\mathrm{e}=20 \mu \mathrm{m}$.

\section{Ecological and economic significance}

Black piedra is an important human disease in Souh America, Asia and Pacific islands. The salty environment within oily hair facilitates promotes the growth of this fungus. The infection results in the formation of brown to black nodes which contain ascomata.

Racodiaceae Link, Abh. Dt. Akad. Wiss. Berlin: 166 (1826) [1824].

Index Fungorum number: IF 81239; Facesoffungi number: FoF 06304, 44 species.

On inclined to vertical siliceous rocks in recesses. Hyphae vertically arranged, lacking interlocking corrugations, lacking lateral spines, thick-walled, fused to form elongated rectangular cells, vertically orientated cells along the axis of the algal filament, overall smooth, rather than a knobby appearance, completely smooth in SEM.

Type - Racodium Fr.

Notes - Racodiaceae was introduced with a single genus. Members of this family are found on inclined to vertical siliceous rocks in recesses where it is cool with no direct rain, but high humidity, and with a temperate/subboreal distribution (Hawksworth et al. 2011, Nimis et al. 2018). Phylogenetic analyses based on the type species Racodium rupestre showed that it forms a distinct clade as genus incertae sedis in Capnodiales (Muggia et al. 2008), and the same result was shown by Crous et al. (2009c) and Ruibal et al. (2009). Racodiaceae was mentioned again to 
accommodate Racodium in Lücking et al. (2017) and Wijayawardene et al. (2017a). This family is poorly studied. We provide a drawing to show its morphology (Fig. 22).

Racodium Fr., Syst. Mycol. (Lundae) 3(1): 229 (1829).

Index Fungorum number: IF 9681; Facesoffungi number: FoF 06305; 5 morphological species (Wijayawardene 2020), 1 species with molecular data.

Type species - Racodium rupestre Pers., Neues Mag. Bot. 1: 123 (1794).

Notes - The black felt-like patches can be seen on extensive parts of rocks. Therefore, the phytosociological name has been given as Racodietum rupestris (Hawksworth et al. 2011). Vainio (1921) listed Coenogonium germanicum as a synonym of $R$. rupestre. Lepraria and Leproloma species mostly often grow mixed with Racodium rupestre, as well as Cystocoleus ebeneus (Hawksworth et al. 2011). Hawksworth et al. (2011) noted an interesting observation made by W. Watson in 1872-1960 that nitric acid used on a mixed collection of Coenogonium germanicum and Racodium rupestre caused the filament hyphae to twist in Coenogonium germanicum, while the dark hyphae were parallel in Racodium rupestre. Phylogenetic analyses indicated that Racodium rupestre is not close to Cystocoleus ebeneus, but forms a distinct clade within Capnodiales (Muggia et al. 2008, Hawksworth et al. 2011).
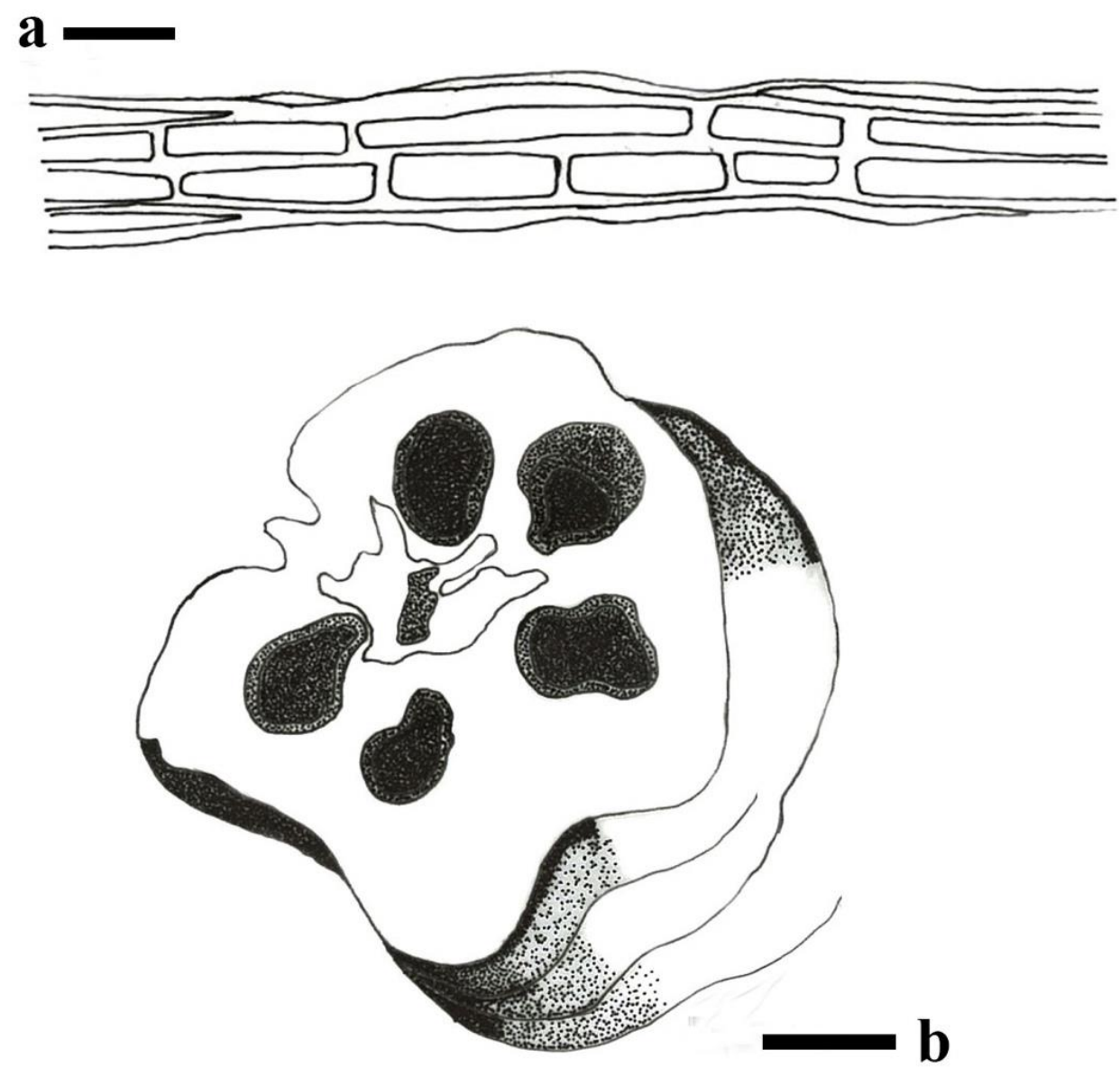

Figure 22 - Racodium rupestre (redrawn from Hawksworth et al. 2011). a Filament. b SEM micrographs of filaments. Scale bars: $a=10 \mu \mathrm{m}, \mathrm{b}=2 \mu \mathrm{m}$.

\section{Ecological and economic significance}

Species of Racodium are rock-inhabiting taxa. Racodium rupestre is widespread in the Alps (Nimis et al. 2018) which were most likely evolved from a rock-inhabiting ancestor (Ruibal et al. 
2009). This is a lichen with a peculiar micro-filamentous growth on hygrophytic sites such as the surfaces of siliceous rocks with no eutrophication in sheltered habitats (Nimis et al. 2018).

Schizothyriaceae Höhn. ex Trotter, Sacc., D. Sacc. \& Traverso [as 'Schizothyrieae'], in Saccardo, Syll. fung. (Abellini) 24(2): 1254 (1928).

Index Fungorum number: IF 81266; Facesoffungi number: FoF 01932, 64 species.

Epiphytic, pathogenic or saprobic on fruits and leaves or twigs of various plants, epiphyllous or hypophyllous on leaves, visible as rounded, small to medium, dark grey to black dots on the host surface, lacking superficial or subcuticular vegetative hyphae expanding on host surface. Sexual morph: Ascomata scattered, solitary to gregarious, superficial, flattened, circular to ellipsoid, light brown or dark brown to black, transparent to opaque, scutate to dimidiate, or orbicular, glabrous, uni-loculate, lacking ostioles, or opening by splitting of the upper wall. Peridium thin-walled, poorly-developed at the base, comprising 3 types of peridial structure; type I: composed of 2-3layered, light brown to dark brown, or black cells of textura angularis to textura globulosa; type II: composed of thin, pale brown to pale grey, transparent, membranous cells; type III: composed of brown to reddish brown, septate, roughly coarse, branching, botryose elements, or loosely packed hyphae. Hamathecium comprising net-like or pseudoparaphysoid-like filaments. Asci 4-8-spored, bitunicate, globose to subglobose, obovoid to clavate, sessile to subsessile, or short pedicellate, apically rounded broad, with an ocular chamber. Ascospores overlapping 3-5-seriate, oblong to ellipsoidal, or claviform, hyaline to subhyaline, septate, constricted at the septum, thin- to thickwalled, smooth to rough, with small guttules. Asexual morph: Hyphomycetous (see Batzer et al. 2008).

Type - Schizothyrium Desm.

Notes - The concept of Schizothyriaceae was originally described as "exciple depressed on cuticle, superficial, membranous, irregular fringed when mature" (Saccardo 1928). Schizothyriaceae is a poorly understood family comprising many doubtful genera due to the lack of molecular data. Hyde et al. (2013) re-circumscribed the genera in Schizothyriaceae based on study of type materials as well as representative specimens and accepted 15 genera viz. Amazonotheca, Chaetoplaca, Henningsiella, Hexagonella, Kerniomyces, Lecideopsella, Linopeltis, Mendogia, Metathyriella, Mycerema, Myriangiella, Neopeltella, Orthobellus, Plochmopeltis and Schizothyrium (= Zygophiala, hyphomycetous asexual morph). Ariyawansa et al. (2013) tentatively placed Hysteropeltella in Schizothyriaceae. Phookamsak et al. (2016) revised the taxonomic placement of genera in Schizothyriaceae based on the study of their type material and representative specimens and also provided detailed taxonomic descriptions of these genera. Phookamsak et al. (2016) accepted only five genera in Schizothyriaceae viz. Hexagonella, Lecideopsella, Mycerema, Plochmopeltis and Schizothyrium. Kerniomyces, Metathyriella and Myriangiella were treated as doubtful genera due to the lack of their type materials and taxonomic literature (Phookamsak et al. 2016). Wijayawardene et al. (2018) tentatively placed these three genera in Schizothyriaceae pending future studies and listed nine genera in this family. Doilom et al. (2018) included Vonarxella in Schizothyriaceae based on the type study. There are presently ten genera listed in Schizothyriaceae, viz. Amazonotheca, Hexagonella, Kerniomyces, Lecideopsella, Metathyriella, Myriangiella, Mycerema, Plochmopeltis, Schizothyrium and Vonarxella (Doilom et al. 2018, Wijayawardene et al. 2018).

The taxonomic placement of Schizothyriaceae has a long history. A detailed literature review was provided by Phookamsak et al. (2016). The phylogenetic placement of Schizothyriaceae was determined by Batzer et al. (2005, 2008) and Crous et al. (2007, 2009) based on Schizothyrium pomi and its asexual morph, Zygophiala. Phylogenetic analyses have shown that Schizothyriaceae belongs to Capnodiales, allied to Mycosphaerellaceae (Batzer et al. 2005, 2008, Crous et al. 2007, 2009, Yang et al. 2010). Evolutionary relationships of the higher-ranking classification using divergence times and molecular dating also support Schizothyriaceae in Capnodiales (Hongsanan et al. 2016, Liu et al. 2017a). 

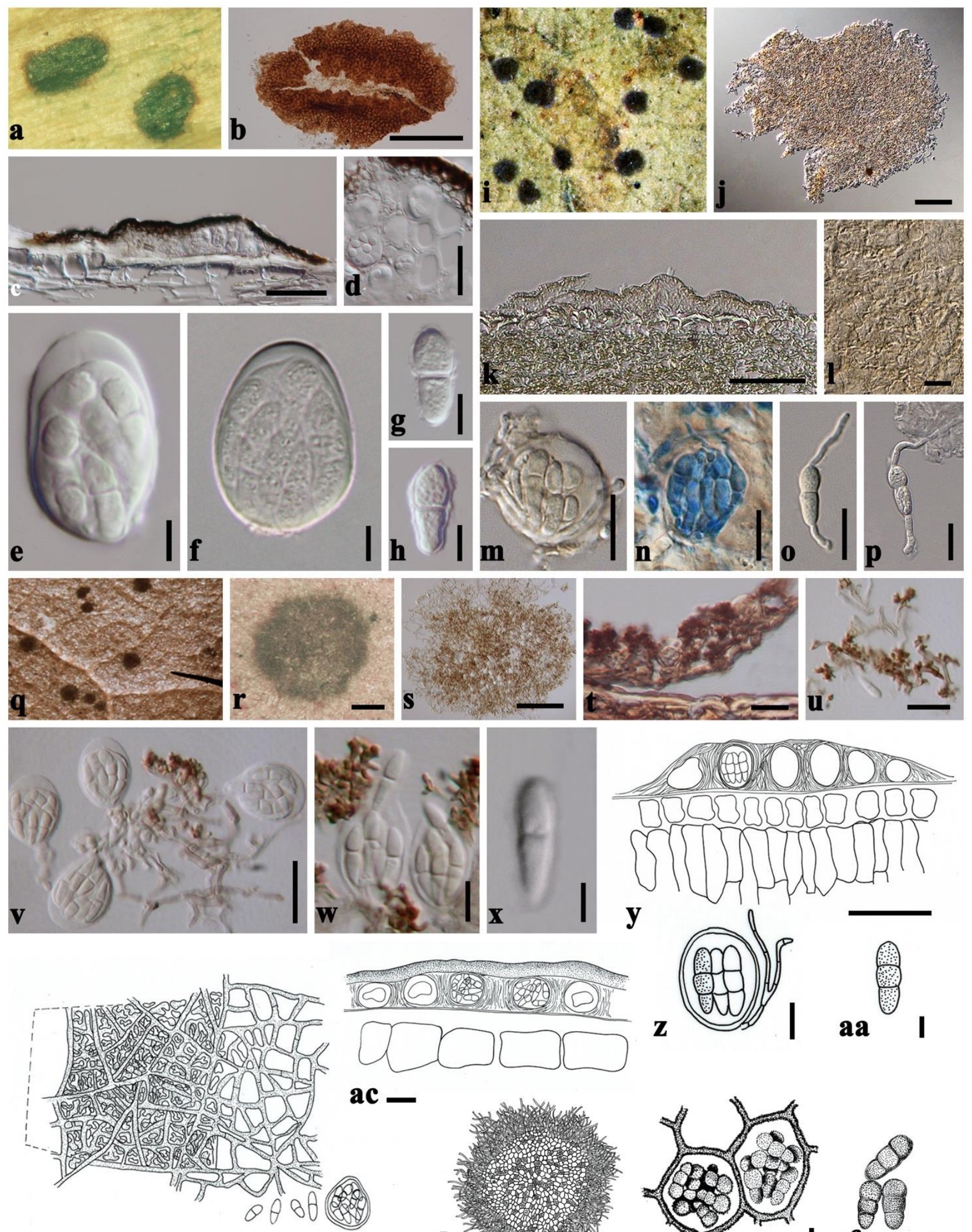

$\mathbf{a b}$
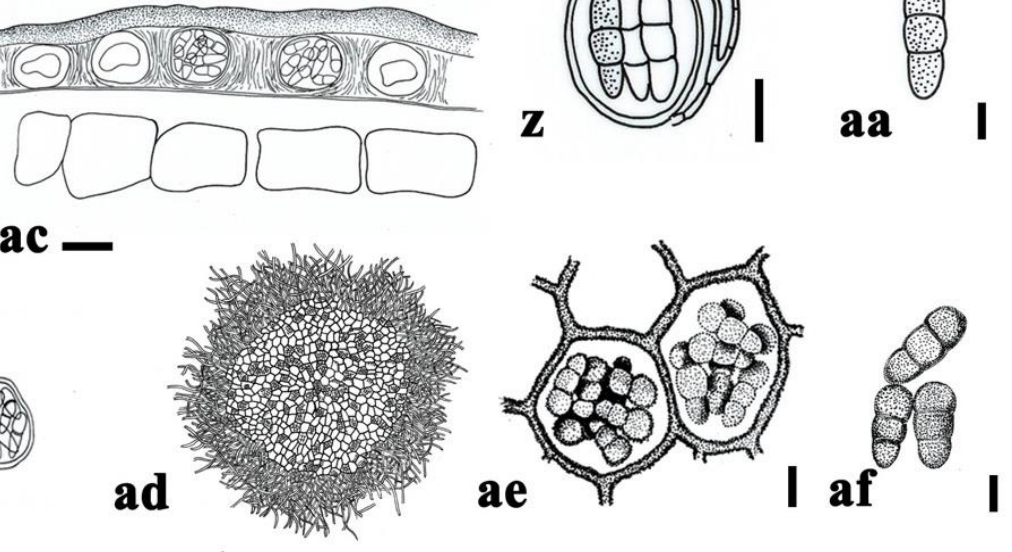

Figure 23 - Genera of Schizothyriaceae. a-h Schizothyrium acerinum (BR5020103861716, lectotype). i-p Lecideopsella paragelatinosa (BPI 667226, holotype). q-x Plochmopeltis intricata (W Krypto 1978-0015085, type). y-aa Amazonotheca santiriae (redrawn from Batista 1959, iconotype). ab, ac Mycerema vochysiacearum (redrawn from Batista et al. 1963, iconotype). ad-af Hexagonella peleae (redrawn from Stevens 1925, iconotype). a, i, q, r, ad Appearance of ascomata/ascostromata on the host surface. $b, j$, s Squash of ascoma/ascostroma visualized under 
the compound microscope. c, k, t, y, ac Section through ascoma/ascostroma. d Network-like structure in horizontal section. e, f, m, n, v, w Asci. g, h, o, p, x, aa, af Ascospores. 1 Peridium structure from above view, composed of light brown, membranous cells. $\mathrm{u}$ The confluent mycelium with botryose elements at the apex. z Ascus with pseudoparaphyses. ab Peridium structure from above view, composed of hyaline to subhyaline, reticular, pseudoparenchymatous cells. ae Asci forming in hexagonal cell meshes. Scale bars: $b, r, s, y=100 \mu \mathrm{m}, \mathrm{c}, \mathrm{k}=50 \mu \mathrm{m}, \mathrm{d}, \mathrm{l}, \mathrm{t}, \mathrm{v}, \mathrm{ab}, \mathrm{ac}=$ $20 \mu \mathrm{m}, \mathrm{e}, \mathrm{f}, \mathrm{u}, \mathrm{w}, \mathrm{z}=10 \mu \mathrm{m}, \mathrm{g}, \mathrm{h}, \mathrm{m}-\mathrm{p}, \mathrm{x}$, aa, ae, af $=5 \mu \mathrm{m}$.

Schizothyrium Desm., Annls Sci. Nat., Bot., sér. 3 11: 360 (1849).

Index Fungorum number: IF 4911; Facesoffungi number: FoF 01933; 42 morphological species (40 species as Schizothyrium, 2 species as Zygophiala; Species Fungorum 2020), >10 species with molecular data.

Type species - Schizothyrium acerinum Desm.

Notes - Eriksson (1981) re-circumscribed the genus based on Schizothyrium pomi and treated S. pomi as a synonym of $S$. acerinum. Eriksson (1981) described the genus as forming inconspicuous vegetative mycelium, with ascomata opening by several cracks. Hyde et al. (2013) examined a representative specimen collected by Desmazières (PC0084488 and BR5020103861716) and found that Schizothyrium did not form superficial or subcuticular vegetative mycelium. Phookamsak et al. (2016) re-examined the same specimen described in Hyde et al. (2013) [FRANCE, Paris, on dry twigs of Acer negundo L, Desmazières, BR5020103861716] and designated this specimen as the lectotype. Detailed description, illustration and generic discussion were also provided in Phookamsak et al. (2016). Boonmee et al. (2017) re-examined the type specimen of S. pomi (MNHN-PC- PC0723481, holotype of Labrella pomi) and mentioned that $S$. acerinum is not conspecific with $S$. pomi based on the difference of hamathecium type. However, they did not observe the asci and ascospores of $S$. pomi as the ascomata were immature.

Schizothyrium species can be epiphytes or pathogens occurring on leaves, stems, or other parts of various vascular plants in both temperate and tropical regions (Eriksson 1981, Phookamsak et al. 2016, Boonmee et al. 2017, Farr \& Rossman 2020). The asexual morph of Schizothyrium has been reported as the hyphomycetous genus Zygophiala. The link between Schizothyrium and Zygophiala was proven by Batzer et al. (2008), Ma et al. (2010) and Gao et al. (2014). Rossman et al. (2015) recommended the use of the older name Schizothyrium over Zygophiala.

\section{Other genera included}

Amazonotheca Bat. \& H. Maia, in Batista, Publicações Inst. Micol. Recife 56: 408 (1959).

Index Fungorum number: IF 155; Facesoffungi number: FoF 01943; 2 morphological species (Species Fungorum 2020), molecular data unavailable.

Type species - Amazonotheca santiriae Bat. \& H. Maia., in Batista, Publicações Inst. Micol. Recife 56: 408 (1959).

Notes - Amazonotheca was introduced to accommodate epiphytic species, characterized by dispersed, brown yellowish, membranous ascomata, translucent in structure, with hyaline, prosenchymatous cells of peridium, 4-8-spored, bitunicate, subglobose to ovoid asci and brown, subcylindrical, 2-septate ascospores (Batista 1959, Phookamsak et al. 2016). Phookamsak et al. (2016) re-described the genus based on the description of Batista (1959) and treated it in Dothideomycetes genera incertae sedis. However, Wijayawardene et al. (2018) tentatively reinstated the genus in Schizothyriaceae pending future studies. Amazonotheca is a poorly known genus with two species A. olivacea and A. santiriae collected from the leaves of Neea madeirana and Santiria nitida in Brazil, respectively. The genus lacks modern taxonomic description and molecular data to clarify its phylogenetic affinities. The generic type is located in the Universidade Federal de Pernambuco (URM), Brazil, but the type specimen could not be loaned. Recollection and molecular data of Amazonotheca are required to resolve its natural placement.

Hexagonella F. Stevens \& Guba ex F. Stevens, Bulletin of the Bernice P. Bishop Museum, Honolulu, Hawaii 19: 89 (1925). 
Index Fungorum number: IF 2334; Facesoffungi number: FoF 01935; 1 morphological species (Species Fungorum 2020), molecular data unavailable.

Type species - Hexagonella peleae F. Stevens \& Guba, in Stevens, Bulletin of the Bernice P. Bishop Museum, Honolulu, Hawaii 19: 89 (1925).

Notes - Hexagonella was introduced as a monotypic genus with $H$. peleae collected on leaves of Pelea rotundifolia from Hawaii. The genus was characterized by rounded, plane, cushion-like ascomata, with dense, woven mycelium, with the central disk surrounded by irregular periphery of sparsely interwoven, loosely, branched, spreading hyphae, hexagonal, mesh-like peridial structure, 8-spored asci, scattered in hexagonal cell-meshes, resting in a space between the sterile cells and brown, ellipsoidal to oblong, 2-septate ascospores (Stevens 1925, Phookamsak et al. 2016). The type specimens of Hexagonella are located in ILLS and BPI (only micro-slide of ascomata available in BPI). Phookamsak et al. (2016) examined the micro-slide from BPI and noted that the ascomata differed from the original description and iconotype described in Stevens (1925). Phookamsak et al. (2016) tentatively placed the genus in Schizothyriaceae based on the protologue described in Stevens (1925).

Kerniomyces Toro, J. Agric. Univ. Puerto Rico 22: 452 (1939).

Index Fungorum number: IF 2564; Facesoffungi number: FoF 07046; 1 morphological species (Species Fungorum 2020), molecular data unavailable.

Type species - Kerniomyces costi Toro, J. Agric. Univ. Puerto Rico 22: 453 (1939).

Notes - Kerniomyces was introduced as a monotypic genus. The species was collected from Costus macrostachys (Costaceae) in Venezuela. Kerniomyces is a poorly known genus that lacks modern taxonomic description and molecular data to clarify its phylogenetic affinities. The type material and protologue of $K$. costi could not be located. Petrak (1950) accommodated Kerniomyces in Myriangiales. Eriksson \& Hawksworth (1985) treated the genus in Schizothyriaceae and this was followed in subsequent studies (Eriksson \& Hawksworth 1987, Kirk et al. 2001, 2008, Lumbsch \& Huhndorf 2010, Hyde et al. 2013, Wijayawardene et al. 2014). However, Phookamsak et al. (2016) treated the genus as doubtful, whereas, Wijayawardene et al. (2018) placed the genus in Schizothyriaceae.

Lecideopsella Höhn., Sber. Akad. Wiss. Wien, Math.-naturw. Kl., Abt. 1 118: 1229 [73 repr.] (1909).

Index Fungorum number: IF 2697; Facesoffungi number: FoF 01936; 4 morphological species (Species Fungorum 2020), molecular data unavailable.

Type species - Lecideopsella gelatinosa Höhn., Sber. Akad. Wiss. Wien, Math.-naturw. K1., Abt. 1 118: 1230 (1909).

Notes - Lecideopsella was introduced to accommodate an epifoliar fungus occurring on Paratropia sp. in Indonesia and is characterized by flattened, dark grey, plane-scutate, membranous ascomata, a delicate, light brown, membranous peridium, 8-spored, bitunicate, globose to obovoid asci and hyaline, oblong, 1-septate ascospores (von Höhnel 1909b, Phookamsak et al. 2016). Von Arx \& Müller (1975) treated Lecideopsella as a synonym of Leptophyma and accommodated the genus in Schizothyriaceae. However, Leptophyma can be distinguished from Lecideopsella in forming loose paraphyses, a colorless epithelium, and being articulariella-like, while Lecideopsella has branched, reticular, cellular filaments inside plane-scutate ascomata (von Höhnel 1909b). Eriksson \& Hawksworth (1987) reinstated Lecideopsella and treated the genus in Schizothyriaceae and this was followed by subsequent authors (Eriksson \& Hawksworth 1987, Kirk et al. 2001, 2008, Lumbsch \& Huhndorf 2010, Hyde et al. 2013, Wijayawardene et al. 2014b). Phookamsak et al. (2016) re-examined the type specimen of Lecideopsella gelatinosa from The Harvard University Herbaria (FH, 00274523). However, the specimen is in poor condition that there is no ascomata of L. gelatinosa on the host. Nevertheless, Phookamsak et al. (2016) tentatively placed Lecideopsella in Schizothyriaceae based on the protologue of von Höhnel (1909b).

Lecideopsella has been found from various flowering plants, mostly in tropical regions, such as India, Indonesia and Uganda (Farr \& Rossman 2020). However, taxa in this genus lack 
molecular data to clarify their phylogenetic affinities and the type material of L. gelatinosa is in poor condition. Recollection, epitypification and molecular data of L. gelatinosa are needed to resolve the generic classification.

Metathyriella Syd., Annls mycol. 25(1/2): 96 (1927).

Index Fungorum number: IF 3146; Facesoffungi number: FoF 07047; 3 morphological species (Species Fungorum 2020), molecular data unavailable.

Type species - Metathyriella roupalae Syd., Annls mycol. 25(1/2): 96 (1927).

Notes - Metathyriella was introduced to accommodate an epiphytic fungus occurring on leaves of Roupala veraguensis (Proteaceae). The genus was originally described as thyriothecial, dimidiate-scutate, or orbicular ascomata, with irregular loose margin and indistinct basal membrane, the membrane covered by flattened, soft convex layer, irregularly lumpy at maturity, yellowish-brown to olive-brown, later more or less intense, periphery in a subhyaline membrane matrix, anastomosed paraphyses. Asci are 8-spored, bitunicate, ellipsoidal, or broadly ovoid to subglobose asci and ascospores are amalgamated, oblong-clavate, and 2-septate (Sydow 1927, Phookamsak et al. 2016). Sydow (1927) accommodated Metathyriella in Hemisphaeriaceae, however, von Arx \& Müller (1975) placed it in Schizothyriaceae. Metathyriella is a poorly known genus, there are only three species and there is no molecular data to clarify its phylogenetic affinities. The type specimen of $M$. roupalae could not be located. Hence, Phookamsak et al. (2016) treated Metathyriella as a doubtful genus. However, Wijayawardene et al. (2018) placed the genus in Schizothyriaceae until the genus is clarified based on molecular data.

Mycerema Bat., J.L. Bezerra \& Cavalc., in Batista et al., Publicações Inst. Micol. Recife 392: 5 (1963).

Index Fungorum number: IF 3301; Facesoffungi number: FoF 01939; 1 morphological species (Phookamsak et al. 2016), molecular data unavailable.

Type species - Mycerema vochysiacearum Bat., J.L. Bezerra \& Cavalc., in Batista et al., Publicações. Instituto de Micologia da Universidade do Recife \& Instituto Nacional de Pesquis 392: 7 (1963).

Notes - Mycerema was introduced to accommodate a single species. The type species was collected from leaves of Vochysiacea sp. in Brazil. The genus was characterized by brown, plane, orbicular, dimidiate, membranous ascomata, with irregular dehiscence, hyaline to subhyaline, reticular, pseudoparenchymatous cells of the peridium, 8-spored, bitunicate, oblong to globose asci and hyaline, claviform, 1-septate ascospores (Batista et al. 1963, Phookamsak et al. 2016). Hyde et al. (2013) examined the type specimen of $M$. vochysiacearum and synonymized the species as Vizella vochysiacearum. Batista et al. (1963) mentioned that M. vochysiacearum was associated with Vizella bingervilliana and Plenotrichaius hiloensis. Phookamsak et al. (2016) re-examined the same specimen as described in Hyde et al. (2013) and found only Vizella bingervilliana on the type specimen, whereas, Mycerema vochysiacearum could not be found. Phookamsak et al. (2016) mentioned that Hyde et al. (2013) might have misidentified Vizella bingervilliana as Mycerema vochysiacearum and thus, they transferred $M$. vochysiacearum to Vizella. Phookamsak et al. (2016) observed the protologue and iconotype of $M$. vochysiacearum and indicated that the protologue did not match with Vizella vochysiacearum as described in Hyde et al. (2013). Phookamsak et al. (2016) considered that the taxon on the host was Vizella bingervilliana (as V. vochysiacearum in Hyde et al. 2013) and reinstated Mycerema and its type species, M. vochysiacearum in Schizothyriaceae. Hyde et al. (2011) and Wijayawardene et al. (2012) reported the asexual morph of Mycerema as the coelomycetous genus Plenotrichaius.

Myriangiella Zimm., Centbl. Bakt. ParasitKde, Abt. I 8: 183 (1902).

Index Fungorum number: IF 3356; Facesoffungi number: FoF 07048; 4 morphological species (Species Fungorum 2020), molecular data unavailable.

Type species - Myriangiella orbicularis Zimm., Centbl. Bakt. ParasitKde, Abt. I 8: 183 (1902). 
Notes - Myriangiella is characterized by flattened, circular, disciform ascostromata, 8spored, bitunicate, ovoid asci, and phragmosporous, hyaline, oblong, septate ascospores (Saccardo 1906, Phookamsak et al. 2016). Von Höhnel (1909a) treated Myriangiella as a synonym of Micropeltis and later von Höhnel (1912) established a new genus Phragmothyriella Höhn. to accommodate $M$. orbicularis and Phragmothyriella moelleriana. Toro (1927) reinstated Myriangiella to accommodate $M$. orbicularis and synonymized $P$. moelleriana (under Myriangiella. Saccardo (1906) accommodated Myriangiella in Myriangiaceae, while Toro (1927) placed the genus in Hemisphaeriaceae. Von Arx \& Müller (1975) treated the genus in Schizothyriaceae. Myriangiella is a poorly documented genus lacking a modern taxonomic treatment. The type specimen and taxonomic literature for Myriangiella could not be located. Phookamsak et al. (2016) treated Myriangiella as a doubtful genus. However, Wijayawardene et al. (2018) tentatively reinstated the genus in Schizothyriaceae pending future studies.

Plochmopeltis Theiss., Brotéria, sér. bot. 12: 87 (1914).

Index Fungorum number: IF 4257; Facesoffungi number: FoF 01940; 5 morphological species (Species Fungorum 2020), molecular data unavailable.

Type species - Plochmopeltis intricata (Ellis \& G. Martin) Theiss., Brotéria, sér. bot. 12(1): 87 (1914).

$\equiv$ Asterina intricata Ellis \& G. Martin, Am. Nat. 18: 69 (1884).

Notes - Plochmopeltis was introduced to accommodate an epiphytic fungus, forming hypophyllous ascomata on leaves of Quercus arenaria in Florida, the USA which was previously identified as Asterina intricata. Plochmopeltis is characterized by brown to dark brown, superficial, dimidiate to scutate, or crustaceous ascomata, without peridial walls, covering by reddish brown hyphae, septate, roughly coarse, with brown to reddish brown mycelium clumps at the top, 8spored, bitunicate, fissitunicate, globose to subglobose, or clavate asci, embedded in subhyaline to light brown, hamathecial networks and hyaline, ellipsoidal to oblong or clavate, septate ascospores (Phookamsak et al. 2016). Theissen (1914) and Petrak (1929) described Plochmopeltis as forming small plectenchymatous peridial cells. However, von Arx (1959) and Phookamsak et al. (2016) recircumscribed the genus based on the type specimen of Asterina intricata and indicated that Plochmopeltis did not form a peridium, but had confluent mycelium with clumps at the apex, covering the asci. Plochmopeltis occurs on various hosts in tropical to subtropical regions, such as Brazil, Cuba, Ecuador, Florida (USA), and the West Indies (von Arx 1959, Müller \& von Arx 1962, Farr \& Rossman 2020). Plochmopeltis differs from other genera in Schizothyriaceae due to the lack of peridial structure and forming confluent mycelium with brown hyphae clumps at the apex covering the asci. Phookamsak et al. (2016) and Wijayawardene et al. (2018) tentatively placed the genus in Schizothyriaceae pending future studies.

Vonarxella Bat., J.L. Bezerra \& Peres, Riv. Patol. veg., Pavia, sér. 4 1(1-2): 61 (1965).

Index Fungorum number: IF 5753; Facesoffungi number: FoF 04673; 1 morphological species (Species Fungorum 2020), molecular data unavailable.

Type species - Vonarxella dipterygis Bat., J.L. Bezerra \& Peres [as 'diptericis'], Riv. Patol. veg., Pavia, sér. 4 1(1-2): 62 (1965).

Notes - The type species was collected from leaves of Dipteryx alata in Brazil and is characterized by flattened, circular, multi-loculate, hemisphaerical ascostromata, with meandering cells, arranged and branching from the central to the outer rim, dark brown to black pseudoparenchymatous cells of peridium, 8-spored or more, bitunicate, fissitunicate, cylindricclavate to clavate asci, with septate, hypha-like pseudoparaphyses and hyaline, obovoid to ellipsoidal, 1-septate ascospores (Doilom et al. 2018). Vonarxella resembles Schizothyrium based on its ascostromata being flattened, and multi-loculate, a peridium comprising irregular meandering arrangement of dark brown, compact cells, poorly-developed at the base, and ascospores are hyaline, 1-septate, slightly constricted at the septum, and wider in upper cell (Doilom et al. 2018). Batista et al. (1965) accommodated the genus in Schizothyriaceae, while von Arx \& Müller (1975) 
treated the genus in Saccardiaceae Höhnel. Doilom et al. (2018) re-examined the type specimen of $V$. dipterygis and reinstated the genus in Schizothyriaceae.

\section{Ecological and economic significance}

Schizothyriaceae is cosmopolitan in distribution. Genera of Schizothyriaceae have been reported on various hosts from both temperate and tropical regions (Farr \& Rossman 2020). Species in Schizothyriaceae are mostly found as epiphytes on dicotyledons (e.g. Acer, Quercus and Prunus). The asexual morph of Schizothyrium has been reported as hyphomycetous (as Zygophiala) causing fly speck on apple and pear fruits (Batzer et al. 2005, 2008, Kirk et al. 2008, Ma et al. 2010). Although, the fungus may not directly affect the growth or development of apple and pear fruits, such fruits with fly speck may be unacceptable to consumers and the crop value can be reduced by more than $90 \%$ (Williamson \& Sutton 2000, Batzer et al. 2002, 2005, 2016).

Teratosphaeriaceae Crous \& U. Braun, Stud. Mycol. 58: 8 (2007).

Index Fungorum number: IF 504465; Facesoffungi number: FoF 06989, ca. 386 species.

Sexual morph: Ascomata superficial to immersed, with in a stroma of brown pseudoparenchymatal cells, globose, unilocular, papillate, ostiolate, canal periphysate, with periphysoids frequently present. Perdium comprises several layers of brown cells of textura angularis, inner layer of flattened, hyaline cells. Pseudoparaphyses frequently present, subcylindrical, branched, septate, anastomosing. Asci 8-spored, bitunicate, fasciculate, frequently with multi-layered endotunica. Ascospores ellipsoid or fusoid to obovoid, septate, hyaline, but becoming pale brown and verruculose, frequently covered in mucoid sheath. Asexual morph: Coelomycetous or hyphomycetous. Conidiomata acervular or pycnidial in coelomycetes, none or sporodochial in hyphomycetes. Conidiomata wall composed of brown globose to angular cells. Conidiophores reduced to conidiogenous cells, mono- or polyblastic, brown, branched or unbranched. Conidiogenous cells arthric or holoblastic or percurrent proliferation or annellidic, brown. Conidia branched or unbranched chains or solitary, oval, avicular to clavate, or ellipsoid in shape, sometimes with marginal frill, 0-1-septate, brown, verruculose to smooth-walled.

Type - Teratosphaeria Syd. \& P. Syd.

Notes - Teratosphaeriaceae was introduced by Crous et al. (2007a) to accommodate Teratosphaeria (with readeriella-like asexual morphs) and 11 asexual genera. Subsequent studies by Crous et al. (2009d, e, 2011c, d), Crous \& Groenewald (2011), Quaedvlieg et al. (2014) and Videira et al. (2016) added several genera into the family. Among the families in Dothideomycetes, Teratosphaeriaceae is one of the largest comprising approximately 60 genera (Wijayawardene et al. 2020). Members of the family are reported with only sexual morphs or as coelomycetous or hyphomycetous morphs (i.e. pleomorphism) (Wijayawardene et al. 2017a). Teratosphaeria has both coelomycetous (Kirramyces and Colletogloeopsis asexual morphs), and hyphomycetous (Batcheloromyces-like) asexual morphs (Crous et al. 2009a, b). The members of Teratosphaeriaceae have a broad range of life modes including saprobes, plant and human pathogens, rock-inhabiting, and endophytes (Crous et al. 2009d, e, 2011c, d, Egidi et al. 2014, Quaedvlieg et al. 2014). Hence, some of the taxa have been recognized as 'extremophilic' (e.g. Constantinomyces fide Egidi et al. 2014).

Bryochiton has been treated as a member in Pseudoperisporiaceae by Hyde et al. (2017) and Wijayawardene et al. (2018). However, in our phylogenetic analyses (Fig. 24), Bryochiton monascus, the type species of Bryochiton groups in Teratosphaeriaceae. Two strains of $B$. perpusillus (CBS 126798 and M202) also reside in Teratosphaeriaceae but are distinct from $B$. monascus. Thus, we conclude that Bryochiton is paraphyletic in Teratosphaeriaceae. In Wijayawardene et al. (2018), Ramopenidiella has been accepted as in Teratosphaeriaceae. However, in our analyses (Fig. 24), Ramopenidiella clusters outside. Teratosphaeriaceae and as the sister clade to Extremaceae. Hence, we regard Ramopenidiella as Capnodiales genera incertae sedis. Fodinomyces and Phacellium have been mistakenly listed as members of Teratosphaeriaceae in Wijayawardene et al. (2018). Kolařík et al. (2015) regarded Fodinomyces as a synonym of Acidiella while Phacellium was regarded as a synonym of Ramularia by Videira et al. (2017). 
Teratosphaeria Syd. \& P. Syd., Annls mycol. 10(1): 39 (1912).

Index Fungorum number: IF 5377; Facesoffungi number: FoF 01713; 36 morphological species (Species Fungorum 2019), several species with molecular data.

Type species - Teratosphaeria fibrillosa Syd. \& P. Syd.

Notes - In morphology, Teratosphaeria resembles Mycosphaerella (current name Ramularia), but Müller \& Oehrens (1982) separated them based on their ascomatal arrangement and periphysate ostioles. Kirk et al. (2001) placed Teratosphaeria in Pleosporaceae. Pleosporaceae and Teratosphaeria have been regarded as members in Clypeosphaeriaceae, Montagnellaceae, Stigmateaceae (Syn. Venturiaceae) and Phaeosphaeriaceae (Müller \& Oehrens 1982, Taylor et al. 2003). Taylor et al. (2003) showed that the type species of Teratosphaeria resided in Mycosphaerella sensu stricto, thus regarded the former as a synonym of the latter. However, Crous et al. (2007a) showed that Teratosphaeria has a distinct phylogenetic lineage in Capnodiales which also clearly separated it from Mycosphaerellaceae. Crous et al. (2007a) compared the morphological characters between the type species and the other species which group in Teratosphaeria sensu stricto. The epitype of Teratosphaeria fibrillosa was designated by Crous et al. (2007a). Crous et al. (2009d, e) showed that Teratosphaeria has Kirramyces and Colletogloeopsis as its asexual morphs. Thus, Kirramyces and Colletogloeopsis have been regarded as synonym of Teratosphaeria (Crous et al. 2009d, e; Art. 59.1).

Teratosphaeria fibrillosa Syd. \& P. Syd., Annls mycol. 10(1): 40 (1912).

Fig. 25

Index Fungorum number: IF 245140; Facesoffungi number: FoF 06990

Description - see Hyde et al. (2013).

Material examined - South Africa, near Wellington, Bains Kloof, on living leaves of Protea grandiflora, 21 February 1912, E.M. Doidge (BPI 619596, authentic specimen).

\section{Other genera included}

Araucasphaeria Crous \& M.J. Wingf., Persoonia 40: 335 (2018).

Index Fungorum number: IF 825397; Facesoffungi number: FoF 06991; 1 morphological species (Species Fungorum 2020), 1 species with molecular data.

Type species - Araucasphaeria foliorum Crous \& M.J. Wingf., Persoonia 40: 335 (2018).

Notes - Crous et al. (2018c) introduced this genus since it is morphologically and phylogenetically distinct from Mycosphaerella araucariae (which has larger ascomata, asci and ascospores) and Pseudoteratosphaeria ('ascomata aggregated in a stroma, ostioles that are lined with hyaline, branched, septate periphysoids, and ascospores encased in a prominent mucoid sheath' fide Quaedvlieg et al. 2014). The genus is represented by only the sexual morph. See description and illustration in Crous et al. (2018c).

Acidiella Hujslová \& M. Kolařík, Fungal Diversity 58: 39 (2013).

Index Fungorum number: IF 564518; Facesoffungi number: FoF 06992; 3 morphological species (Species Fungorum 2020), 3 species with molecular data.

Type species - Acidiella bohemica Hujslová \& M. Kolařík, Fungal Diversity 58: 39 (2013).

Notes - Hujslová et al. (2013) and Quaedvlieg et al. (2014) showed that Acidiella bohemica was accommodated as a distinct clade in Teratosphaeriaceae. See description and illustration in Hujslová et al. (2013), Quaedvlieg et al. (2014), and Crous et al. (2017b).

Acidomyces B.J. Baker, M.A. Lutz, S.C. Dawson, P.L. Bond \& Banfield ex Selbmann, de Hoog \& De Leo, Stud. Mycol. 61: 16 (2008).

Index Fungorum number: IF 511298; Facesoffungi number: FoF 06993; 2 morphological species (Species Fungorum 2019), 2 species with molecular data. 


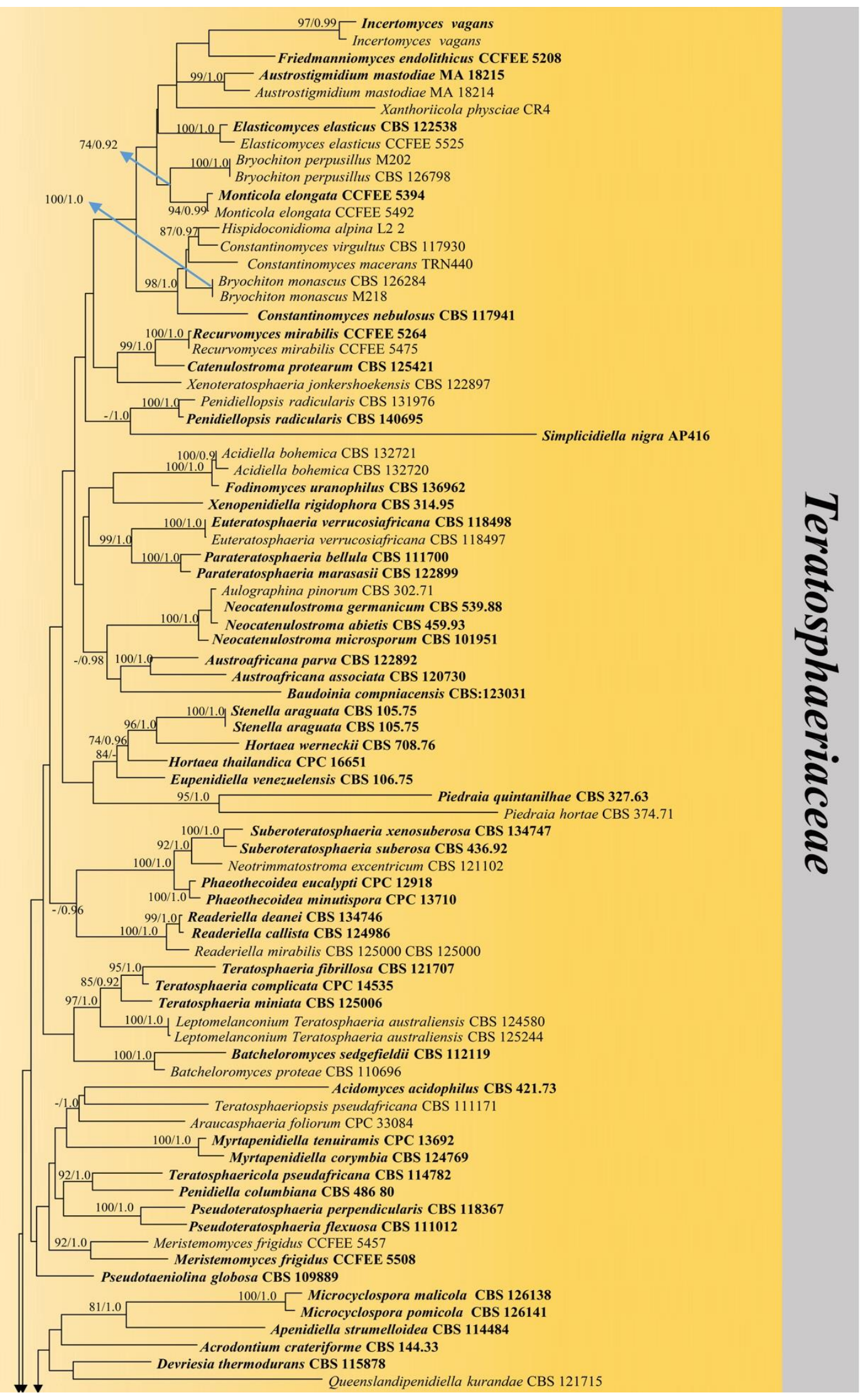

Figure 24 - Phylogram generated from maximum likelihood analysis (RAxML) of Teratosphaeriaceae based on ITS, LSU and rpb-2 sequence data. Maximum likelihood bootstrap values equal or above $70 \%$, Bayesian posterior probabilities equal or above 0.90 (MLBS/PP) are given at the nodes. An original isolate number is noted after the species name. The tree is rooted to Capnodium coartatum (MFLUCC 10-0069) and C. coffeae (CBS 147.52). The ex-type strains are indicated in bold. Hyphen (-) represents support values below $70 \%$ MLBS and 0.90 PP. 


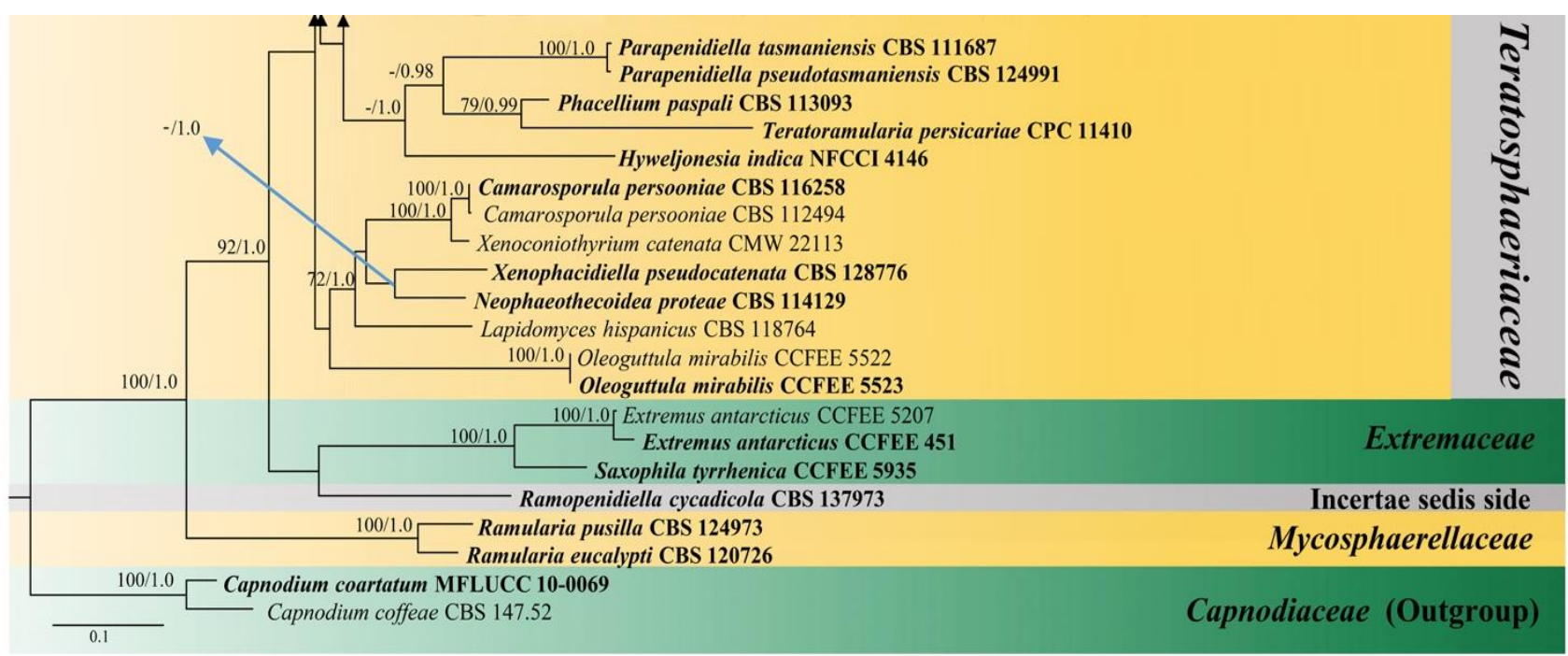

Figure 24 - Continued.

Type species - Acidomyces acidophilus (Sigler \& J.W. Carmich.) Selbmann, de Hoog \& De Leo, Stud. Mycol. 61: 17 (2008).

EScytalidium acidophilum Sigler \& J.W. Carmich., Can. J. Microbiol. 20(2): 267 (1974).

Notes - Baker et al. (2004) introduced Acidomyces but the name was invalid (Art. 35.1; Index Fungorum 2020). Hence, Selbmann et al. (2008) validated the genus. Hujslová et al. (2013) accepted the genus as in Teratosphaeriaceae but Quaedvlieg et al. (2014) did not include the genus in their phylogenetic analyses. See description and illustration in Selbmann et al. (2008), Hujslová et al. (2013).

Acrodontium de Hoog, Stud. Mycol. 1: 23 (1972).

Index Fungorum number: IF 7035; Facesoffungi number: FoF 06994; 17 morphological species (Species Fungorum 2020), 12 species with molecular data.

Type species - Acrodontium crateriforme (J.F.H. Beyma) de Hoog, Stud. Mycol. 1: 26 (1972).

三Chloridium crateriforme J.F.H. Beyma, Centbl. Bakt. ParasitKde, Abt. II 89: 241 (1933).

Notes - Koukol (2010) and Vu et al. (2019) accepted the genus in Teratosphaeriaceae. See description and illustration in Koukol (2010), Prabhugaonkar \& Pratibha (2017) and Vu et al. (2019).

Apenidiella Quaedvl. \& Crous, Persoonia 33: 28 (2014).

Index Fungorum number: IF 807816; Facesoffungi number: FoF 06995; 3 morphological species (Species Fungorum 2020), 3 species with molecular data.

Type species - Apenidiella strumelloidea (Milko \& Dunaev) Quaedvl. \& Crous, Persoonia 33: 28 (2014).

三Cladosporium strumelloideum Milko \& Dunaev, Nov. sist. Niz. Rast. 23: 134 (1986).

Notes - Quaedvlieg et al. (2014) introduced this saprobic, hyphomycetous genus and showed it belongs in Teratosphaeriaceae. Apenidiella is distinct from Penidiella as it has 'conidiophores with a solitary conidiogenous cell that gives rise to a single set of ramoconidia' (Quaedvlieg et al. 2014). See description and illustration in Crous et al. (2007a) and Quaedvlieg et al. (2014).

Aulographina Arx \& E. Müll., Sydowia 14(1-6): 330 (1960).

Index Fungorum number: IF 460; Facesoffungi number: FoF 07645; 2 morphological species (Species Fungorum 2020), 2 species with molecular data.

Type species - Aulographina pinorum (Desm.) Arx \& E. Müll., Sydowia 14(1-6): 332 (1960). 

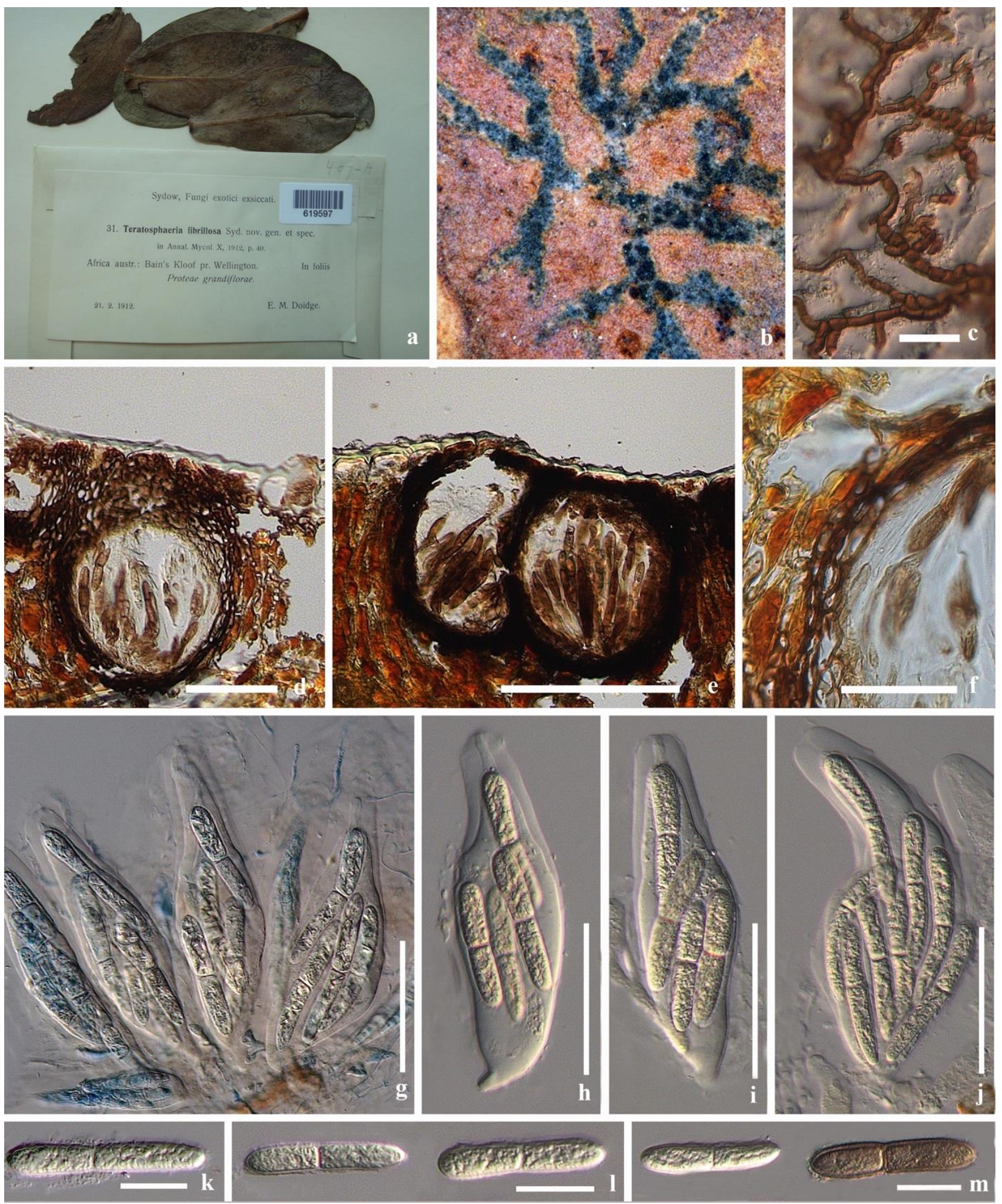

Figure 25 - Teratosphaeria fibrillose (BPI 619596). a Herbarium specimen. b Ascomata arranged under a brown flattened structure. c Septate hyphae. d-e Vertical section through ascoma. f Peridium. g-j Asci. k-m Ascospores. Scale bars: $\mathrm{e}=200 \mu \mathrm{m}, \mathrm{d}=100 \mu \mathrm{m}, \mathrm{f}-\mathrm{j}=50 \mu \mathrm{m}, \mathrm{c}, \mathrm{k}-\mathrm{m}=20$ $\mu \mathrm{m}$.

Notes - Phylogenetically, Aulographina eucalypti (CPC 12986) clusters within the family, and its sequence data was obtained by Cheewangkoon et al. (2012) without morphological diagnosis. Cheewangkoon et al. (2012) doubted the sequence data of the type A. pinorum (CBS $174.90,302.71)$ is correct, as the strain produced an asexual fungus Catenulostroma abietis in culture and the two species are phylogenetically distinct. However, we retain Aulographina until 
more evidence is available. See description and illustration in Cheewangkoon et al. (2012) and Hongsanan et al. (2014b).

Austroafricana Quaedvl. \& Crous, Persoonia 33: 25 (2014).

Index Fungorum number: IF 807793; Facesoffungi number: FoF 06996; 3 morphological species (Species Fungorum 2020), 3 species with molecular data.

Type species - Austroafricana associata (Crous \& Carnegie) Quaedvl. \& Crous, Persoonia 33: 25 (2014). (2007).

三 Mycosphaerella associata Crous \& Carnegie, in Crous et al., Fungal Diversity 26(1): 159

Notes - Austroafricana resembles Teratosphaeria, but is phylogenetically distinct (Quaedvlieg et al. 2014). See description and illustration in Crous et al. (2007d) and Quaedvlieg et al. (2014).

Austrostigmidium Pérez-Ort. \& Garrido-Ben., Lichenologist 47(3): 146 (2015).

Index Fungorum number: IF 811127; Facesoffungi number: FoF 06997; 1 morphological species (Species Fungorum 2020), 1 species with molecular data.

Type species - Austrostigmidium mastodiae Pérez-Ort. \& Garrido-Ben., Lichenologist 47(3): 146 (2015).

Notes - Pérez-Ortega et al. (2015) introduced this lichenicolous genus. The genus was reported with a coelomycetous asexual morph and phylogenetic analyses showed it belongs in Teratosphaeriaceae (Pérez-Ortega et al. 2015). See description and illustration in Pérez-Ortega et al. (2015).

Batcheloromyces Marasas, P.S. van Wyk \& Knox-Dav., Jl S. Afr. Bot. 41(1): 41 (1975).

Index Fungorum number: IF 7344; Facesoffungi number: FoF 06998; 5 morphological species (Species Fungorum 2020), 4 species with molecular data.

Type species - Batcheloromyces proteae Marasas, P.S. van Wyk \& Knox-Dav., J1 S. Afr. Bot. 41(1): 43 (1975).

Notes - Publications by Sutton \& Pascoe (1989), Taylor et al. (1999), Van Wyk et al. (1985) and Crous et al. (2008) re-visited the genus. Crous et al. (2008) and Quaedvlieg et al. (2014) showed that Batcheloromyces belongs in Teratosphaeriaceae. See description and illustration in Crous et al. (2007a, 2008) and Quaedvlieg et al. (2014).

Baudoinia J.A. Scott \& Unter., in Scott, Mycologia 99(4): 594 (2007).

Index Fungorum number: IF 510726; Facesoffungi number: FoF 06999; 5 morphological species (Species Fungorum 2019), 5 species with molecular data.

Type species - Baudoinia compniacensis (Richon) J.A. Scott \& Unter., Mycologia 99(4): 595 (2007).

$\equiv$ Torula compniacensis Richon, Revue mycol., Toulouse 3(no. 11): 17 (1881).

Notes - Scott et al. (2007) introduced this extremophilic saprotroph genus to accommodate Torula compniacensis. Scott et al. (2016) introduced four more species and phylogenetic analyses confirmed their placement in Teratosphaeriaceae. See description and illustration in Scott et al. (2007).

Bryochiton Döbbeler \& Poelt, in Döbbeler, Mitt. bot. StSamml., Münch. 14: 208 (1978).

Index Fungorum number: IF 660; Facesoffungi number: FoF 7000; 5 morphological species (Species Fungorum 2020), 2 species with molecular data. (1978).

Type species - Bryochiton monascus Döbbeler \& Poelt, Mitt. bot. StSamml., Münch. 14: 218

Notes - Bryochiton was placed in Pseudoperisporiaceae by Hyde et al. (2017) and Wijayawardene et al. (2018). However, two species of Bryochiton formed two separate clades 
within Teratosphaeriaceae. Thus, we conclude that Bryochiton is paraphyletic. See description and illustration in Döbbeler (2007), Hyde et al. (2017), and Wijayawardene et al. (2018)

Caatingomyces T.G.L. Oliveira et al., in Hyde et al. Fungal Divers 96: 10 (2019).

Index Fungorum number: IF 827888; Facesoffungi number: FoF 05818; 1 morphological species (Species Fungorum 2020), 1 species with molecular data.

Types - Caatingomyces brasiliensis T.G.L. Oliveira et al., in Hyde et al. Fungal Divers 96: 10 (2019).

Notes - Phylogenetic analyses of Hyde et al. (2019) showed that Caatingomyces belongs in Teratosphaeriaceae as a distinct genus. See description and illustration in Hyde et al. (2019).

Camarosporula Petr., Sydowia 8(1-6): 99 (1954) (= Anthracostroma Petr., Sydowia 8(1-6): 96 (1954).

Index Fungorum number: IF 7477; Facesoffungi number: FoF 07001; 1 morphological species (Species Fungorum 2019), 1 species with molecular data.

Type species - Camarosporula persooniae (Henn.) Petr., Sydowia 8(1-6): 99 (1954).

三 Hendersonia persooniae Henn., Hedwigia 40(4): 97 (1901).

Notes - Petrak (1954) introduced Camarosporula as the conidial morph of Anthracostroma. Wijayawardene et al. (2014b) adopted Anthracostroma over Camarosporula but Rossman et al. (2015) did not agree. Crous et al. (2011d) confirmed that the genus resides in Teratosphaeriaceae. See description and illustration in Swart (1985) and Crous et al. (2011d).

Capnobotryella Sugiy., Pleomorphic Fungi: The Diversity and its Taxonomic Implications (Tokyo): 148 (1987).

Index Fungorum number: IF 11006; Facesoffungi number: FoF 07002; 6 morphological species (Species Fungorum 2020), 1 species with molecular data.

Type species - Capnobotryella renispora Sugiy., Pleomorphic Fungi: The Diversity and its Taxonomic Implications (Tokyo): 148 (1987).

Notes - Vu et al. (2019) confirmed the placement of Capnobotryella in Teratosphaeriaceae. See description and illustration in Titze \& De Hoog (1990) and Vu et al. (2019).

Catenulostroma Crous \& U. Braun, in Crous, Braun \& Groenewald, Stud. Mycol. 58: 13 (2007)

Index Fungorum number: IF 504474; Facesoffungi number: FoF 07003; 7 morphological species (Species Fungorum 2020), 7 species with molecular data.

Type species - Catenulostroma protearum (Crous \& M.E. Palm) Crous \& U. Braun, in Crous, Braun \& Groenewald, Stud. Mycol. 58: 17 (2007).

三Trimmatostroma protearum Crous \& M.E. Palm, Mycol. Res. 103(10): 1303 (1999).

Notes - Crous et al. (2007a) introduced this hyphomycetous genus with a Teratosphaeria sexual morph. Crous et al. (2009e) and Quaedvlieg et al. (2014) transferred several species to Teratosphaeria and Neocatenulostroma respectively. See description and illustration in Crous et al. (2007a, 2009c) and Quaedvlieg et al. (2014).

Constantinomyces Egidi \& Onofri, in Crous et al., Fungal Systematics and Evolution 3: 126 (2019) Index Fungorum number: IF 829388; Facesoffungi number: FoF 07004; 4 morphological species (Species Fungorum 2020), 4 species with molecular data.

Type species - Constantinomyces virgultus Egidi \& Onofri, in Crous et al., Fungal Systematics and Evolution 3: 127 (2019).

Notes - Egidi et al. (2014) introduced this rock-inhabiting genus and confirmed its placement in Capnodiales. Quaedvlieg et al. (2014) showed that it belongs in Teratosphaeriaceae. See description and illustration in Egidi et al. (2014) and Quaedvlieg et al. (2014).

Davisoniella H.J. Swart, Trans. Br. mycol. Soc. 90(2): 289 (1988). 
Index Fungorum number: IF 11065; Facesoffungi number: FoF 07005; 1 morphological species (Species Fungorum 2020), molecular data unavailable.

Type species - Davisoniella eucalypti H.J. Swart, Trans. Br. mycol. Soc. 90(2): 289 (1988).

Notes - The genus has been reported with Teratosphaeria-like sexual morphs. See description and illustration in Crous et al. (2006).

Devriesia Seifert \& N.L. Nick., Can. J. Bot. 82(7): 919 (2004).

Index Fungorum number: IF 28865; Facesoffungi number: FoF 07006; 7 morphological species (Species Fungorum 2020), 9 species with molecular data.

Type species - Devriesia staurophora (W.B. Kendr.) Seifert \& N.L. Nick., Can. J. Bot. 82(7): 919 (2004).

三 Hormodendrum staurophorum W.B. Kendr., Can. J. Bot. 39: 835 (1961).

Notes - Egidi et al. (2014) and Crous et al. (2015b) transferred several species to other genera as they were not congeneric with the type species. See description and illustration in Seifert et al. (2004), Egidi et al. (2014), and Crous et al. (2015b).

Elasticomyces Zucconi \& Selbmann, Stud. Mycol. 61: 11 (2008).

Index Fungorum number: IF 511296; Facesoffungi number: FoF 07007; 1 morphological species (Species Fungorum 2020), 1 species with molecular data.

Type species - Elasticomyces elasticus Zucconi \& Selbmann, Stud. Mycol. 61: 11 (2008).

Notes - Selbmann et al. (2008) introduced this hyphomycetous genus which occurs on the thallus of Usnea antarctica. Quaedvlieg et al. (2014) showed that Elasticomyces elasticus can be accommodated in Teratosphaeriaceae. See description and illustration in Selbmann et al. (2008) and Quaedvlieg et al. (2014).

Eupenidiella Quaedvl. \& Crous, Persoonia 33: 25 (2014).

Index Fungorum number: IF 807797; Facesoffungi number: FoF 07008; 1 morphological species (Species Fungorum 2020), 1 species with molecular data.

Type species - Eupenidiella venezuelensis (Crous \& U. Braun) Quaedvl. \& Crous, Persoonia 33: 25 (2014).

EPenidiella venezuelensis Crous \& U. Braun, in Crous, Braun \& Groenewald, Stud. Mycol. 58: 24 (2007).

Notes - Quaedvlieg et al. (2014) introduced this genus to accommodate Penidiella venezuelensis, an opportunistic human pathogen which was not congeneric with Penidiella sensu stricto. See description and illustration in Crous et al. (2007a) and Quaedvlieg et al. (2014).

Euteratosphaeria Quaedvl. \& Crous, Persoonia 33: 25 (2014).

Index Fungorum number: IF 807799; Facesoffungi number: FoF 07009; 1 morphological species (Species Fungorum 2020), 1 species with molecular data.

Type species - Euteratosphaeria verrucosiafricana (Crous \& M.J. Wingf.) Quaedvl. \& Crous, Persoonia 33: 25 (2014).

三 Mycosphaerella verrucosiafricana Crous \& M.J. Wingf., in Crous et al., Stud. Mycol. 55: 125 (2006).

Notes - Euteratosphaeria verrucosiafricana resembles Teratosphaeria but is phylogenetically distinct (Quaedvlieg et al. 2014). See description and illustration in Crous et al. (2006) and Quaedvlieg et al. (2014).

Friedmanniomyces Onofri, in Onofri et al., Nova Hedwigia 68(1-2): 176 (1999).

Index Fungorum number: IF 28325; Facesoffungi number: FoF 07010; 2 morphological species (Species Fungorum 2020), 2 species with molecular data.

Type species - Friedmanniomyces endolithicus Onofri, in Onofri et al., Nova Hedwigia 68(12): 177 (1999). 
Notes - This hyphomycetous genus comprises two species which have been reported from Antarctica (Onofri et al. 1999, Selbmann et al. 2005). See description and illustration in Onofri et al. (1999) and Selbmann et al. (2005).

Hispidoconidioma Tsuneda \& M.L. Davey, Botany 88(5): 473 (2010).

Index Fungorum number: IF 518303; Facesoffungi number: FoF 07011; 1 morphological species (Species Fungorum 2020), 1 species with molecular data.

Type species - Hispidoconidioma alpinum Tsuneda \& M.L. Davey [as 'alpina'], Botany 88(5): 473 (2010).

Notes - Seifert et al. (2011) treated this genus in Teratosphaeriaceae. See description and illustration in Tsuneda et al. (2010) and Seifert et al. (2011).

Hortaea Nishim. \& Miyaji, Jap. J. med. Mycol. 26(2): 145 (1984).

Index Fungorum number: IF 11101; Facesoffungi number: FoF 07012; 2 morphological species (Species Fungorum 2020), 2 species with molecular data.

Type species - Hortaea werneckii (Horta) Nishim. \& Miyaji, Jap. J. Med. Mycol. 26(2): 145 (1984).

三 Cladosporium werneckii Horta, Rev. med.-cirurg. Brasil 29: 274 (1921).

Notes - Quaedvlieg et al. (2014) showed that Hortaea thailandica belongs in Teratosphaeriaceae. See description and illustration in Bonifaz et al. (2008), Crous et al. (2009c), and Quaedvlieg et al. (2014).

Hyweljonesia R.G. Shivas, Y.P. Tan, Marney \& Abell, in Crous et al., Persoonia 37: 269 (2016).

Index Fungorum number: IF 817134; Facesoffungi number: FoF 07013; 2 morphological species (Species Fungorum 2020), 2 species with molecular data.

Type species - Hyweljonesia queenslandica R.G. Shivas, Y.P. Tan, Marney \& Abell, in Crous et al., Persoonia 37: 269 (2016).

Notes - Crous et al. (2016a) introduced this hyphomycetous genus and confirmed its placement in Teratosphaeriaceae. See description and illustration in Crous et al. (2016a).

Incertomyces Egidi \& Zucconi 2019, in Crous et al. Fungal Systematics and Evolution 3: 127 (2019).

Index Fungorum number: IF 829400; Facesoffungi number: FoF 07014; 1 morphological species (Species Fungorum 2020), 1 species with molecular data. (two names are invalid fide Index Fungorum 2020).

Type species - Incertomyces perditus Egidi \& Zucconi, in Crous et al. Fungal Systematics and Evolution 3: 127 (2019).

Notes - Crous et al. (2019b) validated the invalid name Incertomyces. See description and illustration in Egidi et al. (2014).

Lapidomyces de Hoog \& Stielow, in Crous et al., Fungal Systematics and Evolution 3: 128 (2019).

Index Fungorum number: IF 829405; Facesoffungi number: FoF 07015; 1 morphological species (Species Fungorum 2020), 1 species with molecular data.

Type species - Lapidomyces hispanicus de Hoog \& Stielow, in Crous et al, Fungal Systematics and Evolution 3: 128 (2019).

Notes - Egidi et al. (2014) introduced this rock-inhabiting hyphomycetous genus in Teratosphaeriaceae. Quaedvlieg et al. (2014) agreed with the familial placement. However, Lapidomyces was invalid (Index Fungorum 2020), thus Crous et al. (2019b) validated the genus. See description and illustration in Egidi et al. (2014), Quaedvlieg et al. (2014), Crous et al. (2019b).

Leptomelanconium Petr., Annls mycol. 21(3/4): 179 (1923).

Index Fungorum number: IF 8750; Facesoffungi number: FoF 07016; 7 morphological species (Species Fungorum 2020), 1 species with molecular data. 
Type species - Leptomelanconium asperulum (Moesz) Petr., in Sydow, Annls mycol. 21(3/4): 179 (1923).

三 Melanconium asperulum Moesz, Bot. Közl. 14(5-6): 157 (1915).

Notes - Crous et al. (2009e) transferred Leptomelanconium australiense to Teratosphaeria based on DNA sequence analyses. Wijayawardene et al. (2017a, 2018) tentatively placed the genus in Teratosphaeriaceae. See description and illustration in Wijayawardene et al. (2016a).

Meristemomyces Isola \& Onofri, in Crous et al., Fungal Systematics and Evolution 3: 128 (2019).

Index Fungorum number: IF 829411; Facesoffungi number: FoF 07017; 2 morphological species (Species Fungorum 2020), 2 species with molecular data.

Type species - Meristemomyces frigidus Isola \& Onofri, in Crous et al., Fungal Systematics and Evolution 3: 129 (2019).

Notes - Meristemomyces was invalid (Index Fungorum 2020) thus Crous et al. (2019b) validated it. See description and illustration in Egidi et al. (2014) and Crous et al. (2019b).

Microcyclospora J. Frank, Schroers \& Crous Persoonia 24: 99 (2010).

Index Fungorum number: IF 516842; Facesoffungi number: FoF 07018; 6 morphological species (Species Fungorum 2020), 5 species with molecular data.

Type species - Microcyclospora pomicola Persoonia 24: 100 (2010).

Notes - Frank et al. (2010) introduced this hyphomycetous genus and showed that it belongs in Teratosphaeriaceae. Crous et al. (2013a) introduced a new species, M. quercina and confirmed its placement in Teratosphaeriaceae. See description and illustration in Frank et al. (2010), Crous et al. (2013a).

Monticola Selbmann \& Egidi, in Crous et al., Fungal Systematics and Evolution 3: 128 (2019).

Index Fungorum number: IF 829409; Facesoffungi number: FoF 07019; 1 morphological species (Species Fungorum 2020), 1 species with molecular data.

Type species - Monticola elongata Selbmann \& Egidi, in Crous et al., Fungal Systematics and Evolution 3: 128 (2019).

Notes - Index Fungorum (2019) mentioned that Monticola is invalid, thus Crous et al. (2019b) validated the genus. See description and illustration in Egidi et al. (2014) and Crous et al. (2019b).

Myrtapenidiella Quaedvl. \& Crous, Persoonia 33: 26 (2014).

Index Fungorum number: IF 807801; Facesoffungi number: FoF 07020; 8 morphological species (Species Fungorum 2020), 8 species with molecular data.

Type species - Myrtapenidiella tenuiramis (Crous \& Summerell) Quaedvl. \& Crous, Persoonia 33: 26 (2014).

$\equiv$ Penidiella tenuiramis Crous \& Summerell, Persoonia 23: 127 (2009).

Notes - Quaedvlieg et al. (2014) established this hyphomycetous genus to accommodate Penidiella tenuiramis which was not congeneric with Penidiella sensu stricto. See description and illustration in Crous et al. (2009d) and Quaedvlieg et al. (2014).

Neocatenulostroma Quaedvl. \& Crous, Persoonia 33: 26 (2014).

Index Fungorum number: IF 807805; Facesoffungi number: FoF 07021; 3 morphological species (Species Fungorum 2020), 3 species with molecular data.

Type species - Neocatenulostroma microsporum (Joanne E. Taylor \& Crous) Quaedvl. \& Crous, Persoonia 33: 26 (2014).

三Trimmatostroma microsporum Joanne E. Taylor \& Crous, Mycol. Res. 104(5): 631 (2000)

Notes - The holomorph genus Neocatenulostroma was introduced with a hyphomycetous asexual morph by Quaedvlieg et al. (2014). Neocatenulostroma comprises three species which have been reported as plant pathogens ( $N$. abietis, $N$. microsporum) or occur on rocks (Quaedvlieg et al. 2014). See description and illustration in Quaedvlieg et al. (2014) and Markovskaja et al. (2016). 
Neophaeothecoidea Quaedvl. \& Crous, Persoonia 33: 27 (2014).

Index Fungorum number: IF 807811; Facesoffungi number: FoF 07022; 1 morphological species (Species Fungorum 2020), 1 species with molecular data.

Type species - Neophaeothecoidea proteae (Crous) Quaedvl. \& Crous, Persoonia 33: 27 (2014).

EPhaeothecoidea proteae Crous, Persoonia 20: 71 (2008).

Notes - Quaedvlieg et al. (2014) introduced Neophaeothecoidea to accommodate Phaeothecoidea proteae Crous as it was not congeneric with Phaeothecoidea sensu stricto. See description and illustration in Crous et al. (2008) and Quaedvlieg et al. (2014).

Neotrimmatostroma Quaedvl. \& Crous, Persoonia 33: 27 (2014).

Index Fungorum number: IF 807813; Facesoffungi number: FoF 04960; 4 morphological species (Species Fungorum 2020), 4 species with molecular data.

Type species - Neotrimmatostroma excentricum (B. Sutton \& Ganap.) Quaedvl. \& Crous, Persoonia 33: 27 (2014).

$\equiv$ Trimmatostroma excentricum B. Sutton \& Ganap., N.Z. J1 Bot. 16(4): 529 (1978).

Notes - Neotrimmatostroma was introduced with sexual and hyphomycetous asexual morphs (Quaedvlieg et al. 2014). The genus comprises three species. See description and illustration in Sutton \& Ganapathi (1978), Crous et al. (2007d), and Quaedvlieg et al. (2014).

Oleoguttula Selbmann \& de Hoog, in Crous et al., Fungal Systematics and Evolution 3: 129 (2019).

Index Fungorum number: IF 829418; Facesoffungi number: FoF 07023; 1 morphological species (Species Fungorum 2020), 1 species with molecular data.

Type species - Oleoguttula mirabilis Selbmann \& de Hoog, in Crous et al., Fungal Systematics and Evolution 3: 129 (2019).

Notes - Oleoguttula was listed as an invalid genus in Index Fungorum (2020) and hence, Crous et al. (2019b) validated the genus. See description and illustration in Egidi et al. (2014) and Crous et al. (2019b).

Pachysacca Syd., Annls mycol. 28(5/6): 435 (1930).

Index Fungorum number: IF 3675; Facesoffungi number: FoF 00126; 3 morphological species (Species Fungorum 2020), molecular data unavailable.

Type species - Pachysacca eucalypti Syd., Annls mycol. 28(5/6): 435 (1930).

Notes - Thambugala et al. (2014a) excluded this genus from Dothideaceae and placed it in Teratosphaeriaceae. See description and illustration in Thambugala et al. (2014a).

Parapenidiella Crous \& Summerell, Persoonia 29: 185 (2012).

Index Fungorum number: IF 801783; Facesoffungi number: FoF 07024; 2 morphological species (Species Fungorum 2020), 2 species with molecular data. (2012).

Type species - Parapenidiella tasmaniensis (Crous \& M.J. Wingf.) Crous, Persoonia 29: 185 (1998).

三Mycovellosiella tasmaniensis Crous \& M.J. Wingf., in Crous et al., Mycol. Res. 102(5): 527

Notes - Crous et al. (2012b) introduced this penidiellla-like hyphomycetous genus. Phylogenetically, Parapenidiella resides in Teratosphaeriaceae but is distinct from Penidiella sensu stricto (Quaedvlieg et al. 2014). See description and illustration in Crous et al. (1998), Crous et al. (2012b), and Quaedvlieg et al. (2014).

Parateratosphaeria Quaedvl. \& Crous, Persoonia 33: 28 (2014).

Index Fungorum number: IF 807818; Facesoffungi number: FoF 07025; 6 morphological species (Species Fungorum 2020), 6 species with molecular data. 
Type species - Parateratosphaeria bellula (Crous \& M.J. Wingf.) Quaedvl. \& Crous, Persoonia 33: 28 (2014).

$\equiv$ Mycosphaerella bellula Crous \& M.J. Wingf., Mycotaxon 46: 20 (1993).

Notes - Parateratosphaeria resembles Teratosphaeria and resides in Teratosphaeriaceae as a distinct lineage (Quaedvlieg et al. 2014). See description and illustration in Crous et al. (2008) and Quaedvlieg et al. (2014).

Penidiella Crous \& U. Braun, Stud. Mycol. 58: 17 (2007).

Index Fungorum number: IF 504463; Facesoffungi number: FoF 07026; 4 morphological species (Species Fungorum 2020), 4 species with molecular data.

Type species - Penidiella columbiana Crous \& U. Braun, Stud. Mycol. 58: 18 (2007).

Notes - Crous et al. (2007a) introduced this hyphomycetous genus with P. columbiana as the type species. Subsequent studies showed that Penidiella-like taxa are polyphyletic in Teratosphaeriaceae thus several other genera were introduced viz. Parapenidiella, Penidiellomyces (Quaedvlieg et al. 2014). See description and illustration in Crous et al. (2007a) and Quaedvlieg et al. (2014).

Penidiellomyces Crous, Attili-Angelis, A.P.M. Duarte, Pagnocca \& J.Z. Groenew., Persoonia 38: 85 (2017).

Index Fungorum number: IF 817411; Facesoffungi number: FoF 07027; 2 morphological species (Species Fungorum 2019), 2 species with molecular data.

Type species - Penidiellomyces aggregatus (Crous) Crous \& A.P.M. Duarte, Persoonia: 85 (2016).

$\equiv$ Penidiella aggregata Crous, in Crous \& Groenewald, Persoonia 26: 78 (2011).

Notes - Duarte et al. (2017) introduced this hyphomycetous genus which resembles Penidiella to accommodate Penidiella aggregata Crous. The genus comprises two species (Duarte et al. 2017). See description and illustration in Crous \& Groenewald (2011) and Duarte et al. (2017).

Penidiellopsis Sand.-Den., Gené, Deanna A. Sutton \& Guarro, in Crous et al., Persoonia 36: 439 (2016).

Index Fungorum number: IF 815361; Facesoffungi number: FoF 07028; 2 morphological species (Species Fungorum 2019), 2 species with molecular data.

Type species - Penidiellopsis radicularis Sand.-Den., Gené, Deanna A. Sutton \& Guarro, in Crous et al., Persoonia 36: 439 (2016).

Notes - Crous et al. (2016b) introduced this hyphomycetous genus. Penidiellopsis radicularis resembles Penidiella but is phylogenetically distinct and has been isolated from a human nail (Crous et al. 2016b). See description and illustration in Crous et al. (2016b).

Phaeothecoidea Crous, Fungal Diversity 26(1): 171 (2007).

Index Fungorum number: IF 501267; Facesoffungi number: FoF 07029; 4 morphological species (Species Fungorum 2020), 4 species with molecular data.

Type species - Phaeothecoidea eucalypti Crous \& Summerell, Fungal Diversity 26(1): 171 (2007).

Notes - Crous et al. (2007d) introduced this hyphomycetous genus in Mycosphaerellaceae. However, Quaedvlieg et al. (2014) showed that Phaeothecoidea resides in Teratosphaeriaceae. See description and illustration in Crous et al. (2007d); Quaedvlieg et al. (2014).

Pseudotaeniolina J.L. Crane \& Schokn., Mycologia 78(1): 88 (1986).

Index Fungorum number: IF 11176; Facesoffungi number: FoF 07030; 2 morphological species (Species Fungorum 2020), 1 species with molecular data.

Type species - Pseudotaeniolina convolvuli (Esfand.) J.L. Crane \& Schokn., Mycologia 78(1): 88 (1986). 
$\equiv$ Torula convolvuli Esfand., Sydowia 5(3-6): 370 (1951).

Notes - Egidi et al. (2014) accepted this genus in Teratosphaeriaceae. See description and illustration in Crane \& Schoknecht (1986) and Egidi et al. (2014).

Pseudoteratosphaeria Quaedvl. \& Crous, Persoonia 33: 29 (2014).

Index Fungorum number: IF 807824; Facesoffungi number: FoF 07031; 7 morphological species (Species Fungorum 2020), 7 species with molecular data.

Type species - Pseudoteratosphaeria perpendicularis (Crous \& M.J. Wingf.) Quaedvl. \& Crous, Persoonia 33: 29 (2014).

三Torula convolvuli Esfand., Sydowia 5(3-6): 370 (1951).

Notes - Pseudoteratosphaeria resembles Teratosphaeria but is phylogenetically distinct (Quaedvlieg et al. 2014). See description and illustration in Crous et al. (2006) and Quaedvlieg et al. (2014).

Queenslandipenidiella Quaedvl. \& Crous, Persoonia 33: 29 (2014).

Index Fungorum number: IF 807831; Facesoffungi number: FoF 07032; 1 morphological species (Species Fungorum 2020), 1 species with molecular data.

Type species - Queenslandipenidiella kurandae (Crous \& J.K. Stone) Quaedvl. \& Crous, Persoonia 33: 29 (2014).

三Penidiella kurandae Crous \& J.K. Stone, Fungal Planet, no. 11-21: 16: [2] (2007).

Notes - Queenslandipenidiella was introduced by Quaedvlieg et al. (2014) to contain Penidiella kurandae which was not congeneric with Penidiella sensu stricto. See description and illustration in Crous et al. (2007c) and Quaedvlieg et al. (2014).

Readeriella Syd. \& P. Syd., Annls mycol. 6(5): 484 (1908).

Index Fungorum number: IF 9698; Facesoffungi number: FoF 07034; 22 morphological species (Species Fungorum 2020), 22 species with molecular data.

Type species - Readeriella mirabilis Syd. \& P. Syd., Annls mycol. 6(5): 484 (1908).

Notes - The morphology of Readeriella has been re-visited by Sutton (1980) and Wijayawardene et al. (2016). Crous et al. (2009d) showed that Readeriella resided in Teratosphaeriaceae in their phylogenetic analyses and designated the epitype of Readeriella mirabilis. See description and illustration in Crous et al. (2007a, 2009d), Wijayawardene et al. (2016a).

Recurvomyces Selbmann \& de Hoog, Stud. Mycol. 61: 10 (2008).

Index Fungorum number: IF 511293; Facesoffungi number: FoF 07035; 1 morphological species (Species Fungorum 2020), 1 species with molecular data.

Type species - Recurvomyces mirabilis Selbmann \& de Hoog, Stud. Mycol. 61: 11 (2008).

Notes - Quaedvlieg et al. (2014) accepted Recurvomyces as a genus in Teratosphaeriaceae. See description and illustration in Selbmann et al. (2008) and Quaedvlieg et al. (2014).

Simplicidiella Crous, Attili-Angelis, A.P.M. Duarte, Pagnocca \& J.Z. Groenew., Persoonia: 87 (2016).

Index Fungorum number: IF 817414; Facesoffungi number: FoF 07036; 1 morphological species (Species Fungorum 2020), 1 species with molecular data.

Type species - Simplicidiella nigra A.P.M. Duarte \& Attili-Angelis, Persoonia: 87 (2016).

Notes - Simplicidiella has been reported from a gyne of Atta capiguara (Myrmicinae, Attini tribe). See description and illustration in Duarte et al. (2017).

Stenella Syd., Annls mycol. 28(1/2): 205 (1930).

Index Fungorum number: IF 10082; Facesoffungi number: FoF 07037; ca. 150 morphological species (Species Fungorum 2020), 1 species with molecular data.

Type species - Stenella araguata Syd., Annls mycol. 28(1/2): 205 (1930). 
Notes - Crous et al. (2007b) designated the epitype of Stenella araguata, the type species of Stenella. Quaedvlieg et al. (2014) confirmed that the genus as a member of Teratosphaeriaceae. See description and illustration in Crous et al. (2007b) and Quaedvlieg et al. (2014).

Suberoteratosphaeria Quaedvl. \& Crous, Persoonia 33: 31 (2014).

Index Fungorum number: IF 807836; Facesoffungi number: FoF 07038; 3 morphological species (Species Fungorum 2020), 3 species with molecular data.

Type species - Suberoteratosphaeria suberosa (Crous, F.A. Ferreira, Alfenas \& M.J. Wingf.) Quaedvl. \& Crous, Persoonia 33: 31 (2014).

三 Mycosphaerella suberosa Crous, F.A. Ferreira, Alfenas \& M.J. Wingf., Mycologia 85(4): 707 (1993).

Notes - Suberoteratosphaeria can be distinguished from 'Teratosphaeria by its corky lesions, and less so by ascospores that become brown, verruculose and germinate by two or multiple germ tubes' (Quaedvlieg et al. 2014). See description and illustration in Quaedvlieg et al. (2014).

Teratoramularia Videira, H.D. Shin \& Crous, Stud. Mycol. 83: 104 (2016).

Index Fungorum number: IF 816821; Facesoffungi number: FoF 07039; 4 morphological species (Species Fungorum 2020), 4 species with molecular data.

Type species - Teratoramularia persicariae Videira, H.D. Shin \& Crous, Stud. Mycol. 83: 105 (2016).

Notes - Videira et al. (2016) introduced this genus which resembles Ramularia. However, Ramularia sensu stricto resides in Mycosphaerellaceae, while Teratoramularia resides in Teratosphaeriaceae. See description and illustration in Videira et al. (2016).

Teratosphaericola Quaedvl. \& Crous, Persoonia 33: 32 (2014).

Index Fungorum number: IF 807841; Facesoffungi number: FoF 07040; 1 morphological species (Species Fungorum 2020), 1 species with molecular data.

Type species - Teratosphaericola pseudoafricana (Crous \& T.A. Cout.) Quaedvl. \& Crous, Persoonia 33: 32 (2014).

三 Mycosphaerella pseudoafricana Crous \& T.A. Cout. [as 'pseudafricana'], in Crous et al., Stud. Mycol. 55: 115 (2006).

Notes - Teratosphaericola was introduced by Quaedvlieg et al. (2014) to accommodate Amycosphaerella africana (= Mycosphaerella africana). Teratosphaericola resembles Teratosphaeria in morphology, but is phylogenetically distinct. See description and illustration in Quaedvlieg et al. (2014) and Crous et al. (2019d).

Teratosphaeriopsis Quaedvl. \& Crous, in Quaedvlieg et al., Persoonia 33: 33 (2014)

Index Fungorum number: IF 807843; Facesoffungi number: FoF 07041; 1 morphological species (Species Fungorum 2020), 1 species with molecular data. (2014).

Type species - Teratosphaericola pseudoafricana Quaedvl. \& Crous, Persoonia 33: 33

Notes - Teratosphaeriopsis resembles Teratosphaeria in morphology, but is phylogenetically distinct. See description and illustration in Quaedvlieg et al. (2014).

Xanthoriicola D. Hawksw., Trans. Br. mycol. Soc. 61(1): 66 (1973).

Index Fungorum number: IF 10441; Facesoffungi number: FoF 07042; 1 morphological species (Species Fungorum 2020), 1 species with molecular data.

Type species - Xanthoriicola physciae (Kalchbr.) D. Hawksw., Trans. Br. mycol. Soc. 61(1): 67 (1973).

三 Gymnosporium physciae Kalchbr., Mathem. Természettud. Közlem. 3: 299 (1865).

Notes - Hawksworth \& Punithalingam (1973) introduced this lichenicolous genus. Ruibal et al. (2011) provided phylogenetic evidence for the placement of Xanthoriicola physciae and 
confirmed it as a member of Teratosphaeriaceae. See description and illustration in Hawksworth \& Punithalingam (1973) and Ruibal et al. (2011).

Xenoconiothyrium Crous \& Marinc., Persoonia 27: 42 (2011).

Index Fungorum number: IF 560572; Facesoffungi number: FoF 01731; 1 morphological species (Species Fungorum 2020), 1 species with molecular data.

Type species - Xenoconiothyrium catenatum Crous \& Marinc. [as 'catenata'], Persoonia 27: $42(2011)$.

Notes - Mature conidia of Xenoconiothyrium morphologically resemble Coniothyrium sensu stricto but immature conidia 'occur in short chains when young, and have pores visible at one or either end' (Crous et al. 2011c). See description and illustration in Crous et al. (2011c).

Xenopenidiella Quaedvl. \& Crous, Persoonia 33: 33 (2014).

Index Fungorum number: IF 807845; Facesoffungi number: FoF 07043; 7 morphological species (Species Fungorum 2020), 7 species with molecular data.

Type species - Xenopenidiella rigidophora (Crous, R.F. Castañeda \& U. Braun) Quaedvl. \& Crous, Persoonia 33: 33 (2014).

$\equiv$ Penidiella rigidophora Crous, R.F. Castañeda \& U. Braun, in Crous, Braun \& Groenewald, Stud. Mycol. 58: 21 (2007)

Notes - Xenopenidiella is similar with Penidiella but 'distinct in that conidiophores are dimorphic, not truly penicillate (rather loosely branched at the apex), and conidiogenous cells often appear subdenticulate' (Quaedvlieg et al. 2014). See description and illustration in Crous et al. (2007a) and Quaedvlieg et al. (2014).

Xenophacidiella Crous, in Crous \& Groenewald, Persoonia 26: 82 (2011).

Index Fungorum number: IF 560056; Facesoffungi number: FoF 07044; 1 morphological species (Species Fungorum 2020), 1 species with molecular data.

Type species - Xenophacidiella pseudocatenata Crous, Persoonia 26: 82 (2011).

Notes - Xenophacidiella morphologically resembles Phacidiella but is phylogenetically distinct (Crous \& Groenewald 2011). See description and illustration in Crous \& Groenewald (2011).

Xenoteratosphaeria Quaedvl. \& Crous, Persoonia 33: 34 (2014).

Index Fungorum number: IF 807847; Facesoffungi number: FoF 07045; 1 morphological species (Species Fungorum 2020), 1 species with molecular data.

Type species - Xenoteratosphaeria jonkershoekensis (P.S. van Wyk, Marasas \& Knox-Dav.) Quaedvl. \& Crous, Persoonia 33: 34 (2014).

$\equiv$ Mycosphaerella jonkershoekensis P.S. van Wyk, Marasas \& Knox-Dav., J1 S. Afr. Bot. 41(4): 234 (1975).

= Teratosphaeria jonkershoekensis (P.S. van Wyk, Marasas \& Knox-Dav.) Crous \& U. Braun, in Crous, Braun \& Groenewald, Stud. Mycol. 58: 10 (2007).

Notes - This genus morphologically resembles Teratosphaeria sensu stricto. However, Xenoteratosphaeria is 'distinct in that in culture hyphae terminate in brown, multicellular chlamydospore-like structures' (Quaedvlieg et al. 2014). See description and illustration in Crous et al. (2008) and Quaedvlieg et al. (2014).

\section{Ecological and economic significance}

Several members of Teratosphaeriaceae are reported as plant pathogens (e.g. Teratosphaeria including Kirramyces and Colletogloeopsis). The range of hosts is varied but Eucalyptus species, which are important in timber and other non-timber forest products, are well-known hosts for some genera (such as Neotrimmatostroma, some Teratosphaeria species and some Readeriella species). Myrtapenidiella has been reported from Corymbia sp. and Eucalyptus sp. which are important in 
the timber industry (Quaedvlieg et al. 2014). Further research is essential to clarify the species boundaries of pathogenic species as they share close morphological characters.

Xenodevriesiaceae Crous, in Crous et al., Fungal Systematics and Evolution 3: 123 (2019).

Index Fungorum number: IF 829462; Facesoffungi number: FoF 06987, 1 species.

On leaves of Strelitzia sp. Sexual morph: Undetermined. Asexual morph: Hyphomycetous. Mycelium septate, branched hyphae, brown, smooth-walled. Microconidiophores erect, cylindrical, brown, smooth-walled with truncate ends, sympodial proliferation, reduced to conidiogenous cells. Macroconidiophores erect, cylindrical, straight to geniculate-sinuous, brown, smooth-walled, unbranched or branched at above, septate. Conidiogenous cells terminal or lateral on branched conidiophores, brown, smooth-walled, cylindrical, sympodial proliferation; loci truncate, inconspicuous, somewhat darkened, not refractive. Conidia subcylindrical to narrowly obclavate, obtuse to truncate at apex, truncate at the base, occurring in branched chains, brown, septate, smooth-walled, with guttulate; hila inconspicuous to somewhat darkened and thickened, not refractive (adapted from Crous et al. 2019b).

Type - Xenodevriesia Crous.

Notes - The family was established by Crous et al. (2019b) to accommodate a monotypic genus Xenodevriesia based on phylogenetic placement from sequence data of X. strelitziicola $(=$ Devriesia strelitziicola) which formed a distinct lineage and represents a new family within Capnodiales.
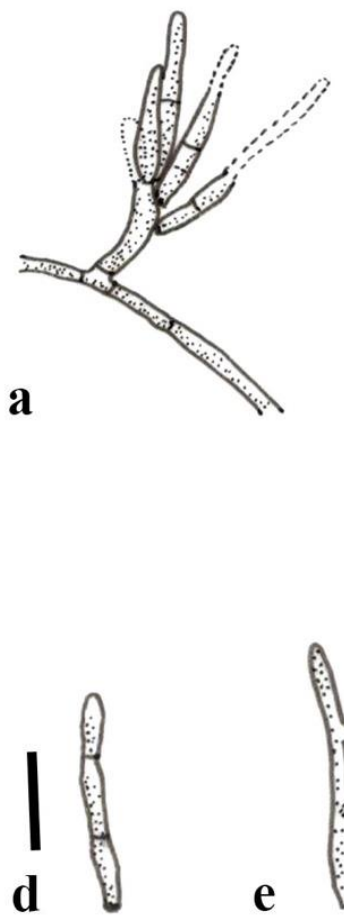

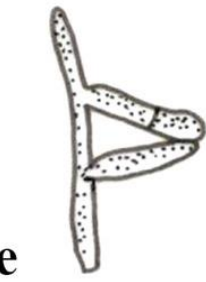

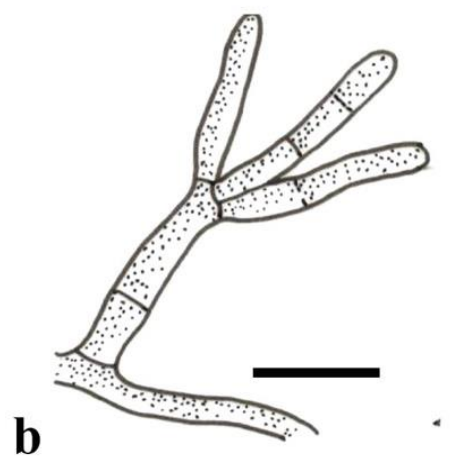
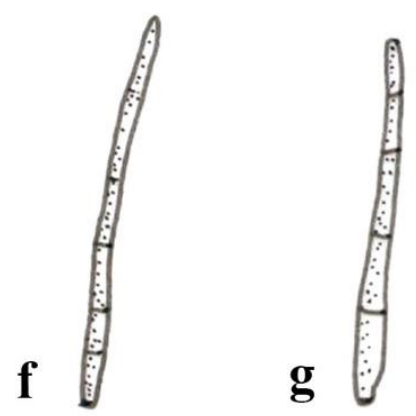
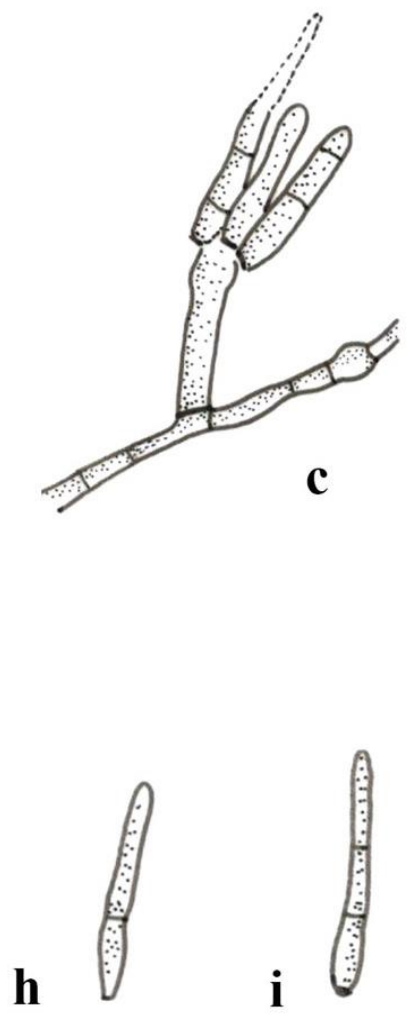

Figure 26 - Xenodevriesia strelitziicola (redrawn from Crous et al. 2009c). a-c Conidiophores giving rise to conidia. $\mathrm{d}-\mathrm{i}$ Conidia. Scale bars: $10 \mu \mathrm{m}$.

Xenodevriesia Crous, in Crous et al., Fungal Systematics and Evolution 3: 123 (2019).

Index Fungorum number: IF 829365; Facesoffungi number: FoF 06988; 1 morphological species (Species Fungorum 2020), 1 species with molecular data.

Type species - Xenodevriesia strelitziicola (Arzanlou \& Crous) Crous.

Notes - Devriesia strelitziicola is the former name of Xenodevriesia strelitziicola which was introduced by Crous et al. (2009c). It contains devriesia-like and pseudocercospora-like taxa, but is 
phylogenetically distinct from both genera (Crous et al. 2009c, 2019b). This species differs from members of Devriesia in not producing chlamydospores (Crous et al. 2019b). Thus, D. strelitziicola was synonymized under the new genus Xenodevriesia and was placed in the new family Xenodevriesiaceae. We were unable to obtain a new collection of this family, thus a drawing of $X$. strelitziicola is provided (Fig. 26).

Xenodevriesia strelitziicola (Arzanlou \& Crous) Crous, in Crous et al., Fungal Systematics and Evolution 3: 124 (2019).

Fig. 26

$\equiv$ Devriesia strelitziicola Arzanlou \& Crous, in Crous, Schoch, Hyde, Wood, Gueidan, Hoog \& Groenewald, Stud. Mycol. 64: 38 (2009).

Index Fungorum number: IF 829366; Facesoffungi number: FoF 08052.

Description - see Crous et al. (2009c).

\section{Ecological and economic significance}

It is unclear whether this genus is pathogenic or saprobic.

\section{Dothideales Lindau.}

$=$ Neocelosporiales Crous, in Crous et al., Persoonia 41: 307 (2018).

Index Fungorum number: IF 90506; Facesoffungi number: FoF 07659.

Dothideales is an interesting and important order in Dothideomycetes and considered as the basis of the class Dothideomycetes. Most of the accepted species in Dothideales are saprobic (occasionally pathogens) and occur mainly on a wide range of woody and herbaceous plants in terrestrial habitats. Luttrell (1973), von Arx \& Müller (1975), Barr (1987b), and Thambugala et al. (2014a) produced significant studies on Dothideales. Neocelosporiales is synonymized under Dothideales in this study based on phylogenetic analyses. Four families are recognized in Dothideales viz. Dothideaceae, Neocelosporiaceae, Saccotheciaceae and Zalariaceae. The divergence time for Dothideales is estimated as 177 MYA (stem age) (Fig. 2).

Accepted families: Dothideaceae, Neocelosporiaceae, Saccotheciaceae and Zalariaceae.

Dothideaceae Chevall. [as 'Dothideae'], Fl. gén. env. Paris (Paris) 1: 446 (1826).

Index Fungorum number: IF 80715; Facesoffungi number: FoF 00066, 151 species.

Biotrophic, saprobic or necrotrophic on twigs and other plant parts, rarely on leaves in terrestrial habitats. Sexual morph: Ascostromata immersed to erumpent or superficial, solitary to scattered, pulvinate or crustose, dark brown to black, globose to subglobose, uniloculate or multiloculate, without a distinct ostiole, apically opening by a lysigenous pore or by dehiscence, multi-layered ascostromata comprising pale to dark brown cells of textura angularis. Peridium of locules multi-layered, lightly pigmented to dark brown, thick-walled cells of textura angularis becoming flattened towards the inner layers. Hamathecium usually lacking pseudoparaphyses, and cellular pseudoparaphyses in some genera (e.g. Stylodothis and Uleodothis). Asci eight to multispored, bitunicate, fissitunicate, saccate to clavate, short-pedicellate, apically rounded with an ocular chamber. Ascospores 1-2-seriate, partially overlapping, muriform, small, hyaline to brown, transversely septate, constricted at the primary septum, sometimes wall smooth to verrucose, at times with a thin mucoid sheath. Asexual morph: Coelomycetous or hyphomycetous. Hyphae lightly pigmented to brown, verruculose, constricted at septa, giving rise to a hormonema-like synasexual morph. Conidiomata pycnidial, stromatic, immersed to erumpent, epidermal to subepidermal, solitary or aggregated, globose to subglobose to flask-shaped, sometimes irregular, dark brown to black, uniloculate to multi-loculate, sometimes convoluted with or without central ostioles. Conidiomata wall multi-layered, hyaline to brownish and dark brown cells of textura angularis. Conidiophores present, or reduced to conidiogenous cells, branched, septate, at the base hyaline to pale brown when present. Conidiogenous cells enteroblastic, phialidic, integrated to discrete, cylindrical or ampulliform to doliiform, determinate, hyaline to brown, smooth-walled, lining the inner cavity. Conidia cylindrical or subcylindrical to ovoid or oblong, hyaline, aseptate to 
one-septate, guttulate, smooth, granular or not (Thambugala et al. 2014a, Crous \& Groenewald 2017).

\section{Type - Dothidea Fr.}

Notes - Generally, Dothideaceae is characterized by immersed to erumpent or superficial, uniloculate to multiloculate ascostromata lacking ostioles, 8- or poly-spored, bitunicate asci and hyaline or brown, transversely septate, or muriform and often guttulate ascospores (Thambugala et al. 2014a, Hyde et al. 2018). We accept 13 genera in Dothideaceae; Delphinella, Dictyodothis, Dothidea, Dothiora, Endoconidioma, Endodothiora, Kabatina, Neocylindroseptoria, Phaeocryptopus, Plowrightia, Stylodothis, Sydowia and Uleodothis. Asteromellopsis, Cylindroseptoria, Hormonema, Neophaeocryptopus, Pringsheimia and Rhizosphaera were included in Dothideaceae by Wijayawardene et al. (2018). Asteromellopsis was introduced by Hess \& Müller (1951) and the type species A. insculpta was described by considering the asexual morph observed in immature ascomata of Dothidea insculpta. However, we do not accept Asteromellopsis as a distinct genus in Dothideaceae because of lack of supportive characters. Therefore, recollection, epitypifycation and multi-gene molecular analyses are needed for the type species of this genus to clarify its placement. Cylindroseptoria and Neophaeocryptopus which had been assigned to the family, were synonymized under Dothiora by Crous \& Groenewald (2016) and Crous et al. (2018a), respectively. Neophaeocryptopus was established by Li et al. (2016a) as a distinct genus in Dothideaceae with the type species $N$. cytisi. Later, $N$. spartii was introduced by Hyde et al. (2017). We have confirmed that Neophaeocryptopus should be treated as a synonym of Dothiora as it grouped within Dothiora in the present phylogenetic analysis (Fig. 27) and also there is no morphological evidence to separate the genus from Dothiora. The asexual genus Hormonema, has been considered the asexual morph of Sydowia polyspora (Thambugala et al. 2014a, Rossman et al. 2015, Humphries et al. 2017). Phylogenetic studies including our analysis show that a putative strain of the type species of Hormonema, H. dematioides and Sydowia polyspora clustered together (Bills et al. 2004, Thambugala et al. 2014a). Therefore, we do not accept Hormonema as a distinct genus in Dothideaceae. However, this genus requires re-collection of the type to carry out further culture and molecular data assay to confirm the status of the genus. We exclude the genus Pringsheimia from Dothideaceae because the sequence data of the type and other species are not available in GenBank and recollecting, molecular analysis and epitypifying are needed to resolve the placement of this genus. However, we suggest to keep Pringsheimia in genera incertae sedis, Dothideales. Further, Orton (1915) reported Rhizosphaera species as the asexual morph of Phaeocryptopus. Humphries et al. (2017) mentioned that, Rhizosphaera pini strains are producing colonies with pycnidium-like structures while, a hormonema-like morph is producing very large conidia. According to our multi-gene phylogenetic analysis, $R$. pini is separated as distinct lineage with Hormonema and Sydowia groups. Other Rhizosphaera species used in our phylogenetic analysis are grouped with Plowrightia species. However, Rhizosphaera abietis the type of Rhizosphaera, has no molecular data and needs to be recollected and sequenced in order to resolve the affinities of Rhizosphaera with Plowrightia in Dothideaceae. Therefore, we do not consider Rhizosphaera as a distinct genus in Dothideaceae.

Dothidea Fr., Observ. mycol. (Havniae) 2: 347 (1818).

Index Fungorum number: IF 1693; Facesoffungi number: FoF 00066, 33 morphological species (Species Fungorum 2020), 8 species with molecular data.

Type species - Dothidea sambuci (Pers.) Fr.

Notes - Dothidea is mainly characterized in having dark brown to black, erumpent to superficial, solitary or scattered, multiloculate ascostromata, with 3-15 locules, with or without ostioles, 8-spored, bitunicate, fissitunicate asci with a short broad pedicel, and 1-septate ascospores with or without a sheath. The asexual morph of Dothidea is undetermined. Members of this genus live in both terrestrial and aquatic habitats and are found worldwide (Lumbsch \& Huhndorf 2010, Wijayawardene et al. 2017a). 


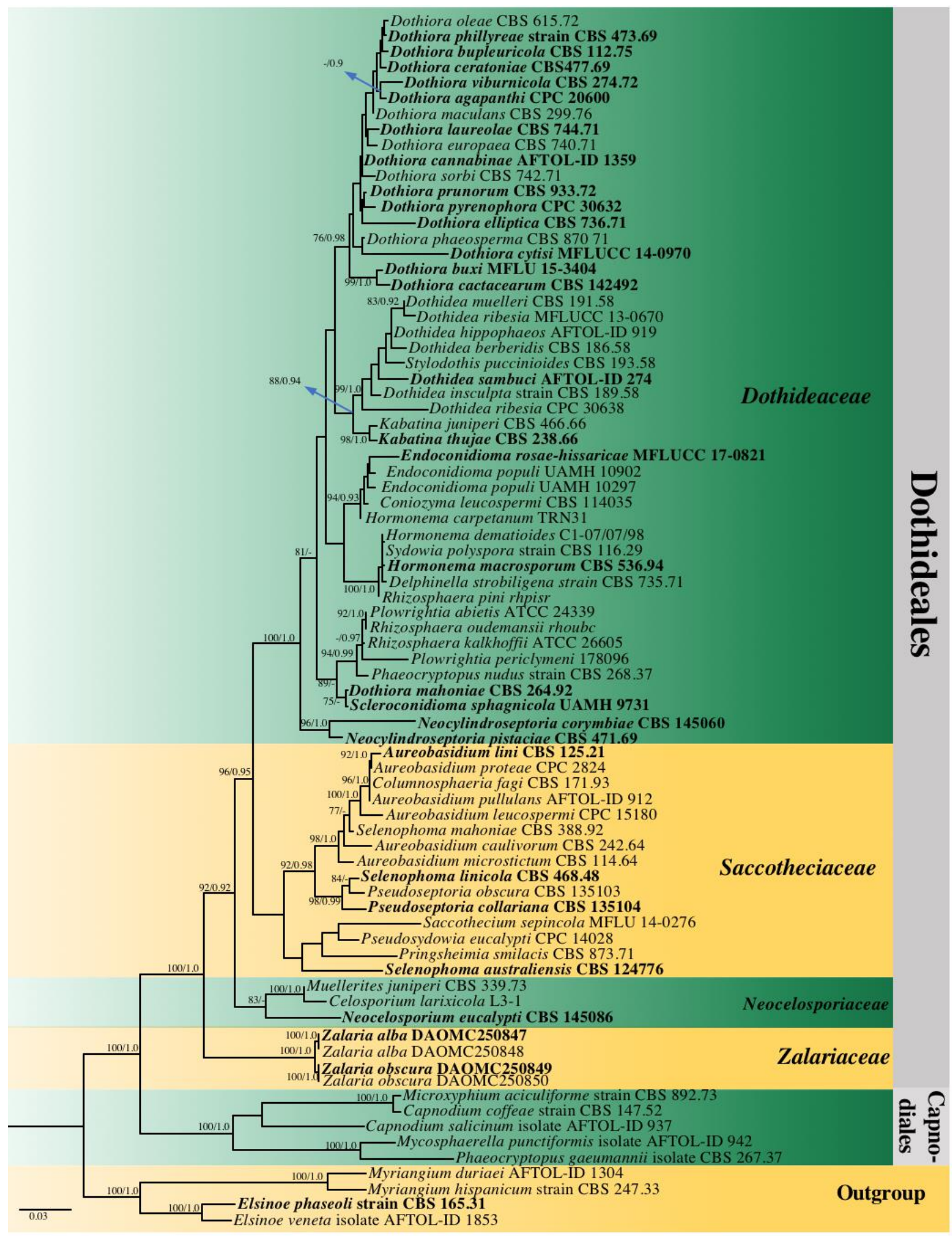

Figure 27 - Phylogram generated from maximum likelihood analysis (RAxML) of Dothideales based on ITS, LSU and SSU sequence data. Maximum likelihood bootstrap values equal or above $70 \%$, Bayesian posterior probabilities equal or above 0.90 (MLBS/PP) are given at the nodes. An original isolate number is noted after the species name. The tree is rooted to Elsinoe phaseoli (CBS 165.3), E. veneta (AFTOL-ID 1853), Myriangium duriaei (AFTOL-ID 1304), and M. hispanicum (CBS 247.33). The ex-type strains are indicated in bold. Hyphen (-) represents support values below $70 \%$ MLBS and 0.90 PP. 
Dothidea sambuci (Pers.) Fr., Syst. mycol. (Lundae) 2(2): 551 (1823).

Fig. 28

三Sphaeria sambuci Pers., Syn. meth. fung. (Göttingen) 1: 14 (1801).

Index Fungorum number: IF 163394; Facesoffungi number: FoF 00067.

Description - see Thambugala et al. (2014a).

Material examined - Austria, Steiermark (Styria) Grazer Bergland, on Sambucus nigra (Adoxaceae), leg D. Baloch 4 October 2002 det. C. Scheuer (GZU 78-2002, epitype).

Notes - As the type specimen is not available, Shoemaker \& Hambleton (2005) introduced an epitype specimen for D. sambuci from Sambucus nigra (Adoxaceae) in Austria. There is no identified asexual morph for $D$. sambuci. According to phylogenetic analysis by Thambugala et al. (2014a), D. sambuci groups with D. insculpta and this was confirmed in our study.

\section{Other genera included}

Delphinella (Sacc.) Kuntze, Revis. gen. pl. (Leipzig) 3(3): 74 (1898).

$\equiv$ Glonium subgen. Delphinella Sacc., Syll. fung. (Abellini) 9: 1103 (1891).

Index Fungorum number: IF 1445; Facesoffungi number: FoF 00074; 6 morphological species (Species Fungorum 2020), 3 species with molecular data.

Type species - Delphinella strobiligena (Desm.) Sacc. ex E. Müll. \& Arx, Beitr. Kryptfl. Schweiz 11(no. 2): 25 (1962).

三Sphaeria strobiligena Desm., Annls Sci. Nat., Bot., sér. 3 6: 75 (1846).

Notes - Delphinella was introduced by Kuntze (1898) based on Sphaeria strobiligena which was assigned as the type species of Delphinella by Müller \& von Arx (1962). Sexual morphs of this genus are characterized by dark brown to black, multiloculate ascostromata with globose to subglobose locules that lack ostioles. Asci are borne at the base of loculus and are polysporous lacking ocular chamber. Ascospores are 2-3-seriate to crowded and hyaline or yellowish (Thanmugala et al. 2014a). The asexual morph of Delphinella abietis was reported as Dothiorella. According to modern taxonomic and molecular analyses Dothiorella belongs to Botryosphaeriaceae (Thanmugala et al. 2014a). von Arx \& Müller (1975) included Delphinella under Dothideaceae. Barr (2001) and Hyde et al. (2013) suggested it should be placed under Dothideaceae. In our study, D. strobiligena grouped within Dothideaceae as a distinct genus.

Dictyodothis Theiss. \& Syd., Annls mycol. 13(3/4): 346 (1915).

Index Fungorum number: IF 1527; Facesoffungi number: FoF 00076; 8 morphological species (Species Fungorum 2020), molecular data unavailable.

Type species - Dictyodothis berberidis (Rehm) Theiss. \& Syd., Annls mycol. 13(3/4): 346 (1915).

三 Curreya berberidis Rehm, Bih. K. svenska VetenskAkad. Handl., Afd. 3 25(no. 6): [4] (1899).

Notes - Dictyodothis was established to accommodate two species, D. berberidis and $D$. excavata in Dothideaceae. von Arx \& Müller (1975) placed Dictyodothis in Pleosporaceae according to morphological character such as "paraphysoids" in the locules. However, Barr (1981) reported "paraphysoids" are the walls and remaining cytoplasmic strands of discharged asci and ascospores which are similar to D. sambuci (Thambugala et al. 2014a). Therefore, Dictyodothis was placed in Dothideaceae by Barr (1981). The sexual morph of this genus is characterized by black, coriaceous and multiloculate ascostromata which are discoid to pulvinate. The cells of the ascomata wall are composed of dark brown to black cells of textura prismatica and textura angularis. Locules are ostiolate and asci contain 1-2-seriate, yellowish brown to dark brown, muriform ascospores. Asexual morphs have not been reported for Dictyodothis (Thambugala et al. 2014a). 

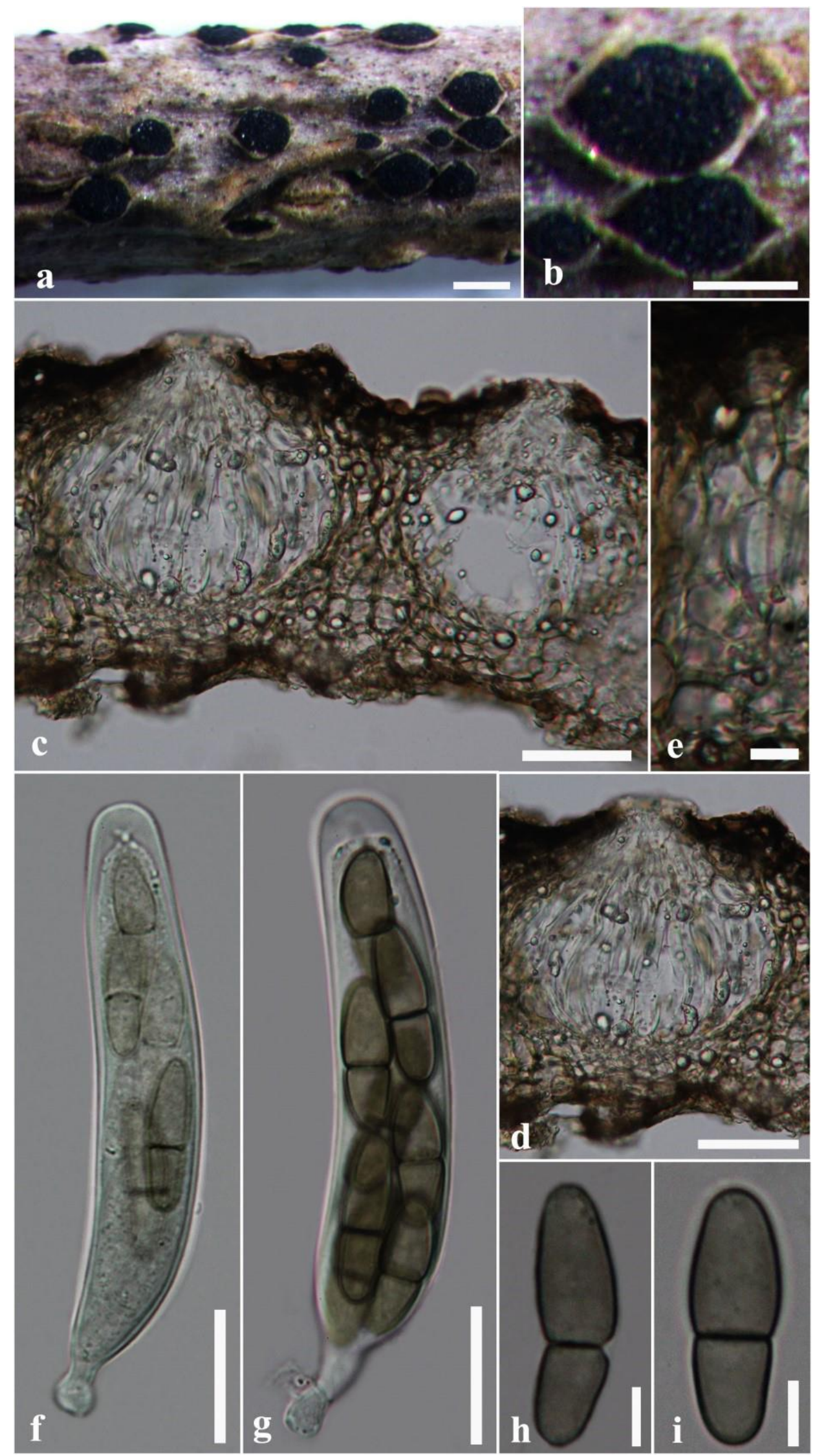

Figure 28 - Dothidea sambuci (GZU 78-2002, epitype). a, b Appearance of ascostromata on the host substrate. $\mathrm{c}-\mathrm{d}$ Vertical section through ascostroma. e Peridium $\mathrm{f}-\mathrm{g}$ Asci h-i Ascospores. Scale bars: $\mathrm{a}=1000 \mu \mathrm{m} \mathrm{b}=500 \mu \mathrm{m}, \mathrm{c}-\mathrm{d}=50 \mu \mathrm{m}, \mathrm{e}=5 \mu \mathrm{m}, \mathrm{f}-\mathrm{g}=20 \mu \mathrm{m}, \mathrm{h}-\mathrm{i}=10 \mu \mathrm{m}$. 
Dothiora Fr., Summa veg. Scand., Sectio Post. (Stockholm): 418 (1849).

= Cylindroseptoria Quaedvl., Verkley \& Crous, Stud. Mycol. 75: 358 (2013).

= Neophaeocryptopus Wanas., Camporesi, E.B.G. Jones \& K.D. Hyde, in Li et al., Fungal Divers 78 (2016).

Index Fungorum number: IF 1702; Facesoffungi number: FoF 00078; 51 morphological species (Species Fungorum 2020), 24 species with molecular data.

Type species - Dothiora pyrenophora (Fr.) Fr., Summa veg. Scand., Sectio Post. (Stockholm): 418 (1849).

DDothidea pyrenophora Fr., K. svenska Vetensk-Akad. Handl., ser. 3 40: 88 (1819).

For synonyms see Index Fungorum (2019).

Notes - Saccardo (1889) and Lindau (1897) included Dothiora in discomycetes. Dothiora was placed in Dothideales by Theissen \& Sydow (1915). Theissen \& Sydow (1917b) moved the genus to Dothioraceae. von Arx \& Müller (1975) and Sivanesan (1984) treated Dothiora under Dothideaceae. Many authors (Barr 1987b, Hawksworth et al. 1995, Lumbsch \& Huhndorf 2010) categorized Dothiora under Dothioraceae as they treated Dothideaceae and Dothioraceae as separate families in Dothideales (Thambugala et al. 2014a). However, Dothideaceae has several genera that show dothiora-like morphology and dothichiza-like asexual morphs in culture (Thambugala et al. 2014a, Crous \& Groenewald 2017). Dothiora is separated from other genera in this family, in having hyaline, one to many septate or muriform ascospores (Thambugala et al. 2014a). Morphologically, Dothiora has a dothichiza-like asexual morph and hormonema-like synasexual morph in culture (Thambugala et al. 2014a, Crous \& Groenewald 2017). The asexual morph of D. pyrenophora has been reported as Dothichiza sorbi. by Sivanesan (1984) according to the formation of pycnidia in cultures (Thambugala et al. 2014a). Some Dothichiza species have phylogenetically similar characters to Dothideales (Bills et al. 2004, Zalar et al. 2008, Thamubugala et al. 2014a), but some are not, such as D. pyrenophora and D. populea (Thambugal et al. 2014a). In our analysis Dothiora formed a clade within Dothideaceae with high boostrap support (76\% MLBS, 0.98 PP, Fig. 27).

Crous \& Groenewald (2016) reported that some Dothiora species have been isolated from dead leaves and fruits of diverse hosts, while Sivanesan (1984) mentioned that Dothiora species can be mostly isolated from dead branches of woody hosts. Crous \& Groenewald (2016) suggested that these species may be saprobes or possibly weak pathogens when plant tissues are stressed (Crous \& Groenewald 2017).

Endoconidioma Tsuneda, Hambl. \& Currah, Mycologia 96(5): 1129 (2004).

Index Fungorum number: IF 28876; Facesoffungi number: FoF 00080; 2 morphological species (Species Fungorum 2020), 2 species with molecular data. (2004).

Type species - Endoconidioma populi Tsuneda, Hambl. \& Currah, Mycologia 96(5): 1129

Notes - Endoconidioma was introduced as a monotypic genus to accommodate E. populi in Dothideaceae. Endoconidioma populi is a melanized taxon belonging to black meristematic fungal group which are cosmopolitan and easily adaptable to extreme environmental conditions (Mirzaei et al. 2015, Wanasinghe et al. 2018c). Endoconidioma rosae-hissaricae was introduced by Wanasinghe et al. (2018c). Morphologically, E. populi has two-celled conidia while they are aseptate in E. rosaehissaricae (Wanasinghe et al. 2018c). This genus is characterized by subglobose to flask-shaped and entirely closed conidiomata, which forms on a black subiculum, a darkly pigmented peridium and locules filled with conidiogenous cells (Thambugala et al. 2014a, Wanasinghe et al. 2018c). Endoconidia are formed endogenously and are hyaline, unicellular and released by dissolution of the conidiogenous and the peridial cells of the conidiomata. Blastic conidia, mostly two-celled, light to dark brown are produced holoblastically from pigmented, undifferentiated hyphae (Tsuneda et al. 2004, Thambugala et al. 2014a). In our phylogenetic analysis, Endoconidioma grouped within Dothideaceae (Fig. 27).

Endodothiora Petr., Annls mycol. 27(5/6): 345 (1929). 
Index Fungorum number: IF 1797; Facesoffungi number: FoF 00082; 1 morphological species (Species Fungorum 2020), molecular data unavailable.

Type species - Endodothiora sydowiana Petr., Annls mycol. 27(5/6): 345 (1929).

Notes - The parasitic genus Endodothiora was introduced to accommodate a single species E. sydowiana Petr., which is immersed in ascostromata of Dothidea puccinioides (Barr 1972). This genus is placed in Dothioraceae based on its parasitic nature on Dothidea collecta, and also immersing in the stroma of the host fungus. Poly-spored asci and multi-septate hyaline ascospores of Endodothiora share similar with those of Sydowia, but the immersed parasitic habitat excludes it from Sydowia (Barr 1972, 2001). Tambugala et al. (2014a) re-examined the type and found different asci with brown ascospores (Dothidea puccinioides) which share the same ascomata that is good proof for E. sydowiana being parasitic on Dothidea puccinioides. Other major sexual morph characters of this genus are subglobose to broadly ellipsoid, coriaceous ascostromata with 2-5 locules, cylindrical to broadly cylindrical asci and oblong, multi-septate ascospores which are constricted at the primary septum. The asexual morph is unknown (Thambugala et al. 2014a). Further investigations of its morphology and DNA based analysis are suggested.

Kabatina R. Schneid. \& Arx, Phytopath. Z. 57: 179 (1966).

Index Fungorum number: IF 8657; Facesoffungi number: FoF 00084; 4 morphological species (Species Fungorum 2020), 4 species with molecular data.

Type species - Kabatina thujae R. Schneid. \& Arx, Phytopath. Z. 57: 180 (1966).

Notes - Kabatina is an asexual genus introduced to accommodate $K$. juniperi and $K$. thujae. Later, Butin \& Schneider (1976), Ramaley (1992) and Butin \& Pehl (1993) added K. populi, K. mahoniae and $K$. abietis, respectively. The unique characters of Kabatina are enteroblastic, phialidic or percurrent, determinate, brown to pale brown conidiogenous cells, with a channel and collarette (Thambugala et al. 2014a). Wijayawardene et al. (2012) placed this genus under Dothioraceae, while Hyde et al. (2013) and Thambugala et al. (2014a) categorized Kabatina as a genus in Dothideaceae. Only ITS sequence data are available for Kabatina species in GenBank. Therefore, Kabatina species need to be sequenced for nuclear ribosomal genes and protein-coding genes in order to obtain a better resolution in the phylogenetic analyses. Kabatina species do not have ex-type sequence data and re-collecting and sequencing are needed to confirm the familial placements (Thambugala et al. 2014a). Kabatina mahoniae was synonymized by Crous et al. (2018a) under Dothiora mahoniae. However, in the present study Kabatina juniperi and K. thujae grouped as a monophyletic clade sister to Dothidea (88 \% MLBS, 0.94 PP, Fig. 27).

Neocylindroseptoria Thambug. \& K.D. Hyde, Fungal Diversity 68: 125 (2014).

Index Fungorum number: IF 550730; Facesoffungi number: FoF 07660; 2 morphological species (this study), 2 species with molecular data.

Type species - Neocylindroseptoria pistaciae (Quaedvl., Verkley \& Crous) Thambug. \& K.D. Hyde, in Thambugala et al., Fungal Diversity 68: 125 (2014).

$\equiv$ Cylindroseptoria pistaciae Quaedvl., Verkley \& Crous, Stud. Mycol. 75: 359 (2013).

Notes - Cylindroseptoria was introduced with two species, C. ceratoniae and $C$. pistaciae. The asexual morph of $C$. pistaciae is characterized by pycnidial, black, erumpent, conidiomata with a central ostiole, and phialidic conidiogenous cells which line the inner cavity. Conidia are aseptate, cylindrical, rarely slightly curved and guttulate. The sexual morph is undetermined (Quaedvlieg et al. 2013). The genus was typified by $C$. ceratoniae. Thambugala et al. (2014a) recognized $C$. ceratoniae as a separate linage from $C$. pistaciae in Dothideaceae based on their phylogenetic analysis. Neocylindroseptoria is therefore introduced to accommodate Cylindroseptoria pistaciae. Subsequently, Crous et al. (2018a) transferred N. pistaciae to Dothiora and introduced Dothiora pistaciae based on their phylogenetic analysis that consisted of only a few LSU sequence data of Dothideaceae. Nevertheless, in the present phylogenetic analysis based on combined ITS, LSU and SSU dataset (Fig. 27) N. pistaciae formed a well-supported, distinct clade basal to Dothideaceae (96\% MLBS, 1.00 PP) with Dothiora corymbiae which was introduced by Crous et al. (2018a). 
Therefore, we suggest Neocylindroseptoria should be kept as a separate genus in Dothideaceae and we introduce $N$. corymbiae for D. corymbiae.

Neocylindroseptoria corymbiae (Crous) Wijesinghe, Thambugala \& K.D Hyde, comb. nov.

$\equiv$ Dothiora corymbiae Crous, in Crous et al., Persoonia 41: 271 (2018).

Index Fungorum number: IF 828175; Faceoffungi number: FoF 07661

Description - see Crous et al. (2018a).

Phaeocryptopus Naumov, Bull. Soc. mycol. Fr. 30(1): 424 (1915).

Index Fungorum number: IF 3902; Facesoffungi number: FoF 00086; 6 morphological species (Species Fungorum 2020), 2 species with molecular data.

Type species - Phaeocryptopus nudus (Peck) Petr., Annls mycol. 36(1): 15 (1938).

Notes - Phaeocryptopus was introduced as a monotypic genus. Petrak (1962), Butin (1970) and Farr (1984) introduced several other species (Thambugala et al. 2014a). Müller \& von Arx (1950) included Phaeocryptopus in Venturiaceae. Rhizosphaera species are accepted as asexual morphs of Phaeocryptopus. However, this relationship has not been clearly established (Winton et al. 2007, Thambugala et al. 2014a). Phylogenetic analysis of Winton et al. (2007) and Schoch et al. (2009a) showed that $P$. gaeumannii clustered in Mycosphaerellaceae, Capnodiales while $P$. nudus nested in Dothioraceae, Dothideales (Thambugala et al. 2014a). In our multi-gene phylogenetic analysis, $P$. nudus is separated with high bootstrap support with its internal node (94\% MLBS, 0.99 PP, Fig. 27) within family Dothideaceae. Phaeocryptopus is separated from other genera in the family in having superficial, gregarious, globose to globose-depressed, black ascostromata (Thambugala et al. 2014a).

Plowrightia Sacc., Syll. fung. (Abellini) 2: 635 (1883).

Index Fungorum number: IF 4262; Facesoffungi number: FoF 00088; 17 morphological species (Species Fungorum 2020), 2 species with molecular data.

Type species - Plowrightia ribesia (Pers.) Sacc., Syll. fung. (Abellini) 2: 635 (1883).

ESphaeria ribesia Pers., Ann. Bot. (Usteri) 11: 24 (1794).

Notes - Barr (1972) synonymized Plowrightia under Dothiora. However, Plowrightia is different from Dothiora based on the pulvinate, erumpent ascostromata, with small locules which height is greater than width (Thambugala et al. 2014a). Phylogetic analyses indicated that Plowrightia is a member of Dothideaceae (Winton et al. 2007, Thambugala et al. 2014a). Theissen \& Sydow (1915) synonymized Plowrightia balansiana, P. rhynchosporae, and Polystomella aphanes under Uleodothis based on morpholocal similarity. Plowrightia and Uleodothis are similar in ascostromatal and ascospore characters (Hyde et al. 2018). In our phylogenetic analyses, Plowrightia abietis is grouped with Rhizosphaera oudemansii (92\% ML, 1.0 PP, Fig. 27). Therefore, we agree with the conclusion of Thambugala et al. (2014a) that Plowrightia abietis and $R$. oudemansii are identical with the latter as the asexual morph of P. abietis. Plowrightia periclymeni formed a separate lineage with $P$. abietis, Rhizosphaera kalkhoffii and $R$. oudemansii (0.97 PP, Fig. 27). In our study, we place Plowrightia as a genus in Dothideaceae. However, more collections and sequence data are needed to confirm its taxonomic placement.

Stylodothis Arx \& E. Müll., Stud. Mycol. 9: 11 (1975).

Index Fungorum number: IF 5299; Facesoffungi number: FoF 00091; 2 morphological species (Species Fungorum 2020), 1 species with molecular data.

Type species - Stylodothis puccinioides (DC.) Arx \& E. Müll., Stud. Mycol. 9: 11 (1975).

三Sphaeria puccinioides DC., Fl. franç., Edn 3 (Paris) 5/6: 118 (1815).

Notes - Stylodothis was introduced to accommodate $S$. puccinioides and $S$. indica (Thambugala et al. 2014a). Stylodothis is different from other genera in the family, in having 4-8 spored asci and ellipsoid to fusiform, brown, 1-septate ascospores (Thambugala et al. 2014a). Morphologically and phylogenetically Stylodothis is closely related to Dothidea (Thambugala et al. 2014a). Stylodothis puccinioides has 4 ascospores in ascus, while $S$. indica has 8 ascospores and 
sometimes with 2 or 3 septa (Thambugala et al. 2014a). A phylogenetic analysis by Schoch et al. (2006) showed S. puccinioides is closely related to Dothidea. We used only S. puccinioides for our phylogenetic analysis as it is the type species of Stylodothis. Nevertheless, members of the genus need recollecting, sequencing and epitypifying in order to confirm its generic status or family placement.

Sydowia Bres., Hedwigia 34(Beibl.): (66) (1895).

Index Fungorum number: IF 5311; Facesoffungi number: FoF 00093; 11 morphological species (Species Fungorum 2020), 4 species with molecular data.

Type species - Sydowia gregaria Bres., Hedwigia 34(Beibl.): (66) (1895).

Notes - Sydowia was transferred to Dothioraceae by Luttrell (1973) mainly based on its phragmosprous ascospores. von Arx \& Müller (1975) placed this genus in Dothideaceae based on morphology, unilocular stromata and ascospores with transverse septa (Thambugala et al. 2014a). Multi-gene phylogenetic analyses based on S. polyspora (Schoch et al. 2006) placed Sydowia in Dothioraceae. However, Thambugala et al. (2014a) accommodated Sydowia in Dothideaceae pending molecular data for the type species. Sydowia eucalypti (Sphaerulina eucalypti) was introduced by Crous et al. (2003b) with its coniothyrium-like and hormonema-like synasexual morphs and Selenophoma asexual state in culture. Following a phylogenetic study, Thambugala et al. (2014a) introduced a new genus, Pseudosydowia to accommodate Sydowia eucalypti in Saccotheciaceae, Dothideales. Hormonema dematioides has been suggested as the asexual morph of $S$. polyspora (Butin 1964, Cheewangkoon et al. 2009, Thambugala et al. 2014a). Bills et al. (2004) showed S. polyspora and $H$. dematioides clustered in the same clade in their phylogeny analysis. In our multi-gene analysis, we confirmed the observations by Bills et al. (2004).

Uleodothis Theiss. \& Syd., Annls mycol. 13(3/4): 305 (1915).

Index Fungorum number: IF 5656; Facesoffungi number: FoF 04463; 8 morphological species (Species Fungorum 2020), molecular data unavailable.

Type species - Uleodothis balansiana (Sacc., Roum. \& Berl.) Theiss. \& Syd., Annls mycol. 13(3/4): 305 (1915).

$\equiv$ Plowrightia balansiana Sacc., Roum. \& Berl., Revue mycol., Toulouse 7(no. 26): 157 (1885).

Notes - Uleodothis was originally positioned in Dothioraceae (Dothideales) by Stevens (1920). Later, Müller \& von Arx (1962) established this in Mycosphaerellaceae (Pseudosphaeriales) and Luttrell (1973) referred it to Venturiaceae (Venturiales). Zhang et al. (2011) treated it as a genus in Dothideomycetes incertae sedis. Uleodothis and Plowrightia have similar characters such as semi-immersed, multi-loculate, pulvinate, dark brown to black ascostromata and 1-septate ascospores. However, Plowrightia has thick-walled locules which develop in the upper stroma, lacking pseudoparaphyses, and ascospores which are constricted at the septum (Thambugala et al. 2014a, Hyde et al. 2018). Uleodothis has thin-walled locules which develop in middle of stroma, persistent pseudoparaphyses and ascospores slightly constricted at the septum or without septation (Theissen \& Sydow 1915, Hyde et al. 2018). Also, Uleodothis has some similar morphological characters to Aplosporella (Aplosporellaceae, Botryosphaeriales) (Hyde et al. 2018). Hyde et al. (2018) re-examined the type specimen of Uleodothis and accepted Uleodothis in Dothideaceae as a sister genus to Plowrightia based on only morphological evidence. Fresh collections and sequence data related to Plowrightia and uleodothis-like taxa are required to further clarify their phylogenetic relationships.

\section{Ecological and economic significance}

Members of Dothideaceae can be biotrophic, saprobic or necrotrophic on twigs, branches, leaves and other plant parts (Thambugala et al. 2014a, Crous \& Groenewald 2017). Therefore, they have a high ecological and economical value in the nature. Most species of this family are boitrophs, nectrotrophs or saprobes. Delphinella plays different ecological roles as saprobic or parasitic on twigs, stems, leaves and cone scales of gymnosperms and dicotyledons wood (Barr 
1972, Thambugala et al. 2014a). Also, members of Dothiora live in terrestrial habitats (dead branches of woody hosts, dead leaves and fruit of diverse hosts) as saprobes or weak pathogens on stressed plant tissues (Crous \& Groenewald 2016, 2017). Endodothiora is parasitic on Dothidea puccinioides (Thambugala et al. 2014a). Kabatina plays a major role as a parasite on branches of Abies, Juniperus, Mahonia, Populus and Thuja species and is associated with needle dieback in conifer hosts. Th Kabatina species cause several important diseases named "Evergreen Disease and Needle Cast of Firs" (Sutton 1980, Tisserat \& Pair 1997, Bills et al. 2004, Cech et al. 2009, Thambugala et al. 2014a). Phaeocryptopus is also parasitic on conifer needles while, Plowrightia ribesia has a wide distribution in Europe as parasitic on Ribes rubrum (Grossulariaceae) (Saccardo 1883, Hoggan 1927, Thambugala et al. 2014a). Sydowia shows parasitic (Sydowia gregaria) and saprobic life modes on conifers or stems and wood (Thambugala et al. 2014a). Uleodothis balansiana plays as an important ecological role as an epiphyte on lower host leaf surface (Hyde et al. 2018).

Neocelosporiaceae Crous, in Crous et al., Persoonia 41: 307 (2018).

Index Fungorum number: IF 828205; Facesoffungi number: FoF 07662, 3 species.

Saprobic on leaves and stems of various plants in terrestrial habitats. Sexual morph: Ascostromata black, forming at the base of the cypress leaves, superficial on host tissue, solitary to gregarious, erumpent, coriaceous, globose, hyaline. Peridium thick-walled, composed of single layers of brown cells, arranged in a textura angularis. Hamathecium comprising septate, branched, hyphae-like, anastomosting, cellular pseudoparaphyses. Asci 8-spored, bitunicate, fissitunicate, subcylindrical to clavate, with an ocular chamber. Ascospores 2-seriate, ellipsoid to fusoid, dark brown, 3-4-septate, constricted at septa, smooth-walled, with mucilaginous sheath. Asexual morph: Hyphomycetous. Mycelium dark brown, spreading, enclosed in mucus, swollen, ellipsoid, or hyphae forming cellular clumps with endoconidia. Conidia hyaline to brown, thin- to thick-walled, 0-3-septate (Crous et al. 2018a).

Type - Neocelosporium Crous.

Notes - Neocelosporiaceae was introduced by Crous (2018a) to accommodate Neocelosporium, Celosporium and Muellerites. These genera share some characters in both sexual and asexual morphs, and in host-specificity. Neocelosporium has hyaline conidia that primarily arise on the surface of hyphae. Celosporium is characterized by dematiaceous hyphae forming clumps with numerous hyaline to brown endoconidia. Muellerites has been reported only by its sexual morph. Crous (2018a) placed this family in the new order Neocelosporiales based on phylogeny. However, they did not include Zalariaceae in their analyses. In our phylogenetic tree (Fig. 27), Neocelosporiaceae formed a clade within Dothideales and basal to the clades of Dothideaceae and Saccotheciaceae. Thus, this family is included as a family in Dothideales.

Neocelosporium Crous, in Crous et al., Persoonia 41: 307 (2018).

Index Fungorum number: IF 828206; Facesoffungi number: FoF 07663; 1 morphological species (Species Fungorum 2020), 1 species with molecular data.

Type species - Neocelosporium eucalypti Crous.

Notes - The type species, N. eucalypti was found on Eucalyptus cyanophylla (Myrtaceae), in New South Wales, in Australia.

Neocelosporium eucalypti Crous, in Crous et al., Persoonia 41: 307 (2018).

Fig. 29

Index Fungorum number: IF 828207; Facesoffungi number: FoF 07664.

Description - see Crous (2018a).

\section{Other genera included}

Celosporium Tsuneda \& M.L. Davey, Botany 88(5): 472 (2010).

Index Fungorum number: IF 518301; Facesoffungi number: FoF 00111; 1 morphological species (Species Fungorum 2020), 1 species with molecular data. 
Type species - Celosporium laricicola Tsuneda \& M.L. Davey [as 'larixicolum'], Botany 88(5): 473 (2010).

Notes - There is only one species of Celosporium. Celosporium is characterized by coelomycetous, dematiaceous hyphae forming terminal or intercalary, black, irregular shaped cellular clumps, with aggregated cellular clumps conidiomata, and 1-3-celled, hyaline endoconidia, released by cell-wall dissolution of the conidiogenous cells (Tsuneda et al. 2010). Based on molecular analysis Thambugala (2014a) placed Celosporium in Dothideales, genera incertae sedis. Crous (2018a) indicated that this genus clustered with Muellerites juniper and Neocelosporium eucalypti within Neocelosporiaceae.

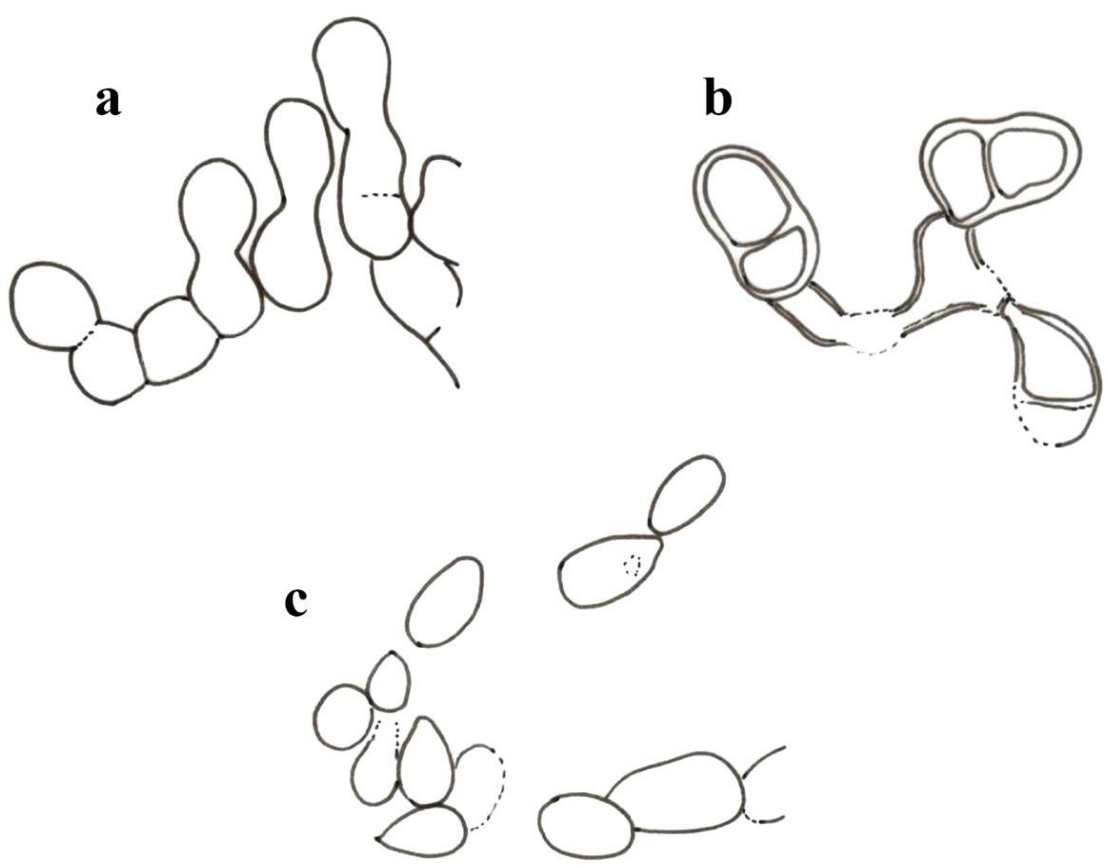

Figure 29 - Neocelosporium eucalypti (redrawn from Crous et al. 2018a, CBS H-23778, holotype). a Brown primary conidia. b Conidial propagules. c Hyaline secondary conidia.

Muellerites L. Holm, Svensk bot. Tidskr. 62: 231 (1968).

Index Fungorum number: IF 3285; Facesoffungi number: FoF 07665; 1 morphological species (Species Fungorum 2020), 1 species with molecular data.

Type species - Muellerites juniperi (E. Müll. \& Arx) L. Holm, Svensk bot. Tidskr. 62: 231 (1968).

三 Gibberidea juniperi E. Müll. \& Arx, Phytopath. Z. 24: 359 (1955).

Notes - There is only one species of Muellerites described on leaves of Juniperus nana Willd. (Cupressaceae) in Switzerland. Muellerites is characterized by globose, small, black ascomata, forming at the base of the cypress leaves, a single thick-walled layered peridium, with 8spored, cylindrical asci, and 3-4-septate, dark brown ascospores (Dai et al. 2014). Based on the morphological characters, Dai et al. (2014) placed Muellerites in Dothidotthiaceae, but Crous (2018a) re-examined and re-positioned the genus to Neocelosporiaceae based on sequence data of the type species.

\section{Ecological and economic significance}

Members in this family usually grow on living or dead leaves or stems of various plants and are mostly saprobic. However, species such as Muellerites juniper (Dai et al. 2014), which grow on wood can damage the woody tissues. They also play an integral role in forest ecosystems by decomposing wood. 
Saccotheciaceae Bonord. [as 'Saccotheciei’], Abh. naturforsch. Ges. Halle 8: 82 (1864).

$=$ Aureobasidiaceae Thambugala \& K.D. Hyde in Hyde et al., Fungal Diversity 68 (1): 133 (2014), isonym.

Index Fungorum number: IF 81613; Facesoffungi number: FoF 07666, 151 species.

Parasitic or saprobic on twigs, wood and leaves or human skin. Sexual morph: Ascomata black, immersed to erumpent, globose to subglobose, uniloculate, sometimes ostiolate. Peridium comprising several layers of brown to dark brown cells of textura angularis. Hamathecium lacking pseudoparaphyses. Asci 8-spored, bitunicate, saccate to broadly clavate with a short bifurcate pedicel or apedicellate, apex broadly rounded with a distinct ocular chamber. Ascospores 2-3seriate, obovoid or elliptic with broad to narrow rounded ends, hyaline, muriform to phragmosporous, 3- to multi-septate or aseptate. Asexual morph: Coelomycetous or hyphomycetous. Hyphomycetous: Stromata present or absent, visible in substomatal cavity, hyaline or lightly pigmented, dark brown with globose to broadly ellipsoidal, round or elongated pseudoparenchymatous cells when present. Colonies spreading, smooth, often covered with slimy masses of conidia, usually with sparse aerial mycelium; light brown, yellow, pink or black. Hyphae with cells commonly wider than long, hyaline, frequently soon becoming brown and thick-walled sometimes thin, smooth, transversely septate. Conidiogenous cells on hyaline hyphae, lateral, terminal or intercalary, cylindrical, clavate or globose, integrated, terminal, with holoblastic, polyblastic conidiogenesis, with numerous synchronously produced conidia. Conidia blastic, straight, ellipsoidal to sphaerical, reniform to sickle-shaped, oblong to cylindrical, sometimes cylindrical with obtuse ends and occasionally with a slightly truncate base, hyaline to dark brown, aseptate. Secondary conidia common; endoconidia often present. Coelomycetous Asexual morph: Conidiomata dark brown, separate or aggregated, scattered, pycnidial or acervular, immersed or superficial, globose, unilocular, thin-walled; walls 2-3 layers thick, composed of lightly pigmented to brown, thick-walled cells of textura angularis, with or without an ostiole. Conidiophores reduced to conidiogenous cells or hyaline, irregularly branched at the base and above, 1- to 3-septate, smooth when present. Conidiogenous cells enteroblastic, phialidic, discrete, determinate or ampulliform, subglobose, obpyriform or obovoid, hyaline to pale brown collarette and channel minute, with apical periclinal thickening, guttulate, formed from the inner cell of the pycnidial wall, slightly tapered towards the apex. Conidia holoblastic, falcate, fusiform, ellipsoidal to obovoid, hyaline or pale brown, becoming pale brown with thicker walls, aseptate, eguttulate or irregularly guttulate, at first thin-walled, smooth-walled or verruculose.

Type - Saccothecium Fr.

Notes - Saccotheciaceae was established by Bonorden (1864) to accommodate Saccothecium and is considered as a distinct family in Dothidelaes. Thambugala et al. (2014a) introduced Aureobasidiaceae to accommodate Aureobasidium, Saccothecium and five other genera. Aureobasidiaceae had in fact already been introduced by Ciferri (1958). Nevertheless, Aureobasidiaceae should be synonymized under Saccotheciaceae as the latter is the oldest available name for the family that contains Aureobasidium and Saccothecium. Seven genera are accepted in this family. Saccotheciaceae can be distinguished from Dothideaceae by only immersed to erumpent, uniloculate ascostromata and aseptate to multi-septate, hyaline ascospores.

Saccothecium Fr., Fl. Scan.: 349 (1836).

Index Fungorum number: IF 4819; Facesoffungi number: FoF 00107; 9 morphological species (Species Fungorum 2020), 2 species with molecular data.

Type species - Saccothecium sepincola (Fr.) Fr.

Notes - Fries (1836) established Saccothecium and subsequently, several species were added to the genus based on morphology (Kirschstein 1938, 1939, Vasilyeva \& Mel'nik 2006). Pande (2008) introduced several Saccothecium species, which had been classified under Pringsheimia or Metasphaeria, but most are invalid (Index Fungorum 2020). This genus is characterized in having immersed to erumpent, uniloculate ascomata and hyaline, 3 to many septate, muriform to phragmosporous ascospores. 
Saccothecium sepincola (Fr.) Fr. [as 'saepincola'], Summa veg. Scand., Sectio Post. (Stockholm): 398 (1849).

Fig. 30

三Sphaeria sepincola Fr. [as‘saepincola'], Observ. mycol. (Havniae) 1: 181 (1815).

Index Fungorum number: IF 119497; Facesoffungi number: FoF 00108.

Description - see Thambugala et al. (2014a).

Material examined - Italy, Collinaccia - Castrocaro e Terra del Sole (province of ForlìCesena [FC]), on the twigs of Cornus sanguinea (Cornaceae), 3 March 2013, Erio Camporesi (MFLU 14-0276).
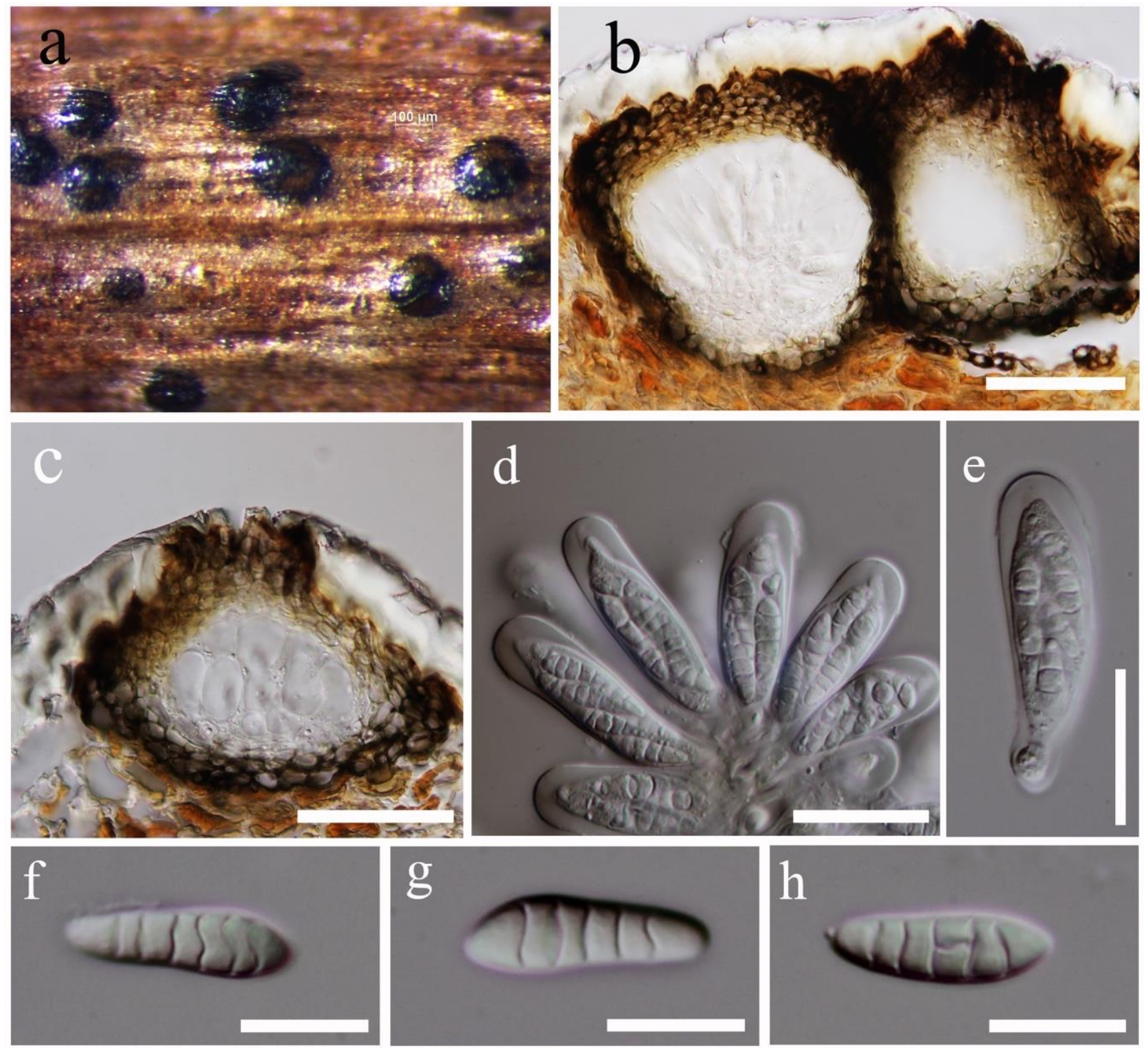

Figure 30 - Saccothecium sepincola (MFLU 14-0276). a Appearance of immersed ascostromata on the host surface. $b$, c Sections through ascostromata. d, e Bitunicate asci. $f-h$ Ascospores. Scale bars: $\mathrm{b}, \mathrm{c}=50 \mu \mathrm{m}, \mathrm{d}, \mathrm{e}=25 \mu \mathrm{m}, \mathrm{f}-\mathrm{h}=10 \mu \mathrm{m}$.

\section{Other genera included}

Aureobasidium Viala \& G. Boyer, Rev. gén. Bot. 3: 371(1891).

Index Fungorum number: IF 7297; Facesoffungi number: FoF 00098; 26 morphological species (Species Fungorum 2020), >7 species with molecular data.

Type species - Aureobasidium vitis Viala \& G. Boyer, Rev. gén. Bot. 3: 371 (1891).

Notes - The members of this genus are parasitic or saprobic on a wide range of plants, fruits and cause human skin diseases (Thambugala et al. 2014a, van Nieuwenhuijzen et al. 2016). No 
sexual morph has been linked to the genus. Aureobasidium is characterized by acervular to sporodochial conidiomata, hyaline to dark brown, aseptate, straight, ellipsoidal to sphaerical, reniform to sickle-shaped conidia.

Columnosphaeria Munk, Dansk bot. Ark. 15(no. 2): 103 (1953).

Index Fungorum number: IF 1193; Facesoffungi number: FoF 00100; 4 morphological species (Species Fungorum 2020), 1 species with molecular data.

Type species - Columnosphaeria sarothamni Munk, Dansk bot. Ark. 15(no. 2): 103 (1953).

Notes - Columnosphaeria is characterized by unilocular, immersed to erumpent ascostromata and hyaline to brown, aseptate, ellipsoidal-fusiform ascospores. Barr (2001) included five species which had been previously referred to Guignardia and Physalospora and placed Columnosphaeria in Dothioraceae. Barr (2001) transfered Discosphaerina fagi to Columnosphaeria based on morphology. Phyllosticta is considered as the current name of Columnosphaeria (Index Fungorum 2020). However, C. sarothamni, the type of Columnosphaeria does not share morphological features with Phyllosticta (Thambugala et al. 2014a). Hormonema, Sarcophoma and Aureobasidium species have been reported as the asexual morphs in culture (Barr 2001) and these asexual morphs are usually reported in Dothideales. Thambugala et al. (2014a) examined the type material of Columnosphaeria (C. sarothamni) and C. fagi, which grouped in Saccotheciaceae in their phylogenetic analysis which is similar to the present analysis. Based on the asexual morphs of Columnosphaeria species and the similarity between $C$. sarothamni and C. fagi, Thambugala et al. (2014a) accepted Columnosphaeria in Saccotheciaceae, Dothideales, although the type has morphological characters like Botryosphaeriaceae. Based on all these facts we also tentatively accept Columnosphaeria in Saccotheciaceae until fresh collections of $C$. sarothamni with DNA molecular data resolve the placement.

Kabatiella Bubák, Hedwigia 46: 297 (1907).

Index Fungorum number: IF 8656; Facesoffungi number: IF 00103; 19 morphological species (Species Fungorum 2020), 6 species with molecular data.

Type species - Kabatiella microsticta Bubák, Hedwigia 46: 297 (1907).

Notes - Kabatiella is characterized by polyblastic synchronous, inconspicuous scars on denticles, vesiculate conidiogenous cells and aseptate, hyaline, oblong to cylindrical conidia. Several authors have synonymized Kabatiella under Aureobasidium (Hermanides-Nijhof 1977, Sivanesan 1984), but Seifert et al. (2011) and Thambugala et al. (2014a) treated these two genera as separate. Kabatiella species need to be sequenced to resolve taxonomic boundaries of Aureobasidium and Kabatiella. No sexual morph has been linked to the genus.

Pseudoseptoria Speg., Anal. Mus. nac. B. Aires, Ser. 3 13: 388 (1910).

Index Fungorum number: IF 9614; Facesoffungi number: FoF 00134; 8 morphological species (Species Fungorum 2020), 3 species with molecular data. (1911).

Type species - Pseudoseptoria donacicola Speg., Anal. Mus. nac. B. Aires, Ser. 3 13: 388

Notes - Pseudoseptoria was established as an asexual genus in order to accommodate Pseudoseptoria donacicola (Spegazzini 1910). This coelomycetous genus is characterized by immersed, unilocular, ostiolate conidiomata of pale brown cells of textura angularis, discrete, determinate or indeterminate, ampulliform conidiogenous cells with a prominent cylindrical papilla and falcate, fusoid, hyaline, aseptate conidia acutely rounded at each end (Sutton 1980, Quaedvlieg et al. 2013, Thambugala et al. 2014a). Wijayawardene et al. (2012) treated this genus in Ascomycota, genera incertae sedis and Quaedvlieg et al. (2013) in Dothioraceae, while Thambugala et al. (2014a) and Wijayawardene et al. (2017a, b) accepted Pseudoseptoria as a distinct genus in Saccotheciaceae.

Pseudosydowia Thambug. \& K.D. Hyde, Fungal Diversity 68: 140 (2014). 
Index Fungorum number: IF 550733; Facesoffungi number: FoF 00105; 2 morphological species (Species Fungorum 2020), 2 species with molecular data.

Type species - Pseudosydowia eucalypti (Verwoerd \& du Plessis) Thambug. \& K.D. Hyde, in Thambugala et al., Fungal Diversity 68: 140 (2014).

$\equiv$ Sphaerulina eucalypti Verwoerd \& du Plessis, S. Afr. J. Sci. 28: 296 (1931).

Notes - The monotypic genus Pseudosydowia was described by Thambugala et al. (2014a) in Saccotheciaceae. The type species of this genus (Pseudosydowia eucalypti) was originally described by Verwoerd \& du Plessis (1931) as Sphaerulina eucalypti and later it was transferred to Sydowia based on its Sclerophoma and Hormonema asexual morphs and the thick-walled ascostromata (Crous et al. 2003b). However, more fresh collections and culture studies of Pseudosydowia need to be made in order to clarify the relationship with other genera in the family. The genus is characterized by amphigenous, subepidermal ascostromata, 2- to multi-seriate, hyaline ascospores, pycnidial to avervular, amphigenous conidiomata and aseptate, brown conidia.

Selenophoma Maire, Bull. Soc. bot. Fr. 53: clxxxvii (1907).

Index Fungorum number: IF 9869; Facesoffungi number: FoF 00109; 83 morphological species (Species Fungorum 2020), 6 species with molecular data.

Type species - Selenophoma catananches Maire [as 'catanaches'], Bull. Soc. bot. Fr. 53: clxxxvii (1906).

Notes - The genus is characterized by immersed, branched, septate, pale brown mycelium, with immersed or superficial, separate or aggregated, scattered pycnidial or avervular, lacking ostioles, conidiophores reduced to conidiogenous cells or hyaline, 1-3-septate, irregularly branched at the base and above. Conidiogenous cells are enteroblastic, phialidic, discrete, determinate, subglobose, obpyriform or obovoid, formed from the inner cell of the pycnidial wall, and hyaline to pale brown. Conidia are holoblastic, fusiform, ellipsoidal to obovoid, aseptate, hyaline or pale brown, eguttulate or irregularly guttulate, smooth- to verruculose-walled (Cheewangkoon et al. 2009, facesoffungi.org 2020). Sutton (1980) accepted five species in Selenophoma and the graminicolous Selenophoma species have been accommodated in Pseudoseptoria which is the earliest available generic name. Sutton (1996) introduced $S$. anniae, while Cheewangkoon et al. (2009) introduced $S$. australiensis with Hormonema as a synasexual morph. In the present phylogenetic analysis, three Selenophoma species ( $S$. australiensis, S. linicola and S. mahoniae) grouped in three different clades (Fig. 27) and this is similar to the results shown by Thambugala et al. (2014a). Therefore, more species including the type of this genus need to be re-collected and sequenced in order to confirm their taxonomic placement.

\section{Ecological and economic significance}

Saccotheciaceae is a species rich family with a cosmopolitan distribution. Members of this family are usually parasitic or saprobic on a wide range of plant twigs, wood and leaves or human skin. Aureobasidium pullulans has potential bioactivity against a wide range of plant diseases (Schena et al. 1999, Ippolito et al. 2000).

\section{Zalariaceae isagie, Z. Humphries \& Seifert, IMA Fungus 8 (2): 307 (2017).}

Index Fungorum number: IF 821627; Facesoffungi number: FoF 07667, 2 species.

Associated with house dust. Sexual morph: Undetermined. Asexual morph: Hyphomycetous. Colonies often covered in slimy masses of conidia or yeast-like cells, occasionally with sparse aerial mycelium; cream-colored, red-brown, olive-brown, dark brown, or black, becoming dark and often leathery with time; margins entire to slightly filiform or fimbriate. Hyphae longitudinally and transversely septate, hyaline and thin-walled when young, frequently becoming melanized and thick-walled with age, may develop into chlamydospores. Conidiogenous cells undifferentiated, intercalary, terminal uncommon, cylindrical, with blastic conidiogenesis occurring from one to two loci per cell. Chlamydospores brown to dark brown, globose to ellipsoidal, 1-septate to aseptate, sometimes constricted at the septum, smooth to lightly rough-walled. Conidia often yeast-like, 
hyaline, aseptate, smooth-walled, ellipsoidal with round or pointed ends, variable in shape and size, indistinct hilum, budding common, polar, bipolar and multilateral (Humphries et al. 2017).

Type - Zalaria Visagie, Z. Humphries \& Seifert.

Notes - Zalariaceae was proposed to accommodate a new genus with two species which resembles the asexual morphs of Aureobasidium and Hormonema. Humphries et al. (2017) treated Zalariaceae as a distinct family in Dothideales mainly based on multi-gene phylogenies. Zalariaceae is phylogenetically distinct from Aureobasidiaceae and Dothideaceae (Thambugala et al. 2014a).
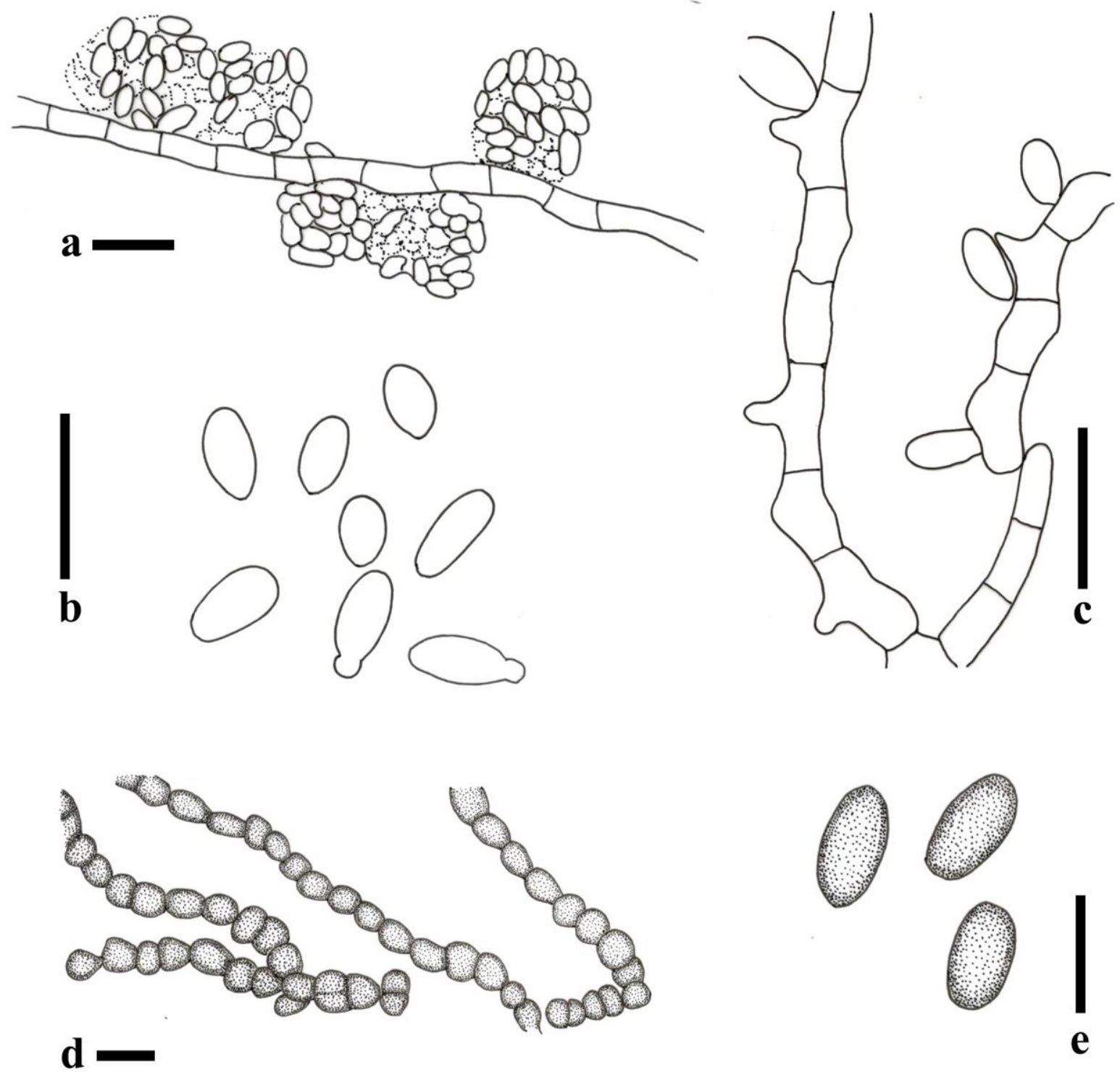

Figure 31 - Zalaria obscura (redrawn from Humphries et al. 2017, DAOMC 250849, ex-type culture). a Intercalary conidiogenous cells. b Conidia. c Intercalary conidiogenous cells. $\mathrm{d}$ Melanized hyphae developing into chlamydospores. e Chlamydospores.

Zalaria Visagie, Z. Humphries \& Seifert, in Humphries et al., IMA Fungus 8(2): 307 (2017).

Index Fungorum number: IF 821628; Facesoffungi number: FoF 07668; 2 morphological species (Species Fungorum 2020), 2 species with molecular data.

Type species - Zalaria obscura Visagie, Z. Humphries \& Seifert.

Notes - Humphries et al. (2017) established the genus with two new species, Zalaria alba and Z. obscura. These species are black yeast-like terrestrial taxa, which grow restrictedly and 
produce conidiogenous cells with holoblastic synchronous or percurrent conidiation. Zalaria is closely related to Hormonema in having only one to two loci per conidiogenous cell, but Zalaria is different as it generally has a more restricted growth. No sexual morph has been reported for Zalaria (Humphries et al. 2017).

Zalaria obscura Visagie, Z. Humphries \& Seifert, in Humphries, Seifert, Hirooka \& Visagie, IMA Fungus 8(2): 309 (2017).

Fig. 31

Index Fungorum number: IF 821630; Facesoffungi number: FoF 07669.

Description - see Humphries et al. (2017).

\section{Ecological and economic significance}

Members of Zalariaceae are indoor species generally associated with house dust and they have been so far reported only from Canada and the USA. Species of this family may be capable of widespread dispersal and also survive in or on many substrates (Humphries et al. 2017).

\section{Myriangiales Starbäck}

Index Fungorum number: IF 90486; Facesoffungi number: FoF 08098.

Myriangiales was introduced by Starbäck (1899) for species characterized by crustose ascostromata and muriform ascospores, based on the type species, Myrangium duriaei (Hyde et al. 2013). Kirk et al. (2008) included three families in order Myriangiales, Cookellaceae, Elsinoaceae and Myriangeaceae. Lumbsch \& Huhndorf (2010) accepted only Elsinoaceae and Myriangeaceae in Myriangiales based on phylogenetic results. Our phylogenetic analyses from ITS, LSU, rpb-2 and SSU (Fig. 32) showed that Myriangiales has two major clades, Elsinoaceae and Myriangeaceae. Both families are well-separated (Fig. 32). Phylogenetic analyses generated from LSU data (not shown) indicated that Endosporium clusters basal to Myriangiales. However, it does not cluster in Myriangiales when using four loci (ITS, LSU, rpb-2 and SSU sequence data are used (Fig. 32). Thus, we retain this genus as incertae sedis. The divergence time for Myriangiales is estimated as 130 MYA (stem age) (Fig. 2).

Accepted families: Elsinoaceae, Myriangeaceae.

Elsinoaceae Höhn. ex Sacc. \& Trotter, Syll. fung. (Abellini) 22: 584 (1913).

Index Fungorum number: IF 82022; Facesoffungi number: FoF 05764, 200 species.

Parasitic or saprotrophic on plant leaves and fruits causing scab and sunken scab-like blemishes. Sexual morph: Pseudoascostromata usually spread around host veins, solitary, aggregated, or gregarious, wart-like or scab-like blemishes, pulvinate, superficial, globose to subglobose, white, pale yellow to brown, multi-loculate, locules scattered in upper part of pseudoascostromata. Cells of pseudoascostromata comprising host cells and inter dispersed light coloured fungal hyphae, opening by unordered break down of the surface layer. Locules with 3-10 asci inside each locule, ostiolate. Ostioles minute. Hamathecium lacking pseudoparaphyses. Asci 8spored, bitunicate, fissitunicate, saccate to globose, with a minute pedicel, and indistinct ocular chamber. Ascospores irregularly arranged, oblong or fusiform with slightly acute ends, hyaline, 2-3 transverse septa, smooth-walled, lacking a sheath. Asexual morph: Coelomycetous "Sphaceloma". Lesions circular, dark brown raised margin, cream-brown. Acervuli subepidermal, pseudoparenchymatous. Conidiophores hyaline to pale-brown, polyphialidic. Conidiogenous cells formed directly from the upper cells of the pseudoparenchyma, monophialidic to polyphidalic, integrated or discrete, determinate, hyaline to pale brown, lacking a thickened region around the phialide channel. Conidia ellipsoidal, hyaline, unicellular, aseptate, biguttulate.

Type - Elsinoe Racib.

Notes - Höhnel (1909a) invalidly introduced "Elsinoëen" based on habitat and development studies. Saccardo \& Trotter (1913) proposed Elsinoaceae, and many studies placed this family in synonymy with Myriangiaceae (Jayawardena et al. 2014) based on pulvinate immersed or erumpent irregular pseudoascostromata and being restricted to foliar pathogens. Elsinoaceae has also been referred as Plectodiscellaceae a family established by Woronichin (1914) based on a single species 
Plectodiscella piri, which he found on the leaves of apples and pear. However, based on observations of their restricted hosts, Barr (1979a, 1987b) and Eriksson (1981) suggested that Elsinoaceae should be treated as a separate family within Myriangiales. Phylogenetic evidence to support this theory was provided by Schoch et al. (2006, 2009a), Boehm et al. (2009a), Hyde et al. (2013) and Jayawardena et al. (2014). Lumbsch \& Huhndorf (2010) included ten genera in Elsinoaceae. Jayawardena et al. (2014) revised this family based on morphology, accepting only two genera, Elsinoe and Molleriella.

Although, Index Fungorum (2020) included Beelia in Elsinoaceae, we retain its position in Chaetothyriaceae based on its asci with a very clear ocular chamber, and hyaline to straw-coloured ascospores, with a narrow mucilage sheath. In Elsinoaceae, they have pseudoascostromata with clear locules, 3-10 asci, with indistinct/minute ocular chambers, and hyaline spores, without mucilage sheath. $\mathrm{Li}$ et al. (2011) mentioned that Beelia is similar to Ainsworthia/Phaeosaccardinula rather than Elsinoe.

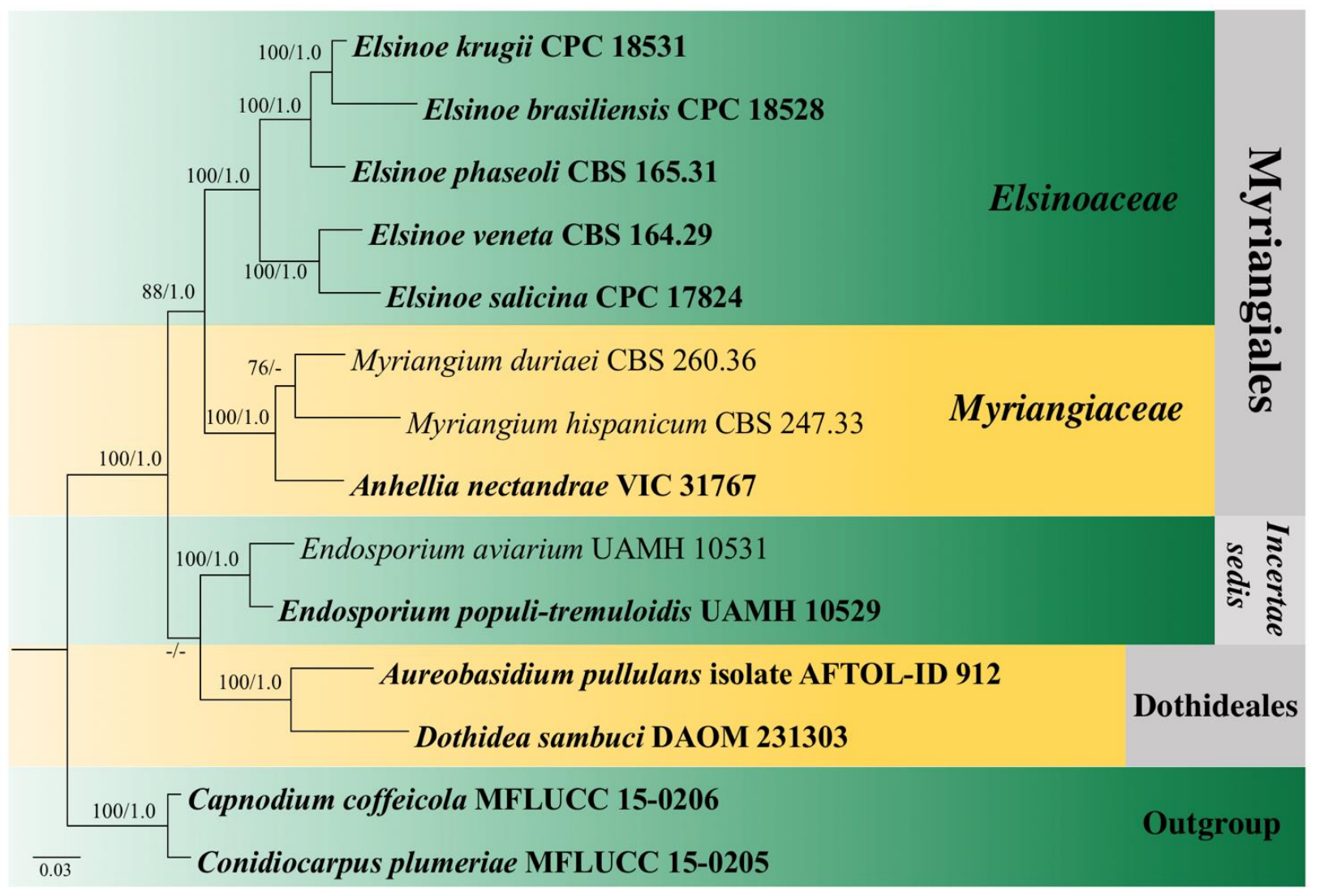

Figure 32 - Phylogram generated from maximum likelihood analysis (RAxML) of Myriangiales based on ITS, LSU, rpb-2 and SSU sequence data. Maximum likelihood bootstrap values equal or above $70 \%$, Bayesian posterior probabilities equal or above 0.90 (MLBS/PP) are given at the nodes. Isolate/specimen number is noted after the species name. The tree is rooted to Capnodium coffeicola (MFLUCC 15-0206), C. plumeriae (MFLUCC 15-0205). The ex-type strains are indicated in bold. Hyphen (-) represents support values below 70 \% MLBS and 0.90 PP.

Elsinoe Racib. [as 'Elsinoë'], Parasit. Alg. Pilze Java's (Jakarta) 1: 14 (1900).

Index Fungorum number: IF 1764; Facesoffungi number: FoF 05846; 194 morphological species (Species Fungorum 2020), >75 species with molecular data.

Type species - Elsinoe canavaliae Racib.

Notes - Elsinoe is the type genus of Elsinoeaceae, and it was established by Raciborski (1900) with descriptions of three species ( $E$. canavaliae, $E$. antidesmae and $E$. meninspermacearum). This genus is an important phytopathogen, causing scab diseases on economically important plants (Hyde et al. 2013, Jayawardena et al. 2014, Fan et al. 2017). 
Sphaceloma de Bary is the asexual morph of Elsinoe. Fan et al. (2017) and Jayawardena et al. (2019) reconstructed the backbone phylogeny of this genus based on ITS, LSU, rpb-2 and tef1. Jayawardena et al. (2019) provided background information to this genus as well as disease symptoms, distribution, hosts, morphology and best genes to identify to the species level.

Elsinoe canavaliae Racib. [as 'canavalliae'], Parasit. Alg. Pilze Java's (Jakarta) 1: 14 (1900).

Index Fungorum number: IF 627279; Facesoffungi number: FoF 05847.

Fig. 33

Description - see Jayawardena et al. (2014).

Material examined - Philippines. Laguna Province: Mount Maquiling, near Los Baños, on Canavalia ensiformis (Fabaceae), Baker, August 1913 (S F66900, isotype).

\section{Other genera accepted}

Molleriella G. Winter, Bolm Soc. broteriana, Coimbra, sér. 1 4: 199 (1886).

Index Fungorum number: IF 522278; Facesoffungi number: FoF 07375; 6 morphological species (Species Fungorum 2020), molecular data unavailable.

Type species - Molleriella mirabilis G. Winter.

Notes - Molleriella, introduced by Winter (1886) was placed in the class Discomycetes. Based on its morphology, Engler et al. (1897), and Hieronymus \& Hennings (1901) placed this genus in Phymatophaeriaceae in Dothideomycetes. Later, Boedjin (1961) placed Molleriella in Saccardaiaceae. It was transferred to Myriangiaceae (Arnaud 1918) and to Elsinoaceae (Kirk et al. 2001, Lumbsch \& Huhndorf 2007, 2010). Jayawardena et al. (2014) accepted this genus in Elsinoaceae based on morphological characters. It is a saprotrophic genus, characterized by locules with 4-10 asci inside each locule, asci with a minute pedicel, and irregularly arranged 6-8-septate, muriform, hyaline ascospores (see morphology in Jayawardena et al. 2014).

Molleriella mirabilis G. Winter, Bolm Soc. broteriana, Coimbra, sér. 1 4: 199 (1886).

Fig. 34

Index Fungorum number: IF 528389; Facesoffungi number: FoF 07376.

Description - see Jayawardena et al. (2014).

Material examined - Africa, S. Thomé Insel, pr. Bate-pá, on Convolvulaceae, A. Moller, June 1885 (S F51162, type).

\section{Ecological and economic significance}

Elsinoe include several plant pathogenic species of major importance causing diseases of a wide variety of plants, appearing to be host-specific (Hyde et al. 2013, Jayawardena et al. 2014, Fan et al. 2017, Jayawardena et al. 2019). Fruit production is especially affected.

Myriangiaceae Nylander, Memoires de la Societe Imperiale des Sciences Naturelles de Cherbourg 2: 9 (1854).

Index Fungorum number: IF 81866; Facesoffungi number: FoF 06552, 76 species.

Saprobic on bark, leaves and branches, some genera epiphytic or parasitic on leaves. Sexual morph: Ascostromata superficial, scattered, solitary or aggregated, coriaceous to sub-carbonaceous, semi-immersed to immersed to erumpent, generally dark, globose to oval, sometimes surrounded by the remains of the ruptured epidermis, multi-loculate, locules generally in the upper layer or scattered throughout the ascostromata. Locules with single ascus, ostiolate. Ostiole minute or asci pushed out through pseudoparenchymatous cells. Hamathecium paraphyses absent. Cells of ascostromata comprising pseudo-parenchymatous cells of pale yellow to brown pigmented textura angularis, textura globusa or textura intrica. Asci 8-spored, bitunicate, fissitunicate, globose to subglobose, apedicellate or with a minute pedicel, apically rounded with indistinct ocular chamber. Ascospores irregularly arranged, oblong or fusiform with slightly acute ends, hyaline to sub-hyaline or brown, muriform, with 1-9-transverse septa, with 0-5-longitudinal septa, smooth-walled to verruculose, rarely having a sheath. Asexual morph: Unknown.

Type - Myriangium Montagne \& Berkeley. 

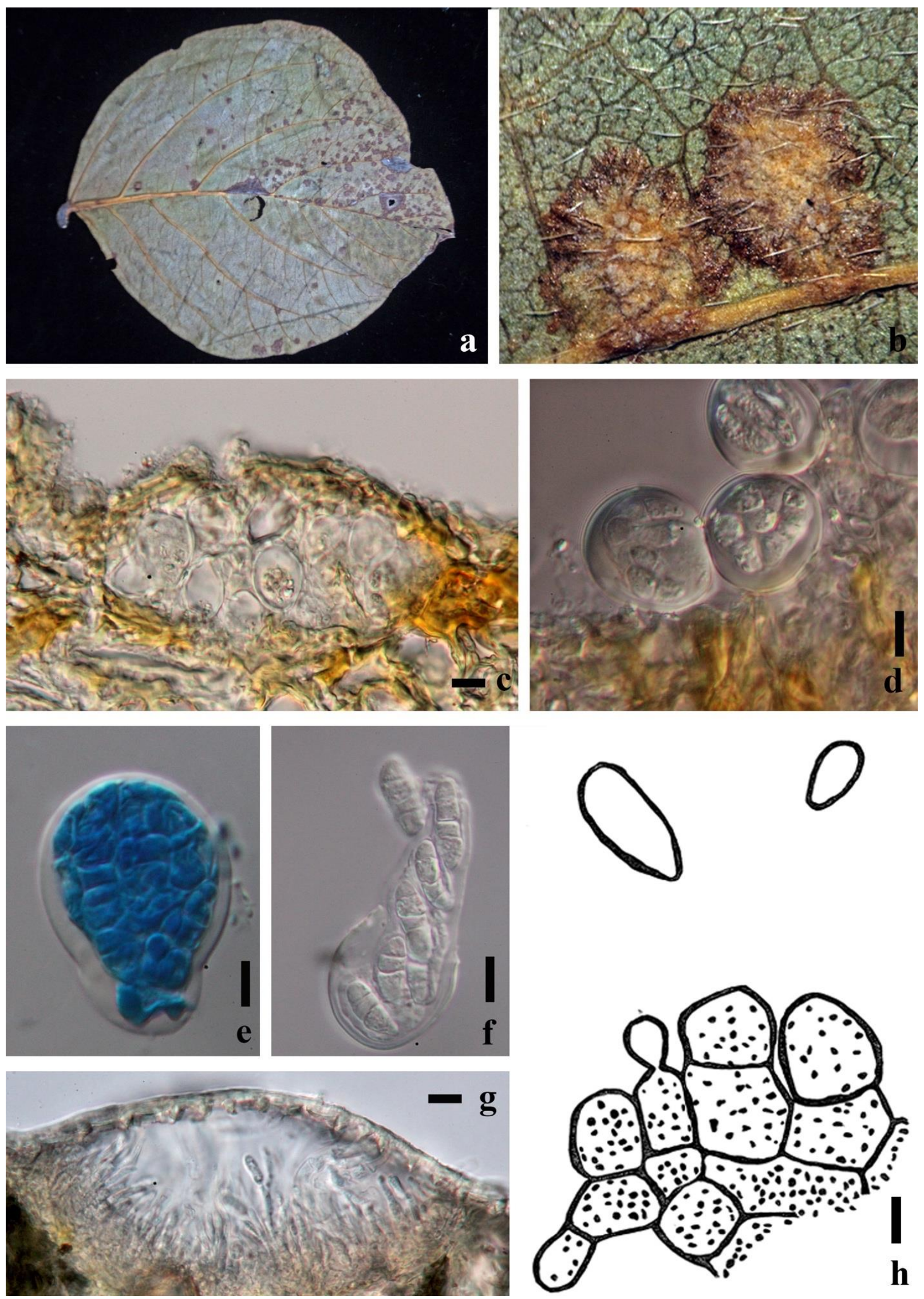

Figure 33 - Elsinoë canavaliae (S F66900, isotype). a Herbarium material. b Pseudoascostromata on host substrate. c Section of pseudoascostroma. $d$ Asci with eight irregularly arranged ascospores. e Ascus stained with cotton blue reagent. f Fissitunicate dehicnese of the ascus. g Section of conidiomata. h Phialidic conidiogenous cells and conidia of Sphaceloma ampelinum material redrawn from Sutton \& Pollok (1973). Scale bars: c, $g=100 \mu \mathrm{m}, \mathrm{d}-\mathrm{f}, \mathrm{h}=10 \mu \mathrm{m}$. 

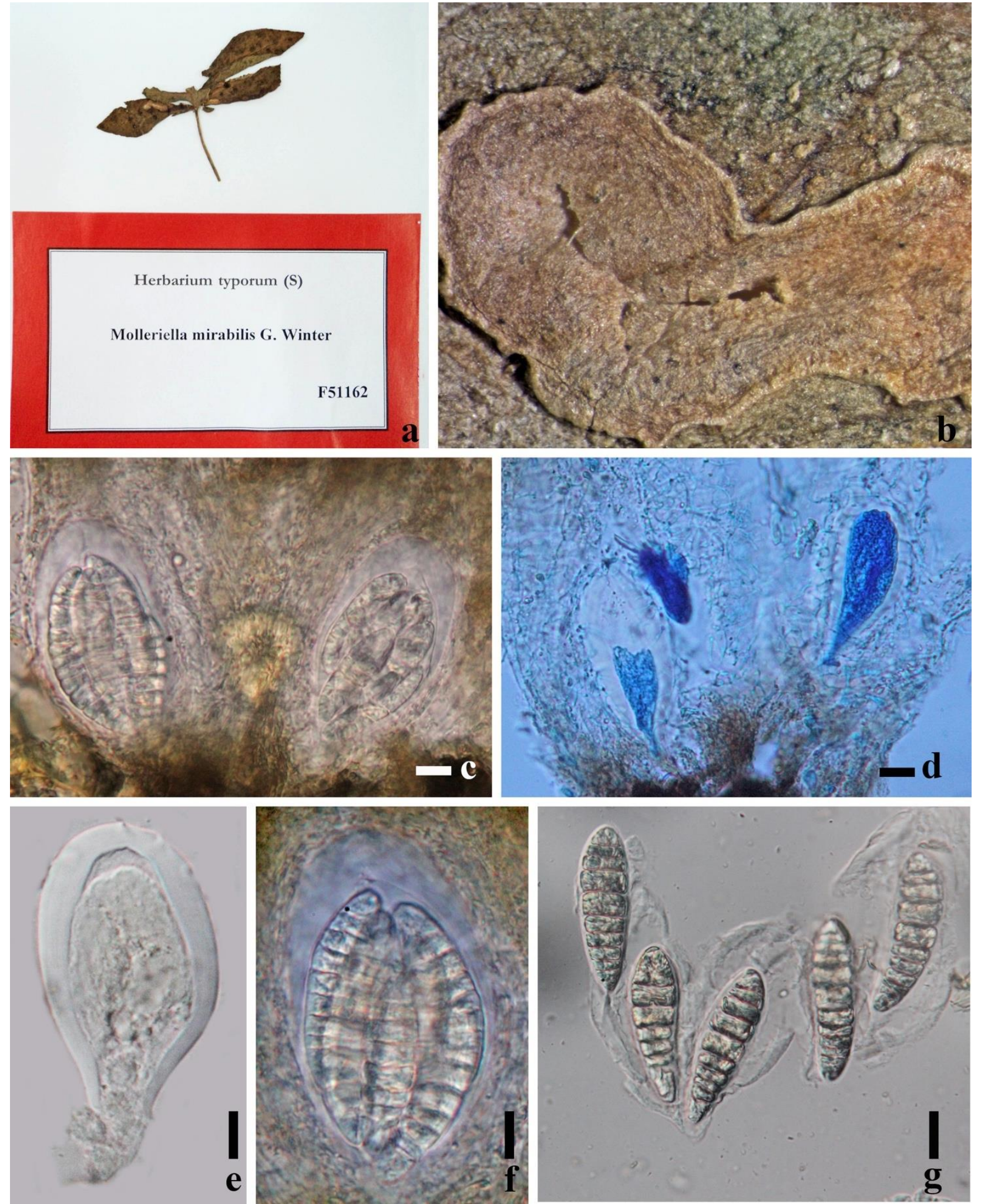

Figure 34 - Molleriella mirabilis (S F51162, type). a Herbarium material. b Pseudoascostromata on host substrate. c, d Section through pseudoascostroma. e Immature ascus. f Mature ascus with irregularly arranged hyaline 6-8-septate ascospores. g Ascospore stained in cotton blue. Scale bars: $\mathrm{c}, \mathrm{d}=100 \mu \mathrm{m}, \mathrm{e}-\mathrm{g}=10 \mu \mathrm{m}$.

Notes - Myriangiaceae was introduced by Nylander (1854) to accommodate Myriangium duriaei and M. curtisii. Due to ascostromata and locules, Clements \& Shear (1931) placed Myriangiaceae in Dothidealeas. However, von Arx (1963) treated this family in Myriangiales. Many studies have placed Elsinoaceae in synonymy with Myriangiaceae. However, Höhnel 
(1909a), Barr (1979a) and Eriksson (1981) were convinced that they were separate families. Schoch et al. (2006), Lumbsch \& Huhndorf (2010) and Jayawardena et al. (2014) provided molecular evidence to maintain Elsinoaceae and Myriangiaceae as separate families. Dissanayake et al. (2014) included ten genera in this family based on morphological characters.

Myriangium Mont. \& Berk., in Berkeley, London J. Bot. 4: 72 (1845).

Index Fungorum number: IF 3361; Facesoffungi number: FoF 06553; 38 morphological species (Species Fungorum 2020), 4 species with molecular data.

Type species - Myriangium duriaei Mont. \& Berk.

Notes - Wolf \& Wolf (1947) considered that M. curtisii, M. duriaei, M. montagnei and M. thwaitesii are parasitic on scale insects. During the study of morphology and cytology of $M$. duriaei and M. curtsii, Miller (1938) found that both of these species occur as parasites on scale insects attacking Nyssa sylvatica and Carya illinoensis.

Myriangium duriaei Mont. \& Berk., in Berkeley, London J. Bot. 4: 73 (1845).

Fig. 35

Index Fungorum number: IF 218324; Facesoffungi number: FoF 08099.

Description - see Dissanayake et al. (2014).

Material examined - Algeria, MC Durieu de Maisonneuve, on Lentiscos vivos (= Pistacia lentiscus, Anacardiaceae) (PC NL 8414, holotype).

\section{Other genera accepted}

Anhellia Raciborski, Parasitische Algen und Pilze Javas 2: 10 (1900).

Index Fungorum number: IF 197; Facesoffungi number: FoF 06538; 9 morphological species (Species Fungorum 2020), 1 species with molecular data.

Type species - Anhellia tristis Racib., Parasit. Alg. Pilze Java's (Jakarta) 2: 10 (1900).

Notes - Anhellia was introduced by Raciborski (1900) in the "Myriangiearum" to accommodate $A$. tristis Racib. This genus remained monotypic until von Arx (1963) introduced $A$. calami, A. escharoides, A. purpurascens, A. lantanae and A. nigra. Luttrell (1973) placed the genus in Myriangiaceae. This genus is characterized with hyaline or yellowish brown, elliptical to oblong, muriform ascospores with 4-5-transverse septa and 1-2-longitudinal septa. Pinho et al. (2012) investigated the phylogenetic position of Anhellia in Myriangiales by analysis of nucleotide sequence data of ITS and LSU gene regions. Subsequently, Hyde et al. (2013) and Jayawardena et al. (2014) in their phylogenetic analyses based on ITS, LSU, rpb-2, SSU and tef1 provided evidence to support the placement of this genus in Myriangiaceae.

Ascostratum Syd. \& P. Syd., Annls mycol. 10(1): 41 (1912).

Index Fungorum number: IF 380; Facesoffungi number: FoF 06539; 2 morphological species (Species Fungorum 2020), molecular data unavailable.

Type species - Ascostratum insigne Syd. \& P. Syd., Annls mycol. 10(1): 41 (1912).

Notes - Ascostratum was introduced by Sydow \& Sydow (1912a) and was typified by Ascostratum insigne. The genus was placed in Dothideomycetes, genera incertae sedis by Lumbsch \& Huhndorf (2010). This genus can be differentiated from other genera of the family by a prominent stalk in ascostromata connecting to the host (Dissanayake et al. 2014). Based on morphology Dissanayake et al. (2014) placed this genus in Myriangiaceae. Fresh collections and sequence data are needed for this genus to establish its familial position in Dothideomycetes.

Butleria Sacc., Annales Mycologici 12: 302 (1914).

Index Fungorum number: IF 692; Facesoffungi number: FoF 06542; 1 morphological species (Species Fungorum 2020), molecular data available for B. bissexguttatus. (1914).

Type species - Butleria inaghatahani Sacc. [as 'inaghatahani'], Annls mycol. 12(3): 303

Notes - Butleria is a monotypic genus and was placed in Myriangiaceae by von Arx \& Müller (1975). However, Barr (1979a) placed this genus in Elsinoacae and Lumbsch \& Huhndorf 
(2007, 2010), Li et al. (2011) and Hyde et al. (2013) followed this classification. This genus has similarities with Elsinoaceae in being a parasite on leaves, but differs in having ascostromata on both sides of the leaves, with single asci with a small ocular chamber in each locule and shows similarity to Myriangiaceae in having globose, single asci in each locule. Butleria can be characterized Myriangiaceae by its brown ascospores. Therefore, Jayawardena et al. (2014) excluded this genus from Elsinoaceae and placed it in Myriangiaceae. Dissanyake et al. (2014) followed this. Fresh collections and sequence data are needed to establish it familial position in Dothideomycetes.

Dictyocyclus Sivan., W.H. Hsieh \& Chi Y. Chen, J. Linn. Soc., Bot. 126(4): 324 (1998).

Index Fungorum number: IF 27900; Facesoffungi number: FoF 06544; 1 morphological species (Species Fungorum 2020), molecular data unavailable.

Type species - Dictyocyclus hydrangeae Sivan., W.H. Hsieh \& Chi Y. Chen, Bot. J. Linn. Soc. 126(4): 324 (1998).

Notes - Sivanesan et al. (1998) introduced this monotypic genus in Parmulariaceae. However, Dictyocyclus has similar characteristics to Myriangium, including single ascus inside each locule and muriform ascospores. Therefore, Dissanayake et al. (2014) based on morphology alone placed this genus in Myriangiaceae. Fresh collections and sequence data are needed to establish its familial position in Dothideomycetes. This is an epifoliar genus, characterized by muriform ascospores with 3-5 transverse septa, and one longitudinal or oblique septum in each of the end cells (Dissanayake et al. 2014).

Eurytheca De Seynes, Bull. Soc. bot. Fr. 25: 88 (1878).

Index Fungorum number: IF 197; Facesoffungi number: FoF 06546; 3 morphological species (Species Fungorum 2020), molecular data unavailable.

Type species - Eurytheca trinitensis Syd. \& P. Syd., Annls mycol. 13(1): 40 (1915).

Notes - Eurytheca was placed in Saccardiaceae by Höhnel (1917b). However, Wolf \& Wolf (1947) mentioned that this genus belongs to "Myriangiaceen". Lumbsch \& Huhndorf (2007) placed this genus in Myriangeaceae and this classification was followed in Hyde et al. (2013) and Dissanayake et al. (2014). This genus has carbonaceous ascostromata and ascospores with 3-6 transverse septa without longitudinal septa (Dissanayake et al. 2014). Fresh collections and phylogenetic analysis are needed to confirm the familial placement of this genus in Dothideomycetes.

Hemimyriangium J. Reid \& Piroz, Can. J. Bot. 44: 650 (1966).

Index Fungorum number: IF 2284; Facesoffungi number: 06548; 3 morphological species (De Almeida et al. 2014, Species Fungorum 2020), molecular data unavailable.

Type species - Hemimyriangium betulae J. Reid \& Piroz., Can. J. Bot. 44: 651 (1966).

Notes - This monotypic genus was placed in Myriangiaceae by Reid and Pirozynski (1966b). Lumbsch \& Huhndorf (2007) placed Hemimyriangium in Elsinoaceae and this was followed in Hyde et al. (2013). However, this taxon appears to be more similar to Myriangium in having superficial ascostromata with a single ascus in each locule and in the arrangement of locules in the outer layer of the ascostromata as well as due to its saprobic nature, but differs by ascospores without longitudinal septa. Therefore, Jayawardena et al. (2014) excluded this genus from Elsinoaceae and Dissanayake et al. (2014) treated it in Myriangiaceae. Fresh collections and molecular analyses are needed to clarify the familial position of this genus.

Mendogia Racib, Parasit. Alg. Pilze Java's (Jakarta) 3: 31 (1900).

Index Fungorum number: IF 3119; Facesoffungi number: FoF 01951; 4 morphological species (Species Fungorum 2020), 1 species with molecular data.

Type species - Mendogia bambusina Racib., Parasit. Alg. Pilze Java's (Jakarta) 3: 31 (1900).

Notes - Mendogia was introduced by Raciborski (1900) and typified by M. bambusina. von Arx \& Müller (1975) treated Mendogia in Schizothyriaceae and this was subsequently followed by 
Kirk et al. (2008), Lumbsch \& Huhndorf (2010), Hyde et al. (2013) and Wijayawardene et al. (2014b). Based on morphology and phylogeny Dai et al. (2017) excluded it from Schizothyriaceae and accepted placement in Myriangiaceae. This genus is characterized by asci separated by paraphysoid-like filaments or pseudoparenchymatous cells.
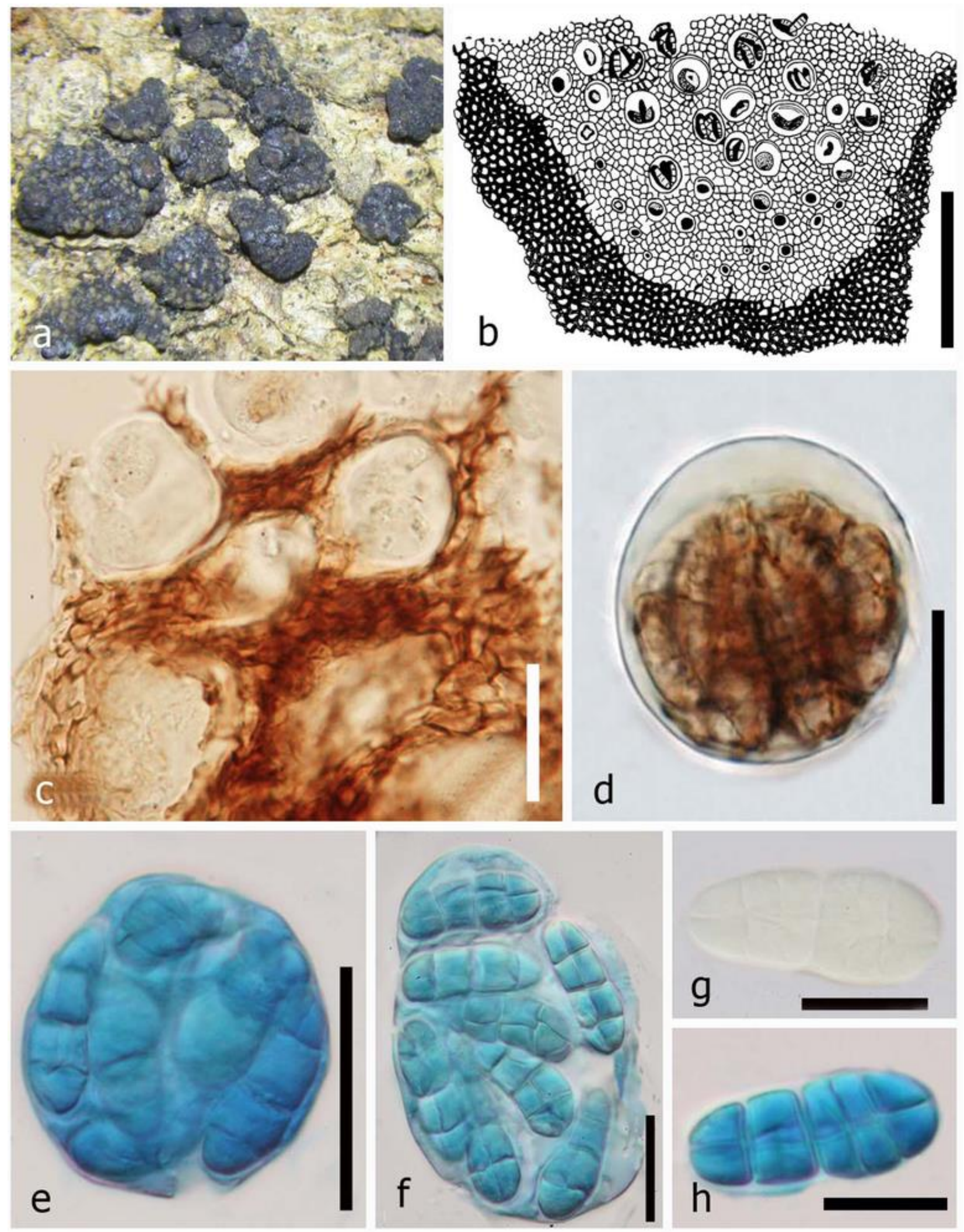

Figure 35 - Myriangium duriaei (PC-NL 8414, holotype). a Ascostromata on host surface. $\mathrm{b}$, c Locules in the cross-section of the ascostromata (Material redrawn from Ernst Albert Gäumann, 1928). d Apedicellate asci with 8 ascospores. e-f Asci stained in cotton blue reagent. 
g muriform, hyaline ascospore. $\mathrm{h}$ Ascospore stained in cotton blue reagent. Scale bars: $\mathrm{b}=500 \mu \mathrm{m}$, $\mathrm{c}-\mathrm{e}=30, \mathrm{f}=20, \mathrm{~g}, \mathrm{~h}=10 \mu \mathrm{m}$.

Micularia Boedijn, Persoonia 2(1): 67 (1961).

Index Fungorum number: IF 3207; Facesoffungi number: 06550; 2 morphological species (Species Fungorum 2020), molecular data unavailable.

Type species - Micularia merremiae Boedijn, Persoonia 2(1): 67 (1961).

Notes - Boedijn (1961) placed this genus in Saccardiaceae. Lumbsch \& Huhndorf (2007, 2010) placed Micularia in Elsinoaceae and this placement was followed by Hyde et al. (2013). Even though it is a parasite on leaves, the inclusion of this genus in Elsinoaceae causes confusion, as it has only one ascus in each locule. Therefore, Jayawardena et al. (2014) excluded this genus from Elsinoaceae and Dissanayake et al. (2014) placed it in Myriangiaceae as it is characterized by ascospores with 1-transverse septum.

Uleomyces Henn., Hedwigia 34: 107 (1895).

Index Fungorum number: IF 5657; Facesoffungi number: FoF 03682; 11 morphological species (Species Fungorum 2020), molecular data unavailable.

Type species - Uleomyces parasiticus Henn., Hedwigia 34: 107 (1895).

Notes - Uleomyces was introduced by Hennings (1895) to accommodate U. parasiticus and was placed in Hypocreaceae. Barr (1997) accepted Uleomyces in Cookellaceae and Lumbsch \& Huhndorf (2010) followed this. Boonmee et al. (2017) accepted this genus in Myriangiaceae based on morphological characters. This genus can be distinguished from other genera of this family by its dark red stromata and being the only fungicolous member.

Zukaliopsis Henn., Hedwigia 43: 367 (1904).

Index Fungorum number: IF 5882; Facesoffungi number: 06554; 2 morphological species (Species Fungorum 2020), molecular data unavailable.

Type species - Zukaliopsis amazonica Henn., Hedwigia 43(6): 367 (1904).

Notes - Theissen \& Sydow (1917b) placed this genus into Myriangiaceae providing a detailed description. Höhnel (1928) proposed that Zukaliopsis is related to Molleriella. However, von Arx (1963) suggested that this genus resembles a transition to Saccardinula more than Molleriella. Dissanyake et al. (2014) studied the isotype of Z. amazonica and observed that it has one ascus in each locule. Therefore, they retained Zukaliopsis in Myriangiaceae. This genus is characterized by muriform ascospores with 4-6-transverse septa, and 0-1-longitudinal septum. However, new collections and molecular data are needed to clarify its familial placement.

\section{Ecological and economic significance}

Species of Myriangiaceae are saprobes or epiphytes and a few species may cause diseases on bark, leaves and branches of various plants or be parasitic on scale insects (Hyde et al. 2013, Dissanyake et al. 2014).

\section{Pleosporomycetidae}

The subclass comprised the single order Pleosporales in Schoch et al. (2006), while Schoch et al. (2009a) included Mytilinidiales and Hysteriales within this subclass. Lumbsch \& Huhndorf (2010) included 28 families and 175 genera in Pleosporomycetidae. Hyde et al. (2013) accepted only Pleosporales, Mytilinidiales and Hysteriales in Pleosporomycetidae. This was supported by Liu et al. (2017a). Our phylogenetic analyses (Fig. 1) indicates that Trypetheliales groups within Pleosporomycetidae, while the MCC tree (Fig. 2) shows that Pleosporomycetidae includes only Gloniales, Hysteriales, Mytilinidiales and Pleosporales. Pleosporomycetidae has a stem age of 238 MYA (Fig. 2).

Gloniales Jayasiri \& K.D. Hyde Index Fungorum number: IF 553002; Facesoffungi number: FoF 03250. 
Boehm et al. (2009a) placed Gloniaceae in Pleosporomycetidae families, incertae sedis, because of inadequate phylogenetic sequence evidence to raise the family to ordinal status. Jayasiri et al. (2017a), however, introduced a new genus, thus increasing the numbers of taxa for this group supported by molecular data and Jayasiri et al. (2018) introduced new order Gloniales. The divergence time for Gloniales is estimated as 109 MYA (stem age) (Fig. 2).

Accepted families: Gloniaceae.

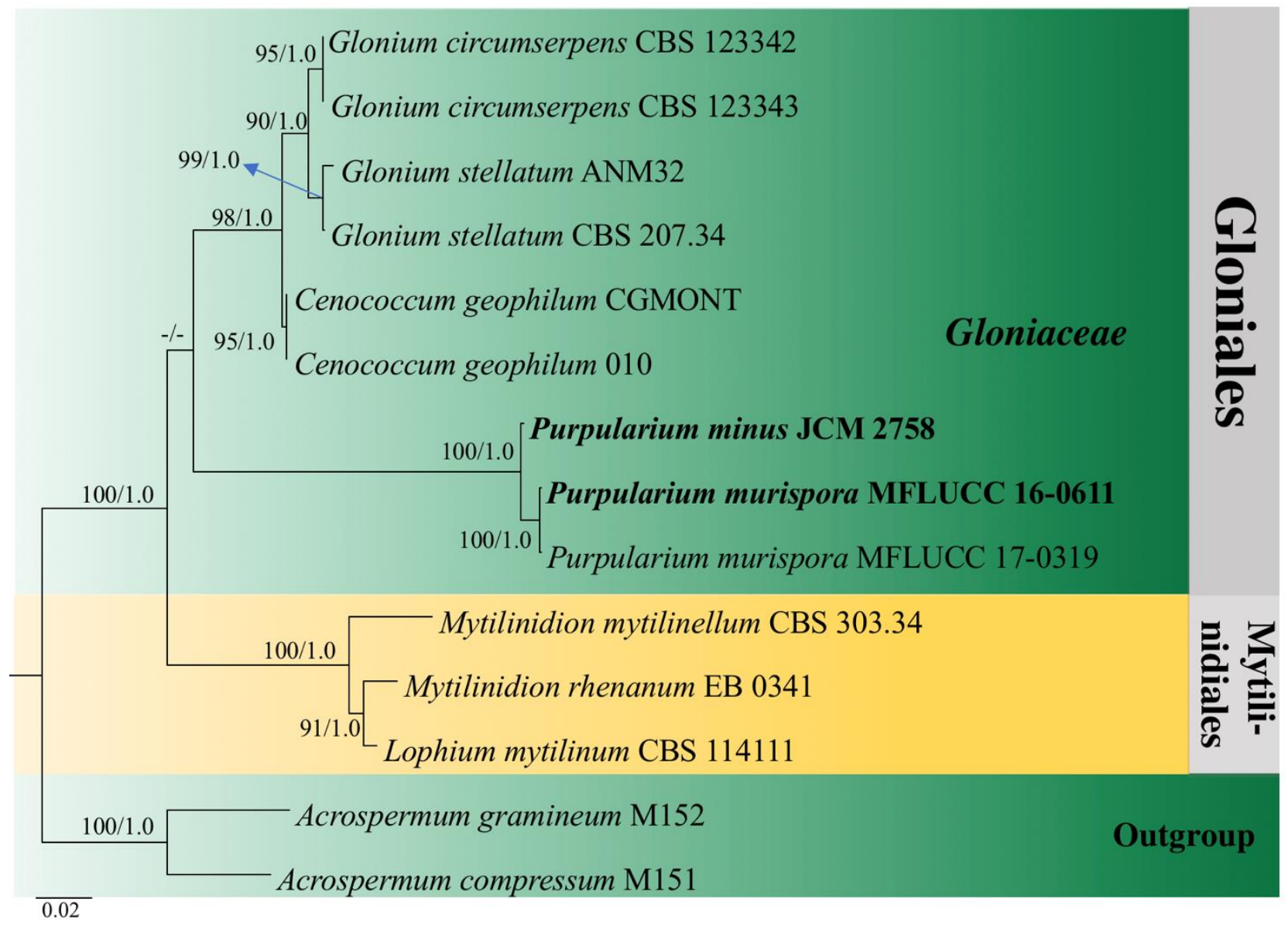

Figure 36 - Phylogram generated from maximum likelihood analysis (RAxML) of Gloniales based on LSU, rpb-2, SSU and tef1 sequence data. Maximum likelihood bootstrap values equal or above $70 \%$, Bayesian posterior probabilities equal or above 0.90 (MLBS/PP) are given at the nodes. Isolate/specimen number is noted after the species name. The tree is rooted to Acrospermium compressum (M151) and A. gramineum (M152). The ex-type strains are indicated in bold. Hyphen (-) represents support values below $70 \%$ MLBS and 0.90 PP.

Gloniaceae (Corda) Boehm et al., Mycol. Res. 113: 468 (2009).

Index Fungorum number: IF 511999; Facesoffungi number: FoF 02166, 40 species.

Saprobic or ectomycorrhizal on bark, wood, pine cones or soil. Sexual morph: Hysterothecia dark, erumpent to superficial, progressively dichotomously branched or scattered to gregarious, Peridium wide, thick, three-layered, carbonaceous and brittle when dry. Hamathecium comprising persistent narrow cellular pseudoparaphyses, septate, wide, hyaline, branched with darkened apices, in a gel matrix. Asci 8-spored, fissitunicate, clavate to cylindrical. Ascospores overlapping 2-seriate, hyaline, lightly pigmented to dark brown, 2-celled to muriform. Asexual morph: psiloglonium stygium-like (Boehm et al. 2009a, Jayasiri et al. 2017a).

Type - Glonium Mühl.

Notes - Boehm et al. (2009b) elevated the genus to family rank and Boehm et al. (2009a) justified reinstating Gloniaceae and, more importantly, recognising it at family rank for a single genus, because of the high support the group received in a four-gene phylogenetic analysis. The 
family comprises two other genera, Cenococcum and Purpurepithecium (Spatafora et al. 2012, Jayasiri et al. 2017a).

Glonium Mühl. Cont. Lab. Plant Disease Sci. Fac. Agric. Gifu Univ.101 (1813).

= Solenarium Spreng., Syst. veg. 4(1): 376, 414 (1827).

= Psiloglonium Höhn., Annls. mycol. 16(1): 149 (1918).

Index Fungorum number: IF 561180; Facesoffungi number: FoF 02167; 36 morphological species (Species Fungorum 2020), 3 species with molecular data.

Type species - Glonium stellatum Muhl. ex Fr.

Notes - Glonium is characterized by varied hysterothecia, one in which the fruiting bodies are frequently bifurcate to a greater (e.g. Glonium stellatum and G. circumserpens) or lesser (e.g. G. graphicum) degree, the former two species with radiating stellate composites, usually seated on subicula. The genus comprises thress species with molecular data, two strains of G. stellatum, from Michigan (CBS 207.34) and Tennessee (ANM 32), the USA, and two of G. circumserpens, isolated from wood (CBS 123342 / BPI 878738) and dolerite stone (CBS 123343 / BPI 878739) from Tasmania.

\section{Other genera included}

Cenococcum Moug. \& Fr., in Fries, Syst. mycol. (Lundae) 3(1): 65 (1829).

Index Fungorum number: IF 7516; Facesoffungi number: FoF 07680; 2 morphological species (Species Fungorum 2020), 1 species with molecular data.

Type species - Cenococcum geophilum Fr., Syst. mycol. (Lundae) 3(1): 66 (1829).

Notes - Cenococcum geophilum exists as sterile mycelia and lacks sexual or asexual spores. Therefore, Cenococcum geophilum is identified primarily on mycelium morphology and mycorrhizal characters (Chilvers 1968, Trappe 1962, Miller et al. 1983).

Purpurepithecium Jayasiri \& K.D. Hyde, in Jayasiri et al., Cryptog. Mycol. 38(2): 246 (2017).

Index Fungorum number: IF 553000; Facesoffungi number: FoF 03109; 2 morphological species (Species Fungorum 2020), 2 species with molecular data.

Type species - Purpurepithecium murisporum Jayasiri \& K.D. Hyde, in Jayasiri et al., Cryptog. Mycol. 38(2): 246 (2017).

Notes - This genus was introduced primarily based on molecular data. Purpurepithecium differs from the type genus Glonium in having scattered to gregarious, navicular, flexuous hysterothecia and a purple pigmented epithecium. Purpurepithecium murisporum is characterized by a Psiloglonium stygium like asexual morph (Lohman 1933a, 1937) and Glonium also shares similar asexual structures.

Purpurepithecium murisporum Jayasiri \& K.D. Hyde, Cryptogamie Mycologie 38 (2): 246 (2017).

Index Fungorum number: IF 553001; Facesoffungi number: FoF 03110.

Description - see Jayasiri et al. (2017a).

Material examined - Thailand, Chiang Mai Province, on decaying scales of a pine cone, 22 July 2015, Subashini C. Jayasiri C 095-B (MFLU 17-0447, paratype), living culture 17-0319.

Notes - Purpurepithecium murisporum is similar to Glonium stellatum in producing hysterothecia, with persistent narrow cellular pseudoparaphyses in a gel matrix, branched with darkened apices and clavate to cylindric asci (Boehm et al. 2009a). Purpurepithecium murisporum differs from Glonium stellatum in that it has navicular hysterothecia, that are scattered to gregarious, with a prominent longitudinal slit, purple pigmented epithecium and hyaline to dark brown muriform ascospores. In the phylogenetic tree, Purpurepithecium strains separate from Glonium and Cenococcum spp. with high statistical support in a separate subclade (Fig. 36). Therefore, Purpurepithecium murisporum can be accommodated as the type for a new genus and in here we provide descriptions and illustrations from the paratype of this species. 

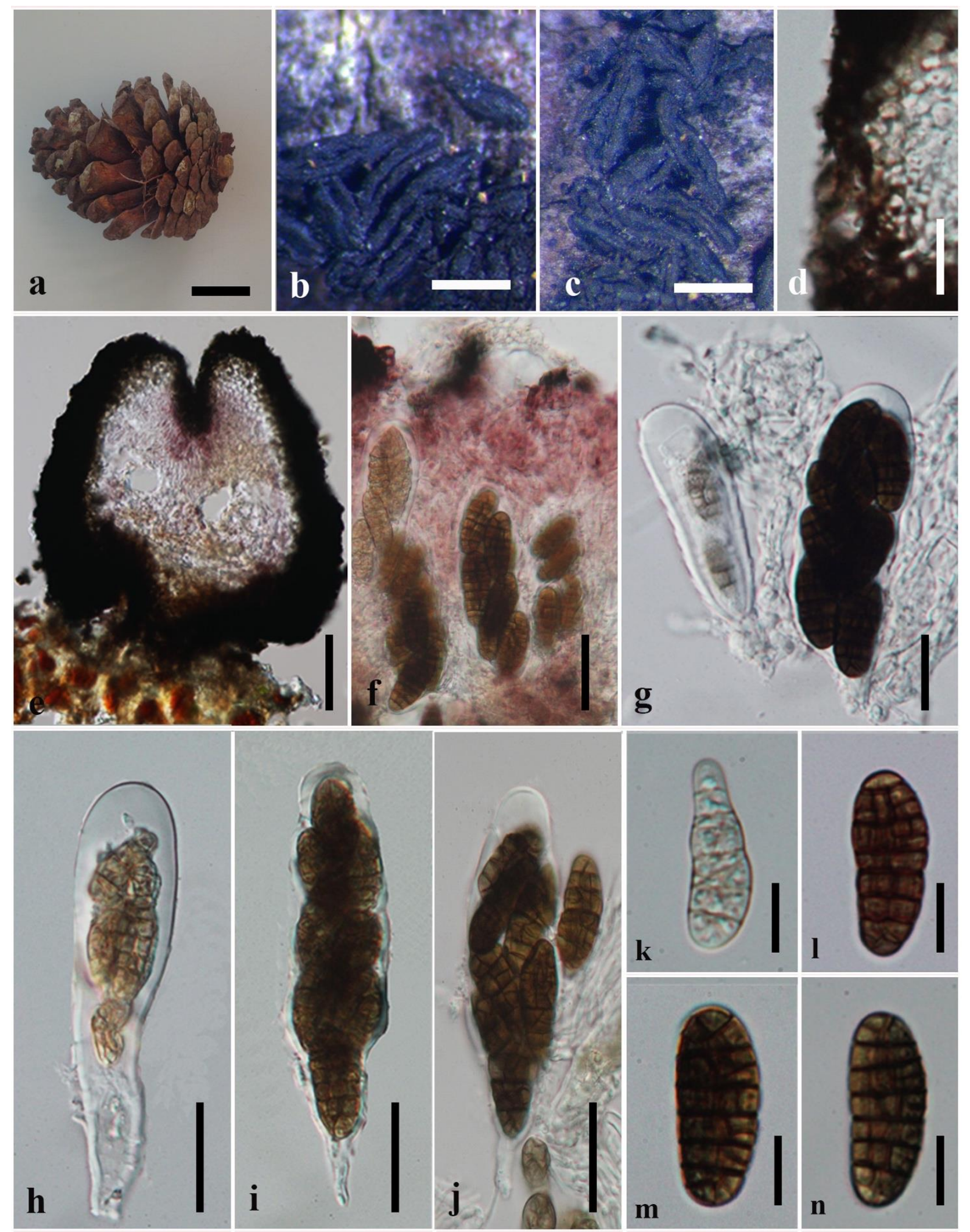

Figure 37 - Purpurepithecium murisporum (MFLU 17-0447, paratype). a A pine cone. b, c View of hysteriothecia on host surface. d Peridium e Section through hysteriothecium. f Epithecium with asci. $\mathrm{g}-\mathrm{j}$ Asci. $\mathrm{k}-\mathrm{n}$ Ascospores. Scale bars: $\mathrm{d}=1 \mathrm{~cm}, \mathrm{e}=20 \mu \mathrm{m}, \mathrm{b}, \mathrm{c}=500 \mu \mathrm{m}, \mathrm{g}-\mathrm{j}=30 \mu \mathrm{m}, \mathrm{k}-\mathrm{n}=$ $10 \mu \mathrm{m}, \mathrm{d}=20 \mu \mathrm{m}$.

\section{Ecological and economic significance}

Cenococcum is a genus of ectomycorrhizal Dothideomycetes belonging to Gloniaceae based on a multi-gene phylogenetic analysis. It is the only genus of mycorrhizal fungi in 
Dothideomycetes and represents an independent origin of mycorrhizae among Ascomycota. Thus, this genus and other associated genera are ecologically important in the ecological aspect (Peter et al. 2006).

Hysteriales Lindau.

Index Fungorum number: IF 90549; Facesoffungi number: FoF 07681

Hysteriales is monotypic. Fungi classified in Hysteriaceae (Hysteriales), Mytilinidiaceae (Mytilinidiales), and Gloniaceae (Gloniales), possess persistent, carbonaceous ascomata that characteristically dehisce by a longitudinal suture. Molecular data supports the inclusion of all three families within Pleosporomycetidae (Schoch et al. 2006, Boehm et al. 2009a, b, Mugambi \& Huhndorf 2009b, Hyde et al. 2013) and in three separate orders (Boehm et al. 2009a, b, Jayasiri et al. 2018). In Hysteriales ascomata are thick-walled, navicular, characteristically dehiscing by an invaginated slit or sulcus (Zogg 1962). In Mytilinidiaceae, taxa possess strongly laterally compressed, thin-walled conchate ascomata, reminiscent of miniature bivalve molluscs. Taxa belonging to Gloniaceae, have dichotomously branched, laterally anastomosed pseudothecia, that form radiating pseudo-stellate composites and dehisce by an inconspicuous, longitudinal, but evaginated slit (Boehm et al. 2009a, b). Coniosporium was previously classified in Hysteriaceae (Wijayawardene et al. 2018), however after DNA sequence analyses, it has been referred to Dothideomycetes genera, incertae sedis (Tsuneda et al. 2018). The divergence time for Hysteriales is estimated as 109 MYA (stem age) (Fig. 2).

Accepted families: Hysteriaceae.

Hysteriaceae Chevall. 1826, Flore Générale des Environs de Paris 1: 432 (1826).

Index Fungorum number: IF 80901; Facesoffungi number: FoF 01838, 175 species.

Lignicolous or corticolous, mainly on well decorticated hardwoods, rarely on conifers. Sexual morph: Ascomata hysterothecia, dense, persistent, thick-walled, carbonaceous, distinctly navicular in outline, bearing a pronounced longitudinal slit running the length of the long axis, immersed to erumpent or entirely superficial, solitary or gregarious, ellipsoid to greatly elongated, sometimes branched, triradiate, or borne on a subiculum. Peridium thick, globose to obovoid, three-layered, composed of small pseudoparenchymatous cells, the outer layer heavily encrusted with pigment and often longitudinally striated on the surface, the middle layer lighter in pigmentation and the inner layer distinctly thin-walled, pallid, and compressed. Hamathecium comprising persistent cellular, or trabeculate, hypha-like, hyaline, septate, pseudoparaphyses, often borne in a gelatinous matrix, with tips darkened or branched at maturity above the asci. Asci 8-spored, bitunicate, fissitunicate, borne in a basal layer, typically clavate to cylindric at maturity, with a distinct ocular chamber. Ascospores overlapping 1-2-seriate, obovoid, clavate, ellipsoid or fusoid, hyaline to light- or darkbrown, 1-several-septate, or muriform; often showing bipolar asymmetry, smooth-walled, foveolate or verruculose, at times surrounded by a gel coating; contents granular, often with oil inclusions, especially when young. Asexual morph: see under notes.

Type - Hysterium Pers.

Notes - Nine genera belong to this family based on morphological and phylogenetic studies viz. Gloniopsis, Graphyllium, Hysterium, Hysterobrevium, Hysterodifractum, Oedohysterium, Ostreichnion, Psiloglonium and Rhytidhysteron (Boehm et al. 2009a, b, de Almeida et al. 2014, Jayasiri et al. 2018). However, five other genera, Actidiographium, Gloniella, Hysterocarina, Hysteroglonium and Hysteropycnis also belong to Hysteriaceae based on morphological similarities (Boehm et al. 2009a). Pseudoparaphyses of Hysteriaceae are cellular (e.g. Hysterobrevium and Oedohysterium) or trabeculate (e.g. Hysterographium and Psiloglonium). Some genera have both types of pseudoparaphyses, such as Hysterium; H. doimaeensis has trabeculate (Jayasiri et al. 2018) and $H$. rhizophorae has cellular pseudoparaphyses (Dayarathne et al. 2020).

Hysterium Pers., Tent. disp. meth. fung. (Lipsiae): 5 (1797).

Index Fungorum number: IF 2464; Facesoffungi number: FoF 0004; 47 morphological species (Species Fungorum 2020), 16 species with molecular data. 
Type species - Hysterium pulicare Pers.

Notes - A historical overview of the nomenclature of Hysterium was presented in Boehm et al. (2009a). This genus is characterised by three- or more transversely-septate, pigmented versicolorous or concolorous asymmetric phragmospores, borne in hysterothecia Boehm et al. (2009a, b).

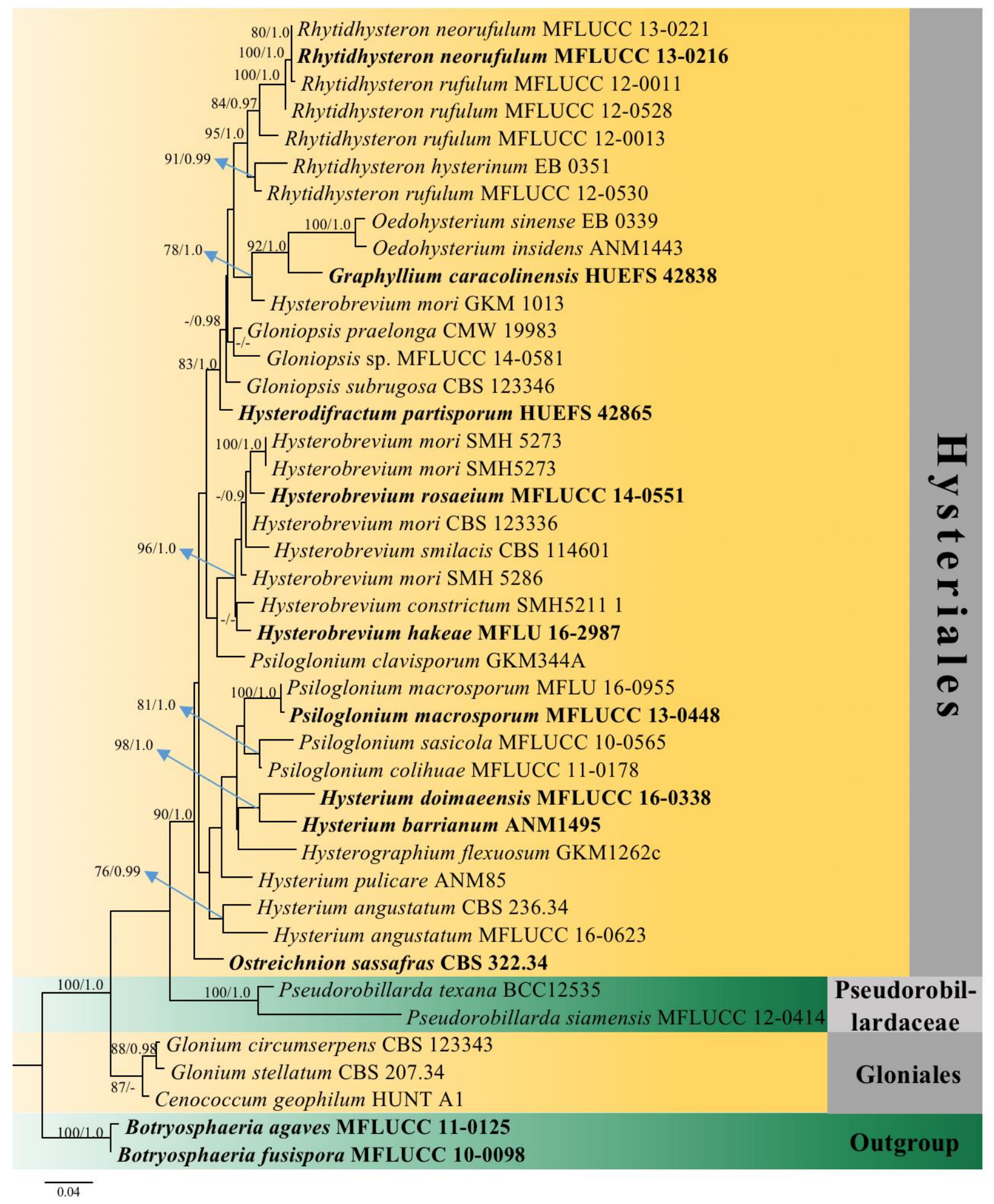

Figure 38 - Phylogram generated from maximum likelihood analysis (RAxML) of Hysteriales based on LSU, rpb-2, SSU and tef1 sequence data. Maximum likelihood bootstrap values equal or above $70 \%$, Bayesian posterior probabilities equal or above 0.90 (MLBS/PP) are given at the nodes. Isolate/specimen number is noted after the species name. The tree is rooted to 
Botryosphaeria agaves (MFLUCC 11-0125) and B. fusispora (MFLUCC 10-0098). The ex-type strains are indicated in bold. Hyphen (-) represents support values below $70 \%$ MLBS and 0.90 PP.

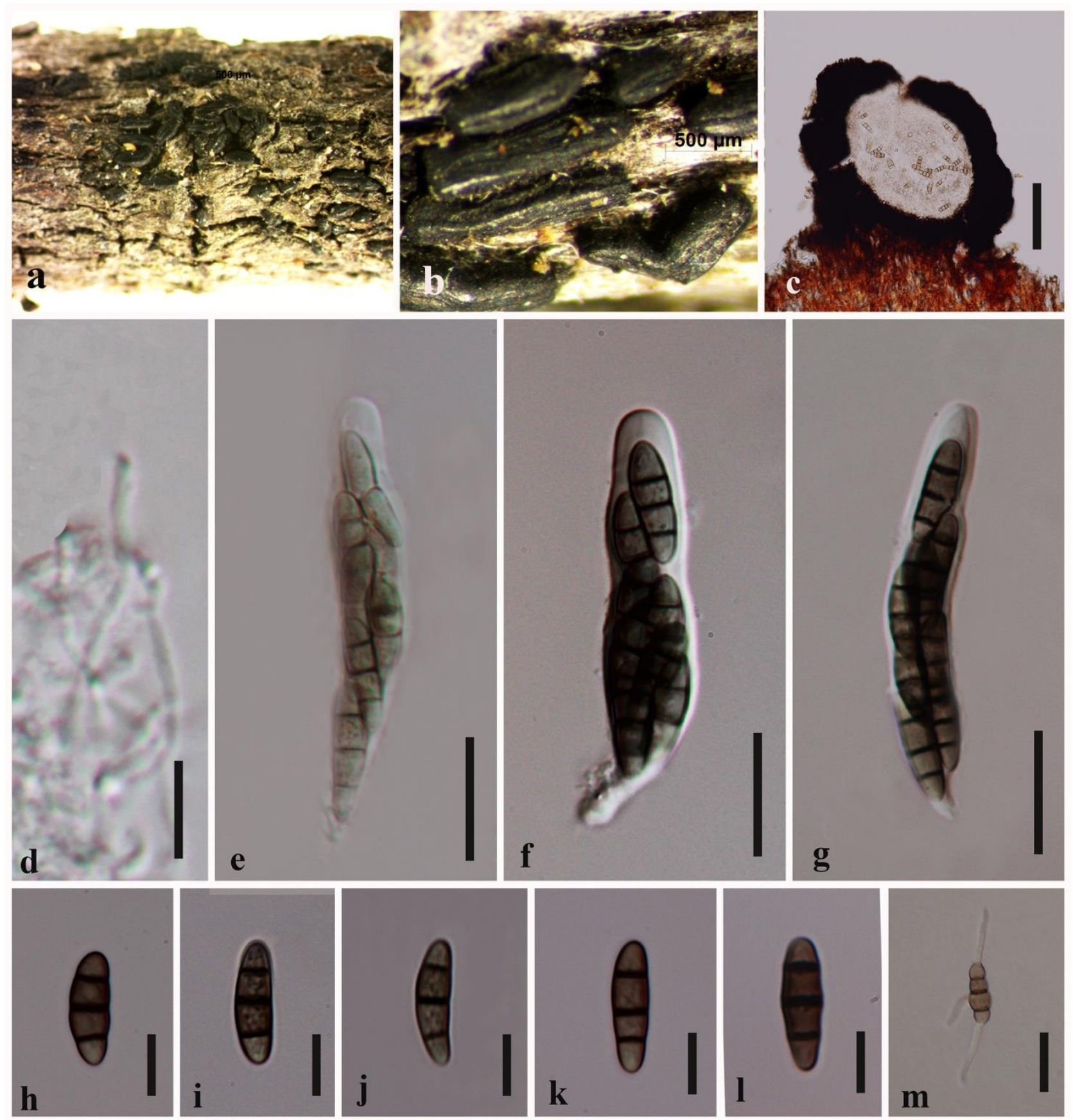

Figure 39 - Hysterium angustatum (MFLU 16-2988). a, b View of hysterothecia on host surface. c Section through hysterothecium. d Pseudoparaphyses. e-g Ascospores. h-1 Asci. m Germinated ascospore. Scale bars: $\mathrm{d}=10 \mu \mathrm{m}, \mathrm{c}=100 \mu \mathrm{m}, \mathrm{e}-\mathrm{g}, \mathrm{m}=20 \mu \mathrm{m}, \mathrm{d}, \mathrm{h}-1=10 \mu \mathrm{m}$

Hysterium angustatum Alb. \& Schwein., Consp. fung. (Leipzig): 55 (1805).

Fig. 39

Index Fungorum number: IF 221405; Facesoffungi number: FoF 04579.

Saprobic on dead wood. Sexual morph: Hysterothecia 208-232 high $\times 256-284$ wide $\times 500$ $600 \mu \mathrm{m}$ long $(\bar{x}=218 \times 268 \times 560 \mu \mathrm{m}, \mathrm{n}=10)$, elongate and depressed conchate, scattered, superficial, base immersed in substrate, surface black, shiny, longitudinally striate, apex compressed, opening by a longitudinal slit. Peridium $40-60 \mu \mathrm{m}(\bar{x}=51, \mathrm{n}=15)$ carbonaceous, brittle, heavily pigmented, small prosenchymatous cells. Hamathecium comprising 0.5-1.5 $\mu \mathrm{m}$, trabeculate, aseptate, branched, pseudoparaphyses, borne in a gelatinous matrix. Asci 55-70 × 8-12 
$\mu \mathrm{m}(\bar{x}=60 \times 9 \mu \mathrm{m}, \mathrm{n}=15), 8$-spored, bitunicate, oblong to clavate, with a short narrow pedicel, apically thickened, with a distinct ocular chamber. Ascospores 15-19 $\times 4-6 \mu \mathrm{m}(\bar{x}=17 \times 5 \mu \mathrm{m}, \mathrm{n}=$ 25 ), crowded to 2-3-seriate, fusiform, hyaline when young and becoming brown at maturity, 3septate, smooth-walled, ornamented, without mucilaginous sheath. Asexual morph: Undetermined.

Culture characteristics - Ascospores germinating on MEA within $24 \mathrm{hrs}$, slow growing at $18^{\circ} \mathrm{C}$ reaching $2 \mathrm{~cm}$ in 14 days, yellow at first, becoming ash when mature and reverse yellow.

Material examined - Australia, Melbourne, Mornington Peninsula, on dead wood, 10 March 2015, EBG Jones, GJ 107 (MFLU 16-2988; HKAS 96316)

Notes - We re-describe and illustrate Hysterium angustatum with a new strain. This is the first report of $H$. angustatum from Australia. Hysterium angustatum strains have little morphological variability in their spores, probably because of early speciation stages (Boehm et al. 2009a).

\section{Other genera included}

Actidiographium Lar.N. Vassiljeva, Mikol. Fitopatol. 34(6): 4 (2000).

Index Fungorum number: IF 28476; Facesoffungi number: FoF 08053; 1 morphological species (Boehm et al. 2009a, Species Fungorum 2020), molecular data unavailable. (2000).

Type species - Actidiographium orientale Lar.N. Vassiljeva, Mikol. Fitopatol. 34(6): 5

Notes - Vasilyeva (2000) established the monotypic genus Actidiographium to accommodate a hysteriaceous taxon with pigmented 1-septate ascospores. However, molecular data are unavailable to confirm placement within Hysteriaceae.

Gloniella Sacc., Syll. fung. (Abellini) 2: 765 (1883).

Index Fungorum number: IF 2089; Facesoffungi number: FoF 08054; 42 morphological species (Species Fungorum 2020), molecular data unavailable.

Type species - Gloniella sardoa Sacc. \& Traverso, Syll. fung. (Abellini) 2: 765 (1883).

Notes - Gloniella was established to accommodate hysteriaceous taxa that have hyaline, 3-9septate phragmospores. Molecular data are unavailable for the type species to confirm its placement within Hysteriaceae.

Gloniopsis De Not., G. bot. ital. 2(7-8): 12, 23 (1847).

Index Fungorum number: IF 2090; Facesoffungi number: FoF 08055; 30 morphological species (Species Fungorum 2020), 9 species with molecular data.

Type species - Gloniopsis decipiens De Not., G. bot. ital. 2(7-8): 12, 23 (1847).

Notes - This genus was reviewed by Boehm et al. (2009b) with only seven species based on morphological and phylogenetic data (Boehm et al. 2009a, b, Hyde et al. 2016, Jayasiri et al. 2019). However, the genus is polyphyletic (Boehm et al. 2009a). The genus is characterised by hyaline to yellow dictyospores, curved, in outline obovoid, ends obtuse to sub- to acuminate, multi-septate, with one or more longitudinal septa, constricted at the first-formed septum, sometimes constricted at additional septa, and usually surrounded by a gelatinous sheath, which may dissipate with age (Boehm et al. 2009a, Jayasiri et al. 2018).

Hysterobrevium E. Boehm \& C.L. Schoch, in Boehm et al., Stud. Mycol. 64: 62 (2010).

Index Fungorum number: IF 515329; Facesoffungi number: FoF 08056; 6 morphological species (Boehm et al. 2009a, Jayasiri et al. 2018, Species Fungorum 2020), 6 species with molecular data.

Type species - Hysterobrevium mori (Schwein.) E. Boehm \& C.L. Schoch, in Boehm et al., Stud. Mycol. 64: 62 (2010).

$\equiv$ Hysterium mori Schwein., Trans. Am. phil. Soc., New Series 4(2): 244 (1832) [1834].

Notes - Hysterobrevium was introduced by Boehm et al. (2009a) with three new combinations. Hysterobrevium is similar to Hysterographium. However, these two genera are phylogenetically distinct and Boehm et al. (2009a) introduced Hysterobrevium as a new genus 
mainly based on molecular data. Ascospores are pigmented or hyaline dictyospores, usually less than $25 \mu \mathrm{m}$ long, and constricted at least at the median septum (Boehm et al. 2009a).

Hysterocarina H. Zogg, Beitr Kenntn Brasil. Hysteriaceen: 59: 42 (1949).

Index Fungorum number: IF 2465; Facesoffungi number: FoF 08057; 1 morphological species (Boehm et al. 2009a, Species Fungorum 2020), molecular data unavailable. (1949).

Type species - Hysterocarina paulistae H. Zogg, Beitr. Kenntn. Brasil. Hysteriaceen 59: 42

Notes - Zogg (1949) introduced this monotypic genus for Hysterocarina paulistae, with pigmented dictyospores from old wood of Eucalyptus sp. in Brazil. An evaginated keel-like fissure in Hysterocarina is interesting, as it seems to belong to an evolutionary trend close to Mytilinidiaceae and Gloniaceae (Boehm et al. 2009a). Molecular data are needed to resolve its taxonomy.

Hysterodifractum D.A.C. Almeida, Gusmão \& A.N. Mill., Phytotaxa 176(1): 304 (2014).

Index Fungorum number: IF 807155; Facesoffungi number: FoF 08058; 1 morphological species (Almeida et al. 2014, Species Fungorum 2020), 1 species with molecular data.

Type species - Hysterodifractum partisporum D.A.C. Almeida, Gusmão \& A.N. Mill., Phytotaxa 176(1): 304 (2014).

Notes - Hysterodifractum differs from all other genera in the Hysteriaceae in having ascospores that disarticulate into part-spores when mature (Almeida et al. 2014). This is the first report of part-spores occurring in a hysteriaceous species.

Hysteroglonium Rehm ex Lindau, Nat. Pflanzenfamilien: 272 (1896).

Index Fungorum number: IF 2467; Facesoffungi number: FoF 08059; 3 morphological species (Almeida et al. 2014, Species Fungorum 2020), molecular data unavailable.

Type species - Hysteroglonium ovatum (Cooke) Lindau, in Engler \& Prantl, Nat. Pflanzenfam., Teil. I (Leipzig) 1(1): 274 (1897).

EHysterium ovatum Cooke, Grevillea 11(no. 59): 107 (1883).

Notes - Hysteroglonium contains saprobes, terrestrial and cosmopolitan species (Lumbsch \& Huhndorf 2010). Only hysteriaceous ascomata are recorded and asexual morph is undetermined (Lumbsch \& Huhndorf 2010, Doilom et al. 2018). Cooke (1883) and Engler \& Prantl (1896) described the type of this genus $H$. ovatum as follows: Ascomata hysterothecia, superficial, longitudinal to host surface, straight, flat or convex on top, black, solitary, scattered, slightly shiny, semi-immersed, becoming superficial. Asci 8-spored, bitunicate, subcylindrical, apically rounded. Ascospores ellipsoid, rounded at both sides, hyaline, guttulate, aseptate, finally becoming pseudotriseptate. Cultures and sequences data are unavailable for this genus and fresh specimens and isotypes need to be designated. Molecular data is needed to confirm placement of this genus.

Oedohysterium E. Boehm \& C.L. Schoch, in Boehm et al., Stud. Mycol. 64: 59 (2009).

Index Fungorum number: IF 515421; Facesoffungi number: FoF 08060; 3 morphological species (Boehm et al. 2009a, Species Fungorum 2020), 2 species with molecular data.

Type species - Oedohysterium insidens (Schwein.) E. Boehm \& C.L. Schoch, in Boehm et al., Stud. Mycol. 64: 59 (2009).

$\equiv$ Hysterium insidens Schwein., Trans. Am. phil. Soc., New Series 4(2): 244 (1832) [1834].

Notes - Oedohysterium and Hysterium possess similar pigmented asymmetric phragmospores. Species of Oedohysterium can be differentiated by an enlarged supra-median cell and species also constitute a distinct clade from Hysterium in phylogenetic analyses (Boehm et al. 2009a).

Ostreichnion Duby, Mém. Soc. Phys. Hist. nat. Genève 16(1): 33 (1862).

Index Fungorum number: IF 3645; Facesoffungi number: FoF 00163; - 3 morphological species (Boehm et al. 2009a), 3 species with molecular data. 
Type species - Ostreichnion americanum Duby, Mém. Soc. Phys. Hist. nat. Genève 16(1): 34 (1862).

Notes - Ostreichnion, previously placed in the Mytilinidiaceae, has been transferred to Hysteriaceae (Boehm et al. 2009a). This was based on sequence data derived from two of the three species, O. curtisii (CBS 198.34) and O. sassafras (CBS 322.34), deposited by Lohman (1934). The genus is characterized by dictyospores or large didymospores ascospores borne in choncate mytilinidioid, fragile fruitbodies, with thin-walled slerenchymatous cells.

Pseudoscypha J. Reid \& Piroz., Can. J. Bot. 44: 351 (1966).

Index Fungorum number: IF 4486; Facesoffungi number: FoF 08061; 1 morphological species (Species Fungorum 2020), molecular data unavailable.

Type species - Pseudoscypha abietis J. Reid \& Piroz., Can. J. Bot. 44: 351 (1966).

Notes - Eriksson (2006) placed Pseudoscypha in Hysteriaceae based only on morphological data. In the original illustrations, no sterile tissue or excipulum was present, and the bitunicate asci and pseudoparaphyses arise directly from an erumpent orange basal stromatic cushion (Reid \& Pirozynski 1966). Fresh material and sequence data are required to confirm the placement of this genus.

Psiloglonium Höhn., Ann. mycol. 16(1/2): 149 (1918).

Index Fungorum number: IF 4507; Facesoffungi number: FoF 08062; 16 morphological species (Species Fungorum 2020), 7 species with molecular data.

Type species - Psiloglonium lineare (Fr.) Petr., Ann. mycol. 21(3/4): 227 (1923).

$\equiv$ Hysterium lineare Fr., Syst. mycol. (Lundae) 2(2): 583 (1823).

= Glonium lineare (Fr.) De Not., G. bot. ital. 2(2): 27 (1847).

Notes - This genus was overviewed by Boehm et al. $(2009 a, b)$ and is very similar to Glonium. Both Psiloglonium and Glonium possess hyaline to yellow didymospores, somewhat constricted at the septum, with obtuse or acuminate ends, typically with cells unequal in size, borne in hysterothecia (Boehm et al. 2009a). However, phylogenetically they are distinct and introduced as two genera by Boehm et al. (2009a, b).

Rhytidhysteron Speg. [as 'Rhytidhysterion'], Anal. Soc. cient. argent. 12(4): 188 (1881).

Index Fungorum number: IF 4740; Facesoffungi number: FoF 08063; 21 morphological species (Species Fungorum 2020), 8 species with molecular data.

Type species - Rhytidhysteron brasiliense Speg., Anal. Soc. cient. argent. 12(4): 188 (1881).

Notes - The genus was introduced to accommodate $R$. brasiliense and $R$. viride and is typified by $R$. brasiliense (Spegazzini 1881, Silva-Hanlin \& Hanlin 1999). Rhytidhysteron is characterized by closed and navicular ascomata, later opening by a longitudinal slit to become irregularly apothecioid at maturity and heavily pigmented, and with thick-walled ascospores (Boehm et al. 2009 b). The genus includes saprobic to weakly pathogenic taxa that grow on woody plants in terrestrial habitats (Yacharoen et al. 2015, Hyde et al. 2020b). Most taxa are involved in wood degradation.

\section{Ecological and economic significance}

Species in Hysteriaceae have little economic impact since they are not harmful to plants or animals. However, secondary metabolites of Hysteriaceae have had rekindled interest in recent years. For example, the major secondary metabolic exudate produced in cultures of Hysterium centramurum Senan. was identified as physcion (Tibpromma et al. 2017). This chemical is useful as a dye in the textile industry and as an antibiotic and anti-cancer agent in the pharmaceutical industry (Velmurugan et al. 2010).

Mytilinidiales E.W.A. Boehm, C.L. Schoch \& Spatafora. Index Fungorum number: IF 511989; Facesoffungi number: FoF 08100. 
Mytilinidiaceae represents a monophyletic group, defining Mytilinidiales (Boehm et al. 2009a). The conchate nature of the fruiting body and the thin-walled peridium are unique characters of this family. Monophyletic sequence data and spore morphology indicate a complex pattern of speciation within the family (Boehm et al. 2009a). Asexual morphs in the family are primarily coelomycetous and less frequently hyphomycetous (Lohman 1932, 1933a, b, Blackwell \& Gilbertson 1985, Speer 1986). The hyphomycetous genus Taeniolella was previously placed in Mytilinidiaceae (Hyde et al. 2013, Wijayawardene et al. 2018), although Ertz et al. (2016) classified it under family Kirschsteiniotheliaceae based on DNA sequence data. Phylogenetic placements of genera in Mytilinidiales are shown in Fig. 40 The divergence time for Mytilinidiales is estimated as 219 MYA (stem age) (Fig. 2).

Accepted families: Mytilinidiaceae.

Mytilinidiaceae Kirschst. [as 'Mytilidiaceae'], Verh. bot. Ver. Prov. Brandenb. 66: 28 (1924).

Index Fungorum number: IF 80901; Facesoffungi number: FoF 03134, 89 species.

Saprobic on wood, bark, resin, cones, scales, needles, seeds, and roots of gymnosperms, much less frequently on angiosperms. Predominantly temperate in distribution. Sexual morph: Ascomata superficial, scattered to gregarious, black, sometimes less connivent, more appressed, hysterioid, grouped in triangular or radiating star-shaped or astral arrangement, fragile, yet persistent, carbonaceous, globoid to obovoid, to strongly laterally compressed erect, bivalve shellshaped structures, standing on edge, with lateral walls more or less connivent, and extended vertically to a prominent longitudinal keel or cristate apex; distinctly clam- or musselshaped. Peridium fragile, thin-walled, scleroparenchymatous, rarely of multiple layers. Hamathecium comprising narrow trabeculate pseudoparaphyses, borne gelatinous matrix, often sparse to lacking at maturity. Asci 8-spored, rarely 4-spored, bitunicate, fissitunicate, cylindrical, with a broad, short pedicel, ocular chamber not well developed, borne on a basal cushion, centrally orientated within the centrum, rarely borne laterally. Ascospores overlapping 1-2-seriate or in one or two fascicles within the ascus, hyaline to pigmented yellow to dark brown, highly variable in septation, showing bipolar symmetry. Asexual morph: Primarily coelomycetous or less frequently hyphomycetous (Lohman 1932, 1933a, b, Blackwell \& Gilbertson 1985, Speer 1986).

Type - Mytilinidion Duby,

Notes - The genera Mytilinidion, Lophium and Quasiconcha formed a monophyletic clade, representing Mytilinidiales (Boehm et al. 2009b). The conchate nature of the hysterothecia and the thin-walled peridium are characteristic features of this group (Boehm et al. 2009a, b, Hyde et al. 2013). Although, Boehm et al. (2009a) and Hyde et al. (2013) mentioned that Mytilinidiaceae have trabeculate pseudoparaphyses, Mytilinidion didymospora introduced by Jayasiri et al. (2018) has cellular-like pseudoparaphyses (see Jayasiri 2018 Fig. 14). Several species of Mytilinidiaceae were shown without clear pictures of hamathecium, thus we suggest that morphological study of hamathecium is needed for future works.

Our multi-gene phylogenetic analysis confirms the placement of Mytilinidiales within the class Dothideomycetes. Gloniales is introduced in this study based on their diverse morphology. Therefore, the Mytilinidiales is a monotypic order with Mytilinidiaceae.

Mytilinidion Duby, Mém. Soc. Phys. Hist. nat. Genève 16(1): 34 (1861) [1862].

Index Fungorum number: IF 3389; Facesoffungi number: FoF 08101; 23 morphological species (Species Fungorum 2020), 12 species with molecular data.

Type species - Mytilinidion aggregatum (DC.) Duby.

$\equiv$ Hysterium aggregatum DC., Fl. franç., Edn 3 (Paris) 5/6: 168 (1815).

Notes - Mytilinidion was established by Duby (1862) with an etymology from Mytilus, a genus of mussels. There are 36 recognised species, occurring on the Pinaceae, Cupressaceae, and Taxodiaceae (Lohman 1932, Zogg 1962, Speer 1986, Barr 1990b, Jayasiri et al. 2018). Mytilinidion species are characterised by yellow to reddish brown, ellipsoid, fusoid, obovoid to elongate, transversely septate, symmetric, ascospores, or scolecospores, thin-walled, globoid to conchate 
hysterothecia, with lateral walls more or less connivent and extended vertically to a cristate apex (Boehm et al. 2009a).

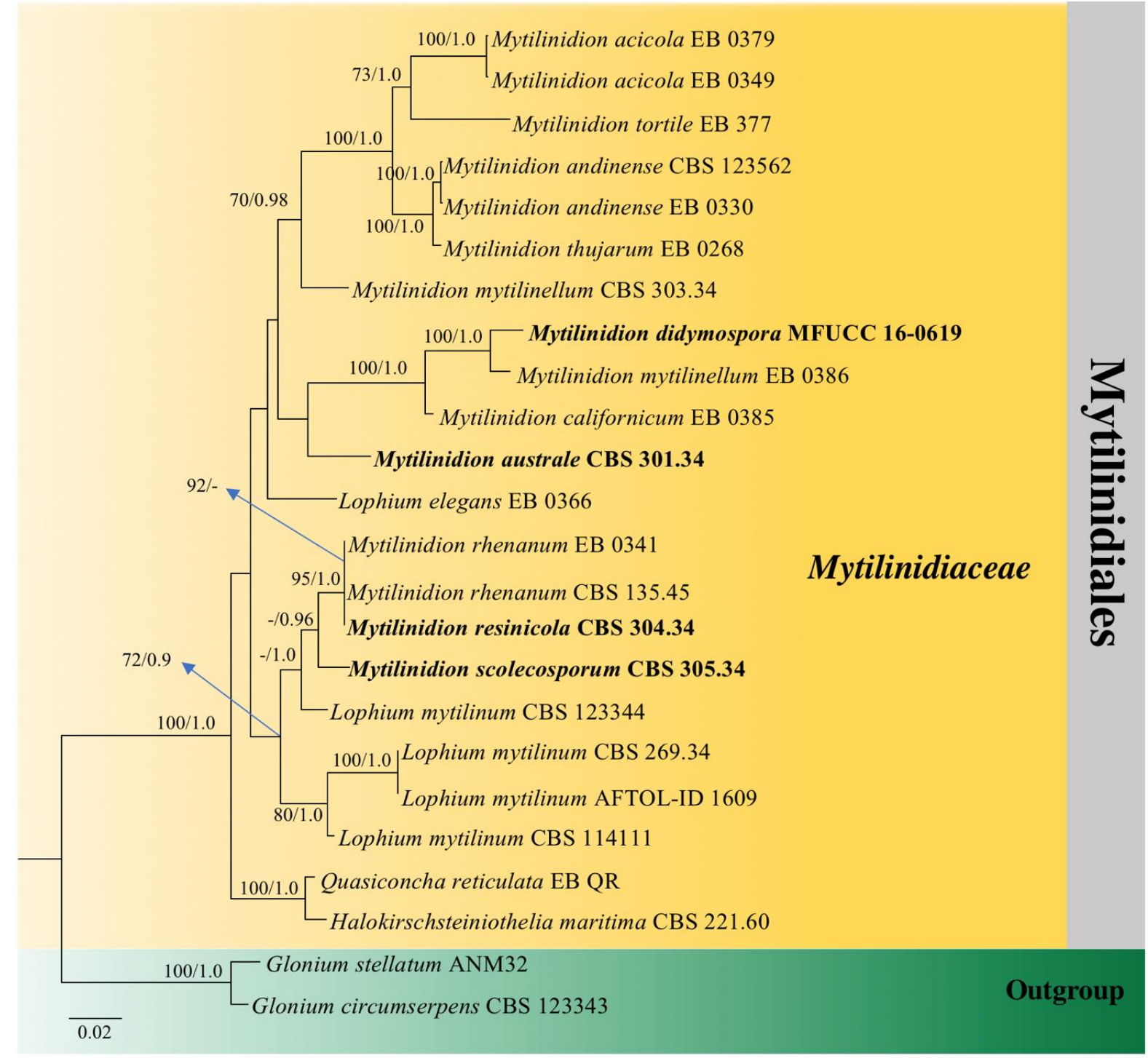

Figure 40 - Phylogram generated from maximum likelihood analysis (RAxML) of Mytilinidiales based on LSU, rpb-2, SSU and tef1 sequence data. Maximum likelihood bootstrap values equal or above $70 \%$, Bayesian posterior probabilities equal or above 0.90 (MLBS/PP) are given at the nodes. Isolate/specimen number is noted after the species name. The tree is rooted to Glonium circumserpens (CBS 123343), G. stellatum (ANM32). The ex-type strains are indicated in bold. Hyphen (-) represents support values below $70 \%$ MLBS and 0.90 PP.

Mytilinidion didymospora Jayasiri, Camporesi \& K.D. Hyde, Mycosphere 9 (4): 824 (2018).Fig. 41 Index Fungorum number: IF 554457; Facesoffungi number: FoF 04584.

Saprobic on dead cones of Cupressus glabra (Cupressaceae). Sexual morph: Hysterothecia 455-835 $\mu \mathrm{m}$ long $\times 108-132 \mu \mathrm{m}$ wide $\times 110-155 \mu \mathrm{m}$ high $(\bar{x}=670 \times 125 \times 132 \mu \mathrm{m}, \mathrm{n}=10)$, navicular, flexuous, superficial on host tissue, scattered or appear as a group, with a longitudinal slit, surface black and shiny. Peridium 15-22 $\mu$ mwide $(\bar{x}=18 \mu \mathrm{m})$, carbonaceous, narrow, thickening equally, composed of cells of textura angularis. Hamathecium comprising $1-1.5 \mu \mathrm{m}$ wide, persistent, septate, hyaline, branched, shorter than the asci. Asci $75-95 \times 4-7 \mu \mathrm{m}(\bar{x}=84 \times 5$ $\mu \mathrm{m}, \mathrm{n}=20$ ), 8-spored, bitunicate, cylindrical to clavate, with short, narrow pedicel. Ascospores 14 $19 \times 2-4 \mu \mathrm{m}(\bar{x}=15 \times 3 \mu \mathrm{m}, \mathrm{n}=20), 1-2$-seriate, asymmetric, cylindrical, one end tapering and 
another end rounded, hyaline to pale brown, 1-septate, not constricted at the septa, guttules present, mucilaginous sheath absent, smooth-walled. Asexual morph: Undetermined.

Culture characteristics - Colonies on MEA attaining 12-15 mm diam. after 7 days at $25^{\circ} \mathrm{C}$, with irregular pale brown edge, brown, with dense aerial mycelium on the surface with brown, reverse similar.

Material examined - Italy, Forlì-Cesena [FC], Province, Montebello - Modigliana, on dead land cones of Cupressus glabra (Cupressaceae), 6 October 2015, Erio Camporesi, IT 2629 (HKAS96319, isotype), living cultures MFUCC16-0619.

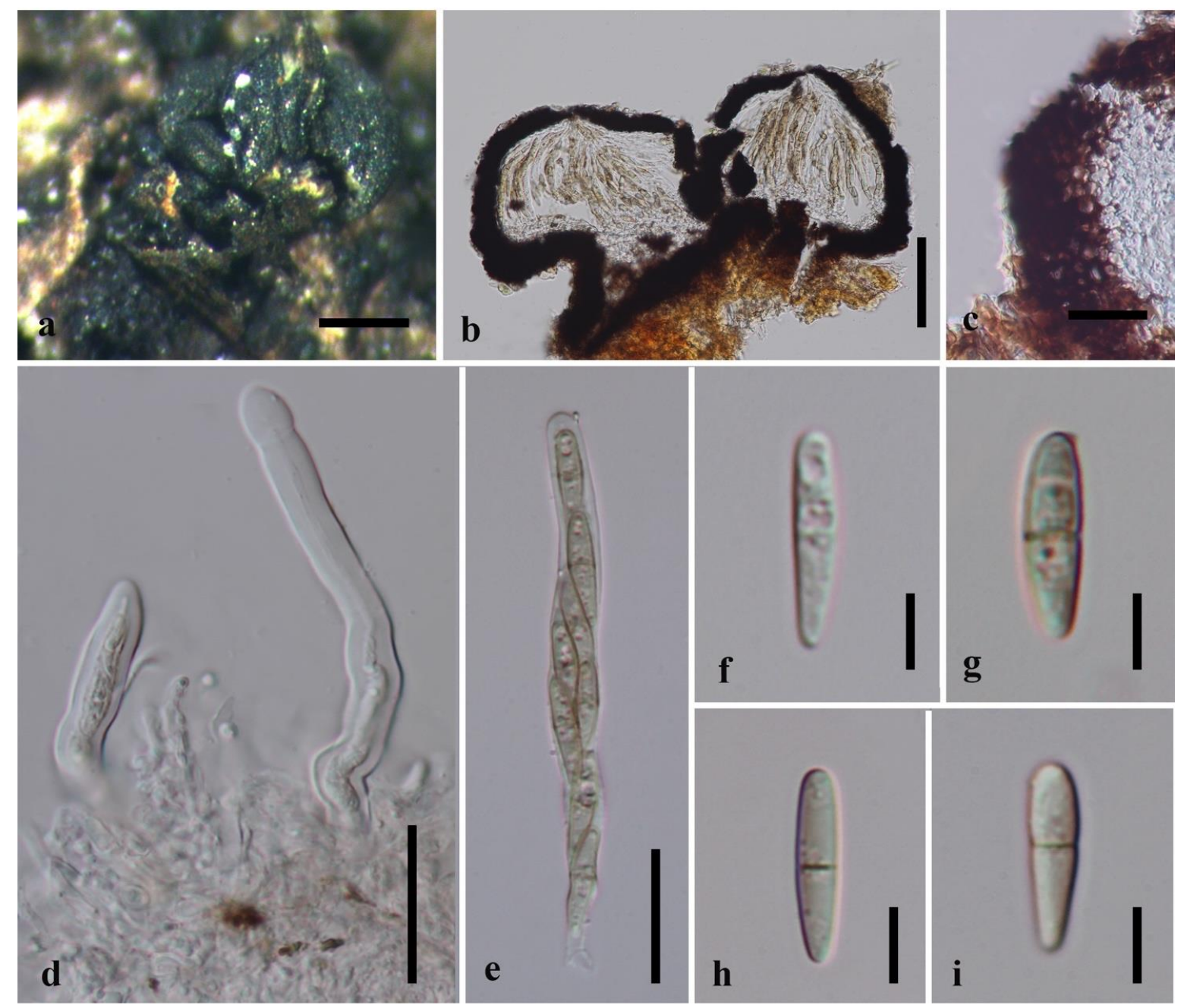

Figure 41 - Mytilinidion didymospora (HKAS96319, isotype). a View of hysterothecia on host surface. $\mathrm{b}$ Section through hysterothecium. c Peridium. d, e Asci. $\mathrm{f}-\mathrm{i}$ Ascospores. Scale bars: $\mathrm{a}=$ $500 \mu \mathrm{m}, \mathrm{b}=200 \mu \mathrm{m}, \mathrm{c}=10 \mu \mathrm{m}, \mathrm{d}, \mathrm{e}=20 \mu \mathrm{m}, \mathrm{f}-\mathrm{i}=5 \mu \mathrm{m}$.

\section{Other genera included}

Actidium Fr., Observ. mycol. (Havniae) 1: 190 (1815).

Index Fungorum number: IF 58; Facesoffungi number: FoF 08102; 6 morphological species (Species Fungorum 2020), molecular data unavailable.

Type species - Actidium hysterioides Fr., Observ. mycol. (Havniae) 2: 353 (1818).

Notes - This genus was established by Fries (1823) to accommodate A. hysterioides, a stellate mytilinidioid fungus found on Pinus and Picea in Europe, with two-celled, symmetric ascospores, light olive to reddish brown, later noted to be faintly longitudinally striate (Barr 1990a). Fries (1823) noted its similarity with Glonium. Zogg (1962) and Barr (1990b) recognised four species, $A$. hysterioides, A. baccarinii, both from Europe, A. pulchra, from China, and A. nitidum. Due to similarities in ascospore morphology, Actidium may have affinities with other didymospored 
hysteriaceous genera (e.g. Actidiographium, Glonium and Psiloglonium), although molecular data are lacking.

Lophium Fr., Observ. mycol. (Havniae) 2: 345 (1818).

Index Fungorum number: IF 2936; Facesoffungi number: FoF 08103; 6 morphological species (Species Fungorum 2020), 4 species with molecular data.

Type species - Lophium mytilinum (Pers.) Fr., Observ. mycol. (Havniae) 2: 345 (1818).

三 Hysterium mytilinum Pers., Syn. meth. fung. (Göttingen) 1: 97 (1801).

Notes - This genus was established by Fries (1823) to accommodate Lophium mytilinum, cosmopolitan in the temperate zones and has been recorded from the Atlantic region (Zogg 1962, Barr 1990b). Lophium is characterised by fragile, conchate hysterothecia, sometimes seated on a foot-like base or sessile directly on the substrate. The thin-walled scleroparenchymatous peridium encloses a basal hamathecium of narrow trabeculate pseudoparaphyses, with very elongate asci, each bearing one fascicle of transversely septate filiform ascospores, often spirally arranged (Boehm et al. 2009a).

Ostreola Darker, Can. J. Bot. 41: 1383 (1963).

Index Fungorum number: IF 3648; Facesoffungi number: FoF 08104; 8 morphological species (Species Fungorum 2020), molecular data unavailable.

Type species - Ostreola consociata Darker, Can. J. Bot. 41:1384 (1963).

Notes - Species of this genus resemble species of Mytilinidion species except for the dictyospored ascospores. Molecular data are lacking for this genus.

Peyronelia Cif. \& Gonz. Frag., Bol. Real Soc. Esp. Hist. Nat.: 333 (1927).

Index Fungorum number: IF 9281; Facesoffungi number: FoF 08105; 4 morphological species (Species Fungorum 2020), molecular data unavailable.

Type species - Peyronelia sirodesmioides Cif. \& Gonz. Frag., Boln Real Soc. Españ. Hist. Nat., Biologica 27: 334 (1927).

Notes - This genus is characterized by hyphomycetous asexual morph and conidiophores reduced to conidiogenous cell. In previous studies Pseudoscypha was placed in Mytilinidiaceae (Hyde et al. 2013, Wijayawardene et al. 2018). Fresh material and sequence data are required to confirm the placement of this genus.

Pseudocamaropycnis Crous, Fungal Biology 120 (11): 1411 (2016).

Index Fungorum number: IF 816144; Facesoffungi number: FoF 08106; 1 morphological species (Species Fungorum 2020), 1 species with molecular data.

Type species - Pseudocamaropycnis pini Crous, Fungal Biology 120 (11): 1412 (2016).

Notes - Crous \& Groenewald (2016) introduced Pseudocamaropycnis based on molecular data. Pseudocamaropycnis is characterized by erumpent, black, elongated, lens-shaped conidiomata, hyaline, septate, branched paraphyses, phialidic conidiogenous cells with minute periclinal thickening and hyaline, cylindrical, straight biguttulate conidia (Crous \& Groenewald 2016) Asexual morph in the Mytilinidiaceae are primarily coelomycetous and less frequently hyphomycetous (Lohman 1932, 1933a, b, Blackwell \& Gilbertson 1985, Speer 1986). Commonly temperate in distribution, mytilinidioid fungi are found in association with wood, bark, resin, cones, scales, needles, seeds, and roots of gymnosperms (Boehm et al. 2019a). Pseudocamaropycnis pini is also identified from needles of Pinus elliotii. However, new collections are needed for this genus with their sexual morph representing the mytilinidioid form.

Quasiconcha M.E. Barr \& M. Blackw., Mycologia 72(6): 1224 (1981) [1980].

Index Fungorum number: IF 4631; Facesoffungi number: FoF 08107; 1 morphological species (Species Fungorum 2020), 1 species with molecular data.

Type species - Quasiconcha reticulata M.E. Barr \& M. Blackw., Mycologia 72(6): 1224 (1981). 
Notes - Quasiconcha was established by Barr \& Blackwell (1980) to accommodate $Q$. reticulata. There is only one recognised species. Quasiconcha reticulata is characterized by conchate, thin-walled mytilinidioid hysterothecia, with 1-septate, highly reticulate ascospores (Boehm et al. 2009a).

Septonema Corda, Icon. fung. (Prague) 1: 9 (1837).

Index Fungorum number: IF 9888; Facesoffungi number: FoF 08108; 39 morphological species (Species Fungorum 2020), molecular data unavailable.

Type species - Septonema secedens Corda, Icon. fung. (Prague) 1: 9 (1837).

Notes - This genus is characterized by hyphomycetous asexual morph. Morphological characters are monoblastic or sympodial conidiogenous cell and ramoconidia in branched chains. Boehm et al. (2009a), Hyde et al. (2013) and Wijayawardene et al. (2018) placed Septonema in Mytilinidiaceae. Fresh material and sequence data are required to confirm the placement of this genus.

Zoggium Lar.N. Vassiljeva, Mikol. Fitopatol. 35(1): 17 (2001).

Index Fungorum number: IF 28536; Facesoffungi number: FoF 08109; 1 morphological species (Species Fungorum 2020), molecular data unavailable.

Type species - Zoggium mayorii (H. Zogg) Lar. N. Vassiljeva [as 'mayori'], Mikol. Fitopatol. 35(1): 17 (2001).

Notes - This genus differs from Lophium and Mytilinidion in having rigid, band-forming ascomata, with a less fragile peridium. Molecular data are presently lacking.

\section{Ecological and economic significance}

Species in Mytilinidiaceae are saprobes on wood involved in nutrient cycling.

Pleosporales Luttr. ex M.E. Barr.

Index Fungorum number: IF 90563; Facesoffungi number: FoF 08715

Pleosporales is the largest order in the Dothideomycetes, comprising a quarter of all dothideomycetous species (Hyde et al. 2013, Liu et al. 2017a). Luttrell (1955) invalidly introduced the order Pleosporales and later validly established by Barr (1987b), based on the family Pleosporaceae with the type species Pleospora herbarum (Barr 1987a). Pleosporalean species show a cosmopolitan distribution in worldwide, as epiphytes, saprobes, endophytes or parasites, pathogens, hyperparasites on fungi or insects and or as lichenized fungi (Zhang et al. 2012b, Hyde et al. 2013, Wanasinghe et al. 2018c, Mapook et al. 2020). Pleosporales are characterised by perithecioid ascomata typically with a papilla and bitunicate, generally fissitunicate asci bearing mostly septate ascospores of different colours and shapes, with or without a gelatinous sheath (Zhang et al. 2012b, Hyde et al. 2013, Jaklitsch \& Voglmayr 2016, Jaklitsch et al. 2018b). Asexual morphs of the Pleosporales are usually coelomycetous, but also can be hyphomycetous (Zhang et al. 2012b, Hyde et al. 2013). Hyde et al. (2013) included 41 families in Pleosporales while in a recent study by Wijayawardene et al. (2018) listed 75 families in Pleosporales. Based on both morphology and phylogeny evidence, Pleosporales comprises 91 families in this study. The divergence time for Pleosporales is estimated as 205 MYA (stem age) (Fig. 2).

Acrocalymmaceae Crous \& Trakun., IMA Fungus 5(2): 404 (2014).

Index Fungorum number: IF 810837; Facesoffungi number: FoF 08135, 7 species.

Pathogens, saprobes. Sexual morph: Ascomata globose, with central beak ostiole, ostiole lined with periphyses; inner layer giving rise to hyaline, cellular pseudoparaphyses, septate, anastomosing. Asci cylindrical, sessile in rosette, 8-spored, bitunicate. Ascospores 2-3-seriate, narrowly fusoid, straight or slightly curved, at the beginning hyaline, 1-septate, with a mucoid sheath, becoming transversely 3-septate after discharge, constricted or not, pale brown. Asexual morph: Coelomycetous. Conidiomata pycnidial, papillate or rostrate, globose, dark brown or black, ostiolate. Conidiophores reduced to conidiogenous cells or a supporting cell. Conidiogenous cells 
ampulliform to doliiform or cylindrical, hyaline, smooth, percurrently proliferating at apex. Conidia hyaline, but becoming pigmented with age, 0-3-septate, continuous, smooth-walled, with mucoid apical and basal appendages.

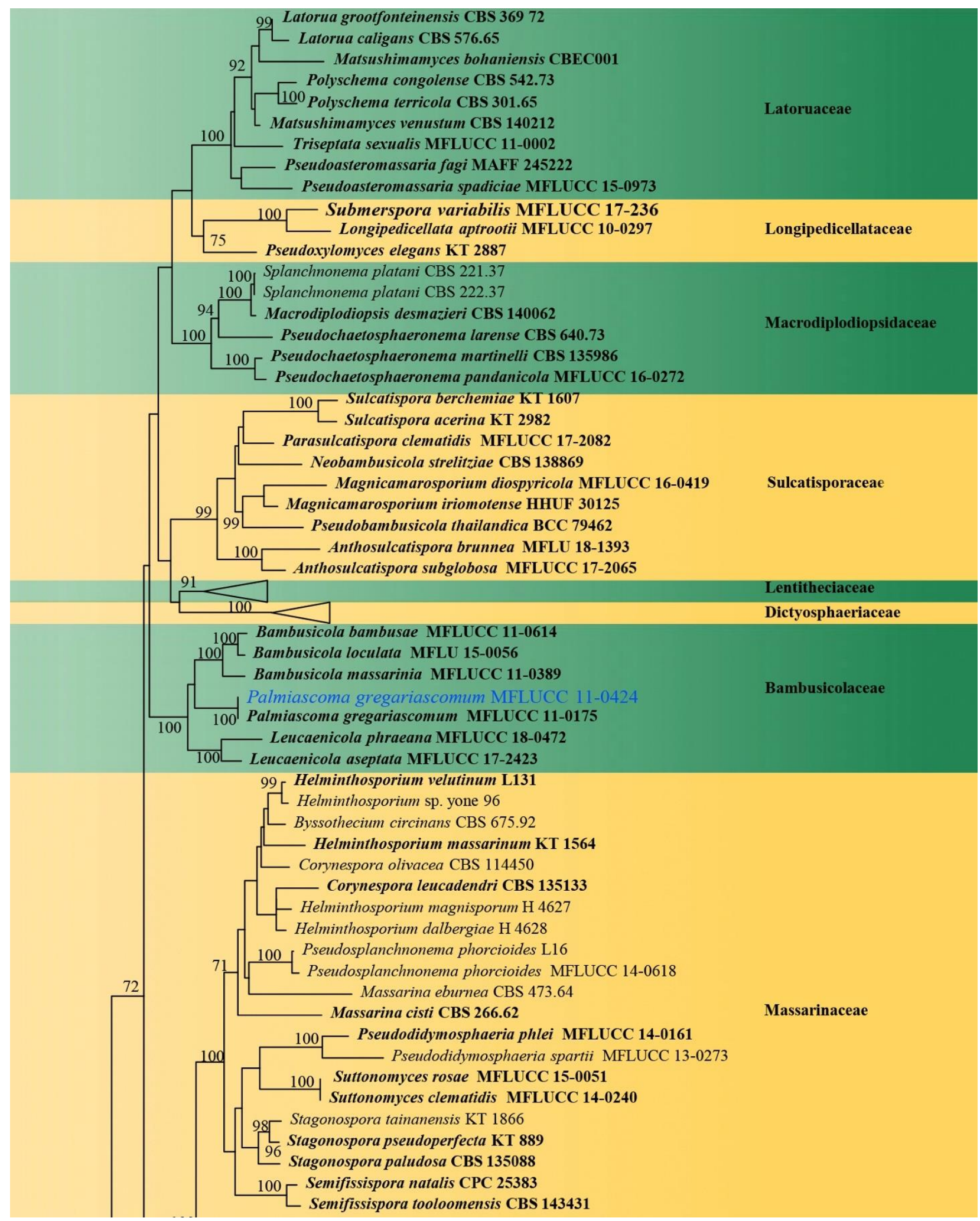

Figure 42 - Phylogram generated from maximum likelihood analysis (RAxML) of Pleosporales based on ITS, LSU, rpb-2, SSU and tef1 sequence data. Maximum likelihood bootstrap values equal or above $70 \%$ are given at the nodes. An original isolate number is noted after the species name. The tree is rooted to Capnodium coffeae (CBS 147.52). The ex-type strains are indicated in bold. 


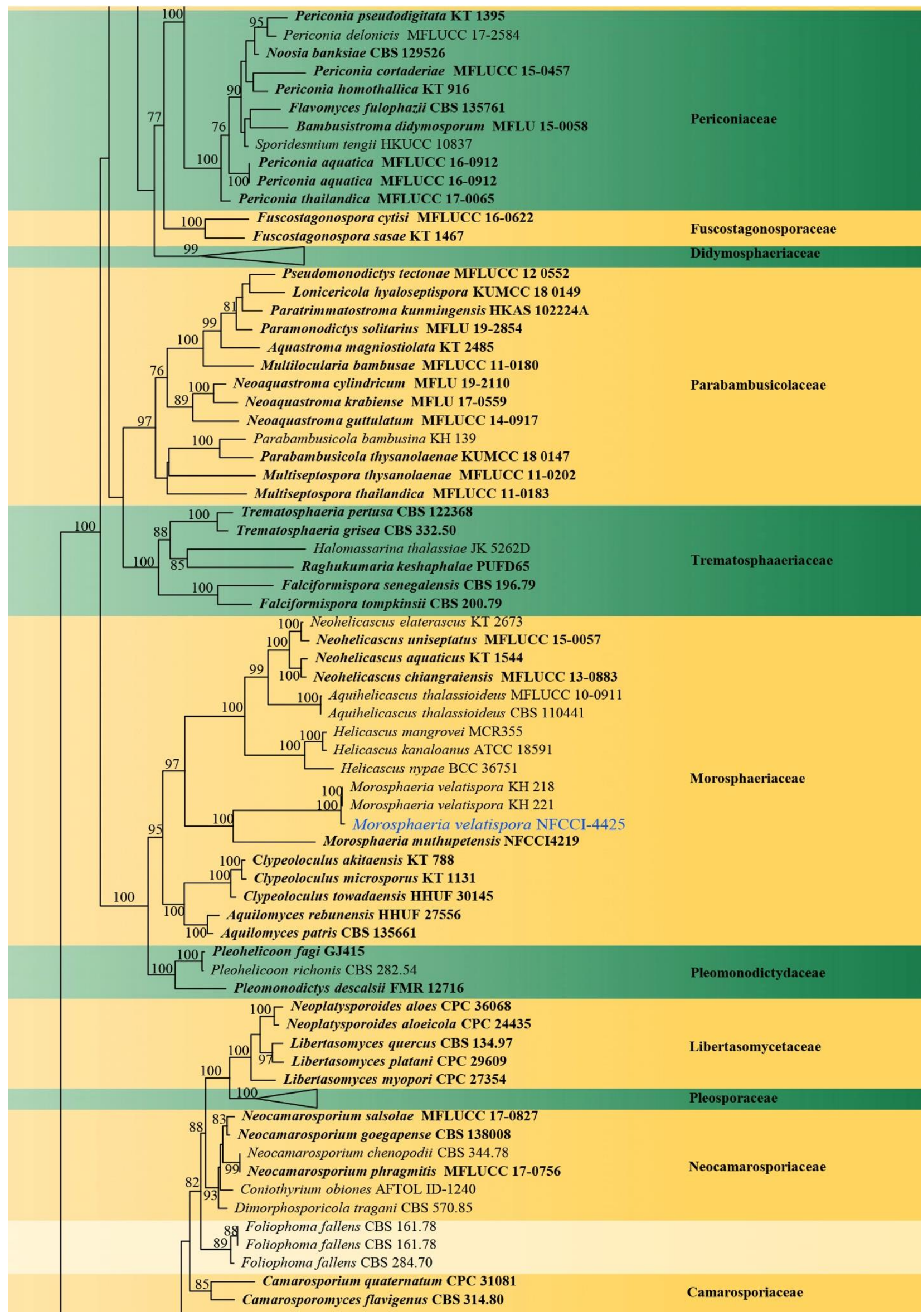

Figure 42 - Continued. 


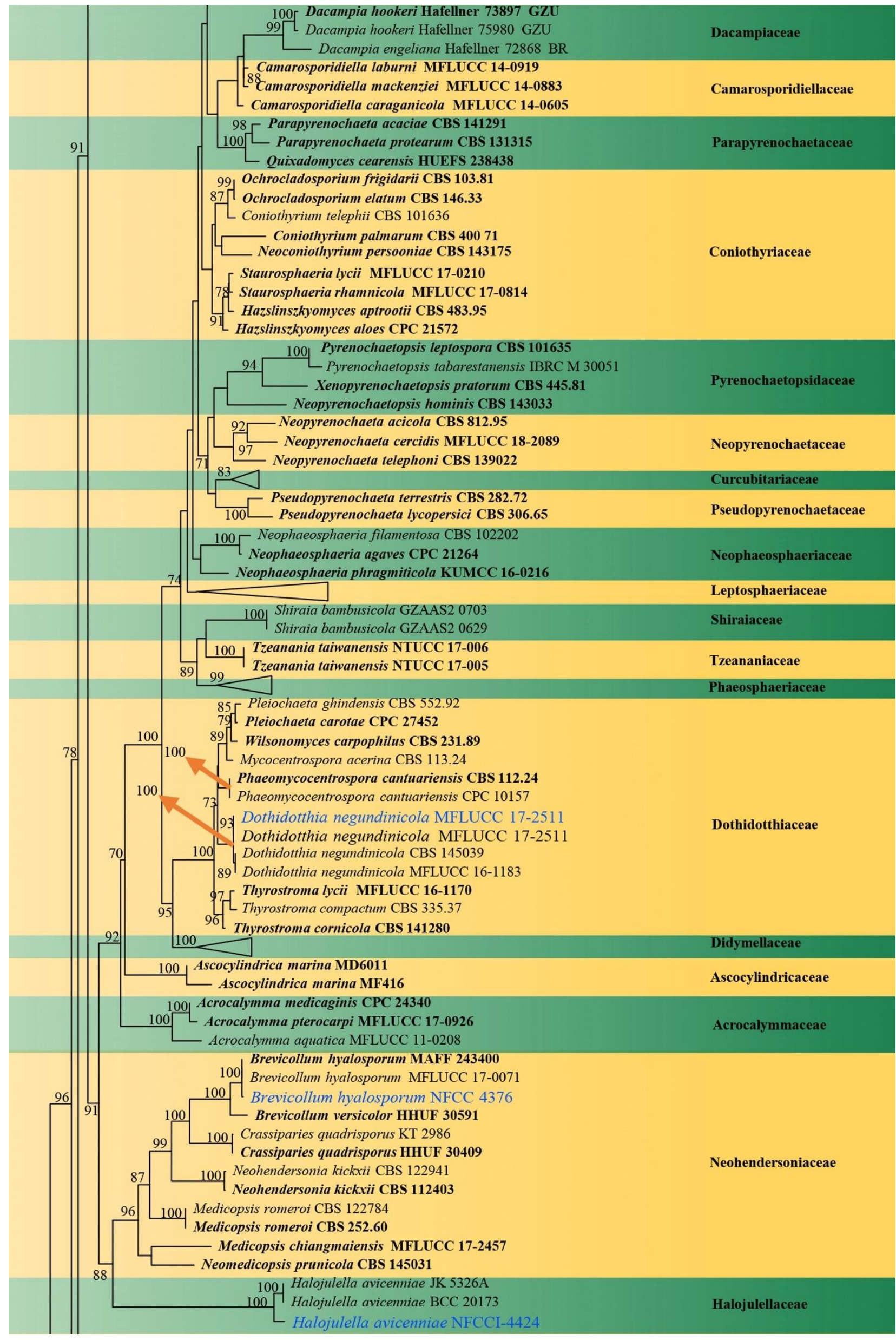

Figure 42 - Continued. 


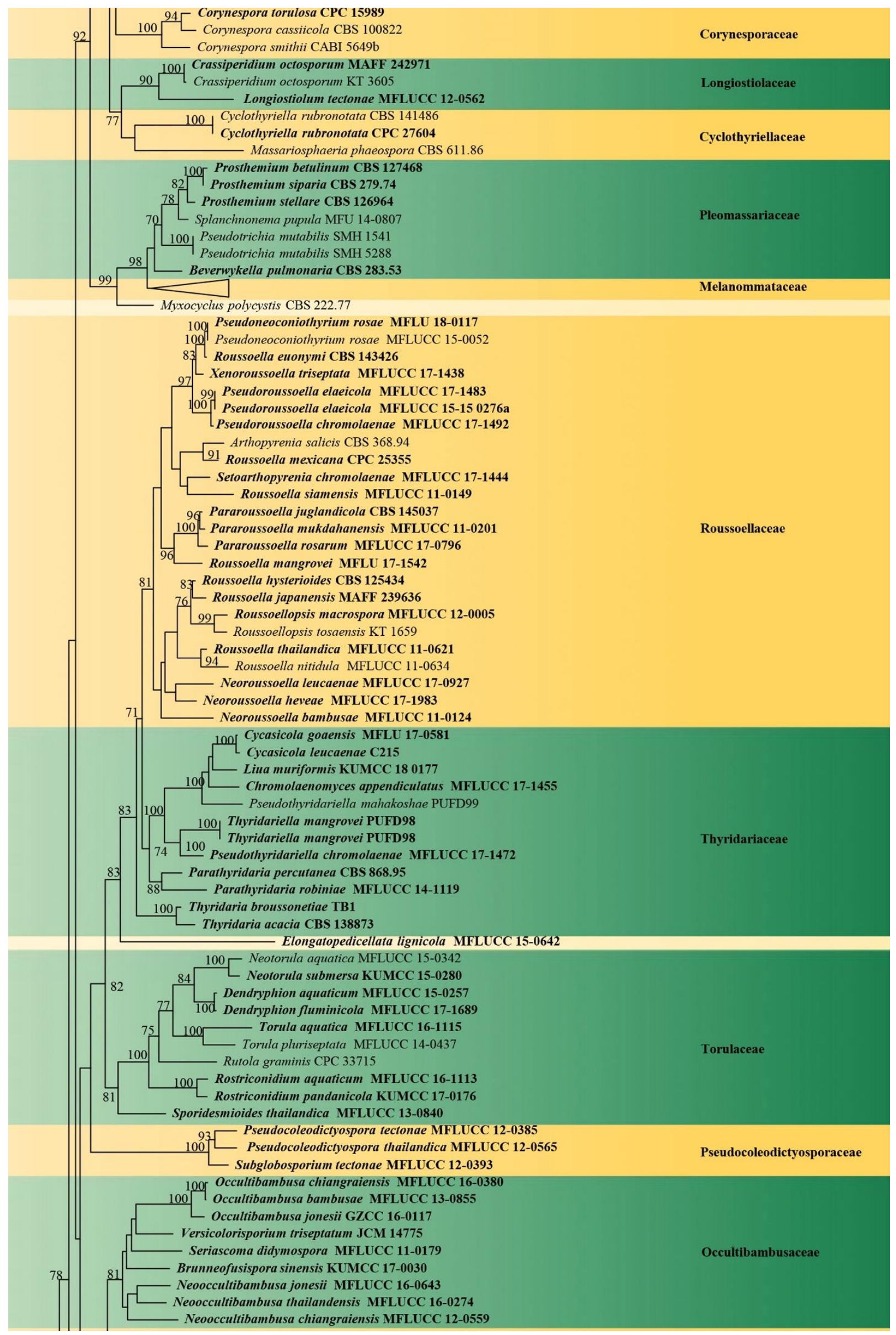

Figure 42 - Continued. 


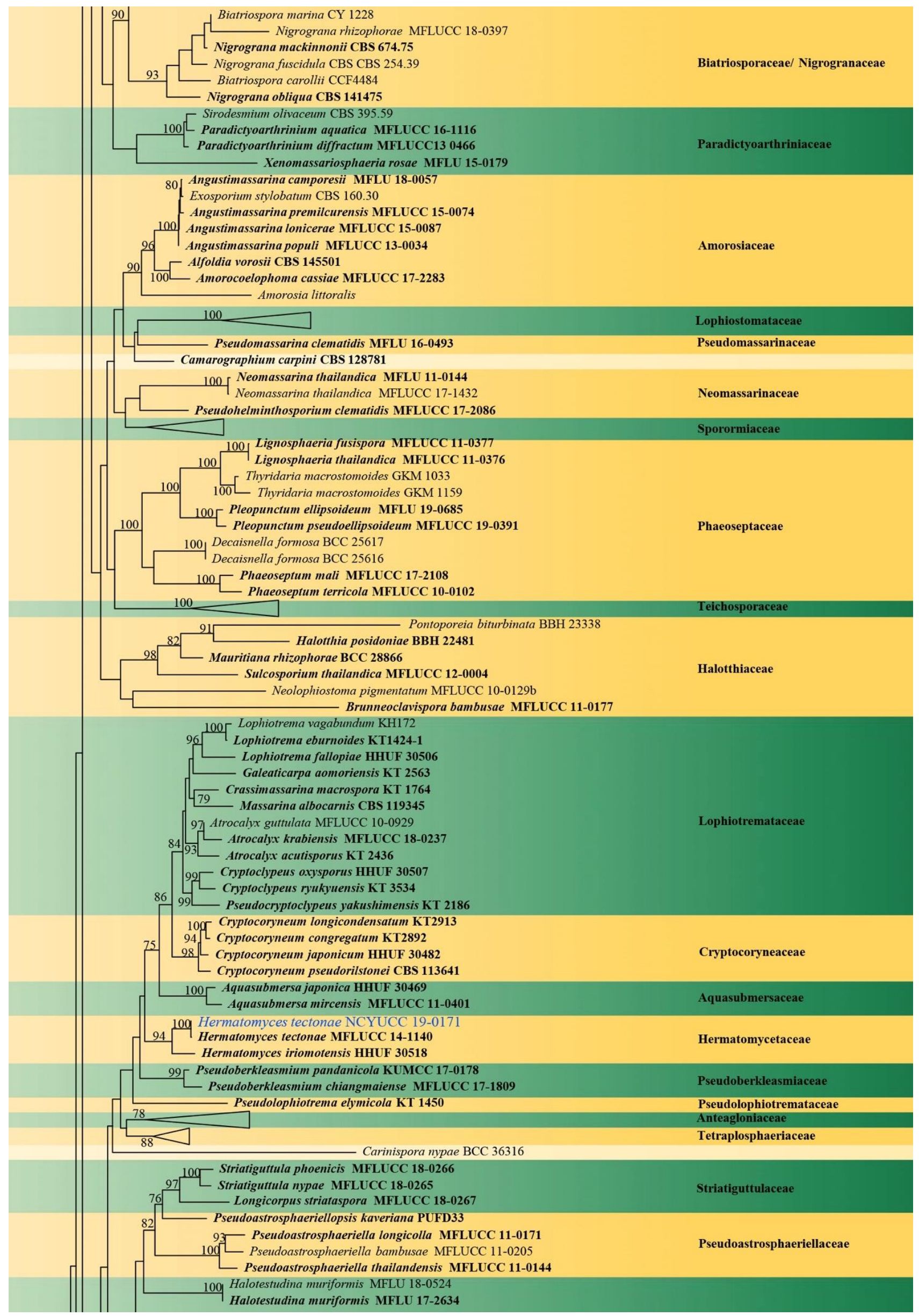

Figure 42 - Continued. 


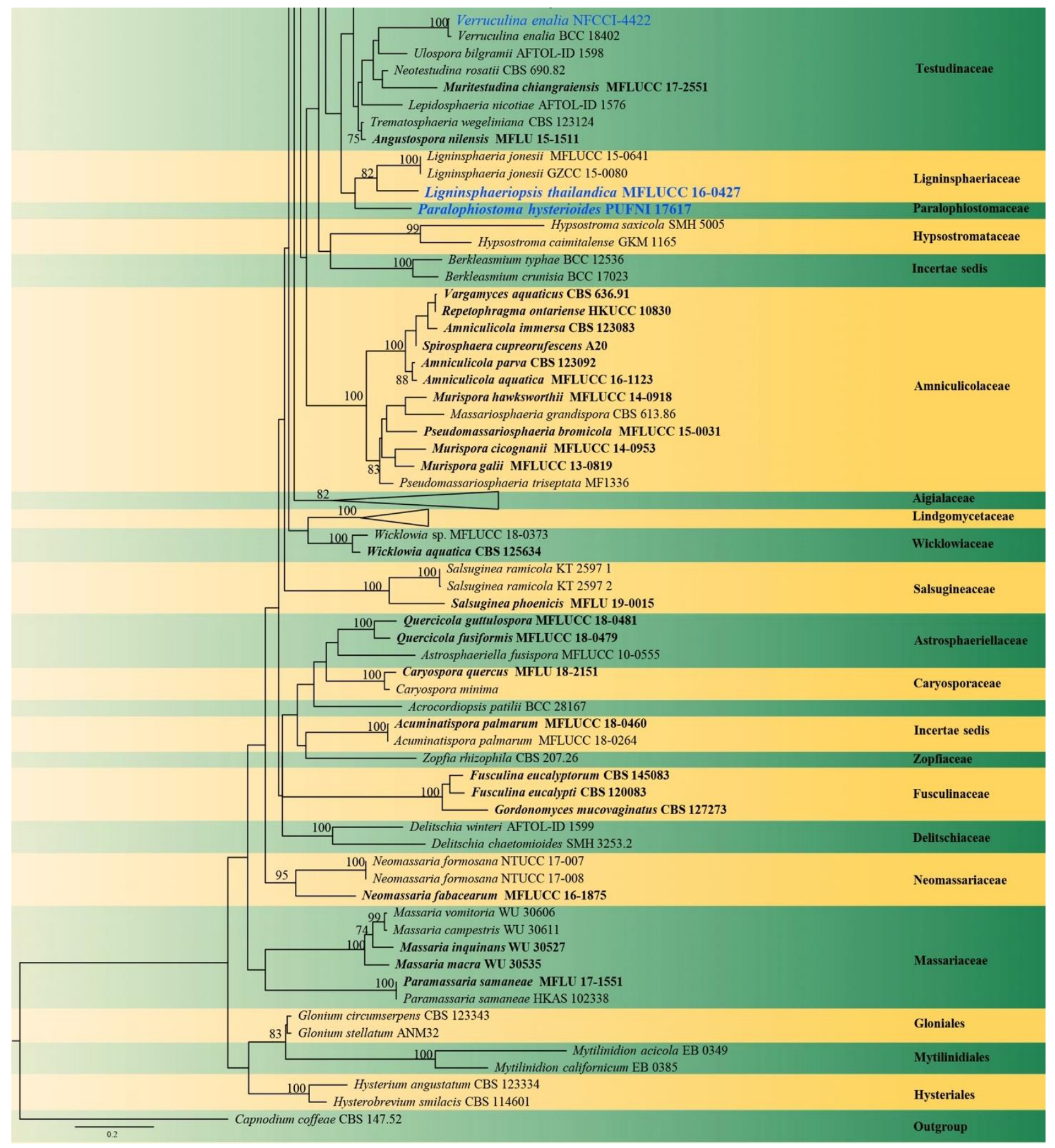

Figure 42 - Continued.

Type - Acrocalymma Alcorn \& J.A.G. Irwin.

Notes - Trakunyingcharoen et al. (2014) introduced Acrocalymmaceae to accommodate Acrocalymma. Liu et al. (2017a) accepted Acrocalymmaceae and provided additional evidence by using divergence times. The family comprises only one genus (Wijayawardene et al. 2017a).

Acrocalymma Alcorn \& J.A.G. Irwin, Trans. Br. Mycol. Soc. 88(2): 163 (1987).

Index Fungorum number: IF 11008; Facesoffungi number: FoF 07097; 7 morphological species (Species Fungorum 2020), 7 species with molecular data.

Type species - Acrocalymma medicaginis Alcorn \& J.A.G. Irwin.

Notes - Alcorn \& Irwin (1987) introduced Acrocalymma with A. medicaginis as the type species. Shoemaker et al. (1991) reported A. medicaginis as the asexual morph of Massarina walkeri. However, Trakunyingcharoen et al. (2014) showed that M. walkeri and A. medicaginis are 
phylogenetically distinct although congeneric, thus, introducing the new combination, A. walkeri. In their phylogenetic analyses, the type species of Rhizopycnis resides in Acrocalymma sensu stricto and hence, Rhizopycnis has been treated as a synonym of Acrocalymma (Trakunyingcharoen et al. 2014).

Species in this genus occur in terrestrial habitats apart from Acrocalymma aquatica (Zhang et al. 2012a). Except for the pathogenic species A. medicaginis and A. vagum, the genus has been reported as saprobes e.g. A. fici on Ficus sp. and A. cycadis on Cycas calcicola (Crous et al. 2014a, Trakunyingcharoen et al. 2014).
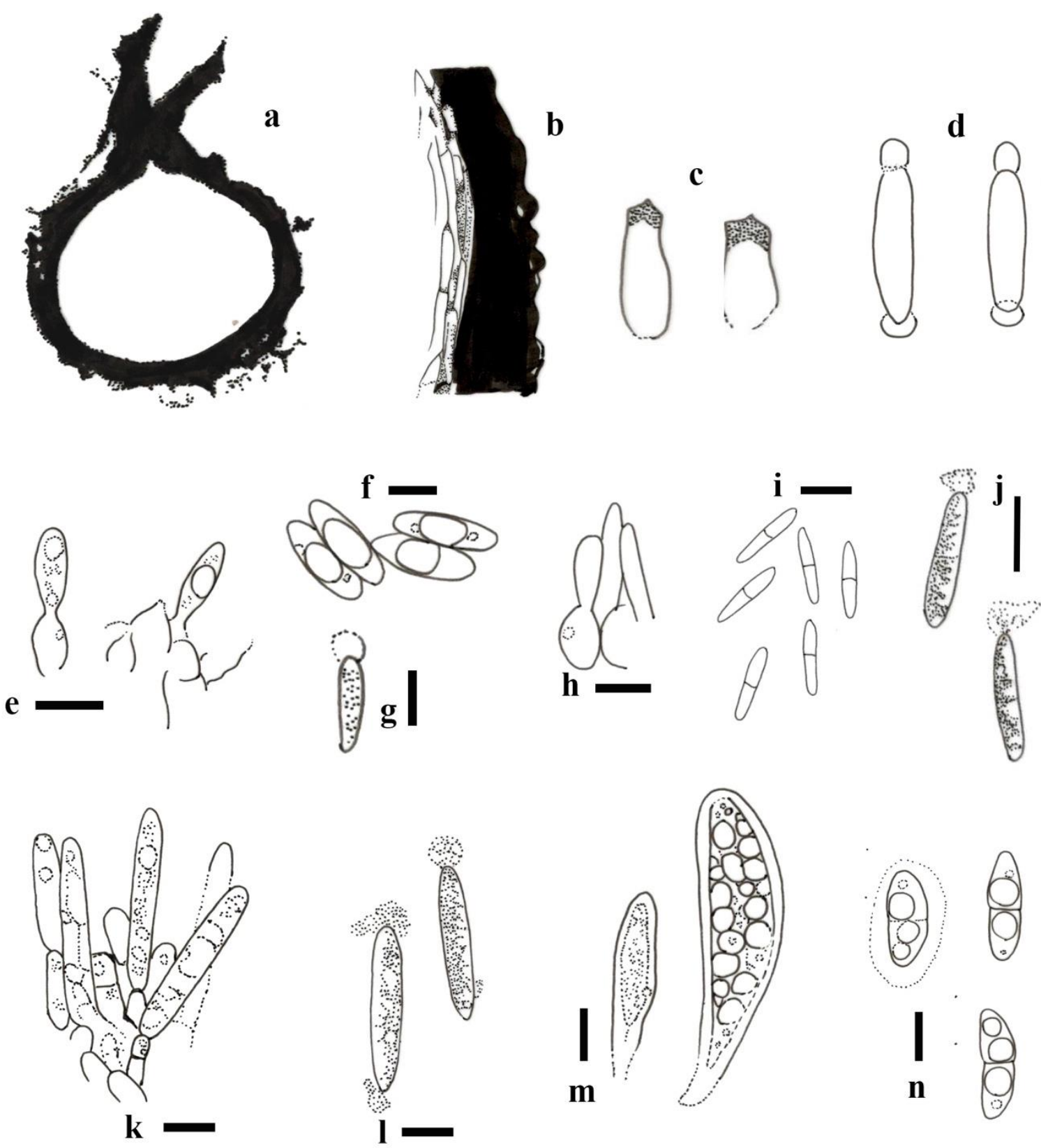

Figure 43 - Morphology of Acrocalymma spp. (a-d = redrawn of A. medicaginis from Alcorn \& Irwin 1987; $\mathrm{e}-\mathrm{g}=$ redrawn of A. medicaginis BRIP 5876a from Trakunyingcharoen et al. 2014; $\mathrm{h}-\mathrm{j}$ $=$ redrawn of of $A$. fici (CBS 317.76) from Trakunyingcharoen et al. 2014; k, $1=$ redrawn of $A$. cycadis CBS H-21683 from Crous et al. 2014a; $\mathrm{m}, \mathrm{n}=$ redrawn sexual characters of $A$. pterocarpi MFLU 18-2112 from Jayasiri et al. 2019). a Verticsl section of conidiomata on PDA. b Conidioma wall. c, e, h, k Conidiogenous cells. d, f, g, i, j, l Conidia. m Asci. $\mathrm{n}$ Ascospores. Scale bars: e, i -n $=10 \mu \mathrm{m}, \mathrm{f}, \mathrm{g}, \mathrm{h}=5 \mu \mathrm{m}$. 


\section{Ecological and economic significance}

Acrocalymma medicaginis has been reported as the causal agent of root and crown rot of Medicago sativa (Alcorn \& Irwin 1987). However, the other species are mainly regarded as saprobes, but this needs to be confirmed. For example, A. pterocarpi (Jayasiri et al. 2019) has been reported from pods of Pterocarpus indicus which is an important plant in forestry, and for indigenous medicine in South-East Asia.

Aigialaceae Suetrong, Sakay., E.B.G. Jones, Kohlm., Volkm.-Kohlm. \& C.L. Schoch, in Suetrong et al., Stud. Mycol. 64: 166 (2009).

Index Fungorum number: IF 515957; Facesoffungi number: FoF 08136, 25 species.

Saprobic on submerged bark or wood of mangrove trees, marine and terrestrial habitats. Sexual morph: Ascomata immersed, semi-immersed, erumpent to superficial, black, scattered or rarely clustered, globose or conical, coriaceous to carbonaceous, ostiolate, with rounded or slit-like ostiole, apapillate. Peridium composed of dark brown, thick-walled cells of textura epidermoidea to angularis, occasionally globulosa. Hamathecium comprising hyaline, anastomosing, trabeculate pseudoparaphyses, embedded in a gelatinous matrix. Asci 8-spored, bitunicate, fissitunicate, obclavate to cylindrical, pedicellate, with or without refractive apical ring, J- ocular chamber. Ascospores 2-seriate, obclavate, ellipsoidal to fusiform, hyaline to brown or dark brown, septate, phragmosporous to muriform, slightly constricted at the septa, smooth-walled, surrounded by a mucilaginous sheath or caps at the ends. Asexual morph: Coelomycetous, reported as pleurophomopsis-like for Fissuroma aggregata (Tanaka \& Harada 2005a); Hyphomycetuos (see Vohník et al. 2019).

Type - Aigialus Kohlm. \& S. Schatz.

Notes - Aigialus was established in Pleosporales by Suetrong et al. (2009) based on phylogenetic analyses and morphology. The family accommodates taxa having carbonaceous ascomata without papilla, trabeculate pseudoparaphyses, cylindrical asci and ascospores with a sheath or gelatinous appendages around the apical cells (Suetrong et al. 2009, Hyde et al. 2013). Three genera, Aigialus, Ascocratera and Rimora, were initially included from marine and mangrove habitats (Suetrong et al. 2009). Fissuroma and Neoastrosphaeriella were later introduced by Liu et al. (2011) from terrestrial habitats. Aigialus, Ascocratera and Rimora share similar features such as carbonaceous, apapillate ascomata, trabeculate pseudoparaphyses, cylindrical asci with an apical apparatus and ascospores with a sheath but differ by their ascospores. The ascospores in Aigialus are brown and muriform, while 1-3-septate in Ascocratera and Rimora (Suetrong et al. 2009). Fissuroma and Neoastrosphaeriella share features such as hemisphaerical, immersed to semiimmersed ascomata with slit-like ostioles, 1-septate ascospores but Fissuroma has cylindro-clavate asci, elongate-fusiform, hyaline ascospores, while Neoastrosphaeriella has obclavate asci, fusiform, brown to dark brown ascospores that are verrucose at maturity (Liu et al. 2011). The family includes six genera viz. Aigialus, Ascocratera, Fissuroma, Neoastrosphaeriella, Posidoniomyces and Rimora (Hyde et al. 2013, Wanasinghe et al. 2018a, Wijayawardene et al. 2018, Vohník et al. 2019).

Aigialus Kohlm. \& S. Schatz, Trans. Br. mycol. Soc. 85(4): 699 (1986).

Index Fungorum number: IF 6002; Facesoffungi number: FoF 08137; 5 morphological species (Species Fungorum 2020), 4 species with molecular data.

Type species - Aigialus grandis Kohlm. \& S. Schatz.

Notes - Kohlmeyer \& Schatz (1985) introduced Aigialus with A. grandis (type species) and A. parvus S. Schatz \& Kohlm. in Melanommatales. Hawksworth et al. (1995) referred it to Massariaceae, Pyrenulales. Tam et al. (2003) showed that the genus was accommodated in Pleosporales, but suggested that further studies were required with more taxa to clarify its natural placement. Jones et al. (2009b) placed Aigialus in the Pleosporales incertae sedis and accepted four species but rejected $A$. rhizophorae as it shared similar morphology with $A$. grandis, but differed in the vertical septation in the subapical cell (Suetrong et al. 2009). Further collections of $A$. rhizophorae were made in Thailand with sequence data that confirmed A. rhizophorae was clearly 
distinct from A. grandis (Suetrong et al. 2009, Jones et al. 2019a). Five species are accepted in Aigialus (Jones et al. 2019b).

Aigialus parvus S. Schatz \& Kolhm., Trans. Br. Mycol. Soc. 85:704 (1986).

Fig. 45

Index Fungorum number: IF 103974; Facesoffungi number: FoF 06528.

Ascomata 400-1000 $\mu \mathrm{m}$ high, 200-830 $\mu \mathrm{m}$ diam. $(\bar{x}=670 \times 425 \mu \mathrm{m}, \mathrm{n}=5)$ wide, subglobose in frontal view, fusiform in sagittal section, laterally compressed, immersed in a black stroma, with a longitudinal furrow at the top, ostiolate, carbonaceous to coriaceous, black, gregarious. 50-150 $\mu \mathrm{m}$ diam., depressed or slightly projecting, circular, ostiolar canal subglobose, filled with branched or forked septate periphyses, 3-4 $\mu \mathrm{m}$ diam. Peridium two-layered, outer layer 60-150 $\mu \mathrm{m}(\bar{x}=98 \mu \mathrm{m}, \mathrm{n}=5)$ thick and clypeoid near the ostiole, $15-45 \mu \mathrm{m}$ at the sides, composed of elongate, more or less irregular cells, encrusted with melanin particles, interspersed with cells of the host, inner layer composed of smaller, hyaline cells that merge with pseudoparaphyses, the peridium extends at the base into the locule with brown strands composed of pseudoparaphyses that separate above, become hyaline and are surrounded by a gelatinous matrix. Hamathecium comprising 1-2 $\mu \mathrm{m}$ diam., trabeculate, unbranched at the base becoming branched, anastomosing above the asci, pseudoparaphyses, embedded in a gelatinous matrix. Asci $360-500 \times 15-20 \mu \mathrm{m}(\bar{x}=$ $455 \times 16 \mu \mathrm{m}, \mathrm{n}=20), 8$-spored, bitunicate, fissitunicate, cylindrical, thick-walled, with a refractive apical plate in the ectoascus and a refractive apical ring in the endoascus. pedicellate. Ascospores 45-62 × 10-22.5 $\mu \mathrm{m}(\bar{x}=54 \times 16 \mu \mathrm{m}, \mathrm{n}=25), 2$-seriate, thick-walled, ellipsoidal to broadly fusiform, muriform, yellow-brown except for hyaline to light brown apical cells, glabrous, with 810 trans-septa and 1-3 longi-septa, with a gelatinous cap around apical and subapical cells.

Culture characteristics - Ascospores germinating on $2 \%$ sea water agar within $24 \mathrm{~h}$ with germ tubes produced from apical and distal ends. Colonies on malt extract sea water agar slow growing, pale brown to dark brown, reverse brown, circular, raised reaching 10 to $20 \mathrm{~mm}$ in diameter in 25 days at room temperature. Mycelium hyaline to brown, producing yellow brown pigments, velvety.

Material examined - India, Tamil Nadu, Pondicherry, Thengaithittu mangroves, $\left(11.59^{\circ} \mathrm{N}\right.$ $79.5^{\circ} \mathrm{E}$ ), on decaying wood of Rhizophora mucronata (Rhizophoraceae), 20 January 2017, B. Devadatha, AMH-10012, living culture, NFCCI-395.

GenBank numbers - ITS: MK026760, LSU: MK026761, rpb-2: MN520612, SSU: MK026763, tef1: MN520611.

\section{Other genera included}

Ascocratera Kohlm., Can. J. Bot. 64(12): 3036 (1986).

Index Fungorum number: IF 25019; Facesoffungi number: FoF 08138; 1 morphological species (Species Fungorum 2020), 1 species with molecular data.

Type species - Ascocratera manglicola Kohlm., Can. J. Bot. 64(12): 3036 (1986).

Notes - Kohlmeyer (1986) introduced Ascocratera with A. manglicola as the type species, and tentatively placed it in Massariaceae, order Melanommatales. This species was described from dead wood of mangrove trees such as Avicennia germinans, Laguncularia racemosa and Rhizophora mangle in the Atlantic and Pacific Oceans (Kohlmeyer 1986). Suetrong et al. (2009) provided sequence data for this species and placed it in Aigialaceae, Pleosporales.

Fissuroma Jian K. Liu, Phookamsak, E.B.G. Jones \& K.D. Hyde, in Liu et al., Fungal Divers. 51(1): 145 (2011).

Index Fungorum number: IF 563456; Facesoffungi number: FoF 08139; 12 morphological species (Species Fungorum 2020), 8 species with molecular data.

Type species - Fissuroma maculans (Rehm) Jian K. Liu, E.B.G. Jones \& K.D. Hyde, Fungal Divers. 51(1): 145 (2011).

$\equiv$ Metasphaeria maculans Rehm, Philipp. j. sci. 8 (5): 401 (1913).

Notes - Fissuroma is typified by F. maculans (Liu et al. 2011). Fissuroma species have been reported from numerous hosts such as Arenga westerhoutii, bamboo, Borassus flabellifer, Calamus 
rotang and Hedychium coronarium, and are widely distributed (Phookamsak et al. 2015b, Niranjan \& Sarma 2018, Tennakoon et al. 2018c, Wanasinghe et al. 2018a). The coelomycetous pleurophomopsis-like asexual morph was reported for $F$. aggregata with globose to subglobose conidiomata, phialidic conidiogenous cells and hyaline, globose conidia (Tanaka \& Harada 2005a). Phookamsak et al. (2015b) showed Fissuroma bambusae formed a coelomycetous asexual morph on MEA, which differs from $F$. aggregata in having oblong conidia.

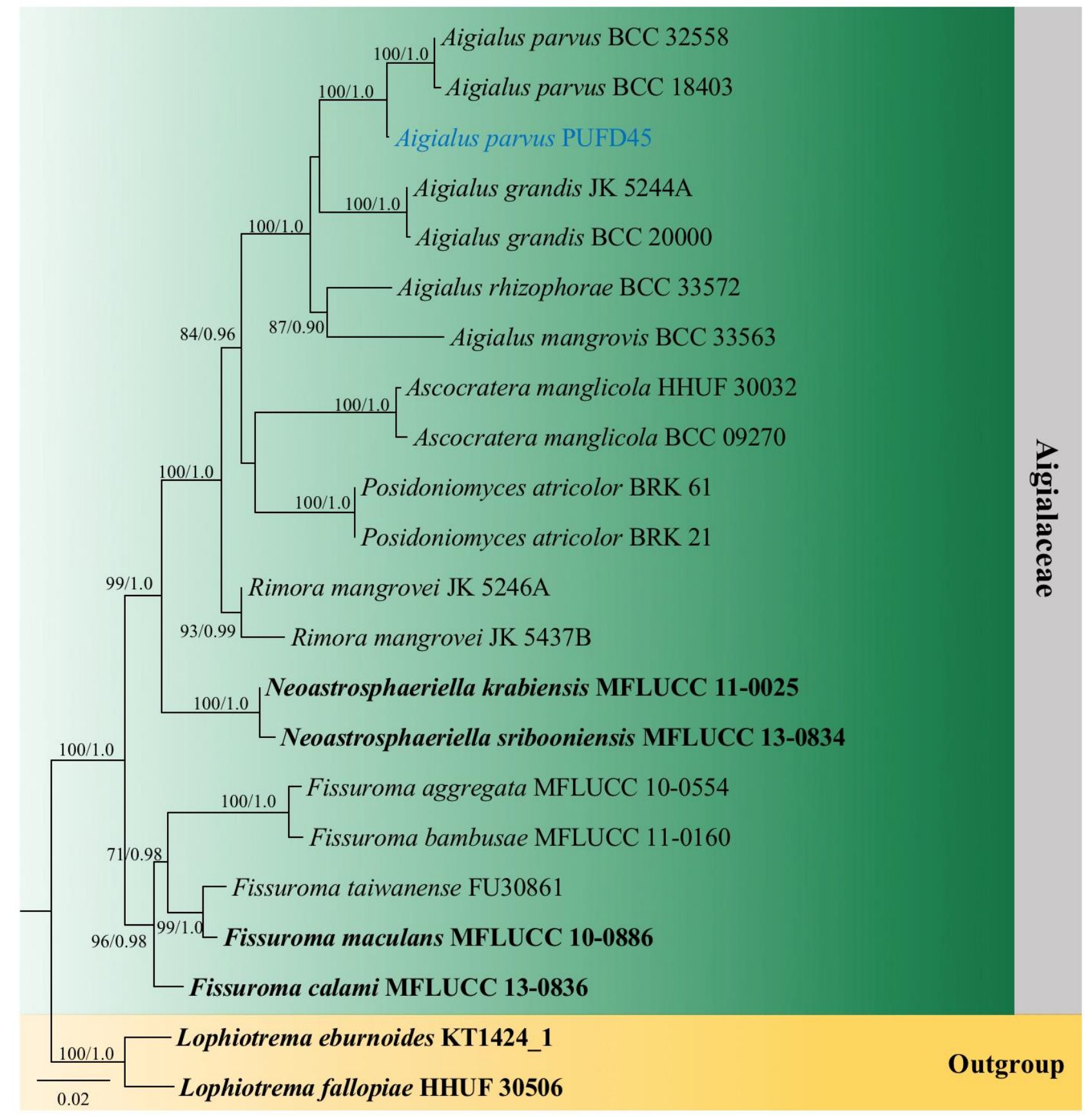

Figure 44 - Phylogram generated from maximum likelihood analysis (RAxML) of genera in Aigialaceae based on LSU, rpb-2, SSU and tef1 sequence data. Maximum likelihood bootstrap values equal or above $70 \%$, Bayesian posterior probabilities equal or above 0.90 (MLBS/PP) are given at the nodes. An original isolate number is noted after the species name. The tree is rooted to Lophiotrema eburnoides (KT1424-1) and L. fallopiae (HHUF 30506). The ex-type strains are indicated in bold. Newly sequence is in blue. Hyphen (-) represents support values below $70 \%$ MLBS and $0.90 \mathrm{PP}$. 

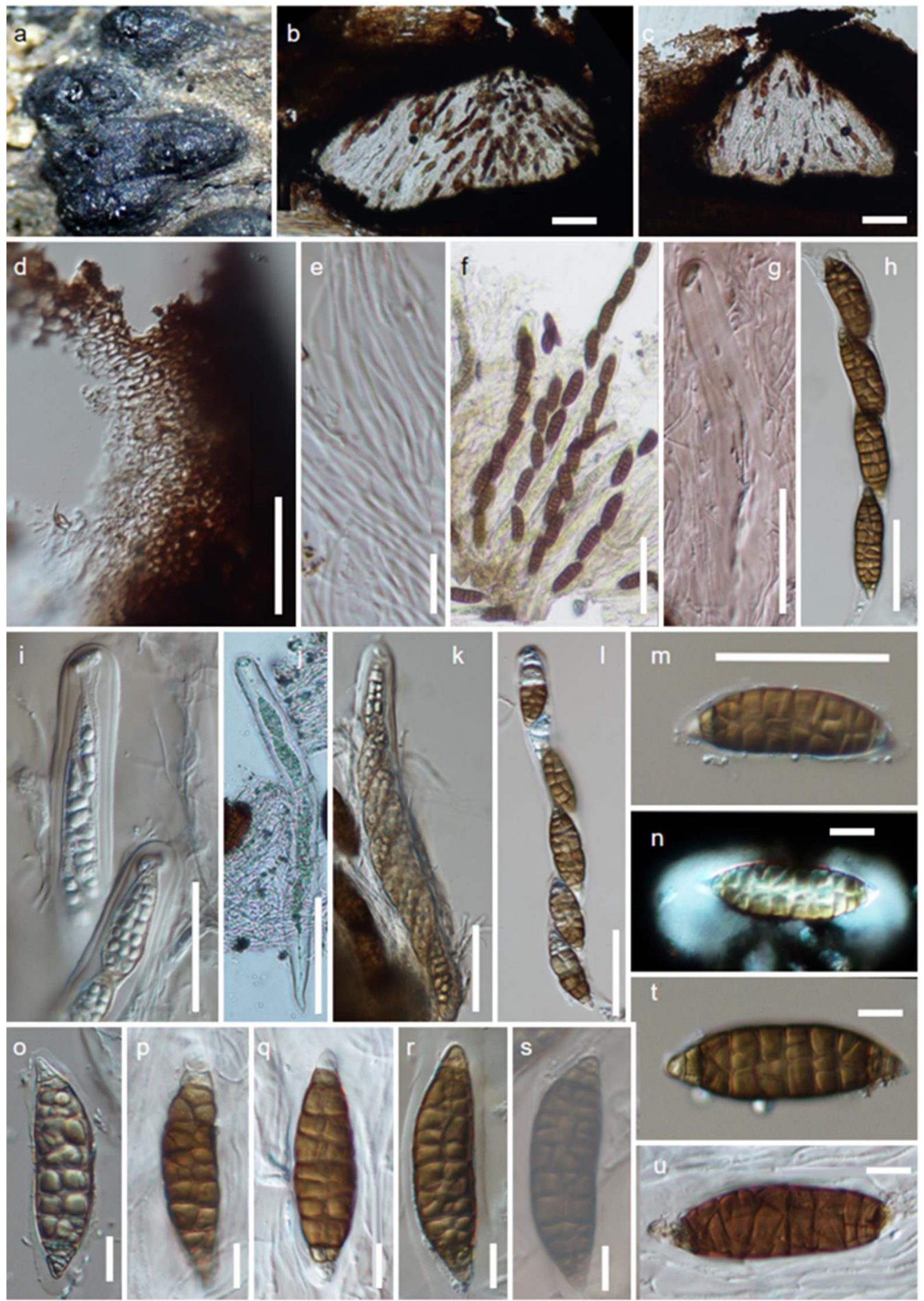

Figure 45 - Aigialus parvus (AMH-10012). a Ascomata erumpent in the decaying wood of Avicennia marina. b, c Longitudinal sections of ascomata. d Section of peridium. e Hyaline filamentous pseudoparaphyses. $\mathrm{f}-\mathrm{l}$ Immature and mature asci. $\mathrm{m}-\mathrm{u}$ Immature and mature ascospores. $\mathrm{n}$ Ascospores in Indian ink showing polar caps. Scale bars: $\mathrm{b}, \mathrm{c}, \mathrm{f}=100 \mu \mathrm{m}, \mathrm{d}, \mathrm{g}-\mathrm{m}=$ $50 \mu \mathrm{m}, \mathrm{e}, \mathrm{n}-\mathrm{u}=10 \mu \mathrm{m}$. 
Neoastrosphaeriella Jian K. Liu, E.B.G. Jones \& K.D. Hyde, in Liu et al., Fungal Divers. 51(1): 148 (2011).

Index Fungorum number: IF 563462; Facesoffungi number: FoF 08150; 5 morphological species (Species Fungorum 2020), 5 species with molecular data.

Type species - Neoastrosphaeriella krabiensis Jian K. Liu, E.B.G. Jones \& K.D. Hyde, in Liu et al., Fungal Divers. 51(1): 148 (2011).

Notes - Neoastrosphaeriella was established by Liu et al. (2011) to accommodate $N$. krabiensis. The holotype specimen was isolated from petiole of the palm Metroxylon sagu in Thailand. Neoastrosphaeriella clustered in a sister group within Aigialaceae based on molecular analyses (Liu et al. 2011, Liu et al. 2017a, Wanasinghe et al. 2018a). Five Neoastrosphaeriella species have been recorded viz. N. alankrithabeejae, N. aquatica, N. krabiensis, N. phoenicis and N. sribooniensis (Niranjan \& Sarma 2018, Liu et al. 2011, Wanasinghe et al. 2018a).

Posidoniomyces Vohník \& Réblová, in Vohník et al., MycoKeys 55: 72 (2019).

Index Fungorum number: IF 830267; Facesoffungi number: FoF 08151, 1 morphological species (Species Fungorum 2020), 1 species with molecular data.

Type species - Posidoniomyces atricolor Vohník \& Réblová, in Vohník et al., MycoKeys 55: 72 (2019).

Notes - Posidoniomyces was introduced by Vohník et al. (2019) with Posidoniomyces atricolor as the type species. Posidoniomyces atricolor was isolated as root mycobionts of the dominant and endemic Mediterranean seagrass Posidonia oceanica from marine habitat. The morphological characters in vivo are brown, septate hyphae, forming intracellular microsclerotia in the hypodermis of the terminal fine roots and finger-like pseudoparenchymatous net on the surface of roots, while two distinct colonial morphotypes (compact and mycelial) are formed in cultures (see Vohník et al. 2019). The sexual morph is undetermined.

Rimora Kohlm., Volkm.-Kohlm., Suetrong, Sakay. \& E.B.G. Jones, in Suetrong et al., Stud. Mycol. 64: 166 (2009).

Index Fungorum number: IF 515958; Facesoffungi number: FoF 08152; 1 morphological species (Species Fungorum 2020), 1 species with molecular data.

Type species - Rimora mangrovei (Kohlm. \& Vittal) Kohlm., Volkm.-Kohlm., Suetrong, Sakay. \& E.B.G. Jones, in Suetrong et al., Stud. Mycol. 64: 166 (2009).

$\equiv$ Lophiostoma mangrovei Kohlm. \& Vittal, Mycologia 78(3): 487 (1986).

Notes - The monotypic genus was established by Suetrong et al. (2009). Initially, it was described from bark and wood of mangrove trees from Belize and India as Lophiostoma mangrovei (Kohlmeyer \& Vittal 1986). It was subsequently transferred to Astrosphaeriella by Hyde et al. (2002) based on the trabeculate pseudoparaphyses. However, Astrosphaeriella mangrovis differs from other species in Astrosphaeriella by their round flattened ascomata, slit-like ostioles and nonmonocotyledonous hosts suggesting it might be a new genus (Hyde et al. 2002, www/marinefungi.org). Suetrong et al. (2009) synonymized Lophiostoma mangrovei and A. mangrovei under $R$. mangrovei.

\section{Ecological and economic significance}

Aigialaceae comprises six genera. All taxa in the Aigialaceae have been currently reported as saprobic fungi from mangrove trees, and various plant hosts from marine and terrestrial habitats, which may play a role in the recycling of nutrients in marine and terrestrial habitats. Members of this family are important decomposers of the complex components of various plant debris such as lignin and cellulose. Bioactive compounds have been described from Aigialus parvus e.g. aigialomycins A and hypothemycin with antimalarial activity (Isaka et al. 2002).

Amniculicolaceae Y. Zhang ter, C.L. Schoch, J. Fourn., Crous \& K.D. Hyde, Stud. Mycol. 64: 95 (2009).

Index Fungorum number: IF 515469; Facesoffungi number: FoF 08153, 18 species. 
Saprobic in freshwater and terrestrial habitats. Sexual morph: Ascomata solitary, scattered or in small groups, erumpent, immersed or nearly superficial, globose, subglobose to lenticular, with rough black surface, usually staining the woody substrate shades of purple, ostiolate. Ostiole with elongate apex and ostiolar canal filled with hyaline cells. Peridium two-layered, outer layer of small heavily pigmented thick-walled cells of textura angularis, inner layer of hyaline thin-walled cells of textura angularis. Hamathecium comprising numerous, hyaline, septate, narrow, trabeculate, pseudoparaphyses, embedded in a gel matrix. Asci 8-spored, bitunicate, fissitunicate, long cylindrical to clavate, short-pedicellate, apially truncate, with an ocular chamber. Ascospores 1-2-seriate, fusiform or narrowly fusiform, hyaline, reddish-brown or pale, 1- to multi-septate, or muriform, constricted at the median septum, generally surrounded by an irregular, hyaline, gelatinous sheath. Asexual morph: Coelomycetous or hyphomycetous, closely related to Anguillospora longissimi, Murispora hawksworthii, Spirosphaera cupreorufescens, Repetophragma ontariense and Vargamyces aquaticus (Zhang et al. 2008b, 2012b, Wanasinghe et al. 2015, Hernández -Restrepo et al. 2017).

Type - Amniculicola Y. Zhang \& K.D. Hyde.

Notes - Amniculicolaceae is a well-supported monophyletic family in Pleosporales (Wanasinghe et al. 2015, Li et al. 2016a). Zhang et al. (2009c) accommodated Amniculicola, Murispora and Neomassariosphaeria in Amniculicolaceae. These genera have a saprobic lifestyle on woody plants from various freshwater habitats in Europe. Hyde et al. (2013) provided a comprehensive transcript to this family with notes and a key to genera of Amniculicolaceae. Wanasinghe et al. (2015) added six new species to Murispora and provided a backbone tree to the family. Ariyawansa et al. (2015a) and Hernandez-Restrepo et al. (2017) introduced two new genera Pseudomassariosphaeria and Vargamyces, respectively. The asexual morphs of Amniculicolaceae are poorly known. Wanasinghe et al. (2015) confirmed that Murispora has a phoma-like coelomycetous asexual morph (M. hawksworthii). Phylogenies indicate that the three Amniculicola species cluster together with putatively named asexual species Anguillospora longissima, Spirosphaera cupreorufescens and Repetophragma ontariense (Zhang et al. 2009c, Seifert et al. 2011, Hyde et al. 2013, Wanasinghe et al. 2015). Repetophragma is characterized by macronematous conidiophores with several annellations which are produced by a few, or numerous, enteroblastic, percurrent proliferations of the conidiogenous cells, and euseptate conidia with a conicotruncate basal cell, which secedes schizolytically (Castañeda-Ruiz et al. 2011). Shenoy et al. (2006) demonstrated that some Repetophragma species were clearly polyphyletic, as they cluster in different families and orders of Sordariomycetes and Dothideomycetes. Based on morphological and genetic similarity Hernandez-Restrepo et al. (2017) synonymized $R$. ontariense under Vargamyces aquaticus. Spirosphaera floriformis (Helotiales) Leotiomycetes and $S$. cupreorufescens have features considered typical of the genus, including a spirally coiled, interwoven conidial filament, the cells of which give rise to one daughter filament, which is also coiled and interwoven, resulting in a large, irregular, globose conidium (Hennebert 1968). The main distinctive feature of $S$. cupreorufescens is the conspicuous copper brown conidia, which are rather irregular and loose (Voglmayr 2004). The sexual morph of Anguillospora longissima has been mentioned as an undescribed species of 'Massarina' (Willoughby \& Archer 1973, Sivanesan 1984, Webster 1992), and agrees with the diagnostic characters of Amniculicola (Zhang et al. 2008b, 2009c). The characters are typical of Amniculicola parva, and therefore, the sexual morph of Anguillospora longissima may be related to Amniculicola parva (Hyde et al. 2013). Rossman et al. (2016) proposed to synonymize Anguillospora longissimi under Amniculicola.

Amniculicola Y. Zhang \& K.D. Hyde, Mycol. Res. 112(10): 1189 (2008).

Index Fungorum number: IF 809; Facesoffungi number: FoF 08154; 6 morphological species (Species Fungorum 2020), 5 species with molecular data.

Type species - Amniculicola lignicola Y. Zhang ter \& K.D. Hyde.

Notes - Amniculicola is the type genus of Amniculicolaceae which was introduced by Zhang et al. (2008b). There are six Amniculicola species listed in Index Fungorum (2020) and all collected from submerged wood in freshwater (Zhang et al. 2008b, 2009c, Rossman et al. 2016). These 
members stain the woody substrate purple and the significance of the purple staining should be further investigated.

\section{Other genera included}

Fusiformispora Phukhams. \& K.D. Hyde, in Phukhams. et al., Fungal Divers 102: 8 (2020).

Index Fungorum number: IF557106; Facesoffungi number: FoF 07242; 1 morphological species (Phukhamsakda et al. 2020), 1 species with molecular data.

Type species - Fusiformispora clematidis Phukhams., M.V. de Bult \& K.D. Hyde, in Phukhams. et al., Fungal Divers 102: 12 (2020).

Notes - Fusiformispora is a monotypic genus which is characterized by obpyriform to compressed globose ascomata, papillate, central ostioles, a multi-layered peridium, trabecular pseudoparaphyses, cylindric-clavate asci with a furcated pedicel and broadly fusiform, hyaline, guttulate ascospores with a mucilaginous sheath. The type Fusiformispora clematidis, resemblances ascospore of Amniculicola. However, their habitat and the characteristics of ascomata and asci are different (Zhang et al. 2008b, Phukhamsakda et al. 2020). See Phukhamsakda et al. (2020) for further details.

Murispora Y. Zhang ter, J. Fourn. \& K.D. Hyde, Stud. Mycol. 64: 95 (2009).

Index Fungorum number: IF 515472; Facesoffungi number: FoF 08155; 7 morphological species (Species Fungorum 2020), 7 species with molecular data.

Type species - Murispora rubicunda (Niessl) Y. Zhang ter, J. Fourn. \& K.D. Hyde, Stud. Mycol. 64: 96 (2009).

EPleospora rubicunda Niessl, Verhandlungen des Naturforschenden Vereines in Brünn 14: 191 (1876).

Notes - Zhang et al. (2009c) introduced Murispora to accommodate Pleospora rubicunda which was pleospora-like but phylogenetically clustered with Amniculicolaceae species. It was a monospecific genus until Wanasinghe et al. (2015) introduced six new species viz. Murispora fagicola, M. galii, M. cardui, M. medicaginicola, M. cicognanii and M. hawksworthii from Italy and the UK. Murispora is a well-supported monophyletic genus and all species have DNA based sequence data. Morphologically, they are easier to distinguish from other species in Amniculicolaceae as the ascospores of this genus are muriform, whereas, Pseudomassariosphaeria and Amniculicola species are fusiform.

Neomassariosphaeria Y. Zhang ter, J. Fourn. \& K.D. Hyde, Stud. Mycol. 64: 96 (2009).

Index Fungorum number: IF 515473; Facesoffungi number: FoF 08156; 1 morphological species (Species Fungorum 2020), 1 species with molecular data.

Type species - Neomassariosphaeria typhicola Y. Zhang ter, J. Fourn. \& K.D. Hyde, Stud. Mycol. 64: 96 (2009).

Notes - Zhang et al. (2009c) presented Neomassariosphaeria (based on Massariosphaeria typhicola) as a new genus in Amniculicolaceae. This genus is characterized by immersed to erumpent, subglobose to lenticular ascomata with a thin peridium, trabeculate pseudoparaphyses, clavate to broadly clavate, short pedicellate asci, fusiform, hyaline to reddish brown, multi-septate ascospores with a gelatinous sheath. Ascomata or hyphae usually stain the woody substrate or cultural medium purple (Zhang et al. 2009c). Ariyawansa et al. (2015a) transferred Neomassariosphaeria to Lindgomycetaceae. However, Wijayawardene et al. (2018) and Jayasiri et al. (2019) accounted this as a member in Amniculicolaceae. Dong et al. (2020) also confirmed that Neomassariosphaeria needs to remain in Amniculicolaceae. Further research of additional morphological and molecular data is required in this genus. 

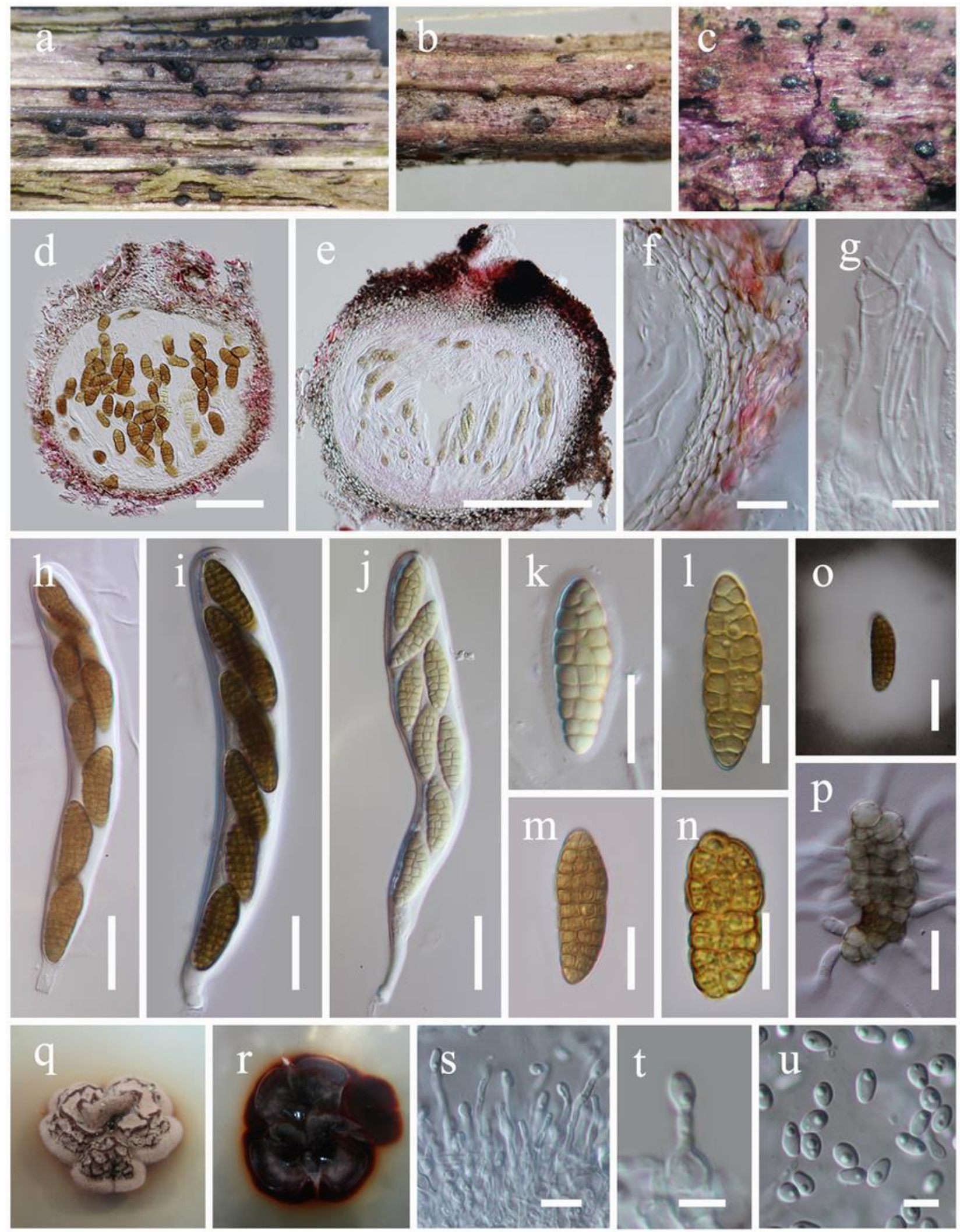

Figure 46 - Morphology of Murispora species. a-c Ascomata on the host surface d, e Section of ascomata f Peridium at the side $g$ Pseudoparaphyses $h-j$ Asci $k-p$ Ascospores. $o$ is in Indian ink. Note the deliquescing sheath in o. q-r Upper (q) and reverse (r) views of colony on PDA s-u Asexual morph of Murispora hawksworthii (MFLU 15-2251) s, t Immature and mature conidia attached to conidiogenous cell u Conidia. Scale bars: $d, e=50 \mu \mathrm{m}, \mathrm{f}, \mathrm{g}=10 \mu \mathrm{m}, \mathrm{h}-\mathrm{j}=20 \mu \mathrm{m}, \mathrm{k}-\mathrm{n}$ $=10 \mu \mathrm{m}, \mathrm{o}, \mathrm{p}=20 \mu \mathrm{m}, \mathrm{s}-\mathrm{u}=5 \mu \mathrm{m}$. 
Pseudomassariosphaeria Phukhams., Ariyaw., Camporesi \& K.D. Hyde, Fungal Divers. 75: 35 (2015).

Index Fungorum number: IF 551367; Facesoffungi number: FoF 00931; 2 morphological species (Species Fungorum 2020), 1 species with molecular data.

Type species - Pseudomassariosphaeria bromicola Phukhams., Ariyaw., Camporesi \& K.D. Hyde, Fungal Divers. 75: 40 (2015).

Notes - Ariyawansa et al. (2015a) introduced Pseudomassariosphaeria to accommodate $P$. bromicola and $P$. grandispora (= Massariosphaeria grandispora). This genus is characterized by globose to erumpent or rarely superficial ascomata with a papillate ostiole covered by periphyses, cellular pseudoparaphyses, cylindrical to clavate, short pedicellate asci with an ocular chamber, fusiform to lunate, granulate ascospores with a wide mucilaginous sheath. Pseudomassariosphaeria bromicola was introduced from a dead terrestrial stem of Bromus sterilis and Pseudomassariosphaeria grandispora (Zhang et al. 2009c) is based on sequence data from a specimen collected from driftwood of Alnus glutinosa from the banks of Garonne River in France. Extensive sampling of these species should be carried out in different regions and hosts to better understand their natural classification.

Vargamyces Tóth, Acta. Biol. Hung. 25: 403 (1980).

Index Fungorum number: IF 10375; Facesoffungi number: FoF 08157; 1 morphological species (Hernandez-Restrepo et al. 2017), 1 species with molecular data.

Type species - Vargamyces aquaticus (Dudka) Tóth, Acta. Biol. Hung. 25: 403 (1980).

三 Camposporium aquaticum Dudka, Ukr. bot. Zh. 23: 91 (1966).

Notes - Vargamyces is a hyphomycetous genus, characterized by sympodially proliferating light brown, long subhyaline conidiophores and dark or brown, fusiform, multi-septate conidia with slightly paler end cells and large guttules (Tóth 1979, Révay et al. 2014). Based on morphological and molecular data, Hernandez-Restrepo et al. (2017) argued that Repetophragma ontariense and Vargamyces aquaticus are conspecific, listed them as synonyms and confirmed the generic placement of Vargamyces in the Amniculicolaceae. See Révay et al. (2014) and HernandezRestrepo et al. (2017) for further details.

\section{Ecological and economic significance}

They are important to the cycling of carbon and nutrients during the decomposition of organic matter specially in freshwater habitats.

Amorosiaceae Thambug. \& K.D. Hyde, Fungal Diversity 74: 252 (2015).

Index Fungorum number: IF 551277; Facesoffungi number: FoF 01084, 15 species.

Fungicolous, endophytic or saprobic on other fungi or dead woody plant materials in terrestrial habitats. Sexual morph: Ascomata solitary or gregarious, immersed to semi immersed, becoming erumpent, coriaceous, dark brown to black, globose to subglobose or conical, uniloculate, ostiolate. Ostiole crest-like, rounded, central, cylindrical, papillate, well-developed, with a pore-like opening or through the cracks of host surface. Peridium comprising several layers of dark brown to lightly pigmented cells of textura angularis, fusing with the stromata. Hamathecium comprising numerous, wide, cellular, septate, branched or unbranched pseudoparaphyses, embedded in a gelatinous matrix. Asci 8-spored, bitunicate, fissitunicate, cylindrical to cylindricclavate, pedicellate, rounded at the apex, with an ocular chamber. Ascospores 1-3-seriate, partially overlapping, fusiform, to cylindrical, or ellipsoidal-fusiform, hyaline, some light brown when mature, 1-3-septate, constricted at the central septum, filled with different sized guttules when immature, surrounded by a mucilaginous sheath. Asexual morph: Coelomycetous or hyphomycetous. Hyphomycetous asexual morph; Chlamydospores occasionally, formed in short chains, arising from the mycelium, individual chlamydospores subhyaline, broadly ellipsoid to subglobose. Conidiophores micronematous to semi macronematous, arising singly and not combined in sporodochia or synemmata, pale brown, unbranched, similar to the mycelium. Conidiogenous cells integrated, terminal or intercalary, where terminal, monoblastic, determinate, 
short cylindrical to elongate-cylindrical, subhyaline to pale brown or brown, smooth-walled. Conidia solitary, dry, lateral, elongate-clavate, pale brown to brown, 1-3-septate, 3-4-septate when mature, constricted at the septa, smooth-walled, lacking any mucilaginous sheath or appendages. Coelomycetous asexual morph; Conidiomata pycnidial, solitary to gregarious, ovoid to globose, covered with hyaline to pale brown, septate, branched hyphal growth. Conidiomata wall comprising few layers of hyaline to brown cells of textura angularis. Conidiogenous cells phialidic, doliform, hyaline, smooth-walled. Conidia cylindrical, hyaline, aseptate, smooth-walled, guttulate.

Type - Amorosia Mantle \& D. Hawksw.

Notes - Amorosiaceae was established by Thambugala et al. (2015b) to accommodate Amorosia and Angustimassarina. Amorosia remains as a monotypic genus, while Angustimassarina contains twelve species (Species Fungorum 2020). Amorosiaceae mainly differs from the other phylogenetically closely families Lophiostomataceae, Teichosporaceae (Floricolaceae) and Sporormiaceae in having hyphomycete asexual morphs with elongate-clavate, uni- to multi-septate conidia and appears to grow within other ascomata of other ascomycetes and may be mycoparasitic. However, Jayasiri et al. (2019) introduced a coelomycetous species associated with fallen pod of Cassia sp. (Fabaceae) and accommodated in a newly established genus (Amorocoelophoma Jayasiri et al.) in Amorosiaceae mainly based on their analyses of gene sequence data. Subsequently, Crous et al. (2019a) included another new genus Alfoldia D.G. Knapp et al. in the family to house an endophytic species associated with roots of woody plants.

Amorosia Mantle \& D. Hawksw., in Mantle et al., Mycol. Res. 110(12): 1373 (2006).

Index Fungorum number: IF 500927; Facesoffungi number: FoF 08158; 1 morphological species (Species Fungorum 2020), 1 species with molecular data.

Type species - Amorosia littoralis Mantle \& D. Hawksw., Mycol. Res. 110(12): 1373.
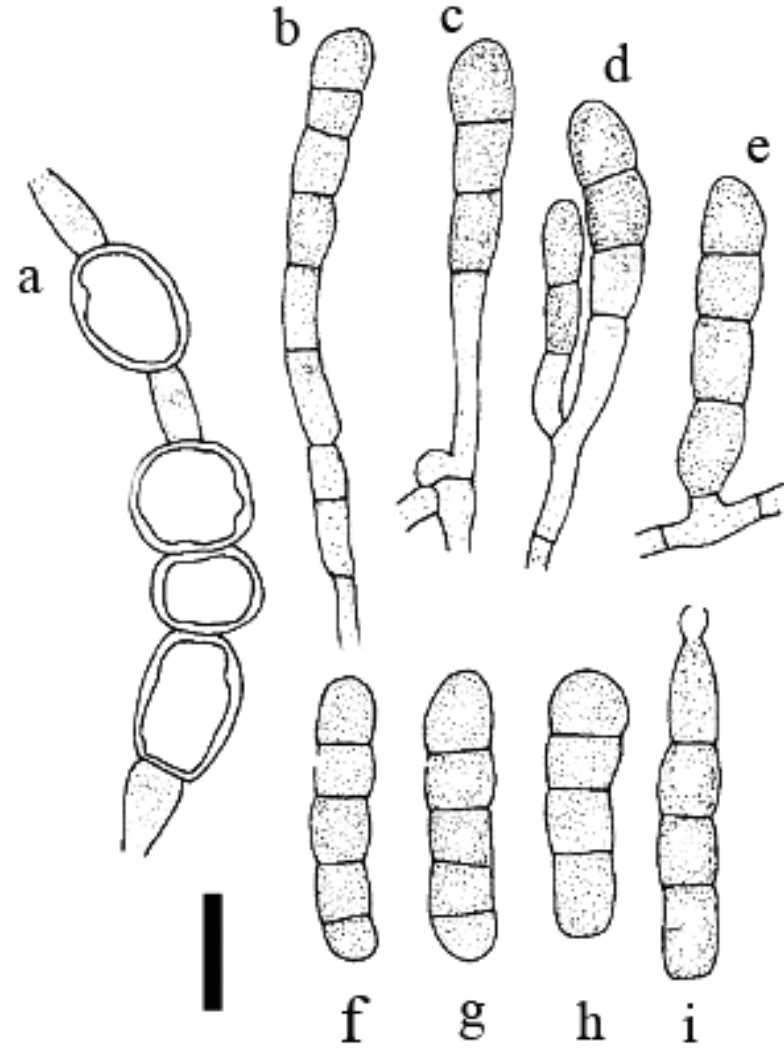

Figure 47 - Amorosia littoralis (redrawn from Mantle et al. 2006, holotype). a Chlamydospores. bd Terminally produced conidiogenous cells and conidia. e Laterally produced conidium and conidiogenous cell. $\mathrm{f}-\mathrm{h}$ Mature septate conidia. i Conidium in which the apical cell is germinating. Scale bar $=10 \mu \mathrm{m}$. 
Notes - The hyphomycete genus Amorosia was established to accommodate A. littoralis (Mantle et al. 2006) in Sporormiaceae based on molecular phylogenetic analysis. Thambugala et al. (2015b) placed Amorosia in a newly introduced family, Amorosiaceae. This genus remains monotypic.

\section{Other genera included}

Alfoldia D.G. Knapp, Imrefi \& Kovács, Persoonia 42: 373 (2019).

Index Fungorum number: IF 830105; Facesoffungi number: FoF 08159 - 1 morphological species (Species Fungorum 2020), 1 species with molecular data.

Type species - Alfoldia vorosii D.G. Knapp, Imrefi \& Kovács, Persoonia 42: 373 (2019).

Notes - Alfoldia is a monotypic genus typified by A. vorosii. This species is identified as a root endophyte associated with woody plant species of semiarid grasslands of the Great Hungarian Plain (Crous et al. 2019a).

Amorocoelophoma Jayasiri, E.B.G. Jones \& K.D. Hyde, Mycosphere 10 (1): 25 (2019).

Index Fungorum number: IF 555529; Facesoffungi number: FoF 05230 - 1 morphological species (Species Fungorum 2020), 1 species with molecular data.

Type species - Amorocoelophoma cassiae Jayasiri, E.B.G. Jones \& K.D. Hyde, Mycosphere 10 (1): 25 (2019).

Notes - Amorocoelophoma is the only known coelomycetous genus of Amorosiaceae. This monotypic genus is typified by $A$. cassiae. This genus is characterized by ovoid to globose conidiomata covered with a hyaline to pale brown, septate, branched hyphal growth and hyaline, cylindrical, aseptate conidia.

Angustimassarina Thambug., Kaz. Tanaka \& K.D. Hyde, Fungal Divers. 74: 253 (2015).

Index Fungorum number: IF 551278; Facesoffungi number: FoF 01085 - 12 morphological species (Species Fungorum 2020), 12 species with molecular data. (2015).

Type species - Angustimassarina populi Thambug. \& K.D. Hyde, Fungal Diversity 74: 254

Notes - Thambugala et al. (2015b) established Angustimassarina with A. populi as generic type. Eleven species have been described, all from Germany and Italy (Thambugala et al. 2015b, Tibpromma et al. 2017, Index Fungorum 2020). Angustimassarina species are considered as fungicolous and they may be parasitic on other fungi and appear to grow within ascomata of other ascomycetes. The genus is characterized by uniloculate ascomata with a pore-like opening or through the cracks of host surface and fusiform to cylindrical or ellipsoidal-fusiform, septate, hyaline ascospores, becoming ocher brown at maturity. The hyphomycetous asexual morph of the genus comprises micronematous to semimacronematous, pale brown conidiophores, integrated, terminal, holoblastic, short-cylindrical to elongate-cylindrical, conidiogenous cells and solitary, elongate-clavate, pale to dark brown, 1-3-septate, conidia (Thambugala et al. 2015b).

\section{Ecological and economic significance}

The species of Amorosiaceae are mycoparasitic and saprobic or endophytic and they have been found on a wide range of host plants. They play a significant role in organic matter decomposition but economic and agricultural importance of these species have not been identified.

Anteagloniaceae K.D. Hyde \& Mapook, Fungal Divers. 63: 33 (2013).

Index Fungorum number: IF 804658; Facesoffungi number: FoF 06700, 11 species.

Saprobic on dead wood. Sexual morph: Ascomata hysterothecial, superficial or sunken in substrate, scattered to aggregated, oval to elongate, or globose to subglobose, black, carbonaceous, straight or curved, rarely branched, without subiculum. Ostiole central, slit-like. Peridium dark brown, thick, comprising a single stratum of dark brown cells of textura epidermoidea. Hamathecium comprising cylindrical to filiform, cellular or trabeculate pseudoparaphyses, embedded in a gelatinous matrix. Asci 8-spored, bitunicate, fissitunicate, elongate cylindric-clavate, 
straight or slightly curved, short-pedicellate, apically rounded, with an ocular chamber. Ascospores 1-seriate, very small, ellipsoidal, hyaline, 1-septate, constricted at septa, widest in the middle and tapering towards the narrow ends, straight, smooth-walled. Asexual morph: Coelomycetous or hyphomycetous.

Type - Anteaglonium Mugambi \& Huhndorf.

Notes - Anteagloniaceae was established by Hyde et al. (2013). Two genera, Anteaglonium and Flammeascoma are accepted in this family (Mugambi \& Huhndorf 2009b, Liu et al. 2015) containing eight and two species, respectively (Liu et al. 2015, Wijayawardene et al. 2017a, Jaklitsch et al. 2018b). Though hysterothecoid ascomata are found in Anteagloniaceae, they are characteristically different from the genera of Hysteriaceae in having small hysteriothecial ascostromata and small ascospores. Molecular data also revealed that it forms a distinct clade within the Pleosporales. All the species of Anteagloniaceae were supported by morphological and molecular data for their placement in this family (Mugambi \& Huhndorf 2009b, Liu et al. 2015, Jayasiri et al. 2016, Jaklitsch et al. 2018b). The family also indicates a parallel evolution of hysterothecial ascomata in Dothideomycetes (Mugambi \& Huhndorf 2009a, b).

Anteaglonium Mugambi \& Huhndorf, Syst. Biodiv. 7(4): 460 (2009).

Index Fungorum number: IF 541631; Facesoffungi number: FoF 06701; 8 morphological species (Species Fungorum 2020), 7 species with molecular data.

Type species - Anteaglonium abbreviatum (Schwein.) Mugambi \& Huhndorf.

三Hysterium abbreviatum Schwein., Trans. Am. phil. Soc., New Series 4(2): 244 (1832).

Notes - Anteaglonium was introduced as the type genus of Anteagloniaceae by Mugambi \& Huhndorf (2009b). Later Flammeascoma was described based on multi-gene phylogeny and placed in Anteagloniaceae by Liu et al. (2015). The asexual morph of Anteaglonium produces pink pigments whereas in Flammeascoma the sexual morph produces orange pigments and has hyaline ascospores. Flammeascoma bambusae produces fusiform, hyaline, 1-septate ascospores (Liu et al. 2015), whereas F. lignicola has olivaceous-brown ascospores (Ariyawansa et al. 2015a).

Anteaglonium parvulum (W.R. Gerard) Mugambi \& Huhndorf, Syst. Biodiv. 7(4): 462 (2009).

三 Hysterium parvulum W.R. Gerard, Bull. Torrey bot. Club 5: 40 (1874).

Fig. 48

Index Fungorum number: IF 543261; Facesoffungi number: FoF 01931.

Saprobic on Morinda citrifolia decaying twig. Sexual morph: Undetermined. Asexual morph: Coelomata 100-120 $\times 170-350 \mu \mathrm{m}$, pycnidial, immersed to erumpent, covered by the host periderm, raised at centrre, scattered, brittle, dark brown, homogenously pigmented, interior lined with a slightly red color. Peridium 20-25 $\mu \mathrm{m}$ wide, composed of brown to dark brown cells of textura globulosa, absent at base. Conidiophores and Conidiogenous cell are insignificant or absent. Conidia 2.1-2.7 $\mu \mathrm{m}(\bar{x}=2.4, \mathrm{n}=20)$, globose, hyaline, densely present, smooth-walled.

Culture characteristics - Thick Colonies on MEA, 17-20 mm diam. within 7 days at $25^{\circ} \mathrm{C}$, short, surface whitish, turning greyish, often with red margin, bottom red.

Material examined - India, Andaman and Nicobar Islands, South Andaman, Kalatan $\left(11^{\circ} 47^{\prime} 52.6 ” \mathrm{~N} 92^{\circ} 42^{\prime} 50^{\prime} \mathrm{E}\right)$, on a twig of Murraya exotica (Rutaceae), 10 August 2016, M. Niranjan \& V.V. Sarma PUFNI 17626 (AMH-10075), living culture NFCCI-4375.

GenBank numbers - ITS: MN582759; SSU: MN582763.

Notes - Anteaglonium species, by virtue of having hysterothecoid ascomata and hyaline twocelled ascospores, are similar to Psiloglonium spp., except for the smaller size of their ascomata and ascospores (Boehm et al. 2009a). Anteaglonium abbreviatum, A. globosum, A. latirostrum and A. parvulum were added to the genus by Mugambi \& Huhndorf (2009b), A. brasiliense by De Almeidia et al. (2014), A. thailandicum by Jayasiri et al. (2016), A rubescens by Jaklitsch et al. (2018b) and A. gordoniae by Jayasiri et al. (2019). Asexual morphs were found in two species, $A$. parvulum and A. thailandicum (Jayasiri et al. 2016) and in A. rubescens (Jaklitsch et al. 2018b) under in vitro conditions. In the present study the asexual morph is reported for the first time from a natural substratum. Cultures in MEA medium show circular growth, apically grey coloured 
appearance and bottom dark red colour. Red colour on the reverse of agar plates was also reported for A. parvulum by Jayasiri et al. (2016) and A. rubescens in CMD, MEA and PDA media (Jaklitsch et al. 2018b).

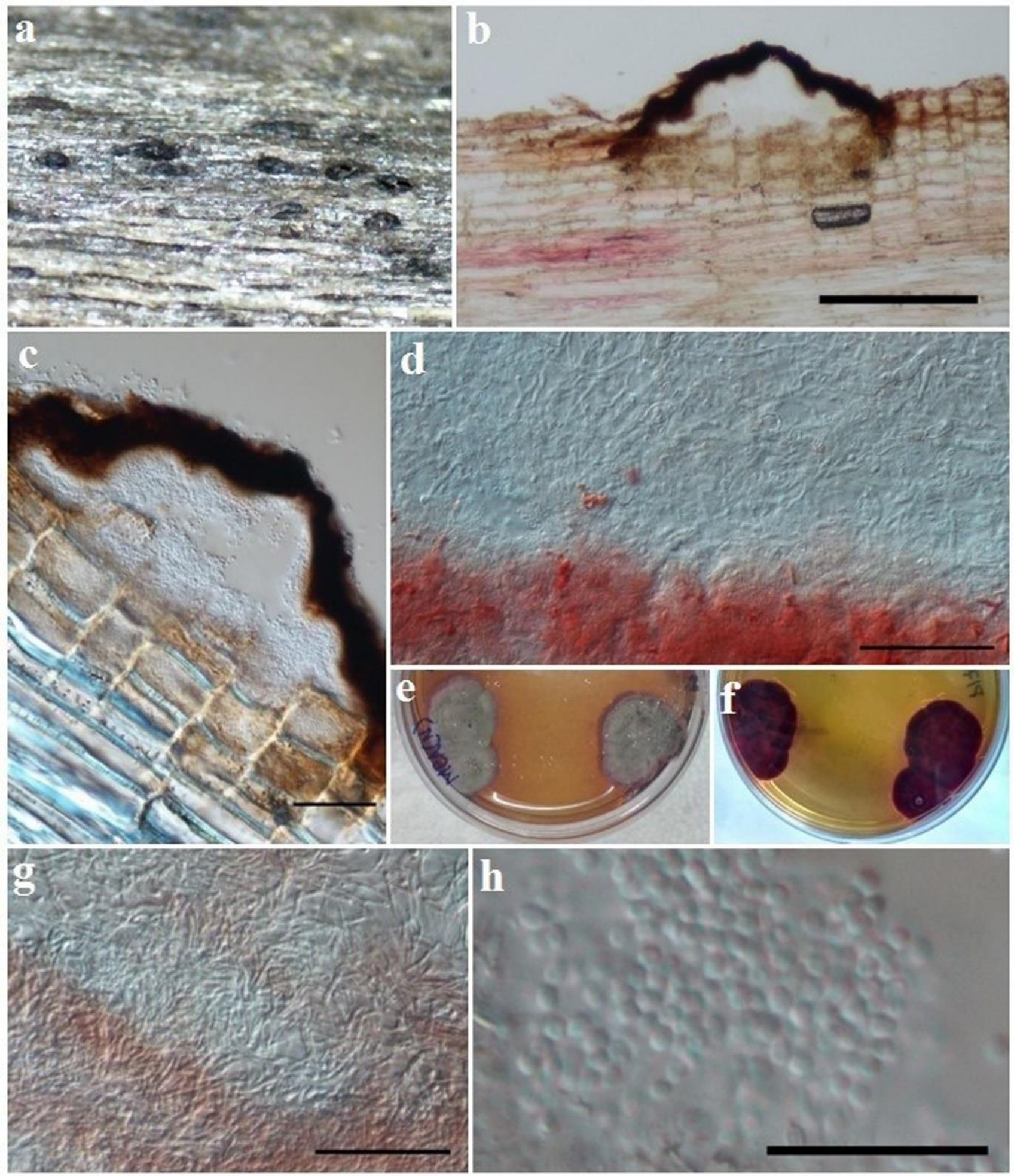

Figure 48 - Anteaglonium parvulum (PUFNI 17626, holotype). a Ascomata. b, c Vertical section. $\mathrm{d}$, $\mathrm{g}$ Rose pigments in sterile hyphae. e, f Asexual morph in petri plates. $\mathrm{h}$ Conidia. Scale bars: $\mathrm{b}=$ $200 \mu \mathrm{m}, \mathrm{c}, \mathrm{d}, \mathrm{g}=50 \mu \mathrm{m}, \mathrm{h}=20 \mu \mathrm{m}$. 


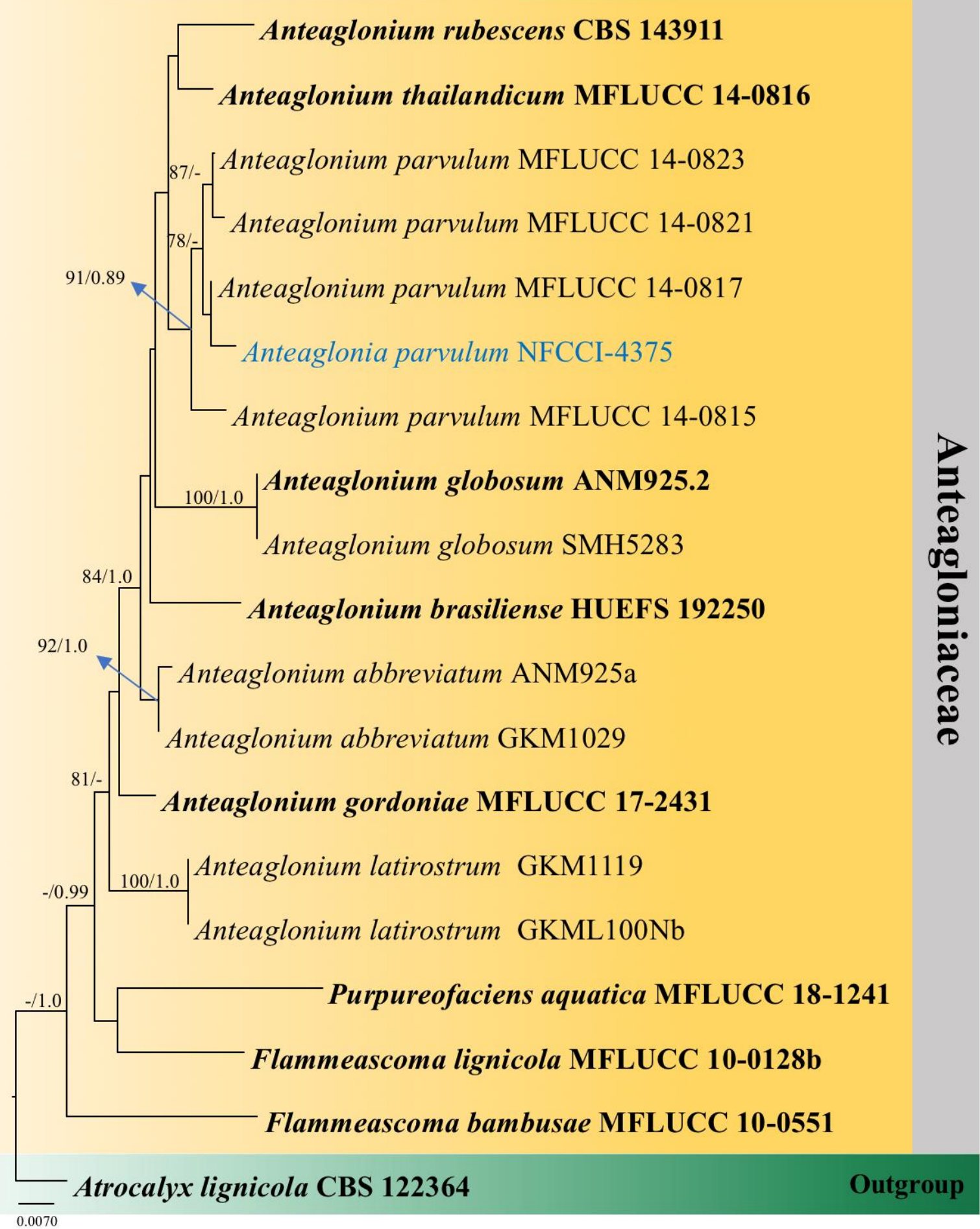

Figure 49 - Phylogram generated from maximum likelihood analysis (RAxML) of Anteaglonium species based on LSU, SSU and tef1 sequence data. Maximum likelihood bootstrap values equal or above $70 \%$, Bayesian posterior probabilities equal or above 0.90 (MLBS/PP) are given at the nodes. An original isolate number is noted after the species name. The tree is rooted to Atrocalyx lignicola (CBS 122364). The ex-type strains are indicated in bold. Newly sequence is in blue. Hyphen (-) represents support values below $70 \%$ MLBS and 0.90 PP.

\section{Other genera included}

Flammeascoma Phookamsak \& K.D. Hyde, Fungal Diversity 72: 63 (2015).

Index Fungorum number: IF 550925; Facesoffungi number: FoF 06702; 2 morphological species (Species Fungorum 2020), 2 species with molecular data. 
Type species - Flammeascoma bambusae Phookamsak \& K.D. Hyde, Fungal Divers 72: 64 (2015).

Notes - Flammeascoma was established in Anteagloniaceae by Liu et al. (2015). Members are saprobes in terrestrial environments. Taxonomic details of this genus are provided in Ariyawansa et al. (2015a) and Lu et al. (2015).

Purpureofaciens W. Dong, H. Zhang \& K.D. Hyde, Fungal Divers (2020).

Index Fungorum number: IF 557804; Facesoffungi number: FoF 08717; 1 morphological species (Dong et al. 2020), 1 species with molecular data. (2020).

Type species - Purpureofaciens aquatica W. Dong, H. Zhang \& K.D. Hyde, Fungal Divers

Notes - The genus was introduced by Dong et al. (2020), with $P$. aquatica as the type species. Purpureofaciens is characterized by conical semi-immersed to superficial ascomata, staining woody substrate purple, cylindrical asci, ellipsoidal, curved, olivaceous ascospores, with acute ends, and producing white to reddish colonies on culture media (Dong et al. 2020). Phylogenetically, this genus is related to Flammeascoma (Dong et al. 2020). However, it differs from Flammeascoma by the conical ascomata with a large, protuberant, ostiolate papilla, cylindrical asci and ellipsoidal, olivaceous ascospores (Liu et al. 2015, Dong et al. 2020).

\section{Ecological and economic significance}

Anteagloniaceae members are saprobes and mostly occur on woody litter (Boehm et al. 2009a, Mugambi \& Huhndorf 2009a, Ariyawansa et al. 2015a, Liu et al. 2015). They produce redorange to pink pigments that are persistent after $3 \% \mathrm{KOH}$ treatment. These pigments have been implicated in the production of anteaglonialides and palmarumycins, which were extracted from cultures of Anteaglonium sp. isolated from a moss (Xu et al. 2015) and exhibit a strong cytotoxic effect against Ewing's sarcoma cell line CHP-100.

Aquasubmersaceae A. Hashim. \& Kaz. Tanaka, in Hashimoto et al., Persoonia 39: 56 (2017).

Index Fungorum number: IF 819235; Facesoffungi number: FoF 08160, 2 species.

Saprobic on woody plants, submerged plant substrate. Sexual morph: Ascomata scattered or grouped, semi-immersed, subglobose, with a papillate ostiolar neck. Peridium comrpises flattened, thin-walled, polygonal cells. Hamathecium comprising septate, branched, pseudoparaphyses. Asci 8-spored, bitunicate, cylindrical, with a short pedicel. Ascospores broadly fusiform with rounded ends, hyaline, septate. Asexual morph: Coelomycetous. Conidiomata pycnidial, globose to ellipsoidal, solitary or scattered, semi-immersed to superficial, dark brown to black, ostiolate. Conidiophores reduced. Conidiogenous cells holoblastic, lageniform, hyaline, smooth, formed from the inner cells of the pycnidial wall. Conidia holoblastic, ellipsoidal, hyaline, aseptate, thin- and smooth-walled, or guttulate (adapted from Zhang et al. 2012a, Hashimoto et al. 2017b)

Type - Aquasubmersa K.D. Hyde \& Huang Zhang.

Notes - The family was established by Hashimoto et al. (2017b), with the generic type Aquasubmersa. Based on the description of Aquasubmersa japonica provided by Ariyawansa et al. (2015a), it has 2-4.5 $\mu \mathrm{m}$ pseudoparaphyses. However, we could not see clearly from the photoplate whether it is cellular or trabeculate pseudoparaphyses. Molecular studies using LSU and SSU sequence data placed Aquasubmersa in Pleosporales (Zhang et al. 2012a, Ariyawansa et al. 2015a). Hashimoto et al. (2017b) indicated that Aquasubmersa formed a sister clade to the clade containing Lophiotremataceae Tanaka and Cryptocoryneaceae. Morphologically, Lophiotremataceae is similar to Aquasubmersaceae in having ascomata with papillate ostiolar neck and pycnidial conidiomata. However, Lophiotremataceae differs from Aquasubmersaceae in having ascomata with a compressed, slit-like ostiole. Cryptocoryneaceae and Hermatomycetaceae have sporodochial conidiomata and cheiroid or lenticular conidia, while Aquasubmersaceae has ellipsoidal conidia. Therefore, Hashimoto et al. (2017b) introduced Aquasubmersaceae to accommodate Aquasubmersa. 
Aquasubmersa K.D. Hyde \& Huang Zhang, Cryptog. Mycol. 33(3): 340 (2012).

Index Fungorum number: IF 800875; Facesoffungi number: FoF 07118; 2 morphological species (Species Fungorum 2020), 2 species with molecular data.

Type species - Aquasubmersa mircensis Huang Zhang \& K.D. Hyde.

Notes - Aquasubmersa was established by Zhang et al. (2012a), with the asexual type species A. mircensis. Ariyawansa et al. (2015a) introduced the second species, A. japonica, with sexual and asexual morphs. This genus was placed in Lophiotremataceae by Doilom et al. (2016). Phylogenetic analyses using ITS, LSU, rpb-2, SSU, and tef1 sequence data support this genus as a sister clade of Lophiotremataceae and Cryptocoryneaceae (Hashimoto et al. 2017b).

Aquasubmersa mircensis Huang Zhang \& K.D. Hyde, Cryptog. Mycol. 33(3): 340 (2012). Fig. 50 Index Fungorum number: IF 800876; Facesoffungi number: FoF 07119.

Description - see Zhang et al. (2012).

Material examined - Thailand, Chiang Mai, Mushroom Research Centre, on submerged wood, 21 April 2011, Huang Zhang m3 (MFLU 11-1001, holotype).
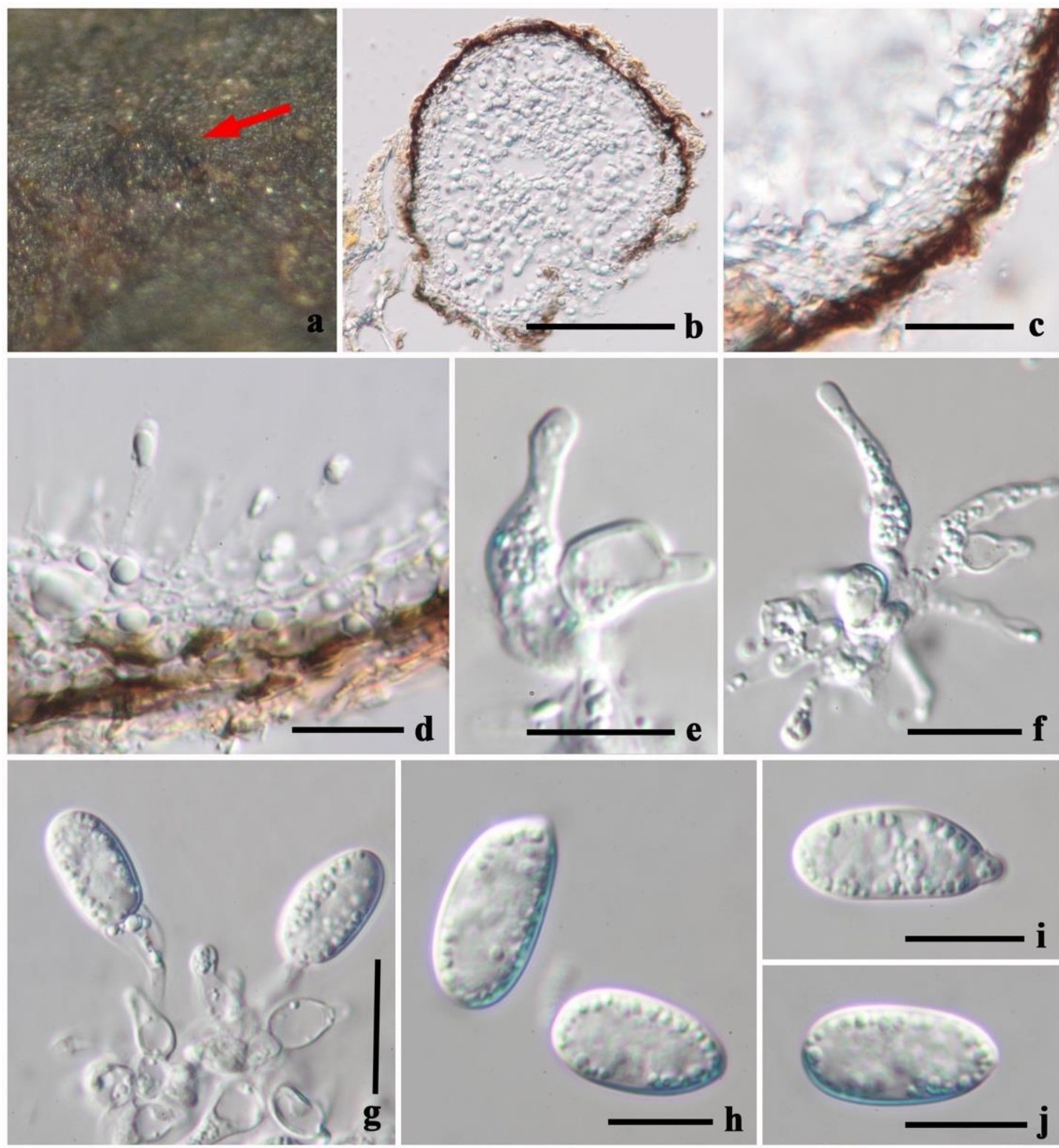

Figure 50 - Aquasubmersa mircensis (MFLU 11-1001, holotype). a Pycnidium on wood surface. b Section of pycnidium. c Peridium. d Peridium with conidiogenous cell. e, f Conidiogenous cells. 
g Conidiogenous cells with conidia. $\mathrm{h}-\mathrm{j}$ Conidia. Scale bars: $\mathrm{b}=100 \mu \mathrm{m}, \mathrm{c}, \mathrm{d}, \mathrm{f}, \mathrm{g}=15 \mu \mathrm{m}, \mathrm{e}, \mathrm{h}-\mathrm{j}$ $=10 \mu \mathrm{m}$.

\section{Ecological and economic significance}

Species in Aquasubmersaceae are saprobic on woody plants, and submerged plant substrate. It probably has some role in decomposing wood.

Arthopyreniaceae Walt. Watson, New Phytol. 28: 107 (1929).

Index Fungorum number: IF 80473; Facesoffungi number: FoF 08161, 61 species.

Non-lichenized on bark in terrestrial, temperate forest habitats. Thallus reduced, ecorticate, whitish or indistinct. Sexual morph: Ascomata scattered, prominent, brown-black, hemisphaerical, carbonaceous, ostiolate. Ostiole round. Involucrellum and excipulum are indistinct, dark brown, carbonized. Excipulum dense, proso- to paraplectenchymatous in thin sections, brown. Hamathecium comprising densely packed, paraphysoids connected to both the base and the top of the centrum, hyaline, straight to irregularly bent, branched and anastomosing. Asci forming in locules between the paraphysiods, 8-spored, fissitunicate, bitunicate, broadly clavate to cylindric clavate, short-pedicellate, with rather broad, non-amyloid ocular chamber. Ascospores irregularly arranged to 2-seriate, oblong with the proximal end slightly tapering, hyaline, occasionally brownish when become old, 1-3-septate, eusepta and rectangular lumina, not or very slightly constricted at the septa, the upper cells often slightly larger than the lower cells, smooth-walled. Asexual morph: Pycnidia erumpent to prominent, visible as brown-black dots. Conidia acrogenous, either macro- or microconidia; macroconidia bacillar, hyaline, aseptate, $10-13 \times 2-2.5 \mu \mathrm{m}$; microconidia acicular, hyaline, aseptate, $7-14 \times 0.8-1 \mu \mathrm{m}$. Chemistry - Unidentified perithecial wall pigment reacting $\mathrm{K}+$ green.

Type - Arthopyrenia A. Massal.

Notes - Arthopyreniaceae was established by Watson (1929) to encompass the genera Acrocordia, Athrismidium, Arthopyrenia, Bottaria, Celothelium, Laurera, Leptorhaphis, Microthelia, Microtheliopsis, Polyblastiopsis, Pseudosagedia, Raciborskiella, and Tomaselli. It includes lichenized and some non-lichenizd fungi based on trentepohlioid photobiont and has branched, anastomosing paraphyses (Watson 1929). These genera were later assigned to different classes, orders and families (Harris 1975, 1995, Aproot et al. 2008, Nelsen et al. 2009, 2011a, Hyde et al. 2013). Subsequently, Arthopyreniaceae was synonymysed with Mycoporaceae (Riedl 1961, von Arx \& Müller 1975) or Pleosporaceae (Poelt 1974, Harris 1975). Arthopyreniaceae was reestablished by Barr (1979a) and considered a synonym of Xanthopyreniaceae (Eriksson 1981). Presently this family comprises a single genus Arthopyrenia (Jaklitsch et al. 2016a, Lücking et al. 2017). However, Liu et al. (2017a) did not accept this family while Wijayawardene et al. (2017a) considered both Arthopyrenia and Magmopsis in Arthopyreniaceae. According to Index Fungorum 2020, there are two species of Magmopsis namely M. argilospila and M. pertenella. These species have been referred to incertae sedis and have characteristics such as nostociform cyanobacteria intermingled with mycelium, preformed ostiole, anastomosed paraphysoids with thin-walled ascospores (Grube 2005); no molecular data are available in Genbank (Wijayawardene et al. 2017a). Therefore, we keep Magmopsis in Dothideomycetes incertae sedis and consider only Arthopyrenia in Arthopyreniaceae. Based on phylogenetic analysis, Arthopyreniaceae is included in Pleosporales where it is close to bambusicolous species in Roussoella and thus, the delineation of this family needs to be assessed (Nelsen et al. 2009, Schoch et al. 2009, Zhang et al. 2009b, Hyde et al. 2013).

Arthopyrenia A. Massal., Ric. auton. lich. crost. (Verona): 165 (1852).

Index Fungorum number: IF 325; Facesoffungi number: FoF 08162; 53 morphological species (Species Fungorum 2020), 4 species with molecular data.

Type species - Arthopyrenia cerasi (Schrad.) A. Massal.

Notes - Arthopyrenia occur as lichenized, lichenicolous or non-lichenized fungi (Coppins 1988). Both asexual morph and sexual morph have been reported in Wijayawardene et al. (2017a). 
Taxa in this genus are characterized by dimidiate perithecoid which are scattered to irregularly confluent ascomata, with an upper thick clypeate wall composed of periderm cell intermixed with dark hypae. The fertile locule below the involucrellum is surrounded by thin, sometimes scarcely detectable, hyaline or brown excipulum composed of compacted hypae. The asci are shaped from obpyriform, obclavate to subcylindric, usually 8 spored. The ascospores are oblong, ovoid, slippershaped, 1-3 septate, hyaline and smooth with a distinct epispore, and branched anastomosed paraphyses, with a trentepohlia photobiont (Coppins 1988, Upreti \& Pant 1993).
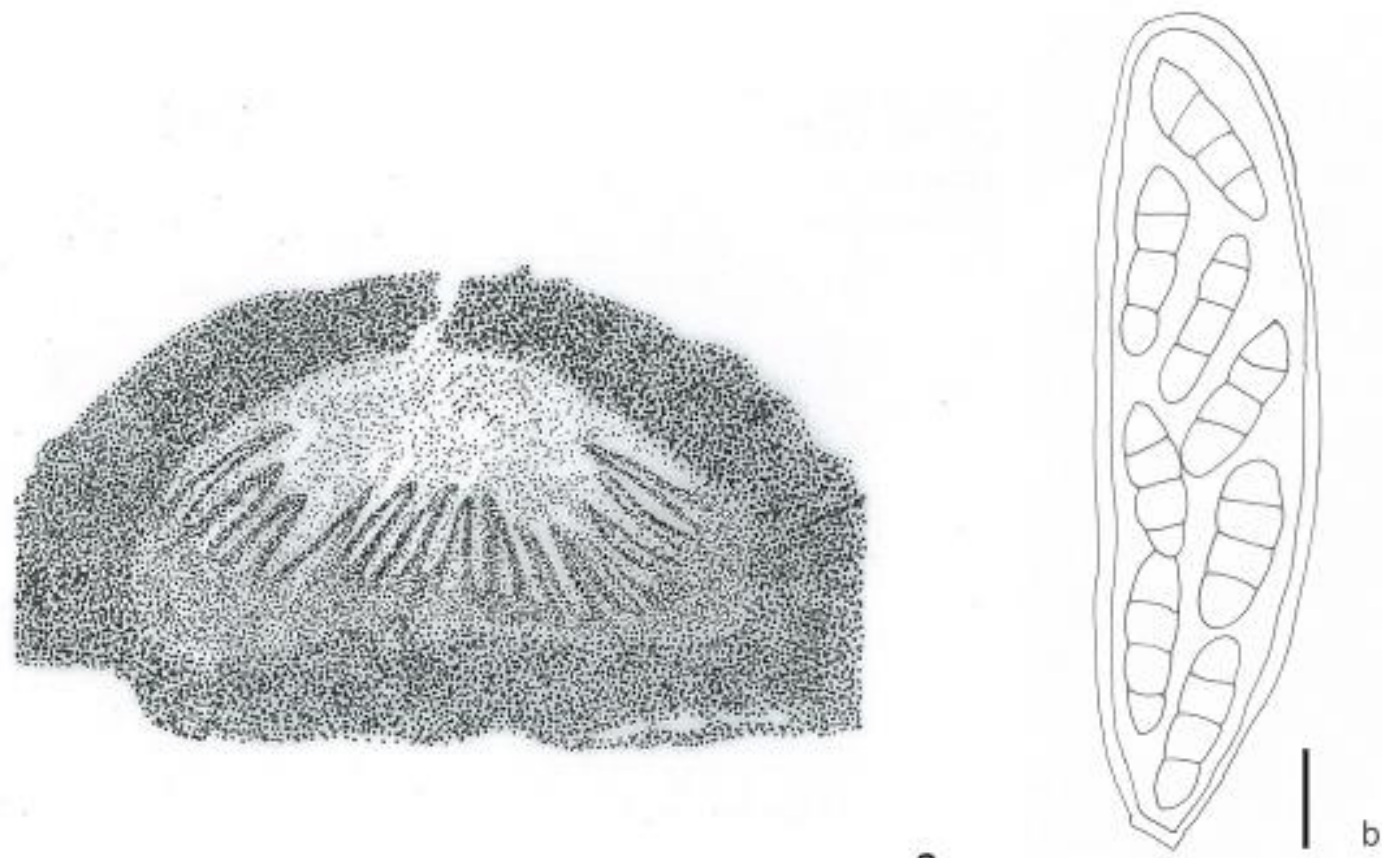

Figure 51 - Arthopyrenia cerasi (redrawn from Hyde et al. 2013). a Section through perithecium. b Individual asci with ascospores. Scale bars: $b=10 \mu \mathrm{m}$.

Mycomicrothelia Keiss1., Rabenh. Krypt.-Fl., Edn 2 (Leipzig) 9(1.2): 7 (1936).

Index Fungorum number: IF 3328; Facesoffungi number: FoF 08163; 8 morphological species (Species Fungorum 2020), molecular data unavailable.

Type species - Mycomicrothelia macularis (Hampe ex A. Massal.) Keiss., Rabenh. Krypt.Fl., Edn 2 (Leipzig) 9(1.2): 36 (1936).

三 Microthelia macularis Hampe ex A. Massal., Miscell. Lichenol.: 28 (1856).

Notes - Mycomicrothelia was introduced by Hawksworth (1985) to Arthopyreniaceae sensu lato and accepted 26 species. Most lichenized Dothidiomycetes are hyaline spored ascospores, while brown ascospores were placed in Mycomicrothelia whereas some species showed the basal position to Trypetheliaceae based on molecular studies (Nelsen et al. 2011a, Aptroot \& Lücking 2016).

\section{Ecological and economic significance}

Taxa in Arthopyrenia have been recorded as lichenized, lichenicolous or non-lichenized fungi (Coppins 1988). Ecology and lifecycle of these fungi are largely unexplored therefore, further investigations are important to explore the origin and evolution of parasitism and symbiosis (Lawery \& Diederich 2003). However, lichens are usually used to monitor the air quality in urban and industrial area (Sancho et al. 2019), production of secondary metabolities (Ranković et al. 2019) and decomposing woody plant and animal debris (Dix \& Webster 1995). 
Ascocylindricaceae Abdel-Wahab et al., in Ariyawansa et al., Fungal Divers. 75:45(2015)

Index Fungorum number: IF 551416; Facesoffungi number: FoF 01041, 1 species.

Saprobic on lignicolous substrates in marine habitats. Sexual morph: Ascomata scattered, immersed, erumpent to superficial, globose to subglobose, dark-brown to black, papillate, ostiolate and ostiole comprises of periphyses. Peridium thin. Hamathecium comprising trabeculate, branched, septate, pseudoparaphyses, embedded in mucilage. Asci 8-spored, bitunicate, fissitunicate, cylindrical with short pedicel, 1-seriate to overlapping 1-seriate, with ocular chamber. Ascospores 1-seriate to overlapping 1-seriate, ellipsoidal, dark brown to black, 1-septate, constricted at the septum, rough and ornamented. Asexual morph: Undetermined.

Type - Ascocylindrica Abdel-Wahab, Bahkali, E.B.G. Jones, Ariyaw. \& K.D. Hyde.

Notes - Ascocylindricaceae was introduced by Ariyawansa et al. (2015a) to accommodate the monotypic genus collected from marine habitat based on morphology and phylogeny. Members of Ascocylindricaceae can be easily separated from the other marine taxa in Pleoporales based on their small ascomata, cylindrical asci and bi-celled dark brown to black ascospores.
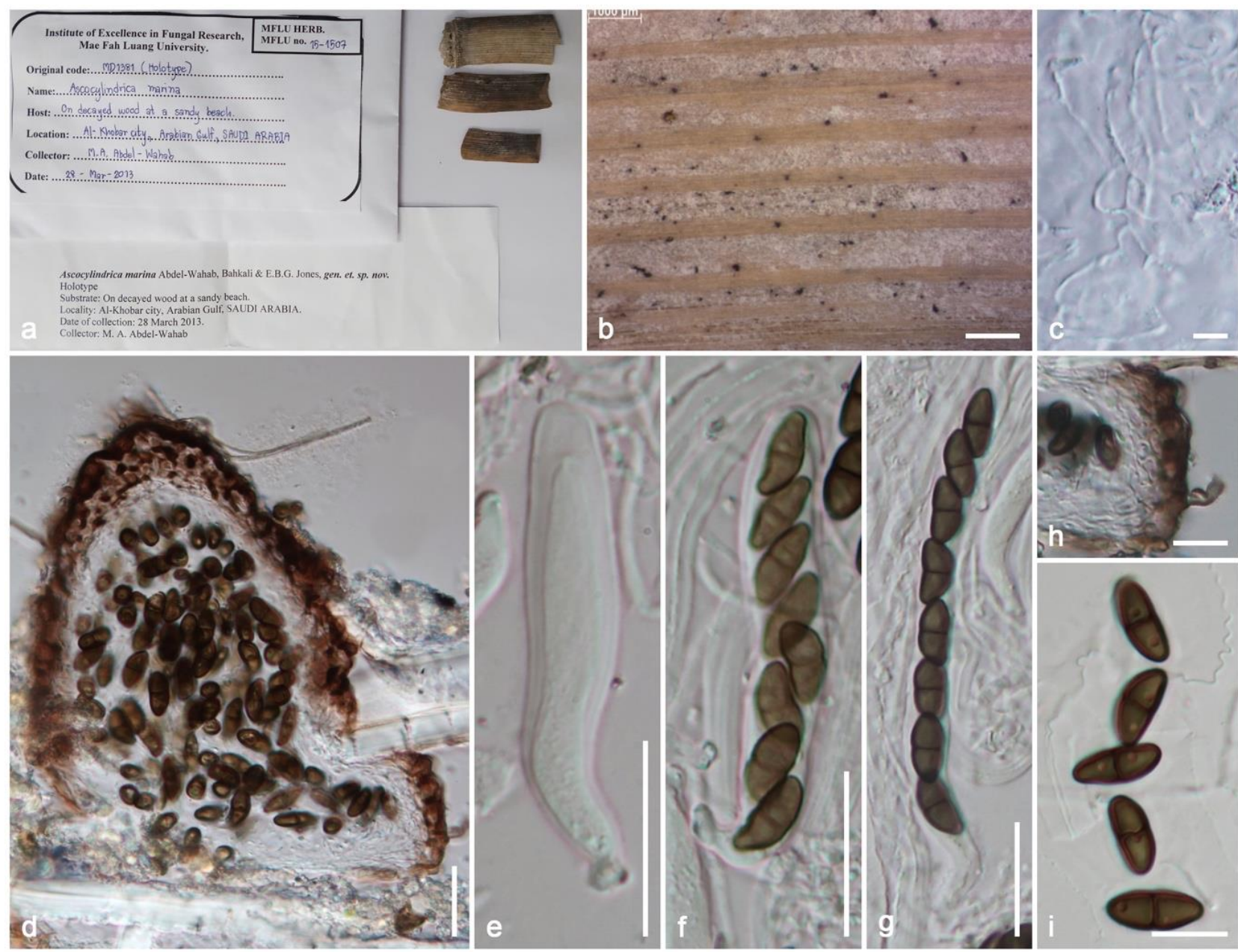

Figure 52 - Ascocylindrica marina (MFLU 15-1507, holotype). a Herbarium details. b Ascomata on the substrate. c Pseudoparaphyses. d Vertical section of the ascoma. e-g Asci. h Peridium. i Ascospores. Scale bars: $\mathrm{b}=1000 \mu \mathrm{m}, \mathrm{d}-\mathrm{g}=20 \mu \mathrm{m}, \mathrm{h}=10 \mu \mathrm{m}, \mathrm{c}=5 \mu \mathrm{m}$.

Ascocylindrica Abdel-Wahab et al., in Ariyawansa et al., Fungal Divers. 75: 46 (2020)

Index Fungorum number: IF 551414; Facesoffungi number: FoF 00954; 1 morphological species (Species Fungorum 2020), 1 species with molecular data.

Type species - Ascocylindrica marina Abdel-Wahab, Bahkali \& E.B.G. Jones.

Notes - Ascocylindrica marina forms a monophyletic genus in Pleospoales (Ariyawansa et al. 2015a). It shares similar morphology with Halokirschsteiniothelia maritima in having small 
ascomata and 1-septate brown ascospores. However, the latter taxon has subconical ascomata with a flattened base, clavate to oblong longer ellipsoidal asci and smooth ascospores, with a submedian septum. Based on multi-gene phylogenetic analyses $H$. maritima was referred to Mytilinidiaceae (Suetrong et al. 2009, Boonmee et al. 2012, Jones et al. 2019a).

Ascocylindrica marina Abdel-Wahab, Bahkali \& E.B.G. Jones, in Ariyawansa et al., Fungal Divers. 75: 46 (2015).

Fig. 52

Index Fungorum number: IF 551415; Facesoffungi number FoF 00955.

Description - see Ariyawansa et al. (2015a).

Material examined - Saudi Arabia, Al-Khobar city, Arabian Gulf, on decayed wood at a sandy beach, 28 March 2013, M.A. Abdel-Wahab MD1381, (MFLU 15-1507, holotype).

\section{Ecological and economic significance}

The species is saprobic and plays a role in recycling organic matter.

Astrosphaeriellaceae Phookamsak \& K.D. Hyde, Fungal Divers 74: 161 (2015).

Index Fungorum number: IF 551632; Facesoffungi number: FoF 01221, 111 species.

Saprobic or parasitic on bamboo, palms, Quercus sp., or stout grasses. Sexual morph: Ascostromata dark opaque, solitary to gregarious, erumpent to superficial, conical or mammiform, with ruptured, reflexed, stellate, host remnants, around the base, uni-loculate, glabrous, brittle, carbonaceous, with minute apical ostiole. Peridium thick-walled, of unequal thickness, poorly developed at the base, composed of thick, opaque and melanized cells, with palisade-like cells at the rim. Hamathecium comprising dense, an astomosing, trabeculate pseudoparaphyses, embedded in a hyaline gelatinous matrix. Asci 8-spored, bitunicate, fissitunicate, cylindrical to cylindricclavate, pedicellate, apically rounded with an ocular chamber, or J- subapical ring. Ascospores overlapping 1-2-seriate, subfusoid to fusiform, obclavate to ellipsoidal, or lemoniform, hyaline to pale brown, or reddish brown, septate, constricted at the septum, smooth-walled, with or without appendages and mucilaginous sheath. Asexual morph: Coelomycetous or hyphomycetous (Pithomyces). Conidiomata pycnidial, scattered, solitary, superficial, conical to hemisphaerical, or globose, uni-to bi-loculate, indistinctly ostiolate. Pycnidial walls thin to thick-walled, composed of several layers of dark brown to black cells of textura angularis to textura intricata. Conidiophores reduced to conidiogenous cells. Conidiogenous cells mono or polyblastic or holoblastic, rhexolytic or phialidic, hyaline to pale brown, cylindrical or cylindric-clavate or ampulliform, septate or aseptate. Conidia globose to obovate, hyaline, aseptate to 3-5-spetate, smooth, verruculose, or spinulose.

Type - Astrosphaeriella Syd. \& P. Syd.

Notes - Phookamsak et al. (2015b) established Astrosphaeriellaceae to accommodate Astrosphaeriella (Sydow \& Sydow 1913a) and Pteridiospora (Penzig \& Saccardo 1897). Wanasinghe et al. (2018a) placed Astrosphaeriellopsis in Astrosphaeriellaceae based on the wellsupported phylogenetic results. Pithomyces is similar to some astrosphaeriella-like taxa. Several strains of Pithomyces containing the ex-type P. flavus form a well-supported monophyletic group within Astrosphaeriellaceae in Wanasinghe et al. (2018a). Thus, Pithomyces was positioned in Astrosphaeriellaceae, and this opinion was followed by Wijayawardene et al. (2018). Javaria was treated as a synonym of Astrosphaeriella (Hyde \& Fröhlich 1998), and there is no molecular data for this genus to confirm its phylogenetic position, so Javaria may still be a unique genus and it has been accepted into this family by Wijayawardene et al. (2018). Another two new genera Quercicola and Xenoastrosphaeriella were introduced into the family by Jayasiri et al. (2019). Liu et al. (2018b) studied the phylogeny of Mycopepon Boise and suggested the genus should be a member of Astrosphaeriellaceae. Thus, there are eight genera included in Astrosphaeriellaceae viz. Astrosphaeriella, Astrosphaeriellopsis, Javaria, Mycopepon, Pithomyces, Pteridiospora, Quercicola and Xenoastrosphaeriella. Previously Astrosphaeriellaceae was recognized to have only coelomycetous asexual morphs, however, Wanasinghe et al. (2018a) emended the asexual morph of this family and suggested that the family should accommodate both coelomycetous and hyphomycetous asexual morphs due to the hyphomycetous asexual morph of Pithomyces 
discovered. Caryosporaceae was introduced to accommodate Caryospora and Acrocordiopsis based on combined LSU, rpb-2, SSU and tef1 sequence data of Pleosporales (Ariyawansa et al. 2015a). However, in our phylogenetic analysis, Caryospora aquatica and Acrocordiopsis patilii are included in Astrosphaeriellaceae group (Fig. 53). Further studies are needed to resolve this problem.

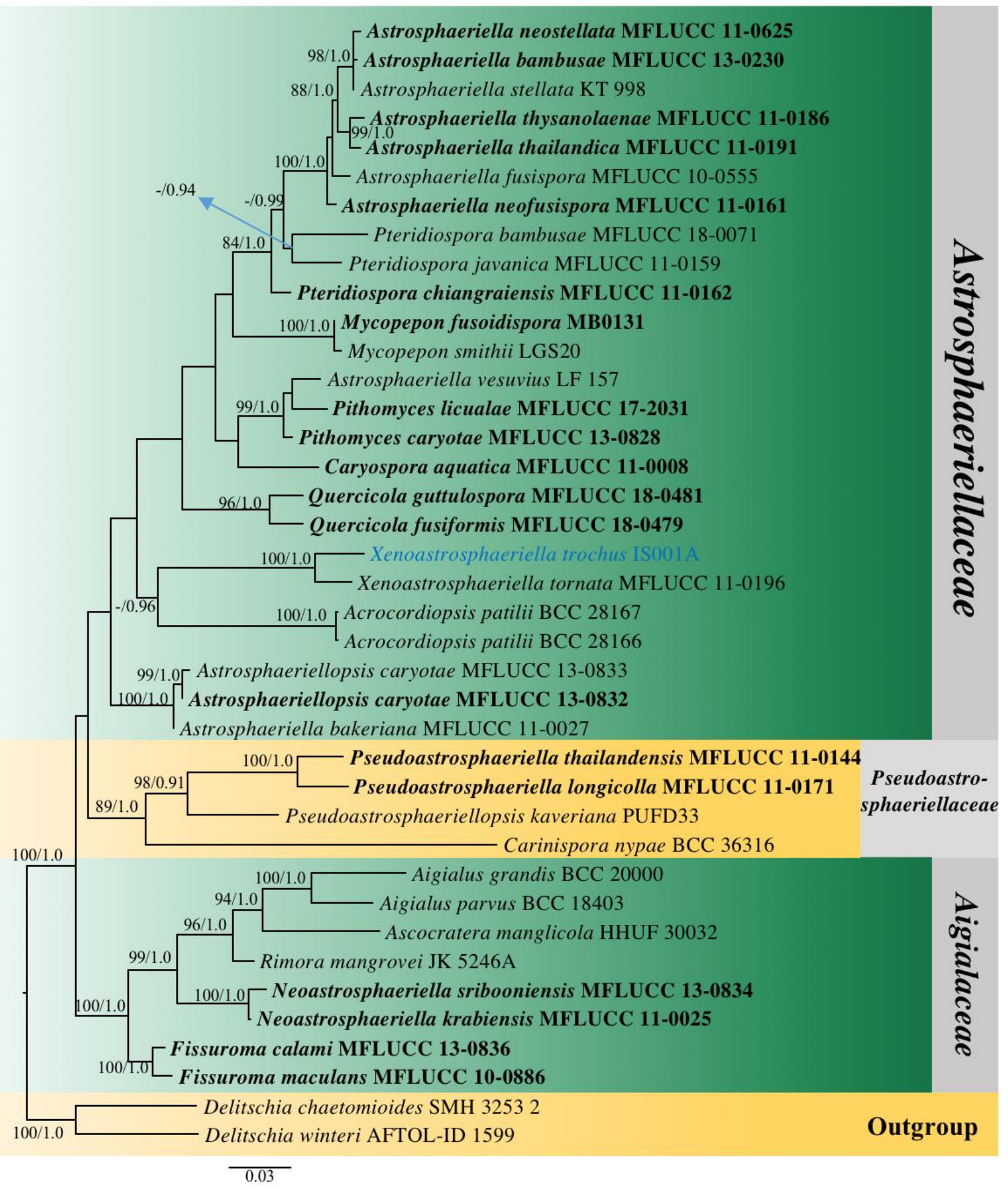

Figure 53 - Phylogram generated from maximum likelihood analysis (RAxML) of genera in Astrosphaeriellaceae based on LSU, rpb-2, SSU and tef1 sequence data. Maximum likelihood bootstrap values equal or above $70 \%$, Bayesian posterior probabilities equal or above 0.90 (MLBS/PP) are given at the nodes. An original isolate number is noted after the species name. The tree is rooted to Delitschia chaetomioides (SHM 3253.2) and D. winteri (AFTOL-ID 1599). The ex- 
type strains are indicated in bold. Newly sequence is in blue. Hyphen (-) represents support values below $70 \%$ MLBS and 0.90 PP.

Astrosphaeriella Syd. \& P. Syd., Annls mycol. 11(3): 260 (1913).

Index Fungorum number: IF 441; Facesoffungi number: FoF 01222; 50 morphological species (Species Fungorum 2020), 9 species with molecular data.

Type species - Astrosphaeriella fusispora Syd. \& P. Syd.

Notes - Astrosphaeriella was introduced by Sydow \& Sydow (1913a), with Astrosphaeriella fusispora as the type. Astrosphaeriella is a common genus on bamboos, palms and stout grasses (Barr 1990a, Zhou et al. 2003, Tanaka \& Harada 2005a, Hu 2010, Liu et al. 2011, Zhang et al. 2012b, Phookamsak et al. 2015b). The morphology of Astrosphaeriella has been well-studied, but the asexual morph of the genus was rarely established until Phookamsak et al. (2015b) described the holomorph of Astrosphaeriella bambusae and confirmed that Astrosphaeriella has coelomycetous asexual morph as mentioned in Tanaka \& Harada (2005a). For morphology of type species see Phookamsak et al. (2015b).

\section{Other genera included}

Astrosphaeriellopsis Phookamsak, J.K. Liu \& K.D. Hyde, Fungal Divers 74: 192 (2015).

Index Fungorum number: IF 551648; Facesoffungi number: FoF 01240; 2 morphological species (Species Fungorum 2020), 2 species with molecular data.

Type species - Astrosphaeriellopsis bakeriana (Sacc.) J.K. Liu, Phookamsak \& K.D. Hyde, Fungal Divers 74: 192 (2015)

इWinterina bakeriana Sacc., Bulletino dell'orto Botanico della R. Universitá di Napoli 6: 45 (1918).

Notes - Astrosphaeriellopsis was introduced by Phookamsak et al. (2015b) to accommodate Astrosphaeriella bakeriana which formed a single clade and separated from Astrosphaeriellaceae under combined dataset of LSU, SSU and tef1 alignments (Liu et al. 2011, Phookamsak et al. 2015b). Thus, Astrosphaeriellopsis was assigned at Pleosporales genera incertae sedis. However, when Wanasinghe et al. (2018a) introduced Astrosphaeriellopsis caryotae and added sequence data of three strains of the species in concatenated DNA dataset, phylogenetic analyses revealed that Astrosphaeriellopsis is within Astrosphaeriellaceae. Astrosphaeriellopsis is characterized by rarely clustered at the base, hemisphaerical, carbonaceous ascostromata and hyaline, becoming brown at maturity, fusiform ascospores with sheath.

Javaria Boise, Acta Amazonica 14 (Supl.): 50 (1984).

Index Fungorum number: IF 25763; Facesoffungi number: FoF 08165; 2 morphological species (Species Fungorum 2020), molecular data unavailable.

Type species - Javaria samuelsii Boise, Acta Amazon. 14 (1-2, Supl.): 50 (1984).

Notes - Javaria was introduced by Boise (1984). Javaria is similar to Astrosphaeriella, but differs in its hyaline ascospores with sheath, and its apical ring can be stained with congo red, as well as its small ascomata (Zhang et al. 2012b). Some mycologists regared Javaria as a synonym of Astrosphaeriella (Hyde \& Fröhlich 1998, Zhang et al. 2012b). However, this has not been confirmed due to the lack of molecular data for Javaria.

Mycopepon Boise, Syst. Ascom. 6(1): 168 (1987).

Index Fungorum number: IF 25196; Facesoffungi number: FoF 04631; 4 morphological species (Species Fungorum 2020), 3 species with molecular data.

Type species - Mycopepon guianensis Boise, Syst. Ascom. 6(1): 168 (1987).

Notes - Recent phylogenetic study showed that Mycopepon fell into Astrosphaeriellaceae with two new species reported (Liu et al. 2018b). In our phylogenetic result (Fig. 53), Mycopepon also clustered in Astrosphaeriellaceae clade. From morphology, Mycopepon is within Astrosphaeriellaceae owing to superficial carbonaceous ascostromata, trabeculate pseudoparaphyses and fusoid ascospores with septa (Liu et al. 2018b). Mycopepon is distinguished 
from other genera of Astrosphaeriellaceae in 2-8 pseudothecial ascostroma. In this study, we follow Liu et al. (2018b) and treat Mycopepon as a member of Astrosphaeriellaceae
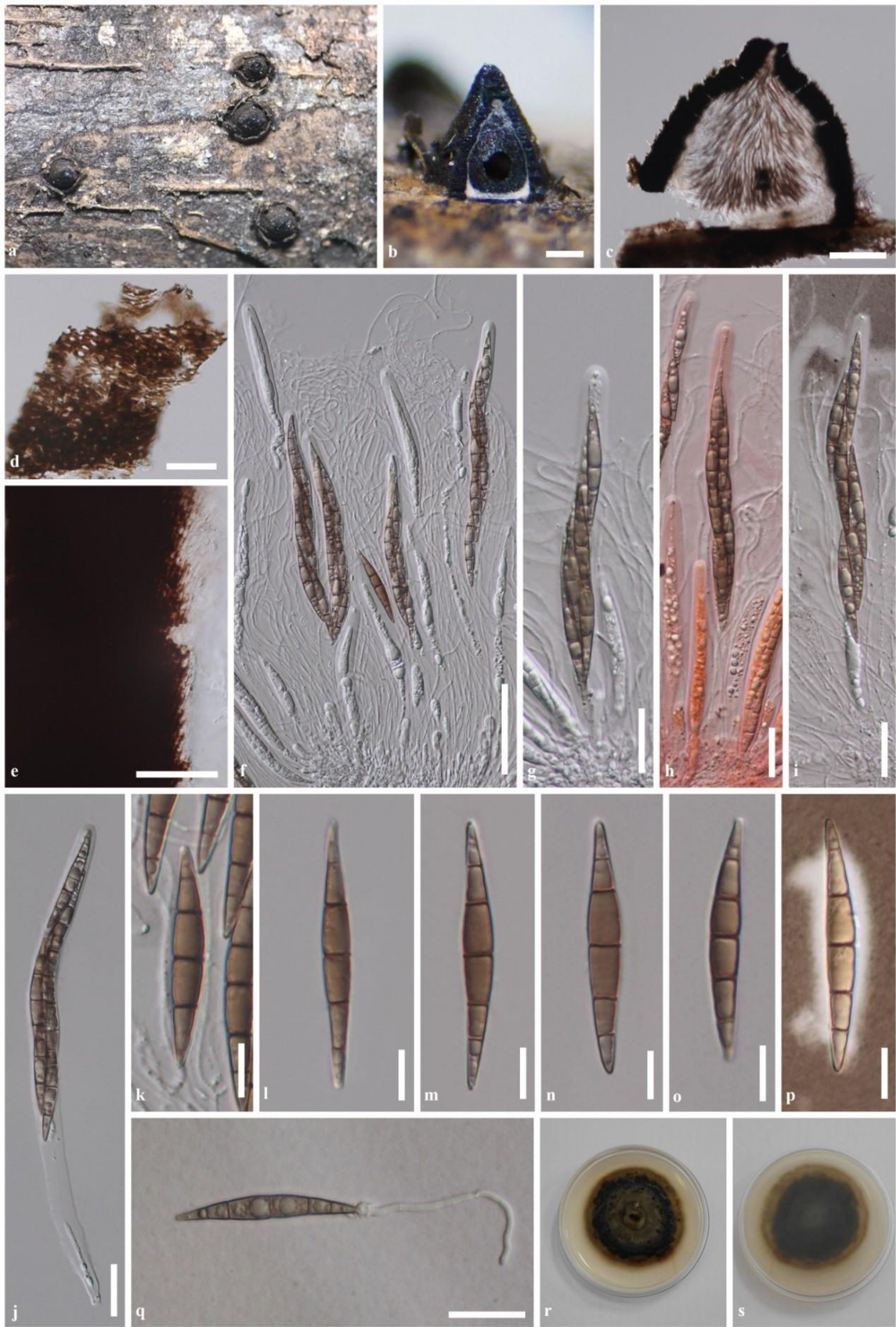

Figure 54 - Xenoastrosphaeriella trochus (KUN-HKAS 107533). a Appearance of ascomata on host surface. b, c Section through ascoma. d, e Section through peridial structures. f Asci with 
trabeculate pseudoparaphyses embedded in a mucilaginous matrix. g, $\mathrm{j}$ Asci. $\mathrm{h}$ Ascus stained by congo red. i Ascus stained by India ink. k-o Ascospores. $\mathrm{p}$ Ascospore stained by India ink. $\mathrm{q}$ Germinated ascospore. $r$, s Culture characteristic on PDA after 4 weeks $(r=$ from above, $s=$ from below). Scale bars: $b, c=200 \mu \mathrm{m}, \mathrm{e}, \mathrm{f}=50 \mu \mathrm{m}, \mathrm{d}, \mathrm{g}-\mathrm{j}, \mathrm{q}=20 \mu \mathrm{m}, \mathrm{k}-\mathrm{p}=10 \mu \mathrm{m}$.

Pithomyces Berk. \& Broome, J. Linn. Soc., Bot. 14: 100 (1873).

Index Fungorum number: IF 9412; Facesoffungi number: FoF 03611; 43 morphological species (Species Fungorum 2020), 6 species with molecular data.

Type species - Pithomyces flavus Berk. \& Broome, J. Linn. Soc., Bot. 14: 100 (1873).

Notes - Pithomyces is similar to other astrosphaeriella-like genera in having dark, carbonaceous ascomata with a poorly developed peridium at the base, trabeculate pseudoparaphyses, cylindrical asci, and fusiform ascospores with acute ends (Wanasinghe et al. 2018a). However, it is distinct from other astrosphaeriella-like taxa in its hyphomycetous asexual morph while others are coelomycetous.

Pteridiospora Penz. \& Sacc., Malpighia 11: 399 (1897).

Index Fungorum number: IF 4536; Facesoffungi number: FoF 01231; 6 morphological species (Species Fungorum 2020), 4 species with molecular data.

Type species - Pteridiospora javanica Penz. \& Sacc., Malpighia 11: 399 (1897).

Notes - Pteridiospora is characterized by superficial, mammiform to conical, carbonaceous ascomata with ostiole, trabeculate pseudoparaphyses, 8-spored, broad-cylindrical to cylindricclavate asci with short pedicel, and hyaline to brown, obclavate to ellipsoidal, septate, asymmetrical ascospores surrounded by irregular, mucilaginous sheath (Phookamsak et al. 2015b, Hyde et al. 2018). Pteridiospora is similar to Astrosphaeriella, but differs in its asymmetrical ascospores, with distinctive mucilaginous sheath. Phylogenetic analyses show that Pteridiospora is a sister clade to Astrosphaeriella within Astrosphaeriellaceae (Phookamsak et al. 2014b, 2015b, Hyde et al. 2018).

Quercicola Jayasiri, E.B.G. Jones \& K.D. Hyde, Mycosphere 10(1): 29 (2019).

Index Fungorum number: IF 555532; Facesoffungi number: FoF 05233; 2 morphological species (Species Fungorum 2020), 2 species with molecular data.

Type species - Quercicola fusiformis Jayasiri, E.B.G. Jones \& K.D. Hyde, Mycosphere 10(1): 30 (2019).

Notes - Quercicola was introduced to accommodate $Q$. fusiformis and $Q$. guttulospora (Jayasiri et al. 2019). Quercicola is distinguished from other genera in Astrosphaeriellaceae in having hyaline, fusiform ascospores without a sheath (Jayasiri et al. 2019).

Xenoastrosphaeriella Jayasiri, E.B.G. Jones \& K.D. Hyde, Mycosphere 10(1): 36 (2019).

Index Fungorum number: IF 555536; Facesoffungi number: FoF 05237; 2 morphological species (Species Fungorum 2020), 2 species with molecular data.

Type species - Xenoastrosphaeriella tornata (D. Hawksw. \& Boise) Jayasiri \& K.D. Hyde, Mycosphere 10(1): 36 (2019).

三Trematosphaeria tornata Cooke, Grevillea 16(no. 79): 91 (1888).

Notes - Xenoastrosphaeriella was introduced by Jayasiri et al. (2019) mainly based on phylogenetic analyses. Xenoastrosphaeriella is similar to Astrosphaeriella because of mammiform to conical, carbonaceous ascostromata and fusiform, reddish brown ascospores (Hawksworth \& Boise 1985). In this paper, we synonymize Astrosphaeriella trochus as Xenoastrosphaeriella trochus based on phylogeny and morphology.

Xenoastrosphaeriella trochus (D. Hawksw.) Phookamsak, H.B. Jiang, \& K.D. Hyde, comb. nov.

三Astrosphaeriella trochus (Penz. \& Sacc.) D. Hawksw., Bot. J. Linn. Soc. 82: 46 (1981).

$\equiv$ Melanomma trochus Penz. \& Sacc., Malpighia 11(9-10): 401 (1897).

Index Fungorum number: IF 111138; Facesoffungi number: FoF 08164. 
Saprobic on Thysanolaena maxima (Poaceae), visible as black, opaque, cone-like, on the host surface. Sexual morph: Ascomata 570-810 $\mu \mathrm{m}$ high, 590-760 $\mu \mathrm{m}$ diam., carbonaceous, dark brown to black, opaque, solitary to gregarious, erumpent through the outer layers of the host tissue, becoming superficial, easily broken, conical to mammiform, with host cortex persisting as ruptured, reflexed, stellate, host remnants, around the base, uni-loculate, rarely bi-loculate, glabrous, ostiolate, with a minute papilla. Peridium $40-110 \mu \mathrm{m}$ wide, of unequal thickness, poorly developed at the base, thicker at sides towards the apex, composed of small, dark opaque, melanized cells of textura prismatica or palisade-like. Hamathecium comprising dense, 0.5-1.5 $\mu \mathrm{m}$ wide, filiform, trabeculate, anastomosing at the apex, pseudoparaphyses, embedded in a hyaline gelatinous matrix. Asci (125-)160-190(-215) × 10-12(-14) $\mu \mathrm{m}(\bar{x}=172.5 \times 11.9 \mu \mathrm{m}, \mathrm{n}=30), 8$-spored, bitunicate, fissitunicate, subcylindrical to cylindric-clavate, short pedicellate, apically rounded, with welldeveloped ocular chamber. Ascospores $(40-) 45-55(-57) \times 4.5-6 \mu \mathrm{m}(\bar{x}=48.2 \times 5.6 \mu \mathrm{m}, \mathrm{n}=30)$, overlapping 1-2-seriate, narrowly elongate fusiform with acute ends, brown to reddish brown, paler at the end cells, (3-)5-septate, slightly constricted at the septa, smooth-walled, with conspicuous mucilaginous sheath surrounded ascospores. Asexual morph: Undetermined.

Culture characteristics - Ascospores germinated on WA after 8 hours at $25^{\circ} \mathrm{C}$ under a dark condition. Colonies on PDA reaching 35-40 mm diam. after 4 weeks at $25-30^{\circ} \mathrm{C}$, colonies circular, dense, slightly raised to convex, or dome-shaped, dull, surface slightly rough with small turfs and brown droplets, edge entire, velvety to floccose; colony from above, drak-green at the margin, grey-greenish at the center; from below, dark brown to black at the margin, paler at the center; not producing pigmentation in agar.

Material examined - China, Yunnan Province, Xishuangbanna, Mengla County, Xishuangbanna tropical botanical garden, on dead stem of Thysanolaena maxima, 27 April 2017, R. Phookamsak, IS001 (KUN-HKAS 107533), living culture, KUMCC 18-0194.

GenBank number - LSU: MT659668, SSU: MT659669, tef: MT653597, rpb-2: MT653598

Hosts - Various unidentified bamboo and stout grasses; Chusquea sp., Phragmites sp., Phyllostachys bambusoides, Thysanolaena maxima (Hawksworth 1981, Hawksworth \& Boise 1985, Hyde \& Fröhlich 1998).

Distributions - Chile, China (Xishuangbanna, Yunnan), Colombia, Ecuador, French Guiana, Japan, Indonesia, South Africa, Taiwan, Uganda (Hawksworth 1981, Hawksworth \& Boise 1985, Hyde \& Fröhlich 1998).

Notes - Astrosphaeriella trochus was designated for Melanomma trochus by Hawksworth (1981). However, the species should be transferred to Xenoastrosphaeriella based on multi-gene phylogeny and morphology. Xenoastrosphaeriella trochus is similar to X. tornata in having conical to mammiform, carbonaceous ascomata, cylindric-clavate asci and broadly fusiform, reddish brown ascospores, but differs in septa number and with or without a sheath (Phookamsak et al. 2015b, this study). Based on the present phylogeny (Fig. 53), X. tornata and X. trochus grouped together with high statistic support (100\% MLBS, 1.0 PP).

Xenoastrosphaeriella trochus is mostly similar to Astrosphaeriella exorrhiza in having (3-)5septate, elongate-fusiform ascospores (Hawksworth \& Boise 1985, Hyde \& Fröhlich 1998). However, the species differs from A. exorrhiza in having smaller asci and ascospores [A. trochus: (44-)48-65(-72) $\times(5-) 6-8(-9) \mu \mathrm{m}$ vs. $(68-) 74-88 \times 8-10 \mu \mathrm{m}$ : A. exorrhiza] (Hawksworth \& Boise 1985, Hyde \& Fröhlich 1998). Astrosphaeriella exorrhiza was found on Thysanolaena maxima in Thailand (Phookamsak et al. 2015b) which is the same host of our new collection from Xishuangbanna, China. These two species maybe conspecific, however, this conspecific status will eventually need to be confirmed by molecular data.

\section{Ecological and economic significance}

Astrosphaeriellaceae is widespread in the world. Taxa in the family are usually saprobic or parasitic on bamboo, palm or stout grasses (Phookamsak et al. 2015b). One genus (Pithomyces) has been reported as human and plant pathogen (Litz \& Cavagnolo 2010). 
Bambusicolaceae D.Q. Dai \& K.D. Hyde, in Hyde et al., Fungal Divers. 63: 49 (2013).

Index Fungorum number: IF 804293; Facesoffungi number: FoF 00586, 15 species.

Saprobic on bamboo culms, pods and palms Sexual morph: Ascomata solitary, scattered, immersed, conical, ostiolate, coriaceous. Peridium thin, composed of brown and thick-walled cells of textura angularis, with the basal part composed of thinner, hyaline cells. Hamathecium comprising relatively thin, dense, anastomosing and branching interascal filaments, usually pseudoparaphyses. Asci 8-spored, bitunicate, fissitunicate, cylindrical, with a short furcate pedicel, apically rounded, with a shallow ocular chamber. Ascospores 2-3-seriate, slightly broad fusiform, hyaline, 1-septate, narrowly rounded at both ends, surrounded by a gelatinous sheath. Asexual morph: Conidiomata small, pycnothyrial, acerous or subglobose, solitary, scattered, immersed to semi-immersed. Conidiophores indistinct. Conidiogenous cells enteroblastic, annelidic, or phialidic, discrete, cylindrical, and smooth. Conidia cylindrical and oblong to ellipsoidal, straight or slightly curved, obtuse at the apex, pale brown to dark brown, aseptate to 1-3-septate.

Type - Bambusicola D.Q. Dai \& K.D. Hyde.

Notes - Bambusicolaceae was introduced to accommodate Bambusicola which consisted of three species. The morphological characters of the family are immersed to superficial, globose to subglobose ascomata, cylindrical to clavate asci and hyaline, fusiform ascospores surrounded by a gelatinous sheath. Bambusicolaceae share similar morphological characters to Tetraplosphaeriaceae (Tanaka et al. 2009). The asexual morphs are produced in culture or found on host culms. Phylogenetic analyses showed that Bambusicolaceae belongs to Pleosporales, and closely related to Massarinaceae and Montagnulaceae (Hyde et al. 2013, Tanaka et al. 2015). Three genera, Bambusicola, Leucaenicola and Palmiascoma are accommodated in Bambusicolaceae.

Bambusicola D.Q. Dai \& K.D. Hyde, Cryptog. Mycol. 33(3): 367 (2012).

Index Fungorum number: IF 801041; Facesoffungi number: FoF 01433; 12 morphological species (Species Fungorum 2020), 12 species with molecular data. (2012).

Type species - Bambusicola massarinia D.Q. Dai \& K.D. Hyde, Cryptog. Mycol. 33(3): 370

Notes - Bambusicola was introduced to accommodate four saprobic species from culms of bamboos collected in northern Thailand. Bambusicola is characterized by cone-shaped ascomata, slightly broad and fusiform ascospores and a coelomycete asexual morph with light brown conidia. Bambusicola comprises species that are widely distributed on bamboo in Asia.

\section{Other genera included}

Leucaenicola Jayasiri, E.B.G. Jones \& K.D. Hyde, in Jayasiri et al., Mycosphere 10(1): 37 (2019).

Index Fungorum number: IF 555538; Facesoffungi number: FoF 05239; 2 morphological species (Species Fungorum 2020), 2 species with molecular data.

Type species - Leucaenicola aseptata Jayasiri, E.B.G. Jones \& K.D. Hyde, in Jayasiriet al., Mycosphere 10(1): 39 (2019).

Notes - Leucaenicola was introduced by Jayasiri et al. (2019) with L. aseptata as type species. Species in Leucaenicola are characterized by immersed to superficial conidiomata, Conidiomatal wall comprising of pseudoparenchymatous cells of textura angularis to textura prismatica, enteroblastic, phialidic conidiogenous cells and aseptate, smooth-walled brown conidia. The sexual morph is unknown.

Palmiascoma Phookamsak \& K.D. Hyde, in Liu et al., Fungal Divers. 72: 65 (2015).

Index Fungorum number: IF 550926; Facesoffungi number: FoF 00428; 1 morphological species (Species Fungorum 2020), 1 species with molecular data.

Type species - Palmiascoma gregariascomum Phookamsak \& K.D. Hyde, Fungal Divers. 72: 65 (2015).

Notes - Palmiascoma was introduced by Liu et al. (2015) and was accommodated in Bambusicolaceae with $P$. gregariascomum as type species. The genus shares similar morphology 
close to Munkovalsaria, Didymosphaeria and Verruculina in having didymosporous, brown and echinulate ascospores. Palmiascoma differs from Bambusicola species in having ellipsoidal, dark brown, echinulate ascospores with broad cellular pseudoparaphyses. The asexual morph was reported as coelomycetous (Liu et al. 2015, Wijayawardene et al. 2018).

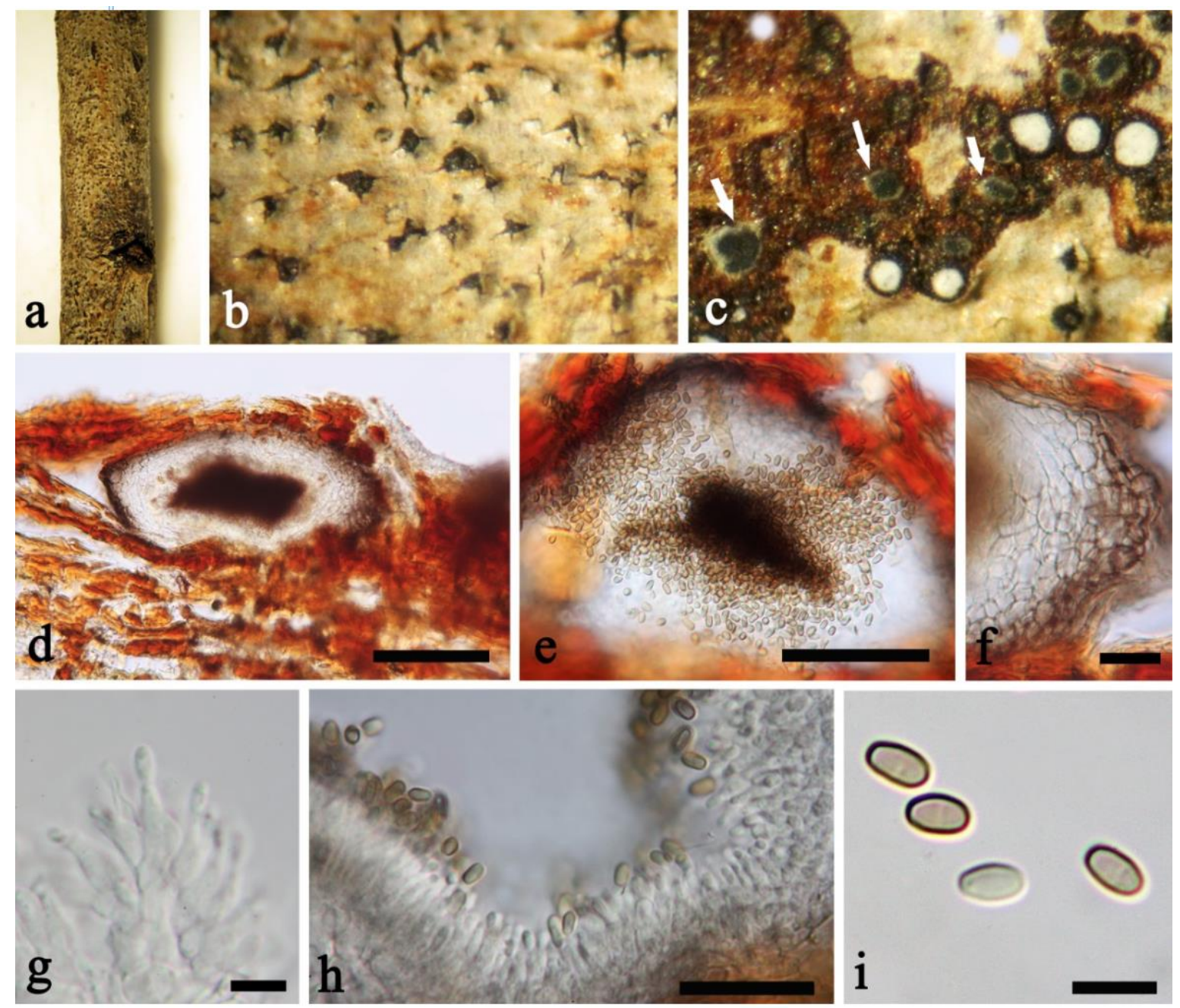

Figure 55 - Palmiascoma gregariascomum (MFLU 12-0752, new host record). a Conidiomata on dead branch of Eucalyptus. b Close up conidiomata on host substrate. c Conidiomata cut through horizontally showing black and hyaline contents, (conidiomata of Palmiascoma gregariascomum showing in black contents (arrow). d Section through conidioma. e Close up conidia in conidioma. $\mathrm{f}$ Peridium. g, h Conidia attached to conidiophores. i Conidia. Scale bars: $\mathrm{d}=100 \mu \mathrm{m}, \mathrm{e}=50 \mu \mathrm{m}, \mathrm{f}$, $\mathrm{h}=20 \mu \mathrm{m}, \mathrm{g}, \mathrm{i}=5 \mu \mathrm{m}$.

Palmiascoma gregariascomum Phookamsak \& K.D. Hyde, Fungal Divers 72: 65 (2015) $\quad$ Fig. 55 Index Fungorum number: IF 550927; Facesoffungi number: FoF 00429.

Saprobic on dead branches of Eucalyptus. Sexual morph: (see Liu et al. 2015). Asexual morph: Conidiomata 85-205 $\mu \mathrm{m}$ high $\times 90-250 \mu \mathrm{m}$ diam., $(\bar{x}=123 \times 200 \mu \mathrm{m}, \mathrm{n}=15)$, pycnidial, solitary, black, solitary to gregarious, aggregated, immersed to semi-immersed, when cut through horizontally locules visible as the black contents and black ascospore dots, globose to subglobose, glabrous, ostiole central, with minute papilla. Ostiole 30-40 $\mu \mathrm{m}$ high, 25-45 $\mu \mathrm{m}$ wide, central, short, slightly sunken, inconspicuous at the surface, periphyses. Conidiomata walls $40-90 \mu \mathrm{m}$ wide, two layers, composed of cells of textura angularis, outer layer black to reddish brown, thickwalled, inner layer comprising 5-7 cell layers, light brown to hyaline, thin-walled. Conidiophores arising from basal cavity of conidiomata mostly reduced to conidiogenous cells, macronematous. Conidiogenous cells discrete, monoblastic, integrated, terminal, ampulliform to cylindrical, hyaline 
to subhyaline, simple, smooth-walled. Conidia $3-4.5 \times 1.7-3 \mu \mathrm{m}(\bar{x}=3.8 \times 2.3 \mu \mathrm{m}, \mathrm{n}=30)$, solitary, oblong to ellipsoidal, initially hyaline, becoming pale brown to brown at maturity, aseptate, with rounded or obtuse ends, smooth-walled.

Material examined - Thailand, Chiang Rai, Muang District, Thasud Sub district, on dead branches of Eucalyptus sp. (Myrtaceae), 5 October 2011, M. Doilom, (MFLU 12-0752), living culture MFLUCC 11-0424.

Notes - Palmiascoma is a monotypic genus with P. gregariascomum as the type and was assigned in Bambusicolaceae (Liu et al. 2015). The species was introduced with both asexual and sexual morphs. The sexual morph occurred on dead frond of palm and asexual morph found on bamboo pieces (Liu et al. 2015). Our new collection of $P$. gregariascomum differs from the type specimen in having shorter and narrower conidia. This may be because of different substrates. Phylogenetic analyses (Fig. 42) indicate that our collection clusters with $P$. gregariascomum (MFLUCC 11-0175) as the same species with high support (100\% MLBS, 1.0 PP). We hereby illustrate this taxon as a new record on Eucalyptus sp.

\section{Ecological and economic significance}

Species of Bambusicolaceae are normally found on decaying plant litter and other organic debris from marine, freshwater and lichens and as parasites of insects (Sutton 1980). They form dark brown to black spots on the hosts especially Poaceae (Dai et al. 2012).

Biatriosporaceae K.D. Hyde, Fungal Divers. 63: 50 (2013)

Index Fungorum number: IF 803357; Facesoffungi number: FoF 08166, 1 species.

Saprobic on decaying submerged intertidal mangrove wood. Sexual morph: Ascomata lying horizontal, immersed in substratum, subglobose to pyriform, solitary or gregarious, black, ostiolate. Peridium thin, composed of brown pseudoparenchymatous cells. Hamathecium comprising dense, thin, anastomosing, branching, trabeculate, pseudoparaphyses, embedded in a gelatinous matrix. Asci 8-spored, bitunicate, fissitunicate, cylindrical, long pedicellate. Ascospores overlapping 1seriate, fusiform, dark brown, with hyaline rounded ends, 1-4-septate toward each end, aseptate in the centre, not constricted at the septa in the centre part, smooth-walled, releasing mucilage from the ends. Asexual morph: Pycnidia solitary or rarely confluent, on upper surface or submerged in agar, globose to subglobose or pyriform, with dark brown, septate mycelial outgrowths, papillate, ostiolate, olivaceous to olivaceous-black, the wall with pseudoparenchymatous cells. Conidiogenous cells hyaline, phialidic, discrete. Conidia ellipsoidal, subhyaline, brown in mass, aseptate.

Type - Biatriospora K.D. Hyde \& Borse.

Notes - The monogeneric family Biatriosporaceae was established by Hyde et al. (2013) to accommodate a marine genus Biatriospora typified by B. marina (Hyde \& Borse 1986) based on morphological and molecular data (Hyde et al. 2013).

Biatriospora K.D. Hyde \& Borse, Mycotaxon 26: 263 (1986).

Index Fungorum number: IF 25748; Facesoffungi number: FoF 08167; 1 morphological species (Species Fungorum 2020), 1 species with molecular data.

Type species - Biatriospora marina K.D. Hyde \& Borse.

Notes - Biatriospora is a monotypic genus and it is morphologically distinct from other genera in the Pleosporales in having ascospores with conical end chambers similar in appearance to those in species of Lulworthia and some species of Spathulospora (Kohlmeyer \& Kohlmeyer 1979). However, these genera differ in ascal morphology, bitunicate in Biatriospora, while unitunicate in Lulworthia and Spathulospora, and in the release of mucilage from the end chambers (Jones 1994, 1995). Biatriospora marina, the type species of the genus was originally collected and described from mangrove roots of Sonneratia alba from Anse Boileau mangrove stand, Seychelles (Hyde \& Borse 1986). Multi-gene phylogenetic analysis indicated that B. marina formed a separate clade, sister to other families of Pleosporales (Suetrong et al. 2009). Ahmed et al. (2014b) combined asexual species, Nigrospora mackinnoii, which is the causal agent of eumycetoma, with 
Biatriospora based on combined datasets of LSU, rpb-2, SSU, tef1 employing Bayesian analysis and maximum likelihood phylogeny (for morphology see Zhang et al. 2012b).

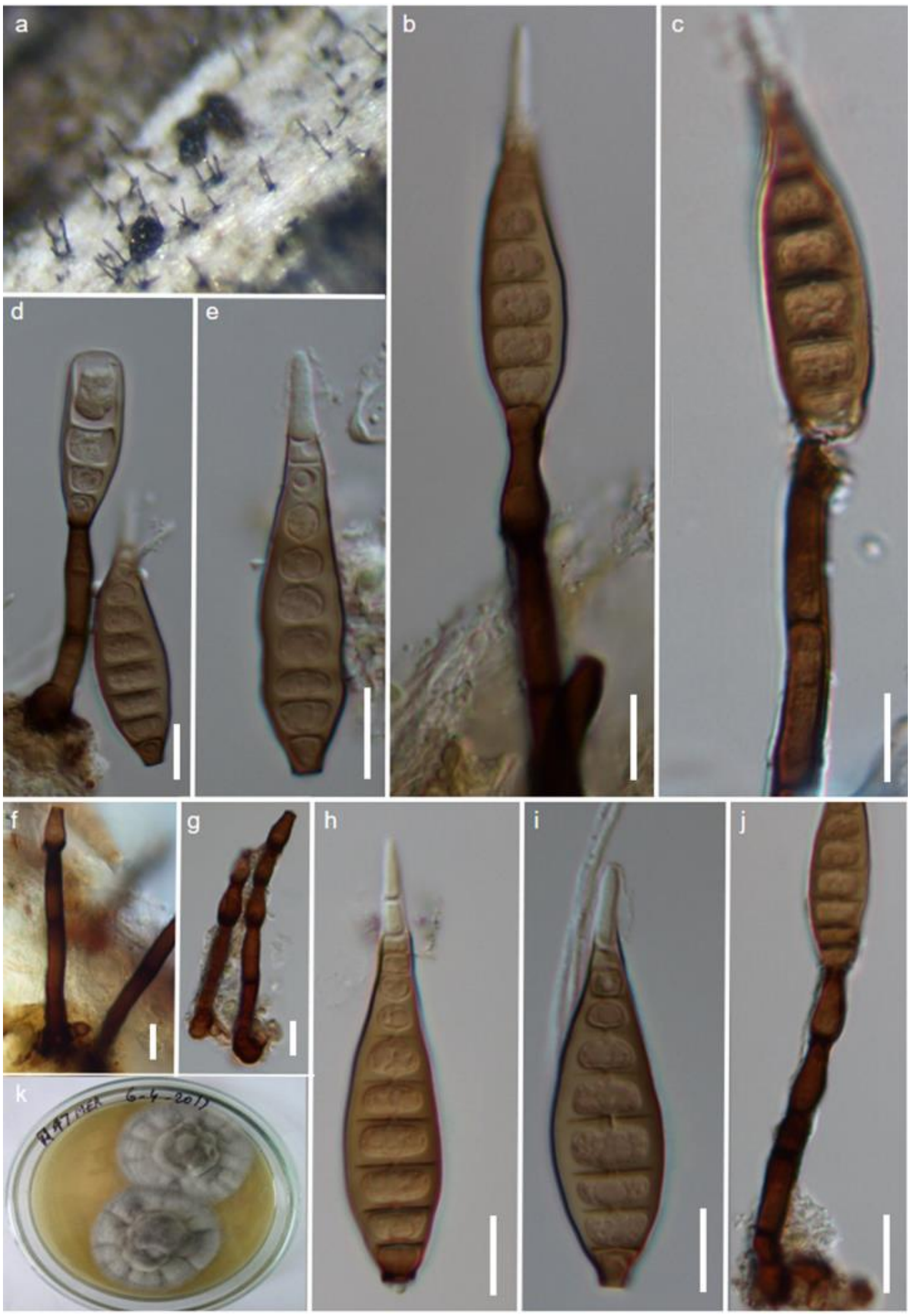

Figure 56 - Biatriospora borsei (AMH-9943, holotype). a Colonies superficial on the surface of decaying wood. $\mathrm{b}-\mathrm{d}$, j Conidiophore bearing conidia. $\mathrm{f}$, g Conidiophores $\mathrm{k}$ Culture on MEA after 30 days of incubation. e, $h$, i Conidia. Scale bars: $b-j=10 \mu \mathrm{m}$. 
Jaklitsch \& Voglmayr (2016) introduced Nigrogranaceae to accommodate Nigrograna species and suggested to terminate the use of Biatriosporaceae, since sequence data are doubtful. Biatrisopora now contains only one species as other species were synonymized under Nigrograna (Kolařík 2018). Biatriospora marina along with the present new species Biatriospora borsei clustered separately from species of Nigrograna excepting $N$. fiscidula. Nigrograna fiscidula was originally known as Melanomma fiscidula but based on molecular sequence differences it was transferred to Nigrograna. While species belonging to Nigrograna produce pycnidial asexual morphs, our new taxon $B$. borsei produced a hyphomycetous asexual morph in culture and clades closely with $B$. marina in the phylogram. Though a pycnidial asexual morph connection has been indicated for $N$. fiscidula it was from natural substrate and not from a culture (Jaklitsch \& Voglmayr 2016). An isolate of Biatrispora marina labelled as CY 1228 used in the present study in phylogenetic analysis was excluded by Jaklitsch \& Voglmayr (2016) in their tree as it clustered separately and also due to the unique morphological features when compared to species belonging to Nigrograna. Jaklitsch \& Voglmayr (2016) suspected whether this isolate indeed represents $B$. marina and mentioned the necessity to get fresh collections and molecular anlaysis of this fungus. Considering these observations, we consider that synonymizing Biatriosporaceae with Nigrogranaceae is not justified. Further, since both Biatriospora and Nigrograna clade closely, Biatriosporaceae may be retained for these two genera based on the chronological priority of the family names.

Biatrisopora borsei B. Devadatha, V.V. Sarma sp. nov.

Fig. 56

Index Fungorum number: IF 555778; Facesoffungi number: FoF 06529.

Etymology - Specific epithet in honour of Indian marine mycologist Dr. B.D. Borse on his contributions to marine mycology.

Saprobic on decaying wood of Avicennia marina Sexual morph: Undetermined. Asexual morph: Colonies on natural substratum velvety to olivaceous brown. Mycelium mostly superficial, comprising pale to medium brown, smooth or verrruculose, septate, extensively ramifying hyphae. Setae and hyphophodia absent. Stromata not developed. Conidiophores 40-115 $\times 2.5-6 \mu \mathrm{m}(\bar{x}=68$ $\times 5 \mu \mathrm{m}, \mathrm{n}=10$ ), borne on superficial smooth, hyaline knots of hyphae, solitary or aggregated, straight to slightly flexuous, cylindrical, pale to medium brown uniform in width and colour, unbranched, smooth, 2-5 septate, not cicatrized, with one percurrent proliferation. Conidial secession schizolytic. Conidia 30-45 $\times 7-9 \mu \mathrm{m}(\bar{x}=43 \times 8 \mu \mathrm{m}, \mathrm{n}=10)$, subclavate, slightly rostrate, straight or slightly asymmetrical, rounded at the tip, pale brownish, apical cell usually hyaline, mostly with 6 pseudosepta, rarely 7-pseudoseptate, not constricted at septa obconically truncate at the base usually with a darkened hilum.

Culture characteristics - Conidia germinating on $2 \%$ sea water agar within $24 \mathrm{~h}$ with germ tubes produced from terminal ends. Colonies on malt extract sea water agar fast growing, reaching diameters of 30 to $50 \mathrm{~mm}$ in 25 days at room temperature, gray to dark brown, cottony, circular, raised, zonate; reversed colonies brown.

Material examined - India, Tamil Nadu, Tiruvarur, Muthupet mangroves $\left(11.24^{\circ} \mathrm{N} 79.5^{\circ} \mathrm{E}\right)$, on decaying wood of Avicennia marina (Acanthaceae), 28 November 2016, B. Devadatha, AMH9943 (holotype), ex-type living culture, NFCCI-4245.

GenBank numbers - ITS: MK358818; LSU: MK358813; SSU: MK358811; tef1: MK330938.

Notes - Biatriospora borsei resembles Elliembia repentioriunda in morphological features such as conidiophores borne on superficial hyphae and conidia that are sub-clavate, slightly rostrate, 6-7 pseudoseptate, apical cell hyaline and similar conidial dimensions. However, B. borsei differs from Ellisembia repentioriunda in having longer conidiophores (30-45 $\times 7-9 \mu \mathrm{m} v \mathrm{~s} 15-35$ $\times 3.5-4.5$ ), in lacking hyaline, subglobose mucilaginous sheaths in the apical cells and by its occurrence in marine habitats. Ellisembia gelatinosa and E. minigelatinosum differ from $B$. borsei in having conidiophores that arise from vegetative hyphae and conidia with a mucilaginous sheath at the apex (Goh \& Hyde 1999). The Ellisembia species compared here lack molecular data for any comparisons of their phylogenetic relationships. 


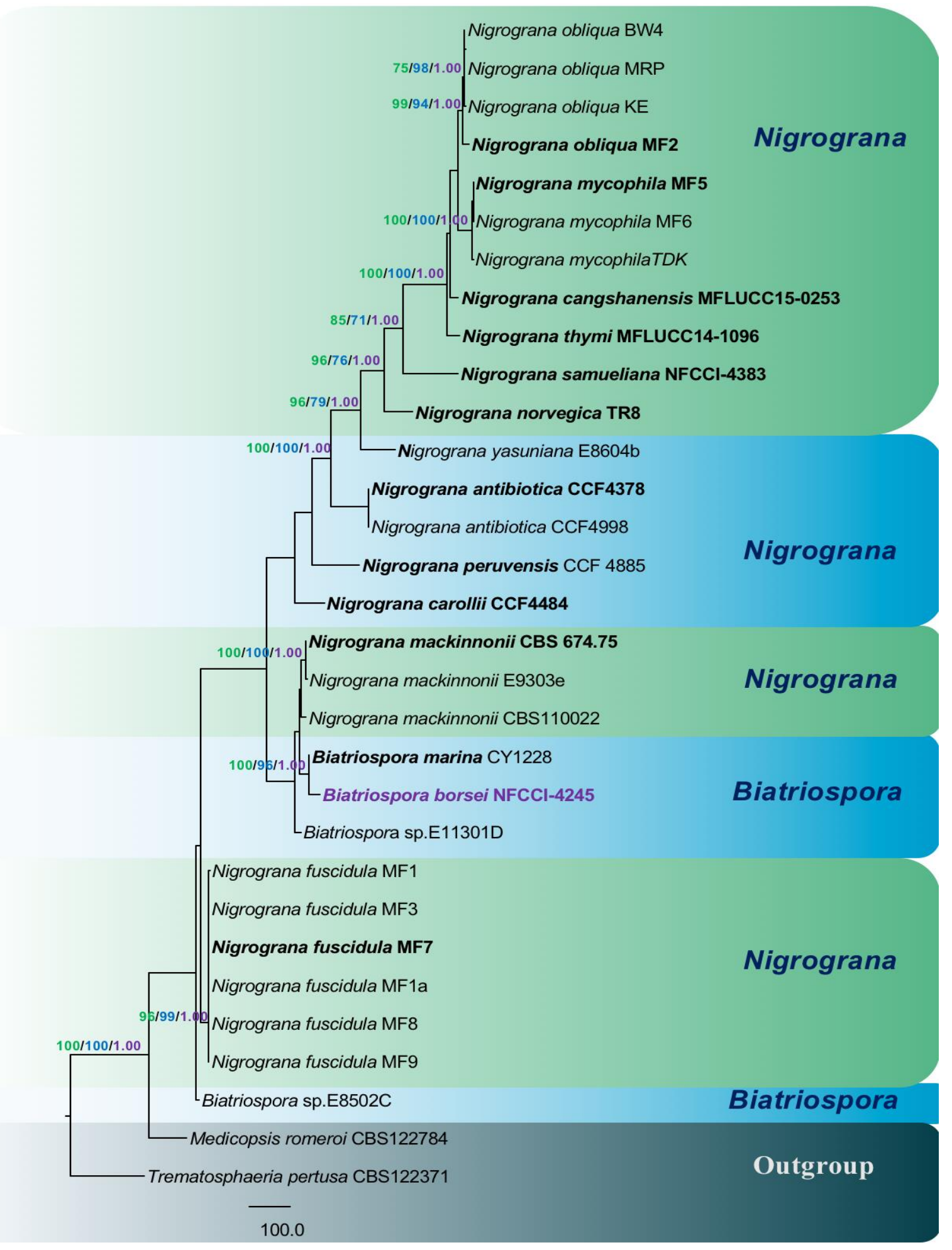

Figure 57 - Phylogram generated from Maximum Parsimony analysis of Biatriospora species and related genera based on ITS, LSU, rpb-2, SSU and tef1 sequence data. Bootstrap support values for maximum likelihood (ML, green), maximum parsimony (MP, blue) equal to or greater than $70 \%$ and the values of Bayesian posterior probabilities (PP, purple) equal to or greater than 0.95 are given above each branch, respectively. The tree is rooted to Medicopsis romeroi (CBS 122784) and Trematosphaeria pertusa (CBS 122371). The new isolate is in purple.

The combined ITS, LSU, rpb-2, SSU, and tef1 sequence datasets comprised 31 strains of Nigrogranaceae and Biatriosporaceae families with Trematosphaeria pertusa and Medicopsis romeroi as the outgroup taxa (Fig. 57). It is topologically similar and congruent with previous 
studies (Hyde et al. 2013, Jaklitsch \& Voglmayr 2016, Ahmed et al. 2018). Our new taxon formed a monophyletic clade along with Biatriospora marina (CY 1228) with significant bootstrap support (ML $100 \%$, MP $71 \%$, and 1.00 PP, Fig. 57). Biatriospora marina is a sexual morph, whereas $B$. borse $i$ is an asexual morph. Both are reported from decaying wood from mangroves (Hyde \& Borse 1986). The morphological details and the multi-gene phylogenetic results suggest that $B$. borse $i$ is a novel species. Hence, based on above observations, we introduce $B$. borsei as a new species.

\section{Ecological and economic significance}

Biatriospora is an economically important genus as the species are human pathogenic, endophytic, and saprobic (Hyde \& Borse 1986, Kolařík et al. 2017, Ahmed et al. 2018). Six epithets for Biatriospora and 12 names for its asexual genus Nigrograna are listed in Species Fungorum (2019). Species of Biatriospora are known to produce an extraordinary diverse set of metabolites, including potent antibiotics (Shaw et al. 2015, Stodůlková et al. 2015).

Camarosporiaceae Wanas., Wijayaw., K.D. Hyde \& Crous, in Wanasinghe et al., Stud. Mycol. 87: 212 (2017).

Index Fungorum number: IF 80150; Facesoffungi number: FoF 03527, 262 species.

Saprobic, endophytic and pathogenic on leaves, wood in terrestrial habitats. Sexual morph: Ascomata immersed to erumpent, aggregated to solitary, globose to subglobose, unilocular, black, ostiolate. Ostiole central, black, papillate. Peridium with several cell layers of cells of textura angularis, outer layer to inner layer brown and reddish brown to hyaline and sub hyaline. Asci pedicellate, cylindrical, bitunicate, 8-spored. Hamathecium of cellular pseudoparaphyses. Ascospores 1-seriate, ellipsoidal, with obtuse ends, medium brown, muriform, 3-8 transverse septa, 1-2 longitudinal septa, constricted at septa. Asexual morph: Conidiomata dimorphic, subcorticolous, pycnidial, solitory to gregarious, globose, partly caespitose, central ostiole, terete, shortly papillate. Conidiomata wall thick-walled, several layers, composed of red brown, smooth cells of textura globulosa to textura angularis. Conidiogenous cells formed by inner cells of the pycnidial wall, doliiform, annellidic thin-walled, hyaline. Conidiophores reduced to conidiogenous cells. Conidia ellipsoidal, clavate, pyroid, straight to slightly curved, yellowish not brown, basal cell paler or hyaline, muriform, 1 longitudinal septum or diagonal septum per cell, 1-2 per conidium, golden wall. Synasexual morph: conidiomata pycnidial, immersed to superficial, separate, brown, globose, 1-2 papillate ostioles, exuding a crystalline conidial mass. Conidiophores reduced to conidiogenous cells. Conidiogenous cells laying on inner cavity, smooth, hyaline, ampulliform. Conidia solitary, subcylindrical, straight, rarely curved, apex obtuse, base truncate, hyaline, smooth-walled.

Type - Camarosporium Schulzer, Verh. K.K.

Notes - Camarosporiaceae was validated to accommodate Camarosporium and Camarosporomyces by Wanasinghe et al. (2017a). This is a well-supported family in Pleosporineae sister to Leptosphaeriaceae in phylogenetic analyses (Wanasinghe et al. 2017a). See Crous \& Groenewald (2017) and Wanasinghe et al. (2017a) for more details.

Camarosporium Schulzer, Verh. K.K. Zool.-Bot. Ges. Wien 17: 717. 1870.

Index Fungorum number: IF 7476; Facesoffungi number: FoF 00405; 261 morphological species (Species Fungorum 2020), 2 species with molecular data.

Type species - Camarosporium quaternatum (Hazsl.) Schulzer.

三 Clinterium quaternatum Hazsl., Verh. zool.-bot. Ges. Wien 15: 451 (1865).

Notes - Camarosporium quaternatum was introduced by Schulzer (1870) with a karstenulalike sexual morph and phoma-like synasexual morph (Crous \& Groenewald 2017). This is the type species of Camarosporium. Schulzer (1870) did not provide illustrations for C. quaternatum but, he mentioned it has close affinity to Clinterium lycii, described by Hazslinszky (1865). Because the type material of $C$. quaternatum has been lost, the original illustrations are described in most recent study by Crous \& Groenewald (2017) from lectotypes to facilitate epitypification (Wanasinghe et al. 2017a). Camarosporium resembles Camarographium, Camarosporiopsis, Camarosporula, 
Dichomera,

Didymellocamarosporium,

Hazslinszkyomyces,

Libertasomyces, Magnicamarosporium, Melanocamarosporium, Melnikia, Murilentithecium, Neocamarosporium, Paracamarosporium, Phragmocamarosporium, Pseudocamarosporium, Pseudohendersonia, Suttonomyces and Xenocamarosporium by conidial shape and the septation. However, these taxa are phylogenetically distinct and have subtle but specific morphological differences (Crous \& Groenewald 2017, Wanasinghe et al. 2017a).

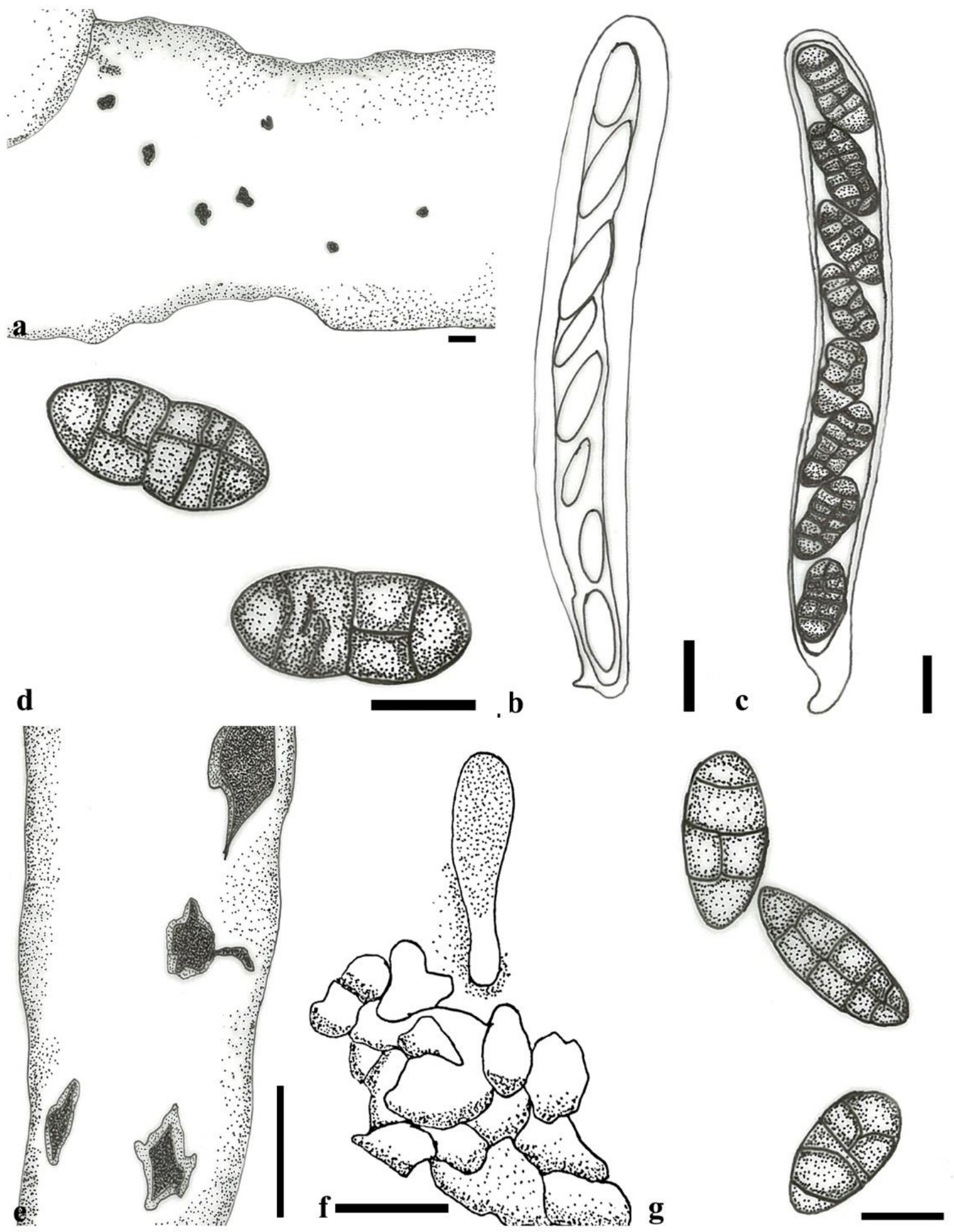

Figure 58 - Camarosporium quaternatum (redrawn from Crous \& Groenewald 2017). a Immersed ascomata on twig. b, c Immature to mature asci d Ascospores e Conidiomata on twig. $\mathrm{f}$ Conidiogenous cells giving rise to Camarosporium conidia. g Conidia. Scale bars: $\mathrm{a}-\mathrm{d}=200 \mu \mathrm{m}, \mathrm{e}=800 \mu \mathrm{m}, \mathrm{f}, \mathrm{g}=10 \mu \mathrm{m}$. 


\section{Other genera included}

Camarosporomyces Crous, IMA Fungus 8: 141 (2017).

Index Fungorum number: IF 820901; Facesoffungi number: FoF 08168; 1 morphological species (Species Fungorum 2020), 1 species with molecular data.

Type species - Camarosporomyces flavigenus (Constant. \& Aa) Crous, in Crous \& Groenewald, IMA Fungus 8(1): 142 (2017).

$\equiv$ Phoma flavigena Constant. \& Aa, Trans. Br. mycol. Soc. 79(2): 343 (1982).

Notes - Camarosporomyces was introduced by Crous \& Groenewald (2017) to accommodate Camarosporomyces flavigenus, a phoma-like fungus which was originally described as Phoma flavigena (Wanasinghe et al. 2017a). Phylogenetically it is closely related to Camarosporium.

\section{Ecological and economic significance}

Some Camarosporium species have been reported as plant pathogens which are distributed worldwide (Wanasinghe et al. 2017a). Camarosporium pistaciae is a common pathogen causing blight of the shoots and panicles in pistachio production in Greece (Assimakopoulou \& Elena 2010, Wanasinghe et al. 2017a). In Europe, Smith et al. (1988) listed C. dalmaticum, C. flaccidum, C. pistaciae, and $C$. strobilinum as plant pathogens. Camarosporium species are reported as causing damage in the cut-flower industry in the USA (Taylor et al. 2001, Wanasinghe et al. 2017a). They are reported as common pathogens of deciduous trees in Europe. Also, C. pini induces severe infection that can result in significant growth reduction to pine plantations (Ivanová \& Bernadovičová 2010, Wanasinghe et al. 2017a).

Camarosporidiellaceae Wanas., Wijayaw., Crous \&amp; K.D. Hyde, Stud. Mycol. 87: 216 (2017). Index Fungorum number: IF 821939; Facesoffungi number: FoF 03528, 23 species.

Saprobic or endophytic or pathogenic on leaves and wood in terrestrial habitats. Sexual morph: Ascomata gregarious to solitary, immersed to erumpent, globose to subglobose, black, unilocular, ostiolate. Ostiole black, papillate. Peridium with several cell layers of textura angularis, with outer layer brown to reddish-brown, inner layer hyaline to sub hyaline. Hamathecium cellular pseudoparaphyses. Asci pedicellate, cylindrical, bitunicate, (2-)4-8-spored. Ascospores 1-seriate, ellipsoidal, mostly with obtuse ends, medium brown, muriform, 3-8 transverse septa, with 1-2 longitudinal septa, constricted at septa. Asexual morph: Coelomycetous. Conidiomata pycnidial, immersed to sub-peridermal, globose, dark brown to black, unilocular. Conidiomata wall thickwalled, dark brown, composed of cells of textura angularis, inner layer with hyaline cells. Ostiole single, circular, central, papillate. Conidiogenous cells enteroblastic, annellidic, integrated to discrete, doliiform, lageniform or cylindrical, smooth, hyaline, formed from the inner cells of the pycnidial wall. Conidia variable in shape, mostly ellipsoidal, curved to straight, truncate at the base, obtuse at the apex, medium brown to dark brown, phragmosporous to muriform, continuous or constricted at the septa.

Type - Camarosporidiella Wanas., Wijayaw., K.D. Hyde.

Notes - Wanasinghe et al. (2017a) introduced Camarosporidiellaceae to accommodate Camarosporidiella which forms a highly-supported monophyletic lineage within the Pleosporineae and phylogenetically distinct from other families in this suborder. Mostly these fungi are saprobic and sometimes can be endophytic or pathogenic or potential opportunistic pathogens on leaves and woody materials. The species in this family are characterized by their gregarious to solitary, globose to subglobose ascomata that having a papillate, central ostiole, peridium containing cell layers of textura angularis, cylindrical, (2-)4-8-spored asci with 1-seriate, ellipsoidal, brown, muriform ascospores is their sexual stage. Their coelomycetous asexual morph is characterized by comprising pycnidial conidiomata, with papillate single ostiole, enteroblastic, annellidic, integrated to discrete, doliiform, lageniform or cylindrical, hyaline conidiogenous cells, pale to dark brown conidia that are phragmosporous to muriform and mostly ellipsoidal. Determinations of Camarosporidiellaceae spp. based solely on morphological data is insufficient for designating new species because of their lack of phenotypic variability. The current understand of ecological and pathogenic aspects of this group is too superficial and extensive sampling should be carried out in 
different regions and hosts. Pathogenetic virulence of this family should be further investigated with more taxon sampling and DNA based sequence analyses.

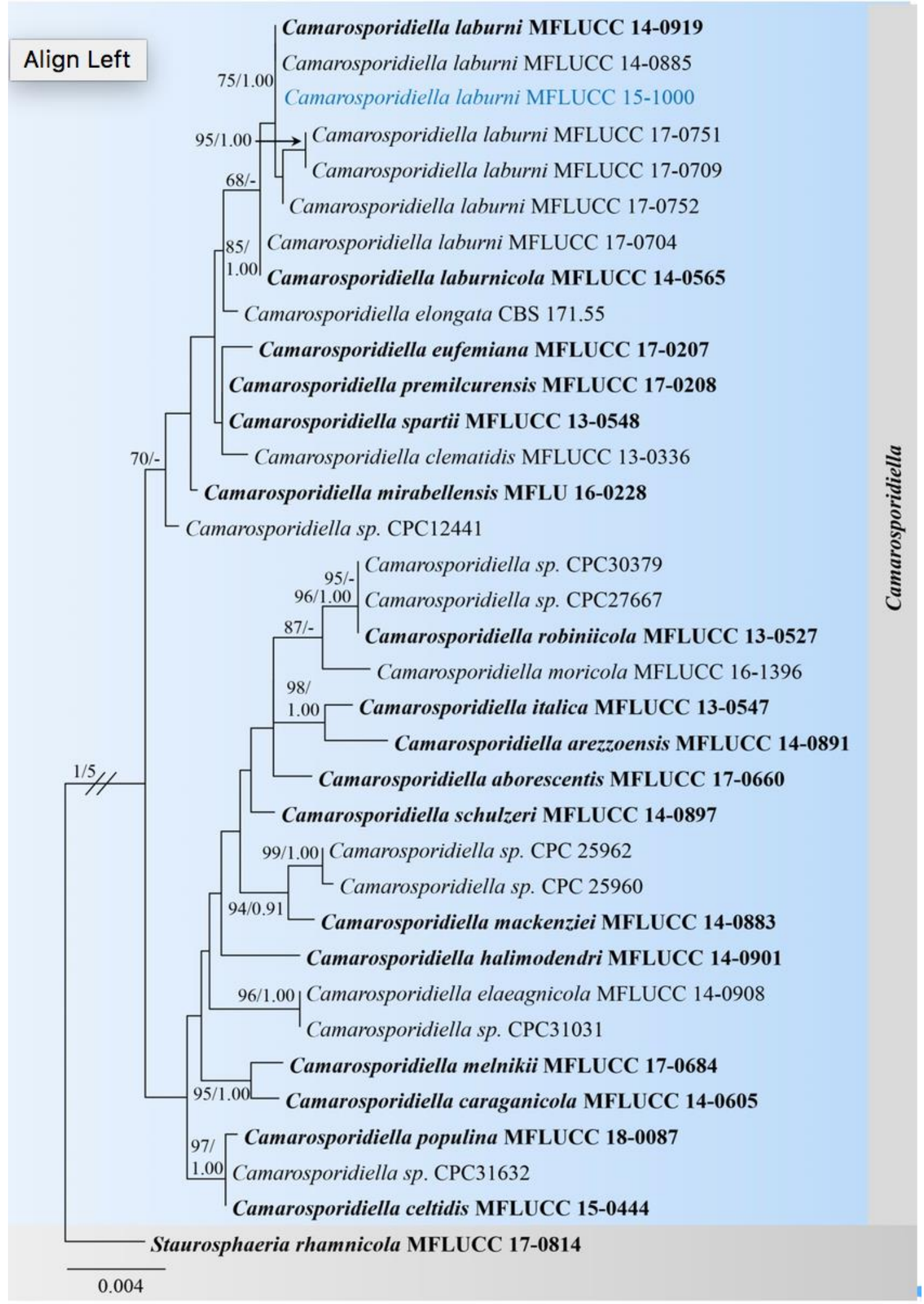

Figure 59 - Phylogram generated from maximum likelihood analysis (RAxML) of Camarosporidiellaceae based on ITS, LSU, SSU, and tef1 sequence data. Maximum likelihood bootstrap values equal or above $70 \%$, Bayesian posterior probabilities equal or above 0.90 (MLBS/PP) are given at the nodes. Isolate/specimen number is noted after the species name. The tree is rooted to Staurosphaeria rhamnicola (MFLUCC 17-0814). The ex-type strains are indicated 
in bold. Newly sequence is in blue. Hyphen (-) represents support values below $70 \%$ MLBS and $0.90 \mathrm{PP}$.

Camarosporidiella Wanas., Wijayaw., K.D. Hyde, Studies in Mycology 87: 216 (2017).

Index Fungorum number: IF 821940; Facesoffungi number: FoF 03529; 23 morphological species (Species Fungorum 2020), several species with molecular data.

Type species - Camarosporidiella caraganicola (Phukhams., Bulgakov \& K.D. Hyde) Phukhams., Wanas. \& K.D. Hyde, Stud. Mycol. 87: 220 (2017).

$\equiv$ Camarosporium caraganicola Phukhams., Bulgakov \& K.D. Hyde, in Liu et al., Fungal Diversity 72: 156 (2015).

Notes - Camarosporidiella was established by Wanasinghe et al. (2017a) with $C$. caraganicola as the type species. Wanasinghe et al. (2017a) accepted 20 species in this genus based on morphological and multi-gene phylogenetic indications. Hyde et al. $(2018,2019)$ added Camarosporidiella populina and $C$. mori which were collected from Russia. Species of Camarosporidiella are less-diverse and distributed throughout a broad range of environments especially in Northern Hemisphere. Camarosporidiella species are saprobes, endophytes or pathogens of a wide range of hosts (Wanasinghe et al. 2017a). Species identification based solely on morphology and plant host association is difficult since many species have overlapping characters. The genus is similar to other camarosporium-like genera and distinguishing these genera can be problematic (Wanasinghe et al. 2017a). LSU is useful for preliminary identification at the generic level. It is recommended to use a combination of ITS, LSU, SSU, and tef1 (Wanasinghe et al. 2017a).
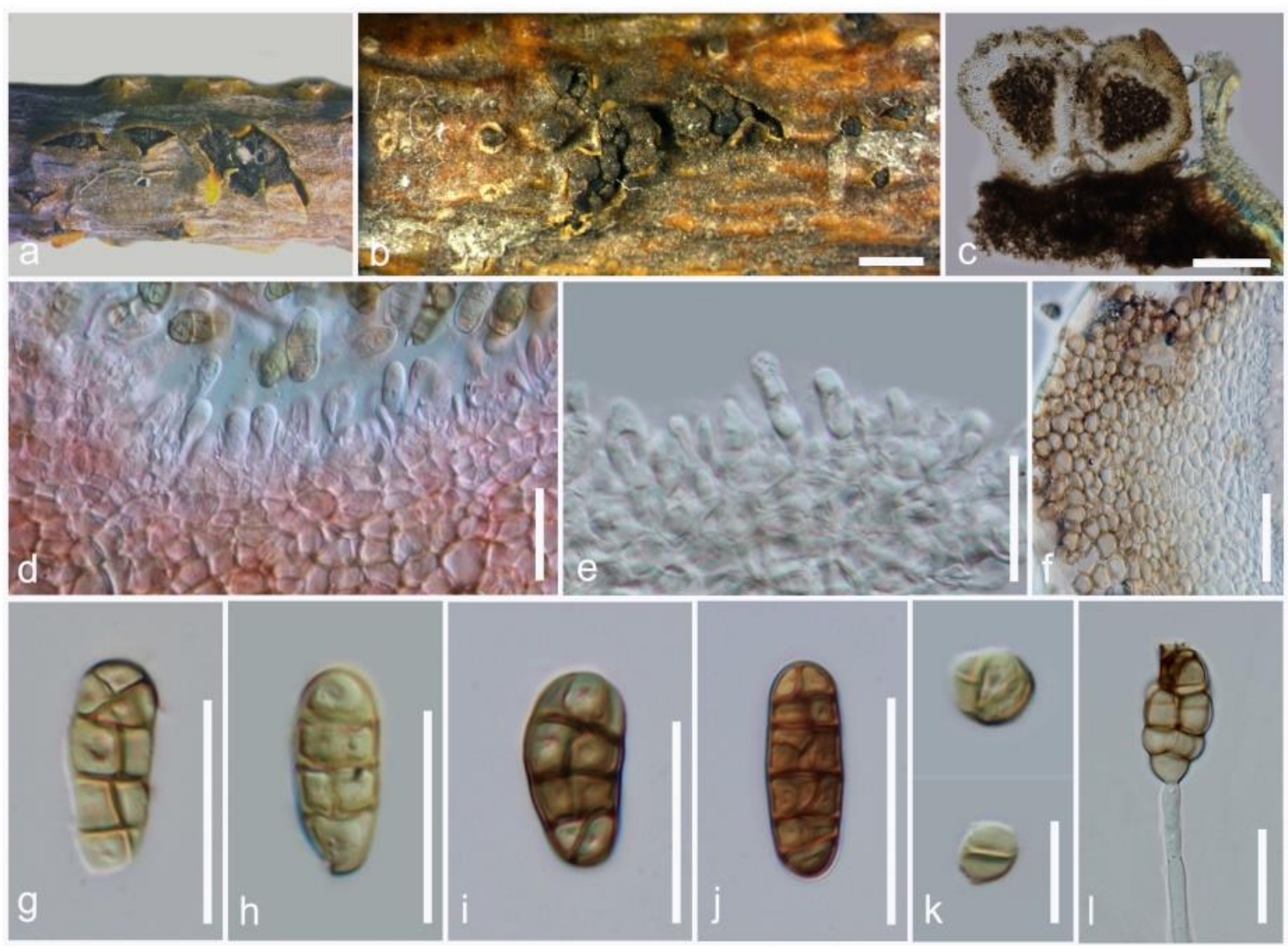

Figure 60 - Camarosporidiella laburni (MFLU 15-2116). a Herbarium specimen. b Conidiomata on the host substrate. c Section through conidimata. $d$, e Conidia attached to conidiogenous cells. $f$ Section through conidiomatal wall. $\mathrm{g}-\mathrm{k}$ Conidia (k upper view). 1 Germinating conidia. Scale bars: $\mathrm{b}=1 \mathrm{~mm}, \mathrm{c}=200 \mu \mathrm{m}, \mathrm{d}=100 \mu \mathrm{m}, \mathrm{g}=50 \mu \mathrm{m}, \mathrm{e}, \mathrm{f}, \mathrm{h}-\mathrm{k}=20 \mu \mathrm{m}, \mathrm{m}=20 \mu \mathrm{m}, \mathrm{l}=10 \mu \mathrm{m}$. 
Camarosporidiella laburni (Pers.) Wanas., Bulgakov, Camporesi \& K.D. Hyde, Stud. Mycol. 87: 233 (2017).

三Sphaeria laburni Pers., Observ. mycol. (Lipsiae) 1: 68 (1796).

Fig. 60

Index Fungorum number: IF 821952; Facesoffungi number: FoF 03540.

Saprobic Sexual morph: Undetermined. Asexual morph: Conidiomata pycnidial, 340-435 $\mu \mathrm{m}$ high, $300-430 \mu \mathrm{m}$ diam. $(\bar{x}=398 \times 313 \mu \mathrm{m}, \mathrm{n}=10)$, solitary or gregarious, black, immersed, sometimes scattered beneath the host periderm or on decorticated wood, fully or partly erumpent, unilocular, with a papillate ostiolate. Ostiole central, ostiolar canal filled with hyaline or pale brown cells. Conidiomatal wall multi-layered, 37-95 $\mu \mathrm{m}$ wide, thick, comprising 10-15 layers, outer layers heavily pigmented, thin-walled, comprising blackish to dark reddish-brown cells of textura angularis, cells towards the inside lighter, inner layer composed of 6-8 layers of hyaline, thikwalled cells of textura angularis. Conidiophores $2.6-7.8 \times 1.3-2.5 \mu \mathrm{m}(\bar{x}=4.6 \times 1.8 \mu \mathrm{m}, \mathrm{n}=20)$ reduced to conidiogenous cells. Conidiogenous cells enteroblastic, annellidic, doliiform, integrated, solitary, hyaline, smooth-walled, and immerged from the inner layer of pycnidium wall. Conidia 13-22 $\times 6-11 \mu \mathrm{m}(\bar{x}=18 \times 7.7 \mu \mathrm{m}, \mathrm{n}=20)$, oval, straight to slightly curved, rounded at both ends, pale brown to brown, muriform, 4-5-transverse septate, with 1-2-longitudinal septa per each cell, smooth-walled.

Material examined - Russia, Rostov region, Rostov-on-Don city, territory of Southern Federal University, parkland, on dead branches (with signs of necrosis) of Caragana arborescens Lam. (Fabaceae), 23 April 2015, Timur S. Bulgakov, T-412 (MFLU 15-2116); living culture MFLUCC 15-1000.

Notes - Our new isolate (MFLUCC 15-1000) clustered within other Camarosporidiella laburni strains in the phylogenetic tree (Fig. 59). Differences of two bases were noted in the ITS region between our new isolate and the ex-type (MFLUCC 14-019). The new collection is similar to the holotype of C. laburni (Wanasinghe et al. 2017a). By considering the morphological and molecular data we designate our new collection as $C$. laburni, which is the first record from Caragana arborescens.

\section{Ecological and economic significance}

They are important to the cycling of carbon and nutrients during the decomposition of organic matter especially in freshwater habitats. Sometimes can be endophytic or pathogenic or potential opportunistic pathogens on leaves and woody materials of commercially valuable crops.

Caryosporaceae Huang Zhang, K.D. Hyde \& Ariyaw., Fungal Divers., 75: 54 (2015).

Index Fungorum number: IF 551417; Facesoffungi number: FoF 00957, 10 species.

Saprobic on submerged wood in freshwater or mangrove habitats or on decaying terrestrial seeds. Sexual morph: Ascomata pseudothecial, erumpent, superficial, hemisphaerical, large, dark brown to black, carbonaceous, ostiolate, solitary or clustered. Ostiole central, circular, brown to black. Peridium thick, carbonized, dark brown, composed of rectangular, often occluded cells. Hamathecium comprising numerous, narrow (less than $1 \mu \mathrm{m}$ wide), hyaline, trabeculate, anastomosing pseudoparaphyses, embedded in a gelatinous matrix. Asci 8-spored, bitunicate, broadly cylindrical to clavate, pedicellate, with an ocular chamber. Ascospores 1-3-seriate, relatively large, broad-fusiform, ovoid or ellipsoidal, hyaline when young, hyaline or brown when mature, 1-(-3)-septate, constricted at the central septa, ends often papillate, often with polar germ pores at each end, with relatively thick-walled, smooth-walled, with or without a mucilaginous sheath (adapted from Ariyawansa et al. 2015a). Asexual morph: Undetermined.

Type - Caryospora De Not.

Notes - Caryosporaceae was established by Ariyawansa et al. (2015a), typified by Caryospora. Caryosporaceae is characterized by erumpent, large and hemisphaerical ascomata and the structure of its ascomata is similar to Astrosphaeriella and Trematosphaeria. The ascospores are broadly fusiform, with relatively thick walls in Caryospora, while elongate-fusiform and thinwalled in Astrosphaeriella and fusoid and thin-walled in Trematosphaeria (Boise 1985a, Hyde \& Fröhlich 1998, Liu et al. 2011). Acrocordiopsis was also placed into this family (Ariyawansa et al. 
2015a). However, the type species of Acrocordiopsis, A. patilii, formed a sister clade with Astrosphaeriella and Astrosphaeriellopsis in Astrosphaeriellaceae (Zhang et al. 2018). The phylogenetic relationship between Caryospora and Acrocordiopsis are not stable as sister groups (Zhang et al. 2018). Further research is needed to resolve their relationship.

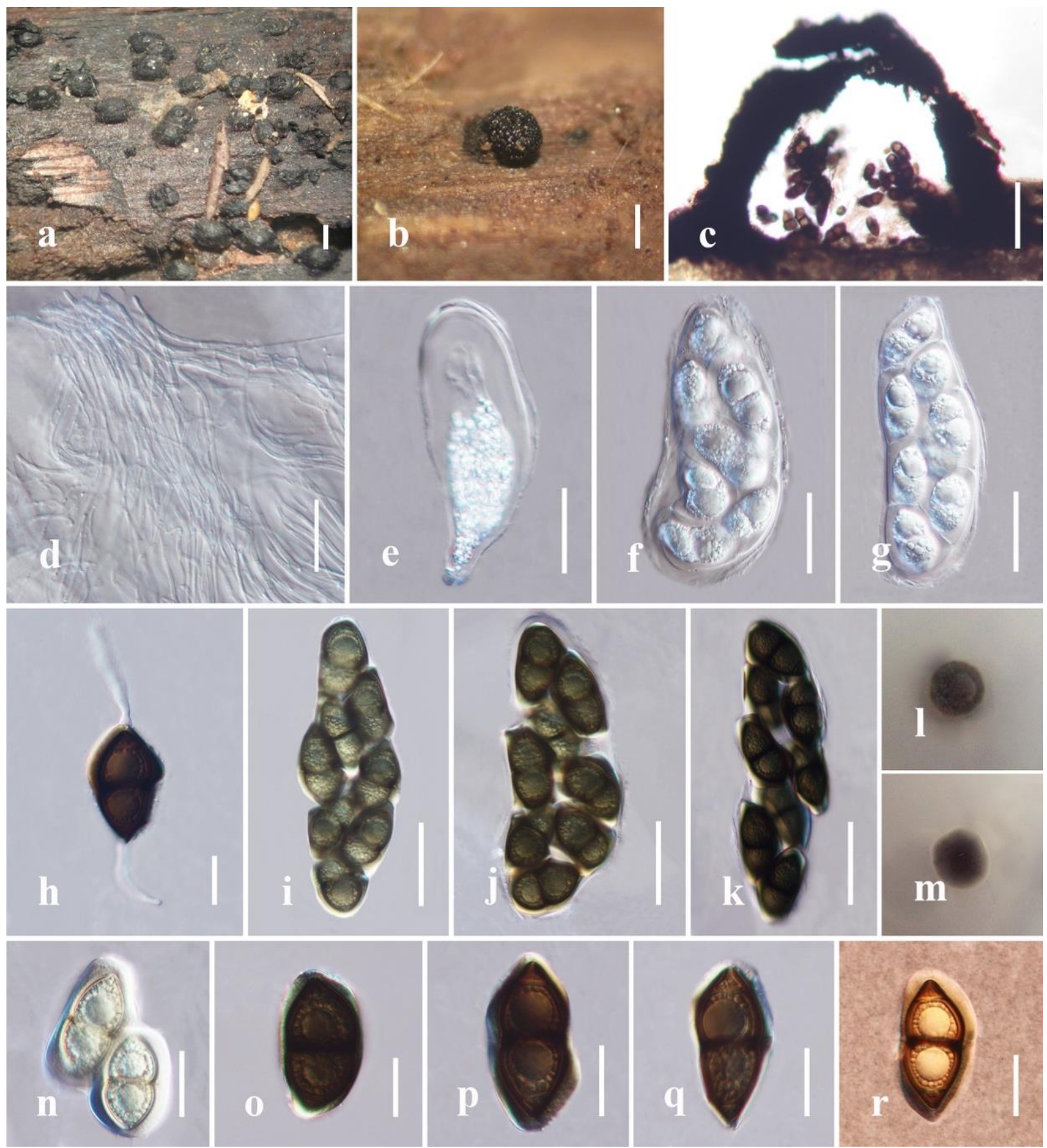

Figure 61 - Caryospora aquatica (MFLU 11-1083, holotype). a Ascomata on submerged wood. b Ascomata with mass of ascospores. c Section of an ascomata. d Hamathecium. e-g Immature asci. h A germinated ascospore. i-k Asci. 1. Colony on PDA (from front). m Colony on PDA (from reverse). $\mathrm{n}$ Immature ascospores. o- $\mathrm{q}$ Mature ascospores. $\mathrm{r}$ Ascospores stained with Indian ink. Scale bars: $\mathrm{a}-\mathrm{b}=200 \mu \mathrm{m}, \mathrm{c}=100 \mu \mathrm{m}, \mathrm{d}=5 \mu \mathrm{m}, \mathrm{e}-\mathrm{g}, \mathrm{i}-\mathrm{j}=50 \mu \mathrm{m}, \mathrm{h}, \mathrm{o}-\mathrm{r}=20 \mu \mathrm{m}, \mathrm{n}=30 \mu \mathrm{m}$.

Caryospora De Not., Micr. Ital. Nov. 9: 7 (1855).

Index Fungorum number: IF 831; Facesoffungi number: FoF 08169; 10 morphological species (Species Fungorum 2020), 3 species with molecular data. 
Type species - Caryospora putaminum (Schwein.) De Not., Micr. Ital., Dec. 9: 7 (1855) De Not., Micr. Ital. Nov. 9: 7 (1855).

三Sphaeria putaminum Schwein., Schr. naturf. Ges. Leipzig 1: 43 [17 of repr.] (1822).

Notes - Caryospora was introduced by De Notaris (1855), and typified by Caryospora putaminum. Earlier, Caryospora was placed in Phaeophragmiae based on its terminal septa (Jeffers 1940), and later Hyde et al. (2013) placed it in Zopfiaceae. Based on the morphology and phylogenetic analyses, Caryospora was transferred to the newly-established family Caryosporaceae by Ariyawansa et al. (2015a). The species of this genus are collected from terrestrial and aquatic habitats (Abdel-Wahab et al. 2000, Raja \& Shearer 2008, Ariyawansa et al. 2015a). Thirteen species have been reported in this genus (Barr 1979b, Hawksworth 1982, Raja \& Shearer 2008, Hawksworth et al. 2010, Hu 2010), but only three have been sequenced (Ariyawansa et al. 2015a, Jayasiri et al. 2019).

Caryospora aquatica Huang Zhang, K.D. Hyde \& Ariyaw., in Ariyawansa et al., Fungal Divers., 75:54 (2015).

Fig. 61

Index Fungorum number: IF 551418; Facesoffungi number: FoF 00958.

Description - see Ariyawansa et al. (2015a).

Material examined - Thailand, Chiang Rai Province, Hui Kang Pla Waterfall, on submerged wood, 18 January 2010, Huang Zhang (MFLU 11-1083, holotype).

\section{Ecological and economic significance}

There are 13 species in Caryosporaceae, collected from multifarious substrates, such as decaying stems, seeds in terrestrial habitats and on driftwood in freshwater habitats (Jeffers 1940, Abdel-Wahab et al. 2000, Raja et al. 2008, Ariyawansa et al. 2015a). Caryospora putaminum was regarded as an appropriate item for anatomical, cytological studies because of its large ascospores and perithecia (Jeffers 1940).

Coniothyriaceae W.B. Cooke, Revta Biol., Lisb. 12: 289 (1983) [1980-1983].

Index Fungorum number: IF 80635; Facesoffungi number: FoF 08170, 464 species.

Pathogenic (Necrotrophic, leaf spot) or saprobic or saprobic on dead branches, Sexual morph: cucurbitaria-like. Ascomata black, superficial to semi-immersed, gregarious, confluent, sometimes scattered beneath the host periderm or on decorticated wood, fully or partly erumpent, globose, black, ostiolate. Ostiole central, short. Peridium composed of blackish to dark brown cells of textura angularis, cells towards the inside lighter, composed of thin-walled cells of textura angularis. Hamathecium comprising numerous, branched septate, cellular pseudoparaphyses. Asci 8-spored, bitunicate, fissitunicate, cylindrical, short pedicellate. Ascospores overlapping 1-seriate, muriform, mostly ellipsoidal, initially hyaline, becoming brown at maturity, slightly paler, conical and narrow at the ends, 4-6-transversely septate, with 1-2 vertical septa, constricted at middle septum. Asexual morph: Conidiomata pycnidial, separate, immersed, globose, dark or pale brown, uni-locular, thin-walled. Peridium brown, thick-walled cells of textura angularis or globulosa. Ostiole central, circular, sometimes papillate. Conidiophores reduced to conidiogenous cells lining the inner cavity. Macroconidiogenous cells hyaline, smooth, doliiform, proliferating percurrently at apex, Macroconidia solitary, ellipsoid, red-brown, with central transverse septum, becoming muriformly septate, smooth-walled. Microconidial cells intermingled with macroconidial cells, hyaline, integrated, proliferating percurrently at apex, subcylindrical. Microconidia globose to ellipsoid, hyaline, aseptate, smooth-walled.

Type - Coniothyrium Corda.

Notes - The family was introduced to accommodate Coniothyrium spp. Later Coniothyriaceae was synonymized to Leptosphaeriaceae by Kirk et al. (2008). Coniothyriaceae was reinstated in Pleosporales as de Gruyter et al. (2013) revealed the distinct phylogenetic relationship between Coniothyrium palmarum and Leptosphaeriaceae. Further de Gruyter et al. (2013) transferred some Phoma spp. to Coniothyrium as they claded in Coniothyriaceae. Hence $C$. minitans and C. sporulosum claded in Montagnulaceae, the two species were included in the new 
genus Paraconiothyrium by Verkley et al. (2004b). Cortinas et al. (2004) showed that Coniothyrium zuluense was accommodated in Mycosphaerellaceae. Cortinas et al. (2006) and Crous et al. (2009b) suggested that $C$. zuluense is well-accommodated in Colletogloeopsis (Phaeosphaeriaceae). Quaedvlieg et al. (2014) reported Colletogloeopsis under Teratosphaeriaceae.

Coniothyrium Corda, Icon. fung. (Prague) 4: 38 (1840).

Index Fungorum number: IF 7765; Facesoffungi number: FoF 08171; 451 morphological species (Species Fungoum 2020), 6 species with molecular data.

Type species - Coniothyrium palmarum Corda, Icon. fung. (Prague) 4: 38 (1840).

Notes - Coniothyrium was considered to be the asexual morph of Leptosphaeria, Mycosphaerella and Massarina (Sivanesan 1984). However, many species were removed from Coniothyrium and included in other genera or upgraded to generic level (Verkley et al. 2004b, 2014, Cortinas et al. 2006). De Gruyter et al. (2013) reinstated Coniothyriaceae (Coniothyrium as family type), which was synonymized under Leptosphaeriaceae (Kirk et al. 2008).

Coniothyrium eucalypticola B. Sutton, Mycol. Pap. 123: 34 (1971).

Fig. 62

Index Fungorum number: IF 311632; Facesoffungi number: FoF 08172.

Description - see Sutton (1980).
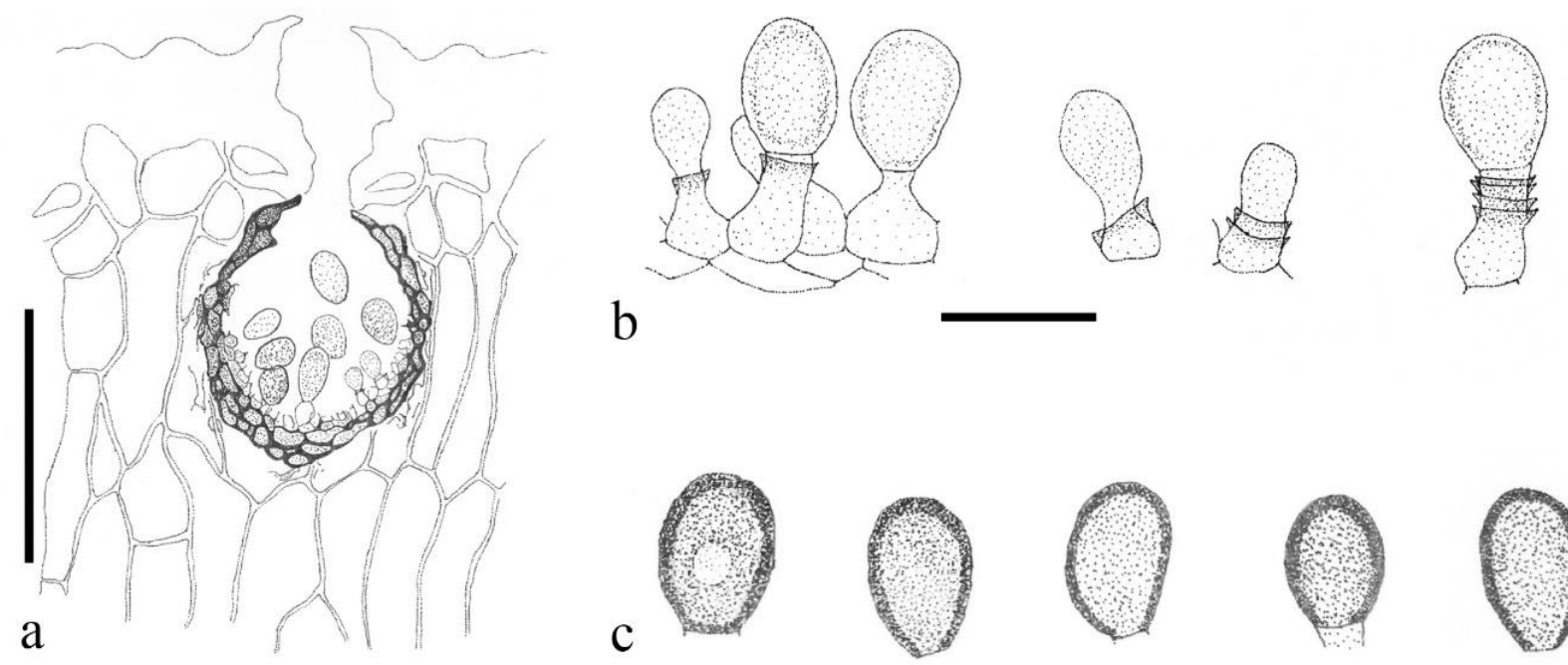

c
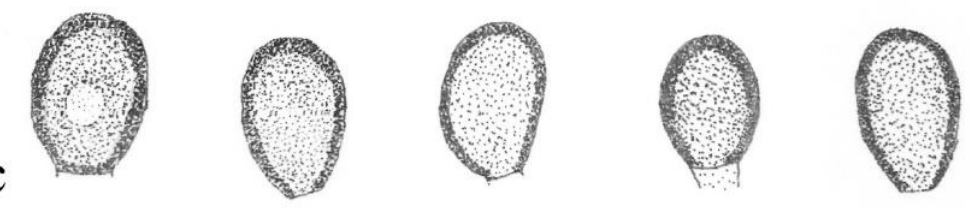

Figure 62 - Coniothyrium eucalypticola (redrawn from Sutton 1980). a vertical section of a conidioma. $\mathrm{b}$ conidiogenous cells. $\mathrm{c}$ conidia. Scale bars: $\mathrm{a}, \mathrm{b}=10 \mu \mathrm{m}$.

\section{Other genera included}

Foliophoma Crous, IMA Fungus 8(1): 142 (2017).

Index Fungorum number: IF 820903; Facesoffungi number: FoF 08173; 2 morphological species (Species Fungorum 2020), 2 species with molecular data.

Type species - Foliophoma fallens (Sacc.) Crous, IMA Fungus 8(1): 142 (2017).

$\equiv$ Phoma fallens Sacc., Syll. fung. (Abellini) 10: 146 (1892).

Notes - Foliophoma was typified with Foliophoma fallens from leaf spot on Nerium oleander (Apocynaceae). Foliophoma is different from phoma-like taxa with eustromatic conidiomata, unito multilocular with 1-3 ostioles and conidiogenous sells with periclinal thickening and apically proliferating. Phoma fallens and $P$. glaucispora are associated with leaf spots and phylogenetically closely related. Hence, they were treated as a single species in Pleospora. Foliophoma fallens was not congeneric with Pleospora herbarum and hence the new genus was introduced.

Neoconiothyrium Crous, Persoonia 39: 379 (2017). 
Index Fungorum number: IF 823385; Facesoffungi number: FoF 08174; 4 morphological species (Species Fungorum 2020), 4 species with molecular data.

Type species - Neoconiothyrium persooniae Crous, Persoonia 39: 379 (2017).

Notes - Crous et al. (2017) revealed Neoconiothyrium as a new genus. Lacking conidiomata and covered in setae and medium brown, finely verruculose, ellipsoid to subclavate, aseptate, becoming cylindrical and at times 1-septate, apex subobtuse, base bluntly rounded conidia make Neoconiothyrium different from Coniothyrium hakeae.

Ochrocladosporium Crous \& U. Braun, Mycol. 58: 46 (2007).

Index Fungorum number: IF 504437; Facesoffungi number: FoF 08175; 3 morphological species (Species Fungorum 2020), 3 species with molecular data.

Type species - Ochrocladosporium elatum (Harz) Crous \& U. Braun, Stud. Mycol. 58: 46 (2007).

三 Hormodendrum elatum Harz, Bull. Soc. Imp. nat. Moscou 44(1): 140 (1871).

Notes - Ochrocladosporium was introduced by Crous et al. (2007b) as genus incertae sedis in Pleosporales. Morphological details of this hyphomycetous genus can bee seen in Crous et al. (2007b). Phylogenetic study by Valenzuela-Lopez et al. (2018) revealed that Ochrocladosporium forms a stable clade within Coniothyriaceae. Wjayawardene et al. (2018) followed this and included Ochrocladosporium in Coniothyriaceae.

Staurosphaeria Rabenh., Klotzschii Herb. Viv. Mycol., Edn Nov, Ser. Sec., Cent. 8: no. 736 (1858) Index Fungorum number: IF 5186; Facesoffungi number: FoF 08176; 4 morphological species (Species Fungorum 2020), 4 species with molecular data.

Type species - Staurosphaeria lycii Rabenh., Klotzschii Herb. Viv. Mycol., Edn Nov, Ser. Sec., Cent. 8: no. 736 (1858).

Notes - Staurosphaeria and Karstenula were assumed to be congeneric in Montagnulaceae. Later the type $K$. rhodostoma was linked to the asexual morph of Microdiplodia frangulae. Staurosphaeria is characterized by red-brown conidia, developing a transverse septum, and later vertical septa, dividing the conidium into four compartments, which is distinct from Camarosporium sensu stricto in that conidia in the latter are unevenly pigmented (pale brown at ends), and multi-septate. Hence, by considering the morphological and phylogenetic support Staurosphaeria was included under Coniothyriaceae by Wanasinghe et al. (2017a).

\section{Ecological and economic significance}

Coniothyrium species are recorded as plant pathogenic on Eucaliptus sp. worldwide. They cause lesions (Coniothyrium eucalypticola), necrotic leaf spots (C. parvum), and leafspots in young leaves (C. ovatum) (Sutton 1975b, 1980).

Corynesporascaceae Sivan., Mycological Research 100: 786 (1996).

= Corynesporaceae Locq., Mycol. gén. struct. (Paris): 207 (1984) Nom. inval., Art. 39.1 (Melbourne).

Index Fungorum number: IF 81981; Facesoffungi number: FoF 06661, 175 species.

Pathogenic and saprobic on leaves. Sexual morph: Ascomata lacking ostioles (cleistothecioid), sphaerical, solitary or aggregated, superficial or immersed in the agar. Peridium thin-walled, composed of brown cells of textura globosa or angularis. Hamathecium comprising paraphysoids. Asci obovoid, initially relatively thick-walled, bitunicate, deliquescent, 8-spored, arising from a hymenium and fasciculate among deliquescent paraphysoids. Ascospores 2-3seriate, pale to dark brown, smooth-walled, 1-euseptate close to the center and indistinctly more or less 1-distoseptate in the upper and lower cell, constricted at the mid-euseptum, often asymmetric, with an indistinct transverse, hyaline area at or near the middle of the somewhat longer basal cell, with three lenticular to globose, granular lumena (adapted from Sivanesan 1996). Asexual morph: Conidiophores macronematous, mononematous, solitary or in groups, straight to flexuous, subhyaline to pale brown, smooth, cylindrical, thick-walled. Conidiogenous cells monotretric, 
integrated, terminal, percurrently proliferating, cylindrical, pale brown to median brown. Conidia solitary or catenate, obclavate, sometimes with a rostrate apex, subhyaline to brown, straight to curved, septate or distoseptate.

Type - Corynesporasca Sivan.

Notes - Corynesporascaceae was established by Sivanesan (1996) based on Corynesporasca Sivan. It was initially referred to Melanommatales sensu Barr based on the morphology (Sivanesan 1996). Corynesporascaceae was accepted as a member of Pleosporales in a revision of Dothideomycetes (Hyde et al. 2013), and this treatment was followed by Wijayawardene et al. (2014b) in the outline of Dothideomycetes. In a comprehensive phylogenetic study of Dothideomycetes performed by Liu et al. (2017a), Corynesporascaceae formed a basal clade to Massarineae and Pleosporineae in Pleosporales. Species of Corynesporascaceae can cause foliar diseases in plants, predominating in the tropics and subtropics (Stone \& Jones 1960, Dixon et al. 2009, Hyde et al. 2013).

a

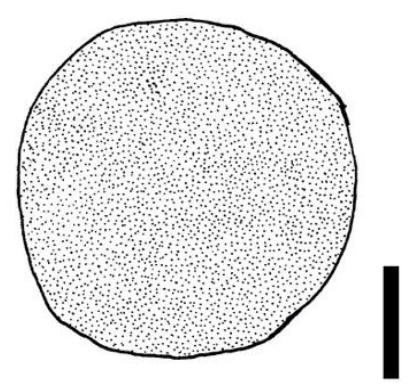

C
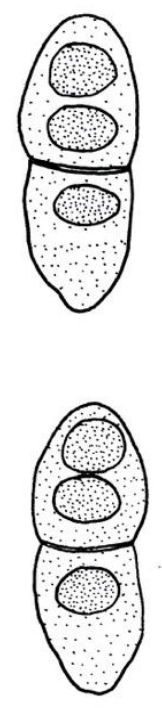

b

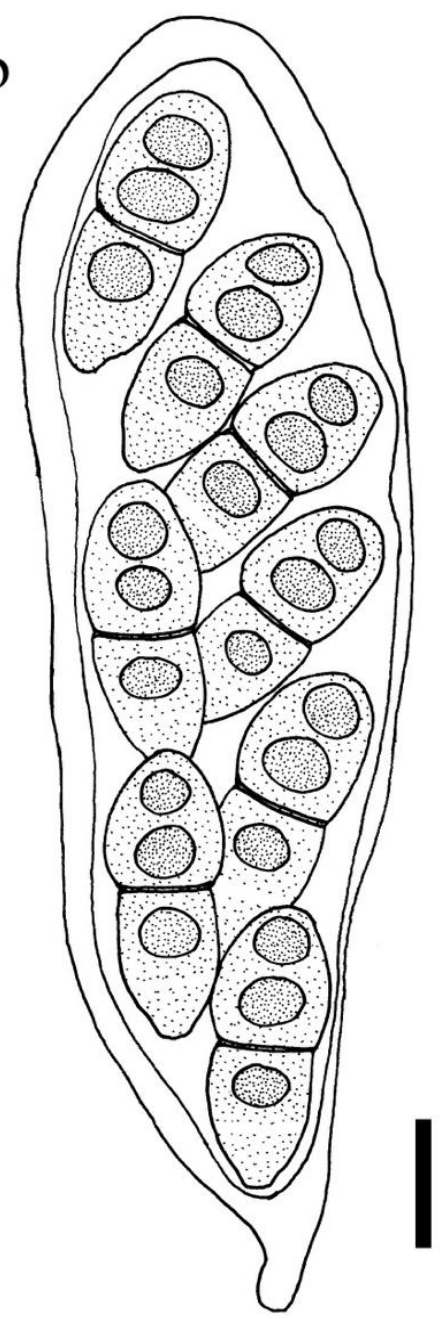

Figure 63 - Corynesporasca caryotae (redrawn from Sivanesan 1996 and Hyde et al. 2013). a Ascoma. b Asci. c Ascospores. Scale bars: $\mathrm{a}=100 \mu \mathrm{m}, \mathrm{b}, \mathrm{c}=20 \mu \mathrm{m}$.

Corynesporasca Sivan., Mycol. Res. 100(7): 786 (1996).

Index Fungorum number: IF 27579; Facesoffungi number: FoF 06662; 1 morphological species (Hyde et al.2013), molecular data unavailable.

Type species - Corynesporasca caryotae Sivan.

Notes - The monotypic genus Corynesporasca was introduced by Sivanesan (1996) to accommodate Co. caryotae. It is characterized by cleistothecioid ascomata, bitunicate and 8-spored asci and oblong, 3-septate ascospores mostly with a supramedian primary septum (Sivanesan 
1996). Sivanesan (1996) linked Corynesporasca with an unnamed Corynespora asexual morph based on culture studies. However, Hyde et al. (2013) did not synonymize Corynesporasca under Corynespora, as Corynespora was shown to be polyphyletic (Tanaka et al. 2005c, 2015, Schoch et al. 2009a, Voglmayr \& Jaklitsch 2017). The type species of Corynespora and Corynesporasca (Corynespora cassiicola and Corynesporasca caryotae) may be unrelated (Hyde et al. 2013). Moreover, Corynespora-like asexual morphs have been shown in many genera (Seifert et al. 2011). Although Corynesporasca was treated as a synonym of Corynespora in several studies (Rossman et al. 2015, Wijayawardene et al. 2017a, 2018), we choose to follow Hyde et al. (2013) and suggest Corynespora and Corynesporasca are distinct genera until molecular data of the type species are available. The phylogenetic relationships of these two genera need to be further revealed.

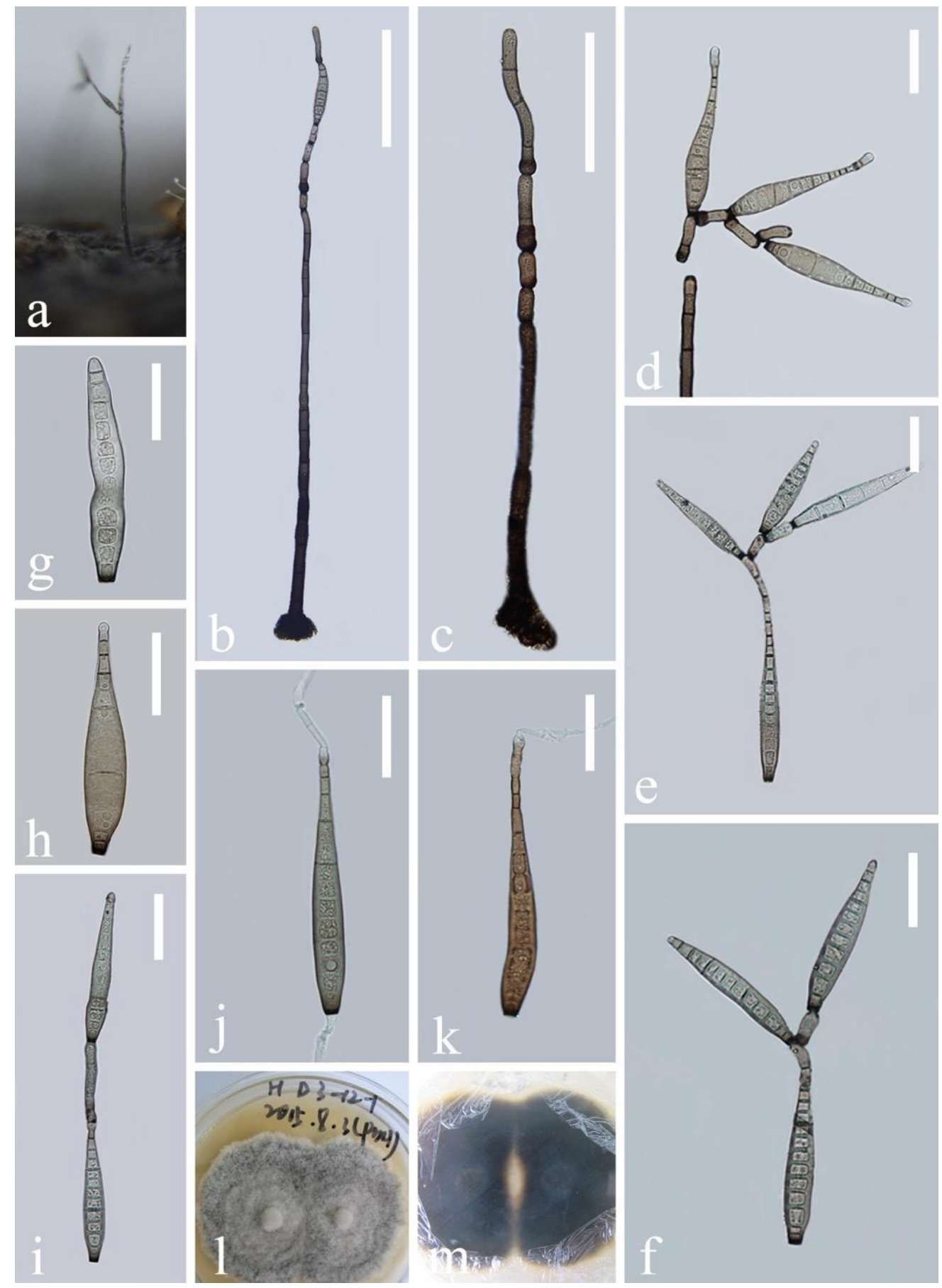

Figure 64 - Corynespora sp. (HKAS 92703) a Fruiting body on natural substrate. $\mathrm{b}, \mathrm{c}$ Conidiophores and conidium. d Conidiogenous cells and conidia. e- $\mathrm{i}$ Conidia. j, k Germinated conidia. $1, \mathrm{~m}$ Colonies on PDA. Scale bars: $\mathrm{b}, \mathrm{c}=100 \mu \mathrm{m}, \mathrm{d}-\mathrm{k}=50 \mu \mathrm{m}$. 


\section{Other genus included}

Corynespora Güssow, Zeitschrift für Pflanzenkrankheiten und Pflanzenschutz 16: 10 (1906).

Index Fungorum number: IF 7795; Facesoffungi number: FoF 06663; 175 morphological species (Species Fungorum 2020), 10 species with molecular data.

Type species - Corynespora cassiicola (Berk. \& M.A. Curtis) C.T. Wei, Mycol. Pap. 34: 5 (1950).

$\equiv$ Helminthosporium cassiicola Berk. \& M.A. Curtis [as 'cassiaecola'], in Berkeley, J. Linn. Soc., Bot. 10(no. 46): 361 (1868) [1869].

= Corynespora mazei Güssow, Zeitschrift für Pflanzenkrankheiten und Pflanzenschutz 16: 13 (1906).

Notes - The type species of Corynespora is an important pathogenic fungus which can cause target spot worldwide (Koenning et al. 2006, Schlub et al. 2009, Fulmer et al. 2012). This genus has been revealed as polyphyletic in several molecular studies (Crous et al. 2015d, Hyde et al. 2016, Voglmayr \& Jaklitsch 2017). Voglmayr \& Jaklitsch (2017) revisited three similar genera, Corynespora, Exosporium and Helminthosporium. Some Corynespora species, for example, $C$. caespitosa, C. endiandrae, C. leucadendri and C. olivacea were transferred to Helminthosporium. Although Voglmayr \& Jaklitsch (2017) placed Corynespora in Corynesporascaceae, they did not mention the relationship between Corynespora and Corynesporasca. There are few DNA sequence data of Corynespora species available in GenBank for phylogenetic purposes and hence more collections and sequence data are needed.

\section{Ecological and economic significance}

Corynesporascaceae species have diverse lifestyles, ranging from saprotrophs to necrotrophs and to biotrophs (Kumar et al. 2012), which may indicate they have important role in the ecosystem. Many Corynespora species are saprobic or pathogenic on plant leaves, mainly causing leaf spots. A detailed study of Corynespora species would be helpful for plant protection.

Cryptocoryneaceae A. Hashim. \& Kaz. Tanaka, Persoonia 39: 56 (2017).

Index Fungorum number: IF 819237; Facesoffungi number: FoF 08177, 16 species.

Saprobic on various plants. Sexual morph: Undetermined. Asexual morph: Conidiomata sporodochial, pulvinate, often confluent, dark brown to black. Conidiophores arising from stromatic cells, simple, septate, hyaline to pale brown. Conidiogenous cells monoblastic, cylindrical to oblong, terminal, determinate, hyaline to pale brown. Conidia solitary, acrogenous, branched, cheiroid, with dark brown to black cap cells firmly united together, multi-armed; basal cells brown, cuneiform, smooth, thin-walled; arms developed downward from the cap cells, cylindrical, multiseptate, branched at base, pale brown, smooth (Schoknecht \& Crane 1977, Hashimoto et al. 2016, 2017b).

Type - Cryptocoryneum Fuckel.

Notes - Species in Cryptocoryneum showed a close relationship with Lophiotremataceae (Hashimoto et al. 2016). Hashimoto et al. (2017b) introduced a new family Cryptocoryneaceae to accommodate Cryptocoryneum lineage that is phylogenetically distinct from Lophiotremataceae.

Cryptocoryneum Fuckel, Jb. nassau. Ver. Naturk. 23-24: 372 (1870) [1869-70].

Index Fungorum number: IF 7827; Facesoffungi number: FoF 08178; 16 morphological species (Species Fungorum 2020), 8 species with molecular data.

Type species - Cryptocoryneum fasciculatum Fuckel.

Notes - The sexual morph of this genus has not been determined. A recent key to species was provided by Hashimoto et al. (2017b).

\section{Cryptocoryneum sp.}

Saprobic on dead and unfallen twigs of Corylus avellana L. Sexual morph: Undetermined. Asexual morph: Sporodochia pulvinate, $259-385 \times 50-100 \mu \mathrm{m}(\bar{x}=307.3 \mu \mathrm{m} \times 70.3 \mu \mathrm{m}, \mathrm{n}=10)$ $\mu \mathrm{m}$, often confluent, dark brown to black. Conidiophores arising from stromatic cells, straight, 
septate, pale brown to hyaline. Conidiogenous cells 4.2-6.9 $\times 4.7-7 \mu \mathrm{m}(\bar{x}=5.4 \mu \mathrm{m} \times 5.5 \mu \mathrm{m}, \mathrm{n}=$ 13) monoblastic, cylindrical to oblong, determinate, terminal, pale brown to hyaline. Conidia solitary, acrogenous, cheiroid, pale brown, cap cells firmly united together, 3-12 cylindrical arms, branched at the base, basal cells cuneiform, cylindrical, smooth, dark brown, 10-20-septate, slightly constricted at the septa, guttulate in each cell, 57-81 $\times 3.5-4.5 \mu \mathrm{m}(\bar{x}=74.5 \times 3.8 \mu \mathrm{m}, \mathrm{n}=$ 25).

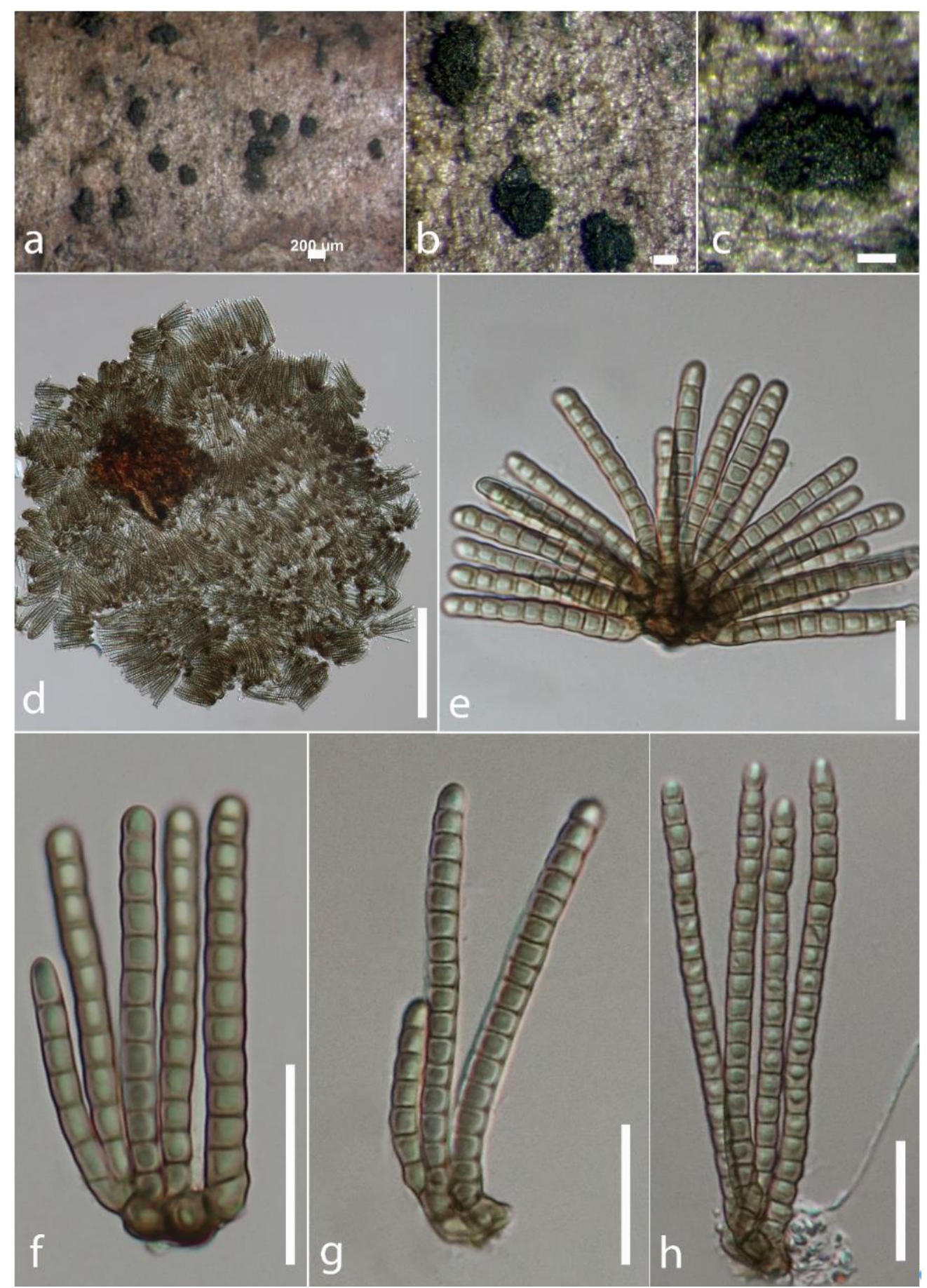

Figure 65 - Cryptocoryneum sp. (MFLU 19-0442). a-c Sporodochium on a dead and land branch of Corylus avellana d Sporodochium. e- $\mathrm{h}$ Development of conidia. Scale bars: $\mathrm{a}=200 \mu \mathrm{m}, \mathrm{b}-\mathrm{d}=$ $100 \mu \mathrm{m}, \mathrm{e}-\mathrm{g}, \mathrm{h}=20 \mu \mathrm{m}, \mathrm{f}=10 \mu \mathrm{m}$.

Material examined - Italy, lives on a dead and unfallen branch of Corylus avellana (Betulaceae), 21 January 2019, Erio Camporesi, IT2737 (MFLU 19-0442). 
Notes - Cryptocoryneum is an asexual genus characterized by stromatic sporodochia, monoblastic conidiogenous cells, cheiroid conidia and conidial arms developing downward from the cap cells. However, we were unable to obtain sequence data from this specimen. Therefore, only morphology is provided here (Fig. 65).

\section{Ecological and economic significance}

Species in Cryptocoryneaceae occur in various plants and play roles as recycling organic matter.

Cucurbitariaceae G. Winter [as 'Cucurbitarieae'], Rabenh. Krypt.-Fl., Edn 2 (Leipzig) 1.2: 308 (1885).

Index Fungorum number: IF 80667; Facesoffungi number: IF 08179, 181 species.

Necrotrophic or saprobic on woody plants or parasitic on other fungi. Sexual morph: Ascomata immersed, semi-immersed, becoming erumpent, to nearly superficial, scattered, or clustered on basal hypostroma, base not easy to remove from the substrate, usually containing host particles, globose to subglobose, turbinate, lenticular or pyriform, brown to black, surface verruculose to coarsely tubercular ostiolate. Ostiole black, inconspicuous or papillate to cylindrical, ostiolar canal filled with hyaline cells or sometimes periphysate. Peridium composed of several layers of textura angularis cells, light brown to reddish-brown, smooth to rough, or hairy. Hamathecium comprising dense, filiform, hyaline, filamentous, septate, cellular pseudoparaphyses. Asci 8-spored, bitunicate, fissitunicate, cylindrical to clavate, with furcate pedicel and minute ocular chamber. Ascospores 1-seriate, or partially overlapping, ellipsoidal, golden brown to dark brown, multi-septate, muriform, constricted at the septa, rarely with a gelatinous sheath, sometimes with appendage cells. Asexual morph: Coelomycetous, phoma- or pyrenochaeta-like (Hyde et al. 2013, Wanasinghe et al. 2017d, Jaklitsch et al. 2018a).

Type - Cucurbitaria Gray

Notes - Cucurbitariaceae is a well-supported monophyletic family in Pleosporales (Doilom et al. 2013, Hyde et al. 2013, Wijayawardene et al. 2014b, Li et al. 2016a). The family was introduced by Winter (1885) and typified by Cucurbitaria berberidis. Intergeneric classification based on phenotypes within Cucurbitariaceae has often been controversial. For example, Barr (1987b) considered 'turbinate or globose or ovoid ascomata, with warted or nearly smooth surfaces, cylindrical or slightly clavate or oblong asci, symmetric and ellipsoid or fusoid or asymmetric and oblong or elongate ascospores' as general features of Cucurbitariaceae and considered the family to belong in Pleosporales. Considering the above phenotypic features, genera such as Cucurbitaria, Cucurbidothis, Otthia, Rhytidiella and Syncarpella were also included in the family (Wanasinghe et al. 2017d). Later phylogenetic studies have shown that Cucurbitariaceae is a heterogeneous group and recent studies have excluded some genera from this family and referred other genera to the family (Hyde et al. 2013, Doilom et al. 2013, Wanasinghe et al. 2017d, Valenzuela-Lopez et al. 2018).

Doilom et al. (2013) revisited Cucurbitariaceae based on DNA sequence data, examination of type species and links to asexual morphs. They epitypified Cucurbitaria berberidis with molecular data and a pyrenochaeta-like asexual morph, illustrated Curreya, Rhytidiella and Syncarpella from their holotypes and discussed their familial affinities. Hyde et al. (2013) also provided a comprehensive transcript to this family with illustrations. Wijayawardene et al. (2014b) included Cucurbidothis, Cucurbitaria, Curreya, Pyrenochaeta, Pyrenochaetopsis, Rhytidiella and Syncarpella as conventional genera in Cucurbitariaceae. However, Cucurbitariaceae members comprise many epithets in Index Fungorum (Doilom et al. 2013) and only a few species have DNA sequence data in GenBank. Thambugala et al. (2015b) introduced a new genus, Neocurreya for Curreya austroafricana, C. grandicipis and C. proteae in Floricolaceae (Pleosporales) based on evidence from morphology and phylogeny. The placement of the type species of Curreya, $C$. conorum is unclear as the latter has not been cultured and there is no DNA sequence data in databases to verify its phylogenetic affinities. Fenestella is relatively poorly studied and the type species of the genus could not be located. Therefore, Phookamsak \& Hyde (2015) revisited 
Fenestellaceae and transferred Lojkania to Testudinaceae, maintaining Fenestella in Fenestellaceae. Wanasinghe et al. (2017) introduced two new taxa which are typical of Fenestella viz. F. ostryae and F. mackenziei. Phylogenetically, these strains shared a close phylogenetic affinity to $F$. fenestrata within Cucurbitariaceae. Thus, with their updated phylogeny where Fenestellaceae was nested in between Cucurbitariaceae and with insufficient morphological grounds to support Fenestellaceae as an independent family, they proposed Fenestella to be transferred to Cucurbitariaceae and Fenestellaceae be synonymized with Cucurbitariaceae.

Jaklitsch et al. (2018a) provided a comprehensive account for Cucurbitariaceae including multi-gene (ITS, LSU, rpb-2, SSU, tef1 and tub2) phylogenetic analyses. They recognised two new species in Cucurbitaria and 19 in Neocucurbitaria (which was introduced by Wanasinghe et al. 2017d). Astragalicola, Cucitella, Parafenestella, Protofenestella, and Seltsamia were described as new genera. Also, they reported that Fenestella should be restricted to the type species $F$. fenestrata. In addition, they have transferred $F$. mackenziei and $F$. ostryae to Parafenestella based on their lack of molecular support with Fenestella and the absence of a well-delimited pseudostromata and ascospore septation. Jaklitsch \& Voglmayr (2020) re-evaluated the boundaries and species composition of Fenestella and related genera of the Cucurbitariaceae. They recognised eight species, of which five are new, in Fenestella, 13 in Parafenestella with eight new species and two in the new genus Synfenestella with one new species.

Cucurbitaria Gray, Nat. Arr. Brit. Pl. (London) 1: 508, 519 (1821).

Index Fungorum number: IF 1348; Facesoffungi number: FoF 08180; 95 morphological species (Species Fungorum 2020), 7 species with molecular data.

Type species - Cucurbitaria berberidis (Pers.) Gray, Nat. Arr. Brit. Pl. (London) 1: 519 (1821).

ESphaeria berberidis Pers., Neues Mag. Bot. 1: 83 (1794).

Notes - Cucurbitaria was described by Gray (1821) and C. berberidis is considered the type of the genus which is usually regarded as saprotrophic or necrotrophic. Cucurbitaria is one of the oldest pyrenomycete genera with a long taxonomic debate. There are over 460 epithets listed in Index Fungorum (2020) including 34 infraspecific taxa, of which at least 340 do not belong to Cucurbitariaceae (Jaklitsch et al. 2017). To date there is DNA sequence data for only a few species, and the validity of taxonomic concepts and other species remaining uncertain. Recent studies have proven that some of these taxa do not belong to Cucurbitaria and group in other families. Jaklitsch \& Voglmayr (2017) demonstrated that species such as C. obducens, C. piceae (both producing muriform ascospores) and $C$. rhododendri (with phragmospores), belong to three different genera of Melanommataceae. Wanasinghe et al. (2017a) revealed that some of the cucurbitaria-like species belong to Camarosporidiellaceae, i.e. Cucurbitaria celtidis, C. elongata, and C. laburni.

Cucurbitaria oromediterranea Jaklitsch \& Voglmayr, in Jaklitsch, Checa, Blanco, Olariaga, Tello \& Voglmayr, Stud. Mycol. 90: 80 (2017).

Fig. 66

Index Fungorum number: IF 822999; Facesoffungi number: FoF 08181.

Description - see Jaklitsch et al. (2018a).

\section{Other genera included}

Allocucurbitaria Valenz.-Lopez, Stchigel, Guarro \& Cano, Stud. Mycol. 90: 51 (2017).

Index Fungorum number: IF 821455; Facesoffungi number: FoF 08182; 1 morphological species (Species Fungorum 2020), 1 species with molecular data.

Type species - Allocucurbitaria botulispora Valenz.-Lopez, Stchigel, Guarro \& Cano, Stud. Mycol. 90: 52 (2017).

Notes - Valenzuela-Lopez et al. (2018) introduced Allocucurbitaria as a monospecific genus that is more similar to phoma-like taxa (with glabrous pycnidia) than to species of pyrenochaetalike taxa (because of its setose conidiomata). In phylogenetic analysis, this genus groups within Cucurbitariaceae (Fig. 67). 

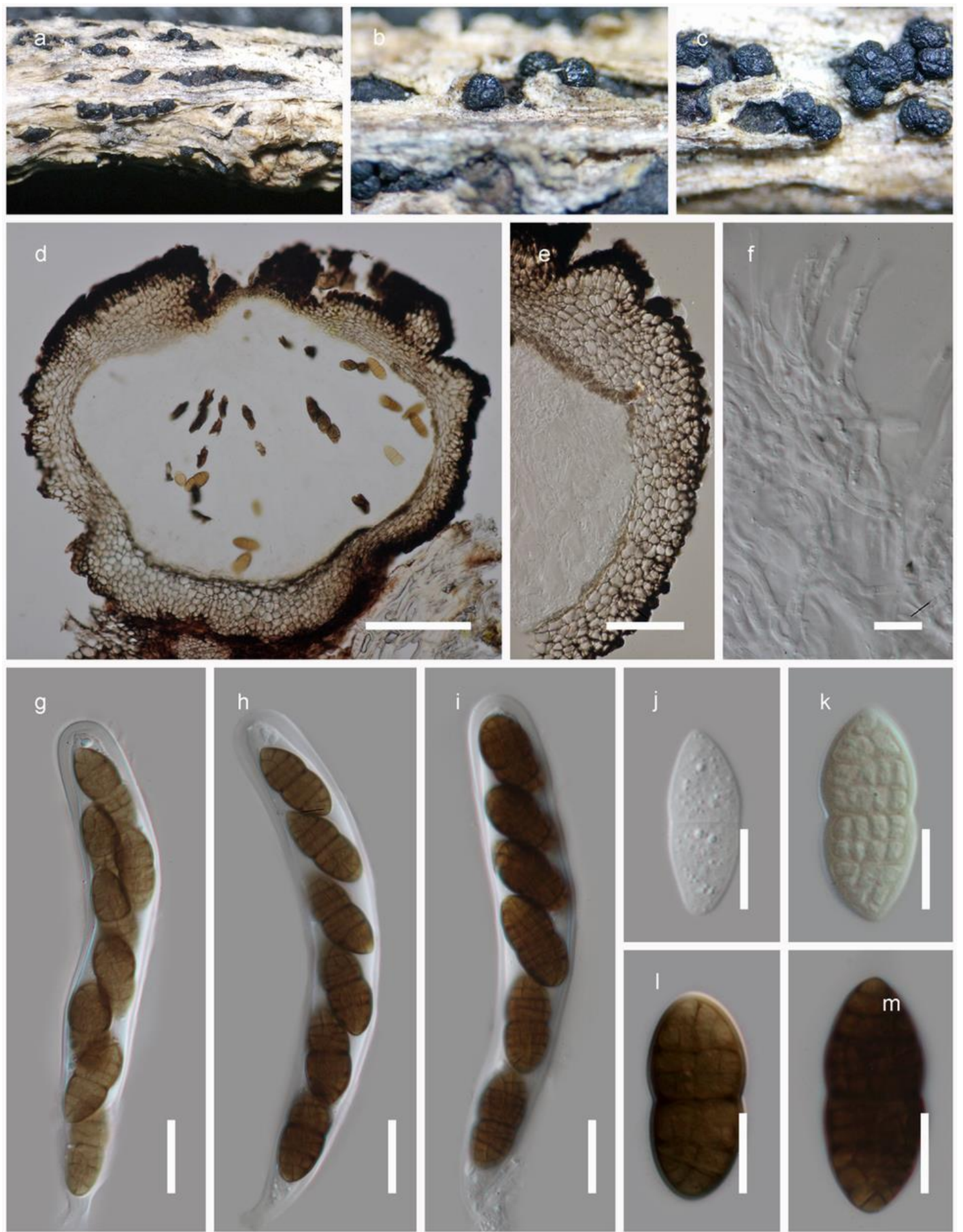

Figure 66 - Cucurbitaria oromediterranea (MFLU 19-0718). a-c Appearance of ascomata on host substrate. d Section of ascoma. e Peridium. f Pseudoparaphyses. g-i Asci. j-m Ascospores. Scale bars: $\mathrm{d}=100 \mu \mathrm{m}, \mathrm{e}=50 \mu \mathrm{m}, \mathrm{f}, \mathrm{j}-\mathrm{m}=10 \mu \mathrm{m}, \mathrm{g}, \mathrm{h}=20 \mu \mathrm{m}$.

Astragalicola Jaklitsch \& Voglmayr, Stud. Mycol. 90: 82 (2018).

Index Fungorum number: IF 823000; Facesoffungi number: FoF 08183; 2 morphological species (Species Fungorum 2020), 2 species with molecular data.

Type species - Astragalicola amorpha Jaklitsch \& Voglmayr, Stud. Mycol. 90: 82 (2017).

Notes - Astragalicola was introduced by Jaklitsch et al. (2018a) to accommodate $A$. amorpha, which differs from Phoma by conidiophores and from Pyrenochaeta by the lack of setae. Wanasinghe et al. (2018c) introduced Astragalicola vasilyevae as the second species of the genus. 
Astragalicola vasilyevae and A. amorpha are known from their sexual morph and asexual morph, respectively (Wanasinghe et al. 2018c).

Cucitella Jaklitsch \& Voglmayr, Studies in Mycology 90: 83 (2017).

Index Fungorum number: IF 823002; Facesoffungi number: FoF 08184; 1 morphological species (Species Fungorum 2020), 1 species with molecular data.

Type species - Cucitella opali Jaklitsch \& Voglmayr, Studies in Mycology 90: 83 (2017).

Notes - Jaklitsch et al. (2018a) introduced Cucitella to accommodate C. opali which was collected from France on Acer opalus. This is similar to Fenestella and Parafenestella by its ascospores with a relatively large number of septa and lighter ends, but they are phylogenetically apart (Jaklitsch et al. 2018a).

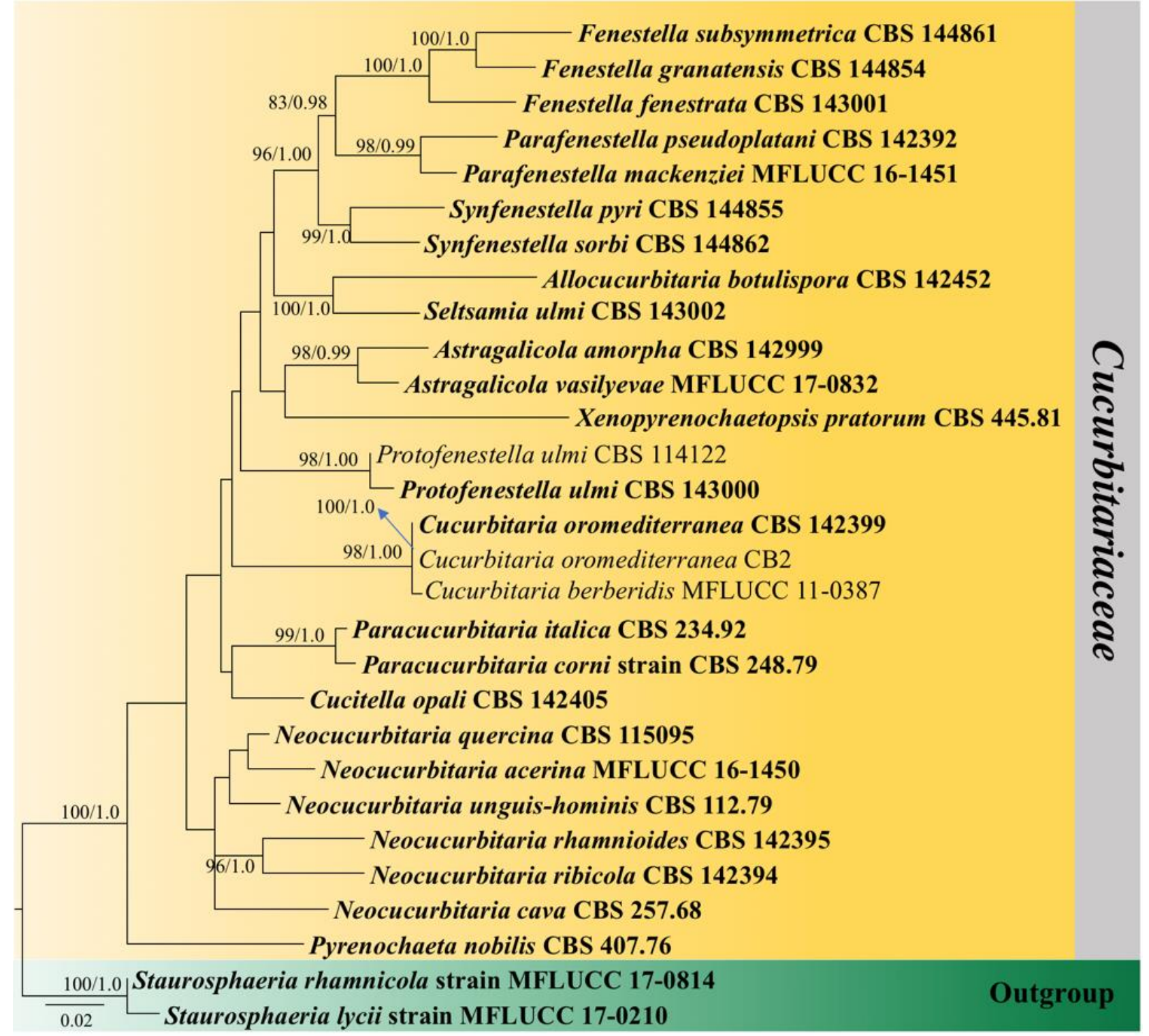

Figure 67 - Phylogram generated from maximum likelihood analysis (RAxML) of genera in Cucurbitariaceae based on ITS, LSU, rpb-2, SSU, tef1, and tub2 sequence data. Maximum likelihood bootstrap values equal or above $70 \%$, Bayesian posterior probabilities equal or above 0.90 (MLBS/PP) are given at the nodes. An original isolate number is noted after the species name. The tree is rooted to Staurosphaeria lycii (MFLUCC 17-0210) and S. rhamnicola (MFLUCC 170814). The ex-type strains are indicated in bold. Hyphen (-) represents support values below $70 \%$ MLBS and 0.90 PP. 
Fenestella Tul. \& C. Tul., Select. fung. carpol. (Paris) 2: 207 (1863).

Index Fungorum number: IF 1983; Facesoffungi number: FoF 00576; 28 morphological species (Species Fungorum 2020), 8 species with molecular data.

Type species - Fenestella princeps Tul. \& C. Tul., Select. fung. carpol. (Paris) 2: 207 (1863).

Notes - Fenestella was introduced by Tulasne \& Tulasne (1863), typified by F. princeps. Phookamsak \& Hyde (2015) maintained the monotypic genus Fenestella in Fenestellaceae due to the lack of a modern taxonomic description of the genus and limited molecular data. Wanasinghe et al. (2017d) introduced two new taxa to $F$. ostryae (Parafenestella ostryae) and $F$. mackenziei (Parafenestella faberi). With the morphological and molecular evidence, they transferred Fenestella to Cucurbitariaceae and Fenestellaceae was synonymized under Cucurbitariaceae. See Jaklitsch \& Voglmayr (2020) for most updated details. Pleurostromella is treated as an asexual morph of Fenestella, thus it is reduced to a synonym of Fenestella.

Neocucurbitaria Wanas., E.B.G. Jones \& K.D. Hyde, Mycosphere 8(3): 408 (2017).

Index Fungorum number: IF 552832; Facesoffungi number: FoF 02902; 22 morphological species (Species Fungorum 2020), 22 species with molecular data.

Type species - Neocucurbitaria unguis-hominis (Punith. \& M.P. English) Wanas., E.B.G. Jones \& K.D. Hyde, Mycosphere 8(3): 412 (2017).

三 Pyrenochaeta unguis-hominis Punith. \& M.P. English, Trans. Br. mycol. Soc. 64(3): 539 (1975).

Notes - Wanasinghe et al. (2017d) introduced Neocucurbitaria to accommodate $N$. acerina, $N$. unguis-hominis (syn. Pyrenochaeta unguis-hominis, the type species of that genus) and $N$. quercina (syn. Pyrenochaeta quercina). This is a well-established genus in Cucurbitariaceae with 22 species, all have DNA sequence data for molecular comparisons.

Paracucurbitaria Valenz.-Lopez, Stchigel, Guarro \& Cano, Stud. Mycol. 90: 49 (2017).

Index Fungorum number: IF 821453; Facesoffungi number: FoF 08185; 2 morphological species (Species Fungorum 2020), 2 species with molecular data.

Type species - Paracucurbitaria corni (Bat. \& A.F. Vital) Valenz.-Lopez, Stchigel, Guarro \& Cano, Stud. Mycol. 90: 50 (2017).

三Plenodomus corni Bat. \& A.F. Vital, Anais Soc. Biol. Pernambuco 15(2): 420 (1957)

Notes - Valenzuela-Lopez et al. (2018) introduced Paracucurbitaria to accommodate $P$. corni and $P$. italica. These two species are phylogenetically monophyletic. However, $P$. corni differs by its ornamented conidiomata while $P$. italica has a glabrous conidiomata. See ValenzuelaLopez et al. (2018) for further details.

Parafenestella Jaklitsch \& Voglmayr, Stud. Mycol. 90: 108 (2017).

Index Fungorum number: IF 823014; Facesoffungi number: FoF 08186; 15 morphological species (Species Fungorum 2020), 15 species with molecular data. (2017).

Type species - Parafenestella pseudoplatani Jaklitsch \& Voglmayr, Stud. Mycol. 90: 109

Notes - Jaklitsch et al. (2018a) introduced Parafenestella with P. pseudoplatani as the type species. They also transferred F. mackenziei and F. ostryae to Parafenestella based on their lack of molecular support with Fenestella and the absence of a well-delimited pseudostromata and ascospore septation. See Jaklitsch \& Voglmayr (2020) for more most updated details.

Protofenestella Jaklitsch \& Voglmayr, Stud. Mycol. 90: 109 (2017).

Index Fungorum number: IF 823018; Facesoffungi number: FoF 08187; 1 morphological species (Species Fungorum 2020), 1 species with molecular data.

Type species - Protofenestella ulmi Jaklitsch \& Voglmayr, Stud. Mycol. 90: 111 (2017).

Notes - Jaklitsch et al. (2018a) introduced Protofenestella with P. ulmi as the type species. Ascospore morphology of Protofenestella ulmi is similar to Fenestella. However, it differs from Fenestella in that ascomata do not form defined clusters (Jaklitsch et al. 2018a). 
Rhytidiella Zalasky, Can. J. Bot. 46(11): 1383 (1968).

Index Fungorum number: IF 4741; Facesoffungi number: FoF 08188; 4 morphological species (Species Fungorum 2020), molecular data unavailable.

Type species - Rhytidiella moriformis Zalasky, Can. J. Bot. 46(11): 1383 (1968).

Notes - Rhytidiella was introduced by (Zalasky 1968) based on R. moriformis, which causes perennial rough-bark of Populus balsamifera (Zhang et al. 2012b). Barr (1987b) temporarily assigned Rhytidiella to Cucurbitariaceae. In the revision of Cucurbitariaceae by Doilom et al. (2013), the authors accepted Rhytidiella as a member in the family. Wijayawardene et al. (2018) likewise kept Rhytidiella as a member of Cucurbitariaceae. However, there are no DNA data available for this genus.

Seltsamia Jaklitsch \& Voglmayr, Stud. Mycol. 90: 111 (2017).

Index Fungorum number: IF 823020; Facesoffungi number: FoF 08189; 1 morphological species (Species Fungorum 2020), 1 species with molecular data.

Type species - Seltsamia ulmi Jaklitsch \& Voglmayr, Stud. Mycol. 90: 113 (2017).

Notes - Jaklitsch et al. (2018a) introduced Seltsamia with S. ulmi as the type species which was collected from Norway, associated with Hapalocystis bicaudata on corticated twigs of Ulmus glabra. Even though phylogenetically Seltsamia ulmi grouped sister to Allocucurbitaria in Cucurbitariaceae, it has close morphological alliances to pleomassaria-like fungi (Jaklitsch et al. 2018a). See Jaklitsch et al. (2018a) for more details.

Syncarpella Theiss. \& Syd., Annls mycol. 13(5/6): 631 (1915).

Index Fungorum number: IF 5331; Facesoffungi number: FoF 08190; 7 morphological species (Species Fungorum 2020), molecular data unavailable.

Type species - Syncarpella tumefaciens (Ellis \& Harkn.) Theiss. \& Syd., Annls mycol. 13(5/6): 633 (1915).

三Sphaeria tumefaciens Ellis \& Harkn., in Ellis \& Everhart, J. Mycol. 2(4): 41 (1886)

Notes - Theissen \& Sydow (1915) introduced Syncarpella in Montagnellaceae with $S$. tumefaciens as the type of the genus. Barr \& Boise (1989) transferred Syncarpella to Cucurbitariaceae based on ascomata characteristics. There are no DNA data available for this genus for molecular analyses. See Zhang et al. (2012b) and Doilom et al. (2013) for more details.

Synfenestella Jaklitsch \& Voglmayr, Persoonia 44: 35 (2019).

Index Fungorum number: IF 829759; Facesoffungi number: FoF 08191; 2 morphological species (Species Fungorum 2020), 2 species with molecular data

Type species - Synfenestella sorbi (P. Karst.) Jaklitsch \& Voglmayr, Persoonia 44: 35 (2019).

$\equiv$ Cucurbitaria sorbi P. Karst., Bidr. Känn. Finl. Nat. Folk 23: 62 (1873).

Notes - Jaklitsch \& Voglmayr (2020) introduced Synfenestella to accommodate two species $S$. pyri and S. sorbi. It is interesting that these taxa having a direct association with Cytospora sp. and Diaporthe impulse, thus parasitism on other fungi may be possible in this genus. See Jaklitsch \& Voglmayr (2020) for further details.

\section{Ecological and economic significance}

They are important to the cycling of carbon and nutrients during the decomposition of organic matter especially in terrestrial habitats.

Cyclothyriellaceae Jaklitsch \& Voglmayr, Stud. Mycol. 85: 39 (2016).

Index Fungorum number: IF 817772; Facesoffungi number: FoF 08192, 21 species.

On bark of moderately decayed twigs, often on and in association with other fungi. Sexual morph: Ascomata commonly clustered in valsoid configuration within $\mathrm{KOH}$-positive tissue or in purple-coloured plant tissue or scattered, immersed to erumpent, more or less globose, black. Peridium pseudoparenchymatous. Ostiolar discs brightly coloured or black, ostioles periphysate. Hamathecium comprising apically free paraphyses, narrow branched, and anastomosing, trabeculate 
pseudoparaphyses. Asci 8-spored, bitunicate, cylindrical to clavate. Ascospores 1-seriate, ellipsoid to fusoid, brown, with several eusepta, thick-walled, with or without a sheath. Asexual morph: pycnidial, historically called aposphaeria-like. Peridium pseudoparenchymatous, consisting of dark cells. Conidiophores reduced to conidiogenous cells, or inconspicuous. Conidiogenous cells phialidic. Conidia cylindrical, oblong to ellipsoid, hyaline or brown, 1-celled, smooth-walled (Jaklitsch \& Voglmayr 2016).

Type - Cyclothyriella Jaklitsch \& Voglmayr.

Notes - The family was established by Jaklitsch \& Voglmayr (2016) to accommodate the distinct clade containing Cyclothyriella based on C. rubronotata and Massariosphaeria based on M. phaeospora.

Cyclothyriella Jaklitsch \& Voglmayr, Stud. Mycol. 85: 41 (2016).

Index Fungorum number: IF 817773; Facesoffungi number: FoF 08193; 1 morphological species (Species Fungorum 2020), 5 species with molecular data (only one species belongs to Cyclothyriellaceae).

Type species - Cyclothyriella rubronotata (Berk. \& Broome) Jaklitsch \& Voglmayr.

三Melogramma rubronotatum Berk. \& Broome, Ann. Mag. nat. Hist., Ser. 3 3: 375 (1859)

Notes - Cyclothyriella rubronotata was known as Thyridaria rubronotata. However, phylogenetic analyses indicated that it did not group with $T$. broussonetiae, the type species of Thyridariai (Hyde et al. 2013, Jaklitsch \& Voglmayr 2016). Thus, Jaklitsch \& Voglmayr (2016) provided a new generic name Cyclothyriella and introduced Cyclothyriellaceae to accommodate this clade (including Cyclothyriella and Massariosphaeria).

\section{Other genus included}

Massariosphaeria (E. Müll.) Crivelli, Diss. Eidgenöss. Techn. Hochschule Zürich 7318: 141 (1983).

三Leptosphaeria subgen. Massariosphaeria E. Müll., Sydowia 4(1-6): 206 (1950).

Index Fungorum number: IF 25819; Facesoffungi number: FoF 08194; 20 morphological species (Species Fungorum 2020), 1 species with molecular data.

Type species - Massariosphaeria phaeospora (E. Müll.) Crivelli, Ueber die Heterogene Ascomycetengattung Pleospora Rabh. 141 (1983).

三Leptosphaeria phaeospora E. Müll., Sydowia 4(1-6): 208 (1950).

Notes - The genus was first established as a section of Leptosphaeria (Müller 1950). Later, Massariosphaeria was introduced by Crivelli (1983). Massariosphaeria is characterised by immersed ascomata, black, papillate ostioles, with black to grayish cells of peridium, abundant, hyaline, septate hamathecium, bitunicate, cylindric-clavate asci, fusiform, multi-septate ascospores, with relatively thick-walled, yellow to brown colour, some with transverse septum only, with the cell above the septum the largest, surrounded by a prominent mucilaginous sheath, sometimes forming red pigments, on the host, especially in culture (Tanaka \& Harada 2004, Van 2005, Wang et al. 2007). Molecular data indicated that Massariosphaeria is polyphyletic (Wang et al. 2007). Since the sequence data of type species $M$. phaeospora is available and it clustered with strains of Cyclothyriella rubronotata (Wang et al. 2007, Hyde et al. 2013, Jaklitsch \& Voglmayr 2016), Massariosphaeria was included in Cyclothyriellaceae (Jaklitsch \& Voglmayr 2016, Wijayawardene et al. 2018).

\section{Ecological and economic significance}

Jaklitsch \& Voglmayr (2016) reported that species in Cyclothyriellaceae are found on bark, decayed twigs or submerged dead twigs, particularly of Acer spp., Aesculus hippocastanum and Ulmus spp. They often occur in association with other fungi such as Nitschkia parasitans (Jaklitsch \& Voglmayr 2016). 

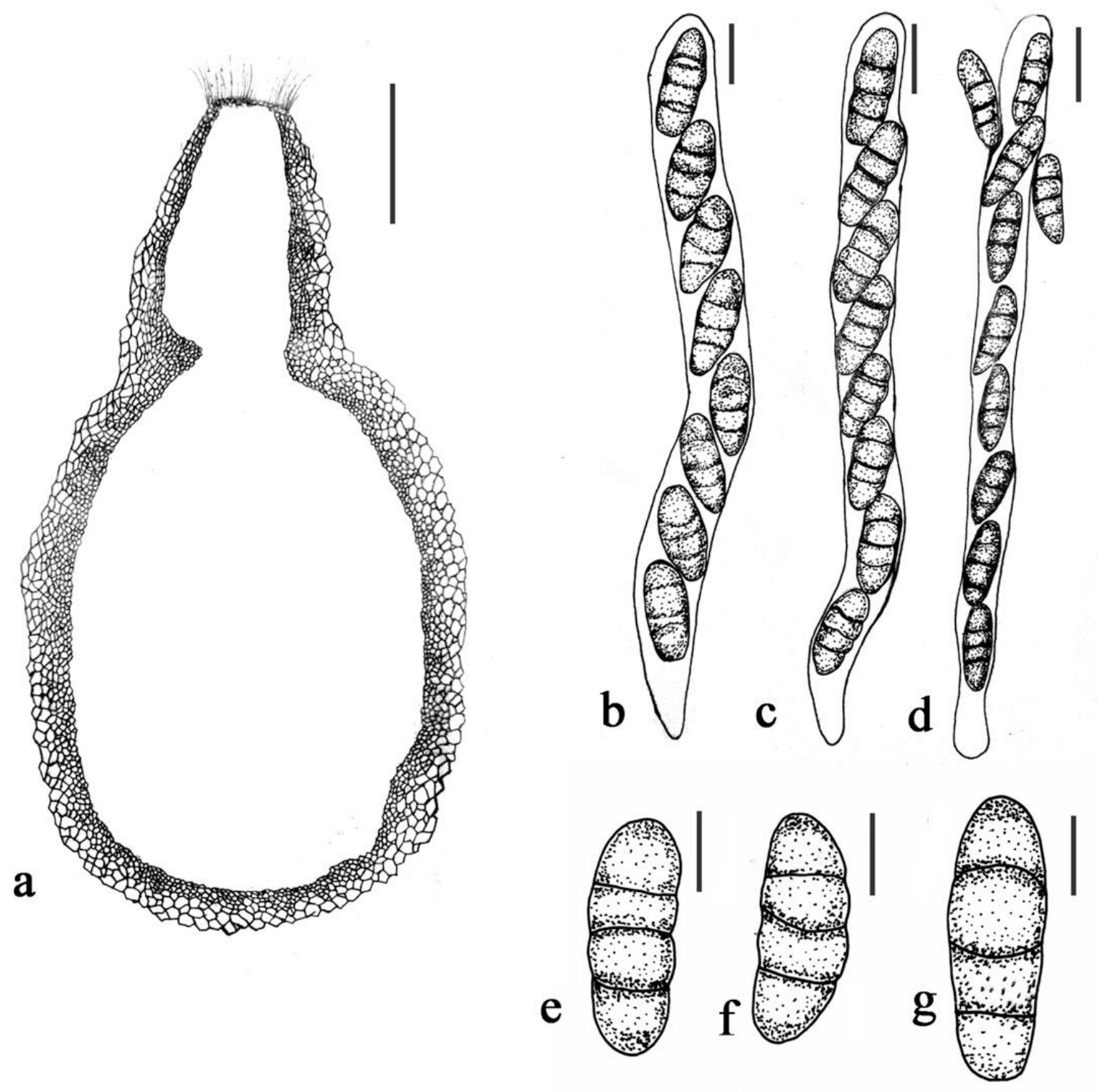

Figure 68 - Cyclothyriella rubronotata (redrawn from Jaklitsch \& Voglmayr 2016). a Ascomata in vertical section. $b, c$ Asci. $d$ Mature asci. $e^{-g}$ Verlucose surface ascospores. $g=100 \mu \mathrm{m}, \mathrm{b}-\mathrm{d}=10$ $\mu \mathrm{m} . \mathrm{e}^{-\mathrm{g}}=7 \mu \mathrm{m}$.

Dacampiaceae Körb., [as 'Dacampieae'] Syst. Lich. Germ.: 322 (1855).

Index Fungorum number: IF 80680; Facesoffungi number: FoF 08195, 35 species.

Biotrophic or necrotrophic on lichens, rarely lichenized, rarely saprobic. Sexual morph: Ascomata perithecioid, mostly uni-locular, with a central ostiole, lacking setae, black, mostly subglobose to obpyriform, rarely elongate or irregularly shaped, solitary and scattered over the substratum or in groups, superficial to immersed-erumpent. Peridium thick, composed of several layers of angular pseudoparenchymatous, radially compressed, thick-walled cells usually of textura angularis, reddish to dark brown, or pale brown to colorless, surrounded by a dark brown involucrellum, rarely also with cephalothecioid plates. Hamathecium comprising numerous, hyaline, septate, usually branched, anastomosing, cellular pseudoparaphyses, sometimes immersed in gel. Asci up to 8-spored, bitunicate, fissitunicate, elongate-clavate to cylindrical, shortpedicellate, with a thick-walled apex and a small, sometimes indistinct ocular chamber, I-, more rarely $\mathrm{K} / \mathrm{I}+$ bluish. Ascospores 1-2-seriate, ellipsoid to fusiform, in most species brown to dark brown, more rarely hyaline to pale brown, 1- or more septate to muriform, often constricted at the septa, smooth or rarely verruculose, perispore present in some species. Asexual morph: pycnidial 
states reported in a few genera, e.g. Aaosphaeria (microsphaeropsis-like), Eopyrenula (colourless, simple microconidia and brown, 1- or more septate macroconidia).

Type - Dacampia A. Massal.

Notes - Dacampiaceae is considered as a heterogeneous assemblage of genera with morphological similarities to taxa of Pleosporales. The family was formerly placed in Dothideales (Eriksson \& Hawksworth 1986). Kirk et al. (2001) accepted 15 genera in this family that was placed in the Pleosporales. Lumbsch \& Huhndorf (2007), as Dothideomycetes, families incertae sedis included Aaosphaeria Aptroot, but excluded Byssothecium, Immotthia, Moristroma, Pseudonitschkia and Sinodidymella, with 11 genera accepted. Hyde et al. (2013) re-included Pseudonitschkia but excluded Cocciscia and Kalaallia, with 10 genera accepted. They considered the family as 'Dothideomycetes, families incertae sedis'. Ertz et al. (2015) sequenced the type of Dacampiaceae and placed the family in the Pleosporales. In the same phylogeny, the lichenicolous genera Polycoccum and Clypeococcum were excluded from the Dacampiaceae and placed in the new family Polycoccaceae within the Trypetheliales. Other members of Polycoccum sensu lato were included in the Pleosporales in Phaeosphaeriaceae. Munkovalsaria was also excluded from the Dacampiaceae and placed in the Didymosphaeriaceae (Pleosporales) (Ertz et al. 2015). The monotypic genus Aaosphaeria was sequenced by Vu et al. (2019) but its familial affinity was not shown. No sequence data are available for Eopyrenula, Leptocucurthis, Pseudonitschkia and Weddellomyces making their placement within the family highly uncertain. Pyrenidium Nyl. was re-described by Doilom et al. (2018) and several members of this genus were sequenced recently and form a distinct lineage within Pleosporales sensu lato for which Pyrenidiaceae was resurrected (Huanraluek et al. 2019). Thus, six genera are tentatively accepted in Dacampiaceae here. Most species of Dacampiaceae are lichenicolous, and most seem to be host-specific. The type of Dacampia is remarkable in being lichenized, and a further genus often included in the Dacampiaceae, Eopyrenula, is a facultative lichen. Several poorly known genera, some with aberrant characters, such as hyaline ascospores and unbranched hamathecial filaments, mainly growing on plants, are provisionally kept in the Dacampiaceae; they are commented on and keyed out below.

The relationships of Dacampiaceae with other families of Pleosporales needs further study with multi-genes analyses, because the backbone of the phylogenetic tree using LSU sequence data is poorly resolved within the Pleosporales where the family appears to be related to the Leptosphaeriaceae (Ertz et al. 2015).

Dacampia A. Massal., Sulla Lec. Hook. Schaer.: 7 (1853).

Index Fungorum number: IF 1401; Facesoffungi number: FoF 08196; 14 morphological species (Species Fungorum 2020), 2 species with molecular data.

Type species - Dacampia hookeri (Borrer) A. Massal.

三Verrucaria hookeri Borrer, in Hooker \& Sowerby, Suppl. Engl. Bot. 1: tab. 2622, Fig. 2 (1831).

Notes - Dacampia, typified by Dacampia hookeri, was introduced by Massalongo (1853). Most species of Dacampia are parasitic and form necrotic patches on the host thallus or tend to be commensalistic. However, the type species is lichenized (except for juvenile stages that might facultatively transform the thallus of Solorina bispora), forming white lichenized thalli with Coccomyxa and external cephalodia with Nostoc (Henssen 1995). It grows on soil in arctic-alpine habitats. The closely related $D$. engeliana is an obligate lichenicolous fungus but modifies its host lichen to form a similar thallus structure as found in D. hookeri (Henssen 1995). Ertz et al. (2015) re-collected the type species and D. engeliana with LSU sequence data available in GenBank. For morphology of type species see Henssen (1995) and Ertz et al. (2015). A key to seven species is given by Halici \& Hawksworth (2008). 

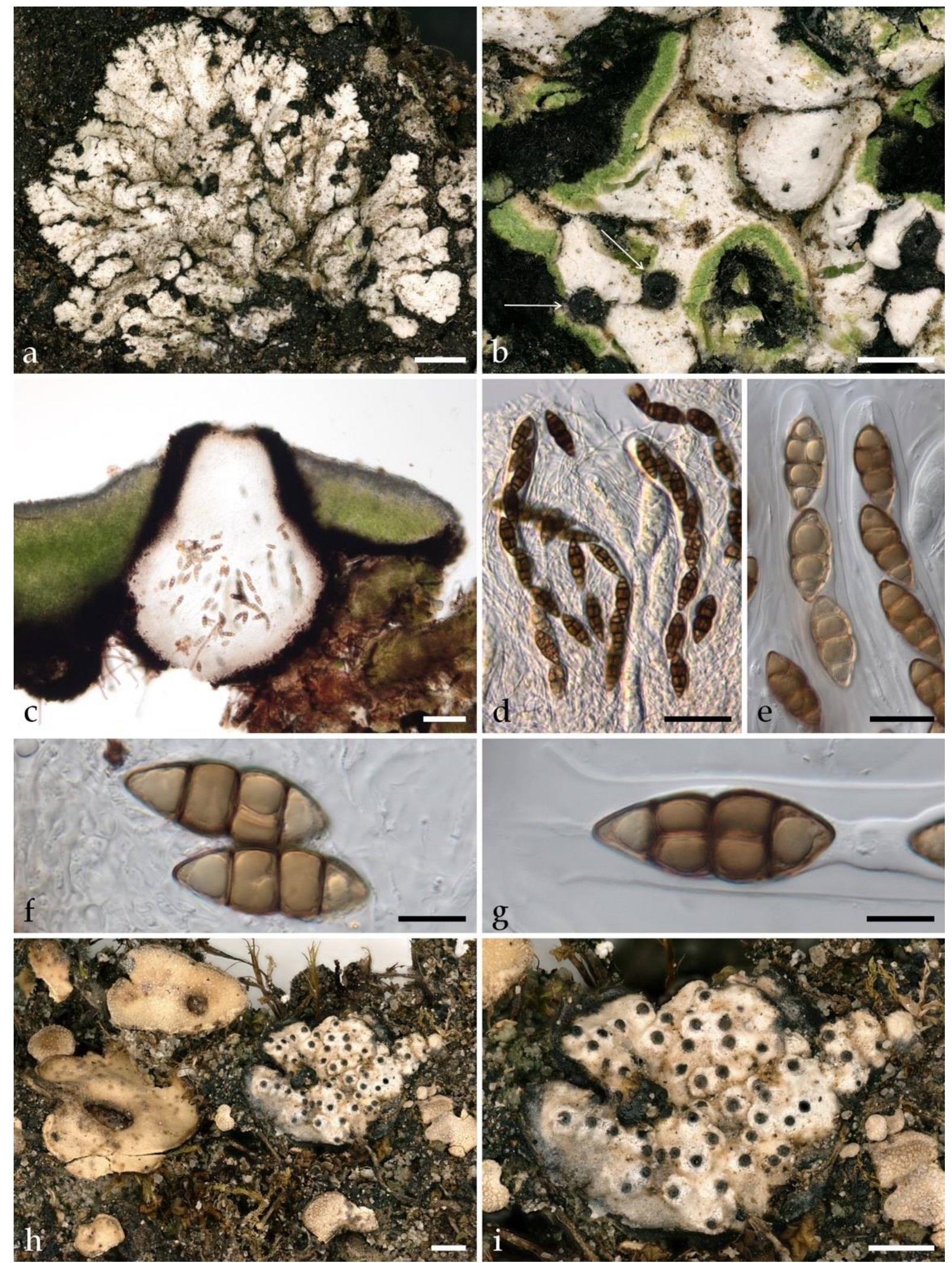

Figure 69 - Morphology of Dacampia ( $-\mathrm{g}=$ D. hookeri; $\mathrm{h}, \mathrm{i}=$ D. engeliana). a thallus on soil (Austria, Ertz 20505). b thallus with two perithecia (arrows), sectioned in several places to show the greenish photobiont of this lichenized species (Austria, Ertz 20505). c Section through a perithecium and the adjoining thallus in water (Austria, Ertz 20505). d Asci with ascospores and pseudoparaphyses in water (Austria, Hafellner 75980). e Upper part of two asci with ascospores, in water (Austria, Ertz 20505). f, g Ascospores in water. h, i Dacampia engeliana parasitizing a squamule of Solorina saccata (Liechtenstein, Hafellner 72868). Scale bars: a, h, i = $1 \mathrm{~mm}, \mathrm{~b}=500$ $\mu \mathrm{m}, \mathrm{c}=100 \mu \mathrm{m}, \mathrm{d}=50 \mu \mathrm{m}, \mathrm{e}=20 \mu \mathrm{m}, \mathrm{f}, \mathrm{g}=10 \mu \mathrm{m}$. 

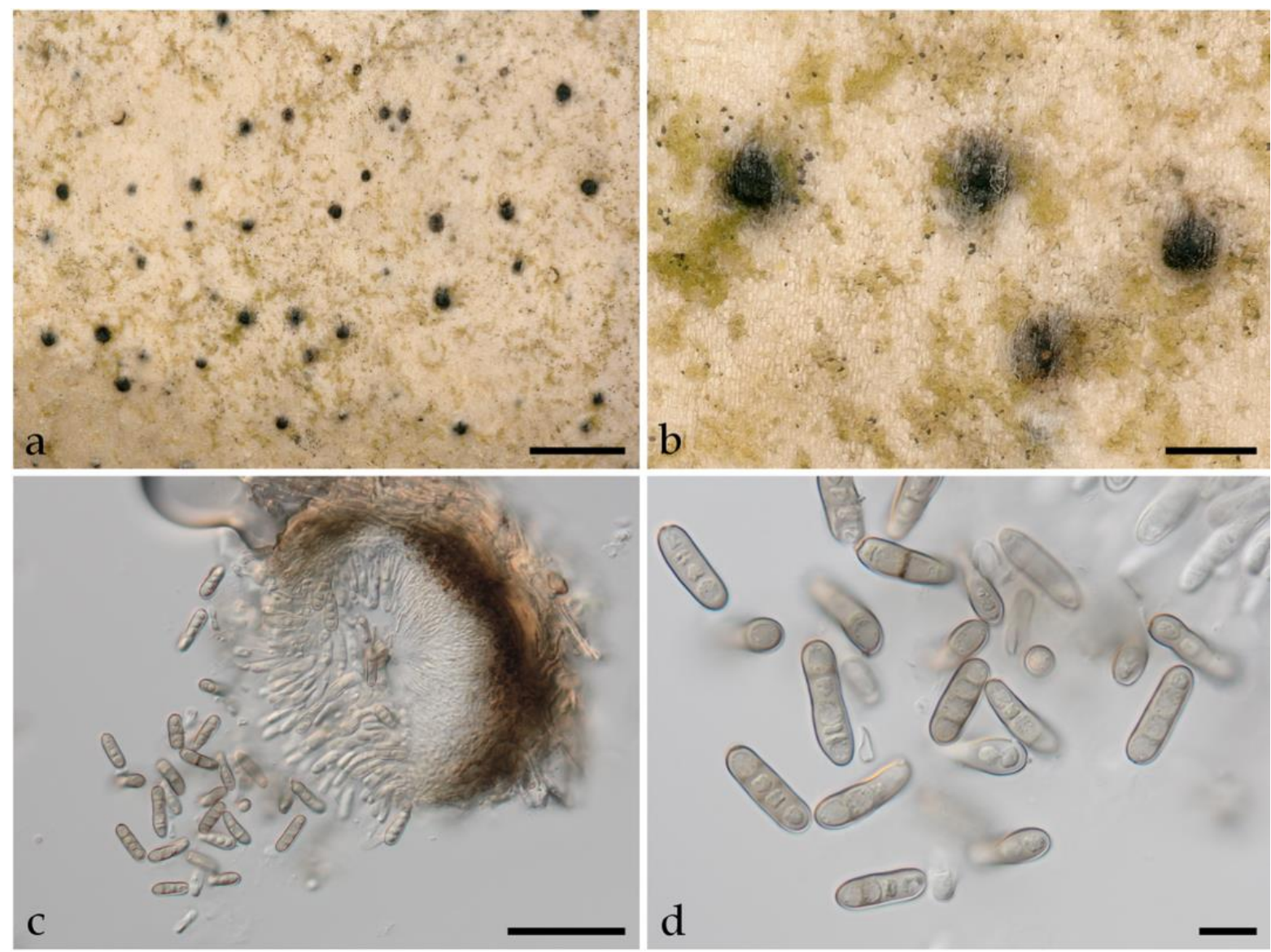

Figure 70 - Eopyrenula grandicula (Norway, Ertz 22496), a, b thallus with pycnidia. c Cross section of one pycnidium broken below, with macroconidia. $\mathrm{d}$ macroconidia. Scale bars: $\mathrm{a}=1 \mathrm{~mm}$, $\mathrm{b}=200 \mu \mathrm{m}, \mathrm{c}=50 \mu \mathrm{m}, \mathrm{d}=10 \mu \mathrm{m}$.

\section{Other genera included}

Aaosphaeria Aptroot, Nova Hedwigia 60 (3-4): 329 (1995).

Index Fungorum number: IF 6184; Facesoffungi number: FoF 08197; 1 morphological species (Species Fungorum 2020), 1 species with molecular data.

Type species - Aaosphaeria arxii (Aa) Aptroot, Nova Hedwigia 60 (3-4): 329 (1995).

$\equiv$ Didymosphaeria arxii Aa, Stud. Mycol. 31: 20 (1989).

Notes - A detailed description can be found in Van der Aa (1989, as Didymosphaeria). The genus was referred to the Dothideales by Aptroot (1995) who also suggested that it could be close to Polycoccum in Dacampiaceae despite different asexual stages. The genus was tentatively accepted in Dacampiaceae by Lumbsch \& Hundorf (2007) and Hyde et al. (2013). The type species was originally collected from soil of corn field (under Zea mays) in Colombia, with a culture isolated (Van der Aa 1989). It was also reported from different plant hosts Coffea, Mangifera, Solidago and Zigyphus (Aptroot 1995). According to the original description, A. arxii has a Microsphaeropsis asexual morph, but the type species of Microsphaeropsis was shown to cluster in Didymellaceae (de Gruyter et al. 2009), so that the asexual morph of Aaosphaeria should be defined as "microsphaeropsis-like". Sequence data (ITS and LSU) were published by Vu et al. (2019).

Eopyrenula R.C. Harris, Michigan Bot. 12(1): 19 (1973).

Index Fungorum number: IF 1842; Facesoffungi number: FoF 08198; 6 morphological species (Species Fungorum 2020), 1 species with molecular data.

Type species - Eopyrenula leucoplaca (Wallr.) R.C. Harris, Michigan Bot. 12(1): 19 (1973).

三Verrucaria leucoplaca Wallr., Fl. crypt. Germ. (Norimbergae) 1: 299 (1831). 
Notes - Species of Eopyrenula are bark-inhabiting, facultatively lichenized with trentepohlioid photobiont. Eopyrenula has been moved from Dothideomycetes to Pezizomycotina by Lücking et al. (2017), but was maintained in Dacampiaceae by Doilom et al. (2018) who redescribed the genus. A placement in the Pyrenulaceae (Eurotiomycetes) is also not excluded because of morphological similarities with Pyrenula from which it differs however by the absence of a well-developed pseudostromatic involucrellum, the absence of a thickened endospore and in having pycnidia with brown, septate macroconidia (Harris 1973). The six species of Eopyrenula were keyed out by Aptroot (2012) who treated the genus as part of Pyrenulaceae. It is provisionally maintained in Dacampiaceae here waiting for molecular data to clarify its phylogenetic position.

Leptocucurthis Aptroot, in Aptroot \& van Iperen, Nova Hedwigia 67 (3-4): 485 (1998).

Index Fungorum number: IF 27903; Facesoffungi number: FoF 08199; 1 morphological species (Species Fungorum 2020), molecular data unavailable.

Type species - Leptocucurthis quadrata Aptroot, in Aptroot \& van Iperen, Nova Hedwigia 67 (3-4): 485 (1998).

Notes - The genus was reported from a fallen tree and from a trunk of Elaeocarpus in montane forest in Papua New Guinea. The genus was placed in Dacampiaceae in the original publication because of similarities with the genus Sinodidymella. It was transferred to Teichosporaceae by Barr (2002). Since Leptocucurthis strongly differs from Dacampia notably by a saprobic life style (or parasitic of tree trunks?), ascomata with a slit-like to stellate with 3-6 radiate splits ostiole, unbranched pseudoparaphyses, long fusiform to cylindrical hyaline 1-septate ascospores, it might be better placed in the Hysteriaceae that produce a slit-like opening to release the spores.

Pseudonitschkia Coppins \& S.Y. Kondr., Edinb J Bot 52(2): 232 (1995).

Index Fungorum number: IF 6272; Facesoffungi number: FoF 08200; 1 morphological species (Species Fungorum 2020), molecular data unavailable.

Type species - Pseudonitschkia parmotrematis Coppins \& S.Y. Kondr., Edinb J Bot 52(2): 232 (1995).

Notes - The genus was accepted in the Dacampiaceae by Kirk et al. (2001) and Hyde et al. (2013) but placed as Dothideomycetes genera incertae sedis by Diederich et al. (2018). This monotypic genus is lichenicolous on Parmotrema and was described from Venezuela (holotype), Paraguay, Malawi, South Africa and Nepal. The holotype of the type species of Pseudonitschkia was re-described and illustrated by Doilom et al. (2018). No DNA sequence data are available.

Weddellomyces D. Hawksw., Notes R. Bot. Gdn Edinb. 43(3): 511 (1986).

Index Fungorum number: IF 25083; Facesoffungi number: FoF 08201; 12 morphological species (Species Fungorum 2020), molecular data unavailable.

Type species - Weddellomyces epicallopisma (Wedd.) D. Hawksw. [as 'epicallopismum'], Notes R. Bot. Gdn Edinb. 43(3): 512 (1986).

三Verrucaria epicallopisma Wedd., Mém. Soc. Imp. Sci. Nat. Cherbourg 17: 372 (1873).

Notes - The genus was referred to the 'Dothideales (?Pyrenidiaceae)', and later accepted in the Dacampiaceae by Kirk et al. (2001), Lumbsch \& Hundorf (2007) and Hyde et al. (2013) but placed as 'Dothideomycetes genera incertae sedis' by Diederich et al. (2018). Calatayud \& Navarro-Rosinés (1998) keyed out eight species. The genus only includes lichenicolous fungi, growing on various host lichens, mainly on saxicolous species (see morphology Navarro-Rosinés \& Roux 1995, Calatayud \& Navarro-Rosinés 1998).

\section{Ecological and economic significance}

Dacampiaceae includes lichenicolous, lichenized and saprobic fungi (Ertz et al. 2015). They surely play roles in ecosystems. However, they are very poorly studied on their interaction with their lichen hosts, host-specificity, virulence, chemical ecology, etc. 
Delitschiaceae M.E. Barr, Mycotaxon. 76: 109 (2000).

Index Fungorum number: IF 82092; Facesoffungi number: FoF 08202, 73 species

Saprobic or hypersaprobic on old herbivore dung, or rarely on aged exposed wood or plants. Colonies solitary or scattered, sometimes gregarious, immersed to erumpent, brown or black. Sexual morph: Ascomata immersed to erumpent, globose to subglobose, or pyriform, brown or black, solitary or scattered, uni-locular pseudothecia, membranous to coriaceous, with a papilla or a well differentiated ostiole. Peridium pseudoparenchymatous exostratum, consists with textura angularis cells. Hamathecium comprising long, branch, anastomosing, cellular or trabeculate pseudoparaphyses. Asci 2(4)-8-spored, mostly 8-spored, bitunicate, fissitunicate, cylindrical to cylindric-clavate, pedicellate, with a J-, refractive apical apparatus. Ascospores 1-2-seriate, rarely 3-seriate, ovoid or ellipsoid, pale to dark brown, unicellular or 2- to multi-cellular, often constricted at the septum, resulting in fragmenting cells, smooth-walled, with a full-length germ slit in each cell, surrounded by a gel coat. Asexual morph: Undetermined.

Type - Delitschia Auersw.

Notes - This family was introduced to accommodate three genera of Sporormiaceae that had periphysate ostiolum and asci with a well-developed and refractive ocular chamber (Barr 2000). Hyde et al. (2013) mentioned that Delitschiaceae has cellular pseudoparaphyses, while Ohleriella and Semidelitschia have trabeculate pseudoparaphyses (Zhang et al. 2012b). We could not see images of hamathecium of these two genera clearly. Thus, future work is needed to confirm that genera in Delitschiaceae have cellular or trabeculate pseudoparaphyses. The families Delitschiaceae, Phaeotrichaceae and Sporormiaceae subdivided by Barr (2000) based on morphological evidence and later Kruys et al. (2006) and Schoch et al. (2009a) confirmed them as three families based on the multi-gene phylogeny. Morphologically this family has periphysate ostiole, wide ascus endotunica, conspicious apical ring and heavily pigmented 1- to multi-septate ascospore with germ slits in each cell (Barr 2000). Hyde et al. (2013) and Wijayawardene et al. (2018) accepted three genera Delitschia, Ohleriella and Semidelitschia in this family.

Delitschia Auersw., Hedwigia 5: 49 (1866).

Index Fungorum number: IF 1443; Facesoffungi number: FoF 08203; 68 morphological species (Species Fungorum 2020), 5 species with molecular data.

Type species - Delitschia didyma Auersw.

Notes - Delitschia typified by Delitschia didyma, was introduced by Auerswald (1866) and assigned to Sphaeriaceae. In previous studies this genus was assign to different families such as Sordariaceae (Winter 1887), and Pleosporaceae (Cain 1934, Moreau 1953, Dennis 1968). Munk (1957) established Sporormiaceae and Delitschia was assigned therein together with other coprophilous genera. Barr (2000) excluded Delitschia from Sporormiaceae and transferred this genus to a new family, Delitschiaceae due to their habit on dung. Keys to Delitschia can be found in Luck-Allen \& Cain (1975) and Hyde \& Steinke (1996).

Delitschia didyma Auersw., Hedwigia 5: 49 (1866)

Fig. 71

Index Fungorum number: IF 177056; Facesoffungi number: FoF 08204

Saprobic on old herbivore dung or aged wood. Sexual morph: Ascomata solitary or scattered, superficial or erumpent, black, globose or subglobose, coriaceous, apex with or without papilla, ostiolate. Peridium thick, comprises 2 layers of red brown to brown cells of textura angularis. Hamathecium comprising numerous, filiform, septate, long, branching, hyaline, cellular pseudoparaphyses. Asci 8-spored, bitunicate, fissitunicate, cylindrical to cylindro-clavate with short pedicel, with J- ocular chamber. Ascospores 1-3-seriate, ellipsoid, reddish brown to brown, 1septate, slightly constricted at the septum, cells often easily separable, each cell with a full-length germ slit. Asexual morph: Undetermined.

Material examined - Italy, on cow dung, 19 July 2012, F. Doveri, MFLU 12-2218.

\section{Other genera included}

Ohleriella Earle, Bull. New York Bot. Gard. 2(no. 7): 349 (1902). 
Index Fungorum number: IF 3558; Facesoffungi number: FoF 08205; 2 morphological species (Species Fungorum 2020), molecular data unavailable.

Type species - Ohleriella neomexicana Earle, Bull. New York Bot. Gard. 2(no. 7): 349 (1902).

Notes - Ohleriella, typified by Ohleriella neomexicana Earle. was introduced by Earle (1902). Ohleriella was included in Fenestellaceae (Barr 1987a, 1990a) but later Barr (2000) excluded Ohleriella from Fenestellaceae and accommodated it in Delitschiaceae due to its habit. Ohleriella has been treated as a synonym in many genera (Ohleria, Sporormiella or Preussia) (Ahmed \& Cain 1972, von Arx \& Müller 1975, Clements \& Shear 1931). This genus differs from other genera in having more than 2-celled ascospores with saprobic on woody material. Morphology and molecular studies are needed to resolve this issue.

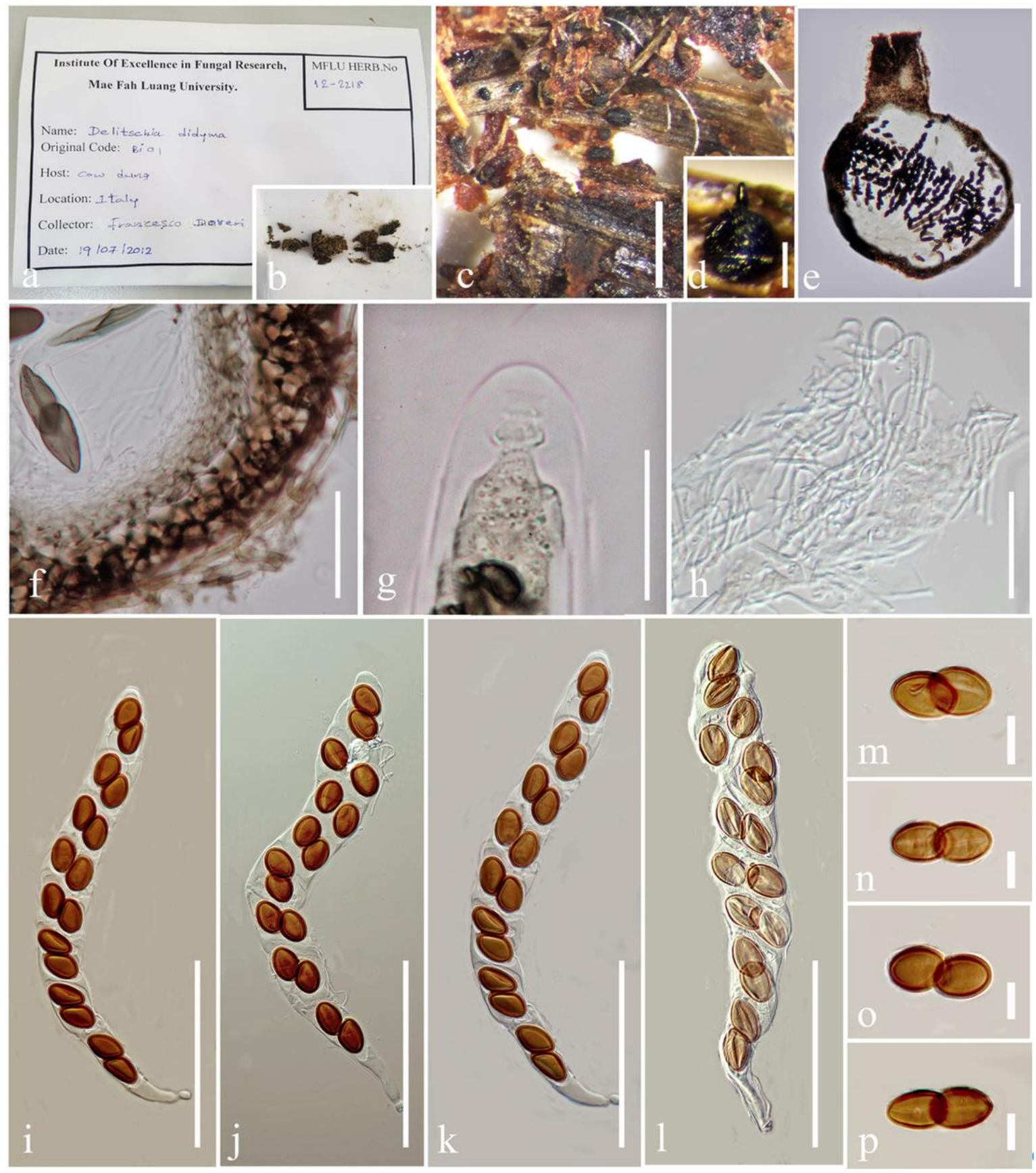

Figure 71 - Delitschia didyma (MFLU 12-2218). a, b Herbarium packet with cow dung specimen. c, d Ascomata on natural substrate. e Cross section of ascoma. f Peridium. g Ocular chamber. h Pseudoparaphyses. i-1 Asci. m-p Ascospores. Scale bars: $c=1000 \mu \mathrm{m}, \mathrm{d}=500 \mu \mathrm{m}, \mathrm{e}=100 \mu \mathrm{m}$, $\mathrm{f}-\mathrm{h}=50 \mu \mathrm{m}, \mathrm{i}-\mathrm{p}=20 \mu \mathrm{m}$. 
Semidelitschia Cain \& Luck-Allen, Mycologia 61: 581 (1969).

Index Fungorum number: IF 4999; Facesoffungi number: FoF 08206; 3 morphological species (Species Fungorum 2020), molecular data unavailable.

Type species - Semidelitschia agasmatica Cain \& Luck-Allen, Mycologia 61: 581 (1969).

Notes - Semidelitschia, typified by Semidelitschia agasmatica was introduced by Cain \& Luck-Allen (1969) and assigned to Sporormiaceae. The type was originally collected on dung of Bos taurus in South Dakota. The morphology of this genus is similar to Delitschia but differs by single-celled, dark ascospores with germination slits (Cain \& Luck-Allen 1969). Barr (2000) transferred Semidelitschia to Delitschiaceae. Semidelitschia is a genus rarely recorded and needs molecular studies to resolve this issue.

\section{Ecological and economic significance}

Delitschiaceae is a small family, usually found as coprophilous fungi. There is no known Ecological and economic significance of Delitschiaceae species, except that they are important for nutrient cycling.

Diademaceae Shoemaker \& C.E. Babc., Can. J. Bot. 70(8): 1618 (1992).

Index Fungorum number: IF 81955; Facesoffungi number: FoF 08207, 8 species.

Parasitic or saprobic on decaying stems and leaves. Colonies dark brown to black with subepidermal or subcuticular and later become superficial. Sexual morph: Ascomata subepidermal or subcuticular and later become superficial, dark brown to black, globose, opening via a flat, circular lid. Peridium consisting of small, pigmented, thick-walled cells of textura angularis. Hamathecium comprising dense, cellular pseudoparaphyses. Asci 8-spored, bitunicate, fissitunicate, clavate or ellipsoidal, with short, broad, furcate pedicel, apically rounded with an ocular chamber. Ascospores 2-seriate, fusiform, brown, with 3 or more transverse septa, with or without longitudinal septa, applanate or rarely terete, with a thick sheath most of the time. Asexual morph: Undetermined.

Type - Diadema Shoemaker \& C.E. Babc.

Notes - Diademaceae was introduced by Shoemaker \& Babcock (1992) based on the ascomata characteristic of opening by a flat, circular lid, and comprised five genera (Clathrospora, Comoclathris, Diadema, Diademosa and Macrospora) (Shoemaker \& Babcock 1992). Later Clathrospora, Comoclathris, Diademosa and Macrospora were transferred to Pleosporaceae (Kruys et al. 2006, Lumbsch \& Huhndorf 2010, Ariyawansa et al. 2014a). Wijayawardene et al. (2018) accepted two genera Diadema and Diademosa in this family. We agree with Ariyawansa et al. (2014a) to transfer Diademosa to Pleosporaceae. This genus needs recollecting to confirm its placement with DNA sequence data. In this study, we accept only Diadema in Diademaceae.

Diadema Shoemaker \& C.E. Babc., Can. J. Bot. 67(5): 1349 (1989).

Index Fungorum number: IF 25293; Facesoffungi number: FoF 08208; 8 morphological species (Species Fungorum 2020), molecular data unavailable.

Type species - Diadema tetramerum Shoemaker \& C.E. Babc.

Notes - Diadema typified by Diadema tetramerum, was introduced by Shoemaker \& Babcock (1989) which assigned to Diademaceae. Most members of this genus are known from culms or stems of Poaceae or Rosaceae (Shoemaker \& Babcock 1989b).

Diadema tetramerum Shoemaker \& C.E. Babc., Can. J. Bot. 67 (5): 1354 (1989).

Fig. 72

Index Fungorum number: IF 136222; Facesoffungi number: FoF 08209.

Description - see Ariyawansa et al. (2014a).

Material examined - USA, California, Mt. Shasta, ridge south of Horse Camp, elevation 8250 ft, on culms of Trisetum spicatum, 2 July 1947, W.B. Cooke (DAOM 20223, holotype). 


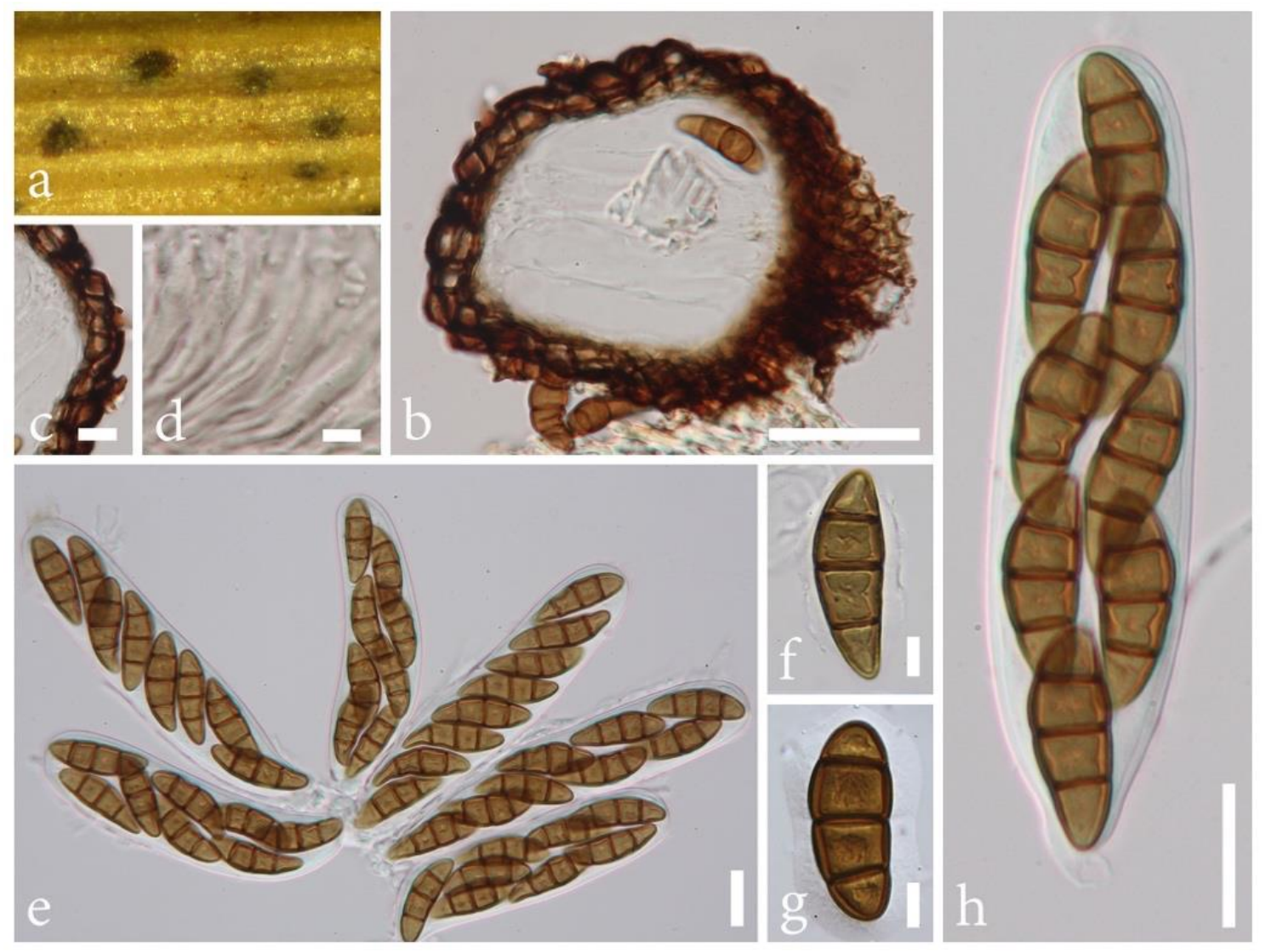

Figure 72 - Diadema tetramerum (DAOM 20223, holotype). a Appearance of immersed ascomata on host substrate. b Cross section of ascoma. c Closeup of the peridium. d Pseudoparaphyses. e, $h$ Asci. f, g Ascospores with mucilaginous sheath. Scale bars: $b=100 \mu \mathrm{m}, \mathrm{c}=10 \mu \mathrm{m}, \mathrm{d}, \mathrm{f}, \mathrm{g}=5 \mu \mathrm{m}$, $\mathrm{e}, \mathrm{h}=20 \mu \mathrm{m}$.

\section{Ecological and economic significance}

There is no known economic or ecological significance of Diademaceae species, except that they are important for nutrient cycling as they are saprobic on a wide variety of plant substrates.

Dictyosporiaceae Boonmee \& K.D. Hyde, Fungal Divers. 80: 462 (2016).

Index Fungorum number: IF 551574; Facesoffungi number: FoF 01256, 132 species.

Saprobic on plant litter and wood, mostly superficial, effused, comprising dark brown, immersed mycelium in host tissues. Sexual morph: Ascomata perithecial, superficial, solitary, subglobose, dark brown, somewhat soft, and collapsing when dry, with an apical ostiole. Peridium membranaceous, dark brown, composed of 2-3 layers of small cells of textura epidermoidea. Hamathecium comprising cylindrical, septate, cellular, pseudoparaphyses. Asci 8spored, bitunicate, fissitunicate, cylindrical, pedicellate, apically rounded with an ocular ch amber. Ascospores 2-seriate, fusiform, hyaline, 1-septate, slightly constricted at septum, with or without mucilaginous sheath. Asexual morph: Hyphomycetous. Colonies superficial, sporodochial, punctiform or effuse, dark brown. Conidiophores present or reduced to conidiogenous cell, micronematous, semi-macronematous to macronematous, mononematous or synnematous, unbranched or rarely branched, hyaline to medium brown. Conidiogenous cells holoblastic, integrated, terminal or sometimes intercalary, determinate, cylindrical to doliiform. Conidia acrogenous or sometimes pleurogenous, solitary, dry, cheiroid, complanate or non-complanate, pale brown to dark brown, smooth- or roughwalled; conidial rows unicellular to multi-septate, euseptate or distoseptate, separated like digits or more tightly compacted together, with or without appendages; appendages when present globose, cylindrical, clavate or hair-like, colourless to translucent. Conidial secession rhexolytic or schizolytic. 
Type - Dictyosporium Corda.

Notes - Dictyosporiaceae was introduced by Boonmee et al. (2016) to accommodate mostly aquatic lignicolous species with cheiroid, digitate, palmate and/or dictyosporous conidia and their sexual morphs that form a monophyletic clade in the class Dothideomycetes. 12 genera with nine being dictyosporous were accepted in Dictyosporiaceae (Yang et al. 2018). Presently, 15 genera are accepted in this family by Wijayawardene et al. (2020). Phylogenetic tree of genera in Dictyosporiaceae is provided in Fig. 74.

Dictyosporium Corda, Weitenweber's Beitr. Nat.: 87 (1836).

Index Fungorum number: IF 8001; Facesoffungi number: FoF 08210; 62 morphological species (Species Fungorum 2020), 24 species with molecular data.

Type - Dictyosporium elegans Corda.

Notes - Dictyosporium, the type genus of Dictyosporiaceae was established by Corda (in Witenweber 1836) with D. elegans Corda as the type species. The genus is characterised by subglobose superficial ascomata, bitunicate cylindrical asci and hyaline, fusiform uniseptate ascospores with or without a sheath; sporodochial colonies, micronematous to macronematous conidiophores and cheiroid, digitate complanate conidia with several parallel rows of cells (Boonmee et al. 2016, Yang et al. 2018). Members of this genus are distributed worldwide on dead wood and plant litter in terrestrial and aquatic habitats (Hyde \& Goh 1998, Ho et al. 2002, Pinnoi et al. 2006, Pinruan et al. 2007, Yang et al. 2018).

Dictyocheirospora heptaspora (Garov) D'souza, Boonmee \& K.D. Hyde , in Boonmee et al., Fungal Diversity 80: 14 (2016).

Fig. 73

$\equiv$ Cattanea heptaspora Garov., Rc. Ist. Lomb., Milano, ser. 2 8: 125 (1875).

Index Fungorum number: IF 551574; Facesoffungi number: FoF 01256.

Saprobic on decaying wood submerged in freshwater habitats. Sexual morph: Undetermined. Sexual morph: Undetermined. Asexual morph: Hyphomycetous. Conidiomata on natural substratum sporodochia, superficial, compact, scattered, circular or subglobose, dark brown to black, velvety. Mycelium immersed, consisted of septate, branched, hyaline, smooth. Conidiophores micronematous, reduced, pale brown, smooth. Conidiogenous cells monoblastic, integrated, terminal, determinate, hyaline to pale brown. Conidia 72-86 $\mu \mathrm{m}(\bar{x}=79 \mu \mathrm{m}, \mathrm{SD}=7, \mathrm{n}$ = 20) long, 20-26 $\mu \mathrm{m}(\bar{x}=23 \mu \mathrm{m}, \mathrm{SD}=3, \mathrm{n}=20)$ wide, acrogenous, solitary, cheiroid, smoothwalled, complanate, yellowish-brown to brown, consisting of 5-7 rows of cells, rows digitate, cylindrical, each rows composed of 10-12 cells, septate, constricted at septa.

Material examined - China, Yunnan Province, Lancang river, saprobic on decaying wood submerged freshwater, May 2017, Z.L. Luo, S-1992 (DLU 1992), living culture DLUCC 1992.

GenBank numbers - ITS: MT756244, LSU: MT756243, tef1: MT776563.

Notes - Phylogenetic analyses showed that our new isolate S-1992 clustered with Dictyocheirospora heptaspora (Fig. 75). Morphologically our species fits well with the morphological characters of D. heptaspora (Tsui et al. 2006). Therefore, we identified our new isolate as D. heptaspora.

\section{Other genera included}

Aquadictyospora Z.L. Luo, K.D. Hyde \& H.Y. Su, Mycosphere 8(10): 1590 (2017).

Index Fungorum number: IF 553861; Facesoffungi number: FoF 03767; 1 morphological species (Species Fungorum 2020), 1 species with molecular data.

Type species - Aquadictyospora lignicola Z.L. Luo, W.L. Li, K.D. Hyde \& H.Y. Su, in Li et al., Mycosphere 8(10): 1591 (2017).

Notes - Aquadictyospora is characterized by sporodochia, circular or subglobose conidiomata, micronematous conidiophores, monoblastic conidiogenous cells and broadly rounded conidia, composed of 4-6 compactly arranged rows with a basal, subglobose, hyaline cell. Only one species is accepted in this genus (Li et al. 2017b). 

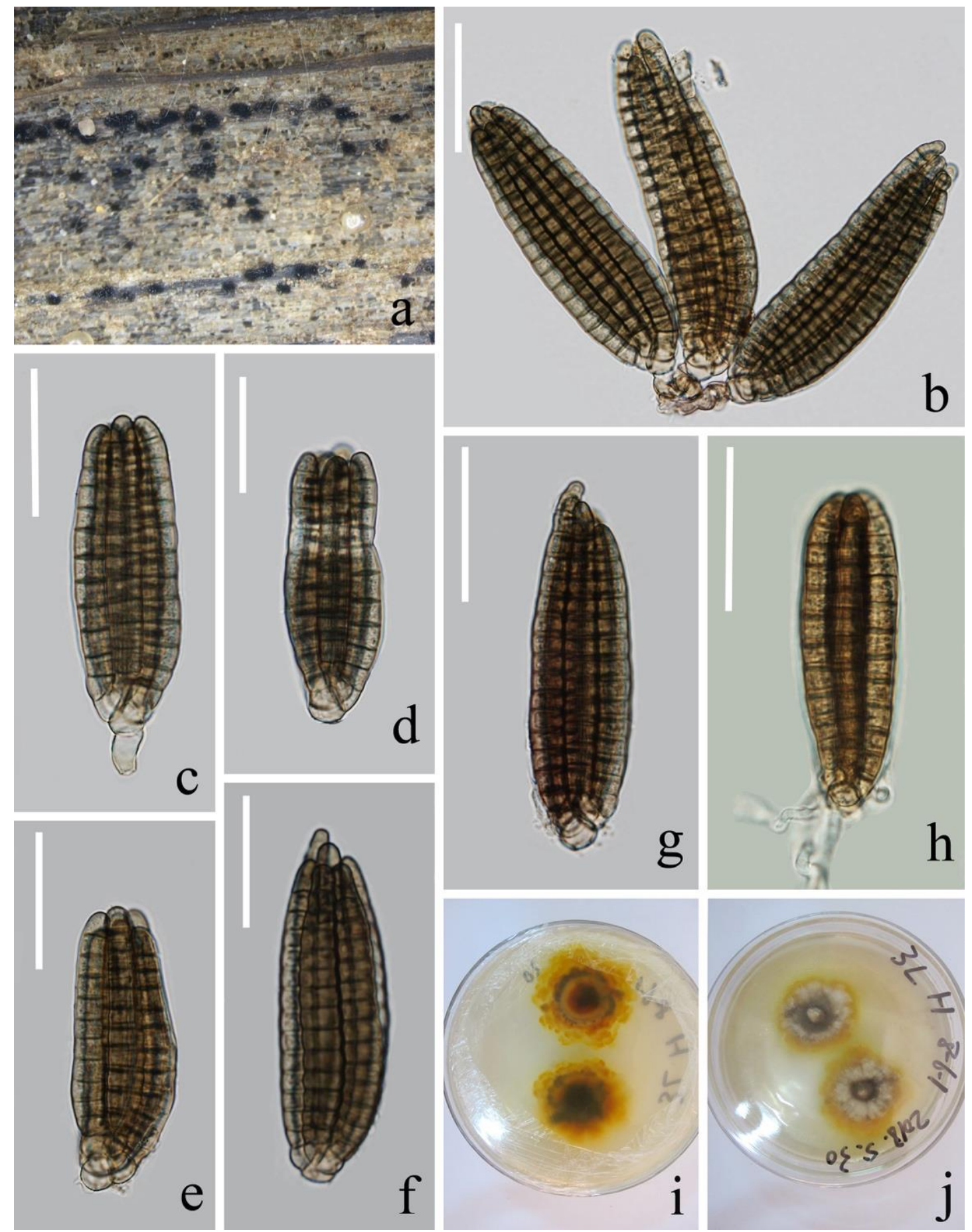

Figure 73 - Dictyocheirospora heptaspora (DLU 1992) a Colonies on wood. b-g Conidia. h Germinating conidium. i, $\mathrm{j}$ Colonies on PDA from surface and reverse. Scale bars: $\mathrm{b}-\mathrm{h}=35 \mu \mathrm{m}$.

Fig. 73

Aquaticheirospora Kodsueb \& W.H. Ho, Bot. J. Linn. Soc. 155(2): 286 (2007)

Index Fungorum number: IF 29188; Facesoffungi number: FoF 08211; 1 morphological species (Species Fungorum 2020), 1 species with molecular data.

Type species - Aquaticheirospora lignicola Kodsueb \& W.H. Ho, Bot. J. Linn. Soc. 155(2): 286 (2007).

Notes - Aquaticheirospora was collected from freshwater habitat. The genus is characterized by euseptate conidia with divergent arms, which are vertically inserted in different planes on a basal cell (Kodsueb et al. 2007). This genus can be distinguished from other genera in Dictyosporiaceae in having synnematous conidiomata and conidia that are produced on conidiogenous cells borne at the apices of synnemata. 
Cheirosporium L. Cai \& K.D. Hyde, Persoonia 20: 55 (2008).

Index Fungorum number: IF 506570; Facesoffungi number: FoF 01257; 2 morphological species (Species Fungorum 2020), 2 species with molecular data.

Type species - Cheirosporium triseriale L. Cai \& K.D. Hyde, Persoonia 20: 56 (2008).

Notes - Cheirosporium is characterized by the production of sporodochial conidiomata, semimacronematous to macronematous conidiophores that possess several distinct sterile branches, and cheiroid, smooth-walled conidia with rhexolytic secession. Abdel-Aziz (2016b) introduced a second species in this genus.

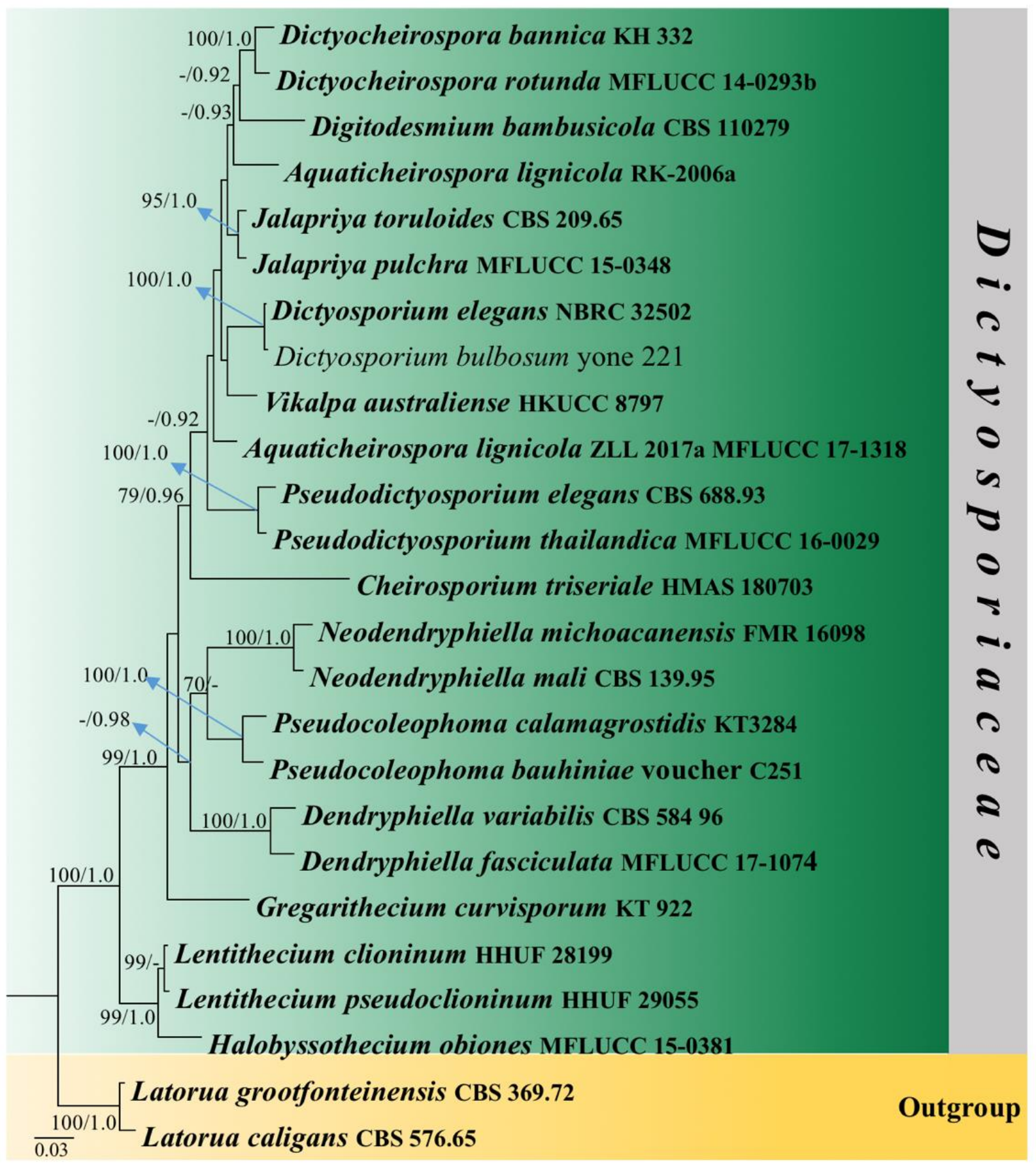

Figure 74 - Phylogram generated from maximum likelihood analysis (RAxML) of genera in Dictyosporiaceae based on ITS, LSU and SSU sequence data. Maximum likelihood bootstrap values equal or above $70 \%$, Bayesian posterior probabilities equal or above 0.90 (MLBS/PP) are given at the nodes. An original isolate number is noted after the species name. The tree is rooted to 
Latorua caligans (CBS 576.65) and L. grootfonteinensis (CBS 369.72). The ex-type strains are indicated in bold. Hyphen (-) represents support values below 70 \% MLBS and 0.90 PP.

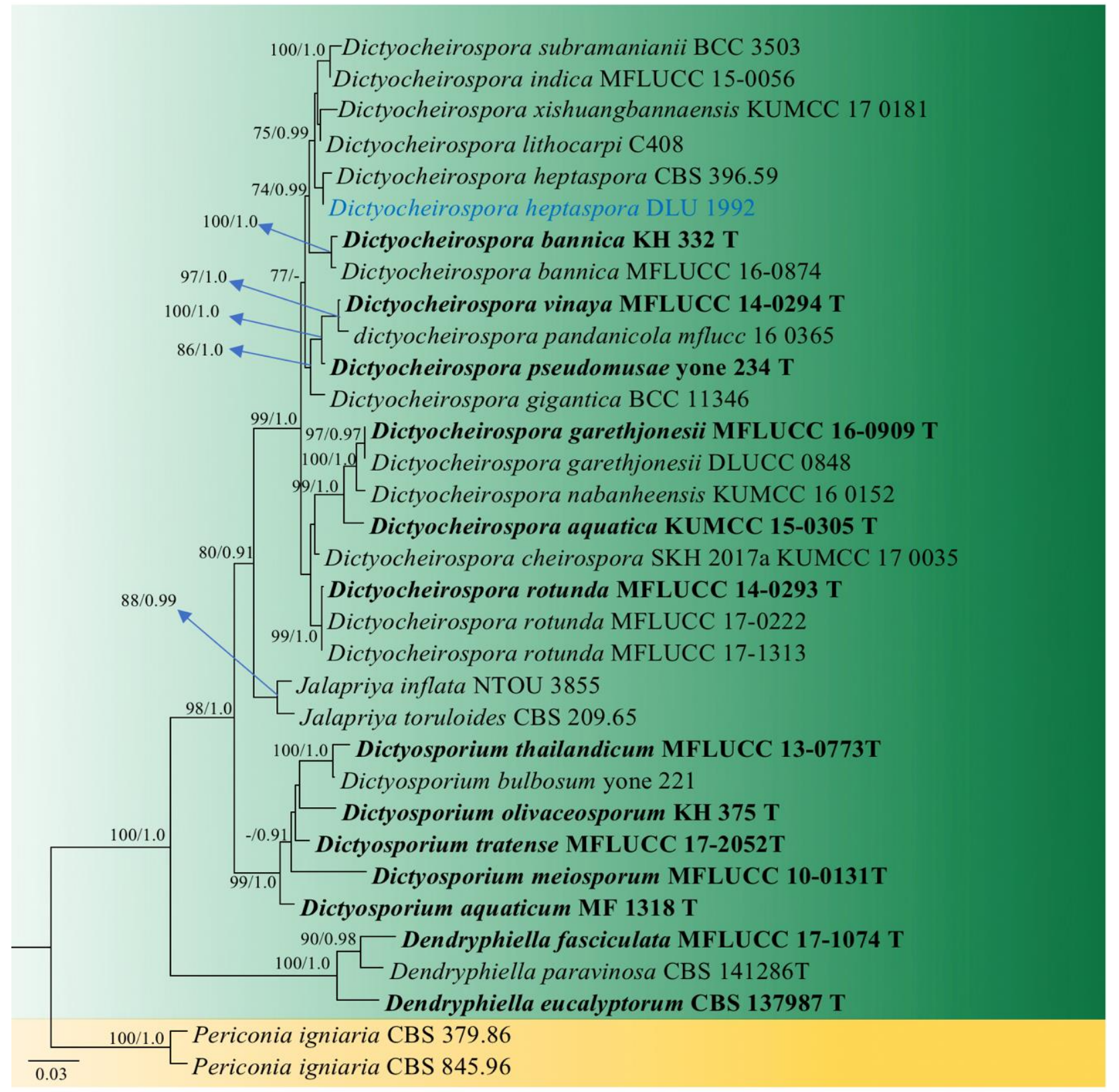

Figure 75 - Phylogram generated from maximum likelihood analysis (RAxML) of Dictyocheirospora species based on ITS, LSU and tef1 sequence data. Maximum likelihood bootstrap values equal or above $70 \%$, Bayesian posterior probabilities equal or above 0.90 (MLBS/PP) are given at the nodes. An original isolate number is noted after the species name. The tree is rooted to Periconia igniaria (CBS 379.86 and CBS 845.96). The ex-type strains are indicated in bold. Hyphen (-) represents support values below 70 \% MLBS and 0.90 PP.

Dendryphiella Bubák \& Ranoj., Annls mycol. 12(4): 417 (1914).

Index Fungorum number: IF 7951; Facesoffungi number: FoF 08212; 14 morphological species (Species Fungorum 2020), 7 species with molecular data.

Type species - Dendryphiella interseminata (Berk. \& Ravenel) Bubák, Annls mycol. 12(4): 417 (1914).

$\equiv$ Helminthosporium interseminatum Berk. \& Ravenel [as 'Helmisporium'], in Berkeley, Grevillea 3(no. 27): 103 (1875). 
Notes - Dendryphiella is an asexual morph genus. It was established by Ranojevic (1914) with $D$. interseminata as type species. The genus is placed in Dictyosporiaceae. It is characterized by macronematous conidiophores with polytretic, integrated conidiogenous cells at the swollen tip and at intercalary swellings and catenate or solitary conidia (Ellis 1971, Matsushima 1971, Rai \& Kamal 1986, Guo \& Zhang 1999, Crous et al. 2014a, 2016a). Liu et al. (2017c) updated the taxonomy of this genus and recently several new species were added to this genus (Hyde et al. 2018, Iturrieta-González et al. 2018, Crous et al. 2019a).

Dictyocheirospora M.J. D'souza, Boonmee \& K.D. Hyde, Fungal Divers. 80: 465 (2016).

Index Fungorum number: IF 551580; Facesoffungi number: FoF 01261; 21 morphological species (Species Fungorum 2020), 11 species with molecular data.

Type species - Dictyocheirospora rotunda M.J. D'souza, Bhat \& K.D. Hyde, Fungal Divers. 80: 465 (2016).

Notes - Dictyocheirospora was introduced by Boonmee et al. (2016) to accommodate species with dark sporodochial colonies that produce aeroaquatic cheiroid dictyospores, all species in this genus are saprobic.

Dictyopalmispora Pinruan, Boonmee \& K.D. Hyde, Fungal Diversity. 80: 457-482 (2016).

Index Fungorum number: IF 551575; Facesoffungi number: FoF 01258; 1 morphological species (Species Fungorum 2020), 1 species with molecular data.

Type species - Dictyopalmispora palmae Pinruan \& K.D. Hyde, Fungal Diversity. 80: 457482 (2016).

Notes - Dictyopalmispora is characterized by euseptate, complanate conidia, with unique hair-like extensions produced from apical cells of all 4 rows (Boonmee et al. 2016).

Digitodesmium P.M. Kirk, Trans. Br. mycol. Soc. 77(2): 284 (1981)

Index Fungorum number: IF 8029; Facesoffungi number: FoF 01264; 7 morphological species (Species Fungorum 2020), 2 species with molecular data.

Type species - Digitodesmium elegans P.M. Kirk, Trans. Br. mycol. Soc. 77(2): 286 (1981)

Notes - Digitodesmium is characterized by punctiform, sporodochial conidiomata and acrogenous, euseptate, cheiroid, digitate conidia with apical gelatinous caps (Boonmee et al. 2016).

Gregarithecium Kaz. Tanaka \& K. Hiray., Stud. Mycol. 82: 88 (2015).

Index Fungorum number: IF 811298; Facesoffungi number: FoF 08213; 1 morphological species (Species Fungorum 2020), 1 species with molecular data.

Type species - Gregarithecium curvisporum Kaz. Tanaka \& K. Hiray., Stud. Mycol. 82: 88 (2015).

Notes - Gregarithecium belongs to family Dictyosporiaceae, and was introduced by Tanaka et al. (2015). Members of this genus have immersed to erumpent, depressed globose to hemisphaerical ascomata with flattened base, fissitunicate 8-spored asci and hyaline broadly fusiform ascospores with a median septum, surrounded by an entire sheath. Gregarithecium is reminiscent of species in Massarina sensu lato (Aptroot 1998, Tanaka \& Harada 2003d. However, Gregarithecium can be distinguished from Massarina sensu lato by stromatic tissue surrounding the ascomata.

Jalapriya M.J. D'souza, Hong Y. Su, Z.L. Luo \& K.D. Hyde, Fungal Divers. 80: 476 (2016).

Index Fungorum number: IF 551583; Facesoffungi number: FoF 01269; 3 morphological species (Species Fungorum 2020), 2 species with molecular data.

Type species - Jalapriya pulchra M.J. D'souza, Hong Y. Su, Z.L. Luo \& K.D. Hyde, Fungal Divers. 80: 476 (2016).

Notes - Jalapriya is characterized by micronematous, unbranched conidiophores, holoblastic, integrated, determinate, terminal conidiogenous cells and solitary, cheiroid, euseptate conidia with 
5-7 rows of cells, rows converging or not converging at apex, apical cells with or without appendages (Boonmee et al. 2016).

Neodendryphiella Iturrieta-González, Dania García \& Gené, MycoKeys 37: 19-38 (2018).

Index Fungorum number: IF 824664; Facesoffungi number: FoF 08214; 3 morphological species (Species Fungorum 2020), 3 species with molecular data.

Type species - Neodendryphiella mali Iturrieta-González, Gené \& Dania García, MycoKeys 37: 19-38 (2018).

Notes - Neodendryphiella was established by Iturrieta-González et al. (2018) based on morphology and phylogeny, species of this genus were reported on herbivore dung in Mexico and Spain. Species in this genus are characterized by semi-macronematous to macronematous, unbranched or branched towards the apical region, smooth to verrucose conidiophores, polytretic, integrated, terminal or intercalary conidiogenous cells and blastocatenate, aseptate or septate, ellipsoidal, doliiform, clavate or subcylindrical conidia.

Pseudocoleophoma Kaz. Tanaka \& K. Hiray., Stud. Mycol. 82: 89 (2015).

Index Fungorum number: IF 811300; Facesoffungi number: FoF 07534; 7 morphological species (Species Fungorum 2020), 7 species with molecular data.

Type species - Pseudocoleophoma calamagrostidis Kaz. Tanaka \& K. Hiray., Stud. Mycol. 82: 89 (2015).

Notes - Pseudocoleophoma was introduced by Tanaka et al. (2015) with two sexual species. Subsequently, two new species were added (Hyde et al. 2016, Jayasiri et al. 2019). Four species are accepted in this genus and all were reported from terrestrial habitats (Tanaka et al. 2015, Hyde et al. 2016, Jayasiri et al. 2019). Members of this genus are characterized by immersed to erumpent, globose to subglobose, ostiolate ascomata, fissitunicate, cylindrical to clavate asci and fusiform, 1septate ascospores with a conspicuous sheath.

Pseudoconiothyrium Crous \& R.K. Schumach., Fungal Systematics and Evolution 3: 57-134 (2019).

Index Fungorum number: IF 829339; Facesoffungi number: FoF 08215; 1 morphological species (Species Fungorum 2020), 1 species with molecular data.

Type species - Pseudoconiothyrium broussonetiae Crous \& R.K. Schumach., Fungal Systematics and Evolution 3: 57-134 (2019).

Notes - Pseudoconiothyrium is characterized by eustromatic, pycnidial conidiomata with a central opening, phialidic, percurrent proliferation of conidiogenous cells and aseptate, subcylindrical to ellipsoid to subglobose, verruculose conidia (Crous et al. 2019a).

Pseudodictyosporium Matsush., Bull. natn. Sci. Mus., Tokyo, N.S. 14: 473 (1971).

Index Fungorum number: IF 9568; Facesoffungi number: FoF 01266; 4 morphological species (Species Fungorum 2020), 4 species with molecular data.

Type species - Pseudodictyosporium wauense Matsush., Bull. natn. Sci. Mus., Tokyo 14(3): 473 (1971).

Notes - Pseudodictyosporium was proposed to accommodate species with dictyosporous conidia, but distinguished from Dictyosporium on account of the long conidiophores and heartshaped conidia. Species in this genus are characterized by macronematous, branched, solitary or grouped conidiophores, monoblastic, integrated, determinate conidiogenous cells and cheiroid conidia with $2-3$ rows of cells.

Vikalpa M.J. D'souza, Boonmee, Bhat \& K.D. Hyde, Fungal Divers. 80: 479 (2016).

Index Fungorum number: IF 551585; Facesoffungi number: FoF 01361; 4 morphological species (Species Fungorum 2020), molecular data unavailable.

Type species - Vikalpa micronesiaca (Matsush.) M.J. D'souza, Bhat \& K.D. Hyde, Fungal Divers. 80: 479 (2016). 
三Dictyosporium micronesiacum Matsush. [as 'micronesicum'], Matsush. Mycol. Mem. 2: 8 (1981).

Notes - Vikalpa was introduced by Boonmee et al. (2016) for species with euseptate conidia with 3 rows of cells each in a different plane.

\section{Ecological and economic significance}

There are mostly saprobic fungi with the ability to decompose lignocellulose in woody litter, softening the wood and releasing nutrients into simple molecules that go back into the soil and can be reused by plants and all other organisms (Yuen et al. 1998, Bucher et al. 2004).

Didymellaceae Gruyter, Aveskamp \& Verkley, Mycol. Res. 113(4): 516 (2009).

$=$ Microsphaeropsidaceae $\mathrm{Q}$. Chen et al.

Index Fungorum number: IF 508292; Facesoffungi number: FoF 08216, >300 species.

Endophytic, pathogenic and saprobic on a wide range of hosts worldwide. Sexual morph: Pseudothecia immersed, rarely superficial, separate or gregarious, globose to flattened, ostiolate, with 2-5(-8) layers of pseudoparenchymatal cells. Ostiole: Asci arising from a broad hymenium among pseudoparaphyses. Hamathecium of mostly cellular pseudoparaphyses. Asci 8-spored, bitunicate, cylindrical to clavate or saccate. Ascospores mostly hyaline, or brownish, 1-septate spores (didymospores) or multi-septate dictyospores. Asexual morph: Coelomycetous. Conidiomata pycnidial, immersed, or semi immersed, sometimes becoming erumpent, uni-locular, pale to medium brown, globose, thin or thick-walled, peridium with cells of textura angularis. Ostiole central, circular, papillate or not. Conidiophores mostly absent, and then either filiform, septate, and branched, or short, irregularly branched and ramified respectively. Conidiogenous cells enteroblastic, phialidic, doliiform to lageniform, ampulliform or cylindrical, hyaline, thin-walled, smooth-walled. Conidia ellipsoid, cylindrical, fusiform, pyriform or globose, hyaline or pigmented, septate or aseptate, thin-walled, guttulate.

Type - Didymella Sacc.

Notes - Species belonging to Didymellaceae are cosmopolitan. They have a wide range of hosts and many are pathogens (Chen et al. 2015). They also include endophytes, fungicolous and lichenicolous taxa. Didymellaceae was introduced by de Gruyter et al. (2009). This family is the largest family in the Pleosporales (Ascomycota, Pezizomycotina, Dothideomycetes). In the beginning, Didymellaceae consisted of Ascochyta, Didymella and Phoma (Aveskamp et al. 2010). Aveskamp et al. (2010) redefined Epicoccum, Peyronellaea Gold. ex Togliani and Stagonosporopsis and introduced Boeremia. After several years of species conflicts, Chen et al. (2015) accepted 17 well supported monophyletic clades in Didymellaceae as individual genera. In the same study, Microsphaeropsis was introduced into new family Microsphaeropsidaceae as these species are distinct from the members of Didymellaceae and phylogenetically this genus is basal to the Didymellaceae (Chen et al., 2015). A phylogenetic analysis conducted by Wanasinghe et al. (2018b) showed that this genus clusters within Didymellaceae and closely related to Macroventuria. Similar results are observed in this study (Fig. 76). In Didymellaceae, sexual morphs are rare compared to the asexual morph. Therefore, it is difficult to compare sexual morphs and exclude this genus under Didymellaceae. In asexual morphs, most of the characters (Chen et al. 2017) are shared and similar to other genera in family Didymellaceae. Hence in this study, we accept Microsphaeropsis in Didymellaceae.

After Chen et al. (2015), several other genera were added to this family. These include Briansuttonomyces (Crous \& Groenewald 2016), Neomicrosphaeropsis (Thambugala et al. 2017a), Didymellocamarosporium (Wijayawardene et al. 2016a), Heracleicola and Neodidymella (Ariyawansa et al. 2015a). Didymellocamarosporium was introduced by Wijayawardene et al. (2016a) as a monotypic genus. Furthermore, Chen et al. (2017) conducted a phylogenetic analysis using DNA sequence data (LSU region) of the type species of this genus and showed that this species is embedded within Neomicrosphaeropsis. Similar results are observed in the phylogenetic analysis conducted in this study (Fig. 76). Therefore, we synonymize Didymellocamarosporium under Neomicrosphaeropsis. Ariyawansa et al. (2015a) introduced Neodidymella. Until now, sequence data for Neodidymella were not available in the NCBI database. Therefore, this genus was 
ignored by previous studies. However, we accept this genus in Didymellaceae with molecular data (Fig. 76). In Wijayawardene et al. (2017a), the following genera have been accepted under Didymellaceae; Chaetasbolisia, Endocoryneum, Endophoma, Mixtura, Monascostrom, Peyronellaea, Phaeomycocentrospora, Platychora and Pseudohendersonia. Phaeomycocentrospora is accepted under Dothidotthiaceae by MarinFelix et al. (2017), Wijayawardene et al. (2018), and Crous et al. (2019a). In addition to that, Endocoryneum is referred to genera incertae sedis in Pezizomycotina (Ascomycota). Phaeomycocentrospora and Endocoryneum are not accepted in Didymellaceae.

Endophoma was introduced by Tsuneda et al. (2011) to Didymellaceae. In this study, they have used ITS, LSU, and tub2 regions in phylogenetic analysis in which Endophoma clusters within the Phoma clade. In addition to that, the authors have mentioned Endophoma elongata (the type species) has close phylogenetic relationships to Phoma eupyrena while mentioning that pairwise similarity across above three gene regions are $100 \%$. Even though it has not mentioned in the recent studies that this genus should be synonymized to Phoma. Wijayawardene et al. (2016a) introduced Pseudohendersonia galiorum to Pseudohendersonia. However, the authors introduced this with only LSU sequence data and Chen et al. (2017) proposed that this is morphologically similar to genera like Ascochyta, Boeremia, Stagonosporopsis and Neomicrosphaeropsis. Therefore, recent studies did not accept this genus under Didymellaceae (Marin-Felix et al. 2017). Before adding this genus under Didymellaceae further studies are necessary. Species of Peyronellaea has been synonymized under Didymella and Phoma by Marin-Felix et al. (2017).

The remaining genera Chaetasbolisia, Mixtura, Monascostrom, and Platychora are ill studied genera in family Didymellaceae. Among them Mixtura and Monascostroma were classified under Phaeosphaeriaceae. Phookamsak et al. (2014c) studied the type material of Mixtura saginata and tentatively placed it in Didymellaceae. Most of the morphological characters of Monascostrom support that it should be a member in Didymellaceae and Schoch et al. (2009a) confirmed its taxonomic placement in Didymellaceae. Therefore, following morphological evidence from Schoch et al. (2009a), Hyde et al. (2013), Phookamsak et al. (2014c), Wijayawardene et al. (2018) and from this study, we accept these four genera under Didymellaceae but we reckon further studies are still necessary. In addition, two new genera were introduced, Anthodidymella (Phukhamsakda et al. 2020) and Vandijckomycella (Hou et al. 2020). Based on the above discussion we accept 35 genera in Didymellaceae.

Didymella Sacc. ex Sacc. Syll. Fung. 1: 545 (1882).

Index Fungorum number: IF 1548; Facesoffungi number: FoF 07278; 418 records (Species Fungorum 2020), 58 species with molecular data.

Type species - Didymella exigua (Niessl) Sacc., Michelia 2: 57 (1880).

$\equiv$ Didymosphaeria exigua Niessl, Oesterr. Bot. Z. 25: 165 (1875).

Notes - Didymella was emended to accommodate Peyronellaea and several other phoma-like species (Chen et al. 2015). They are ubiquitous and occur as pathogens and endophytes on a wide range of hosts (Chen et al. 2015, 2017, Jayasiri et al. 2017b). Most species produce chlamydospores in culture.

\section{Other genera included}

Allophoma Qian Chen \& L. Cai, Stud. Mycol. 82: 162 (2015).

Index Fungorum number: IF 814058; Facesoffungi number: FoF 08217; 11 morphological species (Species Fungorum 2020), 11 species with molecular data.

Type species - Allophoma tropica (R. Schneid. \& Boerema) Qian Chen \& L. Cai, Stud. Mycol. 82: 164 (2015).

$\equiv$ Phoma tropica R. Schneid. \& Boerema, Phytopath. Z. 83(4): 361 (1975)

Notes - Allophoma was introduced by Chen et al. (2015) based on morphological and phylogenetic data. This genus is characterised by ovoid, oblong, aseptate conidia which are ellipsoidal to cylindrical, or slightly allantoid (Chen et al. 2015). Eleven species are accepted in Allophoma (Marin-Felix et al. 2019). 


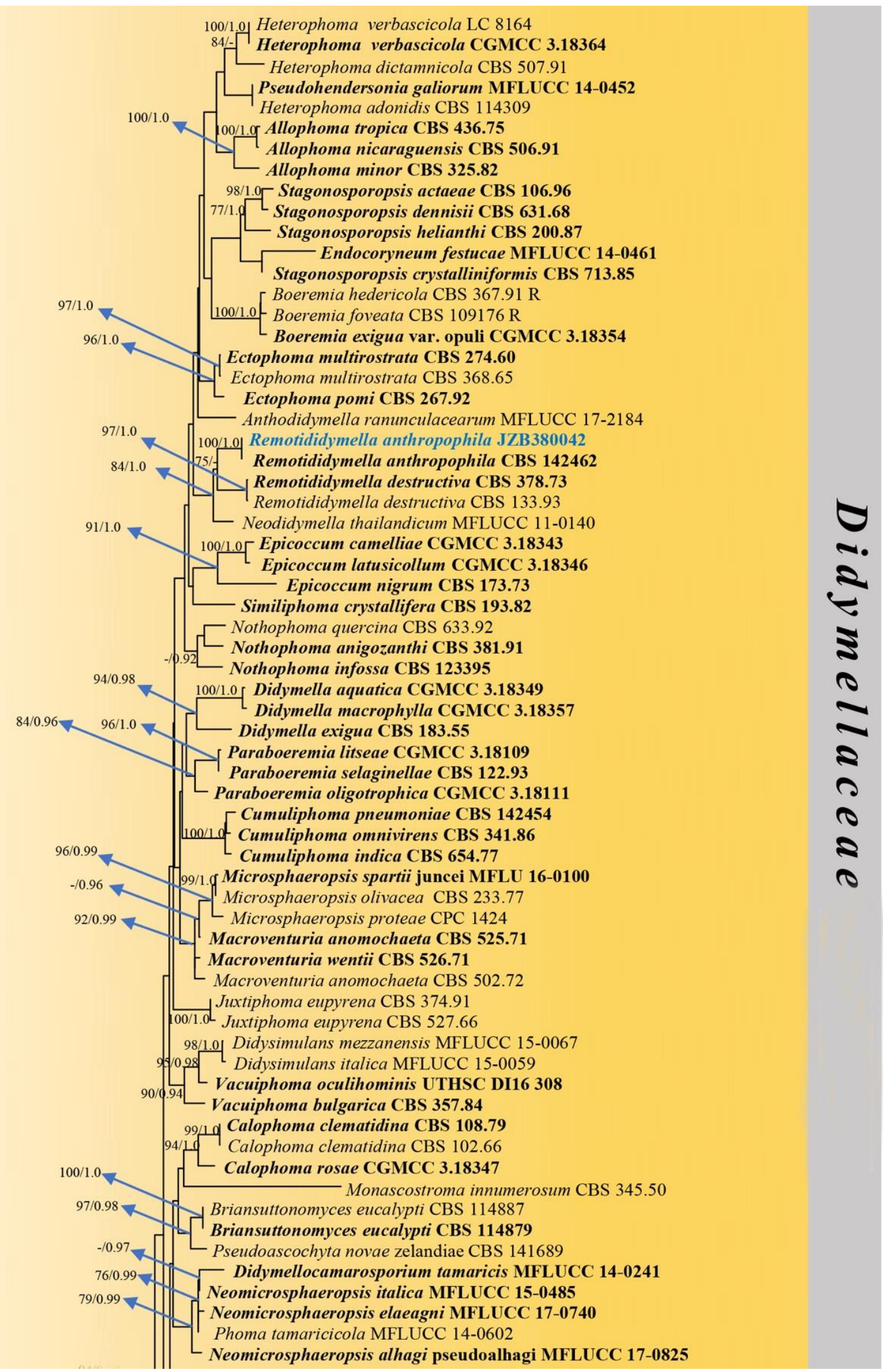

Figure 76 - Phylogram generated from maximum likelihood analysis (RAxML) of genera in Didymellaceae based on ITS, LSU, rpb-2 and tub2 sequence data. Maximum likelihood bootstrap values equal or above $70 \%$, Bayesian posterior probabilities equal or above 0.90 (MLBS/PP) are given at the nodes. An original isolate number is noted after the species name. The tree is rooted to Leptosphaeria conoidea (CBS 616.75) and L. doliolum (CBS 505.75). The ex-type strains are indicated in bold. Newly sequence is in blue. Hyphen (-) represents support values below $70 \%$ MLBS and 0.90 PP. 


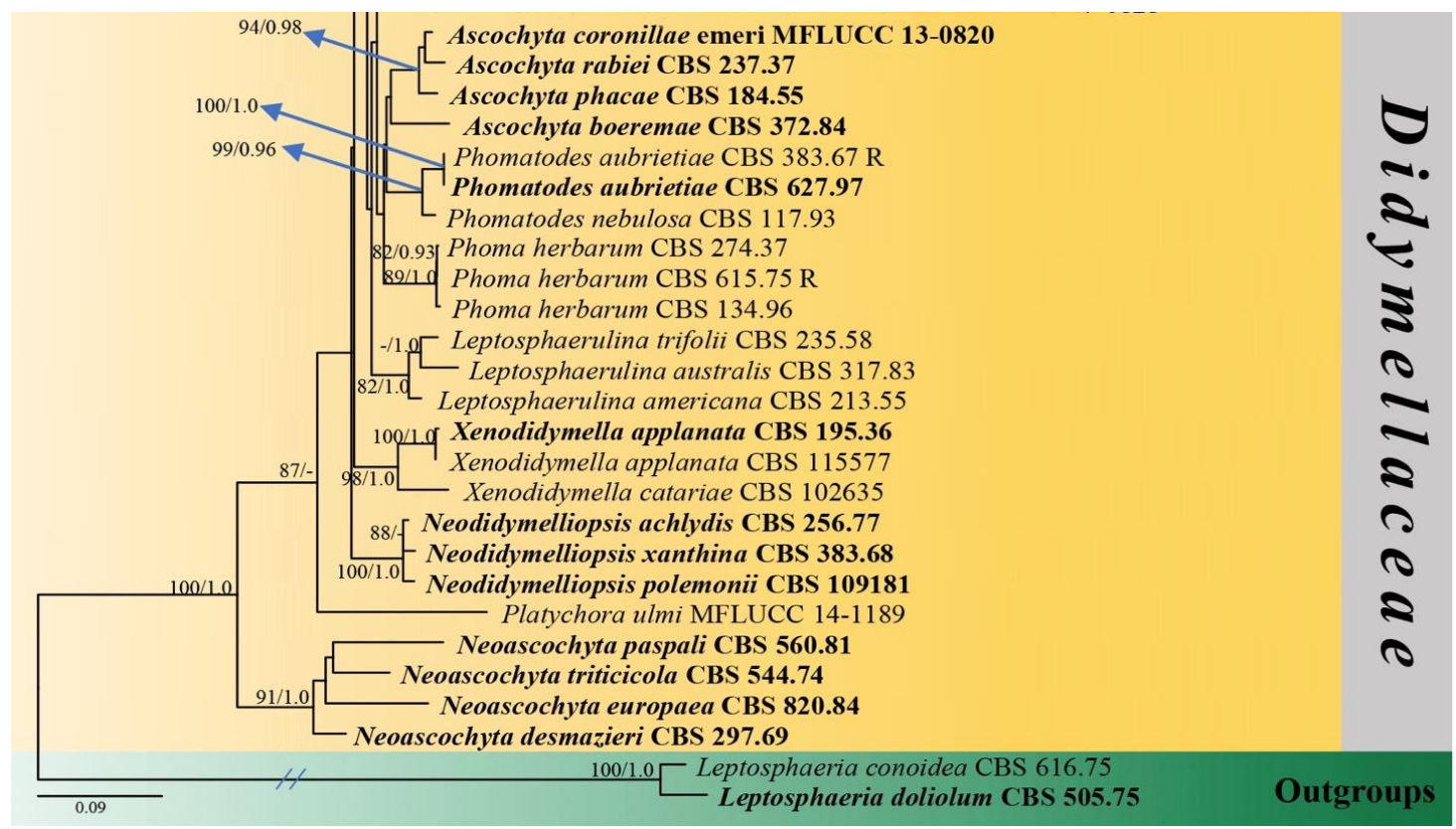

Figure 76 - Continued.

Anthodidymella Phukhams., Camporesi \& K.D. Hyde, in Phukhamsakda et al. 102: 21 (2020). Index Fungorum number: IF 557128; Facesoffungi number: FoF 07255; 3 species with molecular data.

Type species - Anthodidymella ranunculacearum Phukhams., Camporesi \& K.D. Hyde, in Phukhamsakda et al. 102: 27 (2020).

Notes - This genus was introduced by Phukhamsakda et al. (2020) associated with Clematis species. Anthodidymella differs from Didymella in having broad-cylindrical asci, obpyriform and lacks elongated ascospores (Phukhamsakda et al. 2020).

Ascochyta Lib., Plantae Cryptogamae, quas in Arduenna collegit Fasc. 1: 8 (1830).

Index Fungorum number: IF 7239; Facesoffungi number: FoF 07121; 723 morphological species (Species Fungorum 2020), 18 species with molecular data.

Type species - Ascochyta pisi Lib., Pl. crypt. Arduenna, fasc. 1: no. 59. 1830.

Notes - Ascochyta is a well-known pathogenic genus in Didymellaceae. Earlier this genus was described using its sexual morphs and Chen et al. (2015) linked asexual morph to this genus. They are characterised with oblong to ellipsoidal aseptate conidia in Didymellaceae. The hostspecificity of the species belonging to this genus is rather restricted, and they occur mostly on the Campanulaceae, Chenopodiaceae, Leguminosae, Poaceae, Solanaceae and Umbelliferae (Valenzuela-Lopez et al. 2018). Some species are associated with one specific host, but may also be found on other related species of the same genus or family (Boerema \& Bollen 1975). Even though there are 1438 records in Index Fungorum (2020) and 1347 records available in Mycobank (2020), currently only 18 species are accepted including two varieties of Ascochyta medicaginicola (Chen et al. 2017, Jayasiri et al. 2017b, Valenzuela-Lopez et al. 2018, Hyde et al.2018, Wanasinghe et al. 2018b).

Boeremia Aveskamp et al., Stud. Mycol. 65: 36 (2010).

Index Fungorum number: IF 515621; Facesoffungi number: FoF 07128; 21 morphological species (Species Fungorum 2020), 21 species with molecular data.

Type species - Boeremia exigua (Desm.) Aveskamp et al., Stud. Mycol. 65: 36 (2010).

三Phoma exigua Desm., Annls Sci. Nat., Bot., sér. 3 11(2): 282 (1849).

Notes - Boremia differs from the other genera in Didymellaceae based on morphology of the ostiole. They develop smoothly lined ostiole, and have distinct hyaline cells lining their ostiolar openings. In addition, these species develop fewer conidia in culture than on the host (Aveskamp et 
al. 2010). There are 21 species associated with this genus and phylogenetically distinct varieties have been identified for Boeremia exigua.

Briansuttonomyces Crous, Fungal Biol. 120(11): 1412 (2016).

Index Fungorum number: IF 816146; Facesoffungi number: FoF 08218; 1 morphological species (Species Fungorum 2020), 1 species with molecular data.

Type species - Briansuttonomyces eucalypti Crous, Fungal Biology 120(11): 1412 (2016).

Notes - Species belonging to this genus was previously categorised under Coleophoma (Valenzuela-Lopez et al. 2018). Valenzuela-Lopez et al. (2018) defined Briansuttonomyces as a monophyletic lineage in Didymellaceae to accommodate Briansuttonomyces eucalypti. Briansuttonomyces is similar to Coleophoma, but the conidia are 1-septate, and the conidiomata lack paraphyses (Crous \& Groenewald 2016). There is only a single species assigned to this genus.

Calophoma Qian Chen \& L. Cai, Stud. Mycol. 82: 191 (2015).

Index Fungorum number: IF 814063; Facesoffungi number: FoF 08219; 11 morphological species (Species Fungorum 2020), 11 species with molecular data. (2015).

Type species - Calophoma clematidina (Thüm.) Qian Chen \& L. Cai, Stud. Mycol. 82: 192

$\equiv$ Ascochyta clematidina Thüm., Bull. Soc. Imp. nat. Moscou 55: 98 (1880).

Notes - Species belonging to this genus are characterised by their asexual characters such as subglobose, subcylindrical, ellipsoidal, somewhat obclavate-fusiform conidia which are aseptate of with a single septum. These fungi develop chlamydospores which are unicellular or multicellular in culture (Chen et al. 2015). Ten species are recognised (Hyde et al. 2020a).

Chaetasbolisia Speg., Physis, Rev. Soc. Arg. Cienc. Nat. 4(no. 17): 293 (1918).

Index Fungorum number: IF 7559; Facesoffungi number: FoF 07144; 7 morphological species (Species Fungorum 2020), 2 species with molecular data.

Type species - Chaetasbolisia erysiphoides (Griffon \& Maubl.) Griffon \& Maubl., Physis, Rev. Soc. Arg. Cienc. Nat. 4(no. 17): 293 (1918).

三Chaetophoma erysiphoides Griffon \& Maubl., Bull. Soc. mycol. Fr. 25: 60 (1909).

Notes - Chaetasbolisia is a less studied genus in Didymellaceae. Aveskamp et al. (2009) suggested that even though the type of this genus clusters together with the Phoma section Chaetasbolisia (Similar results in De Gruyter et al. 2009), it should be treated as separate genus and recommended restudying both morphological and phylogeny.

Cumuliphoma Valenz.-Lopez, Stchigel, Crous, Guarro \& Cano, Stud. Mycol. 90: 38 (2017).

Index Fungorum number: IF 819878; Facesoffungi number: FoF 08220; 3 morphological species (Species Fungorum 2020), 3 species with molecular data.

Type species - Cumuliphoma omnivirens (Aveskamp et al.) Valenzuela-Lopez, Stchigel, Crous, Guarro \& Cano.

三Phoma omnivirens Aveskamp, Verkley \& Gruyter, Mycologia 101(3): 375 (2009).

Notes - Cumuliphoma was introduced by Valenzuela-Lopez et al. (2018). Species belonging to this genus produce aseptate conidia which are hyaline, smooth- and thin-walled, ellipsoidal to cylindrical, guttulate.

Didysimulans Tibpromma, Camporesi \& K.D. Hyde, Fungal Divers. 83: 76 (2017).

Index Fungorum number: IF 552770; Facesoffungi number: FoF 2884; 2 morphological species (Species Fungorum 2020), 2 species with molecular data.

Type species - Didysimulans mezzanensis Tibpromma, Camporesi \& K.D. Hyde., Fungal Divers.Divers. 83: 76 (2017).

Notes - Didysimulans was introduced by Tibpromma et al. (2017). Species of this genus are similar in morphology to Didymella. However, this genus is distinguished from Didymella by its ovoid to ellipsoidal ascospores. 
Ectophoma Valenz.-Lopez, Cano, Crous, Guarro \& Stchigel, Stud. Mycol. 90: 34 (2017).

Index Fungorum number: IF 819952; Facesoffungi number: FoF 08221; 3 morphological species (Species Fungorum 2020), 2 species with molecular data.

Type species - Ectophoma multirostrata (P.N. Mathur et al.) Valenzuela-Lopez, Cano, Crous, Guarro \& Stchigel, Stud. Mycol. 90: 34 (2017).

三 Ectophoma multirostrata (P.N. Mathur, S.K. Menon \& Thirum.) Valenz.-Lopez, Cano, Crous, Guarro \& Stchigel, Stud. Mycol. 90: 34 (2017).

Notes - Aveskamp et al. (2009) transferred taxa from Sphaeronaema to Phoma. After that Valenzuela-Lopez et al. (2018) introduced this genus to accommodate those taxa in family Didymellaceae. However, the species belonging to Ectophoma constitute a distinct clade in the multi-gene phylogenetic analysis of Didymellaceae (Valenzuela-Lopez et al. (2018). Ectophoma has conidia that are aseptate, hyaline, smooth- and thin walled, oblong to ellipsoidal, and guttulate. There are three species associated with this genus (Species Fungorum 2020).

Epicoccum Link, Mag. Gesell. naturf. Freunde, Berlin 7: 32 (1816) [1815].

Index Fungorum number: IF 8188; Facesoffungi number: FoF 08222; 71 morphological species (Species Fungorum 2020), 30 species with molecular data.

Type species - Epicoccum nigrum Link, Mag. Neuesten Entdeck. Gesammten Naturk. Ges. Naturf. Freunde Berlin 7: 32 (1815).

Notes - Epicoccum was previously characterised with its epicoccoid conidia in family Didymellaceae (Aveskamp et al. 2010). Chen et al. (2015) added irregular pycnidial conidiomata and subcylindrical shaped conidia as an added feature to distinguish these species. Species belonging to this genus are well known pathogens (Chen et al. 2015). There are 146 records available in Index Fungorum (2020) and there are 120 records in MycoBank (2020). However, for most of the species described before the year 2000, sequence data are unavailable and only 29 species are known from culture and sequence data (Chethana et al. 2019).

Heterophoma Qian Chen \& L. Cai, in Chen et al., Stud. Mycol. 82: 165 (2015).

Index Fungorum number: IF 814059; Facesoffungi number: FoF 08223; 6 morphological species (Species Fungorum 2020), 6 species with molecular data.

Type species - Heterophoma sylvatica (Sacc.) Q. Chen \& L. Cai Stud. Mycol. 82: 165 (2015)

$\equiv$ Phoma sylvatica Sacc., Michelia 2(no. 7): 337 (1881).

Notes - This genus is morphologically similar to Phoma but it is not phylogenetically closely related (Chen et al. 2015). Species belonging to this genus develop conidia which are variable in shape (ellipsoidal, oblong, cylindrical, reniform, or slightly allantoid) and aseptate or 1-2 septate (Chen et al. 2015). There are six species in this genus, and those are the only records in both Index Fungorum and Mycobank.

Juxtiphoma Valenzuela-Lopez, Cano, Crous, Guarro, Stchigel, Stud. Mycol. 90: 40 (2017).

Index Fungorum number: IF 821111; Facesoffungi number: FoF 08224; 2 morphological species (Species Fungorum 2020), 2 species with molecular data.

Type species - Juxtiphoma eupyrena (Sacc.) Valenz.-Lopez, Crous, Stchigel, Guarro \& Cano, Stud. Mycol. 90: 40 (2017).

$\equiv$ Phoma eupyrena Sacc., Michelia 1(no. 5): 525 (1879).

Notes - Juxtiphoma was introduced to accommodate Juxtiphoma eupyrena in Didymellaceae. This species was previously known as Phoma eupyrena, which was introduced by Saccardo (1879) and Boerema et al. (2004) added this species to section Phoma. However, after several revisions (Aveskamp et al. 2009, 2010), Valenzuela-Lopez et al. (2018) moved it to a new genus. There is only one species in this genus (Valenzuela-Lopez et al. 2018).

Leptosphaerulina McAlpine, Fungus Diseases of stonefruit trees in Australia: 103. 1902.

Index Fungorum number: IF 2802; Facesoffungi number: FoF 08225; 49 morphological species (Species Fungorum 2020), 10 species with molecular data. 
Type species - Leptosphaerulina australis McAlpine, Fungus Diseases of stone-fruit trees in Australia: 103. 1902.

Notes - Leptosphaerulina was introduced to accommodate the type species L. australis (McAlpine 1902). It was first accommodated in Pleosporaceae (Inderbitzin et al. 2000, Kodsueb et al. 2006) but Kodsueb et al. (2006) assigned this genus under Didymellaceae. Only the sexual morph has been observed. Leptosphaerulina is distinct from Macroventuria and Didymella even though they have hyaline ascospores. Leptosphaerulina produces large, longitudinally and transversally septate ascospores (Aveskamp et al. 2010). There are ten species assigned to this genus (Tennakoon et al. 2019) while there are 62 associated records in Index Fungorum (2020) and 69 records in MycoBank (2020).

Macroventuria Aa, Persoonia 6: 359. 1971.

Index Fungorum number: IF 2972; Facesoffungi number: FoF 08226; 2 morphological species (Species Fungorum 2020), 2 species with molecular data.

Type species - Macroventuria anomochaeta Aa, Persoonia 6: 362 (1971).

Notes - This genus was established by van der Aa (1971). Initially, this genus was assigned to Venturiaceae and then it was assigned to several different families such as Pseudosphaeriaceae by Barr (1982) and then in Pleosporaceae by Eriksson \& Hawksworth (1986), (Kodsueb et al. 2006). Aveskamp et al. (2010) added this genus to Didymellaceae. There are only two species associated with this genus and those are the only records in Index Fungorum and Mycobank.

Microsphaeropsis Syd. \& P. Syd., Annls mycol. 14(5): 369 (1916).

Index Fungorum number: IF 8936; Facesoffungi number: FoF 08716; 45 morphological species (Species Fungorum 2020), 4 species with molecular data.

Type species - Microsphaeropsis olivacea (Bonord.) Höhn. [as 'olivaceus'], Hedwigia 59(5): 267 (1917).

$\equiv$ Coniothyrium olivaceum Bonord., in Fuckel, Jb. nassau. Ver. Naturk. 23-24: 377 (1870) [1869-70].

Notes - Microsphaeropsis was introduced by von Höhnel (1917a). The familial placement of this genus has changed over last years from Phaeosphaeriaceae (Barr 1987b), to Didymosphaeriaceae (Zhang et al. 2012b, Thambugala et al. 2017a), and then to Didymellaceae (De Gruyter et al. 2013, Hyde et al. 2013) and finally to Microsphaeropsidaceae Chen et al. (2015). However, the taxonomic placement of this genus in Didymellaceae is debatable as Chen et al. (2015) mentioned this as basal to Didymellaceae and Wanasinghe et al. (2018b) showed this genus resides within the Didymellaceae. Similar results are observed in our analyses as well (data now shown). Furthermore, Microsphaeropsis species develop pale greenish brown, finely roughened conidia which are hyaline, smooth in many Didymellaceae species. Future studies are necessary to clarify the taxonomic identity and species boundaries. This genus comprises four species (Thambugala et al. 2018, Wanasinghe et al. 2018b).

Mixtura O.E. Erikss. \& J.Z. Yue, Mycotaxon 38: 203 (1990).

Index Fungorum number: IF 25518; Facesoffungi number: FoF 00278; 1 morphological species (Species Fungorum 2020), molecular data unavailable.

Type species - Mixtura saginata (Syd.) O.E. Erikss. \& J.Z. Yue, Mycotaxon 38: 203 (1990).

三Leptosphaeria saginata Syd., Annls mycol. 37(4/5): 377 (1939).

Notes - Mixtura was previously classified under Phaeosphaeriaceae. After studying the type material by Phookamsak et al. (2014c) this genus was tentatively placed in Didymellaceae. Mixtura saginata has been reported causing causes leaf spots on Chusquea serrulata (Zhang et al. 2012b, Phookamsak et al. 2014c).

Monascostroma Höhn., Annls mycol. 16(1/2): 160 (1918).

Index Fungorum number: IF 3246; Facesoffungi number: FoF 00547; 7 morphological species (Species Fungorum 2020), 2 species with molecular data. 
Type species - Monascostroma innumerosum (Desm.) Höhn. [as 'innumerosa'], Annls mycol. 16(1/2): 160 (1918).

三 Hendersonia innumerosa Desm., Annls Sci. Nat., Bot., sér. 3 16: 10 [repr.] (1851)

Notes - Schoch et al. (2009a) showed that this genus groups with members in Didymellaceae. Morphologically this genus fits well within Didymellaceae with few morphological differences. Further studies are needed.

Neoascochyta Qian Chen \& L. Cai, Stud. Mycol. 82: 198 (2015).

Index Fungorum number: IF 814064; Facesoffungi number: FoF 07462; 13 morphological species (Species Fungorum 2019), 13 species with molecular data. (2015).

Type species - Neoascochyta exitialis (Morini) Qian Chen \& L. Cai, Stud. Mycol. 82: 200

ESphaerella exitialis Morini, Nuovo G. bot. ital. 18(1): 37 (1886).

Notes - Neoascochyta was introduced by Chen et al. (2015) to accommodate taxa which are morphologically similar but phylogenetically distinct from Ascochyta. They have fusoid to cylindrical, obclavate-ovoid to ellipsoidal aseptate or single septate conidia and cylindrical to ovoid, or ellipsoidal single septate ascospores (Chen et al. 2015).

Neodidymella Phookamsak, R.H. Perera \& K.D. Hyde, in Ariyawansa et al., Fungal Diversity: 75:61 (2015).

Index Fungorum number: IF 551389; Facesoffungi number: FoF 00904; 1 morphological species (Species Fungorum 2020), 1 species with molecular data.

Type species - Neodidymella thailandica Phookamsak, R.H. Perera \& K.D. Hyde [as 'Neodidymella thailandicum'], in Ariyawansa et al., (2015).

三Neodidymella thailandicum Phookamsak \& K.D. Hyde, [as 'thailandicum'], in Ariyawansa et al., Fungal Divers, 79: 36 (2015).

Notes - Neodidymella was introduced by Ariyawansa et al. (2015a) as a sexual genus under Didymellaceae. Neodidymella forms a sister clade to Remotididymella, which was introduced as an asexual genus by Valenzuela-Lopez et al. (2018). However, Jayasiri et al. (2019) provided the sexual morph of Remotididymella. Morphologically these two genera can be differentiated based on asci. Neodidymella species develop asci which are ellipsoidal to clavate, 1-septate, slightly constricted at the septum (Ariyawansa et al. 2015a), whereas Remotididymella develop asci which are fusiform, 1-3-septate, constricted at middle septum, containing up to four refractive oil globules and are irregular (Jayasiri et al. 2019).

Neodidymelliopsis Qian Chen \& L. Cai, Stud. Mycol. 82: 207 (2015).

Index Fungorum number: IF 814066; Facesoffungi number: FoF 07518; 11 morphological species (Species Fungorum 2020), 11 species with molecular data.

Type species - Neodidymelliopsis cannabis (G. Winter) Qian Chen \& L. Cai, Stud. Mycol. 82: 207 (2015).

三Sphaerella cannabis G. Winter, Hedwigia 11: 145 (1872).

Notes - This genus was introduced by Chen et al. (2015), which forms a distinct clade in Didymellaceae yet is similar to Didymella.

Neomicrosphaeropsis Thambug., Camporesi \& K.D. Hyde, Fungal Diversity 82: 261 (2016).

Index Fungorum number: IF 552089; Facesoffungi number: FoF 02157; 10 morphological species (Species Fungorum 2020), 10 species with molecular data.

Type species - Neomicrosphaeropsis italica Thambug., Camporesi \& K.D. Hyde, Fungal Diversity 82: 264 (2016).

Notes - Neomicrosphaeropsis was introduced by (Thambugala et al. 2017a) to accommodate species which are similar but phylogenetically different from Microsphaeropsis. There are ten species associated with this genus (Thambugala et al. 2017, Wanasinghe et al. 2018a). 
Nothophoma Qian Chen \& L. Cai, Stud. Mycol. 82: 212 (2015).

Index Fungorum number: IF 814060; Facesoffungi number: FoF 08227; 11 morphological species (Species Fungorum 2020), 11 species with molecular data.

Type species - Nothophoma infossa (Ellis \& Everh.) Qian Chen \& L. Cai, Stud. Mycol. 82: 213 (2015).

$\equiv$ Phoma infossa Ellis \& Everh., J. Mycol. 4(10): 102 (1888).

Notes - This genus was introduced by Chen et al. (2015) with the type species Nothophoma infossa (syn. Phoma infossa). Species belonging to this genus have characteristic ovoid, oblong to ellipsoidal aseptate conidia.

Paraboeremia Qian Chen \& L. Cai, Stud. Mycol. 82: 183 (2015).

Index Fungorum number: IF 814061; Facesoffungi number: FoF 08228; 9 morphological species (Species Fungorum 2020), 9 species with molecular data.

Type species - Paraboeremia selaginellae (Sacc.) Qian Chen \& L. Cai, Stud. Mycol. 82: 184 (2015).

$\equiv$ Phyllosticta selaginellae Sacc., Malpighia 11(6-8): 304 (1897).

Notes - Paraboeremia resembles Boeremia, but it is phylogenetically distinct. Species belonging to this genus are characterised by phialidic, globose to flask-shaped conidiogenous cells, and aseptate, guttulate, ellipsoidal, sometimes curved, hyaline to greenish conidia (Chen et al. 2015).

Phoma Sacc., Michelia 2 (6): 4 (1880).

Index Fungorum number: IF 4014; Facesoffungi number: FoF 08229; 2218 morphological species (Species Fungorum 2020), 2 species with molecular data.

Type species - Phoma herbarum Westend., Bull. Acad. Roy. Sci. Belgique, Cl. Sci. 19: 118 (1852).

Notes - When Aveskamp et al. (2010) refined Didymellaceae, they included phomoid taxa that could not be placed in other sections or genera due to the lack or presence of typical sectional characters. They synonymised fifteen species under this genus. However, Chen et al. (2015) assigned characters of sexual morph (Atradidymella) of Phoma herbarum as the type species of this genus. Species belonging to this genus develop fusiform, one septate ascospores and oblong to cylindrical, ellipsoidal, sometimes fusiform aseptate conidia. There are 3292 records in Index Fungorum (2020) and 2818 associated records in Mycobank (2020). However, most of those names are synonymised under several other genera in Didymellaceae, some are assigned to different families and finally, there are only two species accepted under Phoma (Chen et al. 2015, 2017, Valenzuela-Lopez et al. 2018).

Phomatodes Qian Chen \& L. Cai, Stud. Mycol. 82: 191 (2015).

Index Fungorum number: IF 814062; Facesoffungi number: FoF 08230; 2 morphological species (Species Fungorum 2020), 2 species with molecular data. (2015).

Type species - Phomatodes aubrietiae (Moesz) Q. Chen \& L. Cai, Stud. Mycol. 82: 191

ESclerophomella aubrietiae Moesz, Choroby i Szkodniki Roslin (Warsaw) 3: 144 (1926).

Notes - This genus was introduced by Chen et al. (2015) to accommodate taxa which have conidia similar to Phoma but are phylogenetically distinct. Only the asexual morph is observed for this genus and it has characteristic of cylindrical to allantoid conidia which are aseptate.

Platychora Petr., Annls mycol. 23(1/2): 102 (1925).

Index Fungorum number: IF 4169; Facesoffungi number: FoF 08231; 2 morphological species (Species Funforum 2020), 1 species with molecular data.

Type species - Platychora ulmi (J. Schro“t.) Petr., Annls mycol. 23(1/2): 103 (1925).

三Sphaeria ulmi Schleich. ex Fr., Observ. mycol. (Havniae): 173 (1815). 
Notes - Hyde et al. (2013) placed Platychora within Didymellaceae. This was further supported by Hyde et al. (2016) bases on a combined ITS, LSU, rpb-2 and DNA sequence data and referred Platychora ulmi to Didymellaceae.

Pseudoascochyta Valenzuela-Lopez, Stchigel, Cano-Canals, Guarro \& Cano, Persoonia 37: 255 (2016).

Index Fungorum number: IF 817646; Facesoffungi number: FoF 08232; 2 morphological species (Species Fungorum 2020), 2 species with molecular data.

Type species - Pseudoascochyta pratensis Valenzuela-Lopez, Cano-Canals, Stchigel, Guarro \& Cano, Persoonia 37: 255 (2016).

Notes - Species belonging to this genus are similar to Ascochyta, but are phylogenetically distinct. There are two species associated with this genus Pseudoascochyta novae-zelandiae and $P$. pratensis which only differ by their growth rate on OA, smaller pycnidial measurements and conidial size and morphology (Valenzuela-Lopez et al. 2018).

Remotididymella Valenz.-Lopez, Crous, Cano, Guarro \& Stchigel, Stud. Mycol. 90: 35 (2017).

Index Fungorum number: IF 19990; Facesoffungi number: FoF 08233; 3 morphological species (Species Fungorum 2020), 3 species with molecular data.

Type species - Remotididymella destructiva (Plowr.) Valenz.-Lopez, Cano, Crous, Guarro \& Stchigel, Stud. Mycol. 90: 36.

इPhoma destructiva Plowr., Gard. Chron., N.S. 16: 621 (1881).

Notes - Remotididymella was introduced by Valenzuela-Lopez et al. (2018) based on multigene phylogenetic analysis, as taxa distinct from other genera in Didymellaceae. Valenzuela-Lopez et al. (2018) introduced this genus with two species with asexual morphs and Jayasiri et al. (2019) added a new species with sexual morph.

Remotididymella anthropophila anthropophila Valenz.-Lopez, Cano, Guarro \& Stchigel, Stud. Mycol. 90: 35 (2017).

Index Fungorum number: 819991; Facesoffungi number: FoF 06579.

Saprobic or pathogenic on leaves. Sexual morph: Undetermined. Asexual morph: Hyphae brown, smooth- and thin-walled, septate, Conidiomata pycnidial wall of textura angularis cells, 25 layered, composed of subhyaline to pale brown flattened polygonal cells. Conidiogenous cells phialidic, hyaline, smooth-walled, ampulliform to globose, 5-6 $\mu \mathrm{m}$ diam. Conidia 3.7-6.0 × 1.7$3.2 \mu \mathrm{m}$, cylindrical, hyaline, aseptate, smooth- and thin-walled, guttulate. Chlamydospores not observed.

Culture characteristics - Colonies reaching 35-40 mm diam on PDA after 5 days in the dark at $25{ }^{\circ} \mathrm{C}$. Initially white and flattened with immersed mycelium with entire margin, with age become greyish brown. Reverse white and black in the middle with age become back.

Material examined - China, Yellow River Park, Shandong, on leaf spots belong to unknown host, 07 October 2017, Yuanyuan Hao - living culture, JZB380042.

Distributions - China, on unknown plant (this study). The USA, Texas, from human bronchial secretion.

GenBank numbers - ITS: MN648210, LSU: MN640405.

Notes - We isolated Remotididymella anthropophila from leaf spots. Morphology (Fig. 77) and phylogenetic analyses (Fig. 76) indicate that our collection is Remotididymella anthropophila. So far, this species is only reported on humans and this is the first report of $R$. anthropophila associated with a plant.

Similiphoma Valenz.-Lopez, Crous, J.F. Cano, Guarro \& Stchigel, Stud. Mycol 90: 37.

Index Fungorum number: IF 820847; Facesoffungi number: FoF 08234; 1 morphological species (Species Fungorum 2020), 1 species with molecular data.

Type species - Similiphoma crystallifera (Gruyter, Noordel. \& Boerema) Valenz.-Lopez, Crous, J.F. Cano, Guarro \& Stchigel, Stud. Mycol 90: 37 (2017). 
三Phoma crystallifera Gruyter, Noordel. \& Boerema [as 'crystallifer'], Persoonia 15(3): 393 (1993).

Notes - This genus was introduced by Valenzuela-Lopez et al. (2018) to accommodate monophyletic species S. crystallifera. In multi-gene phylogeny, Similiphoma crystallifera is phylogenetically distant from Ectophoma, Epicoccum and Phoma (Valenzuela-Lopez et al. 2018).
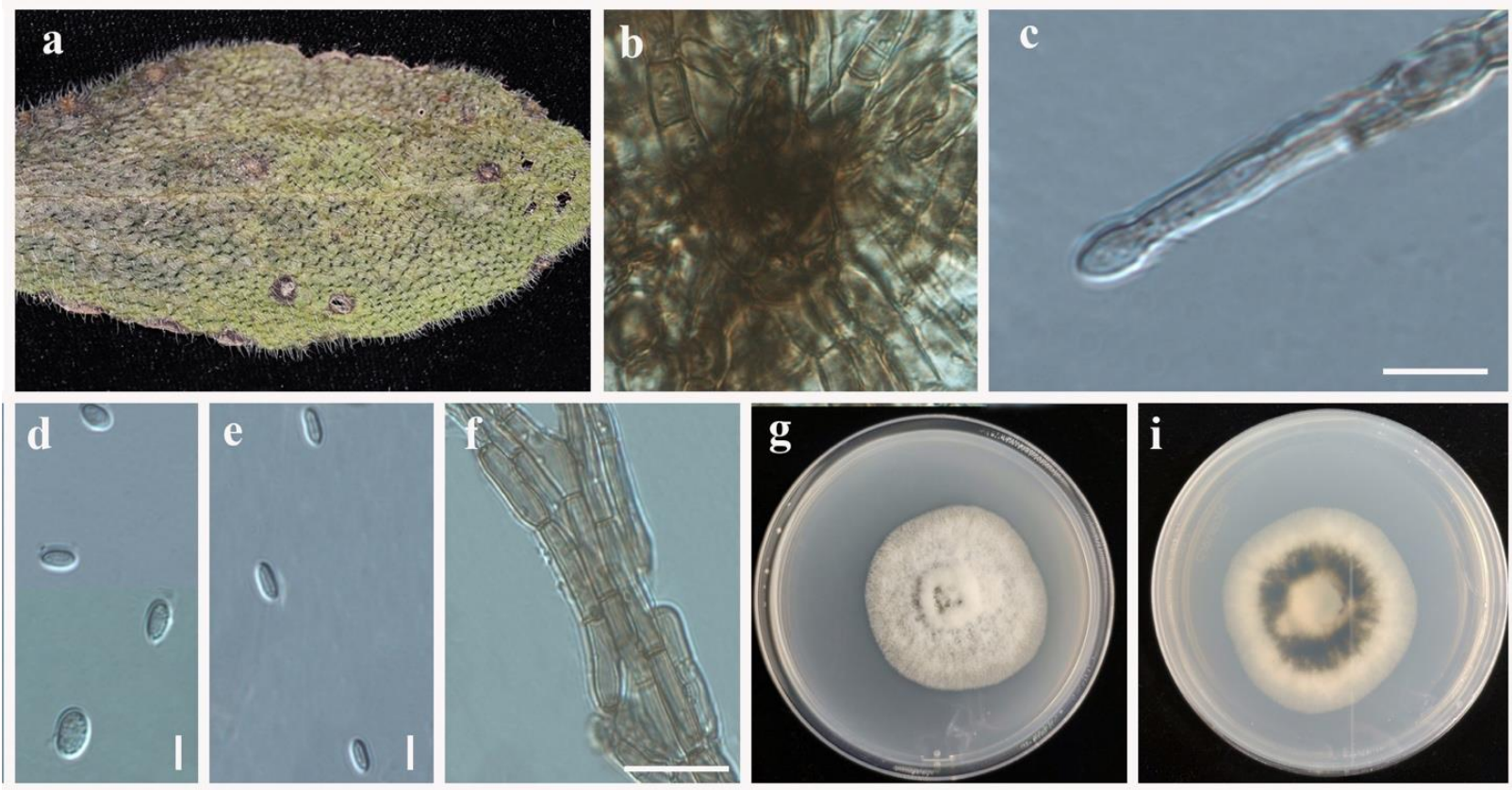

Figure 77 - Remotididymella anthropophila (JZB380042). a Material examined. b Appearance of polygonal cells associated with pycnidia. c Conidiogenus cell developing conidia $\mathrm{d}-\mathrm{f}$ Conidia on PDA. g Mycelia h Upper view of the colony on PDA. i Reverse view of the colony on PDA. Scale bars: $\mathrm{c}, \mathrm{f}=10 \mu \mathrm{m}, \mathrm{d}, \mathrm{e}=3 \mu \mathrm{m}$.

Stagonosporopsis Died. emend. Aveskamp et al., Stud. Mycol. 65: 44 (2010).

Index Fungorum number: IF 10059; Facesoffungi number: FoF 00160; 37 morphological species (Species Fungorum 2020), 30 species with molecular data.

Type species - Stagonosporopsis hortensis (Sacc. \& Malbr.) Petr., Annales Mycologici 19 (1-2): 21 (1921).

三Hendersonia hortensis Sacc. \& Malbr., in Saccardo, Michelia 2(no. 8): 629 (1882).

Notes - Stagonosporopsis was introduced by Diedicke (1912). Previously this genus was synonymised with Ascochyta by Jaczewski (1917) and Petrak (1922). Depending on morphological features such as conidia with up to 3-septa and multi-gene phylogeny Aveskamp et al. (2010) confirmed this genus belongs to Didymellaceae.

Vacuiphoma Valenz.-Lopez, Cano, Crous, Guarro \& Stchigel, Stud. Mycol. 90: 40 (2017).

Index Fungorum number: IF 821451; Facesoffungi number: FoF 08235; 2 morphological species (Species Fungorum 2020), 2 species with molecular data.

Type species - Vacuiphoma bulgarica (Bretag, Gruyter \& Verkley) Valenz.-Lopez, J.F. Cano, Crous, Guarro \& Stchigel, Stud. Mycol 90: 40 (2017).

三Phoma bulgarica Aveskamp, Gruyter \& Verkley, in Aveskamp et al., Stud. Mycol. 65: 47 (2010).

Notes - Vacuiphoma was introduced by Valenzuela-Lopez et al. (2018) to accommodate taxa which are characterised by pycnidial conidiomata that are brown to dark brown, solitary, glabrous, subglobose or obpyriform with textura angularis pycnidial wall and apapillate. The occurrence of empty pycnidial structures gave its name Vacuiphoma. 
Vandijckomycella Hern.-Restr., L.W. Hou, L. Cai \& Crous, in Hou et al., MycoKeys 65: 86 (2020).

Index Fungorum number: IF 833205; Facesoffungi number: FoF 08849; 2 morphological species (Species Fungorum 2020), 2 species with molecular data.

Type species - Vandijckomycella joseae Hern.-Restr., L.W. Hou, L. Cai \& Crous, in Hou, Hernández-Restrepo, Groenewald, Cai \& Crous, MycoKeys 65: 86 (2020).

Notes - Vandijckomycella was introduced by Hou et al. (2020) to accommodate two species isolated from soil samples. Species belonging in this genus are characterised by pycnidia with longer whitish hyphal outgrowths, and with elongated necks (Hou et al. 2020).

Xenodidymella Qian Chen \& L. Cai, Stud. Mycol. 82: 205 (2015).

Index Fungorum number: IF 814065; Facesoffungi number: FoF 08236; 6 morphological species (Species Fungorum 2020), 6 species with molecular data.

Type species - Xenodidymella applanata (Niessl) Q. Chen \& L. Cai, Stud. Mycol. 82: 205 (2015).

三Didymosphaeria applanata Niessl, Oesterr. bot. Z. 25(4): 129 (1875)

Notes - Species belonging to this genus have conidia similar to the Didymella but they are phylogenetically different (Chen et al. 2015). The key morphology of asexual state of this genus is ellipsoidal to allantoids conidia that are subcylindrical, oblong, pyriform which are asepate to single septate. They developed unicellular chlamydospores in culture (Chen et al. 2015).

\section{Ecological and economic significance}

In Didymellaceae several genera are ubiquitous and occurring on a diverse range of substrates (Aveskamp et al. 2008, 2010). This includes many important plant pathogen species with some species which have quarantine concern (Aveskamp et al. 2008, 2010, Chen et al. 2015). Ascochyta, Nothophoma and Stagonosporopsis species are considered serious quarantine organisms in some countries and regions (Vaghefi et al. 2012). Species of Ascochyta are causal agents of blackspot disease in peas (Liu et al. 2016). This disease is one of the most devastating diseases in almost all major pea-growing areas (Bretag et al. 2006).

Even though earlier described species belonging to section Phoma are currently assigned into new genera, most of those taxa have economic significance with great ecological diversity. Most of the species are associated with causing mainly leaf and stem spots (Aveskamp et al. 2008, Zhang et al. 2009c). Since many of these taxa are mostly reported as saprobes and soil microbes it has been suggested they have potential to become pathogenic when a suitable host is encountered (Aveskamp et al. 2008). Phoma hedericola is a frequently occurring causal agent of leaf spots on poison ivy (Hedera helix) and Ph. crinicola is a pathogen of Amaryllidaceae. Xenodidymella applanata is a pathogen of raspberry (Rubus idaeus). Some species belonging to Phoma have been reported as a pathogen on humans (Balis et al. 2006), cattle (Costa et al. 1993) and fish (Ross et al. 1975, Hatai et al. 1986, Voronin 1989, Faisal et al. 2007). Epicoccum layuense has been studied to use as potential biocontrol agent against grapevine trunk pathogens Phaeomoniella chlamydospora and Phaeoacremonium minimum (Del Frari et al. 2019).

Didymosphaeriaceae Munk, Dansk bot. Ark. 15(no. 2): 128 (1953).

Index Fungorum number: IF 80702; Facesoffungi number: FoF 00200, 452 species.

Saprobic, endophytic or pathogenic on woody branches, herbaceous stems, leaves and occasionally human pathogen. Sexual morph: Ascomata immersed to semi-immersed, solitary, scattered, globose to subglobose, central ostiolate with minute papilla, ostiolar canal filled with hyaline cells (periphyses). Peridium thin to thick walled with equal or unequal thickness, slightly thin at the base, composed of several layers of lightly pigmented to dark brown to black, cells of textura angularis, cells towards the inside lighter, darker and fusing with the host tissues at outer. Hamathecium comprising hyaline, broad, septate, narrow, cellular or trabeculate pseudoparaphyses often in a gelatinous matrix. Asci 2-4-spored or 8-spored, bitunicate, fissitunicate, cylindric or oblong, pedicellate, with or without an ocular chamber. Ascospores 1-2-seriate, overlapping, 
ellipsoid or oblong, rounded ends, brown, 1-3-septate or muriform. Asexual morph: Fusicladiumlike and phoma-like (Hyde et al. 2013).

Type - Didymosphaeria Fuckel.

Notes - Munk (1953) introduced Didymosphaeriaceae and typified the family by Didymosphaeria, with D. epidermidis as the type species. Several studies have been conducted on the family. In particular, Ariyawansa et al. (2014b) discussed the confusion surrounding genera of Didymosphaeriaceae and mentioned that the family appears to be a distinct family of Pleosporales based on morphological characteristics. However, the molecular data could not resolve its phylogenetic placement as a distinct family from Montagnulaceae. Ariyawansa et al. (2014b) synonymized Montagnulaceae under Didymosphaeriaceae based on well-resolved phylogenetic data and morphological comparisons. Sixteen genera were accepted in Didymosphaeriaceae by Ariyawansa et al. (2014b) and Wijayawardene et al. (2014c) introduced another two asexual genera Paracamarosporium and Pseudocamarosporium. Crous et al. (2015b, d) introduced Verrucoconiothyrium and Xenocamarosporium and Ariyawansa et al. (2015a) transferred Austropleospora and Pseudopithomyces to Didymosphaeriaceae. Laburnicola and Paramassariosphaeria were introduced by Wanasinghe et al. (2016b) and Kalmusibambusa by Thambugala et al. (2017b). According to the outline of Wijayawardene et al. (2018), Sporidesmiella is also included in Didymosphaeriaceae. Luo et al. (2019) introduced three Sporidesmiella species from freshwater habitats and included within Junewangiaceae. Therefore, we excluded Sporidesmiella from Didymosphaeriaceae. Currently, 32 genera are accepted in Didymosphaeriaceae. Among them some genera are monotypic or contain only a few species with molecular data, i.e. Alloconiothyrium, Barria, Bimuria, Didymosphaeria, Kalmusibambusa, Karstenula, Letendraea, Lineostroma, Neptunomyces, Vicosamyces, Xenocamarosporium. Therefore, fresh collections are needed for these genera.

Didymosphaeria Fuckel, Jb. nassau. Ver. Naturk. 23-24: 140 (1870).

Index Fungorum number: IF 1562; Facesoffungi number: FoF 00036; 195 morphological species (Species Fungorum 2020), 4 species with molecular data.

Type species - Didymosphaeria futilis (Berk. \& Broome) Rehm, Hedwigia 18: 167 (1879).

三Sphaeria futilis Berk. \& Broome, Ann. Mag. nat. Hist., Ser. 2 9: 326 (1852).

Notes - Didymosphaeria is the type genus of Didymosphaeriaceae which was established by Fuckel (1870) to accommodate three species with two-celled ascospores. Didymosphaeria is typified by D. futilis (Berkeley \& Broome 1852, Zhang et al. 2012b; Hyde et al. 2013). Species of Didymosphaeria are characterized in having a peridium consisting of flattened or irregular cells or completely hyphae, a hamathecium consisting of narrow, trabeculate paraphysoids or paraphyses, richly anastomosing above the asci, and brown, thin, distoseptate ascospores (Zhang et al. 2012b). Asexual morphs of Didymosphaeria were reported as coelomycetous, like Dendrophoma sp. or Fusicladiella species (Sivanesan 1984, Zhang et al. 2012b). Despite having 195 morphological species in Species Fungorum (2020), few species have molecular data in GenBank, thus, more collections and sequence data are needed.

\section{Other genera included}

Alloconiothyrium Verkley, Göker \& Stielow, Persoonia, 32: 33 (2014).

Index Fungorum number: IF 800756; Facesoffungi number: FoF 00029; 2 morphological species (Species Fungorum 2020), 2 species with molecular data. (2014).

Type species - Alloconiothyrium aptrootii Verkley, Göker \& Stielow, Persoonia, 32: 33

Notes - Alloconiothyrium was introduced by Verkley et al. (2014), with A. aptrootii as the type species and is characterized in having pycnidial or eustromatic conidiomata, holoblastic, annellidic conidiogenous cells and olivaceous-brown conidia (Verkley et al. 2014). The connection of sexual and as asexual morphs is not proven yet, as no study has obtained any sexual morph for these species 


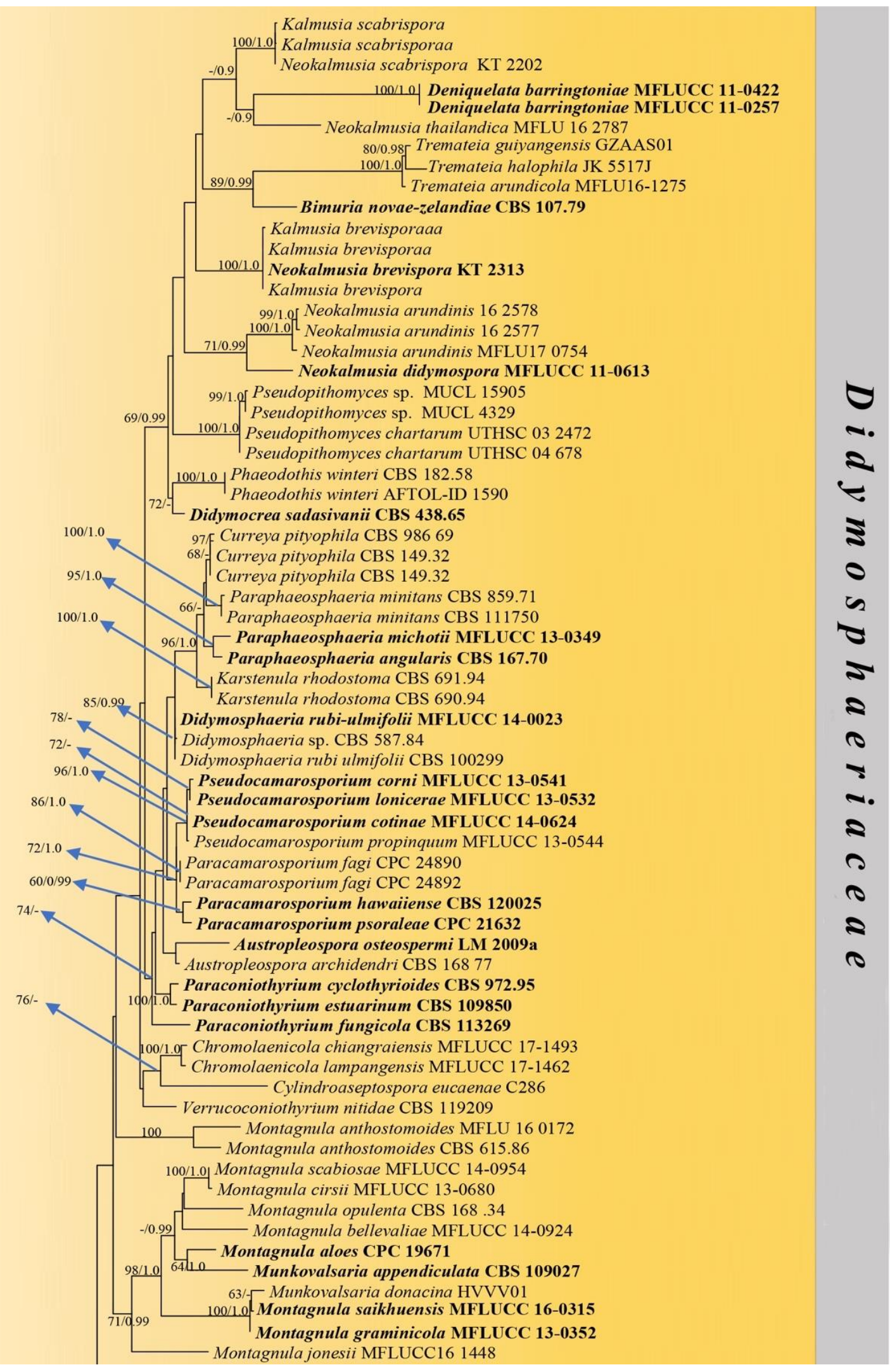

Figure 78 - Phylogram generated from maximum likelihood analysis (RAxML) of Didymosphaeriaceae based on ITS, LSU, SSU, and tef1 sequence data. Maximum likelihood bootstrap values equal or above $70 \%$, Bayesian posterior probabilities equal or above 0.90 (MLBS/PP) are given at the nodes. An original isolate number is noted after the species name. The tree is rooted to Pleospora herbarum (CBS 191.86, IT 956) and P. tarda (CBS 714.68). The extype strains are indicated in bold. Hyphen (-) represents support values below $70 \%$ MLBS and 0.90 PP. 


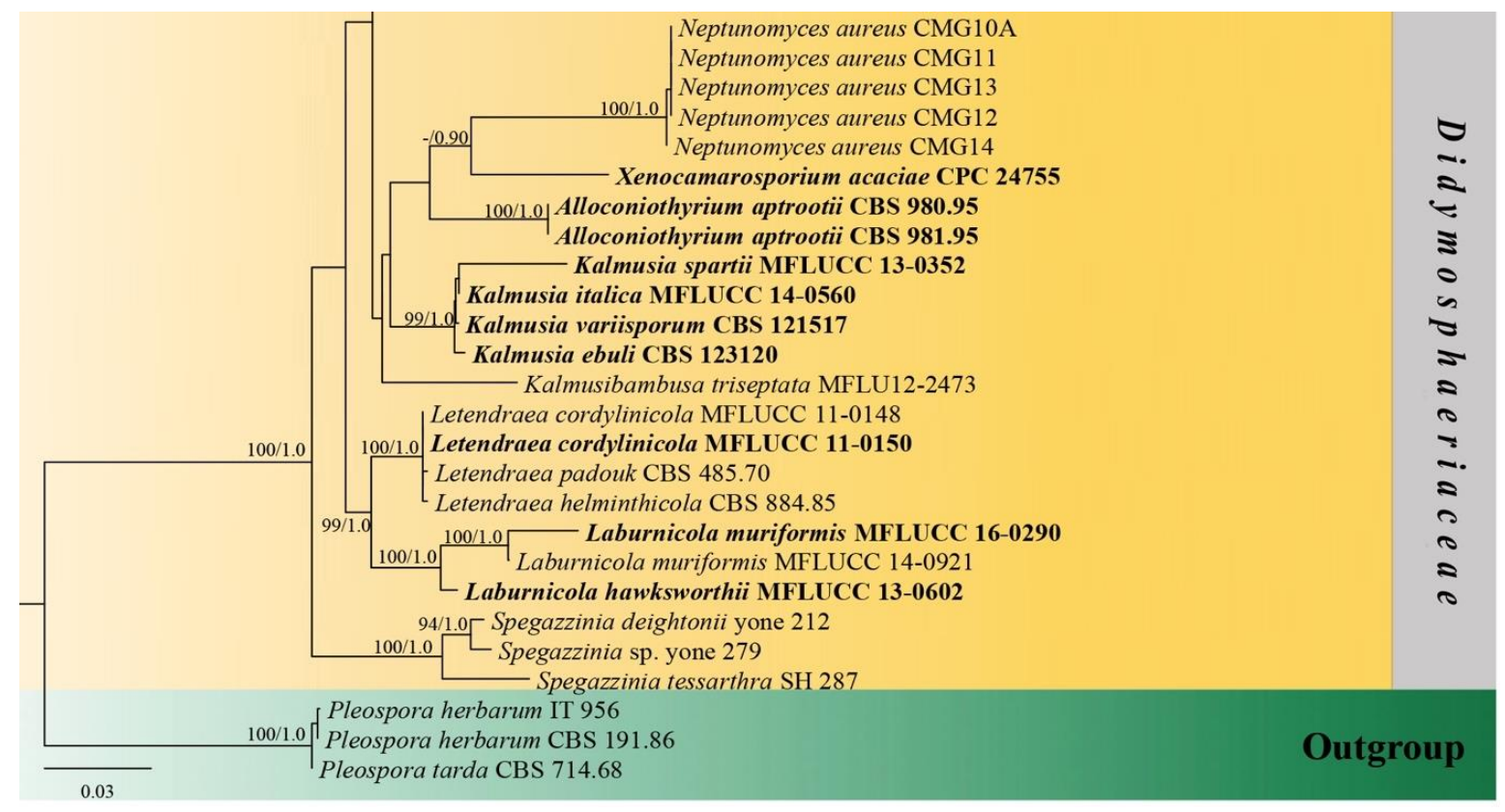

Figure 78 - Continued.

Austropleospora R.G. Shivas \& L. Morin, Fungal Divers. 40(1): 70 (2010).

Index Fungorum number: IF 512742; Facesoffungi number: FoF 00539; 2 morphological species (Species Fungorum 2020), 2 species with molecular data.

Type species - Austropleospora osteospermi R.G. Shivas \& L. Morin, Fungal Divers. 40(1): 70 (2010).

Notes - Morin et al. (2010) introduced Austropleospora to accommodate A. osteospermi as the type species which was collected on Chrysanthemoides monilifera subsp. rotundata (Asteraceae). Austropleospora species are characterized in having scattered and immersed ascomata with a protruding neck, filiform, septate, branched pseudoparaphyses, 6-8-spored, clavate to cylindrical asci and dictyosporous, ellipsoidal, yellowish brown ascospores (Morin et al. 2010). Additionally, Morin et al. (2010) collected Hendersonia osteospermi Wakef. on the same host and identified it as the asexual morph of A. osteospermi According to the ITS sequence analysis Morin et al. (2010) placed Austropleospora under Pleosporales without assigning it to any family. Thambugala et al. (2014d) accommodated Austropleospora in Pleosporaceae based on morphological similarities, but Ariyawansa et al. (2015a) excluded Austropleospora from Pleosporaceae and included in Didymosphaeriaceae. Recently, Austropleospora keteleeriae was introduced by Jayasiri et al. (2019) from decaying cone of Keteleeria fortune.

Barria Z.Q. Yuan, Mycotaxon 51: 313 (1994).

Index Fungorum number: IF 27262; Facesoffungi number: FoF 00031; 1 morphological species (Species Fungorum 2020), No species with molecular data.

Type species - Barria piceae Z.Q. Yuan, Mycotaxon 51: 314 (1994).

Notes - Barria was introduced by Yuan (1994) as a monotypic genus and typified by Barria piceae, according to its "two-celled, pigmented ascospores, pseudoparenchymatous peridium and narrowly cellular pseudoparaphyses. Zhang et al. (2012b) tentatively referred Barria in Phaeosphaeriaceae based on the ascomata, colour and shape of ascospores. Ariyawansa et al. (2014d) broadly discussed the morphology differences between Barria and Phaeosphaeria species and transferred Barria from Phaeosphaeriaceae to Didymosphaeriaceae. Phookamsak et al. (2014c) also accepted that Barria is more similar to genera in Didymosphaeriaceae rather than Phaeosphaeriaceae. Only one species has been recorded in this genus (Species Fungorum 2020).

Bimuria D. Hawksw. et al., N.Z. J1. Bot. 17(3): 267 (1979). 
Index Fungorum number: IF 574; Facesoffungi number: FoF 00032; 1 morphological species (Species Fungorum 2020), 1 species with molecular data.

Type species - Bimuria novae-zelandiae D. Hawksw. et al., N.Z. Jl. Bot. 17(3): 268 (1979).

Notes - Bimuria was introduced by Hawksworth et al. (1979) as a monotypic genus and characterized by a very thin peridium, mostly 2 -spored, fissitunicate asci and muriform, dark brown, verrucose ascospores. Due to the unique morphological characters, Hawksworth et al. (1979) placed the genus in Pleosporaceae and later accommodated it in Phaeosphaeriaceae.

Chromolaenicola Mapook \& K.D. Hyde, Fungal Diversity 101: 20 (2020).

Index Fungorum number: IF 557279; Facesoffungi number: FoF 07783; 5 morphological species (Mapook et al. 2020), 5 species with molecular data.

Type species - Chromolaenicola nanensis Mapook \& K.D. Hyde, Fungal Diversity 101: 25 (2020).

Notes - Chromolaenicola was introduced by Mapook et al. (2020) to accommodate Chromolaenicola nanensis (type species) and four other species, C. chiangraiensis, $C$. lampangensis, C. siamensis, and C. thailandensis. Chromolaenicola shows close phylogenetic affinities with Cylindroaseptospora, but it has oblong or oval to ellipsoid, globose to subglobose conidia that are hyaline to pale brown, aseptate when immature, becoming dark at maturity, 1septate, thick-walled, verruculose, not constricted at the septum, whereas, Cylindroaseptospora has cylindrical conidia, hyaline, aseptate with smooth thin walls (Jayasiri et al. 2019).

Curreya Sacc., Syll. fung. (Abellini) 2: 651 (1883).

= Cucurbidothis Petr., Annls mycol. 19(3-4): 201 (1921).

Index Fungorum number: IF 1356; Facesoffungi number: FoF 08237; 6 morphological species (Species Fungorum 2020), 6 species with molecular data.

Type species - Curreya conorum (Fuckel) Sacc., Sylloge Fungorum 2: 651 (1883).

$\equiv$ Homostegia conorum Fuckel, Jb. nassau. Ver. Naturk. 29-30: 38 (1875) [1877-78].

Notes - Curreya was erected by Saccardo (1883) based on Homostegia conorum. Theissen \& Sydow (1915) classified Curreya in Dothideales and Petrak (1940) classified it under Cucurbitaria Gray. Subsequently, based on coniothyrium-like asexual morphs, Von Arx \& van der Aa (1983) considered Curreya to be closely related to Didymosphaeria, Melanomma, Paraphaeosphaeria or Massarina. Curreya species are mainly characterized in having coniothyrium-like asexual morph, small sclerotial cells in peridium and narrower, thinner-walled asci (Zhang et al. 2012b). Therefore, Barr (1990a) assigned Curreya to Leptosphaeriaceae and Zhang et al. (2012b) referred it to Cucurbitariaceae.

There have been few molecular investigations of Curreya as compared to morphological studies. The generic type, C. conorum, has neither been well studied nor has DNA data. Jaklitsch et al. (2016b) moved Curreya austroafricana to Teichosporaceae and classified it under Teichospora based on both morphological and phylogeny analyses. Vu et al. (2019) referred Curreya pityophila (CBS 149.32) to Didymosphaeriaceae, but without morphological data. We keep Curreya in Didymosphaeriaceae, but recollection of the type specimens and molecular data from type strains are essential to resolve the placement of this genus.

Cylindroaseptospora Jayasiri, E.B.G. Jones \& K.D. Hyde, Mycosphere 10: 67 (2019).

Index Fungorum number: IF 555542; Facesoffungi number: FoF 05243; 2 morphological species (Species Fungorum 2020), 2 species with molecular data.

Type species - Cylindroaseptospora leucaenae Jayasiri, E.B.G. Jones \& K.D. Hyde, Mycosphere 10: 67 (2019).

Notes - Cylindroaseptospora was introduced by Jayasiri et al. (2019) to accommodate $C$. leucaenae as the type species. Cylindroaseptospora species are characterized in having cylindrical aseptate conidia. Two Cylindroaseptospora species accepted in Species Fungorum (2020), C. leucaenae and C. siamensis. 
Deniquelata Ariyawansa \& K.D. Hyde, Phytotaxa 105(1): 13 (2013).

Index Fungorum number: IF 800703; Facesoffungi number: FoF 00034; 3 morphological species (Species Fungorum 2020), 3 species with molecular data.

Type species - Deniquelata barringtoniae Ariyawansa \& K.D. Hyde, Phytotaxa 105(1): 15 (2013).

Notes - Deniquelata was introduced by Ariyawansa et al. (2013c) to accommodate Deniquelata barringtoniae as the type species. Deniquelata species are characterized by immersed, dark brown to black ascomata, with bitunicate asci and brown, muriform ascospores (Ariyawansa et al. 2014d). Deniquelata is considered as a pathogenic genus with fruiting bodies scattered in the necrotic host tissues (Ariyawansa et al. 2013c, 2014d). Only three Deniquelata species (D. barringtoniae, D. quercina and D. vittalii) have been recorded in this genus (Species Fungorum 2020).

Didymocrea Kowalski, Mycologia 57(3): 405 (1965).

Index Fungorum number: IF 1552; Facesoffungi number: FoF 08238; 2 morphological species (Species Fungorum 2020), 2 species with molecular data.

Type species - Didymocrea sadasivanii (T.K.R. Reddy) Kowalski, Mycologia 57(3): 405 (1965).

三Didymosphaeria sadasivanii T.K.R. Reddy, Mycologia 53(5): 471 (1962) [1961].

Notes - Didymocrea was introduced by Kowalski (1965) to accommodate D. sadasivanii which was previously known as Didymosphaeria sadasivanii. The sexual morph of Didymocrea is characterized in having brown to black ascomata, filiform pseudoparaphyses, uni-tunicate asci and two-celled brown ascospores (Kowalski 1965, Ariyawansa et al. 2014d). However, due to their unitunicate asci, Kowalski (1965) assigned this in Hypocreales. Subsequently, researchers concluded that it should be a true pleosporalean fungus with functionally unitunicate asci, and retained it in Pleosporales (Luttrell 1975, Aptroot 1995, Rossman et al. 1999, Kruys et al. 2006, Schoch et al. 2009a, Zhang et al. 2012b). According to the multi-gene phylogeny Ariyawansa et al. (2014d) accepted this genus in Didymosphaeriaceae. The asexual morph of Didymocrea was introduced by Jayasiri et al. (2019) and the morphology bears similarity to species in Canalisporium (Sordariomycetes). Only two species have been recorded in this genus, Didymocrea leucaenae, D. sadasivanii (Species Fungorum 2020).

Julella Fabre, Annls Sci. Nat., Bot., sér. 6, 9: 113. 1879 (1878).

Index Fungorum number: IF 2539; Facesoffungi number: FoF 00038; 6 morphological species (Species Fungorum 2020), 1 species with molecular data.

Type species - Julella buxi Fabre, Annls Sci. Nat., Bot., sér. 6, 9: 113. (1878).

Notes - Julella was introduced by Fabre (1879) with Julella buxi as the type species collected from Buxus sempervirens L. (Buxaceae). Julella species are compatible with Didymosphaeriaceae in having immersed ascomata formed under a clypeus, short neck, 2-layered peridium composed of cells of textura angularis and cylindric or oblong, pedicellate, often with an ocular chamber and oblong to narrowly oblong muriform ascospores but differing in having hyaline ascospores (Ariyawansa et al. 2014d).

Kalmusia Niessl, Verh. nat. Ver. Brünn 10: 204 (1872).

Index Fungorum number: IF 2543; Facesoffungi number: FoF 00040; 27 morphological species (Species Fungorum 2020), 8 species with molecular data.

Type species - Kalmusia ebuli Niessl, Verh. nat. Ver. Brünn 10: 204 (1872).

Notes - Niessl (1872) introduced Kalmusia to accommodate Kalmusia ebuli as the type species (Ariyawansa et al. 2014d, Liu et al. 2015). Kalmusia species are characterized in having immersed to erumpent ascomata, filiform, delicate, septate pseudoparaphyses, bitunicate, clavate asci with narrowly ovoid to clavate, pale brown, 3-septate ascospores (Barr 1992a, Zhang et al. 2012b, Ariyawansa et al. 2014d, Liu et al. 2015). The asexual morph of this genus has coniothyrium-like, Cytoplea, Microsphaeropsis and Paraconiothyrium morphological characters 
(Zhang et al. 2012b, 2014b, Ariyawansa et al. 2014d). There are 27 Kalmusia epithets listed in Species Fungorum (2020).

Kalmusibambusa Phookamsak, Tennakoon, Thambug. \& K.D. Hyde, Mycosphere 8(4): 717 (2017).

Index Fungorum number: IF 553159; Facesoffungi number: FoF 03217; 1 morphological species (Species Fungorum 2020), 1 species with molecular data.

Type species - Kalmusibambusa triseptata Phookamsak, Tennakoon \& K.D. Hyde, Mycosphere 8(4): 718 (2017).

Notes - Kalmusibambusa was introduced by Thambugala et al. (2017b) as a monotypic genus to accommodate a bambusicolous species in Didymosphaeriaceae. Kalmusibambusa species differs from Kalmusia in having multi-loculate, coriaceous, elongated ascostromata, with a slit-like opening through host surface and cylindrical asci (Thambugala et al. 2017b). The connectively of sexual and asexual morphs is not proven yet, as no study has obtained any asexual morph for these species.

Karstenula Speg., Decades Mycologicae Italicae 7-12: no. 94 (in sched.) (1879).

Index Fungorum number: IF 2549; Facesoffungi number: FoF 00042; 22 morphological species (Species Fungorum 2020), 1 species with molecular data.

Type species - Karstenula rhodostoma (Alb. \& Schwein.) Speg., Decades Mycologicae Italicae 7-12: no. 94 (1879).

三Sphaeria rhodostoma Alb. \& Schwein., Consp. fung. (Leipzig): 43 (1805).

Notes - Karstenula is an ambiguous genus, due to its morphological similarities with different families (Zhang et al. 2012b, Ariyawansa et al. 2014d). For instance, Karstenula species share some similarities with Didymosphaeria in having ascomata seated in a subiculum or beneath a clypeal thickening and sometimes apical cells become reddish or orange-brown (Barr 1990a). The ascomata of Karstenula rhodostoma are similar to those found in Byssosphaeria and Herpotrichia, such as the paler area around the ostiole and even in peridium and development under a subiculum. However, based on multi-gene phylogenies Ariyawansa et al. (2014d) revealed that Karstenula is in Didymosphaeriaceae, but further collections are needed for resolve the ambiguity of this genus.

Laburnicola Wanas., Camporesi, E.B.G. Jones \& K.D. Hyde, Fungal Biology 120(11): 1360 (2016).

Index Fungorum number: IF 551955; Facesoffungi number: FoF 01919; 4 morphological species (Species Fungorum 2020), 4 species with molecular data.

Type species - Laburnicola muriformis Wanas., Camporesi, E.B.G. Jones \& K.D. Hyde, Fungal Biol. 120(11): 1364 (2016).

Notes - Laburnicola was introduced by Wanasinghe et al. (2016b) to accommodate Laburnicola muriformis as the type species. Laburnicola species shares some similar morphology with Austropleospora, Deniquelata, Kalmusia, Montagnula and Paraconiothyrium in having immersed ascomata and cylindrical to cylindric-clavate asci with a long pedicel, but it differs in having comparatively large ascospores, with 6-8 transverse septa and 1-2 longitudinal septa (Wanasinghe et al. 2016b). Only four Laburnicola species have been recorded, L. centaureae, $L$. dactylidis, L. hawksworthii and L. muriformis.

Letendraea Sacc., Michelia 2(6): 73 (1880).

Index Fungorum number: IF 2812; Facesoffungi number: FoF 00044; 12 morphological species (Species Fungorum 2020), 4 species with molecular data.

Type species - Letendraea eurotioides Sacc., Michelia 2(no. 6): 73 (1880).

Notes - Letendraea was introduced by Saccardo (1880) to accommodate L. eurotioides, which is characterized by superficial, globose to conical ascomata, filiform pseudoparaphyses, obclavate to cylindrical, 8- spored asci, and fusoid to oblong, 1-septate ascospores (Ariyawansa et al. 2014d). Subsequently however taxonomists, placed it in different families when considering the 
morphological characteristics. For instance, Kodsueb et al. (2006) placed it in Melanommataceae due to similar morphology with Karstenula rhodostoma and Zhang et al. (2012b) referred Letendraea to Montagnulaceae. However, based on multi-gene phylogenies Ariyawansa et al. (2014d) revealed that Letendraea is in Didymosphaeriaceae. 12 Letendraea species are accecpted in Species Fungorum (2020), but sequence data is available for only a few species.

Lineostroma H.J. Swart, Trans. Br. mycol. Soc. 91: 464 (1988).

Index Fungorum number: IF 25262; Facesoffungi number: FoF 01293; 1 morphological species (Species Fungorum 2020), molecular data not available. (1988).

Type species - Lineostroma banksiae (Cooke) H.J. Swart, Trans. Br. mycol. Soc. 91(3): 464

三Didymosphaeria banksiae Cooke, Grevillea 19(no. 92): 90 (1891).

Notes - Lineostroma was introduced by Swart (1988) to accommodate L. banksiae which was previously known as Didymosphaeria banksiae. Lineostroma is characterized in having linear, intra-epidermal ascostromata, trabeculate pseudoparaphyses, asci with a short pedicel and 1-septate ascospores (Swart 1988). Only the type species comprises in this genus.

Montagnula Berl., Icon. fung. (Abellini) 2: 68 (1896).

Index Fungorum number: IF 3265; Facesoffungi number: FoF 00048; 33 morphological species (Species Fungorum 2020), 12 species with molecular data.

Type species - Montagnula infernalis (Niessl) Berl., Icon. fung. (Abellini) 2(2-3): 68 (1896).

三Leptosphaeria infernalis Niessl, Inst. Rev. Cient. Litt., Coimbra 31: 13 (1883).

Notes - Montagnula was introduced by Berlese (1896) to accommodate $M$. infernalis and $M$. gigantean. Based on the morphology and phylogeny, Ariyawansa (2014d) placed Montagnula in Didymosphaeriaceae. Montagnula species are characterized by globose or sphaerical, immersed ascomata with a clypeus, claviform asci, fusoid or ellipsoid ascospores with transverse septa and one or more longitudinal septa (Barr 1990a, Ariyawansa et al. 2014d). Wanasinghe et al. (2016b) transferred two Munkovalsaria species (M. appendiculata and M. donacina) based on phylogenetic analyses. Montagnula species play a vital role as saprobes growing on dead plants, especially dead wood and bark, sometimes on dead leaves (Ariyawansa et al. 2014d). A well-resolved revision of Montagnula is difficult since it lacks molecular data. Therefore, representative species of these Montagnula species need to be recollected and molecular data obtained for clarifying its phylogenetic affinity.

Neokalmusia Ariyaw. \& K.D. Hyde, Fungal. Divers. 68: 92 (2014).

Index Fungorum number: IF 550700; Facesoffungi number: FoF 00050; 6 morphological species (Species Fungorum 2020), 6 species with molecular data.

Type species - Neokalmusia brevispora (Nagas. \& Y. Otani) Kaz. Tanaka, Ariyaw. \& K.D. Hyde, Fungal Diversity 68: 92 (2014).

$\equiv$ Phaeosphaeria arundinacea var. brevispora Nagas. \& Y. Otani, Rep. Tottori Mycol. Inst. 15: 38 (1977).

Notes - Neokalmusia was established to accommodate two bambusicolous taxa, $N$. brevispora and $N$. scabrispora previously referred to Kalmusia (Zhang et al. 2009b, Ariyawansa et al. 2014d). Subsequent phylogenetic studies have shown that these two species belong to Neokalmusia in Didymosphaeriaceae (Hyde et al. 2013, Ariyawansa et al. 2014b). Neokalmusia is characterized by immersed, subglobose to oblong ascomata with several perithecia in a row, a clypeus-like structure composed of thin-walled cells and verrucose ascospores (Ariyawansa et al. 2014d). There are six Neokalmusia epithets in Species Fungorum (2020), N. arundinis, $N$. brevispora, $N$. didymospora, $N$ kunmingensis, $N$. scabrispora and $N$. thailandica.

Neokalmusia arundinis Thambugala \& K.D. Hyde, Mycosphere 8: 722 (2017).

Fig. 79

Index Fungorum number: IF 553161; Facesoffungi number: FoF 03219. 

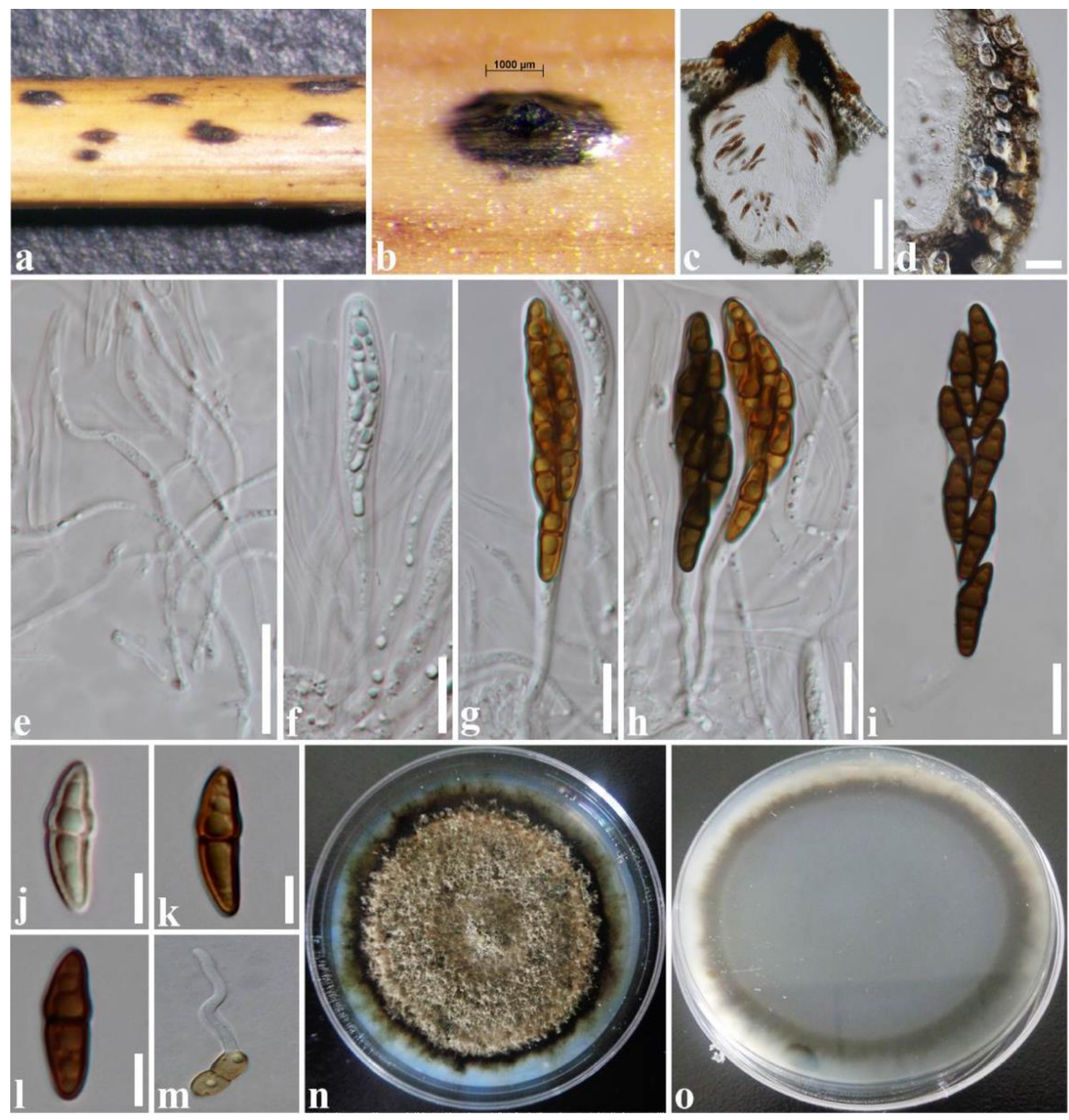

Figure 79 - Neokalmusia arundinis (MFLU 17-0754, new host record). a Ascomata visible as black dots on the host surface. b Close up of ascoma. c Vertical section of ascoma. d Section through peridium. e Pseudoparaphyses. f-i Asci. j-l Ascospores. m Germinated ascospore. $n$ Colony from above. o Colony from below. Scale bars: $c=50 \mu \mathrm{m}, \mathrm{d}-\mathrm{i}=20 \mu \mathrm{m}, \mathrm{j}-\mathrm{m}=5 \mu \mathrm{m}$.

Saprobic on a dead stem of Panicum virgatum. Sexual morph: Ascomata 300-350 × 200-275 $\mu \mathrm{m}(\bar{x}=325 \times 245 \mu \mathrm{m}, \mathrm{n}=5)$, solitary, scattered, gregarious, immersed, under clupeus, globose to sub-globose, coriaceous, uni-loculate, brown to dark brown, shiny, roughened, ostiolate. Peridium 17-25 $\mu \mathrm{m}$ wide, poorly developed, composed of few layers of thin-walled, brown to dark brown, cells of textura angularis, fusing at the outside with the host tissue. Hamathecium comprising 2-3 $\mu \mathrm{m}$ wide, numerous, cellular, pseudoparaphyses, embedded in a mucilaginous matrix. Asci 70-90 $\times$ (7.5-) 8-11.5 $\mu \mathrm{m}(\bar{x}=81.5 \times 8.9 \mu \mathrm{m}, \mathrm{n}=15), 8$-spored, bitunicate, fissitunicate, cylindric-clavate, long pedicellate, apically rounded with an indistinct ocular chamber. Ascospores $12.5-17 \times 3.5-5$ $\mu \mathrm{m}(\bar{x}=14.3 \times 4.1 \mu \mathrm{m}, \mathrm{n}=30)$, overlapping 1-2-seriate, fusiform, initially hyaline, become pale brown to brown at maturity, 1-septate, constricted at the septum, slightly curved, often enlarged near septum in the upper cell, asymmetrical, upper cell shorter than lower cell, smooth-walled, without a mucilaginous sheath. Asexual morph: Undetermined. 
Culture characteristics - Colonies on PDA reaching $25 \mathrm{~mm}$ diam. after 2 weeks at $20-25^{\circ} \mathrm{C}$, colonies medium sparse, circular, flat, surface slightly rough with edge entire, margin well defined, cottony to fairly fluffy with sparse aspects, colony from above: dark brown to black at the margin, white to grey at the centre; reverse, light brown to yellowish at the margin, light brown to grey at the centre; mycelium light brown to whitish grey with tufting; not producing pigments in PDA.

Material examined - China, Yunnan Province, Xishuangbanna, Nabanhe, on dead stem of Panicum virgatum (Poaceae), 20 November 2015, D.S. Tennakoon, DXH 008 (MFLU 17-0754, ibid. HKAS96331), living culture, MFLUCC 17-1782.

GenBank numbers - ITS: MT649882, LSU: MT649878, SSU: MT649879, tef1: MT663766.

Notes - Morphological characters of our specimen largely overlap with Neokalmusia arundinis in having globose to sub-globose, brown to black ascomata, cylindric-clavate, long pedicellate asci and 1-septate, asymmetrical, brown ascospores (Thambugala et al. 2017b). However, our specimen differs from known collections of $N$. arundinis in host occurrence (Panicum virgatum), whereas MFLU 16-2577 and MFLU 16-2578 were collected from Arundo pliniana Turra. We therefore report our collection as a new record of $N$. arundinis from dead stems of grass, Panicum virgatum in China.

Neptunomyces M. Gonçalves, T. Vicente \& A. Alves, MycoKeys 60: 37 (2019).

Index Fungorum number: IF 831436; Facesoffungi number: FoF 08239; 1 morphological species (Species Fungorum 2020), 1 species with molecular data.

Type species - Neptunomyces aureus M. Gonçalves, T. Vicente \& A. Alves, MycoKeys 60: 37 (2019).

Notes - Neptunomyces was introduced by Gonçalves et al. (2019) to accommodate N. aureus as the type species. Neptunomyces is characterized in having aseptate, golden yellow, subcylindrical conidia with rounded apices. Only the type species is recorded in this genus (Species Fungorum 2020). Therefore, more representative Neptunomyces species are needed for expansion of this genus.

Paracamarosporium Wijayaw. \& K.D. Hyde, Cryptog. Mycol. 35(2): 183 (2014).

Index Fungorum number: IF 550563; Facesoffungi number: FoF 08240; 7 morphological species (Species Fungorum 2020), 7 species with molecular data.

Type species - Paracamarosporium psoraleae (Crous \& M.J. Wingf.) Wijayaw. \& K.D. Hyde, Cryptog. Mycol. 35(2): 185 (2014).

$\equiv$ Camarosporium psoraleae Crous \& M.J. Wingf., in Crous et al., Persoonia 31: 235 (2013).

Notes - Wijayawardene et al. (2014c) introduced Paracamarosporium to accommodate Camarosporium psoraleae. Subsequently, Crous et al. (2015b) added Microdiplodia hawaiiensis (Paracamarosporium hawaiiense), Camarosporium leucadendri (Paracamarosporium leucadendri and Paracamarosporium fagi to the genus. Later, Wijayawardene et al. (2016b) introduced Paracamarosporium fungicola which was previously known as Paraconiothyrium fungicola and $P$. tamaricis introduced by Thambugala et al. (2017a). Paracamarosporium mamanes was introduced by Crous \& Groenewald (2017). There are seven Paracamarosporium epithets in Species Fungorum (2020). Both Paracamarosporium and Pseudocamarosporium have pycnidial conidiomata, enteroblastic and phialidic conidiogenesis with percurrent proliferation and muriform conidia (Wijayawardene et al. 2014c). However, Paracamarosporium is distinct from the latter in having hyaline, smooth-walled, guttulate, bacilliform to subcylindrical microconidia (Wijayawardene et al. 2014c).

Paraconiothyrium Verkley, Stud. Mycol. 50(2): 327 (2004).

Index Fungorum number: IF 500080; Facesoffungi number: FoF 00053; 17 morphological species (Species Fungorum 2020), 5 species with molecular data.

Type species - Paraconiothyrium estuarinum Verkley et al., Stud. Mycol. 50(2): 327 (2004).

Notes - Verkley et al. (2004a) introduced Paraconiothyrium to accommodate four species, namely $P$. estuarinum (type species), $P$. brasiliense, $P$. cyclothyrioides and $P$. fungicola. The 
morphological characters of Paraconiothyrium can be variable. The conidiomata can be eustromatic to pycnidial, the conidiogenous cells are phialidic or annelidic, and the conidia smooth-walled or minutely warted and hyaline to brown at later stages of development (Verkley et al. 2004a, Gruyter et al. 2013, Liu et al. 2015). Based on multi-gene phylogeny, Ariyawansa et al. (2014d) observed the paraphyletic nature of Paraconiothyrium within Didymosphaeriaceae.

Paramassariosphaeria Wanas., E.B.G. Jones \& K.D. Hyde, Fungal Biology 120(11): 1367 (2016). Index Fungorum number: IF 552194; Facesoffungi number: FoF 02293; 2 morphological species (Species Fungorum 2020), 2 species with molecular data.

Type species - Paramassariosphaeria clematidicola Wanas., Camporesi, E.B.G. Jones \& K.D. Hyde, Biology 120(11): 1370 (2016).

Notes - Paramassariosphaeria was introduced by Wanasinghe et al. (2016b) to accommodate Paramassariosphaeria clematidicola as the type species, which was collected from Clematis vitalba (Ranunculaceae). Paramassariosphaeria species are characterized in having immersed to semi-erumpent ascomata, with papillate ostioles, cylindric-clavate asci with a long pedicel, and curved-fusoid, asymmetrical ascospores, narrowly rounded at the ends and surrounded by a mucilaginous sheath (Wanasinghe et al. 2016b).

Paraphaeosphaeria O.E. Erikss., Ark. Bot., Ser. 2 6: 405 (1967).

Index Fungorum number: IF 3711; Facesoffungi number: FoF 00057; 29 morphological species (Species Fungorum 2020), 6 species with molecular data.

Type species - Paraphaeosphaeria michotii (Westend.) O.E. Erikss., Arch. Botan. 6: 405 (1967).

三Sphaeria michotii Westend., Bull. Acad. R. Sci. Belg., Cl. Sci., sér. 2 7(5): 87 (1859).

Notes - Paraphaeosphaeria was introduced Eriksson (1967) to accommodate four species with oblong-cylindric ascospores ( $P$. castagnei, P. michotii, P. obtusispora, and P. rusci). Paraphaeosphaeria species are characterized in having immersed to semi-immersed ascomata, bitunicate asci with a short pedicel and multi-septate, broadly elliptical, yellowish brown ascospores (Wong et al. 2000, Ariyawansa et al. 2014d). Paraphaeosphaeria produces coniothyrium-like asexual morphs characterized by eustromatic or pycnidial conidiomata, phialidic, or annelidic conidiogenous cells and aseptate or 1-septate conidia (Verkley et al. 2014). Recent studies confirmed the placement of Paraphaeosphaeria in Didymosphaeriaceae (Ariyawansa et al. 2014d, Verkley et al. 2014, Wanasinghe et al. 2018c). Paraphaeosphaeria comprises 29 epithets in Species Fungorum (2020).

Phaeodothis Syd. \& P. Syd., Annls mycol. 2(2): 166 (1904).

Index Fungorum number: IF 3914; Facesoffungi number: FoF 00059; 21 morphological species (Species Fungorum 2020), 2 species with molecular data.

Type species - Phaeodothis tricuspidis Syd. \& P. Syd., Annls mycol. 2(2): 166 (1904).

Notes - Phaeodothis was placed in Didymosphaeria by von Niessl (1875), and Aptroot (1995) transferred it to Phaeosphaeriaceae. However, Phaeodothis species share similar morphological characteristics with the other genera in Didymosphaeriaceae in having ascomata immersed under a clypeus, a pseudoparenchymatous peridium with small cells, cylindrical asci and brown ascospores (Zhang et al. 2012b, Ariyawansa et al. 2014d), but differs in having a hamathecium consisting of sparse pseudoparaphyses and 1- septate ascospores. Recent studies have also confirmed Phaeodothis in Didymosphaeriaceae (Ariyawansa et al. 2014d). Phaeodothis mori was introduced by Tennakoon et al. (2020).

Pseudocamarosporium Wijayaw. \& K.D. Hyde, Cryptog. Mycol. 35(2): 185 (2014).

Index Fungorum number: IF 550556; Facesoffungi number: FoF 00007; 15 morphological species (Species Fungorum 2020), 15 species with molecular data.

Type species - Pseudocamarosporium propinquum (Sacc.) Wijayaw., Camporesi \& K.D. Hyde, Mycol. 35(2): 191 (2014). 
EHendersonia propinqua Sacc., Michelia 1(no. 5): 516 (1879).

Notes - Pseudocamarosporium was introduced by Wijayawardene et al. (2014c) to accommodate camarosporium-like species, $P$. propinquum (Camarosporium propinquum) as the type species and another four species $P$. corni, $P$. lonicerae, $P$. piceae and $P$. tilicola. Phylogenetically, Pseudocamarosporium shows close affinity to Paracamarosporium, but can be distinguished by having paraphyses in Paracamarosporium.

Pseudopithomyces Ariyaw. \& K.D. Hyde, Fungal Divers. 75: 64 (2015).

Index Fungorum number: IF 551392; Facesoffungi number: FoF 00937; 12 morphological species (Species Fungorum 2020), 12 species with molecular data.

Type species - Pseudopithomyces chartarum (Berk. \& M.A. Curtis) Jin F. Li, Ariyaw. \& K.D. Hyde, Fungal Diversity 75: 38 (2015).

Notes - Pithomyces species are polyphyletic within many different families in the Pleosporales such as Didymellaceae, Didymosphaeriaceae and Astrosphaeriellaceae (Pratibha \& Prabhugaonkar 2015). Morphological characters of Pseudopithomyces are quite similar to Pithomyces. However, Pseudopithomyces species differs from Pithomyces in having chinulate or fusiform, verruculose dark conidia and producing brown to black colonies on the host. Pithomyces produces obovate to oblong, verruculose to spinulose, comparatively lighter conidia and forms whitish to yellowish colonies on the host (Ariyawansa et al. 2015a, Pratibha \& Prabhugaonkar 2015).

Spegazzinia Sacc., Michelia 2 (6): 37 (1880).

Index Fungorum number: IF 9963; Facesoffungi number: FoF 08241; 14 morphological species (Species Fungorum 2020), 6 species with molecular data.

Type species - Spegazzinia ornata Sacc., Michelia 2(no. 6): 172 (1880).

Notes - Spegazzinia was introduced by Saccardo (1880) as a hyphomycetous genus. Spegazzinia was classified in Apiosporaceae, Sordariomycetes (Hyde et al. 1998) based on its morphological characteristics. Tanaka et al. (2015) referred Spegazzinia in Didymosphaeriaceae based on molecular evidence of S. deightonii (S. Hughes) Subram. and S. tessarthra (Thambugala et al. 2017b). The asexual morphs of Spegazzinia have been reported for Didymosphaeriaceae. One of the most important morphology characters of Spegazzinia is its pleomorphism (Mena-Portales et al. 2017). Most species produce two types of conidia in the same mycelium; type "a" which are composed by 4-8 subglobose, very dark cells with very long spines, which are very similar in morphology and size in almost every species; and type "b" which are subsphaerical or broadly ellipsoid, in general flattened in one plane, cruciately septate or muriform, almost always pale brown and smooth, with short spines or lobed (Mena-Portales et al. 2017). There are 14 Spegazzinia species in Species Fungorum (2020).

Tremateia Kohlm. Volkm.-Kohlm. \& O.E. Erikss., Bot. Mar. 38(2): 165 (1995).

Index Fungorum number: IF 6202; Facesoffungi number: FoF 00223; 6 morphological species (Species Fungorum 2020), 6 species with molecular data.

Type species - Tremateia halophila Kohlm. Volkm.-Kohlm. \& O.E. Erikss., Bot. Mar. 38(2): 166 (1995).

Notes - Kohlmeyer et al. (1995) introduced Tremateia in Pleosporaceae as a facultative marine genus which is characterized by depressed globose, immersed ascomata, numerous and cellular pseudoparaphyses, fissitunicate and clavate asci, ellipsoid muriform ascospores, and a phoma-like asexual morph. In recent studies Tremateia species have been placed in Didymosphaeriaceae based on multi-gene phylogeny and morphological characteristics (Ariyawansa et al. 2014d).

Verrucoconiothyrium Crous, Sydowia 67: 110 (2015).

Index Fungorum number: IF 812549; Facesoffungi number: FoF 08241; 5 morphological species (Species Fungorum 2020), 5 species with molecular data. 
Type species - Verrucoconiothyrium nitidae (Crous \& Denman) Crous, Sydowia 67: 110 (2015).

三 Coniothyrium nitidae Crous \& Denman, in Swart, Crous, Denman \& Palm, S. Afr. J. Bot. 64(2): 138 (1998).

Notes - Verrucoconiothyrium was introduced by Crous et al. (2015b) to accommodate coniothyrium-like species with verruculose conidia. There are five Verrucoconiothyrium species in Species Fungorum (2020), V. acaciae, $V$. ambiguum, $V$. eucalyptigenum, $V$. nitidae and $V$. prosopidis.

Vicosamyces Firmino, A.R. Machado \& O.L. Pereira, Fungal Diversity 95: 12 (2019).

Index Fungorum number: IF 822577; Facesoffungi number: FoF 03786; 1 morphological species (Species Fungorum 2020), 1 species with molecular data.

Type species - Vicosamyces venturisporus Firmino, A.R. Machado \& O.L. Pereira, Fungal Diversity 95: 12 (2019).

Notes - Vicosamyces was introduced by Phookamsak et al. (2019) to accommodate Vicosamyces venturisporus which was collected from leaves of Eugenia sp. (Myrtaceae). Vicosamyces species are characterized in having globose to pyriform ascomata, solitary, immersed in large, orange-brown wounds and 2-celled, apiospores. The phylogeny of Vicosamyces showed some close affinities with Austropleospora, but Vicosamyces has 2-celled, apiospores, while Austropleospora has muriform ascospores (Phookamsak et al. 2019).

Xenocamarosporium Crous \& M.J. Wingf., Persoonia 34: 185 (2015).

Index Fungorum number: IF 812422; Facesoffungi number: FoF 01730; 1 morphological species (Species Fungorum 2020), 1 species with molecular data.

Type species - Xenocamarosporium acaciae Crous \& M.J. Wingf., Persoonia 34: 185 (2015).

Notes - Xenocamarosporium was introduced by Crous et al. (2015c) based on their morphological similarities with Camarosporium. Xenocamarosporium differs from Paracamarosporium in lacking paraphyses and from Pseudocamarosporium in lacking muriformly septate. The connectively of sexual and as asexual morphs is not proven yet, as nobody has obtained any sexual morph for these species.

\section{Ecological and economic significance}

Didymosphaeriaceae include some genera which are of economic importance, since they play a negative role by causing plant diseases, such as Austropleospora, Barria and Deniquelata (Ariyawansa et al. 2013c, 2014d, Wijayawardene et al. 2017a). In particular, Ariyawansa et al. (2013c) has proved the pathogenicity of Deniquelata by pinpricking inoculation technique on Barringtonia asiatica leaves.

Dothidotthiaceae Crous \& A.J.L. Phillips, Persoonia 21: 35 (2008).

Index Fungorum number: IF 511706; Facesoffungi number: FoF 06309, 59 species.

Saprobic, endophytic, pathogenic on leaves, wood and branches in terrestrial habitats. Sexual morph: Ascomata solitary, clustered or somewhat gregarious, immersed to erumpent, globose to subglobose, dark brown to black, ostiolate. Ostiole apex somewhat papillate to depressed, coriaceous. Peridium composed of layers of dark brown to black cells of textura angularis, with basal region giving rise to dark brown, thick-walled hyphae, that extend from base of the ascoma into the substrate. Hamathecium comprising hyaline, broad, septate, branched, cellular or trabeculate pseudoparaphyses, embedded in a gelatinous matrix. Asci 8-spored, bitunicate, fissitunicate, clavate, straight to curved, with a pedicel, rounded at apex with an ocular chamber. Ascospores 3-seriate or obliquely 1-seriate, partially overlapping, fusiform to ellipsoidal, pale to medium brown, 1-septate, slightly constricted at septum, rounded at ends, smooth-walled, thinwalled, with or without a gelatinous sheath. Asexual morph: Colonies punctiform, brown to black. Conidiomata immersed, erumpent or nearly superficial, brown to dark brown. Conidiophores macronematous, mononematous, packed closely together forming pulvinate sporodochia, branched 
or unbranched, straight or flexuous, hyaline to brown, or olivaceous brown, smooth or verrucose. Conidiogenous cells monoblastic, holoblatic, polyblastic, enteroblastic, annelledic, integrated, terminal, or intercalary, or conidiophores reduced to conidiogenous cells, percurrent, cylindrical to subcylindrical. Conidia clavate to obclavate, cylindrical, ellipsoid or fusiform, filiform, subhyaline to dark brown, transversely, longitudinally, euseptate, smooth or rough, verrucose or echinulate, with or without appendages around the apical cell.

Type - Dothidotthia Höhn.

Notes - Dothidotthia was placed in Botryosphaeriaceae by Barr (1987b) based on morphological similarities. However, analyses of LSU and SSU sequence data of Dothidotthia taxa showed their distinct placement in Pleosporales and with support from morphological characteristics, Phillipps et al. (2008) therefore introduced a new family Dothidotthiaceae to accommodate Dothidotthia.

Dothidotthia Höhn., Berichte der Deutschen Botanischen Gesellschaft 36: 312 (1918).

Index Fungorum number: IF 1699; Facesoffungi number: FoF 06310; 14 morphological species (Species Fungorum 2020), 4 species with molecular data.

Type species - Dothidotthia symphoricarpi (Ellis \& Everh.) Höhn.

$\equiv$ Plowrightia symphoricarpi Ellis \& Everh., Proc. Acad. nat. Sci. Philad. 42: 249 (1890).

Notes - Dothidotthia is the type genus of Dothidotthiaceae and is typified by Dothidotthia symphoricarpi (Phillips et al. 2008). The asexual morph of Dothidotthia is linked to Thyrostroma (Ramaley 2005, Phillips et al. 2008). Molecular studies showed that Thyrostroma compactum (type species) forms a distinct clade within Dothidotthiaceae, and forms a separate clade to Dothidotthia symphoricarpi, which suggests that they are not congeneric (Crous et al. 2016b, Marin-Felix et al. 2017). This suggestion was confirmed by Senwanna et al. (2019) with the use of molecular data, along with morphology.

Dothidotthia negundinicola (Crous \& Akulov) Senwanna, Wanas., Bulgakov, Phookamsak \& K.D. Hyde, Mycosphere 10(1): 716 (2019).

Fig. 80

$\equiv$ Neodothidotthia negundinicola Crous \& Akulov, in Crouset al., Fungal Systematics and Evolution 3: 93 (2019).

Index Fungorum number: IF 556640; Facesoffungi number: FoF 06139.

Associated with canker on twigs of Acer negundo (Sapindaceae). Sexual morph: Undetermined. Asexual morph: Colonies 180-470 $\mu \mathrm{m}$ diam, partly immersed, ascostromatic, effuse, sporodochial, with partly immersed, basal pseudoparenchymatous ascostroma, erumpent, black, velvety. Conidiophores $(16-) 21-33(-36) \times 5-11 \mu \mathrm{m}(\bar{x}=27.6 \times 8.5 \mu \mathrm{m}, \mathrm{n}=20)$, semimacronematous, septate, branched, subhyaline, smooth, arising from basal ascostroma. Conidiogenous cells 13-26 $\mu \mathrm{m}$ long, monoblastic, integrated, terminal. Conidia (24-)28-36(-38) $\times$ 10-16.5 $\mu \mathrm{m}(\bar{x}=32.2 \times 16.5 \mu \mathrm{m}, \mathrm{n}=75)$, acrogenous, fusiform to obclavate to obpyriform, pale to brown, truncate at base, with a protruding hilum, rounded at apex, 2-septate, constricted at septa, minutely echinulate.

Culture characteristics - Colonies on MEA, reaching $3 \mathrm{~cm}$ diameter after 2 weeks at 25$30{ }^{\circ} \mathrm{C}$, producing dense mycelium, circular, velvety to woolly, rough margin, white to creamy-grey, with aerial mycelium.

Material examined - Russia, Rostov region, Shakhty Park, on dead and dying twig of Acer negundo (Sapindaceae), 1 March 2016, Timur S. Bulgakov, T-1494 (MFLU 16-1788), living culture MFLUCC 17-2511.

GenBank numbers - ITS: MN168763, LSU: MN168760, SSU: MN168758.

Notes - Crous et al. (2019b) reported and illustrated Neodothidotthia negundinicola (CBS 145039) from Acer negundo in Ukraine. Senwanna et al. (2019) synonymized Neodothidotthia negundinicola under Dothidotthia negundinicola based on morphology and phylogeny. The conidial morphology of our fresh specimen resembles Dothidotthia negundinicola (CBS 145039) in having fusiform to obclavate, pale to brown, 2-septate, 24-38 $\times 10-16.5 \mu \mathrm{m}$ and in the combined multi-gene phylogeny. 


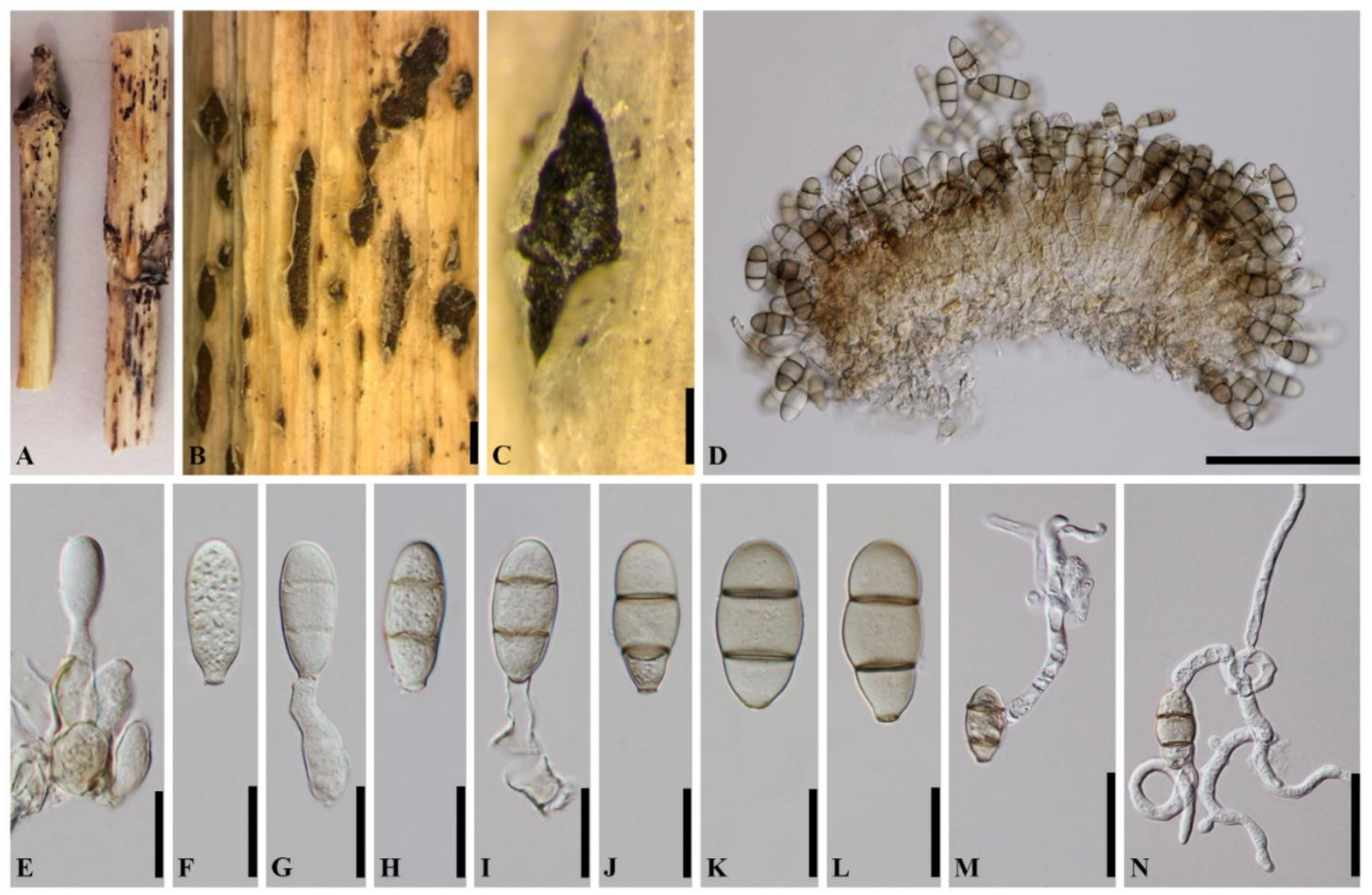

Figure 80 - Dothidotthia negundinicola (MFLU 16-1759). a-c Sporodochia on host surface. d Vertical section of sporodochium. e Conidia attached with the conidiogenous cells. $\mathrm{h}-1$ Conidia. $\mathrm{m}$, $\mathrm{n}$ Germinated conidia. Scale bars: $\mathrm{b}=500 \mu \mathrm{m}, \mathrm{c}=200 \mu \mathrm{m}, \mathrm{d}=100 \mu \mathrm{m}, \mathrm{e}-1=20 \mu \mathrm{m}, \mathrm{m}, \mathrm{n}=40$ $\mu \mathrm{m}$.

\section{Other genera included}

Belizeana Kohlm. \& Volkm.-Kohlm., Bot. Mar. 30(3): 195 (1987).

Index Fungorum number: IF 25091; Facesoffungi number: FoF 06219; 1 morphological species (Species Fungorum 2020), molecular data unavailable.

Type species - Belizeana tuberculata Kohlm. \& Volkm.-Kohlm., Bot. Mar. 30(3): 196 (1987)

Notes - Kohlmeyer \& Volkmann-Kohlmeyer (1987) introduced the monotypic genus Belizeana as a member of Pleosporaceae and reported the asexual morph of Belizeana as phomalike. Lumbsch \& Huhndorf (2007) placed Belizeana in Dothideomycetes, genera incertae sedis. However, this genus was later transferred to Elsinoaceae by Lumbsch \& Huhndorf (2010). Zhang et al. (2012b) accepted Belizeana as Pleosporales, genera incertae sedis. Later, the genus was accepted as a genus in Dothideales incertae sedis (Jones et al. 2015). Based on subglobose, dark brown to black ascomata, clavate to cylindrical asci and 1-septate, ellipsoidal, pale brown ascospores, Pem et al. (2019c) transferred Belizeana to Dothidotthiaceae. Sequence data is requested to confirm its placement in Dothidotthiaceae.

Mycocentrospora Deighton, Taxon 21(5-6): 716 (1972).

Index Fungorum number: IF 9021; Facesoffungi number: FoF 07938; 12 morphological species (Species Fungorum 2020), 2 species with molecular data.

Type species - Mycocentrospora acerina (R. Hartig) Deighton, Taxon 21(5-6): 716 (1972).

$\equiv$ Cercospora acerina $\mathrm{R}$. Hartig, Untersuch. Forstbot. Inst. München 1: 59 (1880).

Notes - Mycocentrospoara was established by Deighton (1972) to accommodate Mycocentrospora acerina. Mycocentrospoara was proposed as pseudocercospora-like in having coloured secondary mycelium, conidiophores and conidia (Deighton 1971, 1973). Crous et al. (2019b) included Mycocentrospoara in Dothidotthiaceae based on molecular phylogenetic studies. 
There are 12 species listed in Index Fungorum (2020), but only Mycocentrospora acerina has molecular data.

Phaeomycocentrospora Crous, H.D. Shin \& U. Braun, Studies in Mycology 75: 61 (2013).

Index Fungorum number: IF 564813; Facesoffungi number: FoF 07939; 1 morphological species (Species Fungorum 2020), 1 species with molecular data.

Type species - Phaeomycocentrospora cantuariensis (E.S. Salmon \& Wormald) Crous, H.D. Shin \& U. Braun, Stud. Mycol. 75: 61 (2013).

$\equiv$ Cercospora cantuariensis E.S. Salmon \& Wormald, J. Bot., Lond. 61: 134 (1923).

Notes - Phaeomycocentrospora was introduced as a genus incertae sedis of Pleosporales by Crous et al. (2013a) and typified by $P$. cantuariensis based on morphology and molecular evidence. Morphologically Phaeomycocentrospora is similar to Pseudocercospora, however, the two genera can be distinguished based on the hyaline hyphae, broad conidiogenous loci and hila of conidia (Crous et al. 2013a). Previously, Phaeomycocentrospora was placed in Didymellaceae following the phylogenetic analysis of Trakunyingcharoen et al. (2014), however, phylogenetic studies of Marin-Felix et al. (2017), Valenzuela-Lopez et al. (2018) and Senwanna et al. (2019) have shown that Phaeomycocentrospora is not closely related to Didymellaceae and groups within Dothidotthiaceae.

Pleiochaeta (Sacc.) S. Hughes, Mycological Papers 36: 39 (1951).

$\equiv$ Ceratophorum subgen. Pleiochaeta Sacc., Syll. fung. (Abellini) 11: 622 (1895).

Index Fungorum number: IF 9443; Facesoffungi number: FoF 07940; 6 morphological species (Species Fungorum 2020), 3 species with molecular data.

Type species - Pleiochaeta setosa (Kirchner) S. Hughes, Mycol. Pap. 36: 39 (1951).

三 Ceratophorum setosum Kirchn., Z. PflKrankh. 2: 327 (1892).

Notes - Pleiochaeta was introduced to accommodate two species, P. setosa and P. albizziae (Hughes 1951b). Combined gene analysis of ITS and LSU gene sequence data by Marin-Felix et al. (2017) showed that Pleiochaeta species belong in Dothidotthiaceae.

Thyrostroma Höhn., Sitzungsberichte der Kaiserlichen Akademie der Wissenschaften Math.naturw. Klasse Abt. I 120: 472 (1911).

Index Fungorum number: IF 10224; Facesoffungi number: FoF 07941; 24 morphological species (Species Fungorum 2020), 12 species with molecular data.

Type species - Thyrostroma compactum (Sacc.) Höhn., Sber. Akad. Wiss. Wien, Math.naturw. Kl., Abt. 1 120: 472 (1911).

三Stegonsporium compactum Sacc., Michelia 2(no. 8): 542 (1882).

Notes - Thyrostroma was introduced by Höhnel (1911). Ramaley (2005) and Phillips et al. (2008) considered Thyrostroma as the asexual morph of Dothidotthia. However, phylogenetic analyses demonstrated that Thyrostroma and Dothidotthia are not congeneric (Crous et al. 2016b, Marin-Felix et al. 2017, Senwanna et al. 2019). Therefore, Senwanna et al. (2019) segregated Thyrostroma from Dothidotthia based on morphological and molecular evidence.

Wilsonomyces Adask., J.M. Ogawa \& E.E. Butler, Mycotaxon 37: 283 (1990).

Index Fungorum number: IF 11250; Facesoffungi number: FoF 07942; 1 morphological species (Marin-Felix et al. 2017), 1 species with molecular data.

Type species - Wilsonomyces carpophilus (Lév.) Adask., J.M. Ogawa \& E.E. Butler, Mycotaxon 37: 283 (1990).

三 Helminthosporium carpophilum Lév., Annls Sci. Nat., Bot., sér. 2 19: 215 (1843).

Notes - Wilsonomyces was established by Adaskaveg et al. (1990) as a monotypic genus with W. carpophilus as the type. Sutton (1997) treated Thyrostroma as a synonym of Wilsonomyces. However, molecular studies based on three nuclear genes (Marin-Felix et al. 2017) shows that Wilsonomyces carpophilus groups away from Thyrostroma compactum and they are morphologically different as well, and hence they are not congeneric. 


\section{Ecological and economic significance}

Members of Dothidotthiaceae form diseases on plants such as canker, dieback, leaf spots and root rot, as well as saprobes throughout tropical and temperate regions (Yuan \& Old 1990, Kuz'michev et al. 2001, Mel'nik \& Popov 2007, Phillips et al. 2008, Bulgakov et al. 2014, Crous et al. 2013a, 2016b, Hyde et al. 2013, Marin-Felix et al. 2017). For example, Pleiochaeta setosa is an important phytopathogen causing devastating diseases in Lupinus spp., legumes and other hosts (Marin-Felix et al. 2017). The species attacks primarily the tap root of albus lupin (Lupinus albus) leading to seedling death, lower plant density, and reduced crop yield (Gan et al. 2009).

Fuscostagonosporaceae Jayasiri, Camporesi \& K.D. Hyde, Fungal Divers. 87: 34 (2017).

Index Fungorum number: IF 553867; Facesoffungi number: FoF 03780, 4 species.

Saprobic on dead stems. Sexual morph: Ascomata immersed, scattered, globose to subglobose. Ostiolar neck clypeate, central, short papillate, with periphyses. Peridium composed of pale brown, compressed cells. Hamathecium comprising trabeculate, branched, anastomosing, pseudoparaphyses, associated with gelatinous material. Asci bitunicate, fissitunicate, cylindrical, with a long stipe. Ascospores narrowly fusiform, hyaline, 1-3-septate, with a sheath covering entire spore. Asexual morph: Conidiomata pycnidial, immersed, scattered, depressed globose, ostiolate. Conidiomatal wall composed of thin-walled cells. Conidiophores reduced to conidiogenous cells. Conidiogenous cells doliiform, annellidic. Conidia globose, yellow to pale brown and 3-septate.

Notes - Fuscostagonosporaceae contains a single genus Fuscostagonospora. This family is characterised by having immersed, globose to subglobose ascomata, trabecular, branched pseudoparaphyses, and narrowly fusiform, hyaline ascospores with a sheath (Hyde et al. 2017). Although, Fuscostagonosporaceae was reported to have trabeculate pseudoparaphyses, some species of Fuscostagonospora have cellular pseudoparaphyses (e.g. Fuscostagonospora cytisi and F. camporesii, Hyde et al. 2017).

Fuscostagonospora Kaz. Tanaka \& K. Hiray, in Tanaka et al., Stud. Mycol. 82: 124 (2015).

Index Fungorum number: IF 552782; Facesoffungi number: FoF 2898; 4 morphological species (Species Fungorum 2020), 4 species with molecular data.

Type species - Fuscostagonospora sasae Kaz. Tanaka \& K. Hiray.

Notes - Tanaka et al. (2015) introduced Fuscostagonospora to accommodate the bambusicolous taxon, $F$. sasae. Morphologically, Fuscostagonospora closely resembles Bambusicola by its narrowly fusiform ascospores and pigmented septate conidia, as well as host preferences (Dai et al. 2012, 2017). However, Fuscostagonospora is different from Bambusicola in having prominent clypeus ascomata. Phylogenetic analyses indicated that Fuscostagonospora formed as a distinct family within Pleosporales (Tanaka et al. 2015, our study). Thus, Tanaka et al. (2015) established Fuscostagonosporaceae to accomodate this genus. Fuscostagonospora is also similar to Stilbospora in having pigmented phragmosporous conidia, however Stilbospora differs from Fuscostagonospora in having acervular conidiomata filled with paraphyses and phylogenetically groups within the Diaporthales in the Sordariomycetes (Tanaka et al. 2015).

Fuscostagonospora cytisi Jayasiri, Camporesi \& K.D. Hyde, in Hyde et al., Fungal Diversity 87: 34 (2017).

Index Fungorum number: IF 552782; Facesoffungi number: FoF 02898.

Fig. 81

Description - see Hyde et al. (2017).

Material examined - Italy, Province of Arezzo, near Croce di Pratomagno, dead aerial branch of Cytisus scoparius (Fabaceae). 19 October 2015, E. Camporesi, IT 2651 (MFLU 15-3607, holotype; PDD, isotype), ex-type living cultures MFLUCC 16-0622, BCC.

\section{Ecological and economic significance}

No economic significance is recorded for this family. Species in this family play roles in recycling organic matters. 


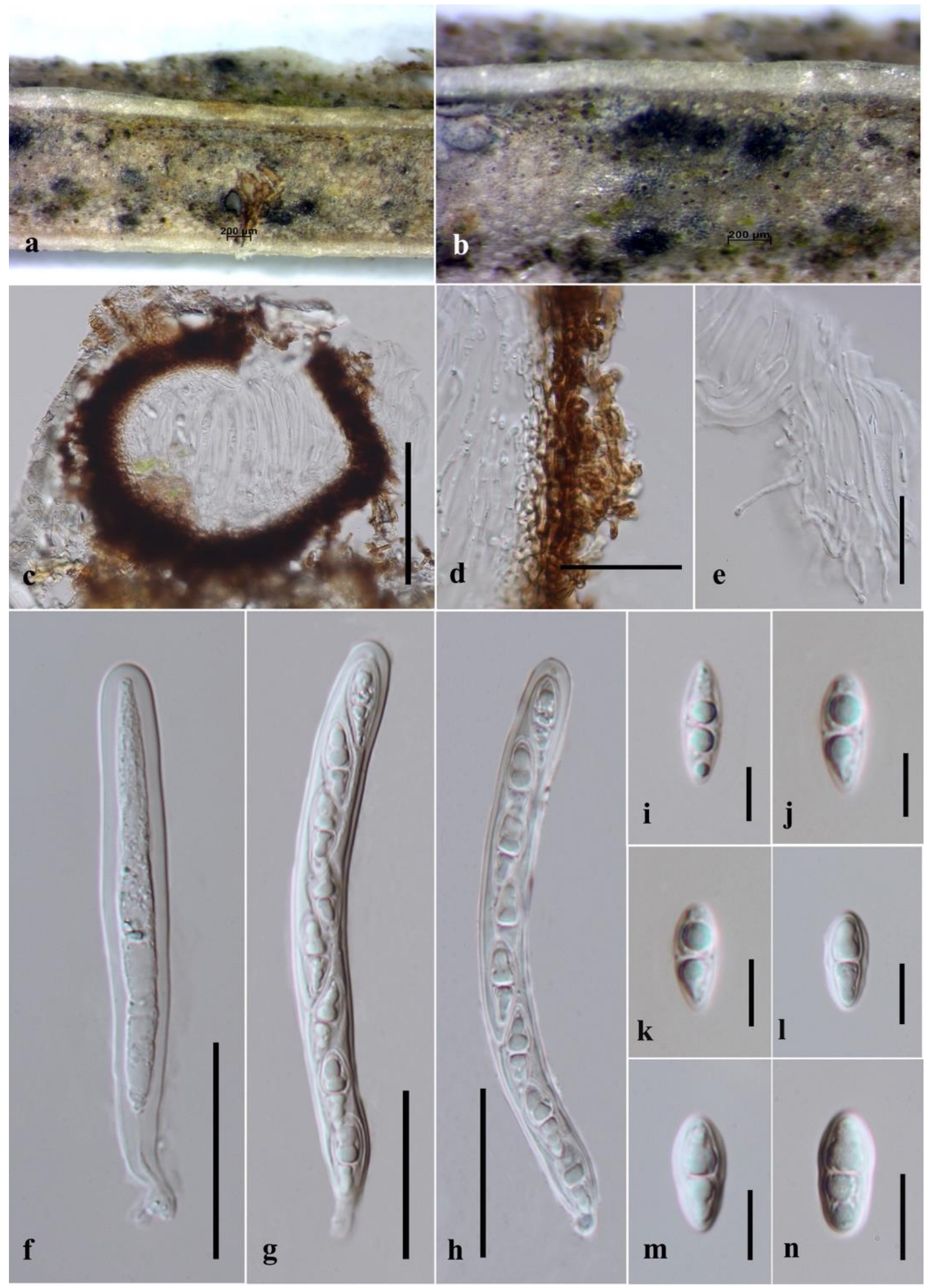

Figure 81 - Fuscostagonospora cytisi (MFLU 15-3607, holotype). a, b Appearance of ascomata on host substrate. c Section through ascomata. d Peridium. e, k Pseudoparaphyses. f-h Asci. i-n Ascospores. Scale bars $\mathrm{c}=100 \mu \mathrm{m}, \mathrm{d}=20 \mu \mathrm{m}, \mathrm{e}=10 \mu \mathrm{m}, \mathrm{f}-\mathrm{h}=30 \mu \mathrm{m}, \mathrm{i}-\mathrm{n}=10 \mu \mathrm{m}$. 
Fusculinaceae P.W. Crous, Persoonia 41: 301 (2018).

Index Fungorum number: IF 828200; Facesoffungi number: FoF 08242, 4 species.

Saprobic on leaves of Eucalyptus socialis. Sexual morph: Undetermined. Asexual morph: Coelomycetous. Conidiomata immersed to erumpent, solitary, pycnidia, brown, globose, have a creamy conidial mass. Conidiomata walls several layers, with cells of textura angularis, the outer layers composed of brown walled cells, Conidiophores lining in the cavity, hyaline cells, subcylindrical and smooth. Conidiogenous cells terminal and intercalary, hyaline, smooth. Conidia solitary, fusoid and apex subobtuse, hyaline, aseptate, guttulate, smooth-walled (adapted from Crous et al. 2018a).

Type - Fusculina Crous \& Summerell.

Notes - Fusculinaceae was introduced by Crous et al. (2018a). There are two genera in this family and they have been reported with asexual morphs (coelomycetous). Crous et al. (2018a) used ITS and LSU in their phylogenetic analyses and indicated that Fusculina and Gordonomyces formed a distinct clade within Pleoporales, therefore the new family Fusculinaceae was introduced to accommodate this clade.
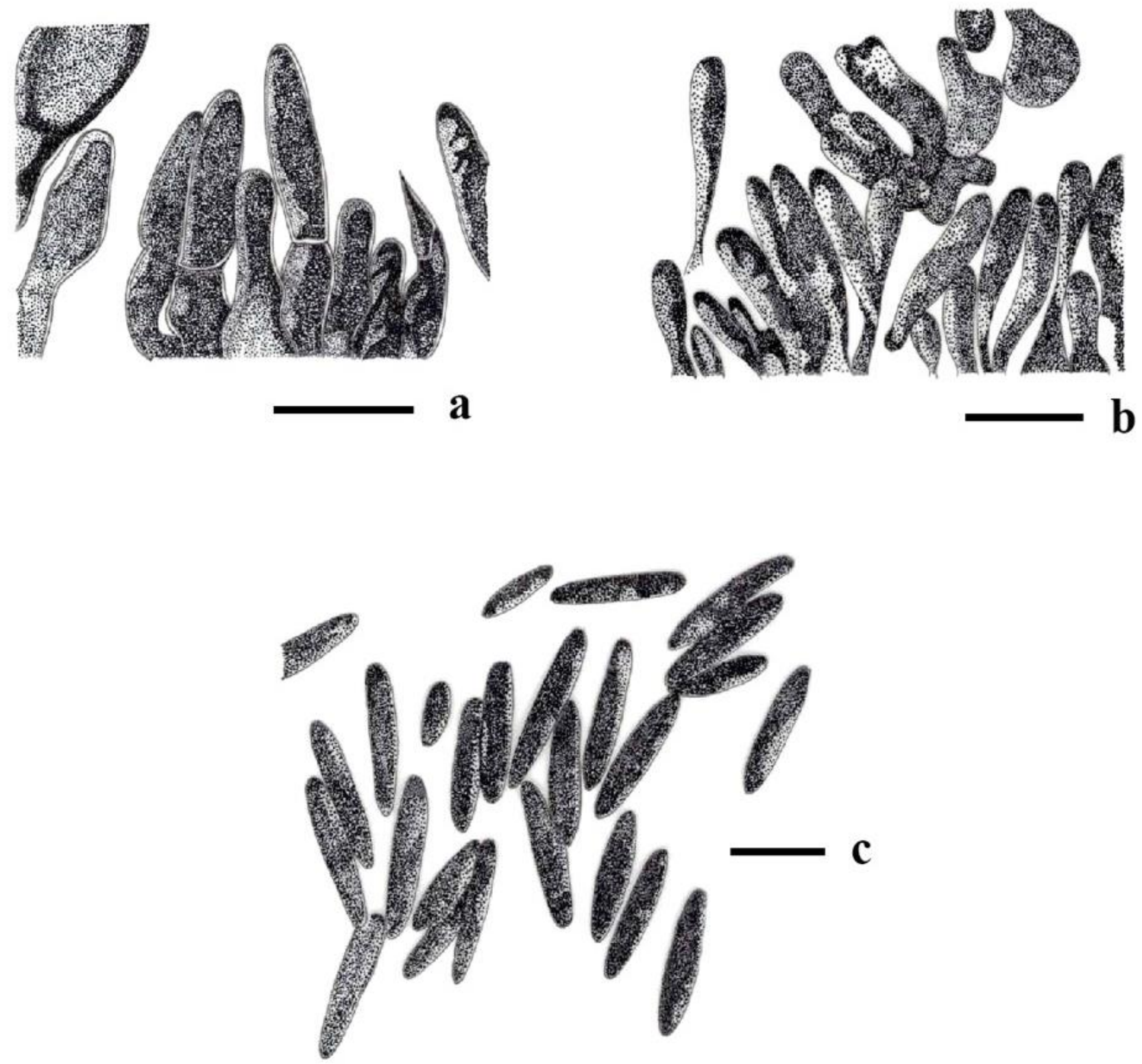

Figure 82 - Fusculina eucalyptorum (redrawn from Crous et al. 2018a, CBS H-23775 holotype). a, $b$ Conidiophores and conidiogenous cells. c Conidia. Scale bars: $\mathrm{a}-\mathrm{c}=10 \mu \mathrm{m}$. 
Fusculina Crous \& Summerell, Fungal Divers. 23: 334 (2006).

Index Fungorum number: IF 510010; Facesoffungi number: FoF 08243; 3 morphological species (Species Fungorum 2020), 3 species with molecular data.

Type species - Fusculina eucalypti Crous \& Summerell, Fungal Divers. 23: 334 (2006).

Notes - Fusculina was introduced by Summerell et al. (2006), with the type species $F$. eucalypti. Two species have been reported with asexual morphs (Summerell et al. 2006, Crous et al. 2018a). Phylogenetic studies indicated that Fusculina clusters with the type species of Gordonomyces in Pleosporales (Crous et al. 2018a, Fig. 42 in this study). Crous et al. (2018a) introduced the new family to accomodate these two genera.

\section{Other genera included}

Gordonomyces Crous \& Marinc., Persoonia 27: 39 (2011).

Index Fungorum number: IF 560568; Facesoffungi number: FoF 08244; 1 morphological species (Species Fungorum 2020), 1 species with molecular data.

Type species - Gordonomyces mucovaginatus Crous \& Marinc., Persoonia 27: 39 (2011)

Notes - Gordonomyces was established as a monotypic genus by Crous et al. (2011c). Based on molecular analysis, the genus is closely related to Fusculina eucalypti. The type species has been reported with an asexual morph on leaf litter of Leucadendron laureolum, at Western Cape Province, Gordon's Bay in South Africa.

\section{Ecological and economic significance}

Species of Fusculinaceae are commonly saprobic on dead stems. Thus, there is noeconomic or ecological significance from this group. However, it might have some roles in decomposition process, but some species are plant pathogens such as Fusculina eucalyptorum (Crous et al. 2018a) associated with leaf spots.

Halojulellaceae Suetrong, K.D. Hyde \& E.B.G. Jones, Phytotaxa 130(1): 18 (2013).

Index Fungorum number: IF 803303; Facesoffungi number: FoF 08245, 1 species.

Saprobic on wood in mangrove habitats. Sexual morph: Ascomata immersed, becoming erumpent or superficial, sphaeroid, short papillate, ostiolate, formed under a clypeus. Peridium 2layered, thickened above with clypeal tissue, small and brown to black pseudoparenchymatous cells at outer layer, hyaline cells at inner layer. Hamathecium comprising simple, cellular, hypha-like, septate, pseudoparaphyses, embedded in a gelatinous matrix. Asci 8-spored, bitunicate, fissitunicate, clavate to cylindrical, with moderately long pedicel with clublike base, and distinctive apical apparatus. Ascospores 1-2-seriate, asymmetric or nearly symmetric, ellipsoid, hyaline or pale golden brown at maturity, muriform, constricted at the septa, smooth or verruculose, thin-walled, surrounded by a mucilaginous sheath, guttulate. Asexual morph: Coelomycetous, phoma-like. Pycnidia in culture brown, thin-walled, with an ostiolate. Conidiophores filiform, septate, branched. Conidia ellipsoidal, hyaline, aseptate, thin-walled, with guttulate.

Type - Halojulella Suetrong, K.D. Hyde \& E.B.G. Jones

Notes - Halojulellaceae was established by Ariyawansa et al. (2013a) to accommodate Halojulella avicenniae (= Julella avicenniae). The morphological characters of this family fit well with most families of Pleosporales having bitunicate and fissitunicate asci as well as cellular pseudoparaphyses among their asci and uniloculate ascomata. However, Halojulellaceae is recognized as a distinct family in Pleosporals based on its immersed, medium-sized ascomata, with pseudoparenchymatous peridial cells, broad cellular pseudoparaphyses, asci with a distinctive apical apparatus, containing hyaline to pale, golden brown, muriform ascospores and a marine habitat (Zhang et al. 2012b, Ariyawansa et al. 2013a). Julella is polyphyletic with some species referred to Trypetheliaceae (Nelsen et al. 2011). Harris (1995) and Aptroot et al. (2008) suggested that some Julella species are closely related to or even part of Arthopyrenia. Halojulella is a monotypic genus in Halojulellaceae and further collections and sequence data are required to resolve the taxonomic assignment of other Julella species. 

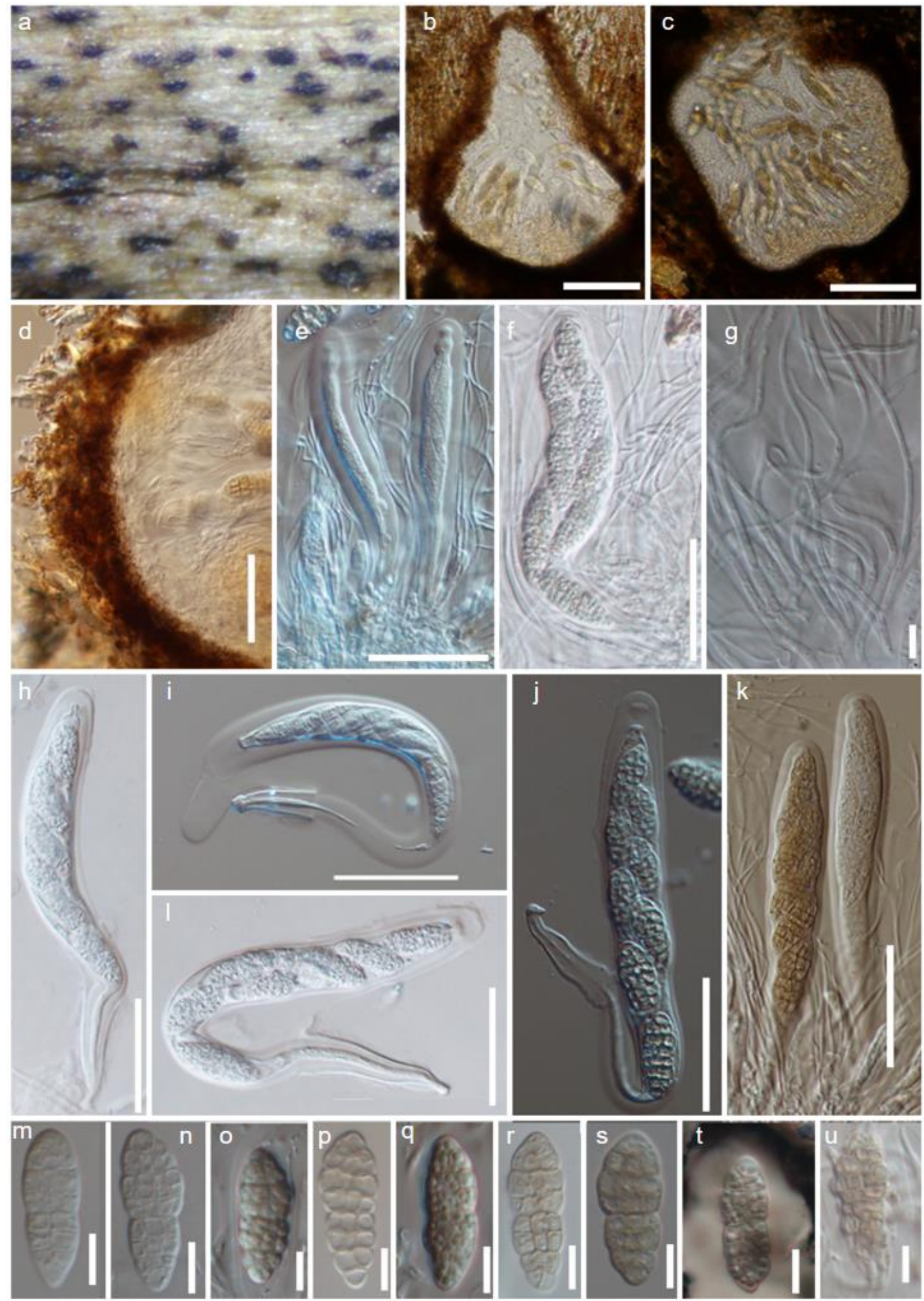

Figure 83 - Halojulella avicenniae (AMH-9996). a Ascomata erumpent on decaying wood. $\mathrm{b}$, c Longitudinal sections of ascomata. d Section of peridium. e, $\mathrm{f}, \mathrm{h}$ Immature asci. g filamentous pseudoparaphyses. i, 1 Asci showing fissitunicate dehiscence. j, k Mature asci. $\mathrm{m}-\mathrm{s}$ Hyaline to brown ascospores. $t$ Wide gelatinous sheath in India ink. $\mathrm{u}$ Germ tubes developed from terminal ends of ascospore. Scale bars: $\mathrm{b}, \mathrm{c}=100 \mu \mathrm{m}, \mathrm{d}-\mathrm{f}, \mathrm{h}-\mathrm{k},=50 \mu \mathrm{m} \mathrm{g}, \mathrm{m}-\mathrm{u}=10 \mu \mathrm{m}$. 

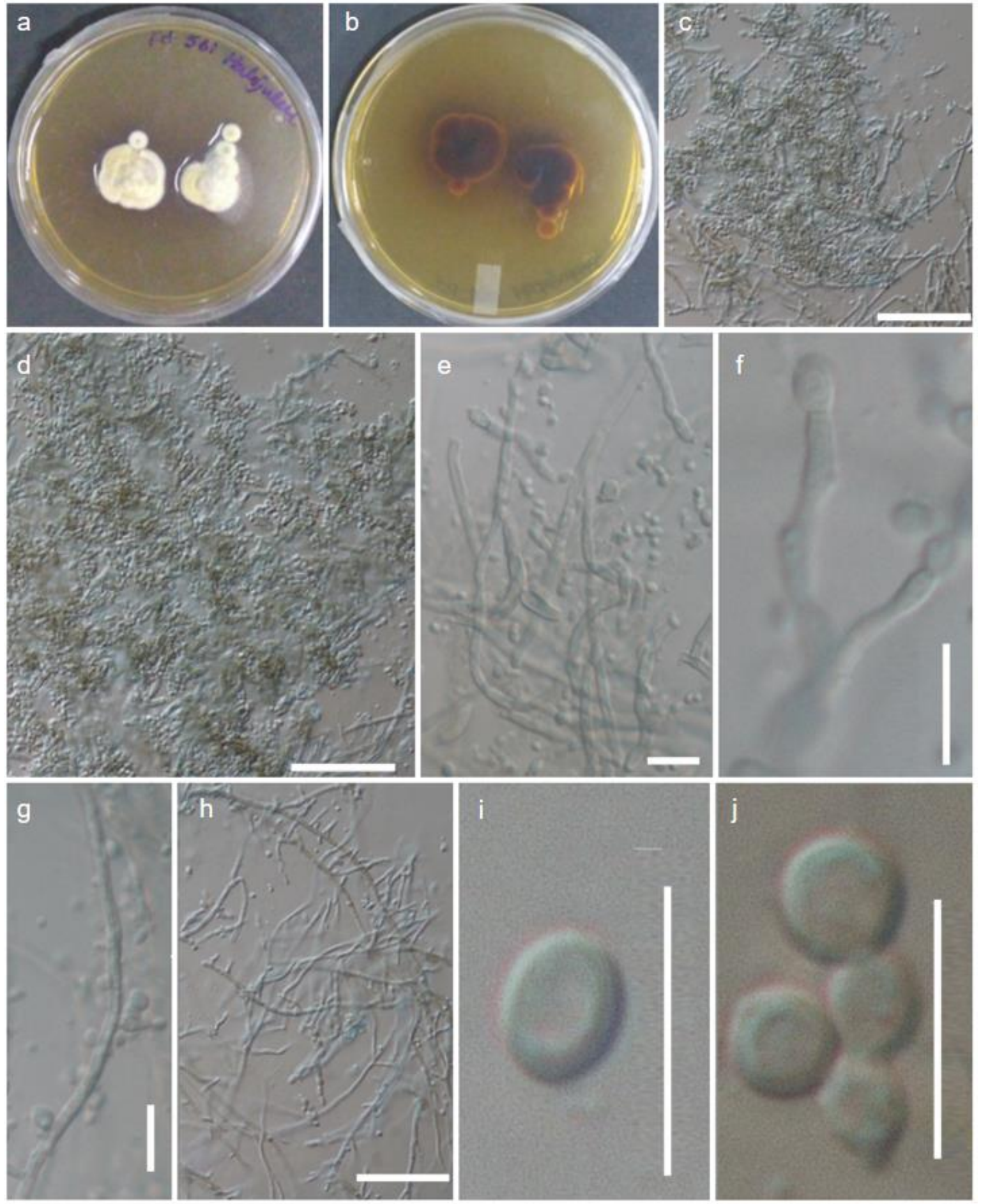

Figure 84 - Halojulella avicenniae (AMH-9996). a-b Culture. c- $\mathrm{h}$ Stages of conidiophore bearing conidia from culture. $\mathrm{i}-\mathrm{j}$ Conidia. Scale bars: $\mathrm{c}, \mathrm{d}, \mathrm{h},=50 \mu \mathrm{m} \mathrm{e}, \mathrm{f}, \mathrm{i}-\mathrm{j}=10 \mu \mathrm{m}$.

Halojulella Suetrong, K.D. Hyde \& E.B.G. Jones, Phytotaxa 130(1): 18 (2013).

Index Fungorum number: IF 803342; Facesoffungi number: FoF 08246; 1 morphological species (Species Fungorum 2020), 1 species with molecular data.

Type species - Halojulella avicenniae (Borse) Suetrong, K.D. Hyde \& E.B.G. Jones.

$\equiv$ Pleospora avicenniae Borse, Curr. Sci. 56(21): 1109 (1987)

Notes - The genus was found on mangrove wood and its type species was Pleospora avicenniae by Borse (1987). Pleospora avicenniae was transferred to Julella by Hyde (1992c). The type species Julella buxi Fabre has 2-spored asci and lacks a well-developed apical apparatus, while asci of $J$. avicenniae are 8-spored and have an unusual, distinct, apical apparatus. 
Phylogenetically, J. avicenniae formed a monophyletic clade in the Pleosporales with high support (Suetrong et al. 2009, Zhang et al. 2012b, Ariyawansa et al. 2013a, Jones et al. 2019a). Ariyawansa et al. (2013a) introduced a new genus Halojulella to accommodate Julella avicenniae (current name Halojulella avicenniae), in a new family Halojulellaceae.

Halojulella avicenniae (Borse) Suetrong, K.D. Hyde \& E.B.G. Jones, Phytotaxa 130(1): 19 (2013).

Fig. 83

Index Fungorum number: IF 803343; Facesoffungi number: FoF 06533.

Saprobic on decaying wood of Avicennia marina, frequently young twigs. Sexual morph: Ascomata 200-400 high $\times 235-360 \mu \mathrm{m}$ diam. $(\bar{x}=305 \times 285 \mu \mathrm{m}, \mathrm{n}=10)$, globose or subglobose, immersed beneath a clypeus, membranous, with ostiolate. Ostiole 100-150 long $\times 80-100 \mu \mathrm{m}$ diam. $(\bar{x}=118 \times 91 \mu \mathrm{m}, \mathrm{n}=5)$, periphysate. Peridium 2-layered, 20-40 $\mu \mathrm{m}(\bar{x}=28 \mu \mathrm{m}, \mathrm{n}=5)$, thickened above with clypeal tissue, outer layer of small pseudoparenchymatous cells, brown, inner layer of hyaline cells. Hamathecium comprising cellular, hypha-like, septate pseudoparaphyses. Asci $125-195 \times 175-30 \mu \mathrm{m},(\bar{x}=195 \times 20 \mu \mathrm{m}, \mathrm{n}=15), 8$-spored, bitunicate, fissitunicate, thickwalled, clavate, moderately long pedicel with club-like base, apically rounded, with an ocular chamber surrounded by distinct apical apparatus, not bluing in IKI (I-), developing from the base of the ascoma. Ascospores $27-40 \times 12.5-15 \mu \mathrm{m},(\bar{x}=35 \times 13 \mu \mathrm{m}, \mathrm{n}=25)$, overlapping 1-2-seriate, ellipsoidal, hyaline, with a central septum when young, becoming yellow to pale brown, or golden brown, with 6-7 transsepta when mature, constricted particularly at the central septum with up to 2-3 longisepta, and surrounded by a large spreading sheath. Asexual morph: Coelomycetous, phoma-like. Conidiophores 10-25 $\times 2-3 \mu \mathrm{m},(\bar{x}=17.5 \times 2.7 \mu \mathrm{m}, \mathrm{n}=10)$, filiform, septate, branched; Conidia 1.5-5 $\times 2-4 \mu \mathrm{m},(\bar{x}=3.5 \times 2.8 \mu \mathrm{m}, \mathrm{n}=15)$, globose to ellipsoidal, hyaline, aseptate, thin-walled.

Culture characteristics - Ascospores germinating on $2 \%$ sea water agar within $24 \mathrm{~h}$ with germ tubes produced from both ends. Colonies on malt extract sea water agar initially yellow when mature turns into brown, reverse brown, reaching 15 to $30 \mathrm{~mm}$ in diameter in 25 days at room temperature. Mycelium hyaline to brown, producing yellow brown pigments, velvety.

Material examined - India, Tamil Nadu, Pondicherry, Veerampattinam mangroves, $\left(11.59^{\circ} \mathrm{N}\right.$ $79.5^{\circ} \mathrm{E}$ ), on decaying wood of Avicennia marina (Acanthaceae), 28 November 2015, B. Devadatha, AMH-9996, living culture, NFCCI-4424.

GenBank numbers - ITS: MK028713, LSU: MK026757, rpb-2: MN532682, SSU: MK026754, tef1: MN532686.

Notes - Our specimen is identical to the type species Halojulella avicenniae (Fig. 83). The asexual morph of our species was found on media and it produced conidiophore and conidia from culture, while fruiting body is not observed (Fig. 84). Phylogenetic analyses (Fig. 42) support our species as $H$. avicenniae by grouping with other strains of $H$. avicenniae with high support (100\% MLBS, 100 PP).

\section{Ecological and economic significance}

The species is saprobic and plays a role in recycling organic matter, such as wood.

Halotthiaceae Ying Zhang, J. Fourn. \& K.D. Hyde, Mycologia 105(3): 604 (2013).

Index Fungorum number: IF563123; Facesoffungi number: FoF 08247, 7 species.

Saprobic or pathogenic on terrestrial, freshwater and marine hosts. Sexual morph: Ascomata medium to large in size, immersed, semi-immersed, erumpent or superficial, sometimes present under a pseudoclypeus, mostly ostiolate. Peridium multi-layered, outer layer of small, irregular brown to dark brown, thick walled, pseudoparanchymatous cells, inner layer black to dark brown, sometimes with large lumina or pseudoparenchymatous cells arranged in textura angularis, sometimes textura prismatica. Hamathecium comprising dense or narrowly cellular, septate, simple or branched pseudoparaphyses. Asci 8-spored, bitunicate, fissitunicate, cylindrical, clavate, subclavate to fusiform, long or short pedicellate, with or withour ocular chamber. Ascospores 1-3seriate, fusiform, clavate, ellipsoid or subellipsoid, sometimes initially hyaline becoming pale 
brown, dark brown to blackish brown at maturity, 1-septate, phragmosporous, distoseptate or dictyosporous, constricted or not at the septum, with or without gelatinous sheath, without appendages. Asexual morph: in Halotthia pycnidial. Conidiophores simple obclavate. Conidia (or spermatia) subglobose, ovoid or ellipsoidal, hyaline.

Type - Halotthia Kohlm

Notes - Halotthiaceae was introduced by Zhang et al. (2013c) with the type species Halotthia, and comprised the genera Mauritiana, Phaeoseptum and Pontoporeia (Hyde et al. 2013, Wijayawardene et al. 2014b). Ariyawansa et al. (2015a) introduced three new genera in to this family, Brunneoclavispora, Neolophiostoma and Sulcosporium. Hyde et al. (2018) removed Phaeoseptum from Halotthiaceae and introduced it to a new family Phaeoseptaceae. Prominent and thick septa in the ascospores can be observed in all members of Halotthiaceae, and can be used as a diagnostic characteristic for this family (Zhang et al. 2013c). All the genera included in this family except Pontoporeia are monotypic. Most of the previously introduced genera were identified in freshwater and marine habitats (Suetrong et al. 2009, Zhang et al. 2013c) but Brunneoclavispora and Sulcosporium were identified from terrestrial habitats (Ariyawansa et al. 2015a). Based on multi-gene phylogenetic analyses, the family formed a monophyletic clade close to Sporormiaceae, Roussoellaceae, Lophiostomataceae and Phaeoseptaceae in Pleosporales (Suetrong et al. 2009, Zhang et al. 2013c, Ariyawansa et al. 2015a, Hyde et al. 2018).

Halotthia Kohlm., Nova Hedwigia 6: 9 (1963).

Index Fungorum number: IF2212; Facesoffungi number: FoF 08248; 1 morphological species (Species Fungorum 2020), 1 species with molecular data.

Type species - Halotthia posidoniae (Durieu \& Monta.) Kohlm., Nova Hedwigia 6: 9 (1963)

$\equiv$ Sphaeria posidoniae Dur. \& Mont., Expl. Sci. Alg., Fl. Algér. 1(livr. 13): 502 (1848) [1846-49].

Notes - Halotthia typified by H. posidoniae was initially described as Sphaeria posidoniae. It was transferred to Pleosporaceae by Kohlmeyer \& Kohlmeyer (1979). Malloch \& Cain (1972) referred the genus to Zopfiaceae, and Jones et al. (2009a) placed it in the Pleosporales incertae sedis. Based on multi-gene analysis with LSU, rpb-2, SSU and tef1, Suetrong et al. (2009) showed it groups with Pontoporeia biturbinata in the Pleosporales, both genera commonly found on Posidonia oceanica and Cymodocea nodosa from the Mediterranean coast and Cyprus (Suetrong et al. 2009). Suetrong et al. (2009) did not assign it to any order and family until Zhang et al. (2013c) introduced Halotthiaceae with Halotthia posidoniae as the type genus.

Halotthia posidoniae (Durieu \& Mont.) Kohlm., Nova Hedwigia 6: 9 (1963).

Fig. 85

Index Fungorum number: IF 331652; Facesoffungi number: FoF 08848.

Material examined - France, PyrénééOrientales, dredged near Banyuls-sur-Mer, on Posidonia oceanica, 19 May 1962, J. Kohlmeyer No. 808c, (NY 01389657, type).

\section{Other genera included}

Brunneoclavispora Phookamsak \& K.D. Hyde, Fungal Divers. 75: 71 (2015).

Index Fungorum number: IF 551326; Facesoffungi number: FoF 00893; 1 morphological species (Species Fungorum 2020), 1 species with molecular data.

Type species - Brunneoclavispora bambusae Phookamsak \& K.D. Hyde, Fungal Divers. 75: $71(2015)$.

Notes - Brunneoclavispora was reported as saprobic on bamboo. The clavate ascospores are a unique characteristic of Brunneoclavispora which differentiates it from other members of Halotthiaceae. This genus shows similar morphological characteristics to Phaeoseptum but differs in having ascospores with tail-like basal appendages (Zhang et al. 2013c, Ariyawansa et al. 2015a) (see detailed morphology Ariyawansa et al. 2015a).

Mauritiana Poonyth, K.D. Hyde, Aptroot \& Peerally, Fungal Diversity 4: 102 (2000). 
Index Fungorum number: IF 337503; Facesoffungi number: FoF 08249; 1 morphological species (Species Fungorum 2020), 1 species with molecular data.

Type species - Mauritiana rhizophorae Poonyth, K.D. Hyde, Aptroot \& Peerally, Fungal Diversity 4: 102 (2000).

Notes - Mauritiana can be distinguished from others of this family by the asci with comparatively shorter pedicel. The genus was reported on Rhizophora mucronata (see detailed morphology Poonyth et al. 2000).

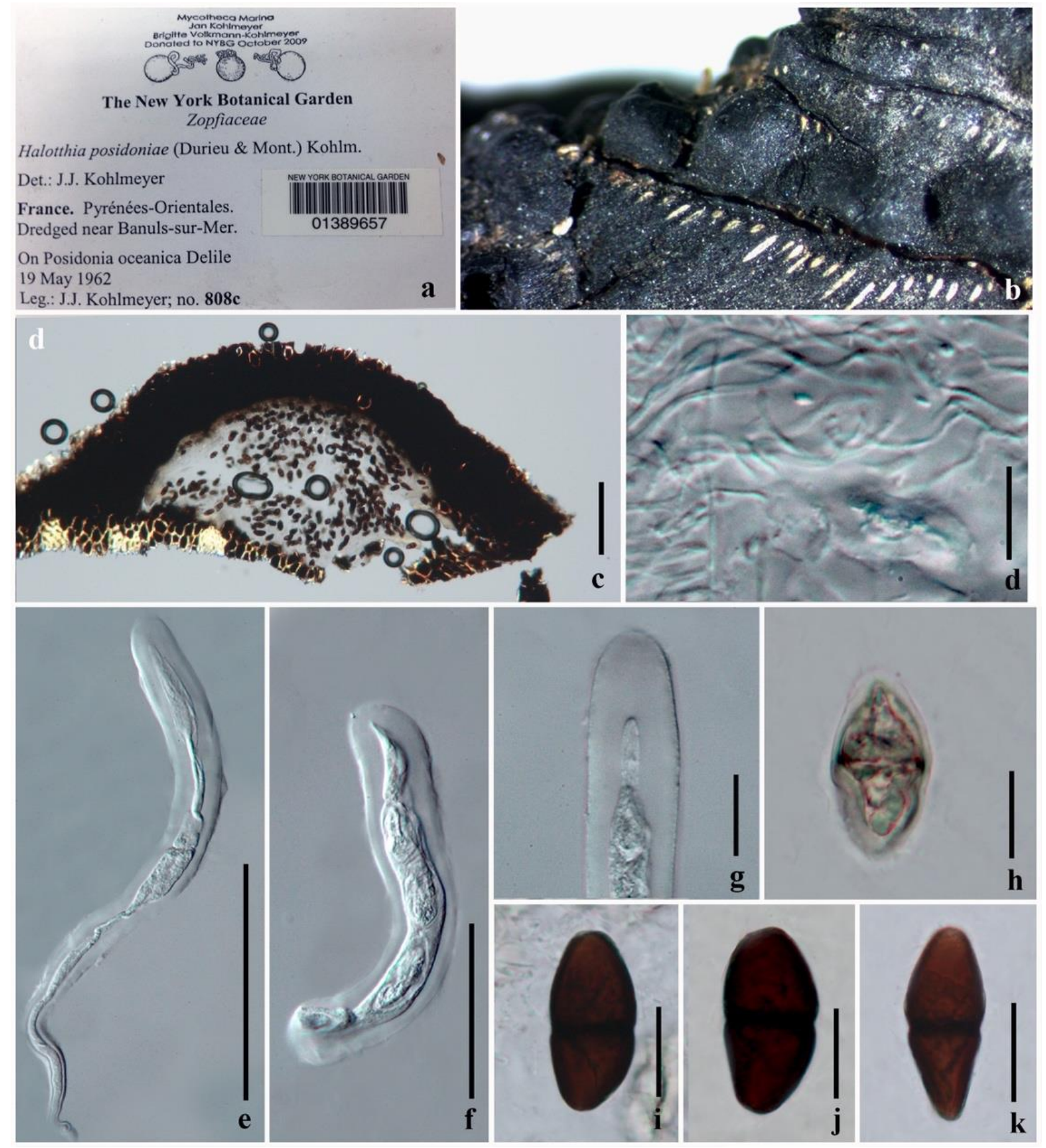

Figure 85 - Halotthia posidoniae (NY 01389657, holotype). a Specimen and description. b Close up of ascomata. c Section through ascomata. d Hamathecium. e-f Asci when immature. g Ocular chamber. $\mathrm{h}$ Ascospores when immature. $\mathrm{i}-\mathrm{k}$ Ascospores. Scale bars: $\mathrm{c}=100 \mu \mathrm{m}, \mathrm{e}, \mathrm{f}=50 \mu \mathrm{m}$, $\mathrm{d}, \mathrm{g}-\mathrm{k}=20 \mu \mathrm{m}$. 
Neolophiostoma S. Boonmee \& K.D. Hyde, Fungal Divers. 75: 74 (2015).

Index Fungorum number: IF 551404; Facesoffungi number: FoF 00961; 1 morphological species (Species Fungorum 2020), 1 species with molecular data.

Type species - Neolophiostoma pigmentatum Boonmee \& K.D. Hyde, Fungal Divers. 75: 74 (2015).

Notes - Neolophiostoma can be characterized by immersed ascomata with carbonaceous peridium, and hyaline, fusiform ascospores. The genus is saprobic on dead wood (see morphology Ariyawansa et al. 2015a).

Pontoporeia (Durieu \& Mont.) Kohlm., Nova Hedwigia 6: 5 (1963).

Index Fungorum number: IF 337503; Facesoffungi number: FoF 08250; 2 morphological species (Species Fungorum 2020), 1 species with molecular data.

Type species - Pontoporeia biturbinata (Durieu \& Mont.) Kohlm., Nova Hedwigia 6: 5 (1963).

三Sphaeria biturbinata Durieu \& Mont., in Durieu, Expl. Sci. Alg., Fl. Algér. 1(livr. 13): 497 (1848) [1846-49].

Notes - Pontoporeia is saprobic on Posidonia oceanica, Suaeda monoica and Avicennia marina. This is the only genus in this family to contain more than one species. Pontoporeia is characterized by irregular peridium, filiform septate pseudoparaphyses, broadly clavate, ovate or ellipsoidal asci and ascospores with germ pore at both ends and a 2-layered wall. It is also the only member of Halotthiaceae with asci lacking an ocular chamber (see morphology Kohlmeyer \& Kohlmeyer 1979, Suetrong et al. 2009, Devadatha \& Sarma 2018, www/marinefungi.org).

Sulcosporium Phookamsak \& K.D. Hyde, in Ariyawansa et al., Fungal Divers. 75: 77 (2015).

Index Fungorum number: IF 551328; Facesoffungi number: FoF 00894; 1 morphological species (Species Fungorum 2020), 1 species with molecular data.

Type species - Sulcosporium thailandicum Phookamsak \& K.D. Hyde [as 'thailandica'], in Ariyawansa et al., Fungal Divers. 75 : 77 (2015).

Notes - The striate, thick walled ascospores are a distinct characteristic of Sulcosporium. It is distinguished from other members of Halotthiaceae by the hamathecium embedded in mucilaginous matrix. The genus was reported as a pathogen on grasses, and causing necrotic leaf spots (see morphology Ariyawansa et al. 2015a).

\section{Ecological and economic significance}

Halotthiaceae is a small family mainly consisting of monotypic genera. They are found as saprobes in marine and terrestrial environments. Halotthia posidoniae, predominantly found in marine environment is pathogenic to Posidonia oceanica. Sulcosporium thailandicum causes necrotic leaf spots on grass blades.

Hermatomycetaceae Locq., Mycol. gén. struct. (Paris): 202 (1984).

Index Fungorum number: IF 80193; Facesoffungi number: FoF 08251, 27 species.

Saprobic on various plants. Sexual morph: Undetermined. Asexual morph: Conidiomata sporodochial, pulvinate, dark brown to black. Conidiophores mononematous, pale brown. Conidiogenous cells monoblastic, integrated, terminal, cylindrical. Conidia dimorphic, lenticular conidia ellipsoidal, muriform, cylindrical, hyaline to brown, trans-septate.

Type - Hermatomyces Speg.

Notes - Hermatomycetaceae was informally proposed by Locquin (1984) and later formalized by Hashimoto et al. (2017b) to accommodate the single genus Hermatomyces. Hermatomycetaceae is monotypic, similar to several other families in Pleosporales (Koukol et al. 2018). In previous studies, Hermatomyces was placed within ascomycota as 'incertae sedis' (Wijayawardene et al. 2012), while Doilom et al. (2017) and Tibpromma et al. (2016a) suggested it belongs in Lophiotremataceae based on phylogenetic analyses using LSU, rpb-2, SSU, and tef1. Morphologically, Hermatomyces is characterized by lenticular to cylindrical, muriform conidia, 
often with subhyaline to pale brown peripheral cells, and dark brown central cells. Conidia are cylindrical and comprise 1-4 columns with 2-11 cells and are irregularly pigmented (Castañeda \& Heredia 2000, Doilom et al. 2017, Hashimoto et al. 2017b).

Hermatomyces Speg., Anal. Mus. nac. B. Aires, ser. 3 13: 445 (1911).

Index Fungorum number: IF 8517; Facesoffungi number: FoF 08252; 27 morphological species (Species Fungorum 2020), 24 species with molecular data.

Type species - Hermatomyces Speg.

Notes - Hermatomyces is a hyphomycetous genus. Hermatomyces species are cosmopolitan in distribution and recorded from both temperate and tropical countries (i.e. Brazil, China, Cuba, Japan, Panama, Philipines, Thailand, Venezuela (Doilom et al. 2017, Hashimoto et al. 2017b, Koukol et al. 2018, Tibpromma et al. 2018). Host-specificity of Hermatomyces has yet to be elucidated and species have been recorded from various plant families (Acanthaceae, Arecaceae, Asteraceae, Fabaceae, Pandanaceae) (Doilom et al. 2017, Hashimoto et al. 2017b, Tibpromma et al. 2017, Koukol et al. 2018, Tibpromma et al. 2018). The connectively of sexual and as asexual morphs is not proven yet, as nobody has obtained any sexual morph for Hermatomyces species (Hashimoto et al. 2017b, Wijayawardene et al. 2017a, Tibpromma et al. 2018).
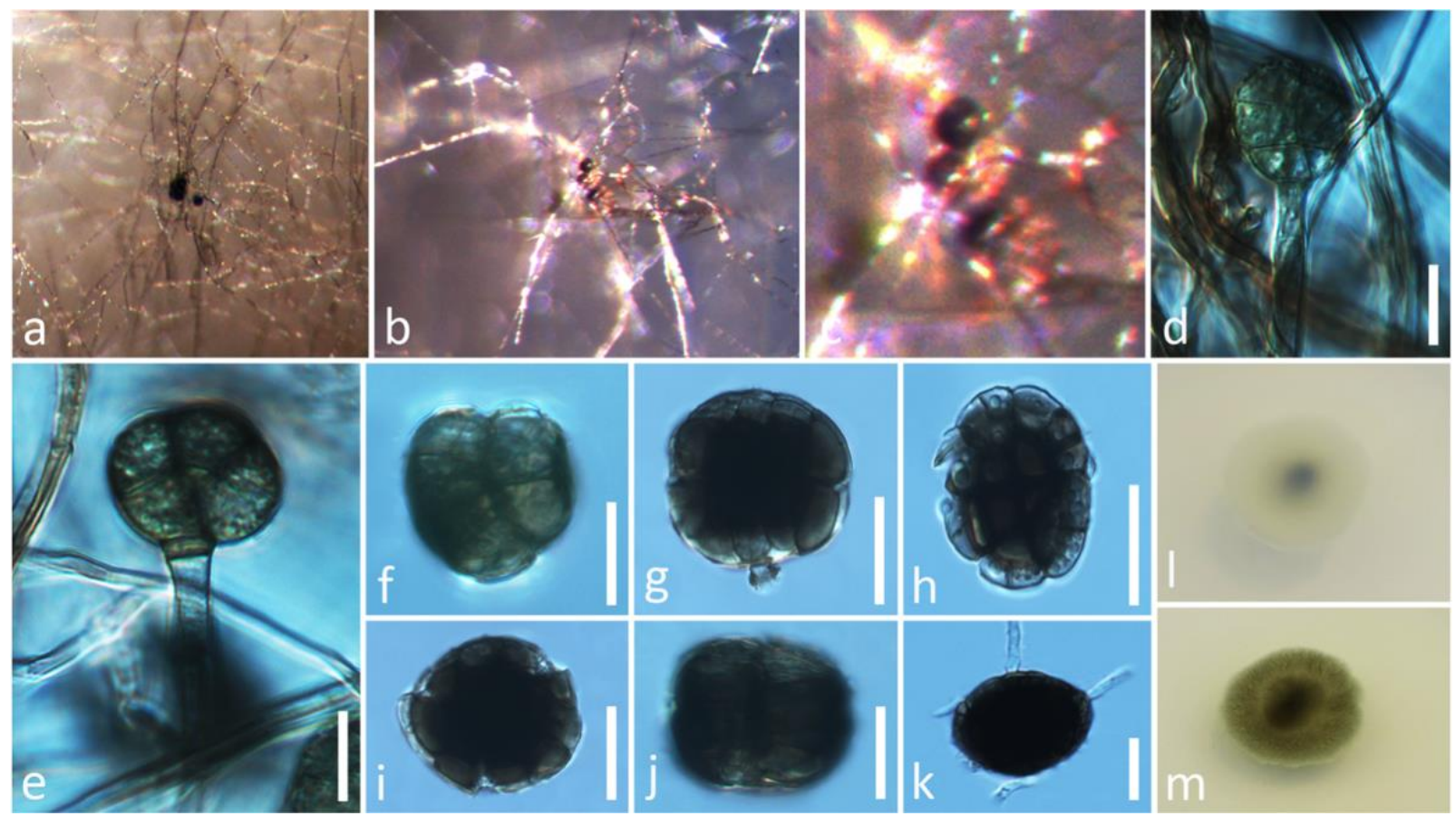

Figure 86 - Hermatomyces tectonae (MFLU 18-2513, new host record). a-c Mycelia and conidia on substrate. $\mathrm{d}$, e Conidia with conidiophores. $\mathrm{f}-\mathrm{j}$ Lenticular conidia. k Germinated conidia. 1 Colony from below. $\mathrm{m}$ Colony from above. Scale bars: $\mathrm{d}-\mathrm{k}=30 \mu \mathrm{m}$.

Hermatomyces tectonae Doilom D.J. Bhat \& K.D. Hyde, Fungal Divers. 82: 119 (2016). $\quad$ Fig. 86 Index Fungorum number: IF 551965; Facesoffungi number: FoF 01850.

Saprobic on dead leaves of Ficus septica Burm.f. Sexual morph: Undetermined. Asexual morph: Hyphomycetous. Colonies on natural blackish brown, velvety, shiny, in small groups, glistening, conidia readily liberated when disturbed. Mycelium superficial, composed of a network of branched, septate, hyaline to pale brown, thick-walled hyphae 1.3-2.6 $\mu \mathrm{m}$ wide. Conidiophores up to $70 \mu \mathrm{m}$ long, 1.5-3.5 $\mu \mathrm{m}$ wide, micronematous, flexuous, pale brown, smooth, unbranched, arising from prostrate hyphae at the centre of circular colony. Conidiogenous cells monoblastic, integrated, terminal, cylindrical, hyaline to sub-hyaline. Lenticular conidia (48-)50-56(-58) $\mu \mathrm{m}$ high $\times(41-) 42-48(-49.5) \mu \mathrm{m}$ diam., monomorphic, disk-shaped, with central cells dark brown to black, with peripheral cells pale brown, thick-walled, smooth-walled. Two halves of the disk- 
shaped conidia symmetrically adpressed, forming a deep constriction at lower and upper end in lateral view, each half with 5-7 cells, hyaline to light brown at lower and upper cells, dark brown in middle cells.

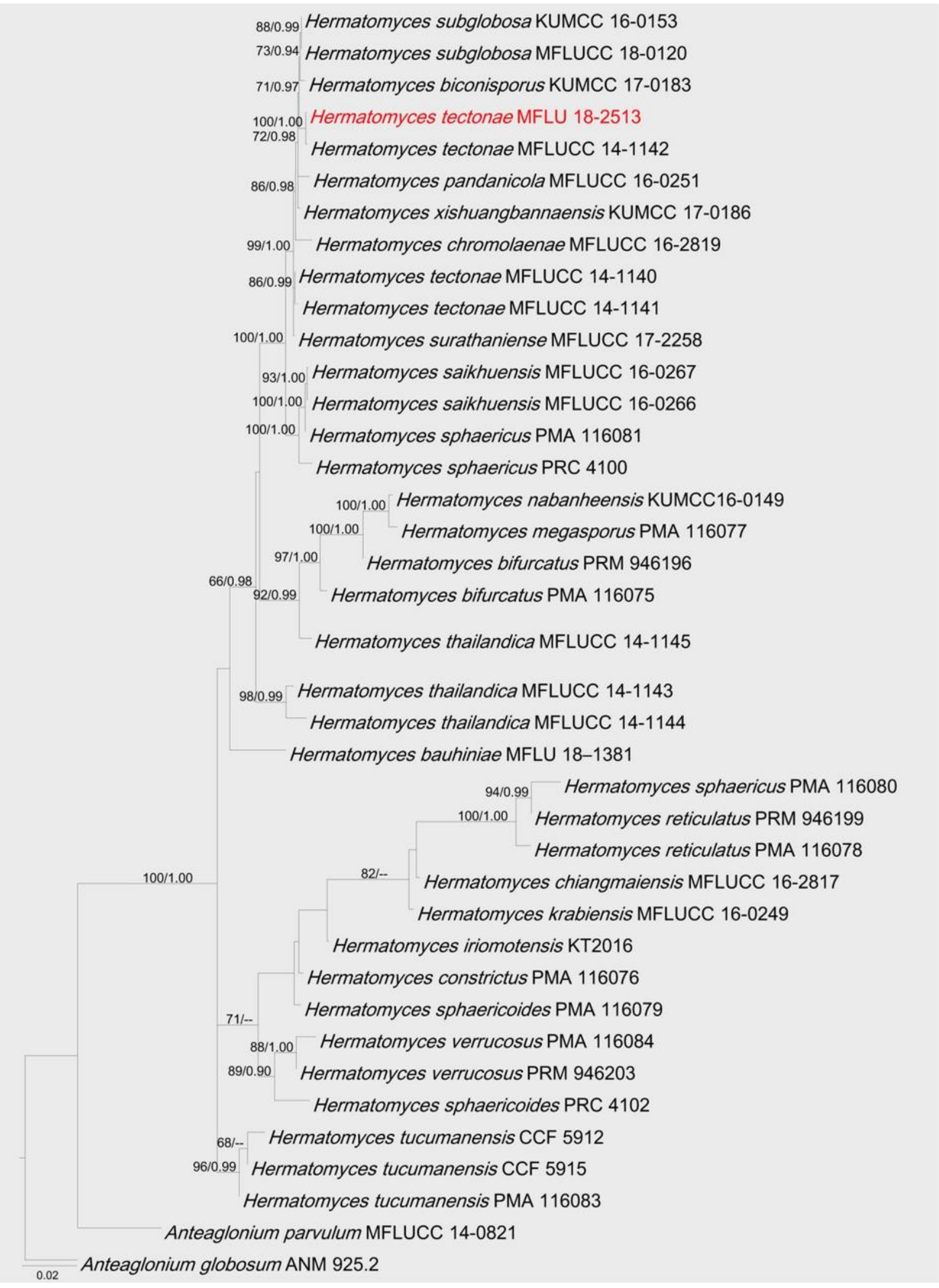

Figure 87 - Phylogram generated from maximum likelihood analysis (RAxML) of Hermatomycetaceae based on ITS, LSU, rpb-2, SSU, and tef1 sequence data. Maximum likelihood bootstrap values equal or above $65 \%$, Bayesian posterior probabilities equal or above 0.90 
(MLBS/PP) are given at the nodes. An original isolate number is noted after the species name. The tree is rooted to Anteaglonium globosum (ANM 925.2) and A. parvulum (MFLUCC 14-0821). Newly sequence is in red. The ex-type strains are indicated in bold. Hyphen (-) represents support values below $70 \%$ MLBS and $0.90 \mathrm{PP}$

Culture characteristics - Conidia germinating on PDA within $10 \mathrm{~h}$ and germ tubes produced from the apex. Colonies growing on PDA, reaching $3 \mathrm{~cm}$ in 8 days at $30{ }^{\circ} \mathrm{C}$, mycelium partly superficial, partly immersed, slightly effuse, cottony, with regular edge, grey above, pastel grey from below; sexual or asexual spores not formed within 60 days.

Material examined - Taiwan, Chiayi, Shihnong Forest Area, decaying leaves of Ficus septica (Moraceae), 25 June 2018, D.S. Tennakoon, XP010 (MFLU 18-2513), living culture, NCYUCC 19-0171.

GenBank numbers - ITS: MT649881, LSU: MT649877, rpb-2: MT663767, SSU: MT649879, tef1: MT663765.

Notes - We report our collection as a new record of $H$. tectonae from dead branch of Ficus septica in Taiwan, based on morphological characters of lenticular muriform conidia, with subhyaline to pale brown peripheral cells, and dark brown central cells. However, other collections of this species are from Tectona grandis (Doilom et al. 2017). Phylogenetic analysis of maximum likelihood and Bayesian inference based on a combined ITS, LSU, rpb-2, SSU and tef1 sequence data supported our taxon, which clustered with H. tectonae (MFLUCC 14-1142) (100\% MLBS, 1.00 BYPP, Fig. 87).

\section{Ecological and economic significance}

Most Hermatomycetaceae species have been reported as saprobes on decaying wood, bark and branches (Doilom et al. 2017, Hashimoto et al. 2017b, Koukol et al. 2018, Hyde et al. 2019). Only two species, $H$. biconisporus and $H$. krabiensis have been recorded from dead leaves (Tibpromma et al. 2018). Pathogens of Hermatomycetaceae species have not yet been reported.

\section{Hypsostromataceae Huhndorf, Mycologia 86: 266 (1994).}

Index Fungorum number: IF 81962; Facesoffungi number: FoF 08253, 2 species.

Saprobic on wood. Sexual morph: Ascomata clustered on a tormentose subiculum, superficial, obpyriform, stalked, pale brown, surface roughened or hairy, with a papillate ostiole. Peridium coriaceous, three-layered of textura angularis cells. Hamathecium comprising numerous, narrow, anastomosing, trabeculate pseudoparaphyses, embedded in a gelatinous matrix. Asci 4-8spored, bitunicate, numerous, elongate clavate long pedicellate, basal on a columnar structure, apically rounded with an ocular chamber with fluoresces in Calcifluor. Ascospores 2-seriate, oblong to narrowly fusiform, pale brown, 3-septate, disarticulating, smooth-walled, without sheath or appendages. Asexual morph: Recorded as pleurophomopsis-like. Pycnidia obpyriform to ampulliform, roughened tuberculate with white, crust-like exudate, ostiolate, with prominent, broad papilla. Conidiogenous cells phialidic, cylindrical to elongate, hyaline, collarettes minute. Conidia ovoid, minute, hyaline, aseptate, and guttulate.

Type - Hypsostroma Huhndorf

Notes - Hypsostromataceae was introduced by Huhndorf (1994) to accommodate two genera, Hypsostroma Huhndorf and Manglicola. Hypsostromataceae members are characterized in having large superficial ascomata with trabeculate pseudoparaphyses, cylindrical to clavate asci and septate, pale brown to brown ascospores (Huhndorf 1994, Hyde et al. 2013). Initially, Hypsostroma was described by Huhndorf (1992) for one species from the Dominican Republic (H. saxicola Huhndorf) and one from Venezuela ( $H$. caimitalense Huhndorf), but were not placed in a family. Later, Huhndorf (1994) referred both species and Manglicola samuelsii Huhndorf in Hypsostromataceae.

Suetrong et al. (2011a) introduced a new family, Manglicolaceae, to accommodate Manglicola guatemalensis in the Jahnulales, as it did not group in the Pleosporales. Manglicola samuelsii remains unresolved due to lack of molecular data to determine the phylogenetic 
placement. Therefore, Hypsostromataceae comprises only Hypsostroma and further collections are needed for the expansion of the family.

Hypsostroma Huhndorf, Mycologia 84(5): 750 (1992).

Index Fungorum number: IF 25538; Facesoffungi number: FoF 08254; 2 morphological species (Species Fungorum 2020), 2 species with molecular data.

Type species - Hypsostroma saxicola Huhndorf.

Notes - Hypsostroma species are characterized in having large superficial ascomata which form on a subiculum, pseudoparenchymatous peridial cells, trabeculate pseudoparaphyses, clavate asci with long pedicels, conspicuous apical apparatus and disarticulating ascospores with germ slits (Huhndorf 1992).

Hypsostroma saxicola Huhndorf, Mycologia 84(5): 750 (1992).

Index Fungorum number: IF 360174; Facesoffungi number: FoF 08255.

Fig. 88

Material examined - Dominican Republic. PRov. PuERT PLATA: Lorna Isabel de Torres, Cordillera Septentrional, 19"46'N, 70"42'W, $700 \mathrm{~m}$; on rock, humid broadleaf forest just below summit, 20 Jan. 1991, R. C. Harris 26462 (NY, holotype).

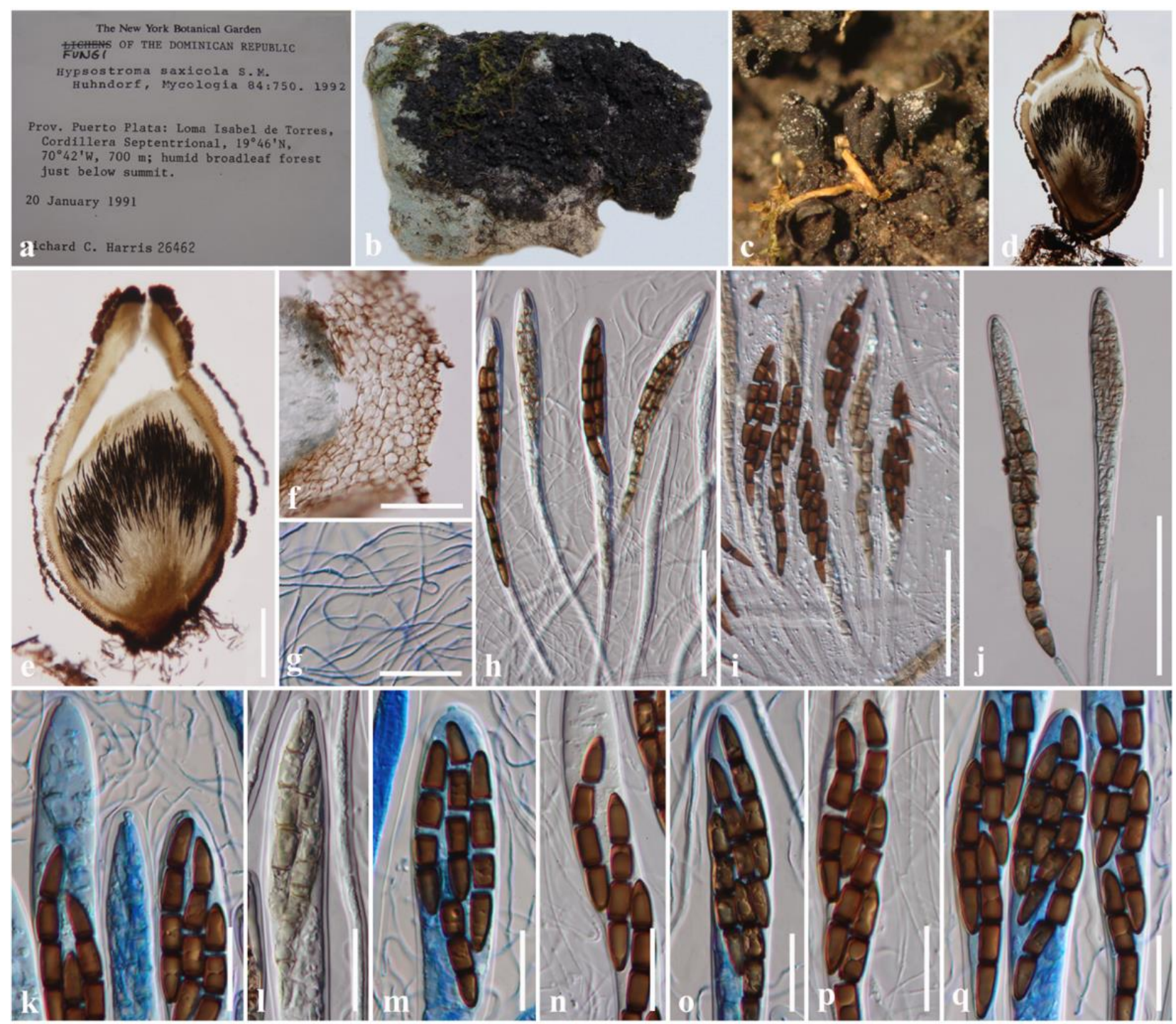

Figure 88 - Hypsostroma saxicola (holotype). a herbarium lable. b Ascomata on rock. c Close up of ascomata. d, e Longitudinal section through ascoma. f Peridium. g Pseudoparaphyses. $\mathrm{h}-\mathrm{j}$ Asci. $\mathrm{k}, 1$ Asci with ocular chamber. $\mathrm{m}-\mathrm{q}$ Ascospores. Scale bars: $\mathrm{d}, \mathrm{e}=500 \mu \mathrm{m}, \mathrm{f}=40 \mu \mathrm{m}, \mathrm{g}, \mathrm{k}-\mathrm{q}=20$ $\mu \mathrm{m}, \mathrm{h}-\mathrm{j}=50 \mu \mathrm{m}$. 


\section{Ecological and economic significance}

Hypsostroma saxicola has been recorded on rock and $H$. caimitalense on decorticated wood as saprobes. Pathogenicity of Hypsostromataceae species is doubtful, because of lack of any pathogenic records. Further collections needed for clarify the life styles of Hypsostromataceae.

Latoruaceae Crous, IMA Fungus 6(1): 176 (2015).

Index Fungorum number: IF 812790; Facesoffungi number: FoF 07742, 24 species.

Saprobic, parasitic on twigs and isolated from soil. Colonies discrete, effuse dark brown to black. Mycelium immersed to superficial, branched, septate, hyaline to brown. Sexual morph: Ascomata mostly scattered, immersed, compressed globose, with central, papillate ostiole. Peridium composed of two layers. Hamathecium comprising numerous, hyaline, septate, branched, cellular pseudoparaphyses. Asci 8-spored, bitunicate, fissitunicate, cylindric to clavate, pedicellate, apically rounded with an ocular chamber. Ascospores overlapping 2-3-seriate, fusiform, brown, 13-septate. Asexual morph: Conidiophores reduced to conidiogenous cells, or erect moniliform, brown. Conidiogenous cells solitary on mycelium, or terminal on conidiophores erect, smooth to verruculose, brown, polyblastic, or reduced to inconspicuous loci on hyphae. Conidia solitary origin acrogenously branched chains, smooth or with warts, septate, fusoid-ellipsoidal, clavate or ovoid, brown, frequently constricted at septa, with cells or septa darker pigmented that the rest of conidium; conidia in chains or not, at times becoming cupulate, with secondary conidia.

Type - Latorua Crous

Notes - Crous et al. (2015a) introduced Latoruaceae to accommodate Latorua and Polyschema in order Pleosporales. These taxa were isolated mainly from soil (Crous et al. 2015a). Matsushimamyces and Pseudoasteromassaria are other accepted genera in the family (Ariyawansa et al. 2015a, Sharma et al. 2015).

Latorua Crous, IMA Fungus 6(1): 175 (2015).

Index Fungorum number: IF 812791; Facesoffungi number: FoF 07743, 1 morphological species (Species Fungorum 2020), 1 species with molecular data. (2015).

Type species - Latorua caligans (Bat. \& H.P. Upadhyay) Crous, IMA Fungus 6(1): 175

$\equiv$ Bahusandhika caligans Bat. \& H.P. Upadhyay, Atas Inst. Micol. Univ. Recife 2: 321 (1965).

Notes - Latorua was originally isolated from soil in Brazil (Crous et al. 2015a). ITS and LSU sequence data are available in GenBank for Latorua caligans. For morphology of type species see Crous et al. (2015a). Crane \& Miller (2016) synonymized Latorua with Bahusandhika based on the similarity of the conidiogenous cells, conidial development and the morphological characters of the conidia without considering phylogenetic analysis.

\section{Other genera included}

Matsushimamyces Rah. Sharma \& Roh. Sharma, IMA Fungus 6(2): 338 (2015), Nom, Illegit. Art 53.1 .

Index Fungorum number: IF 810895; Facesoffungi number: FoF 07744; 2 morphological species (Species Fungorum 2020), 2 species with molecular data.

Type species - Matsushimamyces bohaniensis Rah. Sharma, Roh. Sharma \& Crous, IMA Fungus 6(2): 339 (2015).

Notes - Matsushimamyces is illegitimate as it is later homonym of Matsushimomyces. The type of Matsushimamyces was collected from soil in India (Sharma et al. 2015). The genus was reported from soil and decaying leaves of unidentified trees with a ceomycetous asexual morph (see Sharma et al. 2015). The genus is characterized by solitary, erect, rarely branched conidiophores and solitary conidia that are straight or curved, fusoid to broadly ellipsoid, multi-septate, with apical and basal cells thin-walled, subhyaline to brown, median cells dark brown to black, thickwalled, and roughly to coarsely verruculose (see Sharma et al. 2015). 


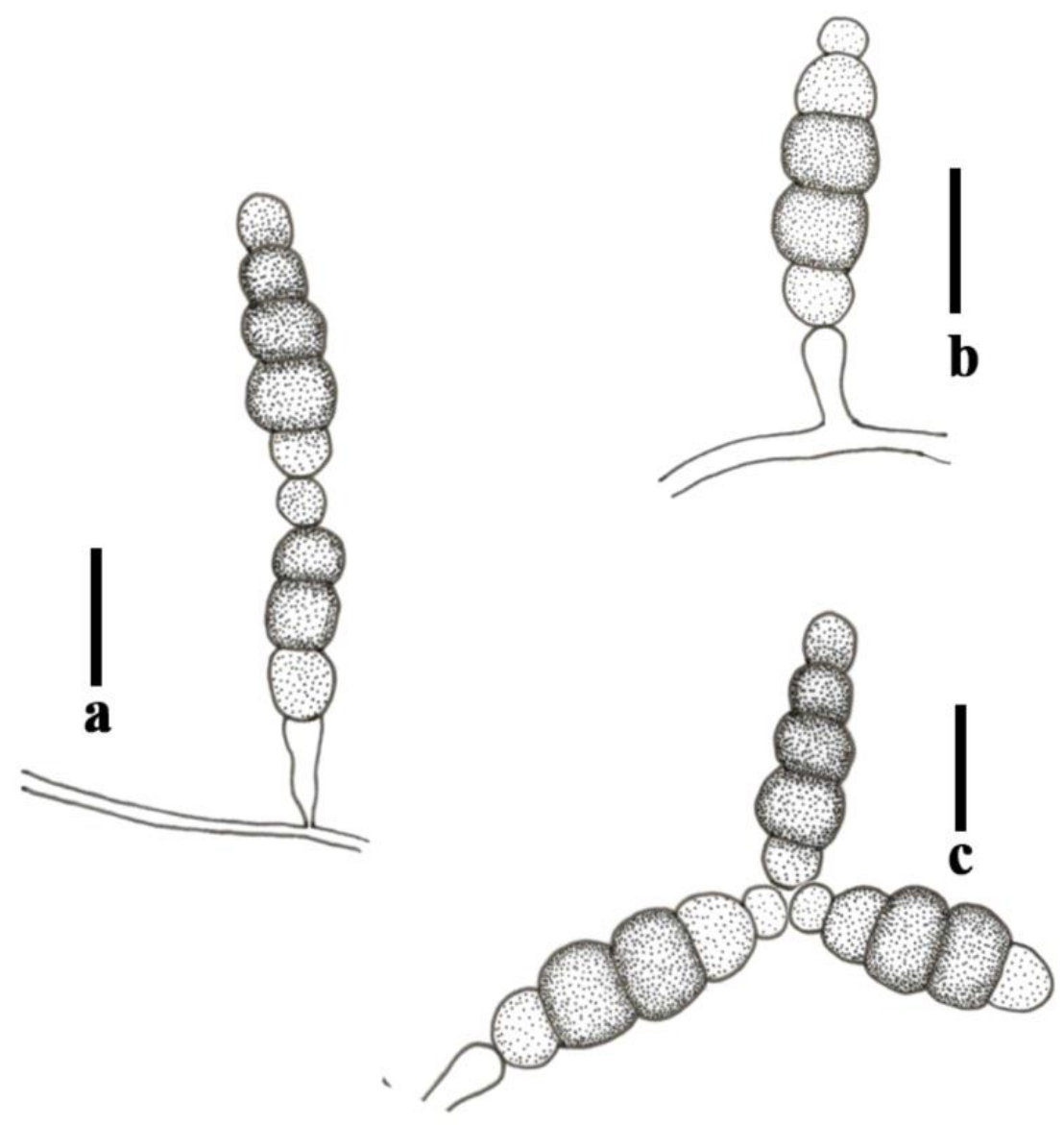

Figure 89 - Latorua caligans (redrawn from Crous et al. 2015, CBS 576.65). a-c Conidiogenous cells giving rise to conidial chains. Scale bar: $\mathrm{a}-\mathrm{c}=10 \mu \mathrm{m}$.

Polyschema H.P. Upadhyay, Mycopath. in Mycol. Appl. 30(3-4): 278 (1966).

Index Fungorum number: IF 9506; Facesoffungi number: FoF 07745; 19 morphological species (Species Fungorum 2020), 4 species with molecular data.

Type species - Polyschema terricola H.P. Upadhyay, Mycol. Appl. 30(3-4): 279(1966).

Notes - Upadhyay (1966) introduced Polyschema with the type Polyschema terricola. The genus is characterised by mono- or polytretic, globose to clavate conidiogenous cells, producing septate, smooth-walled, verrucose or tuberculate, pigmented, solitary conidia (Crous et al. 2015d). These species are found on soil and decaying wood material and human clinical specimen.

Pseudoasteromassaria M. Matsum. \& Kaz. Tanaka, in Ariyawansa et al., Fungal Divers.: 75: 51 (2015).

Index Fungorum number: IF 551448; Facesoffungi number: FoF 00963; 2 morphological species (Species Fungorum 2020), 2 species with molecular data.

Type species - Pseudoasteromassaria fagi M. Matsum. \& Kaz. Tanaka, Fungal Divers.: 75: $53(2015)$.

Notes - Morphological characteristics of Pseudoasteromassaria are similar to Asteromassaria (Pleomassariaceae) (Tibpromma et al. 2017). Both sexual and asexual morphs are recorded for this genus (Tibpromma et al. 2017). The genus contains two species collected from Japan and Thailand as parasitic on twigs of Fagus crenata and saprobic on submerged wood in freshwater habitats, respectively (Ariyawansa et al. 2015a, Tibpromma et al. 2017). The genus is characterized by scattered, immersed, globose ascomata, 8-spored, bitunicate, fissitunicate, cylindric to clavate asci and 2-3 overlapping seriate, brown, fusiform, 1-3-septate ascospores (Ariyawansa et al. 2015a).

Triseptata Boonmee \& Phookamsak, in Boonmee et al., Phytotaxa 447(4): 257 (2020). 
Index Fungorum number: IF 557185; Facesoffungi number: FoF 07229; 1 morphological species (Boonmee et al. 2020), 1 species with molecular data.

Type species - Triseptata sexualis Boonmee \& Phookamsak, in Boonmeeet al., Phytotaxa 447(4): 257 (2020).

Notes - The genus is characterized by immersed, uni- to multi-loculate ascomata, filamentous pseudoparaphyses, cylindrical-clavate asci, with 3-septate, light brown ascospores (Boonmee et al. 2020). Its hyphomycetous characters were found in culture with superficial, globose to subglobose, multi-septate, dark-pigmented conidia (Boonmee et al. 2020). Phylogenetic analyses of Boonmee et al. (2020) and this study (Fig. 42) show that this genus is a member of Latoruaceae.

\section{Ecological and economic significance}

Members of Latoruaceae distributed in Brazil, Namibia, India, Cuba, Japan, and Thailand (Ariyawansa et al. 2015a, Crous et al. 2015a, Sharma et al. 2015, Tibpromma et al. 2017). Taxa in this family are saprobic, parasitic on twigs and also isolated from soil (Ariyawansa et al. 2015a, Crous et al. 2015a, Sharma et al. 2015, Tibpromma et al. 2017).

Lentimurisporaceae N.G. Liu, J.K Liu \& K.D. Hyde, Cryptogamie, Mycologie 39 (2): 270 (2018). Index Fungorum number: IF 824920; Facesoffungi number: FoF 04590, 8 species.

Saprobic or soil-inhabiting in terrestrial. Sexual morph: Unknown. Asexual morph: Hyphomycetous. Colonies on natural substrate superficial, punctiform or powdery, scattered, brown to black. Mycelium mostly immersed. Conidiomata sporodochial. Conidiophores micronematous to macronematous, simple, septate or aseptate. Conidiogenous cells blastic, terminal, hyaline or brown. Conidia muriform or fusiform, cylindrical or rhomboidal, solitary or catenate in simple or branched chains (adapted from Liu et al. 2018c).

Type - Lentimurispora N.G. Liu, Bhat \& K.D. Hyde.

Notes - Lentimurisporaceae was established by Liu et al. (2018c) to accommodate Lentimurispora, Bahusandhika and two Berkleasmium species in Pleosporales. Divergence time estimates showed that Lentimurisporaceae diverged approximately 78 MYA (Liu et al. 2018c). Although two Berkleasmium species were accepted in Lentimurisporaceae, this genus is polyphyletic (Pinnoi et al. 2007, Wang et al. 2007) and the type species Be. concinnum was accommodated in Tubeufiaceae (Tanney \& Miller 2017, Lu et al. 2018). Therefore, we do not accept Berkleasmium as a distinct genus in Lentimurisporaceae.

Lentimurispora N.G. Liu, Bhat \& K.D. Hyde, Cryptogamie, Mycologie 39 (2): 270 (2018).

Index Fungorum number: IF 824921; Facesoffungi number: FoF 04591; 1 morphological species (Species Fungorum 2020), 1 species with molecular data.

Type species - Lentimurispora urniformis N.G. Liu, McKenzie \& K.D. Hyde.

Notes - Liu et al. (2018c) introduced the monotypic genus Lentimurispora which is characterized by micronematous conidiophores, monoblastic conidiogenous cells, and muriform, lenticular conidia with dark brown central cells and paler peripheral cells. Lentimurispora resembles Hermatomyces in having lenticular, muriform conidia, with subhyaline to pale brown peripheral cells and dark brown central cells (Ellis 1971, Tibpromma et al. 2016a). However, Lentimurispora has micronematous conidiophores and hyaline, wedge-shaped conidiogenous cells, while Hermatomyces has short, pale brown conidiophores and cylindrical conidiogenous cells (Ellis 1971, Liu et al. 2018c).

Lentimurispora urniformis N.G. Liu, McKenzie \& K.D. Hyde, in Liu et al., Cryptog. Mycol. 39(2): 273 (2018).

Index Fungorum number: IF 824958; Facesoffungi number: FoF 04592.

Description - see Liu et al. (2018c).

Material examined - Thailand, Phayao Province, Mae Chai District, on decaying wood, 27 September 2016, C.G. Lin, Lin16-5 (MFLU 18-0717, holotype). 

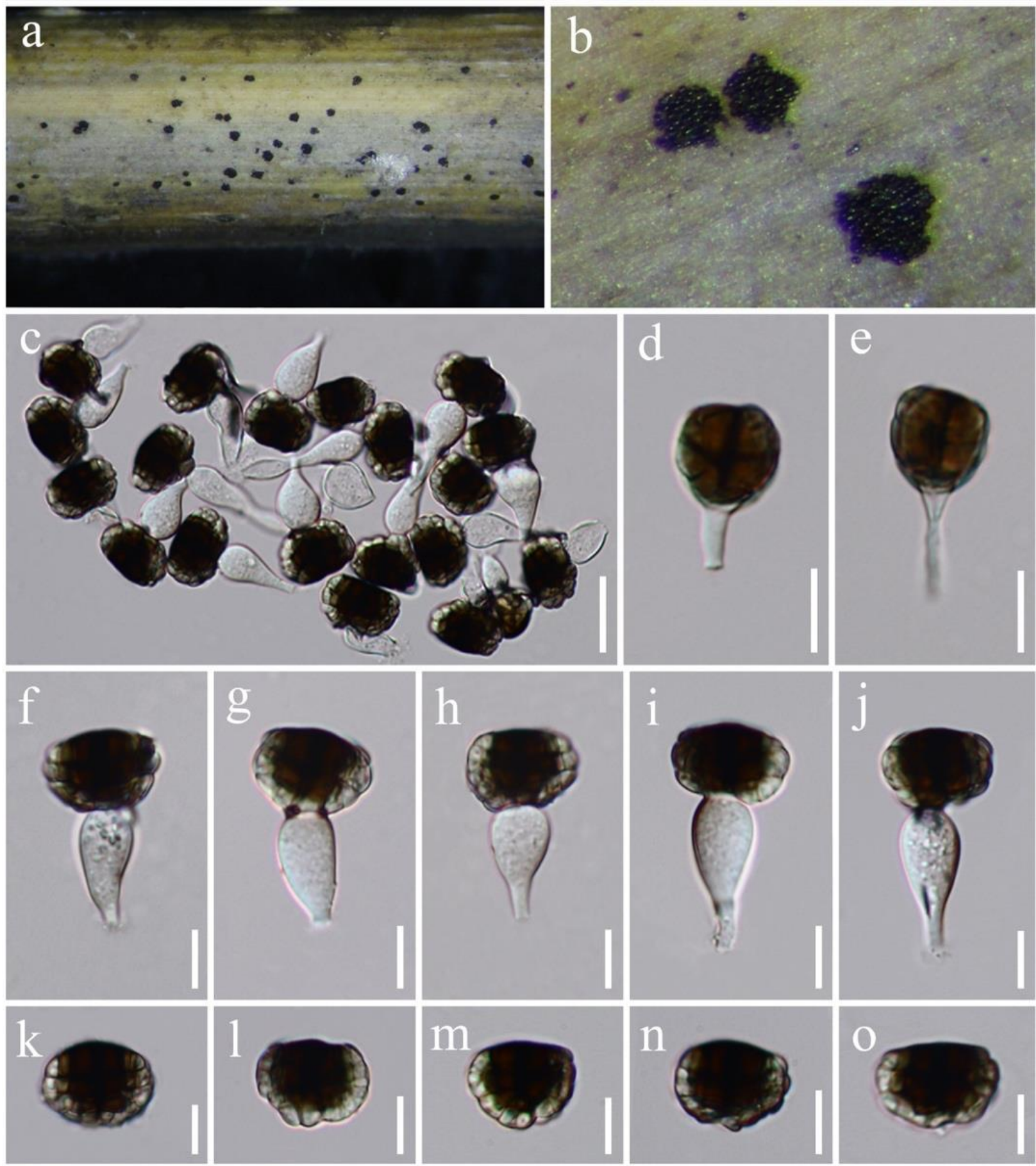

Figure 90 - Lentimurispora urniformis (MFLU 18-0717, holotype) a, b Colonies on natural substrate. $\mathrm{c}, \mathrm{f}-\mathrm{j}$ Mature conidia with peripheral cells and conidiogenous cells attached. $\mathrm{d}$, e Young conidia without pale peripheral cells and conidiogenous cells attached. $\mathrm{k}-\mathrm{o}$ Mature conidia without conidiogenous cells attached. Scale bars: $\mathrm{c}=20 \mu \mathrm{m}, \mathrm{d}-\mathrm{o}=10 \mu \mathrm{m}$.

\section{Other genus included}

Bahusandhika Subram., Journal of the Indian Botanical Society 35(4): 469 (1956).

Index Fungorum number: IF 7319; Facesoffungi number: FoF 07231; 7 morphological species (Species Fungorum 2020), 1 species with molecular data.

Type species - Bahusandhika indica (Subram.) Subram., J. Indian bot. Soc. 35: 469 (1956).

$\equiv$ Polydesmus indicus Subram., J. Indian bot. Soc. 33: 33 (1954).

Notes - Bahusandhika is a torula-like genus characterized by blastic, sphaerical, ovoid, ampulliform conidiogenous cells and catenate, fusiform, cylindrical or rhomboidal, phragmoseptate 
conidia. Pratibha et al. (2014) placed Bahusandhika in Pleosporales based on ITS and LSU sequence data. Later, Latorua Crous was synonymized under Bahusandhika by Crane \& Miller (2016) on the basis of morphology. However, Liu et al. (2018c) suggested to treat them as distinct genera based on phylogenetic analyses, and they pointed out that more sequence data were needed to examine the monophyly of Bahusandhika.

\section{Ecological and economic significance}

Most Lentimurisporaceae species occur as saprobes on decaying wood from terrestrial habitats. As decomposers and recyclers, they are important for nutrient cycling in the ecosystem. Some species, such as B. terrestris, were reported from soil, which indicates they may have functions of synthesis of growth factors, production of soil-aggregating substances (Went \& Stark 1968) and industrial potential for pigments (Akilandeswari \& Pradeep 2016).

Lentitheciaceae Y. Zhang ter, C.L. Schoch, J. Fourn., Crous \& K.D. Hyde, Stud. Mycol. 64: 93 (2009).

Index Fungorum number: IF 515470; Facesoffungi number: FoF 08256, 93 species.

Saprobic on stems and twigs of herbaceous and woody plants in terrestrial or aquatic habitats. Sexual morph: Ascomata scattered to gregarious, immersed to superficial, globose to lenticular, dark brown to black, glabrous or with brown hyphae. Ascomatal opening short-papillate or undeveloped, central with or without brown short setae. Peridium composed of hyaline to brown, polygonal to angular, thin-walled cells. Hamathecium comprising cellular, septate and branched pseudoparaphyses. Asci 8-spored, bitunicate, fissitunicate, cylindrical to broadly clavate, with a short pedicel, and a shallow ocular chamber at rounded apex, basal to somewhat lateral. Ascospores 2-3-seriate, sometimes fasciculate, narrowly fusiform to broadly cylindrical, filiform in some species, straight or slightly curved, hyaline, mostly 1-3-septate (murifom in some species), smoothwalled, surrounded by an entire mucilaginous sheath or elongated appendage-like sheath. Asexual morph: stagonospora-like or dendrophoma-like. Conidiomata pycnidial, globose, ostiolate. Conidiogenous cells blastic or phialidic. Conidia cylindrical to oblong, hyaline to pigmented, onecelled to muriform.

Type - Lentithecium K.D. Hyde, J. Fourn. \& Yin. Zhang.

Notes - Lentitheciaceae is a well-supported monophyletic family in Pleosporales (Wanasinghe et al. 2014a, Tanaka et al. 2015, Liu et al. 2017a). The family was introduced to accommodate Lentithecium, Katumotoa and Keissleriella (Zhang et al. 2009c) with species occurring on herbaceous plants and on submerged wood in freshwater environments (Zhang et al. 2012b). Generally, lentitheceous taxa have narrow peridia, fusiform to broadly cylindrical hyaline ascospores with 1-3 transverse septa and containing refractive globules (Hyde et al. 2013, Zhang et al. 2012b). Hirayama et al. (2010) introduced Tingoldiago which later was regarded as a synonym of Lentithecium, despite the fact that the Lentithecium clade that included Tingoldiago was not well-supported (Zhang et al. 2012b). When Lentithecium was well-established, with their emphasized characters to define the genus, Tingoldiago showed as a robust genus in Lentitheciaceae (Tanaka et al. 2015). Quaedvlieg et al. (2013) included Setoseptoria in Lentitheciaceae which was distinct from other similar taxa in that it has conidiogenous cells with prominent percurrent proliferations, and conidia that tend to become olivaceous and verruculose in older cultures, and disarticulate into phragmospores. Wanasinghe et al. (2014a) introduced Murilentithecium which has muriform ascospores and a camarosporium-like asexual morph. Phookamsak et al. (2015a) introduced a new genus Poaceascoma with scolecospores. t the same time Knapp et al. (2015) introduced Darksidea which has multi-seriate asci and aseptate ascospores that are totally different from other members in this family. At Wijayawardene et al. (2015) and Tanaka et al. (2015) introduced two new genera to this family, Phragmocamarosporium and Neoophiosphaerella, respectively. Li et al. (2016a) introduced Towyspora and most recently Dayarathne et al. (2018) presented Halobyssothecium and Hyde et al. (2020b) introduced Pseudomurilentithecium as the latest new genera in this family. 
Lentithecium K.D. Hyde, J. Fourn. \& Yin. Zhang, Fungal Divers. 38: 234 (2009).

Index Fungorum number: IF 512790; Facesoffungi number: FoF 08257; 10 morphological species (Species Fungorum 2020), 10 species with molecular data.

Type species - Lentithecium fluviatile (Aptroot \& Van Ryck.) K.D. Hyde, Fungal Divers. 38: 234 (2009).

$\equiv$ Massarina fluviatilis Aptroot \& Van Ryck., Nova Hedwigia 73(1-2): 162 (2001).

Notes - Lentithecium species have been reported from freshwater habitats in Belgium, China, Denmark, Egypt, France, Japan, Saudi Arabia and the USA. Thus, this genus seems to be limited to aquatic environments, being mostly recorded on submerged wood and Phragmites species.

\section{Other genera included}

Darksidea D.G. Knapp, Kovács, J.Z. Groenew. \& Crous, Persoonia 35: 95 (2015).

Index Fungorum number: IF 810760; Facesoffungi number: FoF 08258; 6 morphological species (Species Fungorum 2020), 6 species with molecular data.

Type species - Darksidea alpha D.G. Knapp, Kovács, J.Z. Groenew. \& Crous, Persoonia 35: 96 (2015).

Notes - Knapp et al. (2015) introduced Darksidea to accommodate dark septate root endophytic fungi in Lentitheciaceae. Darksidea species are characterized by globose ascomata, hyaline, septate pseudoparaphyses that are intermingled among asci, clavate to ellipsoid, stipitate, 4-6-spored asci with weakly developed ocular chamber, aseptate, ellipsoid, hyaline, guttulate ascospores that are multi-seriate in asci. There are six species in Darksidea viz. D. alpha, D. beta, D. gamma, D. delta, D. epsilon and D. zeta.

Halobyssothecium Dayar., E.B.G. Jones \& K.D. Hyde, Mycological Progress 17 (10): 1165 (2018).

Index Fungorum number: IF 554756; Facesoffungi number: FoF 03928; 1 morphological species (Species Fungorum 2020), 1 species with molecular data.

Type species - Halobyssothecium obiones (P. Crouan \& H. Crouan) Dayar., E.B.G. Jones \& K.D. Hyde, Mycol. Progr. 17 (10): 1165 (2018).

E Pleospora obiones P. Crouan \& H. Crouan, Florule Finistère (Paris): 22 (1867).

Notes - Dayarathne et al. (2018) introduced Halobyssothecium to accommodate Byssothecium obiones ( $=H$. obiones) from salt marsh halophytes. It differs in morphology from the other members in Lentitheciaceae in having versicolored ascospores with brown central cells and hyaline end cells, which resemble Byssothecium.

Katumotoa Kaz. Tanaka \& Y. Harada, Mycoscience 46 (5): 313 (2005).

Index Fungorum number: IF 504386; Facesoffungi number: FoF 08259; 1 morphological species (Species Fungorum 2020), 1 species with molecular data. (2005).

Type species - Katumotoa bambusicola Kaz. Tanaka \& Y. Harada, Mycoscience 46 (5): 313

Notes - Tanaka \& Harada (2005b) established Katumotoa to accommodate the monotypic species, K. bambusicola which was collected in Japan. The genus is characterized by immersed ascomata with a thin peridium comprising thin-walled compressed cells, cellular pseudoparaphyses, cylindric-clavate and fissitunicate asci and fusoid ascospores with an elongated bipolar mucilaginous sheath. See Tanaka \& Harada (2005b), Zhang et al. (2012b) and Tanaka et al. (2015) for further details.

Keissleriella Höhn., Sitzungsberichte der Kaiserlichen Akademie der Wissenschaften Math.naturw. Klasse Abt. I 128: 582 (1919).

Index Fungorum number: IF 2553; Facesoffungi number: FoF 07424; 37 morphological species (Species Fungorum 2020), several species with molecular data. 
Type species - Keissleriella aesculi (Höhn.) Höhn., Sitzungsberichte der Kaiserlichen Akademie der Wissenschaften Math.-naturw. Klasse Abt. I 128: 582 (1919).

三 Pyrenochaeta aesculi Höhn., Ber. dt. bot. Ges. 35(3): 249 (1917).

Notes - Keissleriella is one of the most species rich genera in Lentitheciaceae with 45 taxa in Index Fungorum (39 from Lentitheciaceae). Keissleriella is characterised by an ostiolar neck covered by short dark setae. See Tanaka \& Harada (2005b), Zhang et al. (2012b), Tanaka et al. (2015) and Wanasinghe et al. (2018c) for further details.

Murilentithecium Wanas., Camporesi, E.B.G. Jones \& K.D. Hyde, Cryptog. Mycol. 35 (4): 330 (2014).

Index Fungorum number: IF 550728; Facesoffungi number: FoF 00293; 3 morphological species (Species Fungorum 2020), 3 species with molecular data.

Type species - Murilentithecium clematidis Wanas., Camporesi, E.B.G. Jones \& K.D. Hyde, Cryptog. Mycol. 35 (4): 331 (2014).

Notes - Wanasinghe et al. (2014a) introduced Murilentithecium as a monotypic genus to accommodate $M$. clematidis, which was the first report of muriform spored taxa in Lentitheciaceae. Both sexual and asexual morphs are known. Both conidia and ascospores are muriform in Murilentithecium.

Neoophiosphaerella Kaz. Tanaka \& K. Hiray., Studies in Mycology 82: 100 (2015).

Index Fungorum number: IF 811310; Facesoffungi number: FoF 08260; 1 morphological species (Species Fungorum 2020), 1 species with molecular data.

Type species - Neoophiosphaerella sasicola (Nagas. \& Y. Otani) Kaz. Tanaka \& K. Hiray., Stud. Mycol. 82: 101 (2015).

$\equiv$ Phaeosphaeria sasicola Nagas. \& Y. Otani, Rep. Tottori Mycol. Inst. 15: 39 (1977).

Notes - Neoophiosphaerella has similar morphology to Ophiosphaerella, but they phylogenetically group in different suborders. Also, Ophiosphaerella has globose to subglobose ascomata with a papillate ostiolar neck (Phookamsak et al. 2014c), whereas Neoophiosphaerella has hemisphaerical ascomata without papilla but covered by clypei (Tanaka et al. 2015).

Phragmocamarosporium Wijayaw., Yong Wang bis \& K.D. Hyde, Cryptogamie, Mycologie 36 (2): 217 (2015).

Index Fungorum number: IF 555365; Facesoffungi number: FoF 08850; - 3 morphological species (Species Fungorum 2020), 3 species with molecular data.

Type species - Phragmocamarosporium platani Wijayaw., Yong Wang bis \& K.D. Hyde, Cryptogamie, Mycologie 36 (2): 217 (2015).

Notes - Phragmocamarosporium was introduced by Wijayawardene et al. (2015) to accommodate species which have conspicuous phragmospores.

Pleurophoma Höhn., Sitzungsberichte der Kaiserlichen Akademie der Wissenschaften Math.naturw. Klasse Abt. I 123: 117 (1914)

Index Fungorum number: IF 9467; Facesoffungi number: FoF 07498; 9 morphological species (Species Fungorum 2020), 4 species with molecular data.

Type species - Pleurophoma pleurospora (Sacc.) Höhn., Sitzungsberichte der Kaiserlichen Akademie der Wissenschaften Math.-naturw. Klasse Abt. I 123: 117 (1914).

$\equiv$ Dendrophoma pleurospora Sacc., Syll. fung. (Abellini) 3: 178 (1884).

Notes - Pleurophoma was proposed based on P. pleurospora (De Gruyter et al. 2009) which lacks any known sexual morph (De Gruyter et al. 2010). Tibpromma et al. (2017) introduced Pleurophoma italica as a new species with both sexual and asexual morphs. However, this sexual morph is similar to Keissleriella. Further research should be conducted with extensive taxon sampling to resolve the relationship between Keissleriella and Pleurophoma. 

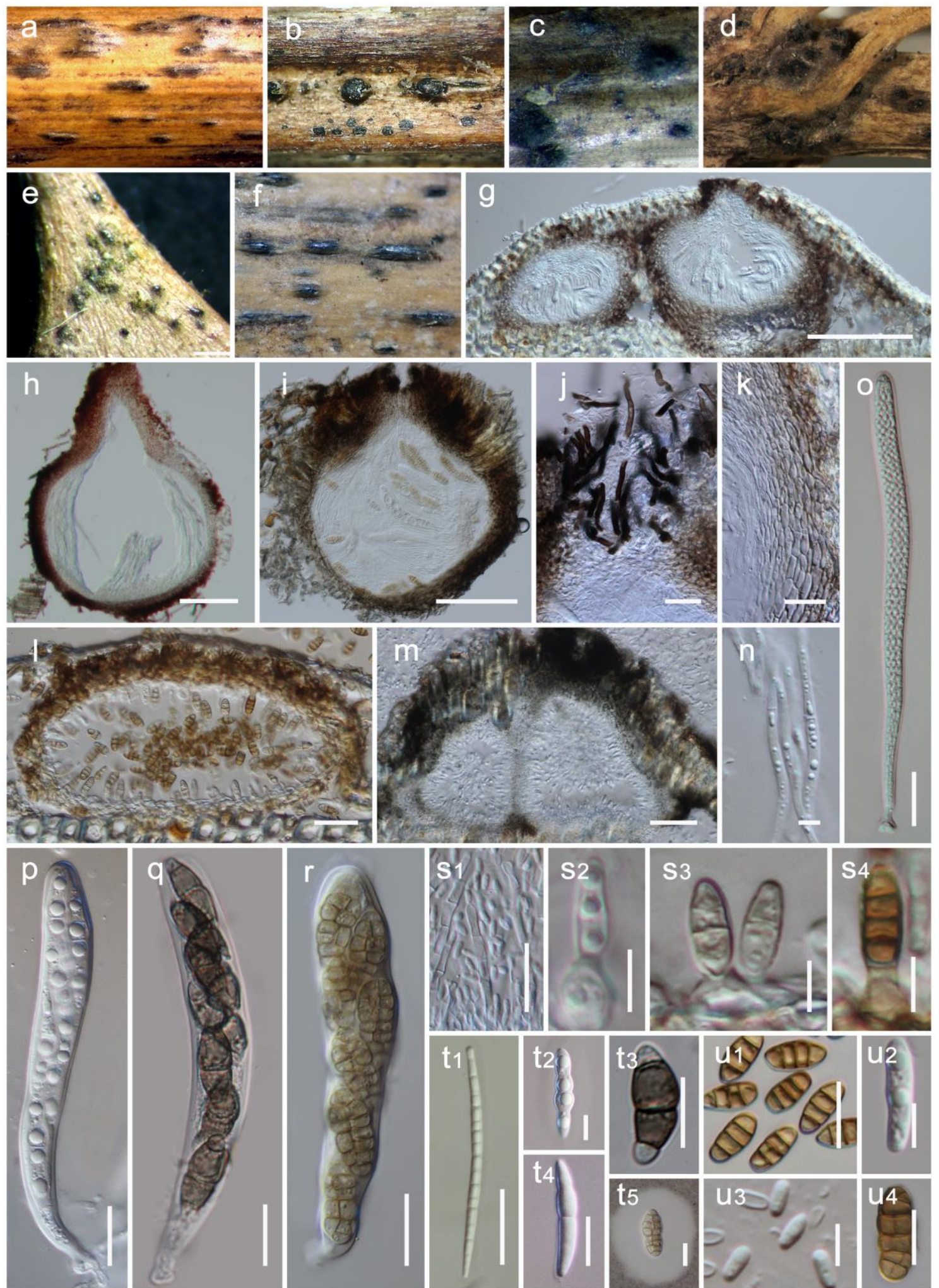

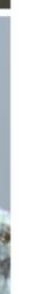




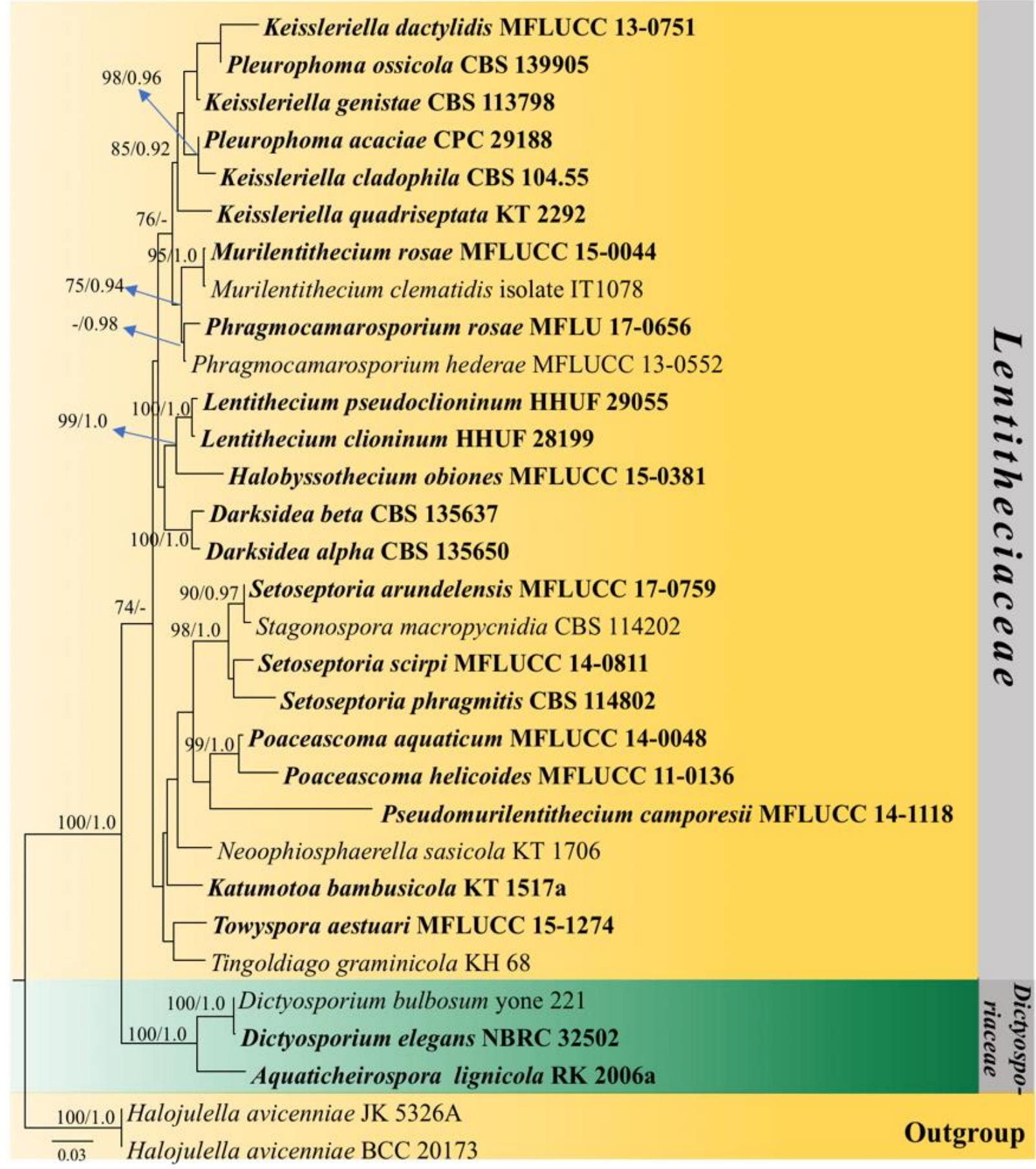

Figure 92 - Phylogram generated from maximum likelihood analysis (RAxML) of genera in Lentitheciaceae based on ITS, LSU, SSU, and tef1 sequence data. Maximum likelihood bootstrap values equal or above $70 \%$, Bayesian posterior probabilities equal or above 0.90 (MLBS/PP) are given at the nodes. An original isolate number is noted after the species name. The tree is rooted to Halojulella avicenniae (BCC 20173 and JK 5326A). The ex-type strains are indicated in bold. Hyphen (-) represents support values below $70 \%$ MLBS and 0.90 PP.

Poaceascoma Phookamsak \& K.D. Hyde, Cryptogamie, Mycologie 36 (2): 231 (2015).

Index Fungorum number: IF 551141; Facesoffungi number: FoF 00622; 4 morphological species (Species Fungorum 2020), 4 species with molecular data.

Type species - Poaceascoma helicoides Phookamsak \& K.D. Hyde, Cryptog. Mycol.36 (2): 232 (2015).

Notes - Poaceascoma was found associated with Poaceae and forms setose ascoma with filiform ascospores. See Phookamsak et al. (2015a) for more details. 
Pseudomurilentithecium Mapook \& K.D. Hyde, Fungal Diversity 100: 69 (2020)

Index Fungorum number: IF 556904; Facesoffungi number: FoF 06791; 1 morphological species (Hyde et al. 2020b), 1 species with molecular data.

Type species - Pseudomurilentithecium camporesii Mapook \& K.D. Hyde, Fungal Diversity 100: 69 (2020).

Notes - Pseudomurilentithecium was found associated with Fabaceae hosts in Italy. This genus is characterized by immersed, subglobose to globose, dark brown to black ascomata, a peridium comprising dark brown cells of textura angularis, cellular pseudoparaphyses. cylindricalclavate asci with a pedicellate, and golden-brown to brown, ellipsoid to broadly fusiform, muriform ascospores with a hyaline gelatinous sheath. Phylogenetically, the type Pseudomurilentithecium camporesii having a sister relationship with Poaceascoma and Setoseptoria (Hyde et al. 2020b).

Setoseptoria Quaedvl., Verkley \& Crous, Studies in Mycology 75: 382 (2013).

Index Fungorum number: IF 804462; Facesoffungi number: FoF 08261; 7 morphological species (Species Fungorum 2020), 6 species with molecular data. (2013)

Type species - Setoseptoria phragmitis Quaedvl., Verkley \& Crous, Stud. Mycol. 75: 383

Notes - Quaedvlieg et al. (2013) introduced Setoseptoria to accommodate saprobic septorialike coelomycetous having setose conidiomata and is typified by S. phragmitis on Phragmites. See Wanasinghe et al. (2018c) for latest phylogenetic arrangement.

Tingoldiago K. Hirayama \& Kaz. Tanaka, Mycologia 102 (3): 740 (2010).

Index Fungorum number: IF 515193; Facesoffungi number: FoF 08262; 1 morphological species (Species Fungorum 2020), 1 species with molecular data.

Type species - Tingoldiago graminicola K. Hirayama \& Kaz. Tanaka, Mycologia 102 (3): 740 (2010).

Notes - Tingoldiago is a monotypic genus found in freshwater environments. The genus is typified by Tingoldiago graminicola, that has lens-shaped ascomata and narrowly fusiform ascospores, each of which has an elongated sheath (Hirayama et al. 2010). See Hirayama et al. (2010) and Tanaka et al. (2015) for more details.

Towyspora Wanas., E.B.G. Jones \& K.D. Hyde, Fungal Divers. 78: 32 (2016).

Index Fungorum number: IF 551787; Facesoffungi number: FoF 01671; 1 morphological species (Species Fungorum 2020), 1 species with molecular data.

Type species - Towyspora aestuari Wanas., E.B.G. Jones \& K.D. Hyde, Fungal Divers. 78: 35 (2016).

Notes - Towyspora aestuari was collected from UK on Phragmites communis. The genus is monotypic and shares most similarities with Setoseptoria in having hyaline, subcylindrical conidiogenous cells and transversely euseptate, hyaline, smooth-walled, subcylindrical conidia, with one large central guttule per cell. Towyspora however, forms a remote clade from Setoseptoria (Li et al. 2016a).

\section{Ecological and economic significance}

They are important to the cycling of carbon and nutrients during the decomposition of organic matter especially in freshwater habitats.

Leptosphaeriaceae M.E. Barr, Mycotaxon 29: 503 (1987).

Index Fungorum number: IF 81843; Facesoffungi number: FoF 01151, ca. 699 species.

Epiphytic, parasitic, saprobic, fungicolus, hemibiotropic or pathogenic on leaves and wood on living leaves of plants in terrestrial habitats Sexual morph: Ascomata immersed, erumpent to superficial, globose, subglobose or obypyriform, black to dark brown, coriaceous, partial carbonaceous ostiolate. Ostiole well-developed, broadly or narrowly conical, with a dark brown to black papilla, ostiolar canal filled with tissue of hyaline cells. Peridium composed of large, 
pigmented, thin-walled, scleroplectenchymatous or plectenchymatous cells, usually arranged in textura angularis. Hamathecium comprising dense, septate, long cellular pseudoparaphyses, embedded in mucilage, and branching. Asci 8-spored, bitunicate, fissitunicate, cylindrical to oblong, with a pedicel and ocular chamber. Ascospores 1-seriate and partially overlapping, fusoid, narrowly fusoid, obovoid, oblong or filiform, brown, reddish brown or yellowish brown, septate and constricted at the septa, smooth-walled, with or without guttules. Asexual morph: Coelomycetous or hyphomycetous. Conidiomata immersed to nearly superficial, depressed globose with a flattened base and cylindrical neck. Ostiole sometimes papillate or with elongated neck. Conidiomata wall scleroplectenchymatous. Conidia oblong, ellipsoidal to subcylindrical. Sclerotia sometimes produced (Boerema et al. 1994, Ariyawansa et al. 2015b). Conidiophores solitary or in small groups, hypophyllous, straight to slightly sinuous, simple, 3-6-septate, pale to chestnutbrown, smooth. Conidiogenous cells tretic, integrated, terminal to intercalary, sympodial, cylindrical, yellowish to pale brown. Conidia dry, solitary, cylindrical to subcylindrical, apex and base rounded, subhyaline to pale brown, aseptate or presenting of transversely septate, often deeply constricted at septa, eguttulate, smooth-walled, hilum thickened and darkened (Ellis 1971, Zhang et al. 2012b).

Type - Leptosphaeria Ces. \& de Not.

Notes - Leptosphaeriaceae was established by Barr (1987a) as a member of Pleosporales. Ariyawansa et al. (2015b) revised the family with robust phylogenetic results. Ten genera were accepted in Ariyawansa et al. (2015b), Alloleptosphaeria, Alternariaster Simmons, Heterospora, Leptosphaeria (generic type), Neoleptosphaeria, Paraleptosphaeria, Plenodomus, Pseudoleptosphaeria, Sphaerellopsis, and Subplenodomus (Zhang et al. 2009c, Gruyter et al. 2013, Ariyawansa et al. 2015b). Quaedvlieg et al. (2013) introduced Acicuseptoria to Leptosphaeriaceae for a septoria-like species recorded on Rumex alpinus. Querciphoma Crous was considered a member of Leptosphaeriaceae based on its phylogenetic placement (Gruyter et al. 2013, Crous \& Groenewald 2017). The note of Ascomycota 2017 included Camposporium Harkn. in Leptosphaeriaceae, however, sequence analyses are needed to confirm the taxonomic position of this genus (Wijayawardene et al. 2017a, Vu et al. 2019). Acicuseptoria and Querciphoma were included in the family based on phylogenetic analysis (Crous \& Groenewald 2017, Wijayawardene et al. 2018). Aiello et al. (2020) synonymized Acicuseptoria under Paraleptosphaeria based on phylogenetic analyses. Currently, 14 genera are accepted in Leptosphaeriaceae. Members of this family usually have single, papillate, immersed or erumpent, perithecial ascomata, scleroplectenchymatous or plectenchymatous cell types of peridium layers, cylindrical to clavate asci with hyaline to brown, transversely septate ascospores (Hyde et al. 2013, Ariyawansa et al. 2015b). The asexual morphs are coelomycetous or hyphomycetous (Gruyter et al. 2013, Hyde et al. 2013, Crous \& Groenewald 2017, Aiello et al. 2020).

Leptosphaeria Ces. \& De Not. (1863).

Index Fungorum number: IF 2800; Facesoffungi number: FoF 02297; 605 species (Species Fungorum 2020), 15 species with molecular data.

Type species - Leptosphaeria doliolum (Pers.) Ces. \& De Not., Comm. Soc. crittog. Ital. 1(fasc. 4): 234 (1863).

三Sphaeria doliolum Pers., Icon. Desc. Fung. Min. Cognit. (Leipzig) 2: 39 (1800).

Notes - Leptosphaeria is typified with Leptosphaeria doliolum and is originally introduced as Sphaeria doliolum Pers. (Cesati \& de Notaris 1863, Barr 1987a). The lectotype of the genus has superficial ascomata, flattened at base, papillate, thick, scleroplectenchyma tissue types of peridium, cylindrical asci with ellipsoid to fusoid ascospores with a coelomycetous asexual morph (Crane \& Shearer 1991, Hyde et al. 2011, 2013). The morphological characters of the type species are given in Hyde et al. (2013) and phylogenetic analysis provided in Ariyawansa et al. 2015b and Dayarathne et al. (2015). The ITS, LSU, SSU, tef1 and rpb-2 sequence data for type species are available in GenBank database (Schoch et al. 2009a). 


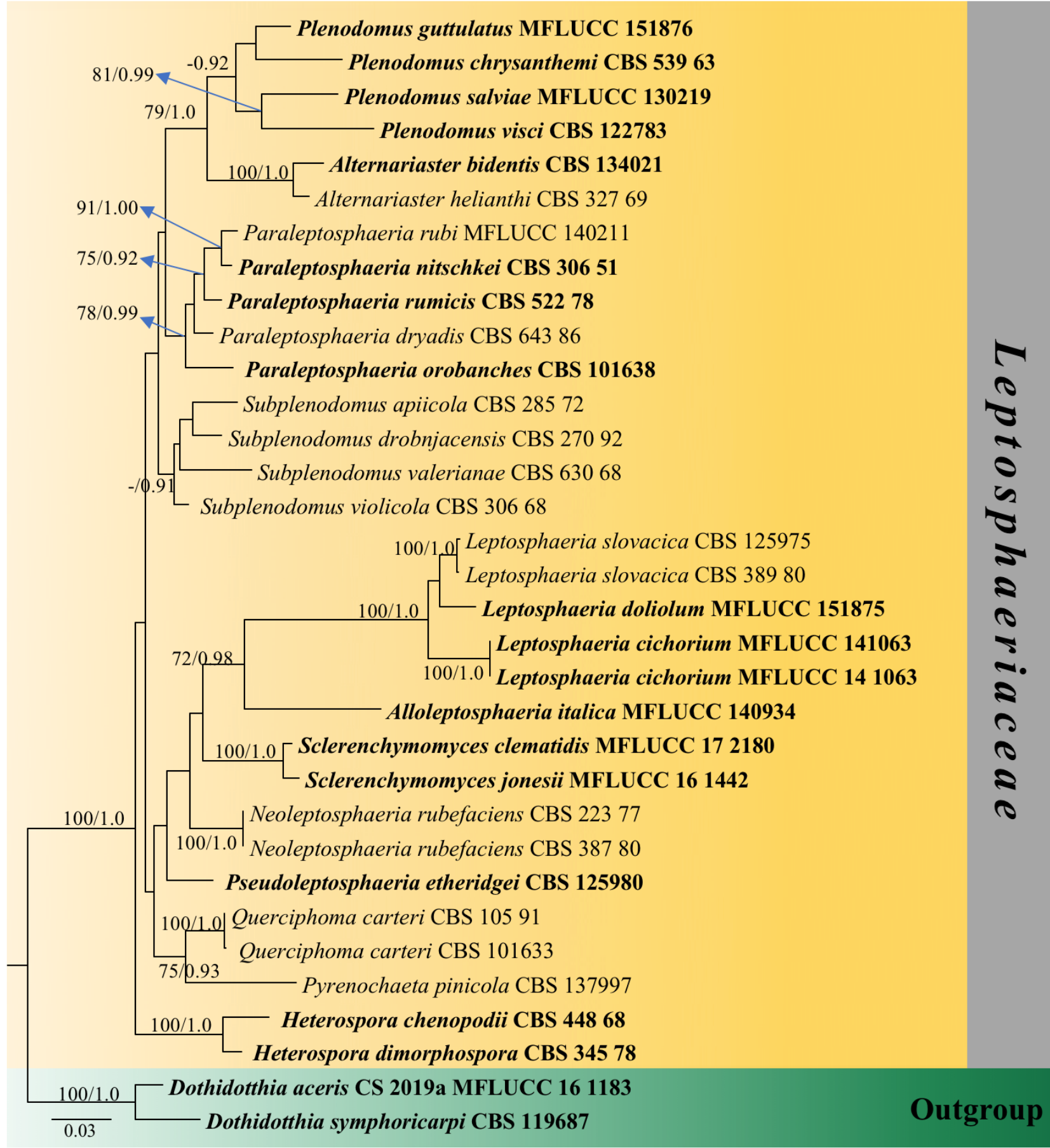

Figure 93 - Phylogram generated from maximum likelihood analysis (RAxML) of genera in Leptosphaeriaceae based on ITS, LSU, and SSU sequence data. Maximum likelihood bootstrap values equal or above $70 \%$, Bayesian posterior probabilities equal or above 0.90 (MLBS/PP) are given at the nodes. An original isolate number is noted after the species name. The tree is rooted to Dothidotthia aceris (MFLUCC 16-1183) and D. symphoricarpi (CBS 119687). The ex-type strains are indicated in bold. Hyphen (-) represents support values below 70 \% MLBS and 0.90 PP.

Leptosphaeria cichorii Phukhams., Camporesi, Ariyaw. \& K.D. Hyde [as 'cichorium'], Fungal Divers 74: 35 (2015).

Fig. 94

三Leptosphaeria cichorium Phukhams., Camporesi, Ariyaw. \& K.D. Hyde, Fungal Divers 74: 35 (2015).

Index Fungorum number: IF 626419; Facesoffungi number: FoF 01156.

Description - see Ariyawansa (2015b). 
Material examined - Italy, Province of Forlì-Cesena [FC], Fiumicello - Premilcuore, on dead stem of Cichorium intybus (Asteraceae), 29 August 2014, E. Camporesi IT 2067, (MFLU 15-1406, holotype).

Notes - Ariyawansa et al. (2015b) introduced Leptosphaeria cichorii for an isolate of Leptosphaeria occurred on Cichorium intybus based on the morphological character and a robust phylogenetic analysis. The morphological characters of $L$. cichorii are compatible with the generic concept of Leptosphaeria in having superficial ascomata, peridium of schleroplectenchymatous cells type, and cylindrical, fusoid, 3-septate ascospores (Fig. 94).

\section{Other genera included}

Alloleptosphaeria Ariyaw., Wanas. \& K.D. Hyde, in Ariyawansa et al. Fungal Divers 74: 11 (2015).

Index Fungorum number: IF 551460; Facesoffungi number: FoF 01152; 3 morphological species (Species Fungorum 2020), 3 species with molecular data.

Type species - Alloleptosphaeria italica Wanas., Camporesi, Ariyaw. \& K.D. Hyde Fungal Divers 74: 29 (2015).

Notes - Alloleptosphaeria was introduced as monotypic genus for a saprobic fungal strain found on Clematis vitalba. It is characterized by scattered, immersed to semi-erumpent, globose or subglobose ascomata with yellowish ascospores (see morphology Ariyawansa et al. 2015b, Wijayawardene et al. 2018). The asexual morph of this genus was reported as globose pycnidial with hyaline aseptate conidia (Crous et al. 2018b, Aiello et al. 2020).

Alternariaster Simmons, CBS Diversity Ser. (Utrecht) 6: 667 (2007).

Index Fungorum number: IF 505049; Facesoffungi number: FoF 01154; 4 morphological species (Species Fungorum 2020), 4 species with molecular data (Hyde et al. 2017).

Type species - Alternariaster helianthi (Hansf.) E.G. Simmons, CBS Diversity Ser. (Utrecht) 6: 667 (2007).

三 Helminthosporium helianthi Hansf., Proc. Linn. Soc. London 155: 49 (1943) [1942-43].

Notes - Alternariaster, typified by Alternaria helianthi was introduced in Simmons (2007) to accommodate a fungal species that cause leaf spots on Helianthus annuus (sunflower). Alternariaster centaureae-diffusae has long filiform, multi-septate ascospores (Ariyawansa et al. 2015b). The asexual morph was segregated from alternaria-like dematiaceous hyphomycetous based on morphology and phylogenetic support (Woudenberg et al. 2013, Hyde et al. 2017, Wijayawardene et al. 2018).

Chaetoplea (Sacc.) Clem., in Clements \& Shear, Gen. fung., Edn 2 (Minneapolis): 275 (1931).

$\equiv$ Pyrenophora subgen. Chaetoplea Sacc. (1883).

Index Fungorum number: IF 959, Facesoffungi number: FoF 06401; 23 morphological species (Species Fungorum 2020), molecular data unavailable.

Type species - Chaetoplea calvescens (Fr. ex Desm.) Clem., in Clements \& Shear, Gen. fung., Edn 2 (Minneapolis): 275 (1931).

ESphaeria calvescens Fr. ex Desm., Annls Sci. Nat., Bot., sér. 2 19: 353 (1843).

Notes - Chaetoplea was previously reported as a member of Phaeosphaeriaceae (Barr 1987a, 1990b). The genus is characterized by scleroplectenchyma cell types of peridium, 3-euseptate ellipsoidal ascospores with longitudinal septa, and hyaline to pale yellow. Phookamsak et al. (2014c) re-examined the lectotype of Chaetoplea calvescens and assigned the genus to Leptosphaeriaceae based on compatible morphology. Epitypification is required to confirm the taxonomic placement of Chaetoplea.

Heterosporicola Crous, Fungal Divers 86: 208 (2017).

Index Fungorum number: IF 821707; Facesoffungi number: FoF 06402; 2 morphological species (Species Fungorum 2020), 2 species with molecular data. 
Type species - Heterosporicola chenopodii (Westend.) Gruyter et al., Stud. Mycol. 75: 18 (2012).

$\equiv$ Phyllosticta chenopodii Westend., Bull. Acad. R. Sci. Belg., Cl. Sci., sér. 2 2(7): 567 (1857).
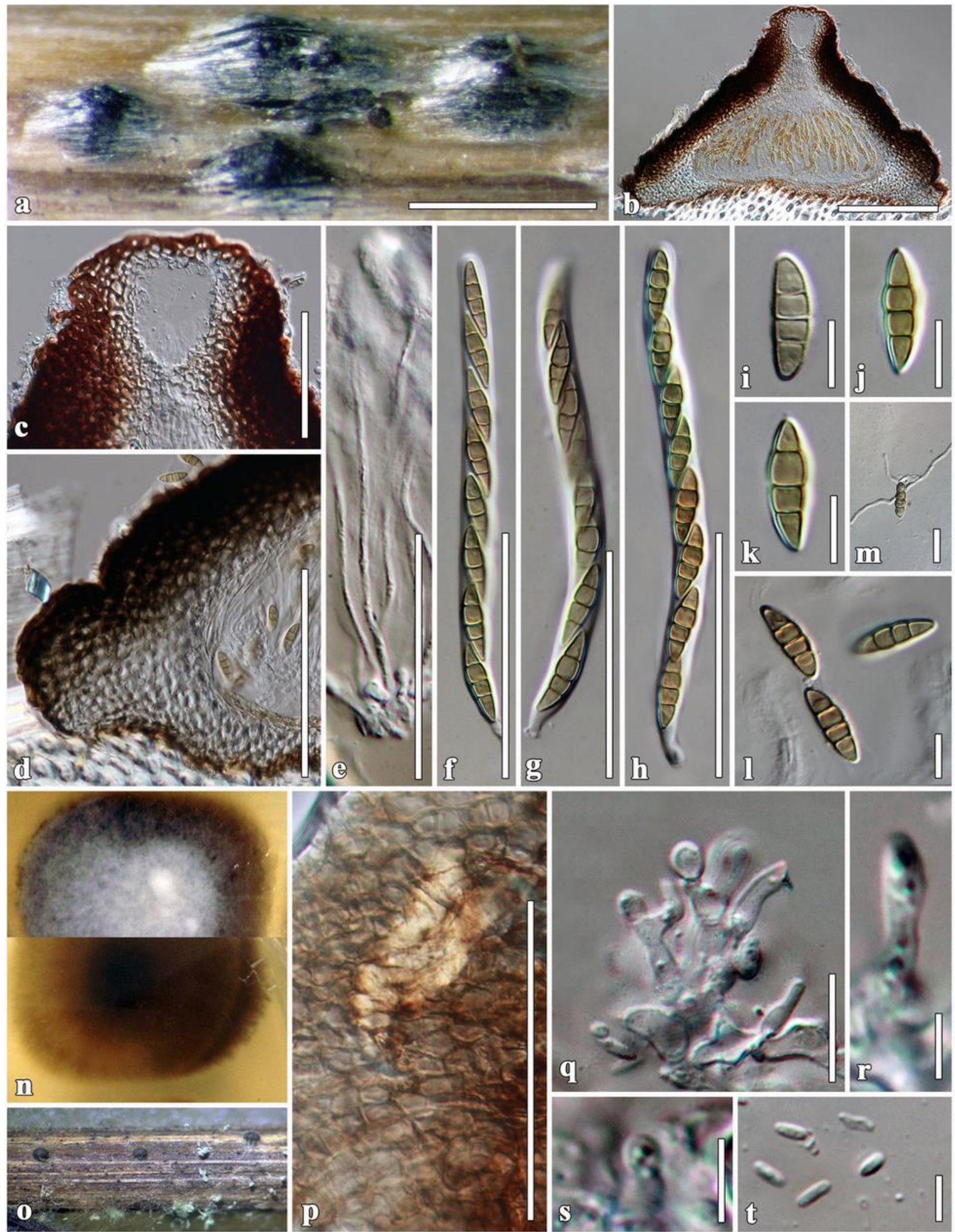

Figure 94 - Leptosphaeria cichorii (MFLU 15-1406, holotype). a Ascomata on host substrate. b Vertical section through ascoma. c Ostiole canal. d Peridium. e Pseudoparaphyses. $\mathrm{f}-\mathrm{h}$ Asci. i-1 Ascospores. m Germinated ascospore. n Culture character on MEA. o Conidiomata on sterile bamboo pieces. $\mathrm{p}$ Peridoum of conidioma. $\mathrm{q}-\mathrm{s}$ Conidiogenous cells and conidia. $\mathrm{t}$ Conidia. Scale bars: $\mathrm{a}=500 \mu \mathrm{m}, \mathrm{b}, \mathrm{d}=100 \mu \mathrm{m}, \mathrm{c}, \mathrm{e}-\mathrm{h}, \mathrm{p}-\mathrm{O}=50 \mu \mathrm{m}, \mathrm{i}-\mathrm{m}, \mathrm{q}=10 \mu \mathrm{m}, \mathrm{r}-\mathrm{t}=5 \mu \mathrm{m}$. 
Notes - Heterosporicola is a legitimate name for Heterospora. The genus was initially introduced as a Phoma sect. Heterospora (Boerema 1997). A study of more than 1,100 strains of Phoma held in the Netherlands culture collections raised Phoma sect. Heterospora to generic rank in Leptosphaeriaceae (Gruyter et al. 2013). Two species are accepted in Heterosporicola but no sexual morph characters are available for this genus (Ariyawansa et al. 2015b, Wijayawardene et al. 2018).

Neoleptosphaeria Ariyaw. \& K.D. Hyde, Fungal Divers 74 (2015).

Index Fungorum number: IF 551464; Facesoffungi number: FoF 01157; 2 morphological species (Species Fungorum 2020), 2 species with molecular data (Ariyawansa et al. 2015a, Wanasinghe et al. 2016a).

Type species - Neoleptosphaeria rubefaciens (Togliani) Ariyaw. \& K.D. Hyde, Fungal Divers 74 (2015).

三Phoma rubefaciens Togliani, Annali Sper. agr., N.S. 7: 1626 (1953).

Notes - Neoleptosphaeria was originally reported as Phoma rubefaciens in Leptosphaeriaceae. Later the sexual morph characters were addressed by Wanasinghe et al. (2016a) with scleroplectenchyma cell types of peridium, broad fusiform, transversely septate ascospores as domain characters.

Ochraceocephala Voglmayr \& Aiello, in Aiello et al., MycoKeys 66: 12 (2020).

Index Fungorum number: IF 833933; Facesoffungi number: FoF 09305; 1 morphological species (Species Fungorum 2020), 1 species with molecular data.

Type species - Ochraceocephala foeniculi Voglmayr \& Aiello, in Aiello et al., MycoKeys 66: 14 (2020).

Notes - Aiello et al. (2020) established Ochraceocephala from symptomatic tissues of Foeniculum vulgare. The genus represented as hyphomycetous asexual morph, verticillate branched conidiophores with phialidic conidiation, and conidia produced in basipetal chains. Phylogenetic analyses in Aiello et al. (2020) indicated that Ochraceocephala is closely related to Plenodomus but it is morphologically distinct.

Paraleptosphaeria Gruyter, Aveskamp \& Verkley, Stud. Mycol. 75: (2012).

Index Fungorum number: IF 821707; Facesoffungi number: FoF 01159; 9 morphological species (Species Fungorum 2020), 9 species with molecular data.

Type species - Paraleptosphaeria nitschkei (Rehm ex G. Winter) Gruyter, Aveskamp \& Verkley, Stud. Mycol. 75 (2012).

三Leptosphaeria nitschkei Rehm ex G. Winter, Flora, Regensburg 55: 510 (1872).

Notes - Paraleptosphaeria was introduced to Leptosphaeriaceae by Gruyter et al. (2013). Paraleptosphaeria nitschkei was formally introduced as Leptosphaeria nitschkei, however, Gruyter et al. (2013) proved that the genus is phylogenetically distantly related to L. doliolum. Paraleptosphaeria members are characterized scleroplectenchyma cell types of peridium, clavate to cylindric-clavate, short pedicellate asci, and hyaline to yellow brownish, transversely septate ascospore (Ariyawansa et al. 2015b). Nine taxa are accepted in Paraleptosphaeria (morphology see Quaedvlieg et al. 2013 as Acicuseptoria rumicis, Ariyawansa et al. 2015b, Tippromma et al. 2017, Wijayawardene et al. 2018, Piątek et al. 2020).

Plenodomus Preuss, Linnaea 24: 145 (1851).

Index Fungorum number: IF 9445; Facesoffungi number: FoF 06403; 36 morphological species (Species Fungorum 2020), 22 species with molecular data (Gruyter et al. 2013, Phookamsak et al. 2019).

Type species - Plenodomus lingam (Tode: Fr.) Höhn., Sitzungsber. Kaiserl. Akad. Wiss., Math. Naturwiss. Cl., Abt. 1. 120: 463 (1911).

$\equiv$ Plenodomus rabenhorstii Preuss, Linnaea 24: 145 (1851).

For synonyms see Index Fungorum 2020. 
Notes - Preuss (1851) introduced Plenodomus typified by P. rabenhorstii. Due to the loss of the holotype specimens, Boerema \& Kesteren (1964) designed P. lingam as the type species of Plenodomus. The genus is saprobic or parasitic on stems and leaves of various plants in terrestrial habitats and is remarkable in having immersed ascomata with scleroplectenchyma cell types of peridium, and 3-5-distoseptate, broadly fusiform ascospores. The classification of Plenodomus was revisited by de Gruyter et al. (2013) and was followed by Ariyawansa et al. (2015b), Marin-Felix et al. (2017), Tennakoon et al. (2017) and Phookamsak et al. (2019).

Pseudoleptosphaeria Ariyaw. \& K.D. Hyde, Fungal Divers: 74: 42 (2015).

Index Fungorum number: IF 551469; Facesoffungi number: FoF 01162; 1 morphological species (Species Fungorum 2020), 1 species with molecular data (Hutchison et al. 2012, Ariyawansa et al. 2015b).

Type species - Pseudoleptosphaeria etheridgei (L.J. Hutchison \& Y. Hirats.) Ariyaw. \& K.D. Hyde, Fungal Divers 74: 42 (2015).

$\equiv$ Phoma etheridgei L.J. Hutchison \& Y. Hirats., in Hutchison, Chakravarty et al., Can. J. Bot. 72(10): 1425 (1994).

Notes - Ariyawansa et al. (2015b) introduced Pseudoleptosphaeria for Leptosphaeria etheridgei, which is distantly related to Leptosphearia sensu stricto. The genus was found associated with black galls and cankers of Populus tremuloides. The genus is characterized by its immersed to superficial globose to pear-shaped conidiomata, pseudoparenchymatous cell types, and ellipsoidal to ovoid or oblong, hyaline, unicellular conidia (Hutchison et al. 1994). The sexual morph is undetermined (Wijayawardene et al. 2018).

Querciphoma Crous, IMA Fungus 8: 147 (2017).

Index Fungorum number: IF 820913; Facesoffungi number: FoF 06404; 1 morphological species (Species Fungorum 2020), 1 species with molecular data.

Type species - Querciphoma carteri (Gruyter \& Boerema), in Crous \& Groenewald, IMA Fungus 8(1): 147 (2017).

$\equiv$ Phoma carteri Gruyter \& Boerema, Persoonia 17: 547 (2002).

Notes - Crous \& Groenewald (2017) introduced Querciphoma for phoma-like strains distinguishable in the uni- to multi-locular conidiomata, with eustromatic structure and brown verruculose conidia. The fungus was isolated from leaves and twigs of Quercus robur and is phylogenetically related to Leptosphaeriaceae taxa. No sexual morph characters are recorded for this genus (Wijayawardene et al. 2017a).

Sclerenchymomyces Phukhams. \& K.D. Hyde, in Phukhamsakda et al., Fungal Diversity 102: 41 (2020).

Index Fungorum number: IF 557110; Facesoffungi number: FoF 07287; 2 morphological species (Species Fungorum 2020), 2 species with molecular data (Phukhamsakda et al. 2020).

Type species - Sclerenchymomyces clematidis Phukhams. \& K.D. Hyde, in Phukhamsakda et al., Fungal Diversity 102: 41 (2020).

Notes - Phukhamsakda et al. (2020) introduced Sclerenchymomyces for a clade comprising Sclerenchymomyces clematidis and $S$. jonesii. The member of Sclerenchymomyces are characterized in having black, shiny, superficial to semi-immersed ascomata with a multilayer of scleroplectenchymatous tissues (Wanasinghe et al. 2016a). Currently, members of this genus can be found as saprobes on plants.

Sphaerellopsis Cooke, Grevillea 12 (6): 23 (1883).

Index Fungorum number: IF 9976; Facesoffungi number: FoF 06405; 7 morphological species (Species Fungorum 2020), 5 species with molecular data (Phookamsak et al. 2019).

Type species - Sphaerellopsis filum (Biv.) B. Sutton, Mycol. Pap. 141: 196 (1977).

$\equiv$ Sphaeria filum Biv., Stirp. Rar. Sic. 3: 12 (1815). 
Notes - Species of Sphaerellopsis are reported as saprobic, pathogenic or mycoparasitic on stems and leaves of herbaceous or woody plants in terrestrial habitats (Trakunyingcharoen et al. 2014, Crous et al. 2016b). Trakunyingcharoen et al. (2014) considered Eudarluca as the sexual morph of Sphaerellopsis and proposed Sphaerellopsis over Eudarluca based on the priority of the oldest name. Phookamsak et al. (2014c) demonstrated that the morphological characters of Eudarluca were more compatible with Phaeosphaeriaceae. Phookamsak et al. (2019) confirmed the phylogenetic placement of Sphaerellopsis in Leptosphaeriaceae. However, sequence data for the type specimens of Eudarluca is required for clarification.

Subplenodomus Gruyter, Aveskamp \& Verkley, Stud. Mycol. 75: 23 (2013).

Index Fungorum number: IF 564769; Facesoffungi number: FoF 06406; 5 morphological species (Species Fungorum 2020), 5 species with molecular data.

Type species - Subplenodomus violicola (P. Syd.) Gruyter, Aveskamp \& Verkley, Stud. Mycol. 75: 23 (2012).

$\equiv$ Phoma violicola Syd., Hedwigia 38 (Beibl.): (137) (1899).

Notes - Based on DNA sequence data, Subplenodomus was introduced for a well-clustered clade of some Phoma-like species (Gruyter et al. 2013). The genus produces thick pycnidial wall of pseudoparenchymatous or sometimes scleroplectenchymatous cell types (Ariyawansa et al. 2015b). Subplenodomus species are known from herbaceous plants or wood substrate (Tibpromma et al. 2017, Wijayawardene et al. 2018).

\section{Ecological and economic significance}

Species of Leptosphaeriaceae can be found in various environments such as parasitic, saprobic, fungicolus, hemibiotropic or pathogenic on leaves and wood on living leaves of plants terrestrial or marine habitats (Ariyawansa et al. 2015b, Dayarathne et al. 2015). Several asexual morphs of Leptosphaeriaceae have been reported as economically important plant pathogens such as Neoleptosphaeria rubefaciens reported in association with skin necrosis on apple fruits (Boerema et al. 1994). Plenodomus lingam (= Leptosphaeria maculans) causes the important blackleg disease of canola and is a cosmopolitan seed-borne pathogen of brassicas (Boerema \& van Kesteren 1964, Van de Wouw et al. 2016. Plenodomus biglobosa, causes black rot disease on Wasabia japonica (Gruyter et al. 2013).

Libertasomycetaceae Crous, in Crous \& Groenewald, IMA Fungus 8(1): 146 (2017).

Index Fungorum number: IF 820911; Facesoffungi number: FoF 08263, 6 species.

Saprobic and pathogenic fungi. Sexual morph: Ascomata immersed in a brown stroma, becoming erumpent, breaking through the host surface, aggregated in clusters, with a central ostiole. Peridium composed of 6-10 layers of brown textura angularis cells. Hamathecium comprising hyphal-like, intermingled among asci, hyaline, smooth, septate, anastomosing, cellular pseudoparaphyses. Asci 8-spored, bitunicate, stipitate, hyaline, smooth, subcylindrical with ocular chamber. Ascospores fasciculate, fusoid-ellipsoidal, brown, muriformly septate, verruculose with obtuse ends, encased in a mucoid sheath. Asexual morph: Conidiomata unilocular, stromatic, separate, globose, immersed, brown, opening via a central ostiole. Peridium composed of 3-6 layers of brown textura angularis cells. Conidiophores reduced to conidiogenous cells. Conidiogenous cells lining the inner cavity, hyaline, smooth, ampulliform to doliiform, with prominent periclinal thickening at the apex, or with tightly aggregated percurrent proliferations at the apex. Conidia solitary, subcylindrical to ellipsoidal, straight to curved, golden brown, 0-1septate, constricted at median septum, apex obtuse, base truncate, with marginal frill, and longitudinal striations, or ellipsoidal, apex obtuse, base truncate to bluntly rounded, hyaline, granular, aseptate, thin- and smooth-walled (Crous \& Groenewald 2017).

Type - Libertasomyces Crous \& Roets.

Notes - Crous \& Groenewald (2017) introduced Libertasomycetaceae to accommodate Libertasomyces and Neoplatysporoides in order Pleosporales. Species of Libertasomycetaceae are saprobic on twigs and leaf litter (Crous et al. 2016a, b, Crous \& Groenewald 2017). 
Libertasomyces Crous \& Roets, in Crous et al., Persoonia 36: 375 (2016b).

Index Fungorum number: IF 817046; Facesoffungi number: FoF 08264; 4 morphological species (Species Fungnorum 2020), 4 species with molecular data.

Type species - Libertasomyces myopori Crous \& Roets, in Crous et al., Persoonia 36: 375 (2016).

Notes - The type of Libertasomyces was collected on twigs of Myoporum serratum in Western Cape Province, South Africa (Crous et al. 2016b). The genuns is characterized by erumpent, dark brown conidiomata, with conidiogenous cells lining the inner cavity, hyaline, smooth, ampulliform to doliiform, phialidic with prominent periclinal thickening, and hyaline, granular, ellipsoid, aseptate (muriformly in L. quercus) conidia, with an obtuse apex (Crous et al. 2016b). ITS and LSU sequence data are available for this genus.
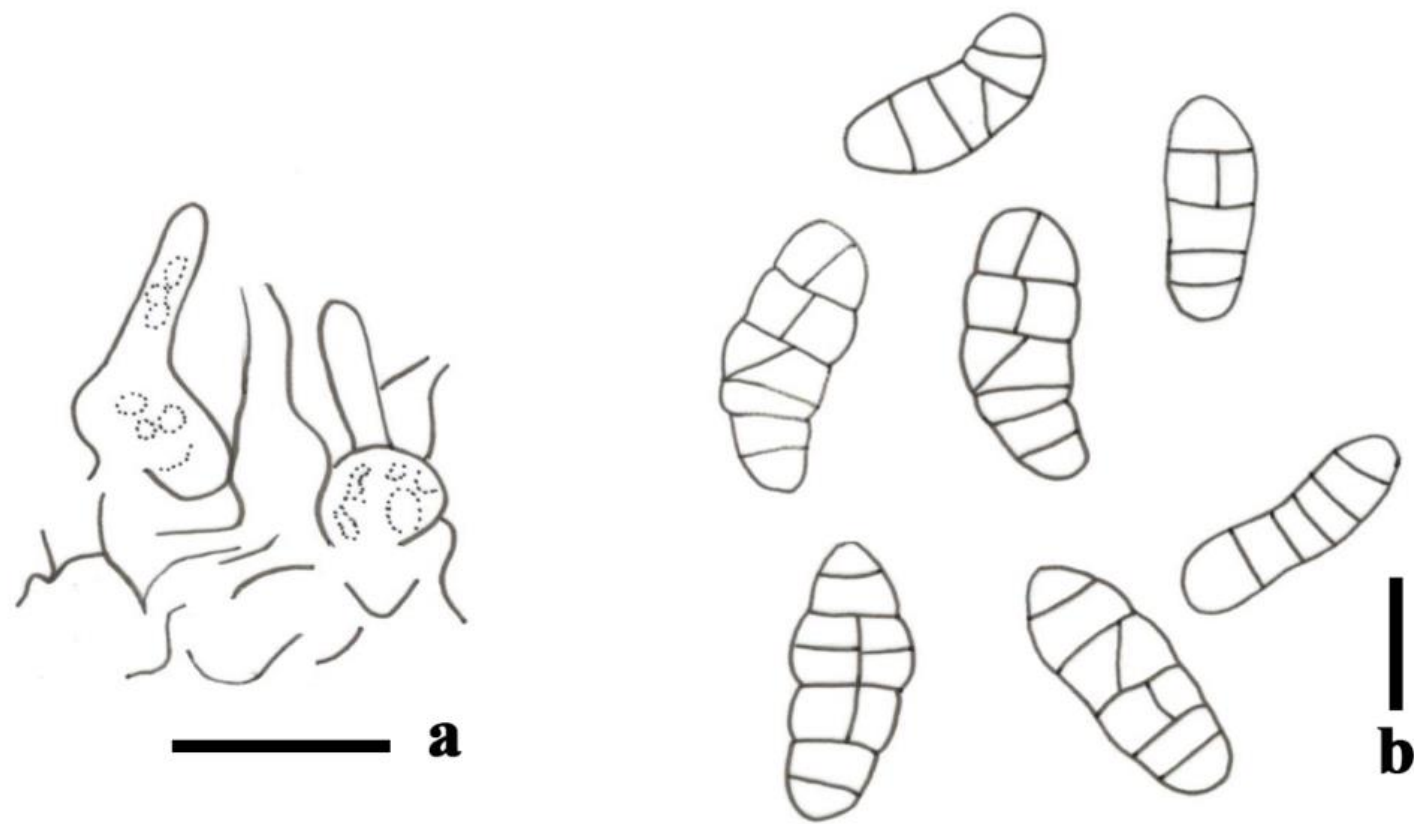

Figure 95 - Libertasomyces quercus (redrawn from Crous \& Groenewald 2017, CBS 134.97). a Conidiogenous cells. $b$ Conidia. Scale bar: $a, b=10 \mu \mathrm{m}$.

\section{Other genus included}

Neoplatysporoides Crous \& M.J. Wingf., Persoonia 34: 197 (2015).

Index Fungorum number: IF 812439; Facesoffungi number: FoF 08265; 2 morphological species (Species Fungorum 2020), 2 species with molecular data.

Type species - Neoplatysporoides aloicola Crous \& M.J. Wingf., Persoonia 34: 197 (2015).

Notes - Crous et al. (2015c) introduced Neoplatysporoides aloicola on leaf litter of Aloe sp. in Tanzania. Neoplatysporoides is also associated with tip dieback of Aloe ferox (Crous et al. 2015c). This genus differs from Libertasomyces in having golden brown conidia that are subcylindrical to ellipsoid, 0-1-septate, and constricted at median septum, while Libertasomyces has hyaline, granular, ellipsoid, widest in middle, aseptate or muriformly septate conidia. Two species, $N$. aloes and N. aloicola are known for the genus (Crous et al. 2015c, 2019e).

\section{Ecological and economic significance}

Members of Libertasomycetaceae are found in Spain, Tanzania and South Africa (Crous et al. 2015c, 2016b, Crous \& Groenewald 2017). Libertasomycetaceae species are saprobic on leaf litter, twigs and pathogenic causing tip dieback of Aloe ferox (Crous et al. 2015c, 2016b, Crous \& Groenewald 2017). 
Ligninsphaeriaceae J. F. Zhang, J. K. Liu \& Z. Y. Liu, in Zhang et al., Phytotaxa 247(2): 112 (2016).

Index Fungorum number: IF 551759; Facesoffungi number: FoF 01661, 2 species with molecular data.

Saprobic on decaying bamboo or submerged wood in terrestrial and aquatic habitats. Sexual morph: Ascomata scattered, solitary, immersed under the host tissue, black, subglobose or obpyriform, clypeate. Ostiole central, with a crest-like opening. Peridium coriaceous to carbonaceous, composed of dark brown to pale or hyaline cells arranged in textura angularis. Hamathecium comprising numerous, filiform, cellular pseudoparaphyses, embedded in a gelatinous matrix. Asci 8-spored, broad-clavate, bitunicate, fissitunicate, apically rounded with a distinct ocular chamber and a tapering, short pedicel. Ascospores 3-4-seriate, broad-fusiform, hyaline to brown, uni- or multi-septate, forming appendages in both ends. Asexual morph: Undetermined.

Type - Ligninsphaeria J.F. Zhang, J.K. Liu, K.D. Hyde \& Z.Y. Liu.

Notes - An independent lineage was formed and introduced as Ligninsphaeria within Pleosporales based on morphological and molecular evidence (Zhang et al. 2016c). We formally introduce the new family Ligninsphaeriaceae to accommodate the monotypic genus Ligninsphaeria. Ligninsphaeria is easily distinguished from other related groups in Pleosporales based on remarkable characteristics and molecular analysis, but more collections of this group are needed to provide informative data to show its natural classification.

Ligninsphaeria J.F. Zhang, J.K. Liu, K.D. Hyde \& Z.Y. Liu, Phytotaxa 247(2): 113 (2016).

Index Fungorum number: IF 551757; Facesoffungi number: FoF 01662; 1 morphological species (Species Fungorum 2020), 1 species with molecular data.

Type species - Ligninsphaeria jonesii J.F. Zhang, J.K. Liu, K.D. Hyde \& Z.Y. Liu, Phytotaxa 247(2): 113 (2016).

Notes - Ligninsphaeria, a monotypic genus, typified with Ligninsphaeria jonesii, which was introduced by Zhang et al. (2016c) and assigned in Pleosporales. Phylogenetic analyses placed Ligninsphaeria as an independent basal lineage of Pleosporales. It is difficult to illustrate the phylogenetic relationship with close genera, and to confirm its natural placement within Pleosporales because of a lack of data. Therefore, more specimens are needed to provide data for this undersampled group.

Ligninsphaeriopsis Phukhamsakda, J.F. Zhang \& K.D. Hyde, gen. nov. Index Fungorum number: IF 557245; Facesoffungi number: FoF 07528.

Etymology - In reference to its similarity to Ligninsphaeria.

Saprobic on submerged wood in stream habitat. Sexual morph: Ascomata solitary, gregarious, scattered, immersed, only black, elongated, and shiny ostioles part are visible, subglobose or compressed globose to obpyriform, flattened base, coriaceous, carbonaceous at outer layer and apex, dark brown to black, rough-walled, papillate, ostiolate. Ostiole central, with a crestlike apex, elongated and laterally compressed, irregular-walled, black, papillate, opened pore, carbonaceous, ostiolate with periphyses. Peridium comprises multilayer, coriaceous to carbonaceous, composed of two strata, an outer stratum thick-walled and black cells arranged in a textura angularis, with carbonaceous, outer layer composed of 2 layers of dark brown to light brown cells of textura angularis and inner layer of dark brown to black cells of textura angularis, cells towards the inside lighter, with 6-7 layers of lightly pigmented, grey brown, inner layer composed of a hyaline gelatinous layer. Hamathecium comprising dense, filiform branches, anastomosing above asci, transverse septate, trabeculate pseudoparaphyses. Asci 8-spored, bitunicate, fissitunicate, broad-clavate with tapering to pedicel, apically rounded, ocular chamber clearly visible when immature. Ascospores 2-seriate or overlapping, broad fusiform, narrow towards the apex, initially hyaline, becoming brown to dark brown at maturity, 6-9-septate, constricted at the septa, with cell above central septum wider, rough-walled, indentations present, with verruculose surface, surrounded by sheath drawn out form polar appendages. Asexual morph Undetermined. 
Type species - Ligninsphaeriopsis thailandica Phukhamsakda, J. F. Zhang \& K. D. Hyde.
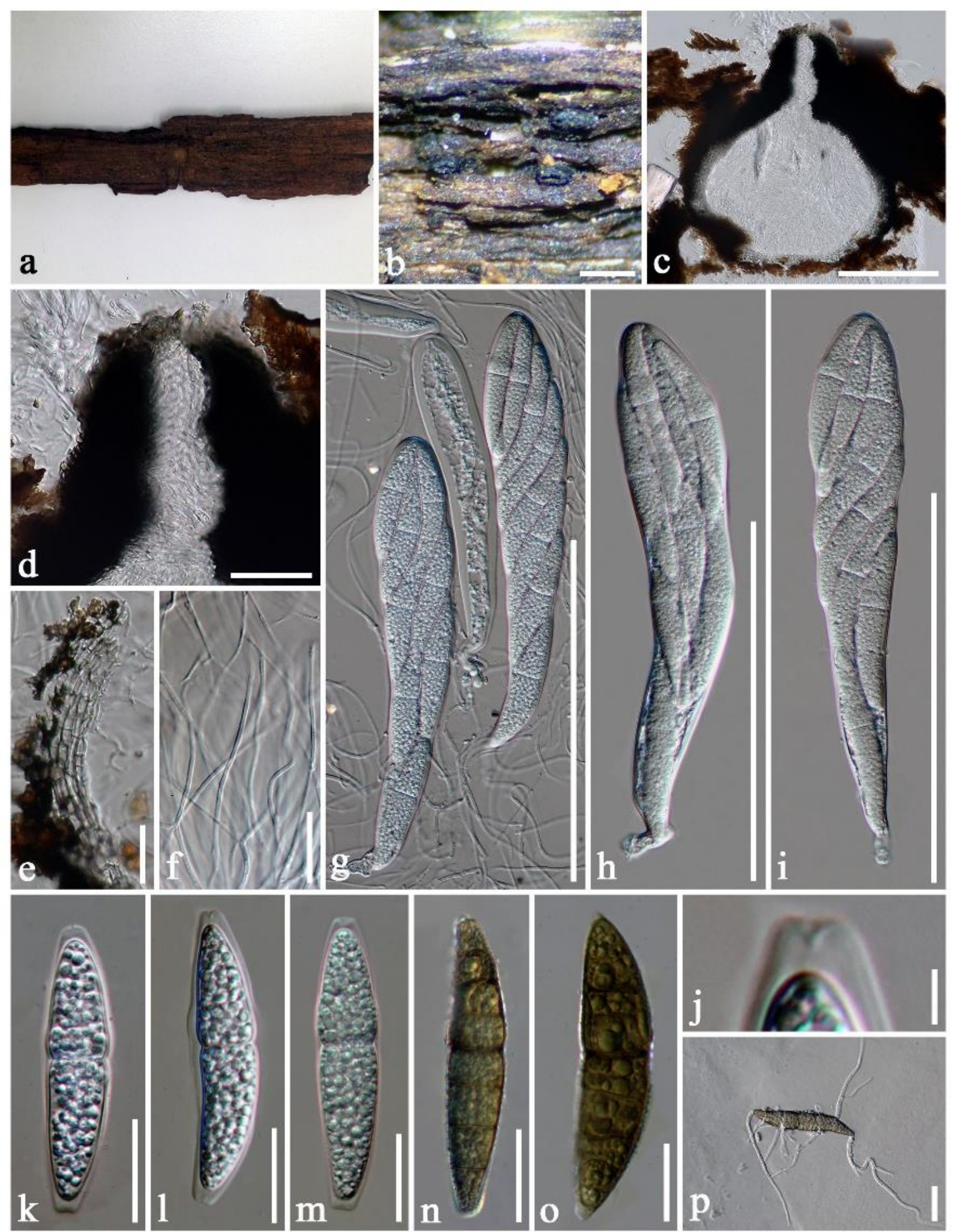

Figure 96 - Ligninsphaeriopsis thailandica (MFLU 20-0423, holotype). a Ascomata on submersed wood. b Close up of ascomata. c Section through ascoma. d Ostioles. e Peridium. f Pseudoparaphyses. $\mathrm{g}-\mathrm{i}$ Asci. $\mathrm{j}$ Sheath tip covering ascospore. $\mathrm{k}-\mathrm{o}$ Ascospores. $\mathrm{p}$ Germinating ascospore. Scale bar: $b-c, g-i=200 \mu \mathrm{m}, d=50 \mu \mathrm{m}, \mathrm{e}-\mathrm{f}, \mathrm{k}-\mathrm{p}=20 \mu \mathrm{m}, \mathrm{j}=5 \mu \mathrm{m}$.

Ligninsphaeriopsis thailandica Phukhamsakda, Feng J.F. \& K.D. Hyde, sp. nov.

Fig. 96

Index Fungorum number: IF 556784; Facesoffungi number: FoF 08266. 
Etymology - Refers to the location where the fungus was collected.

Saprobic on submerged wood in stream habitat. Sexual morph: Ascomata 430-680 × 355$485 \mu \mathrm{m}(\bar{x}=500 \times 415 \mu \mathrm{m}, \mathrm{n}=10)$, on surface of the host, solitary, gregarious, scattered, immersed, only black, elongated, and shiny ostioles part are visible, sub-globose or compressed globose to obpyriform, flattened base, coriaceous, carbonaceous at outer layer and apex, dark brown to black, rough-walled, papillate, ostiolate. Ostiole central, 180-215 × 175-180 $\mu \mathrm{m}$, with a crest-like apex, elongated and laterally compressed, irregular-walled, black, papillate, opened pore, carbonaceous, ostiolate with periphyses. Peridium 30-60(-105 at apex) $\mu \mathrm{m}$ wide, multilayer, coriaceous to carbonaceous, composed of two strata, an outer stratum thick-walled and black cells arranged in a textura angularis, with carbonaceous, outer layer composed of two layers of dark brown to light brown cells of textura angularis and inner layer of dark brown to black cells of textura angularis, cells towards the inside lighter, with the layers of lightly pigmented, grey brown, inner layer composed of a hyaline gelatinous layer. Hamathecium comprising dense, 1.2-2.5 $\mu \mathrm{m}$ wide $(\bar{x}=2 \mu \mathrm{m}, \mathrm{n}=50)$, filiform branches, anastomosing above asci, transverse septate, narowly cellular pseudoparaphyses. Asci 200-350 × 30-50 $\mu \mathrm{m}(\bar{x}=261 \times 35 \mu \mathrm{m}, \mathrm{n}=30)$, 8-spored, bitunicate, fissitunicate, broad-clavate with tapering to pedicel, apically rounded, ocular chamber clearly visible when immature. Ascospores $70-85 \times 15-25 \mu \mathrm{m}(\bar{x}=75 \times 17 \mu \mathrm{m}, \mathrm{n}=50)$, 2-seriate or overlapping, broad fusiform, narrow towards the apex, initially hyaline, becoming brown to dark brown at maturity, 6-9 -septate, constricted at the middle septum, with cell above central septum wider, rough-walled, indentations present, with verruculose surface, surrounded by $3-5 \mu \mathrm{m}$ wide sheath drawn out form polar appendages. Asexual morph: Undetermined.

Culture characteristics - Colonies on MEA reaching $30 \mathrm{~mm}$ diam. after four weeks of incubation at $25{ }^{\circ} \mathrm{C}$, from above dark brown radiating outwards, fairy fluffy, dense, circulate in shape, flattened, umbonate, entire edge, fairly fluffy; reverse black at the middle and dark brown at the edges.

Material examined - Thailand, Krabi, Mueang Krabi, soaked in the stream, 15 December 2015, C. Phukhamsakda (MFLU 20-0423, holotype); ex-type living culture, MFLUCC 16-0427.

GenBank numbers - ITS: MT676012, LSU: MT676009, SSU: MT676011, rpb-2: MT676008, tef1: MT676007.

Notes - In this study, a fresh collection formed a distinct lineage, close to the type species of Ligninsphaeria, Ligninsphaeria jonesii with moderate support. However, it differs from L. jonesii in having larger asci (206-355 $\mu \mathrm{m}$ vs. 163-243 $\mu \mathrm{m})$, but smaller ascospores (70-85 $\mu \mathrm{m}$ vs. 79-125 $\mu \mathrm{m})$. The ascospores of $L$. jonesii are smooth-walled, indistinctly 1 -septate, with a projecting gelatinous cap at both ends, while the new taxon has verrucose, 6-9 -transversely septate ascospores, surrounded by a mucilaginous sheath. Therefore, a new genus Ligninsphaeriopsis is introduced to accommodate Ligninsphaeriopsis thailandica based on morphological evidence coupled with multi-gene phylogenetic results.

\section{Ecological and economic significance}

Only two species are accepted in this family, reported as saprophytes from aquatic and terrestrial habitats. Ligninsphaeriaceae species are decomposers in ecological systems.

Lindgomycetaceae K. Hiray., Kaz. Tanaka \& Shearer, Mycologia 102(3): 733 (2010).

Index Fungorum number: IF 515187; Facesoffungi number: FoF 08267, 24 species.

Saprobic on decaying wood submerged in freshwater or decayed stem in terrestrial habitats or pathogenic Sexual morph: Ascomata subglobose to globose, scattered to crowded, ostiolate. Neck short, central. Peridium composed of hyaline to pale brown, small, thin-walled cells. Hamathecium comprising numerous, filamentous, septate, branched, anastomosing, usually cellular, or trabeculate pseudoparaphyses. Asci 8-spored, fissitunicate, cylindrical to clavate, rounded at the apex, with an ocular chamber. Ascospores uni- to multi-septate, fusiform to cylindrical, hyaline to brown, usually covered with an entire sheath and/or bipolar mucilaginous appendages (adapted from Hirayama et al. 2010). Asexual morph: Coelomycetous. Conidiomata semi-immersed to superficial, single or aggregated, subglobose to ellipsoidal, ostiolate. Conidiomata wall composed of cells of textura 
angularis. Conidiophores lining the acervuli wall or reduced, branched, septate, smooth. Conidiogenous cells determinate, hyaline, smooth, cylindrical to sub-cylindrical, conidiogenesis holoblastic, bearing a single terminal conidium. Conidia unicellular, ellipsoidal, thin-walled, solitary, aseptate or septate, with or without apical and basal appendages, smooth, with or without an irregular mucilaginous sheath (adapted from Hyde 1993, Zhang et al. 2012b, Abdel-Aziz 2016a).

Type - Lindgomyces K. Hiray., Kaz. Tanaka \& Shearer.

Notes - Lindgomycetaceae species have been collected isolated from aquatic and terrestrial environments including ponds, rivers, lakes, and irrigation canals (Hirayama et al. 2010, AbdelAziz \& Abdel-Wahab 2010, Raja et al. 2011, Tsang et al. 2014, Hyde et al. 2016), except for Hongkongmyces which occurred on a human foot with suppurative granulomatous (Tsang et al. 2014). Shearer et al. (2009) provided molecular data and analyses of nine taxa in Lindgomycetaceae, and placed Massarina ingoldiana, Massariosphaeria typhicola, and Lophiostoma breviappendiculatum in Lindgomycetaceae. Similar studies resolved this (Abdel-Aziz 2016a, Raja et al. 2017). Neomassariosphaeria was earlier transferred to Lindgomycetaceae to accommodate Massariosphaeria typhicola (Ariyawansa et al. 2015a). However, this was not accepted by Dong et al. (2020) who retained Neomassariosphaeria in Amniculicolaceae and introduced a new genus Aquimassariosphaeria in Lindgomycetaceae. The relationships in this family have not been well-resolved. Additional morphological and molecular data are needed for this group.

Lindgomyces K. Hiray., Kaz. Tanaka \& Shearer, Mycologia 102(3): 733 (2010).

Index Fungorum number: IF 515188; Facesoffungi number: FoF 08268; 13 morphological species (Species Fungorum 2020), 13 species with molecular data.

Type species - Lindgomyces ingoldianus (Shearer \& K.D. Hyde) K. Hiray., Kaz. Tanaka \& Shearer, in Hirayama et al., Mycologia 102(3): 733 (2010).

三Massarina ingoldiana Shearer \& K.D. Hyde, Mycologia 89(1): 114 (1997).

Notes - Thirteen taxa are accepted in Lindgomyces, which were collected in France, North Carolina and Wisconsin of the USA, and Honshu of Japan (Raja et al. 2011, Raja et al. 2013, 2017). Most species of Lindgomyces were collected from submerged wood in freshwater (Li et al. 2016a), but can also occur on herbaceous material (Shearer \& Hyde 1997).

\section{Other genera included}

Aquimassariosphaeria W. Dong \& Doilom, Fungal Divers (2020).

Index Fungorum number: IF 557825; Facesoffungi number: FoF 08733; 2 morphological species (Species Fungorum 2020), 2 species with molecular data.

Type species - Aquimassariosphaeria kunmingensis W. Dong, Doilom \& K.D. Hyde, Fungal Divers (2020).

$\equiv$ Leptosphaeria typhicola P. Karst., Bidr. Känn. Finl. Nat. Folk 23: 100 (1873).

= Massariosphaeria typhicola (P. Karst.) Leuchtm., Sydowia 37: 168 (1984).

Notes - Aquimassariosphaeria was introduced by Dong et al. (2020) for Massariosphaeria typhicola and a new species A. kunmingensisto to distinguish it from Neomassariosphaeria in Amniculicolaceae. Aquimassariosphaeria species were isolated from freshwater habitats (Dong et al. 2020) and terrestrial habitats (Leuchtmann 1984). Aquimassariosphaeria differs from other genera in Lindgomycetaceae in having ascomata without a clypeus, and narrowly fusiform or vermiform, brown to dark brown, $>3$ transversely septate ascospores, without longitudinal or oblique septa.

Arundellina Wanas., E.B.G. Jones \& K.D. Hyde, Fungal Divers., 80: 59 (2016).

Index Fungorum number: IF 552132; Facesoffungi number: FoF 02208; 1 morphological species (Species Fungorum 2020), 1 species with molecular data.

Type species - Arundellina typhae Wanas., E.B.G. Jones \& K.D. Hyde, in Hyde et al., Fungal Divers 80: 61 (2016). 
Notes - The type species of Arundellina occurred on a dead stem and leaves of Typhaceae in the Arun River, UK. The genus is characterized by immersed, scattered, globose ascomata, with papillate ostioles, a thin peridium comprised of cells of textura angularis, cylindrical to cylindricclavate asci, and golden-pale brown ascospores with 3-4 transverse septa with cone-shaped pointed ends. The asexual morph has not been reported (Hyde et al. 2016).

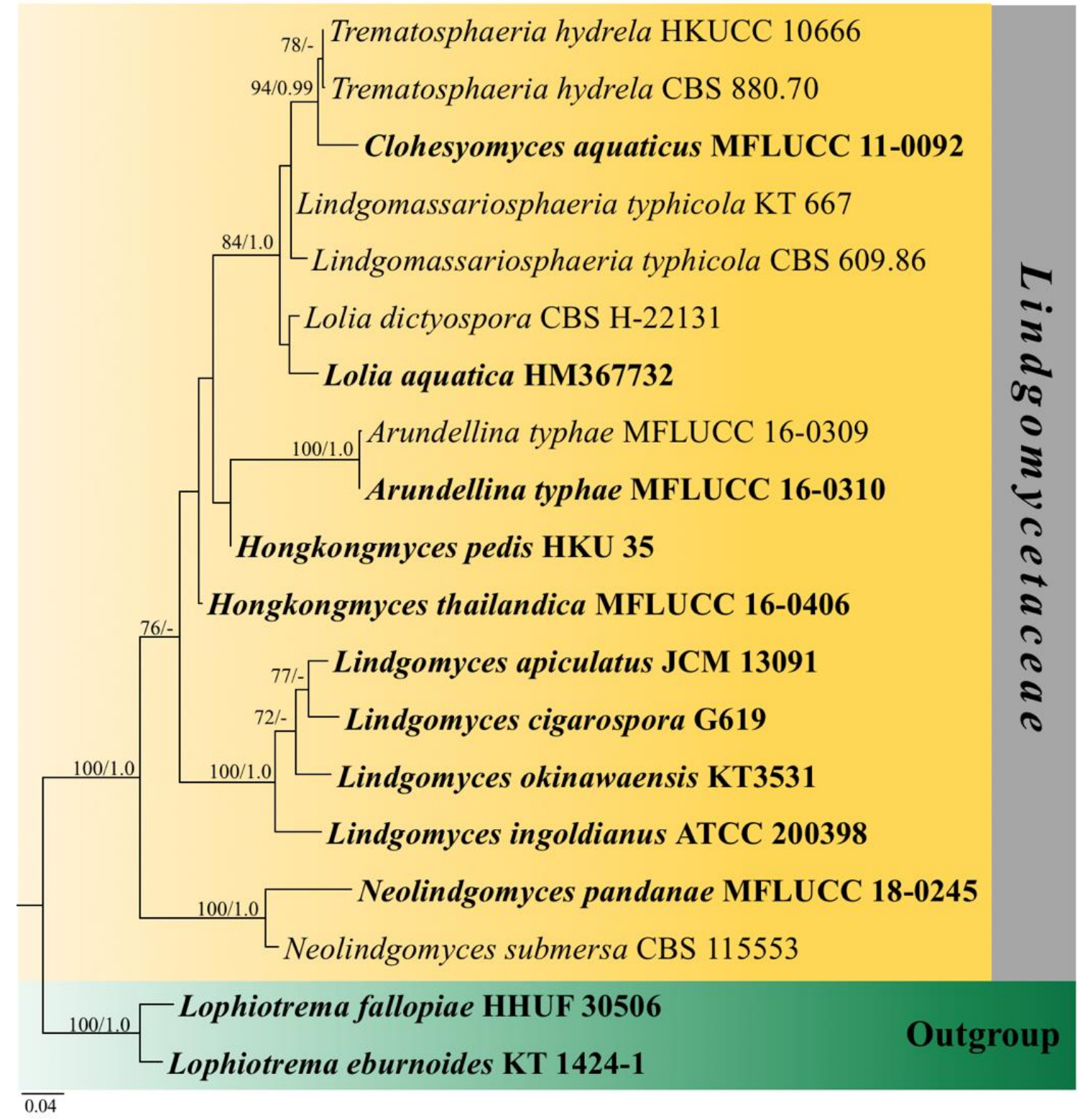

Figure 97 - Phylogram generated from maximum likelihood analysis (RAxML) of genera in Lindgomycetaceae based on ITS, LSU, and SSU sequence data. Maximum likelihood bootstrap values equal or above $70 \%$, Bayesian posterior probabilities equal or above 0.90 (MLBS/PP) are given at the nodes. An original isolate number is noted after the species name. The tree is rooted to Lophiotrema eburnoides (KT 1424-1) and L. fallopiae (HHUF 30506). The ex-type strains are indicated in bold. Hyphen (-) represents support values below 70 \% MLBS and 0.95 PP.

Clohesyomyces K.D. Hyde, Aust. Syst. Bot. 6(2): 170 (1993).

Index Fungorum number: IF 11448; Facesoffungi number: FoF 07164; 1 morphological species (Species Fungorum 2020), 1 species with molecular data.

Type species - Clohesyomyces aquaticus K.D. Hyde, Aust. Syst. Bot. 6(2): 170 (1993).

Notes - Clohesyomyces aquaticus was collected from submerged wood in a freshwater stream in Australia. It was also reported in China (Cai et al. 2006b) and Thailand (Vijaykrishna et al. 
2006). The genus is characterized by subglobose to ellipsoidal, immersed, think-walled conidiomata, conidiophores reduced to discrete, cylindrical, hyaline conidiogenous cells, and holoblastic, unicellular, becoming 1-euseptate, hyaline, guttulate conidia, not constricted at the septum, with a mucilaginous sheath (Hyde 1993). Zhang et al. (2012b) re-collected C. aquaticus and gave a detailed description and provided molecular data and placed Clohesyomyces into Lindgomycetaceae based on combined LSU and SSU sequence analysis. The sexual morph of Clohesyomyces is undetermined (Zhang et al. 2012b).

Clohesyomyces aquaticus K.D. Hyde, Aust. Syst. Bot. 6(2): 170 (1993).

Fig. 98

Index Fungorum number: IF 361053; Facesoffungi number: FoF 07165.

Description - see Zhang et al. (2012b).

Material examined - Thailand, Chiang Mai, Doi Inthanon, on submerged wood, 16 November 2010, Huang Zhang d66 (MFLU 111112); THAILAND, Chiang Mai, Doi Inthanon, on submerged wood, 16 November 2010, Huang Zhang, d66 (MFLU 111114), living culture MFLUCC11-0092 = IFRDCC 2360.

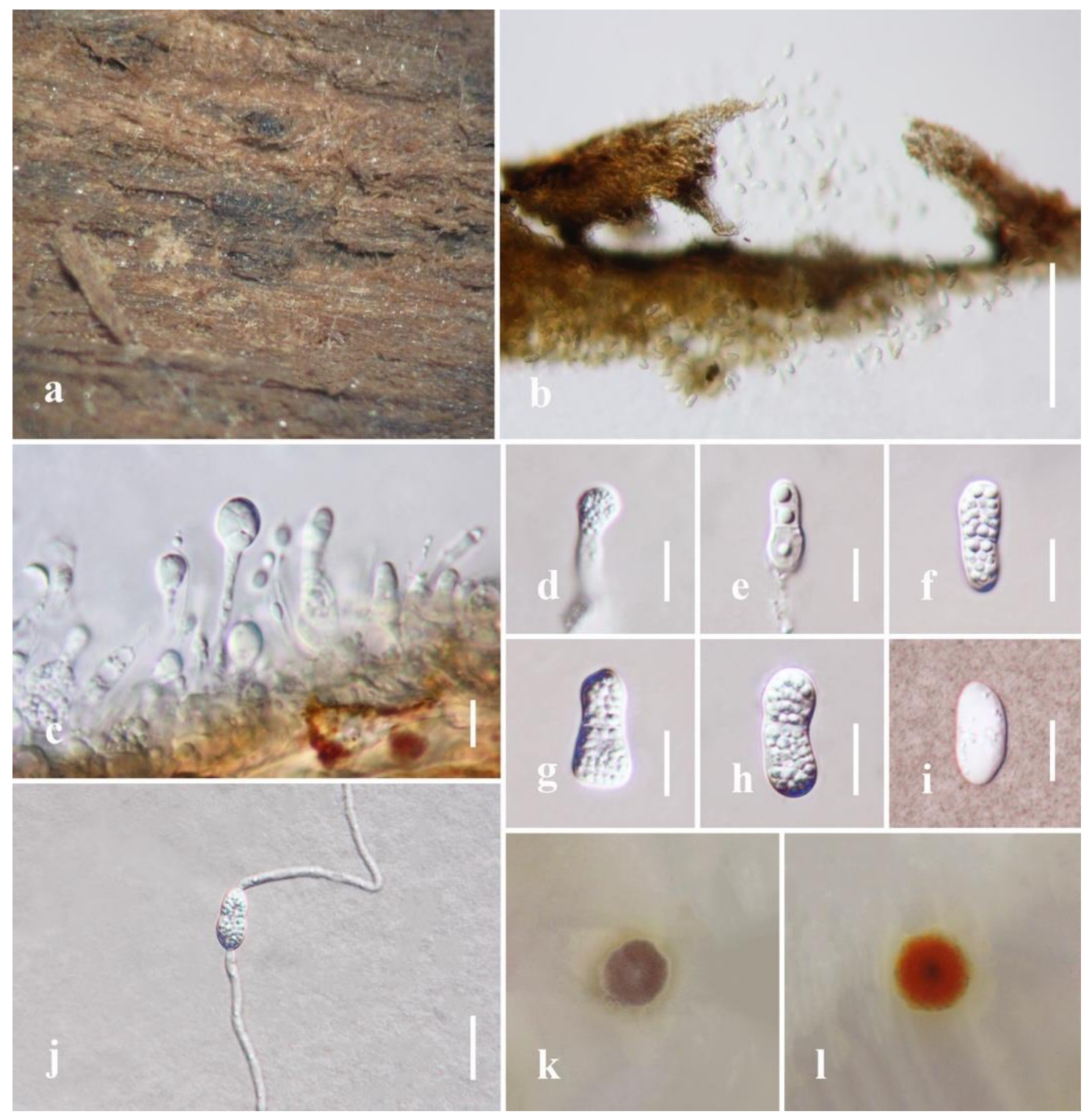

Figure 98 - Clohesyomyces aquaticus (MFLU 11-1112), a Pycnidium on wood surface. b Cross section of the Pycnidium. c Peridium with conidiogenous cells. d, e Immature conidia with conidiogenous cells. $\mathrm{f}-\mathrm{h}$ Mature conidia with septa. i Conidia stained with Indian ink showing 
mucilaginous sheath. $\mathrm{j}$ Germinating conidium. $\mathrm{k}$ Colony on PDA (from front). 1. Colony on PDA (from reverse). Scale bars: $b=100 \mu \mathrm{m}, \mathrm{c}, \mathrm{j}=20 \mu \mathrm{m}, \mathrm{d}-\mathrm{i}=10 \mu \mathrm{m}$.

Hongkongmyces C.C.C. Tsang, J.F.W. Chan, Trend.-Sm., A.H.Y. Ngan, I.W.H. Ling, S.K.P. Lau \& P.C.Y. Woo, Medical Mycol. 52(7): 740 (2014).

Index Fungorum number: IF 805515; Facesoffungi number: FoF 08269; 3 morphological species (Species Fungorum 2020), 3 species with molecular data.

Type species - Hongkongmyces pedis Tsang, Chan, Trendell-Smith, Ngan, Ling, Lau, Woo, Medical Mycol. 52(7): 740 (2014).

Notes - Hongkongmyces was reported as a pathogen of a foot nodule biopsy of a human with suppurative granulomatous in Hong Kong. Species have been collected from various countries, including Hong Kong, China (Hongkongmyces pedis, Tsang et al. 2014), Sukhothai, Thailand (Hongkongmyces thailandicus, Hyde et al. 2017) and Pennsylvania, USA (Hongkongmyces snookiorum, Crous et al. 2018c). The type species is characterized by forming grey colonies on media, composed of grey, narrow, septate, branched hyphae with acute angles, sterile mycelia with no fruiting bodies or sporulating structures (Tsang et al. 2014). Hongkongmyces snookiorum is coelomycetous with globose to ampulliform pycnidia, hyaline, subulate to ampulliform conidiogenous cells with sympodial proliferations, hyaline, ellipsoid to ovoid conidia, while $H$. thailandicus is ascomycetous with globose, short-papillate ascomata, cylindrical to clavate asci, and hyaline, fusiform to cylindrical ascospores with a mucilaginous sheath (Hyde et al. 2017, Crous et al. 2018c). Hyde et al. (2017) showed that $H$. thailandicus (collected from decaying wood) clustered with $H$. pedis (with moderate support), while they are not group together in our study (Fig. 97). This implies more work need to be done in this genus.

Lolia Abdel-Aziz \& Abdel-Wahab, Mycotaxon 114: 36 (2011) [2010].

Index Fungorum number: IF 518528; Facesoffungi number: FoF 08270; 2 morphological species, 2 species with molecular data (Lolia aquatica Abdel-Aziz \& Abdel-Wahab and Lolia dictyospora Abdel-Aziz).

Type species - Lolia aquatica Abdel-Aziz \& Abdel-Wahab, Mycotaxon 114: 36 (2011).

Notes - The asexual morph of the type species was illustrated from a decayed stem of Phragmites australis in irrigation canals of the River Nile (Abdel-Aziz \& Abdel-Wahab, 2010). Subsequently the sexual morph of Lolia aquatica and a new species, L. dictyospora, were described from decayed submerged wood in the River Nile (Abdel-Aziz 2016a). Lolia has acervular conidiomata, clavate, ellipsoidal, cylindrical conidia and apical, sub-apical and basal appendages (Dong et al. 2020). Its sexual morph characters are typical of Lindgomassariosphaeria, but differs based on its fusiform to clavate, transversely septate ascospores, occasionally with one longitudinal or oblique septa.

Neolindgomyces Jayasiri, E.B.G. Jones \& K.D. Hyde, Mycosphere 10(1): 79 (2019).

Index Fungorum number: IF 555555; Facesoffungi number: FoF 05260; 2 morphological species (Species Fungorum 2020), 2 species with molecular data.

Type species - Neolindgomyces pandani Jayasiri, E.B.G. Jones \& K.D. Hyde [as 'pandanae'], in Jayasiri et al., Mycosphere 10(1): 79 (2019).

Notes - Neolindgomyces was erected by Jayasiri et al. (2019) based on phylogenetic analysis. The genus is characterised by subglobose to globose, ostiolate ascomata, filamentous, branched, anastomosing pseudoparaphyses, cylindrical to clavate asci, with an ocular chamber, and multiseptate, hyaline ascospores with a gelatinous sheath.

\section{Ecological and economic significance}

Members of Lindgomycetaceae are generally collected from submerged wood of freshwater and decayed stems in terrestrial habitats in temperate, subtropical and tropical regions (Hirayama et al. 2010, Abdel-Aziz \& Abdel-Wahab 2010, Raja et al. 2011, Tsang et al. 2014, Raja et al. 2017). Hongkongmyces pedis is reported as a pathogen associated with immunoglobulin G4-related 
sclerosing disease (Tsang et al. 2014). An unusual antibiotic polyketide (lindgomycin), extracted from mycelia and culture broth of different Lindgomycetaceae strains, showed antibiotic activities against human and plant pathogenic microorganisms (Wu et al. 2015).

Lizoniaceae Boonmee \& K.D. Hyde, Mycosphere 8(10): 1721 (2017).

Index Fungorum number: IF 553831; Facesoffungi number: FoF 03678, 16 species.

Parasitic, foliicolous on perichaetial leaves of living mosses. Superficial mycelium absents. Sexual morph: Ascomata superficial, solitary or grouped, globose to subglobose, lack, with obscure ostiole. Peridium 3-4 layers of brown cells of textura angularis. Hamathecium comprising numerous, cylindrical, unbranched, septate, cellular pseudoparaphyses. Asci 8-spored, bitunicate, cylindric-clavate, sessile or with short pedicel, rounded at apex. Ascospores 1-2-seriate, ellipsoidal to fusiform, brown, 1-septate, upper cell broader than lower cell. Asexual morph: Undetermined.

Type - Lizonia (Ces. \& De Not.) De Not.

Notes - Phylogenetic placement of Lizonia within Pleosporales and sister to Didymellaceae was presented in Stenroos et al. (2010). However, they did not include enough sequence data of Didymellaceae in their analysis. Our analyses, with more representative species of Didymellaceae, indicate that LSU sequence data of Lizonia sexangularis (strains M179 and M222) belong to Didymellaceae (data not shown). While, rpb-2 could not be aligned well with other species and ITS from both strains are too short (163 bp), thus we did not include ITS and rpb-2 in our analyses. Sequence data of the type species of Lizonia is needed to clarify the true phylogenetic placement of Lizonia. Lizoniaceae shares common characters with genera in Pleosporales, however, it can be recognized as a distinct family based on its bryophilous characteristics. Therefore, we retain this family in Pleosporales based mainly on morphology (Stenroos et al. 2010, Döbbeler \& Hertel 2013, Boonmee et al. 2017).

Lizonia (Ces. \& De Not.) De Not., Hedwigia 4: 23 (1863) [1865].

$\equiv$ Cucurbitaria subgen. Lizonia Ces. \& De Not., Comm. Soc. crittog. Ital. 1(fasc. 4): 215 (1863).

Index Fungorum number: IF 2902; Facesoffungi number: FoF 08271; 16 morphological species (Species Fungorum 2020), 1 species with molecular data.

Type species - Lizonia empirigonia (Ces. \& De Not.) De Not.

Notes - De Notaris (Cesati \& De Notaris 1863) raised the subgenus Cucurbitaria typified by Cucurbitaria empirigonia to generic level with Lizonia empirigonia as the type species. Lizonia was placed in different families by various authors based on its morphology (Cesati \& De Notaris 1863, Hansford 1946, von Arx \& Müller 1975, Döbbeler 1978, Barr 1987a, Eriksson \& Hawksworth 1993). Phylogenetic analyses in Stenroos et al. (2010) showed that L. sexangularis clustered with Didymella within Pleosporales with good support. Lizonia shares common characters with several genera in Pleosporales such as parasitic, superficial, globose to subglobose, black ascomata, lacking setae, bitunicate asci, pseudoparaphyses and septate, hyaline to coloured ascospores, but it differs in its bryophilous habit. Boonmee et al. (2017) placed it in the new family Lizoniaceae.

Lizonia empirigonia (Ces. \& De Not.) De Not. [as emperigonia], Sfer. Ital.: 72 (1863). $\quad$ Fig. 99 $\equiv$ Cucurbitaria emperigonia Ces. \& De Not., Comm. Soc. crittog. Ital. 1(fasc. 3): 215 (1862) Index Fungorum number: IF 145497; Facesoffungi number: FoF 03679.

Description - see Boonmee et al. (2017).

Material examined - Germany, Rheinland -Pfalz: near Mappen Nassoviae, Autumn, Fuckel, in Rabenhorst, Fungi europaei, in the syllvaticis swamps between the valley, in Fuckel, Fungi rhenani, Nr. 891, sub Sphaeria emperigonia, on perichaetial leaves of flowers of Polytrichum commune (B 70 0014162).

\section{Ecological and economic significance}


This family comprises parasitic species found on living leave of mosses. However, there is no information about serious diseases caused by this family.

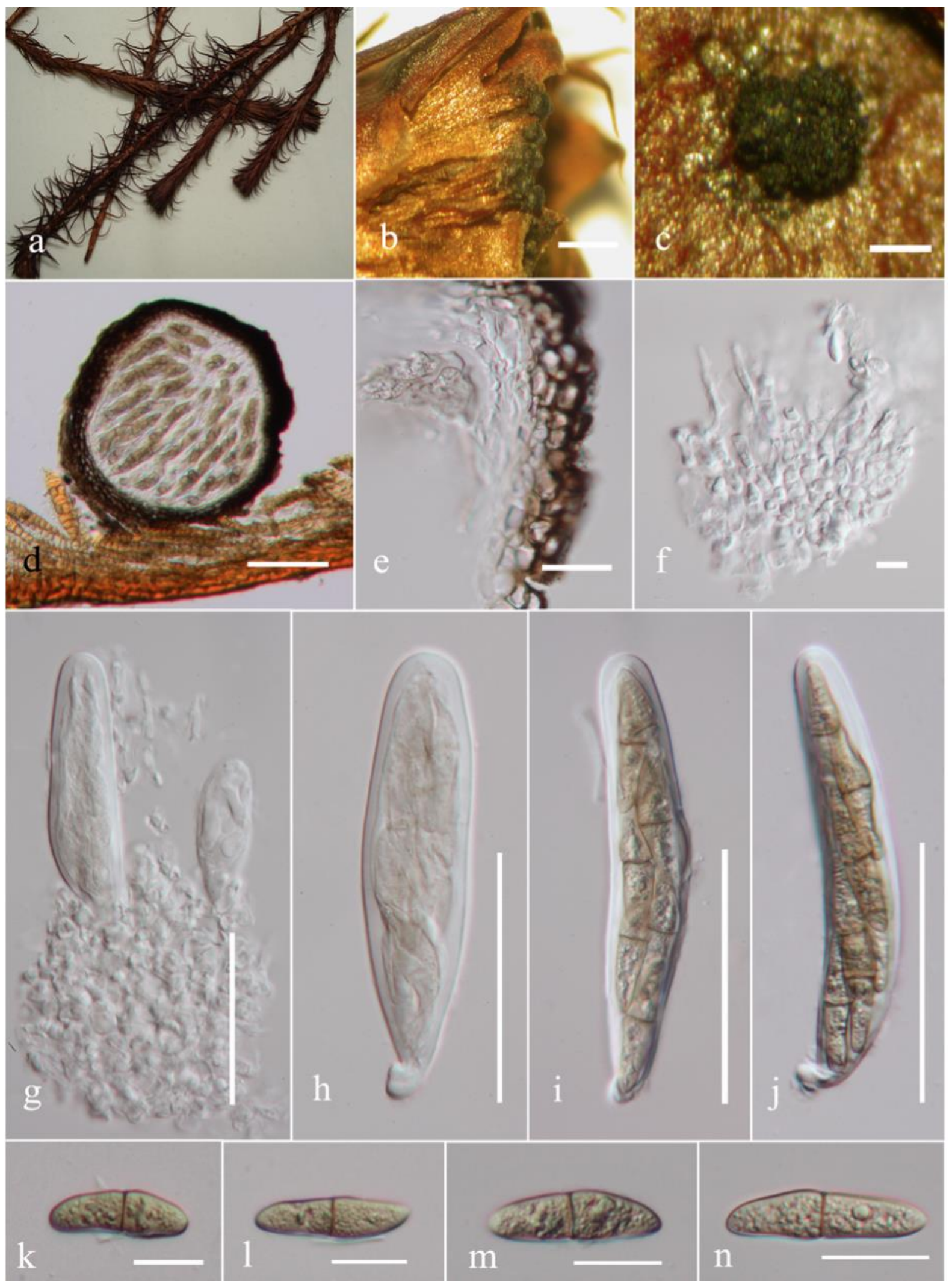

Figure 99 - Lizonia emperigonia (B 70 0014162). a, b Herbarium specimen and habit on leaves. c Appearance of ascomata on leaf surface. d Section of ascoma. e Peridium. $f$ Hamathecium texture. $\mathrm{g}-\mathrm{j}$ immature to mature Asci. $\mathrm{k}-\mathrm{n}$ Ascospores. Scale bars: $\mathrm{b}=500 \mu \mathrm{m}, \mathrm{c}=200 \mu \mathrm{m} \mathrm{d}=100$ $\mu \mathrm{m}, \mathrm{e}=40 \mu \mathrm{m}, \mathrm{f}=10 \mu \mathrm{m}, \mathrm{g}-\mathrm{j}=50 \mu \mathrm{m}, \mathrm{k}-\mathrm{n}=20 \mu \mathrm{m}$. 
Longiostiolaceae Phukhams., Doilom \& K.D. Hyde, in Phukhams. et al., Fungal Diversity 102: 43 (2020).

Index Fungorum number: IF 557086; Facesoffungi number: FoF 07215, 6 species.

Saprobic on dried wood substrate. Sexual morph: Ascomata immersed to semi-immersed, uniloculate, globose to subglobose, Ostiole long, central locate. Peridium thick, comprising several layers with scleroplectenchymatous or pseudoparenchymatous cell types, black to dark brown cells. Hamathecium comprising numerous, cellular pseudoparaphyses. Asci 4-8-spored, bitunicate, fissitunicate, cylindrical to clavate. Ascospores mostly overlapping 1-seriate or 2-3-seriate, broad fusiform, hyaline, brownish at the senescent state, multi-septate. Asexual morph: Pycnidia conidiomata or hyphomycetous-like structures produced in the cultures condition. (Li et al. 2016a, Matsumura et al. 2018).

Type - Longiostiolum Doilom, Ariyaw. \& K.D. Hyde.

Notes - Crassiperidium and Longiostiolum were introduced by Matsumura et al. (2018) and Li et al. (2016a), respectively. The genera were treated as Pleosporales genera incertae sedis. Phukhamsakda et al. (2020), indicated that Crassiperidium clustered with Longiostiolum based on multi-gene phylogenetic analysis. Therefore, they introduce Longiostiolaceae to accommodate the distinct lineage in Pleosporales. Later, Wanasinghe et al. (2020b) designated a neotype for Shearia formosa and based on DNA sequence data, confirmed the family placement of Shearia as Longiostiolaceae. Currently, three genera are accepted in this family which are Crassiperidium, Longiostiolum and Shearia.

Type species - Longiostiolum tectonae Doilom, Bhat \& K.D. Hyde, in Li et al., Fungal Diversity 78: 55 (2016).

Notes - Longiostiolum is found associated with a collection of dried bark of teak from northern Thailand. The genus has remarkable characters of having long ostioles with multi-septate hyaline ascospores. The genus clearly differs from the other genera in suborder Massarineae in having fusiform, multi-septate, hyaline ascospores (morphology see Li et al. 2016a, Wijayawardene et al. 2018, outline).

Longiostiolum Doilom, Ariyaw. \& K.D. Hyde, in Li et al., Fungal Diversity 78: 59 (2016).

Index Fungorum number: IF 551899; Facesoffungi number: FoF 01881; 1 morphological species (Species Fungorum 2020), 1 species with molecular data.

Longiostiolum tectonae Doilom, Bhat \& K.D. Hyde, in Li et al., Fungal Divers 78: 55 (2016).

Index Fungorum number: IF 551900; Facesoffungi number: FoF 01882.

Fig. 100

Description - see Li et al. (2016a).

Material examined - Thailand, Chiang Mai Province, Mae Tang District, on dead bark of Tectona grandis (Lamiaceae), 22 May 2012, M. Doilom (MFLU 15-3532, holotype).

\section{Other genus included}

Crassiperidium Matsum. \& Kaz. Tanaka, in Matsumura et al., Mycosphere 9(6): 1259 (2018).

Index Fungorum number: IF 555726; Facesoffungi number: FoF 05595; 2 morphological species (Species Fungorum 2020), 2 species with molecular data.

Type species - Crassiperidium octosporum M. Matsum. \& Kaz. Tanaka, in Matsumura et al., Mycosphere 9(6): 1259 (2018).

Notes - Crassiperidium was introduced by Matsumura et al. (2018) to accommodate a parasitic fungus found on Fagus crenata in Japan. The genus is similar to Asteromassaria (Pleomassariaceae) and Pseudoasteromassaria (Latoruaceae) but differs from those by its asexual morph characters (Matsumura et al. 2018). The asexual morph of Crassiperidium having pycnidial conidiomata with cylindrical, muti-septate, hyaline conidia.

Shearia Petr., Annales Mycologici 22 (1-2): 180 (1924). 
Index Fungorum number: IF 9914; 3 morphological species (Species Fungorum 2020), 1 species with molecular data.

Type species - Shearia formosa (Ellis \& Everh.) Petr., Sydowia 15 (1-6): 216 (1962).
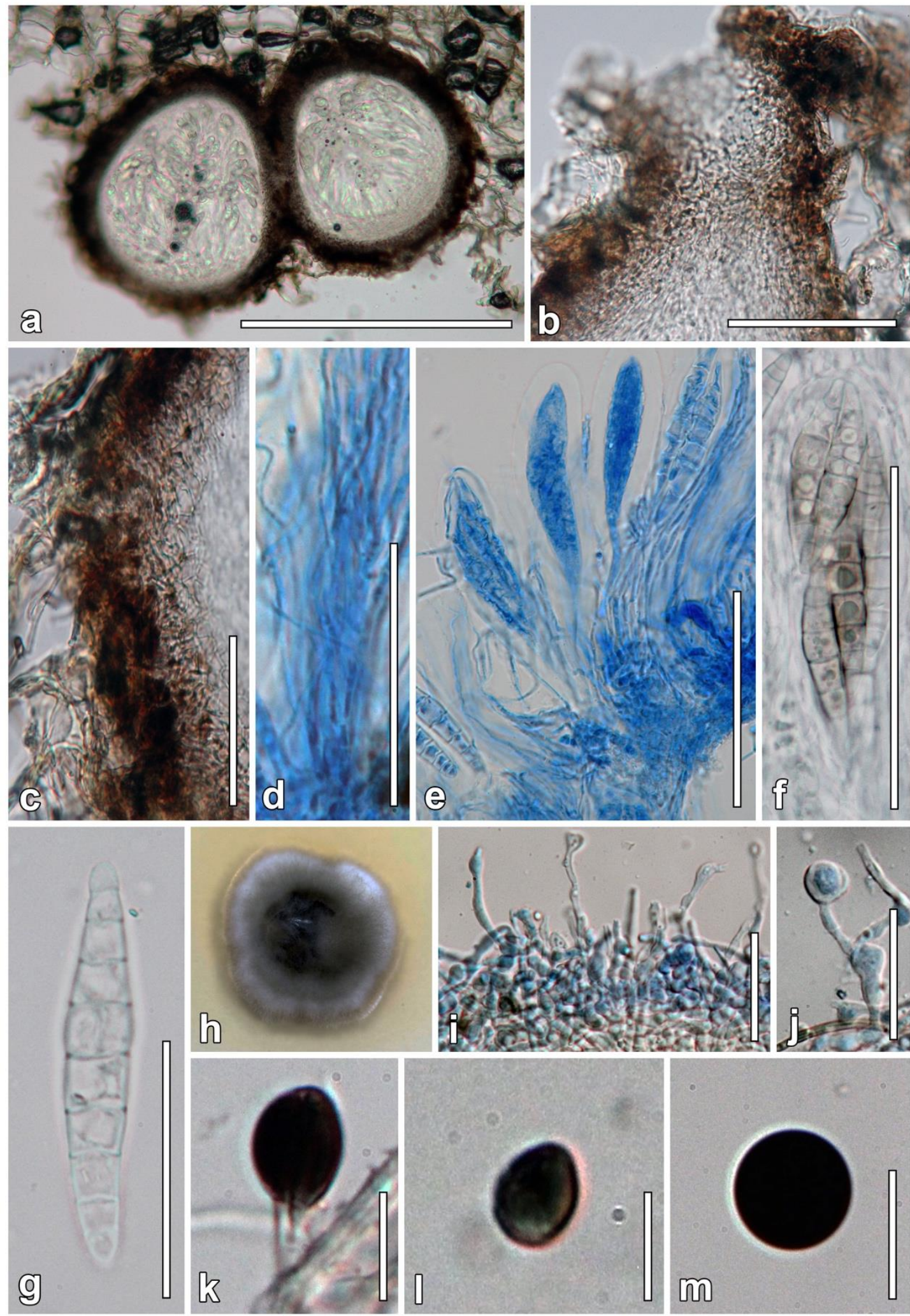

Figure 100 - Longiostiolum tectonae (MFLU 15-3532, holotype). a Ascomata. b Ostiole canal. c Peridium. d Psedoparaphyses. e, f Asci. g Ascospore. h Culture characters on MEA. i-k Conidiogenous cells. $1, \mathrm{~m}$ Conidia. Scale bars: $\mathrm{a}=500 \mu \mathrm{m}, \mathrm{b}, \mathrm{e}, \mathrm{f}=100 \mu \mathrm{m}, \mathrm{c}, \mathrm{d}, \mathrm{g}=50 \mu \mathrm{m}$, $\mathrm{i}, \mathrm{j}=10 \mu \mathrm{m}, \mathrm{k}-\mathrm{m}=5 \mu \mathrm{m}$. 
Notes - Shearia is morphologically highly conspicuous and easy to distinguish from other known dematiaceous coelomycetes (Wanasinghe et al. 2020b). Several studies have discussed the morphology of this genus (Sutton 1980, Wijayawardene et al. 2016a), but the exact family placement was uncertain. In a recent study, Wanasinghe et al. (2020b) designated a neo-type for Shearia formosa based on multi-gene phylogenetic analysis. See Wanasinghe et al. (2020b) for more details.

\section{Ecological and economic significance}

Species of Longiostiolaceae occur on bark of economical dicotyledonous plants such as Fagus crenata and Tectona grandis. These hosts were used in wood-made products such as furniture, musical instruments (Mukaram et al. 2002, Miranda et al. 2011). Crassiperidium species are reported as parasitic species of Fagus sp. in Japan, while Longiostiolum is found associated with Tectona grandis collection from northern part of Thailand (Li et al. 2016a, Matsumura et al. 2018).

Longipedicellataceae Phukhams., J. Bhat \& K.D. Hyde, Mycosphere 7(11): 1722 (2016).

Index Fungorum number: IF 552532; Facesoffungi number: FoF 01408, 3 species.

Saprobic on dead and submerged wood in aquatic habitats. Sexual morph: Ascomata semiimmersed to erumpent, coriaceous, solitary, scattered, sometimes immersed under a pseudoclypeus, subglobose to ellipsoidal, black to brown, ostiolate. Peridium multi-layered, of black to brown cells of textura angularis, sometimes textura prismatica, somewhat carbonaceous, thin, easy to break. Hamathecium comprising few, long, broad, septate, branched, cellular pseudoparaphyses, surrounding asci and along the inner layer of the peridium. Asci 8-spored, bitunicate, fissitunicate, clavate, long-pedicellate, bulbous, thin-walled, with an apical ocular chamber. Ascospores 2seriate, overlapping, ellipsoidal, narrowly subfusiform, conical at apex, hyaline, 1-septate, constricted at septum, guttulate, smooth-walled. Asexual morph: Hyphomycetous. Colonies black to dark-brown, circular, effuse. Mycelium composed of smooth, hyaline to dark brown, septate, branched, hyphae, swollen in ovoid cells (Phukhamsakda et al. 2016). Pseudoxylomyces elegans has holoblastic conidiogenesis, broadly fusiform, 4-7-septate, brown with paler end cell conidia (Tanaka et al. 2015).

Type - Longipedicellata Zhang, K.D. Hyde \& J.K. Liu.

Notes - Phukhamsakda et al. (2016) introduced Longipedicellataceae and included two genera, Longipedicellata and Pseudoxylomyces. Members of Longipedicellataceae were reported as saprobes on woody substrates in aquatic habitats (Phukhamsakda et al. 2016). Longipedicellataceae is characterized by semi-immersed or erumpent, clypeate ascomata on the host tissues, with black to brown ostioles, clavate asci with long pedicels, and 2-celled, hyaline ascospores. Chlamydospore formation is also a significant character of this family (Phukhamsakda et al. 2016).

Longipedicellata H. Zhang, K.D. Hyde \& J.K. Liu, Phytotaxa 247 (2): 104 (2016).

Index Fungorum number: IF 551685; Facesoffungi number: FoF 02665; 1 morphological species (Species Fungorum 2020), 1 species with molecular data.

Type species - Longipedicellata aptrootii (K.D. Hyde \& S.W. Wong) H. Zhang, K.D. Hyde \& J.K. Liu, Phytotaxa 247 (2): 104 (2016).

三Didymella aptrootii K.D. Hyde \& S.W. Wong, Australas. Mycol. 18(3): 54 (1999).

Notes - Longipedicellata aptrootii (三Didymella aptrootii) was collected from a freshwater stream in Thailand (Hyde \& Wong 1999). Zhang et al. (2016b) transferred Didymella aptrootii to Longipedicellata and placed it in Bambusicolaceae according to the phylogeny. However, Phukhamsakda et al. (2016) introduced Longipedicellataceae to accommodate Longipedicellata based on morphology, phylogeny and divergence time estimates.

Longipedicellata aptrootii (K.D. Hyde \& S.W. Wong) H. Zhang, K.D. Hyde \& J.K. Liu, in Zhang et al., Phytotaxa 247(2): 104 (2016).

Fig. 101 
$\equiv$ Didymella aptrootii K.D. Hyde \& S.W. Wong, Australas. Mycol. 18(3): 54 (1999).

Index Fungorum number: IF 551686; Facesoffungi number: FoF 01273.

Description - see Phukhamsakda et al. (2016).

Material examined - Thailand, Chiang Rai Province, on dead and submerged stem of Bambusodeae (Poaceae), 14 June 2015, C. Phukhamsakda, CP015 (MFLU 16-0032, paratype).

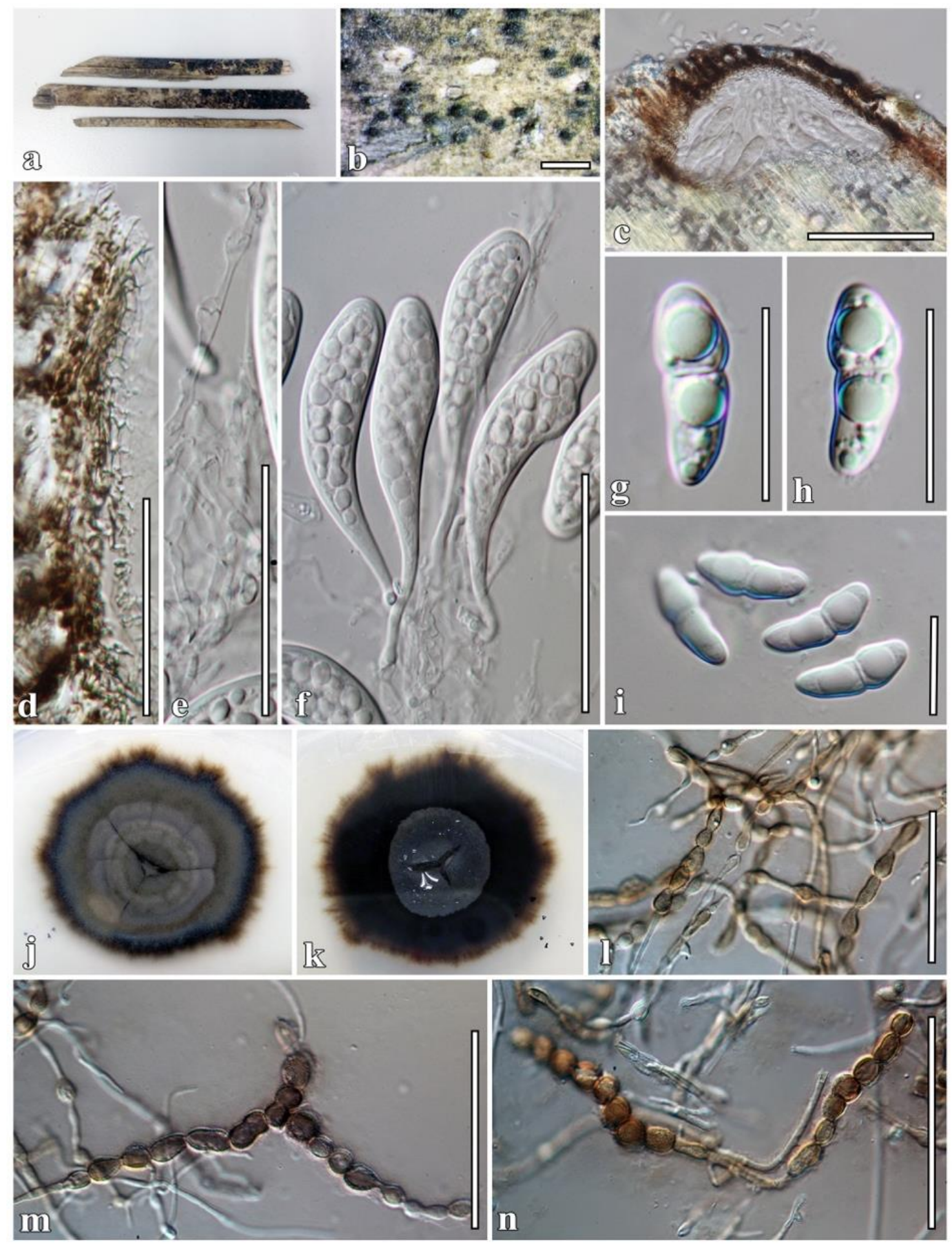

Figure 101 - Longipedicellata aptrootii (MFLU 16-0032, paratype). a Habit on bamboo. $\mathrm{b}$, c Appearance of ascomata on the host surface. c Vertical section of ascoma. d Section of peridium comprising cells of textura prismatica. e Pseudoparaphyses. f Asci with long pedicels. $\mathrm{g}-\mathrm{i}$ Ascospores. j, k Culture characters on PDA. $1-\mathrm{n}$ Chlamydospores. Scale bar: $\mathrm{b}=500 \mu \mathrm{m}, \mathrm{c}=$ $100 \mu \mathrm{m}, \mathrm{d}-\mathrm{f}, 1-\mathrm{n}=50 \mu \mathrm{m}, \mathrm{g}-\mathrm{i}=20 \mu \mathrm{m}$. 


\section{Other genera included}

Pseudoxylomyces Kaz. Tanaka \& K. Hiray., in Tanaka et al., Stud. Mycol. 82: 126 (2015).

Index Fungorum number: IF 811332; Facesoffungi number: FoF 08272; 1 morphological species (Species Fungorum 2020), 1 species with molecular data.

Type species - Pseudoxylomyces elegans (Gohet al.) Kaz. Tanaka \& K. Hiray., Stud Mycol 82: $126(2015)$.

$\equiv$ Xylomyces elegans Goh, W.H. Ho, K.D. Hyde \& C.K.M. Tsui, Mycol. Res. 101(11): 1324 (1997).

Notes - Pseudoxylomyces elegans was found in aquatic habitats on decaying wood (Tanaka et al. 2015, Phukhamsakda et al. 2016). The genus is characterized by dematiaceous mycelia and conidiophores, with thick-walled, terminal or intercalary, septate conidia, which are very similar to the chlamydospore structures in Longipedicellata aptrootii (Phukhamsakda et al. 2016).

Submersispora W. Dong, H. Zhang \& K.D. Hyde, Fungal Divers (2020).

Index Fungorum number: IF 557805; Facesoffungi number: FoF 08719; 1 morphological species (Dong et al. 2020), 1 species with molecular data. (2020).

Type species - Submersispora variabilis W. Dong, H. Zhang \& K.D. Hyde, Fungal Divers

Notes - Submersispora resembles Pseudoxylomyces in having holoblastic conidiogenous cells, but differs by conidial characters (Dong et al. 2020). Phylogenetically, Submersispora nested between Longipedicellata and Pseudoxylomyces with high bootstrap support (Dong et al. 2020).

\section{Ecological and economic significance}

Species of Longipedicellataceae are saprobes and inhabit submerged wood in freshwater in Australia, Brazil, Hong Kong, India, Japan, Seychelles, Thailand and the USA (Tanaka et al. 2015, Phukhamsakda et al. 2016).

Lophiostomataceae Sacc. Syll. fung. (Abellini) 2: 672 (1883).

Index Fungorum number: IF 80966; Facesoffungi number: FoF 00796, 222 species.

Saprobic on twigs, stems or bark of various woody plants and herbaceous plants in terrestrial and aquatic environments. Colonies superficial or semi-immersed, dark-brown to black and carbonaceous. Sexual morph: Ascomata scattered to gregarious, superficial or semi-immersed to densely erumpent, globose to subglobose, dark-brown to black and carbonaceous. Ostiole slit-like, with a small to large, flat, crestlike apex, which is variable in shape and composed of pseudoparenchymatous cells. Peridium thick at the sides, broad at the apex and thinner at the base, one-layered, composed of small, lightly pigmented, thin-walled cells of textura prismatica. Hamathecium comprising septate, long, hyaline, anastomosing and branched, cellular pseudoparaphyses, embedded in gel matrix between and above the asci. Asci 8-spored, bitunicate, fissitunicate, cylindrical to clavate, with furcate pedicel, rounded at the apex with minute ocular chamber. Ascospores 1-seriate or partially 2-seriate, narrowly fusiform with acute ends, hyaline to pale brown, 3-5-septate, slightly constricted at each septum, or muriform, with a distinct oil drop in each cell, smooth-walled, with terminal appendages. Asexual morph: Mycelium septate, smooth to roughened, or verrucose, yellowish-brown, to reddish brown. Pycnidia scattered or semi-immersed, uni-loculate or rarely bi-loculate, subglobose, reddish brown, comprising dark reddish-brown cells. Ostiole circular, surrounded by a thick-walled, well-developed neck, surrounded by flexuous hyphae and an ostiolar canal filled with a tissue of hyaline cells. Conidiophores reduced to conidiogenous cells arising within the acervuli, cylindrical, septate and branched at the base, hyaline. Conidiogenous cells cylindrical, phialidic, formed at the end and on the sides, hyaline, smooth. Conidia subglobose or cylindrical, hyaline, aseptate.

Type - Lophiostoma Ces. \& De Not. 


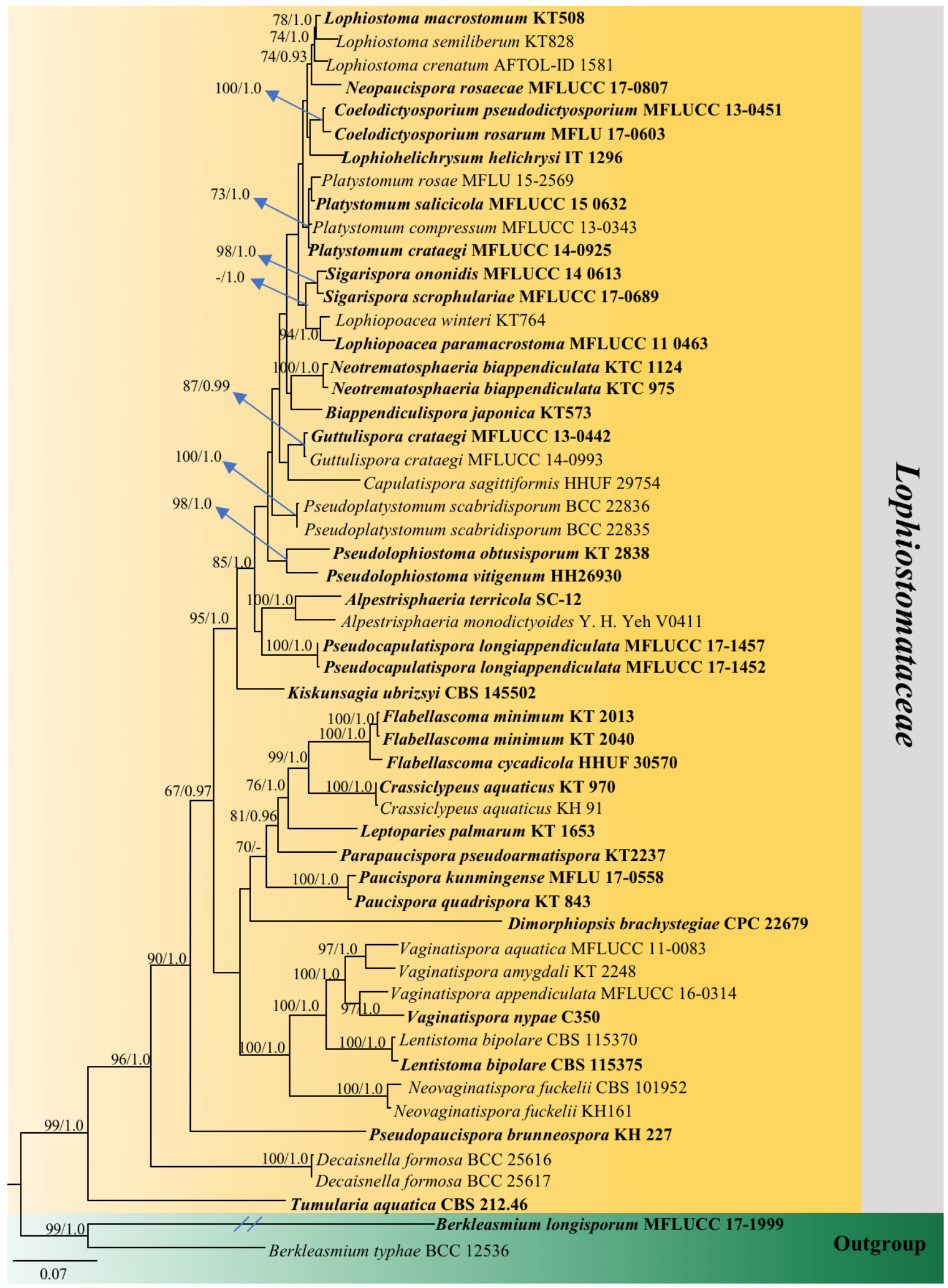

Figure 102 - Phylogram generated from maximum likelihood analysis (RAxML) of genera in Lophiostomataceae based on ITS, LSU, rpb-2, SSU and tef1 sequence data. Maximum likelihood bootstrap values equal or above $70 \%$, Bayesian posterior probabilities equal or above 0.90 (MLBS/PP) are given at the nodes. An original isolate number is noted after the species name. The 
tree is rooted to Berkleasmium longisporum (MFLUCC 17-1999) and B. typhae (BCC 12536). The ex-type strains are indicated in bold. Hyphen (-) represents support values below $70 \%$ MLBS and $0.95 \mathrm{PP}$.

Notes - Lophiostomataceae was introduced by Nitschke (1869) with Lophiostoma, as the type genus. This family has been referred to different orders by various authors (Luttrell 1973, von Arx \& Müller 1975, Barr 1987a, 1992b, Holm \& Holm 1988, Hawksworth et al. 1995, Kirk et al. 2008, Zhang et al. 2012b). Lophiostomataceae are mostly characterized by slot-like ostiole on the top of a flattened neck which mainly occur on twigs, stems or bark (Holm \& Holm 1988, Thambugala et al. 2015b). Thambugala et al. (2015b) accepted 16 genera, while Wijayawardene et al. (2018) accepted 18 genera in Lophiostomataceae. Hashimoto et al. (2018a) introduced seven new genera in Lophiostomataceae. Crous et al. (2019a) and Mapook et al. (2020), also introduced two genera in Lophiostomataceae. We accept 28 genera in this family.

Lophiostoma Ces. \& De Not., Comm. Soc. crittog. Ital. 1(fasc. 4): 219 (1863).

Index Fungorum number: IF 2933; Facesoffungi number: FoF 00403; 110 morphological species (Species Fungorum 2020), 25 species with molecular data.

Type species - Lophiostoma macrostomum (Tode) Ces. \& De Not.

三Sphaeria macrostoma Tode, Fung. mecklenb. sel. (Lüneburg) 2: 12 (1791).

Notes - Lophiostoma is somewhat similar to Lophiotrema and Chesters \& Bell (1970) treated Lophiotrema as a synonym of Lophiostoma. Lophiostoma is distinguished from Lophiotrema by its peridium and asci (Holm \& Holm 1988), while Hirayama \& Tanaka (2011) separated them based on both molecular and morphological studies. Lophiostoma shares similar characteristics with Platystomum. Holm \& Holm (1988) treated Platystomum as a synonym of Lophiostoma but Barr (1990a) and Tanaka \& Harada (2003b) mentioned Lophiostoma and Platystomum as two separate genera.

\section{Other genera included}

Alpestrisphaeria Thambug. \& K.D. Hyde, Fungal Divers.74: 214 (2015).

Index Fungorum number: IF 551232; Facesoffungi number: FoF 00799; 3 morphological species (Species Fungorum 2020), 2 species with molecular data.

Type species - Alpestrisphaeria terricola (G.S. Gong) Thambug. \& K.D. Hyde, Fungal Divers.74: 214 (2015).

三 Trematosphaeria terricola G.S. Gong, Mycol. Progr. 13(1): 38 (2013).

Notes - The type species of this genus was originally described by Zhou et al. (2014). However, Thambugala et al. (2015b) resolved the placement of Trematosphaeria terricola and found that it forms an independent lineage in Lophiostomataceae. Therefore, Thambugala et al. (2015b) introduced a new genus Alpestrisphaeria in Lophiostomataceae to accommodate this species.

Biappendiculispora Thambug., Kaz. Tanaka \& K.D. Hyde, Fungal Divers. 74: 214 (2015).

Index Fungorum number: IF 551528; Facesoffungi number: FoF 01096; 1 morphological species (Species Fungorum 2020), 1 species with molecular data.

Type species - Biappendiculispora japonica Thambug., Wanas., Kaz. Tanaka \& K.D. Hyde, Fungal Divers. 74: 214 (2015).

Notes - Biappendiculispora was introduced by Thambugala et al. (2015b) based on phylogenetic analysis and also based on its unique morphology in having fusiform, pale yellowish to brown ascospores with 7-9-septa and appendages at both ends. The type species of this genus, Biappendiculispora japonica was originally described as Lophiostoma caulium "var. f." by Tanaka \& Harada (2003b).

Capulatispora Thambug. \& K.D. Hyde, Fungal Divers. 74: 216 (2015). 
Index Fungorum number: IF 551234; Facesoffungi number: FoF 00800; 1 morphological species (Species Fungorum 2020), 1 species with molecular data.

Type species - Capulatispora sagittiformis (Kaz. Tanaka \& Hosoya) Thambug. \& K.D. Hyde, Fungal Divers. 74: 216 (2015).

$\equiv$ Lophiostoma sagittiforme Kaz. Tanaka \& Hosoya, Sydowia 60(1): 134 (2008).

Notes - Capulatispora was introduced by Thambugala et al. (2015b) to accommodate Lophiostoma sagittiforme (Tanaka \& Hosoya 2008). The unique morphological characters of this genus differ from other genera in Lophiostomataceae in having small blackened pseudoclypeus and ascospores with drawn-out sheaths that are capped at their tips (Thambugala et al. 2015b).

Coelodictyosporium Thambug. \& K.D. Hyde, Fungal Divers. 74: 218 (2015).

Index Fungorum number: IF 551286; Index Fungorum number: FoF 00802; 3 morphological species (Species Fungorum 2020), 1 species with molecular data.

Type species - Coelodictyosporium pseudodictyosporium (Q. Tian, Camporesi \& K.D. Hyde) Thambug. \& K.D. Hyde, Fungal Divers. 74: 218 (2015).

$\equiv$ Lophiostoma pseudodictyosporium Qing Tian, Camporesi \& K.D. Hyde, in Liu et al., Fungal Divers 72: 114 (2015).

Notes - Coelodictyosporium was formally introduced by Thambugala et al. (2015b) based on its unique morphological characteristics and phylogenetic analysis. The asexual morph of this genus is characterized by brown applanate conidia similar with species of Dictyosporium (Thambugala et al. 2015b).

Crassiclypeus A. Hashim., K. Hiray. \& Kaz. Tanaka, Stud. Mycol. 90: 167 (2018).

Index Fungorum number: IF 823131; Facesoffungi number: FoF 08273; 1 morphological species (Species Fungorum 2020), 1 species with molecular data.

Type species - Crassiclypeus aquaticus A. Hashim., K. Hiray. \& Kaz. Tanaka, in Hashimoto et al., Stud. Mycol. 90: 167 (2018).

Notes - Crassiclypeus aquaticus, the type species of Crassiclypeus was collected from submerged dead twigs of woody plants (Hashimoto et al. 2018a). The sexual morph of this genus is characterized by crest-like, elongated, ostiolar neck; peridium surrounded by brown hyphae and asci with a long stipe; and is similar to species of Flabellascoma, Lentistoma and Neotrematosphaeria (Thambugala et al. 2015b, Hashimoto et al. 2018a). The asexual morph is characterized by globose to subglobose conidiomata; peridium composed of subglobose to rectangular conidia with rounded ends, hyaline and aseptate (Hashimoto et al. 2018a).

Decaisnella Fabre, Annls Sci. Nat., Bot., sér. 6 9: 112 (1879).

Index Fungorum number: IF 1434; Facesoffungi number: FoF 08274; 10 morphological species (Species Fungorum 2020), 1 species with molecular data.

Type species - Decaisnella spectabilis Fabre, Annls Sci. Nat., Bot., sér. 6 9: 112 (1879).

Notes - Decaisnella speciesare terrestrial and marine with a worldwide distribution (Suetrong et al. 2009). This genus is characterized by a slight or well-developed clypeus with asci contain two, four, or eight ascospores (Barr 1986). However, re-collection is needed to verify the generic placement of this genus as placement is uncertain.

Dimorphiopsis Crous, Persoonia 31: 217 (2013).

Index Fungorum number: IF 805832; Facesoffungi number: FoF 01783; 1 morphological species (Species Fungorum 2020), 1 species with molecular data.

Type species - Dimorphiopsis brachystegiae Crous, in Crous et al., Persoonia 31: 217 (2013).

Notes - Dimorphiopsis is characterized by immersed pycnidia to superficial sporodochia, globose to irregular, ellipsoid conidia, golden to dark brown, roughened to warty and flattened basal scar (Crous et al. 2013b).

Flabellascoma A A. Hashim., K. Hiray. \& Kaz. Tanaka, Stud. Mycol. 90: 167 (2018). 
Index Fungorum number: IF 823133; Facesoffungi number: FoF 08275; 4 morphological species (Species Fungorum 2020), 4 species with molecular data.

Type species - Flabellascoma minimum A. Hashim., K. Hiray. \& Kaz. Tanaka, in Hashimoto et al., Stud. Mycol. 90: 169 (2018).

Notes - Flabellascoma is characterized by crest-like ostiolar necks, peridium of uniform thickness and asci with a short stipe similar to Pseudolophiostoma (Hashimoto et al. 2018a). The asexual morph is characterized by globose to subglobose conidiomata; subglobose to rectangular peridium with subglobose conidia, hyaline and aseptate (Hashimoto et al. 2018a).

Guttulispora Thambug., Qing Tian \& K.D. Hyde, Fungal Divers.74: 220 (2015).

Index Fungorum number: IF 551238; Facesoffungi number: FoF 00804; 1 morphological species (Species Fungorum 2020), 1 species with molecular data.

Type species - Guttulispora crataegi Qing Tian, Thambug., Camporesi \& K.D. Hyde in Thambugala et al., Fungal Divers. 74: 220 (2015).

Notes - Guttulispora is characterized by coriaceous, conical ascomata surrounded by a small blackened pseudoclypeus, a 4-8 layered, light brown peridium and hyaline ascospores, constricted at each septum, surrounded by a narrow mucilaginous sheath (Thambugala et al. 2015b).

Kiskunsagia D.G. Knapp, Imrefi \& Kovács, Persoonia 42: 375 (2019).

Index Fungorum number: IF 830107; Facesoffungi number: FoF 08276; 1 morphological species (Species Fungorum 2020), 1 species with molecular data.

Type species - Kiskunsagia ubrizsyi D.G. Knapp, Imrefi \& Kovács, in Crous et al., Persoonia 42: 375 (2019).

Notes - Kiskunsagia comprises a root endophyte, isolated from surface-sterilised roots of semiarid grasslands so only mycelium character is presented and it did not sporulate in culture (Crous et al. 2019a).

Lentistoma A. Hashim., K. Hiray. \& Kaz. Tanaka, Stud. Mycol. 90: 167 (2018).

Index Fungorum number: IF 823136; Facesoffungi number: FoF 08277; 1 morphological species (Hashimoto et al. 2018), 1 species with molecular data.

Type species - Lentistoma bipolare (K.D. Hyde) A. Hashim., K. Hiray. \& Kaz. Tanaka, in Hashimoto et al., Stud. Mycol. 90: 169 (2018).

$\equiv$ Massarina bipolaris K.D. Hyde, Nova Hedwigia 61(1-2): 131 (1995)

Notes - Lentistoma is well-characterized and differentiated from Lophiostoma by its clypeus around the ostiolar neck and peridium (Hashimoto et al. 2018a).

Leptoparies A A. Hashim., K. Hiray. \& Kaz. Tanaka, Stud. Mycol. 90: 167 (2018).

Index Fungorum number: IF 823138; Facesoffungi number: FoF 08278; 1 morphological species (Species Fungorum 2020), 1 species with molecular data.

Type species - Leptoparies palmarum A. Hashim., K. Hiray. \& Kaz. Tanaka, Stud. Mycol. 90: 171 (2018).

Notes - Leptoparies is easily distinguished from other genera in having thin peridium (rectangular cells) and absence of the surrounding brown hyphae (Hashimoto et al. 2018a). The genus is similar to Capulatispora but differs in having an ascus stipe (Tanaka \& Hosoya 2008, Thambugala et al. 2015b).

Lophiohelichrysum Dayarathne, Camporesi \& K.D. Hyde, Fungal Divers. 75: 85 (2015).

Index Fungorum number: IF 551400; Facesoffungi number: FoF 00913; 1 morphological species (Species Fungorum 2020), 1 species with molecular data.

Type species - Lophiohelichrysum helichrysi Dayarathne, Camporesi \& K.D. Hyde in Ariyawansa et al., Fungal Divers. 75: 85 (2015).

Notes - Lophiohelichrysum is characterized by coriaceous ascomata with slit-like ostioles and 1-septate, assymetrical, hyaline to lightly pigmented ascospores (Ariyawansa et al. 2015a). 
Lophiopoacea Ariyaw., Thambug. \& K.D. Hyde, Fungal Divers. 74: 220 (2015).

Index Fungorum number: IF 551240; Facesoffungi number: FoF 00806; 2 morphological species (Species Fungorum 2020), 2 species with molecular data.

Type species - Lophiopoacea paramacrostoma Ariyaw., Thambug., Camporesi \& K.D. Hyde, Fungal Divers. 74: 220 (2015).

Notes - Lophiopoacea shares similar ascospores with Lophiostoma (mostly hyaline, rarely lightly pigmented) but forms a phylogenetically distinct group (Thambugala et al. 2015b).

Neopaucispora Wanas., Gafforov \& K.D. Hyde, Fungal Diversity 89: [65] (2018).

Index Fungorum number: IF 554146; Facesoffungi number: FoF 03986; 1 morphological species (Species Fungorum 2020), 1 species with molecular data.

Type species - Neopaucispora rosaecae Wanas., Gafforov \& K.D. Hyde, Fungal Diversity 89: [65] (2018).

Notes - Neopaucispora differ from other genera in Lophiostomataceae in having 3-septate, fusiform, hyaline to reddish-brown ascospores and mostly brown central cells with prominent guttules (Wanasinghe et al. 2018).

Neotrematosphaeria Thambug., Kaz. Tanaka \& K.D. Hyde, Fungal Divers. 74: 223 (2015).

Index Fungorum number: IF 551242; Facesoffungi number: FoF 00809; 1 morphological species (Species Fungorum 2020), 1 species with molecular data.

Type species - Neotrematosphaeria biappendiculata (Kaz. Tanaka, Y. Harada \& M.E. Barr) Thambug., Kaz. Tanaka \& K.D. Hyde, in Thambugala et al., Fungal Divers. 74: 223 (2015).

$\equiv$ Trematosphaeria biappendiculata Kaz. Tanaka, Y. Harada \& M.E. Barr, Fungal Diversity 19: 149 (2005).

Notes - The type species of this genus, Neotrematosphaeria biappendiculata was originally described as Trematosphaeria biappendiculata by Tanaka et al. (2005c). Neotrematosphaeria species differ from other genera in having pale yellowish to olivaceous-brown ascospores with 5(7)-septa, and appendages at both ends (Thambugala et al. 2015b).

Neovaginatispora A. Hashim., K. Hiray. \& Kaz. Tanaka, Stud. Mycol. 90: 167 (2018).

Index Fungorum number: IF 823147; Facesoffungi number: FoF 08279; 1 morphological species (Hashimoto et al. 2018a), 1 species with molecular data.

Type species - Neovaginatispora fuckelii (Sacc.) A. Hashim., K. Hiray. \& Kaz. Tanaka, Stud. Mycol. 90: 167 (2018).

$\equiv$ Lophiostoma fuckelii Sacc., Michelia 1(no. 3): 336 (1878).

Notes - The morphological characteristics of this genus are similar to Vaginatispora but differ in having a thinner peridium (Hashimoto et al. 2018a).

Parapaucispora A. Hashim., K. Hiray. \& Kaz. Stud. Mycol. 90: 188 (2018).

Index Fungorum number: IF 815297; Facesoffungi number: FoF 08280; 1 morphological species (Hashimoto et al. 2018a), 1 species with molecular data.

Type species - Parapaucispora pseudoarmatispora (Hay. Takah., K. Hiray. \& Kaz. Tanaka) A. Hashim., K. Hiray. \& Kaz. Tanaka, Stud. Mycol. 90: 188 (2018).

$\equiv$ Lophiostoma pseudoarmatisporum Hay. Takah., K. Hiray. \& Kaz. Tanaka, in Li et al., Fungal Diversity 78: 35 (2016).

Notes - According to Li et al. (2016a), Lophiostoma pseudoarmatisporum was placed under Lophiostoma and later Hashimoto et al. (2018a) introduced a new genus and accomodated this species as the type species of Parapaucispora based on morphology and phylogeny. This genus can be distinguished from other genera in Lophiostomataceae in having the single-zoned peridium and absence of a clypeus near the ostiolar neck (Hashimoto et al. 2018a).

Paucispora Thambug., Kaz. Tanaka \& K.D. Hyde, Fungal Divers. 74: 226 (2015). 
Index Fungorum number: IF 551244; Facesoffungi number: FoF 00811; 3 morphological species (Species Fungorum 2020), 3 species with molecular data.

Type species - Paucispora quadrispora (K. Hiray. \& Kaz. Tanaka) Thambug., Kaz. Tanaka \& K.D. Hyde, Fungal Divers. 74: 226 (2015).

$\equiv$ Lophiostoma quadrisporum K. Hiray. \& Kaz. Tanaka, Mycoscience 52(6): 407 (2011).

Notes - Paucispora quadrispora was originally described as Lophiostoma quadrisporum by Hirayama \& Tanaka (2011) using misidentified material of Lophiotrema nucula (Tanaka \& Harada 200b3). According to Thambugala et al. (2015b), the phylogenetic analysis showed $L$. quadrisporum forms a well-supported monophyletic clade with $L$. versicolor as a distinct genus in Lophiostomataceae. The morphological differentiation between L. quadrisporum and L. versicolor also shows that this could be a seperate genus. Therefore, Thambugala et al. (2015b) introduced Paucispora to accommodate L. quadrisporum and L. versicolor. The unique morphological features of this genus are ascomata without hyphal covering and asci containing 2-4 ascospores (Thambugala et al. 2015b).

Platystomum Trevis., Bull. Soc. R. Bot. Belg. 16: 16 (1877).

Index Fungorum number: IF 4185; Facesoffungi number: FoF 00814; 40 morphological species (Species Fungorum 2020), 4 species with molecular data. (1877).

Type species - Platystomum compressum (Pers.) Trevis., Bull. Soc. R. Bot. Belg. 16: 16

三Sphaeria compressa Pers., Syn. meth. fung. (Göttingen) 1: 56 (1801).

Notes - The type species of this genus, Platystomum compressum was originally described as Sphaeria compressa by Cesati \& De Notaris (1863). The species can be saprobes (Kirk et al. 2008). Previously this genus was treated as Pleosporales, genera incertae sedis (Lumbsch \& Huhndorf 2010), but later Hyde et al. (2013) and Wijayawardene et al. (2014b) accepted it as a genus in Platystomaceae. Thambugala et al. (2015b) accepted it as a genus in Lophiostomataceae. Platystomum shares many characters with Lophiostoma (Tanaka \& Harada 2003b), but it has muriform ascospores, lacking a mucilaginous sheath or appendages (Thambugala et al. 2015b).

Pseudocapulatispora Mapook \& K.D. Hyde, Fungal Divers 101: 47 (2020).

Index Fungorum number: IF 557285; Facesoffungi number: FoF 07796; 1 morphological species (Mapook et al. 2020), 1 species with molecular data.

Type species - Pseudocapulatispora longiappendiculata Mapook \& K.D. Hyde, Fungal Divers 101: 47 (2020).

Notes - Pseudocapulatispora is characterized in having a long sheath drawn out to form polar appendages from apex of ascospores with tips of the sheath capped; it was collected from Chromolaena odorata (Asteraceae) in Thailand (Mapook et al. 2020).

Pseudolophiostoma Thambug., Kaz. Tanaka \& K.D. Hyde, Fungal Divers. 74: 235 (2015).

Index Fungorum number: IF 551250; Facesoffungi number: FoF 00820; 5 morphological species (Species Fungorum 2020), 5 species with molecular data.

Type species - Pseudolophiostoma vitigenum (Kaz. Tanaka \& Y. Harada) Thambug., Kaz. Tanaka \& K.D. Hyde, Fungal Divers. 74: 235 (2015).

三Lophiotrema vitigenum Kaz. Tanaka \& Y. Harada, Mycoscience 44(2): 119 (2003).

Notes - The type species of this genus, Pseudolophiostoma vitigenum was originally described as Lophiostoma vitigenum by Tanaka \& Harada (2003b) based on its rather small ascomata and peridia of equal thickness. According to Thambugala et al. (2015b), the ex-type strain of Lophiostoma vitigenum (MAFF 239459) is well-separated from other genera in Lophiostomataceae. Therefore, Thambugala et al. (2015b) introduced the new genus Pseudolophiostoma to accommodate Lophiostoma vitigenum in Lophiostomataceae.

Pseudopaucispora A. Hashim., K. Hiray. \& Kaz. Tanaka, Stud. Mycol. 90: 167 (2018). 
Index Fungorum number: IF 823143; Facesoffungi number: FoF 08281; 1 morphological species (Species Fungorum 2020), 1 species with molecular data.

Type species - Pseudopaucispora brunneospora A. Hashim., K. Hiray. \& Kaz. Tanaka, Stud. Mycol. 90: 167 (2018).

Notes - Pseudopaucispora is similar to Paucispora but differs by peridium, and ascus with a short stipe (Thambugala et al. 2015b, Hashimoto et al. 2018a).

Pseudoplatystomum Thambug. \& K.D. Hyde, Fungal Divers. 74: 237 (2015).

Index Fungorum number: IF 551253; Facesoffungi number: FoF 00822; 1 morphological species (Species Fungorum 2020), 1 species with molecular data.

Type species - Pseudoplatystomum scabridisporum (Abdel-Wahab \& E.B.G. Jones) Thambug. \& K.D. Hyde, in Thambugala et al., Fungal Divers: 74: 40 (2015).

三 Platystomum scabridisporum Abdel-Wahab \& E.B.G. Jones, Mycoscience 41(4): 384 (2000).

Notes - The type species of this genus, Pseudoplatystomum scabridisporum was originally described as Platystomum scabridisporum in Platystomaceae by Abdel-Wahab \& Jones (2000) based on their morphological characteristics. According to the phylogenetic analysis of Suetrong et al. (2009), the two strains of Pseudoplatystomum scabridisporum (BCC 22835 and BCC 22836) clustered in Lophiostomataceae but they did not formally transfer this species to Lophiostomataceae. Thambugala et al. (2015b) confirmed the placement of Pseudoplatystomum scabridisporum in Lophiostomataceae and introduced Pseudoplatystomum to accommodate Pseudoplatystomum scabridisporum in Lophiostomataceae. The type genus differs from Platystomum compressum by smaller ascomata with broadly papillate ostiole and longer asci and transverse and vertical septa in ascospores with verrucose walls (Abdel-Wahab \& Jones 2000).

Quintaria Kohlm. \& Volkm.-Kohlm., Botanica Marina 34: 34 (1991).

Index Fungorum number: IF 25522; Facesoffungi number: FoF 08282; 3 morphological species (Species Fungorum 2020), 1 species with molecular data. (1991).

Type species - Quintaria lignatilis (Kohlm.) Kohlm. \& Volkm.-Kohlm., Bot. Mar. 34(1): 35

三Trematosphaeria lignatilis Kohlm., Marine Ecology, 5(4): 365 (1984).

Notes - Quintaria is characterized in having immersed ascomata with ostioles, fissitunicate asci with J- apical, septate and hyaline ascospores (Kohlmeyer \& Volkmann-Kohlmeyer 1991). The re-collection is needed to verify the generic placement of this genus.

Sigarispora Thambug. \& K.D. Hyde, Fungal Divers. 74: 238 (2015).

Index Fungorum number: IF 551255; Facesoffungi number: FoF 00823; 14 morphological species (Species Fungorum 2020), 14 species with molecular data.

Type species - Sigarispora ravennica (Tibpromma, Camporesi \& K.D. Hyde) Thambug. \& K.D. Hyde, Fungal Divers. 74: 238 (2015).

$\equiv$ Lophiostoma ravennicum Tibpromma, Camporesi \& K.D. Hyde, in Liu et al., Fungal Divers: 72:117 (2015).

Notes - The type species of this genus, Sigarispora ravennica was originally described as Lophiostoma ravennicum by Liu et al. (2015) based on their phylogenetic results, coupled with morphological characteritics. Thambugala et al. (2015b) showed that Lophiostoma ravennicum forms a separate clade in Lophiostomataceae and grouped with new strain. Therefore, Thambugala et al. (2015b) introduce Sigarispora to accommodate Sigarispora ravennica in Lophiostomataceae based on distinct characters of immersed to semi-immersed ascomata, crest-like ostiole and brown, multi-septate ascospores.

Sigarispora ravennica (Tibpromma, Camporesi \& K.D. Hyde) Thambug. \& K.D. Hyde, Fungal Divers.74: 238 (2015).

Fig. 103 


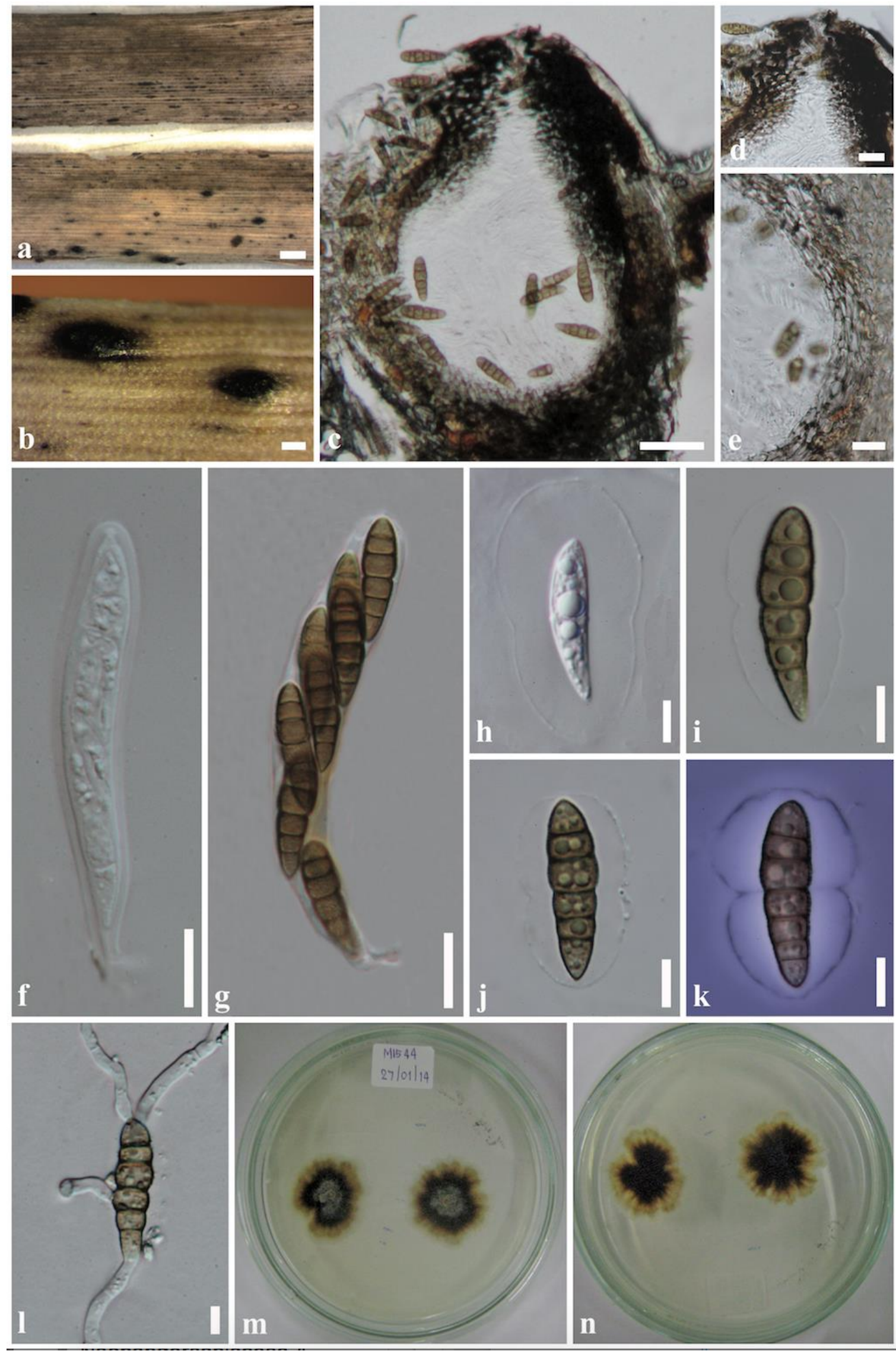

Figure 103 - Sigarispora ravennica (MFU-140692, holotype), a, b Ascomata on host surface. c Cross section of ascoma. d Ostiole. e Peridium. f Asci when immature. g Asci. $\mathrm{h}-\mathrm{j}$ Ascospores. $\mathrm{k}$ Ascospore stained in Indian ink. 1 Germinating ascospore. $\mathrm{m}, \mathrm{n}$ Colonies on MEA media. Scale bars: $\mathrm{a}=500 \mu \mathrm{m}, \mathrm{b}=100 \mu \mathrm{m}, \mathrm{c}=50 \mu \mathrm{m}, \mathrm{d}-\mathrm{g}=10 \mu \mathrm{m}, \mathrm{h}-\mathrm{l}=5 \mu \mathrm{m}$. 
= Lophiostoma ravennicum Tibpromma, Camporesi \& K.D. Hyde, in Liu et al., Fungal Divers. (2015).

Index Fungorum number: IF 551256; Facesoffungi number: FoF 08283

Description - see Liu et al. (2015) as Lophiostoma ravennicum.

Material examined - Italy, Ravenna Province, Marina Romea, on stems of Juncus sp. (Juncaceae), 28 November 2013, E. Camporesi IT1544 (MFLU 14-0692, holotype).

Notes - In this study, Sigarispora ravennica is described, which is the type species of Sigarispora. According to Liu et al. (2015), this species was placed under Lophiostoma. Thambugala et al. (2015b) introduced Sigarispora with Sigarispora ravennica as the type species based on morphology and phylogeny.

Vaginatispora K.D. Hyde, Nova Hedwigia 61(1-2): 234 (1995).

Index Fungorum number: IF 27644; Facesoffungi number: FoF 00828; 9 morphological species (Species Fungorum 2020), 6 species with molecular data.

Type species - Vaginatispora aquatica K.D. Hyde, Nova Hedwigia 61(1-2): 235 (1995).

Notes - Vaginatispora is characterized by immersed to erumpent ascomata, with slotlike ostioles, with numerous periphyses, and 1-septate, narrowly fusiform ascospores, with a thick surrounding papilionaceous sheath (Hyde 1995). Molecular studies based on combined gene analyses showed that Vaginatispora aquatica clusters with Lophiostomataceae based on a new collection from Thailand and the species was transferred to Lophiostoma (Zhang et al. 2014a). Phylogenetic results showed the placement of Vaginatispora in Lophiostomataceae (Thambugala et al. 2015b).

\section{Ecological and economic significance}

Lophiostomataceae species are important for nutrient cycling as they are saprobic on a wide variety of plant substrates. Pseudocapulatispora (Pseudocapulatispora longiappendiculata MFLUCC 17-1452) showed antimicrobial activity against Bacillus subtilis and Mucor plumbeus (Mapook et al. 2020).

Lophiotremataceae K. Hiray. \& Kaz. Tanaka, Mycoscience 52: 405 (2011).

Index Fungorum number: IF 561063; Facesoffungi number: FoF 08284, 57 species.

Saprobic on diverse range of plants. Sexual morph: Ascomata immersed, erumpent at the apex, subglobose to globose scattered or aggregated. Ostiolated with a crest-like ostiolar neck or rarely papillate, mostly elongated and compressed laterally. Peridium pale brown, composed of rectangular to globose cells. Hamathecium comprising filamentous, septate, branched and anastomosed, trabeculate pseudoparaphyses. Asci bitunicate, fissitunicate, cylindrical, with a short stipe or sessile, rounded at the apex, with an ocular chamber and 8-spored. Ascospores obliquely 1seriate and partially overlapping to 2-seriate, fusiform to broadly fusiform or cylindrical, hyaline to brown, 1- to multi-septate, smooth-walled. (Hashimoto et al. 2017b, Hirayama \& Tanaka. 2011). Asexual morph: Conidiomata pycnidial, globose to subglobose, scattered or grouped, semiimmersed to immersed or superficial, ostiolate, rarely papillate. Peridium composed of subglobose to rectangular, pale brown to brown cells. Conidiophores reduced to conidiogenous cells. Conidiogenous cells holoblastic or phialidic, ampulliform to cylindrical, hyaline. Conidia ellipsoidal to cyllindrical with rounded ends or slightly angular ends, hyaline, aseptate or 1-septate or multi-septate, smooth-walled (adapted from Hashimoto et al. 2017b).

Type - Lophiotrema Sacc.

Notes - Lophiotremataceae was introduced by Hirayama \& Tanaka (2011) following a revision of two closely related genera Lophiostoma and Lophiotrema previously considered to belong to family Lophiostomataceae. Based on morphological characters and molecular phylogenetic data using LSU and SSU sequence data, Hirayama \& Tanaka (2011) confirmed the placement of these two genera in separate families, and introduced a new family Lophiotremataceae. Doilom et al. (2016) and Tibpromma et al. (2016a) considered Aquasubmersa and Hermatomyces belonged to the same family. Hashimoto et al. (2017b) revised 
Lophiotremataceae based on morphology and molecular phylogenetic approach using ITS, LSU, rpb-2, SSU, and tef1 and introduced five genera Atrocalyx, Crassimassarina, Cryptoclypeus, Galeaticarpa, and Pseudocryptoclypeus to the family. They also placed Aquasubmersa and Hermatomyces in Aquasubmersaceae and Hermatomycetaceae, respectively.

Lophiotrema Sacc., Michelia 1 (no. 3): 338. (1878).

Index Fungorum number: IF 2934; Facesoffungi number: FoF 08285; 38 morphological species (Species Fungorum 2020), 8 species with molecular data.

Type species - Lophiotrema nucula (Fr.) Sacc., Michelia 1 (no. 3): 338. (1878).

三Sphaeria nucula Fr., K. svenska Vetensk-Akad. Handl., ser. 3 38: 266 (1817).

Notes - Lophiotrema was initially placed under Lophiostomataceae. Later it was transferred to Lophiotremataceae by Hirayama \& Tanaka (2011). This genus has ascomata with a slit-like ostiole and uniform thickness of peridium, asci with a short stipe and pycnidial asexual morphs (Tanaka \& Harada 2003).
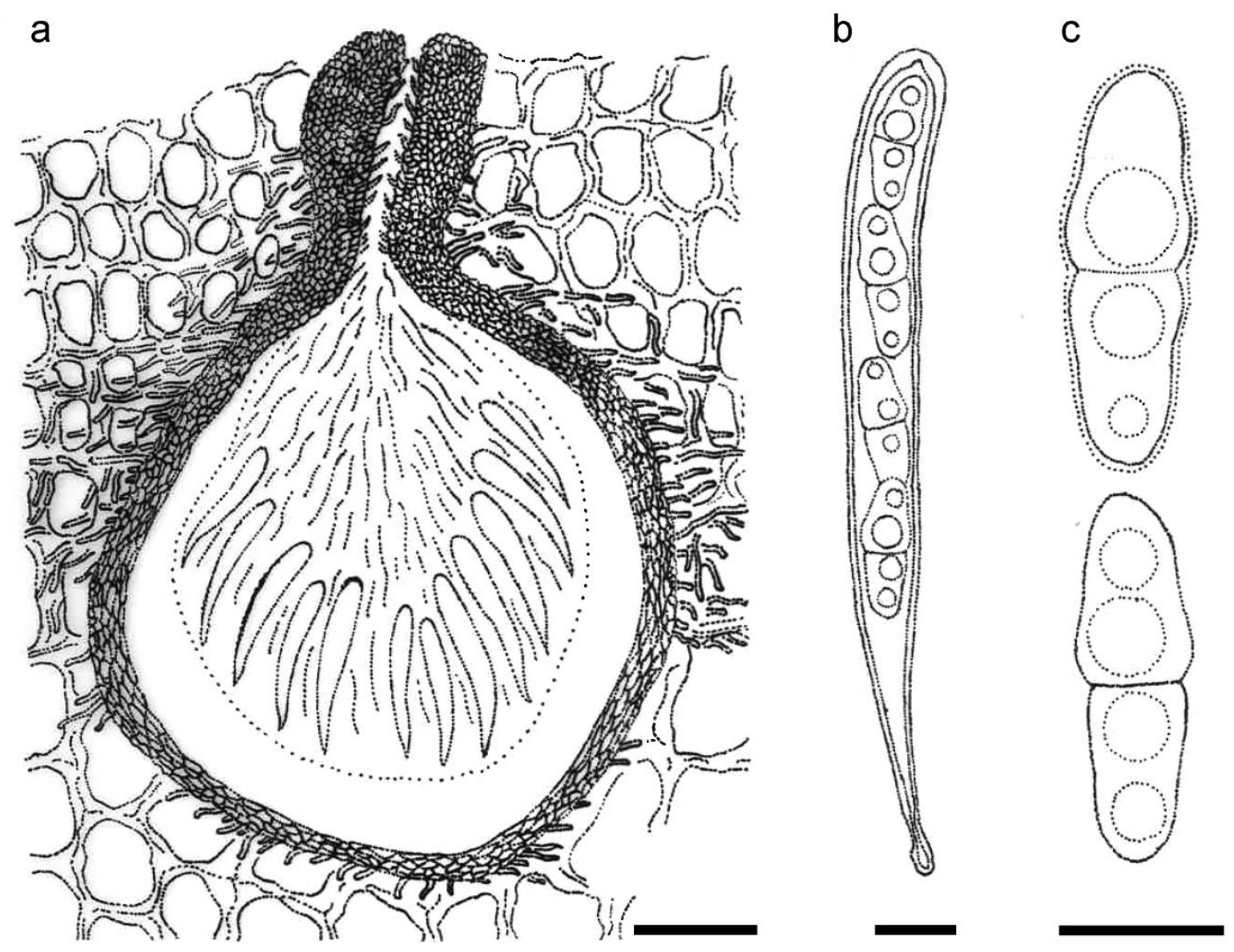

Figure 104 - Lophiotrema nucula (redrawn from culture 4126 in Tanaka \& Harada 2003c). a Cross section of ascoma, b Ascus, c Ascospores. Scale bars: $\mathrm{a}=60 \mu \mathrm{m}, \mathrm{b}, \mathrm{c}=10 \mu \mathrm{m}$.

\section{Other genera included}

Atrocalyx A. Hashim. \& Kaz. Tanaka, Persoonia 39: 59 (2017).

Index Fungorum number: IF 819240; Facesoffungi number: FoF 08286; 7 morphological species (Species Fungorum 2020), 7 species with molecular data.

Type species - Atrocalyx acutisporus A. Hashim. \& Kaz. Tanaka., Persoonia 39: 59 (2017).

Notes - The genus was introduced to accommodate A. acutisporus (type) and A. lignicola. These two species have a crest-like, elongated, laterally compressed ostiolar neck. The peridium around the ostiolar neck and base is well developed. Species are reported as saprobes on woody plants. 
Crassimassarina A. Hashim. \& Kaz. Tanaka, Persoonia 39: 61 (2017).

Index Fungorum number: IF 819243; Facesoffungi number: FoF 08287; 1 morphological species (Species Fungorum 2020), 1 species with molecular data.

Type species - Crassimassarina macrospora A. Hashim. \& Kaz. Tanaka., Persoonia 39: 61 (2017).

Notes - Crassimassarina macrospora was identified as a saprobe on dead twigs of woody plants. Lack of slit-like ostiole in ascomata, ascomatal peridium composed of carbonaceous, thick walled, black cells and multi-septate, large conidia are key morphological characters in distinguishing Crassimassarina from other genera in Lophiotremataceae.

Cryptoclypeus A. Hashim. \& Kaz. Tanaka, Persoonia 39: 63 (2017).

Index Fungorum number: IF 819245; Facesoffungi number: FoF 08288; 2 morphological species (Species Fungorum 2020), 2 species with molecular data.

Type species - Cryptoclypeus ryukyuensis A. Hashim. \& Kaz. Tanaka., Persoonia 39: 63 (2017).

Notes - The genus typified by $C$. ryukyuensis was identified as a saprobe on dead twigs of bamboo. Only two species of Cryptoclypeus are recorded in Index Fungorum, C. ryukyuensis and C. oxysporus and both show similar morphologies in ascomata having less developed clypeus and peridium having rectangular cells.

Galeaticarpa A. Hashim. \& Kaz. Tanaka, Persoonia 39: 64 (2017).

Index Fungorum number: IF 819248; Facesoffungi number: FoF 08289; 1 morphological species (Species Fungorum 2020), 1 species with molecular data.

Type species - Galeaticarpa aomoriensis A. Hashim. \& Kaz. Tanaka., Persoonia 39: 67 (2017).

Notes - Galeaticarpa aomoriensis was identified as saprobic on woody plants. Galeaticarpa shows similar morphological characteristics to Cryptoclypeus and Pseudocryptoclypeus, but it can be distinguished from these two genera by a well-developed clypeus.

Koordersiella Höhn., Sber. Akad. Wiss. Wien, Math.-naturw. Kl., Abt. 1 118: 833 (1909).

Index Fungorum number: IF2582; Facesoffungi number: FoF 06248; 7 morphological species (Species Fungorum 2020), molecular data unavailable.

Type species - Koordersiella javanica Höhn., Sber. Akad. Wiss. Wien, Math.-naturw. K1., Abt. 1 118: 833 (1909).

Notes - Koordersiella was treated as Dothideomycetes genera incertae sedis (Lumbsch \& Huhndorf 2010, Kirk et al. 2013, Rossman et al. 2016). Pem et al. (2019c) placed Koordersiella in Lophiotremataceae by re-examining the type specimen (FH 00301501, FH herbarium). Koordersiella is characterized by regular, small black perithecia, with a multi-layered perithecial wall, thin-walled, sessile asci consisting of 4-8 hyaline, cylindric spindle ascospores (Pem et al. 2019c).

Pseudocryptoclypeus A. Hashim. \& Kaz. Tanaka, Persoonia 39: 67 (2017)

Index Fungorum number: IF 819250; Facesoffungi number: FoF 08290; 1 morphological species (Species Fungorum 2020), 1 species with molecular data.

Type species - Pseudocryptoclypeus yakushimensis A. Hashim. \& Kaz. Tanaka., Persoonia 39: 67 (2017).

Notes - Pseudocryptoclypeus yakushimensis was identified as saprobic on bamboo. Most morphological characters of Pseudocryptoclypeus are similar to those of Cryptoclypeus, but Pseudocryptoclypeus is distinguished by two zones in ascomatal peridium.

\section{Ecological and economic significance}

Lophiotremataceae fungi are mostly recognized as saprobes and there is little evidence available concerning their economic impact. Lophiotrema nucula has been reported on woody 
plants such as Acer, Salix, Quercus, Populus, and Ulmus (Chesters \& Bell 1970) and Lophiotrema fuckelii has been reported on Rubus stems and showing plurivorous relationship with woody and herbaceous plants (Tanaka \& Harada. 2003c). Lophiotrema species also occur on palms (Hyde et al. 2000b), and bamboo (Cai et al. 2003) and saprobic relationships were observed on host plant species in terrestrial (Holm \& Holm 1988), freshwater (Hyde \& Aptroot 1998), and marine environments (Hyde et al. 1992).

Macrodiplodiopsidaceae Voglmayr, Jaklitsch \& Crous, IMA Fungus 6(1): 178 (2015).

Index Fungorum number: IF 812794; Facesoffungi number: FoF 08291, 7 species.

Pathogens or saprobes. Sexual morph: Ascomata immersed, black, solitary to aggregated, globose. Asci cylindric-clavate to broadly clavate. Ascospores 1-seriate and partially overlapping, obovoid, straight to inequilateral, asymmetric, dark brown, eudistoseptate, constricted at septa, surrounded by a mucoid sheath. Asexual morph: Coelomycetous. Conidiomata pycnidial, single or gregarious, globose to collabent, dark brown to black, unilocular, ostiolate. Ostiole single, circular, papillate. Conidiophores reduced to conidiogenous cells. Conidiogenous cells annellidic, indeterminate, cylindrical, hyaline, smooth- and thick-walled. Conidia ellipsoid to obovoid (or clavate), or subglobose to oval, pale brown or hyaline, 3-distoseptate or aseptate, occasionally with a longitudinal septum, base truncate, apex obtuse, thick-walled, surrounded by a large gelatinous sheath (Sutton 1980, Crous et al. 2015a, Wijayawardene et al. 2016a).

Type - Macrodiplodiopsis Petr.

Notes - Macrodiplodiopsidaceae was introduced with Macrodiplodiopsis Petr. as the type genus. Crous et al. (2015a) showed that Pseudochaetosphaeronema larense, the type species of Pseudochaetosphaeronema also resides in Macrodiplodiopsidaceae. Wijayawardene et al. (2020) agreed with this placement. Wijayawardene et al. (2018) treated Pseudochaetosphaeronema in Pleosporales genera incertae sedis. Wijayawardene et al. (2018) listed Pseudomonodictys in Macrodiplodiopsidaceae but we do not accept it in this family.

Macrodiplodiopsis Petr., Annls mycol. 20(5/6): 343 (1922).

Index Fungorum number: IF 8809; Facesoffungi numbe: FoF 08292; 2 morphological species (Species Fungorum 2020), 1 species with molecular data.

Type species - Macrodiplodiopsis desmazieri (Mont.) Petr.

Notes - Sutton (1980) and Wijayawardene et al. (2014a, 2016a) treated the genus as an appendage bearing coelomycetous fungus, although Nag Raj (1993) did not mention the gelatinous sheath. Crous et al. (2015a) also observed the gelatinous sheath of M. desmazieri.

Macrodiplodiopsis desmazieri (as Hendersonia desmazieri Mont.), has been regarded as the asexual morph of Massaria platani (current name: Splanchnonema platani by Shear \& Davidson (1936) but Glawe (1985) rejected this link. However, Crous et al. (2015a) described the sexual morph of M. desmazieri. Wijayawardene et al. (2014a) erroneously reduced Misturatosphaeria and Floricola under Macrodiplodiopsis but Crous et al. (2015a) reinstated the genera.

Macrodiplodiopsis desmazieri (Mont.) Petr., Annls mycol. 20: 343 (1922).

Fig. 105

$\equiv$ Hendersonia desmazieri Mont., Annls Sci. Nat., Bot., sér. 3 12: 310 (1849).

Index Fungorum number: IF 263056; Facesoffungi numbe: FoF 08293.

Description - see Wijayawardene et al. (2014).

Material examined - Italy, Forlì-Cesena Province, Modigliana, Montebello (Ibola Valley), on branches of Platanus acerifolia, 15 April 2013, Erio Camporesi NNW-IT39 (MFLU 13-0090).

\section{Other genus included}

Pseudochaetosphaeronema Punith., Nova Hedwigia 31(1-3): 126 (1979).

Index Fungorum number: IF9562; Facesoffungi number: FoF 08294; 5 morphological species (Species Fungorum 2020), 5 species with molecular data.

Type species - Pseudochaetosphaeronema larense (Borelli \& R. Zamora) Punith., Nova Hedwigia 31(1-3): 127 (1979). 
三Cladosporium strumelloideum Milko \& Dunaev, Nov. sist. Niz. Rast. 23: 134 (1986).

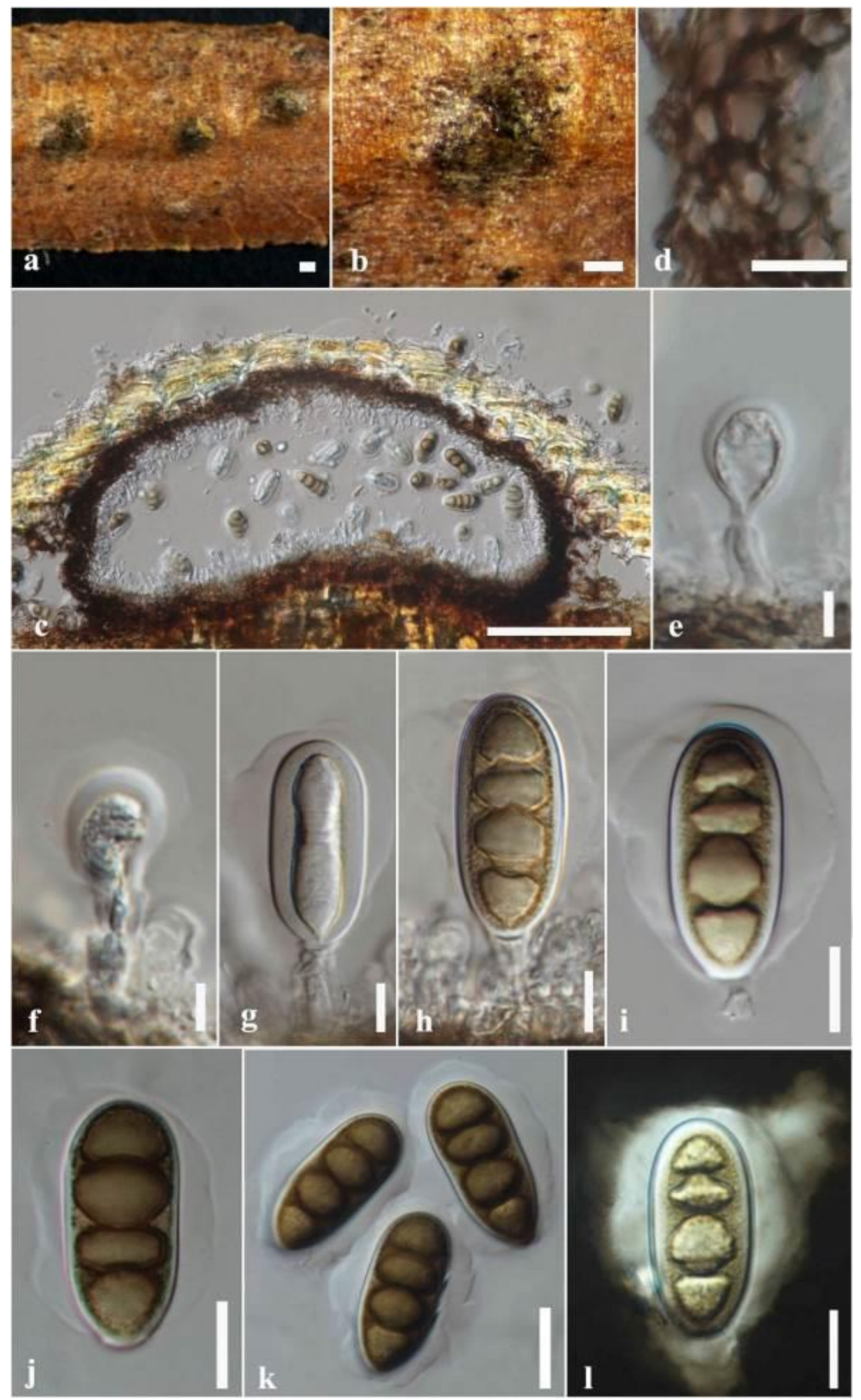

Figure 105 - Macrodiplodiopsis desmazieri (MFLU 13-0090). a, b Conidiomata on host substrate. c Cross section of conidioma. d Peridium e- $\mathrm{h}$ Immature conidia attached to conidiogenous cells. $\mathrm{i}-\mathrm{k}$ conidia. 1 Conidia showing gelatinous sheath stained with Indian ink. Scale bars: $\mathrm{a}, \mathrm{b}=200 \mu \mathrm{m}$, $\mathrm{c}=100 \mu \mathrm{m}, \mathrm{d}, \mathrm{j}, \mathrm{k}=20 \mu \mathrm{m}, \mathrm{e}, \mathrm{f}, \mathrm{i}=5 \mu \mathrm{m}, \mathrm{g}, \mathrm{h}, \mathrm{l}=10 \mu \mathrm{m}$. 
Notes - Punithalingam (1979) introduced this genus with $P$. larense as the type species. Currently the genus comprises five species except the type species viz. P. kunmingense, $P$. martinelli, P. pandanicola, P. siamensis and P. ginkgonis (Nom. Inval. Art. 40.7) (Ahmed et al. 2015, Zhang et al. 2016d, Tibpromma et al. 2018, Jayasiri et al. 2019, Hyde et al. 2020b)

\section{Ecological and economic significance}

The species of Macrodiplodiopsidaceae have been reported as saprobes or endophytes (Sutton 1980, Wijayawardene et al. 2014a, Crous et al. 2015a). As far as we know, there are no reported species as pathogens from economically important hosts.

Massariaceae Nitschke, Verh. Naturh. Ver. preusss. Rheinl. 26: 73 (1869).

Index Fungorum number: IF 80978; Facesoffungi number: FoF 06427, 52 species.

Saprobic or weakly parasitic on terrestrial corticated branches of their hosts or recently dead branches still attached to the trees or on recently fallen branches confined to northern temperate climatic regions. Colonies hyphal or meristematic, hard, spongy, extremely slow growing, culture with black reverse; meristematic colonies with masses of globose, subhyaline to brownish cells. Hyphae hyaline to subhyaline, frequently branching, for hyphal colonies; hyphae of meristematic colonies if present short, torulose. Sexual morph: Ascomata pseudothecial, scattered or clustered in groups, globose, subglobose, pyriform to strongly depressed, immersed in bark or occasionally in outer most wood layer, and embedded in pseudostromatic tissues intermixed substrate cells forming pallid areas often surrounded by blackened zones, often clypeate and ostiolate. Ostiole central or eccentric, short or long, solitary or converging in groups, greyish, whitish, rosy or yellow in median vertical section, projecting through the bark, stout papillate, rounded with rounded pore, with erumpent apex and often surmounted by peaks of stromatic tissues that form coarsely sulcate tips above the bark surface. Peridium thick, firm, opaque, composed of numerous layers of thin-walled, smooth, externally darkly pigmented, compressed angular cells with paler inwards. Hamathecium comprising numerous persistent, indistinctly septate, branching and anastomosing, cellular or trabeculate pseudoparaphyses, $1 \mu \mathrm{m}$ wide in the upper part and up to $4 \mu \mathrm{m}$ wide in the peripheral regions of the ascoma, embedded in a gelatinous matrix. Asci 4-8-spored, thick-walled, bitunicate, fissitunicate, basal and peripheral, oblong, cylindrical or fusoid, less commonly saccate, pedicellate with apically wide ocular chamber and refractive rings. Ascospores 1-3-seriate, large, oblong, cylindrical, ellipsoid or fusoid, rounded or tapered towards subacute ends, straight or slightly inequilateral, hyaline or light to dark brown, always brown after ejection, symmetric, biconoid and symmetrically 1-euseptate initially, becoming 3-disto- and euseptate, not or slightly constricted at the septa, secondary septa closer to primary septum than to ends of ascospore, smooth- and thickwalled, surrounded by a mucilaginous sheath, lumina rhomboid or lenticular in the central cells, conoid in the end cells. Asexual morph: Coelomycetous where known. Conidiophores cylindrical to ampulliform. Conidia small, irregularly subglobose to ellipsoidal, hyaline, aseptate.

Type - Massaria De Not.

Notes - As suggested by Barr (1979b, 1990c), Eriksson (1981) and Kruys et al. (2006) treated Massariaceae as including Trypetheliaceae due to the morphological similarities between the two families. However, Harris $(1986,1989)$ questioned this synonymy stating that Massariaceae is more primitive than Trypetheliaceae. Similarly, Eriksson (1989) and Aptroot (1991) maintained Massariaceae distinct from Trypetheliaceae, consisting of only two genera Decaisnella and Massaria and placed within order Pyrenulales. Schoch et al. (2009a) showed Trypetheliaceae is phylogenetically different from Massaria and re-introduced in Trypetheliales outside of Dothideomycetidae. Barr (1990c) classified Massariaceae in Melanommatales, which was later relocated as Melanommataceae, Pleosporales by Schoch et al. (2006, 2009a) using molecular phylogeny. This family has been subjected to many critical revisions during the past and all of the genera except for Massaria have been transferred to many other families including Aigialaceae and Zopfiaceae (Barr 1979b, 1990c, Eriksson 1981, Schoch et al. 2006, 2009a, Suetrong et al. 2009). Lumbsch \& Huhndorf (2010) accepted four genera in Massariaceae which were excluded during later studies. Hyde et al. (2013) accepted Massaria as the only genus in Massariaceae. The family 
was placed as a monophyletic family basal in the Pleosporales using four gene combined phylogenetic analysis. Neomassaria was introduced as a new genus in Massariaceae based on combined LSU, SSU and tef1 sequence data (Hyde et al. 2016). This was followed by Wijayawardene et al. (2017a, 2018). However, Ariyawansa et al. (2018a) relocated Neomassaria into a new family Neomassariaceae based on LSU, rpb-2, SSU and tef1 combined phylogeny and several morphological differences. Massarioramusculicola was introduced into the family using morphology and molecular phylogeny (Huanraluek et al. 2018).

Massaria De Not., G. bot. ital. 1(1): 333 (1844)

Index Fungorum number: IF 3013; Facesoffungi number: FoF 06428; 50 morphological species (Species Fungorum 2020), 17 species with molecular data.

Type species - Massaria inquinans (Tode) De Not.

三 Massaria inquinans (Tode) De Not., G. bot. ital. 1(1): 333 (1844).

Notes - Massaria was introduced by De Notaris (1844) based on Sphaeria inquinans Tode (1791). With its symmetrical ascospores containing both disto- and eusepta and rhomboid or lenticular lumina in mid cells, morphology of Massaria species is unique in the context of nonlichenised ascomycetes with bitunicate asci (Voglmayr \& Jaklitsch 2011). Voglmayr \& Jaklitsch (2011) used morphology and combined multi-gene (LSU, rpb-2, SSU and tef1) phylogeny and treated 17 Massaria species including seven which were newly introduced. This study suggested a high host-specificity for Massaria species and concluded that their biodiversity is centered on Acer and Rosaceae hosts. Evidence was provided for their hemibiotrophic or weakly parasitic life styles based on the geographic distribution of Massaria species (Voglmayr \& Jaklitsch 2011). For morphology of type species see Voglmayr \& Jaklitsch (2011). Massarioramusculicola was introduced into the family using morphology and molecular phylogeny (Huanraluek et al. 2018).

\section{Other genera included}

Massarioramusculicola Huanral., Thambug. \& K. D. Hyde, Phytotaxa 371(1): 20 (2018).

Index Fungorum number: IF 554425; Facesoffungi number: FoF 04478; 1 morphological species (Species Fungorum 2020), 1 species with molecular data.

Type species - Massarioramusculicola chiangraiensis Huanral., Thambug. \& Hyde, Phytotaxa, 371(1): 20 (2018).

Notes - Massaria differs from Massarioramusculicola in having larger ascomata typically firmly embedded in pseudostromatic tissue intermixed with substrate cells, often surrounded by blackened marginal zones and covered by a dark clypeus and brown to dark brown, larger, 3-distoor euseptate ascospores. The type was originally collected on dead twigs of an unknown host in Thailand. The genus was reported as saprobic, in terrestrial environments (see morphology Huanraluek et al. 2018).

Massarioramusculicola chiangraiensis Huanral., Thambug. \& Hyde, Phytotaxa 371(1): 20 (2018).

Index Fungorum number: IF 554426; Facesoffungi number: FoF 04479.

Fig. 106

Description - see Huanraluek et al. (2018).

Material examined - Thailand, Chiang Rai Province, Mueang District, on dead twig, 28 January 2017, Naruemon Huanraluek, Ts1 (MFLU 18-0632, holotype).

Paramassaria Samarak., \& K. D. Hyde, Fungal Diversity 96(1): 45 (2019).

Index Fungorum number: IF 555521; Facesoffungi number: FoF 05213; 1 morphological species (Species Fungorum 2020), 1 species with molecular data. (2019).

Type species - Paramassaria samaneae Samarak., \& K. D. Hyde, Fungal Diversity, 96(1): 49

Notes - Paramassaria is similar to Massaria but differs from the type genus in having a wide ostiole and lacks an ocular chamber in its asci. The type was originally collected on a dead branch 
of Samanea saman in Thailand. The genus was reported as saprobic, in terrestrial environments (see morphology Hyde et al. 2019).
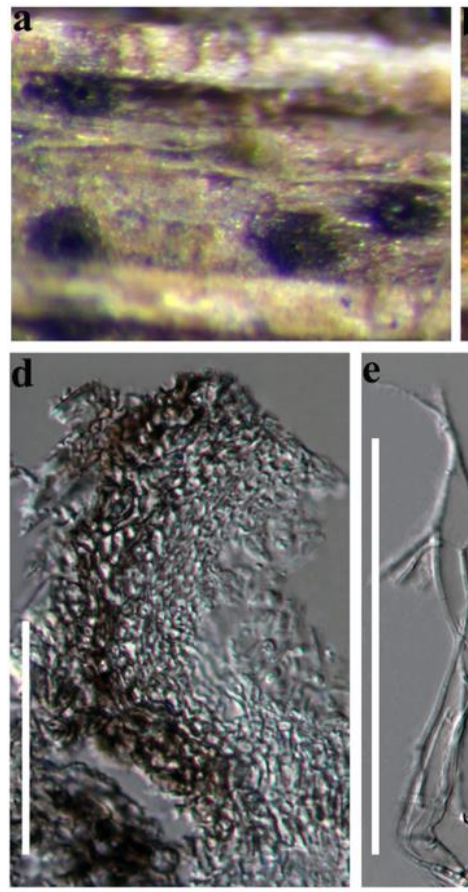

j
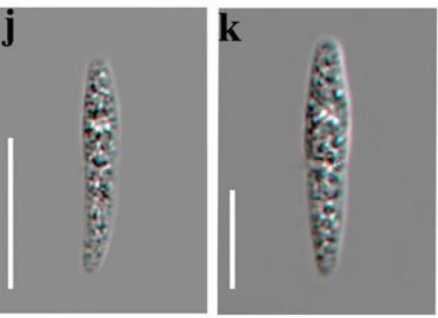
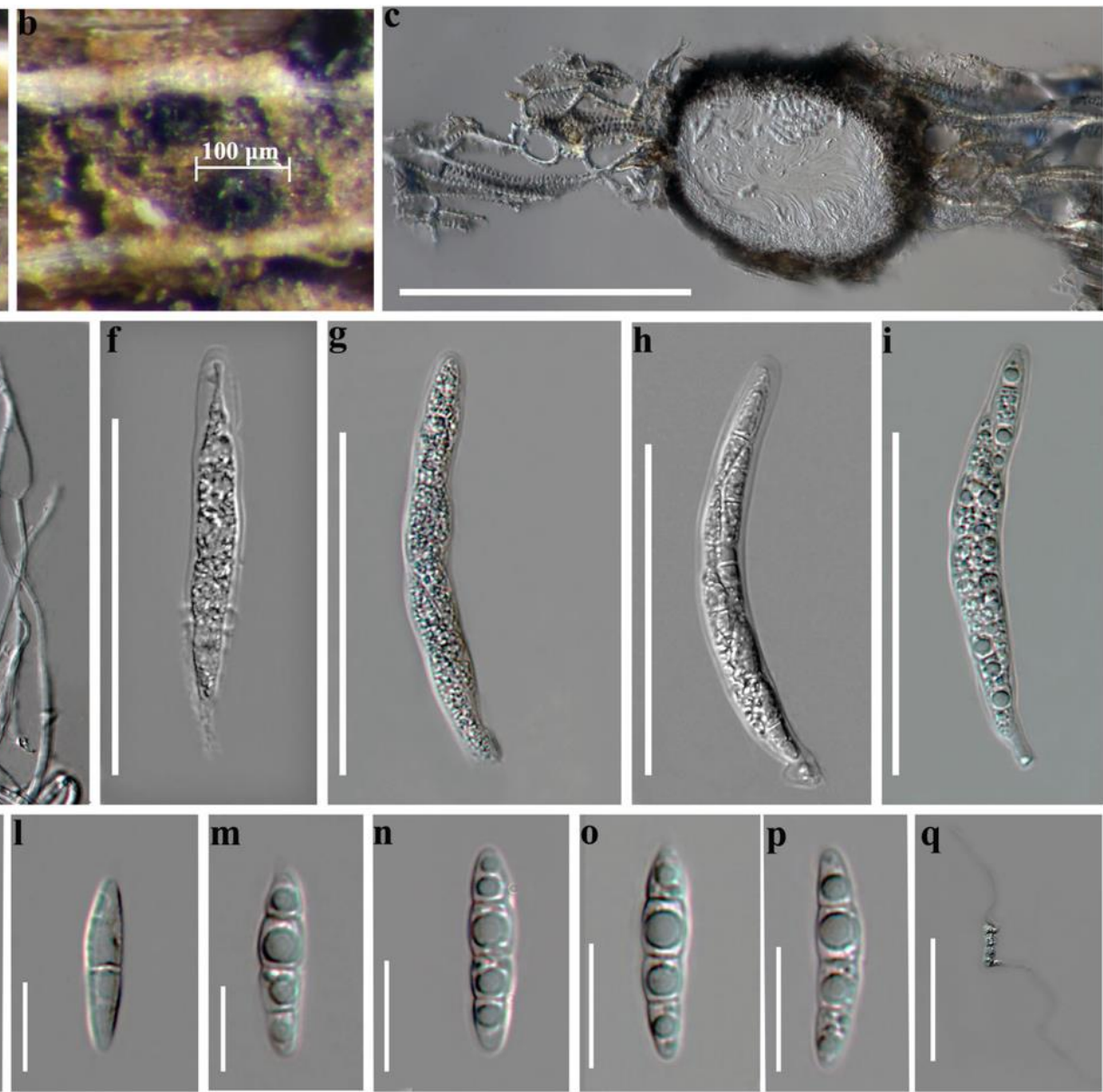

q

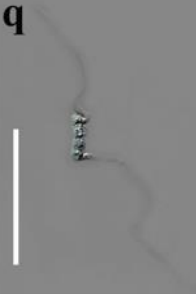

Figure 106 - Massarioramusculicola chiangraiensis (MFLU 180632, holotype). a Appearance of ascomata on host surface. b Ascoma on host surface. c Vertical section through ascoma. d Peridium. e Paraphyses. $\mathrm{f}-\mathrm{i}$ Asci. $\mathrm{j}-\mathrm{p}$ Ascospores. $q$ Germinating ascospore. Scale bars: $\mathrm{c}=50$ $\mu \mathrm{m}, \mathrm{d}, \mathrm{q}=10 \mu \mathrm{m}, \mathrm{e}=20 \mu \mathrm{m}, \mathrm{f}-\mathrm{i}=20 \mu \mathrm{m}, \mathrm{j}-\mathrm{p}=5 \mu \mathrm{m}$.

\section{Ecological and economic significance}

All Massaria species are restricted to corticated branches of their hosts mainly Acer and Rosaceae plants, distributed in northern temperate climatic regions (Voglmayr \& Jaklitsch 2011). Apart from the single record of $M$. inquinans reported from Taiwan (Chen \& Hsieh 1996) and several other Massaria species recorded form North America (Barr 1979b, 1990c), biodiversity of Massaria is concentrated in Europe (Voglmayr \& Jaklitsch 2011). Some species including $M$. campestris, $M$. gigantispora and $M$. vindobonensis have been identified from dead branches still attached to trees indicating their weak pathogenicity or opportunistic growth in plants (Michalopoulos-Skarmoutsos \& Skarmoutsos 1999, Voglmayr \& Jaklitsch 2011).

Massarinaceae Munk, Friesia 5: 305 (1956).

Index Fungorum number: IF 80979; Facesoffungi number: FoF 06497, ca. 626 species.

Saprobic on wood or twigs of plants, hemibiotropic or pathogenic on leaves or living leaves in terrestrial habitats. Sexual morph: Ascomata sometime covered with pseudoclypeus, uniloculate or multiloculate, solitary, gregarious to clustered, immersed to semi-immersed, becoming erumpent, scattered, globose or subglobose, conical at base, papillate or epapillate, ostiolate. Peridium thin, comprising thin hyaline layers, outer layers fusing with the host substrate. Hamathecium comprising dense, filamentous, broad, septate, branching, hyaline cellular pseudoparaphyses, embedded in mucilage, without anastomosing. Asci 8-spored, bitunicate, 
fissitunicate, clavate to cylindrical, short pedicellate, apically rounded, with ocular chamber. Ascospores 2-seriate, partial overlapping, broad fusiform to oblong, hyaline to brown, 1- to multiseptate, constricted at the septa, with or without mucilaginous sheath. Asexual morph: Coelomycetous or hyphomycetous asexual morphs or spermatia characters produced in the culture condition. Conidiomata immersed to nearly superficial, depressed globose with a flattened base and cylindrical neck. Ostiole sometimes papillate or with elongated neck. Conidiomata wall thin, comprising thin hyaline layers. Conidiogenous cells enteroblastic, hyaline. Conidia oblong to globose-ovoid, hyaline to brown, aseptate to multi-septate or dictyosporous, smooth-walled (Chethana et al. 2015, Tanaka et al. 2015, Wijayawardene et al. 2015); hyphomycetous asexual morph. Conidiophores synematous-like, solitary or in small groups, macronematous, mononematous, dark brown, guttulate, multi-septate. Conidiogenous cells in the uppers part of conidiophore, mono- to polytretic, with small pores at the apex. Conidia solitary or in short chains, obclavate, rostrate, pale brown, multi-septate, smooth-walled, with or without guttulate (Tanaka et al. 2015, Zhao et al. 2018); Spermatiogenous cells cylindrical, appearing phialidic. Spermatia globose to subglobose, hyaline, smooth-walled (Tanaka et al. 2015).

Type - Massarina Sacc., Syll. fung. (Abellini) 2: 153 (1883).

Notes - Massarinaceae was established to accommodate fungal taxa having clypeus tissue covering the ascomata. The family originally comprised of Keissleriella, Massarina, Metasphaeria, Pseudotrichia and Trichometasphaeria (Munk 1956). Molecular study has shown that several related genera in Massarinaceae can be classified to different families within the suborder Massarineae (Zhang et al. 2012b, Hyde et al. 2013, Tanaka et al. 2015, Phukhamsakda et al. 2017). The outline of Ascomycota 2017 included Longiostiolum in Massarinaceae, however, the phylogenetic analysis showed its distinct lineages (Li et al. 2016). Currently, eight genera are accepted in Massarinaceae based on both molecular and phylogenetic analyses viz. Byssothecium, Helminthosporium, Massarina, Pseudodidymosphaeria, Pseudosplanchnonema, Semifissispora, Stagonospora and Suttonomyces (Zhang et al. 2012b, Adamčík et al. 2015, Chethana et al. 2015, Tanaka et al. 2015, Thambugala et al. 2015a, Wijayawardene et al. 2015, Crous et al. 2017a). Based on phylogenetic analyses, single strains of Neottiosporina paspali (strain CBS 331.37) clustered along with members of Stagonospora (Massarinaceae). Several studies suggested that the strain should be synonymized under Stagonospora. Molecular data of the type species, Neottiosporina apoda is required for the taxonomic confirmation (Sutton 1974, Quaedvlieg et al. 2013, Thambugala et al. 2015a, Wijayawardene et al. 2015, Crous et al. 2017a).

Massarina Sacc., Syll. fung. (Abellini) 2: 153 (1883).

Index Fungorum number: IF 3016; Facesoffungi number: FoF 06500; ca. 100 morphological species (Species Fungorum 2020), 3 species with molecular data (Tibpromma et al. 2018).

Type species - Massarina eburnea (Tul. \& C. Tul.) Sacc., Syll. fung. (Abellini) 2: 153 (1883).

三Massaria eburnea Tul. \& C. Tul., Select. fung. carpol. (Paris) 2: 239 (1863).

Notes - Massariana is the generic type of Massarinaceae. The members were assigned to Massariana based on morphological characters (Bose 1961, Barr 1992b, Hyde 1995, Tanaka \& Harada 2003d), however only three species have been confirmed by molecular information (Tibpromma et al. 2018). Massarina is characterized by its immersed, hemisphaerical with flattened base or depressed globose ascomata, and broadly fusiform ascospores with rounded ends, hyaline, and multi-septate (Hyde 1995, Tanaka et al. 2015). Asexual morph characters of Massariana has been reported as ceratophoma-like, with aseptate, hyaline conidia or pycnidial conidiomata, enteroblastic conidiogenous cells, and oblong to globose-ovoid, hyaline, one-celled conidia (Tibpromma et al. 2018).

\section{Other genera included}

Byssothecium Fuckel, Bot. Ztg. 19 (no. 35): 251 (1861).

Index Fungorum number: IF 714; Facesoffungi number: FoF 06498; 4 morphological species (Species Fungorum 2020), 1 species with molecular data. 
Type species - Byssothecium circinans Fuckel, Bot. Ztg. 19 (no. 35): 251 (1861).
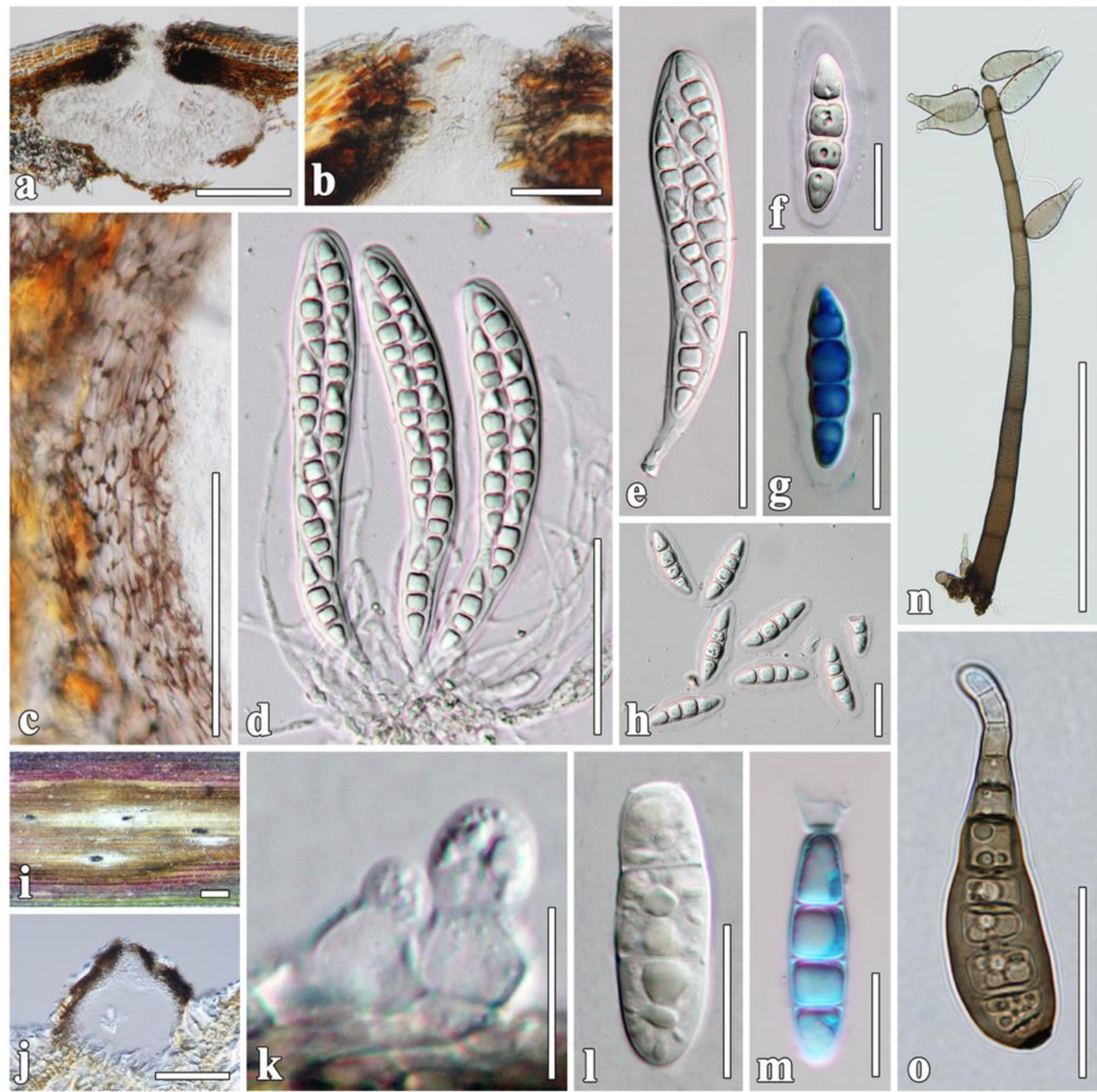

Figure 107 - Morphology of Massarinaceae, a-h Massarina eburnea (IFRD 2006, epitype). a Appearance of Massarina eburnea ascoma located on host substrate. b Ostiole canal. c Peridium. $\mathrm{d}$, e Asci and pseudoparaphyses. $\mathrm{f}-\mathrm{h}$ Ascospores ( $\mathrm{g}$ ascospores stained in Cotton blue). i-m Stagonospora spp. i, j Close up of Stagonospora imperaticola (MFLU 16-2788, holotype) conidiomata located on host surface. $\mathrm{k}$ Conidiogenous cell with developing conidia. 1 Conidia of Stagonospora imperaticola. m Conidia of Stagonospora forlicesenensis (MFLU 16-1337, holotype). n, o Helminthosporium submersum (MFLU 17-1429, holotype). n Conidiophores and conidia. o Mature conidia. Scale bars: $\mathrm{a}, 1, \mathrm{n}=200 \mu \mathrm{m}, \mathrm{b}, \mathrm{j}=100 \mu \mathrm{m}, \mathrm{c}-\mathrm{e}=50 \mu \mathrm{m}, \mathrm{f}-\mathrm{h}, \mathrm{l}-\mathrm{m}, \mathrm{o}=$ $20 \mu \mathrm{m}, \mathrm{k}=10 \mu \mathrm{m}$.

Notes - Byssothecium circinans was reported as a saprobe on woody substrates (Holm 1957, Boise 1983). The genus had been illustrated in Boise (1983) with subglobose ascomata, broadly papillate necks and brown ascospores with Chaetophoma as asexual morph characters. The phylogenetic placement of Byssothecium circinans has been verified in Schoch et al. (2009a) with 
the confirmation in its taxonomic placement in various studies (Zhang et al. 2012b, Hyde et al. 2013, Chethana et al. 2015, Tanaka et al. 2015, Voglmayr \& Jaklitsch 2017).

Helminthosporium Link, Mag. Gesell. naturf. Freunde, Berlin 3 (1-2): 10 (1809).

= Helminthosporiella Hern.-Restr., Sarria \& Crous, in Crous et al., Persoonia 36: 437 (2016).

Index Fungorum number: IF 8495; Facesoffungi number: FoF 06499; ca. 223 morphological species (Species Fungorum 2020), several species with molecular data.

Type species - Helminthosporium velutinum, Mag. Gesell. naturf. Freunde, Berlin 3(1-2): 10 (1809).

Notes - Helminthosporium was introduced for fungal taxa dominantly reported from wood substrates (Voglmayr \& Jaklitsch 2017, Zhao et al. 2018). Species have also been reported as plant pathogens and saprobes on submerged substrates with a worldwide distribution (Kaiser et al. 1979, Semeniuk 1983, Errampalli et al. 2001). Helminthosporium is characterized by its distoseptate conidia, with bud scars at base, hyaline cell on the apex of the conidia (Seifert et al. 2011). The illustration of the sexual morph characters has recently been described by Voglmayr \& Jaklitsch (2017). In the phylogenetic analyses (Fig. 42) Helminthosporiella clustered together with Helminthosporium. Helminthosporiella and Helminthosporium have similar morphology of terminal polytretic conidiogenous cells and distoseptate conidia. However, Helminthosporiella only has catenate conidia while Helminthosporium has both terminal and intercalary conidiogenous cells and solitary conidia (Crous et al. 2016b, Voglmayr \& Jaklitsch 2017). Based on the morphology and phylogeny evidence, we suggest that Helminthosporiella should be synonymized under Helminthosporium.

Pseudodidymosphaeria Thambug. \& K.D. Hyde, in Thambugala et al., Phytotaxa 231(3): 273 (2015).

Index Fungorum number: IF 550959; Facesoffungi number: FoF 00465 - 2 morphological species (Species Fungorum 2020), 2 species with molecular data.

Type species - Pseudodidymosphaeria spartii (Fabre) Thambug., Camporesi \& K.D. Hyde, in Thambugala et al., Phytotaxa 231(3): 274 (2015).

三Didymosphaeria spartii Fabre, Annls Sci. Nat., Bot., sér. 6 9: 83 (1879).

Notes - Pseudodidymosphaeria was proposed for strains that are similar to the isotype of Didymosphaeria spartii that formed a well-supported clade in Massarinaceae (Thambugala et al. 2015a). Pseudodidymosphaeria is characterized by a peridium with brown to hyaline cells of textura angularis and textura prismatica, with broad fusiod, single septate ascospores that are constricted at the septa, and have a wide mucilaginous sheath. Asexual morph produced in cultures have oval to ellipsoidal, hyaline aseptate conidia (Thambugala et al. 2015a, Li et al. 2016a).

Pseudosplanchnonema Chethana \& K.D. Hyde, in Chethana et al., Phytotaxa 231(2): 138 (2015). Index Fungorum number: IF 551021; Facesoffungi number: FoF 00568; 1 morphological species (Species Fungorum 2020), 1 species with molecular data.

Type species - Pseudosplanchnonema phorcioides (I. Miyake) Chethana, Camporesi \& K.D. Hyde, in Chethana et al., Phytotaxa 231(2): 139 (2015).

三 Massaria phorcioides Miyake, Techn. Rep. Imper. Sericult. Exp. Stat. Tokyo 1:316 (1916)

Notes - Chethana et al. (2015) introduced Pseudosplanchnonema for a splanchnonema-like species that was phylogenetically placed in Massarinaceae. The genus was found associated with dead branches of Acer campestre and Morus spp. in Italy and Russia. Pseudosplanchnonema is characterized by its immersed, ostiolate ascomata, 8-spored, clavate, 2-seriate asci and fusiform, dark brown ascospores surrounded by a gelatinous sheath with subglobose to oblong, hyaline, aseptate conidial mass produced in culture (Tanaka et al. 2005b, Chethana et al. 2015).

Semifissispora Swart, Trans. Br. mycol. Soc. 78(2): 259 (1982).

Index Fungorum number: IF 5000; Facesoffungi number: FoF 06501; 5 morphological species (Species Fungorum 2020), 4 species with molecular data. 
Type species - Semifissispora fusiformis Swart, Trans. Br. mycol. Soc. 78(2): 259 (1982).

Notes - Semifissispora was introduced for some fungi associated with leaf litter of Eucalyptus spp. (Swart 1982). Semifissispora is related to Massarinaceae (Crous et al. 2015d). Semifissispora natalis was found associated with the dried part of infected Eucalyptus leaves. However, tests are needed to confirm its pathogenicity (Crous et al. 2015d). Semifissispora has fusiform, hyaline, 1-septate ascospores, prominently constricted at septum and bending at maturity (Swart 1982, Crous et al. 2015d). Asexual morph produced in culture has solitary conidiomata with sub-cylindrical, aseptate and hyaline conidia (Crous et al. 2017a).

Stagonospora (Sacc.) Sacc., Syll. fung. (Abellini) 3: 445 (1884).

$\equiv$ Hendersonia Sacc., Syll. fung. (Abellini) 3: 418 (1884).

Index Fungorum number: IF 10056; Facesoffungi number: FoF 06502; 289 species based on morphological data (Species Fungorum 2020), 21 species with molecular data (Crous et al. 2017a, Thambugala et al. 2017b).

Type species - Stagonospora paludosa (Sacc. \& Speg.) Sacc., Syll. fung. (Abellini) 3: 453 (1884).

三 Hendersonia paludosa Sacc. \& Speg., Michelia 1(no. 3): 353 (1878).

Notes - The generic concept of Stagonospora was originally defined in Castellani \& Germano (1977) with keys to species provided by Sutton (1980). The genus was mentioned as related to Phaeosphaeriaceae (Zhang et al. 2012b). However, molecular data coupled with morphological resemblance of the type species of Stagonospora, (S. paludosa) showed that the genus has an affinity with Massarinaceae (Quaedvlieg et al. 2013). According to phylogenetic results, a single strain of Neottiosporina paspali clustered with Stagonospora members (Sutton \& Alcorn 1974, Quaedvlieg et al. 2013, Tanaka et al. 2015, Thambugala et al. 2017b). The strain should be treated under Stagonospora, however the generic sequence data of Neottiosporina is required. Stagonospora is characterized by its ascomatal wall of textura polygonal to textura subglobosa, oblong asci with short, simple pedicel, hyaline ascospores with pycnidial asexual morph. Stagonospora was originally described for the asexual morph (Sutton 1980), and the sexual morph characters were recently documented in Tanaka et al. (2015) and Crous et al. (2017a).

Suttonomyces Wijayaw., Camporesi \& K.D. Hyde, in Wijayawardene et al., Cryptog. Mycol. 36(2): 220 (2015).

Index Fungorum number: IF 551091; Facesoffungi number: FoF 00468; 2 morphological species (Species Fungorum 2020), 2 species with molecular data.

Type species - Suttonomyces clematidis Wijayaw., Camporesi \& K.D. Hyde, in Wijayawardene et al., Cryptog. Mycol. 36(2): 221 (2015).

Notes - Suttonomyces was introduced to Massarinaceae by Wijayawardene et al. (2015). The genus is characterized by asexual morph characters in having oblong conidia, with a truncate base, pale brown to dark brown, with 1-2 transverse septa and occasionally 1-longitudinal septa (Wijayawardene et al. 2015, Wanasinghe et al. 2018c). Two species are accepted in Suttonomyces.

\section{Ecological and economic significance}

Species of Massarinaceae can be found in various environments occurring as saprobic on wood or twigs, hemibiotropic or pathogenic on leaves in terrestrial habitats (Swart 1982, Seifert et al. 2011, Crous et al. 2017a, Thambugala et al. 2017b, Voglmayr \& Jaklitsch 2017). Byssothecium circinans was mentioned as a weak parasite on Medicago sativa L. (Semeniuk, 1983). Helminthosporium solani is an economically important pathogen of potatoes causing silver scurf disease of tubers (Errampalli et al. 2001). Neottiosporina paspali was found associated with the leaves of Paspalum (Sutton 1980). Semifissispora natalis was associated with leaf litter of Eucalyptus spp. (Swart 1982). Several species of Stagonospora are associated with leaves of various plants, however, pathogenicity study is required (Quaedvlieg et al. 2013, Thambugala et al. 2017b). 
Melanommataceae G. Winter [as 'Melanommeae'], Rabenh. Krypt.-Fl., Edn 2 (Leipzig) 1.2: 220 (1885).

Index Fungorum number: IF 80990; Facesoffungi number: FoF 01023, 337 species.

Saprobic or parasitic on woody plants in terrestrial, marine or freshwater habitats. Sexual morph: Ascomata scattered or gregarious, immersed or semi-immersed to erumpent, superficial, globose to subglobose, carbonaceous or coriaceous, papillate or epapillate, black, with or without a subiculum. Peridium multi-layered, outer layer composed of irregular, thick-walled, brown to black pseudoparenchymatous cells, and inner layer composed of thin-walled, hyaline pseudoparenchymatous cells. Hamathecium comprising long, branched or simple, septate, cellular or trabeculate pseudoparaphyses encircling and anastomosing between the asci and embedded in a gelatinous matrix or hamathecium lacking. Asci 8-spored, bitunicate, fissitunicate, clavate to nearly cylindrical, pedicellate, apically rounded with an ocular chamber. Ascospores 1-seriate or 2-seriate, fusoid to ellipsoidal, or muriform, hyaline or brown, 1- to multi-septate, with or without a mucilaginous sheath, smooth-walled or verrucose. Asexual morph: Mostly coelomycetous and rarely hyphomycetous with various conidium ontogenic structures. Conidiomata pycnidial, superficial, globose to subglobose, black, ostiolate. Peridium comprising irregular, thickwalled, hyaline to brown cells. Conidiophores reduced to conidiogenous cells. Conidiogenous cells holoblastic, monoblastic or enteroblastic phialidic, ampliform to cylindrical, geniculate, hyaline to pale brown. Conidia oblong, cylindrical, ellipsoidal, pyriform to obovoid, hyaline, aseptate to multi-septate, smooth-walled.

Type - Melanomma Nitschke ex Fuckel.

Notes - Winter (1885) introduced Melanommataceae and Melanomma was regarded as the type genus based on its diagnostic character of trabeculate pseudoparaphyses. Taxonomic studies of members of Melanommataceae have been carried out recently (Mugambi \& Huhndorf 2009a, Hyde et al. 2013, Liu et al. 2015, Tian et al. 2015, Li et al. 2016c, Almeida et al. 2017, Gross et al. 2017, Hashimoto et al. 2017a, Jaklitsch \& Voglmayr 2017, Wanasinghe et al. 2018c). Tian et al. (2015) accepted 20 genera with detailed morphological characters of each type species and provided multiple gene (LSU, SSU, rpb-2 and tef1) phylogenetic analyses. However, there are many genera established without sequence data, such as Anomalemma/Exosporiella, Asymmetricospora, Bicrouania, Calyptronectria, Mamillisphaeria, Navicella and Nigrolentilocus. Jaklitsch \& Voglmayr (2016) excluded Ohleria from Melanommataceae and established a new family Ohleriaceae based on morphological differences and phylogeny distinction. Jaklitsch \& Voglmayr (2017) revisited three former taxa of Cucurbitaria and placed Petrakia in Melanommataceae and introduced two new genera, Alpinaria and Praetumpfia. Hashimoto et al. (2017a) introduced a new family Pseudodidymellaceae to accommodate four similar genera, Mycodidymella, Petrakia, Pseudodidymella, and Xenostigmina and restricted Melanommaceae sensu stricto based on morphological characters of both sexual and asexual morphs and phylogenetic circumscription. Five additional genera, Marjia, Melanocucurbitaria, Melanodiplodia, Monoseptella and Uzbekistanica, were were introduced by Wanasinghe et al. (2018c) and they elucidated Pseudodidymellaceae as untenable based on a more reliable backbone bootstrap support. An evolutionary analysis is indispensable to be carried out, more sampling of DNA from missing genera should be obtained and the considerable confusion of sexual and asexual morphs should be removed. In this study, 35 genera are accepted in Melanommataceae.

Melanomma Nitschke ex Fuckel, Jb. nassau. Ver. Naturk. 23-24: 159 (1870).

Index Fungorum number: IF 3070; Facesoffungi number FoF00774; 82 morphological species (Species Fungorum 2020), 5 species with molecular data.

Type species - Melanomma pulvis-pyrius (Pers.) Fuckel.

Notes - This species was based on its small, carbonaceous ascomata, and hyaline or brown, 2-3-septate ascospores (Fuckel 1870, Chesters 1938). A detailed circumscription of Melanomma was given by Barr (1990a). Kirk et al. (2001) accepted 20 species, while 309 epithets are listed in Index Fungorum (2020). Most species have not been well studied since their initial introduction and there is no molecular data available. Melanomma pulvis-pyrius and M. japonicum are the only 
two species with detailed morphological description and illustration and also have a multi-gene analysis to clarify intergeneric taxonomic affinities of Melanomma in the Melanommataceae (Mathiassen 1989, 1993, Barr 1990a, Mugambi \& Huhndorf 2009a, Tian et al. 2015, Hashimoto et al. 2017a, Jaklitsch \& Voglmayr 2017, Wanasinghe et al. 2018c). Aposphaeria, Nigrolentilocus, Phoma-like and Pseudospiropes have been reported as asexual morphs of Melanomma (Chesters 1938, Sivanesan 1984, Hyde et al. 2011, Tian et al. 2015, Jaklitsch \& Voglmayr 2016, 2017, Hashimoto et al. 2017a, Wanasinghe et al. 2018c).

Melanomma pulvis-pyrius (Pers.) Fuckel, Jb. nassau. Ver. Naturk. 23-24: 160 (1870).

Fig. 108

三Sphaeria pulvis-pyrius Pers., Syn. meth. fung. (Göttingen) 1: 86 (1801).

Index Fungorum number: IF 182890; Facesoffungi number: FoF 00775.

Description - see Tian et al. (2015).

Material examined - FRANCE, Ariège, Rimont, Saurine, on bark of Salix caprea L. (Salicaceae), 10 April 2008, Jacques Fournier (IFRD 2001, epitype).

Notes - Zhang et al. (2012b) examined the holotype and neotype of M. pulvis-pyrius and designate an epitype based on its similarity to the neotype. The type species of Melanomma (M. pulvis-pyrius) differs from other genera in Melanommataceae in having small, carbonaceous ascomata, hyaline or brown, 2-3-septate ascospores (Fuckel 1870, Chesters 1938). Beverwykella pulmonari has been reported as asexual morph of $M$. pulvis-pyrius based on phylogenetic analysis (Chesters 1938, Sivanesan 1984), however, Gruyter et al. (2013) indicated that B. pulmonaria is close to Aposphaeria corallinolutea, but is not the asexual morph of $M$. pulvis-pyrius. Tian et al. (2015) found that B. pulmonari represents a single clade in Pleomassariaceae but, Aposphaeria populina clustered with $M$. pulvis-pyrius with high support value in phylogenetic analysis.

\section{Other genera included}

Alpinaria Jaklitsch \& Voglmayr, Sydowia 69: 84 (2017).

Index Fungorum number: IF 819135; Facesoffungi number: FoF 08295; 1 morphological species (Species Fungorum 2020), 1 species with molecular data.

Type species - Alpinaria rhododendri (Niessl) Jaklitsch \& Voglmayr, Sydowia 69: 84 (2017)

三 Cucurbitaria rhododendri Niessl, Verh. nat. Ver. Brünn 10: 202 (1872).

Notes - Alpinaria was introduced to accommodate Cucurbitaria rhododendri which was introduced by Niessl (1872). Initially. C. rhododendri was transferred to Melanomma as Melanomma rhododendri (Rehm 1881, Holm 1968). Jaklitsch \& Voglmayr (2017) epitypified $C$. rhododendri and established the new genus referring to its alpine habitat. Alpinaria is characterized by erumpent, globose, black ascomata with papillate ostiole, septate paraphyses, cylindrical asci and ellipsoid to fusoid, brown, 3-euseptate ascospores. Phylogenetically, Jaklitsch \& Voglmayr (2017) first provided the sequence of A. rhododendri and it clustered in Melanommataceae with strong bootstrap support.

Aposphaeria Sacc., Michelia 2(no. 6): 4 (1880).

Index Fungorum number: IF 7198; Facesoffungi number: FoF 00756; 84 morphological species (Species Fungorum 2020), 2 species with molecular data.

Type species - Aposphaeria pulviscula (Sacc.) Sacc., Michelia 2(no. 6): 4 (1880).

三Phoma pulviscula Sacc., Michelia 1(no. 2): 259 (1878).

Notes - Aposphaeria is characterized by pycnidial, unilocular conidiomata, short, cylindrical, branched conidiophores and hyaline, aseptate, cylindrical or ellipsoidal conidia (Tian et al. 2015). Some Aposphaeria species have been synonymized in other different genera, such as Chaetomastia, Massariosphaeria, Melanomma, Mytilinidion and Rhytidhysteron (Sivanesan 1984, Tanaka \& Harada 2004, de Gruyter et al. 2013, Zhang et al. 2012b, Hyde et al. 2013, Tian et al. 2015). There is no molecular data for the type species, and Tian et al. (2015) suggested to retain Aposphaeria as a genus in Melanommataceae. 


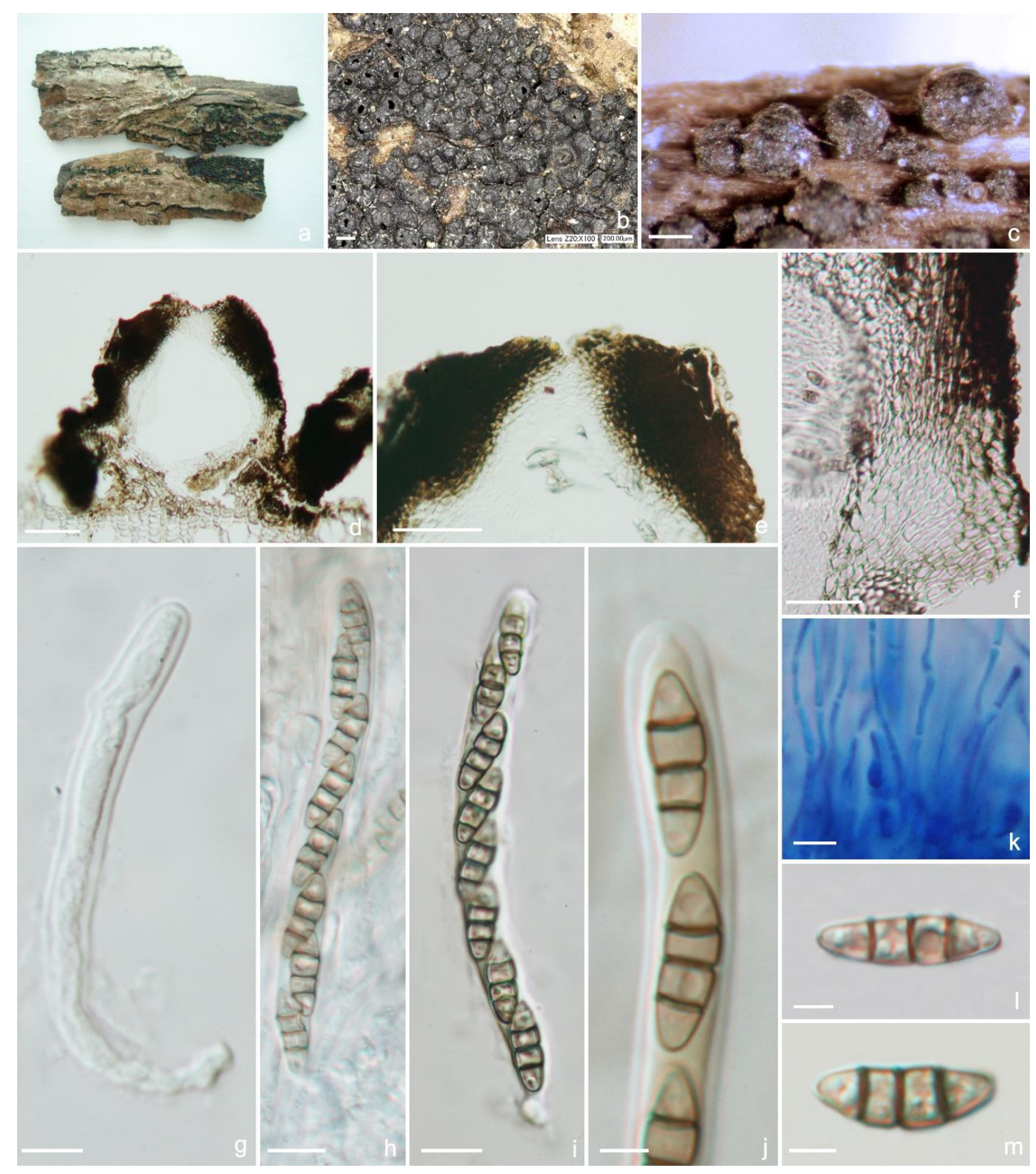

Figure 108 - Melanomma pulvis-pyrius (IFRD 2001, epitype). a Herbarium material. b, c Ascomata on the superficial of host. d Vertical section of ascoma. e, f Vertical section through peridium. $\mathrm{g}-\mathrm{j}$ Asci with ascospores. $\mathrm{k}$ Pseudoparaphyses. $1, \mathrm{~m}$ Ascospores. Scale bars: $\mathrm{b}=\mathrm{c}=200$ $\mu \mathrm{m}, \mathrm{d}=100 \mu \mathrm{m}, \mathrm{e}=50 \mu \mathrm{m}, \mathrm{f}=20 \mu \mathrm{m}, \mathrm{g}-\mathrm{i}=10 \mu \mathrm{m}, \mathrm{j}-\mathrm{m}=5 \mu \mathrm{m}$.

Asymmetricospora J. Fröhl. \& K.D. Hyde, Sydowia 50(2): 183 (1998).

Index Fungorum number: IF 28247; Facesoffungi number: FoF 00758; 1 morphological species (Species Fungorum 2020), molecular data unavailable. (1998).

Type species - Asymmetricospora calamicola J. Fröhl. \& K.D. Hyde, Sydowia 50(2): 184

Notes - Asymmetricospora was based on distinguishing characters of absence of a subiculum, presence of short, dark setae, around the papilla, and its asymmetrical ascospores. However, the exact familial placement of Asymmetricospora was uncertain due to lack of sequence data (Tian et al. 2015, Jaklitsch \& Voglmayr 2017). It is recommended that Asymmetricospora should be maintained in Melanommataceae on account of the trabeculate pseudoparaphyses (Lumbsch \& Huhndorf 2010, Zhang et al. 2012b, Hyde et al. 2013, Wijayawardene et al. 2014b, Tian et al. 2015). 
Bertiella (Sacc.) Sacc. \& P. Syd., in Saccardo, Syll. fung. (Abellini) 14: 19 (1899).

Index Fungorum number: IF 553; Facesoffungi number: FoF 00760; 5 morphological species (Species Fungorum 2020), 3 species with molecular data.

Type species - Bertiella macrospora (Sacc.) Sacc. \& Traverso, Syll. fung. (Abellini) 19: 147 (1910).

EBertia macrospora Sacc., Michelia 2(no. 8): 452 (1882).

Notes - Bertiella is characterised by superficial ascomata, cylindro-clavate asci and hyaline, 1-septate ascospores that may become 3-septate and pale brown when senescent. Bertiella has been placed in Massarina (as M. macrospora). and Lophiostoma (as L. bertiellum by Eriksson \& Yue (1986) and Hyde et al. (2002), respectively. Mugambi \& Huhndorf (2009a) from molecular evidence confirmed placement of Bertiella in Melanommataceae. Two species B. ellipsoidea and $B$. macrospora have been confirmed with morphological characters and molecular evidence. Hashimoto et al. (2017a) proposed Melanommataceae should be restricted to the type genus Melanomma, and placed other Melanommataceae taxa (sensu lato) in an uncertain place in Melanommataceae, including Bertiella. Tian et al. (2015) retained Bertiella in Melanommataceae pending molecular data of new epitypification from Italy which corresponds with Jaklitsch \& Voglmayr (2017) and Wanasinghe et al. (2018c).

Bicrouania Kohlm. \& Volkm.-Kohlm., Mycol. Res. 94(5): 685 (1990).

Index Fungorum number: IF 25435; Facesoffungi number: FoF 00763; 1 morphological species (Species Fungorum 2020), molecular data unavailable.

Type species - Bicrouania maritima (P. Crouan \& H. Crouan) Kohlm. \& Volkm.-Kohlm., Mycol. Res. 94(5): 685 (1990).

ESphaeria maritima P. Crouan \& H. Crouan, Florule Finistère (Paris): 27 (1867).

Notes - Bicrouania maritima is characterized by superficial ascomata lacking a clypeus, thick-walled asci and its association with marine algae. On account of its melanommataceous character and trabeculate pseudoparaphyses, Bicrouania remains in Melanommataceae based on distinguished morphological characters, and thus DNA sequence is essential to verify the appropriate classification (Lumbsch \& Huhndorf 2010, Jones et al. 2009b, Zhang et al. 2012b, Hyde et al. 2013, Wijayawardene et al. 2014b, 2017a, Tian et al. 2015).

Byssosphaeria Cooke, Grevillea 7(no. 43): 84 (1879).

Index Fungorum number: IF 711; Facesoffungi number: FoF 00765; 16 morphological species (Species Fungorum 2020), 9 species with molecular data.

Type species - Byssosphaeria keithii (Berk. \& Broome) Cooke, Grevillea, Grevillea 7(no. 43): 84 (1879).

三Sphaeria keithii Berk. \& Broome, Ann. Mag. nat. Hist., Ser. 4 17: 144 (1876).

Notes - Byssosphaeria comprises approximately 16 species (Species Fungorum 2020) but only nine species are published with detailed descriptions and molecular data, viz. B. jamaicana, $B$. macarangae, B. musae, B. rhodomphala, B. salebrosa, B. schiedermayeriana, B. siamensis, B. taiwanense, B. villosa. Byssosphaeria is a widespread genus distributed from temperate to tropical regions (Barr 1984, Chen \& Hsieh 2004, Li \& Zhuang 2008, Tian et al. 2015, Tennakoon et al. 2018a). Species in Pyrenochaeta or Chaetophoma-like have been reported as asexual morphs of Byssosphaeria (Tian et al. 2015, Wijayawardene et al. 2017a). Barr (1990a) formally described Byssosphaeria as it is characterized by superficial ascomata with bright yellow, orange or red flat apices around the ostiole, with dependant hyphal appendages that merge with the subiculum below and hyaline ascospores. Byssosphaeria has been assigned to Herpotrichia (Bose 1961, Sivanesan 1971, von Arx \& Müller 1975), but it is distinguishable from Herpotrichia on account of the trabeculate pseudoparaphyses, as well as a subiculum (Hyde et al. 2000a). Mugambi \& Huhndorf (2009a), Zhang et al. (2012b), Hyde et al. (2013), Tian et al. (2015), and this study (Fig. 109) confirmed the placement of Byssosphaeria in Melanommataceae with phylogenetic analysis. 


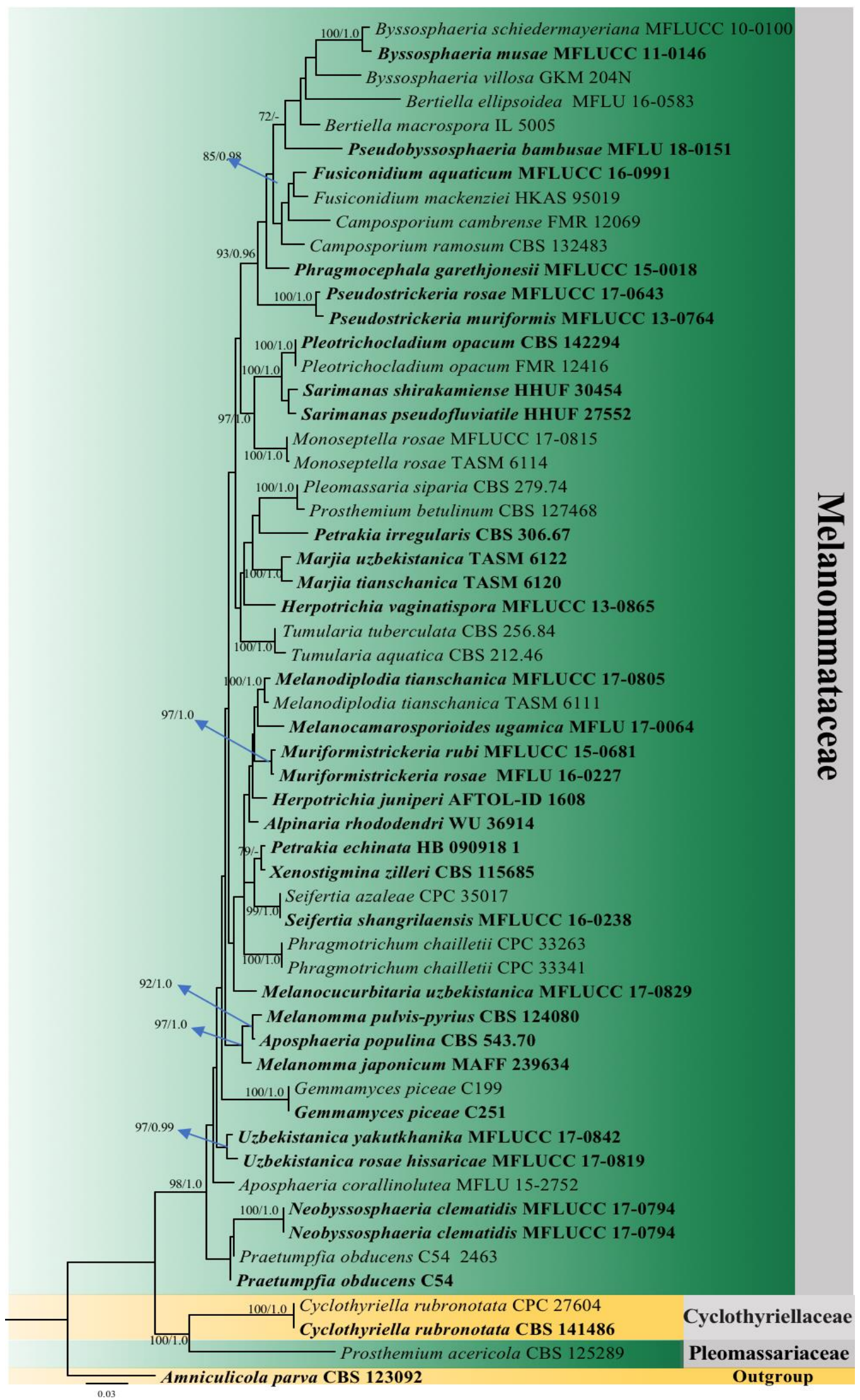

Figure 109 - Phylogram generated from maximum likelihood analysis (RAxML) of genera in Melanommataceae based on ITS, LSU, and SSU sequence data. Maximum likelihood bootstrap values equal or above $70 \%$, Bayesian posterior probabilities equal or above 0.90 (MLBS/PP) are given at the nodes. An original isolate number is noted after the species name. The tree is rooted to Amniculicola parva (CBS 123092). The ex-type strains are indicated in bold. Hyphen (-) represents support values below $70 \%$ MLBS and $0.90 \mathrm{PP}$. 
Camposporium Harkn., Bull. Calif. Acad. Sci. 1(no. 1): 37 (1884).

Index Fungorum number: IF 7479; Facesoffungi number: FoF 08296; 24 morphological species (Species Fungorum 2020), 8 species with molecular data.

Type species - Camposporium antennatum Harkn., Bull. Calif. Acad. Sci. 1(no. 1): 37 (1884).

Notes - Camposporium is characterized by dematiaceous conidiophores, terminal, integrated, denticulate conidiogenous cells, and cylindrical and elongate, multi-septate conidia with one or more cylindrical appendages at the apex (Hughes 1951b, Ellis 1971, Ichinoe 1971, Whitton et al. 2002). The sequence of Camposporium antennatum was provided by Crous et al. (2018b) and it clustered with Fusiconidium mackenziei in Melanommataceae. Hyde et al. (2020b) updated the taxonomic treatment of Camposporium and included the other three species in this genus. Whereas, Fusiconidium lycopodiellae was transferred to Camposporium as $C$. lycopodiellae (Hyde et al. 2020b).

Calyptronectria Speg., Anal. Mus. nac. B. Aires, Ser. 3 12: 412 (1909).

Index Fungorum number: IF 774; Facesoffungi number: FoF 00767; 3 morphological species (Species Fungorum 2020), molecular data unavailable. (1909).

Type species - Calyptronectria platensis Speg., Anal. Mus. nac. B. Aires, Ser. 3 12: 412

Notes - Calyptronectria is characterized by immersed ascomata, filiform, trabeculate pseudoparaphyses, and hyaline, muriform ascospores, as well as a peridium that turns reddish brown in KOH (Spegazzini 1909, Barr 1983, Rossman et al. 1999). Calyptronectria is a poorly known genus with no published DNA data. Due to the distinguished character of trabeculate pseudoparaphyses, Tian et al. (2015) retained Calyptronectria in Melanommataceae.

Exosporiella P. Karst., Finlands mögelsvampar, (Hyphomycetes fennici): 160 (1892).

Index Fungorum number: IF 8236; Facesoffungi number: FoF 01024; 1 morphological species (Species Fungorum 2020), molecular data unavailable.

Type species - Exosporiella fungorum (Fr.) P. Karst., Finlands mögelsvampar, (Hyphomycetes fennici): 161 (1892).

三 Epochnium fungorum Fr., Syst. mycol. (Lundae) 3(2): 449 (1832).

Notes - There is no doubt that the asexual morph Exosporiella and sexual morph Anomalemma are linked, though Anomalemma and Exosporiella have been previously transferred to many different genera, such as Byssosphaeria, Chaetosphaeria, Leptosphaeria and Melanomma (Saccardo 1878, Ellis 1883, Massee 1887, Keissler 1922, Ellis 1971, Sivanesan 1983). Anomalemma was reported as fungicolous (Sivanesan 1983). Tian et al. (2015) examined the isotype of Anomalemma epochnii and found the asexual morph Exosporiella on the surface of adjacent stroma. There are no sequence data in GenBank of either the sexual or the asexual morphs. Anomalemma should be regarded as a synonym of Exosporiella which was proposed earlier (Wijayawardene et al. 2014b). Tian et al. (2015) and subsequent studies followed this and retained Exosporiella in Melanommataceae, pending new collection and epitipification.

Fusiconidium Jun F. Li, Phookamsak \& K.D. Hyde, in Li et al., Phytotaxa 308(2): 208 (2017).

Index Fungorum number: IF 817936; Facesoffungi number: FoF 02516; 3 morphological species (Pratibha et al. 2017, Species Fungorum 2020), 3 species with molecular data.

Type species - Fusiconidium mackenziei Jun F. Li, Phookamsak, Camporesi \& K.D. Hyde, in Li et al., Phytotaxa 308(2): 211 (2017).

Notes - The genus is characterized by septate, unbranched, brown to dark brown, single, cylindrical conidiophores, enteroblastic, integrated, brown, cylindrical or doliiform conidiogenous cells and acrogenous, solitary, rostrate, fusiform to ellipsoidal, euseptate, pale brown to brown conidia with smooth-walled or verruculose. Three species are accepted in Fusiconidium with molecular data, viz. F. aquaticum, F. indicum, and F. mackenziei (Pratibha et al. 2017, Species Fungorum 2020). Morphologically, Fusiconidium resembles Camposporium and Phragmocephala 
in conidial shape in Melanommataceae. However, Phragmocephala has synnematous conidiophores and holoblastic conidiogenous cells (Mason \& Hughes 1951, Whitton et al. 2012, Su et al. 2015) and Camposporium has denticulate conidiogenous cells, and cylindrical and elongate, multi-septate conidia with cylindrical appendages (Crous et al. 2018b). Phylogenetically, Camposporium and Fusiconidium grouped together within Melanommataceae. We treat these two genera as distinct based on morphological characters and phylogenetic analysis.

Herpotrichia Fuckel, Fungi rhenani exsic., suppl., fasc. 7 (nos 2101-2200): no. 2171 (1868).

Index Fungorum number: IF 2307; Facesoffungi number: FoF 00770; 61 morphological species (Species Fungorum 2020), 10 species with molecular data.

Type species - Herpotrichia herpotrichoides (Fuckel) P.F. Cannon, Trans. Br. mycol. Soc. 79(2): 338 (1982).

ESphaeria herpotrichoides Fuckel, Fungi rhenani exsic., fasc. 10: no. 952 (1864).

Notes - Herpotrichia was established by Fuckel (1868) with Herpotrichia rhenana and $H$. rubi without assigning a type. Holm (1979) assigned $\mathrm{H}$. rubi as the generic type as it was validly published two years later $H$. rhenana. However, Holm (1979) and Cannon (1982) assigned $H$. herpotrichoides as generic type as the synonymous Sphaeria herpotrichoides is the earliest name and should be given priority. Herpotrichia is characterized by erumpent to superficial ascomata, clavate to cylindrical, 4-8-spored asci and hyaline to pale brown, 1-septate ascospores (Sivanesan 1984), as well as Pyrenochaeta-like asexual morph (Samuels \& Müller 1978, Schneider 1979, Sivanesan 1984). Morphologically, Herpotrichia resembles Byssosphaeria, Melanomma, Pseudotrichia in having immersed, erumpent to superficial ascomata, usually embedded in a subiculum, and similar characters of ascospores (Bose 1961, Barr 1984). Zhang et al. (2012b) proposed to consider several criteria such as host, location and habitat. Phylogenetically, Herpotrichia is polyphyletic, Herpotrichia diffusa clustered with Byssosphaeria; H. juniper, H. macrotricha and $H$. vaginaspora formed a distinct clade; and $H$. parasitica formed a single clade close to Morosphaeriaceae (Mugambi \& Huhndorf 2009a, Zhang et al. 2012b, Tian et al. 2015, Hashimoto et al. 2017a, Wanasinghe et al. 2018c). Tian et al. (2015) examined the type species $H$. herpotrichoides and retained Herpotrichia in Melanommataceae, pending sequence data for the type species.

Mamillisphaeria K.D. Hyde et al., Nova Hedwigia 62(3-4): 514 (1996).

Index Fungorum number: IF 27612; Facesoffungi number: FoF 00772; 1 morphological species (Species Fungorum 2020), molecular data unavailable.

Type species - Mamillisphaeria dimorphospora K.D. Hyde et al., Nova Hedwigia 62(3-4): 515 (1996).

Notes - Mamillisphaeria was introduced as a monotypic genus with bitunicate, fissitunacate asci, trabeculate pseudoparaphyses and dimorphic ascospores collected from freshwater in tropical Australia. Hyde et al. (1999) discussed the different function between two kinds of ascospores. The hyaline ascospores may be adapted for attachment, enhanced collision and provide nutrient for germination (Hyde et al. 1996, Zhang et al. 2012b), and the brown ascospores cannot germinate may help withstand desiccation and UV radiation during aerial dispersal (Hyde et al. 1996, Zhang et al. 2012b, Tian et al. 2015). Both ascospores have mucilaginous sheaths (Hyde et al. 1996, Tian et al. 2015). Barr (1990a) assigned Mamillisphaeria dimorphospora to Massariaceae, however, based on account of the trabeculate pseudoparaphyses, Hyde et al. (1999) temporarily assigned this species to Melanommataceae, there is no molecular data published for Mamillisohaeria, Tian et al. (2015) followed the conclusion and retained, Mamillisohaeria in Melanommataceae.

Marjia Wanas., Gafforov \& K.D. Hyde, in Wanasinghe et al., Fungal Divers. 89: 85 (2018).

Index Fungorum number: IF 554155; Facesoffungi number: FoF 03996; 2 morphological species (Species Fungorum 2020), 2 species with molecular data.

Type species - Marjia tianschanica Wanas., Gafforov \& K.D. Hyde, in Wanasinghe et al., Fungal Divers. 89: 85 (2018). 
Notes - Wanasinghe et al. (2018c) established Marjia with Marjia tianschanica (generic type) and M. uzbekistanica collected from Uzbekistan, on Cerasus tianschanica and Rosa species. It is characterized by superficial, broadly oblong, dark brown to black ascomata, filamentous, branched, septate, pseudoparaphyses, cylindrical to cylindric-clavate, long pedicellate asci and ellipsoidal to subfusiform, brown, muriform ascospores. Species in Marjia, Gemmamyces, Melanocucurbitaria, Muriformistrickeria, Uzbekistanica, Pseudostrickeria and Praetumpfia have muriform ascospores, but they are phylogenetically distinct (Wanasinghe et al. 2018c).

Melanocamarosporioides D. Pem, Jeewon, Gafforov \& K.D. Hyde, Mycol. Progr. 18: 473 (2019).

Index Fungorum number: IF 554296; Facesoffungi number: FoF 04363; 1 morphological species (Species Fungorum 2020), 1 species with molecular data.

Type species - Melanocamarosporioides ugamica D. Pem, Jeewon, Gafforov \& K.D. Hyde, Mycol. Progr. 18: 474 (2019).

Notes - Melanocamarosporioides ugamica was collected from dead trunk and branches of Lonicera altmannii from Uzbekistan. It is characterized by superficial to erumpent, uniloculate conidiomata, and globose ellipsoidal or ovoid, dark brown, multi-septate conidia (Pem et al. 2019d). Melanocamarosporioides resembles Aposphaeria, Exosporiella and Melanodiplodia as they are coelomycetous genus in Melanommataceae. However, Melanocamarosporioides differs in having multi-septate conidia mostly with 3-4 transverse septa and 1-4 longitudinal septa (Pem et al. 2019d), versus aseptate conidia in Aposphaeria (Saccardo 1880, Tian et al. 2015), 4-septate conidia in Exosporiella (Sivanesan 1983, Zhang et al. 2012b, Tian et al. 2015) and 1-septate conidia in Melanodiplodia (Wanasinghe et al. 2018c). The phylogenies indicate that Melanocamarosporioides clustered with Melanodiplodia and aligned in Melanommataceae with strong bootstrap support (Pem et al. 2019d). Wijayawardene et al. (2016a) first introduced a camarosporium-like taxon Melanocamarosporium galiicola in Melanommataceae, while Melanodiplodia differs in having smaller conidiomata and heavily pigmented dark brown conidiomatal wall. However, M. galiicola is not available in GenBank and Pem et al. (2019d) did not include this species in the phylogenetic analysis.

Melanocamarosporium Wijayaw., Camporesi, Bhat \& K.D. Hyde, Fungal Divers. 77: 160 (2016). Index Fungorum number: IF 551780; Facesoffungi number: FoF 01522; 1 morphological species (Species Fungorum 2020), molecular data unavailable.

Type species - Melanocamarosporium galiicola Wijayaw., Camporesi, Bhat \& K.D. Hyde, Fungal Divers. 77: 160 (2016).

Notes - Melanocamarosporium galiicola has pycnidial, subepidermal conidiomata, erumpent at maturity, dark brown to black, with a papillate ostiole, conidiogenous cells that are enteroblastic, phialidic, with periclinal thickenings, discrete, determinate, hyaline to subhyaline and oblong to ellipsoid conidia with a truncate base, obtuse at apex, muriform, with 2-4 transverse septa and 2-4 longitudinal septa, pale brown to medium brown (Wijayawardene et al. 2016a). The first camarosporium-like species introduced in Melanommataceae was based on morphological distinctness and phylogenetic analysis (Wijayawardene et al. 2014b, Tian et al. 2015b, Wijayawardene et al. 2016a). DNA sequence data are not available in GenBank, Pem et al. (2019d) introduced the second camarosporium-like genus Melanocamarosporioides which is similar to Melanocamarosporium.

Melanocucurbitaria Wanas., Gafforov \& K.D. Hyde, in Wanasinghe et al., Fungal Divers. 89: 87 (2018).

Index Fungorum number: IF 554158; Facesoffungi number: FoF 03999; 1 morphological species (Species Fungorum 2020), 1 species with molecular data.

Type species - Melanocucurbitaria uzbekistanica Wanas., Gafforov \& K.D. Hyde, in Wanasinghe et al., Fungal Divers. 89: 87 (2018).

Notes - Melanocucurbitaria uzbekistanica was collected from Uzbekistan, on branches of Acer pubescens. It is characterized by immersed or semi-erumpent, coriaceous, black, globose to 
subglobose, ostiolate ascomata, septate pseudoparaphyses, bitunicate, cylindrical, asci and 1seriate, muriform, mostly ellipsoidal, with 6-8 transverse septa and 2-4-longitudinal septa, hyaline to brown, asymmetrical ascospores with a mucilaginous sheath. Melanocucurbitaria resembles Marjia, Gemmamyces, Melanocucurbitaria, Muriformistrickeria, Uzbekistanica, Pseudostrickeria and Praetumpfia in having muriform ascospores, however, Melanocucurbitaria separated distinctly from these genera in phylogenetic analysis (Wanasinghe et al. 2018c, Fig. 109 in this study).

Melanodiplodia Wanas., Gafforov \& K.D. Hyde, in Wanasinghe et al., Fungal Divers. 89: 92 (2018).

Index Fungorum number: IF 554160; Facesoffungi number: FoF 04001; 1 morphological species (Species Fungorum 2020), 1 species with molecular data.

Type species - Melanodiplodia tianschanica Wanas., Gafforov \& K.D. Hyde, in Wanasinghe et al., Fungal Divers. 89: 92 (2018).

Notes - Wanasinghe et al. (2018c) established Melanodiplodia to accommodate a diplodialike species which was saprobic on branches of Rosa ecae from Uzbekistan. It is characterized by pycnidial, stromatic, semi-immersed to immersed, globose to subglobose, dark brown to black, ostiolate conidiomata, holoblastic, cylindrical to subcylindrical, hyaline conidiogenous cells and hyaline to dark brown conidia, 1-septate while still attached to conidiogenous cells; detached conidia, hyaline, sepia or blackish brown, unicellular or 1-septate, oval to ovoid, apex obtuse, base truncate or rounded (Wanasinghe et al. 2018c). There is no sexual morph for Melanodiplodia (Wanasinghe et al. 2018c). Melanodiplodia is similar to Coniothyrium, Diplodia, Dothiorella, Forliomyces, Neodeightonia, Paulkirkia, Placodiplodia, Prillieuxina, Spencermartinsia in having 1-septate and brown conidia (Wijayawardene et al. 2016a, Wanasinghe et al. 2018c). However, Melanodiplodia clustered with Muriformistrickeria in a strongly-supported monophyletic clade in phylogenetic analysis (Wanasinghe et al. 2018c).

Monoseptella Wanas., Gafforov \& K.D. Hyde, in Wanasinghe et al., Fungal Divers. 89: 94 (2018).

Index Fungorum number: IF 554162; Facesoffungi number: FoF 04003; 1 morphological species (Species Fungorum 2020), 1 species with molecular data.

Type species - Monoseptella rosae Wanas., Gafforov \& K.D. Hyde, in Wanasinghe et al., Fungal Divers. 89: 94 (2018).

Notes - Monoseptella is characterized by superficial, globose to subglobose, ostiolate ascomata, septate pseudoparaphyses, bitunicate, cylindrical asci and overlapping 1-seriate, broadly fusoid to cylindrical, hyaline, 1-septate ascospores surrounded by a mucilaginous sheath (Wanasinghe et al. 2018c). There are no asexual morphs of Monoseptella reported (Wanasinghe et al. 2018c). Species in Asymmetricospora, Byssosphaeria, Herpotrichia and Sarimanas within Melanommataceae have hyaline, 1-septate ascospores (Tian et al. 2015, Wanasinghe et al. 2018c). However, Asymmetricospora has lenticular ascomata and clavate asci (Tian et al. 2015) versus Monoseptella which has globose to subglobose ascomata and cylindrical asci (Wanasinghe et al. 2018). Herpotrichia has guttulate and ellipsoidal ascospores and Sarimanas has broadly fusiform to ellipsoidal ascospores, while ascospores of Monoseptella are broadly cylindrical and not guttulate. Monoseptella is phylogenetically apart from these similar species in multi-gene phylogenetic analyses (Wanasinghe et al. 2018c), but clustered with Sarimanas and another asexual genus Pleotrichocladium. Wanasinghe et al. (2018c) suggested to merge Monoseptella, Pleotrichocladium and Sarimanas in one genus if the trichocladium-like asexual morphs is reported from both Monoseptella and Sarimanasi genera in the future.

Muriformistrickeria Q. Tian, Wanas., Camporesi \& K.D. Hyde, in Tian et al., Fungal Divers. 74: 267-324 (2015).

Index Fungorum number: IF 551596; Facesoffungi number: FoF 01035; 2 morphological species (Species Fungorum 2020), 2 species with molecular data.

Type species - Muriformistrickeria rubi Q. Tian, Wanas., Camporesi \& K.D. Hyde, in Tian et al., Fungal Divers. 74: 267-324 (2015). 
Notes - Tian et al. (2015) considered the muriform ascospore as the diagnostic character to distinguish Muriformistrickeria from other genera in Melanommataceae. Muriformistrickeria is characterized by flattened, semi-immersed to erumpent, dark brown to black, coriaceous, ostiolate ascomata, bitunicate, cylindrical, asci with short pedicel and 1-seriate, ellipsoidal, muriform, 3-6 transversely septate, with 2-4 vertical septa, hyaline to brown ascospores with a mucilaginous sheath. Muriformistrickeria has coelomycetous asexual morphs with pycnidial conidiomata, enteroblastic, phialidic, hyaline conidiogenous cells and cylindrical or ellipsoidal, hyaline, aseptate conidia (Tian et al. 2015). Wanasinghe et al. (2018c) introduced $M$. rosae on account of the characters of hyaline, subfusiform, slightly curved ascospores with 3-4 transverse septa and 1 vertical septum and phylogenetic distinctness. Other genera introduced with muriform ascospores in Melanommataceae, are Marjia, Gemmamyces, Melanocucurbitaria, Muriformistrickeria, Uzbekistanica, Pseudostrickeria and Praetumpfia (Tian et al. 2015, Jaklitsch \& Voglmayr 2017, Wanasinghe et al. 2018c). Although there is some morphological overlap among these genera, Muriformistrickeria is apart from these genera in phylogenetic analysis (Tian et al. 2015, Wanasinghe et al. 2018c, Pem et al. 2019d).

Navicella Fabre, Annls Sci. Nat., Bot., sér. 6 9: 96 (1879).

Index Fungorum number: IF 3429; Facesoffungi number: FoF 00777; 4 morphological species (Index Fungorum 2020), molecular data unavailable.

Type species - Navicella julii Fabre, Annls Sci. Nat., Bot., sér. 6 9: 96 (1879).

Notes - Barr (1990a) reappraised the type species Navicella julii and described the genus in having immersed to erumpent ascomata, clavate or cylindrical asci, trabeculate pseudoparaphyses and distoseptate ascospores. Navicella was considered to be closely related to Lophiostomataceae (Holm \& Holm 1988, Thambugala et al. 2015b) based on similar morphological characters, while Navicella has conspicuously thickened, distoseptate ascospores and lenticular lumina (Eriksson 1981, Thambugala et al. 2015b). Navicella was suggested to be a member of Melanommataceae based on the similarities in having superficial globose to subglobose, coriaceous ascomata with long, trabeculate pseudoparaphyses and brown ascospores, but differs from other genera of Melanommataceae in having ascospores with euseptate primary septa, while in others are distoseptate, with hyaline appendages at each end (Ariyawansa et al. 2014e, Tian et al. 2015).

Neobyssosphaeria Wanas., E.B.G. Jones \& K.D. Hyde, in Phukhamsakda et al., Fungal Divers 102: 57 (2020).

Index Fungorum number: IF 557189; Facesoffungi number: FoF 07281; 1 morphological species (Species Fungorum 2020), 1 species with molecular data.

Type species - Neobyssosphaeria clematidis Wanas., Phukhams., E.B.G. Jones \& K.D. Hyde, in Phukhamsakda et al., Fungal Divers 102: 57 (2020).

Notes - Neobyssosphaeria was recently established as a monotypic genus from Clematis vitalba with sexual morph, but the asexual morph is unknown (Phukhamsakda et al. 2020). This genus resembles Byssosphaeria in having an orange apex (Zhang et al. 2012b, Hyde et al. 2013, 2018, Tian et al. 2015, Phukhamsakda et al. 2020). However, Neobyssosphaeria is distinguished by its immersed ascomata with periphysate ostioles, cellular pseudoparaphyses and broad fusiform and hyaline ascospores. Phylogenetic analyses indicate that it should be separated from Byssosphaeria in Melanommataceae (Phukhamsakda et al. 2020).

Petrakia Syd. \& P. Syd., in Sydow \& Sydow, Annls mycol. 11(5): 406 (1913).

Index Fungorum number: IF 9277; Facesoffungi number: FoF 01820; 6 morphological species (Species Fungorum 2020), 4 species with molecular data.

Type species - Petrakia echinata (Peglion) Syd. \& P. Syd., Annls mycol. 11(5): 406 (1913).

E Epicoccum echinatum Peglion, Malpighia 8: 459 (1895).

Notes - Petrakia is characterized by sporodochial conidiomata and muriform, brown conidia with cellular, hyaline appendages (Sydow \& Sydow 1913b, Butin et al. 2013, Jaklitsch \& Voglmayr 2017). Petrakia has mycopappus-like propagules as an asexual morph in its life cycles, 
and sexual morph of $P$. echinata was reported by Butin et al. (2013). Based on phylogenetic studies, Phookamsak et al. (2014c), Tian et al. (2015) and Jaklitsch \& Voglmayr (2017) included Petrakia in Melanommataceae. Hashimoto et al. (2017a) proposed Pseudodidymellaceae to accommodate four genera Mycodidymella, Petrakia, Pseudodidymella, and Xenostigmina based on the characters of epiphyllous, lenticular ascomata in sexual morphs and mycopappus-like propagules in their asexual morphs. In this study, the type species $P$. echinata clusters with Xenostigmina zilleri (CBS 115685) with $79 \%$ MLBS, and formed a sister group with Seifertia within Melanommataceae (Fig. 109). We retain Petrakia in Melanommataceae.

Phragmocephala E.W. Mason \& S. Hughes, Naturalist (Hull), ser. 3, 1951: 97 (1951).

Index Fungorum number: IF 9367; Facesoffungi number: FoF 00783; 9 morphological species (Species Fungorum 2020), 2 species with molecular data.

Type species - Phragmocephala elliptica (Berk. \& Broome) S. Hughes, N.Z. J1 Bot. 17(2): 164 (1979).

三 Monotospora elliptica Berk. \& Broome, Ann. Mag. nat. Hist., Ser. 5 7: 130 (1881).

Notes - Phragmocephala elliptica as generic type was originally described as Monotospora elliptica (Mason \& Hughes 1951, Whitton et al. 2012). Phragmocephala species are hyphomycetous and characterized by macronematous, septate, erect, dark brown at the base, pale brown at apex, 4-8-septate conidiophores, holoblastic, terminal, integrated, light brown to pale brown conidiogenous cells and ellipsoidal to subglobose, 4-6 septate dark brown conidia withpale brown apical and basal cells (Mason \& Hughes 1951, Whitton et al. 2012, Su et al. 2015, Tian et al. 2015). The placement of Phragmocephala was confused due to the similarities in conidiogenesis with Endophragmia, but without molecular data (Ellis 1959, 1971, Hughes 1979). Su et al. (2015) provided molecular evidence for $P$. garethjonesii and $P$. atra. Phragmocephala was a distinct clade within Melanommataceae in the multi-gene phylogenetic analysis (Su et al. 2015, Tian et al. 2015, Wanasinghe et al. 2018c).

Phragmotrichum Kunze, in Kunze \& Schmidt, Mykologische Hefte (Leipzig) 2: 84 (1823).

Index Fungorum number: IF 9376; Facesoffungi number: FoF 08297; 5 morphological species (Species Fungorum 2020), 1 species with molecular data.

Type species - Phragmotrichum chailletii Kunze, in Kunze \& Schmidt, Mykologische Hefte (Leipzig) 2: 84 (1823)

Notes - Phragmotrichum is characterized by stromatic to cupulate conidiomata, cylindrical, hyaline conidiophores, thallic, integrated, cylindrical conidiogenous cells, producing unbranched basipetal chains of muriform, fusoid to ellipsoid, brown conidia. The holotype of $P$. chailletii was destroyed during World War II, and Crous et al. (2019c) designated a neotype which was also collected from Switzerland. Sequence data in Phragmotrichum indicated that the type species $P$. chailletii clustered within Melanommataceae (Crous et al. 2019c).

Pleotrichocladium Hern.-Restr., R.F. Castañeda \& Gené, in Hernández-Restrepo et al., Stud. Mycol. 86: 74 (2017).

Index Fungorum number: IF 820277; Facesoffungi number: FoF 08298; 1 morphological species (Species Fungorum 2020), 1 species with molecular data.

Type species - Pleotrichocladium opacum (Corda) Hern.-Restr., R.F. Castañeda \& Gené, in Hernández-Restrepo et al., Stud. Mycol. 86: 75 (2017).

三Sporidesmium opacum Corda, Icon. fung. (Prague) 1: 7 (1837).

Notes - Pleotrichocladium was established by Hernández-Restrepo (2017) to accommodate a widely-distributed species Trichocladium opacum which was originally identified as Sporidesmium opacum based on phylogenetic analysis with strong bootstrap surpport.Pleotrichocladium opacum has pale brown conidiogenous cells and smooth conidia with schizolytic secession while the generic type of Trichocladium, T. asperum has hyaline conidiogenous cells, verrucose conidia and rhexolytic secession (Hambleton et al. 2005, Hernández-Restrepo 2017). Phylogenetically, 
Pleotrichocladium opacum aligned within Melanommataceae, while $T$. asperum was placed in Chaetomiaceae (Hambleton et al. 2005, Hernández-Restrepo 2017, Wanasinghe et al. 2018c).

Praetumpfia Jaklitsch \& Voglmayr, Sydowia 69: 91 (2017).

Index Fungorum number: IF 819139; Facesoffungi number: FoF 08299; 1 morphological species (Species Fungorum 2020), 1 species with molecular data. (2017).

Type species - Praetumpfia obducens (Schumach.) Jaklitsch \& Voglmayr, Sydowia 69: 91

$\equiv$ Sphaeria obducens Schumach., Enum. pl. (Kjbenhavn) 2: 159 (1803)

Notes - Jaklitsch \& Voglmayr (2017) designated a lectotype based on morphological characters and phylogenetic analysis. It is characterized by superficial, globose, subglobose or pyriform, black ascomata, septate pseudoparaphyses, bitunicate, cylindrical, subclavate asci and ellipsoid, pale to medium brown, muriform ascospores with (3)5-7(8) transverse septa and 1-3 longitudinal septa (Jaklitsch \& Voglmayr 2017). The asexual morph of Praetumpfia obducens always occurred on bark while sexual morph was on attached branches (Jaklitsch \& Voglmayr 2017). Praetumpfia obducens is regarded as host specific for Fraxinus, and damages trees to some extent (Petrak 1927, Jaklitsch \& Voglmayr 2017).

Pseudobyssosphaeria H.B. Jiang \& K.D. Hyde, Mycosphere 9(2): 303 (2018).

Index Fungorum number: IF 554471; Facesoffungi number: FoF 08300; 1 morphological species (Species Fungorum 2020), 1 species with molecular data.

Type species - Pseudobyssosphaeria bambusae H.B. Jiang \& K.D. Hyde, in Hyde et al., Mycosphere 9(2): 306 (2018).

Notes - Pseudobyssosphaeria was introduced based on DNA sequence analysis (Hyde et al. 2018). It is characterized by superficial, subglobose, blackened, ostiolate ascomata with outwardly brown, septate, branched hyphae, dark brown, unbranched, septate setae, septate, branched pseudoparaphyses, bitunicate, cylindrical to clavate asci and fusiform, hyaline, 1-septate ascospores. Pseudobyssosphaeria bambusae is similar to Bertiella (Hyde et al. 2018) as they are similar. Hyde et al. (2018) realized problems with DNA sequence analysis and thus introduced Pseudobyssosphaeria temporarily. This was ignored by Pem et al. (2019c) who did not include this genus in their multi-gene phylogenetic analysis.

Pseudodidymella C.Z. Wei, Y. Harada \& Katum., Mycologia 89(3): 494 (1997).

Index Fungorum number: IF 27703; Facesoffungi number: FoF 08301; 2 morphological species (Species Fungorum 2020), 2 species with molecular data.

Type species - Pseudodidymella fagi C.Z. Wei, Y. Harada \& Katum., Mycologia 89(3): 496 (1997).

Notes - Pseudodidymella was originally characterized by lenticular ascomata with a welldeveloped basal stroma, bitunicate, cylindrical asci with a short stipe, fusiform, 1-septate, hyaline ascospores, pycnopleiospora-like asexual morph and produce mycopappus-like propagules in their asexual morphs (Wei et al. 1997, 1998, Gross et al. 2017, Hashimoto et al. 2017a). Pseudodidymella is similar to Mycodidymella, but can be distinguished by its sporodochial conidiomata and appendage-bearing conidia (Wei et al. 1998, Gross et al. 2017). Hashimoto et al. (2017a) proposed to include Pseudodidymella in Pseudodidymellaceae based on mycopappus-like propagules and phylogenetic analysis. There are two species accepted in Pseudodidymella with molecular data, P. fagi and P. minima. We retain Pseudodidymella in Melanommataceae.

Pseudostrickeria Q. Tian, Wanas., Camporesi \& K.D. Hyde, in Tian et al., Fungal Divers. 74: 267324 (2015).

Index Fungorum number: IF 551598; Facesoffungi number: FoF 01032; 3 morphological species (Species Fungorum 2020), 3 species with molecular data.

Type species - Pseudostrickeria muriformis Wanas., Q. Tian, Camporesi \& K.D. Hyde, in Tian et al., Fungal Divers. 74: 267-324 (2015). 
Notes - Tian et al. (2015) established Pseudostrickeria to accommodate Pseudostrickeria muriformis and Pseudostrickeria ononidis based on morphological characters and multi-gene phylogenetic analysis. Subsequently, $P$. rosae was introduced with strong bootstrap support (Wanasinghe et al. 2018c). It is characterized by semi-immersed to erumpent, broadly oblong, globose to subglobose, dark brown to black, coriaceous, ostiolate ascomata, bitunicate, cylindrical to cylindric-clavate, short or bulbous pedicellate asci and ellipsoidal, hyaline to brown, muriform, 3-6 transversely septate, 1-4 longitudinal septate ascospores (Tian et al. 2015, Wanasinghe et al. 2018c). Pseudostrickeria ressembles Gemmamyces, Melanocucurbitaria, Muriformistrickeria and Praetumpfia in having muriform ascospores in Melanommataceae. However, Pseudostrickeria species lack pseudoparaphyses which make them distinct from the above-mentioned genera in Melanommataceae (Tian et al. 2015, Wanasinghe et al. 2018c). In addition, Pseudostrickeria is phylogenetically distinct form other genera with strong support in multi-gene phylogenetic analyses (Fig. 109).

Sarimanas M. Matsum., K. Hiray. \& Kaz. Tanaka, in Liu et al., Fungal Divers. 72:126 (2015).

Index Fungorum number: IF 551052; Facesoffungi number: FoF 00497; 2 morphological species (Species Fungorum 2020), 2 species with molecular data.

Type species - Sarimanas shirakamiense M. Matsum., K. Hiray. \& Kaz. Tanaka, in Liu et al., Fungal Divers. 72:127 (2015).

Notes - Sarimanas was established by Liu et al. (2015) to accommodate S. shirakamiense (generic type) and S. pseudofluviatile based on morphological characters and phylogenetic analysis. It is characterized by immersed, globose to subglobose, ostiolate ascomata, septate pseudoparaphyses, cylindrical to ovoid asci and broadly fusiform, 1-septate, hyaline ascospores with an entire gelatinous sheath. Morphologically, Sarimanas is similar to Massarina, however, phylogenetic analyses indicate that this genus has a close affinity to genera in Melanommataceae (Liu et al. 2015).

Seifertia Partr. \& Morgan-Jones, Mycotaxon 83: 348 (2002).

Index Fungorum number: IF 28681; Facesoffungi number: FoF 08302; 2 morphological species (Species Fungorum 2020), 2 species with molecular data.

Type species - Seifertia azaleae (Peck) Partr. \& Morgan-Jones, Mycotaxon 83: 350 (2002).

三Periconia azaleae Peck, Bull. Buffalo Soc. nat. Sci. 1(2): 69 (1873).

Notes - The generic placement of Seifertia azalea was uncertain according to morphological study, thus, Seifertia was previously treated as Periconia (Peck 1873), Pycnostysanus (Mason 1941) and Sorocybe (Ellis 1976, Carmichael et al. 1980). Seifert et al. (2007) placed Seifertia in Dothideomycetes, as closely related to Mycosphaerella mycopappi and Crous et al. (2009a, 2013b) re-examined Xenostigmina and confirmed that it is a synanamorph of Mycopappus and allied to Seifertia in Pleosporales in combined ITS and LSU phylogenetic analysis. Tian et al. (2015) accepted Xenostigmina and Mycopappus in Melanommataceae, but ruled out Seifertia according to multiple gene phylogenetic analyses. Li et al. (2016c) transferred S. azalea to Melanommataceae with a new species $S$. shangrilaensis collected from living rachides of Rhododendron decorum in South-west China. Seifertia is known to cause bud blight or bud blast disease of Rhododendron in China, Japan, Europe and North America (Mason 1941, Ellis 1976, Partridge \& Morgan-Jones 2002, Glawe \& Hummel 2006, Li et al. 2016c).

Tumularia Descals \& Marvanová, in Marvanová \& Descals, Trans. Br. mycol. Soc. 89(4): 506 (1987).

Index Fungorum number: IF 11216; Facesoffungi number: FoF 08303; 2 morphological species (Species Fungorum 2020), 2 species with molecular data.

Type species - Tumularia tuberculata (Gönczöl) Descals \& Marvanová, in Marvanová \& Descals, Trans. Br. mycol. Soc. 89(4): 506 (1987).

三 Monotosporella tuberculata Gönczöl, Nova Hedwigia 27(1-2): 493 + 495 (1976) 
Notes - Tumularia species are aquatic saprobes and can be found in Europe, North and South America as a hyphomycetous asexual morph, but the sexual morph is unknown (Seifert et al. 2011, Wijayawardene et al. 2012, 2014b, 2017a). Hyde et al. (2013) and Wijayawardene et al. (2018) accepted this genus in Lophiostomataceae. However, phylogenetic analyses indicate that it should be in Melanommataceae (Fig. 109).

Xenostigmina Crous, Mycol. Mem. 21: 154 (1998).

Index Fungorum number: IF 27785; Facesoffungi number: FoF 00781; 2 morphological species (Hashimoto et al. 2017a), 2 species with molecular data.

Type species - Xenostigmina zilleri (A. Funk) Crous, Mycol. Mem. 21: 155 (1998).

三Stigmina zilleri A. Funk, Can. J. Bot. 65(3): 482 (1987).

Notes - Xenostigmina causes brown spot disease in Acer macrophyllum (Funk 1986). It is characterized by sporodochial, conidiomata, verruculose, brown, 1-3-septate conidiophores, verruculose conidiogenous cells and broadly ellipsoidal to obclavate or subcylindrical, muriform, verruculose conidia (Funk 1986, Crous 1998, Tian et al. 2015, Hashimoto et al. 2017a). Crous (1998) revealed that Xenostigmina with its Mycopappus synanamorph is distinct from Stigmina sensu stricto, which has not been shown to reside in Pseudocercospora, but appears to be related to Seifertia (Seifert et al. 2007) in the Dothideomycetes (Crous et al. 2009a). Based on phylogenetic studies, Phookamsak et al. (2014c) and Tian et al. (2015) proposed to include Xenostigmina in Melanommataceae. Hashimoto et al. (2017a) proposed to include two species X. zilleri and a new combination Xenostigmina aceris in Pseudodidymellaceae based on mycopappus-like propagules and phylogenetic analysis. The present multi-gene analysis indicated that Xenostigmina zilleri (CBS 115685) is related to Petrakia echinata (HB 090918.1) and formed a single clade in Melanommataceae (Fig. 109). Thus, Xenostigmina is retained in Melanommataceae.

Uzbekistanica Wanas., Gafforov \& K.D. Hyde, in Wanasinghe et al., Fungal Divers 89: 100 (2018).

Index Fungorum number: IF 554166; Facesoffungi number: FoF 04008; 4 morphological species (Species Fungorum 2020), 4 species with molecular data.

Type species - Uzbekistanica rosae-hissaricae Wanas., Gafforov \& K.D. Hyde, in Wanasinghe et al., Fungal Divers 89: 100 (2018).

Notes - Wanasinghe et al. (2018c) introduced Uzbekistanica typified by the sexual morph species Uzbekistanica rosae-hissaricae and asexual species $U$. yakutkhanika which formed a sister group with $U$. rosae-hissaricae in a distinct monophyletic clade. Uzbekistanica is characterized by broadly oblong ascomata, septate pseudoparaphyses, cylindrical to cylindric-clavate asci, and muriform, ellipsoidal, yellowish brown to brown ascospores. The asexual morph is coelomycetous, with globose conidiomata, holoblastic, cylindrical to subcylindrical, hyaline conidiogenous cells and 1-septate, sepia or brown conidia (Wanasinghe et al. 2018c). Hyde et al. (2020b) introduced the new species, $U$. pruni collected from dead twigs of Prunus armeniaca in Russia.

\section{Ecological and economic significance}

Melanommataceae is widespread in temperate and subtropical regions and species invariably occur on twigs or bark of various woody plants in terrestrial, marine or freshwater habitats. Most species in Melanommataceae are reported as saprobes, endophytes or hyperparasite and occur on woody plants (Partridge \& Morgan-Jones 2002, Seifert et al. 2007, Crous et al. 2009a, 2013b, Tian et al. 2015, Li et al. 2016c, Hashimoto et al. 2017a, Jaklitsch \& Voglmayr 2017, Tibpromma et al. 2017, Wanasinghe et al. 2018c, Pem et al. 2019d). Seifertia is known to cause bud blight or bud blast disease of Rhododendron in China, Japan, Europe and North America (Mason 1941, Ellis 1976, Partridge \& Morgan-Jones 2002, Glawe \& Hummel 2006, Li et al. 2016c). Praetumpfia obducens is regarded as host specific for Fraxinus, and damages trees to some extent, but does not cause dieback (Petrak 1927, Jaklitsch \& Voglmayr 2017). 
Morosphaeriaceae Suetrong, Sakayaroj, E.B.G. Jones \& C.L. Schoch, Stud. Mycol. 64:161 (2009). Index Fungorum number: IF 515953; Facesoffungi number: FoF 08304, 32 species.

Saprobic on lignocellulosic materials in marine, and freshwater habitats, or root endophyte of white poplar. Sexual morph: Ascomata solitary or gregarious, subglobose to lenticular, immersed becoming superficial, ostiolate, papillate, coriaceous, brown to black. Hamathecium numerous, filamenatous, branched, anastomosing, usually cellular pseudoparaphyses. Asci 8-spored, clavate to cylindrical, short pedunculate, thick-walled, bitunicate, fissitunicate, with an ocular chamber and apical apparatus, persistent. Ascospores 2-seriate, fusiform to ellipsoidal, hyaline to brown, 1-3septate, mostly constricted at the septa, surrounded by a mucilaginous sheath. Asexual morph: Undetermined.

Type - Morosphaeria Suetrong, Sakayaroj, E.B.G. Jones \& C.L. Schoch.

Notes - Suetrong et al. (2009) introduced Morosphaeriaceae in Pleosporales for two Massarina species M. ramunculicola and M. velatispora, which did not group in Massarinaceae. Presently, Aquilomyces, Clypeoloculus, Morosphaeria and Helicascus are accepted in this family, with some species collected from freshwater habitats (Suetrong et al. 2009, Hyde et al. 2013, Wijayawardene et al. 2014b, Zhang et al. 2013a, 2014c, 2015b, Tanaka et al. 2015, Luo et al. 2016, Zeng et al. 2018a, Jones et al. 2019a).

Morosphaeria Suetrong, Sakayaroj, E.B.G. Jones \& C.L. Schoch., Stud. Mycol. 64:161 (2009).

Index Fungorum number: IF 515954; Facesoffungi number: FoF 06534; 3 morphological species (Zhang et al. 2013a, Devadatha et al. 2018a), 3 species with molecular data.

Type species - Morosphaeria velatispora (K.D. Hyde \& Borse) Suetrong, Sakay., E.B.G. Jones \& C.L. Schoch, Stud. Mycol. 64: 161 (2009).

Notes - Morosphaeria was introduced by Suetrong et al. (2009) for two Massarina species $M$. ramunculicola and $M$. velatispora. Subsequently, Boonmee et al. (2012) transferred Kirschsteiniothelia elaterascus to Morosphaeria based on phylogenetic analysis. However, this species was transferred to Helicascus by Zhang et al. (2013a). Devadatha et al. (2018a) introduced a new species $M$. muthupetensis. Therefore, three species are accepted in this genus based on morphology and phylogenetic analysis and all are reported from marine habitats (Devadatha et al. 2018a).

Morosphaeria velataspora (K. D. Hyde \& Borse) Suetrong, Sakayaroj, E.B.G. Jones \& Schoch, Stud. Mycol. 64:155 (2009).

三 Massarina velatispora K.D. Hyde \& Borse, Mycotaxon 27: 161 (1986).

Fig. 110

Index Fungorum number: IF 542982; Facesoffungi number: FoF 08305.

Saprobic on wood in mangrove habitats. Sexual morph: Ascomata 200-650 $\mu \mathrm{m}$ high, 350$800 \mu \mathrm{m}$ diam $(\bar{x}=371 \times 522 \mu \mathrm{m}, \mathrm{n}=5)$, immersed to erumpent solitary to gregarious, subglobose, raised, ostiolate, papillate, coriaceous, brown to black. Ostiole 65-330 $\mu \mathrm{m}$ long, 40-180 $\mu \mathrm{m}(\bar{x}=$ $196 \times 108 \mu \mathrm{m}, \mathrm{n}=5)$ diam., conical, black. Peridium 20-70 $\mu \mathrm{m}$ diam. $(\bar{x}=39 \mu \mathrm{m}, \mathrm{n}=10)$, composed of thick-walled polyhedral cells of textura angularis fused with the host tissue. Hamathecium comprising 2-3 $\mu \mathrm{m}$ wide, numerous, septate, branched, filamentous to trabeculate pseudoparaphyses, resembling hyphae, embedded in a gelatinous matrix, anastomosing above the

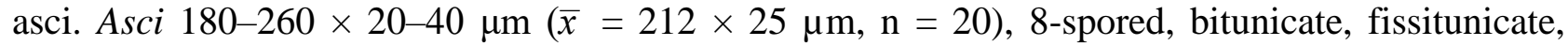
clavate to cylindrical, short to long pedunculate, with an apical apparatus, thick-walled, bitunicate. Ascospores $45-55 \times 12-17 \mu \mathrm{m},(\bar{x}=48 \times 14 \mu \mathrm{m}, \mathrm{n}=50)$, obliquely 1-seriate, fusiform to ellipsoidal, hyaline, 1-3 septate, constricted at the septa, central cells larger, apical cells smaller and elongate, ascospores surrounded by a mucilaginous sheath. Asexual morph: Undetermined.

Culture characteristics - Ascospores germinating on $2 \%$ sea water agar within $24 \mathrm{~h}$ with germ tubes produced from terminal ends. Colonies on malt extract sea water agar fast growth, white to pale pink, reverse pale brown, velvety, lobate, reaching 20 to $40 \mathrm{~mm}$ in diameter in 25 days at room temperature. 
Material examined - India, Tamil Nadu, Parangipettai mangroves, $\left(11.59^{\circ} \mathrm{N} 79.5^{\circ} \mathrm{E}\right)$, on decaying wood of Rhizophora mucronata (Rhizophoraceae), 23 April 2018, B. Devadatha, AMH9995, living culture, NFCCI-4425.

GenBank numbers - ITS: MK026766, LSU: MK026764, rpb-2: MN532683, SSU: MK026765, tef1: MN532688.

Notes - Morphology (Fig. 110) indicates that our new collection is identical to the species Morosphaeria velataspora. This result was supported by phylogenetic analyses in which our collection clustered with another strain of $M$. velatasporai with high bootstrap support (100\% MLBS, 1.0 PP, Fig. 42).

\section{Other genera included}

Aquihelicascus W. Dong, H. Zhang \& Doilom, Fungal Divers (2020).

Index Fungorum number: IF 557806; Facesoffungi number: FoF 08721; 3 morphological species (Dong et al. 2020), 1 species with molecular data

Type species - Aquihelicascus thalassioideus (K.D. Hyde \& Aptroot) W. Dong \& H. Zhang, Fungal Divers (2020).

三 Massarina thalassioidea K.D. Hyde \& Aptroot, Nova Hedwigia 66(3-4): 498 (1998)

$=$ Helicascus thalassioideus (K.D. Hyde \& Aptroot) Huang Zhang \& K.D. Hyde, Sydowia 65(1): 159 (2013)

Notes - Aquihelicascus was introduced to accommodate the three species, A. thalassioideus (type species), A. songkhlaensis and A. yunnanensis (Dong et al. 2020), based on phylogenetic analyses. The three species formed a clade sister to Helicascus but as a different genus. Aquihelicascus differs from Helicascus in having clavate asci, with uncoiled endoascus, 2-seriate, ellipsoidal, symmetrical, hyaline ascospores, with rounded ends, while Helicascus has subcylindrical asci, with coiled endoascus, 1-seriate, obovoid, asymmetrical, brown ascospores, with apiculate ends (Luo et al. 2016, Dong et al. 2020).

Aquilomyces D.G. Knapp, Kovács, J.Z. Groenew. \& Crous, Persoonia 35: 93 (2015).

Index Fungorum number: IF 810756; Facesoffungi number: FoF 08306; 2 morphological species (Species Fungorum 2020), 2 species with molecular data

Type species - Aquilomyces patris D.G. Knapp, Kovács, J.Z. Groenew. \& Crous, Persoonia 35: 93 (2015).

Notes - Aquilomyces patris, a root endophyte of white poplar. Two species are accepted in this genus (Tanaka et al. 2015).

Clypeoloculus Kaz. Tanaka \& K. Hiray., Stud. Mycol. 82: 108 (2015).

Index Fungorum number: IF 811318; Facesoffungi number: FoF 08307; 4 morphological species (Species Fungorum 2020), 4 species with molecular data (2015).

Type species - Clypeoloculus akitaensis Kaz. Tanaka \& K. Hiray., Stud. Mycol. 82: 109

Notes - Clypeoloculus comprises freshwater species which are characterized by globose to subglobose ascomata with a prominent clypeus, clavate asci, and 1-septate, hyaline ascospores with an entire sheath. Four species are accepted in this genus (Tanaka et al. 2015).

Helicascus Kohlm., Can. J. Bot. 47: 1471 (1969).

Index Fungorum number: IF 2255; Facesoffungi number: FoF 08308; 11 morphological species (Species Fungorum 2020), 11 species with molecular data

Type species - Helicascus kanaloanus Kohlm., Can. J. Bot. 47: 1471 (1969).

Notes - Members of Helicascus have immersed ascomata with uni- or multi-locules, bitunicate asci and septate ascospores with or without a mucilaginous sheath (Kohlmeyer 1969, Luo et al. 2016, Jones et al. 2019a). 

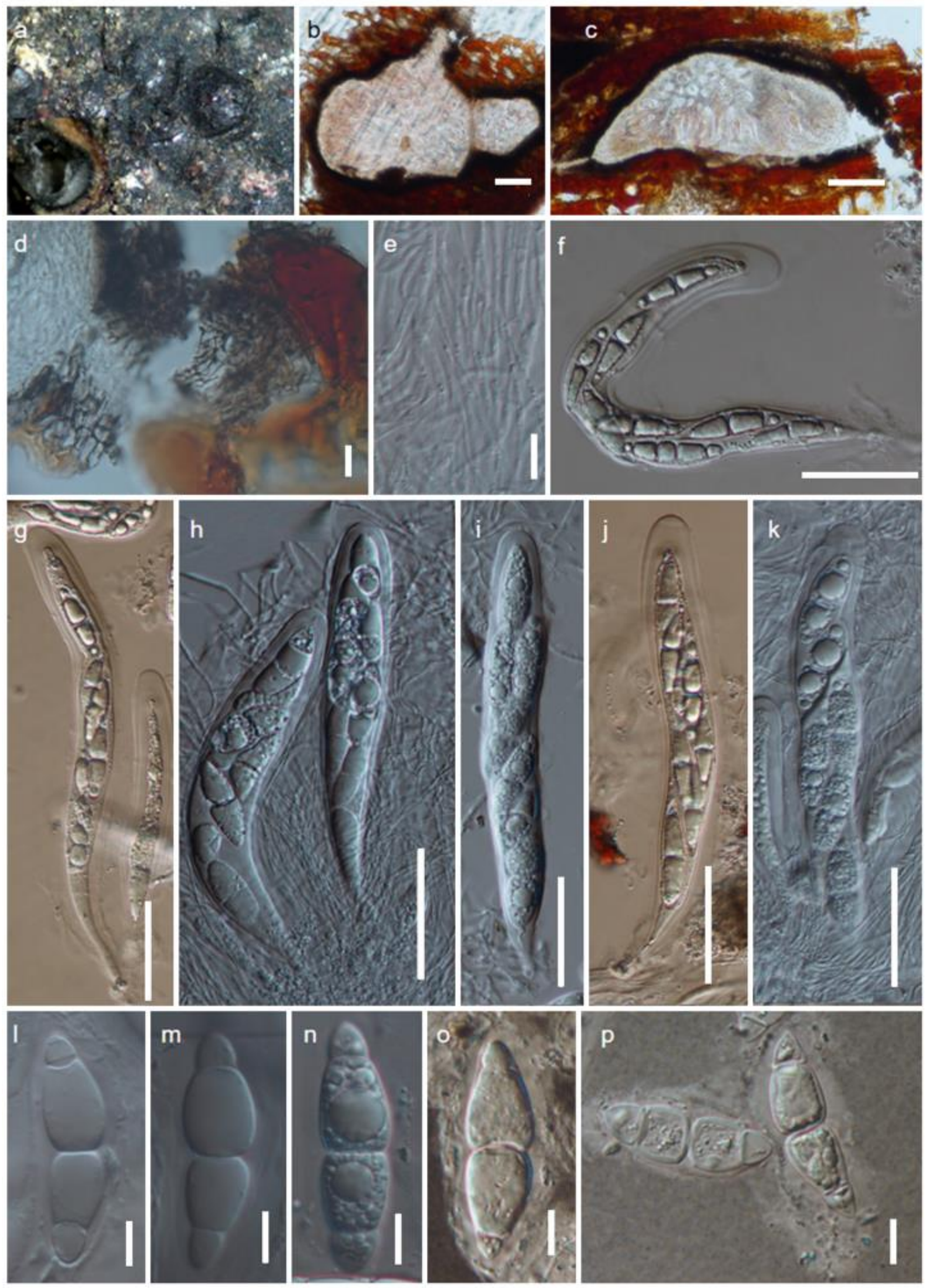

Figure 110 - Morosphaeria velatispora (NFCCI-4425). a Erumpent ascomata on decaying wood. $\mathrm{b}$, c. Longitudinal sections of ascomata. d Peridial wall layers. e Hamathecium showing filamentous pseudoparaphyses. $\mathrm{f}-\mathrm{k}$ Immature and mature asci. $1-\mathrm{n}$ Immature and mature ascospores. o-p Ascospores showing mucilaginous sheath in Indian ink. Scale bars: $b, \mathrm{~d}, \mathrm{f}-\mathrm{h}=50$ $\mu \mathrm{m}, \mathrm{c}, \mathrm{e}, \mathrm{i}-\mathrm{o}=10 \mu \mathrm{m}$. 
Neohelicascus W. Dong, H. Zhang \& Doilom, Fungal Divers (2020).

Index Fungorum number: IF 557807; Facesoffungi number: FoF 08722; 8 morphological species (Dong et al. 2020), X species with molecular data

Type species - Neohelicascus aquaticus (H. Zhang \& K. D. Hyde) W. Dong \& H. Zhang, Fungal Divers (2020).

$\equiv$ Helicascus aquaticus H. Zhang \& K.D. Hyde, Sydowia 65(1): 155 (2013)

Notes - Neohelicascus differs from Aquihelicascus in having brown ascospores, and the base of endoascus is long, narrow and coiled within ectoascus which uncoils to form a long tail-like extension. Aquihelicascus has hyaline ascospores and uncoiled endoascus (Dong et al. 2020). Phylogenetic analyses also supported it as a new genus in Morosphaeriaceae (Dong et al. 2020).

\section{Ecological and economic significance}

Members belonging to this family are saprobic and probably have the ability to decompose lignocellulose in woody litter and softening the wood (Yuen et al. 1998, Bucher et al. 2004). A mucilaginous sheaths and appendages, which are two major adaptations of marine fungi, confer the ability to attach to the surfaces of different substrata in marine environment (Jones 1994, 2006).

Mycoporaceae Zahlbr., Nat. Pflanzenfam., Teil. I (Leipzig) 1(1*): 77 (1903).

Index Fungorum number: IF 81042; Facesoffungi number: FoF 08309, 12 species.

Non-lichenized or facultatively lichenized on bark of trees or on stones. Hyphae thick, almost hydnoid-corticioid, yellowish, consisting of loose, branched, with finely verrucose, cells born at tips of hyphae resembling blastospores. Sexual morph: Ascostromata comprises pale mycelium, loose, copiously branched, with multi-loculate. Locules scattered, aggregated, botryose or immersed in ascostroma, sphaerical or conical, erumpent or superficial, black, globose to subglobose or irregular, without wall of their own. Ostiole an apical pore or an elongated channel. Peridium of pseudoparenchymatous cells, thin-walled, pale brown to brown, hyaline, hymenium often gelatinous, comprises textura globose cells. Hamathecium comprising filiform, often septate, hyaline, pseudoparaphyses. Asci 8-spored, bitunicate, fissitunicate, cylindrical, obclavate or thickest in the middle, with a short-pedicel, ectotunica thin; endotunica very thick in upper half of ascus, thin in lower half without ring structures, with long tapering ocular chamber. Ascospores irregularly arranged, ellipsoidal, fusiform to clavate with upper hemispore broader, hyaline at immature with thin gelatinous sheath asci firmly enclosed in strongly reticulate, brownish at maturity, variably septate, muriform, not constricted at the septa. Asexual morph: Undetermined (adapted from Hyde et al. 2013).

Type - Mycoporum Flot. ex Nyl.

Notes - Mycoporaceae was established by Zahlbruckner (1903) to accommodate a single genus, Mycoporum. von Arx \& Müller (1975) mentioned that the typical characters of this family are unclear and it is difficult to distinguish Mycoporum from Pleosporaceae as some genera have a lichen habit. Lumbsch (1999) placed this family in Dothideales sensu stricto based on structure and development of ascomata in Mycoporum. Cannon \& Kirk (2007) accepted Cyrtidulamay in Mycoporaceae. The family contained only one genus in Hyde et al. (2013) and other recently papers e.g. Wijayawardene et al. (2017a) and Lücking et al. (2017). It has been mentioned of uncertain taxonomic placement in Dothideomycetes (Hyde et al. 2013). Molecular data is required to resolve its position within the Dothideomycetes.

Mycoporum Flot. ex Nyl., Mém. Soc. Imp. Sci. Nat. Cherbourg 3: 186 (1855).

Index Fungorum number: IF 3337; Facesoffungi number: FoF 08310; 12 morphological species (Species Fungorum 2020), molecular data see note below.

Type species - Mycoporum elabens (A. Massal.) Flot. ex Nyl.

三 Rhizocarpon elabens A. Massal., Ric. auton. lich. crost. (Verona): 103 (1852). 

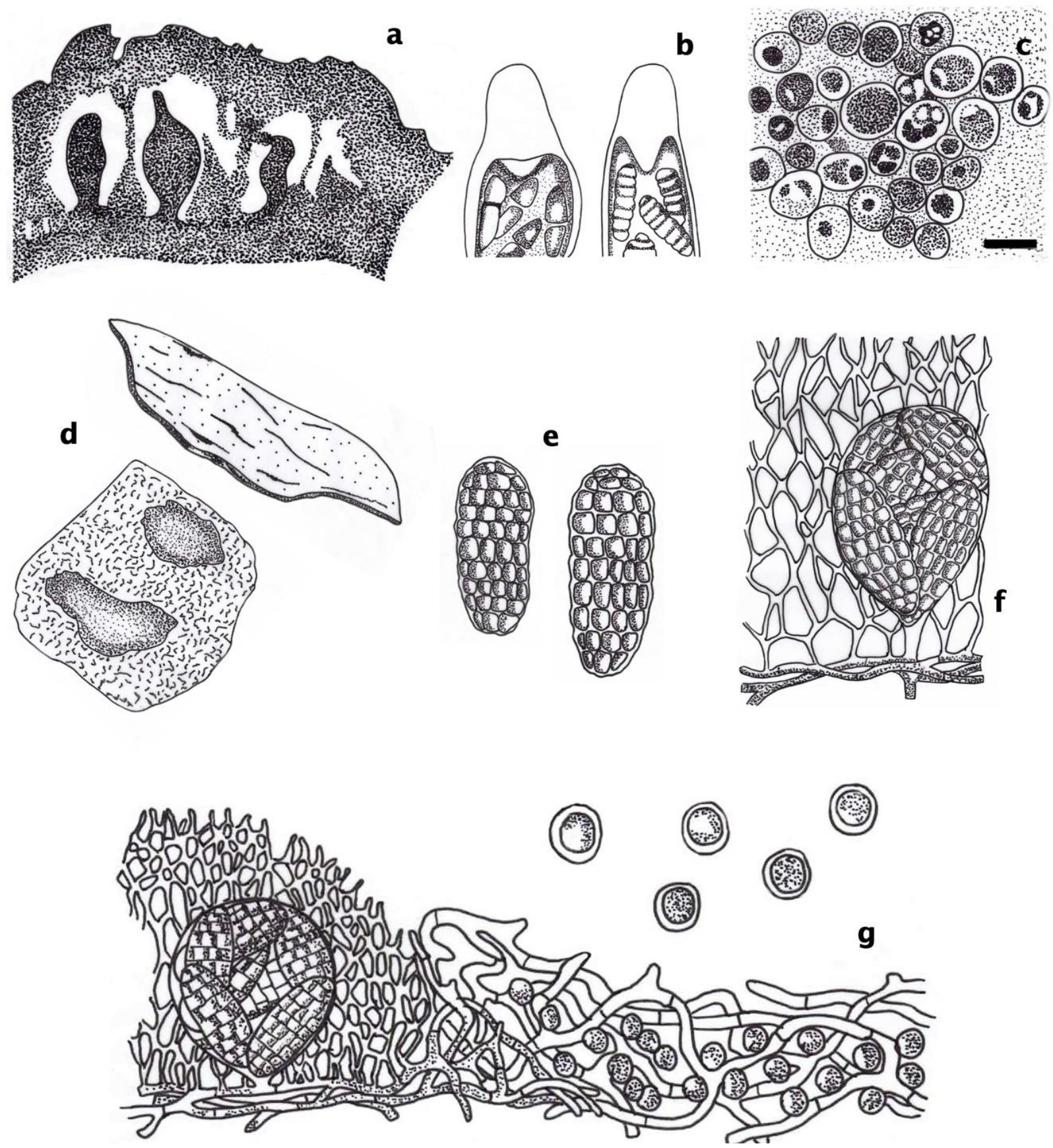

Figure 111 - Morphology of Mycoporum spp. (a-c = redrawn of Mycoporum pycnocarpum from text book of Schneider 1897; d-g = redrawn of Mycoporum elabens from Lumbsch 1999). a Ascostromata. b Bitunicate asci. c Algae associated with M. elabens. d Ascostromata on host surface. e Ascospores. f Asci. g Asci within ascostromata surrounded by Algae.

Notes - The taxonomic placement of Mycoporum is unclear (Eriksson 1981, Hyde et al. 2013). Harris (1973) and Poelt (1969) observed M. elabens (type species) and considered it as nonlichenized. Eriksson (1981) had examined old material and was unable to find any algal cells on the specimen, and noted that Mycoporum is probably related to Arthopyreniaceae. Harris (1995) suggested that Mycoporum does not produce a lichen thallus, and that when algae are present, they are not Trentepohlia algae. Lumbsch (1999) treated this genus as non-lichenized based on algae cells that did not have close contact with Mycoporum hyphae. Aptroot et al. (2008) added several species in this genus, however, none of them have molecular data. Hametner et al. (2014) provided sequence data for Mycoporum sparsellum and indicated that it clustered with Acrocordia gemmate as a sister clade to Trentepohlia abietina strains and are as yet unnamed trentepohlialean lineages. 
However, as this analysis was generated from $18 \mathrm{~S}$ rRNA and rbcL, more sequence data of Mycoporum with multi-genes are needed to clarify the placement of Mycoporaceae.

\section{Ecological and economic significance}

Mycoporum is saprobic on woody tissue lichenized, and has a widespread distribution (Cannon \& Kirk 2007, Kirk et al. 2008).

Neocamarosporiaceae Wanas., Wijayaw., Crous \& K.D. Hyde, Stud. Mycol. 87: 245 (2017).

Index Fungorum number: IF 821966; Facesoffungi number: FoF 03556, 21 species.

Saprobic of leaves and wood. Sexual morph: Ascomata superficial to semi-immersed, confluent, gregarious, fully or partly erumpent, globose, without papillate ostiole. Ostiole central, short, erect or slightly sunken, smooth, hyaline cells filled in ostiole canal. Peridium thin, comprising blackish to brown loosely packed cells of textura angularis. Hamathecium comprising numerous, filamentous, branched septate, cellular pseudoparaphyses. Asci 8-spored, bitunicate, fissitunicate, cylindricalclavate to cylindrical, pedicellate, rounded at apex, with a minute ocular chamber. Ascospores 1-seriately overlapping, muriform, mostly ellipsoidal, initially hyaline, becoming pale brown at maturity, 5-7-transversely septate, with 1-2 longitudinal septa, deeply constricted at middle septum, slightly constricted at remaining septa, rounded at both ends, surrounded by a mucilaginous sheath. Asexual morph: Conidiomata immersed, becoming erumpent, globose, brown to black, ostiolate. Ostiole central and papillate. Conidiomata thinwalled, composed of brown cells of textura angularis. Conidiophores reduced to conidiogenous cells. Conidiogenous cells proliferating several times percurrently near apex, ampulliform to doliiform, separate, hyaline, smooth-walled. Conidia solitary, initially hyaline, aseptate, developing initially a central septum and then becoming muriform, variable from globose to obovoid to ellipsoid, golden brown, finely roughened, thick-walled.

Type - Neocamarosporium Crous \& M.J. Wingf.

Notes - Neocamarosporiaceae is basically similar to the Pleosporaceae by its ascospores, but differs in several other characters. The characteristics of the ascomatal wall and their asexual morphs (coelomycetous and hyphomycetous) are specific from each other. Pleosporaceae species are characterized by thick peridium with several hyaline and pigmented cell layers, while Neocamarosporiaceae species can be identified in having thin peridium with only 2-3 pigmented cell layers and lack hyaline cell layers (Wanasinghe et al. 2017a).

Neocamarosporium Crous \& M.J. Wingf., Persoonia 32: 273 (2014).

Index Fungorum number: IF 808949; Facesoffungi number: FoF 03556; 20 morphological species (Species Fungorum 2020), 20 species with molecular data.

Type species - Neocamarosporium goegapense Crous \& M.J.Wingf.

Notes - Neocamarosporium described from South Africa is similar to Camarosporium based on its pycnidial conidiomata, hyaline, percurrently proliferating conidiogenous cells, and brown, muriform conidia (Crous et al. 2014b).

\section{Other genera included}

Dimorphosporicola Crous, Fungal Biol. 120(11): 1412 (2016).

Index Fungorum number: IF 816148; Facesoffungi number: FoF 08311; 1 morphological species (Species Fungorum 2020), 1 species with molecular data.

Type species - Dimorphosporicola tragani Crous, in Crous \& Groenewald, Fungal Biology 120(11): 1413 (2016).

Notes - Dimorphosporicola species are similar to Coleophoma species, but D. tragani differs from Coleophoma in having percurrently proliferating conidiogenous cells, and dimorphic conidia (Wanasinghe et al. 2017a). Dimorphosporicola and Neocamarosporium differ in macro-conidial morphology (Wanasinghe et al. 2017a). 

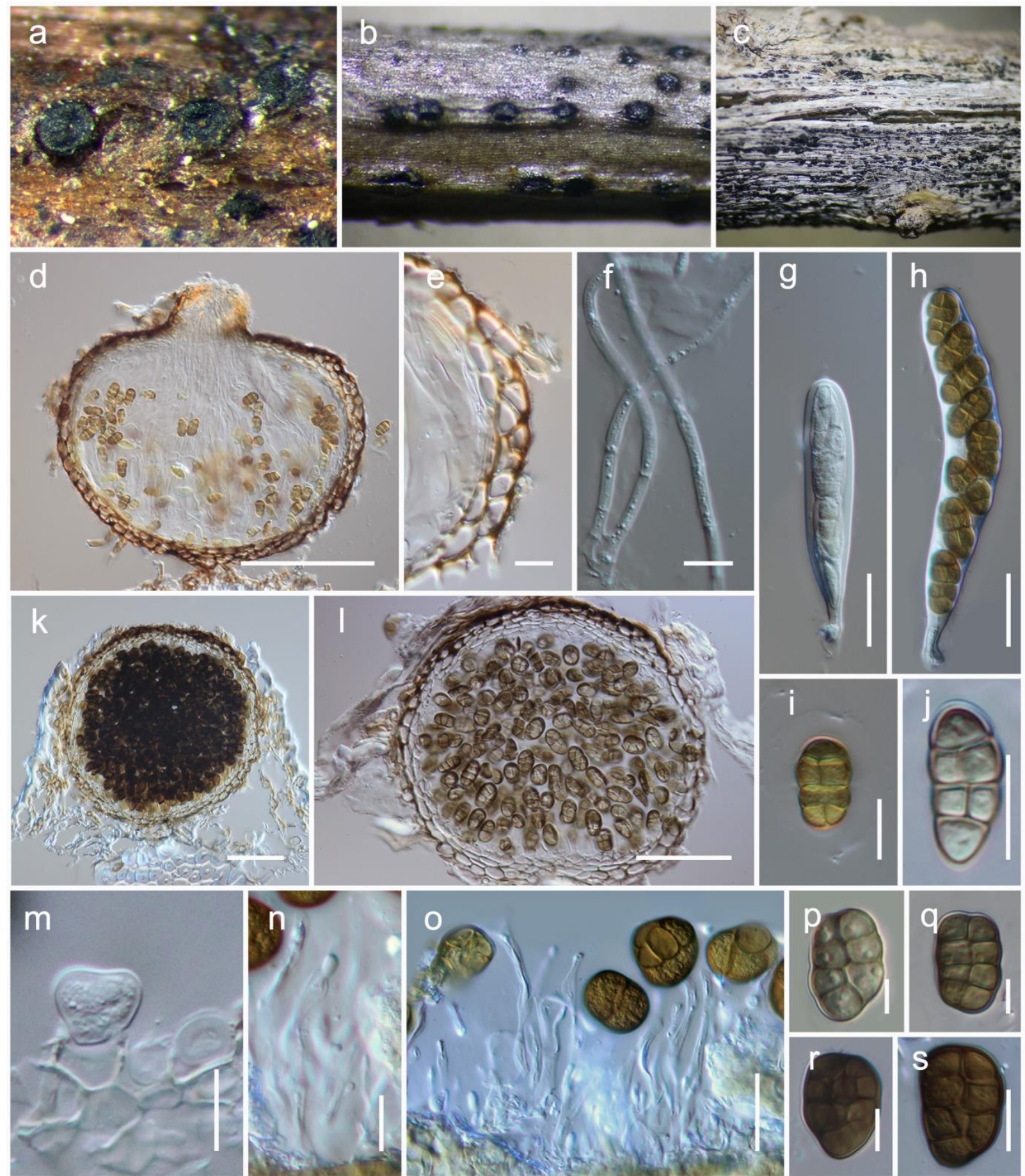

Figure 112 - Neocamarosporium. a Ascomata on the host surface. b, c Conidiomata on the host surface. d Vertical section of ascomata. e Section of peridium. f Pseudoparaphyses. g, h Asci. i, j Ascospores. k, 1 Vertical sections of conidiomata. $\mathrm{m}-\mathrm{n}$ Immature and mature conidia attached to conidiogenous cells. $\mathrm{p}-\mathrm{s}$ Conidia. (Notes $-\mathrm{a}, \mathrm{d}-\mathrm{i}=N$. lamiacearum; $\mathrm{c}, \mathrm{n}, \mathrm{o}, \mathrm{r}, \mathrm{s}=N$. salsolae; $\mathrm{b}, \mathrm{k}$, $\mathrm{m}=N$. korfii $; 1, \mathrm{p}, \mathrm{q}=N$. salicorniicola $; \mathrm{j}=N$. phragmitis $)$. Scale bars: $\mathrm{d}=100 \mu \mathrm{m}, \mathrm{e}, \mathrm{i}, \mathrm{j}, \mathrm{m}, \mathrm{n}=$ $10 \mu \mathrm{m}, \mathrm{f}-\mathrm{h}, \mathrm{o}=20 \mu \mathrm{m}, \mathrm{k}, 1=50 \mu \mathrm{m}, \mathrm{p}-\mathrm{s}=5 \mu \mathrm{m}$.

\section{Ecological and economic significance}

Neocamarosporium species can be found associated with saline, soil niches indicating their potential capability in the degradation and recycling plants (Crous et al. 2014b). However, these fungi can be a potential to study in applicability of agriculture in drought and salinity-affected soils. Therefore, it needs to study possible halotolerant Neocamarosporium species with halophytes and their probable role in the plant tolerance to salinities (Crous et al. 2014b). 
Neohendersoniaceae A. Giraldo \& Crous, Mycol. Progr. 16: 343 (2017).

Index Fungorum number: IF 818515; Facesoffungi number: FoF 07373, 10 species.

Specific endophyte or saprobic on plants, and human pathogens. Sexual morph: Ascomata scattered, immersed, globose to depressed globose, ostiolate, central to excentric, short cylindrical or erumpent at ostiolar neck. Peridium composed of polygonal to rectangular, thin-walled cells. Hamathecium comprising septate, branched and anastomosed, cellular pseudoparaphyses. Asci cylindrical to clavate, bitunicate, fissitunicate, pedicellate. Ascospores 2-seriate, broadly fusiform, 1- or multi-septate, hyaline, smooth-walled. Spermatia subglobose to ellipsoidal. (Tanaka et al. 2017) Asexual morph: Conidiomata single or gregarious, immersed, globose to collabent, papillate, dark brown to black, unilocular or multilocular; thick-walled composed of cells of textura porrecta, intricata or angularis. Ostiole single, papillate. Conidiophores reduced to conidiogenous cells. Conidiogenous cells discrete, determinate or indeterminate, cylindrical, lageniform, doliiform or ampulliform, hyaline, smooth, with percurrent proliferations. Conidia obovoid, cylindrical, clavate or fusiform, basal or apical cells paler than the median cells, distoseptate or euseptate, thick-walled, base truncate, apex obtuse.

Type - Neohendersonia Petrak.

Notes - Neohendersonia pyriforme was described from Fagus sylvatica in Belgium. Sutton \& Pollack (1974) combined Stilbospora kickxii which was stated as a synonym to Neohendersonia pyriforme, into Neohendersonia, and N. kickxii was proposed as the type species. Tanaka et al. (2017) introduced Brevicollum to Noehendersoniaceae and accepted four genera Crassiparies, Medicopsis, Neohendersonia including Brevicollum in this family. Crous et al. (2019b) introduced a new genus Neomedicopsis to the family. The family placement of Mediocopsis is uncertain (Ahmed et al. 2014, Li et al. 2016a), yet Tanaka et al. (2017) suggested that Mediocopsis belongs to Neohendersoniaceae based on the multi-gene phylogenetic analysis.

Neohendersonia Petrak. Annls Mycol. 19: 190 (1921).

Index Fungorum number: IF 9100; Facesoffungi number: FoF 08312; 3 morphological species (Giraldo et al. 2017), 1 species with molecular data.

Type species - Neohendersonia kickxii (Westend.) B. Sutton \& Pollack., Mycopath. Mycol. appl. 52: 334 (1974).

三Stilbospora kickxii Westend., Bull. Acad. R. Sci. Belg., Cl Sci 18: 409 (1851).

Notes - Neohendersonia kickxii is reported as a specific endophyte of beech twigs (Petrini \& Fisher 1988, Kowalski \& Kehr 1996). Though Species Fungorum listed four species in the genus, Giraldo et al. (2017) considered Neohendersonia pyriformis as a synonym of Neohendersonia kickxii. Therefore, from the three species accepted in the genus, only $N$. kickxii has living type material. Neohendersonia kickxii has pycnidial conidiomata and obovoid to pyriform, phragmoseptate, brown conidia (Sutton 1980, Giraldo et al. 2017). Splanchnonema loricatum was considered as the sexual morph of $N$. kickxii. It has large ascomata with a thick ascomatal wall which is wide, although there is no unequivocal evidence for this sexual-asexual connection (Barr 1982, Pegler et al. 2000).

\section{Other genera included}

Brevicollum Kaz. Tanaka, A. Hashim. \& Toy. Sato., Mycologia 109: 610 (2017).

Index Fungorum number: IF 821755; Facesoffungi number: FoF 07374; 2 morphological species (Species Fungorum 2020), 2 species with molecular data.

Type species - Brevicollum hyalosporum Kaz. Tanaka \& Toy. Sato, Mycologia 109: 611 (2017).

Notes - The sexual morphs of Brevicollum are characterized by immersed, globose to depressed globose ascomata, with a central to eccentric, short cylindrical ostiolar neck, a thin ascomatal wall, clavate asci with a shallow ocular chamber, and broadly fusiform, 3-5-septate ascospores. The asexual morph of the genus is unknown (Tanaka et al. 2017). Brevicollum is similar to Crassiparies in ascospore characteristics. However, Brevicollum has 8-spored asci, while Crassiparies has 4-spored asci. They are also phylogenetically apart (Hyde et al. 2018). 
Brevicollum hyalosporum occurs in various plant species as saprobes and endophytes, and is widely distributed in temperate and tropical regions (Tanaka et al. 2017). Brevicollum hyalosporum was identified as a saprobe on branches of Hevea brasiliensis Müll.Arg (Hyde et al. 2018) which is an economically important crop and also on dead twigs of Syzygium samarangense (Myrtaceae) in Japan and Thailand (Tanaka et al. 2017). This species is similar to Massarina palmicola (Massarinaceae) which also has 5-septate, hyaline ascospores with a slightly expanded sheath (Hyde \& Aptroot 1997, Aptroot 1998).

Brevicollum hyalosporum Kaz. Tanaka \& Toy. Sato, Mycologia 109: 4 (2017).

Fig. 113

Index Fungorum number: IF 821756; Facesoffungi number: FoF 06620.

Saprobic on Morinda citrifolia twig. Sexual morph: Ascomata 140-220 × 280-360 $\mu \mathrm{m}(\bar{x}=$ $194 \times 323, \mathrm{n}=5$ ), perithecial, scattered, immersed in bark, erumpent with ostiolar neck, globose to depressed globose, eccentric periphyses neck 148-159 $\times 94-110 \mu \mathrm{m}$, compressed at basal to broad apical region, Peridium 37-87 $\mu \mathrm{m}$ wide Hamathecium comprising 1.8-2 $\mu \mathrm{m}$ wide, septate, branched, anastomosing, pesudoparaphyses. Asci 112-156.6(162.0) $\times(22.0) 23.1-32.3(32.7)(\bar{x}=$ $131.3 \times 27.3, \mathrm{n}=25$ ) bitunicate, clavate, apically broadly rounded, basally narrow, short pedicellate. Ascospores (32.3)32.9-40.0(40.4) $\times(9.1) 10.1-12.9(13.1)(\bar{x}=36.2 \times 11.4, \mathrm{n}=28)$, 2seriate except at the base, fusoid, hyaline to pale grey colored, 1-septate, constricted at the septum, mature spores becoming 3-5 septate with central constricted septa, guttulate, thick sheath, $2 \mu \mathrm{m}$ wide, surrounded ascospores. Asexual morph: undetermined.

Material examined - India, Andaman and Nicobar Islands, Port Blair, NIOT Coco plantation,

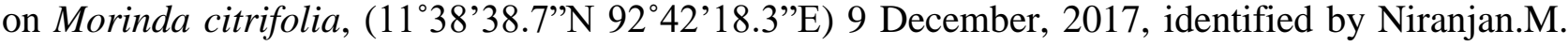
(NFCC culture number: 4376, new host record and new country record).

Distributions - Syzygium samarangense, Japan, Morinda citrifolia India, Hevea brasiliensis Thailand.

Notes - Brevicollum is characterized by immersed ascomata with short ostiolar necks, a thin ascomatal wall, clavate asci with a shallow ocular chamber and broadly fusiform, 3-5-septate ascospores. Two species have been reported, B. hyalosporum and B. versicolor. Phylogenetic tree based on combined LSU, rpb-2, SSU and tef1 sequence data indicates that our strain (NFCCI 4376) clusters with other strains of B. hyalosporum (100\% MLBS, 1.0 PP, Fig. 42). The variations in the measurements of Brevicollum species are provided in Table 1.

Crassiparies M. Matsum., K.Hiray. \& Kaz. Tanaka., Fungal Divers. 78: 63 (2016).

Index Fungorum number: IF 815294; Facesoffungi number: FoF 02024; 1 morphological species (Species Fungorum 2020), 1 species with molecular data.

Type species - Crassiparies quadrisporus M. Matsum., K. Hiray. \& Kaz. Tanaka., Fungal Divers. 78: 63 (2016).

Table 1 - List of Brevicollum species variations in the measurements.

\begin{tabular}{|c|c|c|c|c|}
\hline Fungi & $\begin{array}{l}\text { Ascomata } \\
(\mu \mathrm{m})\end{array}$ & $\operatorname{Asci}(\mu \mathrm{m})$ & Ascospores $(\mu \mathrm{m})$ & No. of septa \\
\hline $\begin{array}{l}\text { B. hyalosporum } \\
\text { (Japan) }\end{array}$ & $\begin{array}{l}300-350 \times \\
200-380\end{array}$ & $122-138 \times 21.5-27$ & $\begin{array}{l}(28-) 30.5-38(-41.5) \times \\
8-12.5\end{array}$ & $\begin{array}{l}\text { 5-septate, sheath sharply } \\
\text { delimited }\end{array}$ \\
\hline $\begin{array}{l}\text { B. hyalosporum } \\
\text { (India) }\end{array}$ & $\begin{array}{l}141-214 \times \\
279-358\end{array}$ & $\begin{array}{l}(111.8) 112-156.6 \\
(162.0) \times(22.0) 23.1- \\
32.3(32.7)\end{array}$ & $\begin{array}{l}(32.3) 32.9-40.0(40.4) \\
\times 1.9(9.1) 10.1-12.9 \\
(13.1)\end{array}$ & $\begin{array}{l}3-5 \text { septate, thick sheath } \\
2 \mu \mathrm{m} \text { wide. }\end{array}$ \\
\hline $\begin{array}{l}\text { B. hyalosporum } \\
\text { (Thailand) } \\
\text { B. versicolor } \\
\text { (Japan) }\end{array}$ & $\begin{array}{l}200-300 \times \\
100-250 \\
320-430 \times \\
250-350 \\
\end{array}$ & $\begin{array}{l}(90-) 92-120(-155) \times \\
17-22(-25) \\
110-160 \times 20-27\end{array}$ & $\begin{array}{l}(23-) 29-43(-44) \times(3- \\
7-12(-13) \\
26-40 \times(7.5-) 9-14\end{array}$ & $\begin{array}{l}3-5 \text {-septate, } \\
\text { mucilaginous sheath } \\
(3-) 5 \text {-septate, sheath } 3- \\
4 \mu \mathrm{m} \text { wide }\end{array}$ \\
\hline
\end{tabular}




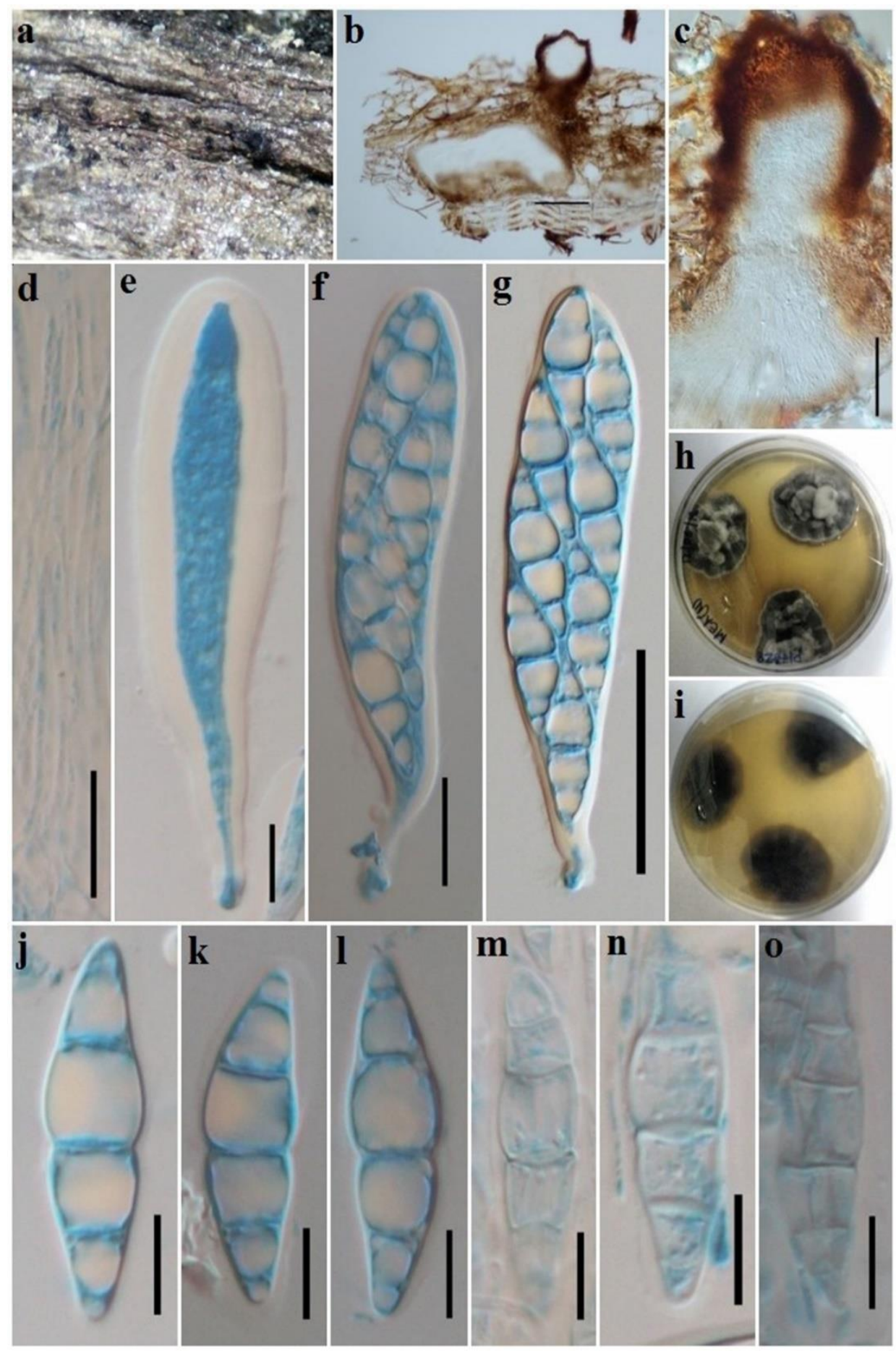

Figure 113 - Brevicollum hyalosporum (PUFNI 17628). a Ascomata on host twig. b, c Ascoma and neck. d Pseudoparaphyses. e-g Asci h, i Culture on media. $\mathrm{j}-\mathrm{o}$ Ascospores. Scale bars: $\mathrm{b}=200 \mu \mathrm{m}$, $\mathrm{c}, \mathrm{g}=50 \mu \mathrm{m}, \mathrm{d}, \mathrm{f}=20 \mu \mathrm{m}, \mathrm{e}, \mathrm{j}-\mathrm{o}=10 \mu \mathrm{m}$.

Notes - Crassiparies is a monotypic genus with $C$. quadrisporus, a putative saprobe on twigs of Acer sp. (Li et al. 2016a). The generic name of Crassiparies, was a combination of the Latin "crassi-" meaning thick and "paries" meaning wall, referring to the thick ascomatal wall of this fungus (Li et al. 2016a). Initially Crassiparies was introduced as Pleosporales, genera incertae sedis. Crassiparies is similar to Massarina as both genera have cylindrical, bitunicate asci and broadly fusiform, 1-septate, hyaline ascospores. Crassiparies has thick ascomatal walls, ascomatal neck without clypei, and 4-spored asci. C. quadrisporus may occur in various plant species as saprobes and endophytes, and are widely distributed in temperate and tropical regions. However, a 
reexamination of specimens revealed that this species actually has thin-walled ascomata (Tanaka et al. 2017).

Medicopsis Gruyter, Verkley \& Crous., Stud. Mycol. 75: 28 (2013).

Index Fungorum number: IF 564791; Facesoffungi number: FoF 08313; 2 morphological species (Species Fungorum 2020), 2 species with molecular data. (2013).

Type species - Medicopsis romeroi (Borelli) Gruyter, Verkley \& Crous., Stud. Mycol. 75: 28

= Pyrenochaeta romeroi Borelli, Dermatologia Venezolana 1: 326 (1959).

Notes - de Gruyter et al. (2013) introduced Medicopsis as a monotypic genus. Tanaka et al. (2017) suggested that Medicopsis belongs to Neohendersoniaceae based on the multi-gene phylogenetic analysis. Asexual morph of the genus includes solitary pycnidia or confluent, globose to pyriform with elongated neck, setose, ostiolate, olivaceous to olivaceous-black, the wall with pseudoparenchymatal cells. Conidiogenous cells are hyaline, phialidic, ampuliform to doliiform, to elongated. Conidia are sub hyaline to yellowish, ellipsoid, aseptate, and catenulate (de Gruyter et al., 2013). Members of this genus can be found as a pathogen of humans and also can occur on plants (Badali et al. 2010, Khan et al. 2011, de Gruyter et al. 2013, Ahmed et al. 2014b). Medicopsis romeroi was described as a human pathogen of tropical origin, and it may cause suppurative subcutaneous or deep nonmycetomatous infections, or a subcutaneous phaeohyphomycotic cyst (Badali et al. 2010).

Neomedicopsis Crous \& Akulov., Fungal Systematics and Evolution. 3: 95 (2019).

Index Fungorum number: IF 829321; Facesoffungi number: FoF 08314; 1 morphological species (Species Fungorum 2020), 1 species with molecular data.

Type species - Neomedicopsis prunicola Crous \& Akulov., Fungal Systematics and Evolution. 3: 95 (2019).

Notes - The genus are characterised by pycnidial conidiomata, globose and erumpent with central ostiole wall of 6-12 layers of brown textura angularis cells. Conidiophores are reduced to conidiogenous cells which are hyaline, smooth, ampulliform with long cylindrical neck, proliferating percurrently. Conidia are solitary, globose to subglobose, pale brown, to dark brown, thick-walled, guttulate, granular, apex obtuse and base is truncate (Crous et al. 2019b).

\section{Ecological and economic significance}

Species of Neohendersoniaceae have been reported in few plants. Neohendersonia kickxii has been reported as a specific endophyte of beech twigs in Europe (Danti et al. 2002, Sieber 2007) and from beech bark in North American forests (Griesmer-Zakhar 2013). Brevicollum was also observed as saprobic on branches of Hevea brasiliensis (Euphorbiaceae). Brevicollum hyalosporum was found on dead twigs of Syzygium samarangense (Myrtaceae) in Japan (Tanaka et al. 2017) as well as from Thailand. Crassiparies quadrisporus was found to be saprobic on twigs of Acer sp. (Li et al. 2016a). Medicopsis includes Medicopsis romeroi identified as a human pathogen (Gruyter et al. 2013) and Neomedicopsis prunicola was isolated as a saprobe on Prunus padus (Crous et al. 2019b).

Neomassariaceae H.A. Ariyaw., Jaklitsch \& Voglmayr, Cryptog. Mycol. 39(3): 367 (2018).

Index Fungorum number: IF 827113; Facesoffungi number: FoF 08315, 2 species.

Saprobic on dead stems in terrestrial habitats. Sexual morph: Ascomata immersed, globose to subglobose, brown to dark brown with central ostiole. Peridium composed of brown cells of textura angularis. Hamathecium comprising cylindrical to filiform, cellular or trabeculate pseudoparaphyses. Asci 8-spored, bitunicate, oblong to cylindrical. Ascospores 1-2-seriate, ellipsoid to fusiform, hyaline, 1-septate, with or without a gelatinous sheath. Asexual morph: Undetermined. (adapted from Ariyawansa et al. 2018a).

Type - Neomassaria Mapook, Camporesi \& K.D. Hyde.

Notes - Neomassariaceae was proposed by Ariyawansa et al. (2018a) to place the 
monophyletic clade of Neomassaria in Pleosporales. The justification of this family was supported by phylogenetic analyses based on single and concatenated LSU, rpb-2, SSU and tef1 DNA sequence data and morphology (Ariyawansa et al. 2018a). Morphologically Neomassariaceae varies from Massariaceae in having small globose to subglobose ascomata, small asci lacking a refractive ring and small hyaline, 1-septate ascospores (Ariyawansa et al. 2018a). Massariaceae contains species having large subglobose to broadly pyriform ascomata, large oblong, fusoid or clavate asci with a refractive ring, comprising 2-3-seriate oblong, narrowly ellipsoidal or fusoid, dark umber to blackish brown, 3-septate ascospores (Voglmayr \& Jaklitsch 2011).

Neomassaria Mapook, Camporesi \& K.D. Hyde in Hyde et al., Fungal Divers. 80: 74 (2016).

Index Fungorum number: IF 552273; Facesoffungi number: FoF 02437; 2 morphological species (Species Fungorum 2020), 2 species with molecular data.

Type species - Neomassaria fabacearum Mapook, Camporesi \& K.D. Hyde.

Notes - Neomassaria was established as a monotypic genus based on multi-gene phylogeny together with morphology. The type strain of Neomassaria fabacearum formed a distinct clade basal to the monophyletic genus Massaria (Hyde et al. 2017). Ariyawansa et al. (2018a) introduced a second species $N$. formosana.

Neomassaria fabacearum Mapook, Camporesi \& K.D. Hyde, in Hyde et al., Fungal Divers. 80: 77 (2016).

Fig. 114

Index Fungorum number: IF 552274; Facesoffungi number: FoF 02438.

Description - see Hyde et al. (2016).

Material examined - Italy, Forlì-Cesena, Cusercoli Civitella di Romagna, on dead branch of Hippocrepis emerus (L.) Lassen (Fabaceae), 11 September 2014, E. Camporesi (MFLU 16-1875, holotype).

\section{Ecological and economic significance}

All the species reported in the genus are saprobes. As they feed on dead organic matter, saprobic fungi decompose it into simple molecules that go back into the soil and can be reused by plants and all other organisms.

Neomassarinaceae Mapook \& K.D. Hyde, Fungal Divers 101: 52 (2020).

Index Fungorum number: IF 557341; Facesoffungi number: FoF 07798, 3 species.

Saprobic on dead leaf or stems of herbaceous plant. Sexual morph: Ascomata immersed or semiimmersed to erumpent, globose to subglobose or obpyriform, light brown to brown, coriaceous, solitary or scattered. Ostiole long neck, carbonaceous, papillate, crest-like, elongated and laterally compressed, with or without hyaline periphyses. Peridium comprising 2-5 layers, pale brown to hyaline cells or dark brown to black cells of textura angularis. Hamathecium comprising cylindrical to filiform, septate, branching, cellular pseudoparaphyses. Asci 8-spored, bitunicate, fissitunicate, cylindrical to cylindric-clavate, with a short pedicel, apically rounded, with an ocular chamber. Ascospores overlapping, 1-2-seriate, fusiform, hyaline to pale brown at maturity, uniseptate, with a narrow sheath or surrounded by hyaline gelatinous sheath; sheath drawn out to form polar appendages from both ends of the ascospores, straight or slightly curved. Asexual morph: Undetermined.

Type - Neomassarina Phookamsak, Jayasiri \& K.D. Hyde.

Notes - Neomassarinaceae is a monotypic family and is close to Sporormiaceae and Amorosiaceae based on analysis of a combined ITS, LSU, rpb-2, SSU and tef1 sequence data (Mapook et al. 2020). Neomassarinaceae and Massarinaceae share some characters including hyaline and fusiform ascospores but they are distinct in the phylogenetic analyses (Hyde et al. 2013, 2016b).

Neomassarina Phookamsak, Jayasiri \& K.D. Hyde, Fungal Divers. 80: 136 (2016). 
Index Fungorum number: IF 552225; Facesoffungi number: FoF 02259; 2 morphological species (Species Fungorum 2020), 2 species with molecular data.

Type species - Neomassarina thailandica Phookamsak, Jayasiri \& K.D. Hyde.
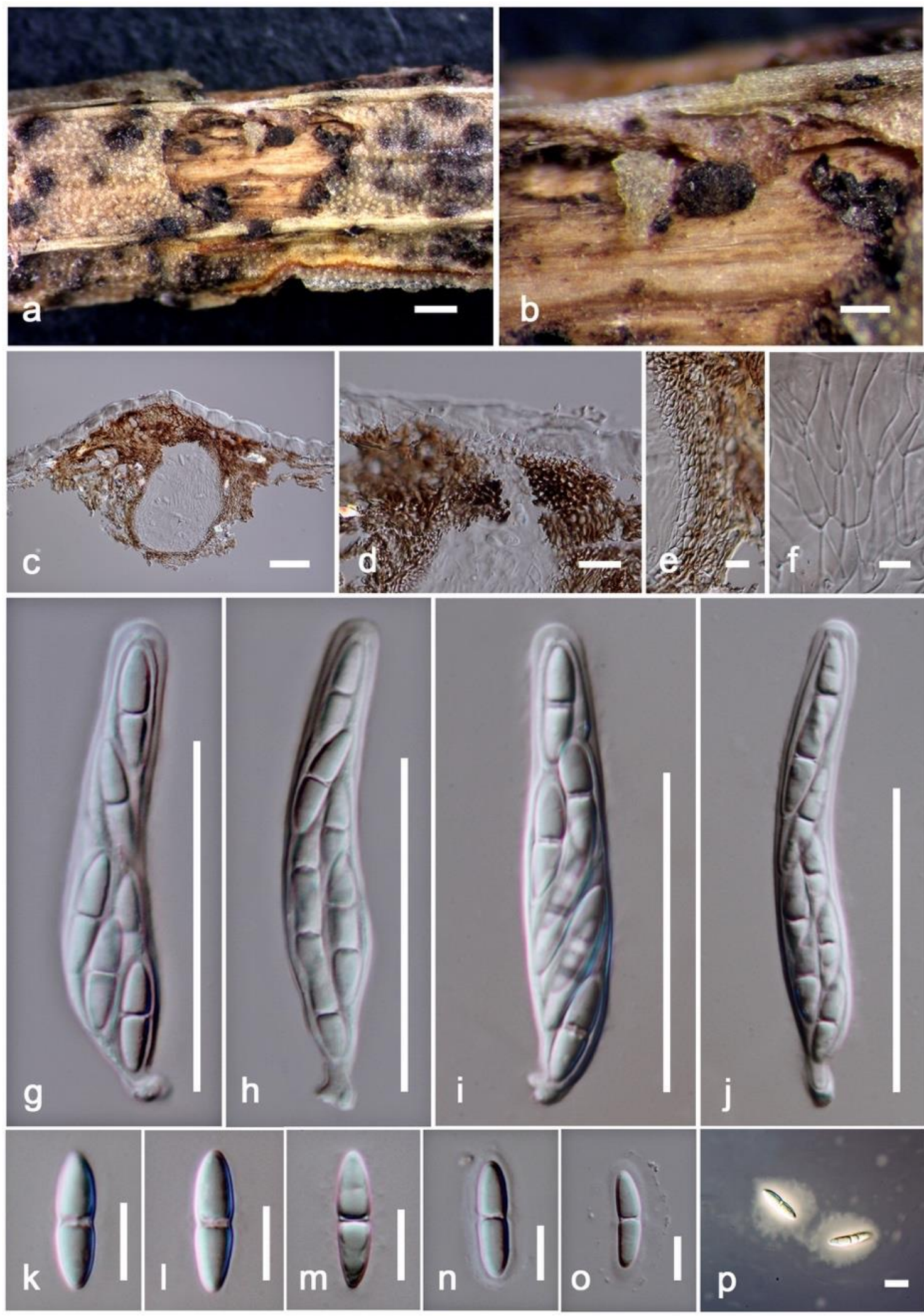

Figure 114 - Neomassaria fabacearum (MFLU 16-1875, holotype). a, b Appearance of ascomata on substrate. c Section through of ascoma. d Ostiole. e Peridium. f Pseudoparaphyses. g-j Asci. $\mathrm{k}-\mathrm{O}$ Ascospores. $\mathrm{p}$ Ascospores surrounded by hyaline gelatinous sheath in Indian ink. Scale bars: $\mathrm{a}=500 \mu \mathrm{m}, \mathrm{b}=200 \mu \mathrm{m}, \mathrm{c}, \mathrm{g}-\mathrm{j}=50 \mu \mathrm{m}, \mathrm{d}, \mathrm{e}=20 \mu \mathrm{m}, \mathrm{f}, \mathrm{k}-\mathrm{p}=10 \mu \mathrm{m}$. 

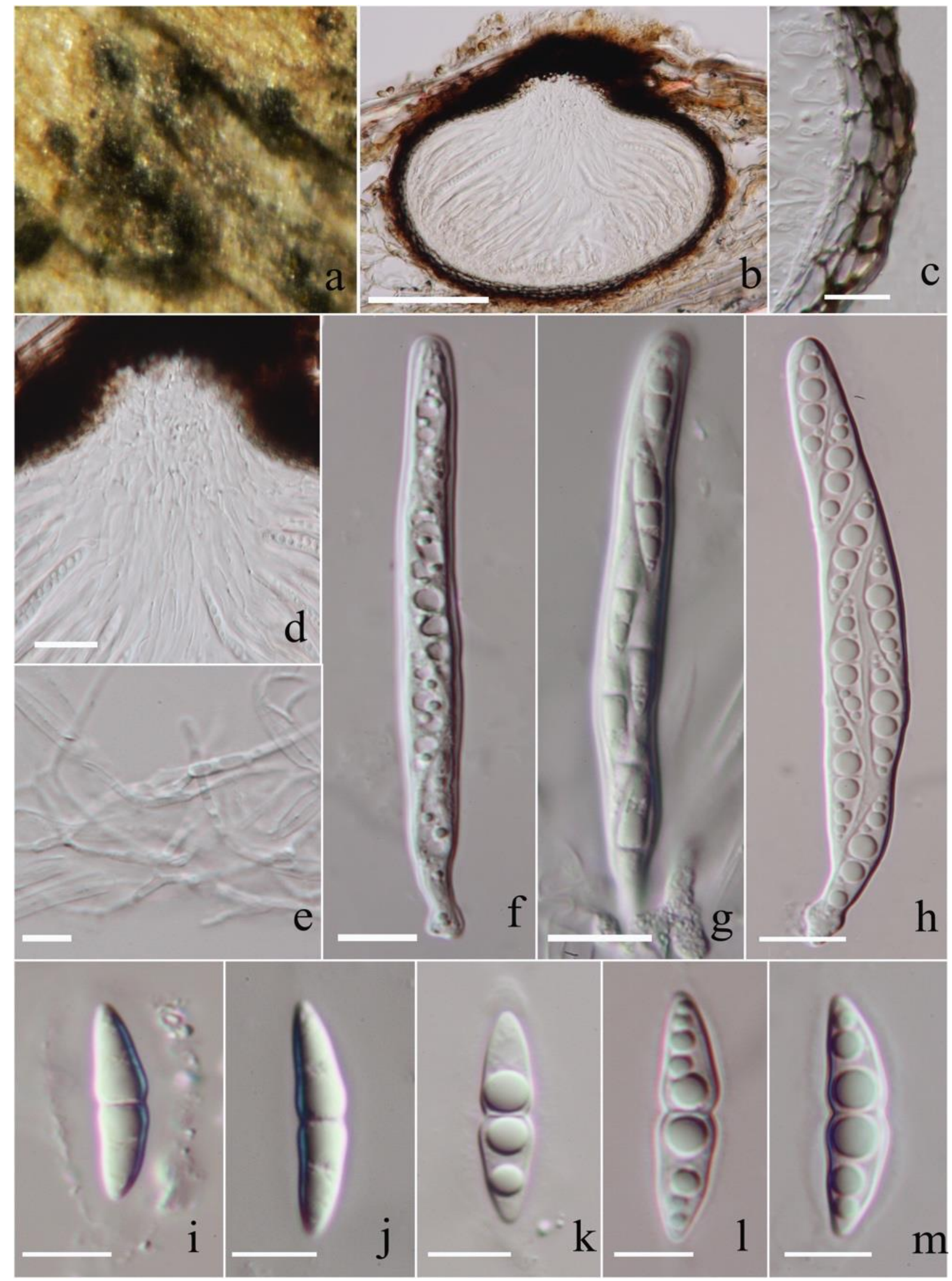

Figure 115 - Neomassarina thailandica (MFLU 11-0144, holotype). a Ascostromata on the host surface. b Section through the ascostroma. c Peridium. d, e Pseudoparaphyses. $\mathrm{f}-\mathrm{h}$ Asci. $\mathrm{i}-\mathrm{m}$ Ascospores. Scale bars $\mathrm{b}=100 \mu \mathrm{m}, \mathrm{c}=20 \mu \mathrm{m}, \mathrm{d}-\mathrm{h}=10 \mu \mathrm{m}, \mathrm{i}-\mathrm{m}=5 \mu \mathrm{m}$.

Notes - Species in Neomassarina were collected from dead leaves or stems from terrestrial habitat in Thailand. Neomassarina is phylogenetically close to Angustimassarina (Amorosiaceae). They are similar in having cylindrical to cylindric-clavate asci with an ocular chamber and hyaline, 
mostly uniseptate ascospores constricted at the septum with a mucilaginous sheath (Thambugala et al. 2015b, Hyde et al. 2016, 2018, Tibpromma et al. 2017, Mapook et al. 2020). However, appendages of ascospores are observed only in Neomassarina. Angustimassarina might be fungicolous as it appeared to grow inside other ascomata (Thambugala et al. 2015b, Tibpromma et al. 2017).

Neomassarina thailandica Phookamsak, Jayasiri \& K.D. Hyde, Fungal Divers. 80: 138 (2016).

Fig. 115

Index Fungorum number: IF 552226; Facesoffungi number: FoF 02260.

Description - see Hyde et al. (2016b).

Material examined - Thailand, Chiang Mai, Muang District, Medicinal Plant Garden in Doi Suthep-Pui, on dead bract-like leaves from flower stalks of Agave angustifolia (Asparagaceae), 23 November 2009, R. Phookamsak, RP0015 (MFLU 11-0144, holotype),

\section{Other genus included}

Pseudohelminthosporium Phukhams. \& K.D. Hyde, in Phukhamsakda et al., Fungal Diversity 102: 59 (2020).

Index Fungorum number: IF 557191; Facesoffungi number: FoF 07283; 1 morphological species (Species Fungorum 2020), 1 species with molecular data.

Type species - Pseudohelminthosporium clematidis Phukhams. \& K.D. Hyde, in Phukhamsakda et al., Fungal Diversity 102: 59 (2020).

Notes - Pseudohelminthosporium was established by Phukhamsakda et al. (2020) and is a monotypic genus. The genus is characterized by hyphomycetous, solitary stipes with monotretic or polytretic conidiogenous cells, broad fusiform or obclavate, phragmosporous hyaline conidia, slightly constricted at the septa, elonged cells at the upper end of conidia, with a large guttule in each cell (Phukhamsakda et al. 2020).

\section{Ecological and economic significance}

Neomassarina chromolaenae (MFLUCC 17-1480) showed antimicrobial activity against Escherichia coli while Neomassarina thailandica (MFLUCC 17-1432) against Mucor plumbeus through pre-screening test (Mapook et al. 2020). These preliminary data may demonstrate that members in Neomassarina might be a potential source of antimicrobial substances. While, Pseudohelminthosporium was found as saprobic on decaying wood material or herbaceous plant in terrestrial habitats (Phukhamsakda et al. 2020).

Neophaeosphaeriaceae Ariyaw. \& K.D. Hyde, Fungal Divers. 74: 45 (2015).

Index Fungorum number: IF 551471; Facesoffungi number: FoF 01164, 4 species.

Saprobic or pathogenic on stems and leaves of herbaceous, or woody plants in terrestrial habitats. Sexual morph: Ascomata scattered or clustered in circular areas, immersed, depressed globose, with a small ostiolar pore slightly penetrating above the surface, under clypeus, coriaceous, papilla not conspicuous. Peridium 3-layered, thin-walled, pigmented, pseudoparenchymatous cells of textura angularis. Hamathecium comprising dense, septate, cellular pseudoparaphyses, embedded in a gelatinous matrix. Asci 8-spored, bitunicate, fissitunicate, broadly cylindrical to oblong, with a short, broad, bulbous, furcate pedicel, apically rounded, with an ocular chamber. Ascospores obliquely 1-seriate and partially overlapping, oblong to broadly fusiform, yellowish brown, mostly 3-septate, verruculose (adapted from Ariyawansa et al. 2015b). Asexual morph: Coelomycetous, coniothyrium-like. Conidiomata pseudoparenchymatous, sometimes stromatic. Conidiogenous cells lining entire locule, holoblastic, proliferating percurrently, usually resulting in conspicuous annellations. Conidia globose, ovoid or ellipsoid, yellowish brown often becoming brown at maturity, aseptate, verrucose to punctuate (adapted from Câmara et al. 2003).

Type - Neophaeosphaeria M.P.S. Câmara, M.E. Palm \& A.W. Ramaley. 
Notes - Neophaeosphaeriaceae was introduced by Ariyawansa et al. (2015b) to accommodate Neophaeosphaeria and its allied species. Based on multi-gene analyses in Ariyawansa et al. (2015b), Neophaeosphaeria with the type species, N. filamentosa, form a distinct monophyletic clade sister to the clades of Coniothyriaceae, Cucurbitariaceae and Leptosphaeriaceae. Therefore, Neophaeosphaeria was excluded from Leptosphaeriaceae and placed in a new family Neophaeosphaeriaceae. The new family also shares some characters with Leptosphaeriaceae. However, Neophaeosphaeriaceae has pseudoparenchymatous peridium, while Leptosphaeriaceae has scleroplectenchymatous peridium (Ariyawansa et al. 2015b).
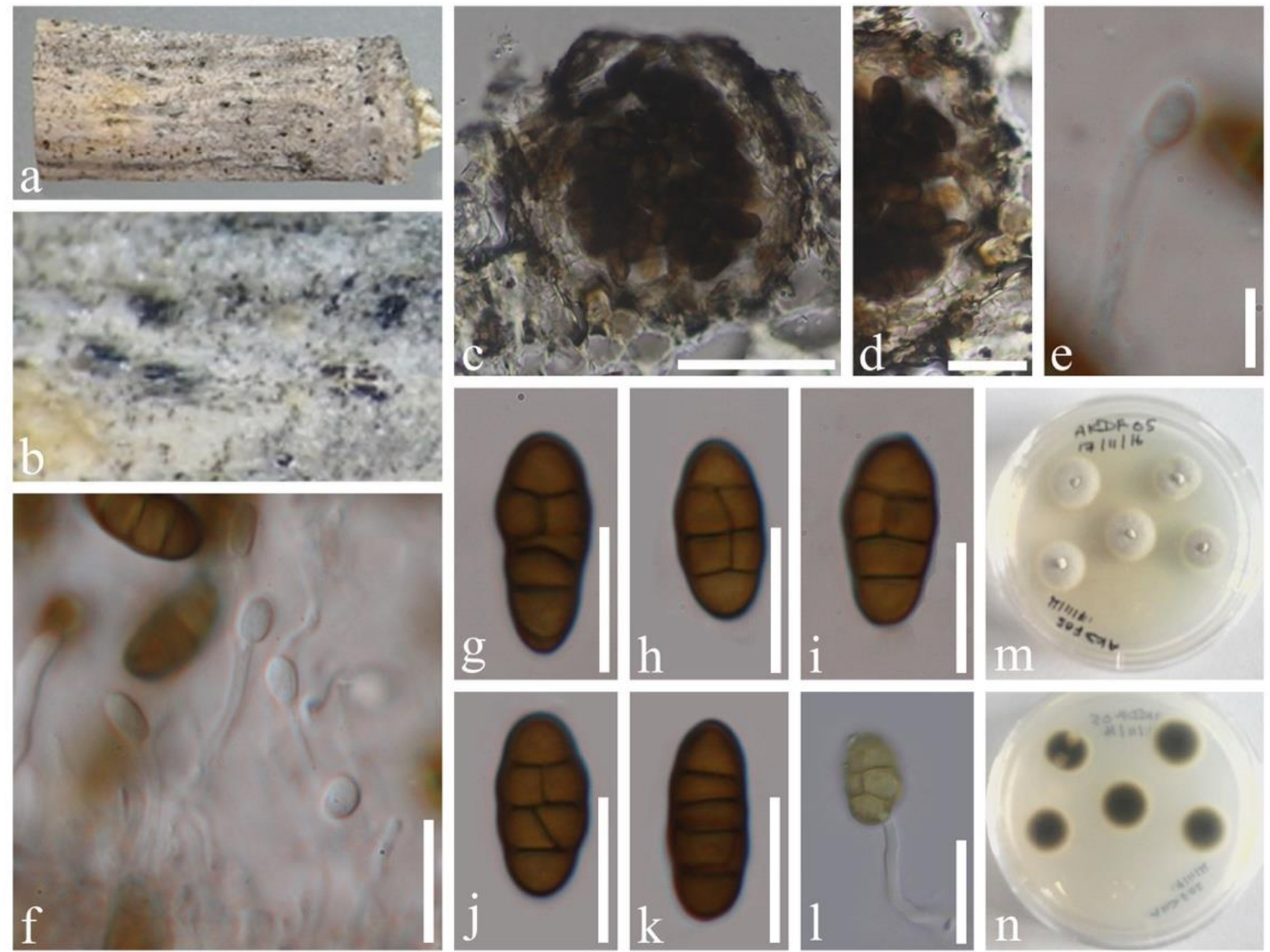

Figure 116 - Neophaeosphaeria phragmiticola (HKAS 97353, holotype). a, b Appearance of conidiomata on host. c Longitudinal section of conidioma. d Conidioma wall. e, f Conidiogenous cells and developing conidia. $\mathrm{g}-\mathrm{k}$ Conidia. 1 Germinated conidium. $\mathrm{m}, \mathrm{n}$ Culture characteristics on PDA $(\mathrm{m}=$ from above, $\mathrm{n}=$ from below). Scale bars: $\mathrm{c}=50 \mu \mathrm{m}, \mathrm{d}-\mathrm{f}=10 \mu \mathrm{m}, \mathrm{g}-1=5 \mu \mathrm{m}$.

Neophaeosphaeria M.P.S. Câmara, M.E. Palm \& A.W. Ramaley, in Câmara et al., Mycol. Res. 107(5): 519 (2003).

Index Fungorum number: IF 28716; Facesoffungi number: FoF 08316; 4 morphological species (Species Fungorum 2020), 4 species with molecular data.

Type species - Neophaeosphaeria filamentosa (Ellis \& Everh.) M.P.S. Câmara, M.E. Palm \& A.W. Ramaley, in Câmara et al., Mycol. Res. 107(5): 519 (2003).

$\equiv$ Leptosphaeria filamentosa Ellis \& Everh., J. Mycol. 4(8): 76 (1888).

Notes - All species in Neophaeosphaeria are presently known from Yucca sp. (Ariyawansa et al. 2015b). De Gruyter et al. (2013) suggested that although Neophaeosphaeria is phylogenetically related to Coniothyrium, Neophaeosphaeria probably belongs in a separate phylogenetic clade. The grouping of $N$. filamentosa with Coniothyrium species was poorly supported (Verkley et al. 2004a, 
De Gruyter et al. 2013). Thus, the placement of the Neophaeosphaeria was confused. Ariyawansa et al. (2015b) indicated that the type species, $N$. filamentosa along with $N$. agaves and $N$. quadriseptata, form a distinct clade within Pleosporales, therefore, they excluded Neophaeosphaeria from Leptosphaeriaceae and introduce a new family to accommodate this distinct lineage.

Neophaeosphaeria phragmiticola A. Karunarathna \& K.D. Hyde, Mycosphere 9(2): 316 (2018).

Index Fungorum number: IF 554111; Facesoffungi number: FoF 03942

Fig. 116

Description - see Hyde et al. (2018).

Material examined - China, Yunnan Province, Erhai Lake, on dead stems of Phragmites australis, 5 October 2016, K.D Hyde, AKDF 05 (HKAS 97353, holotype).

\section{Ecological and economic significance}

There are no reports about Ecological and economic significance of this family. Some species are pathogenic and are characterised by immersed ascomata, with a small ostiolar pore slightly penetrating above the surface. Their appearance on hosts is quite similar to black spots. However, species in this family are poorly known and mostly found on Asparagaceae, with only one species found on Poaceae (Hyde et al. 2018). Thus, more collections and sequence data are needed to expand the Ecological and economic significance of this family.

Neopyrenochaetaceae Valenz.-Lopez, Crous, Cano, Guarro \& Stchigel, Stud. Mycol. 90: 54 (2017).

Index Fungorum number: IF 820416; Facesoffungi number: FoF 07390, 8 species.

Species in Neopyrenochaetaceae were recovered from different habitats with different life modes; from water pipe sample, from Fragaria, from Protea nerifolia, and from the screen of mobile phone. Asexual morph: Conidiomata pycnidial, pale brown to brown, solitary, pycnidial wall composed of cells of textura angularis, setose, ovoid to globose, with a nonpapillate or papillate ostiolar neck. Conidiogenous cells phialidic, ampulliform or lageniform. Conidia ovoid to subcylindrical, hyaline, aseptate, smooth- and thin-walled. Sexual morph: Undetermined.

Type - Neopyrenochaeta Valenz.-Lopez, Crous, Stchigel, Guarro \& J.F. Cano.

Notes - Neopyrenochaetaceae was introduced by Valenzuela-Lopez et al. (2018) while revising the families Cucurbitariaceae and Didymellaceae. It accommodates species that were previously considered as members of Cucurbitariaceae. Along with Neopyrenochaetaceae, other families of Parapyrenochaetaceae, Pseudopyrenochaetaceae and Pyrenochaetopsidaceae were introduced to the Pleosporales, Dothideomycetes (Valenzuela-Lopez et al. 2018). Multi-gene phylogeny of ITS, LSU, rpb-2 and tub2 analyses showed that few taxa previously identified as Pyrenochaeta, were not claded in Cucurbitariaceae and therefore N. acicola (= Pyrenochaeta acicola), $N$. inflorescentiae ( $\equiv P$. inflorescentiae) and $N$. telephoni ( $\equiv$ P. telephoni) were accommodated in the new genus Neopyrenochaeta.

Neopyrenochaeta Valenz.-Lopez, Crous, Stchigel, Guarro \& Cano, Stud. Mycol. 90: 54 (2017).

Index Fungorum number: IF 820313; Facesoffungi number: FoF 07389; 8 morphological species (Species Fungorum 2020), 8 species with molecular data.

Type species - Neopyrenochaeta acicola (Moug. \& Lév.) Valenz.-Lopez, Crous, Stchigel, Guarro \& J.F. Cano, in Valenzuela-Lopez et al., Stud. Mycol. 90: 54 (2017).

Notes - Even though Neopyrenochaeta species are similar to Pyrenochaeta, multi-locus phylogeny showed that these taxa are distant from Pyrenochaeta. Neopyrenochaeta is characterized by pale brown to brown, solitary pycnidial conidiomata, pycnidial wall composed of cells of textura angularis, setose, ovoid to globose, ostiolate, with phialidic, ampulliform or lageniform conidiogenous cells, and aseptate, hyaline, smooth- and thin-walled, ovoid to subcylindrical conidia (Valenzuela-Lopez et al. 2018, Jayasiri et al. 2019). 
Neopyrenochaeta cercidis Jayasiri, E.B.G. Jones \& K.D. Hyde, in Jayasiri et al., Mycosphere 10(1): 91 (2019).

Fig. 117

Index Fungorum number: IF 555561; Facesoffungi number: FoF 05267.

Description - see Jayasiri et al. (2019).

Material examined - China, Guizhou Province, Guizhou University, on fallen pod of Cercis chinensis (Fabaceae), 30 July 2016, S.C. Jayasiri, C 136 (MFLU 18-2089, holotype).
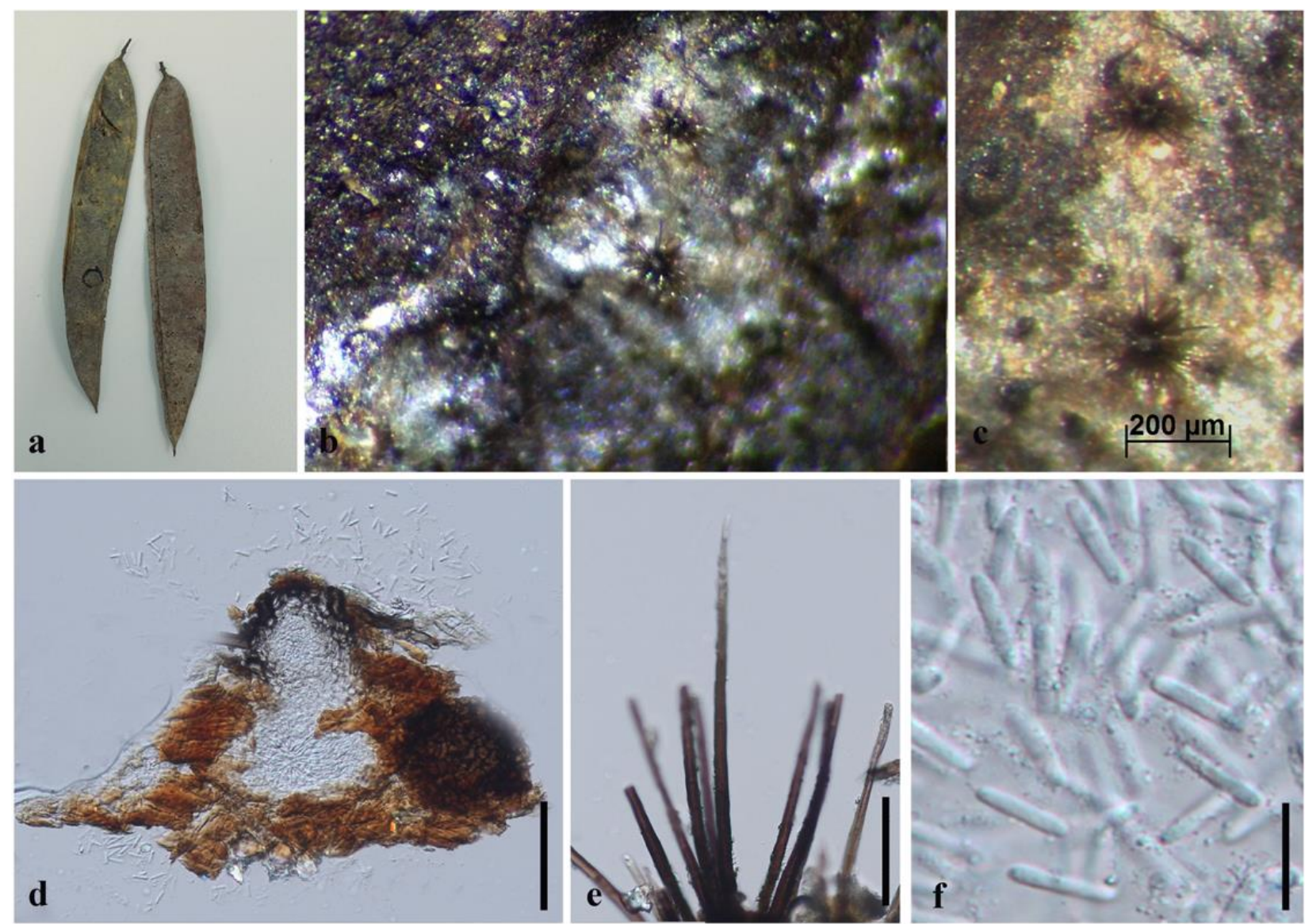

Figure 117 - Neopyrenochaeta cercidis (MFLU 18-2089, holotype). a Seed pods of Cercis chinensis. b, c Conidiomata in the substrate. d Section through conidioma. e Appendages. $f$ Conidia. Scale bars: $\mathrm{a}=1 \mathrm{~cm}, \mathrm{~d}=50 \mu \mathrm{m}, \mathrm{e}=20 \mu \mathrm{m}, \mathrm{f}=30 \mu \mathrm{m}, \mathrm{g}-\mathrm{j}=5 \mu \mathrm{m}$.

\section{Ecological and economic significance}

Saprobic on various host plants and play roles in recycling organic matters.

Nigrogranaceae Jaklitsch \& Voglmayr, Stud. Mycol. 85: 54 (2016).

Index Fungorum number: IF 817780; Facesoffungi number: FoF 08317, 16 species.

Saprobic on decayed twigs of shrubs and trees in terrestrial habitats, sometimes can be endophytic or human pathogenic. Sexual morph: Ascomata immersed-erumpent, sometimes superficial, scattered or aggregated, globose to sub-globose, black, usually seated on or surrounded by a subiculum, ostiolate. Ostiole papillate to cylindrical; periphysate. Peridium pseudoparenchymatous. Hamathecium comprising cellular, septate and branched pseudoparaphyses. Asci 8-spored, bitunicate, fissitunicate, cylindric clavate to broadly clavate, with a knob-like pedicel, and a shallow ocular chamber at rounded apex. Ascospores 2-seriate, fusoid to narrowly ellipsoid, straight or slightly curved, pale to chocolate brown, mostly 1-3-septate, smooth-walled or faintly verruculose. Asexual morph: pyrenochaeta-like, Conidiomata pycnidial, globose, ostiolate. Peridium brown, pseudoparenchymatous. Conidiophores when present filiform, simple to sparsely branched, with pegs and terminal phialides. Phialides ampulliform, lageniform, or subcylindrical. Conidia forming on pegs and phialides, rod-like to ellipsoid, hyaline or 
subhyaline, sometimes pale brown in mass, asaptate, smooth-walled (adapted from Jaklitsch \& Voglmayr 2016).

Type - Nigrograna Gruyter, Verkley \& Crous.

Notes - Nigrogranaceae was introduced to accommodate three new species of Nigrograna. Jaklitsch \& Voglmayr (2016) doubted the validity of the strain of B. marina (type of Biatriosporaceae) in GenBank. In their multi-gene phylogenetic analyses, strains of Biatriospora mackinnonii grouped in Nigrograna. Therefore, they dismissed Biatriosporaceae, and transferred Biatriospora species to Nigrograna. However, based on the type species, Hyde et al. (2017) argued that Biatriosporaceae is distinct and the family should be maintained. Nevertheless, B. marina needs recollecting for sequence analysis to establish if Nigrograna is related, which seems unlikely.
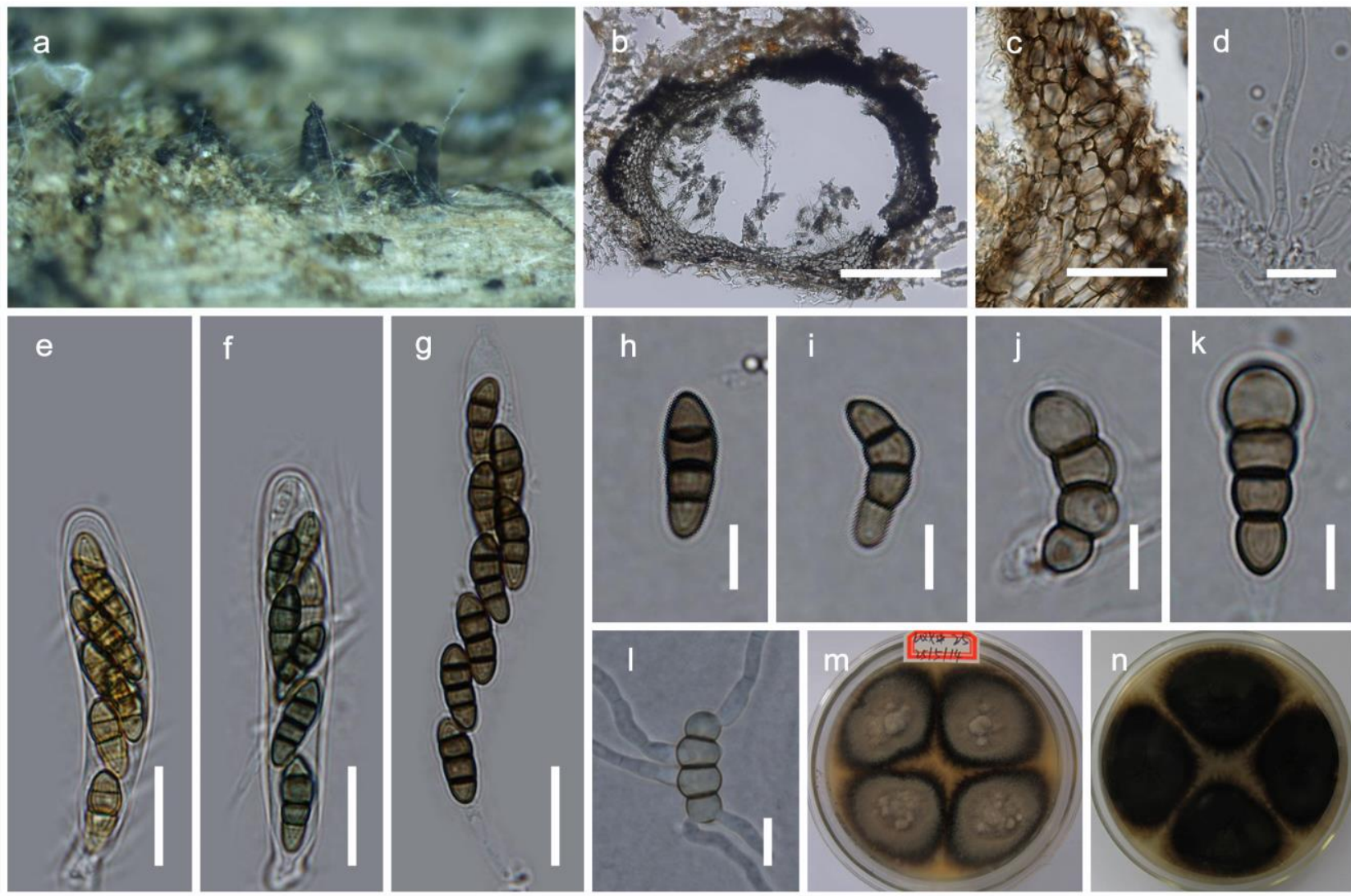

Figure 118 - Nigrograna cangshanensis (HKAS 83978, holotype). a Appearance of ascomata on host substrate. b Section of ascoma. c Peridium. d Pseudoparaphyses. e-g Asci. h-k Ascospores. 1 Germinated ascospore. $\mathrm{m}, \mathrm{n}$ Upper $(\mathrm{m})$ and reverse $(\mathrm{n})$ views of colony on PDA. Scale bars: $\mathrm{b}=100 \mu \mathrm{m}, \mathrm{c}=50 \mu \mathrm{m}, \mathrm{f}=20 \mu \mathrm{m}, \mathrm{d}-\mathrm{g}, \mathrm{l}=10 \mu \mathrm{m}, \mathrm{h}-\mathrm{k}=5 \mu \mathrm{m}$.

Nigrograna Gruyter, Verkley \& Crous, Stud. Mycol. 75: 31 (2012).

Index Fungorum number: IF 564794; Facesoffungi number: FoF 08318; 16 morphological species (Species Fungorum 2020), 16 species with sequence data.

Type species - Nigrograna mackinnonii (Borelli) Gruyter, Verkley \& Crous, Stud. Mycol. 75: 31 (2012).

EPyrenochaeta mackinnonii Borelli, Castellania 4(12): 230 (1976).

Notes - Nigrograna was described by De Gruyter et al. (2013) as a monotypic asexual genus with Nigrograna mackinnonii as a human pathogen. Jaklitsch \& Voglmayr (2016) introduced three new species Nigrograna mycophile, N. norvegica, N. obliqua from Austria and Norway. Also, they synonymized Melanomma fuscidulum (三 Sphaeria fuscidula) as Nigrograna fuscidula. Hyde et al. (2017) and Tibpromma et al. (2017) introduced Nigrograna thymi (Italy) and $N$. cangshanensis (China), respectively. Nigrograna locuta-pollinis was introduced by Zhao et al. (2018) from hive-stored pollen (Brassica campestris). Kolařík (2018) introduced N. antibiotica, N. 
carollii, $N$. peruviensis and $N$. yasuniana by synonymizing the endophytic Biatriospora species in Kolaŕík et al. (2017). Two new species Nigrograna samueliana and N. rhizophorae were introduced from marine habitats by Dayarathne et al. (2020).

Nigrograna cangshanensis Z.L. Luo, Hong Y. Su \& K.D. Hyde, in Tibpromma et al., Fungal Diversity 83: 52 (2017).

Fig. 118

Index Fungorum number: IF 552681; Facesoffungi number: FoF 2888.

Description - see Tibpromma et al. (2017).

Material examined - China, Yunnan Province, saprobic on decaying wood submerged in stream in Cangshan Mountain, March 2014, Z.L. Luo, LQXM 25 (HKAS83978, holotype).

\section{Ecological and economic significance}

They are important to the cycling of carbon and nutrients during the decomposition of organic matter especially in terrestrial habitats.

Occultibambusaceae D.Q. Dai \& K.D. Hyde, Fungal Divers. 82(1): 25 (2017).

Index Fungorum number: IF 552013; Facesoffungi number: FoF 01974, 15 species.

Saprobic on dead bamboo culms or teak branches, forming dark, ascostromata on raised areas, with ostiolate oppening. Sexual morph: Ascostromata solitary, scattered or gregarious, subglobose, uni- or multi-loculate, greyish to dark brown, coriaceous, with a central, papillate, rounded ostiole, internally lined with periphyses. Peridium comprising host and fungal tissues or, only fungal tissue brown and thick-walled to hyaline and thin-walled cells of textura angularis. Hamathecium comprising long, septate, cellular pseudoparaphyses, above the asci. Asci 8-spored, bitunicate, broadly cylindrical to clavate, with a short furcate pedicel, with a shallow ocular chamber. Ascospores 2-3-seriate, slightly broad fusiform, hyaline, pale brown to dark brown, 1-3septate, surrounded by a gelatinous sheath, with guttulate cells. Asexual morph: Coelomycetous, produced on bamboo pieces on WA. Conidiomata eustromatic, immersed to partly immersed, solitary to gregarious, globose to subglobose, conical in section, dark ostiolate, with a short neck. Conidiomata wall with several layers, composed of dark to hyaline cells of textura angularis. Conidiophores reduced to conidiogenous cells. Conidiogenous cells enteroblastic, phialidic, determinate, discrete, ampulliform to cylindrical, smooth-walled. Conidia obovoid, cylindrical to oblong, hyaline to pale brown, asepate or 1-3-septate, rounded at the apex, smooth-walled, guttulate.

Type - Occultibambusa D.Q. Dai \& K.D. Hyde.

Notes - Occultibambusaceae was introduced by Dai et al. (2017) to accommodate the genera Neooccultibambusa, Occultibambusa, Seriascoma and Versicolorisporium. Phookamsak et al. (2019) introduced Brunneofusispora in this family; thus, there are five genera accommodated in this family. Members of this family are normally characterized by immersed, solitary to gregarious ascomata with black ostioles, broadly cylindrical to clavate, bitunicate asci, cellular pseudoparaphyses and broad-fusiform, hyaline to dark brown ascospores with 1-3 septa, and diverse asexual morphs (Hatakeyama et al. 2008, Dai et al. 2017, Doilom et al. 2017). Species of Occultibambusaceae are reported usually on monocotyledons, but have also been found on hardwood trees. Occultibambusaceae are similar to species of Bambusicola and Lophiostoma in having fusiform ascospores and clavate asci (Zhang et al. 2009d, Dai et al. 2012, 2015). However, Bambusicola produces hyaline ascospores and asexual morphs with usually annellidic conidiogenous cells (Dai et al. 2012), while the taxa within Occultibambusaceae have brown ascospores, and no annellidic conidiogenous cells found in asexual morphs (Dai et al. 2017). Occultibambusaceae differs from Lophiostoma by its papillate ostiole, while the species of Lophiostoma are characterized in having a compressed/crest-like ostiole (Zhang et al. 2009d, Thambugala et al. 2015b).

Occultibambusa D.Q. Dai \& K.D. Hyde, Fungal Divers. 82(1): 25 (2017). 
Index Fungorum number: IF 552013; Facesoffungi number: FoF 01974; 7 morphological species (Species Fungorum 2020), 7 species with molecular data.

Type species - Occultibambusa bambusae D.Q. Dai \& K.D. Hyde.

Notes - Occultibambusa is distinct from other genera within Occultibambusaceae in producing black necks at the center of conidiomata. The genus is similar to Bambusicola in having pale brown, oblong conidia, however the annellidic conidiogenous cells in Bambusicola is not known in Occultibambusa. For morphology of type species see Dai et al. (2017).

Occultibambusa aquatica H. Zhang \& K.D. Hyde, Fungal Divers. 80: 81 (2016).

Fig. 119

Index Fungorum number: IF 552016; Facesoffungi number: FoF 01975.

Description - see Hyde et al. (2016).

Material examined - Thailand, Chiang Rai, Hui Kang Pla Waterfall, on submerged bamboo, 16 November 2010, Huang Zhang, a50 (MFLU 11-1141, holotype).

\section{Other genera included}

Brunneofusispora S. K. Huang \& K. D. Hyde, Fungal Divers. 95(1): 36 (2019).

Index Fungorum number: IF 555599; Facesoffungi number: FoF 04862; 1 morphological species (Species Fungorum 2020), 1 species with molecular data. 38 (2019).

Type species - Brunneofusispora sinensis S. K. Huang \& K. D. Hyde, Fungal Divers. 95(1):

Notes - Brunneofusispora was placed within Occultibambusaceae as an independent clade by multi-gene analysis, and it also differs from other genera in morphology. Brunneofusispora is similar to Neooccultibambusa in forming globose to subglobose ascomata, but it differs from the latter in having a long prominent neck (Doilom et al. 2017, Phookamsak et al. 2019). Brunneofusispora can be distinguished from Seriascoma as the latter forms clypeate, multi-loculate ascostromata (Dai et al. 2017). Brunneofusispora differs from Occultibambusa as it forms a long beak in ascomata, while the latter has a short ostiole and papilla (Dai et al. 2017, Phooksmsak et al. 2019). In a recent study, Wanasinghe et al. (2020b) amended the generic description in order to accommodate its coelomycetous asexual morph. See Wanasinghe et al. (2020b) for more details.

Neooccultibambusa Doilom \& K.D. Hyde, Fungal Divers. 82: 126 (2017).

Index Fungorum number: IF 551981; Facesoffungi number: FoF 01852; 4 morphological species (Species Fungorum 2020), 4 species with molecular data.

Type species - Neooccultibambusa chiangraiensis Doilom \& K.D. Hyde, Fungal Divers. 82: 127 (2016).

Notes - Neooccultibambusa is similar to Occultibambusa in having dark brown, fusiform ascospores surrounded by a gelatinous sheath, but Neooccultibambusa produces cylindrical to subcylindrical asci, with 1-3 transverse septate ascospores, while Occultibambusa has broadly cylindrical to clavate asci with 1 transverse septate ascospores (Dai et al. 2017, Doilom et al. 2016). Morphology can be seen in Doilom et al. (2017).

Seriascoma Phookamsak, D.Q. Dai \& K.D. Hyde, Fungal Divers. 82(1): 30 (2017).

Index Fungorum number: IF 552014; Facesoffungi number: FoF 01978; 2 morphological species (Species Fungorum 2020), 2 species with molecular data.

Type species - Seriascoma didymosporum Phookamsak, D.Q. Dai \& K.D. Hyde, Fungal Divers. 82(1): 30 (2016).

Notes - This monotypic genus was established to accommodate a fungus forming elongated, multiloculate, coriaceous ascostromata, embedded beneath a clypeus, erumpent and splitting the host epidemis parallel with the venation to form a slit like opening. Seriascoma differs from other genera in Occultibambusaceae as its ascostromata are under a clypeus, and it is also distinguished from Occultibambusa and Versicolorisporium in its asexual morph (Hatakeyama et al. 2008, Dai et al. 2017). Morphology can be seen in Dai et al. (2017). 

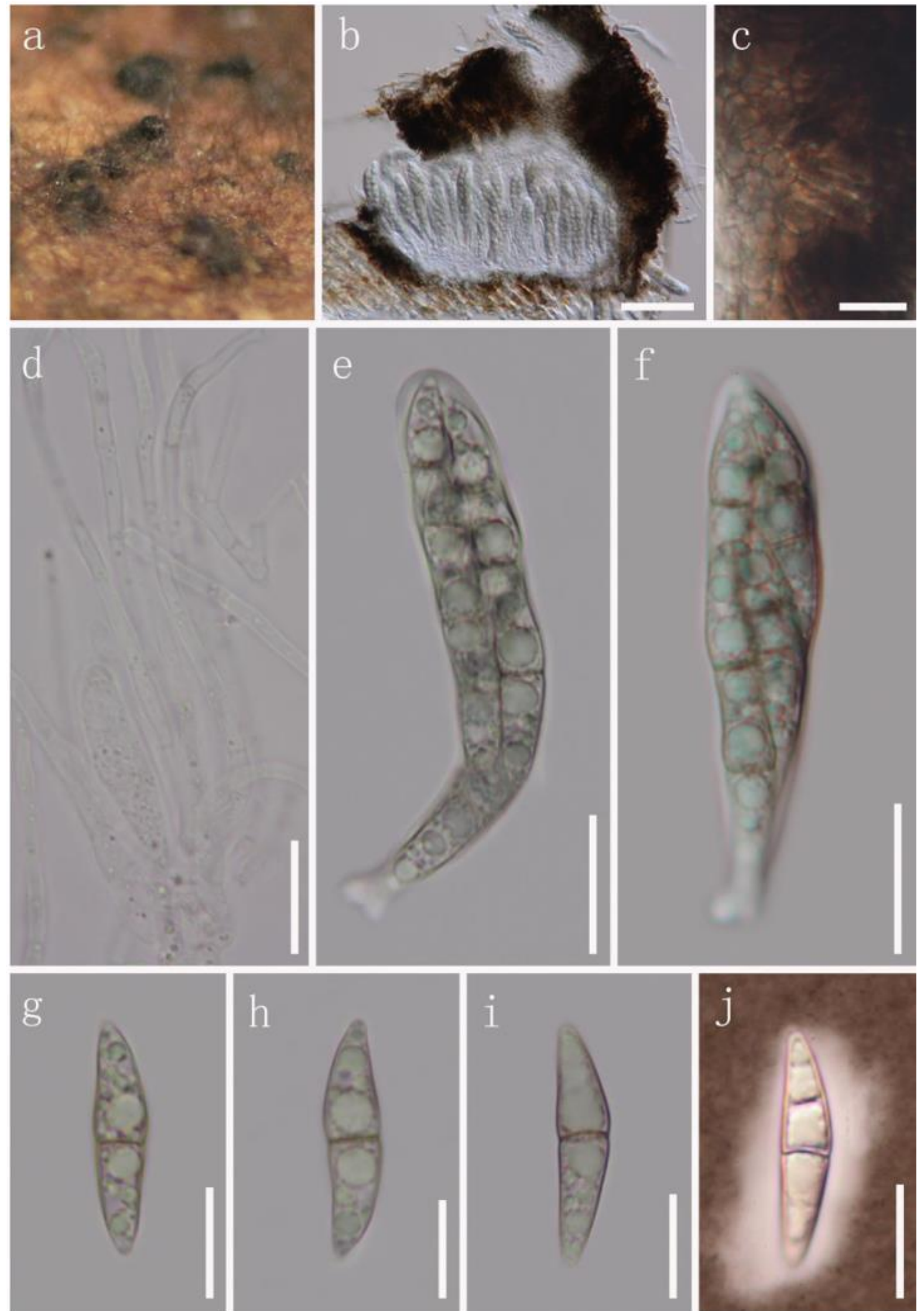

Figure 119 - Occultibambusa aquatica (MFLU 11-1141, holotype). a Appearance of ascomata on host surface. b Vertical section through ascoma. c Section of peridium. d Pseudoparaphyses. e, f Asci. g-i Ascospores. k Ascospore stained with Indian ink. Scale bars $b=50 \mu \mathrm{m}, \mathrm{d}-\mathrm{f}=20 \mu \mathrm{m}$, $\mathrm{c}, \mathrm{g}-\mathrm{j}=10 \mu \mathrm{m}$ 
Versicolorisporium Sat. Hatak., Kaz. Tanaka \& Y. Harada, Mycoscience 49(3): 211 (2008).

Index Fungorum number: IF 510909; Facesoffungi number: FoF 01727; 1 morphological species (Species Fungorum 2020), 1 species with molecular data.

Type species - Versicolorisporium triseptatum Sat. Hatak., Kaz. Tanaka \& Y. Harada, Mycoscience 49(3): 211 (2008).

Notes - Versicolorisporium, a coelomycetous genus, was placed in Pleosporales based on morphology and LSU sequence data. It is characterized by the production of holoblastic, 3-septate, obovoid, versicolored conidia, and differs from similar genera Neohendersonia, Toxosporiella and Toxosporiopsis by the uniloculate pycnidial conidiomata with a periphysate ostiole, lacking paraphyses, and the conidia without black-banded septa. Dai et al. (2017) introduced Occultibambusaceae and included this genus based on multi-gene phylogenetic analyses. (see morphology in Hatakeyama et al. 2008).

\section{Ecological and economic significance}

There are five genera assigned to this family. Seriascoma and Versicolorisporium were only discovered on dead bamboo substrates and reported as monotypic groups. In addition, most species in Occultibambusa were isolated from bamboo except for O. aquatica. Neooccultibambusa was found on various substrates. All of the taxa in Occultibambusaceae were reported as saprophytes, but the pathological experiment has never been carried out especially for those taxa isolated from bamboo, and therefore the further study is proposed to demonstrate whether these species are pathogenetic.

Ohleriaceae Jaklitsch \& Voglmayr, Stud. Mycol. 85: 49 (2016).

Index Fungorum number: IF 817828; Facesoffungi number: FoF 08319, 9 species.

Saprobic on wood or black crusts. Sexual morph: Ascomata superficial or erumpent at the base, globose to subconical, papillate, ostiolate, black. Peridium pseudoparenchymatous, dark. Hamathecium comprising trabeculate pseudoparaphyses. Asci 8-spored, bitunicate, fissitunicate, cylindrical. Ascospores 1-seriate to overlapping, fusoid to narrowly ellipsoid, ellipsoid, brown, 3septate, disarticulatng into two parts. Asexual morph: Coelomycetous. syanamorphs possibly monodictys-like. (adapted from Jaklitsch \& Voglmayr 2016).

Type - Ohleria Fuckel.

Notes - Phylogenetic analyses in Jaklitsch \& Voglmayr (2016) indicated that Ohleriaceae based on Ohleria modesta, is closely related to Hobusis as a separate family and has no affinity to other families with stong backbone support. Ohleriaceae comprises a monotypic genus. DNA based sequence data for this family is lacking.

Ohleria Fuckel, Fungi rhenani exsic., suppl., fasc. 7(nos 2101-2200): no. 2173 (1868).

Index Fungorum number: IF 3557; Facesoffungi number: FoF 00779; 9 morphological species (Species Fungorum 2020), 1 species with molecular data.

Type species - Ohleria modesta Fuckel.

Notes - Fuckel (1870) described an aposphaeria- or phoma-like asexual morph of $O$. rugulosa by association on the natural host. Samuels (1980) synonymized four Ohleria species under O. modesta, transferred some species to Passeriniella, Sporormia or Preussia based on ascospore features, and accepted two additional species $O$. rugulosa and $O$. brasiliensis in the genus based on morphology of available type materials. Samuels (1980) described a hyphomycetous asexual morph in Monodictys for O. brasiliensis Starbäck. Jaklitsch \& Voglmayr (2016) later suggested that $O$. brasiliensis may not be congeneric with Ohleria, and they also interpreted the Monodictys morph as a synanamorph as, for example, described by Grondona et al. (1997).

There are only two strains of the type species, O. modesta available in GenBank. The lectotype of $O$. modesta was recently designated by Jaklitsch \& Voglmayr (2016). Ten epithets are listed in Species Fungorum (2020), while one of them was transferred to Preussia. 

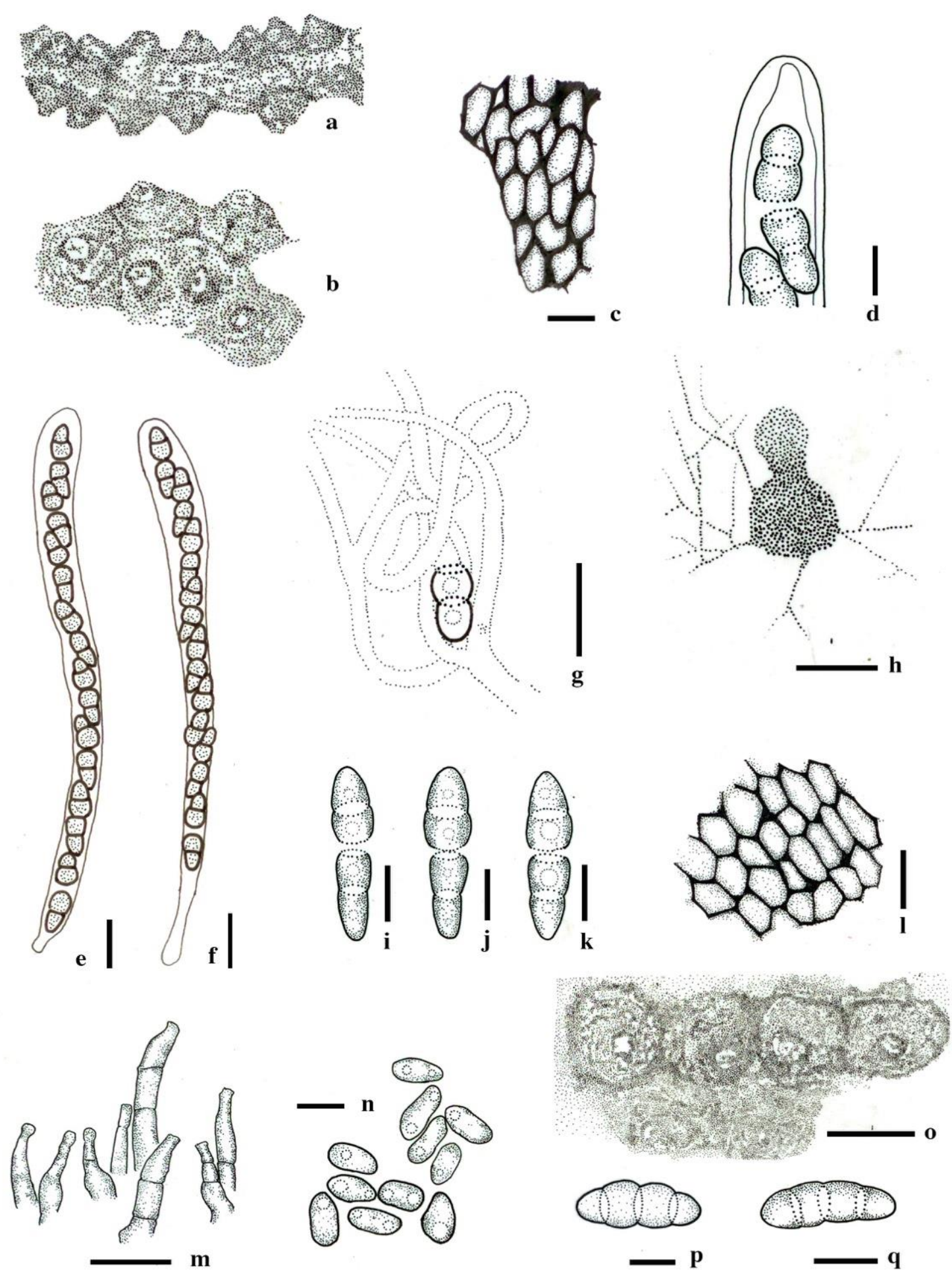

Figure 120 - Ohleria modesta (redrawn from Jaklitsch \& Voglmayr 2016, a-n = Ohleria modesta; $\mathrm{o}-\mathrm{q}=$ Ohleria rugulosa $)$. a, b Ascomata on host surfaces. c Peridium in section. $\mathrm{d}$ e, f Asci. $\mathrm{g}$ Trabeculate pseudoparaphyses. h Pycnidium with conidial drop. i-k Ascospores. 1 Squash mount of pycnidial peridium. $m$ Phialides. $n$ Conidia. o Ascomata on host surface. $\mathrm{p}$, q Ascospores. Scale bars: $\mathrm{v}=300 \mu \mathrm{m}, \mathrm{h}=100 \mu \mathrm{m}, \mathrm{e}-\mathrm{g}, \mathrm{m}=10 \mu \mathrm{m}, \mathrm{i}-\mathrm{k}, \mathrm{p}, \mathrm{q}=5 \mu \mathrm{m}, \mathrm{s}=3 \mu \mathrm{m}$.

\section{Ecological and economic significance}

Species of Ohleria are saprobes on dead wood and thus unlikely to be host-specific. They are poorly known and rarely collected. More fresh collections are needed to indicate their efficiency and interaction with other organisms. 

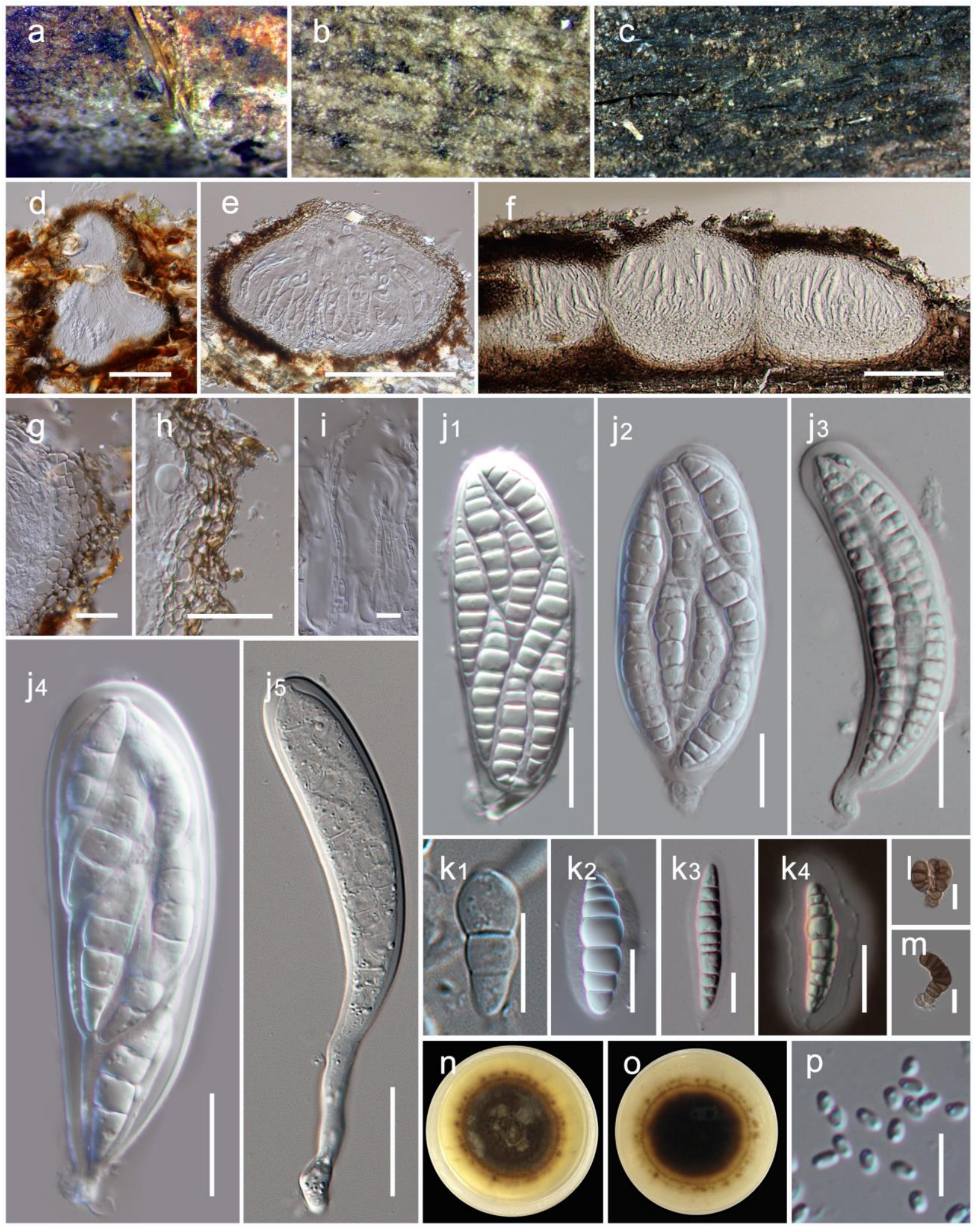

Figure 121 - Parabambusicolaceae. a-c Ascomata on the host surface. d-f Vertical section of ascomata. g, h Section of peridium. i Pseudoparaphyses. j1-j5 Asci. k1-k4 Ascospores (k4 with Indian ink). 1, m, p Conidia. n, o Upper (n) and reverse (o) views of colony on PDA. (Please Notes - a a, e, h, j2, n-p: Neoaquastroma bauhiniae; b, j3, k3: Multiseptospora thailandica; f, j5, k1: Multilocularia bambusae; d, g, i, j4, k2: Neoaquastroma guttulatum; j1, k4 Lonicericola hyaloseptispora; , $\mathrm{m}$ : Paratrimmatostroma kunmingensis). Scale bars: $\mathrm{d}, \mathrm{f}=100 \mu \mathrm{m}, \mathrm{c}=50 \mu \mathrm{m}, \mathrm{g}$, $\mathrm{j} 1-\mathrm{j} 5=20 \mu \mathrm{m}, \mathrm{h}, \mathrm{k} 1-\mathrm{m}=10 \mu \mathrm{m}, \mathrm{p}=5 \mu \mathrm{m}$. 
Parabambusicolaceae Kaz. Tanaka \& K. Hiray., Stud. Mycol. 82: 115 (2015).

Index Fungorum number: IF 811324; Facesoffungi number: FoF 06708, 14 species.

Saprobic in freshwater and terrestrial habitats. Sexual morph: Ascomata scattered or in groups, immersed to erumpent, globose, subglobose to hemisphaerical, with rough black surface, ostiolate. Ostiole short papillate, central, sometimes compressed, composed of heavily melanised cells. Peridium two-layered, outer layer of small heavily pigmented thick-walled cells of textura angularis, inner layer of hyaline thin-walled cells textura angularis. Hamathecium comprising numerous, hyaline, septate, narrow, branched, pseudoparaphyses, embedded in a gel matrix. Asci 8spored, bitunicate, fissitunicate, clavate to broadly cylindrical, pedicellate, apically round, with an ocular chamber. Ascospores overlapping 2-3-seriate, clavate, ellipsoidal to subfusiform, hyaline, reddish-brown or pale, 1- to multi-septate, with the primary septum almost median, with small to large guttules in each cell, generally surrounded by an irregular, hyaline, gelatinous sheath. Asexual morph: Coelomycetous, phoma-like, or sporodochial, monodictys-like hyphomycetous (Tanaka et al. 2015, Phukhamsakda et al. 2018a).

Type - Parabambusicola Kaz. Tanaka \& K. Hiray.

Notes - Tanaka et al. (2015) introduced Parabambusicolaceae to accommodate massarinalike species from bamboo and grasses. They included Aquastroma, Multiseptospora and Parabambusicola (the type) in this family. Li et al. (2016a) introduced Multilocularia which was also collected from bamboo. Wanasinghe et al. (2017b) accounted Neoaquastroma as another genus in this family from decaying wood in Thailand. Phukhamsakda et al. (2018a) introduced two new species to Neoaquastroma from Bauhinia variegata, and Barringtonia acutangular. This confirms that the parabambusicolous taxa are not restricted to bamboo but can be found on different hosts. Wijayawardene et al. (2017a) accepted five genera in this family (Aquastroma, Multilocularia, Multiseptospora, Neoaquastroma, Parabambusicola). Phukhamsakda et al. (2018a) showed that Pseudomonodictys also should be included from their multi-gene phylogenetic analyses. Phookamsak et al. (2019) introduced Lonicericola and Paratrimmatostroma and Hyde et al. (2020b) introduced Paramonodictys as new genus to this family.

Parabambusicola Kaz. Tanaka \& K. Hiray., Stud. in Mycol. 82: 115 (2015).

Index Fungorum number: IF 811327; Facesoffungi number: FoF 08320; 2 morphological species (Species Fungorum 2020), 2 species with molecular data.

Type species - Parabambusicola bambusina (S.C. Teng) Kaz. Tanaka \& K. Hiray., Stud. Mycol. 82: 116 (2015).

三Massarina bambusina Teng, Sinensia, Shanghai 7: 512 (1936).

Notes - Tanaka et al. (2015) introduced Parabambusicola to accommodate massarina-like taxa that have hemisphaerical to depressed globose ascomata, broadly cylindrical asci, and fusiform, multi-septate ascospores. This genus has two species with $P$. bambusina, formerly classified in Massarina (Teng 1936, Aptroot 1998, Tanaka \& Harada 2003b) and P. thysanolaenae (Phookamsak et al. 2019).

\section{Other genera included}

Aquastroma Kaz. Tanaka \& K. Hiray., Stud. Mycol. 82: 115 (2015).

Index Fungorum number: IF 811325; Facesoffungi number: FoF 08321; 1 morphological species (Species Fungorum 2020), 1 species with molecular data

Type species - Aquastroma magniostiolata Kaz. Tanaka \& K. Hiray. Stud. Mycol. (2015).

Notes - Aquastroma magniostiolata was found in Japan on submerged twigs of a woody plant. This genus shares a close affiliation to Quintaria in having multi-septate ascospores and aquatic habitat. However, they are phylogenetically not closely related. See Tanaka et al. (2015) for further details.

Lonicericola Phookamsak, Jayasiri \& K.D. Hyde, Fungal Divers. 95 : 39 (2019).

Index Fungorum number: IF 556139; Facesoffungi number: FoF 04962; 1 morphological species (Species Fungorum 2020), 1 species with molecular data. 
Type species - Lonicericola hyaloseptispora Phookamsak, Jayasiri \& K.D. Hyde, Fungal Divers. 95: 40 (2019).

Notes - Lonicericola formed a distinct lineage with Aquastroma, Multiseptospora, Neoaquastroma, Parabambusicola and clusters with the hyphomycetous genus Pseudomonodictys in multi-gene phylogenetic analyses (Phookamsak et al. 2019). Yasanthika et al. (2020 pers. comm.) will introduce the second species to this genus from Yunnan, China.

Multilocularia Phookamsak, Ariyaw. \& K.D. Hyde, Fungal Divers. 78: 44 (2016).

Index Fungorum number: IF 551946; Facesoffungi number: FoF 01658; 1 morphological species (Species Fungorum 2020), 1 species with molecular data.

Type species - Multilocularia bambusae Phookamsak, Ariyaw. \& K.D. Hyde, Fungal Divers. 78: 45 (2016).

Notes - Multilocularia is a monotypic genus. It forms elongate ascostromata with multiloculate and phragmosporous, hyaline, ellipsoidal ascospores. The genus is commonly found on bamboo as a saprobe and see $\mathrm{Li}$ et al. (2016a) for further details.

Multiseptospora Phookamsak \& K.D. Hyde, Fungal Divers. 72: 156 (2015).

Index Fungorum number: IF 550928; Facesoffungi number: FoF 00430; 2 morphological species (Species Fungorum 2020), 2 species with molecular data.

Type species - Multiseptospora thailandica Phookamsak \& K.D. Hyde, Fungal Divers. 72: 156 (2015).

Notes - Multiseptospora was introduced as a monotypic genus associated with Thysanolaena maxima. It is similar to Falciformispora in its ascospores; however, they differ with regard to their ascomata and host (Liu et al. 2015). Li et al. (2016a) introduced the second species Multiseptospora thysanolaenae from the same host. See Liu et al. (2015) for more details.

Neoaquastroma Wanas., E.B.G. Jones \& K.D. Hyde, Phytotaxa 302 (2): 139 (2017) .

Index Fungorum number: IF 552499; Facesoffungi number: FoF 02609; 4 morphological species (Species Fungorum 2020, Samarakoon et al. 2019), 4 species with molecular data.

Type species - Neoaquastroma guttulatum Wanas., E.B.G. Jones \& K.D. Hyde, Phytotaxa 302 (2): 139 (2017).

Notes - Neoaquastroma was introduced from a dead twig of an herbaceous plant collected in Northern Thailand. Phukhamsakda et al. (2018a) introduced two novel species, $N$. bauhiniae and $N$. krabiense. Samarakoon et al. (2019b) found another species N. cylindricum from Guizhou, China and confirmed that this genus is widely distributed. See Wanasinghe et al. (2017b), Phukhamsakda et al. (2018a) and Samarakoon et al. (2019b) for more details.

Paramonodictys N.G. Liu, K.D. Hyde \& J.K. Liu, Fungal Divers (2020).

Index Fungorum number: IF 557092; Facesoffungi number: FoF 06709; 1 morphological species (Hyde et al. 2020b), 1 species with molecular data.

Type species - Paramonodictys solitarius N.G. Liu, K.D. Hyde \& J.K. Liu (2020).

Notes - Paramonodictys is a monotypic genus which is known by only its hyphomycetous asexual morph. The genus is characterized by subcylindrical or truncated-cone-formed stroma, monoblastic conidiogenous cells and solitary, dictyosporous, muriform, globose or subglobose, olivaceous brown to dark brown conidia. The type Paramonodictys solitarius, is resemblances Monodictys in morphological features. However, it produces conidia directly from stroma and this is different from all other known monodictys-like species (Hyde et al. 2020b).

Paratrimmatostroma Jayasiri, Phookamsak, Bhat \& K.D. Hyde, Fungal Divers. 95: 43 (2019).

Index Fungorum number: IF 556153; Facesoffungi number: FoF 04960; 1 morphological species (Species Fungorum 2020), 1 species with molecular data.

Type species - Paratrimmatostroma kunmingensis Jayasiri, Phookamsak, Bhat \& K.D. Hyde, Fungal Divers. 95: 44 (2019. 
Notes - Phookamsak et al. (2019) introduced Paratrimmatostroma as a monotypic genus which resembles Trimmatostroma. However, they are phylogenetically distinct in that Paratrimmatostroma belongs to Parabambusicolaceae (Pleosporales, Dothideomycetes), whereas Trimmatostroma was recently treated in Mollisiaceae (Helotiales, Leotiomycetes). See Phookamsak et al. (2019) for more details.

Pseudomonodictys Doilom, Ariyaw., Bhat \& K.D. Hyde, Fungal Divers. 75: 88 (2015).

Index Fungorum number: IF 551348; Facesoffungi number: FoF 00906; 1 morphological species (Species Fungorum 2020), 1 species with molecular data.

Type species - Pseudomonodictys tectonae Doilom, Ariyaw., Bhat \& K.D. Hyde, Fungal Divers. 75: 89 (2015).

Notes - Pseudomonodictys was introduced as a monotypic genus. The genus is similar to Monodictys in having semi-macronematous, erect or flexuous, unbranched or irregularly branched conidiophores, holoblastic conidiogenous cells and dictyosporous conidia, but the conidia of Pseudomonodictys have granular contents and colonies on PDA produce red pigments which have not been reported for Monodictys species (Ariyawansa et al. 2015a). See Ariyawansa et al. (2015a) for more details.

\section{Ecological and economic significance}

They are important to the cycling of carbon and nutrients during the decomposition of organic matter especially in terrestrial habitats.

Paradictyoarthriniaceae Doilom, Jian K. Liu \& K.D. Hyde, Fungal Divers., 72: 133 (2015). Index Fungorum number: IF 550921; Facesoffungi number: FoF 00499, 5 species.

Saprobic on dead wood, stem, spathe and spines. Sexual morph: Ascomata small black dots on the host surface, scattered, gregarious, semi-immersed to erumpent through host tissue, uniloculate, globose to subglobose, with papillate ostioles. Peridium thick-walled, of unequal thickness, hyaline inner layers to brown outer layer, pseudoparenchymatous cells, arranged in a textura angularis to textura globulosa. Hamathecium comprising filamentous, cellular pseudoparaphyses, with distinct septa. Asci 8-spored, bitunicate, fissitunicate, broadly cylindrical to cylindric-clavate, subsessile to short pedicellate, apically rounded with well-developed ocular chamber. Ascospores overlapping 1-2-seriate, fusiform, hyaline to brown, asymmetric, septate, constricted at the septa, thick-walled, with sheath. Asexual morph: Colonies on natural substrate, superficial, scattered, gregarious, black, powdery fruiting bodies. Conidiophores macronematous, erect to slightly curved, constricted at septa. Conidiogenous cells blastic, integrated, terminal, determinate. Conidia subglobose to ellipsoidal, very variable in size and shape, solitary or developing in branched chains, circular to irregular with a protruding basal cel, rounded to truncate at the base, brown to black, muriform.

Type - Paradictyoarthrinium Matsush., Matsush.

Notes - Liu et al. (2015) introduced Paradictyoarthriniaceae in Pleosporales Dothideomycetes based on phylogenetic analysis and unique morphology. Members have superficial, gregarious, black, powdery fruiting bodies and macronematous conidiophores with muriform, subglobose to ellipsoidal dark brown conidia. However, it is hard to differentiate them by morphology as their conidia are variable in size and shape. They can be distinguished by DNA sequence data. Wanasinghe et al. (2018c) introduced Xenomassariosphaeria, as the second genus in the family.

Paradictyoarthrinium Matsush., Matsush. Mycol. Mem. 9: 18 (1996).

Index Fungorum number: IF 27676; Facesoffungi number: FoF 00315; 4 morphological species (Species Fungorum 2020), 4 species with molecular data.

Type species - Paradictyoarthrinium diffractum Matsush., Matsush., Matsush. Mycol. Mem. 9: 18 (1996). 

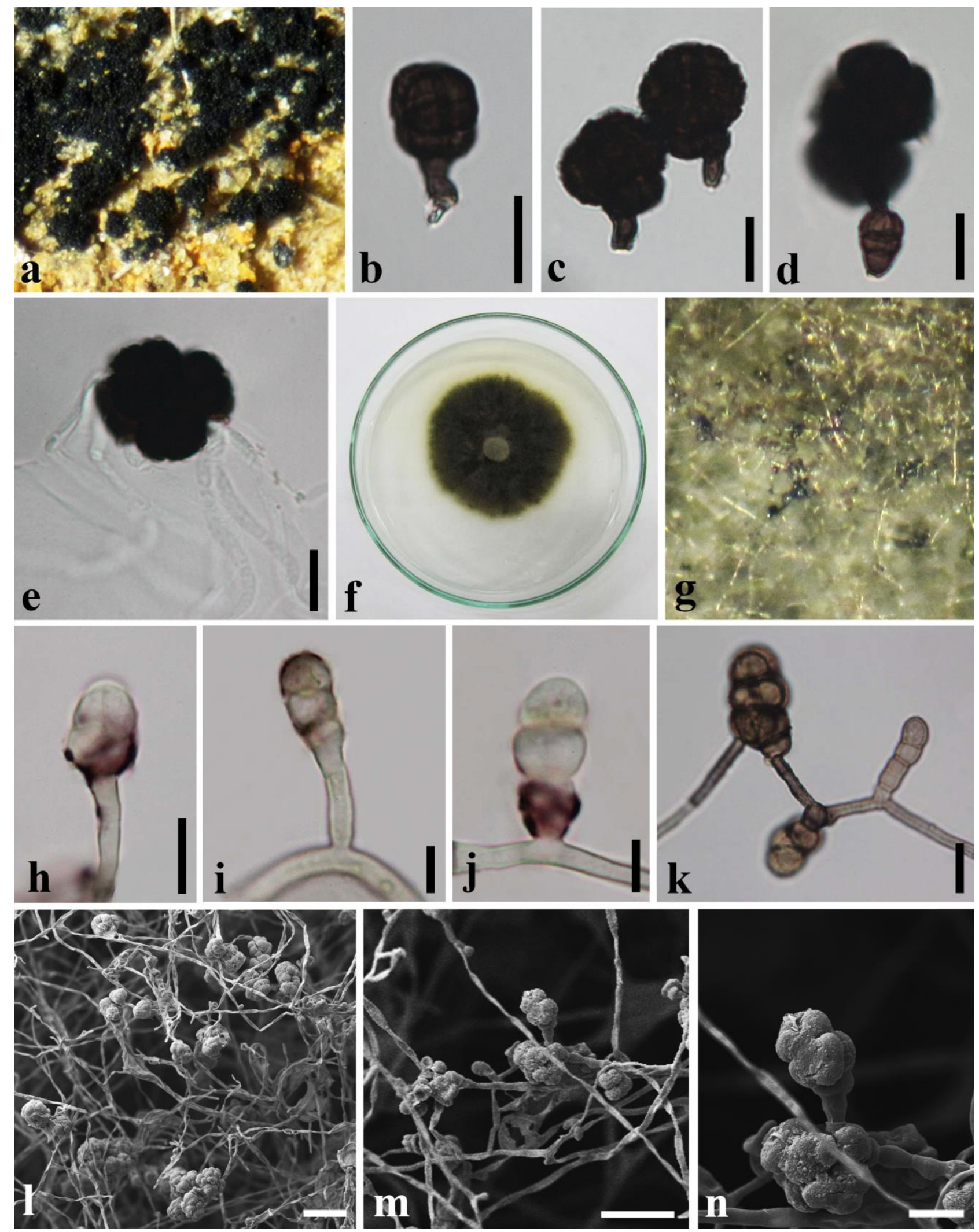

Figure 122 - Paradictyoarthrinium diffractum (MFLU 14-0631). a Colonies on host surface. $\mathrm{b}-\mathrm{d}$ Conidia. e Germinated conidium. f Colony on PDA. g Close up of colony on PDA. $\mathrm{h}-\mathrm{n}$ Conidia with conidiophores on PDA. Notes $-1-n$ Micrograph from SEM. Scale bars: $b-e, h, k, n=$ $10 \mu \mathrm{m}, \mathrm{i}, \mathrm{j}=5 \mu \mathrm{m}, \mathrm{l}=40 \mu \mathrm{m}, \mathrm{m}=50 \mu \mathrm{m}$.

Notes - Paradictyoarthrinium comprises four species $P$. aquatica, $P$. diffractum, $P$. hydei and P. tectonicola (Index Fungorum 2020). Paradictyoarthrinium species have been reported in both terrestrial and aquatic habitats from decaying wood in freshwater, dead twig in stream, dead 
decaying spathe of Cocos nucifera, dead stumps and dead stem of Tectona grandis. They are known in China, India, Thailand and South Africa (Matsushima 1996, Prabhugaonkar \& Bhat 2011, Liu et al. 2015, 2018a, Doilom et al. 2017).

Paradictyoarthrinium diffractum Matsush., Matsush. Mycol. Mem. 9:18 (1996).

Fig. 122

Index Fungorum number: IF 415849; Facesoffungi number: FoF 01854.

Description - see Doilom et al. (2017).

Material examined - Thailand, Chiang Rai Province, Mae Chan District, on dead stems of Tectona grandis, 2 December 2012, M. Doilom (MFLU 14-0631).

\section{Other genus included}

Xenomassariosphaeria Jayasiri, Wanas. \& K.D. Hyde, Fungal Divers. 89: 103 (2018).

Index Fungorum number: IF 415849; Facesoffungi number: FoF 03849, 1 morphological species (Species Fungorum 2020), 1 species with molecular data.

Type species - Xenomassariosphaeria rosae Jayasiri, Camporesi \& K.D. Hyde, in Wanasinghe et al., Fungal Divers. 89: 103 (2018).

Notes - Xenomassariosphaeria was introduced with the type species, X. rosae as the first record of its sexual morph in Paradictyoarthriniaceae by Wanasinghe et al. (2018c). The holotype specimen (MFLU 15-1073) was isolated from dead aerial spines of Rosa canina in Italy. Morphologically, $X$. rosae is similar to Massariosphaeria spp. in having transversely septate ascospores, thick-walled, and surrounded by a prominent gelatinous sheath (Tanaka \& Harada 2004).

\section{Ecological and economic significance}

The species in Paradictyoarthriniaceae are saprobic fungi in both terrestrial and aquatic habitats occurring on various plant tissues such as dead twig, dead stump and dead stem. They are probably involved as decomposers of the complex organic compounds such as lignin and cellulose by secreting enzymes.

Paralophiostomataceae V.V. Sarma \& M. Niranjan. fam. nov.

Facesoffungi number: FoF 06621, 1 species.

Etymology - With reference to a resemblance to Lophiostomataceae.

Saprobic on dead and decaying twigs. Sexual morph: Ascomata perithecoid, scattered, carbonaceous, subglobose, immersed, clypeate, apical long slit-like ostiole, periphysate. Peridium thick with several layers of textura angularis cells. Hamathecium comprising numerous, filamentous, septate, branched, anastomosing pseudoparaphyses in a gelatinous matrix. Asci 8spored, bitunicate, fissitunicate, clavate to cylindrical, apically rounded with ocular chamber, long pedicellate. Ascospores overlapping 1-seriate, fusiform, hyaline to pale brown when young, brown to dark brown at maturity, 1-septate with a constriction when young, 3-septate with constrictions at maturity, central septum strongly constricted, uni-guttulate in each cell, obtuse ends with apical caps, each spore having one, supramedian cell, fully mature spores often splitting into part spores. Asexual morph: Undetermined.

Type - Paralophiostoma V.V. Sarma \& M. Niranjan.

Notes - Paralophiostomaceae resembles Lophiostomataceae, however, it differs from Lophiostomataceae in having wide hysteriothecoid necks in ascomata, cylindrical asci and ascospores that split into part-spores at maturity. Considering septation of ascospores of Lophiostomataceae, out of 24 genera, only 5 genera (Alpestrisphaeria, Guttulispora, Neopaucispora, Parapaucispora and Paucispora) produce 3-sepatate brown ascospores (Thambugala et al. 2015b, Wanasinghe et al. 2018c, Tennakoon et al. 2018b, Hashimoto et al. 2018a). However, they lack sheaths or appendages whereas the new taxon, Paralophiostomaceae produces prominent appendages and a thin (incipient) mucilaginous sheath. The new family also differs from Lophiotremataceae in having longer pedicellate asci and brown ascospores, which split into part spores at maturity. Taxa belonging to Aigialaceae, Ligninsphaeriaceae, 
Lophiostomataceae and Lophiotremataceae have ascomata with slit-like ostioles. Future studies are needed to confirm whether a sub-order Lophiostomatoideae could be raised to include all those families of Pleosporales. In our phylogenetic analysis (Figs. 1 and 42), Paralophiostomaceae forms a distinct family in Pleosporales. Thus, we introduce the new family Paralophiostomaceae based on the monotypic genus Paralophiostoma to be accommodated in Pleosporales.

Paralophiostoma V.V. Sarma \& M. Niranjan gen. nov.

Index Fungorum number: IF 556725; Facesoffungi number: FoF 06622, 1 morphological species (this study), 1 species with molecular data.

Etymology - In reference to its similarity to Lophiostoma.

Type species - Paralophiostoma hysterioides M. Niranjan \& V.V. Sarma.

Saprobic on dead and decaying twigs. Sexual morph: Ascomata perithecoid, scattered, carbonaceous, subglobose, immersed, erumpent with hysterothecoid necks, clypeate, apical long slit-like ostioles, periphysate. Peridium thick-walled with several layers of textura angularis cells. Hamathecium comprising numerous, filamentous, septate, unbranched, trabeculate pseudoparaphyses, anastomosing in a gelatinous matrix. Asci 8-spored, bitunicate, fissitunicate, cylindro-clavate, apically rounded with ocular chamber, long pedicellate. Ascospores overlapping 1-seriate, fusiform, hyaline to pale brown when young, brown to dark brown at maturity, 1-septate with a constriction when young, 3-septate with constrictions at maturity, central septum strongly constricted, uni-guttulate in each cell, obtuse ends with apical caps, each spore having one, supramedian cell, spores often splitting into part spores at maturity. Asexual morph: Undetermined.

Notes - Out of the 24 genera in Lophiostomataceae (Tennakoon et al. 2018b), only Alpestrisphaeria, Biappendiculispora, Guttulispora, Neopaucispora, Parapaucispora, Paucispora and Sigarispora produce 3-septate, brown ascospores but they lack appendages or sheaths. While, Paralophiostoma produces 3-septate, brown ascospores with bipolar appendages and a thin (incipient) sheath. Paralophiostoma is closely related to Guttulispora but differs in having darkbrown ascospores with apical caps, splitting into part spores (Thambugala et al. 2015b). Paralophiostoma has close affinities to Lophiostoma including slit-like ostioles in the ascomata, long pedicellate asci and often phragmosporous, fusiform ascospores. However, the new genus differs from Lophiostoma in having immersed ascomata erumpent with hysterothecoid necks opening with slit-like ostioles, cylindrical asci instead of clavate asci and ascospores splitting into part spores at maturity. Hence based on the morphological and DNA sequence differences, a new genus Paralophiostoma is introduced based on the monotypic species $P$. hysterioides to be accommodated in Paralophiostomataceae.

Paralophiostoma hysterioides V.V. Sarma \& M. Niranjan, sp. nov.

Fig. 123

Index Fungorum number: IF 556724; Facesoffungi number: IF 06623.

Etymology - With reference to the erumpent hysterothecoid necks of the ascomata.

Saprobic on unidentified twigs. Sexual morph: Ascomata 565 high $\times 510$ wide $\mu \mathrm{m}$, immersed perithecoid ascomata with erumpent hysterothecoid to elongate slit-like necks, carbonaceous, scattered, clypeate, sub-globose, apically long slit-like ostioles, periphysate, Peridium 18-20 $\mu \mathrm{m}$ thick with several layers of textura angularis cells. Hamathecium comprising up to $1-1.8 \mu \mathrm{m}$ width, filamentous, trabeculate pseudoparaphyses, hyaline, septate, unbranched, anastomosing, numerous. Asci (121)126-148(153) $\times 10-12.5 \mu \mathrm{m}(\bar{x}=133.8 \times 11.4, \mathrm{n}=25), 8$-spored, bitunicate, fissitunicate, broadly cylindrical, apically rounded with ocular chamber, long pedicellate. Ascospores $23.5-27.5 \times 5.5-7 \mu \mathrm{m}(\bar{x}=26 \times 6.2, \mathrm{n}=25)$, overlapping 1-seriate, fusiform, hyaline to pale brown when young, brown to dark brown at maturity, one septate with constriction when young, 3-septate with constrictions at maturity, central septum strongly constricted, tri-guttulate with each spore having one, supramedian cell, obtuse ends with thick apical caps and a thin (incipient) sheath, fully mature ascospores splitting into part spores. Asexual state: Undetermined. 


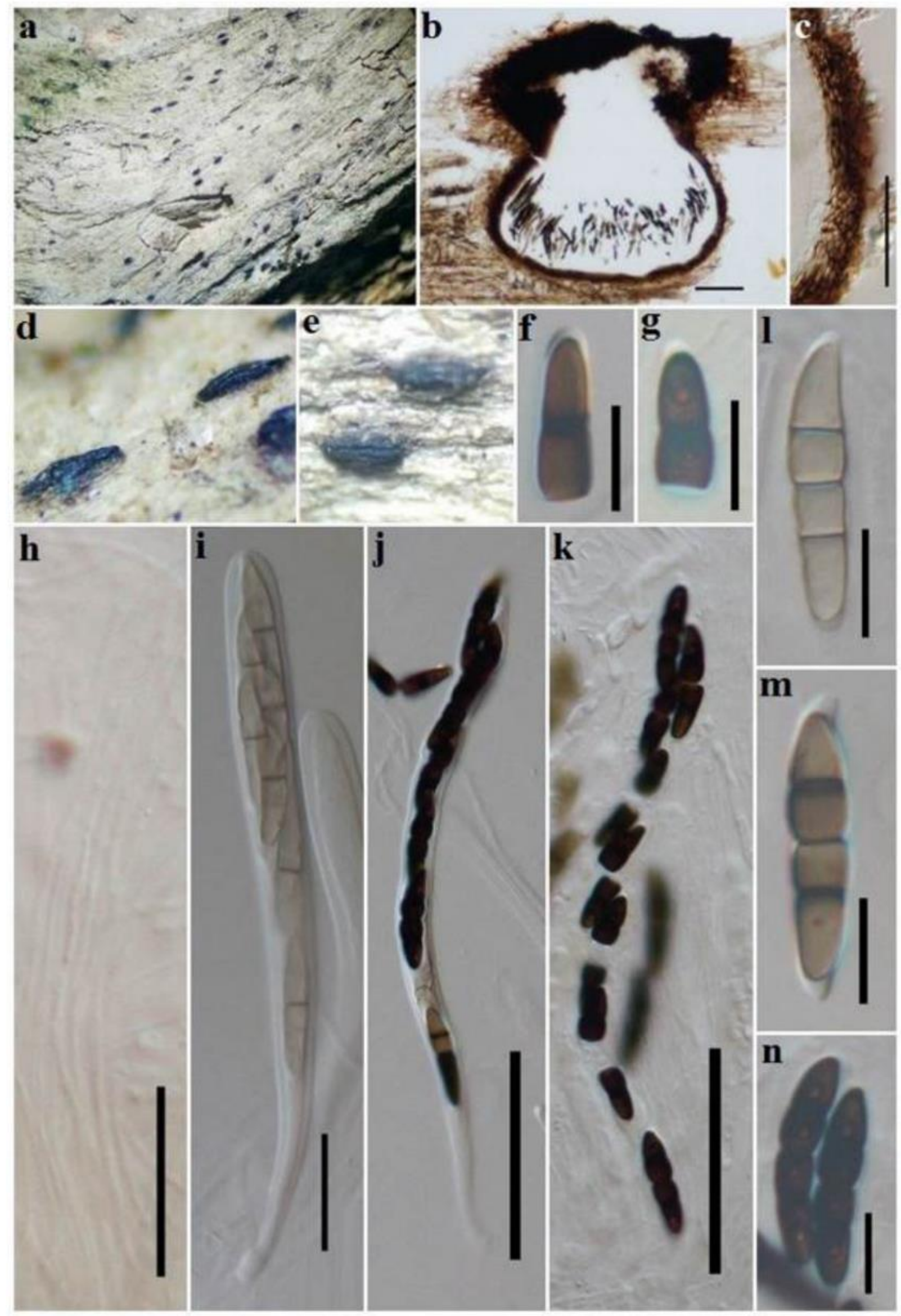

Figure 123 - Paralophiostoma hysterioides (PUFNI 17617, holotype). a Ascomata on host twig. b Ascoma. c Peridium. d, e Slit-like ostiole. f, g Part-spores. h Pseudoparaphyses. i-k Asci. $1-n$ Ascospores. Scale bars: $b=100 \mu \mathrm{m}, \mathrm{c}, \mathrm{j}, \mathrm{k}=50 \mu \mathrm{m}, \mathrm{h}, \mathrm{i}=20 \mu \mathrm{m}, \mathrm{f}, \mathrm{g}, \mathrm{l}-\mathrm{n}=10 \mu \mathrm{m}$. 
Material examined - India, Andaman and Nicobar Islands, South Andaman, Chidiya Tapu, Viewpoint Area, (1 ${ }^{\circ} 28^{\prime} 10.3^{\prime}$ N, $92^{\circ} 41^{\prime} 08.3$ 'E), on identified twig, on 9 December, 2017, M. Niranjan (PUFNI 17617), herbarium-AMH (AMH-9981) and Living culture (NFCC-4397 holotype) Additional specimens examined: Port Blair, Chidiya Tapu, Viewpoint Area (11 $28^{\circ} 46^{\prime \prime} \mathrm{N}$ 92 42'38'E) on unidentified twig (T334F1, T336F2) 20 May, 2018 Niranjan \& Sarma.

GenBank numbers: LSU: MT912850, SSU: MT914175, ITS:MN582758, rpb-2: MT926117.

Notes - Paralophiostoma hysterioides has certain unique features such as long pedicellate asci and ascospores guttulate, with appendages and a thin incipient mucilaginous sheath, and fully mature ascospores splitting into part spores.

\section{Ecological and economic significance}

A single species of this family was found as saprobic on twigs involved in recycling organic matter.

Parapyrenochaetaceae Valenz.-Lopez, Crous, Stchigel, Guarro \& Cano., Stud. Mycol. 90: 64 (2018).

Index Fungorum number: IF 820418; Facesoffungi number: FoF 08322, 3 species.

Endophytic, saprobes associated with a wide host range. Sexual morph: Undertermined. Asexual morph: Conidiomata pycnidial, brown, solitary, pycnidial wall composed of textura angularis cells, setose, globose, ostiolate. Conidiogenous cells phialidic, ampulliform or lageniform. Conidia allantoid or ellipsoidal, hyaline, aseptate, smooth- and thin-walled (Valenzuela-Lopez et al. 2018).

Type - Parapyrenochaeta Valenz.-Lopez, Crous, Stchigel, Guarro \& Cano

Notes - Parapyrenochaetaceae was introduced by Valenzuela-Lopez (2018) after a detailed morphological comparison followed by molecular analysis. The name of the family was derived from its close relationship with Pyrenochaeta. Several isolates previously recognized in Pyrenochaeta, are proposed to be in the new family Parapyrenochaetaceae (Valenzuela-Lopez et al. 2018). Pyrenochaeta previously belonged to Cucurbitariaceae of order Pleosporales which is a family of economic importance including many plant pathogens, endophytes and saprobes with a wide host range. Cucurbitariaceae is a poorly known family, introduced by Winter (1885). In the last revision of Cucurbitariaceae, four sexual genera (Cucurbitaria, Curreya, Rhytidiella and Syncarpella) and two asexual genera (Pyrenochaeta and Pyrenochaetopsis) were accepted (Doilom et al. 2013). The latter two genera are characterised by phoma-like, setose pycnidia, and hyaline, aseptate conidia (De Gruyter et al. 2010, 2013). Generic concept of the genera phoma and pyrenochaeta has been clarified and better delimitation of members in Cucurbitariaceae has been achieved with the establishment of Parapyrenochaetaceae.

Parapyrenochaeta Valenz.-Lopez, Crous, Stchigel, Guarro \& Cano., Stud. Mycol. 90: 64 (2018).

Index Fungorum number: IF 820319; Facesoffungi number: FoF 08323; 2 morphological species (Species Fungorum 2020), 2 species with molecular data.

Type species - Parapyrenochaeta protearum (Crous) Valenz.-Lopez, Crous, Stchigel, Guarro \& Cano., Stud. Mycol. 90:64 (2018).

EPyrenochaeta protearum Crous, Persoonia 27:153 (2011).

Notes - Pyrenochaeta protearum resembles phoma-like taxa in producing single phialides covering the inner source of the pycnidia, and having small, aseptate, hyaline conidia, but also resembles pyrenochaeta-like species due to its setose pycnidia (Crous et al. 2011b). Based on multilocus molecular phylogenetic analysis using ITS and LSU nucleotide sequence data, this fungus has been identified as related to Leptosphaeria, Pyrenochaeta and Pyrenochaetopsis, and was included in Pyrenochaeta (Crous et al. 2011b). Valenzuela-Lopez et al. (2018) accommodated the fungal species into Parapyrenochaeta.

Parapyrenochaeta protearum (Crous) Valenz.-Lopez, Crous, Stchigel, Guarro \& Cano., Stud. Mycol. 90:64 (2018).

Fig. 124 
EPyrenochaeta protearum Crous, in Crous et al., Persoonia 27: 153 (2011).

Index Fungorum number: IF 820320; Facesoffungi number: FoF 08324.

Desciption - see Valenzuela-Lopez et al. (2018).
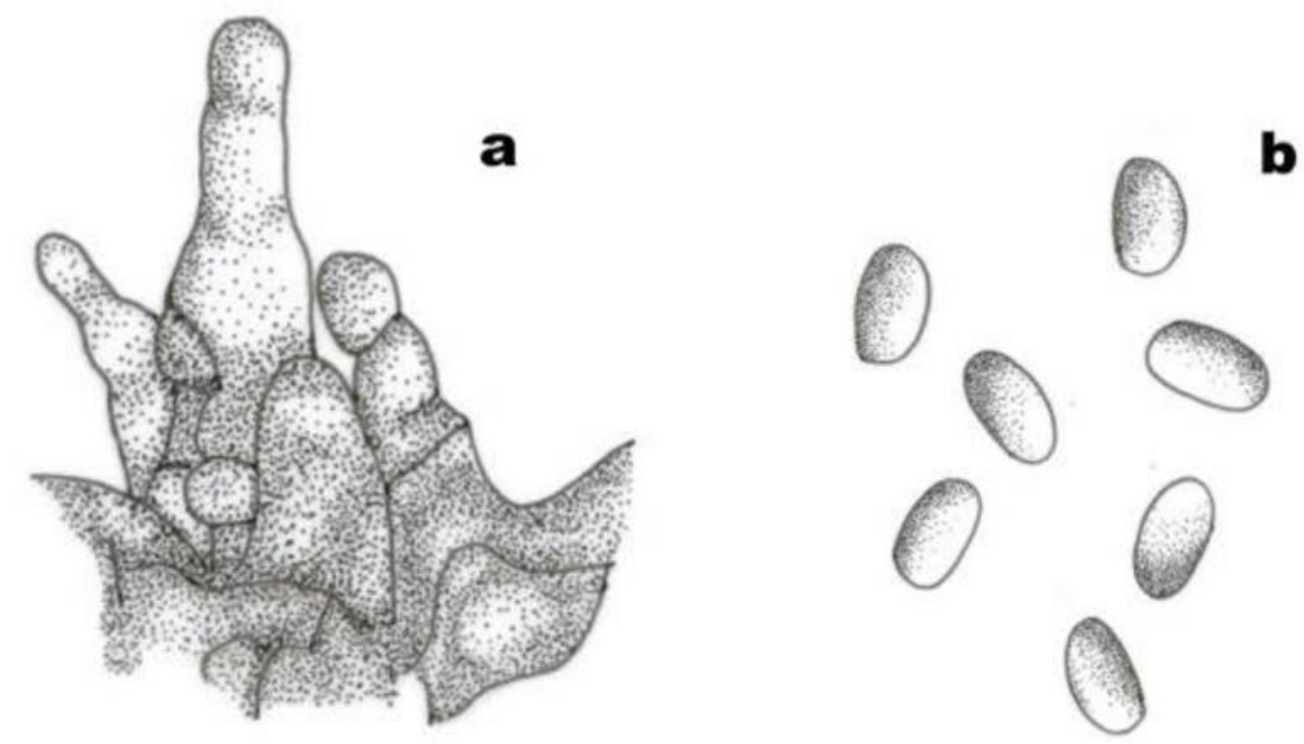

Figure 124 - Parapyrenochaeta protearum (redrawn from Valenzuela-Lopez et al. 2018, CBS 131315). a Conidiophores. b Conidia.

\section{Other genus included}

Quixadomyces Cantillo \& Gusmão., Persoonia 40:317 (2018).

Index Fungorum number: IF 824358; Facesoffungi number: FoF 08325; 1 morphological species (Species Fungorum 2020), 1 species with molecular data.

Type species - Quixadomyces cearensis Cantillo \& Gusmão., Persoonia. 40:317 (2018).

Notes - Quixadomyces cearensis resembles setose pycnidia which are common in some Pleosporales species, but internal structures were not observed at any stage of development. Even though Quixadomyces cearensis resembles Akenomyces, the clamp connections in Akenomyces clearly separates it from Quixadomyces. Megacapitula is another similar genus to Quixadomyces. The integrated or terminal conidiogenous cells on verruculose mycelial cords in Megacapitula distinguishes it from Quixadomyces (Crous et al. 2018c). On the natural substrate Quixadomyces cearensis mycelia are superficial or somewhat immersed in the substrate, hyphae are warty, sinuous, criss-crossed or stringing, verrucose or verruculose, brown and septate. Conidiophores and conidiogenous cells are absent. Propagules emerged directly up from interwoven hyphal strands. Propagules shaped globose to subglobose at first, ellipsoid to ovoid when mature. The wall consists of anastomosed brown to dark olivaceous brown hyphae, textura epidermoidea similis, with some peripheral hyphae around propagule body, smooth or warty, approached at the tip. Colonies on PDA, fast growing, immersed and dark olivaceous to black (Crous et al. 2018c).

\section{Ecological and economic significance}

Currently the fungi of Parapyrenochaetaceae reported in the following hosts. Parapyrenochaeta acaciae was isolated from Australia, Victoria, on leaves of Acacia sp. (Fabaceae) (Valenzuela-Lopez et al. 2018). Parapyrenochaeta protearum which is the type species of family Parapyrenochaetaceae (Valenzuela-Lopez et al. 2018) was observed on symptomless leaves of Protea mundii (Proteaceae), as an endophyte sporulating under moist conditions in Western Cape Province, Hermanus, Fernkloof Nature Reserve South Africa (Crous et al. 2011b). For Quixadomyces species evidence about the isolated host substrate or nutritional relationship was not available (Crous et al. 2018c). 
Periconiaceae Nann., Repert. mic. uomo: 482 (1934).

Index Fungorum number: IF 81124; Facesoffungi number: FoF 06657, 119 species.

= Periconieae Sacc., Syll. Fung. 4: 235. (1886).

Saprobic, pathogenic or endophytic on various hosts. Sexual morph: Ascomata scattered to gregarious, immersed, semi-immersed or erumpent, black or brown, globose to subglobose. Neck central, papillate, with hyaline periphyses. Peridium in longitudinal section composed of several layers of thin or thick-walled, pale brown to brown cells. Hamathecium comprising cellular, branched, anastomosed, pseudoparaphyses. Asci bitunicate, fissitunicate, oblong to cylindrical, 8spored, with a short pedicel and a shallow ocular chamber. Ascospores 2-3-seriate, broadly fusiform, hyaline, 1-septate, smooth-walled, with an entire sheath. Asexual morph: Hyphomycetous. Conidiophores macronematous or micronematous, mononematous, pale to dark brown, branched or unbranched, septate, thick-walled, smooth or verruculose. Conidiogenous cells are monoblastic or polyblastic, integrated or discrete, ovoid to clavate formed on the terminal or intercalary of the stipe, sometimes with small, pimple-like pores. Conidia sphaerical to fusoidellipsoidal, catenate or solitary, pale to dark brown, aseptate, sometimes with a minute, unthickened pore at base, smooth-walled or verruculose.

Type - Periconia Tode, Fung. mecklenb. sel. (Lüneburg) 2: 2 (1791).

Notes - Historically, Periconiaceae has long been neglected and Periconia was included in Massarinaceae (Zhang et al. 2009d, Hyde et al. 2013). Tanaka et al. (2015) resurrected Periconiaceae as a sister taxon of Massarinaceae in Massarineae (Pleosporales, Dothideomycetes) based on their phylogenetic analyses. Phukhamsakda et al. (2016) showed Periconiaceae and Massarinaceae diverging in the late Cretaceous period (around 70 MYA). Four genera are accepted in Periconiaceae.

Periconia Tode, Fung. mecklenb. sel. (Lüneburg) 2: 2 (1791).

Index Fungorum number: IF 9263; Facesoffungi number: FoF 06658; 116 morphological species (Species Fungorum 2020), 22 species with molecular data.

Type species - Periconia lichenoides Tode Fung. mecklenb. sel. (Lüneburg) 2: 2 (1791).

Notes - Most Periconia species are only known as asexual morphs, characterized by macronematous, branched or unbranched conidiophores, blastic, terminal or intercalary conidiogenous cells, and catenate, sphaerical to ellipsoidal or oblong, aseptate conidia usually forming a sphaerical head (Ellis 1971). A few species, such as $P$. homothallica and $P$. pseudodigitata, are known as sexual morphs, characterized by scattered, globose ascomata with a central ostiole, 8-spored, fissitunicate or cylindrical asci with a shallow chamber and short stalk, and hyaline, fusiform, 1-septate ascospores with an entire sheath (Tanaka et al. 2015). Several genera and species, such as Bambusistroma, Flavomyces, Noosia, and Sporidesmium tengii were present in the Periconia lineage in the phylogenetic analyses (Tanaka et al. 2015, Liu et al. 2017b, Thambugala et al. 2017b, Hyde et al. 2018, Jayasiri et al. 2019, Phookamsak et al. 2019), which indicated that Periconia may be polyphyletic (Tanaka et al. 2015).

Periconia thailandica N.G. Liu, K.D. Hyde \& Hongsanan, Phytotaxa 323 (3): 257 (2017). Fig. 125 Index Fungorum number: IF 552956; Facesoffungi number: FoF 03115.

Description - see Liu et al. (2017b).

Material examined - Thailand, Kamphaeng Phet, on decaying bamboo, 12 August 2016, Ningguo Liu, KLN001 (MFLU 17-0211, holotype).

\section{Other genera included}

Bambusistroma D.Q. Dai \& K.D. Hyde, Cryptogamie Mycologie 36 (2): 123 (2015).

Index Fungorum number: IF 551027; Facesoffungi number: FoF 00582; 1 morphological species (Species Fungorum 2020), 1 species with molecular data.

Type species - Bambusistroma didymosporum D.Q. Dai \& K.D. Hyde, Cryptogamie Mycologie 36: 123 (2015). 
Notes - Bambusistroma is a monotypic genus characterized by its subglobose, uniloculate ascomata, 8-spored, bitunicate, cylindrical asci with a short furcate pedicel and a shallow ocular chamber, and 2-3-seriate, hyaline, fusiform, 1-septate ascospores surrounding by a mucilaginous sheath (Adamčík et al. 2015). Asexual morph is unknown. Bambusistroma was originally placed in Massarinaceae by Adamčík et al. (2015). However, this genus was placed in Periconiaceae in several molecular studies (Tanaka et al. 2015, Phukhamsakda et al. 2016, 2017, Thambugala et al. 2017b).

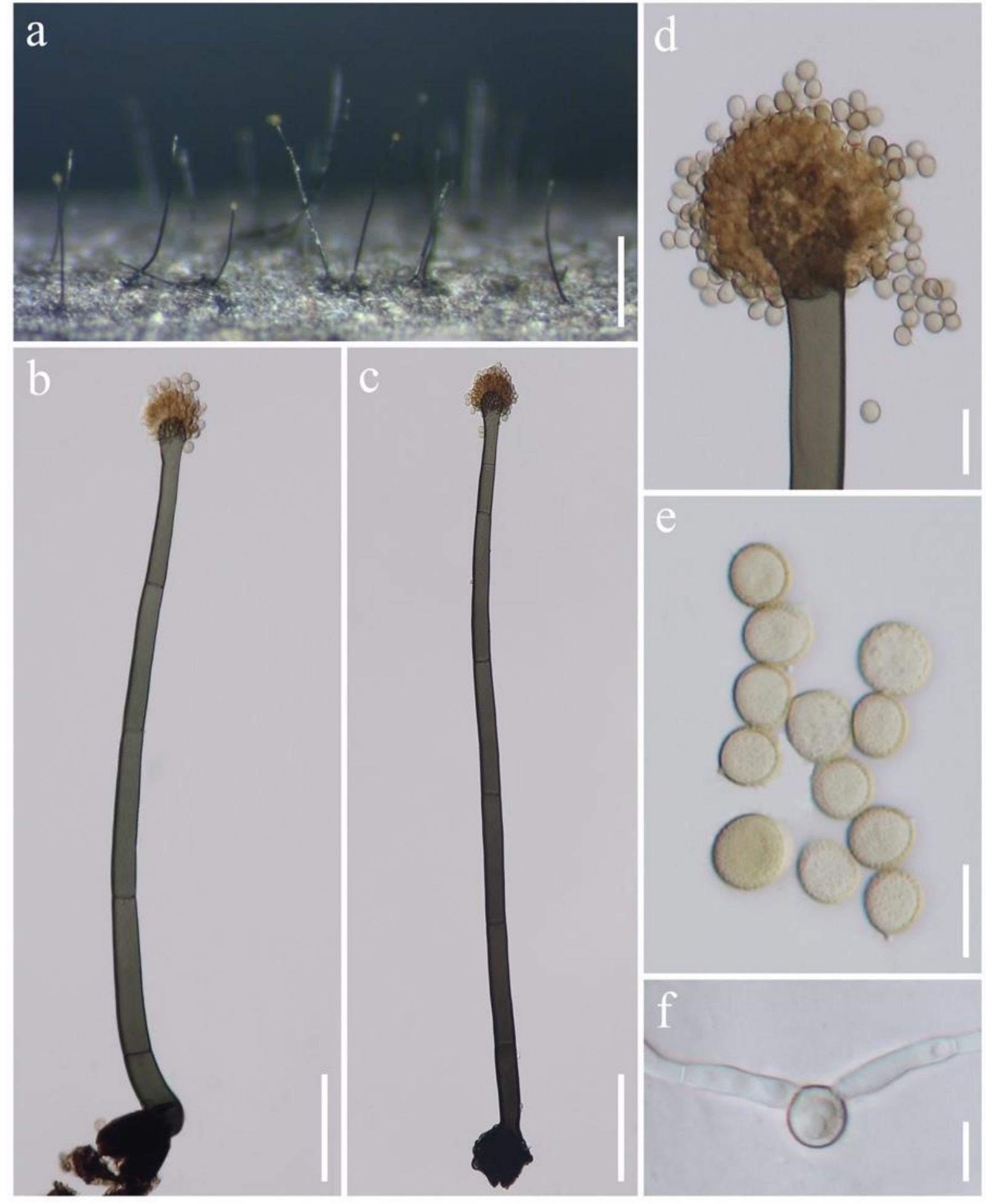

Figure 125 - Periconia thailandica (MFLU 17-0211, holotype). a Colonies on natural substrate. b, c Conidiophores and conidia. d Conidiogenous cells and conidia. e Conidia. f Germinated conidium. Scale bars: $\mathrm{a}=500 \mu \mathrm{m}, \mathrm{b}=30 \mu \mathrm{m}, \mathrm{c}=50 \mu \mathrm{m}, \mathrm{d}=20 \mu \mathrm{m}, \mathrm{e}, \mathrm{f}=10 \mu \mathrm{m}$. 
Flavomyces D.G. Knapp, Kovács, J.Z. Groenew. \& Crous, Persoonia 35: 93 (2015).

Index Fungorum number: IF 810758; Facesoffungi number: FoF 06659; 1 morphological species (Species Fungorum 2020), 1 species with molecular data.

Type species - Flavomyces fulophazii D.G. Knapp, Kovács, J.Z. Groenew. \& Crous, Persoonia 35: 93 (2015).

Notes - Flavomyces fulophazii was reported as a root endophyte and only mycelium morphology is known. Knapp et al. (2015) pointed out this species did not belong to any existing family. Subsequently, Tanaka et al. (2015) carried out a comprehensive study on the suborder Massarineae and Flavomyces fulophazii (CBS 135761) formed a distinct lineage in Periconiaceae in their phylogenetic analyses.

Noosia Crous, R.G. Shivas \& McTaggart, Persoonia 26: 139 (2011).

Index Fungorum number: IF 560172; Facesoffungi number: FoF 06660; 1 morphological species (Species Fungorum 2020), 1 species with molecular data.

Type species - Noosia banksiae Crous, R.G. Shivas \& McTaggart, Persoonia 26: 139 (2011).

Notes - Noosia banksiae is only known in its hyphomycetous asexual morph, which is characterized by micronematous conidiophores, lateral and terminal conidiogenous cells with small, pimple-like pores, and dimorphic conidia. Crous et al. (2011a) placed Noosia in Pleosporales, genera incertae sedis, and this treatment was followed by Wijayawardene et al. (2012, 2014b, 2017a, b, 2018). However, phylogenetic analyses indicated that Noosia belongs to Periconiaceae (Tanaka et al. 2015, Liu et al. 2017b, Thambugala et al. 2017b, Crous et al. 2018c, 2019e).

\section{Ecological and economic significance}

Periconia species include many taxa which have economic importance. Species of this genus have a worldwide distribution as saprobes and endophytes on various herbaceous plant hosts (Rao \& Rao 1964, Carmarán \& Novas 2003, Liu et al. 2017b). Many species in this genus are plant pathogen on various crops, e.g. P. circinata (Leukel 1948). Some species of Periconia have the potential to produce valuable bioactive compounds (Kim et al. 2004, Harnpicharnchai et al. 2009, Zhang et al. 2015a, 2016a).

Phaeoseptaceae S. Boonmee, Thambugala \& K.D. Hyde, Mycosphere 9(2): 323 (2018).

Index Fungorum number: IF 554385; Facesoffungi number: FoF 04462, 8 species.

Saprobic on dead wood in aquatic habitats. Sexual morph: Ascomata erumpent when mature, visible as black spots on the host surface, solitary, scattered, globose to subglobose, dark brown to black, with or without a pseudoclypeus, short papillate, with an apical ostiole. Peridium comprising several layers, outer layers dark brown to black, flattened cells of textura angularis; inner layers hyaline to lightly pigmented cells of textura angularis. Hamathecium comprising cylindrical, branched, septate, anastomosed, cellular pseudoparaphyses. Asci 8-spored, bitunicate, cylindricalclavate, long pedicellate, with a small ocular chamber. Ascospores 2-(-3)-seriate, cylindrical, broadly fusoid to broadly tapering towards the rounded ends, slightly curved, ends asymmetrical, slightly wider at median part, rounded at both ends, light brown, muriform, allantoid, with multitransverse septa, and 1 longitudinal septum in each cell, sometimes with 2 longitudinal septa, constricted and darkened at the septa, smooth-walled (adapted from Zhang et al. 2013c, Hyde et al. 2018, Phukhamsakda et al. 2019a). Asexual morph: Hyphomycetous. Pleopunctum. Mycelium immersed in the substratum, composed of septate, branched, subhyaline to greyish brown hyphae. Conidiophores macronematous, mononematous, cylindrical, branched, medium brown, septate, smooth- and thick-walled. Conidiogenous cells monoblastic, cylindrical, brown. Conidia acrogenous, solitary, broadly oval to ellipsoidal, pale brown when immature, broadly obtuse at apex and dark brown, truncate at base and paler brown when mature, often with a hyaline, elliptical to globose basal cell, muriform, constricted at septa, smooth-walled (adapted from Liu et al. 2019b). 
Type - Phaeoseptum Ying Zhang, J. Fourn. \& K.D. Hyde, in Zhang, Fournier, Phookamsak, Bahkali \& Hyde, Mycologia 105(3): 606 (2013).

Notes - Phaeoseptaceae was established in Pleosporales by Hyde et al. (2018) based on Phaeoseptum which was previously placed in Halotthiaceae (Zhang et al. 2013c). Hyde et al. (2018) accommodated Lignosphaeria Boonmee et al., Neolophiostoma, Decaisnella formosa and Thyridaria macrostomoides, in Phaeoseptaceae. Recently Pleopunctum has been introduced to Phaeoseptaceae (Liu et al. 2019b). Liu et al. (2019a) found the monotypic genus Neolophiostoma formed a clade within Halotthiaceae (Ariyawansa et al. 2015a, Hyde et al. 2016, Phukhamsakda et al. 2016). Even though Hyde et al. (2018) have classified Decaisnella formosa and Thyridaria macrostomoides in Pheoseptaceae; they suggested that recollections and epitypification of these species are needed with DNA sequence data in order to ensure correct placement of these two genera (Abdel-Wahab \& Jones 2003, Mugambi \& Huhndorf 2009b). Lignosphaeria was introduced by Thambugala et al. (2015b), and phylogenetically it formed a sister clade to Thyridaria with a good support. However, Thambugala et al. (2015b) treated Lignosphaeria in Dothideomycetes, genera incertae sedis. This was followed by Pem et al. (2019c). Decaisnella and Thyridaria are retained in Lophiostomataceae and Thyridaceae, respectively. Therefore, we only accept Phaeoseptum and Pleopunctum in Phaeoseptaceae.

Phaeoseptum Ying Zhang, J. Fourn. \& K.D. Hyde, in Zhang, Fournier, Phookamsak, Bahkali \& Hyde, Mycologia 105(3): 606 (2013).

Index Fungorum number: IF 561889; Facesoffungi number: FoF 08326; 6 morphological species (Species Fungorum 2020), 6 species with molecular data.

Type species - Phaeoseptum aquaticum Ying Zhang, J. Fourn. \& K.D. Hyde, in Mycologia 105(3): 606 (2013).

Notes - Phaeoseptum species were reported in freshwater habitats. However, Phukhamsakda et al. (2019a) introduced a third species into the genus, Phaeoseptum mali, as a saprobe from dead wood. Dayarathne et al. (2020) introduced two new species $P$. carolshearerianum and $P$. manglicola which were collected from decaying mangrove wood. Most recently, Wanasinghe et al. (2020a) introduced Phaeoseptum hydei on a dead twig of Delonix regia from Chiang Mai, Thailand.

Phaeoseptum terricola S. Boonmee \& K.D. Hyde, Mycosphere 9(2): 323 (2018).

Fig. 126

Index Fungorum number: IF 554376; Facesoffungi number: FoF 04384.

Description - see Hyde et al. (2018).

Material examined - Thailand, Chiang Mai, Doi Inthanon, Jom Thong, elev. 800-1000 msl., N18 31.576' E 98 29.790', on dead wood, 5 September 2009, S. Boonmee, ITN01 (MFLU10-0032, holotype).

\section{Other genus included}

Pleopunctum N.G. Liu, K.D. Hyde \& J.K. Liu Mycosphere 10(1), 757-775 (2019).

Index Fungorum number: IF 556522; Facesoffungi number: FoF 06113; 2 morphological species (Species Fungorum 2020), 2 species with molecular data.

Type species - Pleopunctum ellipsoideum N.G. Liu, K.D. Hyde \& J.K. Liu, in Mycosphere 10(1), 757-775 (2019).

Notes - Pleopunctum was introduced to accommodate two species ( $P$. ellipticum and $P$. pseudoellipticum) which have hyphomycetous asexual morphs and phylogenetically formed a distinct subclade in Phaeoseptaceae. These novel species have been collected as saprobes on decaying wood in terrestrial habitats in China. Pleopunctum has macronematous, mononematous conidiophores, monoblastic conidiogenous cells and muriform, oval to ellipsoidal conidia often with hyaline and elliptical to globose basal cells which are unique to the genus (Liu et al. 2019b).

\section{Ecological and economic significance}

Inhabitant to the freshwater and saprobic on dead wood and decompose the dead wood materials. 

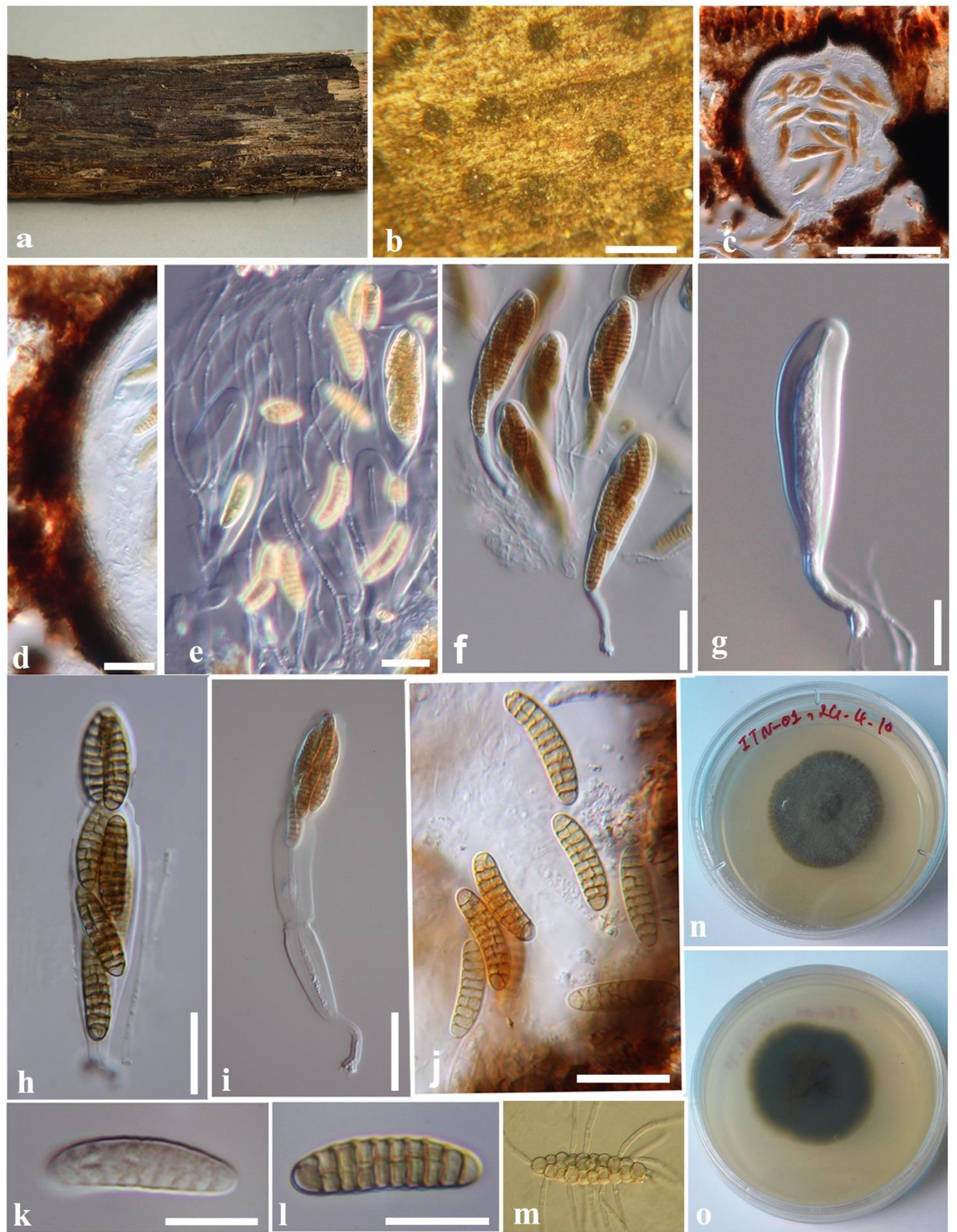

Figure 126 - Phaeoseptum terricola (MFLU 10-0032, holotype). a, b Appearance of ascomata on host surface. c Vertical sections through the ascomata. d. Peridium. e, f Mature and Immature asci with paraphyses. $\mathrm{g}-\mathrm{i}$ Immature and mature asci. $\mathrm{j}-1$ Ascospores. $m$ Growing ascospore. $n$ Front view of the culture on PDA. 0 . Back view of the culture on PDA. Scale bars: $b=500 \mu \mathrm{m}, \mathrm{c}=100$ $\mu \mathrm{m}, \mathrm{d}-\mathrm{I}=20 \mu \mathrm{m}, \mathrm{j}-\mathrm{l}=10 \mu \mathrm{m}$. 
Phaeosphaeriaceae M.E. Barr, Mycologia 71(5): 948 (1979).

Index Fungorum number: IF81637; Facesoffungi number: FoF00232, 794 species.

Pathogenic, saprobic or hyperparasitic mainly on monocotyledons, prominently found on Poaceae and some other herbaceous plants, visible as small black dots on host surface, sometimes produced pink to red pigments tinted host. Sexual morph: Ascomata medium to large sized, solitary, clustered, scattered or gregarious, immersed, semi-immersed to erumpent, or superficial, globose to subglobose, dark brown to black, uni- to bi-loculate, occasionally forming pseudostromata under the clypeus (Neostagonosporella), glabrous or setose ostiolate, papillate with short to long neck. Peridium composed of two types: type I (phaeosphaeria-like) composed of 1-3statra, thin-walled cells of light brown to brown, flattened to broad pseudoparenchymatous cells, arranged in a textura angularis; type II (pleospora-like) composed of several statra, thick-walled cells of dark brown to black, flattened to broad pseudoparenchymatous cells, arranged in a textura angularis to textura prismatica or textura globulosa, paler towards the inner layers to hyaline cells. Hamathecium composed of sparse to dense, broad, cellular pseudoparaphyses, occasionally trabeculate pseudoparaphyses (Neostagonosporella), anastomosing above the asci, embedded in a hyaline gelatinous matrix. Asci 8 -spored, bitunicate, fissitunicate, cylindrical to broadly cylindrical or cylindric-clavate, pedicellate, apically rounded with ocular chamber. Ascospores overlapping 2to multi-seriate, fasciculate or in spiral, dictyosporous, phragmosporous, or scolecosporous, occasionally didymosporous (Embarria), varied in shape, frequently ellipsoidal to fusiform, or filiform, hyaline, light brown to brown, or reddish brown to dark brown, septate, presence or absence of mucilaginous sheath and appendage, smooth- to rough-walled, with, echinulate or verruculose. Asexual morph: Frequently found as coelomycetous, phoma-like and stagonosporalike, occasionally found as dictyosporous coelomycetous (Amarenographium, Camarosporioides, Galiicola, Dlhawksworthia), and some hyphomycetous asexual morphs viz. Bhagirathimyces, Bhatiellae, Edenia and Populocrescentia (Crous et al. 2009a, 2017c, 2019b, Quaedvlieg et al. 2013, Phookamsak et al. 2014c, 2019, Li et al. 2015, Hyde et al. 2016, 2020b, Phukhamsakda et al. 2015, Wanasinghe et al. 2018c, Maharachchikumbura et al. 2019).

Type - Phaeosphaeria I. Miyake.

Notes - Barr (1979a) introduced Phaeosphaeriaceae based on the generic type Phaeosphaeria and also included 14 other genera in this family viz. Comoclathris, Didymella, Eudarluca, Heptameria, Leptosphaeria, Loculohypoxylon, Metameris, Microthelia, Nodulosphaeria, Ophiobolus, Paraphaeosphaeria, Rhopographus, Scirrhodothis and Teichospora. Over the next 35 years, genera in Phaeosphaeriaceae have been revised with inclusions and exclusion by various authors based on morphological characteristics and DNA sequence analyses (Shoemaker 1984, Shoemaker \& Babcock 1989a, Eriksson \& Hawksworth 1993, Kirk et al. 2001, Jones et al. 2009b, Suetrong et al. 2009, Zhang et al. 2009c, 2012b, Lumbsch \& Huhndorf 2010, Hyde et al. 2011, 2013, Quaedvlieg et al. 2013).

Phookamsak et al. (2014c) re-circumscribed the genera in Phaeosphaeriaceae based on the generic type studies and some other representative specimens coupled with multi-gene phylogenetic analyses. They accepted 28 genera in Phaeosphaeriaceae, and this is in agreement with Wijayawardene et al. (2014b). Based on multi-gene phylogenetic analyses, the familial concept of Phaeosphaeriaceae was restricted to the broad sense. Many monotypic genera were introduced based only on phylogenetic analyses such as Acericola, Arezzomyces, Banksiophoma, Bhagirathimyces, Bhatiellae, Brunneomurispora, Camarosporioides, Embarria, Equiseticola, Hydeopsis, Jeremyomyces, Melnikia, Neosphaerellopsis, Neostagonosporella, Ophiobolopsis, Ophiosimulans, Parastagonosporella, Phaeoseptoriella, Piniphoma, Pseudoophiosphaerella, Pseudophaeosphaeria, Vittaliana, Vrystaatia, Xenoseptoria, Yunnanensis (Quaedvlieg et al. 2013, Trakunyingcharoen et al. 2014, Hyde et al. 2016, 2017, 2020b, Tibpromma et al. 2015, Wijayawardene et al. 2016a, Crous et al. 2017b, 2019b, Karunarathna et al. 2017a, Phookamsak et al. 2017, 2019, Wanasinghe et al. 2018c, Bakhshi et al. 2019, Devadatha et al. 2019, Marin-Felix et al. 2019, Yang et al. 2019, Zhang et al. 2019a). More taxon sampling of these genera is required for a better understanding of their phylogenetic affinities and to clarify their classification. 


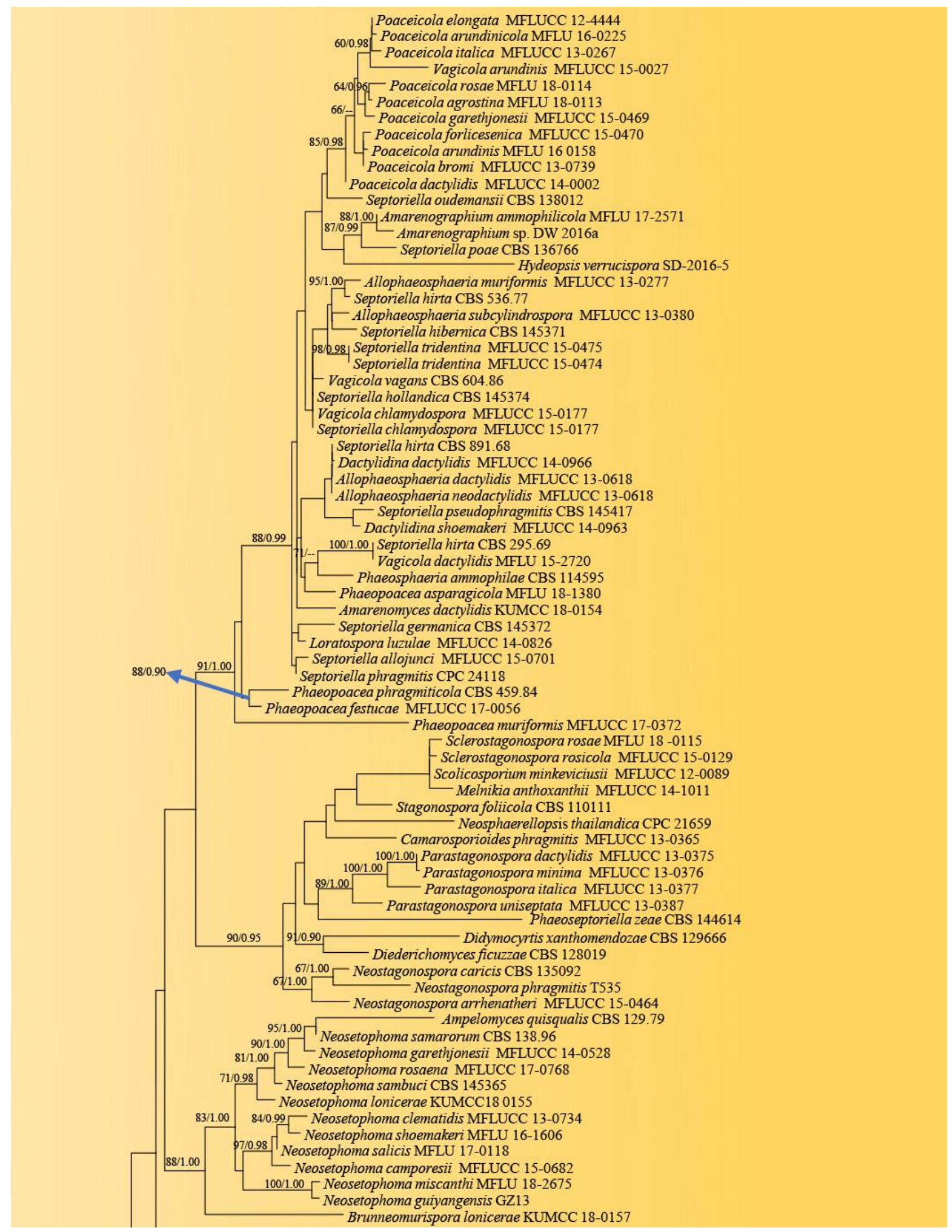

Figure 127 - Phylogram generated from maximum likelihood analysis (RAxML) of genera in Phaeosphaeriaceae based on ITS, LSU, SSU, and tef1 sequence data. Maximum likelihood bootstrap values equal or above $70 \%$, Bayesian posterior probabilities equal or above 0.90 (MLBS/PP) are given at the nodes. An original isolate number is noted after the species name. The tree is rooted to Leptosphaeria doliolum (CBS 505.75) and Paraleptosphaeria dryadis (CBS 643.86). Hyphen (-) represents support values below 70 \% MLBS and 0.90 PP. 


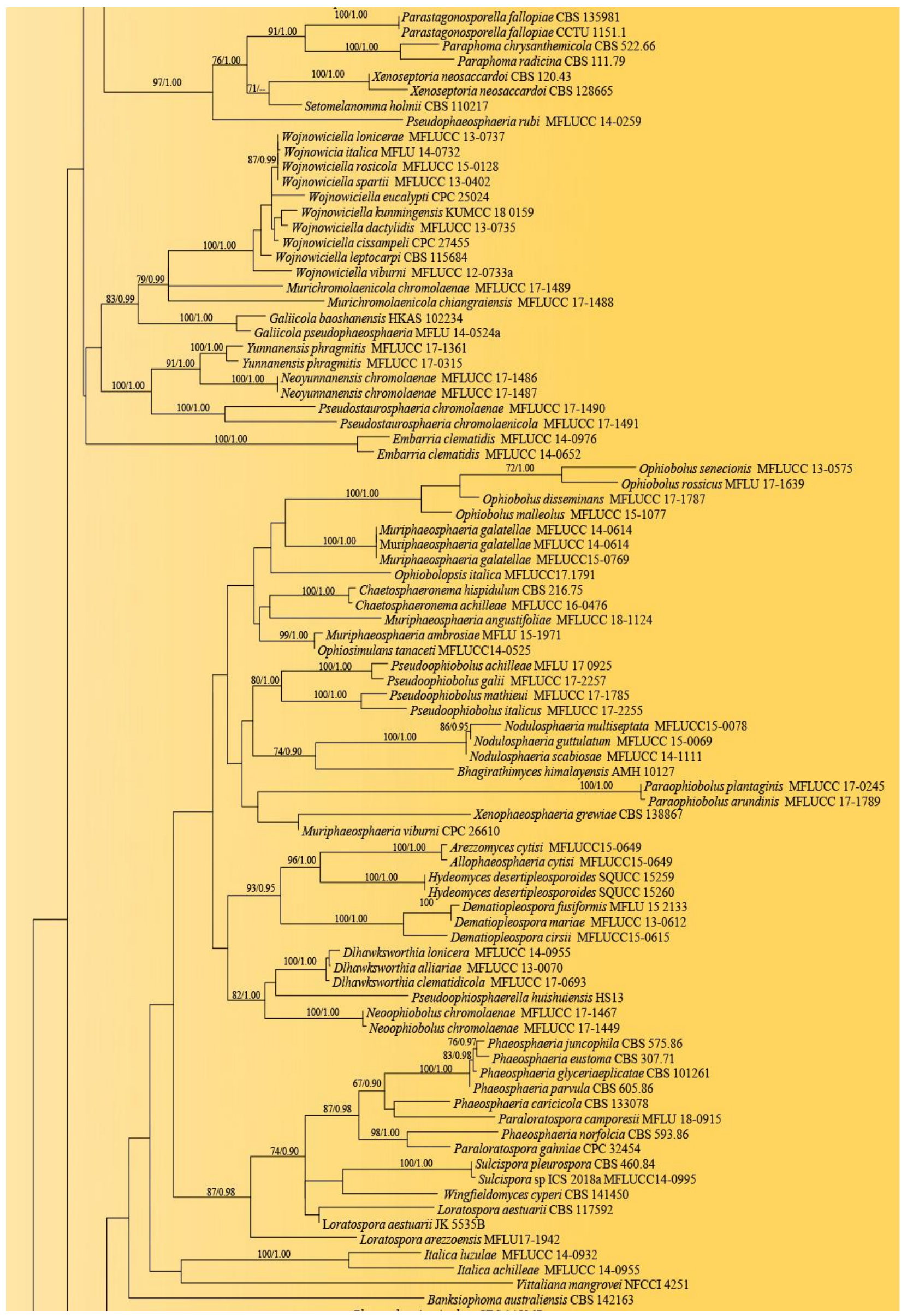

Figure 127 - Continued. 


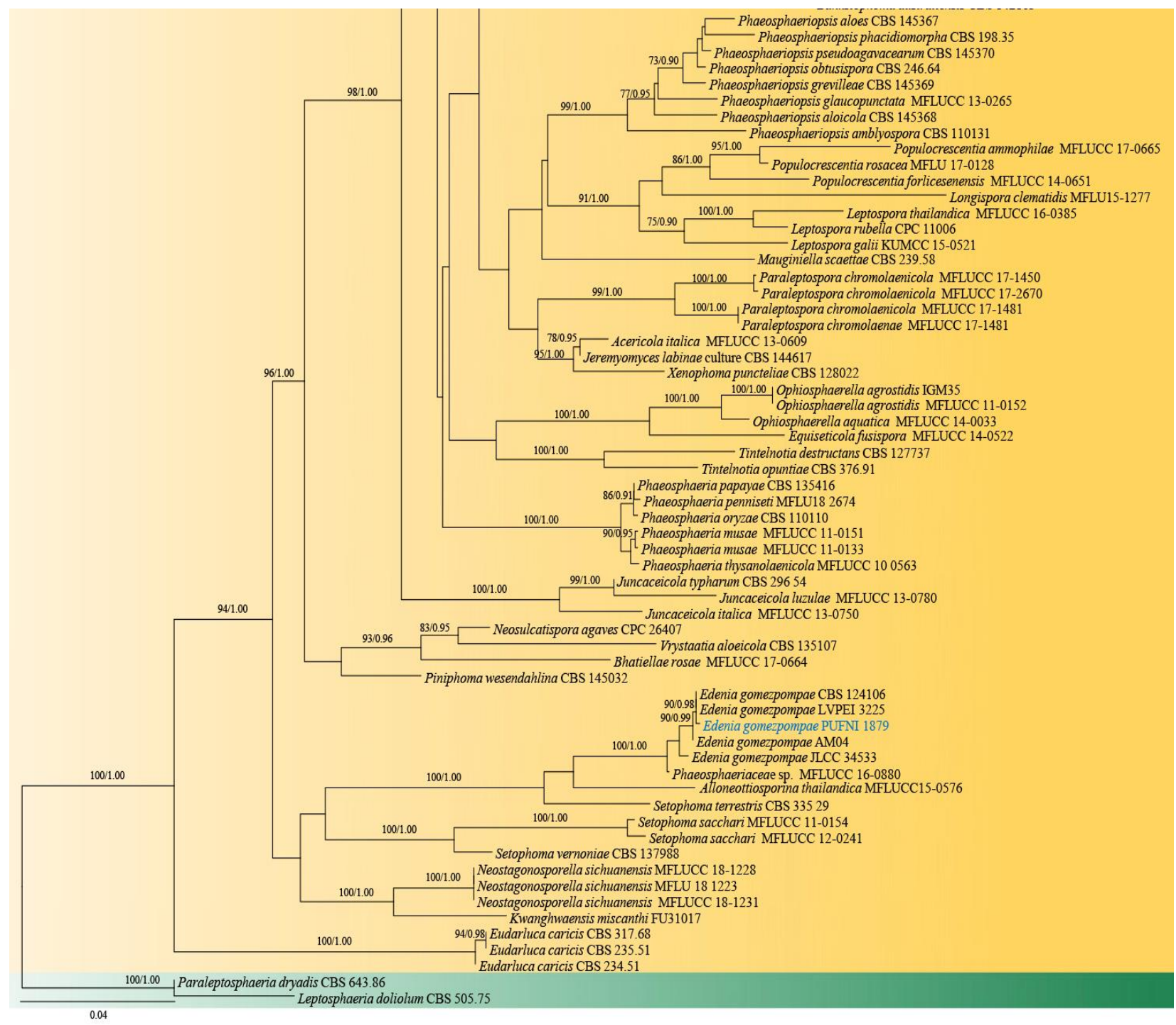

Figure 127 - Continued

Crous et al. (2015a) treated Wojnowicia as a synonym of Septoriella and this is in agreement with Wijayawardene et al. (2017a, 2020). Wijayawardene et al. (2018) listed 52 genera under Phaeosphaeriaceae. However, Marin-Felix et al. (2019) treated Allophaeosphaeria, Poaceicola, and Vagicola as synonyms of Septoriella. This leads Septoriella to be varied in morphology. Marin-Felix et al. (2019) also introduced the monotypic genera: Arezzomyces and Wingfieldomyces in this family. Crous et al. (2019b) also introduced three monotypic genera in Phaeosphaeriaceae viz. Jeremyomyces, Phaeoseptoriella and Piniphoma. Phaeosphaeriaceae has become somewhat confused following various treatments and a detailed study with more taxa and molecular data is required to resolve the taxonomic problematic of this family. Therefore, Hyde et al. (2020b) refrained from synonymizing species and genera to avoid taxonomic confusion. Hyde et al. (2020b) introduced other two new genera, Bhagirathimyces and Paraloratospora to accommodate the hyphomycetous asexual morph species and phaeosphaeria-like species in this family.

Thus, currently 83 genera are accommodated in this family. The asexual morph of Phaeosphaeriaceae was commonly known as coelomycetous (Quaedvlieg et al. 2013, Phookamsak et al. 2014c). However, four hyphomycetous genera have been reported in Phaeosphaeriaceae in recent year (Wanasinghe et al. 2018c, Maharachchikumbura et al. 2019, Hyde et al. 2020b).

Phaeosphaeria I. Miyake, Bot. Mag., Tokyo 23: 93 (1909). 
Index Fungorum number: IF 3951; Facesoffungi number: FoF 00233; 210 morphological species (171 species as Phaeosphaeria, 39 species as Phaeoseptoria; Species Fungorum 2020), 19 species with molecular data.

= Phaeoseptoria Speg., Revta Mus. La Plata 15(2): 39 (1908).

Type species - Phaeosphaeria oryzae I. Miyake, Bot. Mag., Tokyo 23: 93 (1909).

Notes - Members of Phaeosphaeria are found as saprobes, endophytes or pathogens on various hosts worldwide, especially on monocotyledonous plants (Farr \& Rossman 2020). Morphologically, Shoemaker \& Babcock (1989b) divided the genus into six subgenera based on differences in ascospore morphology. Recent phylogenetic analysis has shown that Phaeosphaeria is polyphyletic and many Phaeosphaeria sensu lato were treated in different genera in Phaeosphaeriaceae such as Amarenomyces, Juncaceicola, Loratospora, Neosetophoma, Parastagonospora, Phaeopoacea, Pseudophaeosphaeria, Septoriella, as well as in other families in Pleosporales (Quaedvlieg et al. 2013, Ariyawansa et al. 2014d, 2015a, Tanaka et al. 2015a, Hyde et al. 2016, 2017, 2020b, Tennakoon et al. 2016, Thambugala et al. 2017b, Marin-Felix et al. 2019). Quaedvlieg et al. (2013) designated the epitype of Phaeosphaeria oryzae (Material examined Korea, on leaf of Oryza sativa (Poaceae), collected at Port San Francisco, CA, 29 December 1997, coll. L. Hausch, det. M.E. Palm, BPI 744438, culture ex-epitype CBS 110110 (MBT175330) and synonymized Phaeoseptoria papayae as asexual morph of Phaeosphaeria which is characterized by septoria-like coelomycetous, forming hyaline to brown, cylindrical to subcylindrical conidia (Quaedvlieg et al. 2013, Phookamsak et al. 2014c, Hyde et al. 2017). However, some Phaeosphaeria species also formed coelomycetous asexual morph, with light brown, subglobose to ellipsoidal, or oblong to subcylindrical, (0-)1-2-septate conidia (Crous et al. 2014b, Jayasiri et al. 2019, Phookamsak et al. 2019).

\section{Other genera included}

Acericola Wanas., Camporesi, E.B.G. Jones \& K.D. Hyde, Fungal Diversity 87: 76 (2017).

Index Fungorum number: IF 553257; Facesoffungi number: FoF03388; 1 morphological species (Species Fungorum 2020), 1 species with molecular data.

Type species - Acericola italica Wanas., Camporesi, E.B.G. Jones \& K.D. Hyde, in Hyde et al., Fungal Diversity 87: 78 (2017).

Notes - see Hyde et al. (2017).

Alloneottiosporina Nag Raj, Coelomycetous Anamorphs with Appendage-bearing Conidia (Ontario): 121 (1993).

Index Fungorum number: IF 26427; Facesoffungi number: FoF07107; 3 morphological species (Species Fungorum 2020), 1 species with molecular data.

Type species - Alloneottiosporina carolinensis Nag Raj, Coelomycetous Anamorphs with Appendage-bearing Conidia (Ontario): 122 (1993).

Notes - The coelomycetous asexual genus Alloneottiosporina was introduced by Nag Raj (1993) to accommodate the fungal parasites occurring on living leaves of bamboo and Paspalum distichum in North America and Australia (Nag Raj 1993). Alloneottiosporina is morphologically similar to Neottiosporina, Stagonospora, Tiarospora and Tiarosporella. However, the genus is unique in having gregarious or confluent, elongate, pycnidial conidiomata, immersed to semiimmersed along axis, forming micro- and marcroconidia, with hyaline, varied in shape, septate conidia, with tentaculiform or widely flared mucoid appendages at both ends ( $\mathrm{Li}$ et al. 2020b). The genus is poorly known due to lack of molecular data for the type species. Li et al. (2020b) introduced a new species Alloneottiosporina thailandica based on a comparison of morphology that fits well with the generic concept of Alloneottiosporina. Multi-gene phylogeny showed that the species is sister to Setophoma. Therefore, Li et al. (2020b) tentative placed the genus in Phaeosphaeriaceae. 

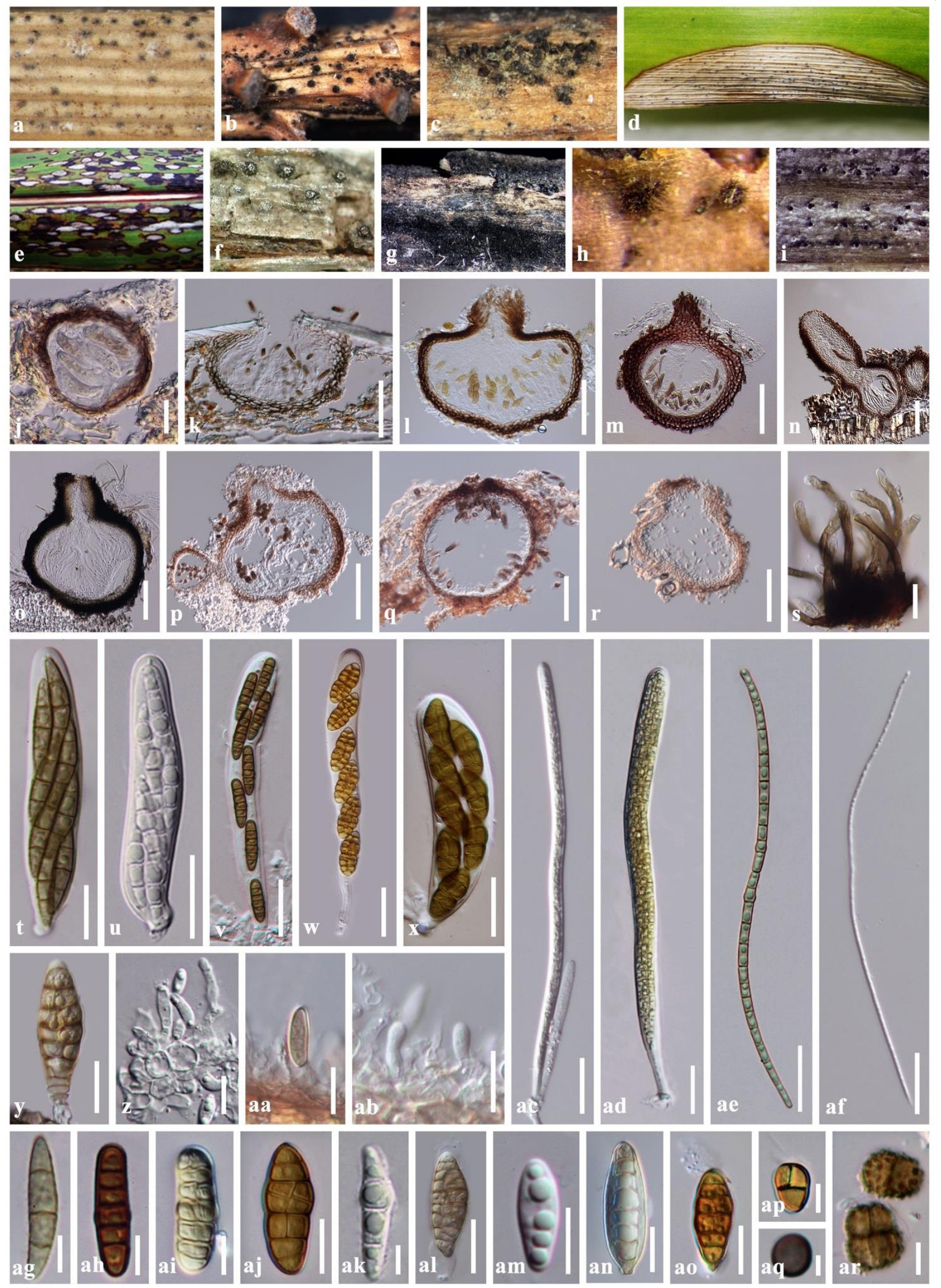

Figure 128 - Morphological characteristics of the genera in Phaeosphaeriaceae. a-i Appearance of ascomata and symptoms (d, e) on the host. j-p Section of ascoma. q, r Section of conidioma. s Conidiophores of Bhatiellae rosae. $\mathrm{t}-\mathrm{x}$, ac, ad Asci. $\mathrm{y}-\mathrm{ab}$ Conidiogenous cells with attached 
conidia. ae-ak Ascospores. al-ar Conidia. Scale bars: $1-\mathrm{p}=100 \mu \mathrm{m}, \mathrm{j}, \mathrm{k}, \mathrm{q}, \mathrm{r}=50 \mu \mathrm{m}, \mathrm{s}-\mathrm{x}, \mathrm{ab}-\mathrm{af}=$ $20 \mu \mathrm{m}, \mathrm{y}-\mathrm{aa}, \mathrm{aj}, \mathrm{al}, \mathrm{an}, \mathrm{ao}=10 \mu \mathrm{m}, \mathrm{ag}-\mathrm{ai}, \mathrm{ak}, \mathrm{am}, \mathrm{ap}, \mathrm{ar}=5 \mu \mathrm{m}, \mathrm{aq}=1 \mu \mathrm{m}$.

Allophaeosphaeria Ariyaw., Camporesi \& K.D. Hyde, in Liu et al., Fungal Diversity 72: 137 (2015).

Index Fungorum number: IF 550997; Facesoffungi number: FoF00494; 3 morphological species (Hyde et al. 2020b, this study), with molecular data.

Type species - Allophaeosphaeria muriformis Ariyaw., Camporesi \& K.D. Hyde, in Liu et al., Fungal Diversity 72: 137 (2015).

Notes - Allophaeosphaeria was introduced by Liu et al. (2015) to accommodate pleosporalike taxa having globose to subglobose ascomata, raised immersed to erumpent through host tissue, with protruding papilla. The peridium composed of two type layers of dark pigmented, carbonaceous cell of the outer layers, with hyaline, thick-walled, pseudoparenchymatous cells of the inner layers. Asci are 8-spored, fissitunicate, cylindrical to cylindric-clavate, with short, narrow to knob-like pedicel, with lacking pseudoparaphyses. Ascospores are muriform, ellipsoidal to broad fusiform, light brown to brown, smooth-walled, with indistinct mucilagenous sheath (Ariyawansa et al. 2015a, Liu et al. 2015). Two species were initially accommodated in this genus viz. A. dactylidis Wanas. et al. and the generic type, A. muriformis (Liu et al. 2015). Ariyawansa et al. (2015a) introduced other three species in this genus based on molecular phylogeny and also reported the asexual morph as coelomycetous, septoriella-like (A. subcylindrospora). Wanasinghe et al. (2018c) introduced a new genus Dactylidina and transferred A. dactylidis to Dactylidina as D. dactylidis. Marin-Felix et al. (2019) attempted to resolve the phylogenetic problem among the genera claded with Septoriella. Based on phylogenetic analysis of ITS, LSU and rpb-2 sequence matrix, Marin-Felix et al. (2019) synonymized Allosphaeosphaeria under Septoriella. Whereas, A. dactylidis was designated as the generic type of the new genus Dactylidina by Wanasinghe et al. (2018c) but the species was currently transferred to Septoriella as S. neodactylidis by Marin-Felix et al. (2019). However, the morphological features of these genera are different in their sexual morphs but overlap in some characters of their asexual morph. The congeneric status of these genera is still questionable. According to the treatment in Hyde et al. (2020b), we tentative reinstate the Allosphaeosphaeria pending further studies.

Amarenographium O.E. Erikss., Mycotaxon 15: 199 (1982).

Index Fungorum number: IF 7113; Facesoffungi number: FoF 00237; 4 morphological species (Species Fungorum 2020), 1 species with molecular data.

Type species - Amarenographium metableticum (Trail) O.E. Erikss., Mycotaxon 15: 199 (1982).

三 Camarosporium metableticum Trail, Scott. Natural., N.S. 2 ('8'): 267 (1886).

Notes - see Phookamsak et al. (2014c), Wijayawardene et al. (2016a), Dayarathne et al. (2020).

Amarenomyces O.E. Erikss., Op. bot. 60: 124 (1981).

Index Fungorum number: IF 151; Facesoffungi number: FoF00235; 2 morphological species (Species Fungorum 2020), 2 species with molecular data.

Type species - Amarenomyces ammophilae (Lasch) O.E. Erikss., Op. bot. 60: 124 (1981).

三 Sphaeria ammophilae Lasch, Flora, Regensburg 33: 282 (1850).

Notes - see Phookamsak et al. (2014c, 2019) and Hyde et al. (2017).

Ampelomyces Ces. ex Schltdl., in Klotzsch, Bot. Ztg. 10: 303 (1852).

Index Fungorum number: IF 7129; Facesoffungi number: FoF00291; 16 morphological species (Species Fungorum 2020), 1 species with molecular data.

Type species - Ampelomyces quisqualis Ces., in Klotzsch, Bot. Ztg. 10: 301 (1852).

Notes - Phookamsak et al. (2014c) re-circumscribed Ampelomyces and accepted Ampelomyces in Phaeosphaeriaceae based on the type species, A. quisqualis (CBS 129.79) which 
was sister to Neosetophoma in their analyses. However, the representative strain CBS 129.79, identified as A. quisqualis is not the type strain and this study, A. quisqualis clustered with other Neosetophoma species. Therefore, the generic status of Ampelomyces is still questionable pending further studies. More taxon sampling and recollection and epitypification of the type species are required.

Aphanostigme Syd., Annls mycol. 24(5/6): 368 (1926).

Index Fungorum number: IF 248; Facesoffungi number: FoF 08327; 21 morphological species (Species Fungorum 2020), molecular data unavailable.

Type species - Aphanostigme solani Syd., Annls mycol. 24(5/6): 368 (1926).

Notes - see Boonmee et al. (2017).

Arezzomyces Y. Marín \& Crous, in Marin-Felix et al., Stud. Mycol. 94: 111 (2019).

Index Fungorum number: IF 829711; Facesoffungi number: FoF 08328; 1 morphological species (Species Fungorum 2020), 1 species with molecular data.

Type species - Arezzomyces cytisi (Wanas., Camporesi, E.B.G. Jones \& K.D. Hyde) Y. Marín \& Crous, in Marin-Felix et al., Stud. Mycol. 94: 111 (2019).

$\equiv$ Allophaeosphaeria cytisi Wanas., Camporesi, E.B.G. Jones \& K.D. Hyde, in Ariyawansa et al., Fungal Diversity75: 97 (2015).

Notes - see Ariyawansa et al. (2015a) and Marin-Felix et al. (2019).

Banksiophoma Crous, in Crous et al., Persoonia 38: 255 (2017).

Index Fungorum number: IF 820932; Facesoffungi number: FoF 08329; 1 morphological species (Species Fungorum 2020), 1 species with molecular data.

Type species - Banksiophoma australiensis Crous, in Crous et al., Persoonia 38: 255 (2017)

Notes - see Crous et al. (2017b).

Bhagirathimyces S.M. Singh \& S.K. Singh, in Hyde et al., Fungal Diversity 100: 93-97 (2020).

Index Fungorum number: IF 830751; Facesoffungi number: FoF 06121; 1 morphological species (Species Fungorum 2020), 1 species with molecular data.

Type species - Bhagirathimyces himalayensis S.M. Singh \& S.K. Singh, in Hyde et al., Fungal Diversity 100: 93-97 (2020).

Notes - Bhagirathimyces was introduced as a monotypic genus to accommodate a hyphomycetous asexual morph. The genus was isolated from cryconite of glacier originated from Indian Himalayas and is characterized by semi-macronematous, mononematous, 1-3-septate conidiophores, with dark brown to blackish brown, lobed, globose to subglobose, clavate, muriform conidia (Hyde et al. 2020b). Bhagirathimyces differs from two other hyphomycetous genera in Phaeosphaeriaceae in having dark brown, muriform, globose to subglobose conidia. Bhatiellae has brown to olivaceous brown, ellipsoidal to fusiform, 5-8-distoseptate conidia (Wanasinghe et al. 2018c). Bhagirathimyces resembles the asexual morph of Populocrescentia in having muriform globose to subglobose conidia. However, the latter has pale brown to dark brown, verrucose or incidentally tuberculate conidia and less septation (Wanasinghe et al. 2018c). Phylogenetic analyses have shown that these two genera are distinct.

Bhatiellae Wanas., Camporesi \& K.D. Hyde, Fungal Diversity 89: 107 (2018).

Index Fungorum number: IF 554171; Facesoffungi number: FoF04013; 1 morphological species (Species Fungorum 2020), 1 species with molecular data.

Type species - Bhatiellae rosae Wanas., Camporesi, E.B.G. Jones \& K.D. Hyde, in Wanasinghe et al., Fungal Diversity 89: 107 (2018).

Notes - Bhatiellae was introduced to accommodate hyphomycetous asexual morph and is characterized by forming sporodochia with tightly aggregated, cylindrical, macronematous, mononematous, unbranched, aseptate, brown to dark brown conidiophores and having polyblastic, sympodial, integrated, terminal, cylindrical, undulate conidiogenous cells with large, cicatrized 
scars. The conidia of Bhatiellae are brown to olivaceous brown, ellipsoidal to fusiform, 5-8distoseptate. The genus is accomodated in Phaeosphaeriaceae based on molecular phylogeny (Wanasinghe et al. 2018c). More taxon sampling of this genus is needed to confirm its phylogenetic placement in this family.

Bricookea M.E. Barr, Mycotaxon 15: 346 (1982).

Index Fungorum number: IF 653; Facesoffungi number: FoF 00239; 2 morphological species (Species Fungorum 2020), molecular data unavailable.

Type species - Bricookea sepalorum (Vleugel) M.E. Barr, Mycotaxon 15: 346 (1982).

三 Metasphaeria sepalorum Vleugel, Svensk bot. Tidskr. 2(4): 369 (1908).

Notes - see Phookamsak et al. (2014c).

Brunneomurispora Phookamsak, Konta, Wanas. \& K.D. Hyde Fungal Diversity 95: 51 (2019)

Index Fungorum number: IF 556165; Facesoffungi number: FoF 05699; 1 morphological species (Species Fungorum 2020), 1 species with molecular data.

Type species - Brunneomurispora lonicerae Phookamsak, Konta, Wanas. \& K.D. Hyde, in Phookamsak et al., Fungal Diversity 95: 52 (2019)

Notes - see Phookamsak et al. (2019).

Camarosporioides W.J. Li \& K.D. Hyde, in Hyde et al., Fungal Diversity 80: 83 (2016).

Index Fungorum number: IF 552209; Facesoffungi number: FoF 02350; 1 morphological species (Species Fungorum 2020), 1 species with molecular data.

Type species - Camarosporioides phragmitis W.J. Li \& K.D. Hyde, Fungal Diversity 80: 83 (2016).

Notes - see Hyde et al. (2016).

Chaetosphaeronema Moesz, Bot. Közl. 14: 152 (1915).

Index Fungorum number: IF 7594; Facesoffungi number: FoF 00241; 7 morphological species (Species Fungorum 2020, Phukhamsakda et al. 2020), 6 species with molecular data.

Type species - Chaetosphaeronema hispidulum (Corda) Moesz, Bot. Közl. 14: 152 (1915).

三Sphaeronaema hispidulum Corda, Icon. fung. (Prague) 4: 39 (1840).

Notes - see De Gruyter et al. (2010), Phookamsak et al. (2014c) and Phukhamsakda et al. (2020).

Dactylidina Wanas., Camporesi \& K.D. Hyde, in Wanasinghe et al., Fungal Diversity 89: 107 (2018).

Index Fungorum number: IF 554173; Facesoffungi number: FoF 04015; 2 morphological species (Wijayawardene et al. 2020), 2 species with molecular data.

Type species - Dactylidina dactylidis (Wanas., Camporesi, E.B.G. Jones \& K.D. Hyde) Wanas. \& K.D. Hyde, in Wanasinghe et al., Fungal Diversity 107: 109 (2018).

三 Allophaeosphaeria dactylidis Wanas., Camporesi, E.B.G. Jones \& K.D. Hyde, in Liu et al., Fungal Diversity 72: 137 (2015).

Notes - Wanasinghe et al. (2018c) and Marin-Felix et al. (2019).

Dematiopleospora Wanas., Camporesi, E.B.G. Jones \& K.D. Hyde, in Wanasinghe et al., Cryptog. Mycol. 35(2): 110 (2014).

Index Fungorum number: IF 550537; Facesoffungi number: FoF 00242; 7 morphological species (Species Fungorum 2020), 7 species with molecular data.

Type species - Dematiopleospora mariae Wanas., Camporesi, E.B.G. Jones \& K.D. Hyde, in Wanasinghe et al., Cryptog. Mycol. 35(2): 110 (2014).

Notes - see Wanasinghe et al. (2014b, 2018c), Ariyawansa et al. (2015a), Hyde et al. (2016) and Huang et al. (2017). 
Didymocyrtis Vain., Acta Soc. Fauna Flora fenn. 49(no. 2): 221 (1921).

Index Fungorum number: IF 1554; Facesoffungi number: FoF 08330; 25 morphological species (24 species as Didymocyrtis, 1 species as Diederichomyces; Species Fungorum 2020), 14 species with molecular data.

= Diederichomyces Crous \& Trakun., in Trakunyingcharoen et al., IMA Fungus 5(2): 393 (2014).

Type species - Didymocyrtis consimilis Vain., Acta Soc. Fauna Flora fenn. 49(no. 2): 221 (1921).

Notes - see Ertz et al. (2015).

Dlhawksworthia Wanas., Camporesi \& K.D. Hyde, in Wanasinghe et al., Index Fungorum 357: 1 (2018).

Index Fungorum number: IF 554390; Facesoffungi number: FoF 04021; 3 morphological species (Species Fungorum 2020), 3 species with molecular data.

Type species - Dlhawksworthia alliariae (Thambug., Camporesi \& K.D. Hyde) Wanas. \& K.D. Hyde, in Wanasinghe et al., Index Fungorum 357: 1 (2018).

$\equiv$ Dematiopleospora alliariae Thambug., Camporesi \& K.D. Hyde, in Hyde et al., Fungal Diversity 80: 89 (2015).

Notes - see Wanasinghe et al. (2018c).

Edenia M.C. González, A.L. Anaya, Glenn, Saucedo \& Hanlin, Mycotaxon 101: 254 (2007).

Index Fungorum number: IF 510872; Facesoffungi number: FoF 00543; 2 morphological species (Species Fungorum 2020), 2 species with molecular data.

Type species - Edenia gomezpompae M.C. González, Anaya, Glenn, Saucedo \& Hanlin, Mycotaxon 101: 254 (2007).

Notes - Edenia was introduced to accommodate an endophytic hyphomycete isolated from leaves of Callicarpa acuminata in Mexico. González et al. (2007) provided a sequence of ITS region and treated the genus in Pleosporaceae without phylogenetic analysis support. Crous et al. (2009a) re-circumscribed the genus based on a collection from symptomatic leaves of Senna alata in Philippines and designated this collection as an epitype of Edenia gomezpompae. Crous et al. (2009a) reported a synanamorph of E. gomezpompae sporulating in culture as a pyronellea-like coelomycete and confirmed its phylogenetic affinity in Phaeosphaeriaceae. In this study, the sexual morph of E. gomezpompae is reported on decaying twigs from India for the first time.

Edenia gomezpompae M.C. González, Anaya, Glenn, Saucedo \& Hanlin, Mycotaxon 101: 254 (2007).

Index Fungorum number: IF 510944; Facesoffungi number: FoF 06588.

Figs 129,130

Saprobic on decaying twigs. Sexual morph: Ascomata 236-250 $\times 335-372 \mu \mathrm{m}$ perithecial, scattered, immersed, coriaceous, globose to subglobose, unilocular, papillate, with centrally ostiolar necks, $115 \times 93 \mu \mathrm{m}$, periphysate. Peridium $27 \mu \mathrm{m}$ wide, outer layer composed of textura porrecta cell layers and inner layers composed of pale brown textura angularis cell layers. Hamathecium 4.2 $\mu \mathrm{m}$ wide at base, narrow towards apical end, filamentous, septate, unbranched, pseudoparaphyses, embedded in a gelatinous matrix. Asci (124-)130-185 × 29-36 $\mu \mathrm{m}(\bar{x}=148 \times 31.7, \mathrm{n}=10), 8$ spored, bitunicate, fissitunicate, clavate, apically obtuse with a distinct ocular chamber, short pedicellate. Ascospores (23-)26.5-32 × 12.5-16 $\mu \mathrm{m}(\bar{x}=32.8 \times 16.2, \mathrm{n}=25)$, overlapping 1-2seriate, initially hyaline, becoming brown to reddish brown with hyaline to pale brown end cells, with mammiform apices, broadly fusiform to ellipsoidal, 1-septate, slightly constricted when young, large guttules in each cell, verruculose. Asexual morph: Pycnidia on culture plates, 230-310 $\times 210-300 \mu \mathrm{m}$, globose, centrally verruculose, ostiolate necks, $25 \mu \mathrm{m}$ with long brown spinous setae, setae 100-130 $\mu \mathrm{m}$, covered below with brown mycelium, outer textura subglobosa and inner textura intricata. Conidia 3.5-5.3 × 1.5-2.1 ( $\bar{x}=4.4 \times 1.8) \mu \mathrm{m}$, hyaline, fusiform, obtuse ends, smooth-walled. 


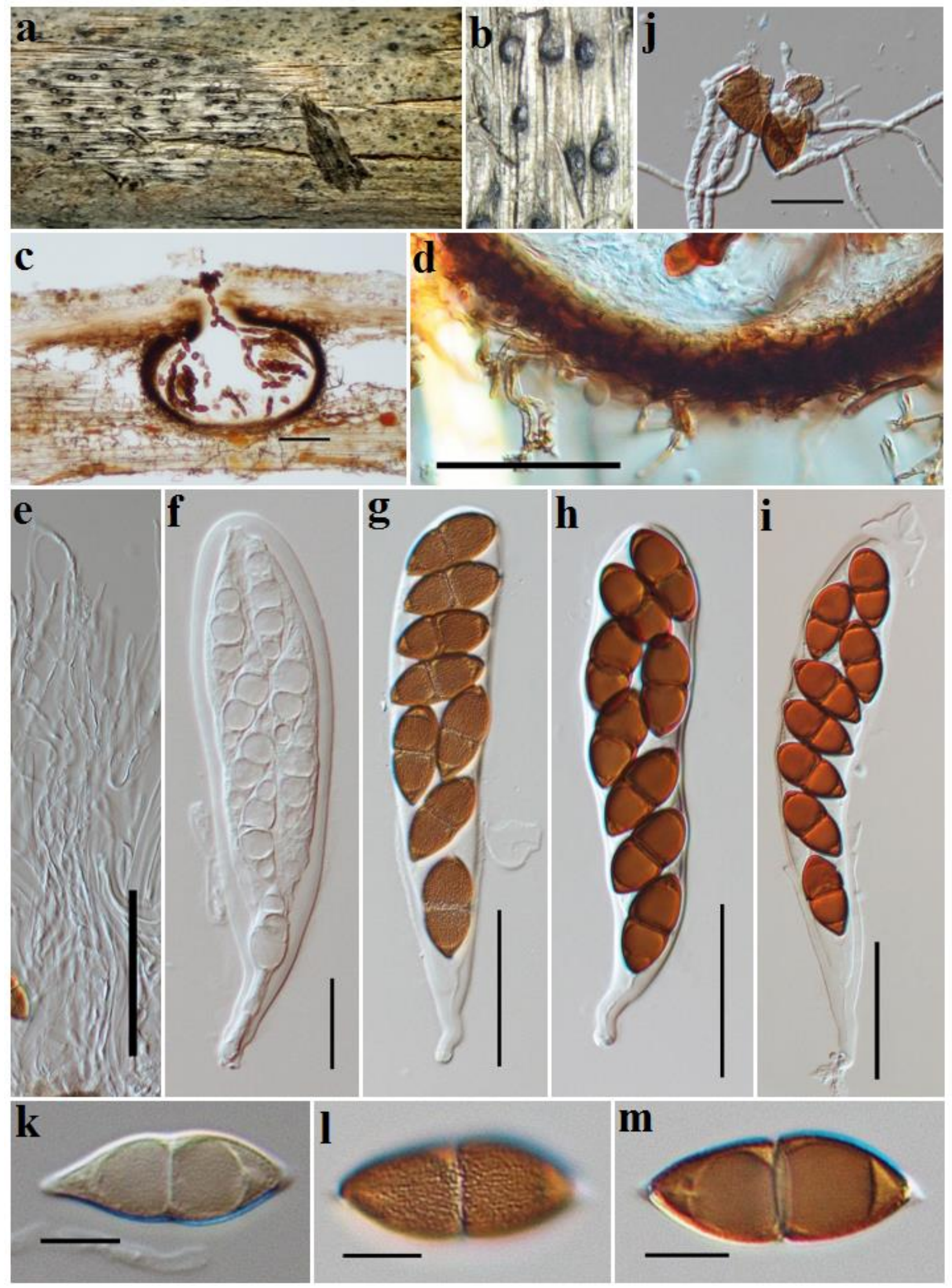

Figure 129 - Edenia gomezpompae (NFCC-4435). a, b Ascomata. c Section of ascoma. $\mathrm{d}$ Peridium. e Pseudoparaphyses. f $-\mathrm{i}$ Asci. j Germinating spore $\mathrm{k}-\mathrm{m}$ Ascospores. Scale bars: $\mathrm{c}=$ $100 \mu \mathrm{m}$. d, e, $\mathrm{g}-\mathrm{i}=50 \mu \mathrm{m}$. h, j $=20 \mu \mathrm{m}$. $\mathrm{k}-\mathrm{m}=10 \mu \mathrm{m}$. 


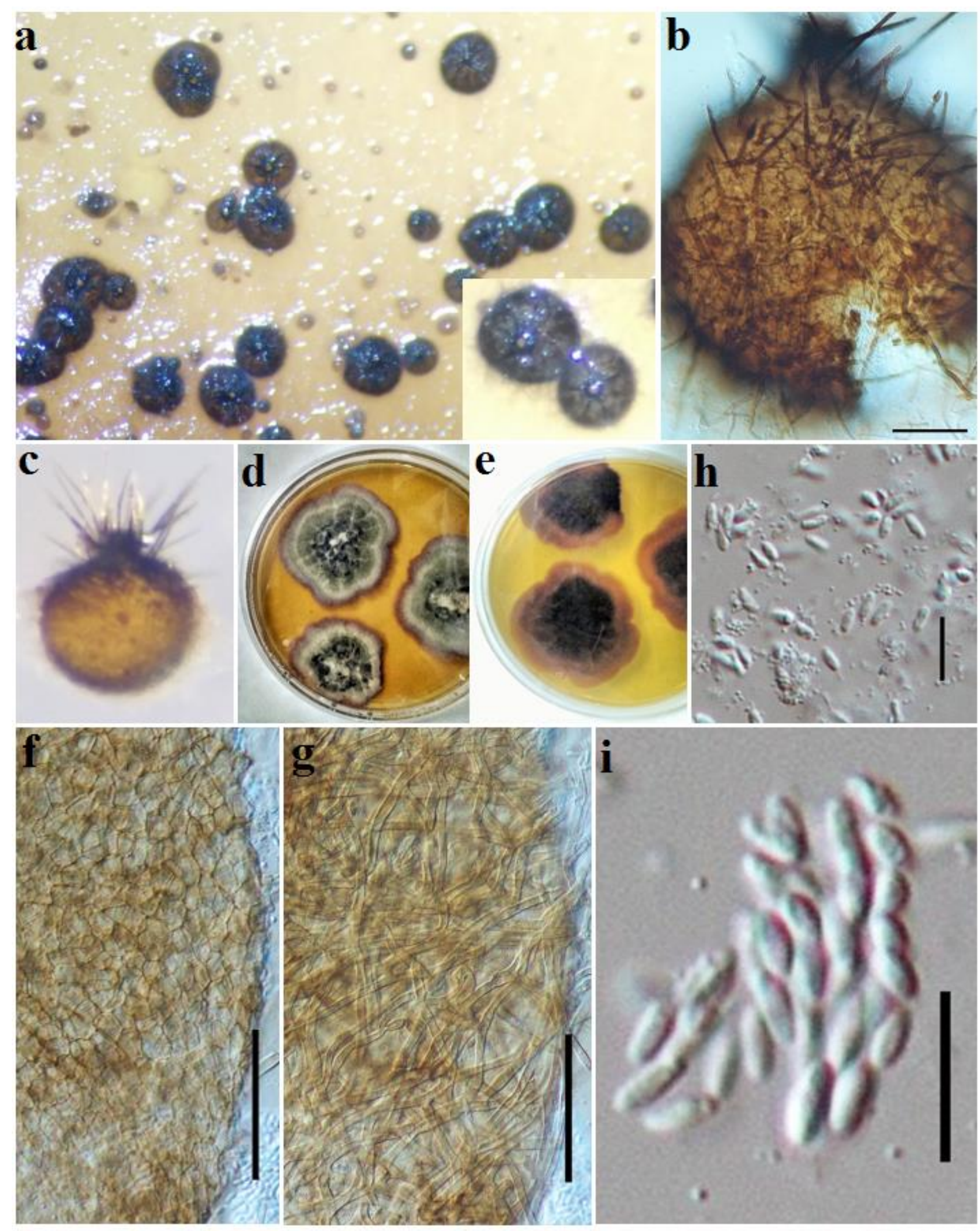

Figure 130 - Edenia gomezpompae (NFCC-4435). a Pycnidia on petri plate. b, c Pycnidium with spines and brown hyphae. d, e Culture on petri plates. f Textura angularis. g Inner wall textura intricate. $\mathrm{h}, \mathrm{i}$ Conidia. Scale bars: $\mathrm{b}, \mathrm{f}, \mathrm{g}=50 \mu \mathrm{m}$. h, i $=10 \mu \mathrm{m}$.

Material examined - INDIA, Andaman and Nicobar Islands, South Andaman, Manjery, Nayashar (11 $\left.34^{\prime} 50.4^{\prime \prime} \mathrm{N} 92^{\circ} 40^{\prime} 47.7^{\prime \prime} \mathrm{E}\right)$, on unidentified decaying twig, 15 May 2018, M. Niranjan \& V.V. Sarma, PUFNI 1879 (AMH-10083; Ajrekar Mycological Herbarium-AMH), living culture, 
NFCC-4435 (National Fungal Culture Collection of India (NFCCI), Agarkar Research Institute (ARI), Pune).

Notes - The isolate AMH 10083 has a close relationship with Edenia in Phaeosphaeriaceae. Edenia consists of two species E. achyranthis and E. gomezpompae (González et al. 2007, Sun et al. 2013). Edenia achyranthis was found on the stem of Achyranthes bidentata as an endophyte in Hebei, China (Sun et al. 2013). Edenia gomezpompae was isolated from leaves of Callicarpa acummata in Mexico (González et al. 2007) as an endophytic hyphomycete. Neither species produced a sexual morph. Phenotypic observations of E. gomezpompae have found that the colonies have sterile mycelium, hyphal branching at a 90 'angle and string-like strands on a PDA plate (Gonzalez et al. 2007). Edenia achyranthis grown on MEA showed the hyphomycetous asexual morph with synnemata bundles producing subhyaline, ellipsoidal conidia (Sun et al. 2013). Crous et al. (2009a) reported the hyphomycetous asexual morph of E. gomezpompae occurring on leaf spots of Senna alata and a synanamorph pyronellea-like coelomycete sporulated in culture and this collection was designated as an epitype of E. gomezpompae. Our isolate AMH 10083 has globose pycnidia rather than synnemata, and ellipsoid conidia. The conidia of isolate AMH 10083 have slightly smaller $(3.5-5.3 \times 1.5-2.1 \mu \mathrm{m})$ compared to E. achyranthis $(3.5-6.1 \times 1.7-2.5 \mu \mathrm{m}$; Sun et al. 2013) and the epitype of E. gomezpompae (11-)13-15(-16) $\times(3.5-) 4.5-5.5(-6) \mu \mathrm{m}$; Crous et al. 2009a). However, the coelomycetous asexual morph of our isolate (AMH 10083) could not be compared with the epitype as Crous et al. (2009a) did not provide a description of the pyronellea-like coelomycete. Phylogenetically, isolate AMH 10083 clustered with E. gomezpompae (Fig. 127). Therefore, we identify our isolate as E. gomezpompae. This is the first report of the sexual morph of Edenia gomezpompae.

Embarria Wanas., Camporesi \& K.D. Hyde, Fungal Diversity 89: 119 (2018).

Index Fungorum number: IF 554169; Facesoffungi number: FoF 08331; 1 morphological species (Species Fungorum 2020), 1 species with molecular data.

Type species - Embarria clematidis (Wanas., Camporesi, E.B.G. Jones \& K.D. Hyde) Wanas. \& K.D. Hyde, in Wanasinghe et al., Fungal Diversity 89: 119 (2018).

$\equiv$ Allophaeosphaeria clematidis Wanas., Camporesi, E.B.G. Jones \& K.D. Hyde, in Ariyawansa et al., Fungal Diversity 75: 99 (2015).

Notes - see Wanasinghe et al. (2018c).

Equiseticola Abdelsalam, Tibpromma, Wanas. \& K.D. Hyde, Phytotaxa 284(3): 173 (2016).

Index Fungorum number: IF 551562; Facesoffungi number: FoF 01242; 1 morphological species (Species Fungorum 2020), 1 species with molecular data.

Type species - Equiseticola fusispora Abdelsalam, Tibpromma, Wanasinghe \& K.D. Hyde., in Abd-Elsalam et al., Phytotaxa 284(3): 173 (2016).

Notes - see Abd-Elsalam et al. (2016).

Eudarluca Speg., Revta Mus. La Plata 15(2): 22 (1908).

Index Fungorum number: IF 1921; Facesoffungi number: FoF 00245; 9 morphological species (Species Fungorum 2020), molecular data unavailable.

Type species - Eudarluca australis Speg., Revta Mus. La Plata 15(2): 22 (1908).

Notes - see Phookamsak et al. (2014c, 2019).

Galiicola Tibpromma, Camporesi \& K.D. Hyde, in Ariyawansa et al., Fungal Diversity: 75: 79 (2015).

Index Fungorum number: IF 551383; Facesoffungi number: FoF 00923; 3 morphological species (Species Fungorum 2020), 3 species with molecular data.

Type species - Galiicola pseudophaeosphaeria Tibpromma, Camporesi \& K.D. Hyde, in Ariyawansa et al., Fungal Diversity 75: 79 (2015).

Notes - see Ariyawansa et al. (2015a), Thambugala et al. (2017b) and Phookamsak et al. (2019). 
Hydeomyces Maharachch., H.A. Ariyaw., Wanas. \& Al-Sadi, Phytotaxa 391(1): 33 (2019).

Index Fungorum number: IF 827328; Facesoffungi number: FoF 05381; 2 morphological species (Species Fungorum 2020), 2 species with molecular data.

Type species - Hydeomyces desertipleosporoides Maharachch., H.A. Ariyaw., Wanas. \& AlSadi, in Maharachchikumbura et al., Phytotaxa 391(1): 34 (2019).

Notes - see Maharachchikumbura et al. (2019) and Zhang et al. (2019a).

Hydeopsis J.F. Zhang, J.K. Liu \& Z.Y. Liu, in Zhang et al., Mycosphere 8(1): 211 (2019).

Index Fungorum number: IF 556247; Facesoffungi number: FoF 05837; 1 morphological species (Species Fungorum 2020), 1 species with molecular data.

Type species - Hydeopsis verrucispora J.F. Zhang, J.K. Liu \& Z.Y. Liu, in Zhang et al., Mycosphere 8(1): 211 (2019).

Notes - Zhang et al. (2019a) introduced the monotypic genus Hydeopsis to accommodate phaeosphaeria-like taxon, characterizing by dark brown to black, subglobose, papillate ascomata, bitunicate, fissitunicate, clavate asci, embedded in cellular pseudoparaphyses and, hyaline to pale yellowish, ellipsoidal to fusiform, 3-septate ascospores with a mucilaginous sheath (Zhang et al. (2019a). Phylogenetic analyses obtained by Zhang et al. (2019a) showed that the genus forms a single lineage closely related to Dactylidina and Phaeopoacea. In this study, Hydeopsis forms unstable lineage in a problematic clade of the genera Allophaeosphaeria, Amarenographium, Amarenomyces, Dactylidina, Poaceicola, Septoriella and Vagicola. Therefore, the generic status is questionable pending further studies.

Italica Wanas., Camporesi \& K.D. Hyde, Fungal Diversity 89: 123 (2018).

Index Fungorum number: IF 554183; Facesoffungi number: FoF 04024; 2 morphological species (Species Fungorum 2020), 2 species with molecular data.

Type species - Italica luzulae (Wanas., Camporesi, E.B.G. Jones \& K.D. Hyde) Wanas. \& K.D. Hyde, Fungal Diversity 89: 126 (2018).

$\equiv$ Dematiopleospora luzulae Wanas., Camporesi, E.B.G. Jones \& K.D. Hyde, in Wijayawardene et al., Fungal Diversity 75: 136 (2016).

Notes - see Wanasinghe et al. (2018c).

Jeremyomyces Crous \& R.K. Schumach., in Crous et al., Fungal Systematics and Evolution 3: 87 (2019).

Index Fungorum number: IF 829307; Facesoffungi number: FoF 08332; 1 morphological species (Species Fungorum 2020), 1 species with molecular data.

Type species - Jeremyomyces labinae Crous \& R.K. Schumach., in Crous et al., Fungal Systematics and Evolution 3: 88 (2019).

Notes - Crous et al. (2019b) introduced a monotypic sexual genus Jeremyomyces to accommodate angustimassarina-like taxon, collected from twig of Salix alba in Germany. The genus is morphologically distinct from other genera in Phaeosphaeriaceae in having didymosporous, hyaline fusiform ascospores (Crous et al. 2019b). However, the genus is phylogenetically close to Acericola, even though these two genera are very different in morphology (Wanasinghe et al. 2018c, Crous et al. 2019b). Both genera are represented by only a single species. Therefore, more taxon sampling and re-sequencing of the type strains of these two genera are needed to clarify their phylogenetic status.

Juncaceicola Tennakoon, Camporesi, Phookamsak \& K.D. Hyde, Cryptog. Mycol. 37(2): 138 (2016).

Index Fungorum number: IF 552126; Facesoffungi number: FoF 02145; 7 morphological species (Species Fungorum 2020), 8 species with molecular data.

Type species - Juncaceicola luzulae Tennakoon, Camporesi, Phookamsak \& K.D. Hyde, in Tennakoon et al., Cryptog. Mycol. 37(2): 148 (2016).

Notes - see Hyde at al. (2016b) and Tennakoon et al. (2016). 
Kwanghwaensis A. Karunarathna, C. H Kuo \& K.D. Hyde, Cryptog. Mycol. 41(6): 124 (2020).

Index Fungorum number: IF 557100; Facesoffungi number: FoF 08333; 1 morphological species (Species Fungorum 2020), 1 species with molecular data.

Type species - Kwanghwana miscanthi A. Karunarathna, C.H. Kuo \& K.D. Hyde, Cryptog. Mycol. 41(6): 124 (2020).

Notes - A monotypic genus Kwanghwana was introduced by Karunarathna et al. (2020) to accommodate phaeosphaeria-like taxon having globose to subglobose ascomata, immersed to semiimmersed in host epidermis, with centrally minute ostioles, thin-walled, pale brown to brown peridium, 8-spored, bitunicate, cylindrical to cylindric-clavate asci, with short pedicel and hyaline, ellipsoidal to fusiform, 3-septate ascospores (Karunarathna et al. 2020). The genus was found as a saprobe on Miscanthus floridulus (Poaceae) in Taiwan. Multi-gene phylogenetic analyses of a combined LSU, SSU, ITS and tef1 showed that Kwanghwana forms a sister lineage with Neostagonosporella (Karunarathna et al. 2020).

Leptospora Rabenh., Hedwigia 1: 116 (1857).

Index Fungorum number: IF 2803; Facesoffungi number: FoF 08334; 15 morphological species (Mapook et al. 2020, Species Fungorum 2020, Phukhamsakda et al. 2020), 9 species with molecular data.

Type species - Leptospora rubella (Pers.) Rabenh, Hedwigia 1: 116 (1857).

三Sphaeria rubella Pers., Syn. meth. fung. (Göttingen) 1: 63 (1801).

Notes - see Hyde et al. (2016), Zhang et al. (2019a), Mapook et al. (2020) and Phukhamsakda et al. (2020).

Longispora Phukhams. \& K.D. Hyde, Fungal Diversity 102: 81 (2020).

Index Fungorum number: IF 557198; Facesoffungi number: FoF 07305; 1 morphological species (Phukhamsakda et al. 2020, Species Fungorum 2020), 1 species with molecular data.

Type species - Longispora clematidis Phukhams. \& K.D. Hyde, Fungal Diversity 102: 81 (2020).

Notes - A monotypic genus Longispora was introduced by Phukhamsakda et al. (2020) to accommodate ophiobolus-like taxon. The generic type, Longispora clematidis also shares morphological characters with Leptospora in producing red pigments in the ostiole. Longispora was collected from dead aerial branch of Clematis vitalba in Italy and is unique in having erumpent to superficial, globose to subglobose ascomata, cupulate when dry, with minute papilla and reddish ostiole, cylindric-clavate asci with bulbose pedicellate embedded in cellular pseudoparaphyses and pale yellowish to yellowish, filiform, multi-septate ascospores, with an enlarge cell at the middle, but not separating into single celled spores. Multi-gene phylogenetic analyses showed that the genus formed a basal lineage with Leptospora and Populocrescentia in Phaeosphaeriaceae (Phukhamsakda et al. 2020).

Loratospora Kohlm. \& Volkm.-Kohlm., Syst. Ascom. 12(1-2): 10 (1993).

Index Fungorum number: IF 26473; Facesoffungi number: FoF 00247; 3 morphological species (Hyde et al. 2020b, this study), 3 species with molecular data.

Type species - Loratospora aestuarii Kohlm. \& Volkm.-Kohlm., Syst. Ascom. 12(1-2): 10 (1993).

Notes - Kohlmeyer \& Volkmann-Kohlmeyer (1993) introduced the monotypic genus Loratospora to accommodate a single species L. aestuarii occurring on Juncus roemerianus. Phookamsak et al. (2014c) examined the type specimen (on slide) and other representative specimens from North Carolina, USA and provided an updated taxonomic description of Loratospora, as well as accepted the genus in Phaeosphaeriaceae. Ariyawansa et al. (2015a) introduced the second species L. luzulae which was collected from dead stem of Luzula nivea (Juncaceae) in Italy. However, the species formed an unstable lineage closely related to Allophaeosphaeria, Dactylidina and Septoriella in subsequent studies (Wanasinghe et al. 2018c, Phookamsak et al. 2019, Hyde et al. 2020b). Hyde et al. (2020b) included a novel species, 
Loratospora arezzoensis based on morphological characteristics. However, the phylogenetic status of this species is not well-resolved and further studies are warranted.

Mauginiella Cavara, Atti R. Accad. Naz. Lincei, Mem. Cl. Sci. Fis., sér. 6 1-2: 65 (1925).

Index Fungorum number: IF 8869; Facesoffungi number: FoF 08335; 1 morphological species (Species Fungorum 2020), 1 species with molecular data.

Type species - Mauginiella scaettae Cavara, Atti R. Accad. Naz. Lincei, Mem. Cl. Sci. Fis., sér. 6 1-2: 65 (1925).

Notes - The pathogenic genus Mauginiella was accommodated in Phaeosphaeriaceae by Wijayawardene et al. (2017a,b, 2020). The genus is represented by its hyphomycetous asexual morph and is characterized by white colony, composed of branched, hyaline, septate, immersed to superficial hyphae, abundant sporulation, homogeneous with powdery appearance. Arthroconidia are hyaline, glistening white in mass, aseptate to 6-septate, arising from 1- to multi-septate, segmented aerial hyphae (Cavara 1925, Abdullah et al. 2005). The genus was reported as a causal agent on inflorescence rot of date palm in many palm-growing countries (Abdullah et al. 2005, ElDeeb et al. 2006, Abed et al. 2019). Phylogenetic analyses obtained in this study shows that the genus belongs to Phaeosphaeriaceae.

Melnikia Wijayaw., Goonas., Bhat \& K.D. Hyde, Fungal Diversity 77: 162 (2016).

Index Fungorum number: IF 551799; Facesoffungi number: FoF 01528; 1 morphological species (Species Fungorum 2020), 1 species with molecular data.

Type species - Melnikia anthoxanthii Wijayaw., Goonas., Camporesi, Bhat \& K.D. Hyde, Fungal Diversity 77: 162 (2016)

Notes - see Wijayawardene et al. (2016a).

Murichromolaenicola Mapook \& K.D. Hyde, in Mapook et al., Fungal Diversity 101: 71 (2020).

Index Fungorum number: IF 557338; Facesoffungi number: FoF 07805; 2 morphological species (Mapook et al. 2020, Species Fungorum 2020), 2 species with molecular data.

Type species - Murichromolaenicola chromolaenae Mapook \& K.D. Hyde, in Mapook et al., Fungal Diversity 101: 72 (2020).

Notes - Murichromolaenicola was introduced by Mapook et al. (2020) to accommodate, $M$. chiangraiensis and the type species, $M$. chromolaenae which were both collected from dead stems of Chromolaena odorata in Thailand. The genus is known from both sexual and asexual morphs having pigmented muriform ascospores and conidia. Multi-gene phylogenetic analyses showed that the genus belongs to Phaeosphaeriaceae (Mapook et al. 2020).

Muriphaeosphaeria Phukhams., Bulgakov \& K.D. Hyde, Phytotaxa 227(1): 60 (2015).

Index Fungorum number: IF 551291; Facesoffungi number: FoF 00868; 4 morphological species (Species Fungorum 2020), 4 species with molecular data.

Type species - Muriphaeosphaeria galatellae Phukhams., Bulgakov \& K.D. Hyde, in Phukhamsakda et al., Phytotaxa 227(1): 60 (2015).

Notes - see Phukhamsakda et al. (2015), Hernández-Restrepo et al. (2016) and Hyde et al. (2016, 2019).

Neoophiobolus Mapook \& K.D. Hyde, in Mapook et al., Fungal Diversity 101: 74 (2020).

Index Fungorum number: IF 557343; Facesoffungi number: FoF 07808; 1 morphological species (Mapook et al. 2020, Species Fungorum 2020), 1 species with molecular data.

Type species - Neoophiobolus chromolaenae Mapook \& K.D. Hyde, in Mapook et al., Fungal Diversity 101: 74 (2020).

Notes - A monotypic genus Neoophiobolus was introduced by Mapook et al. (2020) to accommodate ophiobolus-like taxon. The genus was collected from dead stems of Chromolaena odorata in Thailand. Multi-gene phylogenetic analyses showed that the genus forms a distinct clade with Ophiobolus in Phaeosphaeriaceae (Mapook et al. 2020). 
Neosetophoma Gruyter, Aveskamp \& Verkley, Mycologia 102(5): 1075 (2010).

Index Fungorum number: IF 514648; Facesoffungi number: FoF 00249; 20 morphological species (Species Fungorum 2020, Hyde et al. 2020b), 20 species with molecular data.

Type species - Neosetophoma samarorum (Desm.) Gruyter, Aveskamp \& Verkley, in de Gruyter, Mycologia 102(5): 1075 (2010).

$\equiv$ Phoma samarorum Desm., Pl. Crypt. Nord France, Edn 1 7: no. 349 (1828).

Notes - see De Gruyter et al. (2010), Liu et al. (2015), Karunarathna et al. (2017a), Thambugala et al. (2017b), Tibpromma et al. (2017), Hyde et al. (2018, 2019, 2020), Wanasinghe et al. (2018c), Marin-Felix et al. (2019) and Phookamsak et al. (2019).

Neosphaerellopsis Crous \& Trakun., in Trakunyingcharoen et al., IMA Fungus 5(2): 407 (2014).

Index Fungorum number: IF 810841; Facesoffungi number: FoF 08336; 1 morphological species (Species Fungorum 2020), 1 species with molecular data.

Type species - Neosphaerellopsis thailandica Crous \& Trakun. in Trakunyingcharoen et al., IMA Fungus 5(2): 407 (2014).

Notes - see Trakunyingcharoen et al. (2014).

Neostagonospora Quaedvl., Verkley \& Crous, Stud. Mycol. 75: 364 (2013).

Index Fungorum number: IF 804440; Facesoffungi number: FoF 00250; 7 morphological species (this study), 7 species with molecular data. (2013).

Type species - Neostagonospora caricis Quaedvl., Verkley \& Crous, Stud. Mycol. 75: 364

Notes - Neostagonospora was introduced by Quaedvlieg et al. (2013) to accommodate stagonospora-like taxa. Neostagonospora caricis and $N$. elegiae were initially included in this genus. Based on molecular analyses coupled with morphological characteristics, subsequent authors introduced five new species in Neostagonospora (Yang et al. 2016, Thambugala et al. 2017b, Wanasinghe et al. 2018c, Marin-Felix et al. 2019). Wanasinghe et al. (2018c) introduced $N$. artemisiae from Artemisia austriaca in Russia. Based on a combined LSU, SSU, ITS and tef1 phylogenetic analyses, $N$. artemisiae clustered with $N$. elegiae (Wanasinghe et al. 2018c). However, Marin-Felix et al. (2019) transferred N. artemisiae to Septoriella as S. artemisiae based on phylogenetic analyses of a combined ITS and LSU sequences. According to Hyde et al. (2020b) recommendations, we reinstated the species as $N$. artemisiae until phylogenetic analyses can be resolved phylogenetic status of this species. Thus, there are seven species currently accommodated in this genus.

Neostagonosporella C.L. Yang, X.L. Xu \& K.D. Hyde, in Yang et al., MycoKeys 46: 131 (2019).

Index Fungorum number: IF 556753; Facesoffungi number: FoF 05490; 1 morphological species (Species Fungorum 2020), 1 species with molecular data.

Type species - Neostagonosporella sichuanensis C.L. Yang, X.L. Xu \& K.D. Hyde, Index Fungorum 413: 1 (2019).

Notes - see Yang et al. (2019).

Neosulcatispora Crous \& M.J. Wingf., Persoonia 35: 283 (2015).

Index Fungorum number: IF 814930; Facesoffungi number: FoF 01686; 2 morphological species (Species Fungorum 2020), 2 species with molecular data.

Type species - Neosulcatispora agaves Crous \& M.J. Wingf., in Crous et al., Persoonia 35: 283 (2015).

Notes - see Crous et al. (2015d, 2016b).

Nodulosphaeria Rabenh., Klotzschii Herb. Viv. Mycol., Edn Nov, Ser. Sec., Cent. 8: no. 725 (in sched.) (1858).

Index Fungorum number: IF 3517; Facesoffungi number: FoF 00251; 46 morphological species (Species Fungorum 2020), 13 species with molecular data. 
Type species - Nodulosphaeria hirta Rabenh. Klotzschii Herb. Viv. Mycol., Edn Nov, Ser. Sec., Cent. 8: no. 725 (in sched.) (1858).

Notes - see Phookamsak et al. (2014c), Ariyawansa et al. (2015a), Li et al. (2015), Mapook et al. (2016), Hyde et al. (2016, 2019), Tibpromma et al. (2017) and Chaiwan et al. (2019).

Ophiobolopsis Phookamsak, Wanas. \& K.D. Hyde, Fungal Diversity 87: 316 (2017).

Index Fungorum number: IF 553918; Facesoffungi number: FoF 03796; 1 morphological species (Species Fungorum 2020), 1 species with molecular data.

Type species - Ophiobolopsis italica Phookamsak, Wanas., Camporesi \& K.D. Hyde, in Phookamsak et al., Fungal Diversity 87: 317 (2017).

Notes - see Phookamsak et al. (2017).

Ophiobolus Riess, Hedwigia 1(6): 27 (1854).

Index Fungorum number: IF 3591; Facesoffungi number: FoF 00254; 166 morphological species (Phookamsak et al. 2017, Gafforov et al. 2019, Species Fungorum 2020), 13 species with molecular data.

Type species - Ophiobolus disseminans Riess, Hedwigia 1(6): 27 (1854).

Notes - see Phookamsak et al. (2014c, 2017, 2019), Wanasinghe et al. (2018c) and Gafforov et al. (2019).

Ophiosimulans Tibpromma, Camporesi \& K.D. Hyde, Mycol. Progr. 15(no. 46): 3 (2016).

Index Fungorum number: IF 551566; Facesoffungi number: FoF 01251; 1 morphological species (Species Fungorum 2020), 1 species with molecular data.

Type species - Ophiosimulans tanaceti Tibpromma, Camporesi \& K.D. Hyde, in Tibpromma et al., Mycol. Progr. 15(no. 46): 3 (2016).

Notes - see Tibpromma et al. (2016b).

Ophiosphaerella Speg., Anal. Mus. nac. B. Aires, Ser. 3 12: 401 (1909).

Index Fungorum number: IF 3612; Facesoffungi number: FoF 00256; 9 morphological species (Species Fungorum 2020), 5 species with molecular data. (1909).

Type species - Ophiosphaerella graminicola Speg., Anal. Mus. nac. B. Aires, Ser. 3 12: 401

Notes - see Phookamsak et al. (2014c), Ariyawansa et al. (2015a) and Zhang et al. (2019a).

Paraleptospora Mapook \& K.D. Hyde, in Mapook et al., Fungal Diversity 101: 75 (2020).

Index Fungorum number: IF 557347; Facesoffungi number: FoF 07810; 2 morphological species (Mapook et al. 2020), 2 species with molecular data.

Type species - Paraleptospora chromolaenae Mapook \& K.D. Hyde, in Mapook et al., Fungal Diversity 101: 76 (2020).

Notes - Paraleptospora was introduced by Mapook et al. (2020) and is typified by $P$. chromolaenae. Paraleptospora is similar to Leptospora in producing pigments tinted the host surface. However, the genus forms a separate clade with Leptospora and is sister to Acericola, Jeremyomyces and Xenophoma in Phaeosphaeriaceae.

Paraloratospora Bundhun, Tennakoon, Phookamsak \& K.D. Hyde, in Hyde et al., Fungal Diversity 100: 101 (2020).

Index Fungorum number: IF 557115; Facesoffungi number: FoF 07195; 2 morphological species (Hyde et al. 2020b), 2 species with molecular data.

Type species - Paraloratospora camporesii Bundhun, Jeewon \& K.D. Hyde, in Hyde et al., Fungal Diversity 100: 105 (2020).

Notes - Paraloratospora was introduced by Hyde et al. (2020b) to accommodate phaeosphaeria-like taxa. The genus formed a clade with Phaeosphaeria sensu lato and phylogenetically closed to Wingfieldomyces, Loratospora and Sulcispora (Hyde et al. 2020b). 
Based on phylogenetic and morphological distinctiveness, Hyde et al. (2020b) introduced the genus to accommodate Paraloratospora camporesii and $P$. gahniae.

Paraophiobolus Phookamsak, Wanas. \& K.D. Hyde, Fungal Diversity 87: 318 (2017).

Index Fungorum number: IF 553920; Facesoffungi number: FoF 03798; 2 morphological species (Species Fungorum 2020), 2 species with molecular data.

Type species - Paraophiobolus arundinis Phukhamsakda, Phookamsak, Wanas., Camporesi \& K.D. Hyde, in Phookamsak et al., Fungal Diversity 87: 320 (2017).

Notes - see Phookamsak et al. (2017).

Paraphoma Morgan-Jones \& J.F. White, Mycotaxon 18(1): 58 (1983).

Index Fungorum number: IF 25835; Facesoffungi number: FoF 00259; 10 morphological species (Species Fungorum 2020), 10 species with molecular data.

Type species - Paraphoma radicina (McAlpine) Morgan-Jones \& J.F. White, Mycotaxon 18(1): 60 (1983).

$\equiv$ Pyrenochaeta radicina McAlpine, Fungus Diseases of stone-fruit trees in Australia: 127 (1902).

Notes - see De Gruyter et al. (2010, 2013), Quaedvlieg et al. (2013), Crous et al. (2017b), Moslemi et al. (2018) and Gomzhina et al. (2020).

Parastagonospora Quaedvl., Verkley \& Crous, Stud. Mycol. 75: 362 (2013).

Index Fungorum number: IF 804435; Facesoffungi number: FoF 00260; 18 morphological species (Species Fungorum 2020), 18 species with molecular data.

Type species - Parastagonospora nodorum (Berk.) Quaedvl., Verkley \& Crous, Stud. Mycol. 75: 363 (2013).

$\equiv$ Depazea nodorum Berk., Gard. Chron., London: 601 (1845).

Notes - see Quaedvlieg et al. (2013), Li et al. (2015, 2016a), Thambugala et al. (2017b), Goonasekara et al. (2019) and Marin-Felix et al. (2019).

Parastagonosporella M. Bakhshi, Arzanlou \& Crous, in Bakhshi, Arzanlou, Groenewald, Quaedvlieg \& Crous, Mycol. Progr. 18: 6 (2018).

Index Fungorum number: IF 826900; Facesoffungi number: FoF 08337; 1 morphological species (Species Fungorum 2020), 1 species with molecular data.

Type species - Parastagonosporella fallopiae M. Bakhshi, Arzanlou \& Crous, in Bakhshi, Arzanlou, Groenewald, Quaedvlieg \& Crous, Mycol. Progr. 18: 6 (2018).

Notes - see Bakhshi et al. (2019).

Phaeopoacea Thambug., Dissan. \& K.D. Hyde, Mycosphere 8(4): 752 (2017).

Index Fungorum number: IF 552978; Facesoffungi number: FoF 03200; 4 morphological species (Species Fungorum 2020), 4 species with molecular data.

Type species - Phaeopoacea festucae Dissanayake \& K.D. Hyde, in Thambugala et al., Mycosphere 8(4): 752 (2017).

Notes - Thambugala et al. (2017b) introduced the new genus Phaeopoacea to accommodate P. festucae and P. phragmiticola (三 Phaeosphaeria phragmiticola). The type species of Phaeopoacea, $P$. festucae has been known only from the asexual morph forming pycnidial conidiomata, globose to subglobose, or linear in rows on the host, and didymosporous, brown to dark brown, oblong conidia (Thambugala et al. 2017b). Whereas, Phaeosphaeria phragmiticola was previously treated as a synonym of Septoriella leuchtmannii by Crous et al. (2015a). Based on multi-gene phylogenetic analyses obtained by Li et al. (2015) and Thambugala et al. (2017b), Phaeosphaeria phragmiticola was accommodated in Phaeopoacea. The other two species, P. asparagicola and $P$. muriformis were later included by Hyde et al. (2017, 2019). Phaeopoacea does not form a well-resolved clade and always clustered in a problematic clade with the genera Allophaeosphaeria, Amarenographium, Amarenomyces, Dactylidina, Poaceicola, Septoriella and 
Vagicola (Hyde et al. 2017, 2019, 2020b, Thambugala et al. 2017b, Wanasinghe et al. 2018c, Phookamsak et al. 2019). More taxon sampling and reliable genes are acquired to resolve these generic affinities.

Phaeoseptoriella Crous, Fungal Systematics and Evolution 3: 102 (2019).

Index Fungorum number: IF 829332; Facesoffungi number: FoF 08338; 1 morphological species (Species Fungorum 2020), 1 species with molecular data.

Type species - Phaeoseptoriella zeae Crous, in Crous et al., Fungal Systematics and Evolution 3: 102 (2019).

Notes - see Crous et al. (2019b).

Phaeosphaeriopsis M.P.S. Câmara, M.E. Palm \& A.W. Ramaley, Mycol. Res. 107(5): 519 (2003). Index Fungorum number: IF 28717; Facesoffungi number: FoF 00264; 16 morphological species (Thambugala et al. 2014c, Hyde et al. 2020b, Species Fungorum 2020), 15 species with molecular data.

Type species - Phaeosphaeriopsis glaucopunctata (Grev.) M.P.S. Câmara, M.E. Palm \& A.W. Ramaley [as 'glauco-punctata'], in Câmara et al., Mycol. Res. 107(5): 519 (2003).

三 Cryptosphaeria glaucopunctata Grev., Fl. Edin.: 362 (1824).

Notes - see Phookamsak et al. (2014c), Thambugala et al. (2014c), Tibpromma et al. (2017), Marin-Felix et al. (2019) and Hyde et al. (2020b).

Phaeostagonospora A.W. Ramaley, Mycotaxon 61: 351 (1997).

Index Fungorum number: IF 27759; Facesoffungi number: FoF 00267; 1 morphological species (Species Fungorum 2020), molecular data unavailable.

Type species - Phaeostagonospora nolinae A.W. Ramaley, Mycotaxon 61: 351 (1997).

Notes - see Câmara et al. (2003) and Phookamsak et al. (2014c).

Piniphoma Crous \& R.K. Schumach., in Crous et al., Fungal Systematics and Evolution 3: 105 (2019).

Index Fungorum number: IF 829337; Facesoffungi number: FoF 08339; 1 morphological species (Species Fungorum 2020), 1 species with molecular data.

Type species - Piniphoma wesendahlina Crous \& R.K. Schumach., in Crous et al., Fungal Systematics and Evolution 3: 105 (2019).

Notes - see Crous et al. (2019b).

Poaceicola W.J. Li, Camporesi, Bhat \& K.D. Hyde, in Li et al., Mycosphere 6(6): 696 (2015).

Index Fungorum number: IF 551658; Facesoffungi number: FoF 01298; 10 morphological species (Wijayawardene et al. 2020), 10 species with molecular data.

Type species - Poaceicola arundinis W.J. Li, Camporesi, Bhat \& K.D. Hyde, in Li et al., Mycosphere 6(6): 698 (2015).

Notes - Li et al. (2015) introduced the new genus Poaceicola to accommodate the new coelomycetous asexual taxa, $P$. arundinis and $P$. bromi and also accommodated the sexual combined species $P$. elongata, previously described as Phaeosphaeria elongata in this genus based on molecular phylogeny. Wanasinghe et al. (2018c) reported the sexual morph of the type species, $P$. arundinis forming yellowish brown to light brown, muriform ascospores that is morphologically similar to Allophaeosphaeria and Vagicola dactylidis (Jayasiri et al. 2015, Liu et al. 2015). Whereas, other species of Poaceicola have phragmosporous ascospores (Thambugala et al. 2017b, Wanasinghe et al. 2018c). Based on morphological overlapping and phylogenetic boundaries, Marin-Felix et al. (2019) treated Poaceicola as a synonym of Septoriella. However, this generic status is still debatable as many genera are still phylogenetically unresolved (Thambugala et al. 2017b, Wanasinghe et al. 2018c, Phookamsak et al. 2019, Hyde et al. 2020b, this study). Furthermore, representative taxa of these genera have less reliable genes for phylogenetic analyses 
and have also less taxon sampling. Hence, Hyde et al. (2020b) suggested to reinstate Poaceicola pending further study of the monograph of Phaeosphaeriaceae.

Populocrescentia Wanas., E.B.G. Jones \& K.D. Hyde, Fungal Diversity 75: 111 (2015).

Index Fungorum number: IF 551411; Facesoffungi number: FoF 00952; 3 morphological species (Species Fungorum 2020), 3 species with molecular data.

Type species - Populocrescentia forlicesenensis Wanas., Camporesi, E.B.G. Jones \& K.D. Hyde, in Ariyawansa et al., Fungal Diversity 75: 113 (2015).

Notes - see Ariyawansa et al. (2015a) and Wanasinghe et al. (2018c).

Pseudoophiobolus Phookamsak, Wanas. \& K.D. Hyde, Fungal Diversity 87: 322 (2017).

Index Fungorum number: IF553922; Facesoffungi number: FoF03800; 8 morphological species (Species Fungorum 2020), 8 species with molecular data.

Type species - Pseudoophiobolus mathieui (Westend.) Phookamsak, Wanas., S.K. Huang, Camporesi \& K.D. Hyde, in Phookamsak et al., Fungal Diversity 87: 329 (2017).

三Sphaeria mathieui Westend., Bull. Acad. R. Sci. Belg., Cl. Sci., sér. 2: no. 5 (1859).

Notes - see Phookamsak et al. (2017).

Pseudoophiosphaerella J.F. Zhang, J.K. Liu \& Z.Y. Liu, in Zhang et al., Mycosphere 8(1): 207 (2019).

Index Fungorum number: IF 556244; Facesoffungi number: FoF 05835; 1 morphological species (Species Fungorum 2020), 1 species with molecular data.

Type species - Pseudoophiosphaerella huishuiensis J.F. Zhang, J.K. Liu \& Z.Y. Liu, in Zhang et al., Mycosphere 8(1): 207 (2019).

Notes - see Zhang et al. (2019a).

Pseudophaeosphaeria Jayasiri, Camporesi \& K.D. Hyde, Fungal Diversity 80: 111 (2016).

Index Fungorum number: IF 552207; Facesoffungi number: FoF 02345; 1 morphological species (Species Fungorum 2020), 1 species with molecular data.

Type species - Pseudophaeosphaeria rubi Jayasiri, Camporesi \& K.D. Hyde, in Hyde et al., Fungal Diversity 80: 112 (2016).

Notes - see Hyde et al. (2016).

Pseudostaurosphaeria Mapook \& K.D. Hyde, in Mapook et al. Fungal Diversity 101: 81 (2020).

Index Fungorum number: IF 557354; Facesoffungi number: FoF 07813; 2 morphological species (Mapook et al. 2020), 2 species with molecular data.

Type species - Pseudostaurosphaeria chromolaenicola Mapook \& K.D. Hyde, in Mapook et al. Fungal Diversity 101: 82 (2020).

Notes - Pseudostaurosphaeria was introduced by Mapook et al. (2020) to accommodate the coelomycetous asexual taxa collected from Chromolaena odorata in Thailand. The genus is morphologically similar to Staurosphaeria in Coniothyriaceae but is phylogenetic distinct (Wanasinghe et al. 2017a, Mapook et al. 2020). Pseudostaurosphaeria forms a well-resolved clade and is sister to Yunnanensis. However, the genus can be distinguished from Yunnanensis in having subglobose to obovoid, muriform 2-4-celled conidia, with a single polar appendage from apex (Mapook et al. 2020). Whereas, Yunnanensis has ellipsoidal to obovoid, 3 transverse septa, with 1 longitudinal septum, at the $2^{\text {nd }}$ and the $3^{\text {rd }}$ cell and lacking appendage (Karunarathna et al. 2017a).

Sclerostagonospora Höhn., Hedwigia 59(5): 252 (1917).

Index Fungorum number: IF 9830; Facesoffungi number: FoF 01584; 19 morphological species (Species Fungorum 2020), 11 species with molecular data.

Type species - Sclerostagonospora heraclei (Sacc.) Höhn., Hedwigia 59(5): 252 (1917)

三 Hendersonia heraclei Sacc., Michelia 1(no. 2): 213 (1878). 
Notes - see Crous et al. (2011a, 2016b), Wijayawardene et al. (2016a), Krisai-Greilhuber et al. (2017) and Wanasinghe et al. (2018c).

Scolicosporium Lib. ex Roum., Fungi Selecti Galliaei Exs.: no. 676 (1880).

Index Fungorum number: IF 9848; Facesoffungi number: FoF 01692; 5 morphological species (Species Fungorum 2020), 1 species with molecular data.

Type species - Scolicosporium fagi Lib. ex Roum., in Roumeguère, Revue mycol., Toulouse 2(1): 22 (1880).

Notes - see Wijayawardene et al. (2013a, 2016a).

Septoriella Oudem., Ned. kruidk. Archf, 2 sér. 5: 52 [repr.] (1889).

Index Fungorum number: IF9895; Facesoffungi number: FoF 00304; 33 morphological species (This study), 22 species with molecular data.

= Wojnowicia Sacc., Syll. fung. (Abellini) 10: 328 (1892).

Type species - Septoriella phragmitis Oudem., Ned. kruidk. Archf, 2 sér. $5: 54$ [repr.] (1889)

Notes - Septoriella was re-circumscribed by Crous et al. (2015a). The genus was initially well-known as an asexual genus forming pycnidial, unilocular, globose to subglobose, dark brown, glabrous conidiomata, with circular ostiole, ampulliform to lageniform conidiogenous cells, with proliferating via inconspicuous percurrent proliferations near apex, and fusiform to subcylindrical, pale brown, septate, smooth or minutely verruculose conidia (Crous et al. 2015a). Crous et al. (2015a) confirmed the genus in Phaeosphaeriaceae and treated Wojnowicia as a synonym of Septoriella. The number of species in Septoriella has been subsequently increased based on molecular phylogeny coupled with morphological characteristics (Li et al. 2015, Thambugala et al. 2017b, Marin-Felix et al. 2019, Hyde et al. 2020b).

Setomelanomma M. Morelet, Bull. Soc. Sci. nat. Arch. Toulon et du Var 36(no. 227): 15 (1980).

Index Fungorum number: IF 5011; Facesoffungi number: FoF 00271; 1 morphological species (Species Fungorum 2020), 1 species with molecular data.

Type species - Setomelanomma holmii M. Morelet, Bull. Soc. Sci. nat. Arch. Toulon et du Var 36(no. 227): 15 (1980).

Notes - see Phookamsak et al. (2014c).

Setophoma Gruyter, Aveskamp \& Verkley, Mycologia 102(5): 1077 (2010).

Index Fungorum number: IF 514658; Facesoffungi number: FoF 00273; 13 morphological species (Species Fungorum 2020), 13 species with molecular data.

Type species - Setophoma terrestris (H.N. Hansen) Gruyter, Aveskamp \& Verkley, in de Gruyter et al., Mycologia 102(5): 1077 (2010).

三 Phoma terrestris H.N. Hansen, Phytopathology 19(8): 699 (1929).

Notes - see De Gruyter et al. (2010), Quaedvlieg et al. (2013), Crous et al. (2014c), Phookamsak et al. (2014a, c), Thambugala et al. (2017b), Liu et al. (2019a), Marin-Felix et al. (2019).

Sulcispora Shoemaker \& C.E. Babc., Can. J. Bot. 67(5): 1594 (1989).

Index Fungorum number: IF 39796; Facesoffungi number: FoF 00444; 2 morphological species (Senanayake et al. 2018, Species Fungorum 2020), 2 species with molecular data.

Type species - Sulcispora pleurospora (Niessl) Shoemaker \& C.E. Babc., Can. J. Bot. 67(5): 1594 (1989).

三Leptosphaeria pleurospora Niessl, in Rehm, Hedwigia 27: 172 (1888).

Notes - see Senanayake et al. (2018).

Tiarospora Sacc. \& Marchal, Revue mycol., Toulouse 7(no. 26): 148 (1885).

Index Fungorum number: IF 10232; Facesoffungi number: FoF 00274; 3 morphological species (Species Fungorum 2020), molecular data unavailable. 
Type species - Tiarospora westendorpii Sacc. \& Marchal, Revue mycol., Toulouse 7(no. 26): 148 (1885).

Notes - see Phookamsak et al. (2014c) and Wijayawardene et al. (2016a).

Tintelnotia S.A. Ahmed, Hofmüller, Seibold \& de Hoog, in Ahmed et al., Mycoses 60(4): 247 (2016).

Index Fungorum number: IF 816793; Facesoffungi number: FoF 08339; 2 morphological species (Species Fungorum 2020), 2 species with molecular data.

Type species - Tintelnotia opuntiae (Boerema, de Gruyter \& Noordeloos) S.A. Ahmed \& de Hoog. in Ahmed et al., Mycoses 60(4): 247 (2016).

इPhoma opuntiae Boerema, de Gruyter \& Noordeloos, Persoonia 16: 131 (1995)

Notes - see Ahmed et al. (2017).

Vagicola Chethana \& K.D. Hyde, in Ariyawansa et al., Fungal Diversity 75: 113 (2015).

Index Fungorum number: IF 551346; Facesoffungi number: FoF 00908; 2 morphological species (This study), 2 species with molecular data.

Type species - Vagicola vagans (Niessl) O.E. Erikss., Chethana \& K.D. Hyde, in Ariyawansa et al., Fungal Diversity 75: 115 (2015).

三Pleospora vagans Niessl, Verh. nat. Ver. Brünn 14: 174 (1876).

Notes - Ariyawansa et al. (2015a) introduced a monotypic genus Vagicola based on Phaeosphaeria subgenus Vagispora and is typified by V. vagans. Jayasiri et al. (2015) added V. chlamydospora and $V$. dactylidis to this genus. However, $V$. dactylidis differs from the other two species in having muriform ascospores. Thambugala et al. (2017b) transferred V. chlamydospora to Septoriella and introduced the holomorph species, V. arundinis collected from Arundo plinii in Italy. Marin-Felix et al. (2019) synonymized the genus Vagicola under Septoriella and transferred all species in Vagicola to Septoriella. However, taxa in Septoriella clustered with many genera in Phaeosphaeriaceae and the phylogenetic affinities of these genera are unresolved. Thus, we reinstate the genus until phylogenetic affinities of genera in this problematic clade can be resolved.

Vittaliana Devadatha, Nikita, A. Baghela \& V.V. Sarma, Cryptogam., Mycol. 40(7): 120 (2019).

Index Fungorum number: IF 556887; Facesoffungi number: FoF 04668; 1 morphological species (Species Fungorum 2020), 1 species with molecular data.

Type species - Vittaliana mangrovei Devadatha, Nikita, A. Baghela \& V.V. Sarma, Cryptog. Mycol. 40(7): 124 (2019).

Notes - see Devadatha et al. (2019).

Vrystaatia Quaedvl., W.J. Swart, Verkley \& Crous, Stud. Mycol. 75: 372 (2013).

Index Fungorum number: IF 804448; Facesoffungi number: FoF 00275; 1 morphological species (Species Fungorum 2020), 1 species with molecular data.

Type species - Vrystaatia aloicola Quaedvl., Verkley, W.J. Swart \& Crous, Stud. Mycol. 75: 372 (2013).

Notes - see Quaedvlieg et al. (2013).

Wingfieldomyces Y. Marín \& Crous, in Marin-Felix et al., Stud. Mycol. 94: 113 (2019).

Index Fungorum number: IF 829671; Facesoffungi number: FoF 08341; 1 morphological species (Species Fungorum 2020), 1 species with molecular data.

Type species - Wingfieldomyces cyperi (Crous \& M.J. Wingf.) Y. Marín \& Crous, in MarinFelix et al., Stud. Mycol. 94: 113 (2019).

三Setophoma cyperi Crous \& M.J. Wingf., in Crous et al., Persoonia 36: 385 (2016).

Notes - See Marin-Felix et al. (2019).

Wojnowiciella Crous, Hern.-Restr. \& M.J. Wingf., Persoonia 34: 201 (2015). 
Index Fungorum number: IF 812443; Facesoffungi number: FoF 01729; 9 morphological species (Species Fungorum 2020), 9 species with molecular data.

Type species - Wojnowiciella eucalypti Crous, Hern.-Restr. \& M.J. Wingf., Persoonia 34: 201 (2015).

$\equiv$ Wojnowicia viburni Wijayaw., Yong Wang bis \& K.D. Hyde, in Wijayawardene, Song, Bhat, McKenzie, Chukeatirote, Wang \& Hyde, Sydowia 65(1): 132 (2013).

Notes - see Wijayawardene et al. (2013b), Crous et al. (2015a, 2016b), Hernández-Restrepo et al. (2016) and Phookamsak et al. (2019).

Xenophaeosphaeria Crous \& M.J. Wingf., in Crous et al., Persoonia 33: 253 (2014).

Index Fungorum number: IF 810612; Facesoffungi number: FoF 08342; 1 morphological species (Species Fungorum 2020), 1 species with molecular data.

Type species - Xenophaeosphaeria grewiae Crous \& M.J. Wingf., in Crous et al., Persoonia 33: 253 (2014).

Notes - see Crous et al. (2014b).

Xenophoma Crous \& Trakun., in Trakunyingcharoen et al., IMA Fungus 5(2): 404 (2014).

Index Fungorum number: IF 810835; Facesoffungi number: FoF 08343; 1 morphological species (Species Fungorum 2020), 1 species with molecular data.

Type species - Xenophoma puncteliae (Diederich \& Lawrey) Crous \& Trakun., in Trakunyingcharoen et al., IMA Fungus 5(2): 404 (2014).

三 Phoma puncteliae Diederich \& Lawrey, in Lawrey, Diederich, Nelsen, Freebury, Van den Broeck, Sikaroodi \& Ertz, Fungal Diversity 55: 207 (2012).

Notes - see Trakunyingcharoen et al. (2014).

Xenoseptoria Quaedvl., H.D. Shin, Verkley \& Crous, Stud. Mycol. 75: 371 (2013).

Index Fungorum number: IF 804446; Facesoffungi number: FoF 00277; 1 morphological species (Species Fungorum 2020), 1 species with molecular data.

Type species - Xenoseptoria neosaccardoi Quaedvl., H.D. Shin, Verkley \& Crous, Stud. Mycol. 75: 371 (2013).

Notes - see Quaedvlieg et al. (2013).

Yunnanensis Karun., Phookamsak \& K.D. Hyde, Mycosphere 8(10): 1823 (2017).

Index Fungorum number: IF 553842; Facesoffungi number: FoF 03725; 2 morphological species (Mapook et al. 2020, Species Fungorum 2020), 2 species with molecular data.

Type species - Yunnanensis phragmitis Karun. \& K.D. Hyde, in Karunarathna et al., Mycosphere 8(10): 1823 (2017).

Notes - see Karunarathna et al. (2017a) and Mapook et a. (2020).

\section{Ecological and economic significance}

Species of Phaeosphaeriaceae are commonly found on monocotyledonous and herbaceous plants, as well as some other soft woody plants in both terrestrial and aquatic environments (Hyde et al. 2013, 2016b, 2017, 2019, 2020b, Phookamsak et al. 2014b, c, 2017, 2019, Ariyawansa et al. 2015a, Wanasinghe et al. 2018c, Devadatha et al. 2019, Marin-Felix et al. 2019). Phaeosphaeriaceous species can be found as endophytes, saprobes or pathogens on plants causing yield losses of the major crops as well as infecting humans (Quaedvlieg et al. 2013, Phookamsak et al. 2014b, Li et al. 2020b). Species of some genera have the ability to produce secondary metabolites reported to have antimicrobial activities (Mapook et al. 2020).

Pleomassariaceae M.E. Barr, Mycologia 71(5): 949 (1979).

Index Fungorum number: IF 81634; Facesoffungi number: FoF 06430, 58 species.

Saprobic or parasitic on woody substrates or lichens in terrestrial environments. Sexual morph: Ascomata medium to large, solitary, scattered or in groups, superficial to immersed in or 
erumpent from the peridium of woody host, globose or depressed globose, ostiolate. Ostiole flattened, papillate, open via minute slit or a small conical swelling in the host. Peridium thickened at sides, thin at the base and at the apex, comprises of one to several cell layers. Hamathecium comprising narrow cellular pseudoparaphyses. Asci 8-spored, bitunicate, fissitunicate, oblong, cylindrical or clavate, with a furcate pedicel and minute ocular chamber. Ascospores partially overlapping, obliquely 1-2-seriate, clavate, oblong to ellipsoidal, brown, mostly distoseptate, often euseptate, 1-septate to multi-septate or muriform, constricted at the septa, smooth-walled to verruculose, surrounded by a gelatinous sheath. Asexual morph: Coelomycetous or hyphomycetous, Beverwykella, Myxocyclus, Prosthemium are currently reported asexual morphs for the family.

Type - Prosthemium Kunze

Notes - Pleomassariaceae was introduced with Pleomassaria as the type by Barr (1979b) to include fungi characterized by distoseptate, dark brown ascospores and ascomatal walls which are thickened at sides and thin at the base (Hyde et al. 2013, Wijayawardene et al. 2014a). After the initial introduction of Asteromassaria and Splanchnonema into the family (Barr 1979b), many genera were included into or excluded from the family during past revisions based on host, morphology and asexual morph (Hawksworth 1985, Aptroot 1991, Barr 1993a). Based on the morphological similarities excluding ascospore septation, Pleomassaria was treated as a synonym of Splanchnonema (Barr 1993a), though it was not followed by many studies (Zhang et al. 2012b). Molecular studies conducted by Zhang et al. (2009c) placed Pleomassariaceae within Melanommataceae similar to the study by Tanaka et al. (2010). Subsequently Zhang et al. (2012b) showed a well-supported monophyletic clustering of Pleomassaria siparia and four Prosthemium species basal to Melanommataceae. Hence, Pleomassariaceae was reinstated as a separate family in Pleosporales. Lumbsch \& Huhndorf (2010) accepted Lichenopyrenis, Peridiothelia, Pleomassaria, Splanchnonema and Asteromassaria in Pleomassariaceae; however, the latter was excluded by Hyde et al. (2013). Wijayawardene et al. (2018) accepted seven genera in the family, Beverwykella, Lichenopyrenis, Myxocyclus, Peridiothelia, Prosthemium (previously known as Pleomassaria) Pseudotrichia and Splanchnonema. Pleomassariaceae consists of both sexual and asexual morphs. The asexual morphs include both hyphomycetous (Beverwykella) and coelomycetous (Myxocyclus and Prosthemium) taxa. Long before the inclusion of molecular phylogeny in fungal identification, doubts arose on the connection between Pleomassaria siparia and Prosthemium betulinum based on observations of the two spore types in the same host sites (Winter 1887, Allescher 1903). Hantula et al. (1998) confirmed $P$. betulinum as the asexual morph of $P$. siparia. According to International Code of Nomenclature for algae, fungi and plants (McNeil et al. 2012), Wijayawardene et al. (2014a) and Rossman et al. (2015) proposed to adopt the older asexual typified name Prosthemium as the generic name over the younger sexual name Pleomassaria. Even though Prosthemiaceae (1847) was validated before Pleomassariaceae (1979), it was proposed to conserve the family name Pleomassariaceae to maintain the nomenclatural stability rather than to adopt the long forgotten asexual family name Prosthemiaceae. This is because the name Prosthemiaceae has never been used in fungal classification since its introduction.

Prosthemium Kunze, Mykologische Hefte (Leipzig) 1: 17 (1817).

Index Fungorum number: IF 9534; Facesoffungi number: FoF 06431; 8 morphological species (Species Fungorum 2020), 7 species with molecular data.

Type species - Prosthemium betulinum Kunze.

Notes - Prosthemium is the asexual morph of Pleomassaria (Hantula et al. 1998, Hyde et al. 2013, Wijayawardene et al. 2014a). The genus is characterized by globose to subglobose conidiomata, with circular ostioles and brown euseptate conidia with distinct central cell (Tanaka et al. 2010). Sexual morph of this genus is characterized with medium- to large sized ascomata, cellular pseudoparaphyses, clavate to oblong asci and large and muriform ascospores (Barr 1982, Sivanesan 1984). The genus includes saprobes from terrestrial and temperate climatic regions. Seven Prosthemium species were resolved using combined gene analysis of ITS, LSU and tub sequence data available in the GenBank (Ariyawansa et al. 2016). For morphology of type species, see Tanaka et al. (2010). 
Prosthemium alni Qing Tian, Camporesi \& K.D. Hyde, Mycol Progress 371(1): 20 (2017).

Index Fungorum number: IF 554426; Facesoffungi number: FoF 03120.

Fig. 131

Description - see Tian et al. (2017).

Material examined - Italy, Province of Forlì-Cesena, near San Benedetto in Alpe, on dead branch of Alnus glutinosa (Betulaceae), 20 April 2016, Erio Camporesi, IT-2928 (MFLU 17-0282, holotype).
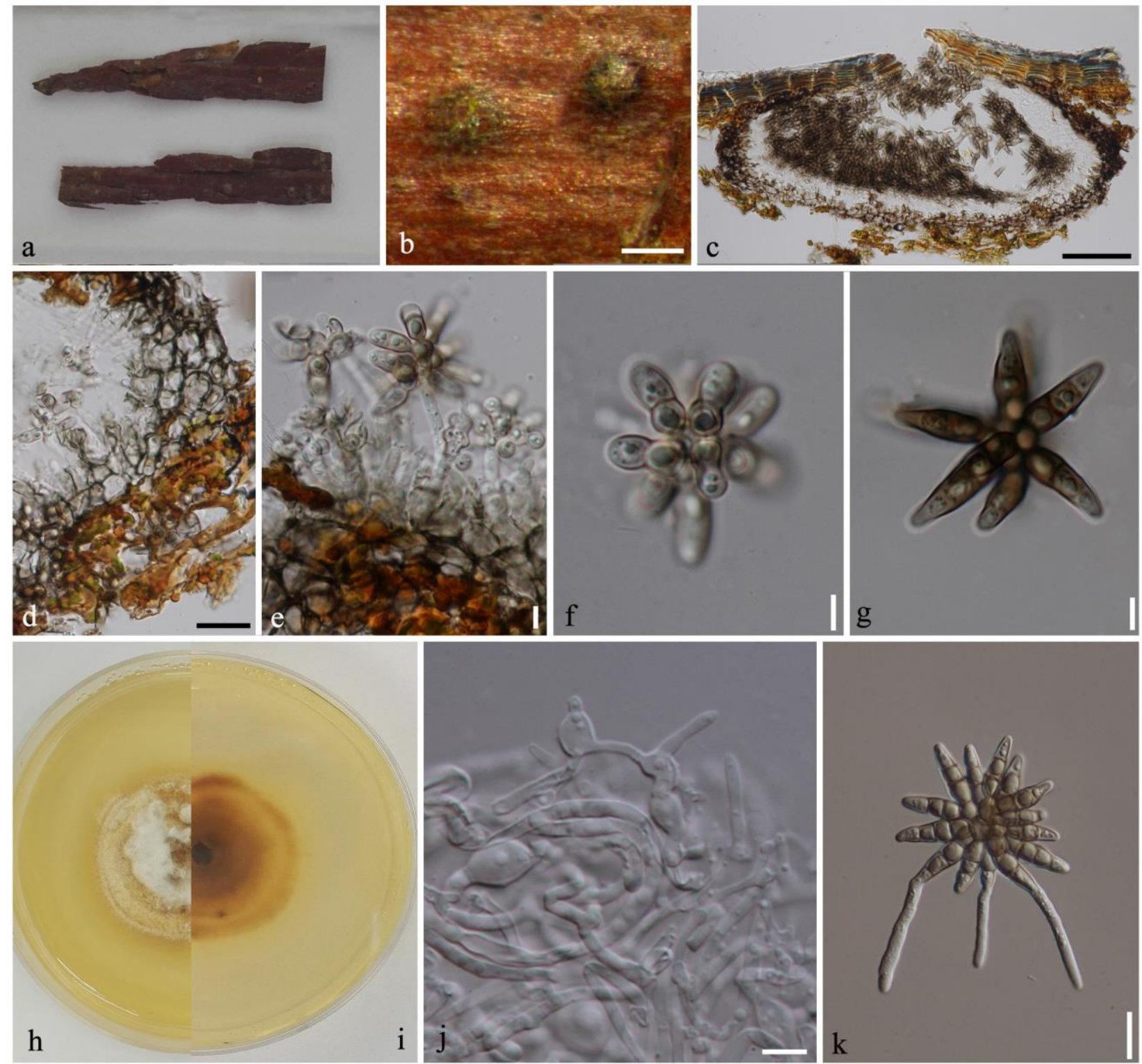

Figure 131 - Prosthemium alni (MFLU 17-0282, holotype). a Branches of Alnus glutinosa. b Appearnace of raised, black conidiomata on host surface. c Vertical section through conidioma. $\mathrm{d}$ Vertical section through peridium. e Conidiogenous cells and developing conidia. f Immature conidia. g Mature conidia. h-i Upper view (h) and reverse view (i) of the colony on MEA. j Vegetative hyphae with premature conidiophores. k Germinating conidia on MEA after 12 hrs. Scale bars: $\mathrm{b}=500 \mu \mathrm{m}, \mathrm{c}=50 \mu \mathrm{m}, \mathrm{d}, \mathrm{j}=20 \mu \mathrm{m}, \mathrm{k}=10 \mu \mathrm{m}, \mathrm{e}-\mathrm{g}=5 \mu \mathrm{m}$.

\section{Other genera included}

Beverwykella Tubaki, Trans. Mycol. Soc. Japan 16(2): 138 (1975).

Index Fungorum number: IF 7364; Facesoffungi number: FoF 00762; 3 morphological species (Species Fungorum 2020), 1 species with molecular data. 
Type species - Beverwykella pulmonaria (Beverw.) Trans. Mycol. Soc. Japan 16(2): 139 (1975).

$\equiv$ Papulaspora pulmonaria Beverw., Antonie van Leeuwenhoek 20: 11 (1954).

Notes - Species of Beverwykella are aero-aquatic in nature and can found throughout the temperate to subtropical Northern Hemisphere (Voglmayr \& Delgado-Rodríguez 2003). Initially, Beverwykella was considered as the asexual morph of Melanomma pulvis-pyrius (Zhang et al. 2009c) and placed in Melanommataceae (Hyde et al. 2013, Wijayawardene et al. 2014a). Later many studies opposed to the connection between M. pulvis-pyrius and B. pulmonaria (de Gruyter et al. 2013). Tian et al. (2015) assigned a reference specimen for the type species and transferred the genus to Pleomassariaceae (Tian et al. 2015). The genus was reported as saprobic, hyphomycetous, and aquatic (see morphology Tian et al. 2015, Wijayawardene et al. 2017a).

Lichenopyrenis Calat., M.J. Sanz \& Aptroot, Mycol. Res. 105(5): 634 (2001).

Index Fungorum number: IF 28494; Facesoffungi number: FoF 06433; 1 morphological species (Species Fungorum 2020), molecular data unavailable.

Type species - Lichenopyrenis galligena Calat., M.J. Sanz \& Aptroot, Mycol. Res. 105(5): 634 (2001).

Notes - Lichenopyrenis is well characterized and placed in Pleomassariaceae attributing to its perithecioid ascomata with a cellular (textura angularis) wall, cellular pseudoparaphyses, fissitunicate asci and distoseptate ascospores (Calatayud et al. 2001). The species of this genus considered to be a parasitic lichenicolous, terrestrial (see morphology Calatayud et al. 2001, Wijayawardene et al. 2017b, outline).

Myxocyclus Riess, Beitr. Mykol. 2: 62 (1852).

Index Fungorum number: IF 9053; Facesoffungi number: FoF 06434; 1 morphological species (Wijayawardene et al. 2017a), 1 species with molecular.

Type species - Myxocyclus confluens Riess, Beitr. Mykol. 2: 63 (1852).

Notes - Sutton (1975a, 1977, 1980) transferred Hendersonia polycystis to Myxocyclus as $M$. polycystis and treated it as the synonym of M. confluens. Myxocyclus cenangioides introduced by Petrak (1927), was later excluded from the genus since the it is not congeneric with the type species (Sutton 1980). Tanaka et al. (2005c) showed Splanchnonema argus as the sexual morph of $M$. polycystis based on co-occurrence. Since $S$. argus is not the type species of Splanchnonema and it lacks sequence data to confirm whether it belong to Splanchnonema sensu stricto, Myxocyclus was not reduced under Splanchnonema. (see Wijayawardene et al. 2016a, 2017b; morphology, outline).

Peridiothelia D. Hawksw., Bull. Br. Mus. Nat. Hist., Bot. 14(2): 120 (1985).

Index Fungorum number: IF 25729; Facesoffungi number: FoF 06435; 3 morphological species (Species Fungorum 2020), molecular data unavailable.

Type species - Peridiothelia fuliguncta (Norman) D. Hawksw., Bull. Br. Mus. Nat. Hist., Bot. 14(2): 121 (1985).

三 Microthelia fuliguncta Norman, Öfvers. K. Svensk. Vetensk.-Akad. Förhandl. 41(no. 8): 36 (1884).

Notes - Three terrestrial species of Peridiothelia collected from Europe and distinguished primarily by ascospore size are accepted in this genus (Hawksworth 1985). Initially the genus was placed in Phaeosphaeriaceae (Eriksson \& Hawksworth 1991) but later transferred to Pleomassariaceae (Barr 1992a). (see Hawksworth 1985, morphology, Wijayawardene et al. 2018, outline).

Pseudotrichia Kirschst., Annls mycol. 37(1/2): 125 (1939).

Index Fungorum number: IF 4497; Facesoffungi number: FoF 00784; 11 morphological species (Species Fungorum 2020), 6 species with molecular.

Type species - Pseudotrichia stromatophila Kirschst., Annls mycol. 37(1/2): 125 (1939). 
Notes - Members of Pseudotrichia are characterized based on size and number of septa of their ascospores. This genus has been subjected to many revisions. Based on ascomatal and peridial characters, the genus was accommodated in Didymosphaeriaceae (Thambugala et al. 2014b), and later moved to Melanommataceae based on multi-gene analysis (Liu et al. 2015). Based on multigene phylogenetic analysis, Pseudotrichia was excluded from Melanommataceae and repositioned in Pleomassariaceae (Tian et al. 2015). Due to the high morphological and phylogenetic diversity, some species in this genus have been excluded and repositioned in a new genus Thysanolaenae in Didymosphaeriaceae (Tian et al. 2015). The genus consists of mainly terrestrial saprobes with a cosmopolitan distribution (see Wijayawardene et al. 2018, outline).

Splanchnonema Corda, Deutschl. Fl., 3 Abt. (Pilze Deutschl.) 2: 115 (1829).

Index Fungorum number: IF 5153; Facesoffungi number: FoF 06437; 37 morphological species (Wijayawardene et al. 2017a, Species Fungorum 2020), 2 species with molecular.

Type species - Splanchnonema pustulatum Corda, Deutschl. Fl., 3 Abt. (Pilze Deutschl.) 2: 115 (1829).

Notes - Corda introduced Splanchnonema and assigned Splanchnonema pustulatum as the type species (Barr 1982). Initially twelve species were described and currently there are 37 species in this genus (Wijayawardene et al. 2017a). Splanchnonema species are saprobic, terrestrial and distributed in China, Europe, India and North America (Lumbsch \& Huhndorf 2010). Zhang et al. (2012b) accepted the genus in Pleomassariaceae followed by many others (Hyde et al. 2013, Wijayawardene et al. 2017a, 2018, outline).

\section{Ecological and economic significance}

Pleomassariaceae is a very diverse family, usually distributed in terrestrial habitats. Taxa in this family are usually saprobic on woody plants, occasionally act as endophytes or phellophytes (Kowalski \& Kehr 1992, Tanaka et al. 2005c, Hyde et al. 2013). There are reports on some genera causing diseases on plants leading to economic and ecological loss. Splanchnonema platani causes branch dieback disease on Platanus $\times$ hispanica plants in Germany (Kehr \& Krauthausen 2004). Some taxa such as Prosthemium betulinum infect and damage ecologically important trees such as birch, which are regarded as tolerant to industrial pollution (Hečkovà et al. 2013). Lichenopyrenis galligena is considered as a parasite on the host thallus (Calatayud et al. 2001).

Pleomonodictydaceae Hern.-Restr., J. Mena \& Gené, in Hernández-Restrepo et al., Stud. Mycol. 86: 76 (2017).

Index Fungorum number: IF 820279; Facesoffungi number: FoF 08344, 4 species.

Saprobic on wood and bark. Sexual morph: Undetermined. Asexual morph: Conidiophores micro- to semi-macronematous, sometimes reduced to conidiogenous loci in the hyphae. Conidiogenous cells mono- or polyblastic. Conidia solitary or in short chains, normally variable in shape, dark brown to black, muriform, verrucose to tuberculate.

Type - Pleomonodictys Hern.-Restr., J. Mena \& Gené.

Notes - Hernández-Restrepo et al. (2017) indicated that Pleomonodictys capensis formed a lineage sister to Pleomonodictys descalsii FMR 12716, while distant to other clades in Pleosporales. Thus, Pleomonodictydaceae was introduced to accommodate Pleomonodictys.

Pleomonodictys Hern.-Restr., J. Mena \& Gené, in Hernández-Restrepo et al., Stud. Mycol. 86: 77 (2017)

Index Fungorum number: IF 820280; Facesoffungi number: FoF 08345; 2 morphological species (Species Fungorum 2020), 2 species with molecular data.

Type species - Pleomonodictys descalsii Hern.-Restr., J. Mena \& Gené.

Notes - Pleomonodictys was introduced for $P$. descalsii and $P$. capensis, previously accommodated in Monodictys. Pleomonodictys differs from Monodictys in having verrucose to tuberculate conidia and/or hyphae. Hernández-Restrepo et al. (2017) provided a multi-gene 
phylogenetic analysis and placed Pleomonodictys in Pleomonodictydaceae, Pleosporales (Hernández-Restrepo et al. 2017).

Pleomonodictys descalsii Hern.-Restr., J. Mena \& Gené, in Hernández-Restrepo et al., Stud. Mycol. 86: 77 (2017).

Index Fungorum number: IF 820821; Facesoffungi number: FoF 08346.

Description - see Hernández-Restrepo et al. (2017).

Notes - Hernández-Restrepo et al. (2017) described Pleomonodictys descalsii which differs from $P$. capensis in having smaller conidia. We were unable to get a fresh collection of Pleosmonodictys, therefore, a drawing of Pleomonodictys descalsii is provided (Fig. 132).
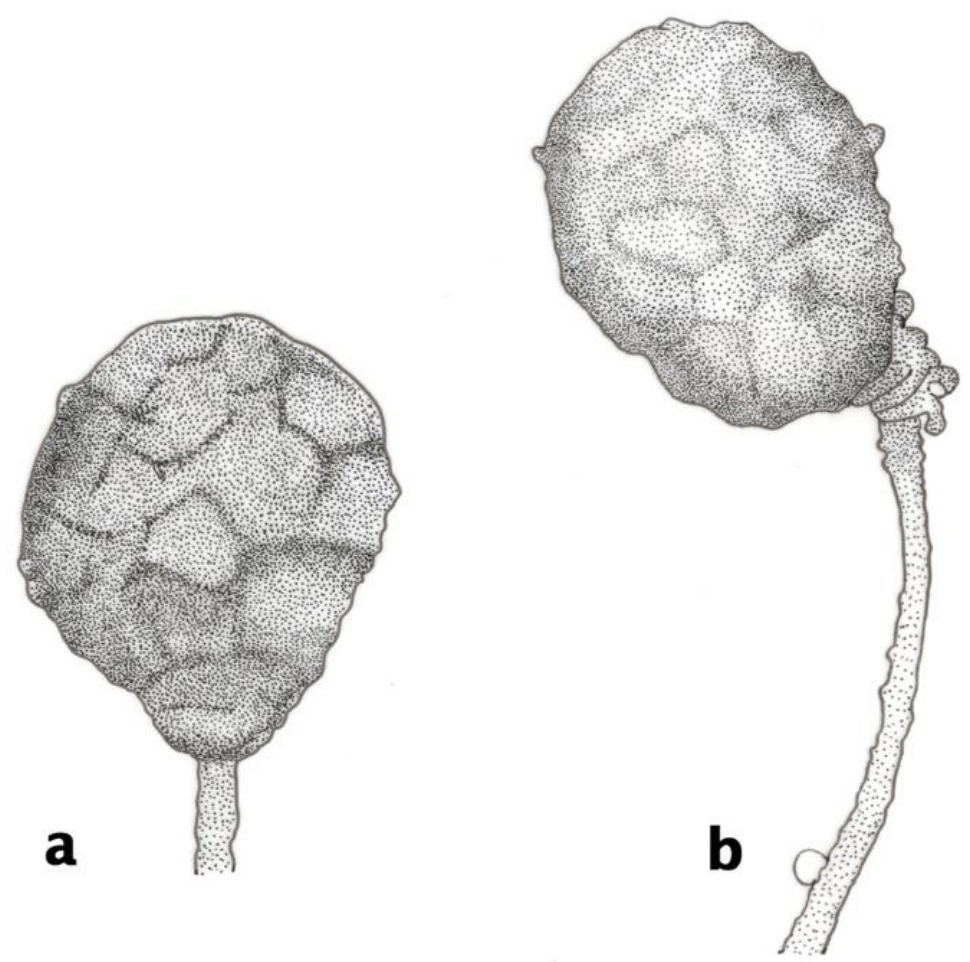

Figure 132 - Pleomonodictys descalsii (redrawn from FMR 12716, ex-type in Hernández-Restrepo et al. 2017). a-b Conidiophores and conidia.

\section{Other genus included}

Pleohelicoon Jayasiri, E.B.G. Jones \& K.D. Hyde, in Jayasiri et al., Mycosphere 10(1): 98 (2019). Index Fungorum number: IF 555565; Facesoffungi number: FoF 05271; 2 morphological species (Species Fungorum 2020), 2 species with molecular data.

Type species - Pleohelicoon fagi Jayasiri, E.B.G. Jones \& K.D. Hyde, in Jayasiri et al., Mycosphere 10(1): 99 (2019).

Notes - Jayasiri et al. (2019) introduced this genus to accommodate Helicoon species belonging to Pleosporales, while other helicoon-like species belong to Tubeufiales (Lu et al. 2018). Phylogenetic analysis indicated that Pleohelicoon clustered with Pleomonodictys within Pleomonodictydaceae (Jayasiri et al. 2019). Pleomonodictys differs from Pleohelicoon in having blastic conidia that are formed solitary or in short chains, muriform, verrucose to tuberculate and variable in shape. Pleohelicoon has tightly coiled 7-9 times to form an ovoid sphaerical, ellipsoidal, hollow, doliiform spore body, with multi-septate conidial filament (Jayasiri et al. 2019).

\section{Ecological and economic significance}


Members in this family are found saprobic on bark and decorticated wood in temperate zonein Spain and South Africa (Hernández-Restrepo et al. 2017), and play a role in nutrient recycling.

Pleosporaceae Nitschke, Verh. naturh. Ver. preuss. Rheinl. 26: 74 (1869).

Index Fungorum number: IF 81188; Facesoffungi number: FoF 00500, >2000 known species.

Pathogenic to human or saprobic on woody and dead herbaceous stems or leaves. Sexual morph: Ascomata perithecial, initially immersed and becoming erumpent to nearly superficial, black, globose, subglobose or ovoid, sometimes hairy or setose, ostiolate. Ostiole papillate or apapillate, occasionally with a pore-like ostiole, ostiolar canal filled with or without periphyses. Peridium thin, usually thick at the sides, thinner at the base. Hamathecium comprising hyaline, septate, cellular pseudoparaphyses interspersed with asci. Asci 8-spored, bitunicate, fissitunicate, cylindric-clavate, with an ocular chamber. Ascospores 1-2-seriate, partially overlapping, phragmosporous or muriform, brown or pale brown, with or without mucilaginous sheath. Asexual morph: Coelomycetous or hyphomycetous, and the conidiogenous cells can be phialidic, annellidic or sympodial blastic.

Type - Stemphylium botryosum Wallr.

Notes - Pleosporaceae was introduced based on the immersed ascomata and pseudoparaphyses, which was assigned to Sphaeriales. Pleosporaceae was earlier placed in Pseudosphaeriaceae by Theissen \& Sydow (1917a) and then later raised to ordinal rank as the Pseudosphaeriales. Luttrell (1955) assigned Pleosporaceae under Pleosporales and treated Pseudosphaeriales as a synonym of Pleosporales. Later, availability of molecular data, and multigene phylogenetic studies confirmed the familial placement of Pleosporaceae with respect to other families in Pleosporales (Lumbsch \& Huhndorf 2010, Zhang et al. 2012b). Alternaria, Bipolaris, phoma-like and Stemphylium are more common asexual morphs in Pleosporaceae and they are saprobes or parasites on various hosts. Boonmee et al. (2011) transferred Allonecte from Tubeufiaceae to Pleosporaceae. Ariyawansa et al. (2015c) revised the family and accepted 18 genera. According to Wijayawardene et al. (2018), 16 genera are accepted in Pleosporaceae based on morphological and molecular data. Pem et al. (2019c) accepted Gibbago in Pleosporaceae based on morphological and molecular data. In this study, we accept 23 genera in Pleosporaceae.

Stemphylium Wallr., Fl. crypt. Germ. (Norimbergae) 2: 300 (1833).

Index Fungorum number: IF 10081; Facesoffungi number: FoF 07388; 99 species (Species Fungorum 2020), 31 species with molecular data.

Type species - Stemphylium botryosum Wallr.

Notes - Stemphylium typified by S. botryosum is a monophyletic genus in Pleosporaceae (Woudenberg et al. 2017). However, the sexual morph to which Stemphylium is linked, Pleospora, is known to be polyphyletic. With the agreement of the one fungus-one name initiative, the use of Stemphylium over Pleospora has been recommended by the Working Group on Dothideomycetes of the International Committee on the Taxonomy of Fungi (Rossman et al. 2015). Stemphylium comprises dematiaceous hyphomycete asexual morphs which are unique in forming phaeodictyospores, with percurrent proliferation of its conidiophores, and apically swollen conidiogenous cells (Köhl et al. 2009) (morphology see: Zhang et al. 2012b, Ariyawansa et al. 2015c, Crous et al. 2016b, Woudenberg et al. 2017).

\section{Other genera included}

Allonecte Syd., Annls mycol. 37(4/5): 378 (1939).

Index Fungorum number: IF 139; Facesoffungi number: FoF 08347; 3 morphological species (Species Fungorum 2020), molecular data unavailable.

Type species - Allonecte lagerheimii (Pat.) Syd., Annls mycol. 37(4/5): 379 (1939).

三 Broomella lagerheimii Pat., in Patouillard \& Lagerheim, Bull. Soc. mycol. Fr. 11(4): 229 (1895). 
Notes - This genus has superficial ascomata that develop from a intramatrical hypostroma and cylindrical asci that contain wide, hyaline, uniseptate ascospores (Müller \& von Arx 1962, Crane et al. 1998). Allonecte was excluded from the Tubeufiaceae and transferred to Pleosporaceae by Boonmee et al. (2011) because the ascospores are fusiform-ellipsoidal, grey-brown and 1-septate which are typical characters of Pleosporaceae.

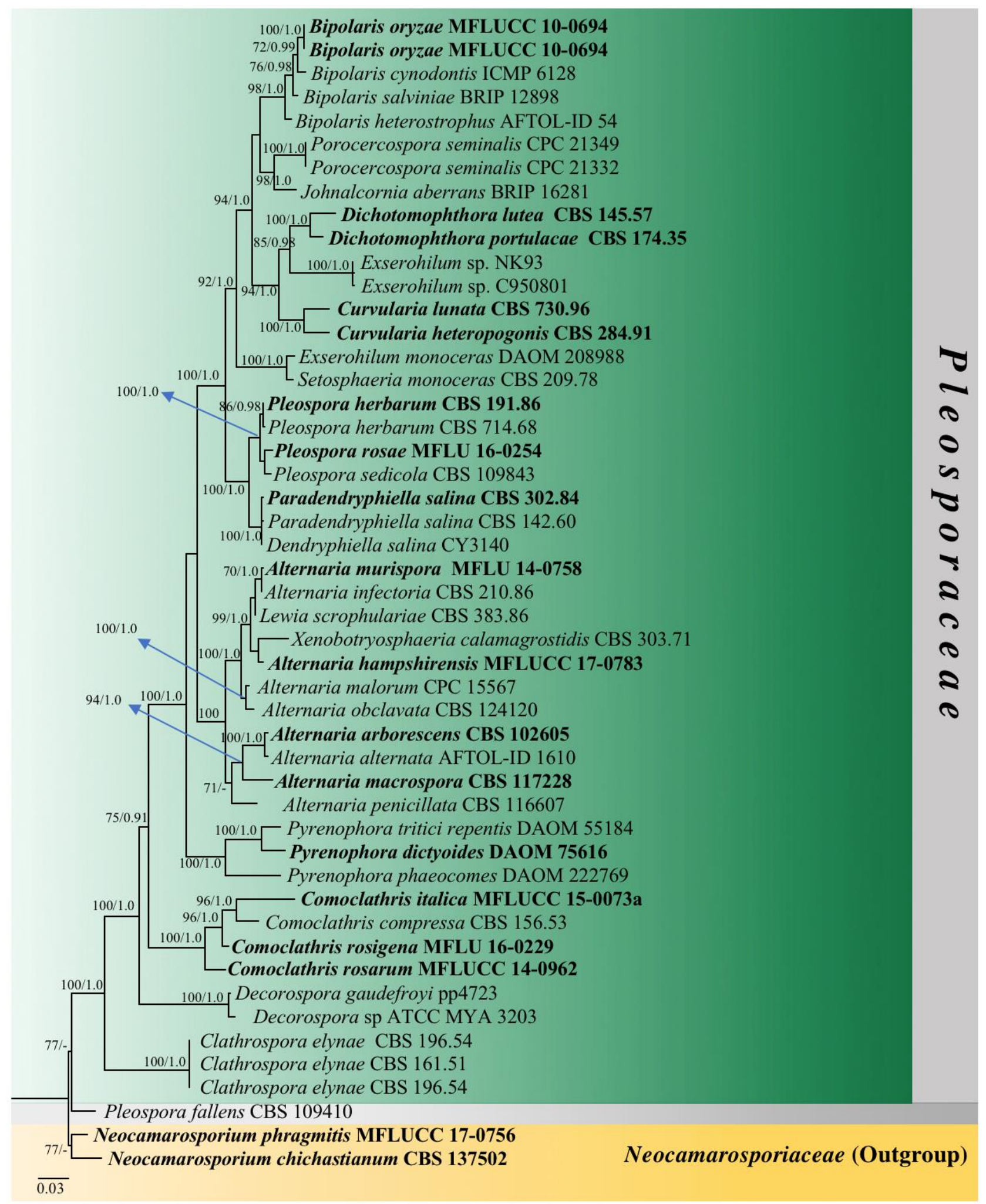

Figure 133 - Phylogram generated from maximum likelihood analysis (RAxML) of genera in Pleosporaceae based on ITS, LSU, rpb-2 and SSU sequence data. Maximum likelihood bootstrap values equal or above $70 \%$, Bayesian posterior probabilities equal or above 0.90 (MLBS/PP) are 
given at the nodes. An original isolate number is noted after the species name. The tree is rooted to Neocamarosporium chichastianum (CBS 137502) and $N$. phragmitis (MFLUCC 17-0756). The extype strains are indicated in bold. Hyphen (-) represents support values below $70 \%$ MLBS and 0.90 PP.

Alternaria Nees, Syst. Pilze (Würzburg): 72 (1817).

Index Fungorum number: IF 7106; Facesoffungi number: FoF 00501; 589 morphological species (Species Fungorum 2019), >50 species with molecular data.

Type species - Alternaria tenuis Nees, Syst. Pilze., t. 5:68 (1817).

Notes - Alternaria is a ubiquitous genus. Diagnostic morphological characters include the production of dark-coloured multi-celled conidia with longitudinal and transverse septa (phaeodictyospores), and a beak of tapering apical cells. The sexual morph was formerly known in Lewia. Based on the combined multi-gene analysis by Ariyawansa et al. (2015c), Alternaria consists of 24 internal clades and six monotypic lineages revealing the paraphyletic nature within the Alternaria complex.

Bipolaris Shoemaker, Can. J. Bot. 37(5): 882 (1959).

Index Fungorum number: IF 7375; Facesoffungi number: FoF 00503; 45 morphological species (Bhunjun et al. 2020), 45 species with molecular data (Bhunjun et al. 2020). (1959).

Type species - Bipolaris maydis (Y. Nisik. \& C. Miyake) Shoemaker, Can. J. Bot. 33: 882

$\equiv$ Helminthosporium maydis Y. Nisik. \& C. Miyake, Journal of Plant Protection, Tokyo 13(1): 23 (1926).

Notes - Bipolaris comprises plant pathogens associated with over 60 host genera (Sivanesan 1987). The sexual morph of is Cochliobolus (Drechsler 1934). Manamgoda et al. (2014) made a revision of Bipolaris based on molecular data and accepted 47 species and clarified the taxonomy, host associations, the geographic distributions as well as the species synonymies. There are currently 45 accepted species in the genus based on an updated review of the genus (Bhunjun et al. 2020).

Clathrospora Rabenh., Hedwigia 1(18): 116 (1857).

Index Fungorum number: IF 1089; Facesoffungi number: FoF 00505; 20 species (Species Fungorum 2020), 2 species with molecular data.

Type species - Clathrospora elynae Rabenh., Hedwigia 1: 116 (1857).

Notes - The unique morphological characters of Clathrospora are ascomata with circular lidlike opening and applanate, muriform ascospores.

Comoclathris Clem., Gen. fung. (Minneapolis): 37 (1909).

Index Fungorum number: IF 1198; Facesoffungi number: FoF 00507; 34 species (Species Fungorum 2020), 18 species with molecular data.

Type species - Comoclathris lanata Clem., Gen. fung. (Minneapolis): [173] (1909).

Notes - Comoclathris is characterised by circular lid-like openings ascomata, applanate reddish brown to dark reddish brown, muriform ascospores, with a single longitudinal septum. Shoemaker \& Babcock (1992) provided a key to 21 species of Comoclathris.

Comoclathris galatellae D. Pem, T.S. Bulgakov \& K.D. Hyde, sp. nov.

Fig. 134

Index Fungorum number: IF 556799; Facesoffungi number: FoF 07386.

Etymology - Name reflects the host from which the fungus is isolated.

Holotype - MFLU 17-2454.

Saprobic or parasitic on Galatella villosa. Sexual morph: Ascomata 200-550 × 230-340 $\mu \mathrm{m}$ $(\bar{x}=205 \times 235 \mu \mathrm{m}, \mathrm{n}=10)$, immersed, erumpent to superficial, broadly to narrowly oblong and flattened, ostiolate. Ostiole papillate, dark brown to black, smooth. Peridium $10-30 \mu \mathrm{m}$ thin, coriaceous, 1-2 layers, composed of dark-brown cells of textura angularis. Hamathecium 
comprising 1.8-3 $\mu \mathrm{m}$ wide, hyaline, septate, broad, dense pseudoparaphyses. Asci 50-90 × 14-17 $\mu \mathrm{m}(\bar{x}=70.4 \times 15.8 \mu \mathrm{m}, \mathrm{n}=20), 8$-spored, bitunicate, fissitunicate, cylindrical to clavate, with furcate pedicel and minute ocular chamber. Ascospores $20-30 \times 6-8 \mu \mathrm{m}(\bar{x}=25.7 \times 7.4 \mu \mathrm{m}, \mathrm{n}=$ 20), 1-seriate or partially overlapping, mostly ellipsoidal, brown or pale brown, muriform, 2-4 transverse septa, 1-2 longitudinal septa, without sheath. Asexual morph: Coelomycetous. Conidia $2-4 \times 1-2 \mu \mathrm{m}(\bar{x}=3.8 \times 1.4 \mu \mathrm{m}, \mathrm{n}=20)$, oval to ellipsoid, hyaline, aseptate, guttulate, thin- or thick-walled.

Culture characteristics - Ascospores germinating on MEA within $24 \mathrm{~h}$. Colonies growing on MEA, reaching $2 \mathrm{~cm}$ diam. in 1 week at $16{ }^{\circ} \mathrm{C}$. Mycelium dense, circular, slightly raised, surface smooth, edge well-defined, thinly hairy, above whitish, reverse yellowish in the middle, whitish at the edge.

Material examined - Russia, Ukraine, Donetsk region, Donetsk city, Donetsk Botanical garden, steppe community, on dead branches of Galatella villosa (L.) Rchb.f. (Asteraceae), 17 May 2017, T.S. Bulgakov, DNK-032 (MFLU 17-2454, holotype) ex-type living culture MFLUCC 180773.

Notes - Isolate MFLUCC 18-0773 was obtained from dead branches of Galatella villosa in Russia. This isolate clustered with the type isolate of Comoclathris permunda (MFLUCC 14-0974) with strong bootstrap support (98\% MLBS, 1.00 PP, Fig. 135). However, C. galatellae differs from $C$. permunda in having larger ascomata $(200-550 \times 230-340 \mu \mathrm{m} v s 150-200 \mu \mathrm{m} \times 150-200$ $\mu \mathrm{m})$, shorter asci $(50-90 \times 14-17 \mu \mathrm{m} v s$ 90-110 $\times 19-22 \mu \mathrm{m})$ and ascospores septation $(2-4$ transverse septa, 1-2 longitudinal septa vs. 3 transverse septa, 1 longitudinal septa). A comparison of 514 ITS (+5.8S) nucleotides between $C$. galatellae and $C$. permunda (MFLUCC 14-0974) shows $1.6 \%$ base pairs difference. We introduce $C$. galatellae as a new species in Comoclathris based on morphological and DNA sequence data.

Curvularia Boedijn, Bull. Jard. bot. Buitenz, 3 Sér. 13(1): 123 (1933).

Index Fungorum number: IF 7847; Facesoffungi number: FoF 00510; 165 species (Species Fungorum 2020), 79 species with molecular data.

Type species - Curvularia lunata (Wakker) Boedijn, Bull. Jard. bot. Buitenz, 3 Sér. 13(1): 127 (1933).

三Acrothecium lunatum Wakker, in Wakker \& Went, De Ziektan van het Suikerriet op Java: 196 (1898).

Notes - The asexual genus Curvularia is an important pathogen in humans and plants. Curvularia has morphological similarities to Bipolaris (Sivanesan 1987) in having short, slightly curved conidia showing intermediate conidial characters between these two genera. The sexual morph was previously known in Pseudocochliobolus (morphology see Seifert et al. 2011, Wijayawardene et al. 2018, outline).

Decorospora Inderb., Kohlm. \& Volkm.-Kohlm., in Inderbitzin, Kohlmeyer, Volkmann-Kohlmeyer \& Berbee, Mycol. Progr. 1(4): 657 (2002).

Index Fungorum number: IF 28671; Facesoffungi number: FoF 00514; 1 species (Species Fungorum 2020), 1 species with molecular data.

Type species - Decorospora gaudefroyi (Pat.) Inderb., Kohlm. \& Volkm.-Kohlm., in Inderbitzin et al., Mycologia 94(4): 657 (2002).

$\equiv$ Pleospora gaudefroyi Pat., Tab. analyt. Fung. (Paris)(6): 40 (Fig. 602) (1886).

Notes - The monotypic genus Decorospora was introduced for a marine ascomycete Decorospora gaudefroyi previously known as Pleospora gaudefroyi. The morphological characters include black, erumpent ascomata, septate and branched pseudoparaphyses, fissitunicate, clavate asci with thick wall, as well as yellow-brown ascospores with 7 transverse and 1-3 longitudinal septa with a gelatinous sheath and a tripartite outer boundary. There is no report of the asexual morph (morphology see Ariyawansa et al. 2015c, Wijayawardene et al. 2018, outline).

Diademosa Shoemaker \& C.E. Babc., Can. J. Bot. 70(8): 1641 (1992). 
Index Fungorum number: IF 22422; Facesoffungi number: FoF 00516; 4 morphological species (Species Fungorum 2019), molecular data unavailable.

Type species - Diademosa californiana (M.E. Barr) Shoemaker \& C.E. Babc., Can. J. Bot. 70(8): 1641 (1992).

三 Graphyllium californianum M.E. Barr, Mem. N. Y. bot. Gdn 62: 40 (1990).

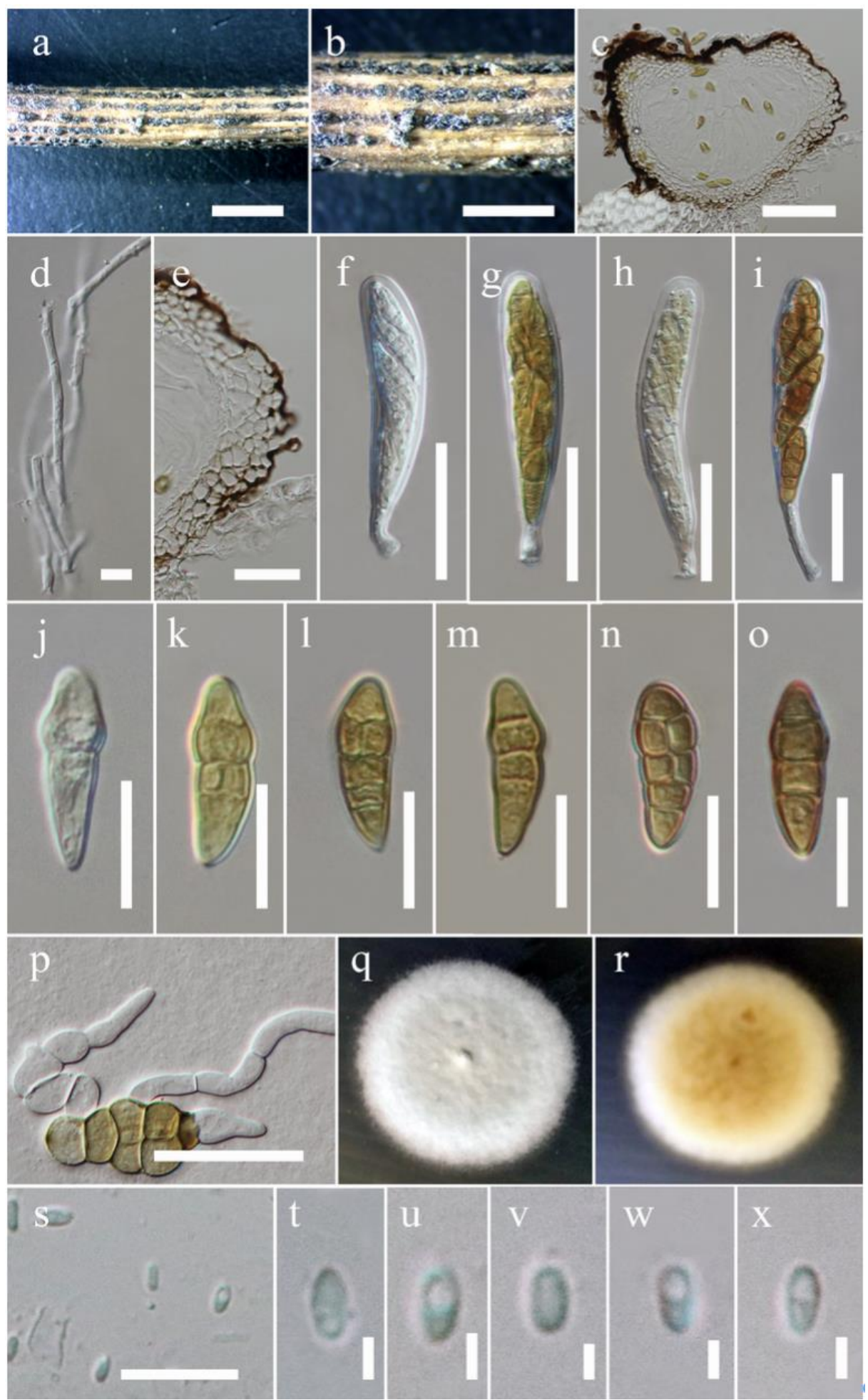

Figure 134 - Comoclathris galatellae (MFLU 17-2454, holotype). a Type material. b Appearance of black ascomata on the host. c Section of ascomata. d Hamathecium. e Peridium. f-i Asci with ascospores. $\mathrm{j}-\mathrm{o}$ Ascospores. $\mathrm{p}$ Germinated ascospore. $\mathrm{q}, \mathrm{r}$ Culture characteristics (q: above view; $r$ : reverse view). $\mathrm{s}-\mathrm{x}$ Conidia formed from culture. Scale bars: $\mathrm{a}=2000 \mu \mathrm{m}, \mathrm{b}=1000 \mu \mathrm{m}, \mathrm{c}=50 \mu \mathrm{m}$, $\mathrm{d}, \mathrm{s}=10 \mu \mathrm{m}, \mathrm{e}=40 \mu \mathrm{m}, \mathrm{f}-\mathrm{i}=50 \mu \mathrm{m}, \mathrm{j}-\mathrm{o}=20 \mu \mathrm{m}, \mathrm{p}=50 \mu \mathrm{m}, \mathrm{t}-\mathrm{x}=2 \mu \mathrm{m}$. 


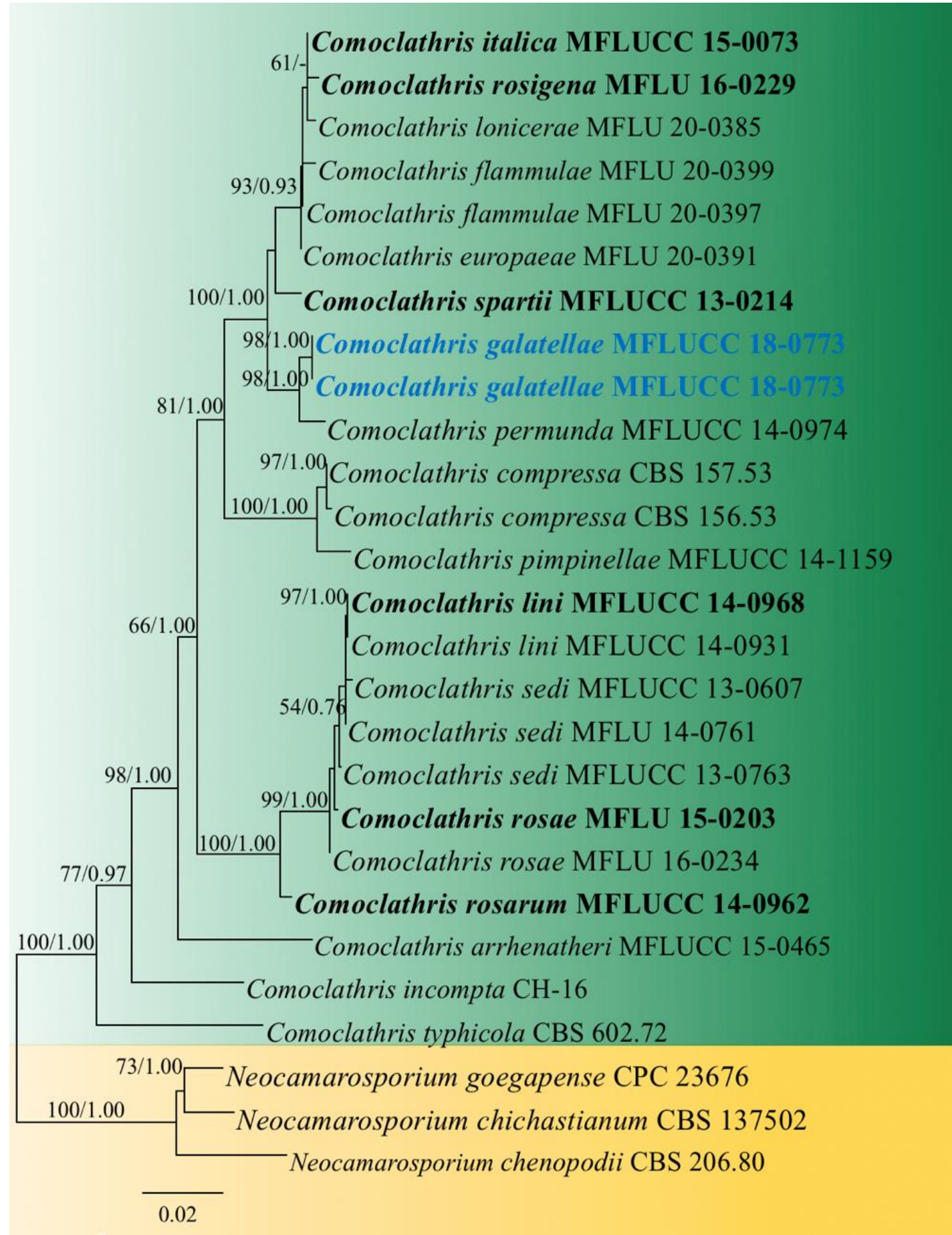

Figure 135 - Phylogram generated from maximum likelihood analysis (RAxML) of Comoclathis species based on ITS, LSU and SSU sequence data. Maximum likelihood bootstrap values equal or above $70 \%$, Bayesian posterior probabilities equal or above 0.90 (MLBS/PP) are given at the nodes. An original isolate number is noted after the species name. The tree is rooted to Neocamarosporium chichastianum (CBS 137502) and N. goegapense (CPC 23676). The ex-type strains are indicated in bold. Hyphen (-) represents support values below $70 \%$ MLBS and 0.90 PP.

Notes - Diademosa is easily identified based on its ascomatal opening through a circular lid and ascospores often circular in end view. Diademosa differs from Comoclathris in having cylindrical ascospores, often round in section, but constricting to one end of the spore, compared to the flattened ascospores of Comoclathris. Diademosa was placed in Pleosporaceae by Ariyawansa et al. (2014a) based on morphological similarities to other genera in the family. The asexual morph is unknown (morphology see Ariyawansa et al. 2014a). 
Dichotomophthora Mehrl. \& Fitzp., Mycologia 27(5): 550 (1935).

Index Fungorum number: IF 506175; Facesoffungi number: FoF 08348; 5 morphological species (Species Fungorum 2020), 3 species with molecular data.

Type species - Dichotomophthora portulacae Mehrl. \& Fitzp. ex M.B. Ellis, Dematiaceous Hyphomycetes (Kew): 388 (1971).

Notes - Dichotomophthora was revised by Marin-Felix et al. (2019) and four species associated with leaf spots on wide range of host plants were accepted. Crous et al. (2019b) reported closest hits of Dichotomophthora basellae using LSU sequence of isolate CPC 33044 with that of Dichotomophthora lutea, Curvularia papendorfii, Bipolaris cactivora and Drechslera helianthi. Closest hits using the rpb-2 sequence had highest similarity to Dichotomophthora basellae, Dichotomophthora lutea and Bipolaris cactivora.

Exserohilum K.J. Leonard \& Suggs, Mycologia 66(2): 289 (1974).

Index Fungorum number: IF 8241; Facesoffungi number: FoF 00518; 35 species (Species Fungorum 2020), 15 species with molecular data.

Type species - Exserohilum turcicum (Pass.) K.J. Leonard \& Suggs, Mycologia 66(2): 291 (1974).

$\equiv$ Helminthosporium turcicum Pass., Boln Comiz. Agr. Parmense 10: 3 (1876).

Notes - Exserohilum was established by Leonard \& Suggs (1974) to accommodate species which were previously classified in Bipolaris whereby the conidial hilum was distinctly protuberant. A new genus Setosphaeria was also introduced to place the sexual morphs of Exserohilum which is distinct from Keissleriella based on the lack of clypeus, lysigenous development of the ostiole, occurrence of setae on the perithecial wall, the absence of periphyses in the ostiole and the hyphomycetous conidial states. The asexual name Exserohilum has priority over Keissleriella (morphology see Ariyawansa et al. 2015, Wijayawardene et al. 2018, outline).

Extrawettsteinina M.E. Barr, Contr. Univ. Mich. Herb. 9(8): 538 (1972).

Index Fungorum number: IF 1967; Facesoffungi number: FoF 00520; 2 species (Species Fungorum 2020), molecular data unavailable. (1972).

Type species - Extrawettsteinina minuta M.E. Barr, Contr. Univ. Mich. Herb. 9(8): 538

Notes - Extrawettsteinina is characterized by superficial, conical ascomata, comprising saccate bitunicate asci and ellipsoidal, obovate-clavate, septate, smooth and hyaline ascospores which turn dull brown at maturity (Barr 1972). No molecular data are available for this genus and hence the generic type needs to be collected (morphology see Ariyawansa et al. 2015c, Wijayawardene et al. 2018, outline).

Gibbago E.G. Simmons, Mycotaxon 27: 108 (1986).

Index Fungorum number: IF 11081; Facesoffungi number: FoF 00522; 1 morphological species (Species Fungorum 2020), 1 species with molecular data.

Type species - Gibbago trianthemae E.G. Simmons, Mycotaxon 27: 108 (1986).

Notes - Gibbago was accommodated in Pleosporaceae based on its morphological similarities to Alternaria, Embellisia, Ulocladium and Stemphylium and this was followed by Wijayawardene et al. (2014b) and Ariyawansa et al. (2015c). Gibbago was referred to Dothideomycetes, genera incertae sedis in Wijayawardene et al. (2018). Pem et al. (2019c) confirmed the placement of Gibbago based on morphological and phylogenetic data (morphology see Pem et al. 2019c)

Johnalcornia Y.P. Tan \& R.G. Shivas, in Tan, Madrid, Crous \& Shivas, Australas. Pl. Path. 43(6): 592 (2014).

Index Fungorum number: IF 807731; Facesoffungi number: FoF 00524; 1 morphological species (Species Fungorum 2020), 1 species with molecular data. 
Type species - Johnalcornia aberrans (Alcorn) Y.P. Tan \& R.G. Shivas, in Tan, Madrid, Crous \& Shivas, Australas. Pl. Path. 43(6): 592 (2014).

三Bipolaris aberrans Alcorn, Mycotaxon 39: 364 (1990).

Notes - Johnalcornia was introduced for Bipolaris aberrans (= Johnalcornia aberrans). Johnalcornia is phylogenetically related to Bipolaris, Curvularia and Porocercospora and was accepted as a separate genus in Pleosporaceae (Tan et al. 2014). Johnalcornia differs from Porocercospora in having distinct conidia-like chlamydospores and thick-walled, geniculate conidiophores, with conidiogenous cells that have conspicuous scars (morphology see Tan et al. 2014)

Paradendryphiella Woudenb. \& Crous, Stud. Mycol. 75(1): 207 (2013).

Index Fungorum number: IF 803750; Facesoffungi number: FoF 00530; 2 species (Species Fungorum 2020), 2 species with molecular data.

Type species - Paradendryphiella salina (G.K. Sutherl.) Woudenb. \& Crous, Stud. Mycol. 75(1): 207 (2013).

三 Cercospora salina G.K. Sutherl., New Phytol. 15: 43 (1916).

Notes - Paradendryphiella was established to accommodate two species Dendryphiella arenariae and D. salina (= Cercospora salina). The morphological characters of the genus are simple or branched conidiophores with a new head or a short, inconspicuous sympodial rachis and holoblastically produced cylindrical to obclavate, straight or slightly flexuous, 1-7 transverse septa, pale to medium brown conidia. Cultures and sequence data are available however there is no mention of the holotype of the type species or ex-type culture (morphology see Jones et al. 2015, Wijayawardene et al. 2018, outline).

Platysporoides (Wehm.) Shoemaker \& C.E. Babc., Can. J. Bot. 70(8): 1648 (1992).

Index Fungorum number: IF 22438; Facesoffungi number: FoF 00532; 11 species (Species Fungorum 2020), molecular data unavailable.

Type species - Platysporoides chartarum (Fuckel) Shoemaker \& C.E. Babc., Can. J. Bot. 70(8): 1650 (1992).

$\equiv$ Pleospora chartarum Fuckel, Jb. nassau. Ver. Naturk. 23-24: 133 (1870).

Notes - Platysporoides was introduced as a subgenus of Pleospora. Later, Platysporoides was raised to generic rank and was placed in the Pleosporaceae based on its 'applanodictyospore' and 'terete pored beak of the ascomata' by Shoemaker \& Babcock (1992). Twelve species are accommodated in the genus. The asexual morph is unknown. There is no DNA sequence data available for the genus in Genbank hence fresh re-collection is required (morphology see Ariyawansa et al. 2015c, Wijayawardene et al. 2018, outline).

Pleoseptum A.W. Ramaley \& M.E. Barr, Mycotaxon 54: 76 (1995).

Index Fungorum number: IF 6197; Facesoffungi number: FoF 07387; 1 species (Species Fungorum 2020), molecular data unavailable. (1995).

Type species - Pleoseptum yuccaesedum A.W. Ramaley \& M.E. Barr, Mycotaxon 54: 76

Notes - Pleoseptum is a monotypic genus. Pleoseptum forms a camarosporium-like asexual morph. The genus was previously accepted in Phaeosphaeriaceae (Hyde et al. (2013), however Phookamsak et al. (2014c) placed it in Pleosporaceae based on the peridium structure which is very thick, composed of heavily pigmented, thick-walled cells with ostiole and typical of Pleosporaceae. Molecular data is unavailable and fresh collections are needed (morphology see Phookamsak et al. 2014c, Wijayawardene et al. 2018, outline).

Porocercospora Amaradasa, Amundsen, Madrid \& Crous, Mycologia 106(1): 81 (2014).

Index Fungorum number: IF 803981; Facesoffungi number: FoF 00536; 1 morphological species (Species Fungorum 2020), 1 species with molecular data. 
Type species - Porocercospora seminalis (Ellis \& Everh.) Amaradasa, Amundsen, H. Madrid \& Crous, Mycologia 106(1): 81 (2014).

$\equiv$ Cercospora seminalis Ellis \& Everh., J. Mycol. 4(1): 4 (1888).

Notes - Porocercospora seminalis was isolated from sterile Buchloe" dactyloides seeds. Porocercospora is characterized by densely aggregated conidiophores, subcylindrical, medium brown conidiogenous cells, solitary, and medium brown conidia. The sexual morph is unknown (morphology see Amaradasa et al. 2014).

Prathoda Subram., J. Indian bot. Soc. 35: 73 (1956).

Index Fungorum number: IF 9526; Facesoffungi number: FoF 09131; - 2 species (Species Fungorum 2020), molecular data unavailable.

Type species - Prathoda saparva Subram., J. Indian bot. Soc. 35: 73 (1956).

Notes - The genus Prathoda was introduced by Subramaniam (1956) with Prathoda saparva as type species and was resurrected by Simmons (2007). Prathoda is mentioned as a synonym of Alternaria in Index Fungorum and Mycobank (2020), but its molecular phylogeny and relationship with Alternaria is still not resolved. Therefore, we leave Prathoda as a separate genus in Pleosporaceae.

Pseudoyuconia Lar.N. Vassiljeva, Nov. sist. Niz. Rast. 20: 71 (1983).

Index Fungorum number: IF 25842; Facesoffungi number: FoF 00537; 1 species (Species Fungorum 2020), molecular data unavailable.

Type species - Pseudoyuconia thalictri (G. Winter) Lar.N. Vassiljeva, Nov. sist. Niz. Rast. 20: 71 (1983).

ELeptosphaeria thalictri G. Winter, Hedwigia 11: 147 (1872).

Notes - The monotypic genus Pseudoyuconia was introduced to accommodate Leptosphaeria thalictri G. Winter (as P. thalictra). No molecular data are available for this genus. Therefore, fresh collections of the type species are needed (morphology see Ariyawansa et al. 2015c, Wijayawardene et al. 2018, outline).

Pyrenophora Fr., Summa veg. Scand., Sectio Post. (Stockholm): 397 (1849).

Index Fungorum number: IF 4596; Facesoffungi number: FoF 000009; 108 species (Species Fungorum 2020), 16 species with molecular data.

Type species - Pyrenophora phaeocomes (Rebent.) Fr., Summa veg. Scand., Sectio Post. (Stockholm): 397 (1849).

三Sphaeria phaeocomes Rebent., Prodr. fl. neomarch. (Berolini): 338 (1804).

Notes - Pyrenophora is characterized by immersed, erumpent to nearly superficial ascomata, asci usually with a large apical ring with a clear ocular chamber, lack of pseudoparaphyses and muriform, terete ascospores (Sivanesan 1984). The type species Pyrenophora phaeocomes has Drechslera asexual morph (Sivanesan 1984).

Tamaricicola Thambug., Camporesi \& K.D. Hyde, Fungal Divers. 82: 257 (2016).

Index Fungorum number: IF 552087; Facesoffungi number: FoF 02153, 1 species (Species Fungorum 2020), 1 species with molecular data.

Type species - Tamaricicola muriformis Thambug., Camporesi \& K.D. Hyde, Fungal Divers. 82: 257 (2016).

Notes - The unique characteristics of Tamaricicola are immersed ascomata, transversely 3septate ascospores, lacking a mucilaginous sheath and a phoma-like coelomycetous asexual morph (Thambugala et al. 2016) (morphology see Thambugala et al. 2016, Wijayawardene et al. 2018, outline).

Typhicola Crous, in Crous et al., Fungal Systematics and Evolution 3: 121 (2019).

Index Fungorum number: IF 829599; Facesoffungi number: FoF 07524; 1 morphological species (Species Fungorum 2020), 1 species with molecular data. 
Type species - Typhicola typharum (Desm.) Crous, in Crous et al., Fungal Systematics and Evolution 3: 122 (2019).

ESphaeria scirpicola var. typharum Desm., Pl. Crypt. Nord France, Edn 1: no. 1428 (1848)

Notes - Typhicola is characterized by globose ascomata, anastomosing pseudoparaphyses, bitunicate subcylindrical asci and ellipsoid 3-septate ascospores. The asexual morph is undetermined (morphology see Crous et al. 2019b)

\section{Ecological and economic significance}

Pleosporaceae is a large family distributed worldwide especially in tropical regions. Species are usually saprobic, endophytic, opportunistic human, and plant pathogens. Some genera like Alternaria produce toxic compounds such as alternariols, altenuene, tentoxin and tenuazonic acid causing infection of fruits, vegetables and grains (Bullerman 2003). Others such as Bipolaris are commonly associated with leaf spots, leaf blights, root and foot rots, and other disease symptoms of high value field crops in the Poaceae, including rice, maize, wheat and sorghum (Manamgoda et al. 2014).

Pseudoastrosphaeriellaceae Phookamsak \& K.D. Hyde, Fungal Divers 74: 181 (2015).

Index Fungorum number: IF 551650; Facesoffungi number: FoF 01233, 9 species.

Saprobic on bamboo, mangroves or palms. Sexual morph: Ascostromata brown to dark brown, scattered, solitary to gregarious, immersed to erumpent through host surface by papilla, slightly conical or hemisphaerical to lenticular, uni- to bi-loculate, coriaceous, ostiolate, papillate, or with short to long neck. Peridium of unequal thickness, thick at the sides, composed of hyaline to dark brown peudoparenchymatous cells, comprising host cells plus fungal tissue, inner layer arranged in textura angularis to textura prismatica, outer layer arranged in textura prismatica to textura porrecta or arranged in textura angularis. Hamathecium comprising trabeculate pseudoparaphyses. Asci 8-spored, bitunicate, clavate to cylindric-clavate, pedicellate, apically rounded, with ocular chamber. Ascospores overlapping 1-3-seriate, fusiform with rounded or acute ends, hyaline or brown to reddish brown, septate, constricted at the septum, with or without striations, or with longitudinal ridges towards the ends, with or without mucilaginous sheath. Asexual morph: Coelomycetous. Conidiomata pycnidial, scattered, solitary, immersed, conical or hemisphaerical to globose, ostiolate. Pycnidial walls of unequal thickness, composed of dark brown to black, pseudoparenchymatous cells, arranged in textura angularis to textura intricata. Conidiophores arising from the basal cavity, cylindrical, unbranched or branched, reduced to conidiogenous cells. Conidiogenous cells holoblastic, phialidic, discrete, hyaline, cylindric-clavate or ampulliform, septate, smooth-walled. Conidia globose to subglobose, or oblong, hyaline, aseptate, smooth-walled.

Type - Pseudoastrosphaeriella Phookamsak, Z.L. Luo \& K.D. Hyde.

Notes - Pseudoastrosphaeriellaceae was introduced to accommodate a single genus Pseudoastrosphaeriella by Phookamsak et al. (2015b). Species of Pseudoastrosphaeriella were previously placed in Astrosphaeriella based on coriaceous ascomata with a papilla or necks and striate ascospores (Hawksworth \& Boise 1985). Later Phookamsak et al. (2015b) found that the Pseudoastrosphaeriella species forming a clade apart from Astrosphaeriella in their phylogenetic analyses. Based on morphological comparisons and phylogenetic analyses, Hyde et al. (2017) accommodated Carinispora in Pseudoastrosphaeriellaceae, and Phookamsak et al. (2019) introduced another novel genus, Pseudoastrosphaeriellopsis. Until now, there are three genera accommodated in the family and only Pseudoastrosphaeriella has been reported to have an asexual morph.

Pseudoastrosphaeriella Phookamsak, Z.L. Luo \& K.D. Hyde, Fungal Divers 74: 182 (2015).

Index Fungorum number: IF 551641; Facesoffungi number: FoF 01234; 6 morphological species (Species Fungorum 2020), 4 species with molecular data.

Type species - Pseudoastrosphaeriella thailandensis Phookamsak \& K.D. Hyde. 


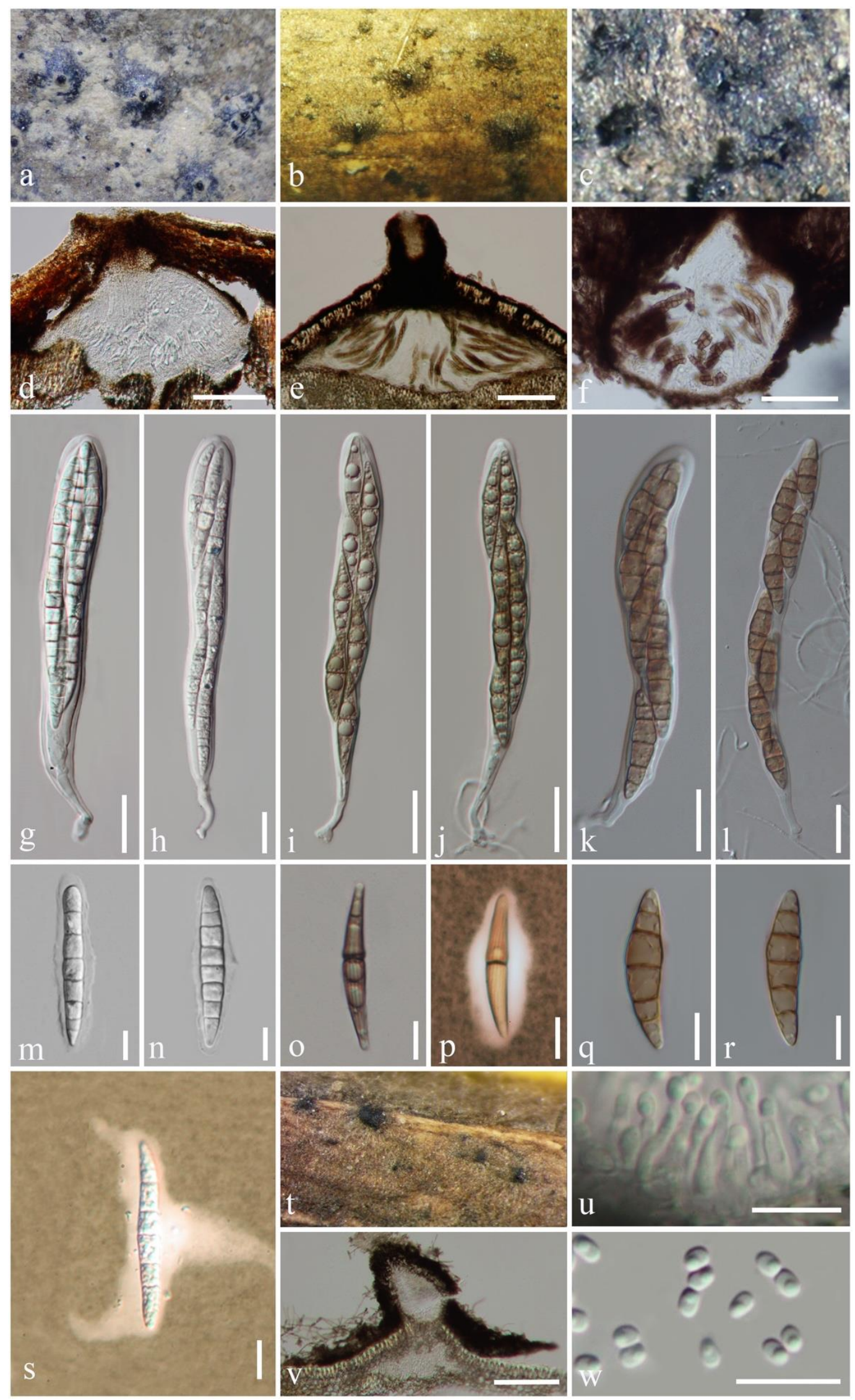

Figure 136 - Sexual and asexual morph of Pseudoastrosphaeriellaceae from their holotypes. a Ascomata of Carinispora nypae. b Ascomata of Pseudoastrosphaeriella thailandensis. c Ascomata of Pseudoastrosphaeriellopsis kaveriana. d Section through ascoma of $C$. nypae. e Section through ascoma of $P$. thailandensis (MFLU 11-0180, paratype). f Section through ascoma of $P$. kaveriana. $\mathrm{g}$, h Asci of C. nypae. i, j Asci of P. thailandensis. k, 1 Asci of P. kaveriana. m, n, s Ascospores of 
C. nypae. o, $\mathrm{p}$ Ascospores of $P$. thailandensis. q, $\mathrm{r}$ Ascospores of $P$. kaveriana. t Conidiomata of $P$. thailandensis on bamboo pieces on WA. u Conidiogenous cells of $P$. thailandensis. v Section through conidioma of $P$. thailandensis. w Conidia of $P$. thailandensis. Scale bars: $\mathrm{d}=200 \mu \mathrm{m}$, e, $\mathrm{f}$, $\mathrm{v}=100 \mu \mathrm{m}, \mathrm{g}-\mathrm{l}=20 \mu \mathrm{m}, \mathrm{m}-\mathrm{s}, \mathrm{u}, \mathrm{w}=10 \mu \mathrm{m}$.

Notes - Pseudoastrosphaeriella is similar to Astrosphaeriella in morphology, but is distinguished by molecular evidence (Phookamsak et al. 2015b). Pseudoastrosphaeriella aequatoriensis and $P$. papillata lack sequence data. For the morphology of the type species, see Phookamsak et al. (2015b).

\section{Oher genera included}

Carinispora K.D. Hyde, Bot. J. Linn. Soc. 110(2): 97 (1992).

Index Fungorum number: IF 26300; Facesoffungi number: FoF 08349; 2 morphological species (Species Fungorum 2020), 1 species with molecular data.

Type species - Carinispora nypae K.D. Hyde, Bot. J. Linn. Soc. 110(2): 99 (1992).

Notes - Carinispora was introduced to accommodate a marine Dothideomycetes by Hyde (1992a). Later another species, C. velatispora (Hyde 1994) was placed in the genus. The genus is characterized by immersed to erumpent, ostiolate, coriaceous ascomata with minute papilla, 8spored, bitunicate, fissitunicate, cylindric-clavate to clavate, shortly pedicellate asci, and hyaline, fusiform, multi-septate ascospores surrounded by sheath. The genus was positioned in Pseudoastrosphaeriellaceae based on morphology and phylogeny (Hyde et al. 2017).

Pseudoastrosphaeriellopsis Devadatha, Wanas., Jeewon \& V.V. Sarma, Fungal Divers 95: 63 (2019).

Index Fungorum number: IF 555790; Facesoffungi number: FoF 05706; 1 morphological species (Species Fungorum 2020), 1 species with molecular data.

Type species - Pseudoastrosphaeriellopsis kaveriana Devadatha, Wanas., Jeewon \& V.V. Sarma, Fungal Divers 95: 63 (2019).

Notes - Pseudoastrosphaeriellopsis was introduced in Pseudoastrosphaeriellaceae by Phookamsak et al. (2019) based on morphological and phylogenetic analyses. The genus is similar to Pseudoastrosphaeriella with immersed, erumpent, uni-loculate, coriaceous, brown ascomata and short papillate asci, with trabeculate pseudoparaphyses (Phookamsak et al. 2015b), but differs in ascospore characters. For details of the morphology of the type of Pseudoastrosphaeriellopsis see Phookamsak et al. (2019).

\section{Ecological and economic significance}

Pseudoastrosphaeriellaceae species have been only found from Asia (Hyde 1992a, 1994, Hyde et al. 2017, Phookamsak et al. 2015b, 2019), and are saprobic on bamboo, palms or mangroves.

Pseudoberkleasmiaceae Phukhams \& K.D. Hyde, Fungal Divers. 96 : 59 (2019).

Index Fungorum number: IF 555489; Facesoffungi number: FoF 05311, 3 species.

Saprobic on decaying wood. Sexual morph: Undetermined. Asexual morph: hyphomycetous, dictyosporous. Colonies on natural substratum sporodochia, superficial, compact, scattered, irregular, dark-brown to black, glistening. Mycelium immersed in the substrate, septate, branched. Conidiophores micronematous, mononematous, reduced, hyaline. Conidiogenous cells holoblastic, monoblastic, integrated, terminal, determinate. Conidia acrogenous, solitary, broadly ellipsoidal to obovoid, brown, olivaceous green, muriform, guttulate, smooth-walled, with or without guttules, usually with conidiogenous cell attached (adapted from Hyde et al. 2019).

Type - Pseudoberkleasmium Tibpromma \& K.D. Hyde.

Notes - Berkleasmium is considered as polyphyletic (Pinnoi et al. 2007, Hu et al. 2010, Lu et al. 2018). The type species of Berkleasmium has been moved to Tubeufiales (Tanney \& Miller 2017, Lu et al. 2018). The family was introduced by Hyde et al. (2019) to accommodate a 
berkleasmium-like hyphomycete which formed a clade related to Hermatomytaceae within Pleosporales (Hyde et al. 2019).

Pseudoberkleasmium Tibpromma \& K.D. Hyde, Fungal Divers. 93: 50 (2018).

Index Fungorum number: IF 555331; Facesoffungi number: FoF 08350; 3 morphological species, 3 species with molecular data.

Type species - Pseudoberkleasmium pandanicola Tibpromma \& K.D. Hyde.

Notes - Phylogenetic analyses indicated that Pseudoberkleasmium separates from the Hermatomycetaceae in Pleosporales (Tibpromma et al. 2018). Pseudoberkleasmium chiangmaiense was introduced in Hyde et al. (2019).

Pseudoberkleasmium pandanicola Tibpromma \& K.D. Hyde, Fungal Divers. 93: 51 (2018).

Index Fungorum number: IF 555332; Facesoffungi number: FoF 04510.

Fig. 137

Description - see Tibpromma et al. (2018).

Material examined - China, Yunnan Province, Xishuangbanna, on fallen dead and decaying leaf sheath of Pandanus sp., 28 April 2017, R. Phookamsak \& N.I. de Silva XTBG14 (HKAS 99622, holotype).
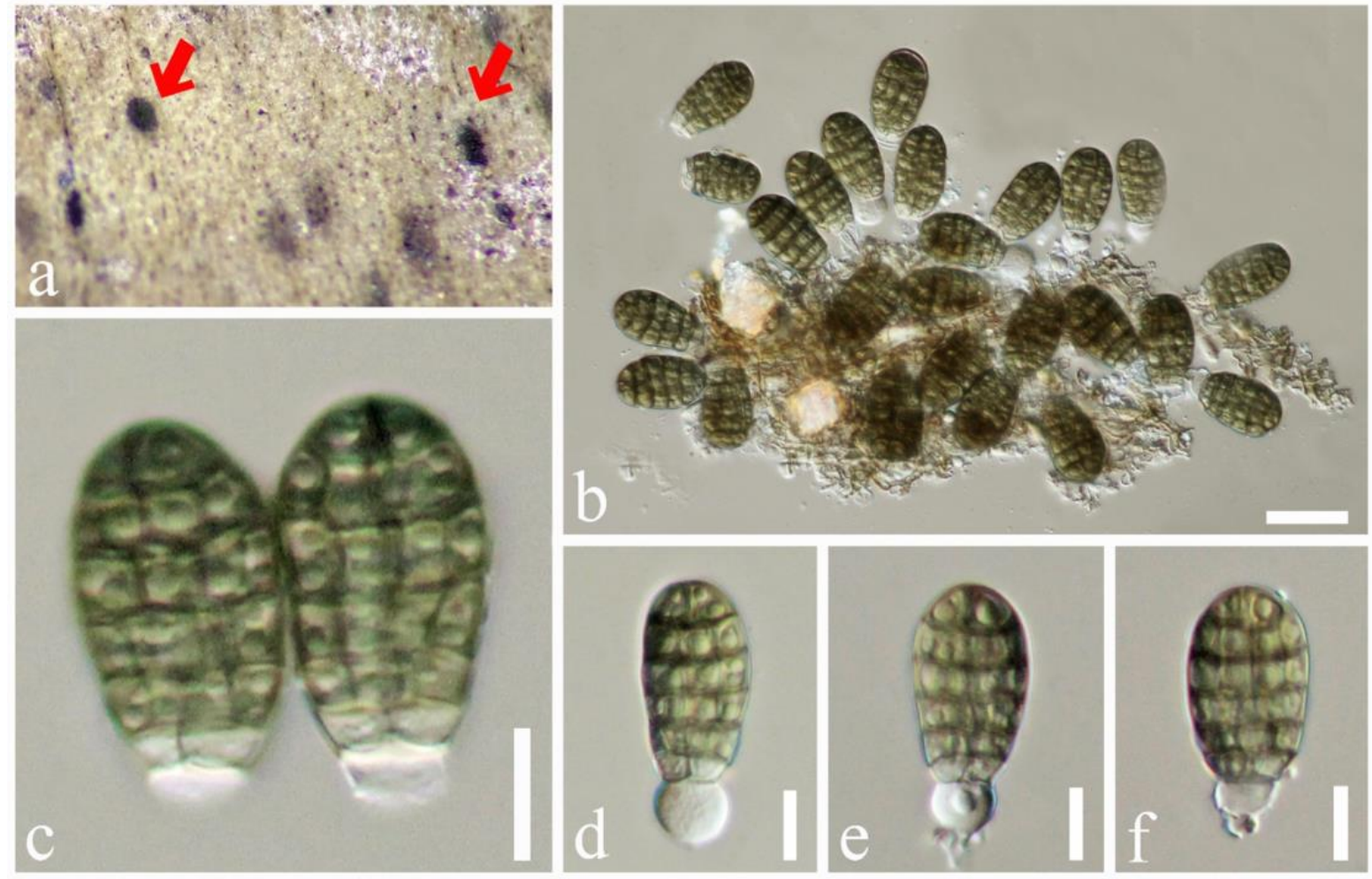

Figure 137 - Pseudoberkleasmium pandanicola (HKAS 99622, holotype). a Colonies on natural substrate. b Conidiogenous cells with conidiophores and conidia. c Conidia. $d-f$ Conidia attached with conidiogenous cells. Scale bars: $b=20 \mu \mathrm{m}, \mathrm{c}-\mathrm{f}=10 \mu \mathrm{m}$.

\section{Ecological and economic significance} matter.

Species in Pseudoberkleasmiaceae are saprobic on wood, and play a role in recycling organic

Pseudocoleodictyosporaceae Doilom \& K.D. Hyde, Fungal Divers. 82: 107-182(2017).

Index Fungorum number: IF 551979; Facesoffungi number: FoF 01856, 4 species.

Saprobic on bark of dead and living Tectona grandis. Asexual morph: Colonies on natural substrate, punctiform, sporodochial, superficial, gregarious, scattered, numerous, black. Hyphae 
sometimes superficial and sometimes immersed, pale brown to brown, septate, slightly constricted at the septa. Conidiophores wide, micronematous, erect to slightly curved, constricted at the septa, arising from hyphae. Conidiogenous cells blastic, integrated, terminal, determinate. Conidia dictyosporous to bulbil-like, very variable in size and shape; globose to ellipsoidal to irregular, with a protruding basal cell; truncate at the base, initially pale brown, becoming brown to dark brown, muriform, horizontal on conidiogenous cell. Sexual morph: Undetermined.

Type - Pseudocoleodictyospora Doilom \& K.D. Hyde.

Notes - Pseudocoleodictyosporaceae was established by Doilom et al. (2017) to accommodate two genera, Pseudocoleodictyospora and Subglobosporium. In combined multi-gene phylogenetic analysis with LSU, rpb-2 and SSU, Pseudocoleodictyosporaceae constituted a wellsupported clade adjacent to Roussoellaceae and Torulaceae (Doilom et al. 2017). The species in Pseudocoleodictyosporaceae were distinct from its sister clades, supporting its establishment as a new family. All the species from this family are recorded as saprobes on the bark of living or dead teak (Doilom et al. 2017).

Pseudocoleodictyospora Doilom \& K.D. Hyde. Fungal Divers. 82: 107-182(2017).

Index Fungorum number: IF 551980; Facesoffungi number: FoF 01857; 3 morphological species (Species Fungorum 2020), 3 species with molecular data

Type species - Pseudocoleodictyospora tectonae Doilom \& K.D. Hyde.

Notes - Genus Pseudocoleodictyospora was named for its similarities with Coleodictyospora in dark sporodochia, dictyosporous, to bulbil-like, muriform, horizontal conidia produced on conidiogenous cell, but Pseudocoleodictyospora lacks a hyaline sheath. Due to the lack of sequence data for Coleodictyospora, no strain of Coleodictyospora was used in the phylogenetic analysis used for the introduction of this genus (Doilom et al. 2017). Morphology of type species see Doilom et al. (2017).

Pseudocoleodictyospora tectonae Doilom, Bhat \& K.D. Hyde, in Doilom et al., Fungal Divers. 82: 107-182(2017).

Index Fungorum number: IF 551969; Facesoffungi number: FoF 01859.

Description - see Doilom et al. (2017).

Material examined - Thailand, Chiang Rai Province, Mae Chan District, on dead bark of Tectona grandis, 1 July 2012, M. Doilom, (MFLU 15-3527, holotype).

\section{Other genus included}

Subglobosporium Doilom \& K.D. Hyde, Fungal Divers. 82: 138 (2016).

Index Fungorum number: IF 551982; Facesoffungi number: FoF 01861; 1 species (Species Fungorum 2020), 1 species with molecular data.

Type species - Subglobosporium tectonae Doilom \& K.D. Hyde, in Doilom et al., Fungal Divers, Fungal Divers. 82: 107-182 (2017).

Notes - Conidia of Subglobosporium are in punctiform, superficial colonies in pits or cracks on bark, black, globose to subglobose on natural substrates. In combined genes of LSU, rpb-2 and SSU phylogenetic analysis, Subglobosporium forms a distinct clade within Pseudocoleodictyosporaceae basal to the Pseudocoleodictyospora clade.

\section{Ecological and economic significance}

Most species from Pseudocoleodictyosporaceae were identified and reported from teak (Tectona grandis L.f.) as saprobes. They have been only reported from Thailand (Farr \& Rossman 2019).

Pseudolophiotremataceae K.D. Hyde \& Hongsanan, in Hongsanan et al., Phytotaxa 383(1): 97 (2018).

Index Fungorum number: IF 555430; Facesoffungi number: FoF 05108, 2 species. 
Saprobic on herbaceous plants. Sexual morph: Ascomata grouped, immersed, globose. Ostiolar neck crest-like, elongated, laterally compressed. Peridium uniform, comprises thin-walled, pale brown cells. Hamathecium comprising numerous, septate, branched, anastomosing, pseudoparaphyses. Asci 8-spored, bitunicate, fissitunicate, cylindrical. Ascospores 2-seriate, fusiform, hyaline, 1-septate, smooth-walled. Asexual morph: Undetermined.

Type - Pseudolophiotrema A. Hashim. \& Kaz. Tanaka.

Notes - Two genera are accepted in this family, Clematidis and Pseudolophiotrema introduced by Li et al. (2016a) and Hashimoto et al. (2017b), respectively. Hongsanan et al. (2018) established Pseudolophiotremataceae based on the distinct lineage of Pseudolophiotrema elymicola which was treated as Pleosporales genus incertae sedis (Hashimoto et al. 2017b). They also provided MCC tree as additional evidence to support its familial status. Phukhamsakda et al. (2020) indicated that Clematidis clustered with Pseudolophiotrema. They retain the name Pseudolophiotremataceae to accommodate these two genera.
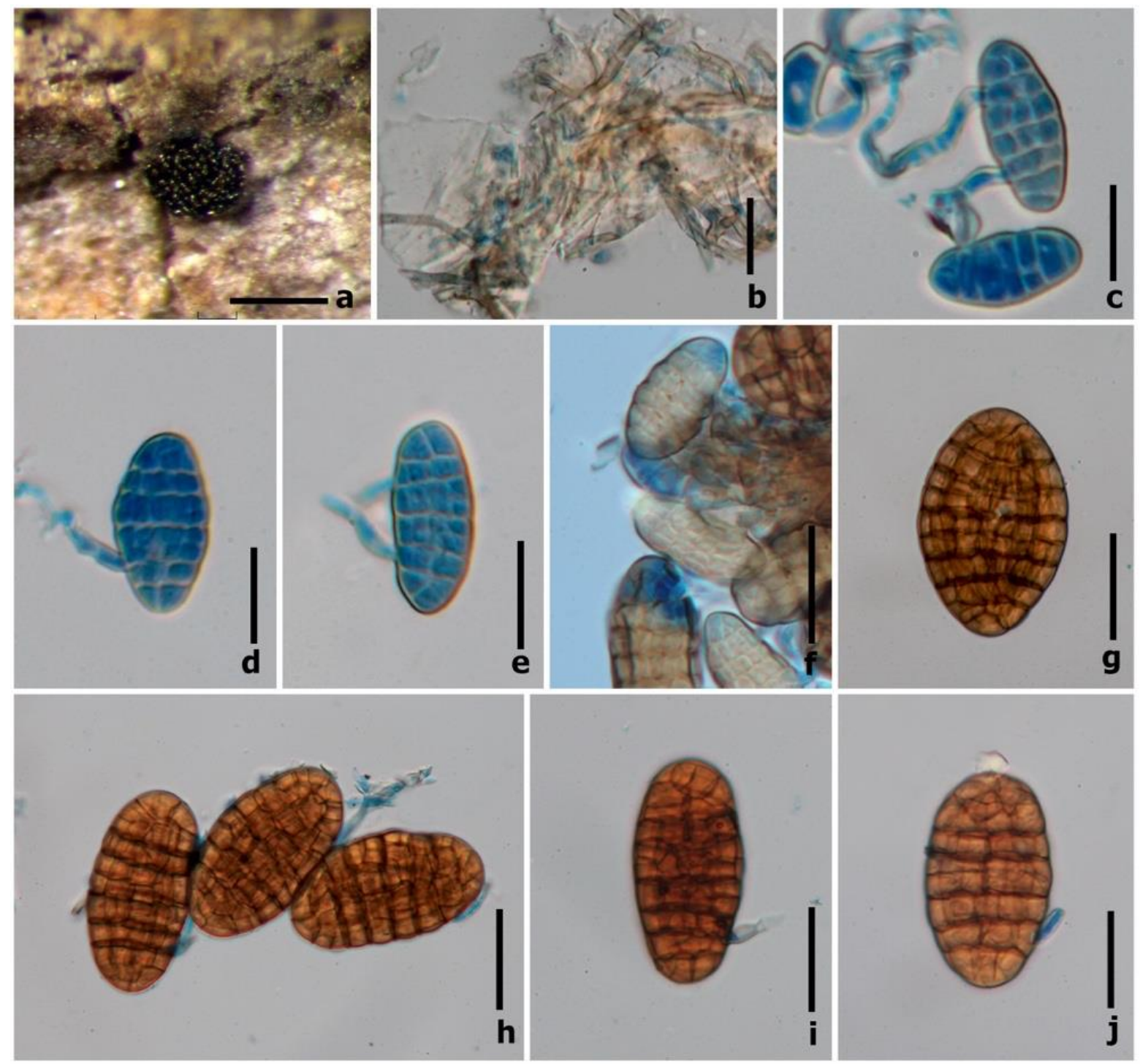

Figure 138 - Pseudocoleodictyospora tectonae (MFLU 15-3527, holotype). a Colony on dead bark. b Mycelia on host surface. c, d Immature conidia with conidiophores. e Immature conidia. g, h Conidia. i, j Conidia with conidiophores. Notes $-\mathrm{b}-\mathrm{j}$ Stained in lactophenol cotton blue. Scale bars: $\mathrm{a}=200 \mu \mathrm{m}, \mathrm{b}-\mathrm{j}=20 \mu \mathrm{m}$.

Pseudolophiotrema A. Hashim. \& Kaz. Tanaka, in Hashimoto et al. Persoonia 39: 70 (2017). 
Index Fungorum number: IF 819254; Facesoffungi number: FoF 08351, 1 morphological species (Species Fungorum 2020), 1 species with molecular data.

Type species - Pseudolophiotrema elymicola A. Hashim. \& Kaz. Tanaka

Notes - Morphologically, Pseudolophiotrema is similar to Lophiotrema but can be distinguished in having thinner ascomatal walls, composed of compressed cells, while the ascomatal wall of Lophiotrema comprises rectangular cells (Holm \& Holm 1988, Hashimoto et al. 2017b). Pseudolophiotrema is also similar to Atrocalyx, but dffers in having well-developed peridium around the ostiolar neck and base (Hashimoto et al. 2017b). Hashimoto et al. (2017b) treated Pseudolophiotrema as Pleosporales genus incertae sedis. Hongsanan et al. (2018) established Pseudolophiotremataceae to accommodate this genus based on phylogeny and divergence time estimation.

a

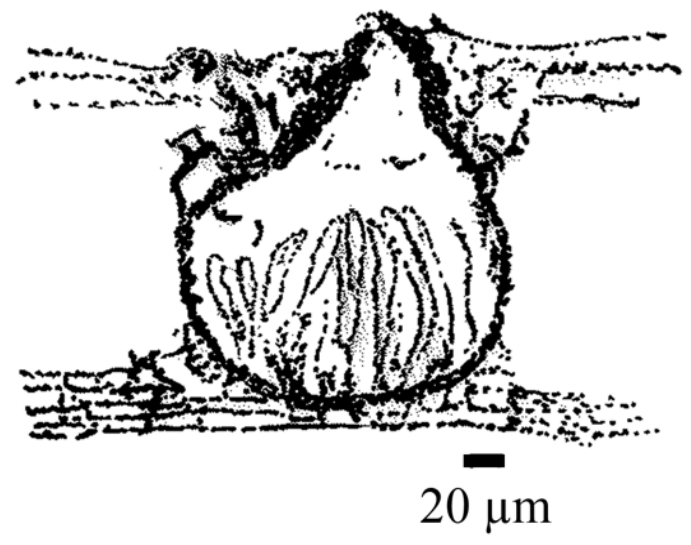

$\mathrm{C}$

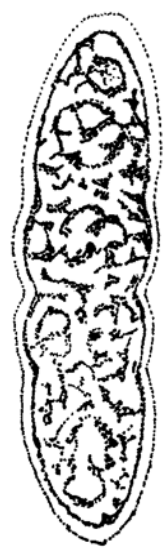

b

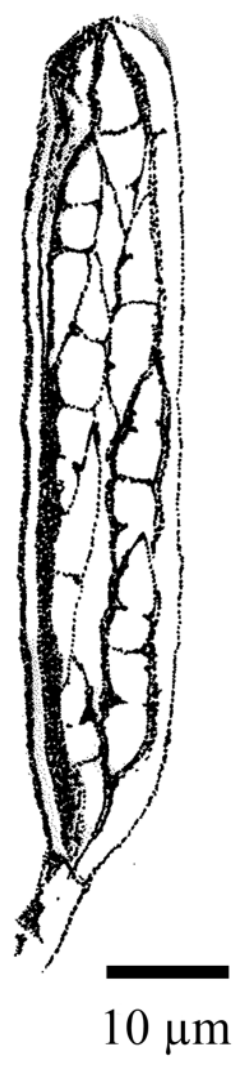

$5 \mu \mathrm{m}$

Figure 139 - Pseudolophiotrema elymicola (redrawn from Hashimoto et al. 2017b). a Ascomata in longitudinal section. b Asci. c Ascospores.

\section{Other genus included}

Clematidis Tibpromma, Camporesi \& K.D. Hyde, in Li et al., Fungal Divers 78: 60 (2016).

Index Fungorum number: IF 551867; Facesoffungi number: FoF 01813, 1 morphological species (Species Fungorum 2020), 1 species with molecular data.

Type species - Clematidis italica Tibpromma, Camporesi \& K.D. Hyde, in Li et al., Fungal Diversity 78: 60 (2016). 
Notes - The genus is similar to Lophiotrema but differs in having fusiform, 1-septate, straight or slightly curved, hyaline ascospores, while Lophiotrema has elliptic-fusiform, 3-septate, brown ascospores (Li et al. 2016a).

\section{Ecological and economic significance}

Species of Pseudolophiotremataceae are similar to Lophiotrema species (Li et al. 2016a, Hashimoto et al. 2017b). The members can be found as saprobes on herbaceous plants in terrestrial habitats. No asexual morph has been reported in this family.

Pseudomassarinaceae Phukhams. \& K.D. Hyde, in Phukhamsakda et al., Fungal Diversity 102: 99 (2020).

Index Fungorum number: IF 557104; Facesoffungi number: FoF 07212, 1 species.

Saprobic on dried herbaceous plants. Sexual morph: Ascomata immersed, uniloculate, obpyriform to sub-globose, coriaceous. Ostiole central, carbonaceous, papillate. Peridium multilayer. Hamathecium comprising dense, trabeculate pseudoparaphyses. Asci 8-spored, bitunicate, fissitunicate, oblong, apically rounded, furcated pedicellate. Ascospores 2-seriate, overlapping, broad fusiform, acute at both ends, hyaline, with transversely septate. Asexual morph: Undetermined.

Type - Pseudomassarina Phukhams. \& K.D. Hyde.

Notes - The new family Pseudomassarinaceae was introduced to accommodate a monotypic genus, Pseudomassarina, a fungal collection collected from Clematis vitalba in Italy. Inter familial phylogeny within the Pleosporales showed that Pseudomassarinaceae formed a distinct lineage related to Amorosiaceae, Halotthiaceae, Lophiostomataceae, Neomassarinaceae, Phaeoseptaceae, Sporormiaceae (Phukhamsakda et al. 2020). Currently, one genus, Pseudomassarina, is accepted in Pseudomassarinaceae.

Pseudomassarina Phukhams. \& K.D. Hyde, in Phukhamsakda et al., Fungal Diversity 102: 101 (2020).

Index Fungorum number: IF 557097; Facesoffungi number: FoF 07213, 1 morphological species (Phukhamsakda et al. 2020), 1 species with molecular data.

Type species - Pseudomassarina clematidis Phukhams, Camporesi \& K.D. Hyde.

Notes - Pseudomassarina, typified with $P$. clematidis and is introduced by Phukhamsakda et al. (2020). The taxon formed a distinct lineage in Pleosporales (Fig. 42) with obpyriform, coriaceous, ascomata with carbonaceous, papillate, with 1-transverse septum, deeply constricted at the septum, cell above septum longer and wider than below cell ascospores.

Pseudomassarina clematidis Phukhams, Camporesi \& K.D. Hyde, in Phukhamsakda et al., Fungal Diversity 102: 101 (2020).

Fig. 140

Index Fungorum number: IF 557098; Facesoffungi number: FoF 07214.

Description - see Phukhamsakda et al. (2020).

Material examined - Italy, Forlì-Cesena Province, Fiumicello-Premilcuore, on dead aerial branch of Clematis vitalba, 20 March 2016, E. Camporesi, IT 2335 (MFLU 16-0493, holotype).

\section{Ecological and economic significance}

Species of Pseudomassarinaceae can be found associated with climbing dicotyledonous plants such as Clematis vitalba. Currently, the family was recorded as saprobe from Europe country.

Pseudopyrenochaetaceae Valenz.-Lopez, Crous, Stchigel, Guarro \& Cano, Stud. Mycol. 90: 52 (2017).

Index Fungorum number: IF 820426; Facesoffungi number: FoF 08352, 2 species.

Plant pathogen, parasitic on roots. Sexual morph: Undetermined. Asexual morph: Coelomycetous. Conidiomata pycnidial, solitary, setose, globose to subglobose, brown to dark 
brown, papillate, ostiolate. Conidiophores simple, filiform, septate. Conidiogenous cells phialidic, intercalary, disposed along the conidiophores as short side projections. Conidia cylindrical to allantoid, hyaline, aseptate, smooth- and thin-walled.

Type - Pseudopyrenochaeta Valenz.-Lopez, Crous, Stchigel, Guarro \& Cano

Notes - In the phylogenetic analysis of Valenzuela-Lopez et al. (2018), the type species of Pyrenochaeta ( $P$. nobilis) was distant from Cucurbitariaceae and did not group with strains of Pyrenochaeta lycopersici and P. terrestris. Therefore, Valenzuela-Lopez et al. (2018) treated Pyrenochaeta nobilis as species incertae sedis and transferred P. lycopersici and P. terrestris to the new genus Pseudopyrenochaeta. They also introduced Pseudopyrenochaetaceae to accommodate Pseudopyrenochaeta (Valenzuela-Lopez et al. 2018).

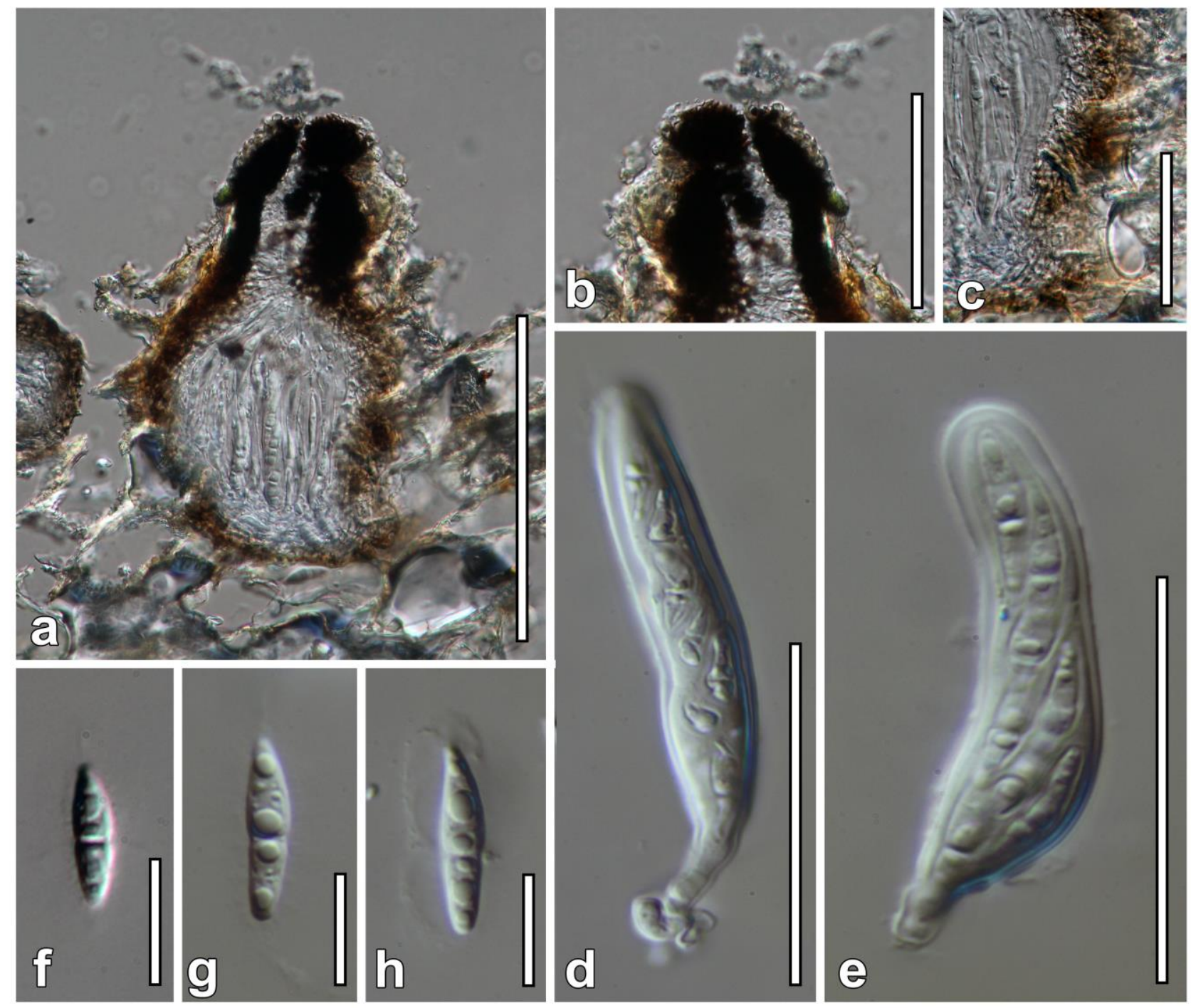

Figure 140 - Pseudomassarina clematidis (MFLU 16-0493, holotype). a Ascoma. b Ostiole canal. c Peridium. d, e Asci. f-h Ascospores. Scale bars: $\mathrm{a}=100 \mu \mathrm{m}, \mathrm{b}-\mathrm{e}=50 \mu \mathrm{m}, \mathrm{f}-\mathrm{h}=10 \mu \mathrm{m}$.

Pseudopyrenochaeta Valenz.-Lopez, Crous, Stchigel, Guarro \& Cano, in Valenzuela-Lopez et al., Stud. Mycol. 90: 53 (2017).

Index Fungorum number: IF 820427; Facesoffungi number: FoF 08353; 2 morphological species (Species Fungorum 2020), 2 species with molecular data.

Type species - Pseudopyrenochaeta lycopersici (R.W. Schneid. \& Gerlach) Valenz.-Lopez, Crous, Stchigel, Guarro \& J.F. Cano. 
Notes - Pseudopyrenochaeta was introduced based on the phylogenetic analyses by Valenzuela-Lopez et al. (2018). The strain of the type species (CBS 306.65) was treated as Pyrenochaeta lycopersici and its phylogenetic placement was located in Cucurbitariaceae (de Gruyter et al. 2010). de Gruyter et al. (2013) placed it as incertae sedis. Valenzuela-Lopez et al. (2018) indicated that $P$. lycopersici forms a distinct lineage outside Cucurbitariaceae and as a new genus Pseudopyrenochaeta. They also introduced Pseudopyrenochaetaceae to accommodate this new genus.

Pseudopyrenochaeta lycopersici (R.W. Schneid. \& Gerlach) Valenz.-Lopez, Crous, Stchigel, Guarro \& J.F. Cano, in Valenzuela-Lopez et al., Stud. Mycol. 90: 53 (2017).

三 Pyrenochaeta lycopersici R.W. Schneid. \& Gerlach, Phytopath. Z. 56: 121 (1966).

Index Fungorum number: IF 820431; Facesoffungi number: FoF 08354.

Description - see Valenzuela-Lopez et al. (2018).
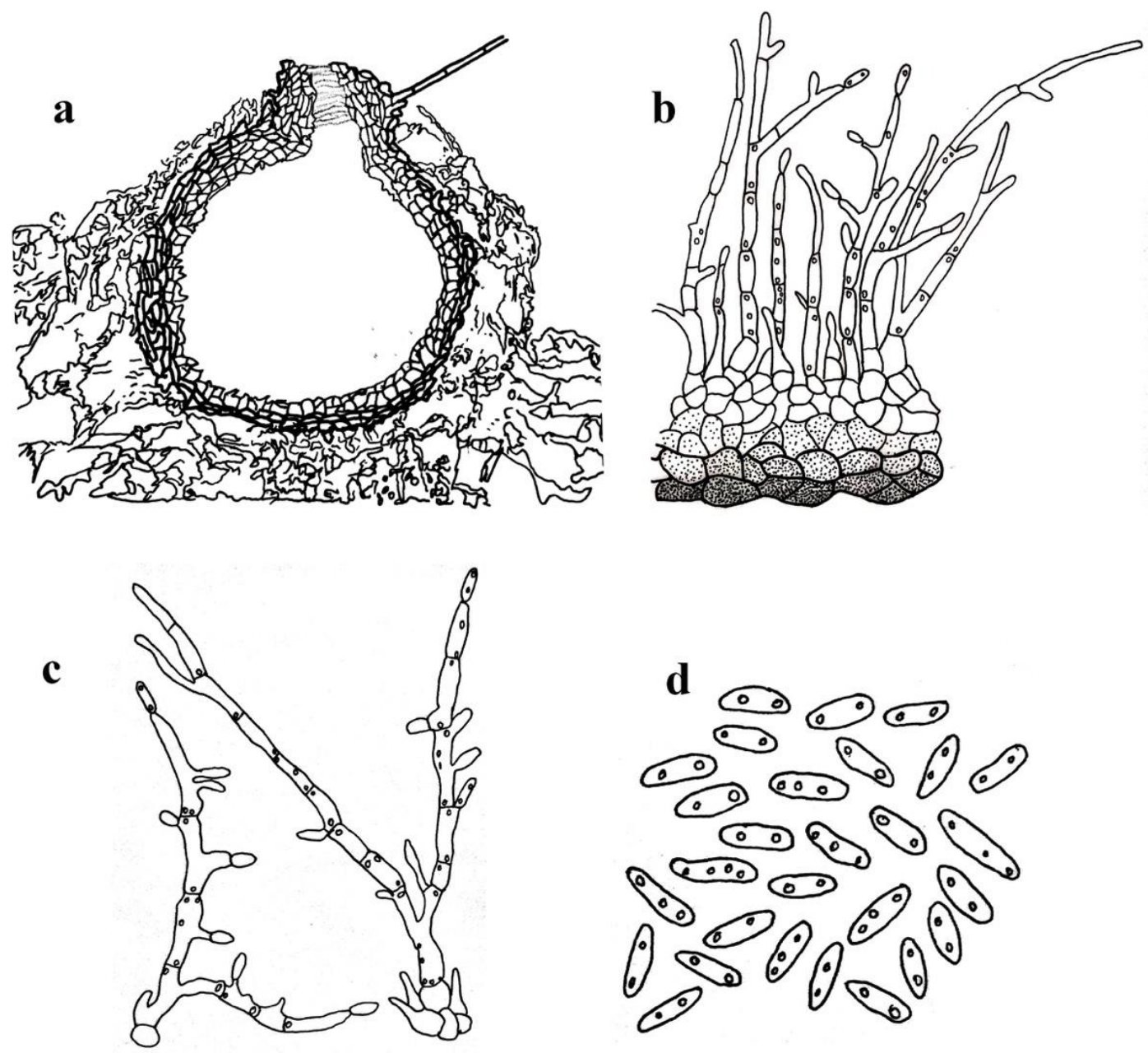

Figure 141 - Pseudopyrenochaeta lycopersici (redrawn from Pyrenochaeta lycopersici in Schneider and Gerlach 1966). a Conidiomata. b Conidiophores arising on inner layer of conidiomata. c Conidiogenous cells and conia on Conidiophores. $d$ Aseptate Conidia.

\section{Ecological and economic significance}

Member of this family are soil-borne fungal pathogens. Pseudopyrenochaeta lycopersici (= Pyrenochaeta lycopersici) causes significant yield losses in tomato crops (corky root disease on tomato, Aragona et al. 2014). It also infects pepper, eggplant and tobacco, melon, cucumber, spinach and safflower (Aragona et al. 2014). 
Pyrenochaetopsidaceae Valenz.-Lopez, Crous, Cano, Guarro \& Stchigel (2018).

Index Fungorum number: IF 820308; Facesoffungi number: FoF 08355, 17 species.

Saprobic or pathogenic on living/dead leaf or opportunistic human-pathogenic. Sexual morph: Undetermined. Asexual morph: Conidiomata subglobose to ovoid, pale brown to brown solitary or confluent, without papillate and ostiolar neck. Pycnidial wall composed of thin-walled cells of textura angularis. Conidiogenous cells phialidic, hyaline, discrete or integrated in septate, acropleurogenous conidiophores. Conidia ovoid, cylindrical to allantoid, hyaline, aseptate, guttulate with smooth-walled

Type - Pyrenochaetopsis Gruyter, Aveskamp \& Verkley.

Notes - Pyrenochaetopsidaceae was introduced by Valenzuela-Lopez et al. (2018) based on both morphology and phylogeny support. The sexual morph is unknown for this family (de Gruyter et al. 2010, 2013, Valenzuela-Lopez et al. 2018).

Pyrenochaetopsis Gruyter, Aveskamp \& Verkley, Mycologia 102(5): 1076 (2010).

Index Fungorum number: IF 514653; Facesoffungi numberi: FoF 08356; 15 morphological species (Species Fungorum 2020), 10 species with molecular data.

Type species - Pyrenochaetopsis leptospora (Sacc. \& Briard) Gruyter, Aveskamp \& Verkley

Notes - Pyrenochaetopsis was introduced to accommodate phoma-like species with setose pycnidia (de Gruyter et al. 2010). This genus is characterized by setose pycnidia which are similar to Pyrenochaeta based on phoma-like conidiogenesis but they are can distinguished by molecular data (de Gruyter et al. 2010). Previously, Pyrenochaetopsis was in Cucurbitariaceae (de Gruyter et al. 2010, 2013, Hyde et al. 2013). However, it was included in Pyrenochaetopsidaceae by Valenzuela-Lopez et al. (2018).

Pyrenochaetopsis leptospora (Sacc. \& Briard) Gruyter, Aveskamp \& Verkley (2010).

Fig. 142

三Pyrenochaeta leptospora Sacc. \& Briard, Revue mycol., Toulouse 11(no. 41): 16 (1889)

Index Fungorum number: IF 514654; Facesoffungi number: FoF 08357.

Description - see Valenzuela-Lopez et al. (2018).
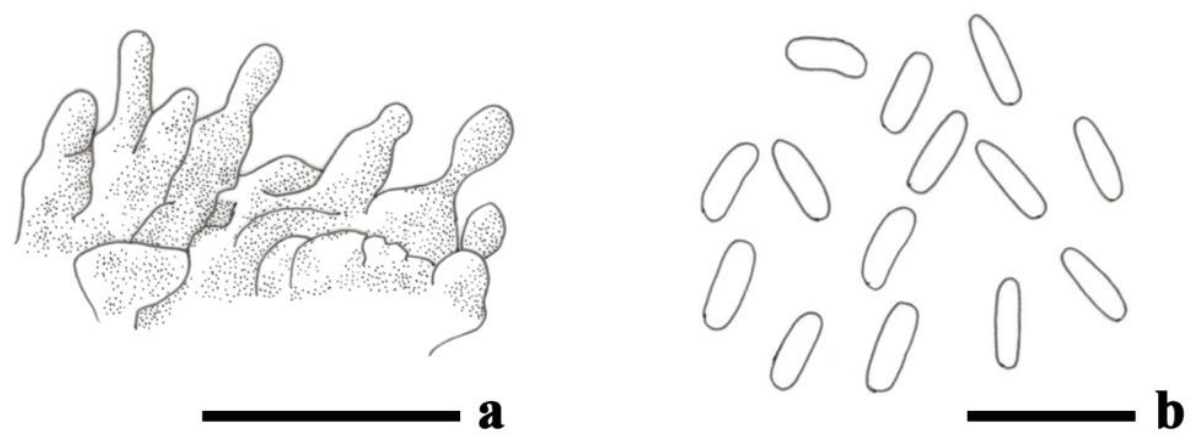

Figure 142 - Pyrenochaetopsis leptospora (redrawn from epitype CBS 101635 in ValenzuelaLopez et al. 2018). a Conidiogenous cells. $b$ Conidia. Scale bar: $a-b=10 \mu \mathrm{m}$.

\section{Other genera included}

Neopyrenochaetopsis Valenz-Lopez, Cano, Guarro \& Stchigel, Stud. Mycol. 90: 63 (2017).

Index Fungorum number: IF 820309; Facesoffungi number: FoF 08358; 1 species (Species Fungorum 2020), 1 species with molecular data.

Type species - Neopyrenochaetopsis hominis Valenz.-Lopez, Cano, Guarro \& Stchigel, Stud. Mycol. 90: 63 (2017).

Notes - This genus is characterised by brown, solitary or confluent, glabrous, subglobose to ovoid pycnidium, with ostiolate, wall comprises textura angularis cells, phialidic, ampulliform to globose conidiogenous cells, ovoid to cylindrical, aseptate, hyaline, smooth- and thin-walled conidia (Valenzuela-Lopez et al. 2018). Valenzuela-Lopez et al. (2018) introduced this genus in 
Pyrenochaetopsidaceae based on it being different from other taxa in the production of smallersized conidia, and a yellow diffusing pigment on MEA and OA. Phylogenetically, the only strain of this genus, CBS 143033 from a clinical sample, formed a distinct lineage at the base of Pyrenochaetopsidaceae (Valenzuela-Lopez et al. 2018, this study).

Xenopyrenochaetopsis Valenz.-Lopez, Crous, Stchigel, Guarro \& Cano, Stud. Mycol. 90: 62 (2017).

Index Fungorum number: IF 820311; Facesoffungi number: FoF 08359; 1 species (Species Fungorum 2020), 1 species with molecular data.

Type species - Xenopyrenochaetopsis pratorum (P.R. Johnst. \& Boerema) Valenz.-Lopez, Crous, Stchigel, Guarro \& Cano, Stud. Mycol. 90: 62 (2017).

$\equiv$ Phoma pratorum P.R. Johnst. \& Boerema, N.Z. J1 Bot. 19(4): 395 (1982).

Notes - Phylogenetically, Valenzuela-Lopez et al. (2018) indicated that Pyrenochaetopsis pratorum clustered outside Pyrenochaetopsis sensu stricto. Therefore, Xenopyrenochaetopsis was established to accommodate Xenopyrenochaetopsis pratorum (= Pyrenochaetopsis pratorum). Xenopyrenochaetopsis is characterized by pale brown to brown, solitary or confluent, glabrous, globose pycnidium, with ostiolate, wall comprises textura angularis cells, phialidic, hyaline conidiogenous cells, cylindrical, aseptate, hyaline, smooth- and thin-walled conidia, with guttulate (Valenzuela-Lopez et al. 2018).

\section{Ecological and economic significance}

The members of this family can be found in clinical specimens of humans such as blood, dermatitis, ear lesion, skin, sputum and toe nail and also from river and associated with leaf spot (Boerema et al. 2004, Crous et al. 2011b, Valenzuela-Lopez et al. 2018). They are also important for nutrient cycling as they are saprobic.

Roussoellaceae J.K. Liu, Phookamsak, D.Q. Dai \& K.D. Hyde, in Liu et al., Phytotaxa 181(1): 7 (2014).

Index Fungorum number: IF 804651; Facesoffungi number: FoF 08360, 73 species.

Saprobic on various hosts especially bamboo and palms or human pathogen. Sexual morph: Ascostromata solitary or gregarious, visible as raised, black, shiny to dull, rounded, dome-shaped to elongated linear, occasionally covered by black, dirt elements, sparse on host surface, immersed to semi-immersed, uni- to multi-loculate, glabrous ostiolate, papillate. Locules immersed in a clypeus, or erumpent through host tissue by black protruding papilla, subglobose to ampulliform, or domeshaped to wedge-shaped, or quadrilateral, with a flattened base, ostiole individually central, with intra-epidermal papilla, or somewhat erumpent through host tissue. Ascomata immersed to semiimmersed, solitary to gregarious, globose to subglobose, or ampulliform, glabrous to setose. Peridium composed of several layers of brown to dark brown pseudoparenchymatous cells, intermixed with the host tissue, arranged in textura angularis to textura prismatica. Hamathecium comprising dense, filiform, septate, branched, anastomosed, narrowly cellular pseudoparaphyses, embedded in a gelatinous matrix. Asci 8-spored, bitunicate, cylindrical to cylindric-clavate, or clavate, pedicellate, apically rounded, with well-developed ocular chamber. Ascospores overlapping 1-2-seriate, ellipsoidal to fusiform, septate, hyaline or brown to dark brown, constricted at the septum, smooth- to rough-walled, with poroid, reticulate, echinulate or striated ornamentation, surrounded by a wide mucilaginous sheath. Asexual morph: Coelomycetous, cytoplea-like, melanconiopsis-like, neomelanconium-like or cyclothyrium-like. Conidiomata pycnidial, stromatic, immersed under a clypeus to erumpent through host epidermis by minute papilla, globose to subglobose, or dome-shaped, dark brown to black, uni- to multi-loculate; locules separated by vertical columns of dark pigmented pseudoparenchyma. Pycnidial walls comprising several layers of brown to dark brown pseudoparenchymatous cells, arranged textura angularis. Conidiophores reduced to conidiogenous cells. Conidiogenous cells holoblastic, annellidic, discrete, hyaline, cylindrical to ampulliform, or doliform, unbranched, aseptate or septate, smooth, arising from the inner cavity of conidioma. Conidia globose, oblong or ellipsoidal, base obtuse to 
truncate, narrower towards the apex, hyaline to brown or dark brown, aseptate or septate, smoothto rough-walled, with minutely warty, or verrucose.

Type - Roussoella Sacc.

Notes - Roussoellaceae was introduced by Liu et al. (2014) and is typified by Roussoella with $R$. nitidula as the type species. The family was introduced to the Pleosporales, accommodating ascomycetous taxa having raised, black, dome-shaped to elongated linear ascostromata, with uni- to multi-loculate, immersed in a clypeus, cylindrical to clavate, bitunicate asci, with brown, 2-celled ornamented ascospores and forming coelomycetous asexual morph (Liu et al. 2014). Three genera were accommodated in this family viz. Neoroussoella, Roussoella and Roussoellopsis (Liu et al. 2014, Dai et al. 2017). Ariyawansa et al. (2015a) introduced a monotypic genus Elongatopedicellata in Roussoellaceae. Jaklitsch \& Voglmayr (2016) treated Roussoellaceae as a synonym of Thyridariaceae based on their phylogenetic results of a combined ITS, LSU, rpb-2, SSU and tef1 data matrix. However, the familial statement of Roussoellaceae is debatable due to the differences of morphological features coupled with multi-gene phylogeny (Tibpromma et al. 2017, Wanasinghe et al. 2018c, Jayasiri et al. 2019, Jiang et al. 2019, Karunarathna et al. 2019, Phookamsak et al. 2019). Wanasinghe et al. (2018c) introduced two novel genera, Pararoussoella and Pseudoneoconiothyrium to accommodate roussoella-like taxa in Thyridariaceae. However, Phookamsak et al. (2019) transferred these two genera to Roussoellaceae based on multi-gene phylogenetic analyses coupled with morphological characteristics. Mapook et al. (2020) introduced three more genera viz. Pseudoroussoella, Setoarthopyrenia and Xenoroussoella in Roussoellaceae. Based on morphological characteristics, Ariyawansa et al. (2014b) treated Appendispora in Roussoellaceae whereas Hyde et al. (2017) and Doilom et al. (2018) also treated Immotthia in Roussoellaceae. The coelomycetous genus Cytoplea has been reported as the asexual morph of Roussoella, however, there is no proven for the link between these two genera (Hyde et al. 1996, Liu et al. 2014). Therefore, Wijayawadene et al. (2014b) treated Cytoplea as a separated genus and accommodated Cytoplea in Roussoellaceae. Presently, 12 genera are accommodated in this family (Wijayawadene 2018, 2020, Phookamsak et al. 2019, Mapook et al. 2020).

Roussoella Sacc., Atti dell'Istituto Veneto Scienze, 6: 410 (1888).

Index Fungorum number: IF 4799; Facesoffungi number: FoF 01689; 33 morphological species (Mapook et al. 2020, Phukhamsakda et al. 2020, Species Fungorum 2020), 22 species with molecular data.

Type species. Roussoella nitidula Sacc. \& Paol., Atti Inst. Veneto Sci. lett., ed Arti, Sér. 6 6: 410 (1888).

Notes - Roussoella sensu stricto is characterized by uni- to multi-loculate ascostromata, immersed in a clypeus, visible as raised, black dome-shaped or elongate linear on host surface, bitunicate, cylindrical to subcylindrical asci, with brown, 2-celled ornamented ascospores and cytoplea-like asexual morph. The genus mainly occurs on bamboo and palms (Liu et al. 2014, Dai et al. 2017, Thambugala et al. 2017b, Jiang et al. 2019). Roussoella-like is polyphyletic, many genera were established to accommodate Roussoella sensu lato such as Neoroussoella, Pararoussoella and Pseudoroussoella (Liu et al. 2014, Wanasinghe et al. 2018c, Mapook et al. 2020). There are 43 species epithets of Roussoella in Species Fungorum (2020). However, some other species were synonymized under Neoroussoella, Pararoussoella and Pseudoroussoella in Roussoellaceae as well as transferring to other families based on multi-gene phylogeny coupled with morphology (Jaklitsch \& Voglmayr 2016, Crous et al. 2019b, Jayasiri et al. 2019, Phukhamsakda et al. 2020).

\section{Other genera included}

Appendispora K.D. Hyde, Sydowia 46(1): 29 (1994).

Index Fungorum number: IF 27283; Facesoffungi number: FoF 08361; 2 morphological species (Species Fungorum 2020), molecular data unavailable.

Type species - Appendispora frondicola K.D. Hyde, Sydowia 46(1): 30 (1994). 
Notes - Hyde (1994a) introduced a monotypic genus Appendispora to accommodate A. frondicola which was collected from dead rachis of Oncosperma horridum in Brunei. The genus is characterized by subglobose or irregularly, multi-loculate ascostromata, immersed in darkened pseudoclypeus, with minute ostiolar canel, cracked through host surface, 8-spored, fissitunicate, cylindrical, pedunculate, fissitunicate, with an ocular chamber and faint ring, embedded in hyaline, trabeculate pseudoparaphyses and brown, fusiform, 1-septate ascospores, with an irregular ridged ornamentation and narrow appendages at each end (Hyde 1994a, Ariyawansa et al. 2014b). Hyde (1994a) treated the genus in Didymosphaeriaceae and this was followed from many subsequent authors (Lumbsch \& Huhndorf 2010, Zhang et al. 2012b, Hyde et al. 2013). Ariyawansa et al. (2014) re-circumscribed the genus and treated Appendispora in Roussoellaceae due to its morphological characteristics fits well with the familial concept of Roussoellaceae. Many subsequent authors followed Ariyawansa et al. (2014b)'s treatment (Dai et al. 2017, Wijayawadene et al. 2017a, 2018, 2020, Jiang et al. 2019). However, phylogenetic affinity of the genus is unresolved due to the lack of molecular data for the generic type.

Cytoplea Bizz. \& Sacc., in Bizzozero, Atti Inst. Veneto Sci. lett., ed Arti, Sér. 6 3: 307 (1885).

Index Fungorum number: IF 7902; Facesoffungi number: FoF 01788; 17 morphological species (Species Fungorum 2020), 1 species with molecular data.

Type species - Cytoplea arundinicola Bizz. \& Sacc., in Bizzozero, Atti Inst. Veneto Sci. lett., ed Arti, Sér. 6 3: 307 (1885).

Notes - The genus Cytoplea was introduced by Bizzozero (1885) to accommodate the coelomycetous asexual morph, which is characterized by superficial, pulvinate, confluent, effuse shell-like, multi-loculate conidiostromata, with more than five locules, distinctly minute euboid, olive-fuligineum, ovoid-oblong, continuous conidia, initially subcatenulate, stipitate, with filiform paraphyses (Bizzozero 1885). The genus was reported as asexual morph of Roussoella when Hyde et al. (1996) obtained cytoplea-like asexual morph on the living culture of Roussoella hysterioides and was introduced as Cytoplea hysterioides. However, the species is regarded as a synonym of Roussoella hysterioides (Species Fungorum 2020). The treatment provided by Hyde et al. (1996) was accepted from subsequent authors (Hyde 1997, Kang et al. 1998, Verkley et al. 2004). However, the congeneric status of Cytoplea and Roussoella is questionable due to the type species, Cytoplea arundinicola lacks molecular data to confirm the phylogenetic affinity. Liu et al. (2014) mentioned that Cytoplea was a possible synonym of Roussoella, however, the connection of these two genera must be confirmed based on molecular data. Thus, Wijayawardene et al. (2014b) treated these two genera as a separated genus pending further studies. Cytoplea hederae strain CBS 359.68 was obtained the ITS and LSU sequence data by Vu et al. (2019) and the NCBI BLASTn search shows that this strain is closely related to Melanconium hedericola (Melanconidaceae Diaporthales). However, the strain CBS 359.68 is not the type strain and C. hederae is not the type species of Cytoplea. Thus, we tentative place the genus Cytoplea in Roussoellaceae pending further studies.

Elongatopedicellata Jin F. Zhang, Jian K. Liu, K.D. Hyde \& Zi Y. Liu, Fungal Divers. 75: 118 (2015).

Index Fungorum number: IF 551484; Facesoffungi number: FoF 00959; 1 morphological species (Species Fungorum 2020), 1 species with molecular data.

Type species - Elongatopedicellata lignicola Jin F. Zhang, Jian K. Liu, K.D. Hyde \& Zi Y. Liu, in Ariyawansa et al., Fungal Divers. 75: 118 (2015).

Notes - A monotypic genus Elongatopedicellata was introduced by Ariyawansa et al. (2015a) to accommodate an ascomycetous taxon having immersed to erumpent, subglobose to obpyriform, coriaceous ascomata, with long ostiolar neck, bitunicate, clavate asci, with a long pedicellate and hyaline, fusiform, 1-septate ascospores, surrounded by a distinct mucilaginous sheath (Ariyawansa et al. 2015a). Asexual morph of this genus is undetermined. The genus was found as a saprobe on dead branch in northern Thailand. Only two sequence data are available in GenBank (KX421368, KX421369) for this genus. Phylogenetically, Phookamsak et al. (2019) used 
ITS, LSU, and tef1 in their analyses of taxa in Roussoellaceae and showed that this genus formed at the basal of Roussoellaceae as in (Ariyawansa et al. 2015a). However, we included SSU of Elongatopedicellata in our analyses (Fig. 42) and found that this genus is unstable. However, we retain this genus in Roussoellaceae but note that more collection, analyses of sequence data, and more gene regions are needed to clarify its placement.

Immotthia M.E. Barr, Mycotaxon 29: 504 (1987).

Index Fungorum number: IF 25106; Facesoffungi number: FoF 08362; 2 morphological species (Species Fungorum 2020), molecular data unavailable.

Type species - Immotthia hypoxylon (Ellis \& Everh.) M.E. Barr, Mycotaxon 29: 504 (1987).

三Amphisphaeria hypoxylon Ellis \& Everh., J. Mycol. 2(4): 41 (1886).

Current name: Immotthia atrograna (Cooke \& Ellis) M.E. Barr, Mycotaxon 46: 71 (1993).

Notes - Barr (1987) introduced the monotypic genus Immotthia to accommodate a hyperparasitic ascomycete, Amphisphaeria hypoxylon as Immotthia hypoxylon occurring on Hypoxylon species, or forms compressed ascostromata on decorticated wood. The genus is characterized by small to medium sized, globose to subglobose ascomata on blackened hypostroma, with unequal thickness peridium, fissitunicate, cylindrical asci, 1-seriate, brown to reddish brown, ellipsoidal to fusiform, 1-septate ascospores and coelomycetous asexual morph, with brown, ellipsoidal, aseptate conidia (Hyde et al. 2017). Immotthia was previously treated in Dacampiaceae and Teichosporaceae (Barr 1987a, 2002, Jaklitsch \& Scheuer 2002, Zhang et al. 2012b, Akulov \& Hayova 2016). However, Hyde et al. (2017) studied the type specimen and other collection of $I$. hypoxylon (三Amphisphaeria hypoxylon) and treated the genus in Roussoellaceae and this was followed by Doilom et al. (2018). However, the phylogenetic affinity of this genus needs to be confirmed with molecular data of the type species.

Neoroussoella Jian K. Liu, Phookamsak \& K.D. Hyde, Phytotaxa 181(1): 21 (2014).

Index Fungorum number: IF 550668; Facesoffungi number: FoF 08363; 7 morphological species (Phukhamsakda et al. 2020, Species Fungorum 2020, Yuan et al. 2020), 7 species with molecular data.

Type species - Neoroussoella bambusae Phookamsak, Jian K. Liu \& K.D. Hyde, Phytotaxa 181(1): 23 (2014).

Notes - Liu et al. (2014) introduced Neoroussoella to accommodate a saprobic roussoellalike taxon, collected from dead branch of Bambusa sp. in northern Thailand. The genus can be distinguished from Roussoella in having uni-locolate ascomata and its coelomycetous asexual morph forming hyaline to pale brown, smooth-walled conidia (Liu et al. 2014, Jayasiri et al. 2019, Karunarathna et al. 2019). Phookamsak et al. (2019) introduced $N$. heveae based on multi-gene phylogeny with moderate support, although, the morphological features of this species do not fitwell with Neoroussoella. Meanwhile, Karunarathna et al. (2019) introduced N. alishanense, collected from Pennisetum purpureum Schumach. and bamboo (Poaceae) in Taiwan and Thailand. In their analysis, $N$. heveae clustered with Pararoussoella (Karunarathna et al. 2019). This species needs to be revisited.

Pararoussoella Wanas., E.B.G. Jones \& K.D. Hyde, Fungal Divers. 89: 169 (2018).

Index Fungorum number: IF 554218; Facesoffungi number: FoF 04056; 3 morphological species (Species Fungorum 2020), 3 species with molecular data.

Type species - Pararoussoella rosarum Wanas., E.B.G. Jones \& K.D. Hyde, in Wanasinghe et al., Fungal Divers. 89: 171 (2018).

Notes - Wanasinghe et al. (2018c) introduced Pararoussoella as a monotypic genus in Thyridariaceae to accommodate a roussoella-like taxon which having solitary, immersed, subglobose to ampulliform ascomata, bitunicate, cylindrical asci, and dark brown, ellipsoidal, 1septate ascospores, with longitudinal striations. The coelomycetous asexual morph was reported by Crous et al. (2019b) based on P. juglandicola characterized by globose, brown, pycnidial 
conidiomata, phialidic conidiogenous cells, with periclinal thickening at apex and hyaline to brown, subcylindrical, aseptate conidia. Phookamsak et al. (2019) transferred this genus to Roussoellaceae.

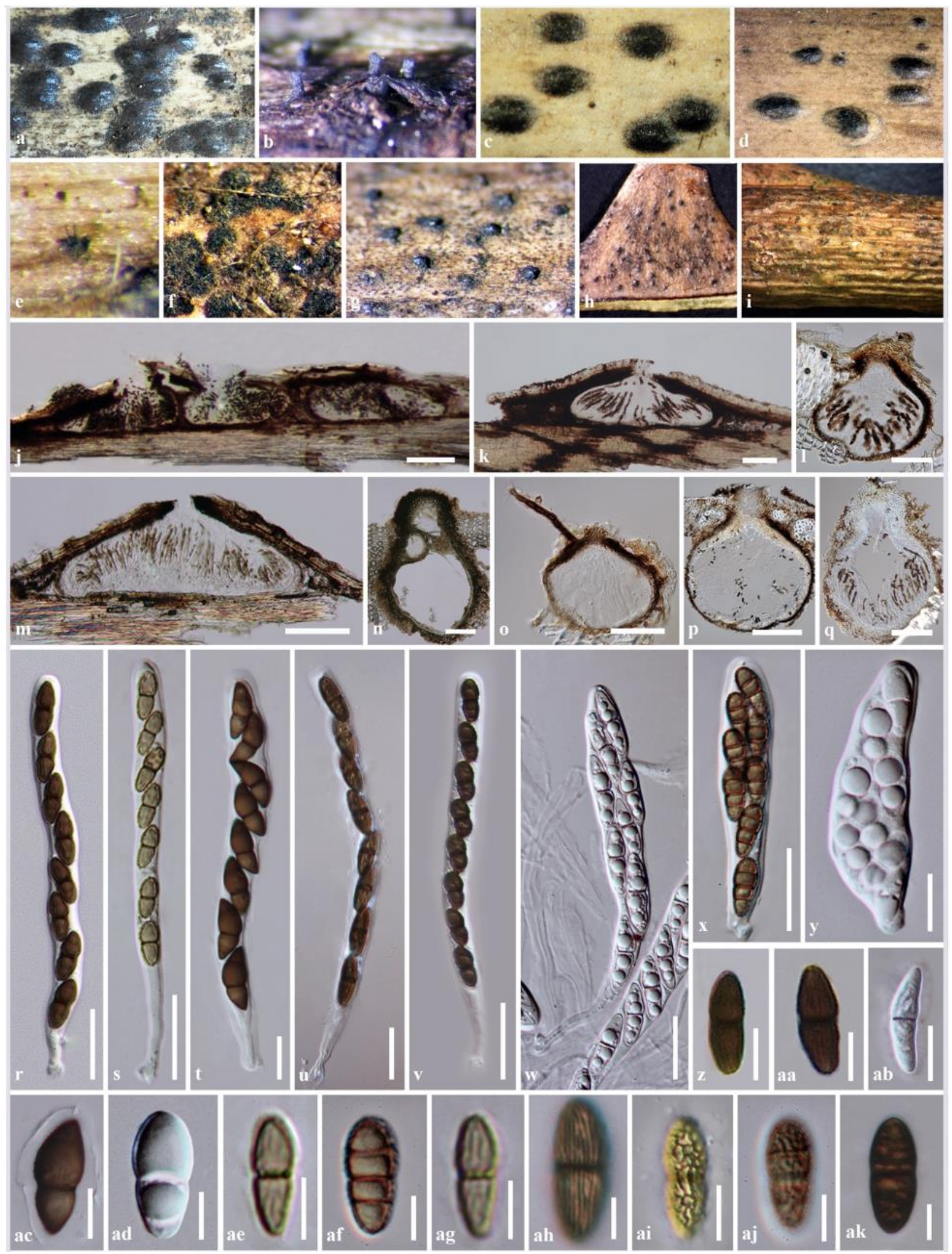

Figure 143 - Morphological characteristics of the sexual morphs of genera in Roussoellaceae. $\mathrm{a}-\mathrm{i}$ Appearance of ascostromata and ascomata on the host surface. $\mathrm{j}, \mathrm{k}, \mathrm{m}$ Ascostromata with uni- to multi-loculate. 1, n-q Ascomata. $r-y$ Asci. z-ak Ascospores. Scale bars: j, $k=200 \mu \mathrm{m}, \mathrm{m}, \mathrm{p}, \mathrm{q}=$ $100 \mu \mathrm{m}, 1, \mathrm{n}, \mathrm{o}=50 \mu \mathrm{m}, \mathrm{r}-\mathrm{x}=20 \mu \mathrm{m}, \mathrm{y}, \mathrm{z}, \mathrm{aa}, \mathrm{ab}, \mathrm{ac}=10 \mu \mathrm{m}, \mathrm{ad}-\mathrm{ak}=5 \mu \mathrm{m}$. 

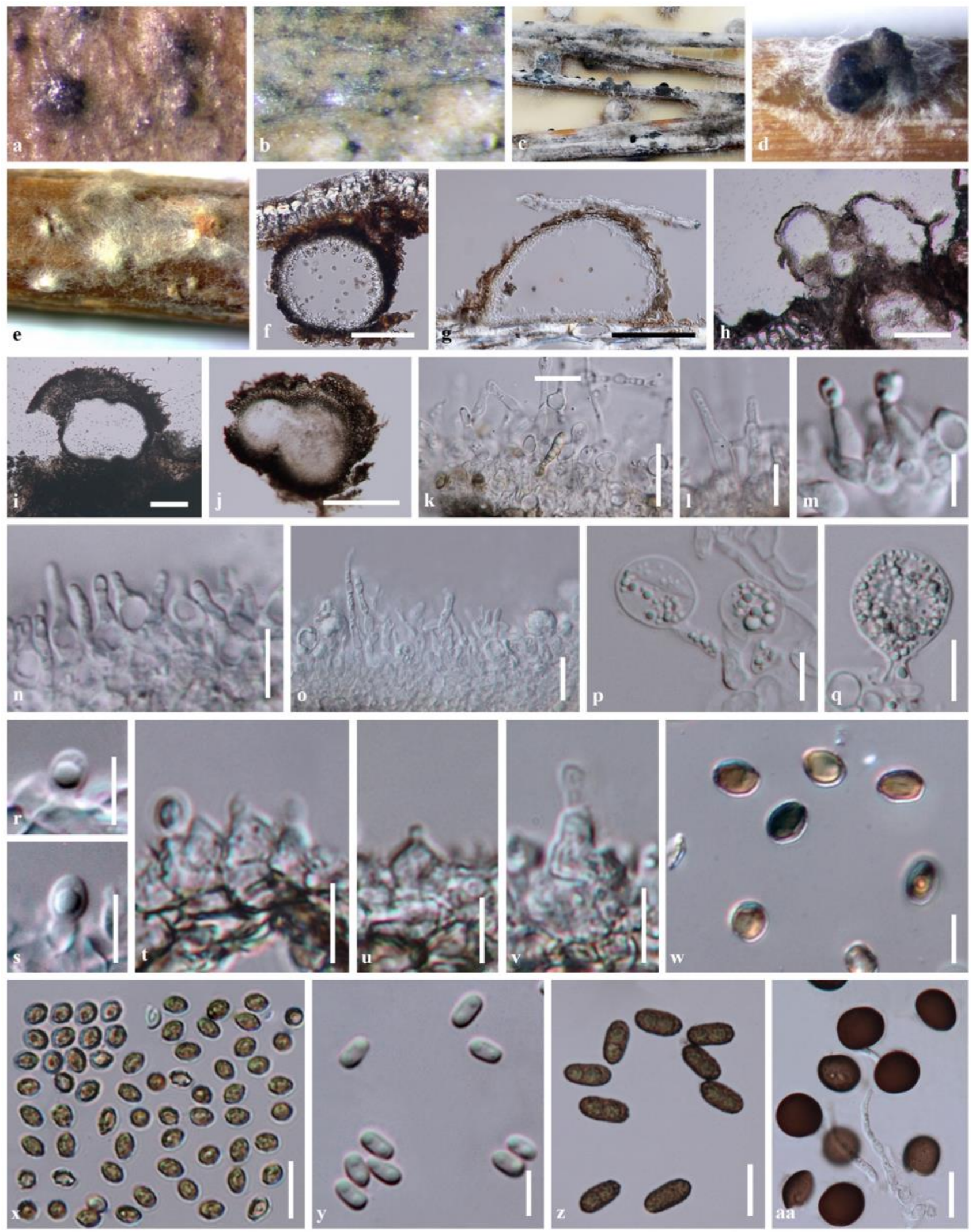

Figure 144 - Morphological characteristics of the asexual morphs of genera in Roussoellaceae. a, b Appearance of conidiomata on the host surface. $c-e$ Conidiomata forming on bamboo pieces. $f-j$ Section of conidiomata. $k-v$ Conidiogenous cells. $w-a a$ Conidia. Scale bars: $h-j=200 \mu \mathrm{m}, \mathrm{g}=100$ $\mu \mathrm{m}, \mathrm{f}=50 \mu \mathrm{m}, \mathrm{o}, \mathrm{aa}=20 \mu \mathrm{m}, \mathrm{k}, \mathrm{n}, \mathrm{p}, \mathrm{q}, \mathrm{x}, \mathrm{z}=10 \mu \mathrm{m}, \mathrm{l}, \mathrm{m}, \mathrm{r}-\mathrm{w}, \mathrm{y}=5 \mu \mathrm{m}$.

Pseudoneoconiothyrium Wanas., Phukhams., Camporesi \& K.D. Hyde, Index Fungorum 357: 1 (2018). 
Index Fungorum number: IF 554388; Facesoffungi number: FoF 04054; 1 morphological species (Species Fungorum 2020), 1 species with molecular data.

Replaced synonym: Neoconiothyrium Wanas., Phukhams., Camporesi \& K.D. Hyde, in Wanasinghe et al., Fungal Divers. 89: 165 (2018).

Type species - Pseudoneoconiothyrium rosae (Phukhams., Camporesi \& K.D. Hyde) Phukhams., Camporesi \& K.D. Hyde, Index Fungorum 357: 1 (2018).

$\equiv$ Neoconiothyrium rosae Phukhams., Camporesi \& K.D. Hyde, Fungal Divers. 89 (2018).

Notes - A monotypic genus Pseudoneoconiothyrium was introduced by Wanasinghe et al. (2018c) [as Neoconiothyrium Wanas. et al.] to accommodate coniothyrium-like taxon. The genus was found as a saprobe occurring on dead spines of Rosa canina (Rosaceae) in Italy and is characterized by stromatic, pycidial, immersed to semi-immersed, globose to subglobose conidiomata, broadly ampulliform, holoblastic, annellidic conidiogenous cells, with several distinct percurrent proliferations and subglobose to ellipsoidal, golden-brown to orange-brown, aseptate, rough-walled conidia (Wanasinghe et al. 2018c). The sexual morph is unknown for this genus. Phookamsak et al. (2019) transferred this genus to Roussoellaceae based on multi-gene phylogeny and this is in agreement with Jiang et al. (2019) and Karunarathna et al. (2019).

Pseudoroussoella Mapook \& K.D. Hyde, Fungal Divers 101: 88 (2020).

Index Fungorum number: IF 557351; Facesoffungi number: FoF 07818; 2 morphological species (Mapook et al. 2020), with molecular data.

Type species - Pseudoroussoella elaeicola (Konta \& K.D. Hyde) Mapook \& K.D. Hyde, Fungal Divers 101: 88 (2020).

三 Roussoella elaeicola Konta. \& K.D. Hyde, in Phookamsak et al., Fungal Diversity 95: 69 (2019).

Notes - Pseudoroussoella was introduced by Mapook et al. (2020) to accommodate roussoella-like taxa having immersed to erumpent, globose to subglobose, coriaceous, uni-loculate ascomata, with protruding ostiolar neck, bitunicate, cylindrical asci, and yellowish brown to dark brown, oval to ellipsoidal, 1-septate ascospores, rough-walled with reticulate ornamentation (Phookamsak et al. 2019, Mapook et al. 2020). Pseudoroussoella has coniothyrium-like asexual morph, which is characterized by semi-immersed to superficial, globose to obpyriform, uniloculate, papillate conidiomata, holoblastic, ampulliform to oblong, hyaline, unbranched conidiogenous cells and oblong to oval, pale brown to yellowish brown, or reddish brown, aseptate, veruculose conidia (Mapook et al. 2020).

Roussoellopsis I. Hino \& Katum., J. Jap. Bot. 40: 86 (1965).

Index Fungorum number: IF 4800; Facesoffungi number: FoF 01778; 3 morphological species (Species Fungorum 2020), 2 species with molecular data.

Type species - Roussoellopsis japonica (I. Hino \& Katum.) I. Hino \& Katum., J. Jap. Bot. 40: 86 (1965).

$\equiv$ Didymosphaeria japonica I. Hino \& Katum., Bull. Faculty of Agriculture, Yamaguchi University 5: 229 (1954).

Notes - Phookamsak et al. (2014b) designated the epitype specimen and obtained the molecular data for Roussoellopsis macrospora. Meanwhile, Liu et al. (2014) accepted the genus in Roussoellaceae based on molecular phylogeny of representative species, $R$. macrospora and $R$. tosaensis. Roussoellopsis often forms a distinct clade, close to Roussoella sensu lato (Liu et al. 2014, Phookamsak et al. 2014b, 2019, Dai et al. 2017, Jiang et al. 2019, Karunarathna et al. 2019). However, the genus can be distinguished from Roussoella in having cylindric-clavate to clavate asci, with trabeculate pseudoparaphyses, pale yellowish to dark brown, fusiform, with acute ends 1septate, rough-walled with echinulate, or longitudinal striations ascospores and forming melanconiopsis-like or neomelanconium-like asexual morph (Liu et al. 2014, Phookamsak et al. 2014b). More taxon sampling and molecular data for the type species are required for a better understanding of the natural placement of this genus. 
Setoarthopyrenia Mapook \& K.D. Hyde, Fungal Divers 101: 92 (2020).

Index Fungorum number: IF557361; Facesoffungi number: FoF 07820; 1 morphological species (Mapook et al. 2020), with molecular data.

Type species - Setoarthopyrenia chromolaenae Mapook \& K.D. Hyde, Fungal Divers 101: 92 (2020).

Notes - A monotypic genus Setoarthopyrenia was introduced by Mapook et al. (2020) to accommodate the sexual morph taxon forming solitary, semi-immersed, globose to subglobose, ascomata, with setae near the papilla, bitunicate, cylindric-clavate to obclavate asci and hyaline, fusiform, 1-septate ascospores. The genus was found as a saprobe on dead stem of Chromolaena odorata (Asteraceae) in Thailand. The asexual morph of Setoarthopyrenia is unkown. Multi-gene phylogenetic analyses showed that the genus is closely related to Arthopyrenia sp. strain UTHSC: DI16-362 in Roussoellaceae (Mapook et al. 2020).

Xenoroussoella Mapook \& K.D. Hyde, Fungal Divers 101: 93 (2020).

Index Fungorum number: IF 557367; Facesoffungi number: FoF 07822; 1 morphological species (Mapook et al. 2020), with molecular data.

Type species - Xenoroussoella triseptata Mapook \& K.D. Hyde, Fungal Divers 101: 94 (2020).

Notes - Xenoroussoella was introduced by Mapook et al. (2020) to accommodate a saprobic species which was collected from Chromolaena odorata in Thailand. The genus is characterized by immersed, solitary, globose to subglobose ascomata, with protruding ostiolar neck, cylindricclavate to clavate asci, and brown to dark brown, ellipsoid to obovoid, 3-septate ascospores (Mapook et al. 2020). The asexual morph of Xenoroussoella is unkown. The species can be distinguished from other genera of Roussoellaceae in having ellipsoid to obovoid, 3-septate ascospores (Mapook et al. 2020). Multi-gene phylogenetic analyses showed that the genus is closely related to Arthopyrenia sp. strain UTHSC: DI16-334 in Roussoellaceae (Mapook et al. 2020).

\section{Ecological and economic significance}

Most species of Roussoellaceae were found as saprobes mostly on bamboo and palms (Liu et al. 2014, Phookamsak et al. 2014b, 2019, Dai et al. 2017, Jiang et al. 2019). Some other species have also been reported from grasses, shrubs and dead wood in both terrestrial and aquatic environments (Fallah \& Shearer 2001, Ariyawansa et al. 2015a, Tibpromma et al. 2017b, Hyde et al. 2018, Wanasinghe et al. 2018c, Crous et al. 2018b, 2019b, Karunarathna et al. 2019, Phookamsak et al. 2019). Some species in Roussoellaceae have also been reported as human pathogens (Ahmed et al. 2014a, Almagro-Molto et al. 2017, Mochizuki et al. 2017). Nevertheless, some species can produce the secondary metabolite compounds inhibit the phytopathogenic fungi or produced antimicrobial activities against bacteria (Takekawa et al. 2013, Ferreira et al. 2015, Honmura et al. 2015, Phukhamsakda et al. 2018b).

Salsugineaceae K.D. Hyde \& Tibpromma, Fungal Divers. 63: 227 (2013).

Index Fungorum number: IF 804579; Facesoffungi number: FoF 08364, 4 species.

Saprobic on decaying wood submerged in brackish waters in mangroves. Colonies dark brown to black pseudoclypeus, coriaceous or carbonaceous, comprising host cells and solitary. Sexual morph: Ascomata immersed, beneath a raised dark brown to black pseudoclypeus, coriaceous or carbonaceous, comprising host cells and dark fungal hyphae, solitary, in section subglobose to flask-shaped, or conical with a protruding papilla. Papilla conspicuous, central, coneshaped, brown to black, ostiolate. Peridium comprising a single layer of, light brown cells of textura porrecta. Hamathecium comprising numerous, filiform, branched, septate, hyaline, trabeculate pseudoparaphyses. Asci 8-spored, bitunicate, fissitunicate, cylindrical to cylindroclavate, with an apical apparatus, rounded, with an ocular chamber and ring. Ascospores 1seriate, obovoid, or broad ellipsoidal, symmetrical with rounded ends, or tapering toward sub-acute 
ends, hyaline, dark brown to black, 1-septate in centre or lower third cell, constricted at the septum, with colourless, germ pore at both ends or lacking, smooth-walled. Asexual morph: Undetermined.

Type - Salsuginea K.D. Hyde.

Notes - Salsugineaceae was introduced by Hyde et al. (2013) by using both morphology and phylogeny to support. The family can be found in wood submerged in mangroves (Hyde 1991, Alias \& Jones 2009). Hyde et al. (2013) and Wijayawardene et al. (2018) accepted two genera, Salsuginea and Acrocordiopsis in this family.
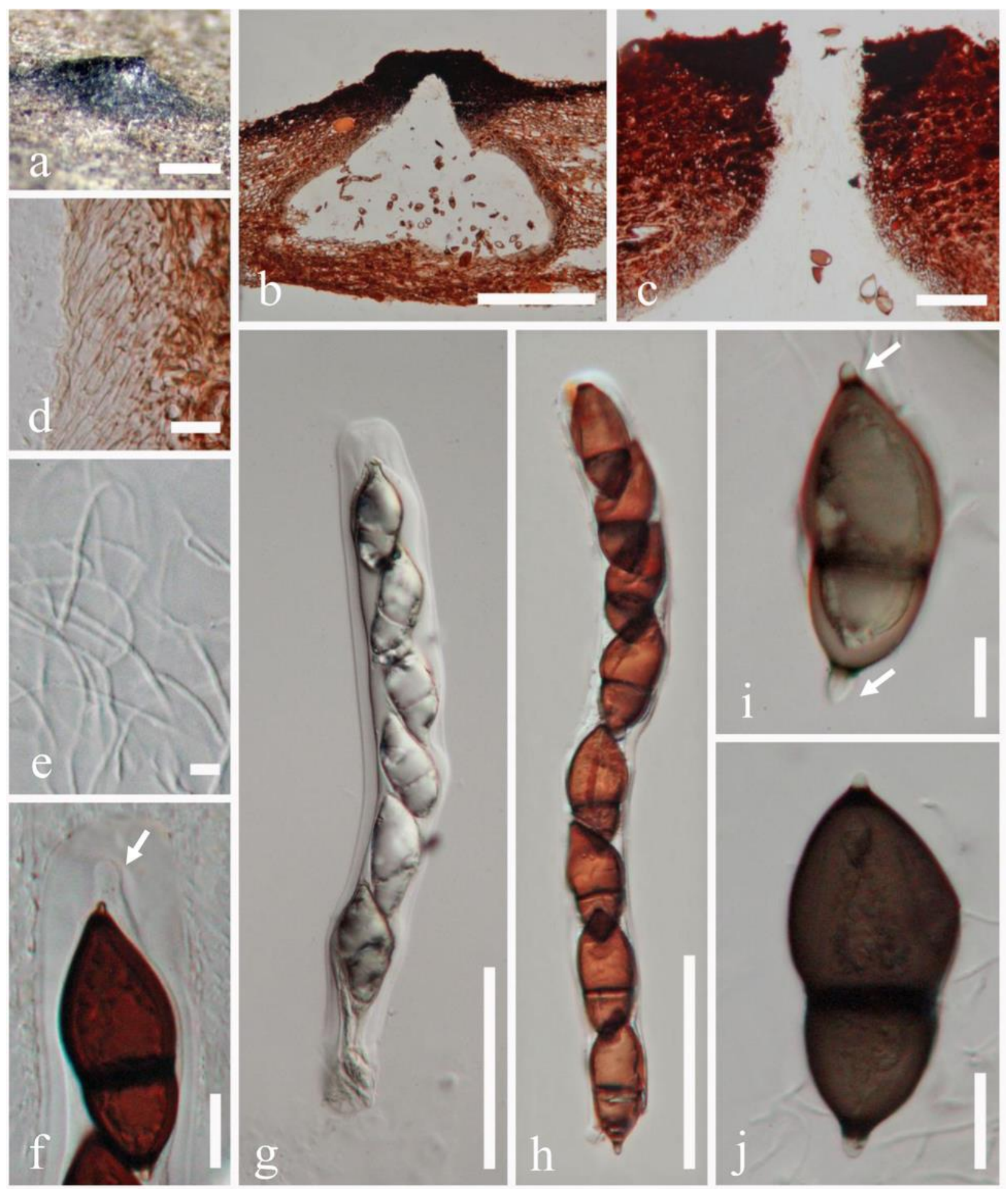

Figure 145 - Salsuginea ramicola (BRIP 17102a, holotype). a Appearance of psuedoclypeus on host substrate. b Section of ascomata. c Ostiolatec. d Section of peridium. e Pseudoparaphyses. f Ocular chamber. g, h Asci with ascospores. i, j Ascospores with apical germ pores. Scale bars: a, b $=500 \mu \mathrm{m}, \mathrm{c}=100 \mu \mathrm{m}, \mathrm{d}=20 \mu \mathrm{m}, \mathrm{e}=5 \mu \mathrm{m}, \mathrm{f}=20 \mu \mathrm{m}, \mathrm{g}, \mathrm{h}=100 \mu \mathrm{m}, \mathrm{i}, \mathrm{j}=20 \mu \mathrm{m}$. 
Salsuginea K.D. Hyde, Bot. Mar. 34(4): 315 (1991).

Index Fungorum number: IF 25680; Facesoffungi number: FoF 08365; 2 morphological species (Species Fungorum 2020), 2 species with molecular data.

Type species - Salsuginea ramicola K.D. Hyde.

Notes - Salsuginea typified by Salsuginea ramicola, was collected from submerged wood in mangroves. Salsuginea is similar to Helicascus but differs in having ascospores with apical germ pores/extensions and peridium of textura porrecta cells (Hyde 1991). Dayarathne et al. (2020) added another species, S. rhizophorae.

Salsuginea ramicola K.D. Hyde, Bot. Mar. 34(4): 316 (1991).

Fig. 145

Index Fungorum number: IF 354934; Facesoffungi number: FoF 08366.

Saprobic on decaying wood submerged in brackish waters in mangroves. Sexual morph: Ascomata 850-1100 $\times 320-400 \mu \mathrm{m}(\bar{x}=904 \times 354 \mu \mathrm{m}, \mathrm{n}=5)$, immersed, apical erumpent, solitary, subglobose to flask-shaped, smooth-walled, protruding papilla, conspicuous ostiole, dark to black. Ostiole central, cone-shaped, brown to black. Peridium 20-60 $\mu \mathrm{m}$ thick, comprising of light brown cells of textura porrecta, merging at the outside with the host, where textura angulata cells. Hamathecium comprising numerous, filiform, 2-3 $\mu \mathrm{m}$ wide, branched, septate, hyaline. Asci 300 $350 \times 20-30 \mu \mathrm{m}(\bar{x}=379 \times 27.3 \mu \mathrm{m}, \mathrm{n}=20), 8$-spored, fissitunicate, cylindrical-clavate, with an apical apparatus consisting of a large distinctive ocular chamber and prominent ring, sessile. Ascospores 60-75 $\times 20-30 \mu \mathrm{m}(\bar{x}=64 \times 26 \mu \mathrm{m}, \mathrm{n}=30)$, 1-seriate, obovoid, tapering toward subacute ends, brown, dark brown to black, 1-septate in lower third cell, constricted at the septa, colorless germ pore at each end, smooth walled. Asexual morph: Undetermined.

Material examined - Thailand, Ranong, $09^{\circ} 58^{\circ} \mathrm{N}, 098^{\circ} 37^{\circ} \mathrm{E}$, in mangrove, on submerged decaying wood of Aegiceras cornicelarum in brackish water, October 1988, K.D. Hyde, BRIP 17102a, holotype).

\section{Other genus included}

Acrocordiopsis Borse \& K.D. Hyde, Mycotaxon 34(2): 535 (1989).

Index Fungorum number: IF 25277; Facesoffungi number: FoF 00786; 2 morphological species (Species Fungorum 2020), 1 species with molecular data.

Type species - Acrocordiopsis patilii Borse \& K.D. Hyde, Mycotaxon 34(2): 536 (1989).

Notes - Acrocordiopsis was first collected from mangrove wood in Indian Ocean. In Acrocordiopsis the ascomata form a thin, black pseudostromata conical or semiglobose, superficial, carbonaceous on the host surface and cylindrical, bitunicate, 8-spored asci, with hyaline, 1-septate, obovoid or ellipsoid ascospores (Borse \& Hyde 1989, Alias \& Jones 2009). Jones et al. (2009b) assigned Acrocordiopsis to Melanommataceae based on morphological characters. Later, Jones \& Pang (2012) considered the phylogenetic placement of A. patilii as unresolved. In phylogenetic analyses of Hyde et al. (2013) Acrocordiopsis belonged to Salsugineaceae and also this genus shares few characteristics that unite into Salsugineaceae. Phylogenetic analysis of Zhang et al. (2018) indicated that A. patilii clustered with Astrosphaeriella and Astrosphaeriellopsis in an unsupported clade. However, this genus is placed in Salsugineaceae with note that new sequence data are required.

\section{Ecological and economic significance}

Salsugineaceae is a small family and its members are important for nutrient cycling as they are saprobic on a wide variety of plant substrates. On the other hand, Acrocordiopsis have been found as investigated for antimicrobial activity and potentially active secondary metabolites (Zainuddin et al. 2010)

Shiraiaceae Y.X. Liu, Zi Y. Liu \& K.D. Hyde, Phytotaxa 103(1): 53 (2013).

Index Fungorum number: IF 803884; Facesoffungi number: FoF 06202, 3 species.

Endophytic or parasitic on bamboo and wood. Sexual morph Ascostromata pinkish or dark brown to black, irregular, scattered, tuberculate, fleshy, easily peeling off host tissues without 
damage, multi-loculate. Locules immersed, arranged in a peripheral layer, subglobose or obpyriform, ostiolate. Peridium of locules comprising a single layer of light brown-walled cells or comprising several layers of thick-walled, brown to dark brown, heavily pigmented small cells of textura angularis. Hamathecium comprising relatively narrow, numerous, cellular pseudoparaphyses. Asci 6- or 8-spored, bitunicate, fissitunicate, cylindrical, with a pedicel and an ocular chamber. Ascospores 1-seriate or distichously arranged, fusiform, hyaline or brown, muriform. Asexual morph forming in young ascostromata. Asexual locules immersed, arranged in rows or irregularly arranged, subglobose to ampulliform, lining comprising thick-walled cells of textura angularis. Conidiophores reduced to conidiogenous cells, arising all around the basal region of the locules. Conidiogenous cells holoblastic, unbranched, discrete, indeterminate, cylindrical, septate, hyaline, smooth. Conidia fusiform, muriform, asymmetrical, hyaline to light brown, with irregularly arranged transverse and longitudinal septa, acute at base, apex obtuse, or obtuse at both ends, smooth- and thick-walled.

Type - Shiraia Henn.

Notes - This family was introduced by Liu et al. (2013) based on its unique morphological characteristics and the fact the family forms a distinct phylogenetic lineage from Phaeosphaeriaceae using LSU sequence data with high statistic support. The family contains three genera, Shiraia, Grandigallia, and Rubroshiraia (Hyde et al. 2013, Ariyawansa et al. 2013b, Dai et al. 2019). Because of lack of molecular evidence, Grandigallia is suggested to be included in the family based on morphological characteristics (Ariyawansa et al. 2013b).

Shiraia Henn., Bot. Jb. 28(3): 274 (1900).

Index Fungorum number: IF 5025; Facesoffungi number: FoF 06203, 1 morphological species (Species Fungorum 2020), 1 species with molecular data.

Type species - Shiraia bambusicola Henn.

Notes - This genus is distributed in China, Japan and Korea and prefers to live on bamboo (Liu et al. 2013, Farr \& Rossman 2019). The genus is economically important as a Chinese traditional medicine (Hyde et al. 2013, Liu et al. 2013). Shiraia is characterized by superficial, pinkish, fleshy, multi-loculate ascostromata forming near ends of host branches or near petiole bases, 6-spored, bitunicate, fissitunicate, cylindrical asci with a long pedicel and a distinct ocular chamber, and hyaline to light brown, fusiform, muriform, symmetrical ascospores for its sexual morph. Asexual morph is coelomycetous and is characterized by holoblastic conidiogenous cells bearing asymmetrical, hyaline to light brown, fusiform, muriform conidia with acute basal, obtuse apex, or both obtuse ends (Hyde et al. 2013, Liu et al. 2013).

Shiraia bambusicola Henn., Bot. Jb. 28(3): 274 (1900).

Figs 146, 147

Index Fungorum number: IF 158454; Facesoffungi number: FoF 06203.

Description - see Hyde et al. (2013).

\section{Other genera included}

Grandigallia M.E. Barr, Hanlin, Cedeño, Parra \& R. Hern., Mycotaxon 29: 196 (1987).

Index Fungorum number: IF 12090; Facesoffungi number: FoF 06204; 1 morphological species (Species Fungorum 2020), molecular data unavailable.

Type species - Grandigallia dictyospora M.E. Barr, Hanlin, Cedeño, Parra \& R. Hern., Mycotaxon 29: 196 (1987).

Notes - Grandigallia is similar to Shiraia in conspicuous stromatic tissue, papillate ostiole and muriform ascospores (Ariyawansa et al. 2013b). However, the genus differs in having black ascostromata and a Polylepis (Rosaceae) host (Hyde et al. 2013). Thus, the genus was placed in Shiraiaceae temporarily. Fresh samples of the genus are needed to and sequenced to confirm the position of Grandigallia in Pleosporales. 

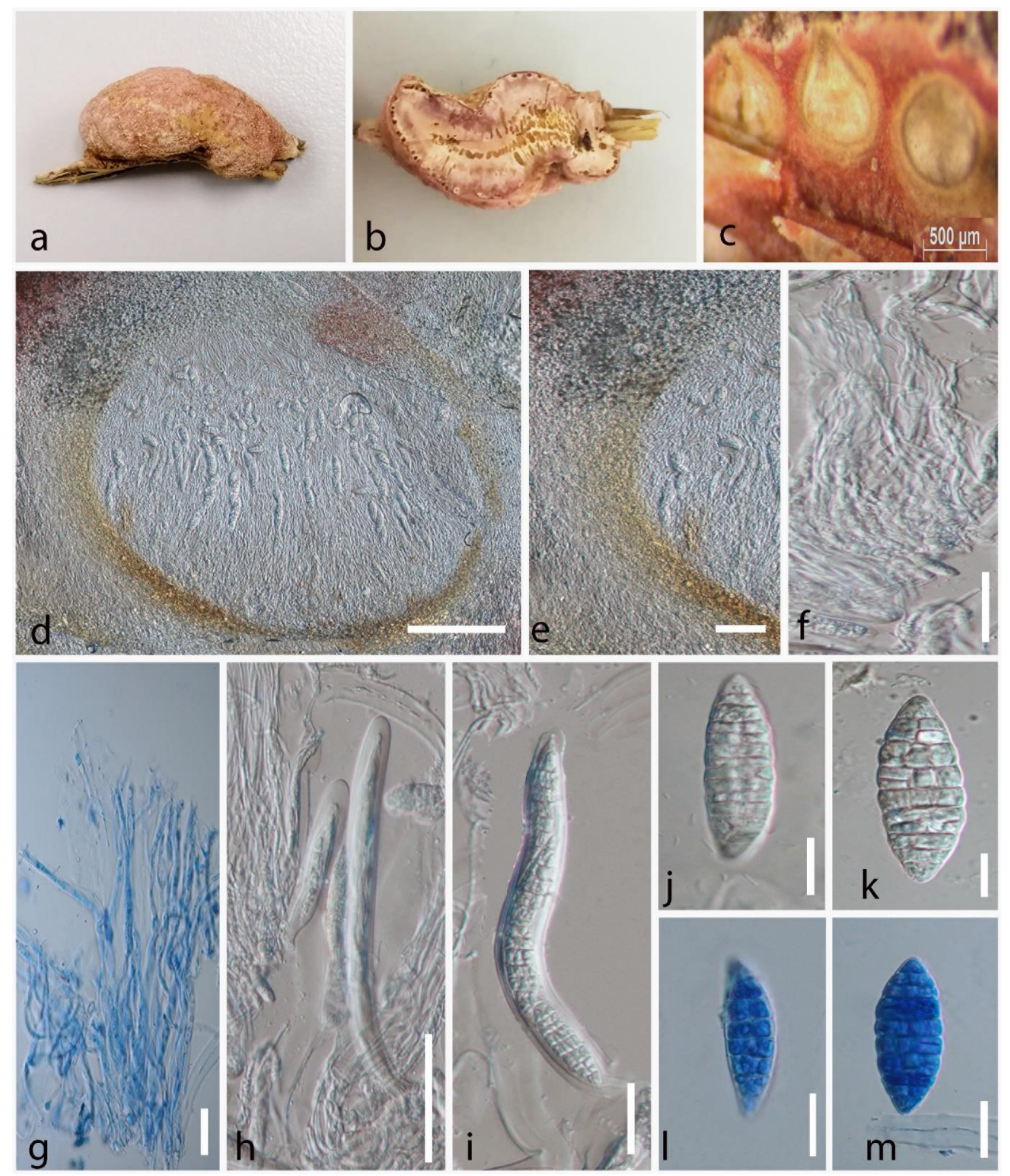

Figure 146 - Sexual morph of Shiraia bambusicola (MFLU 12-2041, epitype). a Ascostroma with yellow ascospore mass. b, c Cross section of ascostroma. d Vertical section of ascoma. e Wall of ascoma. f Pseudoparaphyses. g Pseudoparaphyses stained in cotton blue. h, i Asci. j, k Ascospores. $1, \mathrm{~m}$ Ascospores stained in cotton blue. Scale bars: $\mathrm{d}=300 \mu \mathrm{m}, \mathrm{e}-\mathrm{g}=50 \mu \mathrm{m}, \mathrm{h}, \mathrm{i}=100 \mu \mathrm{m}, \mathrm{j}-\mathrm{m}=$ $30 \mu \mathrm{m}$.

Rubroshiraia D.Q. Dai \& K.D. Hyde, MycoKeys 58: 14 (2019).

Index Fungorum number: IF 12090; Facesoffungi number: FoF 06204; 1 morphological species (Species Fungorum 2020), 1 species with molecular data.

Type species - Rubroshiraia bambusae D.Q. Dai \& K.D. Hyde, MycoKeys 58: 16 (2019). 

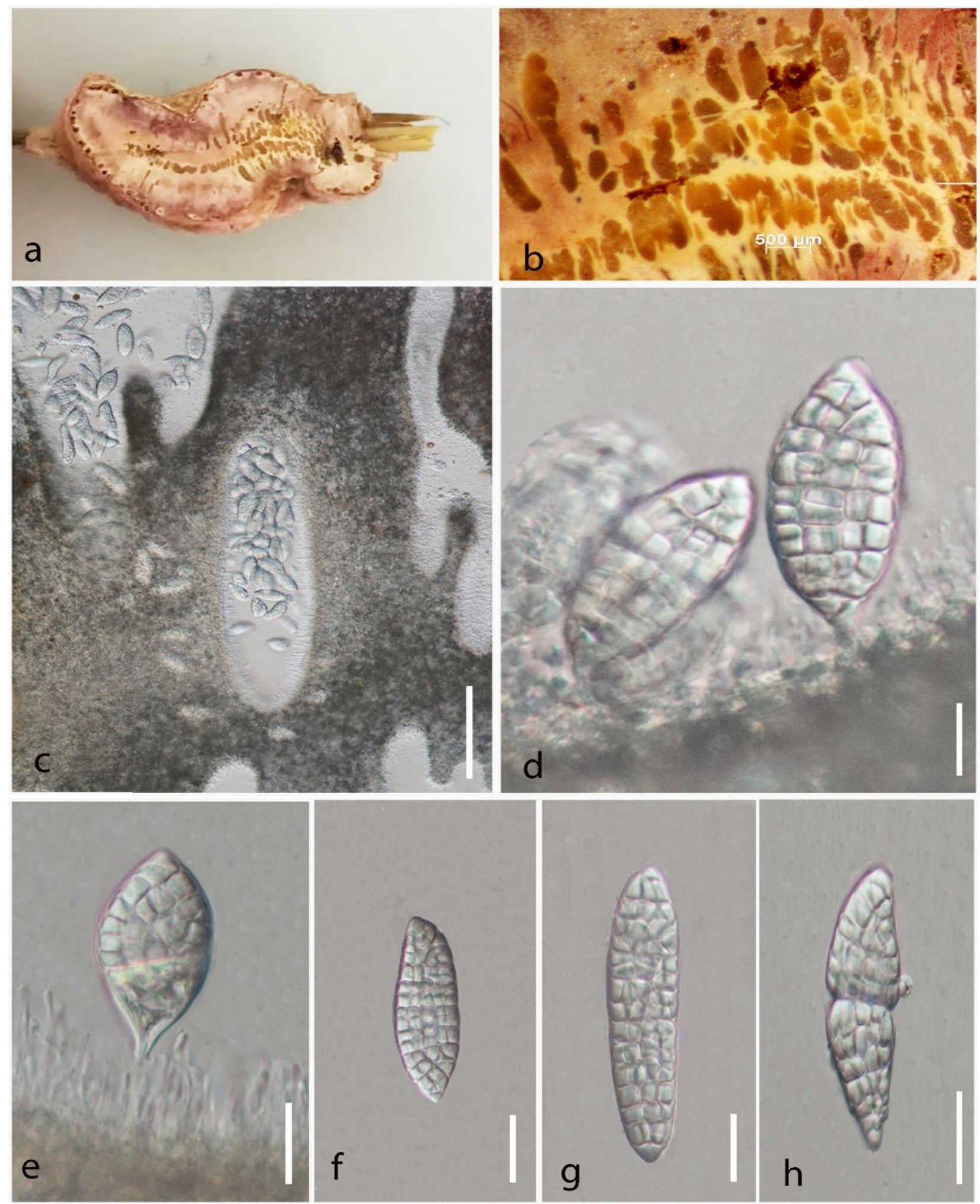

Figure 147 - Asexual morph of Shiraia bambusicola (MFLU 12-2041, epitype). a, b Horizontal section of conidiomata. c Vertical section of conidioma. $\mathrm{d}$, e Conidiogenesis cells and developing conidia. $\mathrm{f}-\mathrm{h}$ Conidia. Scale bars: $\mathrm{c}=100 \mu \mathrm{m}, \mathrm{d}-\mathrm{h}=30 \mu \mathrm{m}$.

Notes - Rubroshiraia was introduced by Dai et al. (2019) based on morphology and phylogeny. The genus has typical morphology of Shiraiaceae, which is large, dark red and fleshy ascostromata, parasitism on bamboo host and similar efficacy of medical treatment (Dai et al. 2019). However, it differs from Shiraia bambusicola in having smaller and darker ascostromata and filiform ascospores, spirally arranged in asci. Dai et al. (2019) provided molecular data of type 
species, and confirmed it phylogenetically close to Shiraia bambusicola. Production of the ascostromatal metabolites hypocrellin A and B were examined by Dai et al. (2019).

\section{Economic significance}

Ascostromata of Shiraia bambusicola are used as a traditional Chinese medicine and is of medicinal importance because of the metabolite hypocrellin, which has promising applications in photodynamic therapy (PDT) for anti-cancer treatments (Deininger et al. 2002, Miller et al. 2008, Yang et al. 2001, Zhang et al. 1998).

Sporomiaceae Munk, Dansk bot. Ark. 17 (no.1): 450 (1957).

Index Fungorum number: IF 81414; Facesoffungi number: FoF 06565, 164 species.

Saprobic on wood, plant debris, soil, dung and exceptionally endophytic on various substrates. Sexual morph: Ascomata immersed to erumpent or superficial, globose to pyriform, solitary or gregarious, scattered, perithecioid or cleistothecioid, ascolocular pseudothecia, dark pigmented, membraneous or coriaceous. Peridium smooth or hairy, dark-pigmented cells of textura angularis, outermost cells thick-walled. Hamathecium comprising abundant cellular pseudoparaphyses, lacking periphyses. Asci usually 8-spored, fissitunicate, J-, clavate, globose or cylindrical, usually with a pedicel, apical apparatus scarcely developed, non-refractive, with a narrow endotunica. Ascospores often partly overlapping inside the asci, 1-3-seriate, sometimes fasciculate or crowded, oval to cylindrical, dark brown, exceptionally one-celled, usually septate and poly-celled, muriform, thick-walled, smooth, exceptionally ornamented, constricted at septa and fragmenting into part-spores at maturity, often with germ slits, with or without surrounded by a mucilaginous sheath. Asexual morph: Coelomycetous. Conidiomata subglobose, immersed, dark brown. Pycnidial wall dark brown to light brown cells of textura angularis. Conidiophores reduced to conidiogenous cells. Conidiogenous cells enteroblastic, phialidic, hyaline, oblong to clavate. Conidia oblong, suboboviod, hyaline to brown, 1-transverse septum.

Type - Sporormia De Not.

Notes - Sporormiaceae was established by Munk (1957) with Sporormia as the type genus. The members of this family are known as saprobic on dung, plant debris, soil, wood or exceptionally endophytic (Hausmann et al. 2002, Burney et al. 2003, van Geel et al. 2003, Kruys \& Wedin 2009, Gonzalez-Menendez et al. 2017). Barr (1987b) synonymized Sporormiaceae under Phaeotrichaceae. However, Phaeotrichaceae was considered as members of Sordariales based on its unitunicate asci, thus the family status of Sporormiaceae was reinstated as an independent family. In Barr (2000), coprophilous bitunicate fungi were classified into three families based on their morphology; these are Delitschiaceae, Phaeotrichaceae and Sporormiaceae. The robust phylogenetic analyses confirmed that Delitschiaceae, Phaeotrichaceae and Sporormiaceae represent a distant relationship (Kruys et al. 2006, Schoch et al. 2009a, Liu et al. 2017a). Sporormiaceae comprises nine genera, Chaetopreussia, Forliomyces, Pleophragmia, Preussia, Sparticola, Sporormia, Sporormiella, Sporormurispora and Westerdykella.

Sporormia De Not., Micr. Ital. Novi 5: 10 (1845).

$\equiv$ Hormospora De Not., G. bot. ital. 2(1): 46 (1844).

Index Fungorum number: IF 5169; Facesoffungi number: FoF 06569; 28 morphological species (Species Fungorum 2020), 3 species with molecular data.

Type species - Sporormia fimetaria (Rabenh) De Not., Micr. Ital. Novi 5; 10 (1845).

三Sphaeria fimetaria Rabenh., Klotzschii Herb. Viv. Mycol., Edn 1: no. 1733 (1845).

Notes - Sporormia is coprophilous on dung of several animals in terrestrial habitats (Ahmed \& Asad 1986, Barr 2000, Kruys \& Wedin 2009, Zhang et al. 2012b, Gonzalez-Menendez et al. 2017). Sporormia fimetaria is characterized by black, papillate ascomata, thin peridium, with 1620-celled ascospores, easily separating into part spores and lacking germ slits (Zhang et al. 2012b). Asexual morph characters of Sporormia is not verified. 

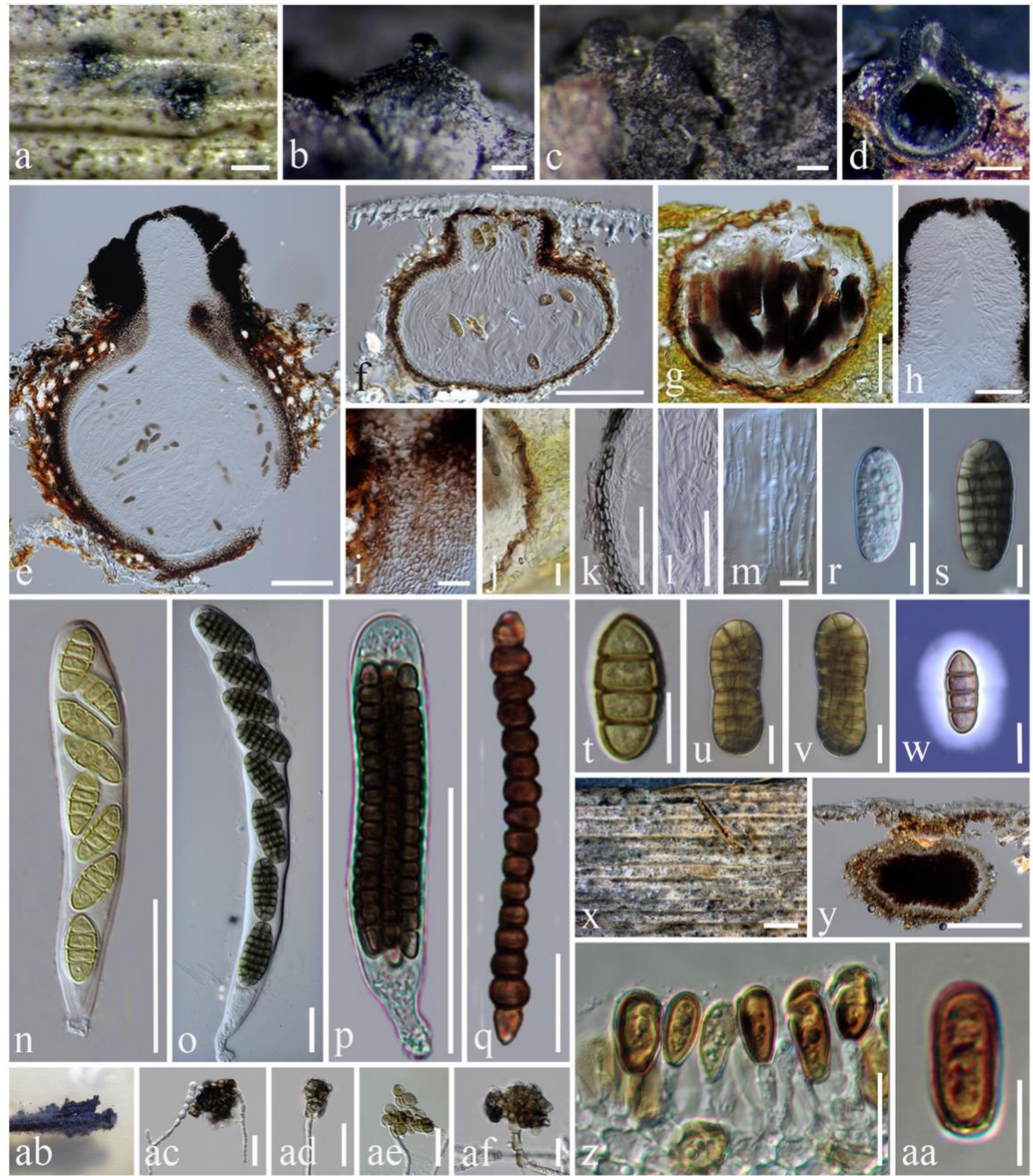

Figure 148 - Morphology of Sporormiaceae. a-d Appearance of Sporormiaceae ascomata on host substrates. e-g Vertical section of partial ascomata. h Ostiole canal. i-k Section of partial peridium layers. 1, m Hamathecium. n-p Asci. q-w Ascospores (w ascospores stained in India ink reagent). $\mathrm{x}$ Conidiomata located on host surface. y Vertical section of conidioma. z Conidiogenous cell with developing conidia. aa Conidia. ab Mycelium formed on pine. ac-af Development of conidiophores with conidiogenous cells and conidia. Scale bars: $\mathrm{a}-\mathrm{d}=200 \mu \mathrm{m}, \mathrm{e}, \mathrm{f}=100 \mu \mathrm{m}, \mathrm{g}, \mathrm{h}, \mathrm{k}, \mathrm{l}, \mathrm{n}, \mathrm{p}=50$ $\mu \mathrm{m}, \mathrm{i}, \mathrm{o}, \mathrm{y}, \mathrm{ac}-\mathrm{af}=20 \mu \mathrm{m}, \mathrm{j}, \mathrm{m}, \mathrm{q}-\mathrm{w}, \mathrm{z}=10 \mu \mathrm{m}, \mathrm{x}=1 \mathrm{~cm}, \mathrm{aa}=5 \mu \mathrm{m}$. (a, f, k, 1, n, t, w $=$ Sparticola junci MFLU 15-1405; ab-af = Cultures of Sparticola junci MFLUCC 15-0030; b-e, h, i, m, o, r-s, $\mathrm{u}-\mathrm{v}=$ Sporormurispora atraphaxidis MFLU 18-0116; $\mathrm{g}, \mathrm{j}, \mathrm{p}-\mathrm{q}=$ Sporormia fimetaria MFLU 122218; $\mathrm{x}-\mathrm{aa}=$ Forliomyces uniseptata MFLU 16-0031). 


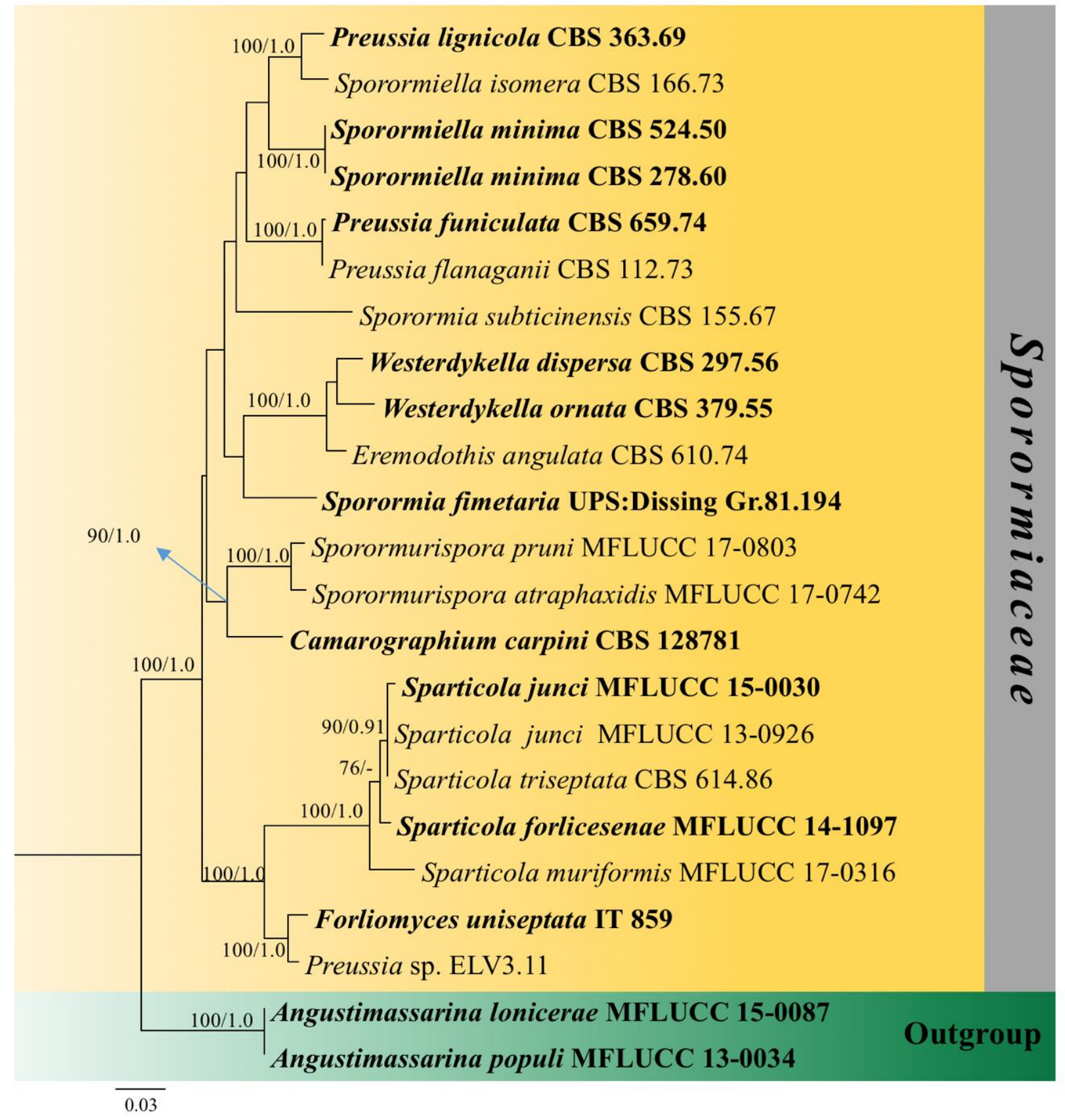

Figure 149 - Phylogram generated from maximum likelihood analysis (RAxML) of genera in Sporormiaceae based on ITS, LSU, and SSU sequence data. Maximum likelihood bootstrap values equal or above $70 \%$, Bayesian posterior probabilities equal or above 0.90 (MLBS/PP) are given at the nodes. An original isolate number is noted after the species name. The tree is rooted to Angustimassarina lonicerae (MFLUCC 15-0087) and A. populi (MFLUCC 13-0034). The ex-type strains are indicated in bold. Hyphen (-) represents support values below $70 \%$ MLBS and 0.90 PP.

\section{Other genera included}

Chaetopreussia Locq.-Lin., Revue Mycol., Paris 41(2): 185 (1977).

Index Fungorum number: IF 961; Facesoffungi number: FoF 06566; 1 morphological species (Species Fungorum 2020), molecular data unavailable. (1977).

Type species - Chaetopreussia chadefaudii Locq.-Lin., Revue Mycol., Paris 41(2): 187

Notes - Chaetopreussia is a monotypic genus that is compatible with the family concepts of Sporormiaceae by its morphological characteristics. The genus was found associated with camel dung collected from the central Sahara (Locquin-Linard 1977). Chaetopreussia is characterized by 
its cleistothecioid ascomata covered with brown setae; 3-septate ascospores, brown without germ slits (Kruys \& Wedin 2009). Asexual morph has not been reported. The molecular data of the type species, $C$. chadefaudii are required for the confirmation of its taxonomic placement.

Forliomyces Phukhams., Camporesi \& K.D. Hyde, Cryptog. Mycol. 37(1): 82 (2016).

Index Fungorum number: IF 8495; Facesoffungi number: FoF 01824; 1 morphological species (Species Fungorum 2020), 1 species with molecular data.

Type species - Forliomyces uniseptatus Phukhams., Camporesi \& K.D. Hyde, Cryptog. Mycol. 37(1): 84 (2016).

Notes - Forliomyces was introduced for saprobic fungal strains associated with Salvia sp. and Spartium junceum (Wijayawardene et al. 2016a). The type species formed a relationship with the endophytic fungal strains while they appear as saprobes in the natural environments (Phukhamsakda et al. 2016). Forliomyces is characterized by its immersed, subglobose conidiomata; enteroblastic conidiogenous cells, with oblong, brown, granulate conidia with an abscission scar. Pinkish to red pigments radiated in both liquid and solid media types were also mentioned as an important character (Phukhamsakda et al. 2016).

Pleophragmia Fuckel, Jb. Nassau. Ver. Naturk. 23- 24: 243 (1870).

Index Fungorum number: IF 4220; Facesoffungi number: FoF 06567; 4 morphological species (Species Fungorum 2020), molecular data unavailable.

Type species - Pleophragmia leporum Fuckel, Jb. nassau. Ver. Naturk. 23-24: 243 (1870)

= Pleospora leporum (Fuckel) Höhn., Sber. Akad. Wiss. Wien, Math.-naturw. Kl., Abt. 1 129: 163 (1920).

Notes - Pleophragmia was formally assigned to Sporormiaceae in Fuckel (1870) and was typified by Pleophragmia leporum. The genus was originally reported as a coprophilous fungus in terrestrial habitats (Fuckel 1870). Pleophragmia is characterized by gregarious, immersed to erumpent, globose to subglobose, coriaceous ascomata with a short papillate; peridium thin and composed of cells of textura angularis with clavate to cylindro-clavate, with a relatively long pedicellate ascus. The ascospores are narrow oblong to cylindrical with rounded ends, muriform, dark brown, without germ-slit at the surface. There is no asexual morph reported for this genus (Zhang et al. 2012b). A monograph of the genera included in Sporormiaceae was done by Kruys \& Wedin (2009). Based on the morphological information, Pleophragmia shares similar morphology with Sporormia, however, Pleophragmia is distinguishable by its muriform ascospores. The molecular data of the type speciesis required for taxonomic confirmation.

Preussia Fuckel, Hedwigia 6: 175 (1867).

Index Fungorum number: IF 4363; Facesoffungi number: FoF 06568; 53 morphological species (Species Fungorum 2020), 30 with molecular data.

Type species - Preussia funiculata (Preuss) Fuckel, Jb. nassau. Ver. Naturk. 23-24: 91 (1870)

$\equiv$ Perisporium funiculatum Preuss, Fung. Hoyersw.: no. 145 (1851).

Notes - Preussia was introduced by Fuckel (1866) for species that have cleistothecioid ascomata, bitunicate asci, multi-septate ascospores, separating into parts with a germ slit on the surface walls. Members of Preussia were found associated with various habitats such as endophytic in the leaves of terrestrial plants, saprobic or coprophilous on dung, decaying wood and submerged plant debris (Guarro et al. 1997, Kruys \& Wedin 2009, Kruys 2015). Preussia, Sporormiella and Spororminula have been demonstrated to have similar morphological characters, the only distinction being the papillate ostiole is absent in Preussia species. Recent molecular data analysis showed that there are non-polyphyletic results within Preussia, Sporormiella and Spororminula (von Arx 1973, Kruys \& Wedin 2009, Zhang et al. 2012b, Hyde et al. 2013). Several Preussia specimens were also found mixed with taxa reported from soil samples ( $\mathrm{Li}$ et al. 2016a).

Sparticola Phukhams., Ariyaw., Camporesi \& K.D. Hyde, Cryptog. Mycol. 37(1): 84 (2016). 
Index Fungorum number: IF 551921; Facesoffungi number: FoF 01827; 4 morphological species (Species Fungorum 2020), 4 species with molecular data.

Type species - Sparticola junci Phukhams., Camporesi \& K.D. Hyde, Cryptog. Mycol. 37(1): 84 (2016).

Notes - Sparticola was introduced for a saprobic species that is found in terrestrial habitats. Members of Sparticola were found associated with both dicotyledonous and monocotyledonous plants (Leuchtmann 1987, Phukhamsakda et al. 2016, Thambugala et al. 2017b, Karunarathna et al. 2017b). Based on the molecular data analysis, Sparticola species cluster with the endophyte isolates and another saprobic fungus, Forliomyces basal to Sporormiaceae. Sparticola species are characterized in having globose, black, coriaceous, ascomata with papillate, comprised of thinwalled cells of textura angularis, ascospores with transverse septa and sometime 1-2 longitudinal septa, but lacking germ slit (Phukhamsakda et al. 2016).

Sporormiella Ellis \& Everh. N. Amer. Pyren. (Newfield): 136 (1892).

Index Fungorum number: IF 415062; Facesoffungi number: FoF 07980; 58 morphological species (Species Fungorum 2020), 14 species with molecular data.

Type species - Sporormiella nigropurpurea Ellis \& Everh, N. Amer. Pyren. (Newfield): 136 (1892).

Notes - Sporormiella is a coprophilous species and was synonymized under Preussia due to morphological similarity and indistinguishable in the currently phylogeny (Zhang et al. 2012b, Hyde et al. 2013). Sporormiella is characterized by ostiolate ascomata that produce part spores ascospores with germ-slits on the surface (Ahmed \& Cain 1972). However, the sequence data for the type species is not available, thus its placement is still doubtful. Hence, we reinstate Sporormiella and maintain it as a distinct genus in Sporormiaceae.

Sporormurispora Wanas., Bulgakov, Gafforov \& K.D. Hyde, Fungal Divers. 89: 157 (2018).

Index Fungorum number: IF 554209; Facesoffungi number: FoF 04048; 2 morphological species (Species Fungorum 2020), 2 species with molecular data.

Type species - Sporormurispora atraphaxidis Wanas., Bulgakov, E.B.G. Jones \& K.D. Hyde, Fungal Divers. 89: 157 (2018).

Notes - Wanasinghe et al. (2018c) introduced Sporormurispora for two dictyospore fungi that clustered in Sporormiaceae in their phylogenetic analysis. The genus was found as saprobes in terrestrial habitats and it is characterized by black, uniloculate ascomata with an ostiole, thick, mostly ellipsoidal, brown, muriform ascospores. Asexual morph is undetermined.

Westerdykella Stolk, Trans. Br. Mycol. Soc. 38 (4): 422 (1955).

Index Fungorum number: IF 5772; Facesoffungi number: FoF 06570; 13 morphological species (Species Fungorum 2020), 7 species with molecular data.

Type species - Westerdykella ornata Stolk, Trans. Br. mycol. Soc. 38(4): 422 (1955).

Notes - Westerdykella was described as coprophilous producing cleistothecioid ascomata, small asci with short pedicel, encasing one-celled ascospores, verruculose but without germ slits (Kruys \& Wedin 2009). Members of Westerdykella have been found in various environmental conditions such as dung, mud, plant material and soil (Clum 1955, Ito \& Nakagiri 1995, Cain 1961, Malloch \& Cain 1972). Asexual morph produced in culture has conidiomata with sub-cylindrical, aseptate and hyaline conidia (Sue et al. 2014, Crous et al. 2017a).

\section{Ecological and economic significance}

The members of Sporormiaceae appear to be widespread and most likely play a saprobic role in the decomposition of plant organic material within these ecosystems. Westerdykella reniformis has been reported to produce the antibiotic metabolites melinacidin IV and chetracin B (Ebead et al. 2012). Several secodary metabolites of Sporormiaceae have been investigated in GonzalezMenendez et al. (2017) and Phukhamsakda et al. (2019b). 
Striatiguttulaceae S.N. Zhang, K.D. Hyde \& J.K. Liu, MycoKeys 49: 110 (2019).

Index Fungorum number: IF 828272; Facesoffungi number: FoF 05032, 3 species.

Saprobic on palms distributed in mangrove habitats. Sexual morph: Stromata or ascomata black, scattered to gregarious, immersed, and erumpent to superficial, with a papilla or a short to long neck, ampulliform, subglobose or conical, uni-loculate or bi-loculate, coriaceous to carbonaceous, ostiolate, periphysate, papillate, clypeate or not clear, glabrous or somewhat interwoven pale brown hyphae or setae. Peridium composed of several brown to hyaline cell layers. Hamathecium comprising trabeculate pseudoparaphyses. Asci 8-spored, bitunicate, cylindricclavate, pedicellate. Ascospores 1-2-seriate or 3-seriate, fusiform or ellipsoidal, hyaline to brown, 1-3-septate, with longitudinal striations and paler end cells, surrounded by a mucilaginous sheath. Asexual morph: Undetermined.

Type - Striatiguttula S.N. Zhang, K.D. Hyde \& J.K. Liu.

Notes - Zhang et al. (2019b) established the pleosporalean family Striatiguttulaceae based on morphology, phylogeny and divergence time estimation. The family contains two genera Longicorpus and Striatiguttula, with three species collected from mangrove palms.
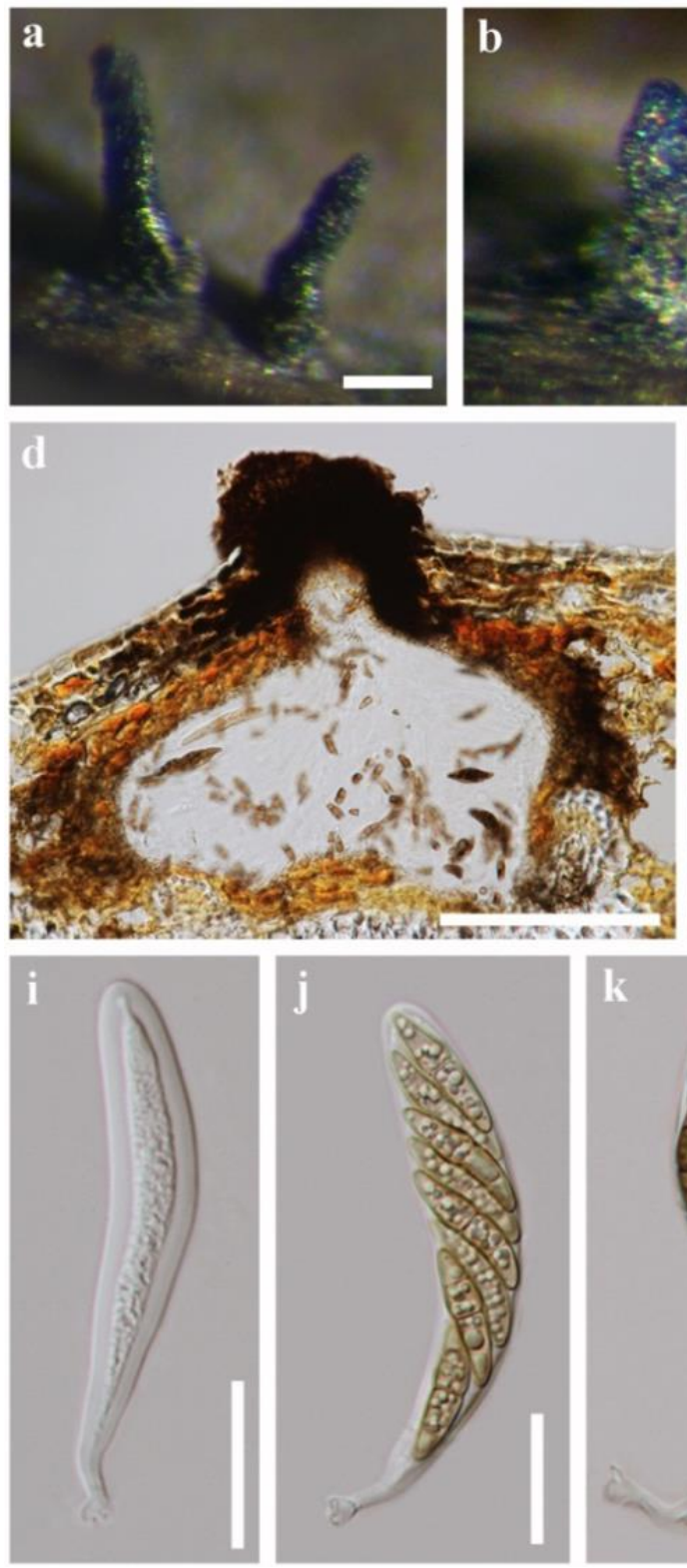
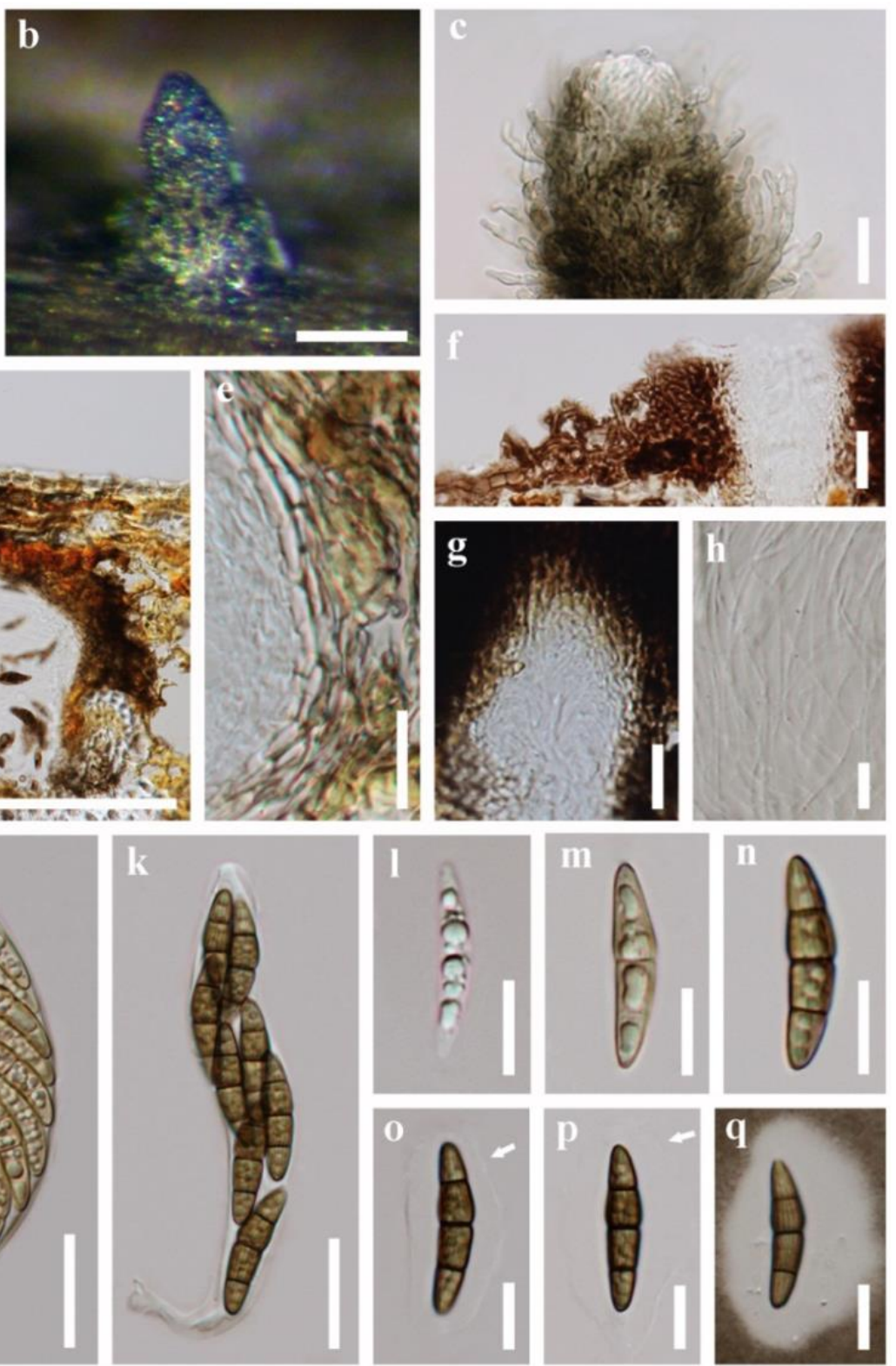

Figure 150 - Striatiguttula nypae (MFLU 18-1576, holotype). a, b Appearance of ascomata on host surface. c Neck of ascomata with setae. d Vertical section through an ascoma. e Structure of peridium. f Structure of clypeus and wall of the neck. g Ostiole. h Pseudoparaphyses. i-k Ascus. 
1-q Ascospores. Notes - arrowhead showing mucilaginous sheath. Scale bars: $a, b, d=100 \mu \mathrm{m}, \mathrm{c}$, $\mathrm{f}-\mathrm{g}, \mathrm{i}-\mathrm{k}=20 \mu \mathrm{m}, \mathrm{e}, \mathrm{h}, \mathrm{l}-\mathrm{q}=10 \mu \mathrm{m}$.

Striatiguttula S.N. Zhang, K.D. Hyde \& J.K. Liu, MycoKeys 49: 111 (2019).

Index Fungorum number: IF 828273; Facesoffungi number: FoF 05033; 2 morphological species (Species Fungorum 2020), 2 species with molecular data.

Type species - Striatiguttula nypae S.N. Zhang, K.D. Hyde \& J.K. Liu

Notes - Two species Striatiguttula nypae and S. phoenicis are included in this genus. The type species is illustrated below.

Striatiguttula nypae S.N. Zhang, K.D. Hyde \& J.K. Liu, in Zhang et al., MycoKeys 49: 112 (2019).

Index Fungorum number: IF 828274; Facesoffungi number: FoF 05034.

Fig. 150

Description - see Zhang et al. (2019b).

Material examined - Thailand. Ranong, on decayed rachis of Nypa fruticans Wurmb (Arecaceae), 3 December 2016, S.N. Zhang, (MFLU 18-1576, holotype).

\section{Other genus included}

Longicorpus S.N. Zhang, K.D. Hyde \& J.K. Liu, MycoKeys 49: 117 (2019).

Index Fungorum number: IF 828276; Facesoffungi number: FoF 05036; 1 morphological species (Species Fungorum 2020), 1 species with molecular data.

Type species - Longicorpus striataspora (K.D. Hyde) S.N. Zhang, K.D. Hyde \& J.K. Liu, MycoKeys 49: 117 (2019).

三Trematosphaeria striataspora K.D. Hyde, Bot. J. Linn. Soc. 98(2): 142 (1988).

Notes - Longicorpus is distinct from Striatiguttula in phylogeny and its ascospores having relatively larger middle cells and paler end cells (Zhang et al. 2019b). Longicorpus accommodates a single species L. striataspora (三 Trematosphaeria striataspora) (Hyde 1988, 1992a), and an epitype was designed in Zhang et al. (2019b).

\section{Ecological and economic significance}

Species of Striatiguttulaceae that were found so far are manglicolous, and may well adapt to the varying salinity in mangroves by tidal water. However, there is no economic or ecological significance reported of them in previous study (Zhang et al. 2019b).

Sulcatisporaceae Kaz. Tanaka \& K. Hiray., Stud. Mycol. 82: 119 (2015).

Index Fungorum number: IF 814431; Facesoffungi number: FoF 06031, 9 species.

Saprobic on various hosts. Sexual morph: Ascomata grouped or scattered, immersed to erumpent, globose from surface view, subglobose to hemisphaerical in transverse section. Ostiolar neck central, papillate, periphysate. Peridium comprising many layers of compressed cells, inadequately developed at the base. Hamathecium comprising branched, anastomosed, cellular or trabeculate pseudoparaphyses. Asci 8-spored, clavate, with short stalk. Ascospores overlapping, roughly fusiform, hyaline, 1-septate, surrounded completely by a sheath. Asexual morph: Conidiomata pycnidial, globose. Conidiogenous cells cylindrical to doliiform, phialidic or annellidic. Conidia ellipsoid to subglobose, hyaline to dark brown, 1- to multi-septate, sometimes muriform, with or without striation (adapted from Tanaka et al. 2015).

Type - Sulcatispora Kaz. Tanaka \& K. Hiray.

Notes - Sulcatisporaceae currently accommodates the genera Magnicamarosporium, Neobambusicola, Pseudobambusicola and Sulcatispora (Tanaka et al. 2015). Neobambusicola initially belonged to Bambusicolaceae (Crous et al. 2014b), but it was transferred to Sulcatisporaceae since it phylogenetically formed a well-supported clade with Magnicamarosporium and Sulcatispora, sister to Bambusicolaceae (Tanaka et al. 2015). The species belonging to Sulcatisporaceae differ from those of the Bambusicolaceae in having 
subglobose to obovoid muriform conidia (Magnicamarosporium) or conidia bearing 1 to many septations, with or without striation (Neobambusicola) (Tanaka et al. 2015). Pseudoparaparaphyses of this family was reported as both cellular (e.g. Anthosulcatispora) and trabeculate (e.g. Parasulcatispora and Sulcatispora).

Sulcatispora Kaz. Tanaka \& K. Hiray., Stud. Mycol. 82: 120 (2015).

Index Fungorum number: IF 811294; Facesoffungi number: FoF 01712; 2 morphological species (Species Fungorum 2020), 2 species with molecular data.

Type species - Sulcatispora acerina Kaz. Tanaka \& K. Hiray. Stud Mycol. 82: 120 (2015).

Notes - Species of Sulcatispora are recognised by conidia having striate ornamentation (Tanaka et al. 2015). Some species in Phaeophleospora and Sclerostagonospora also have striated conidia but they phylogenetically belong to Mycosphaerellaceae and Phaeosphaeriaceae, respectively (Taylor \& Hyde 2003, Crous et al. 2007d, 2009c, 2011a, Lawrey et al. 2012). The ascomata of Sulcatispora species resemble those of the species belonging to Massarina sensu stricto, except that the former lack a conspicuous clypeus as compared to the latter (Tanaka et al. 2015). Sulcispora is phylogenetically close to Bambusicola and species of both genera have similar asexual morphs. However, Sulcispora has globose to subglobose ascomata, and clavate with short stalk asci, while Bambusicola has conical ascomata with compressed bases and narrower asci (Dai et al. 2012).

\section{Other genera included}

Anthosulcatispora Phukhams. \& K.D. Hyde, Fungal Diversity 102: 117 (2020).

Index Fungorum number: IF 557201; Facesoffungi number: FoF 07340; 2 morphological species (Phukhamsakda et al. 2020), 2 species with molecular data.

Type species - Anthosulcatispora subglobosa Phukhams. \& K.D. Hyde, Fungal Diversity 102: 119 (2020).

Notes - Species of Anthosulcatispora are saprobic on stems of herbaceous plants (Phookamsak et al. 2019, Phukhamsakda et al. 2020). The asexual morph of Anthosulcatispora resembles that of Neobambusicola and Pseudobambusicola in terms of the solitary, unilocular pycnidia, phialidic conidiogenesis and hyaline conidia (Phukhamsakda et al. 2020). However, Neobambusicola and Pseudobambusicola comprise globose pycnidia and two types of conidia, while Anthosulcatispora consists of subglobose conidiomata, elongated cylindrical to truncate conidiogenous cells and oblong, aseptate conidia (Crous et al. 2014b, Rupcic et al. 2018, Phukhamsakda et al. 2020). Furthermore, Neobambusicola brunnea was transferred to Anthosulcatispora based on phylogenetic analyses (Phookamsak et al. 2019, Phukhamsakda et al. 2020) and following this, it is reported that the sexual morph of Anthosulcatispora comprises brown ascospores while the sexual morph of Sulcatispora consists of hyaline, broadly fusiform ascospores completely surrounded by a sheath (Tanaka et al. 2015).

Magnicamarosporium Kaz. Tanaka \& K. Hiray., Stud. Mycol. 82: 119 (2015).

Index Fungorum number: IF 811292; Facesoffungi number: FoF 01684; 2 morphological species (Species Fungorum 2020), 2 species with molecular data.

Type species - Magnicamarosporium iriomotense Kaz. Tanaka \& K. Hiray., Stud. Mycol. 82: 120 (2015).

Notes - Magnicamarosporium is characterised by pycnidial conidiomata and subglobose to obovoid or at times muriform dark brown euseptate conidia (Tanaka et al. 2015, Phukhamsakda et al. 2017). The genus closely resembles Camarosporium in its muriform brown conidia, but Magnicamarosporium possesses larger conidiomata along with a conspicuous ostiole, long paraphyses with mucilaginous coating, and larger conidia (Tanaka et al. 2015). Magnicamarosporium belongs to Sulcatisporaceae while Camarosporium is accommodated in Pleosporineae (Crous et al. 2015b). 
Index Fungorum number: IF 552777; Facesoffungi number: FoF 02897.

Description - see Phukhamsakda et al. (2017).

Material examined - THAILAND, Krabi Province, Muang City, on dead and twigs of Diospyros malabarica (Ebenaceae), 15 December 2015, C. Phukhamsakda, Kr009 (MFLU 170001, holotype).

Neobambusicola Crous \& M.J. Wingf., Persoonia 33: 255 (2014).

Index Fungorum number: IF 810614; Facesoffungi number: FoF 06695; 1 morphological species (Species Fungorum 2020, Phukhamsakda et al. 2020), 1 species with molecular data.

Type species - Neobambusicola strelitziae Crous \& M.J. Wingf., Persoonia 33: 255 (2014).

Notes - Neobambusicola was initially accommodated in Bambusicolaceae and it shared morphological resemblance to Bambusicola (Crous et al. 2014b). Both genera possess reduced conidiophores with percurent proliferations and conidia which turn pale brown on maturity (Dai et al. 2012, Hyde et al. 2013). However, Neobambusicola was later transferred to Sulcatisporaceae owing to the phylogenetetic support with the novel genera Sulcatispora and Magnicamarosporium than Bambusicola (Tanaka et al. 2015).

Parasulcatispora Phukhams. \& K.D. Hyde, in Phukhamsakda et al., Fungal Diversity: 102: 119 (2020).

Index Fungorum number: IF 557204; Facesoffungi number: FoF 01686; 1 morphological species (Phukhamsakda et al. 2020), 1 species with molecular data

Type species - Parasulcatispora clematidis Phukhams. \& K.D. Hyde, in Phukhamsakda et al., Fungal Diversity: 102: 121 (2020).

Notes - Parasulcatispora is characerised by semi-immersed to erumpent and sub-globose to compressed ascomata, short ostioles, anastomosing trabecular pseudoparaphyses and broad fusiform, hyaline euseptate ascospores with mucilaginous sheath (Phukhamsakda et al. 2020). Parasulcatispora is different from Sulcatispora in that it possesses compressed ascomata which are not covered by a pseudoclypeus and its asci and ascospores are narrower (Phukhamsakda et al. 2020).

Pseudobambusicola Hern.-Restr. \& Crous, MycoKeys 33: 9 (2018).

Index Fungorum number: IF 824299; Facesoffungi number: FoF 07393; 1 morphological species (Species Fungorum 2020), 1 species with molecular data. (2018).

Type species - Pseudobambusicola thailandica Hern.-Restr. \& Crous, MycoKeys 33: 11

Notes - Pseudobambusicola, so far only described in its asexual morph, is characterised by pycnidial conidiomata which produce macro- and micro-conidia (Rupcic et al. 2018). Species of Pseudobambusicola shares close morphological resemblance with Bambusicola and Neobambusicola species. However, while the taxon of Pseudobambusicola comprises hyaline conidia and phialidic conidiogenesis, while species of Bambusicola are reported to have pale brown to brown conidia and annellidic conidiogenous cells (Dai et al. 2012, 2017). Similarly, Pseudobambusicola differs from Neobambusicola in possessing dark brown and smooth to slightly verruculose hyphae surrounding the conidiomata. The latter, in their maturity, usually develop a cylindrical neck. Pseudobambusicola species also produces chlamydospores in culture contrary to species of Neobambusicola (Rupcic et al. 2018).

\section{Ecological and economic significance}

Saprotrophic fungi are able to regulate nutrient cycle in the terrestrial ecosystem through secretion of lignocellulolytic enzymes, thereby, representing significant decomposers of plant litter (Baldrian \& Valášková 2008, Crowther et al. 2012). 


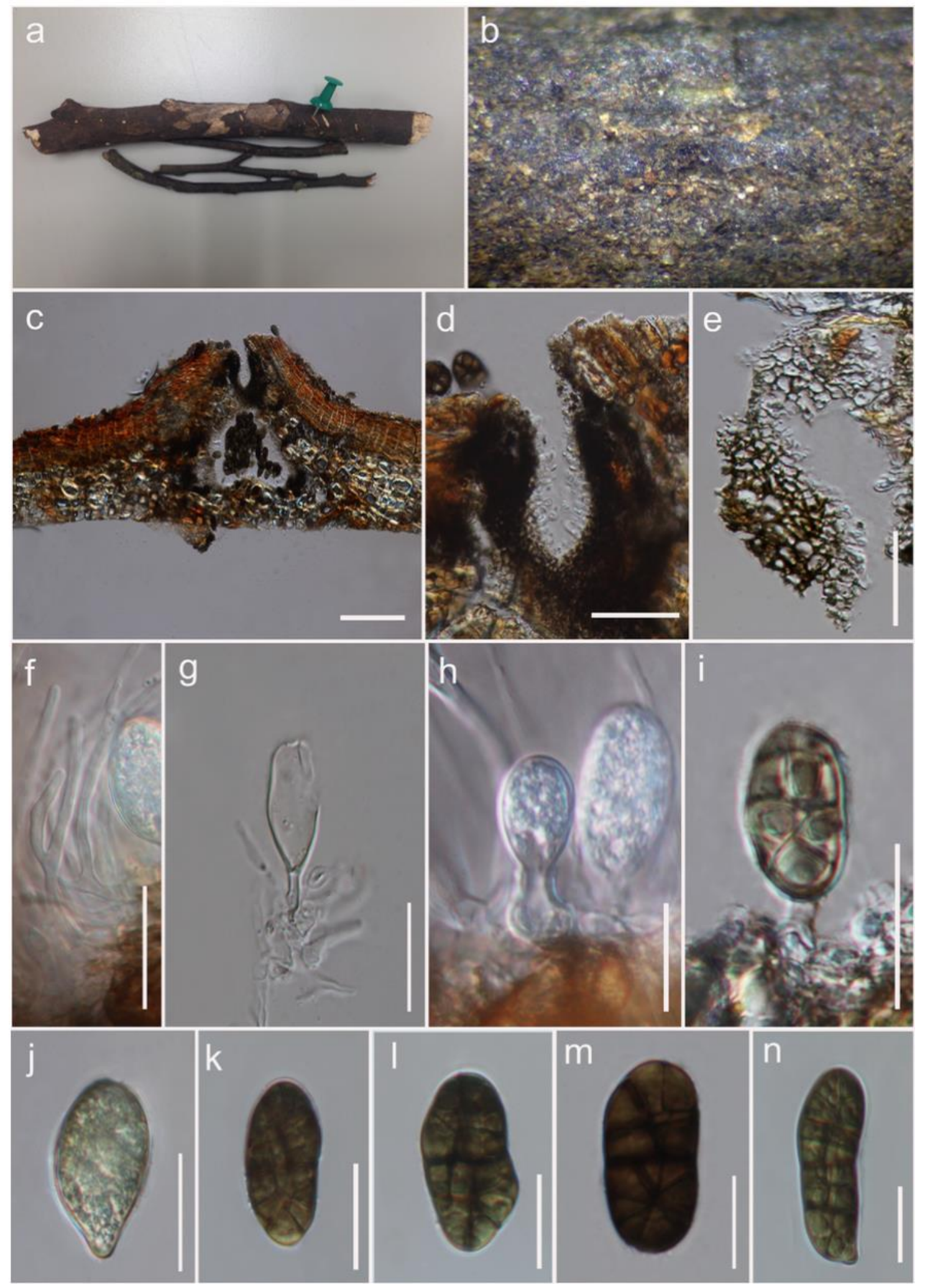

Figure 151 - Magnicamarosporium diospyricola (MFLU 17-0001, holotype). a Herbarium material. b Appearance of conidiomata on host surface. c Vertical section of conidioma. d Ostiole. e Pycnidial wall. f Paraphyses. g-i Conidiogenous cells and developing conidia. $\mathrm{j}-\mathrm{n}$ Conidia. Scale bars: $\mathrm{c}=100 \mu \mathrm{m}, \mathrm{d}=50 \mu \mathrm{m}, \mathrm{e}, \mathrm{f}=30 \mu \mathrm{m}, \mathrm{g}, \mathrm{i}-\mathrm{n}=20 \mu \mathrm{m}, \mathrm{h}=10 \mu \mathrm{m}$.

Teichosporaceae M.E. Barr, Mycotaxon 82: 374 (2002).

Index Fungorum number: IF 82136; Facesoffungi number: FoF 00830, 88 species.

Saprobic on woody branches, bark or leaves. Sexual morph: Ascomata semi-immersed, erumpent to superficial, solitary or aggregated, coriaceous to carbonaceous, dark brown to black, 
pyriform or globose to subglobose, dark brown to black, ostiolate. Ostiole central, papillate to elongate, pore rounded, apex variously coloured. Peridium thin-walled with equal thickness, slightly thin at the base, composed of several layers of lightly pigmented to dark brown to black, textura angularis cells, cells towards the inside lighter, at the outside, darker and fusing with the host tissues. Hamathecium comprising 1-2 $\mu \mathrm{m}$ wide, numerous, septate, branching, anastomosing, cellular or trabeculate pseudoparaphyses, embedded in a gelatinous matrix. Asci 4-8-spored, bitunicate, fissitunicate, cylindrical to subclavate, pedicellate, with a small ocular chamber. Ascospores 1-2-seriate, overlapping, fusoid or clavate, oblong, rounded ends, symmetric or asymmetric, initially hyaline or brown, 1-3-septate or muriform, usually septate, rarely with a gelatinous sheath. Asexual morph: Coelomycetous, forming pycnidia that contain brown septate or brown, rarely hyaline, aseptate conidia.

Type - Teichospora Fuckel.

Notes - Teichosporaceae was established by Barr (2002) to accommodate eight genera, Bertiella, Byssothecium, Chaetomastia, Immotthia, Loculohypoxylon, Moristroma, Sinodidymella and the type genus Teichospora by using morphological characteristics. Most of these Teichosporaceae genera have been previously included in Decampiaceae (Barr 1987b) based on their peridium structure, ascus morphology and tropic states. Later, Moristroma, Byssothecium and Bertiella were transferred to Chaetothyriomycetidae, Massarinaceae and Melanommataceae, respectively (Lumbsch \& Huhndorf 2010). Jaklitsch et al. (2016b) revised Teichosporaceae and illustrated the morphological similarities of Teichospora species and all genera which previously included in Floricolaceae were transferred and synonymized under Teichospora. Consequently, all the genera which were accepted in Thambugala et al. (2015b) in Floricolceae, became synonyms of Teichospora and thus the family became monotypic. However, the monotypic nature of Teichosporaceae is doubtful, due to some distinct morphological differences within species. According to the recent outline of Wijayawardene et al. (2018), twelve genera are accepted in Teichosporaceae. After in-depth morphological and phylogeny analyses, we keep Floricolaceae (Thambugala et al. 2015b) genera in Teichosporaceae. We excluded Neocurreya from Teichosporaceae, but this needs more verification with molecular data.

Teichospora Fuckel, Jb. nassau. Ver. Naturk. 23-24: 160 (1870).

Index Fungorum number: IF 180961; Facesoffungi number: FoF 08367; 50 morphological species (Species Fungorum 2020), 19 species confirmed with molecular data.

Type - Teichospora trabicola Fuckel (designated by Fuckel 1870).

Notes - Teichospora was erected by Fuckel (1870) and typified by Teichospora trabicola Fuckel and in the meantime, another four species were also included, viz. Teichospora brevirostris, T. dura, T. morthieri and T. obducens. Teichospora has unique morphological characteristics, such as ascospores being ellipsoid to oblong, symmetrical to slightly asymmetrical, muriform, 3(-4-5) thick and dark transverse septa with 1-3 longitudinal septa and 1 or $2 \mathrm{~V}$ - or Y-septa in terminal cells. The asexual morph of Teichospora is reported as coelomycetous, pycnidial, with conidiophores reduced to conidiogenous cells and brown unicellular (coniothyrium-like), rarely hyaline unicellular (aposphaeria-like) or several celled brown conidia (Jaklitsch et al. 2016b, Wijayawardene et al. 2017a). According to the multi-gene phylogenetic analyses in this study, Teichospora species are nested together as a separate clade with high bootstrap support (Fig. 152). However, three Teichospora species (T. kingiae, T. nephelii, and T. quercus) are nested independently from the Teichospora type species (Fig. 152). Teichospora kingiae shares most close similarities with Floricola species, in having cylindrical to subcylindrical conidiogenius cells, plae brown to dark brown, 1-3- septate conidia (Kohlmeyer \& Volkmann-Kohlmeyer 2000, Crous et al. 2016a). As well as, asexual morphs of T. nephelii and T. quercus differ from the other Teichospora species by ampulliform to subcylindrical conidiogenous cells and ellipsoid, apex acutely rounded, unicellular, hyaline, with a truncate base conidia (Crous et al. 2016a, 2018b). Therefore, further taxonomic work is needed to precisely resolve identification, phylogenetic position and relationships between above three species and Teichospora. 
Teichospora grandicipis (Joanne E. Taylor \& Crous) Jaklitsch \& Voglmayr, Mycol. Progr. 15(no. 31): 9 (2016).

$\equiv$ Coniothyrium grandicipis Joanne E. Taylor \& Crous, in Crous et al. CBS Diversity Ser. (Utrecht) 2: 60 (2004).

Index Fungorum number: IF 815659; Facesoffungi number: FoF 08368.

Saprobic on leaves of Protea grandiceps. Asexual morph: Conidiomata $230-260 \mu \mathrm{m}(\bar{x}=240$ $\mu \mathrm{m}, \mathrm{n}=10$ ) diam., immersed, dark brown to black, solitary, globose to sub-globose. Peridium 12$16 \mu \mathrm{m}$ wide, 2-3 layers of light brown, textura prismatica cells. Conidiophores indistinct. Conidiogenous cells hyaline, cylindrical, slightly tapering towards apex and smooth walled. Alpha conidia $3.5-5.5 \times 1.2-3 \mu \mathrm{m}(\bar{x}=4 \times 1.9 \mu \mathrm{m}, \mathrm{n}=30)$, hyaline, one-celled, straight, fusiform to clavate with obtuse ends, biguttulate. Beta conidia not seen.

Material examined - South Africa, Western Cape Province, Elgin, on leaves of Protea grandiceps, 20 July 1998, J.E. Taylor \& S. Denman, PREM 56616 (holotype).

Notes - Curreya grandicipis (Coniothyrium grandicipis) was introduced by Crous et al. (2011b) based on coniothyrium-like asexual morphs reported in species of Curreya. Later, Curreya grandicipis was synonymized under Neocurreya due to the doubtful phylogeny investigations (Thambugala et al. 2015b). However, Jaklitsch et al. (2016b) transferred Neocurreya grandicipis to Teichospora based on both morphological and phylogenetic results.

\section{Other genera included}

Asymmetrispora Thambugala \& K.D. Hyde, Fungal Divers. 74: 249 (2015).

Index Fungorum number: IF 551259; Facesoffungi number: FoF 00833; 2 morphological species (Index Fungorum 2020), 2 species with molecular data.

Type species - Asymmetrispora tennesseensis (Mugambi, A.N. Mill. \& Huhndorf) Thambugala \& K.D. Hyde, Fungal Divers. 74: 248 (2015).

$\equiv$ Misturatosphaeria tennesseensis Mugambi, A.N. Mill. \& Huhndorf, in Mugambi \& Huhndorf, Stud. Mycol. 64: 114 (2009).

Notes - Asymmetrispora was introduced by Thambugala et al. (2015b) to accommodate $A$. tennesseensis (type species) and A. mariae based on asymmetrical ascospores. These species were previously known as Misturatosphaeria tennesseensis and $M$. mariae, respectively. Asymmetrispora species differ from Misturatosphaeria in having semi-immersed to erumpent, globose to pyriform ascomata, without a subiculum, and pale to dark brown, fusiform to broadly clavate, muriform, smooth-walled, ascospores lacking a mucilaginous sheath (Mugambi \& Huhndorf 2009a, Zhang et al. 2013b). Jaklitsch et al. (2016b) illustrated a broad description on Floricolaceae and synonymized Asymmetrispora species under Teichospora and considered $T$. trabicola as type species. A. tennesseensis and T. trabicola (type species of Teichospora), show distinct morphological differences, such as A. tennesseensis has fusiform, 3-septate ascospores, hyaline when young, pale brown to dark brown at mature with constricted middle septum, whereas T. trabicola has brown and muriform, ellipsoid to clavate ascospores (Jaklitsch et al. 2016b). According to the muti-gene phylogeny herein, Asymmetrispora species are nested more distantly from Teichospora species (Fig. 152). Therefore, based on morphological and phylogenetic ambiguities of Asymmetrispora species with Teichospora species, we consider Asymmetrispora as an individual genus in Teichosporaceae.

Aurantiascoma Thambugala \& K.D. Hyde, Fungal Divers. 74: 249 (2015).

Index Fungorum number: IF 551262; Facesoffungi number: FoF 00834; 1 morphological species (Index Fungorum 2020), 1 species with molecular data.

Type species - Aurantiascoma minimum (Mugambi, A.N. Mill. \& Huhndorf) Thambug. \& K.D. Hyde, Fungal Divers. 74: 249 (2015).

$\equiv$ Misturatosphaeria minima Mugambi, A.N. Mill. \& Huhndorf, in Mugambi \& Huhndorf, Stud. Mycol. 64: 114 (2009).

Notes - Aurantiascoma minimum was previously known as Misturatosphaeria minima, which was collected from decorticated woody branches and is based on smaller ascomata (Mugambi \& 
Huhndorf 2009a). Jaklitsch et al. (2016b) synonymized Aurantiascoma under Teichospora and erected Misturatosphaeria minima as Teichospora parva. However, the morphological characters of Teichospora parva are distinctly different from the type species of Teichospora (T. trabicola), which has hyaline, fusiform, 1-(-3)-septate ascospores with one of the central cells broader than others, constricted at the central septum and thin mucilaginous sheath that extends at the apex of the spores, whereas T. trabicola has brown, rarely hyaline, muriform ascospores which are not or slightly constricted at the septa (Jaklitsch et al. 2016b). According to the multi-gene phylogeny herein, Aurantiascoma species nested separately from Teichospora species (Fig. 152). However, $T$. nephelii and T. quercus show a close phylogeny affinity with Aurantiascoma species (Fig. 152). Teichospora quercus has some morphological similarities with Aurantiascoma species in having dark brown, erumpent, globose to subglobose ascomata, cylindrical-clavate, short pedicellate asci, rounded at apex and fusiform or ellipsoid-fusoid, 1-3-septate ascospores (Mugambi \& Huhndorf 2009a, Crous et al. 2018b). The connectivity between Teichospora nephelii and Aurantiascoma species is not yet proven, as asexual morph is unknown for Aurantiascoma species. Further taxonomic work is needed to resolve identification, phylogenetic position and relationships between the above two species and Aurantiascoma. Based on morphology and phylogeny support, we accept Aurantiascoma as a separate genus as mentioned by Thambugala et al. (2015b).

Chaetomastia (Sacc.) Berl., Icon. fung. (Abellini) 1(1): 38 (1890).

Index Fungorum number: IF 946; Facesoffungi number: FoF 08369; 10 morphological species (Species Fungorum 2020), no species with molecular data.

Type species - Chaetomastia hirtula (P. Karst.) Berl., Icon. fung. (Abellini) 1(1): 38 (1891).

三Sphaeria hirtula P. Karst., Fungi Fenniae Exsiccati, Fasc. 23: no. 825 (1869).

Notes - Chaetomastia was introduced by Saccardo (1883) (as a subgenus of Melanomma) to accommodate five species, $M$. canescens, $M$. cucurbitarioides, M. hirtulum, M. hispidulum and $M$. pilosellum. Chaetomastia was assigned in Teichosporaceae by Barr (2002) based on its saprobic or hyper-saprobic lifestyle, occurring on woody stems and peridium structure. Chaetomastia species are characterized in having superficial, globose or subglobose, black, coriaceous ascomata, thin, 1layered, heavily pigmented peridium, mostly 4-spored, broadly cylindrical asci and ellipsoid to broadly fusoid, 3-septate brown ascospores (Zhang et al. 2012b).

Floricola Kohlm. \& Volkm.-Kohlm., Bot. Mar. 43(4): 385 (2000).

Index Fungorum number: IF 28417; Facesoffungi number: FoF 00896; 2 morphological species (Index Fungorum 2020), 2 species with molecular data.

Type species - Floricola striata Kohlm. \& Volkm.-Kohlm., Bot. Mar. 43(4): 385 (2000).

Notes - Floricola was introduced to accommodate the coelomycetous species $F$. striata as the type species. Ariyawansa et al. (2015a) introduced F. viticola from dead branch of Vitis vinifera. Thambugala et al. (2015b) provided a broad illustration on these coelomycetous asexual morphs and introduced a novel family, Floricolaceae with Floricola as the type genus. Jaklitsch et al. (2016b) revised Floricolaceae and synonymized as Teichosporaceae which had been introduced by Barr (2002) and T. trabicola was designated as the type species. However, there are distinct morphological differences in asexual morphs between Floricola and Teichospora. The asexual morph of Teichospora is coelomycetous, pycnidial, with conidiophores reduced to conidiogenous cells and brown unicellular (coniothyrium-like), rarely hyaline unicellular (aposphaeria-like) or several celled brown conidia (Jaklitsch et al. 2016b, Wijayawardene et al. 2017a), whereas in Floricola, conidiomata are pycnidial, scattered, immersed to erumpent, conidiophores reduced to conidiogenous cells, conidiogenous cells with annellations, enteroblastic, discrete, phialidic, determinate, cylindrical to elongate ellipsoidal conidia, round apex, 3-distoseptate, pale brown to dark brown, smooth-walled (Thambugala et al. 2015b). According to the multi-gene phylogeny herein, Floricola species nested separately from Teichospora species (Fig. 152). Therefore, we keep Floricola and Teichospora as two distinct genera in Teichosporaceae. 


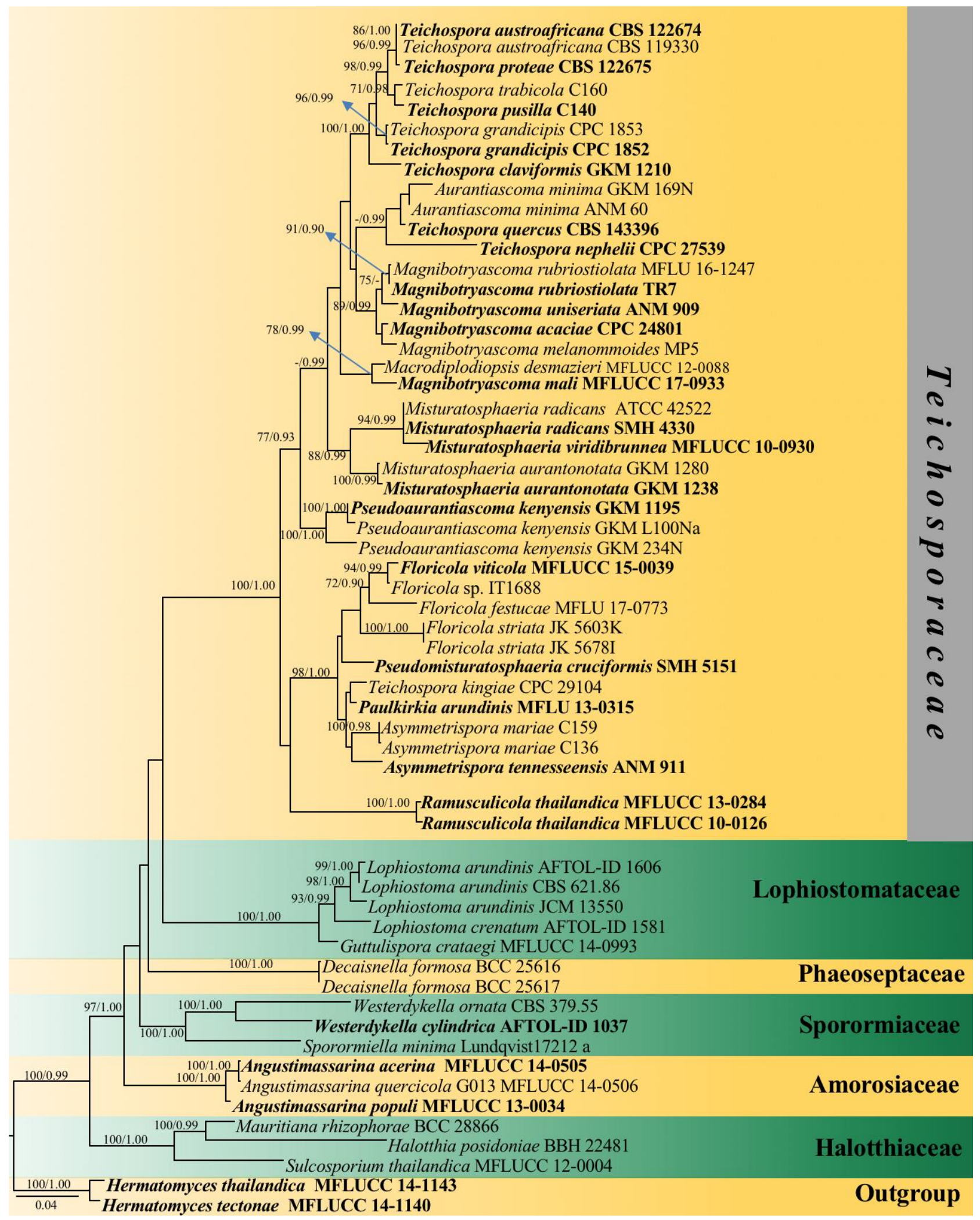

Figure 152 - Phylogram generated from maximum likelihood analysis (RAxML) of genera in Teichosporaceae based on ITS, LSU, and tef1 sequence data. Maximum likelihood bootstrap values equal or above $70 \%$, Bayesian posterior probabilities equal or above 0.90 (MLBS/PP) are given at the nodes. An original isolate number is noted after the species name. The tree is rooted to Hermatomyces tectonae (MFLUCC 14-1140) and H. thailandica (MFLUCC 14-1143). The ex-type strains are indicated in bold. Hyphen (-) represents support values below $70 \%$ MLBS and 0.90 PP. 


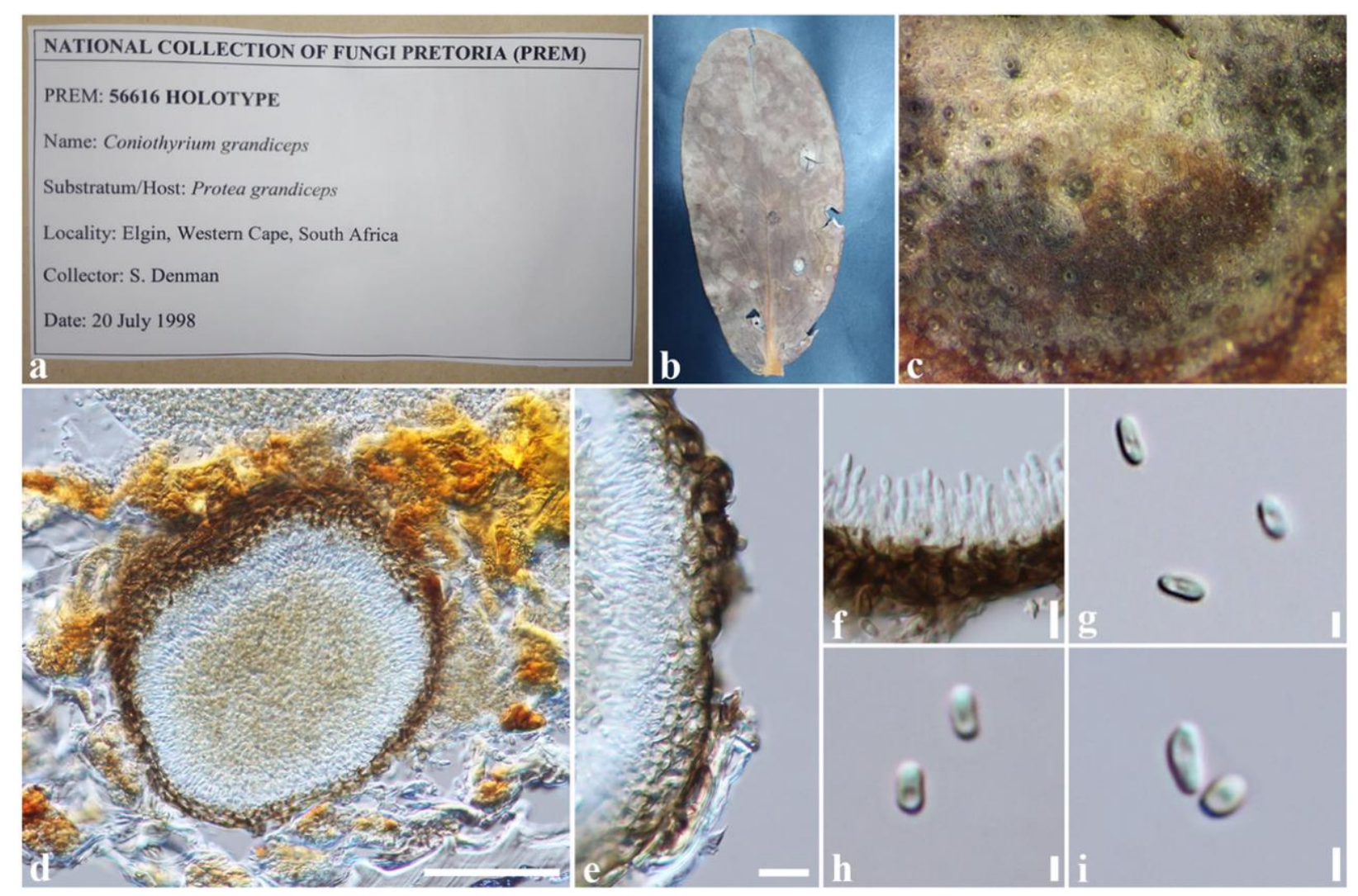

Figure 153 - Teichospora grandicipis (PREM 56616, holotype). a, b Herbarium. c Close up of conidiomata on host. d Sections through conidiomata. e Peridium. f Conidiogenous cells. g-i Conidia. Scale bars: $\mathrm{d}=50 \mu \mathrm{m}, \mathrm{e}=10 \mu \mathrm{m}, \mathrm{f}-\mathrm{i}=5 \mu \mathrm{m}$.

Loculohypoxylon M.E. Barr, Mycotaxon 3(3): 326 (1976).

Index Fungorum number: IF 2915; Facesoffungi number: FoF 08370; 1 morphological species (Species Fungorum 2020), no species with molecular data.

Type species - Loculohypoxylon grandineum (Berk. \& Ravenel) M.E. Barr, Mycotaxon 3(3): 326 (1976).

三Diatrype grandinea Berk. \& Ravenel, Grevillea 4(no. 31): 95 (1876)

Notes - Loculohypoxylon has immersed or widely erumpent ascomata, oblong or clavate asci, 4-8 spores per ascus and light to dark brown, 1-celled, broadly elliptic or subglobose ascospores with germ slit (Barr 1976). According to the classification of Wijayawardene et al. (2018), Loculohypoxylon is included within Teichosporaceae, but needs further verification with molecular data.

Magnibotryascoma Thambug. \& K.D. Hyde, Fungal Divers. 74: 249 (2015).

Index Fungorum number: IF 551266; Facesoffungi number: FoF 00835; 2 morphological species (Index Fungorum 2020), 2 species with molecular data.

Type species - Magnibotryascoma uniseriatum (Mugambi, A.N. Mill. \& Huhndorf) Thambugala \& K.D. Hyde, Fungal Divers. 74: 249 (2015).

三 Misturatosphaeria uniseriata Mugambi, A.N. Mill. \& Huhndorf, in Mugambi \& Huhndorf, Stud. Mycol. 64: 116 (2009).

Notes - Jaklitsch et al. (2016b) provided a broad investigation on Floricolaceae and synonymized all genera under Teichospora and illustrated Teichospora trabicola as type species. However, the morphological characters of Magnibotryascoma species are distinctly different from T. trabicola in having brown to fusiform to elliptical, 1-3-septate, ascospores, whereas T. trabicola has muriform ascospores which are not or slightly constricted at the septa (Jaklitsch et al. 2016b). According to the multi-gene phylogeny herein, Magnibotryascoma species nested separately from 
Teichospora species (Fig. 152). However, Magnibotryascoma mali constitutes an independent lineage sister to Macrodiplodiopsis desmazieri (Fig. 152). Magnibotryascoma mali differs from Macrodiplodiopsis desmazieri in having superficial, globose conidiomata, enteroblastic, phialidic conidiogenous cells and unicellular, reddish-brown conidia, whereas $M$. desmazieri has immersed conidioma, annellidic conidiogenous cells, and 3-distoseptate conidia (Wijayawardene et al. 2014a). The morphological characters of Magnibotryascoma mali closely resembles Magnibotryascoma acaciae in oval to broad-oboviod, unicellular, reddish-brown conidia (Crous et al. 2016a). Therefore, further taxonomic work is needed to resolve identification, phylogenetic position and relationships between Magnibotryascoma mali and other Magnibotryascoma species. We treat Magnibotryascoma as a separate genus in Teichosporaceae based on both morphology and phylogeny evidence.

Misturatosphaeria Mugambi \& Huhndorf, Stud. Mycol. 64: 108 (2009).

Index Fungorum number: IF 515583; Facesoffungi number: FoF 00831; 11 morphological species (Index Fungorum 2020), 3 species with molecular data.

Type species - Misturatosphaeria aurantiinotata Mugambi \& Huhndorf, Stud. Mycol. 64: 108 (2009).

Notes - Misturatosphaeria was introduced to accommodate $M$. aurantonotata (type species), M. claviformis, M. cruciformis, M. kenyensis, M. minima, M. uniseptata, M. tennesseensis and $M$. uniseriata from decorticated woody branches. Thambugala et al. (2015b) re-analyzed Misturatosphaeria species using multi-gene phylogeny and included three species $M$. radicans (ATCC 42522 \& SMH 4330), M. aurantonotata (GKM 1280 \& GKM 1238) and Misturatosphaeria sp. (SMH 4737). Jaklitsch et al. (2016b) synonymized all Misturatosphaeria species under Teichospora and considered T. trabicola as type species. The morphological characters of $M$. aurantonotata differ from $T$. trabicola in having long pedicellate asci, brown to dark brown (initially hyaline), fusiform, 3-septate ascospores with a mucilaginous sheath when the spores are in young stage, whereas $T$. trabicola has brown and muriform, ellipsoid to clavate ascospores without a mucilaginous sheath (Jaklitsch et al. 2016b). According to the multi-gene phylogeny herein, Misturatosphaeria species nested separately from Teichospora species (Fig. 152). Therefore, we keep Misturatosphaeria as a separate genus in Teichosporaceae.

Paulkirkia Wijayaw., Wanas., Tangthir., Camporesi \& K.D. Hyde, Fungal Divers. 77: 198 (2016). Index Fungorum number: IF 551793; Facesoffungi number: FoF 01677; 1 morphological species (Species Fungorum 2020), 1 species with molecular data.

Type species - Paulkirkia arundinis Wijayaw., Wanas., Tangthir., Camporesi \& K.D. Hyde (2016).

Notes - Paulkirkia species have subepidermal to superficial, globose or subglobose, dark brown to black conidiomata, holoblastic, cylindrical to funnel-shaped, unbranched, hyaline to pale brown, conidiogenous cells, ellipsoidal or oblong to irregular, pale to dark brown, 0-1 septate conidia (Wijayawardene et al. 2016a). According to the recent classification of Wijayawardene et al. (2018), Paulkirkia is included within Teichosporaceae, but further collections are needed for expansion of the genus.

Pseudoaurantiascoma Thambugala \& K.D. Hyde, Fungal Divers. 74: 249 (2015).

Index Fungorum number: IF 551273; Facesoffungi number: FoF 00837; 1 morphological species (Index Fungorum 2020), 1 species with molecular data.

Type species - Pseudoaurantiascoma kenyense (Mugambi \& Huhndorf) Thambugala \& K.D. Hyde, Fungal Divers. 74: 250 (2015).

三Misturatosphaeria kenyensis Mugambi \& Huhndorf, Stud. Mycol. 64: 113 (2009).

Notes - Pseudoaurantiascoma was introduced by Thambugala et al. (2015b) to accommodate Misturatosphaeria kenyensis based on its similarity with Aurantiascoma. Jaklitsch et al. (2016b) synonymized Pseudoaurantiascoma under Teichospora and illustrated Teichospora trabicola as type species. However, we treat Pseudoaurantiascoma as a separate genus from Teichospora based 
on morphological differences of ascospores and phylogeny analyses in this study. Because the morphological characters of Pseudoaurantiascoma kenyense are distinctly different from $T$. trabicola in having 2-seriate, hyaline, fusiform, 1-3-septate (mostly1-septate) ascospores with small mucilaginous sheath that extends at the apex of ascospores (Thambugala et al. (2015b), whereas $T$. trabicola has partly 2-seriate, ellipsoid to clavate, brown and muriform ascospores without a mucilaginous sheath (Jaklitsch et al. 2016b). Phylogeny analyses also indicate $T$. trabicola and P. kenyense grouped in well separated sub clades (Fig. 152).

Pseudomisturatosphaeria Thambugala \& K.D. Hyde, Fungal Divers. 74: 249 (2015).

Index Fungorum number: IF 551275; Facesoffungi number: FoF 00838; 1 morphological species (Index Fungorum 2020), 1 species with molecular data.

Type species - Pseudomisturatosphaeria cruciformis (Mugambi \& Huhndorf) Thambugala \& K.D. Hyde, Fungal Divers. 74: 251 (2015).

三 Misturatosphaeria cruciformis Mugambi \& Huhndorf, Stud. Mycol. 64: 113 (2009).

Notes - Thambugala et al. (2015b) introduced Pseudomisturatosphaeria based on its similarity to Misturatosphaeria. Jaklitsch et al. (2016b) synonymized Pseudomisturatosphaeria under Teichospora giving broad illustrations and considered Teichospora trabicola as the type species. However, P. cruciformis can be distinguish from $T$. trabicola in having oblong to elliptical ascospores with distinct constricted middle septum, whereas T. trabicola has ellipsoid to clavate ascospores without a distinct constricted middle septum. Therefore, we keep Pseudomisturatosphaeria as a separate genus in Teichosporaceae.

Ramusculicola Thambugala \& K.D. Hyde, Fungal Divers. 74: 249 (2015).

Index Fungorum number: IF 551264; Facesoffungi number: FoF 00839; 1 morphological species (Index Fungorum 2020), 1 species with molecular data.

Type species - Ramusculicola thailandica Thambugala \& K.D. Hyde, Fungal Divers. 74: 251 (2015).

Notes - Ramusculicola was introduced to accommodate species having semi-immersed to partially erumpent, coriaceous ascomata, a comparatively thin-walled peridium and short pedicellate asci. Jaklitsch et al. (2016b) synonymized Ramusculicola species under Teichospora and pointed out morphological similarities of Ramusculicola species with Teichospora parva (Aurantiascoma) and T. kenyensis (Pseudoaurantiascoma) from their hyaline didymospores. However, Ramusculicola species can be distinguished from these species by its semi immersed to erumpent ascomata, whereas $T$. parva and T. kenyensis have distinct superficial to erumpent ascomata (Mugambi \& Huhndorf 2009a). The type species of Teichospora, T. trabicola is undoubtedly different from Ramusculicola species in having ellipsoid to oblong, muriform and dark brown mature ascospores (Jaklitsch et al. 2016b). Therefore, we keep Ramusculicola as a separate genus in Teichosporaceae.

Sinodidymella J.Z. Yue \& O.E. Erikss., Mycotaxon 24: 295 (1985).

Index Fungorum number: IF 25734; Facesoffungi number: FoF 08371; 5 morphological species (Species Fungorum 2020), no species with molecular data.

Type species - Sinodidymella verrucosa (Petr.) J.Z. Yue \& O.E. Erikss., Mycotaxon 24: 295 (1985).

三Amphididymella verrucosa Petr., Meddn Göteb. Bot. 17: 129 (1947).

Notes - Sinodidymella species are characterized in having radial ridges in ascomata. According to the recent classification of Wijayawardene et al. (2018), Sinodidymella is included within Teichosporaceae, but needs further verification with molecular data.

\section{Ecological and economic significance}

Most of the reported Teichosporaceae species occur as saprobes on decaying wood, bark and branches (Ariyawansa et al. 2015a, Jaklitsch et al. 2016b). A few species have been recorded as leaf-inhabiting (Teichospora acaciae and T. grandicipis), or on senescent leaves and inflorescences 
(Floricola striata). Pathogenicity of Teichosporaceae species is doubtful, lacking any pathogenic records.

Testudinaceae Arx, Persoonia 6(3): 366 (1971).

Index Fungorum number: IF 81456; Facesoffungi number: FoF 08372, 20 species.

Saprobic on dead or decaying wood, parasitic on fungi, pathogenic on humans, isolated from soil, decaying plant materials and woody substrata, in terrestrial, freshwater and marine habitats. Sexual morph: Ascomata cleistothecial or perithecial, globose to subglobose, carbonaceous, darkbrown to black, immersed, clypeate, papillate, ostiolate or lacking ostioles, periphysate. Peridium multi-layered, thick-walled cells of textura angularis. Hamathecium comprising branched, septate, cellular or trabeculate pseudoparaphyses, evanescent to persistent. Asci 8-spored, thick-walled, bitunicate, fissitunicate, clavate to cylindrical, short pedicellate, lacking an apical structure or with an ocular chamber, evanescent to persistent. Ascospores 1-seriate, relatively small, ellipsoidal, brown or hyaline, 1-septate or multi-septate, or muriform, with or without ornamentation on spore surface, with or without furrows, verrucose to verruculose. Asexual morph: Undetermined.

Type - Testudina Bizz.

Notes - Testudinaceae was established by von Arx (1971) to accommodate Testudina, Neotestudina Lepidosphaeria, Argynna (transferred to Argynnaceae) and Pseudophaeotrichum (synonymized as Neotestudina). This family is characterized by astomatous ascomata with a dark peridium, bitunicate asci and dark 2-celled ascospores (about $10 \mu \mathrm{m}$ long) and placed in Pseudosphaeriales (= Pleosporales). Hamathecium of Testudinaceae can be cellular (e.g. Lepidosphaeria and Muritestudina) and trabeculate pseudoparaphyses (e.g. Halotestudina and Lojkania). Hawksworth \& Booth (1974) considered Testudinaceae as a synonym of Zopfiaceae, but based on SEM studies of the ascospores Hawksworth (1979) regarded Zopfiaceae as a synonym of Testudinaceae. Subsequently, Eriksson (1981) accepted both families and later Zopfiaceae was validated by Eriksson \& Hawksworth (1992). The phylogenetic relationships of selected coprophilous Pleosporales were investigated by Kruys et al. (2006). The molecular studies revealed that Lepidosphaeria nicotiae, Neotestudina rosatii, Ulospora bilgramii and Verruculina enalia formed a strongly supported clade in Pleosporales (Suetrong et al. 2009). These genera are known to share similar morphological features, such as dark, 1-septate ascospores with or without germpores, and with or without ornamentation.

Verruculina enalia was earlier treated under Didymosphaeriaceae but multi-gene phylogenetic analyses by Schoch et al. (2006) and Suetrong et al. (2009) suggested it as a member of the Testudinaceae. Molecular studies by Suetrong et al. (2009) showed that Massarina ricifera, an obligate marine species, shares a sister group relationship with $U$. bilgramii, $N$. rosatii and Quintaria lignatilis formed a sister group to Testudinaceae with weak support. Hyde et al. (2013) also accepted Testudinaceae as a family in Dothideomycetes including five genera. A freshwater genus Angustospora was introduced by Li et al. (2016a) in Testudinaceae based on its morphology and molecular phylogeny. Phookamsak \& Hyde (2015) transferred Lojkania from Fenestellaceae to Testudinaceae based on its morphological similarities with Verruculina. Muritestudina was established by Wanasinghe et al. (2017c) based on its distinct hyaline, ellipsoidal, muriform ascospores, in contrast to other genera and supported by multi-gene analyses. Currently, Testudinaceae comprises Angustospora, Halotestudina, Lepidosphaeria, Lojkania, Muritestudina, Neotestudina, Testudina, Ulospora and Verruculina. The identification of taxa from Testudinaceae was mainly based on a few uncertain morphological characters and limited molecular data. Hence this family requires fresh collections in order to provide molecular data and better taxonomic assignment.

Testudina Bizz., Atti Ist. Veneto Sci. lett. ed Arti, Sér. 3: 303 (1885).

Index Fungorum number: IF 5381; Facesoffungi number: FoF 08373; 1 morphological species (Species Fungorum 2020), molecular data unavailable.

Type species - Testudina terrestris Bizz., Fl. Ven. Funghi 3: 303 (1885). 
Notes - The monotypic genus Testudina was introduced by Bizzozero (1885). It was reported as parasitic on other fungi, or as saprobic on decaying wood of Abes and Pinus or on the fallen leaves of Taxus in Europe (Hawksworth \& Booth 1974, Hawksworth 1979). Testudina had been earlier placed in Cephalothecaceae (Höhnel 1917b), then transferred to Pseudeurotiaceae (Malloch \& Cain 1971), and von Arx (1971) assigned it to Testudinaceae based on its dark-walled ascomata and bitunicate asci with 1-septate dark ascospores (Hyde et al. 2013). Cultures and molecular data are unavailable for this genus (Schoch et al. 2009a, b, Suetrong et al. 2009) hence fresh collections are needed to affirm its natural taxonomic placement in this family (Zhang 2012b; Hyde et al. 2013).

\section{Other genera included}

Angustospora Abdel-Aziz, Fungal Divers. 78: 54 (2016).

Index Fungorum number: IF 551714; Facesoffungi number: FoF 01632; 1 morphological species (Species Fungorum 2020), 1 species with molecular data.

Type species - Angustospora nilensis Abdel-Aziz, Fungal Divers. 78 : 54 (2016).

Notes - Angustospora is an aquatic genus, which was introduced based on morphology and phylogenetic analyses. Angustospora resembles Caryospora in having large ascospores with a median septum and additional septa near the poles of the ascospores. Angustospora differs from species of Caryospora in having smaller ascomata and 8-spored, clavate asci. Phylogenetic results placed this genus in Testudinaceae but distant from Caryospora ( $\mathrm{Li}$ et al. 2016a). This genus was collected from River Nile, Egypt, as a saprobe growing on submerged decayed wood with only the sexual morph (for morphology see Li et al. 2016a, Wijayawardene et al. 2018).

Halotestudina Dayarathne \& K.D. Hyde Mycosphere 11(1): 69 (2020).

Index Fungorum numbe: IF 556583; Facesoffungi number: FoF 06170; 1 morphological species (Species Fungorum 2020), 1 species with molecular data.

Type species - Halotestudina muriformis Dayarathne \& K.D. Hyde Mycosphere 11(1): 69 (2020).

Notes - Halotestudina is a genus described from marine habatits. It differs from other genera in Testudinaceae in having brown muriform ascospores with constriction at each septum. Halotestudina shares similar characters with Muritestudina in having muriform ascospores. However, Muritestudina is distinguished by its hyaline ascospores enclosed in a thick gelatinous sheath and its occurrence in terrestrial habitats (Wanasinghe et al. 2017c). Multi-gene phylogenetic analyses revealed that Halotestudina muriformis formed a separate clade within Testudianace with moderate bootstrap support, sharing a sister relation with Angustospora nilensis (MFLU 15-1511) and Trematosphaeria wegeliniana (CBS 123124). Cultures and sequence data are available for the type species.

Lepidosphaeria Parg.-Leduc, C. r. hebd. Séanc. Acad. Sci., Paris, Sér. D 270: 2786 (1970).

Index Fungorum number: IF 2747; Facesoffungi number: FoF 04643; 1 morphological species (Species Fungorum 2020), 1 species with molecular data. (1970).

Type species - Lepidosphaeria nicotiae Parg.-Leduc, Pubbl. Staz. Zool. Napoli, 1 270: 2786

Notes - Lepidosphaeria is distinguished from other genera in Testudinaceae by its ascospores that are 2-3-seriate, ornamented, finely echinulate, oblong, tuberculate with brown to pale brown, 1-septate and darker at septum, constricted at septum, minute granules (Hawksworth 1979, Doilom et al. 2018). Zopfia punctata was synonymized as Lepidosphaeria punctata by Hawksworth \& Booth (1974), later referred to as Zopfiofoveola punctata by Hawksworth (1979). Multi-gene sequence analyses showed that L. nicotiae nested with species of Ulospora and Verruculina (Schoch et al. 2009a). Cultures and molecular data are available for this taxon (Kruys \& Wedin 2009, Wijayawardene et al. 2018).

Lojkania Rehm, Növényt. Közlem. 4: 2 (1905). 
Index Fungorum number: IF 2919; Facesoffungi number: FoF 00580; 10 morphological species (Species Fungorum 2020), molecular data unavailable.

Type species - Lojkania hungarica Rehm, Növényt. Közlem. 4: 2 (1905).

Notes - Lojkania is typified by Lojkania melasperma (as L. hungarica) and was introduced by Rehm (1905) under Fenestellaceae based on its trabeculate pseudoparaphyses (Barr 1979a, 1987b, Hyde et al. 2013, Zhang et al. 2012b). It was earlier considered under Herpotrichia (Sivanesan 1972, 1984, von Arx \& Müller 1975, Barr 1984, Yuan \& Barr 1994). Barr (1984) recircumscribed Lojkania species from North America and distinguished the genus from Herpotrichia. Lojkania was transferred to Melanommatales by Eriksson \& Hawksworth (1991). Phookamsak \& Hyde (2015) excluded Lojkania from Fenestellaceae. Based on examination of the type material, they provisionally placed it under Testudinaceae due to its morphological similarities with Verruculina. Lojkania is distinguishable from Verruculina in having ovoid to obpyriform ascomata, smooth-walled ascospores and its occurrence in terrestrial habitats. Verruculina is an obligate marine taxon that has papillate ascomata and ascospores that are verrucose or verruculose. Lojkania is distinct from Fenestella in having immersed pseudoclypeate ascomata with short to long papilla, trabeculate pseudoparaphyses and didymosporous, brown ascospores (Hyde et al. 2013, Phookamsak \& Hyde 2015). Lojkania includes ten accepted names in Index Fungorum (2019). Five species have been referred to other genera based on molecular studies. The type species, Lojkania hungarica lacks molecular data (for morphology see Phookamsak \& Hyde 2015). Hence, fresh collections are needed to confirm its placement under Testudinaceae.

Muritestudina Wanasinghe, E.B.G. Jones \& K.D. Hyde, Studies in Fungi 2(1): 226 (2017). Index Fungorum number: IF 554051; Facesoffungi number: FoF 03866; 1 morphological species (Species Fungorum 2020), 1 species with molecular data.

Type species - Muritestudina chiangraiensis Wanasinghe, E.B.G. Jones \& K.D. Hyde, Studies in Fungi 2(1): 227 (2017).

Notes - The monotypic genus Muritestudina was reported as saprobic on dead twigs from a terrestrial habitat. Muritestudina chiangraiensis is distinct from other genera of Testudinaceae in having cylindrical-clavate asci and hyaline, smooth-walled, ellipsoidal, muriform ascospores with large guttules (Wanasinghe et al. 2017c). A comparison of morphological features of Muritestudina with the other seven genera of Testudinaceae was provided by Wanasinghe et al. (2017c).

Neotestudina Segretain \& Destombes, C. r. hebd. Séanc.Acad. Sci., Paris 253: 2579 (1961).

Index Fungorum number: IF 3484; Facesoffungi number: FoF 04644; 3 morphological species (Species Fungorum 2020), 1 species with molecular data.

Type species - Neotestudina rosatii Segretain \& Destombes,C. r. hebd. Séanc. Acad. Sci., Paris 253: 2579 (1961).

Notes - Neotestudina is distinguished from other genera of the family in having cleistothecioid and globose ascomata, opening by a split and broadly truncate ascospores (Barr 1990a). Barr (1990a) referred it to Didymosphaeriaceae based on its ascospore morphology. Subsequent phylogenetic studies based on sequence data obtained from Neotestudina rosatii confirmed its placement under Testudinaceae (Kruys et al. 2006). Neotestudina species have been recorded from Australia, Cameroun, Guinea, India Nigeria and the USA (Hawksworth 1979, Barr 1987b). They are reported as saprobes on dead wood and pathogens on humans (Barr 1987b, Hawksworth \& Diederich 1988, Pilsczek \& Augenbraun 2007, Taylor 2015). Cultures and sequence data are available for the type species (Wijayawardene et al. 2018, outline).

Ulospora D. Hawksw., Malloch \& Sivan., in Hawksworth, Can. J. Bot. 57: 96 (1979).

Index Fungorum number: IF 5664; Facesoffungi number: FoF 04645; 1 morphological species (Species Fungorum 2020), 1 species with molecular data.

Type species - Ulospora bilgramii (D. Hawksw., C. Booth \& Morgan-Jones) D. Hawksw., Malloch \& Sivan., Can. J. Bot. 57: 96 (1979).

EZopfia bilgramii D. Hawksw., C. Booth \& Morgan-Jones, Mycol. Pap. 135: 10 (1974) 
Notes - Ulospora is a monotypic genus characterized in having subglobose, carbonaceous ascomata, lacking ostioles, asci that are ovoid to pyriform and ellipsoidal, dark brown, 1-septate ascospores with 3-6 fissures and germ slits (Hawksworth 1979). It was reported from terrestrial and marine habitats, sediments and plant materials (see Zhang et al. 2008b, phylogeny), Lumbsch \& Huhndorf (2010, outline), Kirk et al. (2013, genus accepted), Jaklitsch et al. (2016a, classification), and Wijayawardene et al. (2018, outline). Cultures and molecular data are available for this genus.

Verruculina (Kohlm.) Kohlm. \& Volkm-Kohlm., Mycol. Res. 94: 689 (1990).

Index Fungorum number: IF 25469; Facesoffungi number: FoF 06535; 1 morphological species (Species Fungorum 2020), 1 species with molecular data. (1990).

Type species - Verruculina enalia Kohlm. \& Volkm-Kohlm., Mycol. Res. 94(5): 689

Notes - Verruculina is a monotypic and an obligate marine genus. It is characterized by ascomata that are subglobose, ampulliform or depressed ellipsoidal and papillate, cylindrical asci with a faint apical apparatus and ascospores that are dark brown, ellipsoidal, 1-septate, constricted at the septum, and verrucose to verruculose.

Verruculina enalia (Kohlm.) Kohlm. \& Volkm.-Kohlm., Mycol. Res. 94: 689 (1990).

Fig. 154

$\equiv$ Didymosphaeria enalia Kohlm., Ber. dt. bot. Ges. 79: 28 (1966).

Index Fungorum number: IF 128209; Facesoffungi number: FoF 05281.

Saprobic on wood in mangrove habitats. Sexual morph: Ascomata 200-470 $\mu \mathrm{m}$ high, 120 $400 \mu \mathrm{m}$ diam., $(\bar{x}=318 \times 250 \mu \mathrm{m}, \mathrm{n}=10)$ subglobose, ampulliform or depressed ellipsoidal, black, carbonaceous, partly or completely immersed, clypeate, solitary, ostiolate, papillate. Ostioles 60$130 \mu \mathrm{m}$ long, $40-80 \mu \mathrm{m}$ diam $(\bar{x}=90 \times 65 \mu \mathrm{m}, \mathrm{n}=5)$, periphysate. Peridium $12-50 \mu \mathrm{m}$ thick, onestratum, composed of about six or more layers of irregular roundish or elongate, thick-walled cells of textura angularis. Hamathecium comprising 1.5-2 $\mu \mathrm{m}$ diam., septate, rarely branched pseudoparaphyses. Asci $110-130 \times 8-12.5 \mu \mathrm{m}(\bar{x}=119 \times 9.5 \mu \mathrm{m}, \mathrm{n}=10)$, thick-walled, bitunicate, 8-spored, cylindrical, persistent, pedicellate, fissitunicate, with a faint apical apparatus. Ascospores 17.5-20 × 8-10 $\mu \mathrm{m}(\bar{x}=19 \times 9 \mu \mathrm{m}, \mathrm{n}=50), 2$-seriate, ellipsoidal, dark-brown, 1-septate, constricted at the septum, verrucose to verruculose, sometimes with a distinct small, hyaline tubercle at each apex, probably a germ pore. Asexual morph: Undetermined.

Culture characteristics - Ascospores germinating on $2 \%$ sea water agar within $24 \mathrm{~h}$ with germ tubes produced from terminal ends. Colonies on malt extract sea water agar fast growing, gray to pale brown, brown at margins, reverse brown, filamentous, lobate, reaching 20 to $40 \mathrm{~mm}$ in diameter in 25 days at room temperature.

Material examined - India, Tamil Nadu, Tiruvarur, Muthupet mangroves $\left(11.24^{\circ} \mathrm{N} 79.5^{\circ} \mathrm{E}\right)$, on decaying wood of Avicennia marina (Acanthaceae), 28 April 2015, B. Devadatha, AMH-9993, living culture NFCCI-4422.

GenBank numbers - ITS:MK028711, LSU: MK026758, rpb-2 = MN532684, SSU = MK026759, tef1 = MN532687.

Notes - Verruculina enalia shares similar characters with other genera of the family but is distinct in having papillate ascomata and ascospores that are verrucose or verruculose (Suetrong et al. 2009). Verruculina enalia was first described as Didymosphaeria enalia, later Barr (1990a) assigned it to Lokjania. It was transferred to Verruculina by Kohlmeyer \& Volkmann-Kohlmeyer (1990). Further molecular studies resulted in its placement under Testudinaceae (Suetrong et al. 2009). It is a core mangrove species, frequently reported from decaying mangrove wood and exclusively occurs in marine environments while other genera in the Testudinaceae are from terrestrial or freshwater habitats. Phylogenetic analysis (Fig. 42) and morphological characters (Fig. 154) indicate that our strain (NFCCI-4422) is identical to Verruculina enalia.

\section{Ecological and economic significance}

Testudinaceae is distributed worldwide. Taxa in this family are saprobic, parasitic on fungi and humans, collected from different substrates like soil, decaying plant material and woody 
substrata. They occur in terrestrial, freshwater and marine habitats (Hyde et al. 2013, Wanasinghe et al. 2017c).
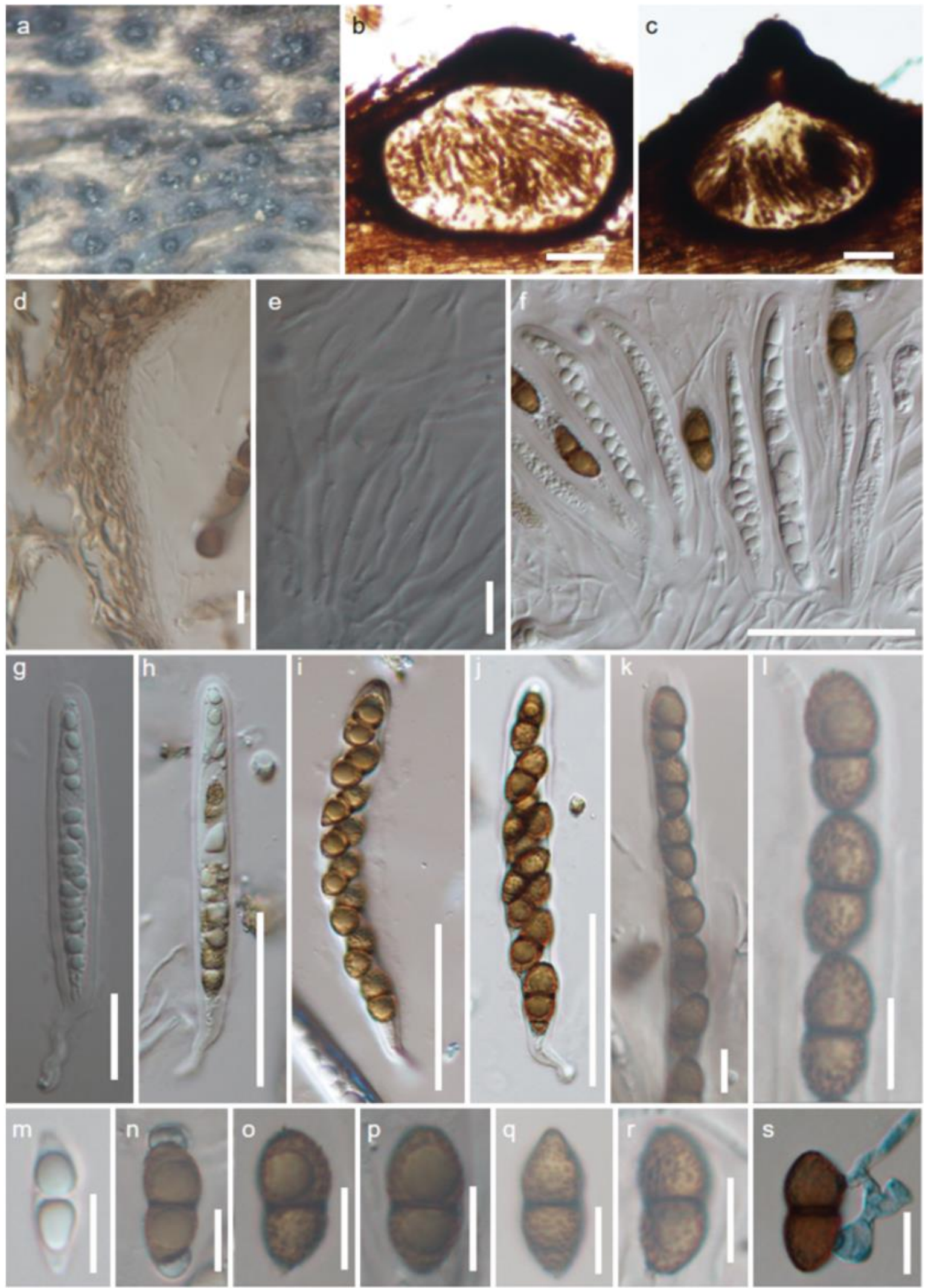

Figure 154 - Verrculilna enalia (AMH-9993). a, b Ascomata erumpent on Avicennia marina. b-c Longitudinal section of ascomata. d Section through peridium. e Pseudoparaphyses. $\mathrm{f}-\mathrm{k}$ Immature and mature asci. 1 Verrucose to verruculose ascospores with ornamentation. 
$\mathrm{m}-\mathrm{r}$ Immature hyaline and mature brown to dark brown ascospores. s Germinating ascospore stain in cotton blue. Scale bars: $\mathrm{b}, \mathrm{c}=100 \mu \mathrm{m}, \mathrm{f}, \mathrm{h}-\mathrm{k}=50 \mu \mathrm{m}$. $\mathrm{d}, \mathrm{e}, \mathrm{m}-\mathrm{s}=10 \mu \mathrm{m}$.

Tetraplosphaeriaceae Kaz. Tanaka \& K. Hiray., Stud. Mycol. 64: 177 (2009).

Index Fungorum number: IF 515253; Facesoffungi number: FoF 06665, 41 species.

Mostly saprobic on decaying bamboo, some soil and water inhabiting. Sexual morph: Ascomata scattered to clustered, immersed to superficial, globose to subglobose, or oval to elongate, glabrous or with brown hyphae at sides. Beak absent or short-papillate to cylindrical, central, with periphyses. Peridium composed of rectangular to polygonal or cylindrical, hyaline to brown cells, sometimes with rim-like structure at the sides. Hamathecium comprising septate, branched, cellular or trabeculate pseudoparaphyses. Asci 8-spored, fissitunicate, cylindrical to clavate, short-stalked, sometimes with an ocular chamber. Ascospores 1-2-seriate, narrowly fusiform to broadly cylindrical, straight or slightly curved, hyaline to pale brown, 1-3-septate, constricted at the septum, smooth, surrounded by an entire mucilaginous sheath or narrow appendage-like sheath. Asexual morph: Hyphomycetous. Colonies on natural substrate effuse, black, scattered. Conidiophores micronematous to macronematous, erect, unbranched, septate, brown. Conidiogenous cells monoblastic, terminal or indistinguishable from creeping hyphae. Conidia solitary, globose to long obpyriform, composed of 3-8 columns or internal hyphal structure, brown to dark brown, mostly verrucose at the base, with 2-8 setose appendages arising from apical or/and basal part.

Type - Tetraploa Berk. \& Broome.

Notes - Tanaka et al. (2009) established Tetraplosphaeriaceae typified by Tetraplosphaeria to accommodate five new genera, Polyplosphaeria, Pseudotetraploa, Quadricrura, Tetraplosphaeria and Triplosphaeria. However, Tetraplosphaeria was treated as a synonym of Tetraploa due to nomenclatural priority. Most Tetraplosphaeriaceae species were reported from bamboo (Tanaka et al. 2009, Li et al. 2016a), while Tetraploa species occur on diverse hosts (Hyde et al. 2013). Species in this family have massarina-like sexual morphs which are characterized by hyaline, 1-3-septate ascospores surrounded by sheath, and asexual morphs which are characterized by conidia with setose appendages (Tanaka et al. 2009, Hyde et al. 2013, Tibpromma et al. 2018).

Tetraploa Berk. \& Broome, Ann. Mag. nat. Hist., Ser. 2 5: 459 (1850).

= Tetraplosphaeria Kaz. Tanaka \& K. Hirayama, Studies in Mycology 64: 177 (2009).

Index Fungorum number: IF 10199; Facesoffungi number: FoF 06666; 15 morphological species (Species Fungorum 2020), 8 species with molecular data (Hyde et al. 2020b).

Type species - Tetraploa aristata Berk. \& Broome, Annals and Magazine of Natural History 5: 459 (1850).

Notes - Tetraploa is the type genus of Tetraplosphaeriaceae, introduced by Berkeley \& Broome (1850) based on T. aristate. Tanaka et al. (2009) introduced sexual morph genus Tetraplosphaeria with Tetraploa sensu stricto asexual morphs observed from culture. The sexual morph is characterized by globose to subglobose, glabrous ascomata with short-papillate to cylindrical beak, fissitunicate, cylindrical to clavate, short-stalked, 8-spored asci, and fusiform, hyaline, 1-septate ascospores with mucilaginous appendage-like sheath. (Tanaka et al. 2009). Asexual morph is characterized by micronematous conidiophores, monoblastic conidiogenous cells, and short-cylindrical, brown conidia with 4 setose appendages at the apex and conidia composed of 4 columns (Ellis 1971, Tanaka et al. 2009). Tetraploa species have usually been reported saprobic on herbaceous plants or rotten wood (Ellis 1949, Révay 1993), while they can also be isolated from soil or raindrops (Ando 1992, Watanabe 2002).

\section{Other genera included}

Byssolophis Clem., The genera of Fungi 83: 286 (1931).

Index Fungorum number: IF 706; Facesoffungi number: FoF 06225; 2 morphological species (Species Fungorum 2020), 1 species with molecular data (Schoch et al. 2009, Zhang et al. 2009). 
Type species - Byssolophis byssiseda (Flageolet \& Chenant.) Clem., The genera of Fungi: 286 (1931).

$\equiv$ Schizostoma byssisedum Flageolet \& Chenant., in Chenantaise, Bull. Soc. mycol. Fr. 35: 125 (1919).

Notes - Taxonomy of Byssolophis has long been controversial. The genus was included in Lophiostomataceae (von Arx \& Müller 1975, Barr 1979a, Lumbsch \& Huhndorf 2010), but it was referred to Pleosporales genera incertae sedis based on molecular data by Schoch et al. (2009a) and Zhang et al. (2009c, 2012b). Pem et al. (2019b) accepted Byssolophis in Tetraplosphaeriaceae based on morphology and phylogenetic analyses. Byssolophis is characterized by superficial or immersed, carbonaceous, glabrous ascomata with a slit-like ostiole, 8-spored, bitunicate, fissitunicate, short-pedicellate asci with an ocular chamber, and overlapping 2-seriate, fusiform to cylindrical, 1-3-septate, hyaline to pale brown ascospore surrounded by a narrow appendagelike sheath (Pem et al. 2019b). Asexual morph of Byssolophis has not been reported.

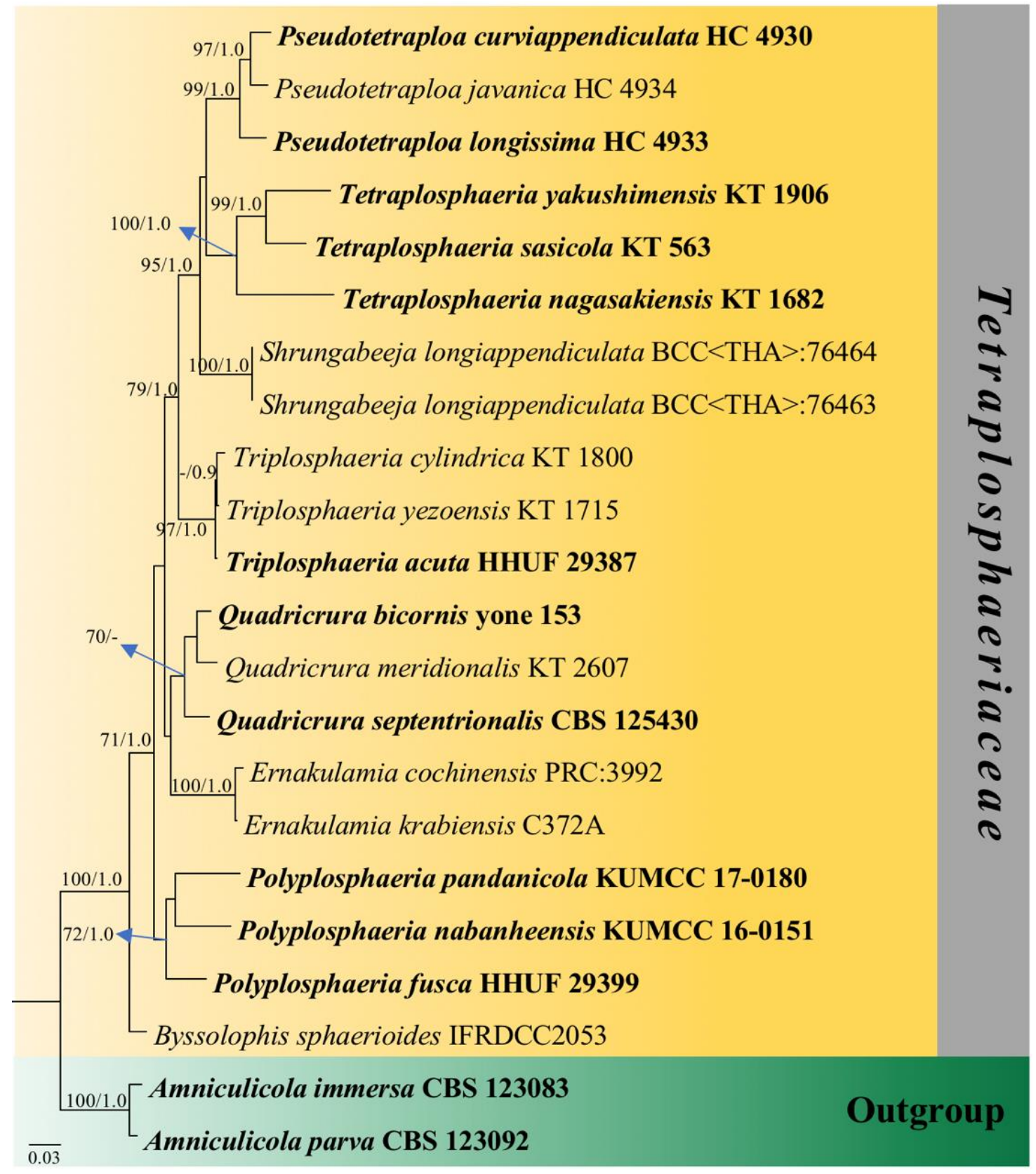

Figure 155 - Phylogram generated from maximum likelihood analysis (RAxML) of genera in Tetraplosphaeriaceae based on ITS, LSU, SSU, tef1 and tub2 sequence data. Maximum likelihood bootstrap values equal or above $70 \%$, Bayesian posterior probabilities equal or above 0.90 
(MLBS/PP) are given at the nodes. An original isolate number is noted after the species name. The tree is rooted to Amniculicola immersa (CBS 123083) and A. parva (CBS 123092). The ex-type strains are indicated in bold. Hyphen (-) represents support values below $70 \%$ MLBS and 0.90 PP.

Ernakulamia Subram., Kavaka 22/23: 67 (1994).

Index Fungorum number: IF 28737; Facesoffungi number: FoF 06667; 3 morphological species (Species Fungorum 2020), 3 species with molecular data (Delgado et al. 2017, Jayasiri et al. 2019).

Type species - Ernakulamia cochinensis (Subram.) Subram., Kavaka 22/23: 67 (1994).

三 Petrakia cochinensis Subram., Beih. Sydowia 1: 15 (1957).

Notes - Subramanian (1994) introduced Ernakulamia for Petrakia cochinensis. Delgado et al. (2017) provided sequence data for E. cochinensis and accommodated it in Tetraplosphaeriaceae. Jayasiri et al. (2019) described the second species, E. krabiensis from decaying pods septum of Acacia sp. Hyde et al. (2020b) described the third species, E. tanakae from a decaying spathe of Cocos nucifera and presented an updated phylogenetic tree for Tetraplosphaeriaceae. Ernakulamia is characterized by micronematous or semi-macronematous conidiophores and brown, muriform conidia with appendages (Subramanian 1994, Jayasiri et al. 2019, Hyde et al. 2020b).

Polyplosphaeria Kaz. Tanaka \& K. Hirayama, Studies in Mycology 64: 192 (2009).

Index Fungorum number: IF 515256; Facesoffungi number: FoF 06668; 5 morphological species (Species Fungorum 2020), 5 species with molecular data (Tibpromma et al. 2018).

Type species - Polyplosphaeria fusca Kaz. Tanaka \& K. Hirayama, Studies in Mycology 64: 193 (2009).

Notes - Li et al. (2016a) described the second species $P$. thailandica saprobic on decaying bamboo. Tibpromma et al. (2018) introduced three Polyplosphaeria species from Pandanaceae and provide an updated synopsis of its asexual morph. Sexual morph is characterized by globose ascomata with central beak, fissitunicate, clavate, short-stalked, 8-spored asci, and 2-seriate, fusiform, 1(-3)-septate hyaline to pale olive-brown ascospores with an entire sheath (Tanaka et al. 2009). Its asexual morph has micronematous conidiophores, monoblastic conidiogenous cells and brown, muriform, globose, obovoid, pyriform, ellipsoidal conidia with one or two forms of appendages (Tanaka et al. 2009, Li et al. 2016a, Tibpromma et al. 2018).

Polyplosphaeria thailandica C.G. Lin, Yong Wang bis \& K.D. Hyde, Fungal Divers. 78 : 55 (2016).

Index Fungorum number: IF 551791; Facesoffungi number: FoF 01676.

Fig. 156

Description - see Li et al. (2016a).

Material examined - Thailand, Phetchaburi, Cha-am District, Kao Yai, Khao Nang Panthurat Forest Park, $12^{\circ} 49^{\prime} 48.5^{\prime \prime} \mathrm{N} 99^{\circ} 57^{\prime} 05.5^{\prime \prime} \mathrm{E}$, on decaying bamboo, 28 July 2015, Chuan-Gen Lin, KNP 8-2 (MFLU 15-3273, holotype)

Pseudotetraploa Kaz. Tanaka \& K. Hirayama, Studies in Mycology 64: 193 (2009).

Index Fungorum number: IF 515257; Facesoffungi number: FoF 06669; 4 morphological species (Species Fungorum 2020), 4 species with molecular data (Tanaka et al. 2009, Hyde et al. 2020).

Type species - Pseudotetraploa curviappendiculata (Sat. Hatak., Kaz. Tanaka \& Y. Harada) Kaz. Tanaka \& K. Hirayama, Studies in Mycology 64: 195 (2009).

$\equiv$ Tetraploa curviappendiculata Sat. Hatak., Kaz. Tanaka \& Y. Harada, Mycoscience 46(3): 196 (2005).

Notes - Tanaka et al. (2009) transferred three species previously identified as Tetraploa and established Pseudotetraploa. Hyde et al. (2020b) described the fourth species, P. rajmachiensis from decaying culms of Dendrocalamus stocksii. Conidial morphology of Pseudotetraploa resembles Tetraploa, but Pseudotetraploa differs in having obpyriform to long obpyriform, 
distoseptate conidia with generally short and curved setose appendages. Sexual morph of Pseudotetraploa is unknown.

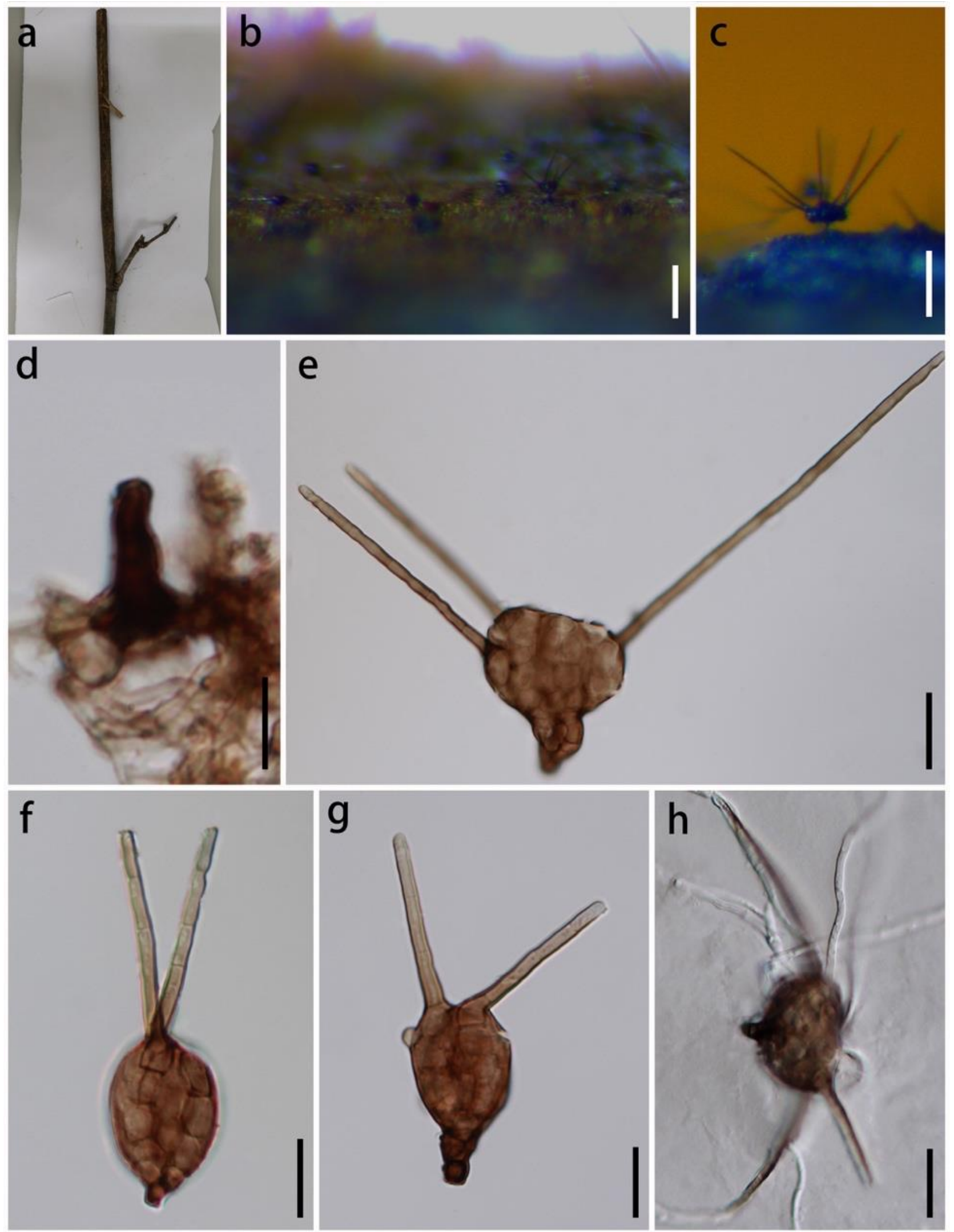

Figure 156 - Polyplosphaeria thailandica (MFLU 15-3273, holotype). a Bamboo host. b, c Colonies on natural substrate. d Conidiophore. e-g Conidia. h Germinated spore. Scale bars: b, $\mathrm{c}=100 \mu \mathrm{m}, \mathrm{d}=10 \mu \mathrm{m}, \mathrm{e}=20 \mu \mathrm{m}, \mathrm{f}, \mathrm{g}=15 \mu \mathrm{m}, \mathrm{h}=30 \mu \mathrm{m}$. 
Quadricrura Kaz. Tanaka, K. Hirayama \& Sat. Hatak., Studies in Mycology 64: 196 (2009).

Index Fungorum number: IF 515258; Facesoffungi number: FoF 06670; 3 morphological species (Species Fungorum 2020), 3 species with molecular data (Tanaka et al. 2009).

Type species - Quadricrura septentrionalis Kaz. Tanaka, K. Hirayama \& Sat. Hatak., Studies in Mycology 64: 198 (2009).

Notes - Quadricrura was introduced to accommodate $Q$. bicornis, $Q$. meridionalis and $Q$. septentrionalis. It is characterized by micronematous conidiophores, globose to subglobose, brown to dark brown conidia with two forms of appendages. Quadricrura resembles some Polyplosphaeria species in forming two forms of appendages from both apical and basal part of conidia. Sexual morph of Quadricrura is unknown.

Shrungabeeja V.G. Rao \& K.A. Reddy, Indian Journal of Botany 4 (1): 109 (1981).

Index Fungorum number: IF 9919; Facesoffungi number: FoF 06671; 5 morphological species (Species Fungorum 2020), 2 species with molecular data.

Type species - Shrungabeeja vadirajensis V.G. Rao \& K.A. Reddy, Indian Journal of Botany 4 (1): 113 (1981).

Notes - Zhang et al. (2009a) described S. begonia and S. melicopes from China. Shrungabeeja was referred to as Ascomycota, genera incertae sedis (Hyde et al. 2011, Wijayawardene et al. 2012). Ariyawansa et al. (2015a) provided sequence data for $S$. longiappendiculata and assigned Shrungabeeja in Tetraplosphaeriaceae. Unlike other genera in Tetraplosphaeriaceae, Shrungabeeja has macronematous, long conidiophores and subglobose or turbinate, aseptate, pedicellate conidia with 3-7 filiform or horn-like appendages (Zhang et al. 2009a, Ariyawansa et al. 2015a). Sexual morph of Shrungabeeja is unknown.

Triplosphaeria Kaz. Tanaka \& K. Hirayama, Studies in Mycology 64: 186 (2009).

Index Fungorum number: IF 515255; Facesoffungi number: FoF 06672; 4 morphological species (Species Fungorum 2020), 4 species with molecular data (Tanaka et al. 2009).

Type species - Triplosphaeria maxima Kaz. Tanaka \& K. Hirayama, Studies in Mycology 64: 188 (2009).

Notes - Triplosphaeria was introduced to accommodate species with Massarina-like sexual morph and Tetraploa-like asexual morph. Sexual morph of Triplosphaeria is characterized by subglobose ascomata with none to short beak, fissitunicate, 8-spored, cylindrical to clavate, shortstalked asci, and fusiform, 1-septate, hyaline ascospores with entire sheath. Its asexual morph has micronematous conidiophores, monoblastic conidiogenous cells, and ovoid to obpyriform, brown conidia with 3 setose appendages and conidia composed of 3 columns with distosepta (Tanaka et al. 2009).

\section{Ecological and economic significance}

Tetraplosphaeriaceae species seem to have a specific host preference, bamboo, especially Polyplosphaeria, Pseudotetraploa, Quadricrura and Triplosphaeria and they might play important role in bamboo protection.

Thyridariaceae Q. Tian \& K.D. Hyde, in Hyde et al., Fungal Divers. 63: 254 (2013).

Index Fungorum number: IF 805172; Facesoffungi number: FoF 08374, 43 species.

Saprobic under periderm or immersed in woody plant substrates. Sexual morph: Ascomata perithecial, immersed or semi-immersed, gregarious, circular, globose, coriaceous, black, smoothwalled, with or without a subiculum. Peridium 2-layered, outer layer composed of irregular, thickwalled, brown to black cells of textura angularis, and inner layer composed of slightly, larger cells of textura angularis. Hamathecium comprising long, branched or simple, septate, cellular, encircling the asci and embedded in a gelatinous matrix. Asci 8-spored, bitunicate, fissitunicate, thick-walled, cylindrical to subclavate, with a pedicel, apically rounded with an ocular chamber. Ascospores overlapping 1-2-seriate, ellipsoid to fusiform, oblong, hyaline to pale brown or dark brown to blackish-brown, 2-3-septate, or multi-septate or muriform, constricted at the medium 
septum, septa darkened, straight or curved, ends rounded, smooth-walled, with or without a mucilaginous sheath. Asexual morph: Cyclothyrium.

Type - Thyridaria Sacc.

Notes - Hyde et al. (2013) introduced Thyridariaceae to accommodate Thyridaria based on its unique morphology and clustering in a unique family in the Dothideomycetes. The placement of Thyridaria has been unclear with the genus referred to Didymosphaeriaceae, Lophiostomataceae, Melanommataceae, Platystomaceae, Pleosporaceae, and Sphaeriaceae (Wehmeyer 1941, 1975, Munk 1957, Luttrell 1973, Müller \& von Arx 1973, Dennis 1978, Barr 1979a, b, 2003, Mugambi \& Huhndorf 2009a, b). Schoch et al. (2009a) confirmed the placement of Thyridaria in the Pleosporales with strong support. Jaklitsch \& Voglmayr (2016) introduced a new genus, Parathyridaria and provided an update multi-gene analyses that indicated Roussoellaceae should be a synonym of Thyridariaceae and accepted five genera in Thyridariaceae, Neoroussoella, Thyridaria, Roussoella, Roussoellopsis and Parathyridaria. However, Roussoellaceae is a wellresolved family in Pleosporales which is in agreement with the results of several studies (Liu et al. 2014, Ariyawansa et al. 2015a, Dai et al. 2017, Tibpromma et al. 2017, Hyde et al. 2018, Wanasinghe et al. 2018c, Wijayawardene et al. 2018, Jayasiri et al. 2019, Jiang et al. 2019, Phookamsak et al. 2019). Wanasinghe et al. (2018c) introduced three new genera, Cycasicola, Neoconiothyrium and Pararoussoella in Thyridariaceae. However, Neoconiothyrium and Pararoussoella have been transferred to Roussoellaceae based on good support in a phylogenetic study (Jayasiri et al. 2019, Phookamsak et al. 2019). Devadatha et al. (2018b) introduced a new marine genus Thyridariella with two species based on morphological differences and phylogenetic support. Phookamsak et al. (2019) established Liua. Mapook et al. (2020) subsequently introduced Chromolaenomyces and Pseudothyridariella in Thyridariaceae. Thus, there are seven genera accepted in Thyridariaceae, viz. Chromolaenomyces, Cycasicola, Liua, Parathyridaria, Pseudothyridariella, Thyridaria and Thyridariella with morphological data and phylogenetic analyses.

Thyridaria Sacc., Grevillea 4(no. 29): 21 (1875).

Index Fungorum number: IF 5463; Facesoffungi number: FoF 08375; 30 morphological species (Species Fungorum 2020), 3 species with molecular data.

Type species - Thyridaria broussonetiae (Sacc.) Traverso, Fl. ital. crypt., Pars 1: Fungi. Pyrenomycetae. Xylariaceae, Valsaceae, Ceratostomataceae (Florence) 1(2): 301 (1906).

三 Cucurbitaria broussonetiae Sacc., Atti Soc. Veneto-Trent. Sci. Nat. 2(1): 166 (1873).

Notes - The placement of Thyridaria has been uncertain and it was assigned to Didymosphaeriaceae, Melanommataceae, Platystomaceae, Pleosporaceae and Sphaeriaceae at various times (Wehmeyer 1941, 1975, Munk 1957, Luttrell 1973, Müller \& Arx 1973, Dennis 1978, Barr 1979a, b, 2003). Barr (2003) summarized the various descriptions of Thyridaria and suggested that the genus can be characterized in having an ample subiculum surrounding ascomata, which formed under the periderm or in woody plant substrates, with ascospores having both thickened and darkened septa and walls. Jaklitsch \& Voglmayr (2016) examined several thyridarialike genera, and applied a multi-gene analysis to clarify intergeneric taxonomic affinities of Thyridaria in the Pleosporales.

Thyridaria broussonetiae (Sacc.) Traverso, Fl. ital. crypt., Pars 1: Fungi. Pyrenomycetae. Xylariaceae, Valsaceae, Ceratostomataceae (Florence) 1(2): 301 (1906).

Index Fungorum number: IF 569945; Facesoffungi number: FoF 08376.

Fig. 157

三 Cucurbitaria broussonetiae Sacc., Atti Soc. Veneto-Trent. Sci. Nat. 2(1): 166 (1873).

= Thyridaria incrustans Sacc., Atti Soc. Veneto-Trent. Sci. Nat. 2(1): 170 (1873)

= Melogramma incrustans (Sacc.) Cooke, Grevillea 13(no. 68): 109 (1885)

Description - see Hyde et al. (2013).

Material examined - Italy: Veneto, Padova, in rotting branch of Broussonetia papyrifera, Martio 1873, (S F6232, holotype of Thyridaria incrustans). 


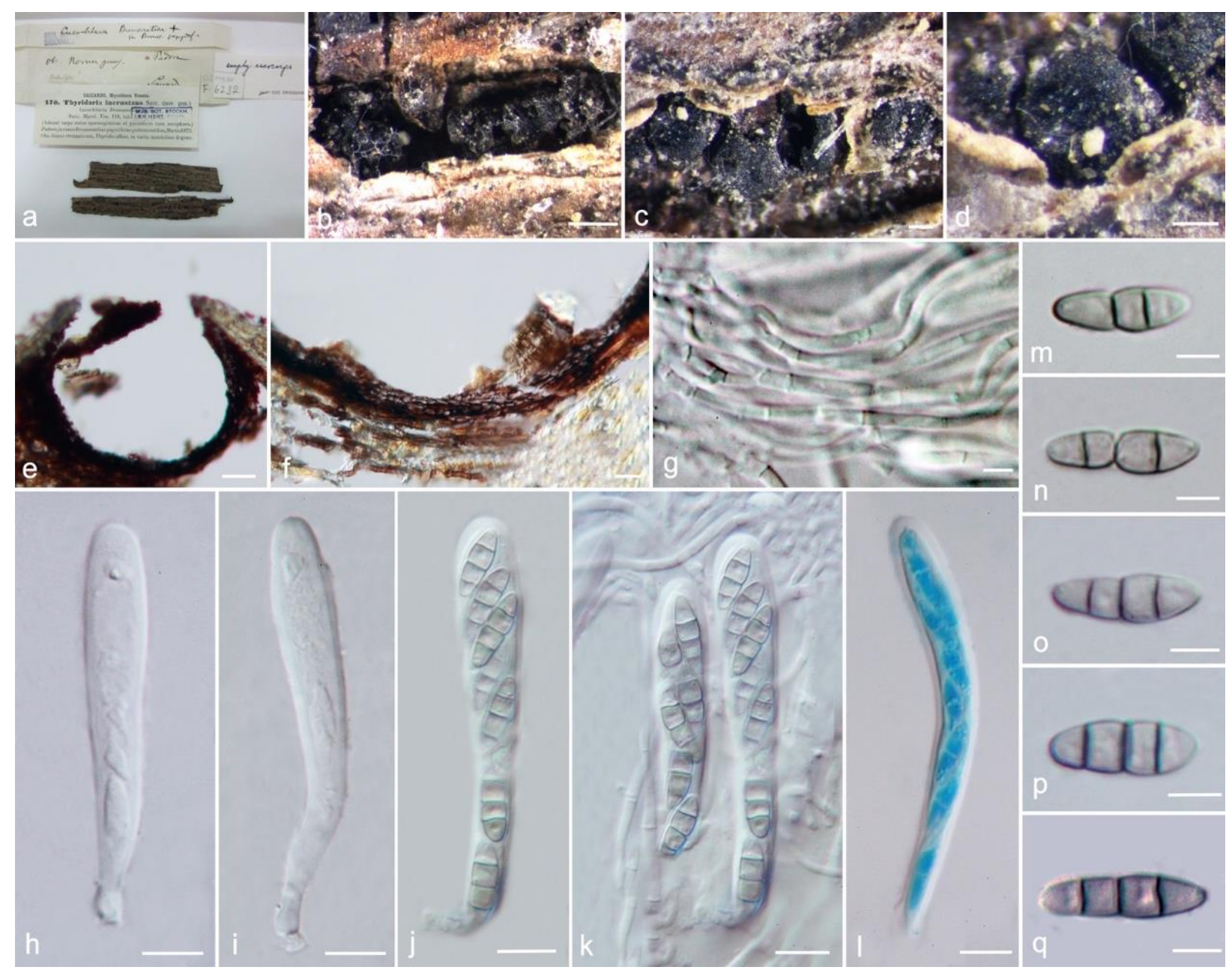

Figure 157 - Thyridaria broussonetiae (S F6232, holotype). a Herbarium material. b-d Ascomata semi-immersed in the host. e Vertical hand section of ascoma. f Vertical hand section through peridium. g Pseudoparaphyses. $\mathrm{h}-1$ Asci with ascospores (Note 1 shows asci stain with cotton blue). $\mathrm{m}-\mathrm{q}$ Ascospores. Scale bars: $\mathrm{b}=500 \mu \mathrm{m}, \mathrm{c}, \mathrm{d}=200 \mu \mathrm{m}, \mathrm{e}=50 \mu \mathrm{m}, \mathrm{f}=25 \mu \mathrm{m}, \mathrm{g}, \mathrm{m}-\mathrm{q}=5 \mu \mathrm{m}, \mathrm{h}-1$ $=10 \mu \mathrm{m}$.

\section{Other genera included}

Chromolaenomyces Mapook \& K.D. Hyde, Fungal Divers 101: 96 (2020).

Index Fungorum number: IF 557333; Facesoffungi number: FoF 07824; 1 morphological species (Mapook et al. 2020), 1 species with molecular data.

Type species - Chromolaenomyces appendiculatus Mapook \& K.D. Hyde, Fungal Divers 101: 96 (2020).

Notes - Chromolaenomyces was introduced to accommodate Chromolaenomyces appendiculatus as a saprobe on dead stems of Chromolaena odorata by Mapook et al. (2020). It is characterized by coriaceous, globose to subglobose, light brown to brown cylindrical ascomata with a protruding ostiole, cylindrical asci with a short pedicel and 1-seriate, irregular arrangement, oval to broadly fusiform, aseptate ascospores with a narrow sheath, drawn out to form polar appendages from both ends. These characters differentiate it from Thyridariella which has clavate asci with moderately long pedicel and muriform ascospores, however, Chromolaenomyces species have cylindrical asci with a short pedicel and aseptate ascospores (Devadatha et al. 2018b, Mapook et al. 2020). Phylogenetically, Chromolaenomyces appendiculatus forms a distinct clade and a sister relationship with Thyridariella mangrovei (Mapook et al. 2020). Therefore, Chromolaenomyces was introduced with one species based on multi-gene analyses with LSU, ITS, rpb-2, SSU and tef1 sequence data and its morphological distinctness. 
Cycasicola Wanas., E.B.G. Jones \& K.D. Hyde, Fungal Divers. 89: 161 (2018).

Index Fungorum number: IF 554213; Facesoffungi number: FoF 04052; 2 morphological species (Species Fungorum 2020), 2 species with molecular data.

Type species - Cycasicola goaensis Wanas., E.B.G. Jones \& K.D. Hyde, Fungal Divers. 89: 161 (2018).

Notes - Cycasicola was established to accommodate the type species Cycasicola goaensis based on phylogenetic analyses (Wanasinghe et al. 2018c) and it was isolated form petiole of Cycas sp. from India. The genus clustered with Pararoussoella as a single lineage. The genus is characterized by globose, dark brown, unilocular conidiomata with papillate ostiole, phialidic, ampulliform, hyaline conidiogenous cells and fusiform to cylindrical, continuous, hyaline to pale brown, aseptate, guttulate conidia (Wanasinghe et al. 2018c). Jayasiri et al. (2019) introduced the second species $C$. leucaenae based on morphological distinctiveness and phylogenetic support (Jeewon \& Hyde 2016, Jayasiri et al. 2019).

Liua Phookamsak \& K.D. Hyde, Fungal Divers. 95: 1-273 (2019).

Index Fungorum number: IF 556175; Facesoffungi number: FoF 05709; 1 morphological species (Species Fungorum 2020), 1 species with molecular data.

Type species - Liua muriformis Phookamsak \& K.D. Hyde, in Phookamsak et al., Fungal Divers. 95: 1-273 (2019).

Notes - Phookamsak et al. (2019) established Liua to accommodate a novel species Liua muriformis already introduced above in Thyridariaceae based on morphological features and phylogenetic analyses. It is characterized by uni-loculate, globose to subglobose, dark brown to black conidiomata, holoblastic, phialidic, ampulliform to cylindrical, aseptate, occasionally 1-2septate, hyaline conidiogenous cells and phragmosporous to muriform, oblong to ellipsoidal or obovoid, dark brown conidia. The type species L. muriformis is phylogenetically related to Cycasicola goaensis and C. leucaenae. However, L. muriformis has dark brown, muriform or phragmosporous conidia, $C$. goaensis and C. leucaenae have pale yellowish, aseptate conidia (Wanasinghe et al. 2018c, Jayasiri et al. 2019).

Parathyridaria Jaklitsch \& Voglmayr, Stud. Mycol. 85: 48 (2016).

Index Fungorum number: IF 817775; Facesoffungi number: FoF 08377; 5 morphological species (Species Fungorum 2020), 5 species with molecular data.

Type species - Parathyridaria ramulicola Jaklitsch, J. Fourn. \& Voglmayr, Stud. Mycol. 85: 48 (2016).

Notes - Jaklitsch \& Voglmayr (2016) established Parathyridaria to accommodate Parathyridaria percutanea and $P$. ramulicola (type species). Parathyridaria was isolated from plant substrates or sometimes reported as a human pathogen (Jaklitsch \& Voglmayr 2016, Tibpromma et al. 2017, Crous et al. 2018b, Wanasinghe et al. 2018c). The genus is characterized by immersed, globose, grey to black ascomata without subiculum, papillate and periphysate ostioles, branched and trabeculate pseudoparaphyses, bitunicate, narrowly clavate asci, fusoid, where upper part is slightly broader than the lower part, multi-septate or 1-septate, pale to greyish brown, guttulate ascospores, with occasionally a hyaline gelatinous sheath, globose to subglobose, black pycnidia, with thin pseudoparenchymatous wall (Jaklitsch \& Voglmayr 2016, Tibpromma et al. 2017), phialidic conidiogenous cells, ellipsoid, unicellular and hyaline to pale brown conidia (Ahmed et al. 2014a). Since Parathyridaria has been introduced in Thyridariaceae (Dothideomycetes), many species were subsequently transferred to this genus based on morphological distinctiveness and phylogenetic evidence (Jaklitsch \& Voglmayr 2016, Tibpromma et al. 2017, Crous et al. 2018b, Wanasinghe et al. 2018c). Parathyridaria comprises five accepted species, $P$. percutanea, $P$. philadelphi, $P$. ramulicola, $P$. robiniae, and $P$. rosae.

Pseudothyridariella Mapook \& K.D. Hyde, Fungal Divers 101: 98 (2020).

Index Fungorum number: IF557357; Facesoffungi number: FoF 07826 - 2 morphological species (Mapook et al. 2020), 2 species with molecular data. 
Type species - Pseudothyridariella chromolaenae Mapook \& K.D. Hyde, Fungal Divers 101: 98 (2020).

Notes - Pseudothyridariella was introduced to accommodate the type species Pseudothyridariella chromolaenae and a new combination species P. mahakashae (Mapook et al. 2020). The genus is primarily characterized by immersed, obpyriform, yellowish brown to brown ascomata with a protruding ostiole, cylindric-clavate asci and hyaline to dark brown, ellipsoid to broadly fusiform, muriform ascospores surrounded by a hyaline gelatinous sheath (Mapook et al. 2020). Pseudothyridariella species resemble Thyridariella as both genera have ellipsoid to broadly fusiform, muriform ascospores with a hyaline gelatinous sheath (Devadatha et al. 2018b, Mapook et al. 2020). However, Parathyridaria has ascospores with a hyaline gelatinous sheath which is constricted at the central septum, while Thyridariella has ascospores surrounded by a wide circular gelatinous sheath, not constricted at the central septum (Devadatha et al. 2018b, Mapook et al. 2020). Phylogenetically, Pseudothyridariella chromolaenae forms a sister clade with $P$. mahakashae and clustered with other genera in Thyridariaceae with strong bootstrap support (Mapook et al. 2020).

Thyridariella Devadatha, V.V. Sarma, K.D. Hyde, D.N. Wanas. \& E.B.G. Jones, Mycol. Progr.: 17 (7): 797 (2018).

Index Fungorum number: IF 823259; Facesoffungi number: FoF 03860; 2 morphological species (Species Fungorum 2020), 2 species with molecular data.

Type species - Thyridariella mangrovei Devadatha, V.V. Sarma, K.D. Hyde, D.N. Wanas. \& E.B.G. Jones, Mycol. Progr. 17 (7): 798 (2018).

Notes - Thyridariella was introduced to accommodate two marine species, T. mangrovei and T. mahakoshae which are regarded as saprobes on decaying wood of Avicennia marina (Devadatha et al. 2018b). The genus is primarily characterized by semi-immersed to immersed, globose to subglobose, ostiolate ascomata with reddish brown neck, clavate asci with moderately long pedicel and hyaline, muriform, fusiform to ellipsoidal, guttulate ascospores with a mucilaginous sheath (Devadatha et al. 2018b). Thyridariella species resemble Parathyridaria as both genera have a lateral thickening of the ostiolar neck and guttulate ascospores (Jaklitsch \& Voglmayr 2016, Devadatha et al. 2018b). However, Parathyridaria has pale to greyish brown ascospores that are occasionally muriform while Thyridariella has hyaline, muriform ascospores (Jaklitsch \& Voglmayr 2016, Devadatha et al. 2018b). Phylogenetically, T. mangrovei and T. mahakoshae clustered together with strong support and formed a sister relationship with Cycasicola and Liua (Devadatha et al. 2018b, Phookamsak et al. 2019).

\section{Ecological and economic significance}

Most Thyridariaceae species are reported as saprobes or endophytes occurring on Acer, Avicennia, Leucaena, Lonicera, Ribes, Sambucus and Ulmus (Jaklitsch \& Voglmayr 2016, Tibpromma et al. 2017, Crous et al. 2018b, Wanasinghe et al. 2018c). Parathyridaria percutanea was reported causing human subcutaneous mycoses in two clinical isolates (Ahmed et al. 2014a, b).

Torulaceae Corda, Deutschl. Fl., 3 Abt. (Pilze Deutschl.) 2: 71 (1829).

Index Fungorum number: IF 81478; Facesoffungi number: FoF 01740, 85 species.

Saprobic in terrestrial and freshwater habitats. Sexual morph: Undetermined. Asexual morph: Hyphomycetous. Colonies discrete, dark brown to black, effuse, dry, velvety. Mycelium mostly immersed. Conidiophores erect, or reduced to conidiogenous cells, brown, subcylindrical, with or without apical branches. Conidiogenous cells mono- to polyblastic, doliiform to ellipsoid or clavate, brown, smooth to verruculose, sometimes cupulate. Conidia mostly subcylindrical, phragmosporous, sometimes in branched chains, sometimes solitary, acrogenous, brown, dry, septate, smooth-walled to verrucose. Conidial secession schizolytic.

Type - Torula Pers.

Notes - Torulaceae is known only from its asexual characters. It is characterized by immersed mycelium, erect, micro- or macronematous, straight or flexuous, subcylindrical 
conidiophores, with or without apical branches and doliiform to ellipsoid or clavate, brown, smooth to verruculose, and mono- to polyblastic conidiogenous cells. Conidia are subcylindrical, phragmosporous, acrogenous, brown, dry, and smooth to verrucose, characteristically produced in branched chains (Crous et al. 2015a, Hyde et al. 2016, Su et al. 2016, Li et al. 2017a). Crous et al. (2015a) accepted Dendryphion and Torula in this family based on phylogenetic relationships of Torulaceae. Currently, Dendryphion, Neotorula, Rostriconidium, Rutola, Sporidesmioides and Torula are accommodated in Torulaceae (Hyde et al. 2016, Li et al. 2016b, Su et al. 2016, Crous et al. 2019c).

Torula Pers., Ann. Bot. (Usteri) 15: 25 (1795).

Index Fungorum number: IF 10248; Facesoffungi number: FoF 01740; 49 morphological species (Species Fungorum 2020, this study), 17 species with molecular data (Li et al. 2020a, this study).

Type species - Torula herbarum (Pers.) Link.

$\equiv$ Monilia herbarum Pers., Syn. meth. fung. (Göttingen) 2: 693 (1801).

Notes - Torula is characterized by terminal or lateral, monoblastic or polyblastic conidiogenous cells which have a basally thickened and heavily melanized wall, with the apex thinwalled and frequently collapsing and becoming coronate (Crane \& Miller 2016, Li et al. 2017a). Crous et al. (2015a) introduced three new species and discussed the phylogenetic relationships of Torula. Su et al. (2016, 2018) and Li et al. (2017a, 2020a) re-investigated phylogenetic relationships of Torula based on DNA sequence analyses from nucleotides and protein genes.

Torula thailandica N.G. Liu, Jian K. Liu \& K.D. Hyde, sp. nov.

Fig. 158

Index Fungorum number: IF 557091; Facesoffungi number: FoF 06655.

Etymology - Referring to the country in which the species was collected.

Holotype - MFLU 19-2856.

Saprobic on decaying wood. Sexual morph: Undetermined. Asexual morph: Colonies effuse on host, powdery, black. Conidiophores 1.4-4.2 $\mu \mathrm{m}$ wide, micronematous to semi-macronematous, mononematous, solitary, erect, subhyaline to paler brown smooth to minutely smooth, thin-walled, consisting of 1-2 cells, without apical branches, with ampulliform cells, arising from prostrate hypha, sometimes absent. Conidiogenous cells $2-9.3 \times 2-3.9 \mu \mathrm{m}(\bar{x}=5.3 \times 3 \mu \mathrm{m}, \mathrm{n}=6)$, monoblastic, terminal, dark brown to black, smooth to minutely verruculose, thick-walled, ellipsoid to coronal. Conidia 14-23(-52.5) $\times 4.5-6.6 \mu \mathrm{m}(\bar{x}=18.1 \times 5.6 \mu \mathrm{m}, \mathrm{n}=30)$, solitary, acrogenous, phragmosporous, rarely in branched chains, chiefly subcylindrical, greyish-brown to blackishbrown, 2-8-septate, composed of moniliform cells, slightly constricted at some septa, minutely verruculose to verruculose. Conidial secession schizolytic.

Culture characteristics - Conidia germinating on water agar within $24 \mathrm{~h}$. Germ tubes produced from both sides. Colonies on MEA velvety, circular, greyish brown in the center, greyish white in the periphery from above.

Material examined - Thailand, Phrae Province, Rong Kwang, on decaying wood, 10 January 2018, N.G. Liu, N002, (MFLU 19-2856, holotype); ex-type living culture, GZCC 20-0011.

GenBank numbers - ITS: MN907426; LSU: MN907428; SSU: MN907427.

Notes - Torula thailandicum is similar to T. chiangmaiensis and T. pluriseptata. However, conidia of $T$. thailandicum have less septa (2-8-septate vs 4-12-septate and 3-10-septate) and are shorter $(14-23 \mu \mathrm{m}$ vs. $25.5-70 \mu \mathrm{m}$ and 23.5-36 $\mu \mathrm{m})$ than those of $T$. chiangmaiensis and $T$. pluriseptata. Phylogenetic analyses also confirmed they are distinct species.

\section{Other genera included}

Dendryphion Wallr., Fl. crypt. Germ. (Norimbergae) 2: 300 (1833).

Index Fungorum number: IF 7952; Facesoffungi number: FoF 01741; 30 morphological species (Species Fungorum 2020), 5 species with molecular data.

Type species - Dendryphion comosum Wallr., Fl. crypt. Germ. (Norimbergae) 2: 300 (1833). 

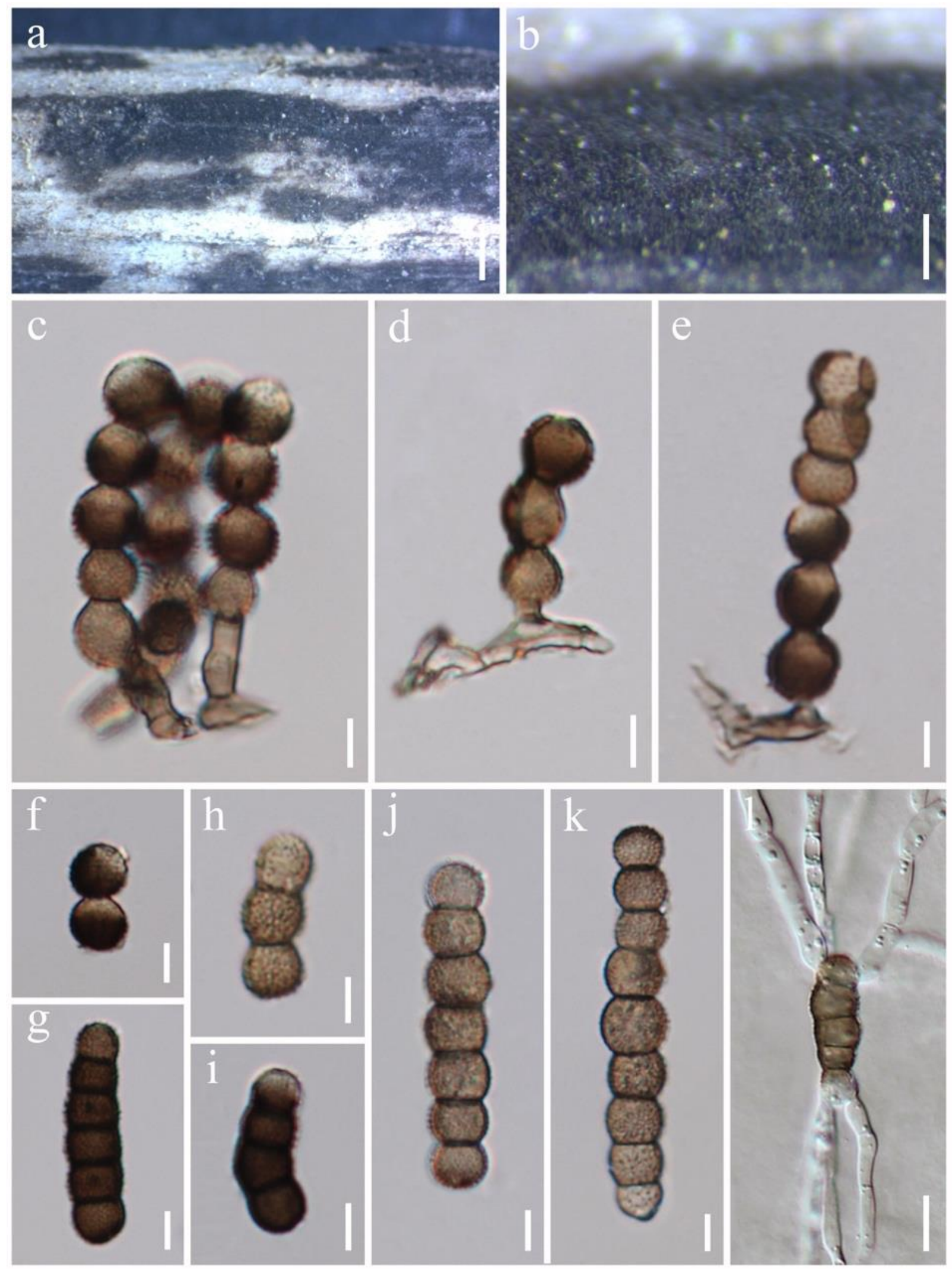

Figure 158 - Torula thailandica (MFLU 19-2856, holotype). a, b Colonies on the host. b Mass of conidia. c-e Conidiophores bearing conidia. f Conidiogenous cells. g-k Conidia. 1 Germinated conidia. Scale bars: $\mathrm{a}=1000 \mu \mathrm{m}, \mathrm{b}=200 \mu \mathrm{m}, \mathrm{c}-\mathrm{k}=5 \mu \mathrm{m}, \mathrm{l}=10 \mu \mathrm{m}$.

Notes - Ellis (1971) reported that Dendryphion species were common on dead stems of herbaceous plants and decaying wood. Crous et al. (2014a) introduced Dendryphion europaeum and found it closely related to Torula based on ITS sequence data. Crous et al. (2015a) accepted 
Dendryphion in Torulaceae based on LSU sequence data. The genus is characterized by macronematous conidiophores, with terminal and intercalary conidiogenous cells on branches, and solitary or catenate, clavate, obclavate to subcylindrical conidia, which are rounded at the apex.

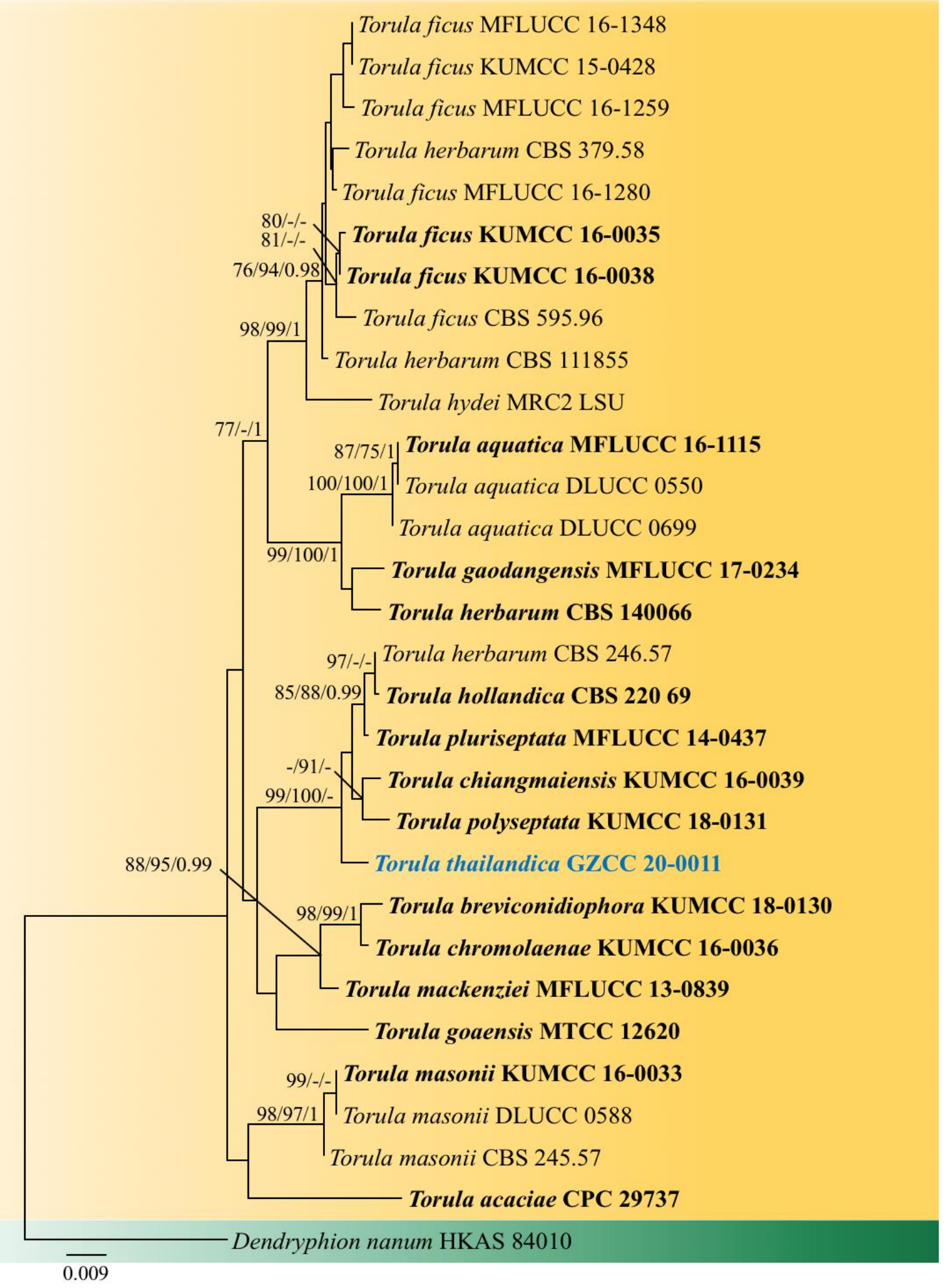

Figure 159 - Phylogram generated from maximum likelihood analysis (RAxML) of Torula species based on ITS, LSU, SSU and tef1 sequence data. Maximum likelihood and maximum parsimony bootstrap values equal or above $75 \%$, Bayesian posterior probabilities equal or above 0.95 are given at the nodes. The isolate/specimen number is noted after the species name. The tree is rooted to Dendryphion nanum (HKAS 84010). The ex-type strains are indicated in bold. Newly sequence is in blue. Hyphen (-) represents support values below $75 \%$ MLBS and 0.95 PP. 
Neotorula Ariyaw., Z.L. Luo \& K.D. Hyde, Fungal Divers. 80: 393 (2016).

Index Fungorum number: IF 551826; Facesoffungi number: FoF 01748; 2 morphological species (Species Fungorum 2020), 2 species with molecular data.

Type species - Neotorula aquatica Z.L. Luo \& K.D. Hyde, Fungal Divers. 80: 393 (2016).

Notes - Neotorula is characterized by polytretic conidiophores comprising a few cells. Phylogenetically, this genus forms a clade as an independent genus in Torulaceae.

Rostriconidium Z.L. Luo, K.D. Hyde \& H.Y. Su, Mycol. Progr. 17(5): 536 (2018).

Index Fungorum number: IF 823172; Facesoffungi number: FoF 03764; 2 morphological (Species Fungorum 2020), 2 species species with molecular data.

Type species - Rostriconidium aquaticum Z.L. Luo, K.D. Hyde \& H.Y. Su, Mycol. Progr. 17(5): 536 (2018).

Notes - Rostriconidium is characterized by solitary, erect, septate, straight to flexuous, dark brown to black conidiophores, monotretic or polytretic conidiogenous cells and solitary, dry, rostrate, septate conidia with a subhyaline apex. Phylogenetic analysis of combined ITS, LSU, rpb2, and tef1 sequence data in Su et al. (2018) indicated that two strains of Rostriconidium aquaticum (MFLUCC 16-1113 and KUMCC 15-0491) form a separate clade between Sporidesmioides and Neotorula in Torulaceae (Su et al. 2018).

Rutola J.L. Crane \& Schokn., Can J Bot. 55 (24): 3015 (1978).

Index Fungorum number: IF 9768; Facesoffungi number: FoF 06656; 1 morphological species (Species Fungorum 2020), 1 species with molecular data.

Type species - Rutola graminis (Desm.) Crane \& Schokn., Can J Bot 55 (24): 3013 (1977).

三Torula graminis Desm. ex Fr., Systema Mycologicum 3: 502 (1832).

Notes - Crane \& Schoknecht (1977) transferred Torula graminis to a new genus Rutola. Rutola is characterized by monoblastic conidiogenous cells integrated on micronematous conidiophores and simple or branched conidial chains. It differs from Torula in lacking the diagnostic coronate conidiogenous cells (Crane \& Schoknecht 1977). Crous et al. (2019c) designated the lectotype and epitype of $R$. graminis. Based on LSU sequence data, Rutola formed a monophyletic clade in Torulaceae (Crous et al. 2019c).

Sporidesmioides Jun F. Li, Phookamsak \& K.D. Hyde, Mycol. Progr. 15(10): 1171 (2016).

Index Fungorum number: IF 817934; Facesoffungi number: FoF 02515; 1 morphological species (Species Fungorum 2020), 1 species with molecular data.

Type species - Sporidesmioides thailandica Jun F. Li, Phookamsak \& K.D. Hyde, Mycol. Progr. 15(10): 1171 (2016).

Notes - Sporidesmioides is characterized by large ampulliform, septate and dark brown conidia with paler apical cells and a conspicuous, hyaline, flexuous sheath at the tip, straight or curved, septate, dematiaceous, conidiophores with thick walls and dark, protuberant, polyblastic, conidiogenous loci. In phylogenetic analysis of combined LSU, SSU, rpb-2 and tef1 sequence data, Sporidesmioides was placed in Torulaceae (Li et al. 2016b).

\section{Ecological and economic significance}

Torulaceae species occur in diverse habitats worldwide. They are mostly saprobic in terrestrial and freshwater habitats. As decomposers and recyclers, species in this family are involved in nutrient cycling and supply members of other kingdoms with nutrients. Thus, they are important for ecological balance.

Trematosphaeriaceae K.D. Hyde, Y. Zhang ter, Suetrong \& E.B.G. Jones, Cryptog. Mycol. 32(4): 347 (2011).

Index Fungorum number: IF 543789; Facesoffungi number: FoF 08378, 103 species.

Saprobic on lignocellulosic material of mangrove and terrestrial habitats. Sexual morph Ascomata solitary, scattered, or in groups, initially immersed, becoming erumpent, to semi- 
immersed, subglobose, black; apex with a short papilla. Peridium coriaceous, comprising heavily pigmented thick-walled cells of textura angularis. Hamathecium comprising relatively wide, branching, anastomosing, cellular pseudoparaphyses, embedded in mucilage. Asci 8-spored, bitunicate, fissitunicate, cylindro-clavate, pedicellate, with an ocular chamber. Ascospores 1-2seriate, fusiform, hyaline or dark brown, trans-septate, and variously ornamented. Asexual morph in culture spermatial. Spermatia subglobose, hyaline.

Type - Trematosphaeria Fuckel, Jb. nassau.

Notes - Trematosphaeriaceae was established in Suetrong et al. (2011b) for a family which was considered as nomen nudem by Lumbsch \& Huhndorf (2010) to include the genera Falciformispora, Halomassarina and Trematosphaeria. Trematosphaeriaceae species are characterized by medium-sized rounded ascomata with a papillate ostiole, a relatively wide, coriaceous peridium, cellular pseudoparaphyses and cylindro-clavate asci (Suetrong et al. 2011b). The ascospores are 2 to multi-celled and hyaline or brown. Phylogenetic analysis inferred from combined SSU, LSU, rpb-2 and tef1 showed that these genera form a strongly supported clade in Pleosporales (Schoch et al. 2009a, Suetrong et al. 2009, Zhang et al. 2009c, Hyde et al. 2013). This family comprises Bryosphaeria, Falciformispora, Hadrospora, Halomassarina, Raghukumaria and Trematosphaeria (Phookamsak et al. 2014c, Wijayawardene et al. 2017a, Jone et al. 2019a).

Trematosphaeria Fuckel, Jb. Nassau. Ver. Naturk. 23-24: 161 (1870).

Index Fungorum number: IF 5522; Facesoffungi number: FoF 08379; 86 morphological species (Species Fungorum 2020), 6 species with molecular data.

Type species - Trematosphaeria pertusa Fuckel, Jahrbücher des Nassauischen Vereins für Naturkunde 23-24: 161 (1870).

Notes - Trematosphaeria pertusa, is characterized by semi-immersed to erumpent ascomata, cellular pseudoparaphyses, cylindric-clavate asci, and fusiform, 1-septate reddish brown to dark brown ascospores (Clements \& Shear 1931, Boise 1985a, b, Zhang et al. 2008a). No asexual morph connection is known in Trematosphaeria (Boise 1985a, Phookamsak et al. 2014c). Phoma or Aposphaeria have been reported as an asexual morph of the genus from cultural studies of $T$. heterospora. However, T. heterospora is now placed in Lophiostoma (Barr 1992b). A zalerion-like asexual morph was reported for Hadrospora with conidia being produced on PDA after 4 months (Tanaka \& Harada 2003a). Jones et al. (2009b), however, treated Zalerion maritima, as the asexual morph of Lulwoana (Lulworthiales). However, Tanaka et al. (2015) reported a spermatial morph with subglobose, hyaline spermatia in a culture obtained from Trematosphaeria pertusa.

Trematosphaeria confusa (Garov.) Boise \& D. Hawksw., Mycologia 77(2): 232 (1985). Fig. 160 三Verrucaria confusa Garov., Tentam. Dispos. Lich. Langob.: 77 (1865).

Index Fungorum number: IF 105837; Facesoffungi number: FoF 08380.

Saprobic on decaying wood of Rhizophora sp. Sexual morph: Ascostromata 600-760 $\mu \mathrm{m}$ wide, 540-570 $\mu \mathrm{m}$ high, solitary, erumpent to superficial, immersed only at the base, carbonaceous, conical, with a flattened base, apex papillate. Hamathecium comprising up to $2.6 \mu \mathrm{m}$ wide. septate, hyaline, pseudoparaphyses. Asci (130-)170-190(-200) × (15-)16-18(-20) $\mu \mathrm{m}$, bitunicate, narrowly clavate, short-stalked, rounded at the apex. Ascospores 1-2-seriate, overlapping, (30-)35-37(-39) $\times$ (7.5-)8-11(-12) $\mu \mathrm{m}$, fusiform, hyaline to brown, 3-septate, constricted at the middle septum, slightly pointed at the ends, the second cell slightly swollen, surrounded by a thin mucilaginous sheath. Asexual morph: Undetermined.

Material examined - Thailand, Ranong Province, Amphoe Maung, Mu 4 Tombol Ngao, Ranong Mangrove Research Center (GPS: $9^{\circ} 43^{\prime}$ to $9^{\circ} 57^{\prime} \mathrm{N}$; $98^{\circ} 29^{\prime}$ to $98^{\circ} 39^{\prime} \mathrm{E}$ ) on decaying wood of Rhizophora sp. (Rhizophoraceae), 7 December 2016, M.C. Dayarathne, MCD 045 (MFLU 180532).

Notes - The conical ascostromata and reddish ascospores of this species are characteristic features of Trematosphaeria (Tanaka et al. 2005a). Trematosphaeria confusa was established to include a Trematosphaeria species which comprises three septate ascospores surrounded by a thin mucilaginous sheath. Most species of the genus are saprotrophs or hemibiotrophs of terrestrial 
woody plants (Boise 1985a), while T. confusa is reported from freshwater and terrestrial habitats (Shearer 1993).
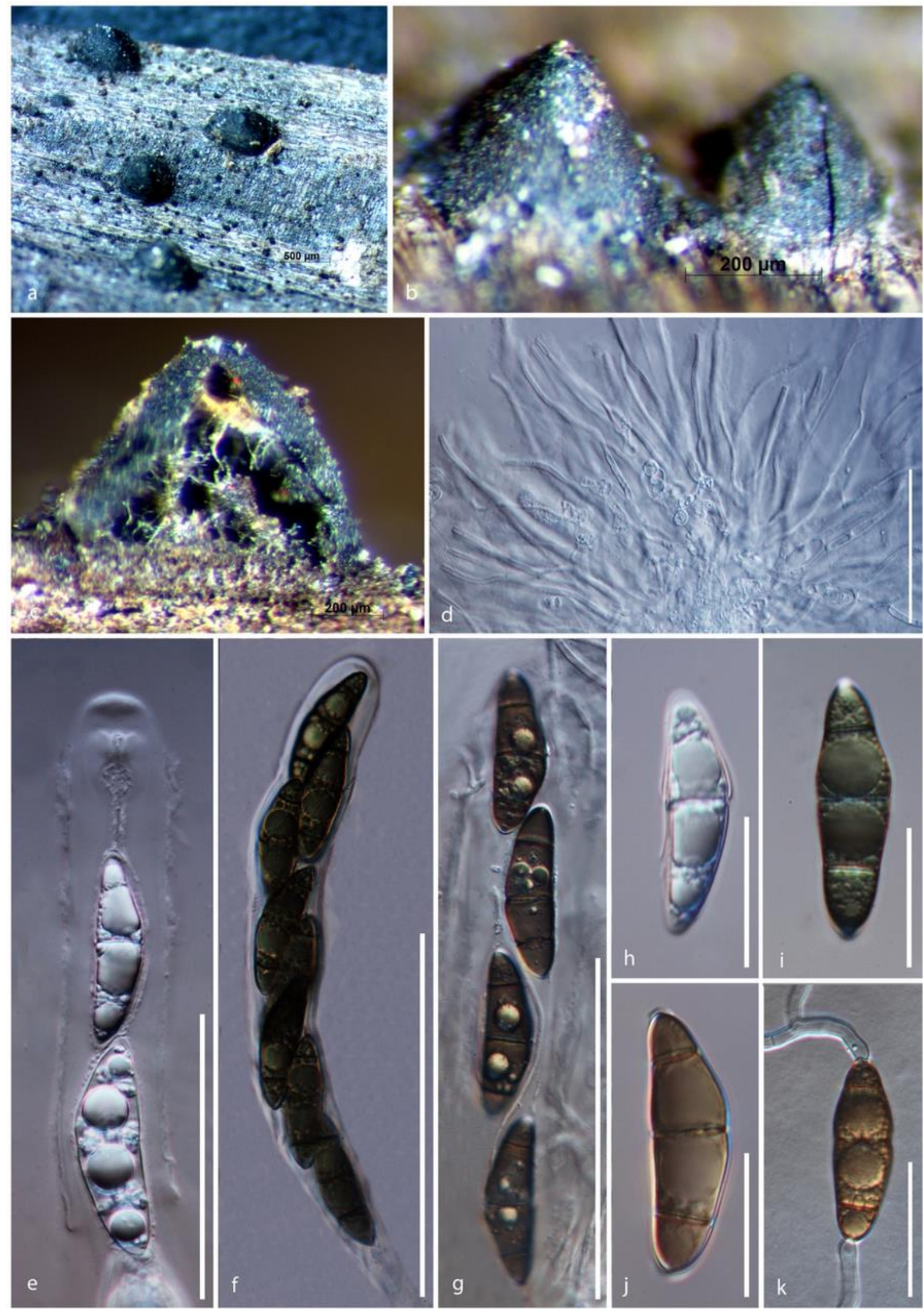

Figure 160 - Trematosphaeria confusa (MFLU 18-0532). a, b Ascomata on decaying wood. c Section of ascoma. d Pseudoparaphyses. e-g Asci. $\mathrm{h}-\mathrm{j}$ Ascospores. k Germinating ascospore. Scale bars: $\mathrm{a}=500 \mu \mathrm{m}, \mathrm{b}, \mathrm{c}=200 \mu \mathrm{m}, \mathrm{f}=100 \mu \mathrm{m}, \mathrm{e}, \mathrm{g}=50 \mu \mathrm{m}, \mathrm{h}-\mathrm{k}=20$. 


\section{Other genera included}

Bryosphaeria Döbbeler, Mitt. bot. StSamml., Münch. 14: 151 (1978).

Index Fungorum number: IF 671; Facesoffungi number: FoF 08381; 9 morphological species (Species Fungorum 2020), molecular data unavailable.

Type species - Bryosphaeria cinclidoti (Racov.) Döbbeler, Mitt. bot. StSamml., Münch. 14: 158 (1978).

ELeptosphaeria cinclidoti Racov., Mem. Mus. natn. Hist. nat., Paris, Ser. B, N.S. 10: 150 (1959).

Notes - Döbbeler (1978) introduced Bryosphaeria in Dothideomycetes, genera incertae sedis by transferring Leptosphaeria cinclidoti (current name Bryosphaeria cinclidoti) which was placed in Leptosphaeriaceae. Bryosphaeria is characterized by globose or subglobose ascomata, with the surface being covered by brown, branched setae, bitunicate, fissitunicate asci and hyaline to dark brown, fusiform, 1-5-septate ascospores (Döbbeler 1978, Li et al. 2014). Bryosphaeria best fits Trematosphaeriaceae in having bitunicate, cylindric-clavate asci, a peridium with thick-walled cells of textura angularis, with dark brown outer layers and hyaline inner layers, and hyaline to dark brown, fusiform ascospores, but differs in septation of the ascospores (1-5-septate in Bryosphaeria versus 3-septate in Trematosphaeria) and surface and papillae of the ascomata (setose, rarely with visible papillae in Bryosphaeria versus glabrous and with a short papillae in Trematosphaeria). Hence, based on these similar morphologies, Li et al. (2014) placed Bryosphaeria in Trematosphaeriaceae. Sequence data are not available for Bryosphaeria species and fresh material for sequencing is necessary to establish the taxonomical position of this genus.

Falciformispora K.D. Hyde, Mycol. Res. 96(1): 26 (1992).

Index Fungorum number: IF 25457; Facesoffungi number: FoF 08382; 5 morphological species (Species Fungorum 2020), 4 species with molecular data.

Type species - Falciformispora lignatilis K.D. Hyde, Mycol. Res. 96(1): 27 (1992).

Notes - Falciformispora was introduced for a single species found on intertidal mangrove wood. This genus is unique in having subglobose to ovoid, erumpent and eventually superficial ascomata by sloughing off of the upper woody cells, asci arising from ascogenous tissue at the base of the ascoma, and hyaline, straight or slightly curved, 6-(7)-8-septate ascospores, that are slightly constricted at the septa and surrounded by a thin mucilaginous sheath and a single scythe-like appendage at the base (Hyde 1992). There are four species within this genus with sequence data, $F$. lignatilis, $F$. senegalensis, $F$. tompkinsii and $F$. uttaraditensis, and their placement within Trematosphaeriaceae is clear (Ahmed et al. 2014b, Hyde et al. 2020b).

Hadrospora Boise, Mem. N. Y. bot. Gdn 49: 310 (1989).

Index Fungorum number: IF 25305; Facesoffungi number: FoF 00285; 1 morphological species (Species Fungorum 2020), molecular data unavailable.

Type species - Hadrospora fallax (Mouton) Boise, Mem. N. Y. bot. Gdn 49: 310 (1989).

三Trematosphaeria fallax Mouton, Bull. Soc. R. Bot. Belg. 25(no. 1): 155 (1886).

Notes - Hadrospora was introduced to accommodate two species, originally described as Trematosphaeria species by Boise (1989). A second species, Hadrospora clarkii is listed as Trematosphaeria clarkii in Index Fungorum (2020). Hardrospora is a poorly known genus which lacks sequence data in GenBank and Phookamsak et al. (2014c) tentatively placed this genus in Trematosphaeriaceae based it on its morphological characters. Hadrospora species need recollecting and sequencing to determine their taxonomical position.

Halomassarina Suetrong, Sakayaroj, E.B.G. Jones, Kohlm., Volkm.-Kohlm. \& C.L. Schoch, Stud. Mycol. 64: 161 (2009).

Index Fungorum number: IF 515951; Facesoffungi number: FoF 08383; 1 morphological species (Species Fungorum 2020), 1 species with molecular data.

Type species - Halomassarina thalassiae (Kohlm. \& Volkm.-Kohlm.) Suetrong et al., in Suetrong et al., Stud. Mycol. 64: 161 (2009). 
三 Massarina thalassiae Kohlm. \& Volkm.-Kohlm., Can. J. Bot. 65(3): 575 (1987).

Notes This monotypic genus was introduced by Suetrong et al. (2009) to accommodate Massarina thalassiae within Trematosphaeriaceae.

Raghukumaria Devadatha, V.V Sarma et E.B.G Jones, in Jones et al., Bot. Mar. 63(2): 163 (2019) [2020].

MycoBank: MB829062; Facesoffungi number: FoF 08384; 1 morphological species (Jones et al. 2020), 1 species with molecular data.

Type species - Raghukumaria keshaphalae Devadatha, V.V Sarma et E.B.G Jones, in Jones et al., Bot. Mar. 63(2): 163 (2019) [2020].

Notes - Raghukumaria shares some characters with Halomassarina and Falciformispora, but can be distinguished in having immersed ascomata, without a clypeus and periphyses, covered by hyphae-like setae and broadly fusiform ascospores, with narrowly rounded ends, rough-walled or slightly verruculose, lacking globules, appendages or gelatinous sheaths (Jones et al. 2019a). Phylogenetic analyses indicated that this genus formed as a distinct lineage within Trematosphaeriaceae (Jones et al. 2019a, this study).

\section{Ecological and economic significance}

Most species of Trematosphaeriaceae are saprotrophs or hemibiotrophs of terrestrial or marine woody plants (Boise 1985a, Hyde 1992b), but three species: Trematosphaeria confusa T. hydrela and T. pertusa, are reported from freshwater habitats (Shearer 1993, Hyde 1995), and three other species: T. mangrovei, T. lineolatispora and T. malaysiana are known from marine habitats (Mckeown et al. 2001). Trematosphaeria pertusa usually grows on the surface of decaying terrestrial wood, but can also survive within freshwater (Shearer 1993). Bryospheria species have been reported from Pseudoleskeella catenulate, Schistidium apocarpum and Lescuraea sp. as saprobes. Hadrospora has been reported from various hosts and habitats, both terrestrial and freshwater, from Belgium, China, Italy, Japan, Switzerland, and the USA (Boise 1989, Shearer \& Crane 1971, Fisher \& Webster 1992, Tanaka \& Harada 2003a, Zhang et al. 2012b). Falciformispora and Halomassarina species are also saprobes on various marine substrates and Halomassarina is a widely collected tropical species from intertidal and subtidal mangrove wood or fishing crafts (Kohlmeyer \& Volkmann-Kohlmeyer 1987).

Tzeananiaceae H.A. Ariyaw., A.J.L. Phillips \& Chuang, MycoKeys 37: 8 (2018).

Index Fungorum number: IF 825566; Facesoffungi number: FoF 08385, 1 species.

Developing on a fruiting body of Ophiocordyceps macroacicularis. Sexual morph: Undetermined. Asexual morph: Conidiomata pycnidial, solitary or aggregated, erumpent, globose, dark brown to black. Conidiomatal wall composed of textura angularis cells. Conidiophores reduced to conidiogenous cells. Conidiogenous cells phialidic, hyaline, smooth-walled, ampulliform. Conidia cylindrical, hyaline, with guttulate. (adapted from Ariyawansa et al. 2018b).

Type - Tzeanania H.A. Ariyaw., A.J.L. Phillips \& Chuang.

Notes - Tzeananiaceae was established by Ariyawansa et al. (2018b) to accommodate the single genus Tzeanania. Phylogenetic analyses indicated that two strains of Tzeanania formed a distinct clade within Pleosporales (Ariyawansa et al. 2018b, this study).

Tzeanania H.A. Ariyaw., A.J.L. Phillips \& Chuang, in Ariyawansa et al., MycoKeys 37: 8 (2018).

Index Fungorum number: IF 825567; Facesoffungi number: FoF 08386; 1 morphological species (Species Fungorum 2020), 1 species with molecular data.

Type species - Tzeanania taiwanensis H.A. Ariyaw., A.J.L. Phillips \& Chuang.

Notes - Tzeanania was introduced based on morphology and phyologeny. The genus is characterized by pycnidial coelomycete found on fruiting body of Ophiocordyceps macroacicularis.

Tzeanania taiwanensis H.A. Ariyaw., A.J.L. Phillips \& Chuang, MycoKeys 37: 9 (2018). Fig. 161 
Index Fungorum number: IF 825568; Facesoffungi number: FoF 08387.

Description - see Ariyawansa et al. (2018b).

Material examined - Taiwan. Cueifong, Nantou County (latitude: N24 06' 20"longitude: E121 11' 13"), developing on a fruiting body of Ophiocordyceps macroacicularis, 9 July 2017, Wei-Yu Chuang (NTUH 17-005, holotype).

Figure 161 - Tzeanania taiwanensis (NTUH 17-005, holotype). a Upper and lower view of colonies on PDA. b Conidiomata. c Close up of conidioma. d Close up of conidiomatal wall. e-f Conidiogenous cells. g Conidia. Background is ascomata of Ophiocordyceps macroacicularis. Scale bars: $\mathrm{c}=50 \mu \mathrm{m}, \mathrm{d}=10 \mu \mathrm{m}, \mathrm{e}-\mathrm{h}=5 \mu \mathrm{m}$.

\section{Ecological and economic significance}

There are not many species of Pleosporales associated with entomogenous fungi. This family was found on the fruiting body of Ophiocordyceps macroacicularis. Ariyawansa et al. (2018b) noted that the nutritional mode of Tzeanania taiwanensis or its interaction with $O$. macroacicularis is unclear. Thus, future study is needed to understand the interaction between this unusual fungus and its host.

Wicklowiaceae Ariyaw. \& K.D. Hyde, Fungal Divers. 75: 126 (2015).

Index Fungorum number: IF 551445; Facesoffungi number: FoF 00966, 1 species.

Saprobic on submerged decorticated woody debris in aquatic habitats. Sexual morph: Ascomata immersed, becoming erumpent, solitary to gregarious, appearing as a black, oval to circular, shallow, subglobose, ostiolate. Peridium comprising several layers of small pseudoparenchymatous cells, arranged in a textura angularis, fusing at the outside with the host cells. Hamathecium comprising, densely, septate, cellular pseudoparaphyses, embedded in a gelatinous matrix. Asci 8-spored, bitunicate, fissitunicate, broadly clavate, pedicellate, rounded at the apex, with a wide, shallow, ocular chamber. Ascospores overlapping 2-3-seriate, ellipsoidal, hyaline, 1-septate, slightly constricted at the septum, with or without appendages. Asexual morph: Undetermined.

Type - Wicklowia Raja, A. Ferrer \& Shearer.

Notes - Wicklowiaceae was proposed by Ariyawansa et al. (2015a) to place monotypic freshwater ascomycetous genus Wicklowia in order Pleosporales based on both morphology and phylogeny. Wicklowiaceae shows close phylogenetic relationship to Lindgomycetaceae (Fig. 42), but can be separated from all known freshwater ascomycetous genera by its subglobose, immersed to erumpent, black ascomata, with cellular pseudoparaphyses in a gelatinous matrix and broadly clavate asci, bearing cylindrical, hyaline, uni-septate ascospores surrounded by a gelatinous sheath.

Wicklowia Raja, A. Ferrer \& Shearer, Mycoscience 51 (3): 210 (2010).

Index Fungorum number: IF 515225; Facesoffungi number: FoF 08388; 1 morphological species (Species Fungorum 2020), 1 species with molecular data.

Type species - Wicklowia aquatica Raja, A. Ferrer \& Shearer.

Notes - Wicklowia was introduced based on morphological characteristics and LSU sequence data. Boonmee et al. (2019) introduced a second species, W. submersa from a stream in southern Thailand.

Wicklowia aquatica Raja, A. Ferrer \& Shearer, Mycoscience 51(3): 211 (2010).

Fig. 162

Index Fungorum number: IF 5515226; Facesoffungi number: FoF 08389.

Description - see Raja et al. (2010).

Material examined - USA, Florida, Apalachicola National Forest, Apalachicola River at Fort Gadsden Landing, 29 $56^{\prime} 00^{\prime \prime} \mathrm{N}, 85^{\circ} 0^{\prime} 00^{\prime \prime} \mathrm{W}$, on submerged decorticated woody debris, 14 January 2006, Huzefa A. Raja \& J.L. Crane, F76-2 (ILL 40790 = H.A. Raja \& J.L. Crane F76-2, holotype); 
Costa Rica. Alajuela, Caño Negro Reserve, Rio Frio, 10530 0000N, 84450 0000W, water temp. 27C, pH 5, 15 December 2005, A. Ferrer \& M. Salazar, (AF289-1).
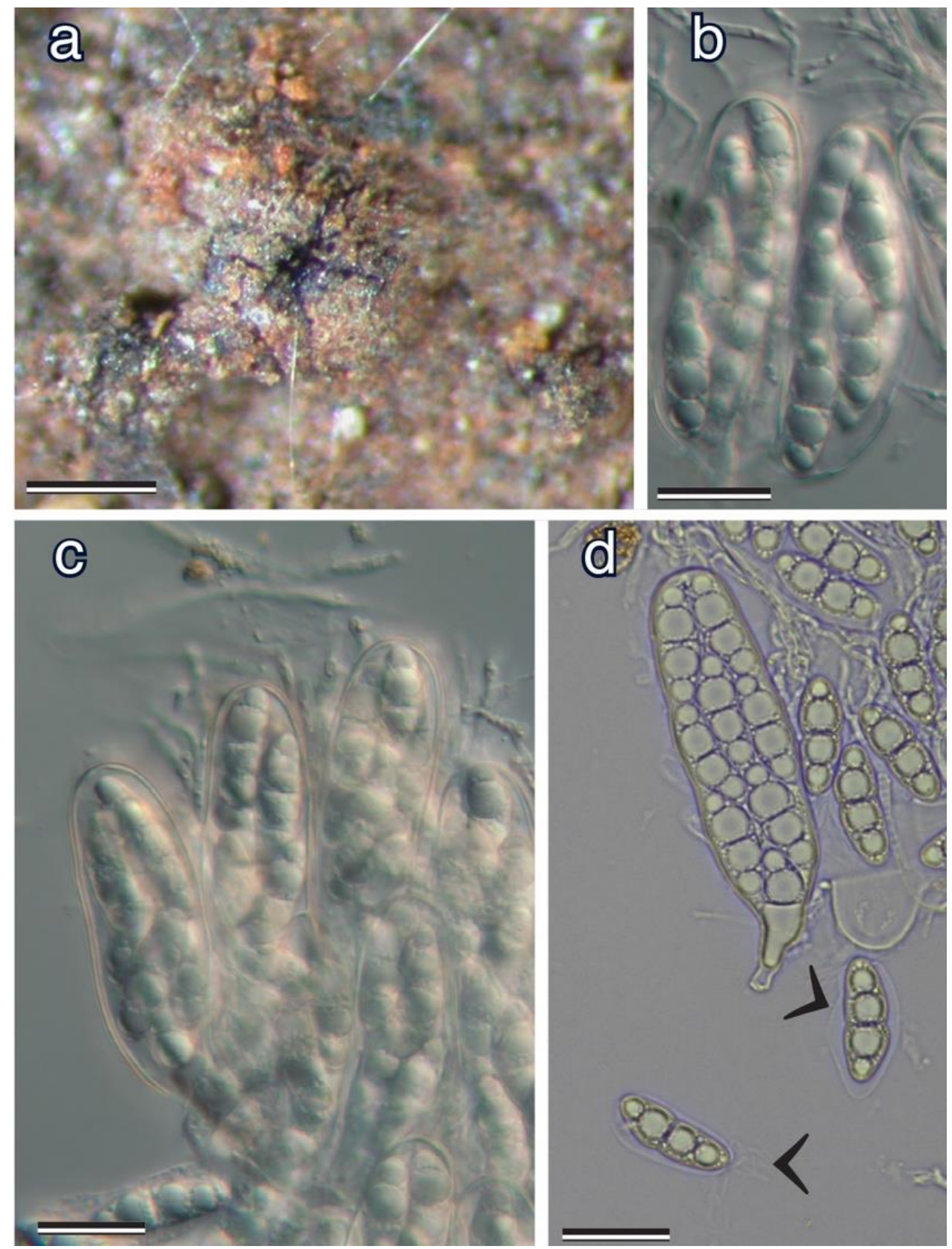

Figure 162 - Wicklowia aquatica (AF289-1 and F76-2). a Ascomata on wood (AF289-1; Picture: Astrid Ferrer). b, c Asci (G76-2). d Asci and ascospores (AF289-1; Picture: Astrid Ferrer); note arrowhead showing gelatinous sheath and appendages on the ascospores. Scale bars: $\mathrm{a}=100 \mu \mathrm{m}$, $\mathrm{b}-\mathrm{d}=20 \mu \mathrm{m}$.

\section{Ecological and economic significance}

Species in this family are saprobes. They feed on dead organic matter and decompose it into simple molecules that go back into the soil and can be reused by plants and all other organisms. Three new nonadride derivatives, tetrahydroepiheveadride (1), dideoxoepiheveadride (2) and deoxodihydroepiheveadride (3), and two new C-9 compounds., waquafranone A (I) and B (II), which were suggestive of precursors of nonadrides, along with the known compounds. epiheveadride (4), deoxoepiheveadride (5), dihydroepiheveadride (6), sydonic acid (9), 
hydroxysydonic acid (10), folipastatin (11), and agonodepside B (12) were isolated from Wicklowia aquatica.

Zopfiaceae Arnaud ex D. Hawksw., Syst. Ascom. 11(1): 77 (1992).

Index Fungorum number: IF 81951; Facesoffungi number: FoF 08390, 13 species.

Saprobic mostly on surface of roots or wood, terrestrial and marine, widespread. Sexual morph: Ascomata cleistothecial or perithecial, superficial or partially erumpent, solitary or clustered, subglobose to globose, rounded above, carbonaceous, dark brown to black, immersed or not immersed under a stroma and clypeus, lacking ostioles and breaking on the top of ascomata at maturity, or ostiolate. Peridium thin- to thick-walled, composed of cells of textura angularis. Hamathecium comprising numerous, septate, filamentous, hyaline, branched, anastomosing, cellular pseudoparaphyses, embedded in a gelatinous matrix. Asci 1-8-spored, bitunicate, fissitunicate, clavate to cylindrical, globose or saccate, short or long pedicellate, dissolving at maturity. Ascospores crowded or partially overlapping, obovate to pyriform or oblong to ellipsoid, hyaline or yellow, to brown when immature, completely black at maturity, aseptate or 1-3-septate, distoseptate, mostly septate at the middle or upper cell, broader than the lower cell, with umbonate ends, smooth-walled or slightly roughened, ornamented or not ornamented. Asexual morph: "cladosporium"-like (Wijayawardene et al. 2012).

Type - Zopfia Rabenh.

Notes - The details of Zopfiaceae were outlined in Zhang et al. (2012b) and Hyde et al. (2013). The family comprises six genera, Celtidia, Coronopapilla, Rechingeriella, Richonia, Zopfia and Zopfiofoveola (Wijayawardene et al. 2018). The species in Zopfiaceae mostly lack sequence data. Thus, fresh material needs to be collected, examined and sequenced for epitypifications to verify their natural placement.

Zopfia Rabenh., Fungi europ. exsicc.: no. 1734 (1874).

Index Fungorum number: IF 5875; Facesoffungi number: FoF 08391; 5 morphological species (Species Fungorum 2020), 1 species with molecular data.

Type species - Zopfia rhizophila Rabenh.

Notes - Zopfia rhizophila was reported on dry roots of Asparagus in Germany. Its classification was outlined in Zhang et al. (2012b). Sequence data is available only for Zopfia rhizophila in GenBank (2020).

Zopfia rhizophila Rabenh. Fungi europ. exsicc.: no. 1734 (1874).

Fig. 163

Index Fungorum number: IF 209329; Facesoffungi number: FoF 08392.

Description - see Hyde et al. (2013).

Material examined - Germany, on dry roots of Asparagi radicibus, 18 August 1874, Wilhelm Zopt (IMI 175866, holotype).

\section{Other genera included}

Celtidia J.D. Janse, Ann. Jard. Bot. Buitenzorg 14(1): 202 (1897).

Index Fungorum number: IF 867; Facesoffungi number: FoF 08393; 1 morphological species (Species Fungorum 2020), molecular data unavailable.

Type species - Celtidia duplicispora J.D. Janse, Ann. Jard. Bot. Buitenzorg 14(1): 202 (1897).

Notes - Celtidia is characterized by echinulate ascospores. It was reported from root nodules of Celtis in Java. There is no sequence data for $C$. duplicispora in GenBank. Fresh collections are needed for further study.

Coronopapilla Kohlm. \& Volkm.-Kohlm., Mycol. Res. 94(5): 686 (1990).

Index Fungorum number: IF 25439; Facesoffungi number: FoF 08394; 2 morphological species (Species Fungorum 2020), 1 species with molecular data. 
Type species - Coronopapilla avellina Kohlm. \& Volkm.-Kohlm., Mycol. Res. 94(5): 687 (1990).

Notes - Kohlmeyer \& Volkmann-Kohlmeyer (1991) examined the holotype material of Caryospora mangrovei (IMI 327272) from Brunei and synonymized it under Coronopapilla avellina. $\mathrm{Vu}$ et al. (2019) provided sequence data for Coronopapilla mangrovei (and its higher order classification). The genus is distinguished from other genera in Zopfiaceae in having ascomata with a stroma or clypeus, 1-3-septate, distoseptate, smooth-walled ascospores, constricted at the central of septum.

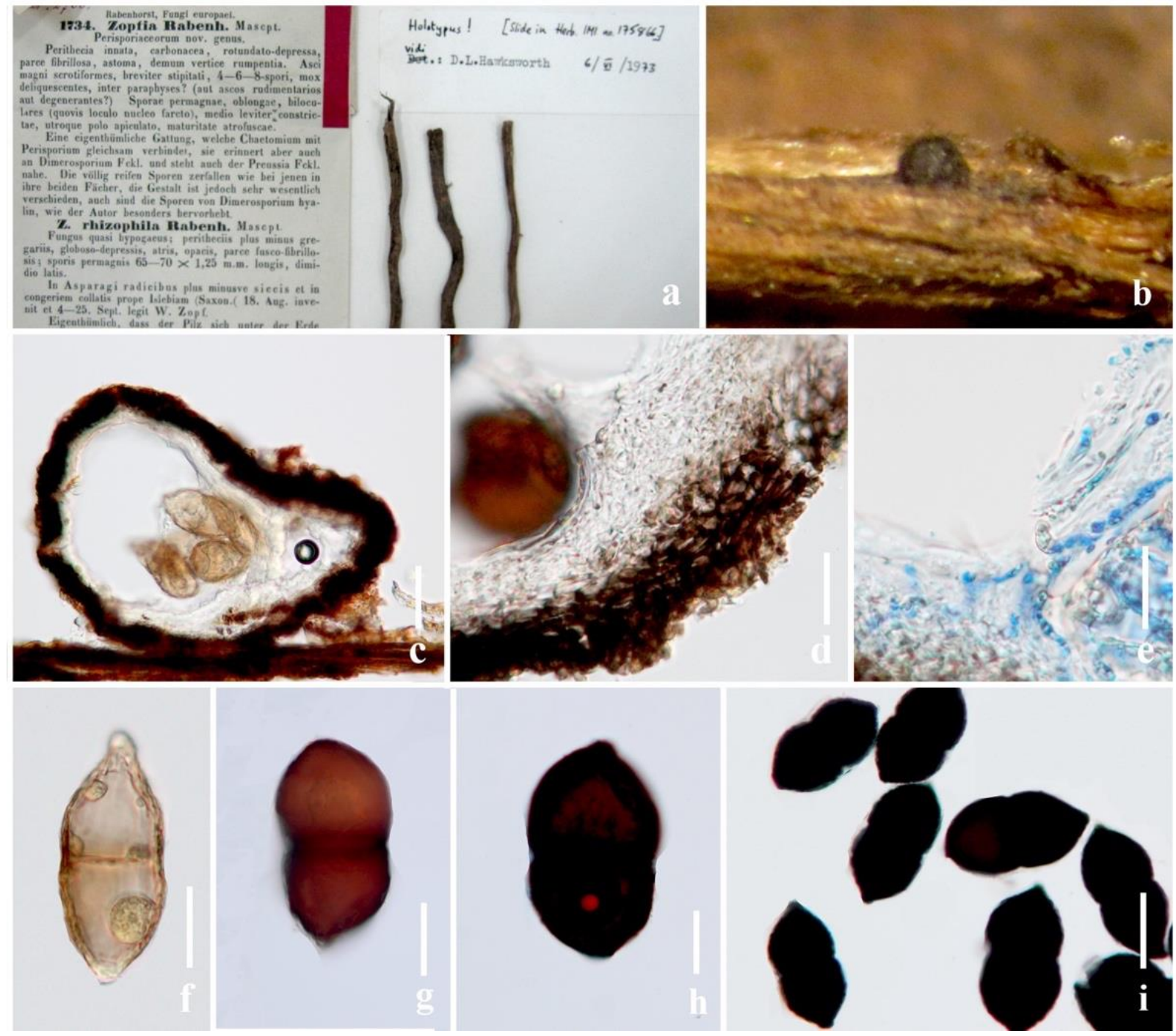

Figure 163 - Zopfia rhizophila (IMI 175866, holotype). a, b Habit, ascomata on host substrate. c Section through ascoma. d Peridium comprising 2-layers. e Pseudoparaphyses embedded in a gelatinous matrix in Cotton blue reagent. $f, g$ Ascospores when immature. $h$, i Ascospores at maturity. Scale bars: $\mathrm{c}, \mathrm{i}=40 \mu \mathrm{m}, \mathrm{d}-\mathrm{h}=20 \mu \mathrm{m}$.

Rechingeriella Petr., in Rechinger et al., Annln naturh. Mus. Wien 50: 465 (1940).

Index Fungorum number: IF 4660; Facesoffungi number: FoF 08395; 3 morphological species (Species Fungorum 2020), molecular data unavailable.

Type species - Rechingeriella insignis Petr., Annln naturh. Mus. Wien 50: 465 (1940).

Notes - Rechingeriella was found on dead roots of Allium scabriscapum Boiss. in Iran. Additional details such as history of its classification were provided in Zhang et al. (2012b). Rechingeriella has ascomata without a stroma or clypeus and 1-septate, ornamented ascospores with swollen cells. 
Richonia Boud., Revue mycol., Toulouse 7(no. 27): 224 (1885).

Index Fungorum number: IF 4751; Facesoffungi number: FoF 08396; 1 morphological species (Species Fungorum 2020), molecular data unavailable.

Type species - Richonia variospora Boud., Revue mycol., Toulouse 7(no. 27): 224 (1885).

Notes - Richonia variospora is known from roots of Asparagus officinalis from several localities in France. Richonia differs from Coronopapilla in having 1-septate, ornamented ascospores, with an undulating sheath, irregularly ridged at maturity.

Zopfiofoveola D. Hawksw., Can. J. Bot. 57(2): 98 (1979).

Index Fungorum number: IF 5878; Facesoffungi number: FoF 08397; 1 morphological species (Species Fungorum 2020), molecular data unavailable.

Type species - Zopfiofoveola punctata (D. Hawksw. \& C. Booth) D. Hawksw., Can. J. Bot. 57(2): 98 (1979).

三Zopfia punctata D. Hawksw. \& C. Booth, Mycol. Pap. 153: 23 (1974).

Notes - Hawksworth (1979) synonymized Zopfia punctata under Zopfiofoveola punctata and established Zopfiofoveola as a monotypic genus with some hesitations as it was only known from a microscopic preparation obtained from earthworm excrements in Sweden. Zopfiofoveola differs from Zopfia by evenly distributed ornamentation on the elongate ascospores with pale minute pits and less pronounced apical papilla than those of Zopfia (Hawksworth \& Booth 1974, Hawksworth 1979). Fresh collections and molecular data are needed to clarify if Zopfiofoveola is distinct from Zopfia.

\section{Ecological and economic significance}

Zopfiaceae species have been reported as saprobic on the surface of roots or wood from terrestrial and marine habitats occurring widely in countries, such as, France, Germany and Iran. They play a role in the decomposition of materials from terrestrial and marine habitats and the recycling of nutrients in soil.

\section{Acknowledgements}

Sinang Hongsanan would like to thanks National Natural Science Foundation of China for supporting the project Biodiversity, Taxonomy, Phylogeny, Evolution and Phytogeography of phytopathogens in Dothideomycetes from Southern China (grant no. 31950410548) for funding this research. Ning Xie would like to thank Project of DEGP (2019KTSCX150). Kevin D Hyde thanks the Thailand Research Fund for the grant RDG6130001 entitled "Impact of climate change on fungal diversity and biogeography in the Greater Mekong Subregion". Rungtiwa Phookamsak thanks CAS President's International Fellowship Initiative (PIFI) for young staff (grant no. Y9215811Q1), the Yunnan Provincial Department of Human Resources and Social Security (grant no. Y836181261), and National Science Foundation of China (NSFC) project code 31850410489 (grant no. Y81I982211) and Chiang Mai University for financial research support. Dhanushka Wanasinghe would like to thank CAS President's International Fellowship Initiative (PIFI) for funding his postdoctoral research (number 2019PC0008) and the 64th batch of China Postdoctoral Science Foundation (grant no.: Y913083271). Vemuri V. Sarma would like to thank SERB, Department of Science and Technology, Government of India, for funding a project (SERB/SB/SO/PS/18/2014 dt.19.5.2015) and Ministry of Earth Sciences (MOES), Govt. of India for funding a project (Sanction order: MOES/36/OO1S/Extra/40/ 2014/PC-IV dt. 14.01.2015); the Department of Biotechnology, Pondicherry University for facilities; forest departments of Andaman and Nicobar Islands and Tamil Nadu, India are thanked for providing permission to collect samples. Saranyaphat Boonmee would like to thank the National Research Council of Thailand (projects no. 61215320013 and No. 61215320023), the Thailand Research Fund (project no. TRG6180001) and Plant Genetic Conservation Project under the Royal Initiation of Her Royal Highness Princess Maha Chakri Sirindhorn - Mae Fah Luang University. Alan JL Phillips acknowledges the support from UIDB/04046/2020 and UIDP/04046/2020 Centre grants from FCT, 
Portugal (to BioISI). Saowaluck Tibpromma would like to thank the International Postdoctoral Exchange Fellowship Program (number Y9180822S1), CAS President's International Fellowship Initiative (PIFI) (number 2020PC0009), China Postdoctoral Science Foundation, and the Yunnan Human Resources and Social Security Department Foundation for funding her postdoctoral research. Nalin Wijayawardene thanks National Natural Science Foundation of China (No. NSFC 31950410558). Dong-Qin Dai would like to thank the National Natural Science Foundation of China (No. NSFC 31760013), the Scientific Research Foundation of Yunnan Provincial Department of Education (2017ZZX186) and and the Thousand Talents Plan, Youth Project of Yunnan Provinces for finance support. R Jeewon would like to thank the University of Mauritius and Mae Fah Luang University for support. Mingkwan Doilom thanks the 5th batch of Postdoctoral Orientation Training Personnel in Yunnan Province (grant no.: Y934283261) and the 64th batch of China Postdoctoral Science Foundation (grant no.: Y913082271). M Niranjan thanks SERB, Govt. of India for a fellowship. Huang Zhang would like to thank Natural Science Foundation of China (NSF 31500017). Jadson DP Bezerra thanks the Conselho Nacional de Desenvolvimento Científico e Tecnológico (CNPq), the Coordenação de Aperfeiçoamento de Pessoal de Nível Superior (CAPES, Finance Code 001), and the Fundação de Amparo à Ciência e Tecnologia de Pernambuco (FACEPE) for fellowship. B. Devadatha thanks MOES, Govt. of India for a fellowship. Hai-Xia Wu would like to the Fundamental Research Funds for the Central Non-profit Research Institution of CAF (grant no. CAFYBB2019QB005), and the Ten Thousand Talents Plan, Youth Top Project of Yunnan Provinces for finance support. Ausana Mapook thanks to Research and Researchers for Industries (RRI) under Thailand Research Fund for a personal grant (PHD57I0012). Putarak Chomnunti would like to thank Mae Fah Luang University (Grant No. DR256201012003) and Diversity-Based Economy Development Office and National Research Council of Thailand Research (Grant No. T2561022) for the financial support. Satinee Suetrong thanks the collaborative project between BIOTEC and Department of Marine and Coastal Resources (DMCR), Ministry of Natural Resources and Environmentunder a project: Marine Microbes for National Reserves: Alternative Ways of State Property. Napalai Chaiwan would like to thank the Thailand Research Fund (PHD60K0147).

We would like to thank Huzefa Raja who provided the plate of Wicklowia aquatica, Junfu Li who provided description and notes of Pleomonodictydaceae, Dong Wei who provided notes of Aquamassaiosphaeria, and Areerat Manowong who processed facesoffungi numbers.

\section{References}

Abd-Elsalam KA, Tibpromma S, Wanasinghe DN, Camporesi E, Hyde KD. 2016 - Equiseticola gen. nov. (Phaeosphaeriaceae), from Equisetum sp. in Italy. Phytotaxa. 284(3),169-180.

Abdel-Aziz FA, Abdel-Wahab MA. 2010 - Lolia aquatica gen. et sp. nov. (Lindgomycetaceae, Pleosporales), a new coelomycete from freshwater habitats in Egypt. Mycotaxon 114, 33-42.

Abdel-Aziz FA. 2016a - The genus Lolia from freshwater habitats in Egypt with one new species. Phytotaxa 267, 279-288.

Abdel-Aziz FA. 2016b - Two new cheirosporous asexual taxa (Dictyosporiaceae, Pleosporales, Dothideomycetes) from freshwater habitats in Egypt. Mycosphere 7, 448-457.

Abdel-Wahab MA, Jones EBG. 2000 - Three new marine ascomycetes from driftwood in Australia sand dunes. Mycoscience 41, 379-388.

Abdel-Wahab MA, Jones EBG. 2003 - Decaisnella formosa sp. nov. (Ascomycota, Massariaceae) from an Australian sandy beach. Canadian Journal of Botany 81, 598-600

Abdullah SK, Asensio L, Monfort E, Gomez-Vidal S et al. 2005 - Occurrence in Elx, SE Spain of inflorescence rot disease of date palms caused by Mauginiella scaettae. Journal of phytopathology 153(7-8), 417-422.

Abed RM, Idan GR, Abbas RA, Salman NT. 2019 - Isolation and Identification of Fungi Caused Data Palms Inflorescence Rot Disease in Some Area of Diyala-Iraq and Control of Disease by Sodium Chloride Salt. Journal of Pure and Applied Microbiology 13(1), 459-463 
Adamčík S, Cai L, Chakraborty D, Chen X-H et al. 2015 - Fungal biodiversity profiles 1-10. Cryptogamie Mycologie 36, 121-166.

Adaskaveg JE, Ogawa JM, Buttler EE. 1990 - Morphology and ontogeny of conidia in Wilsonomyces carpophilus gen. nov. and comb. nov., causal pathogen of shot hole disease of Prunus species. Mycotaxon 31, 275-290.

Ahmed SA, Desbois N, Quist D, Miossec C et al. 2015 - Phaeohyphomycosis caused by a novel species, Pseudochaetosphaeronema martinelli. Journal of Clinical Microbiology 53, 29272934.

Ahmed SA, González GM, Tirado-Sánchez A, Moreno-López LM et al. 2018 - Nigrograna mackinnonii, not Trematosphaeria grisea (syn., Madurella grisea), is the main agent of black grain eumycetoma in Latin America. Journal of Clinical Microbiology 56, e01723-17.

Ahmed SA, Hofmüller W, Seibold M, De Hoog GS et al. 2017 - Tintelnotia, a new genus in Phaeosphaeriaceae harbouring agents of cornea and nail infections in humans. Mycoses 60(4), 244-253.

Ahmed SA, Stevens DA, van de Sande WWJ, Meis JF, de Hoog GS. 2014a - Roussoella percutanea, a novel opportunistic pathogen causing subcutaneous mycoses. Medical Mycology 52, 689-698.

Ahmed SA, van de Sande WWJ, Stevens DA, Fahal A et al. 2014b - Revision of agents of blackgrain eumycetoma in the order Pleosporales. Persoonia 33, 141-154.

Ahmed SI, Asad F. 1968 - Sporormia fimicola sp. nov. and Sporormiella inaequalis sp. nov. from West Pakistan. Sydowia 21, 290-294.

Ahmed SI, Cain RF. 1972 - Revision of the genera Sporormia and Sporormiella. Canadian Journal of Botany 50, 419-478.

Aiello D, Vitale A, Polizzi G, Voglmayr H. 2020 - Ochraceocephala foeniculi gen. et sp. nov., a new pathogen causing crown rot of fennel in Italy. MycoKeys 66, 1-22.

Akilandeswari P, Pradeep BV. 2016 - Exploration of industrially important pigments from soil fungi. Applied Microbiology and Biotechnology 100, 1631-1643.

Akulov OY, Hayova VP. 2016 - Immotthia atrograna (Dacampiaceae, Ascomycota), a new for Ukraine fungicolous fungus from the Carpathians. Ukrainian Botanical Journal 73, 84-89.

Alcorn JL, Irwin JAG. 1987 - Acrocalymma medicaginis gen. et sp. nov. causing root and crown rot of Medicago sativa in Australia. Transactions of the British Mycological Society 88, 163167.

Alias SA, Jones EBG. 2009 - Marine fungi from mangroves of Malaysia. Institute of Ocean and Earth Sciences, University Malaya, Malaysia pp 108.

Allescher A. 1903 - Die Pilze Deutschlands, Oesterreichs und der Schweiz. 7. Abth. Fungi Imperfecti: GefaX rbt-sporige Sphaerioideen, sowie Nectrioideen, Leptostromaceen, Excipulaceen und Familien der Ordnung Melanconieen. Dr. L. Rabenhorst's Kryptogamenflora von Deutschland, Oesterreich und der Schweiz. Band 1. Aufl. 2. Verlag von Eduard Kummer: Leipzig.

Almagro-Molto M, Haas A, Melcher C, Nam-Apostolopoulos YC, Schubert S. 2017 - First case of Roussoella percutanea bursitis. Diagnostic Microbiology and Infectious Disease 87, 172174.

Almeida DAC, Gusmão LFP, Miller AN. 2017 - A new species of Bertiella (Melanommataceae) from Brazil and a key to accepted species. Mycosphere 8, 392-396.

Aly AH, Debbab A, Proksch P. 2012 - Fungal endophytes: unique plant inhabitants with great promises. Applied Microbiology and Biotechnology 90, 1829-1845

Amaradasa B, Madrid H, Groenewald JZ, Crous P, Amundsen K. 2014 - Porocercospora seminalis gen. et comb. nov., the causal organism of buffalo grass false smut. Mycologia 106, 77-85.

Ando K. 1992 - A study of terrestrial aquatic Hyphomycetes. Transactions of the Mycological Society of Japan 33, 415-425.

Aptroot A, Lücking R, Sipman HJM, Umaña L, Chaves JL. 2008 - Pyrenocarpous lichens with bitunicate asci: a first assessment of the lichen biodiversity inventory in Costa Rica. Bibliotheca Lichenologica 97, 1-162. 
Aptroot A, Lücking R. 2016 - A first collaborative attempt at a global revision of Trypetheliaceae (Ascomycota: Dothideomycetes: Trypetheliales). The Lichenologist 48, 607-608.

Aptroot A. 1991 - A monograph of the Pyrenulaceae (excluding Anthracothecium and Pyrenula) and the Requienellaceae, with notes on the Pleomassariaceae, the Trypetheliaceae and Mycomicrothelia (lichenized and non-lichenized Ascomycetes). Bibliotheca Lichenologica $44,1-178$.

Aptroot A. 1995 - Redisposition of some species excluded from Didymosphaeria (Ascomycotina). Nova Hedwig 60, 325-379.

Aptroot A. 1998 - A world revision of Massarina (Ascomycota). Nova Hedwigia 66, 89-162.

Aptroot A. 2006 - Mycosphaerella and its anamorphs 2. Conspectus of Mycosphaerella. CBS Biodiversity Series 5. Utrecht, The Netherlands.

Aptroot A. 2012 - A world key to the species of Anthracothecium and Pyrenula. The Lichenologist 44, 5-53.

Aragona M, Minio A, Ferrarini A, Valente MT et al. 2014 - De novo genome assembly of the soilborne fungus and tomato pathogen Pyrenochaeta lycopersici. BMC Genomics 15, 313.

Ariyawansa HA, Phookamsak R, Tibpromma S, Kang JC, Hyde KD. 2014a - A Molecular and Morphological Reassessment of Diademaceae. Scientific World Journal 1-11.

Ariyawansa HA, Camporesi E, Thambugala KM, Mapook A et al. 2014b - Confusion surrounding Didymosphaeria-phylogenetic and morphological evidence suggest Didymosphaeriaceae is not a distinct family. Phytotaxa 176, 102-119.

Ariyawansa HA, Hyde KD, Jayasiri SC, Buyck B et al. 2015a - Fungal diversity notes 111-252taxonomic and phylogenetic contributions to fungal taxa. Fungal Diversity 75, 27-274.

Ariyawansa HA, Hyde KD, Tanaka K, Maharachchik-Umbura SSN et al. 2016 - Additions to Karst Fungi 3: Prosthemium sinense sp nov., from Guizhou Province, China. Phytotaxa 284, 28129.

Ariyawansa HA, Jaklitsch WM, Voglmayr H. 2018a - Additions to Taiwan fungal flora 1: Neomassariaceae fam. nov. Cryptogamie Mycologie 39, 359-373.

Ariyawansa HA, Jones EB, Suetrong S, Alias SA et al. 2013a - Halojulellaceae a new family of the order Pleosporales. Phytotaxa 130, 14-24.

Ariyawansa HA, Kang JC, Alias SA, Chukeatirote E, Hyde KD. 2013b - Towards a natural classification of Dothideomycetes: The genera Dermatodothella, Dothideopsella, Grandigallia, Hysteropeltella and Gloeodiscus (Dothideomycetes incertae sedis). Phytotaxa 147, 35-47.

Ariyawansa HA, Maharachchikumbura SS, Karunarathne SC, Chukeatirote E et al. 2013c Deniquelata barringtoniae gen. et sp. nov., associated with leaf spots of Barringtonia asiatica. Phytotaxa 105, 11-20.

Ariyawansa HA, Phillips AJ, Chuang WY, Tsai I. 2018b - Tzeananiaceae, a new pleosporalean family associated with Ophiocordyceps macroacicularis fruiting bodies in Taiwan. MycoKeys 37, 1-17.

Ariyawansa HA, Phukhamsakda C, Thambugala KM, Bulgakov TS et al. 2015b - Revision and phylogeny of Leptosphaeriaceae. Fungal Diversity 74, 19-51.

Ariyawansa HA, Tanaka K, Thambugala KM, Phookamsak R et al. 2014d - A molecular phylogenetic reappraisal of the Didymosphaeriaceae (= Montagnulaceae). Fungal Diversity 68, 69-104.

Ariyawansa HA, Thambugala K, Manamgoda D, Jayawardena R et al. 2015c - Towards a natural classification and backbone tree for Pleosporaceae. Fungal Diversity 71, 85-139.

Ariyawansa HA, Thambugala KM, Kang JC, Alias SA et al. 2014e - Towards a natural classification of Dothideomycetes 2: The genera Cucurbidothis, Heterosphaeriopsis, Hyalosphaera, Navicella and Pleiostomellina (Dothideomycetes incertae sedis). Phytotaxa $176,7-17$.

Arnaud G. 1918 - Lés Asterinées. Ann Éc Natl Agric Montp 2 16, 1-288.

Arnold RH. 1972 - Melanodothis caricis, n. gen., n. sp. and 'Hyalodothis? caricis'. Canadian Journal of Botany. 49, 2187-2196 
Arzanlou M, Groenewald JZ, Gams W, Braun U et al. 2007 - Phylogenetic and morphotaxonomic revision of Ramichloridium and allied genera. Studies in Mycology 58, 57-93.

Aveskamp MM, de Gruyter J, Woudenberg JHC, Verkley GJM, Crous PW. 2010 - Highlights of the Didymellaceae: a polyphasic approach to characterise Phoma and related pleosporalean genera. Studies in Mycology 65, 1-60.

Aveskamp MM, Gruyter J de, Crous PW. 2008 - Biology and recent developments in the systematics of Phoma, a complex genus of major quarantine significance. Fungal Diversity $31,1-18$.

Aveskamp MM, Verkley GJM, Gruyter J de, Murace MA et al. 2009 - DNA phylogeny reveals polyphyly of Phoma section Peyronellaea and multiple taxonomic novelties. Mycologia 101, 363-382.

Badali H, Chander J, Gulati N, Attri A. 2010 - Subcutaneous phaeohyphomycotic cyst caused by Pyrenochaeta romeroi. Medical Mycology 48, 763-768.

Baker BJ, Lutz MA, Dawson SC, Bond PL, Banfield JF. 2004 - Metabolically active eukaryotic communities in extremely acidic mine drainage. Applied and Environmental Microbiology 70, 6264-6271.

Bakhshi M, Arzanlou M, Babai-Ahari A, Groenewald JZ, Crous PW. 2015 - Is morphology in Cercospora a reliable reflection of generic affinity?. Phytotaxa 213(1), 22-34.

Bakhshi M, Arzanlou M, Groenewald JZ, Quaedvlieg W, Crous PW. 2019 - Parastagonosporella fallopiae gen. et sp. nov. (Phaeosphaeriaceae) on Fallopia convolvulus from Iran. Mycological Progress 18, 203-214.

Baldrian P, Valášková V. 2008 - Degradation of cellulose by basidiomycetous fungi. FEMS Microbiology Reviews 32, 501-521.

Balis E, Velegraki A, Fragou A, Pefanis A et al. 2006 - Lung mass caused by Phoma exigua. Scandinavian Journal of Infectious Diseases 38, 552-555.

Barnes I, Crous PW, Wingfield MJ, Wingfield BD. 2004 - Multigene phylogenies reveal that red band needle blight of Pinus is caused by two distinct species of Dothistroma, D. septosporum and D. pini. Studies in Mycology, 50, 551-565.

Barnes I, Van der Nest A, Mullett MS, Crous PW, Drenkhan R, Musolin DL, Wingfield MJ. 2016 Neotypification of Dothistroma septosporum and epitypification of D. pini, causal agents of Dothistroma needle blight of pine. Forest Pathology 48, 388-407.

Barr ME, Blackwell M. 1980 - A new genus in the Lophiaceae. Mycologia 72, 1224-1227.

Barr ME, Boise JR. 1989 - Syncarpella (Pleosporales, Cucurbitariaceae). Memoirs of the New York Botanical Garden 49, 298-304.

Barr ME, Huhndorf SM. 2001 - Loculoascomycetes. In: McLaughlin DJ, McLaughlin EG, Lemke PA (eds) The mycota VII, part A. Systematics and evolution. Springer Verlag, Berlin, pp 283-305.

Barr ME. 1972 - Preliminary studies on the Dothideales in temperate North America. Contributions from the University of Michigan Herbarium 9, 523-638.

Barr ME. 1976 - Hypoxylon grandineum: a Loculoascomycete. Mycotaxon 3, 325-329.

Barr ME. 1979a - A classification of Loculoascomycetes. Mycologia 71, 935-995.

Barr ME. 1979b - On the Massariaceae in North America. Mycotaxon 9, 17-37.

Barr ME. 1981 - The genus Curreya: an example of taxonomic confusion in the Ascomycetes. Mycologia 73, 599-609.

Barr ME. 1982 - On the Pleomassariaceae (Pleosporales) in North America. Mycotaxon 15, 349383.

Barr ME. 1983 - Muriform ascospores in class ascomycetes. Mycotaxon 18, 149-157.

Barr ME. 1984 - Herpotrichia and its segregates. Mycotaxon 20, 1-38.

Barr ME. 1986 - On Julella, Delacourea, and Decaisnella, three dictyosporous genera described by JH Fabre. Sydowia 38, 11-19.

Barr ME. 1987a - New taxa and combinations in the Loculoascomycetes. Mycotaxon 29, 501-505.

Barr ME. 1987b - Prodromus to class Loculoascomycetes. Amherst, Massachusetts, University of Massachusetts, USA 
Barr ME. 1990a - Melanommatales (Loculoascomycetes). North American Flora 13(II), 1-129.

Barr ME. 1990b - Some dictyosporous genera and species of Pleosporales in North America. Memoirs of the New York Botanical Garden 62, 1-92.

Barr ME. 1990c - V. Massariaceae. In North American Flora, ser. II (13): Melanommatales (Loculoascomycetes). New York Botanical Garden, New York, pp 66-82.

Barr ME. 1992a - Additions to and notes on the Phaeosphaeriaceae (Pleosporales, Loculoascomycetes). Mycotaxon 43, 371-400.

Barr ME. 1992b - Notes on the Lophiostomataceae (Pleosporales). Mycotaxon 45, 191-221.

Barr ME. 1993a - Notes on the Pleomassariaceae. Mycotaxon 49, 129-142.

Barr ME. 1993b - Redisposition of some taxa described by J.B. Ellis. Mycotaxon 46, 45-76.

Barr ME. 1997 - Notes on some 'dimeriaceous' fungi. Mycotaxon 64, 149-171.

Barr ME. 2000 - Notes on coprophilous bitunicate Ascomycetes. Mycotaxon 76, 105-112.

Barr ME. 2001 - Revisionary studies on the Dothioraceae. Harvard Papers in Botany 6, 25-34.

Barr ME. 2002 - Teichosporaceae, another family in the Pleosporales. Mycologia 82, 373-389.

Barr ME. 2003 - The affinities of Thyridaria. Mycotaxon 88, 271-278.

Batista AC, Bezerra JL, Cavalcante W. de A, Maia H da Silva. 1963 - Mycerema e outros novos gêneros de Stomiopeltoideae, da familia Micropeltaceae. Publicações do Instituto de Micologia da Universidade do Recife 392, 1-40.

Batista AC, Bezerra JL, Peres GE. 1965 - Vonarxella e outros novos Ascomycetes. Rivista di Patologia Vegetale 61-69.

Batista AC, Costa CAA, Ciferri R. 1957 - Orgânogênese e sistemática dos fungos Trichopeltinaceae (Theiss.) emend. nobis. Publicações do Instituto de Micologia da Universidade do Recife 90, 1-24.

Batista AC, Nascimento ML. 1957 - Alguns novos fungos imperfeitos do complex de fumagina. Anais da Sociedade de Biologia de Pernambuco 15, 345-353.

Batista AC. 1959 - Monografia dos fungos Micropeltaceae. Publicações do Instituto de Micologia da Universidade do Recife 56, 1-519.

Batzer JC, Arias MMD, Harrington TC, Gleason ML. 2008 - Four species of Zygophiala (Schizothyriaceae, Capnodiales) are associated with the sooty blotch and flyspeck complex on apple. Mycologia 100, 246-258.

Batzer JC, Gleason ML, Harrington TC, Tiffany LH. 2005 - Expansion of the sooty blotch and flyspeck complex on apples based on analysis of ribosomal DNA gene sequences and morphology. Mycologia 97, 1268-1286.

Batzer JC, Gleason ML, Weldon B, Dixon PM, Nutter Jr FW. 2002 - Evaluation of postharvest removal of sooty blotch and flyspeck on apples using sodium hypochlorite, hydrogen peroxide with peroxyacetic acid, and soap. Plant Disease 86, 1325-1332.

Batzer JC, Weber RW, Mayfield DA, Gleason ML. 2016 - Diversity of the sooty blotch and flyspeck complex on apple in Germany. Mycological Progress 15, 2.

Beimforde C, Feldberg K, Nylinder S, Rikkinen J et al. 2014 - Estimating the Phanerozoic history of the Ascomycota lineages: combining fossil and molecular data. Molecular Phylogenetics and Evolution78, 386-398.

Bensch K, Braun U, Groenewald JZ, Crous PW. 2012 - The genus Cladosporium. Studies in Mycology 72, 1-401.

Bensch K, Groenewald JZ, Braun U, Dijksterhuis J et al. 2015 - Common but different: the expanding realm of Cladosporium. Studies in Mycology 82, 23-74.

Bensch K, Groenewald JZ, Dijksterhuis J, Starink-Willemse M et al. 2010 - Species and ecological diversity within the Cladosporium cladosporioides complex (Davidiellaceae, Capnodiales). Studies in Mycology 67, 1-94.

Bensch K, Groenewald JZ, Meijer M, Dijksterhuis J et al. 2018 - Cladosporium species in indoor environments. Studies in Mycology 89, 177-301.

Berkeley MJ, Broome CE. 1850 - Notices of British fungi (438-501). The Annals and magazine of natural history $5,455-466$. 
Berkeley MJ, Broome CE. 1852 - Notices of British Fungi (615-639). The Annals and mMagazine of natural history 9, 317-329.

Berlese AN. 1896 - Icones fungorum. II. Fasc, 29-6.

Bezerra JDP, Sandoval-Denis M, Paiva LM, Silva GA et al. 2017 - New endophytic Toxicocladosporium species from cacti in Brazil, and description of Neocladosporium gen. nov. IMA Fungus 8, 77-97.

Bhunjun, CS, Dong Y, Jayawardena RS et al. 2020 - A polyphasic approach to delineate species in Bipolaris. Fungal Diversity. Fungal Diversity 102, 225-256.

Bills GF, Collado J, Ruibal C, Peláez F, Platas G. 2004 - Hormonema carpetanum sp. nov., a new lineage of dothideaceous black yeasts from Spain. Studies in Mycology 50, 149-157.

Bizzozero G. 1885 - Funghi Veneti novi vel critici. Atti dell’Istituto Veneto Scienze 3, 303-309.

Blackwell M, Gilbertson RL. 1985 - Quasiconcha reticulata and its anamorph from conifer roots. Mycologia 77, 50-54.

Boedijn KB. 1961 - Myriangiales from Indonesia. Persoonia 2, 63-75.

Boehm EWA, Mugambi G, Miller AN, Huhndorf S et al. 2009a - A molecular phylogenetic reappraisal of the Hysteriaceae, Mytilinidiaceae and Gloniaceae (Pleosporomycetidae, Dothideomycetes) with keys to world species. Studies in Mycology 64, 49-83.

Boehm EWA, Schoch CL, Spatafora JW. 2009b - On the evoluation of the Hysteriaceae and Mytilinidiaceae (Pleosporomycetidae, Dothideomyceetes, Ascomycota) using four nuclear genes. Mycological Research 113, 461-479.

Boerema GH, Bollen GJ. 1975 - Conidiogenesis and conidial septation as differentiating criteria between Phoma and Ascochyta. Persoonia 8, 111-444.

Boerema GH, de Gruyer J, Noordeloos ME, Hamers MEC. 2004 - Phoma identification manual. Differentiation of specific and infra-specific taxa in culture CABI Publishing, Wallingford, UK.

Boerema GH, Gruyter J, Kesteren HA. 1994 - Contributions towards a monograph of phoma (coelomycetes) - III-1. Section Plenodomus: Taxa often with a Leptosphaeria teleomorph. Persoonia 15, 431-487.

Boerema GH, Kesteren HA. 1964 - The nomenclature of two fungi parasitizing brassica. Persoonia $3,17-28$.

Boerema GH. 1997 - Contributions towards a monograph of phoma (coelomycetes) - V. subdivision of the genus in sections. Mycotaxon 64, 321-333.

Boise J. 1983 - On Trematosphaeria circinans and reinstatement of the genus Byssothecium. Mycologia 75, 666-669.

Boise JR. 1984 - New and interesting fungi (Loculoascomycetes) from the Amazon. Acta Amazonica 14, 49-53.

Boise JR. 1985a - An amended description of Trematosphaeria. Mycologia 77:230-237

Boise JR. 1985b - New combinations in the Pleomassariaceae and the Massarinaceae. Mycotaxon $22,477-482$.

Boise JR. 1989 - On Hadrospora, a new genus in the Phaeosphaeriaceae and Byssothecium alpestris. Memoirs of the New York Botanical Garden 49, 308-310.

Bonifaz A, Badali H, De Hoog GS, Cruz M et al. 2008 - Tinea nigra by Hortaea werneckii, a report of 22 cases from Mexico. Studies in Mycology 61, 77-82.

Bonorden HF. 1864 - Abhandlungen aus dem Gebiete der Mykologie. Abhandlungen der Naturforschenden Gesellschaft zu Halle 8, 1-168.

Boonmee S, Calabon MS, Phookamsak R, Elgorban AM, Hyde KD. 2020 - Triseptata sexualis gen. et sp. nov. in Latoruaceae (Pleosporales). Phytotaxa 447, 252-264.

Boonmee S, D'souza MJ, Luo ZL, Pinruan U et al. 2016 - Dictyosporiaceae fam. nov. Fungal Diversity 80, 457-482.

Boonmee S, Ko-Ko TW, Chukeatirote E, Hyde KD et al. 2012 - Two new Kirschsteiniothelia species with Dendryphiopsis anamorphs cluster in Kirschsteiniotheliaceae fam. nov. Mycologia 104, 698-714. 
Boonmee S, Phookamsak R, Hongsanan S, Doilom M et al. 2017 - Mycosphere notes 51-101. Revision of genera in Perisporiopsidaceae and Pseudoperisporiaceae and other Ascomycota genera incertae sedis. Mycosphere 8, 1695-1801.

Boonmee S, Sorvongxay T, Huanraluek N, Hyde KD. 2019 - Wicklowia submersa sp. nov. (Wicklowiaceae, Pleosporales), a second species in a monotypic family. Phytotaxa 411, 7383.

Boonmee S, Zhang Y, Chomnunti P, Chukeatirote E et al. 2011 - Revision of lignicolous Tubeufiaceae based on morphological reexamination and phylogenetic analysis. Fungal Diversity 51, 63-102.

Borse BD, Hyde KD. 1989 - Marine fungi from India. III. Acrocordiopsis patilii gen. et sp. nov. from mangrove wood. Mycotaxon 34, 535-540.

Bose SK. 1961 - Studies on Massarina Sacc. and related genera. Journal of Phytopathology 41, 151-213.

Bose T, Reynolds DR, Berbee ML. 2014 - Common, unsightly and until now undescribed: Fumiglobus pieridicola sp. nov., a sooty mold infesting Pieris japonica from western North America. Mycologia 106, 746-756.

Bradshaw RE, Zhang S. 2006 - Biosynthesis of dothistromin. Mycopathologia 162, 201-213.

Bradshaw RE. 2004 - Dothistroma (red-band) needle blight of pines and the dothistromin toxin: A review. Forest Pathology 34, 163-185.

Braun U, Crous P. 2016 - (2415) Proposal to conserve the name Cercospora (Ascomycota: Mycosphaerellaceae) with a conserved type. Taxon. 65(1), 185.

Braun U, Crous PW, Dugan F, Groenewald JZ, Hoog GS de. 2003 - Phylogeny and taxonomy of Cladosporium-like hyphomycetes, including Davidiella gen. nov., the teleomorph of Cladosporium s. str. Mycological Progress 2, 3-18.

Braun U, Crous PW, Nakashima C. 2014 - Cercosporoid fungi (Mycosphaerellaceae) 2. Species on monocots (Acoraceae to Xyridaceae, excluding Poaceae). IMA Fungus 5(2), 203-390.

Braun U, Crous PW, Nakashima C. 2015 - Cercosporoid fungi (Mycosphaerellaceae) 3. Species on monocots (Poaceae, true grasses). IMA fungus 6(1), 25-98.

Braun U, Crous PW, Schubert K. 2008 - Taxonomic revision of the genus Cladosporium s. lat. 8. Reintroduction of Graphiopsis (= Dichocladosporium) with further reassessments of cladosporioid hyphomycetes. Mycotaxon 103, 207-216.

Braun U, Heuchert B, Diederich P. 2009 - Two new and another interesting lichenicolous hyphomycete. Herzogia 22, 165-171.

Braun U, Nakashima C, Crous PW. 2013 - Cercosporoid fungi (Mycosphaerellaceae) 1. Species on other fungi, Pteridophyta and Gymnospermae. IMA Fungus 4(2), 265-345.

Braun U. 1995 - A monograph of Cercosporella, Ramularia and allied genera (phytopathogenic Hyphomycetes) Vol. 1. IHW-Verlag Eching, 1-333.

Braun U. 1996 - Taxonomic notes on some species of the Cercospora complex (IV). Sydowia, 48, 205-217.

Braun U. 1998 - A monograph of Cercosporella, Ramularia and allied genera (phytopathogenic hyphomycetes): Vol. 1. IHW-Verlag, Eching, Munich, Germany.

Bretag TW, Keane PJ, Price TV. 2006 - The epidemiology and control of ascochyta blight in field peas: a review. Australian Journal of Agricultural Research 57, 883-902.

Bucher VVC, Hyde KD, Pointing SB, Reddy CA. 2004 - Production of wood decay enzymes, mass loss and lignin solubilization in wood by diverse freshwater fungi. Microbial Ecology 48, 331-337.

Bulgakov TS, Vasilyev NP, Zmitrovich IV. 2014 - Summarizing of 10-years investigation on mycobiota of alien trees and shrubs in arboretum of the «Otradnoye» Research Station of the Komarov Botanical Institute. Botany: history, theory, practice (on the occasion of the 300th anniversary of the founding of the V.L. Komarov Botanical Institute of the Russian Academy of Sciences). V.L. Komarov Botanical Institute, St. Petersburg, Russia: 31-39 (in Russian).

Bullerman LB. 2003 - Spoilage fungi in food - An Overview. Caballero, B. 2003. Encyclopedia of Food Sciences and Nutrition (Second Edition), pp 5511-5522. 
Burney DA, Robinson GS, Burney LP. 2003 - Sporormiella and the late Holocene extinctions in Madagascar. Proceedings of the National Academy of Sciences of the United States of America 100, 10800-10805.

Butin H, Holdenrieder O, Sieber TN. 2013 - The complete life cycle of Petrakia echinata. Mycological Progress 12, 427-435.

Butin H, Pehl L. 1993 - Kabatina abietis sp. nov., associated with browing of fir needles. Mycological Research 97, 1340-1342.

Butin H, Schneider R. 1976 - Kabatina populi nov. spec. Phytopathologische Zeitschrift, Journal of Phytopathology 85, 39-42.

Butin H. 1964 - Überzwei Nebenfruchtformen von Sydowia polyspora (Gref.et v. Tav.) Müller. Sydowia 17, 114-118.

Butin H. 1970 - Zwei neue arten der gattung phaeocryptopus naumov. Phytopathologische Zeitschrift, Journal of Phytopathology 68, 269-275.

Cai L, Guo XY, Hyde KD. 2008 - Morphological and molecular characterization of a new anamorphic genus Cheirosporium, from freshwater in China. Persoonia 20, 53-58.

Cai L, Jeewon R, Hyde KD. 2006a - Phylogenetic investigations of Sordariaceae based on multiple gene sequences and morphology. Mycological Research 110, 137-150.

Cai L, Ji KF, Hyde KD. 2006b - Variation between freshwater and terrestrial fungal communities on decaying bamboo culms. Antonie van Leeuwenhoek 89, 293-301.

Cai L, Zhang K, McKenzie EHC, Hyde KD. 2003 - Freshwater fungi from bamboo and wood submerged in the Liput River in the Philippines. Fungal Diversity 13, 1-12.

Cain RF, Luck-Allen ER. 1969 - Semidelitschia, a new genus of the Sporormiaceae. Mycologia 61, 580-585.

Cain RF. 1934 - Studies of coprophilous Sphaeriales in Ontario. University of Toronto Studies, Biological Series, No. 3

Cain RF. 1961 - Studies of coprophilous ascomycetes. VII. Preussia. Canadian Journal of Botany 39, 1633-1666.

Calatayud V, Navarro-Rosinés P. 1998 - Weddellomyces xanthoparmeliae sp. nov. and additions to the chorology of other species of the genus. Mycotaxon 69, 503-514.

Calatayud V, Sanz MJ, Aptroot A. 2001 - Lichenopyrenis galligena (Pleomassariaceae), a new genus of gall-forming lichenicolous fungi on Leptochidium. Mycological Research 105, 634637.

Câmara MP, Ramaley AW, Castlebury LA, Palm ME. 2003 - Neophaeosphaeria and Phaeosphaeriopsis, segregates of Paraphaeosphaeria. Mycological Research 107, 516-522.

Cannon PF, Kirk PM. 2007 - Fungal Families of the World. CABI Bioscience, Wallingford, UK, pp $1-456$.

Cannon PF. 1982 - Anote on the nomenclature of Herpotrichia. Transactions of the British Mycological Society 79, 338-339.

Carmarán CC, Novas MV. 2003 - A review of Spegazzini taxa of Periconia and Sporocybe after over 115 years. Fungal Diversity 14, 67-76.

Carmichael JW, Kendrick WB, Conners IL and Sigler L. 1980 - Genera of Hyphomycetes. University of Alberta Press, Edmonto, pp 396.

Castañeda-Ruíz FC, Heredia G. 2000 - Two new dematiaceous hyphomycetes on Cyathea from Mexico. Cryptogamie Mycologie 21, 221-228.

Castañeda-Ruíz RF, Heredia G, Arias RM, Mckenzie EHC et al. 2011 - A new species and redisposed taxa in repetophragma. Mycosphere 2, 273-289.

Castellani E, Germano EG. 1977 - Le Stagonosporae graminicola. Annali della Facolta di Scienze Agrarie della Universita degli Studi di Torino 10, 1-132.

Cavara F. 1925 - Mauginiella scaettae Cav. nuovo ifomicete parassita della palma da datteri in Cirenacia. Boletin Orto. Botanico Napoli 8, 207-211.

Cech TL, Perny, B, Talgø V. 2009 - Neue ergebnisse zur KabatinaNadelschütte der Tannen (Kabatina abietis). Forstschutz Aktuell 48, 27. 
Cesati V, De Notaris G. 1863 - Schema di classificazione degle sferiacei italici aschigeri piu' o meno appartenenti al genere Sphaeria nell'antico significato attribuitoglide Persono. Commentario della Società Crittogamologica Italiana 1, 177-420.

Chaiwan N, Wanasinghe DN, Camporesi E, Tibpromma S, Boonmee S, Lumyong S, Hyde KD. 2019 - Molecular taxonomy reveals the sexual morph of Nodulosphaeria digitalis in Phaeosphaeriaceae from Campanula trachelium in Italy. Phytotaxa. 400(1), 1-3.

Cheewangkoon R, Groenewald JZ, Hyde KD, To-anun C, Crous PW. 2012 - Chocolate Spot disease of Eucalyptus. Mycological Progress 11, 61-69.

Cheewangkoon R, Groenewald JZ, Summerell BA, Hyde KD et al. 2009 - Myrtaceae, a cache of fungal biodiversity. Persoonia 23, 55-85.

Chen CY, Hsieh WH. 1996 - New records of Ascomycetes from Taiwan. Fungal Science 11, 1729.

Chen CY, Hsieh WH. 2004 - Astrosphaeriella from Taiwan, including two new species. Botanical Bulletin of Academia Sinica 45, 171-178.

Chen Q, Hou LW, Duan WJ, Crous PW, Cai L. 2017 - Didymellaceae revisited. Studies in Mycology 87, 105-159.

Chen Q, Jiang JR, Zhang GZ, Cai L, Crous PW. 2015 - Resolving the Phoma enigma. Studies in Mycology 82, 137-217.

Chesters CGC, Bell A. 1970 - Studies in the Lophiostomataceae Sacc. Mycological Papers 120, $55-77$.

Chesters CGC. 1938 - Studies on British pyrenomycetes II. A comparative study of Melanomma pulvis-pyrius (Pers.) Fuckel, Melanomma fuscidulum Sacc. and Thyridaria rubronotata (B.\&Br.) Sacc. Transactions of the British Mycological Society 22, 116-150.

Chethana KWT, Jayawardene RS, Zhang W, Zhou YY et al. 2019 - Molecular characterization and pathogenicity of fungal taxa associated with cherry leaf spot disease. Mycosphere 10, 490530.

Chethana KWT, Liu M, Ariyawansa HA, Konta S et al. 2015 - Splanchnonema-like species in Pleosporales: introducing Pseudosplanchnonema gen. nov. in Massarinaceae. Phytotaxa 231, 133-144.

Chilvers GA. 1968 - Some distinctive types of eucalypt mycorrhiza. Australian Journal of Botany $16,49-70$.

Chomnunti P, Bhat DJ, Jones EBG, Chukeatirote E et al. 2012 - Trichomeriaceae, a new sooty mould family of Chaetothyriales. Fungal Diversity 56, 63-76.

Chomnunti P, Hongsanan S, Aguirre-Hudson B, Tian Q et al. 2014) The sooty moulds. Fungal Diversity 66, 1-36.

Chomnunti P, Schoch CL, Aguirre-Hudson B, KoKo TW et al. 2011 - Capnodiaceae. Fungal Diversity $51,103-134$.

Ciferri R, Batista AC, Campos CA. 1956 - Taxonomy of Piedraia hortai and systematic position of the Piedraiaceae family. Publicações do Instituto de Micologia da Universidade do Recife $45,1-9$.

Ciferri R. 1958 - Man Mic Med, edn 2 (Pavia) 1, 178.

Clements FE, Shear CL. 1931 - Genera of fungi, edn 2. i-vii, 58 plates. H.W. Wilson Company, USA, New York, pp 496.

Clum FM. 1955 - A new genus in the Aspergillaceae. Mycologia 47, 899-901.

Cooke MC. 1871 - Handbook of British Fungi: with full descriptions of all the species, and illustrations of the genera (Vol. 1). Macmillan and Company, 1-981

Cooke MC. 1883 - North American fungi. Grevillea. 11, 106-111.

Coppins BJ. 1988 - Notes on the genus Arthopyrenia in the British Isles. The Lichenologist 20, 305-325.

Cortinas MN, Burgess T, Dell B, Xu D et al. 2006 - First record of Colletogloeopsis zuluense comb. nov., causing a stem canker of Eucalyptus in China. Mycological Research 110, 229 236. 
Cortinas MN, Koch N, Thain J et al. 2004 - First record of the Eucalyptus stem canker pathogen, Coniothyrium zuluense from Hawaii. Australasian Plant Pathology 33, 309.

Costa EO, Gandra CR, Pires MF, Couthino SD et al. (1993). Survey of bovine mycotic mastitis in dairy herds in the State of São Paulo, Brazil. Mycopathologia 124, 13-17.

Crane JL, Miller AN. 2016 - Studies in genera similar to Torula: Bahusaganda, Bahusandhika, Pseudotorula, and Simmonsiella gen. nov. IMA Fungus 7, 29-45.

Crane JL, Schoknecht JD. 1977 - Revision of Torula species. Rutola, a new genus for Torula graminis. Canadian Journal of Botany 55, 3013-3019.

Crane JL, Schoknecht JD. 1986 - Revision of Torula and Hormiscium species. New names for Hormiscium undulatum, Torula equina, and Torula convolvuli. Mycologia 78, 86-91.

Crane JL, Shearer CA, Barr ME. 1998 - A revision of Boerlagiomyces with notes and a key to the saprobic genera of Tubeufiaceae. Canadian Journal of Botany 76, 602-612.

Crane JL, Shearer CA. 1991 - A nomenclator of Leptosphaeria V. Cesati \& G. de notaris (mycota - ascomycotina - loculoascomycetes). Illinois Natural History Survey Bulletin 34, 1-355.

Crivelli PG. 1983 - Ueber die heterogene Ascomycetengattung Pleospora Rabh. Vorschlag für eine Aufteilung, Zürich. Diss ETH Nr 7318, pp 1-215.

Crous PW SR, Quaedvlieg W, van der Bank M, Zhang Y et al. 2014a - Fungal Planet description sheets: 214-280. Persoonia 32, 184-306.

Crous PW, Barreto RW, Alfenas AC, Alfenas RF, Groenewald JZ. 2010 - What is Johansonia?. IMA Fungus 1, 117-122.

Crous PW, Braun U, Groenewald JZ. 2007a - Mycosphaerella is polyphyletic. Studies in Mycology 58, 1-32.

Crous PW, Braun U, Hunter GC, Wingfield MJ et al. 2013a - Phylogenetic lineages in Pseudocercospora. Studies in Mycology 75, 37-114.

Crous PW, Braun U, Schubert K, Groenewald JZ. 2007b - Delimiting Cladosporium from morphologically similar genera. Studies in Mycology 58, 33-56.

Crous PW, Braun U, Wingfield MJ, Wood AR et al. 2009a - Phylogeny and taxonomy of obscure genera of microfungi. Persoonia 22, 139-161.

Crous PW, Braun U. 2003 - Mycosphaerella and its anamorphs: 1. Names published in Cercospora and Passalora. CBS Biodiversity Series No. 1. Westerdijk Fungal Biodiversity Institute, Utrecht, the Netherlands.

Crous PW, Carnegie AJ, Wingfield MJ, Sharma R et al. 2019a - Fungal Planet description sheets: 868-950. Persoonia 42, 291-473.

Crous PW, Carris LM, Giraldo A, Groenewald JZ et al. 2015a - The Genera of Fungi - fixing the application of the type species of generic names - G 2: Allantophomopsis, Latorua, Macrodiplodiopsis, Macrohilum, Milospium, Protostegia, Pyricularia, Robillarda, Rotula, Septoriella, Torula, and Wojnowicia. IMA Fungus 6, 163-198.

Crous PW, Groenewald JZ, Gams W. 2003a - Eyespot of cereals revisited: ITS phylogeny reveals new species relationships. European Journal of Plant Pathology 109, 841-850.

Crous PW, Groenewald JZ, Mansilla JP, Hunter GC, Wingfield MJ. 2004 - Phylogenetic reassessment of Mycosphaerella spp. and their anamorphs occurring on Eucalyptus. Studies in Mycology 50, 195-214.

Crous PW, Groenewald JZ, Shivas RG, Edwards J et al. 2011a - Fungal Planet description sheets: 69-91. Persoonia 26, 108-156.

Crous PW, Groenewald JZ, Summerell BA et al. 2009b - Co-occurring species of Teratosphaeria on Eucalyptus. Persoonia 22, 38-48.

Crous PW, Groenewald JZ, Wingfield MJ, Aptroot A. 2003b - The value of ascospore septation in separating Mycosphaerella from Sphaerulina in the Dothideales: a Saccardoan myth? Sydowia 55, 136-152.

Crous PW, Groenewald JZ. 2011 - Why everlastings don't last. Persoonia 26, 70-84.

Crous PW, Groenewald JZ. 2016 - They seldom occur alone. Fungal Biology 120, 1392-1415.

Crous PW, Groenewald JZ. 2017 - The Genera of Fungi - G 4: Camarosporium and Dothiora. IMA Fungus 8, 131-152. 
Crous PW, Luangsa-Ard JJ, Wingfield MJ, Carnegie AJ et al. 2018a - Fungal Planet description sheets: 785-867. Persoonia 41, 238-417.

Crous PW, Schoch CL, Hyde KD, Wood AR et al. 2009c - Phylogenetic lineages in the Capnodiales. Studies in Mycology 64, 17-47.

Crous PW, Schubert K, Groenewald JZ, Summerell B et al. 2007c - Hoornsmania pyrina; Alternaria thalictrigena; Mycosphaerella elaeocarpi; Sphaceloma banksiicola; Valsaria ceratoniae; Penidiella kurandae; Exophiala placitae; Falcocladium thailandicum; Neofusicoc, In: Fungal Planet, A Global Initiative to Promote the Study of Fungal Biodiversity 11-21.

Crous PW, Schumacher RK, Akulov A, Thangavel R et al. 2019b - New and Interesting Fungi 2. FUSE 3, 57-134.

Crous PW, Schumacher RK, Wingfield MJ, Akulov A et al. 2018b - New and Interesting Fungi 1. FUSE 1, 169-215.

Crous PW, Schumacher RK, Wingfield MJ, Lombard et al. 2015b - Fungal Systematics and Evolution: FUSE 1. Sydowia 67, 81-118.

Crous PW, Schumacher RK, Wood AR, Groenewald JZ. 2019c - The Genera of Fungi - G5: Arthrinium, Ceratosphaeria, Dimerosporiopsis, Hormodochis, Lecanostictopsis, Lembosina, Neomelanconium, Phragmotrichum, Pseudomelanconium, Rutola, and Trullula. FUSE 5, 7798.

Crous PW, Shivas RG, Quaedvlieg W, vander Ban KM et al. 2013b - Fungal Planet description sheets: 154-213. Persoonia 31, 188-296.

Crous PW, Summerell BA, Carnegie AJ, Mohammed C et al. 2007d - Foliicolous Mycosphaerella spp. and their anamorphs on Corymbia and Eucalyptus. Fungal Diversity 26, 143-185.

Crous PW, Summerell BA, Carnegie AJ, Wingfield MJ, Groenewald JZ. 2009d - Novel species of Mycosphaerellaceae and Teratosphaeriaceae. Persoonia 23, 119-146.

Crous PW, Summerell BA, Carnegie AJ, Wingfield MJ. 2009e - Unravelling Mycosphaerella: do you believe in genera? Persoonia 23, 99-118.

Crous PW, Summerell BA, Mostert L, Groenewald JZ. 2008 - Host specificity and speciation of Mycosphaerella and Teratosphaeria species associated with leaf spots of Proteaceae. Persoonia 20, 59-86.

Crous PW, Summerell BA, Shivas RG et al. 2012 - Fungal Planet description sheets: 107-127. Persoonia: Molecular Phylogeny and Evolution of Fungi 28, 138-182.

Crous PW, Summerell BA, Shivas RG, Romberg M et al. 2011b - Fungal Planet description sheets: 92-106. Persoonia 27, 130-162.

Crous PW, Summerell BA, Swart L, Denman S et al. 2011c - Fungal pathogens of Proteaceae. Persoonia 27, 20-45.

Crous PW, Tanaka K, Summerelp BA, Groenewald JZ. 2011d - Additions to the Mycosphaerella complex. IMA Fungus 2, 49-64.

Crous PW, Wingfield MJ, Burgess TI, Carnegie AJ et al. 2017a - Fungal Planet description sheets: 625-715. Persoonia 39, 270-467.

Crous PW, Wingfield MJ, Burgess TI, Hardy GESJ et al. 2017b - Fungal Planet description sheets: 558-624. Persoonia 38, 240-384.

Crous PW, Wingfield MJ, Burgess TI, Hardy GESJ et al. 2018c - Fungal Planet description sheets: 716-784. Persoonia 40, 240-393.

Crous PW, Wingfield MJ, Burgess TI, Hardy GSJ et al. 2016a - Fungal Planet description sheets: 469-557. Persoonia 37:218-403.

Crous PW, Wingfield MJ, Cheewangkoon R, Carnegie AJ et al. 2019d - Foliar pathogens of eucalypts. Studies in Mycology 94, 125-298.

Crous PW, Wingfield MJ, Guarro J, Hernández-Restrepo M et al. 2015c - Fungal Planet description sheets: 320-370. Persoonia 34, 167-266.

Crous PW, Wingfield MJ, Le Roux JJ, Richardson DM et al. 2015d Fungal Planet description sheets: 371-399. Persoonia 35, 264-327 
Crous PW, Wingfield MJ, Lombard L, Roets F et al. 2019e - Fungal Planet description sheets: 951-1041. Persoonia 43, 223-425.

Crous PW, Wingfield MJ, Mansilla JP, Alfenas AC, Groenewald JZ. 2006 - Phylogenetic reassessment of Mycosphaerella spp. and their anamorphs occurring on Eucalyptus. II. Studies in Mycology 55, 99-131.

Crous PW, Wingfield MJ, Mohammed C, Yuan ZQ. 1998 - New foliar pathogens of Eucalyptus from Australia and Indonesia. Mycological Research 102, 527-532.

Crous PW, Wingfield MJ, Richardson DM, Le Roux JJ et al. 2016b - Fungal Planet description sheets: 400-468. Persoonia 36, 316-458.

Crous PW, Wingfield MJ, Schumacher RK, Summerell BA et al. 2014b - Fungal Planet description sheets: 281-319. Persoonia 33, 212-289.

Crous PW, Wingfield MJ. 1996 - Species of Mycosphaerella and their anamorphs associated with leaf blotch disease of Eucalyptus in South Africa. Mycologia 88, 441-458.

Crous PW. 1998 - Mycosphaerella spp. and their anamorphs associated with leaf spot diseases of Eucalyptus. Mycol Memories 21, 1-170.

Crous PW. 2007 - Hoornsmania pyrina. Fungal Planet. No. 11. Westerdijk Fungal Biodiversity Institute, Utrecht, the Netherlands

Crous PW. 2009 - Taxonomy and phylogeny of the genus Mycosphaerella and its anamorphs. Fungal Diversity 38, 1-24.

Crowther TW, Boddy L, Jones TH. 2012 - Functional and ecological consequences of saprotrophic fungus-grazer interactions. ISME J 6, 1992-2001.

Curzi M. 1932 - De fungis et morbis africanis. I. De quibusdam hyphomycetibus parasitis Somalie. Bolletino della Stazione di Patologia Vegetale di Roma 12, 149-168.

Da Hora Júnior BT, de Macedo DM et al. 2014 - Erasing the past: a new identity for the Damoclean pathogen causing South American leaf blight of rubber. PLoS One 9, e104750.

Da Silva M, Pinho DB, Pereira OL, Fernandes FM, Barreto RW. 2016 - Naming potentially endangered parasites: foliicolous mycobiota of Dimorphandra wilsonii, a highly threatened Brazilian tree species. PloS one 11, e0147895.

Dai D, Bhat DJ, Liu J, Chukeatirote E, Zhao R, Hyde KD. 2012 - Bambusicola, a new genus from bamboo with asexual and sexual morphs. Cryptogamie Mycologie 33, 363-790.

Dai DQ, Bahkali AH, Bhat DJ, Xiao YP, et al. 2014 - Towards a natural classification of Dothideomycetes 3: The genera Muellerites, Trematosphaeriopsis, Vizellopsis and Yoshinagella (Dothideomycetes incertae sedis). Phytotaxa 176, 18-27.

Dai DQ, Bahkali AH, Li WJ, Bhat DJ et al. 2015 - Bambusicola loculata sp. nov. (Bambusicolaceae) from bamboo. Phytotaxa 213, 122-130.

Dai DQ, Phookamsak R, Wijayawardene NN, Li WJ et al. 2017 - Bambusicolous fungi. Fungal Diversity $82,1-105$.

Dai DQ, Wijayawardene NN, Tang LZ, Liu C et al. 2019 - Rubroshiraia gen. nov., a second hypocrellin-producing genus in Shiraiaceae (Pleosporales). MycoKeys 58, 1-26.

Danti R, Sieber TN, Sanguineti G. 2002 - Endophytic mycobiota in bark of European beech (Fagus sylvatica) in the Apennines. Mycological Research 106, 1343-1348.

Dayarathne MC, Jones EBG, Maharachchikumbura SSN, Devadatha B et al. 2020 - Morphomolecular characterization of microfungi associated with marine based habitats. Mycosphere $11,1-188$.

Dayarathne MC, Phookamsak R, Ariyawansa HA, Jones EBG et al. 2015 - Phylogenetic and morphological appraisal of Leptosphaeria italica sp. nov. (Leptosphaeriaceae, Pleosporales) from Italy. Mycosphere 6, 634-642.

Dayarathne MC, Wanasinghe DN, Jones EBG, Chomnunti P, Hyde KD. 2018 - A novel marine genus Halobyssothecium (Lentitheciaceae) and epitypification of Halobyssothecium obiones comb. nov. Mycological Progress 17, 1161-1171.

De Almeida DAC, Gusmão LFP, Miller AN. 2014 - A new genus and three new species of hysteriaceous ascomycetes from the semiarid region of Brazil. Phytotaxa 176, 298-308. 
De Gruyter J, Aveskamp MM, Woudenberg JHC, Verkley GJM et al. 2009 - Molecular phylogeny of Phoma and allied anamorph genera: Towards a re-classification of the Phoma complex. Mycological Research 113, 508-519.

De Gruyter J, Woudenberg JHC, Aveskamp AA, Verkley GJM et al. 2013 - Redisposition of phoma-like anamorphs in Pleosporales. Studies in Mycology 75, 1-36.

De Gruyter J, Woudenberg JHC, Aveskamp MM, Verkley GJM et al. 2010 - Systematic reappraisal of species in Phoma section Paraphoma, Pyrenochaeta and Pleurophoma. Mycologia 102, 1066-1081.

de Hoog GS, Guarro J, Gené J, Figueras MJ. 2000 - Atlas of Clinical Fungi. 2nd edn. Centraalbureau voor Schimmelcultures, Utrecht, Netherlands, and Universitat Rovira I Virgili, Reus, Spain

de Hoog GS, Oorschot CAN van, Hijwegen T. 1983 - Taxonomy of the Dactylaria complex. II. Dissoconium gen. nov. and Cordana Preuss. Proceedings van de Koninklijke Nederlandse Akademie van Wetenschappen Section C 86, 197-206.

De Notaris G. 1844 - Cenni sulla tribù dei Pirenomiceti sferiacei e descrizione di alcuni generi spettanti alla medesima. Giornale Botanico Italiano 1, 322-335.

De Notaris. 1855 - Micromyc Ital. Novi 9:7

De Wit PJGM. 2016 - Cladosporium fulvum Effectors: Weapons in the Arms Race with Tomato. Annual Review of Phytopathology 4, 54, 1-23.

Deighton FC. 1971 - Studies on Cercospora and allied genera. III. Centrospora. Mycological Papers 124, 1-13.

Deighton FC. 1972 - Mycocentrospora, a new name for Centrospora Neerg. Taxon 21, 716-716.

Deighton FC. 1973 - Studies on Cercospora and allied genera. IV. Cercosporella Sacc., Pseudocercosporella gen. nov. Mycological Papers 133, 1-42.

Deighton FC. 1976 - Studies on Cercospora and allied genera. VI. Pseudocercospora Speg., Pantospora Cif. and Cercoseptoria Petr. Mycological Papers 140, 1-169.

Deighton FC. 1987 - New species of Pseudocercospora and Mycovellosiella, and new combinations into Pseudocercospora and Phaeoramularia. Transactions of the British Mycological Society 88(3), 365-391.

Deininger MH, Weinschenk T, Morgalla MH, Meyermann R, Schluesener HJ. 2002 - Release of regulators of angiogenesis following hypocrellin-A and -B photodynamic therapy of human brain tumor cells. Biochemical and Biophysical Research Communications 298, 520-530.

Del Frari G, Cabral A, Nascimento T, Ferreira RB, Oliveira H. 2019 - Epicoccum layuense a potential biological control agent of esca-associated fungi in grapevine. PloS one 14, $\mathrm{e} 0213273$.

Delgado G, Koukol O, Cáceres O, Piepenbring M. 2017 - The Phylogenetic Placement of Ernakulamia cochinensis within Pleosporales (Dothideomycetes, Ascomycota). Cryptogamie Mycologie 38, 435-451.

Delgado G, Miller AN, Piepenbring M. 2018 - South Florida microfungi: Castanedospora, a new genus to accommodate Sporidesmium pachyanthicola (Capnodiales, Ascomycota). Cryptogamie, Mycologie, 39, 109-127.

Dennis RWG. 1968 - British Ascomycetes. Ver1ag.J. Cramer, Stuttgart. pp. 369422.

Dennis RWG. 1978 - British ascomycetes, 3rd edn. J. Cramer, Vaduz.

Devadatha B, Mehta N, Wanasinghe DN, Baghela A, Sarma VV. 2019 - Vittaliana mangrovei Devadatha, Nikita, A. Baghela \& VV Sarma, gen. nov, sp. nov. (Phaeosphaeriaceae), from mangroves near Pondicherry (India), based on morphology and multigene phylogeny. Cryptogamie, Mycologie 40(7), 117-132.

Devadatha B, Sarma VV, Jeewon R, Jones EBG. 2018a - Morosphaeria muthupetensis sp. nov. (Morosphaeriaceae) from India: morphological characterization and multigene phylogenetic inference. Botanica Marina 61, 395-405.

Devadatha B, Sarma VV, Jeewon R, Wanasinghe DN et al. 2018b - Thyridariella, a novel marine fungal genus from India: morphological characterization and phylogeny inferred from multigene DNA sequence analyses. Mycological Progress 17, 791-804. 
Devadatha B, Sarma VV. 2018 - Pontoporeia mangrovei sp. nov, a new marine fungus from an Indian mangrove along with a new geographical and host record of Falciformispora lignatilis. Current Research in Environmental \& Applied Mycology (Journal of Fungal Biology) 8, 238-246.

Diederich P, Lawrey JD, Ertz D. 2018 - The 2018 classification and checklist of lichenicolous fungi, with 2000 non-lichenized, obligately lichenicolous taxa. Bryologist 121, 340-425.

Diedicke H. 1912 - Die Abteilung Hyalodidymae der Sphaerioideen. Annales Mycologici 10, 135152.

Dissanayake AJ, Jayawardena RS, Boonmee S, Thambugala KM et al. 2014 - The status of Myriangiaceae (Dothideomycetes). Phytotaxa 176, 219-237.

Dix NJ, Webster J. 1995 - Fungal Ecology. Chapman \& Hall, Cambridge, Great Britain.

Dixon LJ, Schlub RL, Pernezny K, Datnoff LE. 2009 - Host specialization and phylogenetic diversity of Corynespora cassiicola. Phytopathology 99, 1015-1027.

Döbbeler P, Hertel H. 2013 - Bryophilous ascomycetes everywhere: Distribution maps of selected species on liverworts, mosses and Polytrichaceae. Herzogia 26, 361-404.

Döbbeler P. 1978 - Moosbewohnende Ascomyceten I. Die pyrenocarpen, den Gametophyten besiedelnden Arten. Mitteilungen der Botanischen Staatssammlung München 14, 1-360.

Döbbeler P. 2007 - Ascomycetes on Polytrichadelphus aristatus (Musci). Mycological research $111,1406-1421$.

Doilom M, Dissanayake AJ, Phillips AJL, Boonmee S et al. 2017 - Microfungi on Tectona grandis (teak) in Northern Thailand. Fungal Diversity 82, 107-182.

Doilom M, Hyde KD, Phookamsak R, Dai DQ et al. 2018 - Mycosphere Notes 225-274: types and other specimens of some genera of Ascomycota. Mycosphere 9, 647-754.

Doilom M, Liu JK, Jaklitsch WM, Ariyawansa HA et al. 2013 - An outline of the family Cucurbitariaceae. Sydowia 65, 167-192.

Doilom M, Taylor JE, Bhat DJ, Chukeatirote E et al. 2016 - Checklist of fungi on teak. Mycosphere 7, 656-678.

Dong W, Wang B, Hyde KD, McKenzie EHC et al. 2020 - Freshwater Dothideomycetes. Fungal Diversity (in prep.)

Drechsler C. 1934 - Phytopathological and taxonomic aspects of Ophibolus, Pyrenophora, Helminthosporium and a new genus, Cochliobolus. Phytopathology 24, 953-983.

Drummond AJ, Suchard MA, Xie D, Rambaut A. 2012 - Bayesian phylogenetics with BEAUti and BEAST 1.7. Journal of Molecular Biology 29, 1969-1973.

Duarte AP, Attili-Angelis D, Baron NC, Groenewald JZ et al. 2017 - Riding with the ants. Persoonia 38, 81-99.

Duby JE. 1862 - Mémoire sur la tribu des Hystérinées de la famille des Hypoxylées (Pyrénomycètes). Memoires de la Société de physique et d'histoire naturelle de Genève 16, $15-70$.

Dugan FM, Braun U, Groenewald JZ, Crous PW. 2008 - Morphological plasticity in Cladosporium sphaerospermum. Persoonia 21, 9-16.

Ebead GA, Overy DP, Berrué F, Kerr RG. 2012 - Westerdykella reniformis sp. nov., producing the antibiotic metabolites melinacidin Iv and chetracin B. IMA fungus 3, 189-201.

Egidi E, Hoog GS de, Isola D, Onofri S et al. 2014 - Phylogeny and taxonomy of meristematic rock-inhabiting black fungi in the Dothideomycetes based on multi-locus phylogenies. Fungal Diversity 65, 127-165.

El-Deeb HM, Lashin SM, Arab YA. 2006 - Distribution and pathogenesis of date palm fungi in Egypt. InIII International Date Palm Conference 736, 421-429.

Ellis JB. 1883 - New species of North American fungi. American Midland Naturalist 17, 194-196.

Ellis MB. 1949 - Tetraploa. Transactions of the British Mycological Society 32, 246-251.

Ellis MB. 1957 - Some species of Teratosperma. Mycological Papers 69, 1-7.

Ellis MB. 1959 - Clasterosporium and some allied Dematiaceae Phragmosporae. II. Mycological Papers (CMI) 72, 1-75.

Ellis MB. 1971 - Dematiaceous Hyphomycetes. Commonwealth Mycological Institute, Kew, UK. 
Ellis MB. 1976 - More Dematiaceous Hyphomycetes. Commonwealth Mycological Institute, Kew, Surrey, England.

Engler A, Krause K, Pilger RKF, Prantl KAE. 1897 - Phymatosphaeriaceae. Die Natürlichen Pflanzenfamilien nebst ihren Gattungen und wichtigeren Arten, W. Engelmann, Leipzig, 502 pp.

Engler A, Krause K, Pilger RKF, Prantl KAE. 1897 - Phymatosphaeriaceae. Die Natürlichen Pflanzenfamilien nebst ihren Gattungen und wichtigeren Arten, W. Engelmann, Leipzig, $502 \mathrm{pp}$.

Engler HGA, Prantl KAE. 1896 - Nat Pflanzenfamilien 1, 272.

Engler HGA, Prantl KAE. 1897 - Die Natürlichen Pflanzenfamilien nebst ihren Gattungen und wichtigeren Arten. 1(1), 1-513.

Eriksson OE, Hawksworth DL. 1985 - Outline of the ascomycetes - 1985. Systema Ascomycetum $4,1-79$.

Eriksson OE, Hawksworth DL. 1986 - Outline of the Ascomycetes - 1986. Systema Ascomycetum $5,185-324$.

Eriksson OE, Hawksworth DL. 1987 - Notes on ascomycete systematics. Nos 464-551. Systema Ascomycetum 6, 237-258.

Eriksson OE, Hawksworth DL. 1991 - Outline of the Ascomycetes-1990. Syst Ascomycetum, Reprint of Volumes 1-4 (1982-1985) 9, 39-271.

Eriksson OE, Hawksworth DL. 1992 - Notes on ascomycete systematics 1294-1417. Systema Ascomycetum 11, 49-82.

Eriksson OE, Hawksworth DL. 1993 - Outline of the ascomycetes - 1993. Systema Ascomycetum $12,51-257$.

Eriksson OE, Yue JZ. 1986 - Bertiella (Sacc.) Sacc. \& Sydow, a synonym of Massarina Sacc. Mycotaxon 27, 247-253.

Eriksson OE. 1981 - The families of bitunicate ascomycetes. Nordic Journal of Botany 1, 800.

Eriksson OE. 1989 - NaClO, sodium hypochlorite, a powerful agent in studies of ascospore morphology. Systema Ascomycetum 8, 29-57.

Eriksson OE. 2006 - Outline of Ascomycota. Myconet 12, 1-88.

Errampalli D, Saunders JM, Holley JD. 2001 - Emergence of silver scurf (Helminthosporium solani) as an economically important disease of potato. Plant Pathology 50, 141-153.

Ertz D, Diederich P, Lawrey JD, Berger F et al. 2015 - Phylogenetic insights resolve Dacampiaceae (Pleosporales) as polyphyletic: Didymocyrtis (Pleosporales, Phaeosphaeriaceae) with Phoma-like anamorphs resurrected and segregated form Polycoccum (Trypetheliales, Polycoccaceae fam. nov.). Fungal Diversity 74, 53-89.

Ertz D, Heuchert B, Braun U, Freebury CE et al. 2016 - Contribution to the phylogeny and taxonomy of the genus Taeniolella, with a focus on lichenicolous taxa. Fungal Biology 120, 1416-1447.

Ertz D, Lawrey JD, Common RS, Diederich P. 2014 - Molecular data resolve a new order of Arthoniomycetes sister to the primarily lichenized Arthoniales and composed of black yeasts, lichenicolous and rock-inhabiting species. Fungal Diversity 66, 113-137.

Fabre JH. 1879 - Essai sur les Sphériacées du département de Vaucluse. Annales des Sciences Naturelles Botanique series 3 6, 66-118.

Faisal M, Elsayed E, Fitzgerald SD, Silva V, Mendoza L. 2007 - Outbreaks of phaeohyphomycosis in the chinook salmon (Oncorhynchus tshawyscha) caused by Phoma herbarum. Mycopathologia 163, 41-48.

Fallah PM, Shearer CA. 2001 - Freshwater ascomycetes: new or noteworthy species from north temperate lakes in Wisconsin. Mycologia 93, 566-602.

Fan XL, Barreto RW, Groenewald JZ, Bezerra JDP et al. 2017 - Phylogeny and taxonomy of the scab and spot anthracnose fungus Elsinö (Myriangiales, Dothideomycetes). Studies in Mycology 87, 1-41.

Farr DF, Rossman AY. 2019 - Fungal Databases, U.S. National Fungus Collections, ARS, USDA. Retrieved May 30, 2019, from https://nt.ars-grin.gov/fungaldatabases/ 
Farr DF, Rossman AY. 2020 - Fungal Databases, Systematic Mycology and Microbiology Laboratory, ARS, USDA. from http://nt.ars-grin.gov/fungaldatabases/

Farr ML. 1984 - The didymosporous dimeriaceous fungi reported on leaves of Rubiaceae. Mycologia 76, 793-803.

Ferreira EL, Williams DE, Ioca LP, Morais-Urano RP et al. 2015 - Structure and biogenesis of roussoellatide, a dichlorinated polyketide from the marine-derived fungus Roussoella sp. DLM33. Organic Letters 17, 5152-5155.

Fisher PJ, Webster J. 1992 - A Trematosphaeria endophyte from rice roots and its Zalerion anamorph. Nova Hedwigia 54, 77-81.

Fotedar R, Sandoval-Denis M, Kolecka A, Zeyara A, Malki AA, Shammari HA, Marri MA, Kaul R, Boekhout T. 2019 - Toxicocladosporium aquimarinum sp. nov. and Toxicocladosporium qatarense sp. nov., isolated from marine waters of the Arabian Gulf surrounding Qatar. International Journal of Systematic and Evolutionary Microbiology 69:2992-3000

Frank J, Crous PW, Groenewald JZ, Oertel B et al. 2010 - Microcyclospora and Microcyclosporella: novel genera accommodating epiphytic fungi causing sooty blotch on apple. Persoonia 24, 93-105.

Friend RJ. 1965 - What is Fumago vagena? Transactions of the British Mycological Society 4, 371-375.

Fries EM. 1823 - Systema Mycologicum, sistens fungorum ordines, genera et species hucusque cognitas, II, pars II, 276-620.

Fries FL. 1836 - Scan, 349.

Fröhlich J, Hyde KD. 1998 - Fungi from palms. XXXIX. Asymmetricospora gen. et sp. nov. (Melanommataceae). Sydowia 50, 182-186.

Fuckel L. 1866 - Fungi Rhenani Exsiccati Cent. XVI-XVIII 17-18, 1601-1800.

Fuckel L. 1868 - Fungi rhenani exsic. 7: no. 2171.

Fuckel L. 1870 - Beiträge zur Kenntniss der Rheinischen Pilze. Jahrb Nassau Verh Naturk 23-24, $1-459$.

Fulmer AM, Walls JT, Dutta B, Parkunan V et al. 2012 - First report of target spot caused by Corynespora cassiicola on cotton in Georgia. Plant Disease Journal 96, 1066-1066.

Funk A. 1986 - Stigmina zilleri sp. nov., associated with brown leaf spot of broadleaf maple. Canadian Journal of Botany 65, 482-483.

Gafforov Y, Phookamsak R, Jiang HB, Wanasinghe DN, Juliev M. 2019 - Ophiobolus hydei sp. nov. (Phaeosphaeriaceae, Ascomycota) from Cirsium and Phlomoides in Uzbekistan. Botany 97(12), 671-180.

Gan MJT, Ash GJ, Cowley RB, Savocchia S, Luckett D. 2009 - Genetic variation of Pleiochaeta setosa from Lupinus albus. Australasian Plant Pathology 38, 518-524.

Gao L, Zhang M, Zhao W, Hao L et al. 2014 - Molecular and morphological analysis reveals five new species of Zygophiala associated with flyspeck signs on plant hosts from China. PLoS ONE 9(10), e110717.

Giraldo A, Crous PW, Schumacher RK, Cheewangkoon R et al. 2017 - The Genera of Fungi - G3: Aleurocystis, Blastacervulus, Clypeophysalospora, Licrostroma, Neohendersonia and Spumatoria. Mycological Progress 16, 325-348.

Glawe DA, Hummel RL. 2006 - North American records for Seifertia azaleae, cause of Rhododendron bud blight disease. Pacific Northwest Fungi 1, 1-6.

Glawe DA. 1985 - Hapalocystis berkeleyi and Macrodiplodiopsis desmazieresii in artificial culture. Mycologia 77, 880-886.

Goh TK, Hyde KD. 1999 - Fungi on submerged wood and bamboo in the Plover Cove Reservoir, Hong Kong. Fungal Diversity 3, 57-85.

Gomzhina MM, Gasich EL, Khlopunova LB, Gannibal PB. 2020 - Paraphoma species associated with Convolvulaceae. Mycological Progress. 19(3), 185-194.

Gonçalves MFM, Vicente TFL, Esteves AC, Alves A. 2019 - Neptunomyces aureus gen. et sp. nov. (Didymosphaeriaceae, Pleosporales) isolated from algae in Ria de Aveiro, Portugal. Mycokeys 60, 31-44. 
Gond SK, Kharwar RN, White JF. 2014 - Will fungi be the new source of the blockbuster drug taxol? Fungal Biology Reviews 28, 77-84.

González MC, Anaya AL, Glenn AE, Saucedo-Garcia A et al. 2007 - A new endophytic ascomycete from El Eden ecological reserve, Quintana Roo, Mexico. Mycotaxon 101, 251260.

Gonzalez-Menendez V, Martin J, Siles JA, Gonzalez-Tejero MR et al. 2017 - Biodiversity and chemotaxonomy of Preussia isolates from the Iberian Peninsula. Mycological Progress 16, 713-728.

Goonasekara ID, Camporesi E, Bulgakov TS, Phookamsak R, Jayawardena RS, Saichana N, McKenzie EHC. 2019 - Two novel species of Parastagonospora (Phaeosphaeriaceae, Pleosporales) on grasses from Italy and Russia. Asian Journal of Mycology 2(1), 170-182.

Griesmer-Zakhar RE. 2013 - Beech bark disease distribution and resistance in Michigan and fungal endophyte ecology of resistant and susceptible beech (Fagus grandifolia Ehrh.) Master's thesis, Michigan Technological University, pp 7.

Groenewald JZ, Nakashima C, Nishikawa J, Shin HD, Park JH, Jama AN, Groenewald M, Braun U, Crous PW. 2013 - Species concepts in Cercospora: spotting the weeds among the roses. Studies in Mycology 75, 115-170.

Groenewald M, Groenewald JZ, Crous PW. 2005 - Distinct species exist within the Cercospora apii morphotype. Phytopathology 95(8), 951-959.

Gronchi V. 1931 - The acidophile property of a fungus isolated from N/10 HC1. Bollettino dell'Istituto Sieroterapico Milanese 10, 237-250.

Grondona I, Monte E. 1997 - Garcia-Acha I. Pyrenochaeta dolichi: an example of a confusing species. Mycological Research 101, 1404-1408.

Gross A, Beenken L, Dubach V, Queloz V et al. 2017 - Pseudodidymella fagi and Petrakia deviata: two closely related tree pathogens new to central Europe. Forest Pathology, e12351.

Guarro J, Abdullah SK, Gene J, Al-Saadoon AH. 1997 - A new species of Preussia from submerged plant debris. Mycological Progress 101, 305-308.

Guatimosim E, Schwartsburd PB, Barreto RW, Crous PW. 2016 - Novel fungi from an ancient niche: Cercosporoid and related sexual morphs on ferns. Persoonia: Molecular Phylogeny and Evolution of Fungi 37, 106-141.

Guo YL, Zhang ZY. 1999 - A new species of Dendryphiella. Mycosystema 18, 236-237.

Guo YL. 1986 - Studies on hyphomycetes of Shennongjia. I. Cercospora, Cercosporidium and Mycovellosiella. Acta Mycologica Sinica, Supplementum 1, 334-341.

Halici MG, Hawksworth DL. 2008 - Two new species of Dacampia (Ascomycota, Dacampiaceae), with a key to and synopsis of the known species of the genus. Fungal Diversity $28,49-54$

Hall T. 2004 - BioEdit v. 7.0.1. Department of Microbiology, North Carolina State University. Available at www.mbio.ncsu.edu/ BioEdit/bioedit.htm

Hambleton S, Nickerson NL, Seifert KA. 2005 - Leohumicola, a new genus of heat-resistant hyphomycetes. Studies in Mycology 53, 29-52

Hametner C, Stocker-Wörgötter E, Rindi F, Grube M. 2014 - Phylogenetic position and morphology of lichenized Trentepohliales (Ulvophyceae, Chlorophyta) from selected species of Graphidaceae. Phycol Res 62, 170-186

Hansford CG. 1946 - The foliicolous Ascomycetes, their parasites and associated fungi. Mycological Papers 15 1-240

Hantula J, Hallaksela AM, Kurkela T. 1998 - Relationship between Prosthemium betulinum and Pleomassaria siparia. Mycological Research 102, 1509-1512

Hariot. 1890 - J Bot (Morot) 4, 91.

Harnpicharnchai P, Champreda V, Sornlake W, Eurwilaichitr L. 2009 - A thermotolerant $\beta$ glucosidase isolated from an endophytic fungi, Periconia sp., with a possible use for biomass conversion to sugars. Protein Expr Purif 67, 61-69.

Harris R. 1986 - The family Trypetheliaceae (Loculoascomycetes: lichenized Melanommatales) in Amazonian Brazil. Acta Amazonica 14, 55-80. 
Harris RC. 1973 - The corticoloios pyrenolichens of the Great Lakes region. Mich Bot 12, 3-68.

Harris RC. 1975 - A taxonomic revision of the genus Arthopyrenia Massal. s. lat. (Ascomycetes) in North America. Ph.D. Thesis, Michigan State University, USA 288.

Harris RC. 1989 - A sketch of the family Pyrenulaceae (Melanommatales) in Eastern North America. Emoirs of the New York Botanical Garden 49, 74-107.

Harris RC. 1995 - More Florida lichens. Including the 10c tour of the pyrenolichens. The New York Botanical Garden.

Hashimoto A, Hirayama K, Takahashi H, Matsumura M et al. 2018a - Resolving the Lophiostoma bipolare complex: Generic delimitations within Lophiostomataceae. Studies in Mycology 90, 161-189.

Hashimoto A, Matsumura M, Hirayama K, Fujimoto R, Tanaka K. 2017a - Pseudodidymellaceae fam. nov.: phylogenetic affiliations of mycopappus-like genera in Dothideomycetes. Studies in Mycology 87, 187-206.

Hashimoto A, Matsumura M, Hirayama K, Tanaka K. 2017b - Revision of Lophiotremataceae (Pleosporales, Dothideomycetes): Aquasubmersaceae, Cryptocoryneaceae, and Hermatomycetaceae fam. nov. Persoonia 39, 51-73.

Hashimoto A, Matsumura M, Hirayama K, Yonezawa H, Tanaka K. 2016 - Taxonomy and phylogeny of Cryptocoryneum (Pleosporales, Dothideomycetes). Mycological Progress 15, 45 .

Hashimoto A, Sasaki Y, Harada Y, Tanaka K. 2018b - Collapsimycopappus: A new leaf pathogen with mycopappus-like propagules in Mycosphaerellaceae. Forest Pathology, e12452

Hassan O, Chang T. 2019 - Phylogenetic and morphological reassessment of Mycosphaerella nawae, the causal agent of circular leaf spot in persimmon. Plant Disease. 103(2), 200-213.

Hatai K, Fujimaki Y, Egusa S. 1986 - A visceral mycosis in ayu fry, Plecoglossus altivelis Temmink and Schlegel, caused by a species of Phoma. Journal of Fish Diseases 9, 111-116.

Hatakeyama S, Tanaka K, Harada Y. 2008 - Bambusicolous fungi in Japan (7): a new coelomycetous genus, Versicolorisporium. Mycoscience 49, 211-214.

Hausmann S, Lotter AF, Leeuwen JFN van, Ohlendorf CH et al. 2002 - Interactions of climate and land use documented in the varved sediments of Seebergsee in the Swiss Alps. The Holocene 12, 279-289.

Hawksworth D, Boise J. 1985 - Some additional species of Astrosphaeriella, with a key to the members of the genus. Sydowia 38, 114-124.

Hawksworth DL, Booth C. 1974 - A revision of the genus Zopfia Rabenh. Mycological Papers $135,1-38$.

Hawksworth DL, Chea CY, Sheridan JE. 1979 - Bimuria novae-zelandiae gen. et sp. nov., a remarkable ascomycete isolated from a New Zealand barley field. New Zealand Journal of Botany 17, 267-273.

Hawksworth DL, Diederich P. 1988 - A synopsis of the genus Polycoccum (Dothideales), with a key to accepted species. Transactions of the British Mycological Society 90, 293-312.

Hawksworth DL, Kirk PM, Sutton BC, Pegler DN. 1995 - Ainsworth \& Bisby's dictionary of the fungi, 8th edn. CAB International, Wallingford.

Hawksworth DL, Punithalingam E. 1973 - New and interesting microfungi from Slapton, South Devonshire: Deuteromycotina. Transactions of the British Mycological Society 61, 57-69.

Hawksworth DL, Santesson R, Tibell L. 2011 - Racoleus, a new genus of sterile filamentous lichen-forming fungi from the tropics, with observations on the nomenclature and typification of Cystocoleus and Racodium. IMA Fungus 2, 71-79.

Hawksworth DL, Webb JA, Wiltshire PEJ. 2010 - Caryospora callicarpa: found in archaeological and modern preparations - but not collected since 1865. Article in Field Mycology 11, 55-59.

Hawksworth DL. 1979 - Ascospore sculpturing and generic concepts in the Testudinaceae (syn. Zopfiaceae). Canadian Journal of Botany 57, 91-99.

Hawksworth DL. 1981 - Astrosphaeriella Sydow, a misunderstood genus of melanommataceous Pyrenomycetes. Botanical Journal of the Linnean Society 82, 35-59. 
Hawksworth DL. 1982 - A new species of Caryospora from Eugenia in East Africa. Transactions of the British Mycological Society 79, 69-74.

Hawksworth DL. 1985 - A redisposition of the species referred to the ascomycete genus Microthelia. Bulletin of the British Museum (Natural History) 14, 43-181.

Hazslinszky FA. 1865 - Beitrag zur Kentniss der Sph€arien des Lyciums. Verhandlungen.

Hečkovà Z, Adamčíkovà K, Strelkovà M, Rózovà Z. 2013 - Ascomycetes and their anamorphs associated with shoots of silver birch (Betula pendula) growing in the urban greenery of Nitra in Slovak Republic. Folia Oecol 40, 137-140.

Hennebert GL. 1968 - New species of Spirosphaera. Transactions of the British Mycological Society 51, 13-24.

Hennings P. 1895 - Fungi Goyazenses. Hedwigia 34, 88-116.

Henssen A. 1995 - Studies on the biology and structure of Dacampia (Dothideales), a genus with lichenized and lichenicolous species. Cryptogamic Botany 5, 149-158.

Hermanides-Nijhof EJ. 1977 - Aureobasidium and allied genera. Studies in Mycology 15, 141222.

Hernández-Restrepo M, Gené J, Castañeda-Ruiz RF, Mena-Portales J et al. 2017 - Phylogeny of saprobic microfungi from Southern Europe. Studies in Mycology 86, 53-97.

Hernández-Restrepo M, Schumacher RK, Wingfield MJ, Ahmad I et al. 2016 - Fungal Systematics and Evolution: FUSE 2. Sydowia 68, 193-230

Hess H, Müller E. 1951 - Zur Entwicklungsgeschichte von Dothidella insculpta (Wallr.) Thesis. et Syd. Berichte der Schweizerischen Botanischen Gesellschaft 61, 5-34.

Hieronymus G, Hennings P. 1901 - Myriangeaceae. Hedwigia 40: 81,102, 168-169.

Hirayama K, Tanaka K, Raja HA, Miller AN, Shearer CA. 2010 - A molecular phylogenetic assessment of Massarina ingoldiana sensu lato. Mycologia 102, 729-746.

Hirayama K, Tanaka K. 2011 - Taxonomic revision of Lophiostoma and Lophiotrema based on reevaluation of morphological characters and molecular analyses. Mycoscience 52, 401-412.

Ho WH, Yanna HKD, Hodgkiss IJ. 2002 - Seasonality and sequential occurrence of fungi on wood submerged in Tai Po Kau Foreststream, Hong Kong. Fungal Diversity 10, 21-43.

Hoggan IA. 1927 - The parasitism of Plowrightia ribesia on the currant. Transactions of the British Mycological Society 12, 27-IN7.

Holm L, Holm K. 1988 - Studies in the Lophiostomataceae with emphasis on the Swedish species. Acta Universitatis Upsaliensis Symbolae Botanicae Upsalienses 28, 1-50.

Holm L. 1957 - Etudes taxonomiques sur les pleosporaces. Symbolae Botanicae Upsalienses 14, 1188.

Holm L. 1968 - Taxonomical notes on ascomycetes VI. On the genus Gibberidea Fuck. and some alleged relatives. Svensk Botanisk Tidskrift 62, 217-242.

Holm L. 1979 - Index nominum genericorum (plantarum). In: Farr ER, Leussink JA, Stafleu FA (eds), The Hague, W. Junk, pp 189.

Hongsanan S, Bahkali AH, McKenzie EHC, Chukeatirote E, Hyde KD. 2014a - Trichopeltinaceae (Dothideomycetes), an earlier name for Brefeldiellaceae, with a new species of Trichopeltina. Phytotaxa 176, 270-282.

Hongsanan S, Hyde KD, Bahkali AH, Camporesi E et al. 2015a - Fungal biodiversity profiles 1120. Cryptogamie Mycologie 36, 355-380.

Hongsanan S, Hyde KD, Phookamsak R, Wanasinghe DN et al. 2020 - Refined families of Dothideomycetes: Orders and families incertae sedis in Dothideomycetes. Fungal Diversity (in prep.).

Hongsanan S, Hyde KD. 2017 - Phylogenetic placement of Micropeltidaceae. Mycosphere 8, 1930-1942.

Hongsanan S, Li YM, Liu JK, Hofmann T et al. 2014b - Revision of genera in Asterinales. Fungal Diversity 68, 1- 68 .

Hongsanan S, Sánchez-Ramírez S, Crous PW, Ariyawansa HA, Zhao RL, Hyde KD. 2016a - The evolution of fungal epiphytes. Mycosphere 7, 1690-1712. 
Hongsanan S, Tian Q, Hyde KD, Chomnunti P. 2015b - Two new species of sooty moulds, Capnodium coffeicola and Conidiocarpus plumeriae in Capnodiaceae. Mycosphere 6, 814824.

Hongsanan S, Tian Q, Hyde KD, Hu DM. 2016b - The asexual morph of Trichomerium gloeosporum. Mycosphere 7, 1473-1479.

Hongsanan S, Zeng YJ, Hyde KD, Xie N. 2018 - Familial status of Lophiotremataceae and its related families in Pleosporales. Phytotaxa 383, 093-102.

Hongsanan S, Zhao RL, Hyde KD. 2017 - A new species of Chaetothyrina on branches of mango, and introducing Phaeothecoidiellaceae fam. nov. Mycosphere 8, 137-146.

Honmura Y, Takekawa H, Tanaka K, Maeda H et al. 2015 - Computation-assisted structural elucidation of epoxyroussoeone and epoxyroussoedione isolated from Roussoella japanensis KT1651. Journal of Natural Products 78, 1505-1510.

Hou L, Hernández-Restrepo M, Groenewald JZ, Cai L, Crous PW. 2020 - Citizen science project reveals high diversity in Didymellaceae (Pleosporales, Dothideomycetes) MycoKeys 65, 4999.

Hu DM, Cai L, Chen H, Bahkali AH, Hyde KD. 2010 - Four new freshwater fungi associated with submerged wood from Southwest Asia. Sydowia 62, 191-203.

Hu HL. 2010 - Morphological and molecular studies of selected Dothideomycetes. PhD diss. The University of Hong Kong, Pokfulam.

Huang SK, Jeewon R, Wanasinghe DN, Manawasinghe IS et al. 2017 - Phylogenetic taxonomy of Dematiopleospora fusiformis sp. nov. (Phaeosphaeriaceae) from Russia. Phytotaxa 316(3), 239-249

Huanraluek N, Ertz D, Phukhamsakda C, Hongsanan S et al. 2019 - The family Pyrenidiaceae resurrected. Mycosphere 10, 634-654.

Huanraluek N, Thambugala KM, Wang Y, Hyde KD. 2018 - Introducing Massarioramusculicola, a novel genus in Massariaceae. Phytotaxa 371, 17-24.

Huelsenbeck JP, Ronquist F. 2001 - MRBAYES: Bayesian inference of phylogenetic trees. Bioinformatics 17, 754-755.

Hughes SJ, Atkinson TJ, Seifert KA. 2012 - New Zealand fungi 37. Two new species of the sooty mould genus Metacapnodium with dictyoseptate ascospores. New Zealand Journal of Botany 50, 381-387.

Hughes SJ, Seifert KA. 2012 - Taxonomic and nomenclatural notes on Sooty mould names based on species mixtures: Hormiscium handelii and Torula lechleriana. Mycoscience 53, 17-24.

Hughes SJ. 1951a - Annellophora nom.nov. (= Chaetotrichum Syd. non Rabenh.). Transactions of the British Mycological Society. 34, 544-550.

Hughes SJ. 1951b - Studies on Micro-fungi. III. Mastigosporium, Camposporium, and Ceratosporium. Mycological Papers 36, 1-43.

Hughes SJ. 1966 - New Zealand fungi 7. Capnocybe and Capnophialophora, new form genera of sooty moulds. New Zealand Journal of Botany 4, 333-353.

Hughes SJ. 1970 - New Zealand Fungi 14. Antennaria, Antennularia, Antennatula, Hyphosoma, Hormisciella, and Capnobotrys gen. nov. New Zealand Journal of Botany 8, 153-209.

Hughes SJ. 1972 - New Zealand fungi 17. Pleomorphism in Euantennariaceae and Metacapnodiaceae, two new families of sooty moulds. New Zealand Journal of Botany 10, 225-242.

Hughes SJ. 1974 - New Zealand Fungi 22. Euantennaria with Antennatula and Hormisciomyces states. New Zealand Journal of Botany 12, 299-356.

Hughes SJ. 1975 - New Zealand Fungi 24. Capnokyma corticola gen. nov., sp. nov., a hyphomycetous sooty mould. New Zealand Journal of Botany 13, 637-644.

Hughes SJ. 1976 - Sooty moulds. Mycologia 68, 693-820.

Hughes SJ. 1981 - New Zealand fungi 31. Capnobotrys, an anamorph of Metacapnodiaceae. New Zealand Journal of Botany 19, 193-226. 
Hughes SJ. 2000 - Antennulariella batistae n.sp. and its Capnodendron and Antennariella synanamorphs with notes on Capnodium capsuliferum. Canadian Journal of Botany 78, 1215-1226.

Huhndorf SM. 1992 - Neotropical ascomycetes 2. Hypsostroma, a new genus from the Dominican Republic and Venezuela. Mycologia 84, 750-758.

Huhndorf SM. 1994 - Neotropical Ascomycetes 5. Hypsostromataceae, a new family of Loculoascomycetes and Manglicola samuelsii, a new species from Guyana. Mycologia 86, 266-269.

Hujslová M, Kubátová A, Kostovčík M, Kolařík M. 2013 - Acidiella bohemica gen. et sp. nov. and Acidomyces spp. (Teratosphaeriaceae), the indigenous inhabitants of extremely acidic soils in Europe. Fungal Diversity 58, 33-45.

Humphries Z, Seifert KA, Hirooka Y, Visagie CM. 2017 - A new family and genus in Dothideales for Aureobasidium-like species isolated from house dust. IMA Fungus 8, 299-315.

Hutchison LJ, Chakravarty P, Kawchuk LM, Hiratsuka Y. 1994 - Phoma etheridgei sp. nov. from black galls and cankers of trembling aspen (Populus tremuloides) and its potential role as a bioprotectant against the aspen decay pathogen Phellinus tremulae. Canadian Journal of Botany 72, 1424-1431.

Hyde KD, Aptroot A, Fröhlich J, Taylor JE. 2000a - Fungi from palms. XLIII. Lophiostoma and Astrosphaeriella species with slit-like ostioles. Nova Hedwigia 70, 143-160.

Hyde KD, Aptroot A. 1997 - Fungi from palms. XXXIII. The genus Massarina, with a new species. Nova Hedwigia 64, 491-504.

Hyde KD, Aptroot A. 1998 - Tropical freshwater species of the genera Massarina and Lophiostoma (ascomycetes). Nova Hedwigia 66, 489-502.

Hyde KD, Borse BD. 1986 - Marine fungi from Seychelles V. Biatriospora marina gen. et sp. nov. from mangrove wood. Mycotaxon 26, 263-270.

Hyde KD, Chaiwan N, Norphanphoun C et al. 2018 - Mycosphere notes 169-224. Mycosphere 9, 71-430.

Hyde KD, de Silva NI, Jeewon R, Bhat DJ et al. 2020a - AJOM new records and collections of fungi: 1-100. Asian Journal of Mycology 3, 22-294.

Hyde KD, Dong Y, Phookamsak R, Jeewon R et al. 2020b - Fungal diversity notes 1151-1276: taxonomic and phylogenetic contributions on genera and species of fungal taxa. Fungal Divers: $100,5-277$.

Hyde KD, Eriksson OE, Yue JZ. 1996 - Roussoëlla, an ascomycete genus of uncertain relationships with a Cytoplea anamorph. Mycological Research 100, 1522-1528.

Hyde KD, Fröhlich J. 1998 - Fungi from palms XXXVII. The genus Astrosphaeriella, including ten new species. Sydowia 50, 81-132.

Hyde KD, Goh KT. 1998 - Fungi on submerged wood in Lake Barrine, north Queensland, Australia. Mycological Research 102, 739-749.

Hyde KD, Hongsanan S, Jeewon R, Bhat DJ et al. 2016 - Fungal diversity notes 367-490: taxonomic and phylogenetic contributions to fungal taxa. Fungal Diversity 80, 1-270.

Hyde KD, Jones EBG, Liu J-K, Ariyawansa H et al. 2013 - Families of Dothideomycetes. Fungal Diversity 63, 1-313.

Hyde KD, McKenzie EHC, KoKo TW. 2011 - Towards incorporating anamorphic fungi in a natural classification - checklist and notes for 2010. Mycosphere 2, 1-88.

Hyde KD, Norphanphoun C, Abreu VP, Bazzicalupo A et al. 2017 - Fungal diversity notes 603708: Taxonomic and phylogenetic notes on genera and species. Fungal Diversity 87, 1-235.

Hyde KD, Steinke TS. 1996 - Two new species of Delitschia from submerged wood. Mycoscience 37, 99-102.

Hyde KD, Taylor JE, Fröhlich J. 2000b - Genera of ascomycetes from palms. Fungal Diversity Res Ser. 2. Fungal Diversity Press, Hong Kong.

Hyde KD, Tennakoon DS, Jeewon R, Bhat DJ et al. 2019 - Fungal diversity notes 1036-1150: taxonomic and phylogenetic contributions on genera and species of fungal taxa. Fungal Diversity 96, 1-242. 
Hyde KD, Vrijmoed LLP, Chinnaraj S, Jones EBG. 1992 - Massarina armatispora sp. nov., a new intertidal ascomycete from mangroves. Botanica Marina 35, 325-328.

Hyde KD, Wong SW, Jones EBG. 1996 - Tropical Australian freshwater fungi. 11. Mamillisphaeria dimorphospora gen. et sp. nov. and notes on fresh water ascomycetes with dimorphic ascospores. Nova Hedwigia 62, 513-520.

Hyde KD, Wong SW, Jones EBG. 1999 - Ultrastructure of the dimorphic ascospores in Mamillisphaeria dimorphospora. Mycol Res 103(10):1284-1288

Hyde KD, Wong SW. 1999 - Didymella aptrootii sp. nov. from bamboo submerged in freshwater. Australasian Mycologist 18, 54-59.

Hyde KD, Wong WS, Aptroot A. 2002 - Marine and estuarine species of Lophiostoma and Massarina. In: Hyde KD (ed) Fungi in marine environments, Fungal Diversity Research Series 7. Hong Kong University Press, Hong Kong, pp 93-109.

Hyde KD. 1988 - Studies on the tropical marine fungi of Brunei. Botanical Journal of the Linnean Society 98, 135-151.

Hyde KD. 1991 - A new amphisphaeriaceous fungus from intertidal fronds of Nypa fruticans. Transactions of the Mycological Society of Japan 32, 265-271.

Hyde KD. 1992a - Fungi from decaying inter-tidal fronds of Nypa fruticans, including three new genera and four new species. Botanical Journal of the Linnean Society 110, 95-110.

Hyde KD. 1992b - Intertidal mangrove fungi from the west coast of Mexico, including one new genus and two new species. Mycological Research 96, 25-30.

Hyde KD. 1992c - Julella avicenniae (Borse) comb. nov. (Thelenellaceae) from intertidal mangrove wood and miscellaneous fungi from the NE coast of Queensland. Mycological Research 96, 939-942.

Hyde KD. 1993 - Tropical Australian freshwater fungi. vi. Tiarosporella paludosa and Clohesyomyces aquaticus gen. et sp. nov. (Coelomycetes). Australian Systematic Botany 6, 169-173.

Hyde KD. 1994a - Fungi from palms. XI. Appendispora frondicola gen. et sp. nov. from Oncosperma horridum in Brunei. Sydowia 46, 29-34.

Hyde KD. 1994b - Fungi from palms. XII. Three new intertidal ascomycetes from submerged palm fronds. Sydowia 46, 257-264.

Hyde KD. 1995 - The genus Massarina, with a description of M. eburnea and an annotated list of Massarina names. Mycological Research 99, 291-296.

Hyde KD. 1997 - The genus Roussoëlla, including two new species from palms in Cuyabeno, Ecuador. Mycological Research 101, 609-616.

Ichinoe M. 1971 - Camposporium species from Japan. Transactions of the Mycological Society of Japan 12, 79-88.

Inderbitzin P, Jones EBG, Vrijmoed LLP. 2000 - A new species of Leptosphaerulina from decaying mangrove wood from Hong Kong. Mycoscience 41, 233-237.

Ippolito A, El Ghaouth A, Wilson CL, Wisniewski M. 2000 - 'Control of Postharvest Decay of Apple Fruit by Aureobasidium pullulans and Induction of Defense Responses', Postharvest Biology and Technology 19, 265-272.

Isaka M, Yangchum A, Intamas S, Kocharin K et al. 2002 - Aigialomycins and related polyketide metabolites from the mangrove fungus Aigialus parvus BCC 5311. Tetrahedron 65, 43964403.

Ismail SI, Batzer JC, Harrington TC, Crous PW et al. 2016 - Ancestral state reconstruction infers phytopathogenic origins of sooty blotch and flyspeck fungi on apple. Mycologia 108, 15-36.

Isola D, Zucconi L, Onofri S, Caneva G et al. 2016 - Extremotolerant rock inhabiting black fungi from Italian monumental sites. Fungal Diversity 76:75-96.

Ito T, Nakagiri A. 1995 - Amauroascus purpureus, a new species of the Amauroascaceae (Ascomycotina). Mycotaxon 55, 347-352.

Iturrieta-González I, Gené J, GuarroJ, Castañeda-Ruiz RF, García D. 2018 - Neodendryphiella, a novel genus of the Dictyosporiaceae (Pleosporales). MycoKeys 37, 19-38. 
Ivanová H, Bernadovičová S. 2010 - Species diversity of microscopic fungi on Austrian pines growing in urban greenery of Nitra town. Folia Oecol 37, 168-180.

Jackson SL, Maxwell A, Neumeister-Kemp HG, Dell B, Hardy GESJ. 2004 - Infection, hyperparasitism and conidiogenesis of Mycosphaerella lateralis on Eucalyptus globulus in Western Australia. Australasian Plant Pathology 33, 49-53.

Jaczewski AA. 1917 - Opredelitel' gribov. 2, 1-803.

Jaklitsch W, Baral HO, Lücking R, Lumbsch HT. 2016a - Ascomycota. In: Frey W (ed) Syllabus of Plant Families - Adolf Engler's Syllabus der Pflanzenfamilien. Part 1/2, $13^{\text {th }}$ edn, Borntraeger Science Publishers, Stuttgart.

Jaklitsch W, Scheuer Ch, Voglmayr H. 2002 - Notes on the genus Immotthia (Pleosporales, Ascomycetes), including some type studies. Österr Z Pilzk 11, 93-106.

Jaklitsch WM, Checa J, Blanco MN, Olariaga I et al. 2018a - A preliminary account of the Cucurbitariaceae. Studies in Mycology 90, 71-118.

Jaklitsch WM, Fournier J, Voglmayr H. 2018b - Two unusual new species of Pleosporales: Anteaglonium rubescens and Atrocalyx asturiensis. Sydowia 70, 129-140.

Jaklitsch WM, Olariaga I, Voglmayr H. 2016b - Teichospora and the Teichosporaceae. Mycological Progress 15, 31.

Jaklitsch WM, Voglmayr H. 2016 - Hidden diversity in Thyridaria and a new circumscription of the Thyridariaceae. Studies in Mycology 85, 35-64.

Jaklitsch WM, Voglmayr H. 2017 - Three former taxa of Cucurbitaria and considerations on Petrakia in the Melanommataceae. Sydowia 69, 81-95.

Jaklitsch WM, Voglmayr H. 2020 - Fenestelloid clades of the Cucurbitariaceae. Persoonia 44, 140.

Janex-Favre MC. 1971 - Recherches sur l'ontogenie, l'organisation et les asques de quelques pyrenolichens. Revue Bryologique et Lichénologique 37, 421-469.

Jayasiri SC, Hyde KD, Jones EBG, Ariyawansa HA et al. 2017a - A new hysteriform Dothideomycete (Gloniaceae, Pleosporomycetidae Incertae sedis), Purpurepithecium murisporum gen. et sp. nov. on pine cone scales. Cryptogamie Mycologie 38, 241-251.

Jayasiri SC, Hyde KD, Jones EBG, Jeewon R et al. 2017b - Taxonomy and multigene phylogenetic evaluation of novel species in Boeremia and Epicoccum with new records of Ascochyta and Didymella (Didymellaceae). Mycosphere 8, 1080-1101.

Jayasiri SC, Hyde KD, Jones EBG, McKenzie EHC et al. 2019 - Diversity, morphology and molecular phylogeny of Dothideomycetes on decaying wild seed pods and fruits. Mycosphere $10,1-186$.

Jayasiri SC, Hyde KD, Jones EBG, Peršoh D et al. 2018 - Taxonomic novelties of hysteriform Dothideomycetes. Mycosphere 9, 803-837.

Jayasiri SC, Jones EBG, Kang JC, Promputtha I et al. 2016 - A new species of genus Anteaglonium (Anteagloniaceae, Pleosporales) with its asexual morph. Phytotaxa 263, 233-244.

Jayasiri SC, Wanasinghe DN, Ariyawansa HA, Jones EB, Kang JC, Promputtha I, Bahkali AH, Bhat DJ, Camporesi E, Hyde KD. 2015 - Two novel species of Vagicola (Phaeosphaeriaceae) from Italy. Mycosphere 6(6), 716-728.

Jayawardena RS, Ariyawansa HA, Singtripop C, Li YM et al. 2014 - A re-assessment of Elsinoaceae (Myriangiales, Dothideomycetes). Phytotaxa 176, 120-138.

Jayawardena RS, Hyde KD, Jeewon R, Ghobad-Nejhad M et al. 2019 - One stop shop II: taxonomic update with molecular phylogeny for important phytopathogenic genera: 26-50 (2019). Fungal Diversity 94, 41-129.

Jeewon R, Hyde KD. 2016 - Establishing species boundaries and new taxa among fungi: recommendations to resolve taxonomic ambiguities. Mycosphere 7, 1669-1677.

Jeffers WF. 1940 - Studies on Caryospora putaminum. Mycologia 32, 550-566.

Jiang HB, Hyde KD, Jayawardena RS, Doilom M et al. 2019 - Taxonomic and phylogenetic characterizations reveal two new species and two new records of Roussoella (Roussoellaceae, Pleosporales) from Yunnan, China. Mycological Progress 18, 577-591. 
Jiang YL, Wu YM, Yang B, Xu JJ, Zhang ZG et al. 2017 - Cladosporium, Phialophora, Pseudoramichloridium \& Ticogloea spp. nov. from China. Mycotaxon 132, 677-683.

Johanson CJ. 1884 - Svampar från Island. Bestämda af C.J. Johanson. Öfversigt af Kongl. Vetenskaps-Akademiens Föhandlingar 41(9), 157-174.

Jones E, Devadatha B, Abdel-Wahab M, Dayarathne MC et al. 2019a - Phylogeny of new marine Dothideomycetes and Sordariomycetes from mangroves and deep-sea sediments. Botanica Marina 1-28.

Jones EBG, Pang K-L, Abdel-Wahab MA, Scholz B et al. 2019b - An online resource for marine fungi. Fungal Diversity 96, 347-433.

Jones EBG, Pang KL. (eds) 2012 - Marine fungi and fungal-like organisms. Walter de Gruyter GmbH \& Co. KG, Berlin/Boston.

Jones EBG, Sakayaroj J, Suetrong S, Somrithipol S, Pang KL. 2009a - Classification of marine origin and evolution of fundamental reproductive and ecological traits. Systematic Biology 58, 224-239.

Jones EBG, Sakayaroj J, Suetrong S, Somrithipol S, Pang KL. 2009b - Classification of marine ascomycota, anamorphic taxa and basidiomycota. Fungal Diversity 35, 1-187.

Jones EBG, Suetrong S, Sakayaroj J, Bahkali AH et al. 2015 - Classification of marine Ascomycota, Basidiomycota, Blastocladiomycota and Chytridiomycota. Fungal Diversity 73, $1-72$.

Jones EBG. 1994 - Fungal adhesion. Presidential address 1992. Mycological Research 98, 961981.

Jones EBG. 1995 - Ultrastructure and taxonomy of the aquatic ascomycetous order Halosphaeriales. Canadian Journal of Botany 73, S790-S801.

Jones EBG. 2006 - Form and function of fungal spore appendages. Mycoscience 47:167-183.

Kaiser WJ, Ndimande BN, Hawksworth DL. 1979 - Leaf-scorch disease of sugarcane in Kenya caused by a new species of Leptosphaeria. Mycologia 71, 479-492.

Kamal. 2010 - Cercosporoid fungi of India. Bishen Singh Mahendra Pal Singh, Dehra Dun.

Kang JC, Kong RYC, Hyde KD. 1998 - Studies on the Amphisphaeriales 1. Amphisphaeriaceae (sensu stricto) and its phylogenetic relationships inferred from 5.8S rDNA and ITS2 sequences. Fungal Diversity 1, 147-157.

Karunarathna A, Papizadeh M, Senanayake IC, Jeewon R et al. 2017a - Novel fungal species of the Phaeosphaeriaceae with an asexual/sexual connection. Mycosphere 8(10), 1818-1834

Karunarathna A, Phookamsak R, Jayawardena RS, Cheewangkoon R et al. 2019 - Neoroussoella alishanense sp. nov on Pennisetum purpureum (Poaceae) with an asexual/sexual morph connection. Phytotaxa 406, 218-236.

Karunarathna A, Phookamsak R, Jayawardena RS, Hyde KD, Kuo CH. 2020 - Kwanghwaensis miscanthi gen. et sp. nov. (Phaeosphaeriaceae, Pleosporales) on Miscanthus floridulus (Poaceae). . Cryptogamie, Mycologie 41(6), 119-132.

Karunarathna A, Phookamsak R, Wanasinghe DN, Wijayawardene NN et al. 2017b - Taxonomy and phylogeny of Sparticola muriformis sp. nov. on decaying grass. Mycosphere 8, 603-614.

Katoh K, Rozewicki J, Yamada KD. 2019 - MAFFT online service: multiple sequence alignment, interactive sequence choice and visualization. Briefings in Bioinformatics 20, 1160-1166.

Kehr R, Krauthausen HJ. 2004 - First report of damage to Plane trees (Platanus x hispanica) in Germany caused by the fungus Splanchnonema platani. Nachrichtenbl Deut Pflanzenschutzd $56,245-251$.

Keissler K. 1922 - Mykologische mitteilungen. Annalen des Naturhistorischen Museums in Wien $35,1-35$.

Khan Z, Ahmad S, Kapila K, Ramaswamy. 2011 - Pyrenochaeta romeroi: a causative agent of Phaeohyphomycotic cyst. J Med Microbiol 60, 842-846.

Kim S, Shin DS, Lee T, Oh KB. 2004 - Periconicins, two new fusicoccane diterpenes produced by an endophytic fungus Periconia sp. with antibacterial activity. Journal of Natural Products $67,448-450$. 
Kirk P, Cannon P, Minter D, Stalpers JA. 2008 - Dictionary of the Fungi. 10th edn. CAB International, Wallingford.

Kirk PM, Cannon PF, David JC, Stalpers JA. 2001 - Ainsworth \& Bisby's dictionary of the fungi, 9th edn. CABI, Wallingford.

Kirk PM, Stalpers JA, Braun U, Crous PW et al. 2013 - A without-prejudice list of generic names of fungi for protection under the International Code of Nomenclature for algae, fungi, and plants. IMA Fungus 4, 381-443.

Kirk PM. 1981 - New or interesting microfungi II. Dematiaceous hyphomycetes from Ester common, surrey. Transactions of the British Mycological Society 77, 279-297.

Kirschner R. 2009 - Cercosporella and Ramularia. Mycologia 101, 110-119.

Kirschstein W. 1938 - Pilze: Sphaerellaceae. Kryptogamen-Flora Mark Brandenburg 7, 305-448.

Kirschstein W. 1939 - Über neue, seltene und kritische Ascomyceten und Fungi imperfecti. II. Annales Mycologici 37, 88-140.

Knapp DG, Kovacs GM, Zajta E, Groenewald JZ, Crous PW. 2015 - Dark septate endophytic pleosporalean genera from semiarid areas. Persoonia 35, 87-100.

Kodsueb R, Dhanasekaran V, Aptroot A, Lumyong S et al. 2006 - The family Pleosporaceae: intergeneric relationships and phylogenetic perspectives based on sequence analyses of partial 28SrDNA. Mycologia 98, 571-583.

Kodsueb R, Lumyong S, HoWH, Hyde KD et al. 2007 - Morphological and molecular characterization of Aquaticheirospora and phylogenetics of Massarinaceae (Pleosporales). Botanical Journal of the Linnean Society 155, 283-296.

Koenning SR, Creswell TC, Dunphy EJ, Sikora EJ, Mueller JD. 2006 - Increased occurrence of target spot of soybean caused by Corynespora cassiicola in the southeastern United States. Plant Disease Journal 90, 974-974.

Köhl J, Groenenboom-de Haas BH, Goossen-van de Geijn HM, Speksnijder A et al. 2009 Pathogenicity of Stemphylium vesicarium from different hosts causing brown spot in pear. European Journal of Plant Pathology 124, 151-162.

Kohlmeyer J, Kohlmeyer E. 1979 - Marine Mycology: The higher fungi. Academic Press, New York.

Kohlmeyer J, Schatz S. 1985 - Aigialus gen. nov. (Ascomycetes) with two new marine species from mangroves. Transactions of the British Mycological Society 85, 699-707.

Kohlmeyer J, Vittal BPR. 1986 - Lophiostoma mangrovis, a new. marine ascomycete from the tropics. Mycologia 78, 489-492.

Kohlmeyer J, Volkmann-Kohlmeyer B, Eriksson OE. 1995 - Fungi on Juncus roemerianus 2. New Dictyosporous ascomycetes. Botanica Marina 38, 165-174.

Kohlmeyer J, Volkmann-Kohlmeyer B, Eriksson OE. 1998 - Fungi on Juncus roemerianus. 11. More new ascomycetes. Canadian journal of botany 76, 467-477.

Kohlmeyer J, Volkmann-Kohlmeyer B. 1987 - Marine fungi from Aldabra, the Galapagos, and other tropical islands. Canadian Journal of Botany 65, 571-582.

Kohlmeyer J, Volkmann-Kohlmeyer B. 1990 - Revision of marine species of Didymosphaeria (Ascomycotina). Mycological Research 94, 685-690.

Kohlmeyer J, Volkmann-Kohlmeyer B. 1991 - Illustrated key to the filamentous higher marine fungi. Botanica Marina 34, 1-61.

Kohlmeyer J, Volkmann-Kohlmeyer B. 1993 - Atrotorquata and Loratospora: new ascomycete genera on Juncus roemerianus. Systema Ascomycetum. 12, 7-22.

Kohlmeyer J, Volkmann-Kohlmeyer B. 2000 - Fungi on Juncus roemerianus 14. Three new coelomycetes, including Floricola, anam.-gen. nov. Botanica marina 43, 385-392.

Kohlmeyer J. 1969 - Marine fungi of Hawaii including the new genus Helicascus. Canadian Journal of Botany 47, 1469-1487.

Kohlmeyer J. 1986 - Ascocratera manglicola gen. et sp. nov. and key to the marine Loculoascomycetes on mangroves. Canadian Journal of Botany 64, 3036-3042.

Koike ST, Baameur A, Groenewald JZ, Crous PW. 2011 - Cercosporoid leaf pathogens from whorled milkweed and spineless safflower in California. IMA Fungus 2, 7-12. 
Kolařík M, Spakowicz DJ, Gazis R, Shaw J et al. 2017 - Biatriospora (Ascomycota: Pleosporales) is an ecologically diverse genus including facultative marine fungi and endophytes with biotechnological potential. Plant Systematics and Evolution 303, 35-50.

Kolař́k M. 2018 - New taxonomic combinations in endophytic representatives of the genus Nigrograna. Czech Mycology 70, 123-126.

Kolařík MI, Hujslová MA, Vazquéz-Campos XA. 2015 - Acidotolerant genus Fodinomyces (Ascomycota: Capnodiales) is a synonym of Acidiella. Czech Mycology 67, 37-38

Koukol O, Delgado G, Hofmann TA, Piepenbring M. 2018 - Panama, a hot spot for Hermatomyces (Hermatomycetaceae, Pleosporales) with five new species, and a critical synopsis of the genus. IMA Fungus 9, 107-141.

Koukol O. 2010 - What do we know about Acrodontium crateriforme?. Mykologick Listy 111, $12-$ 18.

Kowalski DT. 1965 - The development and cytology of Didymocrea sadasavanii. Mycologia. 57, 404-416.

Kowalski T, Kehr RD. 1992 - Endophytic fungal colonization of branch bases in several forest tree species. Sydowia 44, 137-168.

Kowalski T, Kehr RD. 1996 - Fungal endophytes of living branch bases in several European tree species. In: Redlin SC, Carris LM (eds), Endophytic Fungi in Grasses and Woody Plants, American Phytopathological Society Press, St Paul, MN, pp 67-86.

Krisai-Greilhuber I, Chen Y, Jabeen S, Madrid H et al. 2017 - Fungal systematics and evolution: FUSE 3. Sydowia 69, 229-264

Kruys Å, Eriksson OE, Wedin M. 2006 - Phylogenetic relationships of coprophilous Pleosporales (Dothideomycetes, Ascomycota), and the classification of some bitunicate taxa of unknown position. Mycological Research 110, 527-536.

Kruys ̊̊, Wedin M. 2009 - Phylogenetic relationships and an assessment of traditionally used taxonomic characters in the Sporormiaceae (Pleosporales, Dothideomycetes, Ascomycota), utilising multi-gene phylogenies. System Biodivers 7, 465-478.

Kruys $\AA .2015$ - New species of Preussia with eight-celled ascospores (Sporormiaceae, Pleosporales, Ascomycota). Phytotaxa 234, 143-150.

Kumar S, Singh R, Gond DK, Saini DC. 2012 - Two new species of Corynespora from Uttar Pradesh, India. Mycosphere 3, 864-869.

Kuntze O. 1898 - Revisio generum plantarum. A Felix Leipzig 3, 1-576.

Kuz'michev EP, Sokolova ES, Kulikova EG. 2001 - Common fungal diseases of Russian forests. Gen. Tech. Rep. NE-279. Newtown Square, PA; U.S Department of Agriculture, Forest Service, Northeastern Research Station, pp 137.

Laemmlen FF. 2011 - Sooty mold. integrated pest management for home gardeners and landscape professionals. Pest notes, University of California. Agriculture and Natural Resources, USA. Retrieved November 12, 2012, from http://www.ipm.ucdavis.edu/PDF/ PESTNOTES/pnsootymold.pdf

Lawrey JD, Diederich P, Nelsen MP, Freebury C et al. 2012 - Phylogenetic placement of lichenicolous Phoma species in the Phaeosphaeriaceae (Pleosporales, Dothideomycetes). Fungal Diversity 55, 195-213.

Leonard KJ, Suggs EG. 1974 - Setosphaeria prolata, the ascigerous state of Exserohilum prolatum. Mycologia 66, 281-297.

Letrouit-Galinou MA, Parguey-Leduc A, Janex-Favre MC. 1994 - Ascoma structure and ontogenesis in ascomycete systematics. In: Hawksworth DL (ed) Ascomycete systematics. Problems and perspectives in the nineties. NATO ASI, vol 269. Plenum Press, New York and London, pp 23-36.

Leuchtmann A. 1984 - Über Phaeosphaeria Miyake und andere bitunicate Ascomyceten mit mehrfach querseptierten Ascosporen. Sydowia 37, 75-194.

Leuchtmann A. 1987 - Phaeosphaeria padellana und Massariosphaeria triseptata, zwei neuebitunicate ascomyceten aus den alpen. Mycologia Helvetica 2, 183-191. 
Leukel RW. 1948 - Periconia circinata and its relation to Milo disease. Journal of agricultural research 77, 201-222.

Li GJ, Hyde KD, Zhao RL, Hongsanan S et al. 2016a - Fungal diversity notes 253-366: taxonomic and phylogenetic contributions to fungal taxa. Fungal Diversity 78:1-237

Li HY, Sun GY, Zhai XR, Batzer JC et al. 2012 - Dissoconiaceae associated with sooty blotch and flyspeck on fruits in China and the United States. Persoonia 28, 113-125.

Li JF, Bhat DJ, Phookamsak R, Mapook A et al. 2016b - Sporidesmioides thailandican gen. et sp. nov. (Dothideomycetes) from northern Thailand. Mycological Progress 15, 1169-1178.

Li JF, Jeewon R, Mortimer PE, Doilom M, Phookamsak R, Promputtha I. 2020a - Multigene phylogeny and taxonomy of Dendryphion hydei and Torula hydei spp. nov. from herbaceous litter in northern Thailand. PLoS ONE 15:e0228067

Li JF, Phookamsak R, Jeewon R, Bhat DJ et al. 2017a - Molecular taxonomy and morphological characterization reveal new species and new host records of Torula species (Torulaceae, Pleosporales). Mycological Progress 16, 447-461.

Li JF, Phookamsak R, Mapook A, Boonmee S et al. 2016c - Seifertia shangrilaensis sp. nov. (Melanommataceae), a new species from Southwest China. Phytotaxa 273, 34-42.

Li WJ, Bhat DJ, Camporesi E, Tian Q, Wijayawardene NN, Dai DQ, Phookamsak R, Chomnunti P, Bahkali AH, Hyde KD. 2015 - New asexual morph taxa in Phaeosphaeriaceae. Mycosphere 6, 681-708.

Li WJ, Bhat JD, Hyde KD, Wang Y. 2014 - Towards a natural classification of Dothideomycetes 4: The genera Bryopelta, Bryorella, Bryosphaeria, Lophiosphaerella and Maireella (Dothideomycetes incertae sedis). Phytotaxa 176, 28-41.

Li WJ, McKenzie EHC, Liu JK (Jack), Bhat DJ et al. 2020b - Taxonomy and phylogeny of hyaline-spored coelomycetes. Fungal diversity 100, 279-801

Li WL, Luo ZL, Liu JK, Bhat DJ et al. 2017b - Lignicolous freshwater fungi from China I: Aquadictyospora lignicola gen. et sp. nov. and new record of Pseudodictyosporium wauense from northwestern Yunnan Province. Mycosphere 8, 1587-1597.

Li WY, Zhuang WY. 2008 - Notes on the genus Byssosphaeria (Melanommataceae) from China. Mycosystema 27, 48-53.

Li YM, Wu H, Cheng H, Hyde KD. 2011 - Morphological studies in Doithideomycetes: Elsinö̈ (Elsinoaceae), Butleria and three excluded genera. Mycotaxon 115, 507-520.

Liew ECY, Aptroot A, Hyde KD 2000 - Phylogenetic significance of the pseudoparaphyses in Loculoascomycete taxonomy. Molecular Phylogeny \& Evolution 16, 392-402.

Lindau. 1897 - Engler Prantl Nat Pflanzenfam Teil I (Leipzig) 1, 373.

Lindemuth R, Wirtz N, Lumbsch HT. 2001 - Phylogenetic analysis of nuclear and mitochondrial rDNA sequences supports the view that loculoascomycetes (Ascomycota) are not monophyletic. Mycological Research 105, 1176-1181.

Litz CE, Cavagnolo RZ. 2010 - Polymerase chain reaction in the diagnosis of onychomycosis: a large, single-institute study. British Journal of Dermatology 163, 511-514.

Liu D. 2011 - Piedraiain molecular detection of human fungal pathogens. CPC press, pp 958

Liu F, Wang J, Li H, Wang W, Cai L. 2019a - Setophoma spp. on Camellia sinensis. Fungal Systematics and Evolution 4, 43-57.

Liu JK, Hyde KD, Jeewon R, Phillips AJ et al. 2017a - Ranking higher taxa using divergence times: a case study in Dothideomycetes. Fungal Diversity 84, 75-99.

Liu JK, Hyde KD, Jones EBG, Ariyawansa HA et al. 2015 - Fungal diversity notes 1-110: taxonomic and phylogenetic contributions to fungal species. Fungal Diversity 72, 1-197.

Liu JK, Luo ZL, Liu NG, Cheewangkoon R, To-Anun C. 2018a - Two novel species of Paradictyoarthrinium from decaying wood. Phytotaxa 338, 285-293.

Liu JK, Phookamsak R, Dai DQ, Tanaka K et al. 2014 - Roussoellaceae, a new pleosporalean family to accommodate the genera Neoroussoella gen. nov., Roussoella and Roussoellopsis. Phytotaxa 181, 1-33. 
Liu JK, Phookamsak R, Jones EBG, Zhang Y et al. 2011 - Astrosphaeriella is polyphyletic, with species in Fissuroma gen. nov., and Neoastrosphaeriella gen. nov. Fungal Diversity 51, 135154.

Liu LL, Long QD, Kang JC, Zhang X et al. 2018b - Morphology and phylogeny of Mycopepon. Mycosphere 9, 779-789.

Liu N, Xu S, Yao X, Zhang G et al. 2016 - Studies on the Control of Ascochyta Blight in Field Peas (Pisum sativum L.) Caused by Ascochyta pinodes in Zhejiang Province, China. Frontiers in Microbiology 7, 481.

Liu NG, Hongsanan S, Yang J, Bhat DJ et al. 2017b - Periconia thailandica (Periconiaceae), a new species from Thailand. Phytotaxa 323, 253-263.

Liu NG, Hongsanan S, Yang J, Lin CG et al. 2017c - Dendryphiella fasciculata sp. nov. and notes on other Dendryphiella species. Mycosphere 8, 1575-1586.

Liu NG, Hyde KD, Bhat DJ, Jumpathong J, Liu JK. 2019b - Morphological and phylogenetic studies of Pleopunctum gen. nov. (Phaeoseptaceae, Pleosporales) from China. Mycosphere 10, 757-775.

Liu NG, Lin CG, Liu JK, Samarakoon MC et al. 2018c - Lentimurisporaceae, a new pleosporalean family with divergence times estimates. Cryptogamie Mycologie 39, 259-282.

Liu YJ, Hall DB. 2004 - Body plan evolution of ascomycetes, as inferred from an RNA polymerase II Phylogeny. Proceedings of the National Academy of Sciences 101, 4507-4512.

Liu YX, Hyde KD, Ariyawansa HA, Li WJ et al. 2013 - Shiraiaceae, new family of Pleosporales (Dothideomycetes, Ascomycota). Phytotaxa 103, 51-60

Locquin M. 1984 - Mycologie générale et structurale.1-551.

Locquin-Linard M. 1977 - Á propos des genres non ostiolés placés dans la famille des Microascaceae. Revue de Mycologie 41, 509-523.

Lohman ML. 1932 - Three new species of Mytilidion in the proposed subgenus Lophiopsis. Mycologia 24, 477-484.

Lohman ML. 1933a - Hysteriaceae: Life histories of certain species. Annual report of the Michigan Academy of Science 17, 229-288.

Lohman ML. 1933b - Septonema toruloideum: A stage of Mytilidion scolecosporum. Mycologia $25,34-43$.

Lohman ML. 1934 - A cultural and taxonomic study of Hysterium hyalinum. Annual report of the Michigan Academy of Science 19, 133-140.

Lohman ML. 1937 - Studies in the genus Glonium as represented in the Southeast. Bulletin of the Torrey Botanical Club 64, 57-73.

Lu YZ, Liu JKJ, Hyde KD, Jeewon R et al. 2018 - A taxonomic reassessment of Tubeufiales based on multi-locus phylogeny and morphology. Fungal Diversity 92, 131-344.

Luck-Allen ER, Cain RF. 1975 - Additions to the genus Delitschia. Canadian Journal of Botany 53, 1827-1887.

Lücking R, Hodkinson BP, Leavitt SD. 2017 - The 2016 classification of lichenized fungi in the Ascomycota and Basidiomycota-approaching one thousand genera. Bryologist 119,

Lumbsch HT, Huhndorf SM. 2007 - Outline of ascomycota-2007. Myconet 13, 1-58.

Lumbsch HT, Huhndorf SM. 2010 - Outline of Ascomycota 2009. Myconet 14, 1-64.

Lumbsch HT. 1999 - The ascoma development in Mycoporum elabens (Mycoporaceae, Dothideales). Plant biology 1, 321-326.

Luo ZL, Hyde KD, Liu JKJ, Maharachchikumbura SS, Jeewon R, Bao DF, Bhat DJ, Lin CG, Li WL, Yang J, Liu NG. 2019 - Freshwater Sordariomycetes. Fungal Diversity 99, 451-660.

Luo ZL, Yang J, Liu JK, Su HY et al. 2016 - Two new species of Helicascus (Morosphaeriaceae) from submerged wood in northern Thailand. Phytotaxa 270, 182-190.

Luttrell ES. 1955 - The ascostromatic Ascomycetes. Mycologia 47, 511-532.

Luttrell ES. 1973 - Loculoascomycetes. In: Ainsworth GC, Sparrow FK, Sussman AS (eds), The fungi. An advanced treatise, a taxonomic review with keys: ascomycetes and fungi imperfecti. Academic Press, New York, pp 135-219. 
Luttrell ES. 1975 - Centrum development in Didymosphaeria sadasivanii (Pleosporales). American Journal of Botany 62, 186-190.

Ma Y, Zhang R, Sun G, Zhu H et al. 2010 - A new species of Zygophiala associated with the flyspeck complex on apple from China. Mycological Progress 9, 151-155.

Maharachchikumbura SSN, Ariyawansa HA, Wanasinghe DN, Dayarathne MC, Al-Saady NA, Al-Sadi AM. 2019 - Phylogenetic classification and generic delineation of Hydeomyces desertipleosporoides gen. et sp. nov. (Phaeosphaeriaceae) from Jebel Akhdar Mountain in Oman. Phytotaxa 391, 28-38

Maharachchikumbura SSN, Haituk S, Pakdeeniti P, Al-Sadi AM et al. 2018 - Phaeosaccardinula coffeicola and Trichomerium chiangmaiensis, two new species of Chaetothyriales (Eurotiomycetes) from Thailand. Mycosphere 9, 769-778.

Malloch D, Cain RF. 1971 - Four new genera of cleistothecial Ascomycetes with hyaline ascospores. Canadian Journal of Botany 49, 847-854.

Malloch D, Cain RF. 1972 - The Trichocomataceae: Ascomycetes with Aspergillus, Paecilomyces and Penicillium imperfect states. Canadian Journal of Botany. 50, 2613-2628.

Manamgoda DS, Rossman AY, Castlebury LA, Crous PW et al. 2014 - The genus Bipolaris. Studies in Mycology 79, 221-288.

Mantle PG, Hawksworth DL, Pazoutová S, Collinson SJ, Rassing BR. 2006 - Amorosia littoralis gen. sp. nov., a new genus and species name for the scorpinoneand caffeine-producing hyphomycete from the littoral zone in The Bahamas. Mycological Research 110, 1371-1378.

Mapook A, Boonmee S, Ariyawansa HA, Tibpromma S et al. 2016 - Taxonomic and phylogenetic placement of Nodulosphaeria. Mycological Progress 15(4), 34.

Mapook A, Hyde KD, McKenzie EHC, Gareth Jones EBG et al. 2020 - Taxonomic and phylogenetic contributions to fungi associated with the invasive weed Chromolaena odorata (Siam weed). Fungal Diversity 101, 1-175.

Marin-Felix Y, Groenewald L, Cai L, Chen Q et al. 2017 - Genera of phytopathogenic fungi: GOPHY 1. Studies in Mycology 86, 99-216.

Marin-Felix Y, Hernández-Restrepo M, Iturrieta-González I, García D et al. 2019 - Genera of phytopathogenic fungi: GOPHY 3. Studies in Mycology 94, 1-124.

Markovskaja S, Kačergius A, Davydenko K, Fraser S. 2016 - First record of Neocatenulostroma germanicum on pines in Lithuania and Ukraine and its co-occurrence with Dothistroma spp. and other pathogens. Forest pathology 46, 522-533.

Mason EW, Hughes SJ. 1951 - Phragmocephala gen. nov., hyphomycetarum. Naturalist 97-105.

Mason EW. 1941 - Annotated account of fungi received at the Imperial Bureau of Mycology. Mycological Papers 5, 1-144.

Massalongo AB. 1853 - Nota sulla Lecidea Hookeri di Schaerer. Ramanzini, Verona, pp 1-9.

Massee G. 1887 - British pyrenomycetes. Grevillea 16, 34-39.

Mathiassen G. 1989 - Some corticolous and lignicolous Pyrenomycetes s. lat. (Ascomycetes) on Salix in Troms, N. Norway. Somemerfeltia 9, 1-100.

Mathiassen G. 1993 - Corticolous and lignicolous pyrenomycetes s. lat. (Ascomycetes) on Salix along a mid-Scandinavian transect. Somemerfeltia 20, 1-180.

Matsumura M, Kato W, Hashimoto A, Takahashi YS et al. 2018 - Crassiperidium (Pleosporales, Dothideomycetes), a new ascomycetous genus parasitic on Fagus crenata in Japan. Mycosphere 9, 1256-1267.

Matsushima T. 1971 - Microfungi of the Solomon Islands and Papua-New Guinea. Kobe, Japan.

Matsushima T. 1996 - Matsushima Mycological Memoirs 9, 1-54.

McAlpine D. 1902 - Fungus diseases of stone-fruit trees in Australia, and their treatment. Agriculture Department of Victoria, Australia, Melbourne.

Mckeown TA, Alias SA, Moss ST, Jones EBG. 2001 - Ultrastructural studies of Trematosphaeria malaysiana sp. nov. and Leptosphaeria pelagica. Mycological Research 105, 615-624.

McNeill J, Barrie FR, Buck WR, Turland N. (eds) 2012 - International Code of Nomenclature for algae, fungi, and plants (Melbourne Code) adopted by the Eighteenth International Botanical 
Congress Melbourne, Australia, July 2011 [Regnum Vegetabile no. 154.] Ruggell: A.R.G. Gantner Verlag.

McTaggart AR, Shivas RG, Braun U. 2007 - Annellosympodia orbiculata gen. et sp. nov. and Scolecostigmina flagellariae sp. nov. from Australia. Australasian Plant Pathology. 36, 573579.

Mel'nik VA, Popov ES, Shabunin DA. 2007 - Contributions to the studies of mycobiota in Novgorod and Pskov regions. I. Hyphomycetes. Mikologia i Fitopatologia 41, 515-525 (in Russian).

Mena-Portales J, Cantillo-Perez T, Minter DW. 2017 - A new species of the conidial fungal genus Spegazzinia (Pleosporales, Didymosphaeriaceae) collected on sugarcane in Cuba. Phytotaxa 331, 295-298.

Michalopoulos-Skarmoutsos H, Skarmoutsos G. 1999 - Pathogenicity of fungi affecting black locust (Robinia pseudoacacia) in Greece. Phytoparasitica 27, 233-234.

Miller GG, Brown K, Ballangrud AM, Barajas O et al. 2008 - Preclinical assessment of hypocrellin $\mathrm{B}$ and hypocrellin $\mathrm{B}$ derivatives as sensitizers for photodynamic therapy of cancer: progress update. Photochem Photobiol 65, 714-722.

Miller JH. 1938 - Studies in the development of two Myriangium species and the systematic position of the order Myriangiales. Mycologia 30, 158-181.

Miller OR, Miller SL, Palmer JG. 1983 - Description and identification of selected mycorrhizal fungi in pure culture. Mycotaxon 18, 457-481.

Minnis AM, Kennedy AH, Grenier DB, Rehner SA, Bischoff JF. 2011 - Asperisporium and Pantospora (Mycosphaerellaceae): epitypifications and phylogenetic placement. Persoonia: Molecular Phylogeny and Evolution of Fungi 27, 1-8.

Miranda I, Sousa V, Pereira H. 2011 - Wood properties of teak (Tectona grandis) from a mature unmanaged stand in East Timor. Journal of Wood Science 57, 171-178.

Mirzaei S, Moghadam JN, Khaledi E, Abdollahzadeh J et al. 2015 - Molecular and morphological characterization of Endoconidioma populi from Kurdistan province, Iran. Mycologia Iran 2, $127-133$.

Mochizuki K, Nishida T, Murata K, Ishida K et al. 2017 - Roussoella solani causing keratomycosis, with an observed both sexual and asexual morphs. Journal of Infection and Chemotherapy 23, 651-654.

Montagne C. 1849 - De Capnodio. novum fungorum genus. Annales des Sciences Naturelles Botanique sér 3 11, 233-234.

Moreau C. 1953 - Les genres Sorrlaria et Plerrragr. Encycyl. Mycol. 25, 1-130

Morin L, Shivas RG, Piper MC, Tan YP. 2010 - Austropleospora osteospermi gen. et sp. nov. and its host specificity and distribution on Chrysanthemoides monilifera ssp. rotundata in Australia. Fungal Diversity 40: 65-74.

Moslemi A, Ades PK, Crous PW, Groom T et al. 2018 - Paraphoma chlamydocopiosa sp. nov. and Paraphoma pye sp. nov., two new species associated with leaf and crown infection of pyrethrum. Plant Pathology 67(1), 124-135.

Mugambi GK, Huhndorf SM. 2009a - Molecular phylogenetics of Pleosporales: Melanommataceae and Lophiostomataceae recircumscribed (Plesporomycetidae, Dothideomycetes, Ascomycota). Studies in Mycology 64, 103-121.

Mugambi GK, Huhndorf SM. 2009b - Parallel evolution of hysterothecial ascomata in ascolocularous fungi (Ascomycota, Fungi). Systematics and Biodiversity 7, 453-464.

Muggia L, Hafellner J, Wirtz N, Hawksworth DL, Grube M. 2008 - The sterile microfilamentous lichenized fungi Cystocoleus ebeneus and Racodium rupestre are relatives of plant pathogens and clinically important dothidealean fungi. Mycological Research 112, 50-56.

Mukarami R, Tanaka F, Norimoto M. 2002 - Relationship between bending quality and wood species. Wood Research 89, 21-22.

Muller E, Oehrens E. 1982 - On the genus Teratosphaeria (Ascomycetes). Sydowia 35, 138-142.

Müller E, von Arx JA. 1962 - Beitrage zur Kryptogamenflora der Schweiz 11, 1-922. 
Müller E, von Arx JA. 1973 - Pyrenomycetes: Meliolales, Coronophorales, Sphaeriales. New exotic fungi. Grevillea 17, 42-43.

Müller E, von Arx JA.1950 - Einige aspekte zur systematik pseudopharilaler ascomyceten. Berichte der Schweizerischen Botanischen Gesellschaft 60, 329-397.

Müller E. 1950 - Die schweizerischen Arten der Gattung Leptosphaeria und ihrer Verwandten. Sydowia 4, 185-319.

Munk A. 1953 - The system of the pyrenomycetes. A contribution to a natural classification of the group Sphaeriales sensu Lindau. Dansk Botanisk Arkiv 15, 1-163.

Munk A. 1956 - On Metasphaeria coccodes (Karst.) Sacc. (Massarinaceae n. fam.). Friesia. 5, 305.

Munk A. 1957 - Danish pyrenomycetes: A preliminary flora. Dansk Botanisk Arkiv 17, 1-491.

Nag Raj TR. 1993 - Coelomycetous anamorphs with appendage-bearing conidia. Mycologue Publications, Waterloo, Ontario, Canada 1101.

Nannfeldt JA. 1932 - Studien uber die Morphologie und Systematik der nicht-lichenisierten, inoperkulaten Discomyceten. Nova acta Regiae Societatis Scientiarum Upsaliensis IV 8, 1368.

Nannizzi A. 1934 - Repertorio sistematico dei miceti dell'uomo e degli animali. SA Poligrafica Meini.

Navarro-Rosinés P, Roux C. 1995 - Le genre Weddellomyces (Dothideales, Dacampiaceae) en Catalogne et en Provence. Mycotaxon 53, 161-187.

Nelsen MP, Lücking R, Grube M, Mbatchou JS et al. 2009 - Unravelling the phylogenetic relationships of lichenised fungi in Dothideomyceta. Studies in Mycology 64, 135-144.

Nelsen MP, Lücking R, Mbatchou JS, Andrew CJ et al. 2011a - New insights into relationships of lichen-forming Dothideomycetes. Fungal Diversity 51, 155-162.

Nelsen MP, Rivas-Plata E, Andrew CJ, Lücking R, Lumbsch HT. 2011b - Phylogenetic diversity of trentepohlialean algae associated with lichen-forming fungi. Journal of Phycology 47, 282-290.

Nelson S. 2008 - Sooty molds. Plant Disease Journal 52, 1-6.

Niessl G. 1872 - Beiträge zur Kenntniss der Pilze. Beschreibung neuer und wenig bekannter Pilze. Verh Naturf Vereins Brünn 10, 153-217.

Nieuwenhuijzen EJ van, Miadlikowska JM, Houbraken JAMP, Adan OCG et al. 2016 - Wood staining fungi revealed taxonomic novelties in Pezizomycotina: New order Superstratomycetales and new species Cyanodermella oleoligni. Studies in Mycology 85, 107-124.

Nimis PL, Hafellner J, Roux C, Clerc P et al. 2018 - The lichens of the Alps-an annotated checklist. MycoKeys 31, 1-634.

Niranjan M, Sarma VV. 2018 - New Ascomycetous fungi in the family Aigialaceae from Andaman Islands, India. Current Research in Environmental \& Applied Mycology (Journal of Fungal Biology) 8, 351-359.

Nitschke TRJ. 1869 - Grundlage eines Systems der Pyrenomyceten. Verhandlungen des Naturhistorischen Vereins der Preussischen Rheinlande, Westfalens und des Regierungsbezirks Osnabrück 26, 70-77.

Nylander JAA, Wilgenbusch JC, Warren DL, Swofford DL. 2008 - AWTY (are we there yet?): a system for graphical exploration of MCMC convergence in Bayesian phylogenetics. Bioinformatics 24, 581-583.

Nylander W. 1854 - Essai d'une nouvelle classification des Lichens. Mémoires de la Société Impériale des Sciences Naturelles de Cherbourg 2, 5-16.

Onofri S, Pagano S, Zucconi L, Tosi S. 1999 - Friedmanniomyces endolithicus (Fungi, Hyphomycetes), anam.-gen. and sp. nov., from continental Antarctica. Nova Hedwigia 68, $175-181$.

Onofri S, Zucconi L, Isola D, Selbmann L. 2014 - Rock-inhabiting fungi and their role in deterioration of stone monuments in the Mediterranean area. Plant Biosystems 148, 384-391. 
Orton CR. 1915 - Structural parallelism between spore-forms in the ascomycetes. Mycologia 7, 21-27.

Ou YH, Zhou RJ, Fu JF, Xu HJ. 2015 - Paracercospora dictamnicola sp. nov. from China. Mycological Progress 14, 15.

Pande A. 2008) Ascomycetes of Peninsular India. Scientific Publishers Journals Dept., India.

Partridge EC, Morgan-Jones G. 2002 - Notes on hyphomycetes, LXXXVIII. New genera in which to classify Alysidium resinae and Pycnostysanus azaleae, with a consideration of Sorocybe. Mycotaxon 83, 335-352.

Pattengale ND, Alipour M, Bininda-Emonds OR, Moret BM, Stamatakis A. 2009 - How many bootstrap replicates are necessary? In: Annual international conference on research in computational molecular biology. Springer, Berlin, pp 184-200.

Peck CH. 1873 - Descriptions of new species of fungi. Bulletin of the Buffalo Society of Natural Sciences 1, 41-72.

Pegler DN, Roberts PJ, Spooner BM. 2000 - New British records. Mycologist 14, 29-31.

Pem D, Hongsanan S, Doilom M, Tibpromma S et al. 2019a - https://www.dothideomycetes.org: An online taxonomic resource for the classification, identification, and nomenclature of Dothideomycetes. Asian Journal of Mycology 2, 287-297.

Pem D, Hyde KD, Doilom M, Camporesi E et al. 2019b - Multigene phylogenetic analyses to establish new Valsaria species and taxonomic significance of spore ornamentation. PloS one 14, e0217982.

Pem D, Jeewon R, Bhat DJ, Doilom M et al. 2019c - Mycosphere Notes 275-324: A morphotaxonomic revision and typification of obscure Dothideomycetes genera (incertae sedis). Mycosphere 10, 1115-1246.

Pem D, Jeewon R, Gafforov Y, Hongsanan S et al. 2019d - Melanocamarosporioides ugamica gen. et sp. nov., a novel member of the family Melanommataceae from Uzbekistan. Mycological Progress 18, 471-481.

Penzig AJO, Saccardo PA. 1897 - Diagnoses fungorum novorum in insula Java collectorum. Ser. I. Malpighia 11, 387-409.

Pereira-Carvalho RD, Inácio CA, Dianese JC. 2010 - Plurispermiopsis: a new capnodiaceous genus from the Brazilian Cerrado. Mycologia 102, 1163-1166.

Pérez-Ortega S, Garrido-Benavent I, De Los Ríos A. 2015 - Austrostigmidium, a new austral genus of lichenicolous fungi close to rock-inhabiting meristematic fungi in Teratosphaeriaceae. The Lichenologist 47, 143-156.

Pérez-Ortega S, Garrido-Benavent I, Grube M, Olmo R, de los Ríos A. 2016 - Hidden diversity of marine borderline lichens and a new order of fungi: Collemopsidiales (Dothideomyceta). Fungal Diversity 80, 285-300.

Peter M, Kohler A, Ohm RA, Kuo A et al. 2006 - Ectomycorrhizal ecology is imprinted in the genome of the dominant symbiotic fungus Cenococcum geophilum. Nature Communications 7, 12662.

Petrak F. 1922 - Mykologische Notizen IV. Annales Mycologici 20, 300-345.

Petrak F. 1925 - Mykologische Notizen. VIII. Annales Mycologici. 23(1-2), 1-143.

Petrak F. 1927 - Mykologische Notizen. IX. Annales Mycologici 25, 193-343.

Petrak F. 1929 - Mykologische Notizen. X Annales Mycologici 27, 324-410.

Petrak F. 1950 - Index of Fungi. 1936-1939. 1-117. UK, Kew; Commonwealth Mycological Institute.

Petrak F. 1953 - Colletogloeum n. gen., eine neue Melanconieen-Gattung. Sydowia 7(5-6), 367369.

Petrak F. 1954 - Anthracostroma n. gen., eine neue Gattung der dothidealen Pyrenomyzeten. Sydowia 8, 96-99.

Petrak F. 1962 - Mykologische bemerkungen. Sydowia 15, 204-217.

Petrini O, Fisher PJ. 1988 - A comparative study of fungal endophytes in xylem and whole stems of Pinus sylvestris and Fagus sylvatica. Transactions of the British Mycological Society 91, 233-238. 
Phillips AJL, Alves A, Pennycook SR, Johnston PR et al. 2008 - Resolving the phylogenetic and taxonomic status of dark-spored teleomorph genera in the Botryosphaeriaceae. Persoonia 21, $29-55$.

Phookamsak R, Boonmee S, Norphanphoun C, Wanasinghe DN et al. 2016 - Schizothyriaceae. Mycosphere 7, 154-189.

Phookamsak R, Hyde KD, Jeewon R, Bhat DJ et al. 2019 - Fungal diversity notes 929-1035: taxonomic and phylogenetic contributions on genera and species of fungi. Fungal Diversity 95, 1-273.

Phookamsak R, Hyde KD. 2015 - Fenestellaceae. Mycosphere 6, 402-413.

Phookamsak R, Li WJ, Dai DQ, Singtripop C, Hyde KD. 2015a - Poaceascoma gen et sp. nov., a new genus with scolecospores in Lentitheciaceae. Cryptogamie Mycologie 36, 225-236.

Phookamsak R, Liu JK, Manamgoda DS, Chukeatirote E et al. 2014a - The sexual state of Setophoma. Phytotaxa 176, 260-269.

Phookamsak R, Liu JK, Manamgoda DS, Wanasinghe DN, Ariyawansa HA, Mortimer PE, Chukeatirote E, McKenzie EHC, Hyde KD. 2014b - Epitypification of two bambusicolous fungi from Thailand. Cryptogamie Mycologie 35, 239-256.

Phookamsak R, Liu JK, McKenzie EH, Manamgoda DS et al. 2014c - Revision of Phaeosphaeriaceae. Fungal Diversity 68, 159-238.

Phookamsak R, Norphanphoun C, Tanaka K, Dai DQ et al. 2015b - Towards a natural classification of Astrosphaeriella-like species; introducing Astrosphaeriellaceae and Pseudoastrosphaeriellaceae fam. nov. and Astrosphaeriellopsis, gen. nov. Fungal Diversity 74, 143-197.

Phookamsak R, Wanasinghe DN, Hongsanan S, Phukhamsakda C et al. 2017 - Towards a natural classification of Ophiobolus and ophiobolus-like taxa; introducing three novel genera Ophiobolopsis, Paraophiobolus and Pseudoophiobolus in Phaeoshaeriaceae (Pleosporales). Fungal Diversity 87, 299-339.

Phukhamsakda C, Ariyawansa HA, Phookamsak R, Chomnunti P et al. 2015 - Muriphaeosphaeria galatellae gen. et sp. nov. in Phaeosphaeriaceae (Pleosporales). Phytotaxa 227, 55-65.

Phukhamsakda C, Bhat DJ, Hongsanan S, Tibpromma S et al. 2017 - Magnicamarosporium diospyricola sp. nov. (Sulcatisporaceae) from Thailand. Mycosphere 8, 512-520.

Phukhamsakda C, Bhat DJ, Hongsanan S, Xu JC et al. 2018a - Two novel species of Neoaquastroma (Parabambusicolaceae, Pleosporales) with their phoma-like asexual morphs. Mycokeys 34, 47-62.

Phukhamsakda C, Hongsanan S, Ryberg M, Ariyawansa HA et al. 2016 - The evolution of Massarineae with Longipedicellataceae fam. nov. Mycosphere 7, 1713-1731.

Phukhamsakda C, Jeewon R, McKenzie EHC, Xu JC. 2019a - Morphology and phylogeny of Phaeoseptum mali sp. nov. (Phaeoseptaceae, Pleosporales) on bark of Malus halliana. Asian Journal of Mycology 2, 118-128.

Phukhamsakda C, Macabeo AP, Huch V, Cheng T et al. 2019b - Sparticolins A-G, Biologically Active Oxidized Spirodioxynaphthalene Derivatives from the Ascomycete Sparticola junci. Journal of Natural Products 82, 2878-2885.

Phukhamsakda C, Macabeo AP, Yuyama KT, Hyde KD, Stadler M. 2018b - Biofilm Inhibitory Abscisic Acid Derivatives from the Plant-Associated Dothideomycete Fungus, Roussoella sp. Molecules 23, 2190.

Phukhamsakda C, McKenzie EHC, Phillips AJL, Jones EBG et al. 2020 - Microfungi associated with Clematis (Ranunculaceae) with an integrated approach to delimiting species boundaries. Fungal Diversity 102, 1-203.

Piątek M, Rodriguez-Flakus P, Domic A, Palabral-Aguilera AN et al. 2020 - Phylogenetic placement of Leptosphaeria polylepidis, a pathogen of Andean endemic Polylepis tarapacana, and its newly discovered mycoparasite Sajamaea mycophila gen. et sp. nov. Mycological Progress 19, 1-14.

Pilsczek FH, Augenbraun M. 2007 - Mycetoma fungal infection: multiple organisms as colonizers or pathogens?. Revista da Sociedade Brasileira de Medicina Tropical 40, 463-5. 
Pinho DB, Honorato J, Nicoli A, Hora BT et al. 2012 - Phylogenetic placement of the genus Anhellia and the description of A. nectandrae sp. nov. Mycologia 104, 1291-1298.

Pinnoi A, Jeewon R, Sakayaroj J, Hyde KD, Jones EBG. 2007 - Berkleasmium crunisia sp. nov. and its phylogenetic affinities to the Pleosporales based on $18 \mathrm{~S}$ and $28 \mathrm{~S}$ rDNA sequence analyses. Mycologia 99, 378-384.

Pinnoi A, Lumyong S, Hyde KD, Jones EBG. 2006 - Biodiversity of fungi on the palm Eleiodoxa conferta in Sirindhorn peat swamp forest, Narathiwat, Thailand. Fungal Diversity 22, 205218.

Pinruan U, Hyde KD, Lumyong S, McKenzie EHC, Jones EBG. 2007 - Occurrence of fungi on tissues of the peat swamp palm Licuala longicalycata. Fungal Diversity 25:157-173.

Poelt J. 1969 - Bastimmungsschlüssel europäischer Flechten. Cramer, Lehre.

Poelt J. 1974 - Classification. In: Ahmadjian V, Hale ME (eds), The lichens. New York Academic Press, pp 599-632.

Poonyth AD, Hyde KD, Aptroot A, Peerally A. 2000 - Mauritiana rhizophorae gen. et sp. nov. (Ascomycetes, Requienellaceae), with a list of terrestrial saprobic mangrove fungi. Fungal Diversity 4, 101-116.

Prabhugaonkar A, Bhat DJ. 2011 - New record of Megacapitula villosa and Paradictyoarthrinium diffractum from India. Mycosphere 2, 463-467.

Prabhugaonkar A, Pratibha J. 2017 - Isolation of Acrodontium crateriforme as a pitcher trap inquiline. Current Research in Environmental \& Applied Mycology (Journal of Fungal Biology) 7, 203-207.

Prasher IB, Verma RK. 2015 - Two new species of Acroconidiella from India. JNBR 4, 111-114.

Pratibha J, Ashish P, Mao AA. 2017 - Fusiconidium indicum (Melanommataceae) a novel species of asexual Ascomycetes. Phytotaxa 326, 108-114.

Pratibha J, Prabhugaonkar A. 2015 - Multi-gene phylogeny of Pithomyces with the sexual morph of P. flavus Berk. \& Broome. Phytotaxa 218, 84-90.

Pratibha J, Prabhugaonkar A, Hyde KD, Bhat DJ. 2014 - Phylogenetic placement of Bahusandhika, Cancellidium and Pseudoepicoccum (asexual Ascomycota). Phytotaxa 176, 68-80.

Preuss CGT. 1851 - Ubersicht untersuchter pilze, besonders aus der umgegend Hoyerswerda.

Punithalingam E. 1979 - Sphaeropsidales in culture from humans. Nova Hedwigia 31, 119-158.

Quaedvlieg W, Binder M, Groenewald JZ, Summerell BA et al. 2014 - Introducing the consolidated species concept to resolve species in the Teratosphaeriaceae. Persoonia 33, 140 .

Quaedvlieg W, Groenewald JZ, de Jesús Yáñez-Morales M, Crous PW. 2012 - DNA barcoding of Mycosphaerella species of quarantine importance to Europe. Persoonia: Molecular Phylogeny and Evolution of Fungi 29, 101-115.

Quaedvlieg W, Kema GHJ, Groenewald JZ, Verkley GJM, Seifbarghi S, Razavi M, Mirzadi Gohari A, Mehrabi R, Crous PW. 2011 - Zymoseptoria gen. nov.: a new genus to accommodate Septoria-like species occurring on graminicolous hosts. Persoonia: Molecular Phylogeny and Evolution of Fungi 26, 57-69.

Quaedvlieg W, Verkley GJM, Shin HD, Barreto RW et al. 2013 - Sizing up Septoria. Studies in Mycology 75, 307-390.

Rabenhorst L. 1870 - Kryptogamen-Flora von Sachsen, der Ober-Lausitz, Thüringen und Nordböhmen. 2. Abth, 1-418.

Raciborski M. 1900 - Batavia, Indonesia, Staatsdruckerei. Parasitische Algen und Pilze Javas 1, 139.

Rai AN, Kamal. 1986 - Fungi of Gorakhpur-XLII. Kavaka 14, 31-36.

Raja HA, Oberlies NH, Figueroa M, Tanaka K et al. 2013 - Freshwater ascomycetes: Minutisphaera (Dothideomycetes) revisited, including one new species from Japan. Mycologia 105, 959-976.

Raja HA, Paguigan ND, Fournier J, Oberlies NH. 2017 - Additions to Lindgomyces (Lindgomycetaceae, Pleosporales, Dothideomycetes), including two new species occurring on 
submerged wood from North Carolina, USA, with notes on secondary metabolite profiles. Mycological Progress 16, 535-552.

Raja HA, Shearer CA. 2008 - Freshwater ascomycetes: new and noteworthy species from aquatic habitats in Florida. Mycologia 100, 467-489.

Raja HA, Tanaka K, Hirayama K, Miller AN, Shearer CA. 2011 - Freshwater ascomycetes: two new species of Lindgomyces (Lindgomycetaceae, Pleosporales, Dothideomycetes) from Japan and USA. Mycologia 103, 1421-1432.

Ramaley AW. 1991 - Clypeispora and its Mycosphaerella teleomorph. Mycotaxon 40, 13-22

Ramaley AW. 1992 - Tectacervulus mahoniae, Kabatina mahoniae, and Selenophoma mahoniae, three new fungi on Mahonia repens. Mycotaxon 43, 437-452.

Ramaley AW. 2005 - The connection of Dothidotthia aspera (Botryosphaeriaceae) to a hyphomycetous anamorphic fungus, Thyrostroma negundinis. Mycotaxon 94, 127-132.

Rambaut A. 2014 - FigTree v1.4: Tree figure drawing tool. http://treebio.ed.ac.uk/software/figtree/

Ranković B, Kosanić M. 2019 - Lichens as a potential source of bioactive secondary metabolites. In Lichen secondary metabolites. Springer, Cham, pp 1-29.

Ranojevic NV. 1914 - Dritter beitrag zur pilzflora serbiens. Annales Mycologici 12, 393-421.

Rao PR, Rao D. 1964 - The genus Periconia from india. Mycopathologia et mycologia applicata 22, 285-310.

Rehm H. 1905 - Contributiones mycologicae ad floram Hungariae. Mykologische Beiträge zur Flora Ungarns. Növénytani Közlemények 4, 2.

Rehm HJ. 1881 - Ascomyceten in getrockneten Exemplaren herausgegeben. Bericht des Naturhistorischen Vereins in Augsburg 26, 1-132.

Reid J, Pirozynski KA. 1966 - A new loculoascomycete on Abies balsamea (L.) Mill. Canadian Journal of Botany 44, 351-354.

Révay Á, Gönczöl J, Merényi Zs, Bratek Z. 2014 - Re-examination of Vargamyces aquaticus - a dematiaceous hyphomycete species. Sydowia 66, 69-78.

Révay A. 1993 - Some new or interesting hyphomycetes from Hungary. Nova Hedwigia 56, 73482.

Reynolds DR, Gilbert GS. 2005 - Epifoliar fungi from Queensland, Australia. Australian Systematic Botany 18, 265-289.

Reynolds DR, Gilbert GS. 2006 - Epifoliar fungi from Panama. Cryptogamie Mycologie. 27, 249270.

Reynolds DR. 1971 - The sooty mold ascomycetes genus Limacinula. Mycologia 63, 1173-1209.

Riedl H. 1961 - Die Arten der Gattung Mycoporellum Mull. Arg. sensu A. Zahlbruckner. Catal., nebst Bemerkungen zum System dothidealer Flechten. Sydowia 15, 257-287.

Ross AJ, Yasutake T, Leek S. 1975 - Phoma herbarum, a fungal plant saprophyte, as a fish pathogen. Journal of the Fisheries Research Board of Canada 32, 1648-1652.

Rossman AY, Allen WC, Braun U, Castlebury LA et al. 2016 - Overlooked competing asexual and sexually typified generic names of Ascomycota with recommendations for their use or protection. IMA Fungus 7, 285-304.

Rossman AY, Crous PW, Hyde KD, Hawksworth DL et al. 2015 - Recommended names for pleomorphic genera in Dothideomycetes. IMA Fungus 6, 507-523.

Rossman AY, Samuels GJ, Rogerson CT, Lowen R. 1999 - Genera of Bionectriaceae, Hypocreaceae and Nectriaceae (Hypocreales, Ascomycetes). Studies in Mycology 41, 1-248.

Ruibal C, Gueidan C, Selbmann L, Gorbushina AA et al. 2009 - Phylogeny of rock-inhabiting fungi related to Dothideomycetes. Studies in Mycology 64, 123-133.

Ruibal C, Millanes AM, Hawksworth DL. 2011 - Molecular phylogenetic studies on the lichenicolous Xanthoriicola physciae reveal Antarctic rock-inhabiting fungi and Piedraia species among closest relatives in the Teratosphaeriaceae. IMA fungus 2, 97-103.

Rupcic Z, Chepkirui C, Hernández-Restrepo M, Crous PW, Luangsa-Ard JJ, Stadler M. 2018 New nematicidal and antimicrobial secondary metabolites from a new species in the new genus, Pseudobambusicola thailandica. MycoKeys 33, 1-23.

Saccardo PA, Trotter A. 1913 - Supplementum Universale Pars IX. Sylloge Fungorum 22, 1-1612. 
Saccardo PA. 1878 - Fungi Italici autographice delineati a Prof. P.A. Saccardo. Patavii 1878. Fascicoli V-VIII. Michelia 1, 326-350.

Saccardo PA. 1879 - Fungi Gallici lecti a cl. viris P. Brunaud, C.C. Gillet et Abb. Letendre. Michelia 1, 500-538.

Saccardo PA. 1880 - Fungi Gallici lecti a cl. viris P. Brunaud, Abb. Letendre, A. Malbranche, J. Therry vel editi in Mycotheca Gallica C. Roumeguèri. Series II. Michelia 2, 39-135.

Saccardo PA. 1883 - Sylloge Pyrenomycetum, Vol. II. Sylloge Fungorum. 2, 1-815

Saccardo PA. 1889 - Discomyceteae et Phymatosphaeriaceae. Sylloge Fungorum 8, 1-1143

Saccardo PA. 1906 - Sylloge Fungorum 18, 1-839.

Saccardo PA. 1928 - Sylloge fungorum omnium hucusque cognitorum. Vol. XXIV. Sectio II. Supplementum universale Pars X. Curante Alex Trotter. 705-1438.

Samarakoon MC, Hyde KD, Hongsanan S et al. 2019a - Divergence time calibrations for ancient lineages of Ascomycota classifcation based on a modern review of estimations. Fungal Diversity 96, 285-346.

Samarakoon MC, Hyde KD, Promputtha I, Hongsanan S et al. 2016 - Evolution of Xylariomycetidae (Ascomycota: Sordariomycetes). Mycosphere 7, 1746-1761.

Samarakoon MC, Wanasinghe DN, Liu JK, Hyde KD, Promputtha I. 2019b - The genus Neoaquastroma is widely distributed; a taxonomic novelty, $N$. cylindricum sp. nov. (Parabambusicolaceae, Pleosporales) from Guizhou, China. Asian Journal of Mycology 2, 235-244

Samuels GJ and Müller E. 1978 - Life history studies of Brazilian Ascomycetes 4. Sydowia 31, $157-168$

Samuels GJ. 1980 - Ascomycetes of New Zealand 1. Ohleria brasiliensis and its Monodictys anamorph, with notes on taxonomy and systematics of Ohleria and Monodictys. New Zealand Journal of Botany 18, 515-523

Sancho LG, Pintado A, Green TG. 2019 - Antarctic studies show lichens to be excellent biomonitors of climate change. Diversity 11, 42.

Santos SAP, Santos C, Silva S, Pinto G et al. 2013 - The effect of sooty mold on fluorescence and gas exchange properties of olive tree. Turkish Journal of Biology 37, 620-628.

Schena L, Ippolito A, Zahavi T, Cohen L, Nigro F, Droby S. 1999 - 'Genetic Diversity and Biocontrol Activity of Aureobasidium pullulans Isolates against Postharvest Rots', Postharvest Biology and Technology 17, 189-199.

Schlub RL, Smith LJ, Datnoff LE, Pernezny K. 2009 - An overview of target spot of tomato caused by Corynespora cassiicola. Acta Horticulturae 808, 25-28.

Schneider R. 1979 - Die Gattung Pyrenochaeta de Notaris. Mitt. Biol. Bundesandt. Land-Forstw. Berlin-Dahlem 18, 1-73.

Schoch CL, Crous PW, Groenewald JZ, Boehm EWA et al. 2009a - A class-wide phylogenetic assessment of Dothideomycetes. Studies in Mycology 64, 1-15.

Schoch CL, Shoemaker RA, Seifert KA, Hambleton S et al. 2006 - A multigene phylogeny of the Dothideomycetes using four nuclear loci. Mycologia 98 1041-1052.

Schoch CL, Sung GH, López-Giráldez F, Townsend JP et al. 2009b - The Ascomycota Tree of Life: A phylum wide phylogeny clarifies the origin and evolution of fundamental reproductive and ecological traits. Systematic Biology 58, 224-239.

Schoknecht JD, Crane JL. 1977 - Revision of Torula and Hormiscium species. Torula occulta, T. diversa, T. elasticae, T. bigemina and Hormiscium condensatum reexamined. Mycologia 69, 533-546.

Schubert K, Braun U, Groenewald JZ, Crous PW. 2007a - Cladosporium leaf-blotch and stem rot of Paeonia spp. caused by Dichocladosporium chlorocephalum gen. nov. Studies in Mycology 58, 95-104.

Schubert K, Braun U. 2005 - Taxonomic revision of the genus Cladosporium sl 4. Species reallocated to Asperisporium, Dischloridium, Fusicladium, Passalora, Pseudoasperisporium and Stenella. Fungal Diversity 20, 187-208. 
Schubert K, Greslebin A, Groenewald JZ, Crous PW. 2009 - New foliicolous species of Cladosporium from South America. Persoonia 22, 111-122.

Schubert K, Groenewald JZ, Braun U, Dijksterhuis J et al. 2007b - Biodiversity in the Cladosporium herbarum complex (Davidiellaceae, Capnodiales), with standardisation of methods for Cladosporium taxonomy and diagnostics. Studies in Mycology 58, 105-156.

Schulzer S. 1870 - Mykologische Beiträge. Verhandlungen der Zoologisch- Botanischen Gesellschaft Wien 20, 635-658.

Scott JA, Ewaze JO, Summerbell RC, Arocha-Rosete Y et al. 2016 - Multilocus DNA sequencing of the whiskey fungus reveals a continental-scale speciation pattern. Persoonia 37, 13-20.

Scott JA, Untereiner WA, Ewaze JO, Wong B, Doyle D. 2007 - Baudoinia, a new genus to accommodate Torula compniacensis. Mycologia 99, 592-601.

Seifert K, Morgan-Jones G, Gams W, Kendrick B. 2011 - The genera of hyphomycetes. CBS Biodiversity Series no. 9: 1-997. CBS-KNAW Fungal Biodiversity Centre, Utrecht, Netherlands.

Seifert KA, Hughes SJ, Boulay H, Louis-Seize G. 2007 - Taxonomy, nomenclature and phylogeny of three cladosporium-like hyphomycetes, Sorocybe resinae, Seifertia azaleae and the Hormoconis anamorph of Amorphotheca resinae. Studies in Mycology 58, 235-245.

Seifert KA, Hughes SJ. 2000 - Spiropes dictyosporus, a new synnematous fungus associated with sooty moulds. New Zealand Journal of Botany 38, 489-492.

Seifert KA, Nickerson NL, Corlett M, Jackson ED et al. 2004 - Devriesia, a new hyphomycete genus to accommodate heat-resistant, cladosporium-like fungi. Canadian Journal of Botany 82, 914-926.

Selbmann L, De Hoog GS, Mazzaglia A, Friedmann EI, Onofri S. 2005 - Fungi at the edge of life: cryptoendolithic black fungi from Antarctic desert. Studies in Mycology 51, 1-32.

Selbmann L, De Hoog GS, Zucconi L, Isola D et al. 2008 - Drought meets acid: three new genera in a dothidealean clade of extremotolerant fungi. Studies in Mycology 61, 1-20.

Semeniuk G. 1983 - Association of Trematosphaeria circinans with crown and root rot of alfalfa in South Dakota. Mycologia 75, 744-747.

Senanayake IC, Jeewon R, Camporesi E, Hyde KD, Zeng YJ, Tian SL, Xie N. 2018 -Sulcispora supratumida sp. nov. (Phaeosphaeriaceae, Pleosporales) on Anthoxanthu modoratum from Italy. MycoKeys 38, 35-46

Senwanna C, Wanasinghe DN, Bulgakov TS, Wang Y et al. 2019 - Towards a natural classification of Dothidotthia and Thyrostroma in Dothidotthiaceae (Pleosporineae, Pleosporales). Mycosphere 10, 701-738.

Sharma R, Sharma R, Crous PW. 2015 - Matsushimamyces, a new genus of keratinophilic fungi from soil in central India. IMA fungus 6, 337-343.

Shaw JJ, Spakowicz DJ, Dalal RS, Davis JH et al. 2015 - Biosynthesis and genomic analysis of medium-chain hydrocarbon production by the endophytic fungal isolate Nigrograna mackinnonii E5202H. Applied Microbiology and Biotechnology 99, 3715-3728.

Shear CL, Davidson RW. 1936 - The life histories of Botryosphaeria melanops and Massaria platani. Mycologia 28, 476-482.

Shearer CA, Crane JL. 1971 - Fungi of the Chesapeake Bay and its tributaries. I. Patuxent River. Mycologia 63, 237-260.

Shearer CA, Hyde KD. 1997 - Massarina ingoldiana, a new ascomycete from freshwater habitats. Mycologia 89, 114-119.

Shearer CA, Raja HA, Miller AN, Nelson P et al. 2009 - The molecular phylogeny of freshwater Dothideomycetes. Studies in Mycology 64, 145-153.

Shearer CA. 1993 - Reexamination of eight taxa originally described in Leptosphaeria on members of the Asteraceae. Mycologia 85, 825-834.

Shenoy BD, Jeewon R, Wu WP, Bhat DJ, Hyde KD. 2006 - Ribosomal and rpb2 DNA sequence analyses suggest that Sporidesmium and morphologically similar genera are polyphyletic. Mycological Research 110, 916-928. 
Shoemaker RA, Babcock CE, Irwin JAG. 1991 - Massarina walkeri n. sp., the teleomorph of Acrocalymma medicaginis from Medicago sativa contrasted with Leptosphaeria pratensis, $L$. weimeri n. sp., and L. viridella. Canadian Journal of Botany 69, 569-573.

Shoemaker RA, Babcock CE. 1989a - Bricookea barrae n. sp. compared with Bricookea sepalorum. Studies in Mycology 31, 165-169

Shoemaker RA, Babcock CE. 1989b - Phaeosphaeria. Canadian Journal of Botany 67, 1500-1599.

Shoemaker RA, Babcock CE. 1992 - Applanodictyosporous Pleosporales: Clathrospora, Comoclathris, Graphyllium, Macrospora, and Platysporoides. Canadian Journal of Botany 70, 1617-1658.

Shoemaker RA, Hambleton S. 2005 - Dothidea sambuci and Diaporthe spiculosa Canadian Journal of Botany 83, 484-490.

Shoemaker RA. 1984 - Canadian and some extralimital Nodulosphaeria and Entodesmium species. Canadian Journal of Botany 62, 2730-2753

Sieber TN. 2007 - Endopytic fungi in forest trees: are they mutualists?. Fungal Biology Reviews 21, 75-89.

Silva AA, Cavalcante WA, Leal FB. 1973) - Um novo gênero da família Schizothyriaceae, em Leguminosae. Publicações do Instituto de Micologia da Universidade do Recife 691, 1-16.

Silva-Hanlin DM, Hanlin RT. 1999 - Small subunit ribosomal RNA gene phylogeny of several loculoascomycetes and its taxonomic implications. Mycological Research 103, 153-160.

Silvestro D, Michalak I. 2012 - raxmlGUI: a graphical front-end for RAxML. Organisms Diversity \& Evolution 12, 335-337.

Simmons EG. 2007 - Alternaria: an identification manual. CBS Fungal Biodiversity Center, Utrercht.

Singtripop C, Hongsanan S, Li JF, de Silva NI et al. 2016 - Chaetothyrina mangiferae sp. nov., a new species of Chaetothyrina. Phytotaxa 255, 21-33.

Sivanesan A, Hsieh WH, Chen CV. 1998 - A new monotypic genus of a parmulariaceous dictyosporous ascomycete from Taiwan. Botanical Journal of the Linnean Society 126, $323-$ 326.

Sivanesan A. 1971 - The genus Herpotrichia Fuckel. Mycological Papers 127, 1-37.

Sivanesan A. 1983 - Studies on ascomycetes. Transactions of the British Mycological Society 81, 313-332.

Sivanesan A. 1984 - The bitunicate ascomycetes and their anamorphs. J. Cramer, Vaduz, p 701.

Sivanesan A. 1987 - Graminicolous species of Bipolaris, Curvularia, Drechslera, Exserohilum and their teleomorphs. Mycological Papers 158, 1-261.

Sivanesan A. 1996 - Corynesporasca caryotae gen. et sp. nov. with a Corynespora anamorph, and the family Corynesporascaceae. Mycological Research 100, 783-788.

Smith AL. 1911 - A monograph of the British lichens. A descriptive catalogue of the species in the Department of Botany, British Museum, part II, British Museum, London.

Smith IM, Dunez J, Lelliott RA, Phillips DH, Archer SA. 1988 - European handbook of plant diseases. Blackwell Scientific Publications, Oxford, UK, pp 1-583.

Spatafora JW, Owensby AC, Douhan GW, Boehm EWA, Schoch CL. 2012 - Phylogenetic placement of the ectomycorrhizal genus Cenococcum in Gloniaceae (Dothideomycetes). Mycologia 104, 758-765.

Species Fungorum. 2020) http://www.speciesfungorum.org/Index.htm

Speer EO. 1986 - A propos de champignons du Brésil III. Mytilidion resinae sp. nov. (Hysteriales) et sa forme conidienne, Camaroglobulus resinae gen. et spec. nov. (Sphaeropsidales). Bulletin trimestriel de la Société mycologique de France 102, 97-100.

Spegazzini C. 1881 - Fungi argentini additis nonnullis brasiliensibus montevideensibusque. Pugillus quartus (Continuacion). Anales de la Sociedad Científica Argentina 12, 174-189.

Spegazzini C. 1888 - Fungi Guarinitici. Pugillus II. Anales de la Sociedad Científica Argentina. 26(1), 5-74.

Spegazzini C. 1909 - Mycetes Argentinenses. Series IV. Anales del Museo Nacional de Historia Natural Buenos Aires 19, 257-458. 
Spegazzini C. 1910 - Mycetes argentinenses (Series V). Anales del Museo Nacional de Historia Natural Buenos Aires 20, 329-467.

Spegazzini CL. 1918 - Notas micológicas. Physics (Buenos Aires) 4, 281-295.

Starbäck K. 1899 - Ascomyceten der ersten Regnellschen Expedition I. Bihang till Kungliga svenska Vetenskaps-Akademiens Handlingar, Afd 3 25, 68.

Stenroos S, Laukka T, Huhtinen S, Döbbeler P et al. 2010 - Multiple origins of symbioses between ascomycetes and bryophytes suggested by a five-gene phylogeny. Cladistics 26, 281-300.

Sterflinger K, Piñar G. 2013 - Microbial deterioration of cultural heritage and works of art-tilting at windmills?. Applied Microbiology and Biotechnology 97, 9637-9646.

Sterflinger K. 2000 - Fungi as geologic agents. Geomicrobiology Journal 17, 97-124.

Sterflinger K. 2010 - Fungi: their role in biodeterioration of cultural heritage. Fungal Biology Reviews 24, 1-2.z

Stevens FL. 1920 - Dothidiaceous and Other Porto Rican Fungi. Botanical Gazette 69, 248-257.

Stevens FL. 1925 - Hawaiian fungi. Bernice P. Bishop Museum bulletin 19, 1-189.

Stodůlková E, Man P, Kuzma M, Černý J et al. 2015 - A highly diverse spectrum of naphthoquinone derivatives produced by the endophytic fungus Biatriospora sp. CCF 4378. Folia Microbiol 60, 259-267.

Stone WJ, Jones JP. 1960 - Corynespora blight of sesame. Phytopathology 50, 263-266.

Stukenbrock EH, Quaedvlieg W, Javan-Nikhah M, Zala M, Crous PW, McDonald BA. 2012 Zymoseptoria ardabiliae and Z. pseudotritici, two progenitor species of the septoria tritici leaf blotch fungus Z. tritici (synonym: Mycosphaerella graminicola). Mycologia 104(6), 13971407.

Su HY, Hyde KD, Maharachchikumbura SSN, Ariyawansa HA et al. 2016 - The families Distoseptisporaceae fam. nov., Kirschsteiniotheliaceae, Sporormiaceae and Torulaceae, with new species from freshwater in Yunnan Province, China. Fungal Diversity 80, 375-409.

Su HY, Udayanga D, Luo ZL, Manamgoda DS et al. 2015 - Hyphomycetes from aquatic habitats in Southern China: species of curvularia (Pleosporaceae) and Phragmocephala (Melannomataceae). Phytotaxa 226, 201-216.

Su XJ, Luo ZL, Jeewon R, Bhat DJ et al. 2018 - Morphology and multigene phylogeny reveal new genus and species of Torulaceae from freshwater habitats in northwestern Yunnan, China. Mycological Progress 17, 531-545.

Subramanian CV. 1963 - On Arthrobotryum coonoorense. Proceedings of the Indian Academy of Sciences Section B 58(6), 348-350.

Subramanian CV. 1994 - Hyphomycetes from South East Asia - novelties from Singapore and Malaysia. Kavaka 22/23, 52-76.

Sue PK, Gurda GT, Lee R, Watkins T et al. 2014 - First report of Westerdykella dispersa as a cause of an angioinvasive fungal infection in a neutropenic host. Journal of Clinical Microbiology 52, 4407-4411.

Suetrong S, Boonyue N, Pang KL, Ueapattanakit J et al. 2011a - A taxonomic revision and phylogenetic reconstruction of the Jahnulales (Dothideomycetes), and the new family Manglicolaceae. Fungal Diversity 51, 163-188.

Suetrong S, Hyde KD, Zhang Y, Bahkali AB, Jones EBG. 2011b - Trematosphaeriaceae fam. nov. (Dothideomycetes, Ascomycota). Cryptogamie Mycologie 32, 343-358.

Suetrong S, Schoch CL, Spatafora JW, Kohlmeyer J et al. 2009 - Molecular systematics of the marine Dothideomycetes. Studies in Mycology 64, 155-173.

Sugiyama J, Hosoya T. 2019 - Antennatula katumotoi, a new euantennariaceous sooty mould, with a Hormisciomyces-like synasexual morph from central Honshu, Japan. Mycoscience 60, 302306.

Summerell BA, Groenewald JZ, Carnegie AJ, Summerbell RC, Crous PW. 2006 - Eucalyptus microfungi known from culture. 2. Alysidiella, Fusculina and Phlogicylindrium genera nova, with notes on some other poorly known taxa. Fungal Diversity 23, 323-350. 
Sun BD, Chen AJ, Gao WW, Zhou YG et al. 2013 - A new endophytic ascomycete associated with the medicinal plant, achyranthes Bidentata blume (Amaranthaceae). Pakistan Journal of Botany 45(1), 319-323.

Sutton BC, Alcorn JL. 1974 - Neottiosporina. Australian Journal of Botany 22, 517-530.

Sutton BC, Ganapathi A. 1978 - Trimmatostroma excentricum sp. nov. on Eucalyptus from NewZealand and Fiji. New Zealand Journal of Botany 16, 529-533.

Sutton BC, Pascoe IG. 1989 - Reassessment of Peltosoma, Stigmina and Batcheloromyces and description of Hyphothyrium gen. nov. Mycological Research 92, 210-222.

Sutton BC, Pollack FG. 1974 - Microfungi on Cercocarpus. Mycopathologia et mycologia applicata 52, 331-351.

Sutton BC, Pollok FG. 1973 - Gleosporium cercocarpi and Sphaceloma cercocarpi. Mycologia 65, 1128.

Sutton BC. 1971 - Staninwardia gen. nov. (Melanconiales) on Eucalyptus. Transactions of the British Mycological Society 57, 539-542.

Sutton BC. 1974 - Miscellaneous coelomycetes on Eucalyptus. Nova Hedwigia 25, 161-172.

Sutton BC. 1975a - Coelomycetes V. Coryneum. Mycological Papers 138, 1-224.

Sutton BC. 1975b - Eucalyptus microfungi. Satchmopsis gen. nov., and new species of Coniella, Coniothyrium and Harknessia. Nov Hedwigia 26, 1-16.

Sutton BC. 1977 - Coelomycetes VI. Nomenclature of generic names proposed for Coelomycetes. Mycological Papers 141, 1-253.

Sutton BC. 1980 - The Coelomycetes. Fungi imperfecti with pycnidia, acervuli and stromata. Commonwealth Mycological Institute, Kew, pp 1-696.

Sutton BC. 1996 - Records of microfungi from Crete. Bocconea 5, 335-350.

Sutton BC. 1997 - On Stigmina, Wilsonomyces and Thyrostroma (Hyphomycetes). Arnoldia 14, $33-35$.

Swart HJ. 1982 - Australian Leaf-Inhibiting fungi. Xii: Semifissispara gen. nov. on dead Eucalyptus leaves. Transactions of the British Mycological Society 78, 259-264.

Swart HJ. 1985 - Australian leaf-inhabiting fungi XIX: Conidiogenesis in Camarosporula persooniae. Transactions of the British Mycological Society 84, 733-735.

Swart HJ. 1988 - Australian leaf-inhabiting fungil. XXIX. Some ascomycetes on Banksia. Transactions of the British Mycological Society 91, 453-465.

Sydow H, Sydow P. 1913a - Novae fungorum species X. Annales Mycologici 11, 254-271.

Sydow H, Sydow P. 1913b - Novae fungorum species XI. Annales Mycologici 11, 402-408.

Sydow H. 1926 - Fungi in intinere costaricensi collecti, pars secunda. Annales Mycologici. 24, 283-426.

Sydow H. 1927 - Fungi in itinere costaricense collecti. Annales Mycologici 25(1-2), 1-160.

Takekawa H, Tanaka K, Fukushi E, Matsuo K et al. 2013 - Roussoellols A and B, tetracyclic fusicoccanes from Roussoella hysterioides. Journal of Natural Products 76, 1047-1051.

Tam WY, Pang KL, Jones EBG. 2003 - Ordinal placement of selected marine Dothideomycetes inferred from SSU ribosomal DNA sequence analysis. Botanica Marina 4, 487-494.

Tan YP, Madrid H, Crous P, Shivas R. 2014 - Johnalcornia gen. et. comb. nov., and nine new combinations in Curvularia based on molecular phylogenetic analysis. Australasian Plant Pathology 43, 589-603.

Tanaka E, Harada Y. 2003a - Hadrospora fallax (Pleosporales) found in Japan. Mycoscience 44, $245-248$.

Tanaka K, Harada Y, Barr ME. 2005a - Trematosphaeria: taxonomic concepts, new species from Japan and key to species. Fungal Diversity 19, 145-156.

Tanaka K, Harada Y. 2003b - Pleosporales in Japan (1): the genus Lophiostoma. Mycoscience 44, 85-96.

Tanaka K, Harada Y. 2003c - Pleosporales in Japan (2): Lophiotrema. Mycoscience 44, 115-121.

Tanaka K, Harada Y. 2003d - Pleosporales in Japan (3): The genus Massarina. Mycoscience 44, $173-185$. 
Tanaka K, Harada Y. 2004 - Pleosporales in Japan (4): The genus Massariosphaeria. Mycoscience 45, 96-105.

Tanaka K, Harada Y. 2005a - Bambusicolous fungi in Japan (4): a new combination, Astrosphaeriella aggregata. Mycoscience 46, 114-118.

Tanaka K, Harada Y. 2005b - Bambusicolous fungi in Japan (6): Katumotoa, a new genus of phaeosphaeriaceous ascomycetes. Mycoscience 46, 313-318.

Tanaka K, Hashimoto A, Matsumura M, Sato T. 2017 - Brevicollum, a new genus in Neohendersoniaceae, Pleosporales. Mycologia 109, 1-12.

Tanaka K, Hatakeyama S, Harada Y. 2005b - Three new freshwater ascomycetes from rivers in Akkeshi, Hokkaido, northern Japan. Mycoscience 46, 287-293.

Tanaka K, Hirayama K, Yonezawa H, Hatakeyama S et al. 2009 - Molecular taxonomy of bambusicolous fungi: Tetraplosphaeriaceae, a new pleosporalean family with Tetraploa-like anamorphs. Studies in Mycology 64, 175-209.

Tanaka K, Hirayama K, Yonezawa H, Sato G et al. 2015 - Revision of the Massarineae (Pleosporales, Dothideomycetes). Studies in Mycology 82, 75-136.

Tanaka K, Hosoya T. 2008 - Lophiostoma sagittiforme sp. nov., a new ascomycete (Pleosporales, Dothideomycetes) from Island Yakushima in Japan. Sydowia 60, 131-145.

Tanaka K, Mel'nik VA, Kamiyama M, Hirayama K, Shirouzu T. 2010 - Molecular phylogeny of two coelomycetous fungal genera with stellate conidia, Prosthemium and Asterosporium, on Fagales trees. Botany 88, 1057-1071.

Tanaka K, Ooki Y, Hatakeyama S, Harada Y, Barr ME. 2005c - Pleosporales in Japan (5): Pleomassaria, Asteromassaria, and Splanchnonema. Mycoscience 46, 248-260.

Tanney J, Miller AN. 2017 - Asexual-sexual morph connection in the type species of Berkleasmium. IMA Fungus 8, 99-105.

Taylor JE, Crous PW, Swart L. 2001 - Foliicolous and caulicolous fungi associated with Proteaceae cultivated in California. Mycotaxon 78, 75-103.

Taylor JE, Crous PW, Wingfield MJ. 1999 - Batcheloromyces species occurring on Proteaceae in South Africa. Mycological Research 103, 1478-1484.

Taylor JE, Groenewald JE, Crous PW. 2003 - A phylogenetic analysis of Mycosphaerellaceae leaf spot pathogens of Proteaceae. Mycological Research 107, 653-658.

Taylor JE, Hyde KD. 2003 - Microfungi of tropical and temperate palms. Fungal Diversity Research Series 12, Hong Kong University Press, Hong Kong, pp 1-459.

Taylor JW. 2015 - Evolutionary perspectives on human fungal pathogens. Cold Spring Harbor Perspectives in Medicine 5, 1-18.

Tehler A. 1990 - A new approach to the phylogeny of Euascomycetes with a cladistic outline of Arthoniales focussing on Roccellaceae. Canadian Journal of Botany 68, 2458-2492.

Tehler A. 1995 - Morphological data, molecular data, and total evidence in phylogenetic analysis. Canadian Journal of Botany 73, S667-S676.

Teng SC. 1936 - Additional fungi from China. II. Sinensia 7, 490-527.

Tennakoon DS, Hyde KD, Phookamsak R, Wanasinghe DN, Cam- poresi E, Promputtha I. 2016 Taxonomy and phylogeny of Juncaceicola gen. nov. Phaeosphaeriaceae, Pleosporinae, Pleosporales. Cryptogamie, Mycologie 37, 135-156

Tennakoon DS, Jeewon R, Kuo CH, Hyde KD. 2018a - Phylogenetic and morphological characterization of Byssosphaeria macarangae sp. nov., and B. taiwanense sp. nov. from Macaranga tanarius. Phytotaxa 364, 211-226.

Tennakoon DS, Kuo C-H, Jeewon R, Thambugala KM, Hyde KD. 2018b - Saprobic Lophiostomataceae (Dothideomycetes): Pseudolophiostoma mangiferae sp. nov. and Neovaginatispora fuckelii, a new record from Mangifera indica. Phytotaxa 364, 157-171.

Tennakoon DS, Kuo CH, Hyde KD. 2020 - Multi-locus phylogeny reveals Phaeodothis mori sp. nov. (Didymosphaeriaceae, Pleosporales) from dead leaves of Morus australis. Phytotaxa $428,241-254$. 
Tennakoon DS, Phookamsak R, Kuo CH, Goh TK et al. 2018c - Morphological and phylogenetic evidence reveal Fissuroma taiwanense sp. nov. (Aigialaceae, Pleosporales) from Hedychium coronarium. Phytotaxa 338, 265-275.

Tennakoon DS, Phookamsak R, Wanasinghe DN, Yang JB et sl. 2017 - Morphological and phylogenetic insights resolve Plenodomus sinensis (Leptosphaeriaceae) as a new species. Phytotaxa 324, 73-82.

Tennakoon DS, Thambugala KM, De Silva NI, Kuo CH, Hyde KD. 2019 - Leaf litter saprobic Didymellaceae (Dothideomycetes): Leptosphaerulina longiflori sp., nov. and Didymella sinensis, a new record from Roystonea regia Asian Journal of Mycology 2, 87-100.

Thambugala KM, Ariyawansa HA, Li YM, Boonmee S et al. 2014a - Dothideales. Fungal Diversity 68, 105-158.

Thambugala KM, Ariyawansa HA, Liu ZY, Chukeatirote E, Hyde KD. 2014b - Towards a natural classification of Dothideomycetes 6: The genera Dolabra, Placostromella, Pleosphaerellula, Polysporidiella and Pseudotrichia (Dothideomycetes incertae sedis). Phytotaxa 176, 55-67.

Thambugala KM, Camporesi E, Ariyawansa HA, Phookamsak R, Liu ZY, Hyde KD. 2014c Phylogeny and morphology of Phaeosphaeriopsis triseptata sp. nov., and Phaeosphaeriopsis glaucopunctata. Phytotaxa 176, 238-250

Thambugala KM, Chunfang Y, Camporesi E, Bahkali AH et al. 2015a - Pseudodidymosphaeria gen. nov. in Massarinaceae. Phytotaxa 231, 271-282.

Thambugala KM, Daranagama DA, Phillips AJL, Bulgakov TS et al. 2017a - Microfungi on Tamarix. Fungal Diversity 82, 239-306.

Thambugala KM, Hyde KD, Camporesi E, Liu ZY. 2018 - Microsphaeropsis ononidicola sp. nov. (Microsphaeropsidaceae, Pleosporales) from Ononis spinosa L. Current Research in Environmental \& Applied Mycology (Journal of Fungal Biology) 8, 217-223.

Thambugala KM, Hyde KD, Tanaka K, Tian Q et al. 2015b - Towards a natural classification and backbone tree for Lophiostomataceae, Floricolaceae, and Amorosiaceae fam.nov. Fungal Diversity 74, 199-266.

Thambugala KM, Singtripop C, Chunfang YU, Mckenzie EH et al. 2014d - Towards a natural classification of Dothideomycetes 7: the genera Allosoma, Austropleospora, Dangeardiella, Griggsia and Karschia (Dothideomycetes incertae sedis). Phytotaxa 181, 34-46.

Thambugala KM, Wanasinghe DN, Phillips AJL, Camporesi E et al. 2017b - Mycosphere notes 150: grass (Poaceae) inhabiting Dothideomycetes. Mycosphere 8, 697-796.

Theissen F, Sydow H. 1915 - Die Dothideales. Kritisch-systematische riginaluntersuchungen. Annales Mycologici 13, 147-746.

Theissen F, Sydow H. 1917a - Die Gattung Parodiella. AnnalMycol 15, 125-142.

Theissen F, Sydow H. 1917b - Synoptische Tafeln. Annales Mycologici 15, 389-491.

Theissen F. 1914 - Annotacoes à Mycoflora Brasileira. Brotéria Série Botânica. 12, 13-31.

Theissen F. 1916 - Mykologische Abhandlungen. Verh. der Kaiserlich- Koniglichen ZoologischBotanischen Gesell. Wien 66, 296-400.

Thirumalachar MJ, Mishra JN. 1953 - Contribution to the study of fungi of Bihar, India - I. Sydowia 7, 29-83.

Thwaites GHK. 1849 - XXVI.-Note on Cystocoleus, a new genus of minute plants. The Annals and magazine of natural history 3, 241-242.

Tian Q, Chomnunti P, Bhat JD, Alias SA et al. 2014 - Towards a natural classification of Dothideomycetes 5: The genera Ascostratum, Chaetoscutula, Ceratocarpia, Cystocoleus, and Colensoniella (Dothideomycetes incertae sedis). Phytotaxa 176, 42-54.

Tian Q, Liu JK, Hyde KD, Wanasinghe DN, Boonmee S et al. 2015 - Phylogenetic relationships and morphological reappraisal of Melanommataceae (Pleosporales). Fungal Diversity 74, 267-324.

Tibpromma S, Bhat J, Doilom M, Lumyong S et al. 2016a - Three new Hermatomyces species (Lophiotremataceae) on Pandanus odorifer from Southern Thailand. Phytotaxa 275, 127 139. 
Tibpromma S, Hyde KD, Jeewon R, Maharachchikumbura SSN et al. 2017 - Fungal diversity notes 491-602: taxonomic and phylogenetic contributions to fungal taxa. Fungal Diversity 83, 1261.

Tibpromma S, Hyde KD, McKenzie EHC, Bhat DJ et al. 2018 - Fungal diversity notes 840-928: micro-fungi associated with Pandanaceae. Fungal Diversity 93, 1-160.

Tibpromma S, Liu JK, Promputtha I, Camporesi E et al. 2016b - Ophiosimulans tanaceti gen. et sp. nov. (Phaeosphaeriaceae) on Tanacetum sp. (Asteraceae) from Italy. Mycological Progress 15(5), 46. DOI 10.1007/s11557-016-1187-7

Tibpromma S, Promputtha I, Phookamsak R, Boonmee S, Camporesi E, Yang JB, Bhakali AH, McKenzie EHC, Hyde KD. 2015 - Phylogeny and morphology of Premilcurensis gen. nov. (Pleosporales) from stems of Senecio in Italy. Phytotaxa 236(1), 40-52

Tisserat NA, Pair JC. 1997 - Susceptibility of selected juniper cultivars to cedar-apple rust, Kabatina tip blight, Cercospora needle blight and Botryosphaeria canker. Journal of Environmental Horticulture 15, 160-163.

Titze A, De Hoog GS. 1990 - Capnobotryella renispora on roof tile. Antonie van Leeuwenhoek $58,265-269$.

Tode F. 1791 - Fungi Mecklenburgenses selecti, Fasciculus 2. F. Lemke, Lüneburg

Toro RA. 1927 - Fungi of Santo Domingo - I. Mycologia 19, 66-85.

Tóth S. 1979 - Vargamyces, a new genus of hyphomycetes on submerged plant debris. Acta Botanica Hungarica 25, 403-410.

Trakunyingcharoen T, Lombard L, Groenewald JZ, Cheewangkoon R et al. 2014 - Mycoparasitic species of Sphaerellopsis, and allied lichenicolous and other genera. IMA Fungus 5, 391414.

Trappe JM. 1962 - Fungus associates of ectotrophic mycorrhizae. Bot Rev 28, 538-606.

Trovão J, Tiago I, Soares F, Paiva DS et al. 2019 - Description of Aeminiaceae fam. nov., Aeminium gen. nov. and Aeminium ludgeri sp. nov. (Capnodiales), isolated from a biodeteriorated art-piece in the Old Cathedral of Coimbra, Portugal. MycoKeys 28, 57-73.

Tsang CC, Chan JF, Trendell-Smith NJ, Ngan AH et al. 2014 - Subcutaneous phaeohyphomycosis in a patient with IgG4-related sclerosing disease caused by a novel ascomycete, Hongkongmyces pedis gen. et sp. nov.: first report of human infection associated with the family Lindgomycetaceae. Medical Mycology 52, 736-747.

Tsui CKM, Berbee ML, Jeewon R, Hyde KD. 2006 - Molecular phylogeny of Dictyosporium and allied genera inferred from ribosomal DNA. Fungal Diversity 21, 157-166.

Tsuneda A, Davey ML, Tsuneda I, Currah RS. 2010 - Two new dothideomycetous endoconidial genera from declining larch. Botany 88, 471-487.

Tsuneda A, Davey ML, Tsuneda I, Hudgins A, Currah RS. 2011 - Endophoma, a new didymellaceous endoconidial genus from bat-cave soil. Mycologia 103, 1146-1155.

Tsuneda A, Hambleton S, Currah RS. 2018 - The anamorph genus Knufia and its phylogenetically allied species in Coniosporium, Sarcinomyces, and Phaeococcomyces Botany 89, 523-536.

Tulasne LR, Tulasne C. 1863 - Selecta Fungorum Carpologia vol 2, Paris, pp 1-319.

Upadhyay HP. 1966 - Soil fungi from North-East Brazil, II. Mycopathologia 30, 276-286.

Upreti DK, Pant G. 1993 - Notes on Arthopyrenia species from India. Bryologist 96, 226-232.

Vaghefi N, Pethybridge SJ, Ford R et al. 2012 - Stagonosporopsis spp. associated with ray blight disease of Asteraceae. Australasian Plant Pathology 41, 675-686.

Vaghefi N, Pethybridge SJ, Shivas RG, Nelson SC. 2016 - Confirmation of Paracercospora egenula causing leaf spot of eggplant in Hawaii. Australasian Plant Disease Notes 11, 35.

Vainio EA. 1921 - Lichenographia Fennica I. Pyrenolichenes usque proximi Pyrenomycetes et Lichenes Imperfecti. Acta Societatis pro Fauna et Flora Fennica 49, 1-274.

Valenzuela-Lopez N, Cano-Lira JF, Guarro J, Sutton DA et al. 2018 - Coelomycetous Dothideomycetes with emphasis on the families Cucurbitariaceae and Didymellaceae. Studies in Mycology 90, 1-69. 
Van de Wouw AP, Cozijnsen AJ, Hane JK, Brunner PC et al. 2010 - Evolution of linked avirulence effectors in Leptosphaeria maculans is affected by genomic environment and exposure to resistance genes in host plants. PLoS Pathogens 6, e1001180.

Van de Wouw AP, Marcroft SJ, Howlett BJ. 2016 - Blackleg disease of canola in Australia. Crop and Pasture Science 67, 273-283.

van den Hoek C, Mann DG, Jahns HM. 1995 - Algae: An Introduction to Phycology. Cambridge University Press, Cambridge, UK.

Van der Aa, HA. 1989 - Polycoccum peltigerae and Didymosphaeria arxii sp. nov. and their anamorphs. Studies in Mycology 31, 15-22.

van Geel B, Buurman J, Brinkkemper O, Schelvis J et al. 2003 - Environmental reconstruction of a Roman Period settlement site in Uitgeest (The Netherlands), with special reference to coprophilous fungi. Journal of Archaeological Science 30, 873-883.

Van RG. 2005 - Fungi on Common Reed (Phragmites australis): Fungal Diversity, Community Structure and Decomposition Processes. PhD thesis, University of Gent.

Van Wyk PS, Marasas WF, Knox-Davies PS. 1985 - Batcheloromyces leucadendri sp. nov. on Leucadendron spp. in South Africa. South African Journal of Botany 51, 344-346.

Vasilyeva LN, Mel'nik VA. 2006 - New pyrenomycetous species from Korea and South Africa. Mikologiya i Fitopatologiya 40, 89-92.

Vasilyeva LN. 2000 - Hysteriaceous fungi in the Russian Far East III. Glonium and Actidiographium. Mikologiya i Fitopatologiya 34, 3-5.

Velmurugan P, Kim M J, Park JS, Karthikeyan K et al. 2010 - Dyeing of cotton yarn with five water soluble fungal pigments obtained from five fungi. Fibers and Polymers 11, 598-605.

Verkley GJ, Quaedvlieg W, Shin HD, Crous PW. 2013 - A new approach to species delimitation in Septoria. Studies in Mycology 75, 213-305.

Verkley GJM, da Silva M, Wicklow DT, Crous PW. 2004a - Paraconiothyrium, a new genus to accommodate the mycoparasite Coniothyrium minitans, anamorphs of Paraphaeosphaeria, and four new species. Studies in Mycology 50, 323-335.

Verkley GJM, Dukik K, Renfurm R, Göker M, Stielow JB. 2014 - Novel genera and species of coniothyrium-like fungi in Montagnulaceae (Ascomycota). Persoonia. 32, 25-51.

Verkley GJM, Starink-Willemse M, van Iperen A, Abeln ECA. 2004b - Phylogenetic analyses of Septoria species based on the ITS and LSU-D2 regions of nuclear ribosomal DNA. Mycologia 96, 558-571.

Verwoerd L, du Plessis SJ. 1931 - Descriptions of some new species of South African fungi and of species not previously recorded in South Africa III. South African Journal of Science 28, 290-297.

Videira SI, Groenewald JZ, Braun U, Shin HD, Crous PW. 2016 - All that glitters is not Ramularia. Studies in Mycology 83, 49-163.

Videira SI, Groenewald JZ, Kolecka A, van Haren L, Boekhout T, Crous PW. 2015a - Elucidating the Ramularia eucalypti species complex. Persoonia 34, 50-64.

Videira SI, Groenewald JZ, Verkley GJ, Braun U, Crous PW. 2015b - The rise of Ramularia from the Mycosphaerella labyrinth. Fungal Biology 119(9), 823-843.

Videira SIR, Groenewald JZ, Nakashima C, Braun U et al. 2017 - Mycosphaerellaceae-Chaos or clarity? Studies in Mycology 87, 257-421.

Vijaykrishna D, Jeewon R, Hyde KD. 2006 - Molecular taxonomy, origins and evolution of freshwater ascomycetes. Fungal Diversity 23, 351-390.

Voglmayr H, Delgado-Rodríguez G. 2003 - New species, notes and key to the aeroaquatic genera Beverwykella and Ramicephala gen. nov. Mycological Research 107, 236-244.

Voglmayr H, Jaklitsch WM. 2011 - Molecular data reveal high host specificity in the phylogenetically isolated genus Massaria (Ascomycota, Massariaceae). Fungal Diversity 46, 133-170.

Voglmayr H, Jaklitsch WM. 2017 - Corynespora, Exosporium and Helminthosporium revisitedNew species and generic reclassification. Studies in Mycology 87, 43-76. 
Voglmayr H. 2004 - Spirosphaera cupreorufescens sp. nov., a rare aeroaquatic fungus. Studies in Mycology 50, 221-228.

Vohník M, Borovec O, Kolaříková Z, Sudová R, Réblová M. 2019 - Extensive sampling and highthroughput sequencing reveal Posidoniomyces atricolor gen. et sp. nov. (Aigialaceae, Pleosporales) as the dominant root mycobiont of the dominant Mediterranean seagrass Posidonia oceanica. MycoKeys 55, 59-86.

von Arx JA, Müller E. 1975 - A re-evaluation of the bitunicate Ascomycetes with keys to families and genera. Studies in Mycology 9, 1-159.

von Arx JA. 1959 - Über die Ascomycetengattung Plochmopeltis Theiss. Persoonia 1: 1-5

von Arx JA. 1963 - Die Gattungen der Myriangiales. Persoonia 2, 421-475.

von Arx JA. 1971 - Testudinaceae, a new family of Ascomycetes.Persoonia 6, 365-369.

von Höhnel F. 1909a - Fragmente zur Mykologie (VI. Mitteilung, Nr. 182 bis 288). Sitzungsberichte der Kaiserlichen Akademie der Wissenschaften in Wien MathematischNaturwissenschaftliche Classe, Abt. 1 118, 275-452.

von Höhnel F. 1909b - Fragmente zur Mykologie: VIII. Mitteilung (Nr. 354 bis 406). Sitzungsberichte der Kaiserlichen Akademie der Wissenschaften Math.-naturw. Klasse Abt. I. 118, 1157-1246.

von Höhnel F. 1917a - Fungi imperfecti. Beiträge zur Kenntnis derselben Hedwigia 59, 236-284.

von Höhnel FXR. 1909c - Fragmente zur Mykologie: VII. Mitteilung (Nr. 289 bis 353). Sber Akademie der Wissenschaften in Wien Mathematisch-Naturwissenschaftliche Classe, Abteilung 1 118, 847-848.

von Höhnel FXR. 1911 - Fragmente zur Mykologie. XIII Mitteilung (Nr. 642 bis 718). Sitzungsberichte der Kaiserlichen Akademie der Wissenschaften. Mathematischnaturwissenschaftliche Classe, Abteilung 1 120, 379-484.

von Höhnel FXR. 1917b - System der Phacidiales v. H. Sonderabdruck. Berichte der Deutschen Botanischen Gesellschaft 25, 416-422.

Von Niessl G. 1875) Notizen iiber neue und kritische Pyrenomyceten. Verh Naturf Ver Briinn 14, $165-217$.

Voronin LV. 1989 - Phoma Sacc. species from the water and fish of freshwater reservoirs. Mikologia i Fitopatologia 23, 19-27.

Vu D, Groenewald M, de Vries M, Gehrmann T et al. 2019 - Large-scale generation and analysis of filamentous fungal DNA barcodes boosts coverage for kingdom fungi and reveals thresholds for fungal species and higher taxon delimitation. Studies in Mycology 92, 135154.

Wanasinghe DN, Camporesi E, Hu DM. 2016a - Neoleptosphaeria jonesii sp. nov., a novel saprobic sexual species Leptosphaeriaceae. Mycosphere 7, 1368-1377.

Wanasinghe DN, Hyde KD, Jeewon R, Crous PW et al. 2017a - Phylogenetic revision of Camarosporium (Pleosporineae, Dothideomycetes) and allied genera. Studies in Mycology 87, 207-256.

Wanasinghe DN, Hyde KD, Konta S, To-Anun C, Jones EBG. 2017b - Saprobic Dothideomycetes in Thailand: Neoaquastroma gen. nov. (Parabambusicolaceae) introduced based on morphological and molecular data. Phytotaxa 302, 133-144.

Wanasinghe DN, Jeewon R, Jones EBG, Boonmee S et al. 2018a - Novel palmicolous taxa within Pleosporales: multigene phylogeny and taxonomic circumscription. Mycological Progress 17, 571-590.

Wanasinghe DN, Jeewon R, Peršoh D, Jones EBG et al. 2018b - Taxonomic circumscription and phylogenetics of novel didymellaceous taxa with brown muriform spores. Studies in Fungi 3, $152-175$.

Wanasinghe DN, Jeewon R, Tibpromma S, Jones EBG, Hyde KD. 2017c - Saprobic Dothideomycetes in Thailand: Muritestudina gen. et sp. nov. (Testudinaceae) a new terrestrial pleosporalean ascomycete, with hyaline and muriform ascospores. Studies in Fungi 2, 219-234. 
Wanasinghe DN, Jones EBG, Camporesi E, Boonmee S et al. 2014a - An exciting novel member of Lentitheciaceae in Italy from Clematis Vitalba. Cryptogamie Mycologie 35, 323-337.

Wanasinghe DN, Jones EBG, Camporesi E, Boonmee S et al. 2014b - Dematiopleospora mariae gen. sp. nov., from Ononis spinosa in Italy. Cryptogamie, Mycologie 35(2), 105-117

Wanasinghe DN, Jones EBG, Camporesi E, Dissanayake AJ et al. 2016b - Taxonomy and phylogeny of Laburnicola gen. nov. and Paramassariosphaeria gen. nov. (Didymosphaeriaceae, Massarineae, Pleosporales). Fungal Biology 120, 1354-1373.

Wanasinghe DN, Jones EG, Camporesi E, Mortimer PE et al. 2015 - The genus Murispora. Cryptogamie Mycologie 36, 419-448.

Wanasinghe DN, Mortimer PE, Senwanna C, Cheewangkoon R. 2020a - Saprobic Dothideomycetes in Thailand: Phaeoseptum hydei sp. nov., a new terrestrial ascomycete in Phaeoseptaceae. Phytotaxa. 449, 149-163.

Wanasinghe DN, Phookamsak R, Jeewon R, Wen Jing Li et al. 2017d - Fenestellaceae with descriptions of new Fenestella species and Neocucurbitaria gen. nov. Mycosphere 8, 397414.

Wanasinghe DN, Phukhamsakda C, Hyde KD, Jeewon R et al. 2018c - Fungal diversity notes 709839: taxonomic and phylogenetic contributions to fungal taxa with an emphasis on fungi on Rosaceae. Fungal Diversity 89, 1-236.

Wanasinghe DN, Wijayawardene NN, Xu J, Cheewangkoon R et al. 2020b - Taxonomic novelties in Magnolia-associated pleosporalean fungi in the Kunming Botanical Gardens (Yunnan, China). PLoS ONE 15, e0235855.

Wang HK, Aptroot A, Crous PW, Hyde KD, Jeewon R. 2007 - The polyphyletic nature of Pleosporales: an example from Massariosphaeria based on rDNA and RBP2 gene phylogenies. Mycological Research 111, 1268-1276.

Wang MM, Li CL, Sun KM, Pan HQ, Li W. 2016 - Three new records of endophytic fungi isolated from marine algae in China. Mycosystema 35, 636-640.

Wang MM, Shenoy BD, Li W, Cai L. 2017 - Molecular phylogeny of neodevriesia, with two new species and several new combinations. Mycologia 109, 965-974.

Watanabe T. 2002 - Pictorial atlas of soil and seed fungi: morphologies of cultured fungi and key to species, 2nd edn. CRC Press, Boca Raton.

Watson W. 1929 - The classification of lichens II. New Phytologist 28, 85-116.

Webster J. 1992 - Anamorph-teleomorph relationships. In: Bärlocher F (ed) The ecology of aquatic hyphomycetes. Springer-Verlag, pp 99-117.

Wehmeyer LE. 1941 - A revision of Melanconis, Pseudovalsa, Prosthecium, and Titania. University of Michigan Studies, Scientific Series 14, 1-161.

Wehmeyer LE. 1975 - The pyrenomycetous fungi. Mycologia Memoir No. 6. The New York Botanical Garden. J. Cramer Publishing, Germany.

Wei CZ, Harada Y, Katumoto K. 1997 - Pseudodidymella fagi gen. et sp. nov. and its hyphomycete anamorph Pycnopleiospora fagi gen. et sp. nov. on Fagus crenata in Japan. Mycologia 89, 494-502.

Wei CZ, Harada Y, Katumoto K. 1998 - Mycodidymella aesculi gen. et sp. nov. and its synanamorphs Blastostroma aesculi gen. et sp. nov. and Mycopappus aesculi sp. nov. on Aesculus turbinata in Japan. Mycologia 90, 334-345.

Wei SL, Zhang TY. 2003 - Allantophomoides, a new genus in Coelomycetes. Mycosystema 22, 911.

Went FW, Stark N. 1968 - The biological and mechanical role of soil fungi. PNAS 60, 497-504.

Whitton SR, McKenzie EHC, Hyde KD. 2002 - Microfungi on the Pandanaceae: Two new species of Camposporium and key to the genus. Fungal Diversity 11, 177-187.

Whitton SR, McKenzie EHC, Hyde KD. 2012 - Fungi associated with Pandanaceae. Fungal Diversity Research Series 21, 1-457.

Wijayawardene DNN, McKenzie EHC, Hyde KD. 2012 - Towards incorporating anamorphic fungi in a natural classification-checklist and notes for 2011. Mycosphere 3, 157-228. 
Wijayawardene NN, Camporesi E, Bhat DJ, Song Y et al. 2014a - Macrodiplodiopsis in Lophiostomataceae, Pleosporales. Phytotaxa 176, 192-200.

Wijayawardene NN, Camporesi E, Song Y, Dai DQ, Bhat DJ, Mckenzie EHC, Chukeatirote E, Mel'Nik VA, Wang Y, Hyde KD. 2013a - Multi-gene analyses reveal taxonomic placement of Scolicosporium minkeviciusii in Phaeosphaeriaceae (Pleosporales). Cryptogamie, Mycologie 34(4), 357-366.

Wijayawardene NN, Crous PW, Kirk PM, Hawksworth DL et al. 2014b - Naming and outline of Dothideomycetes-2014 including proposals for the protection or suppression of generic names. Fungal Diversity 69, 1-55.

Wijayawardene NN, Hyde KD, Al-Ani LKT, Tedersoo L et al. 2020 - Outline of Fungi and fungilike taxa. Mycosphere 11, 1060-1456.

Wijayawardene NN, Hyde KD, Bhat DJ, Camporesi E et al. 2014c - Camarosporium-like species are polyphyletic in Pleosporales; introducing Paracamarosporium and Pseudocamarosporium gen. nov. in Montagnulaceae. Cryptogamie Mycologie 35, 177-198.

Wijayawardene NN, Hyde KD, Bhat DJ, Goonasekara ID et al. 2015 - Additions to Brown Spored Coelomycetous Taxa in Massarinae, Pleosporales: Introducing Phragmocamarosporium gen. nov. and Suttonomyces gen. nov. Cryptogamie Mycologie 36, 213-224.

Wijayawardene NN, Hyde KD, Lumbsch HT, Liu JK et al. 2018 - Outline of Ascomycota: 2017. Fungal Diversity 88, 167-263.

Wijayawardene NN, Hyde KD, Rajeshkumar KC, Hawksworth DL et al. 2017a - Notes for genera: Ascomycota. Fungal Diversity 86, 1-594.

Wijayawardene NN, Hyde KD, Tibpromma S, Wanasinghe DN et al. 2017b - Towards incorporating asexual fungi in a natural classification: checklist and notes 2012- 2016. Mycosphere 8, 1457-1554.

Wijayawardene NN, Hyde KD, Wanasinghe DN, Papizadeh M et al. 2016a - Taxonomy and phylogeny of dematiaceous coelomycetes. Fungal Diversity 77, 1-316.

Wijayawardene NN, Song Y, Bhat DJ, McKenzie EHC, Chukeatirote E, Wang Y, Hyde KD. 2013 b - Wojnowicia viburni, sp. nov., from China and its phylogenetic placement. Sydowia 65(1), 129-138

Wijayawardene NN, Tibpromma S, Hyde KD, An YL, Camporesi E, Wang Y. 2016b - Additions to Pseudocamarosporium; two new species from Italy. Studies in Fungi 1, 1-10.

Williamson SM, Sutton TB. 2000 - Sooty blotch and flyspeck of apple: etiology, biology, and control. Plant Disease 84, 714-724.

Willoughby LG, Archer JF. 1973 - The fungal spora of a freshwater stream and its colonization pattern onwood. Freshwater biology 3, 219-239.

Wingfield MJ, De Beer ZW, Slippers B et al. 2012 - One fungus, one name promotes progressive plant pathology. Molecular plant pathology 13(6), 604-613.

Winter G. 1885 - Pilze-Ascomyceten. In GL Rabenhorst's Kryptogamen-Flora von Deutschland, Oesterreich und der Schweiz 1, 65-528.

Winter G. 1886 - Boletim da Sociedade Broteriana. Coimbra 4, 199.

Winter G. 1887 - Ascomyceten. Rabenhorst's Kryptogamen-Flora 1, 1-928.

Winton LM, Stone JK, Hansen EM, Shoemaker RA. 2007 - The systematic position of Phaeocryptopus gaeumannii. Mycologia 99, 240-252.

Witenweber WR. 1836 - Beiträge zur gesammten Natur- und Heilwissenschaften.

Wolf FA, Wolf FT. 1947 - The fungi. Wiley, New York, Volume 2, 538 pp.

Wong MK, Goh TK, Hyde KD. 2000 - Paraphaeosphaeria schoenoplecti sp. nov. from senescent culms of Schoenoplectus litoralis in Hong Kong. Fungal Diversity 4, 171-179.

Woronichin NN. 1914 - Plectodiscella piri, der Vertreter einer neuen Ascomyceten-Gruppe. Mykologisches Zentralblatt 4, 225-233.

Woronichin NN. 1915 - Les fumagines de Sotschi. Trudy Byuro po Prikladnoj Botanik 8, 769-807.

Woronichin NN. 1925 - Über die Capnodiales. Annales Mycologici 23, 174-178.

Woudenberg JHC, Groenewald JZ, Binder M, Crous PW. 2013 - Alternaria redefined. Studies in Mycology 75, 171-212. 
Woudenberg JHC, Hanse B, Van Leeuwen GCM, Groenewald JZ et al. 2017 - Stemphylium revisited. Studies in Mycology 87, 77-103.

Wu B, Wiese J, Labes A, Kramer A, Schmaljohann R, Imhoff JF. 2015 - Lindgomycin, an unusual antibiotic polyketide from a marine fungus of the Lindgomycetaceae. Marine Drugs 13, 4617-4632.

Wu HX, Schoch CL, Boonmee S, Bahkali AH. 2011 - A reappraisal of Microthyriaceae. Fungal Diversity 51, 189-248.

$\mathrm{Xu} \mathrm{Y,} \mathrm{Mafezoli} \mathrm{J,} \mathrm{Oliverira} \mathrm{MCF,} \mathrm{U'ren} \mathrm{JM} \mathrm{et} \mathrm{al.} 2015$ - Anteaglonialides A-F and Palmarumycins CE1-CE3 from Anteaglonium sp. FL0768, a fungal endophyte of the spike moss Selaginella arenicola. Journal of Natural Products 78, 2738-2747.

Yacharoen S, Tian Q, Chomnunti P, Boonmee S et al. 2015 - Patellariaceae revisited. Mycosphere 6, 290-326.

Yang CL, Xu XL, Wanasinghe DN, Jeewon R, Phookamsak R, Liu YG, Liu LJ, Hyde KD. 2019 Neostagonosporella sichuanensis gen. et sp. nov. (Phaeosphaeriaceae, Pleosporales) on Phyllostachys heteroclada (Poaceae) from Sichuan Province, China. MycoKeys 46, 119150.

Yang HL, Sun GY, Batzer JC, Crous PW et al. 2010 - Novel fungal genera and species associated with the sooty blotch and flyspeck complex on apple in China and the United States. Persoonia 24, 29-37.

Yang HY, Zhang WG, Ma LP, Wang SW, Zhang ZY. 2001 - An approach to enhancing the phototoxicity of a novel hypocrellin congener to MGC803 cells. Dyes and Pigments 51, 103 110.

Yang J, Liu JK, Hyde KD, Jones EBG, Liu ZY. 2018 - New species in Dictyosporium, new combinations in Dictyocheirospora and an updated backbone tree for Dictyosporiaceae. MycoKeys 36, 83-105.

Yang JW, Yeh YH, Kirschner R. 2016 - A new endophytic species of Neostagonospora (Pleosporales) from the coastal grass Spinifex littoreus in Taiwan. Botany 94(8), 593-598.

Yasanthika WAE, Dissanayake LS, Wanasinghe DN, Karunarathna SC et al. 2020 - Lonicericola fuyuanensis sp. nov. (Parabambusicolaceae) a new terrestrial pleosporalean ascomycete from Yunnan, China. Phytotaxa 446, 103-113.

Yuan HS, Lu X, Dai YC, Hyde KD et al. 2020 - Fungal diversity notes 1277-1392: taxonomic and phylogenetic contributions to fungal taxa. Fungal Diversity (in press).

Yuan ZQ, Barr ME. 1994 - Species of Chaetoplea on desert plants in China. Mycotaxon 52, 495499.

Yuan ZQ, Old KM. 1990 - A new species of Thyrostroma from Australia. Mycological Research 94, 573-576.

Yuan ZQ. 1994 - Barria, a new ascomycetous genus in the Phaeosphaeriaceae. Mycotaxon. 51, 313-316.

Yuen TK, Hyde KD, Hodgkiss IJ. 1998 - Physiological growth parameters and enzyme production in tropical freshwater fungi. Material und Organismen 32, 2-16.

Zahlbruckner A. 1903 - Lichenes, Spezieller Teil. In: Engler A, Prantl K (eds) Die Naturlichen Pflanzenfamilien, Abt. 1, t. 1. Engelmann, Leipzig, pp 49-249.

Zainuddin N, Alias SA, Lee CW, Ebel N et al. 2010 - Antimicrobial activities of marine fungi from Malaysia. Botanica Marina 53, 507-513

Zalar P, Gostinčar C, de Hoog GS, Urši č V et al. 2008 - Redefinition of Aureobasidium pullulans and its varieties. Studies in Mycology 61, 21-38.

Zalasky H. 1968 - Rhytidiella moriformis n. gen., n. sp. causing rough-bark of Populus balsamifera. Canadian Journal of Botany 46, 1383-1387.

Zeng M, Huang SK, Hyde KD, Zhao Q. 2018a - Helicascus alatus (Morosphaeriaceae), a new freshwater species from southwestern China. Phytotaxa 351, 210-218.

Zeng XY, Hongsanan S, Hyde KD, Chomnunti P, Wen TC. 2018b - Translucidithyrium thailandicum gen. et sp. nov.: a new genus in Phaeothecoidiellaceae. Mycological Progress 17, 1087-1096. 
Zhang D, Tao X, Chen RD, Liu JM et al. 2015a - Pericoanosin A, a polyketide synthasenonribosomal peptide synthetase hybrid metabolite with new carbon skeleton from the endophytic fungus Periconia sp. Organic Letters 17, 4304-4307.

Zhang D, Tao X, Liu JM, Chen RD et al. 2016a - Pericoanosin G, a new cytochalasan with unprecedented 7/6/5 tricyclic ring system from the endophytic fungus Periconia sp. Tetrahedron Lett 57, 796-799.

Zhang H, Dong W, Hyde KD, Bahkali AH et al. 2016b - Molecular data shows Didymella aptrootii is a new genus in Bambusicolaceae. Phytotaxa 247, 99-108.

Zhang H, Hyde KD, Abdel-Wahab MA, Abdel-Aziz FA et al. 2013a - A modern concept for Helicascus with a Pleurophomopsis-like asexual state. Sydowia 65, 147-166.

Zhang H, Hyde KD, Mckenzie EH, Bahkali AH, Zhou D. 2012a - Sequence data reveals phylogenetic affinities of Acrocalymma aquatica sp. nov., Aquasubmersa mircensis gen. et sp. nov. and Clohesyomyces aquaticus (freshwater coelomycetes). Cryptogamie Mycologie 33, 333-346.

Zhang H, Hyde KD, Zhao Y, McKenzie EH, Zhou D. 2014a - Freshwater ascomycetes: Lophiostoma vaginatispora comb. nov. (Dothideomycetes, Pleosporales, Lophiostomaceae) based on morphological and molecular data. Phytotaxa 176, 184-191.

Zhang J, Cao EH, Li JF, Zhang TC, Ma WJ. 1998 - Photodynamic effects of hypocrellin A on three human malignant cell lines by inducing apoptotic cell death. J Photochem Photobiol B 43, 106-111.

Zhang JF, Liu JK, Hyde KD, Liu YX et al. 2016c - Ligninsphaeria jonesii gen. et. sp. nov., a remarkable bamboo inhabiting ascomycete. Phytotaxa 247, 109-117.

Zhang JF, Liu JK, Jeewon R, Wanasinghe DN, Liu ZY. 2019a - Fungi from Asian Karst formations III. Molecular and morphological characterization reveal new taxa in Phaeosphaeriaceae. Mycosphere 10(1), 202-220

Zhang JJ, Zhou P, Dou ZP, Fournier J, Zhang Y. 2015b - Helicascus unilocularis sp. nov., a new freshwater pleosporalean ascomycete from the Caribbean area. Mycological Progress 14, 47.

Zhang K, Ma LG, Zhang XG. 2009a - New species and records of Shrungabeeja from southern China. Mycologia 101, 573-578.

Zhang SN, Hyde KD, Gareth Jones EB, Cheewangkoon R, Liu JK. 2018 - Acuminatispora palmarum gen. et sp. nov. from mangrove habitats. Mycological Progress 17, 1173-1188.

Zhang SN, Hyde KD, Jones EBG, Jeewon R. 2019b - Striatiguttulaceae, a new pleosporalean family to accommodate Longicorpus and Striatiguttula gen. nov. from palms. MycoKeys 49, 99-129.

Zhang T, Deng X, Yu Y, Zhang M, Zhang Y. 2016d - Pseudochaetosphaeronema ginkgonis sp. nov., an endophyte isolated from Ginkgo biloba. International Journal of Systematic and Evolutionary Microbiology 664377-4381.

Zhang Y, Crous PW, Schoch CL, Hyde KD. 2012 b - Pleosporales. Fungal Diversity 53, 1-221.

Zhang Y, Fournier J, Bahkali AH, Hyde KD. 2013b - Misturatosphaeria mariae sp. nov. from France, a first record of Misturatosphaeria in Europe. Mycoscience 54, 106-109.

Zhang Y, Fournier J, Crous PW, Pointing SB, Hyde KD. 2009b - Phylogenetic and morphological assessment of two new species of Amniculicola and their allies (Pleosporales). Persoonia 23, $48-54$.

Zhang Y, Fournier J, Crous PW, Zhang X et al. 2014b - Neotypification and phylogeny of Kalmusia. Phytotaxa 176:164-173.

Zhang Y, Fournier J, Phookamsak R, Bahkali Ali H, Hyde KD. 2013c - Halotthiaceae fam. nov. (Pleosporales) accommodates the new genus Phaeoseptum and several other aquatic genera. Mycologia 105, 603-609.

Zhang Y, Fournier J, Pointing SB, Hyde KD. 2008a - Are Melanomma pulvis-pyrius and Trematosphaeria pertusa congeneric? Fungal Diversity 33, 47-60.

Zhang Y, Jeewon R, Fournier J, Hyde KD. 2008b - Multi-gene phylogeny and morphotaxonomy of Amniculicola lignicola: a novel freshwater fungus from France and its relationships to the Pleosporales. Mycological Research 112, 1186-1194. 
Zhang Y, Liu YJ, Zhou YP, Zhang XD et al. 2014c - Helicascus gallicus sp. nov., a new freshwater pleosporalean ascomycete from France. Phytotaxa 183, 183-192.

Zhang Y, Schoch CL, Fournier J, Crous PW et al. 2009c - Multi-locus phylogeny of the Pleosporales: a taxonomic, ecological and evolutionary re-evaluation. Studies in Mycology 64, 85-102.

Zhang Y, Wang HK, Fournier J, Crous PW et al. 2009d - Towards a phylogenetic clarification of Lophiostoma/Massarina and morphologically similar genera in the Pleosporales. Fungal Diversity 38, 225-251.

Zhao G, Liu X, Wu W. 2007 - Helicosporous hyphomycetes from China. Fungal Diversity 26, $313-524$

Zhao N, Luo ZL, Hyde KD, Su HY et al. 2018 - Helminthosporium submersum sp. nov. (Massarinaceae) from submerged wood in north-western Yunnan Province, China. Phytotaxa 348, 269-278.

Zhaxybayeva O, Gogarten JP. 2002 - Bootstrap, Bayesian probability and maximum likelihood mapping: exploring new tools for comparative genome analyses. BMC genomics 3:4

Zheng H, Yu ZF, Xu JP, Castañeda-Ruiz RF, Qiao M. 2020 - Ramichloridium endophyticum sp. nov., a novel species of endophytic fungus from Potamogeton pectinatus. International Journal of Systematic and Evolutionary Microbiology 7, :3433-3439

Zhou DQ, Cai L, Hyde KD. 2003 - Astrosphaeriella and Roussoella species on bamboo from Hong Kong and Yunnan, China, including a new species of Roussoella. Cryptogamie Mycologie 24, 191-197.

Zhou Y, Gong G, Zhang S, Liu N et al. 2014 - A new species of the genus Trematosphaeria from China. Mycological Progress 13, 33-43.

Zogg H. 1949 - Beiträge zur Kenntnis der brasilianischen Hysteriaceen. Berichte der Schweizerischen botanischen Gesellschaft 59, 39-42.

Zogg H. 1962 - Die Hysteriaceae s. str. und Lophiaceae, unter besonderer Berücksichtigung der mitteleuropäischen Formen. Beiträge zur Kryptogamenflora der Schweiz, Band 11, 1-190. 